\title{
THE TECTONO-STRATIGRAPHIC DEVELOPMENT AND HYDROCARBON HABITAT OF THE CARBONIFEROUS IN NORTHERN ENGLAND
}

\author{
Volume 1
}

Text

A thesis submitted for the degree of Doctor of Philosophy

by

Alastair James Fraser

Department of Geology and Applied Geology,

University of Glasgow.

January 1995 
ProQuest Number: 13815584

All rights reserved

INFORMATION TO ALL USERS

The quality of this reproduction is dependent upon the quality of the copy submitted.

In the unlikely event that the author did not send a complete manuscript and there are missing pages, these will be noted. Also, if material had to be removed, a note will indicate the deletion.

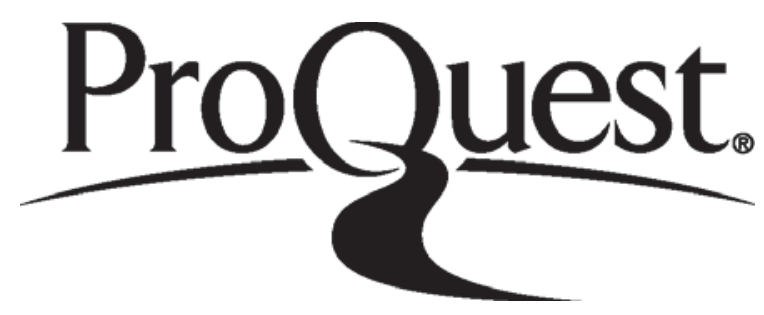

ProQuest 13815584

Published by ProQuest LLC (2018). Copyright of the Dissertation is held by the Author.

All rights reserved.

This work is protected against unauthorized copying under Title 17, United States Code Microform Edition (C) ProQuest LLC.

ProQuest LLC.

789 East Eisenhower Parkway

P.O. Box 1346

Ann Arbor, Ml $48106-1346$ 
Thesis
10051
Cop?
vol!

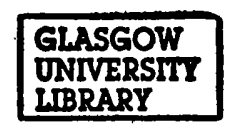




\section{Thesis Declaration}

The material presented in this thesis is the result of research carried out between September 1989 and December 1994 at BP Exploration, 301 St Vincent Street, Glasgow and in the Department of Geology and Applied Geology, University of Glasgow, under the supervision of Dr. Stuart Haszeldine.

This thesis is based on my own independent research and any published or unpublished material used by me has been given full acknowledgement in the text.

Alastair James Fraser

January 1995

We certify that Alastair James Fraser has undertaken the bulk of the work involved in this thesis. Specifically: background geology, data base collation, well and seismic interpretation, sequence stratigraphic analysis and hydrocarbon geology. We have assisted with advice and help of a general, technical and conceptual nature as would be expected in the course of normal Ph.D. supervision and advice. Alastair James Fraser has written the thesis and papers within it himself, and is resposible for its content.
R.S.Haszeldine
R.L.Gawthorpe
D.F. Nash
C.C.Ebdon
R.P.Steele
B.C.Mitchener

\section{A.C.Higgins}

A.R.E.Strank 


\section{ABSTRACT}

Over 70 years of exploration in the Carboniferous of northern England has resulted in the discovery of recoverable reserves totalling 75 million barrels of oil and 27 billion cubic feet of gas contained in 36 oil and gas fields. During this time the petroleum industry has amassed a substantial quantity of borehole and reflection seismic information. Integrating this essentially subsurface database with information derived from surface exposure has permitted a hitherto unachievable understanding of the Carboniferous in terms of its structural and stratigraphic development and hydrocarbon habitat.

One of the key objectives of this study has been to attempt to answer the question: "Is the East Midlands unique as an oil province in northern England?" To achieve this, data from an extensive inventory of 'successful' intra-Carboniferous tests has been synthesized and used to identify and calibrate the key factors controlling the specific hydrocarbon environments. These factors have in turn been used to assess the remaining 10-15 sub-basins in northern England where Carboniferous sediments were deposited and where the play may be potentially developed.

Regional seismic lines tied to borehole data and exposure studies from several northern England Carboniferous basins have been interpreted using a sequence stratigraphic approach. This has been used to develop a consistent tectono-stratigraphic framework in tying between different basins of the northern England Carboniferous. The strong NWSE and NE-SW structural trends which control the basin geometry were inherited from the Late Palaeozoic, Caledonian orogeny. These fault trends were consistently reactivated throughout the Carboniferous in both an extensional and compressional sense. The main influence on Carboniferous basin evolution in northern England was the Variscan collision type orogeny. The Variscan plate cycle controlled the development of syn-rift (extension), post-rift (thermal subsidence), and inversion (compression) megasequences or cycles from Late Devonian to Early Permian times. Depositional 
sequences developed within these Carboniferous megasequences are primarily controlled by episodic rifting and periodic fault reactivation with eustatic sea level changes providing only minor control at the subsequence level.

The main hydrocarbon source rocks (pro-delta shales) are confined to isolated, syn-rift depocentres. Syn-rift siliciclastic reservoirs (sandstones and conglomerates) are also restricted to the rifted half-graben. Carbonate grainstone reservoirs (limestones) rim the margins of the deeper half-graben where terrigenous input has been limited. Delta top channel and mouth bar reservoirs (sandstones) are best developed where they axially infill remnant syn-rift bathymetry. The late Carboniferous-early Permian culmination of the Variscan orogeny is seen to be the main trap forming event. All hydrocarbon discoveries to date display some element of Variscan inversion in their geometry. Variscan tectonics have also exerted a subtle but important control on play fairway evolution.

Mesozoic burial ensured hydrocarbon generation which post-dated Variscan trap formation. Still later Tertiary thermal uplift inverted and modified many basins and traps. These now represent the main controls on the present day distribution of hydrocarbons in the Carboniferous of northern England. Several key areas where Carboniferous source rocks have generated significant hydrocarbons during the Mesozoic have been identified; the East Midlands being the most significant in terms of discovered hydrocarbons and perceived future potential. 
Abstract 


\section{ACKNOWLEDGEMENTS}

Firstly, I would like to thank my many colleagues at BP for their support and assistance in completing this thesis. Of particular note is Dave Nash, Chief Geologist at BP Eakring in the late 1980's, for having the foresight to see that a regional evaluation of the northern England Carboniferous play was long overdue. The fact that the study led to BP's eventual withdrawal from UK Land exploration shows the value in his original vision. I have to thank my colleagues Brian Mitchener, Alex Kay, Tim Bevan, Chris Ebdon, Richard Steel, Andrew Horbury, Angela Strank, Alan Higgins, Neil Taylor, Jake Hossack, Mark Houchen and John Hurst who made important contributions in the early part of the study and several of whom co-authored the papers attached as appendices. I would also like to thank the members of the BP drawing offices in Eakring, Glasgow and London for their assistance in drafting the many figures and plates which illustrate the text. In particular, I would like to thank Keith Greenwood, Paul Batey, Martin Kirk and Malcolm Kelsey. I would also like to pay a special tribute to Sjoerd Schuyleman, Technical Manager UK Land in the late 1980's, for his encouragement and support in embarking on this thesis.

In the academic world, I had particular help from my supervisor Stuart Haszeldine (Glasgow University) and Rob Gawthorpe (Manchester University), both of whom provided the technical challenges and discussion over the past 5 years that have led to the formulation of many of the ideas contained in this thesis.

BP Exploration are thanked for providing much of the data, and all of the funding and time to complete this study. I would also like to acknowledge the assistance of Martin Stephenson of Enterprise Oil in providing access to seismic data for the Edale Gulf, Bowland Basin and Solway Basin.

Finally I would like to thank my wife Jane, not only for her efforts in pulling together the references and typing much of the text, but also for her support, understanding and considerable patience while I have been carrying out the research for this study. I can now get back to the DIY! 


\section{CONTENTS}

ABSTRACT

Page No.

ACKNOWLEDGEMENTS

i

CONTENTS

LIST OF PLATES, FIGURES, TABLES \& ENCLOSURES

iv

vi

$\mathrm{x}$

1

1.1 Rationale 1

1.1.1 Stratigraphic philosophies 2

1.1.2 Petroleum habitat

1.2 Thesis outline 7

9

1.3 Database 11

1.3.1 Limits of the study 11

1.3.2 Well Control 12

1.3.3 Seismic 13

1.3.4 Surface Geology 13

1.3.5 Gravity and Magnetics $\quad 13$

1.4 Exploration History

Chapter 2. REGIONAL STRUCTURAL FRAMEWORK 23

2.1 Introduction 23

2.2 Tectonic Provinces 24

2.3 Pre-Caledonian History $\quad 28$

2.4 Caledonian Inheritance $\quad 29$

2.4.1 Caledonide Microplate Collisions 29

2.4.2 The Caledonides of northern England . 33

2.4.3 Caledonian granites $\quad 35$

2.5 Variscan Plate Cycle $\quad 36$

2.5.1 Regional Variscan Tectonics 38

2.5.1.1. Variscan plate reconstruction 38

2.5.1.2. Variscan extension 39

2.5.1.3. Variscan compression 43

2.5.2 Variscan structural development in northern England 44 2.5.2.1 Major trends 44

2.5.2.2 Late Devonian-Dinantian rifting 48

2.5.2.3 Intra-Dinantian inversion $\quad 50$

2.5.2.4 Silesian extension $\quad 52$ 
2.5.2.5 Variscan compression $\quad 55$

2.5.3 Geodynamic interpretation 61

2.5.3.1 Late Devonian-Dinantian rifting 61

2.5.3.2 Late Dinantian and Silesian tectonics 66

2.5.3.3 Variscan inversion 67

$\begin{array}{lll}2.5 .4 & \text { Summary } & 69\end{array}$

2.6 Post Carboniferous Tectonics $\quad 71$

2.6.1 Permo-Triassic events 71

2.6.2 Later Mesozoic events 71

2.6.3 Cenozoic events 73

$\begin{array}{ll}2.7 \text { Summary } & 74\end{array}$

Chapter 3. TECTTONO-STRATIGRAPHIC DEVELOPMENT

$\begin{array}{ll}3.1 \text { Introduction } & 78\end{array}$

3.2 Carboniferous Tectono-stratigraphy of northern England 81

3.2.1 Tectono-stratigraphic evolution of the 85

Widmerpool Gulf

3.2.2 Tectono-stratigraphic evolution of the 107

Gainsborough Trough

3.2.3 Tectono-stratigraphic evolution of the Edale Gulf 111

3.2.4 Tectono-stratigraphic evolution of the Bowland Basin 115

3.2.5 Tectono-stratigraphic evolution of the Leeds Basin 117

3.2.6 Tectono-stratigraphic evolution of the Cleveland Basin 117

3.2.7 Tectono-stratigraphic evolution of the 119

Stainmore Trough

3.2.8 Tectono-stratigraphic evolution of the 124

Northumberland Trough-Solway Basin

$\begin{array}{ll}3.3 \text { Tectono-stratigraphic summary } & 127\end{array}$

3.3.1 Syn-rift megasequence (late-Devonian-early Brigantian) 128

3.3.2 Post-rift megasequence (late Brigantian- 142

late Westphalian C)

3.3.3 Inversion megasequence (late Westphalian C- 149 early Permian)

3.4 Conclusions

Chapter 4. PALAEOGEOGRAPHY AND FACIES EVOLUTION 155

4.1 Introduction $\quad 155$

4.2 Regional palaeogeographic setting $\quad 157$

4.3 Late Devonian Sequence EC1a - early syn-rift I. 158 
4.4 Courceyan Sequence EC1b - late syn-rift I. 158

4.5 Chadian Sequence EC2 - post rift I (regression) 160

4.6 Late Chadian - Arundian Sequence EC3 - 163 early syn-rift II (transgressive)

4.7 Holkerian Sequence EC3 - late syn-rift II (transgressive) 165

4.8 Asbian Sequence EC4 - post rift II (regressive) 166

4.9 Late Asbian - Early Brigantian Sequence EC5 - 169 syn rift III (transgressive)

4.10 Early-Mid Brigantian Sequence EC6 - post rift III (regressive) 172

4.11 Late Brigantian Sequence LC1a - post rift 174

4.12 Early Pendleian Sequence LCla - post rift 175

4.13 Late Pendleian-Arnsbergian Sequence LC1b - post rift 176

4.14. Chockierian - Alportian Sequence LC1b - post rift 178

4.15 Kinderscoutian Sequence LC1c - post rift 179

4.16 Marsdenian Sequence LC1c - post rift 182

4.17 Yeadonian Sequence LC1c - post rift 184

4.18 Early Westphalian 'A' Sequence LC1c - post rift 185

4.19 Late Westphalian 'A'-Westphalian 'C' Sequence LC2-post rift 186

4.20 Late Westphalian 'C' - Early Permian (Variscan) 188

Sequence $\mathrm{V}$ - inversion

$\begin{array}{ll}\text { Chapter 5. HYDROCARBON GEOLOGY } & 191\end{array}$

5.1 Reservoir, Seal and Source Distribution 191

5.1.1 Reservoir

5.1.1.1 Syn-rift alluvial fans and fan deltas $\quad 191$

5.1.1.2 Carbonate margins \& associated facies $\quad 193$

5.1.1.3 Clastic delta systems $\quad 197$

5.1.2 Retaining hydrocarbons 214

5.1.2.1 Seal Capacity and Extent. 214

5.1.2.2 Trap occurrence and integrity. 217

5.1.3 Source rock distribution. 218

5.1.4 Source rock distribution summary 232

5.2 Tectono-Sedimentary Controls on the Hydrocarbon Habitat 236

5.2.1 Trap Formation 236

5.2.2 Burial History and Hydrocarbon Generation 238

5.2.2.1 Late Carboniferous Generation 246

5.2.2.2 Mesozoic Generation 247

5.3 Play Fairway Analysis $\quad 250$

$\begin{array}{lll}5.3 .1 & \text { Syn-rift clastics } & 252\end{array}$ 
5.3.2 Carbonate Shelf Margins 253

5.3.3 Secondary Carbonate Plays 256

5.3.3.1 Waulsortian Mudmounds 256

5.3.3.2 Chadian Grainstone Shoals 258

5.3.3.3 Shelf Carbonates $\quad 259$

5.3.3 Clastic delta systems 259

5.3.3.1 Description 259

5.3.3.2 Assessment of the Clastic delta play in northern England

Chapter 6. CONCLUSIONS

REFERENCES

\section{APPENDICES}

Appendix A. Borehole database with Dinantian facies \& Carbonate reservoir production data

Appendix B Depth conversion of regional seismic profiles

Appendix C Geochemical data, reports \& sample locations

Appendix D The THETA thermal modelling program

Appendix E Copy of: FRASER, A.J., NASH, D.F., STEELE, R.P. \& EBDON, C.C. 1990. A regional assessment of the intra-Carboniferous play of northern England. In: BROOKS, J. (ed). Classic Petroleum Provinces. Geological Society of London, Special Publication, 50, 417-440.

Appendix F. Copy of: EBDON, C.C., FRASER, A.J., HIGGINS, A.C., MITCHENER, B.C. \& STRANK, A.R.E. 1990. The Dinantian Stratigraphy of the East Midlands: A seismostratigraphc approach. Journal of the Geological Society, London, 147, 519-536.

Appendix G. Copy of: FRASER, A.J. \& GAWTHORPE ,R.L. 1990. Tectonostratigraphic development and hydrocarbon habitat of the Carboniferous in northern England. In: HARDMAN, R.F.P. \& BROOKS, J. (eds). Tectonic Events Responsible for Britain's Oil and Gas Reserves. Geological Society of London, Special Publication, 55, 49-86.

Appendix H (Volume 2) Summarised well logs (1:10,000 scale) of key boreholes used in the regional seismic interpretation (Plates 3.2-3.20) and palaeofacies mapping (Plates 4.1-4.21). 


\section{LIST OF PLATES, FIGURES, TABLES \& ENCLOSURES}

\section{LIST OF PLATES (Volume 2)}

\section{Exploration history and database}

\subsection{Licence position March 1989}

1.02 Carboniferous oil and gas fields and cumulative reserves

1.03 Reported surface and near surface hydrocarbon occurrences

1.04 East Midlands hydrocarbon province: Structural elements and fields

1.05 Study area showing hydrocarbon discoveries and shows

1.06 Dinantian database map

1.07 NCB Boreholes and upper Carboniferous outcrop

1.08 Seismic database

1.09 Bouguer anomaly

1.10 First order derivative of Bouguer anomaly

1.11 Aeromagnetic survey

\section{Tectono-stratigraphic development}

2.01 Caledonian structural elements

2.02 Plate reconstruction for the Early Carboniferous

2.03 Idealised crustal scale sections: Pre and Post Variscan collision

2.04 Dinantian structural elements

2.05 Central England rift system: Regional cross sections

2.06 Chronostratigraphy of the Carboniferous system in Northern England

2.07 Sequence stratigraphy correlation: Widmerpool Gulf-Bowland BasinStainmore Trough

2.08 Basin development: Widmerpool Gulf and Hathern Shelf

2.09 Chadian-Mid Brigantian syn-rift isopachs; sequences EC2-EC6

2.10 Late Brigantian-Westphalian C post-rift isopachs; sequences LC2-LC6

2.11 Variscan uplift and erosion

2.12 Post Variscan isopachs

2.13 Neogene and Quaternary uplift 


\section{Regional seismic and geological interpretation}

3.01 Location of regional seismic profiles and cross sections

$3.02 \mathrm{~N}-\mathrm{S}$ geological section across East Midlands hydrocarbon province

3.03 Regional seismic and depth section across the Southern North Sea Basin

3.04 Composite seismic and interpreted geological section across the Widmerpool Gulf

3.05 Regional well correlation across the Widmerpool Gulf

3.06 Composite seismic and interpreted geological section across the Gainsborough Trough

3.07 Composite seismic and interpreted geological section across the SE Gainsborough Trough

3.08 Composite seismic and interpreted geological section: Welton Oilfield

3.09 Composite seismic and interpreted geological section: Eakring Oilfield

3.10 Composite seismic and interpreted geological section: Egmanton Oilfield

3.11 Composite seismic and interpreted geological section: Calow Gasfield

3.12 Composite seismic and interpreted geological section across the Edale Gulf

3.13 Composite seismic and interpreted geological section across the western Bowland Basin

3.14 Composite seismic and interpreted geological section across the Pendle Monocline \& Bowland Basin

3.15 Composite seismic and interpreted geological section across the Leeds Basin

3.16 Composite seismic and interpreted geological section across the Cleveland Basin

3.17 Composite seismic and interpreted geological section across Western Stainmore

3.18 Composite seismic and interpreted geological section across Western Stainmore

3.19 Composite seismic and interpreted geological section across the Solway Basin

3.20 Composite seismic and interpreted geological section across the Northumberland Basin

3.21 Summarised stratigraphy of the East Midlands showing megasequence and sequence stratigraphy 


\section{Palaeogeography and facies evolution}

4.01 Late Devonian Palaeofacies (EC1a)

4.02 Courceyan Palaeofacies (EC1b)

4.03 Chadian Palaeofacies (EC2)

4.04 Late Chadian - Arundian Palaeofacies (EC3)

4.05 Holkerian Palaeofacies (EC3)

4.06 Late Holkerian - mid Asbian Palaeofacies (EC4)

4.07 Late Asbian - early Brigantian Palaeofacies (EC5)

4.08 Early - mid Brigantian Palaeofacies (EC6)

4.09 Late Brigantian Palaeofacies (LC1a)

4.10 Early Pendleian Palaeofacies (LCla)

4.11 Late Pendleian - Arnsbergian Palaeofacies (LC1b)

4.12 Chokierian - Alportian Palaeofacies (LC1b)

4.13 Early - mid Kinderscoutian Palaeofacies (LC1c)

4.14 Late Kinderscoutian Palaeofacies (LC1c)

4.15 Middle Marsdenian Palaeofacies (LC1c)

4.16 Late Marsdenian Palaeofacies (LClc)

4.17 Earliest Yeadonian Palaeofacies (LC1c)

4.18 Yeadonian Palaeofacies ( $\mathrm{LClc}$ )

4.19 Earliest Westphalian A Palaeofacies (LC1c)

4.20 Westphalian A - B Palaeofacies (LC2)

4.21 Variscan - Post Westphalian C Inversion Palaeogeography (V1)

5. Hydrocarbon habitat and play fairway analysis

5.01 Northern England Carboniferous play fairway summary

5.02 Maximum Palaeo burial of basal Namurian fluvio-deltaic reservoirs

5.03 Vitrinite reflectance at Top Dinantian

5.04 Summary of Dinantian and Namurian source rock distribution and potential

5.05 Summary of Late Mesozoic Hydrocarbon Generation

5.06 Carboniferous Play Fairways - 1. Syn-rift Sandstones

5.07 Carboniferous Play Fairways - 2. Carbonate Shelf Margins

5.08 Carboniferous Play Fairways - 3. Clastic Delta Systems

5.09 Carboniferous Play Fairways - 4. Quartzose Fluvial Sands

5.10 Carbonate margin play assessment

5.11 Clastic delta play assessment

5.12 Intra-Carboniferous play summary 


\section{LIST OF FIGURES}

Page No.

\section{Chapter 1}

1.1 Northern England Carboniferous: Plot of recoverable reserves additions 1 against exploration and appraisal drilling; the 'Creaming Curve'.

1.2 Depth cross-section of an 'Exxon-type' conceptional depositional sequence.

1.3 Cross-sections of a 'genetic' depositional sequence.

1.4 Northern England Carboniferous: Distribution of (a) recoverable hydrocarbons and (b) number of fields by province.

1.5 Northern England Carboniferous: Cumulative recoverable reserves.

1.6 Northern England Carboniferous: Field size distribution.

1.7 Example of early mapping of the Eakring oilfield based on Coal Board and production well data.

1.8 BP onshore UK oil production: 1940-1988.

1.9 BP operated onshore UK wells: 1939-1989.

\section{Chapter 2}

2.1 Caledonian tectonic provinces of England and Wales.

2.2 Caradoc palaeogeography of Cadomia, Baltica, Laurentia and Avalonia.

2.3 Sketch map of N.W. Europe showing major Pre-Cambrian cratons, foldbelts and sutures.

2.4 Carboniferous structural elements: northern England and the

2.5 Northern England Dinantian tectonics: Schematic models for the development of intra-Dinantian unconformities and their seismic expression.

2.6 Restored isopachs for post rift sequences LC1-LC2 (NamurianWestphalian 'C') for northern England and the Southern North Sea.

2.7 Late Carboniferous inversion structures in the East Midlands.

2.8 Inversion styles in northern England.

2.9 Decompacted, sediment-loaded basement subsidence plot for the Ratcliffe-on-Soar borehole, Widmerpool Gulf; modelled using the THETA program.

2.10 Model for late Devonian-Carboniferous tectonics in northern England.

2.11 Model for Variscan compression and inversion in northern England. 
2.12 Schematic displacement vector for the Midlands microcraton during the Carboniferous.

2.13 Permian - early Cretaceous rift systems of England \& Wales.

Chapter 3

3.1 Model for the seismo-stratigraphic evolution of an extensional basin. 81

3.2 Structural setting of the western Widmerpool Gulf. 85

3.3 Dinantian-early Namurian seismo-stratigraphy of the Widmerpool Gulf. 87

3.4 Composite sketch of seismo-stratigraphic interpretation, 93 western Widmerpool Gulf.

3.5 Sequence architecture, southern margin of the Widmerpool Gulf. 94

3.6 Sequence architecture, northern margin of the Widmerpool Gulf. 98

3.7 Seismic line BP-85-31. Development of carbonate mudmounds 99 within seismic sequence EC6 on the Hathern Shelf.

3.8 EC6-LC1a (Brigantian-Pendleian) seismic facies analysis in the Widmerpool Gulf.

3.9 Middleton-Wirksworth area south Derbyshire Dome. Asbian-Brigantian shelf margins (sequences EC4 \& EC6).

3.10 East west seismic line along the axis of the Widmerpool Gulf showing the westerly progradation (and eventual abandonment) of the Namurian Ashover delta (sequence LC1c).

3.11 Sequence stratigraphy and sedimentary facies analysis Ilkeston-1.

3.12 Seismic lines BP-85-162 and BP-85-166 showing the development of Chadian (EC2) mudmounds on the hangingwall of the Askern-Spital fault, northern margin of the Gainsborough Trough.

3.13 Example of an Asbian (EC4) rimmed shelf margin at Castleton, north Derbyshire Dome.

3.14 Northwest face of Hope Cement Works Quarry, Derbyshire showing progradational character of late Asbian-Brigantian (EC5) shoaling sequence.

3.15 Early syn-rift conglomerates from the Cross Fell inlier, western Stainmore (sequence ECla).

3.16 Chatburn Limestone (sequence EC1b). Chatburn road cut. Ramp carbonates developed following the initial marine transgression into the syn-rift.

3.17 Thornton Limestone (sequence EC2). Scrosthorpe Lane Quarry. Shallow ramp grainstone shoals developed on the upper part of the hangingwall dipslope. 
3.18 Thornton Limestone (sequence EC2) from the High Ings Barn borehole. Porosity development in grainstone facies following burial dolomitisation and dissolution.

3.19 Haw Crag (sequence EC3) northern Bowland; Boulders of proximal ramp and Waulsortian mud mound carbonates derived from footwall erosion along the south Craven fault system at the onset of EC3 rifting.

3.20 Worston Shale, BP Minerals borehole MHD-3, southern Bowland High (sequence EC3). Typical syn-rift basinal deposits comprising thinly bedded hemipelagic mudstones and distal calciturbidites.

3.21 Worston Shale Croasdale Beck, northern Bowland Basin (EC3). Syn-sedimentary slumps and folds in interbedded hemipelagics and distal calciturbidites generated by slope instability during EC3 rifting.

3.22 Great Scar Limestone (sequence EC4) at Malham Cove.

3.23 Castleton, Derbyshire, southern margin of the Edale Gulf.

Present day topography picks out the exhumed EC4 shelf margin.

3.24 Pendleside Limestone (EC4/EC5 boundary), Green Pike, Slaidburn. An excellent example of a major sequence boundary occurring in the middle of a lithostratigraphic unit.

3.25 Pendleside Limestone (sequence EC5) BP minerals borehole BHD-11, Sykes anticline. Debris flow deposits from the Bowland High during EC5 rifting

3.26 Pendleside Limestone (sequence EC5) BP Minerals borehole BHW-4, Sykes anticline. Secondary porosity development in boulder bed facies.

3.27 Pendleside Limestone (sequence EC5) BP Minerals borehole BHD-11, Sykes anticline. Vuggy porosity in boulder beds associated with hydrocarbon shows.

3.28 Bradwell Dale, Derbyshire. The mid-Brigantian inversion demonstrated at outcrop by the marked unconformity between the Upper Monsal Dale Beds (early Brigantian; EC5) and the Eyam Limestones (late Brigantian; EC6).

3.29 Middle Peak, Wirksworth, Derbyshire. Metre scale cyclic sequence of shelf grainstones, packstones and wackestones.

3.30 Dale Quarry, Wirksworth, Derbyshire.

Hangingwall carbonate margin (sequence EC6).

3.31 Coalhills complex, Wirksworth, Derbyshire. Brigantian (EC6)

mudmounds developed on the hangingwall dipslope of the western Widmerpool Gulf.

3.32 Coalhills complex, Wirksworth, Derbyshire. Brigantian (EC6) mudmound, showing detail of poorly connected vuggy, porosity developed within brachiopod rich zones.

3.33 Pendle Grit turbidites (sequence LC1a), Trough of Bowland. 
3.34 A regional view of the Castleton area in Derbyshire.

3.35 Edale Shales (sequence LC1a) Castleton, Derbyshire.

3.36 Mam Tor, Derbyshire. The succession at Mam Tor contains basinal pro-delta mudstones and the delta front turbidites associated with the Kinderscout delta system.

3.37 Kinderscout Grit, Holybank Quarry, Tintwhistle..

3.38 Birchen Edge, Derbyshire. Distributary channel sands, Crawshaw sandstone (sequence LC1c).

3.39 Butterwell open cast site, near Morpeth, Northumberland, showing Upper Westphalian 'A'-Westphalian 'B' coal measures (LC2).

3.40 Blockley's Quarry, Hadley . Barren Measures, alluvial fan red beds, Etruria Formation (sequence VI).

3.41 Skipton anticline, Central Bowland. Tightly folded lower Carboniferous (sequence EC1) carbonates deformed during the late Carboniferous-early Permian, Variscan inversion event.

\section{Chapter 4}

4.1 Dovedale Derbyshire. Chadian (EC2) Waulsortian build-up.

4.2 Dunald Mill Quarry, near Carnforth, Lancashire. This locality comprises late Asbian (EC5) shelf grainstones situated on the northern margin of the Lancaster Fells Basin.

4.3 Windy Knoll, Castleton, Derbyshire. Fissure fills and hydrocarbons in shelf carbonates.

4.4 Schematic palaeogeography for the late Dinantian-early Namurian, showing the extent of Yoredale facies deposition over northern England and the Southern North Sea.

4.5 Schematic depositional model for the Kinderscout delta system.

\section{Chapter 5}

5.1 Schematic palaeogeography for the late Devonian syn-rift of northern England and the Southern North Sea.

5.2 Schematic palaeogeography for the late Dinantian of northern England and the Southern North Sea.

5.3 Schematic palaeogeography for the late Namurian-early Westphalian of northern England and the Southern North Sea.

5.4 Simplified Namurian isopachs for the East Midlands based on borehole and seismic data.

5.5 Distributary channel facies. Gamma-ray log profile and core sedimentological interpretation (Askham-1). 
5.6 Distributary mouth bar/crevasse splay facies. Gamma-ray log profile and core sedimentological interpretation (Cropwell Butler-2).

5.7 Crevasse channel facies. Gamma-ray log profile and core sedimentological interpretation (Fiskerton-1).

5.8 Minor distributary mouth bar facies. Gamma-ray log profile and core sedimentological interpretation (Ladybrook-1).

5.9 Palaeofacies map for the Ashover delta in the East Midlands.

5.10 Palaeofacies map for the Chatsworth delta in the East Midlands.

5.11 Palaeofacies map for the Crawshaw delta in the East Midlands.

5.12 Maturity against depth profile for the Bardney- 1 borehole in the East Midlands based on vitrinite reflectance data.

5.13 Maturity against depth profile for the well 39/9-1 in the Southern North Sea Basin based on vitrinite reflectance data.

5.14 Porosity v permeability plot for late Namurian-Westphalian ' $A$ ' channel sandstone facies based on core analysis data from boreholes in the East Midlands.

5.15 Porosity v permeability plot for late Namurian-Westphalian ' $A$ ' mouth bar sandstone facies based on core analysis data from boreholes in the East Midlands.

5.16 Porosity $v$ depth plot for late Namurian-Westphalian ' $A$ ' channel sandstone facies based on core analysis data from boreholes in the East Midlands.

5.17 Crawshaw sandstone isoporosity map for the East Midlands.

5.18 Faunal facies at the maximum transgression of the Gastrioceras Subcranatum Marine Band.

5.19 Depth to top Chatsworth grit reservoir in the Calow gas field, East Midlands.

5.20 Sketch of the early Permian palaeogeography of eastern England and the Southern North Sea showing the extent of base Permian Rotliegend and Zechstein evaporite seals.

5.21 East-west scale cross section of the Eakring oilfield in the East Midlands highlighting the stacked nature of the reservoir channel and mouth bar sand bodies.

$5.22 \mathrm{Oil} /$ source rock correlation based on carbon isotope analyses of East Midlands source rock and oil samples.

5.23 Delta advance during the middle to late syn-rift and early post-rift and its relationship with source rock distribution and age in northern England. 
5.24 Model for the evolution of the late Dinantian-Namurian deep water deltas in the rift basins in the south of the study area from the shallow water systems in the north.

5.25 Maturity against depth profile for the Rufford-1 borehole in the East Midlands based on vitrinite reflectance data.

5.26 Plot of Lower Bunter Shale and Mercia Mudstone velocities from boreholes in the East Midlands against the standard Lower Bunter Shale compaction curve.

5.27 Subsidence history and source rock maturity for the Rufford-1 borehole in the East Midlands modelled using the 'THETA' programme.

5.28 Restored post-Carboniferous isopachs and the location of the major hydrocarbon discoveries in northern England.

5.29 Schematic palaeogeography for the late Westphalian of northern England and the Southern North Sea.

5.30 Present day heat flow map for northern England.

\section{Chapter 6}

6.1 Evolution of the hydrocarbon system in the Carboniferous of the East Midlands.

\section{LIST OF TABLES}

2.1 Development of the Variscan Orogeny in Northwest Europe: Timing of key events.

3.1 Tectono-stratigraphy of the northern England Carboniferous.

\section{LIST OF ENCLOSURES}

1. Widmerpool Gulf: N-S regional seismic profile (uninterpreted) 
xix 


\section{$\underline{\text { CHAPTER } 1 \text { INTRODUCTION }}$}

\subsection{RATIONALE}

In the late 1980's it was becoming apparent from discouraging drilling results, that the well established Upper Carboniferous clastic delta play fairway in the East Midlands was more-or-less exhausted in terms of mappable, economic prospects (Fig 1.1). At that time, BP held a large acreage portfolio in this province (Plate 1.1) and there was therefore a requirement to identify a new play system or relinquish the acreage on the basis of diminishing returns. Indications were that the lightly explored, Lower Carboniferous (Dinantian) could offer some potential. It was argued that many of the past failures could be attributed to drilling in unfavourable structural/stratigraphic settings i.e. in low porosity and permeability, peritidal shelf carbonates some distance from a mature basinal marine petroleum source facies.

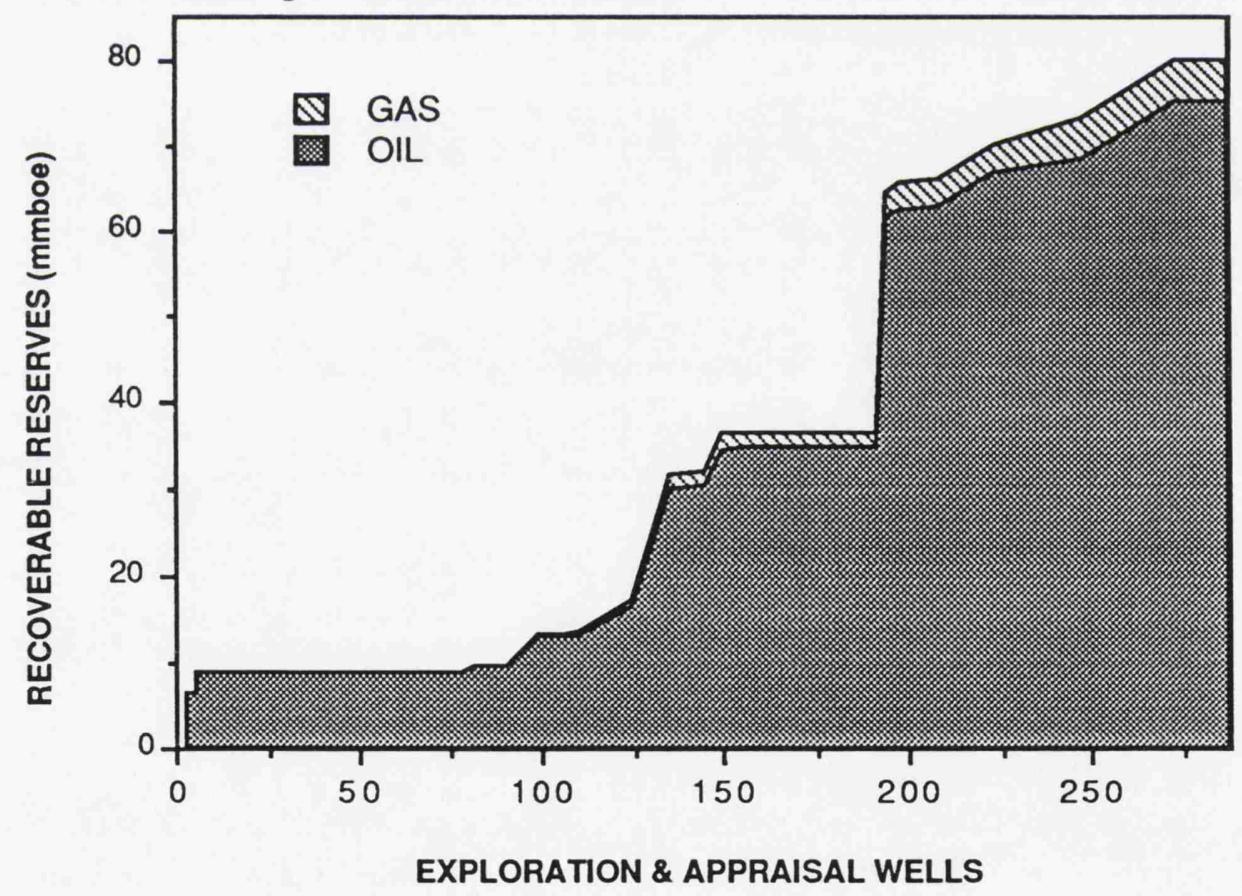

Figure 1.1 Northern England Carboniferous : Plot of recoverable reserves additions against exploration and appraisal drilling: the 'Creaming curve'. A profile typical of an over-mature play system. The last 100 wells have contributed only minor reserve additions suggesting that the intra-Carboniferous play has plateaued and that future discoveries will be limited. (Data compiled from in-house BP files). 
This study was initiated with three main objectives in mind;

(i) to provide a comprehensive synthesis of all geological/ geophysical data in northern England.

(ii) to derive an overview of hydrocarbon prospectivity on a regional, per basin and per licence basis.

(iii) to obtain a relative basin/acreage ranking and recommend a future exploration strategy for BP in northern England.

Since the petroleum geology of the northern England Carboniferous was last fully evaluated (Kent 1966) there have been significant advances in exploration geology, particularly in the realms of seismic stratigraphy and fairway analysis. This thesis sets out to apply these new techniques to the Carboniferous problem in order to fully evaluate remaining hydrocarbon prospectivity in northern England.

\subsubsection{Stratigraphic philosophies}

Previous methods of stratigraphic correlation of the northern England Carboniferous have involved the use of lithostratigraphy, chronostratigraphy (interpreted ages and absolute ages), biostratigraphy and conventional wire-line log signatures. These methods of stratigraphic prediction are valid, but often confuse what is a relatively simple regional stratigraphic model. Any of these methods used in isolation can often lead to mis-correlations.

Lithostratigraphy as applied to outcrop and exploration wells is a simple vertical scheme of sediment classification relating to a group of sediments deposited in a specific depositional environment (defined from outcrop, cores, cuttings or wireline log character) with only general chronostratigraphic constraints and little or no biostratigraphic calibration. Lithostratigraphic units defined as such can be traced over a 
relatively narrow geographic area. Over a more widespread geographic area, such as northern England, lithostratigraphic boundaries are inevitably diachronous. This renders the development of regional facies models impossible particularly in extensional tectonic settings where differing lithostratigraphic terminologies are often applied in individual half-graben.

Chronostratigraphy, if properly applied, is an estimate of the approximate age of a rock unit either by comparison to adjacent macrofossil dated outcrop, or an interpreted age from in situ microfossils in exploration wells. Unfortunately, in exploration wells, the absolute ages assigned by various contractors and consultant biostratigraphers to the same microfossil groups often vary, and stage boundaries often change. Numerical age schemes applied to sedimentary rock units are even more equivocal since they are generally derived from chronostratigraphic interpretations and ultimately from biostratigraphic data.

Biostratigraphic (micro- or macro-palaeontological) data is a fundamental uninterpreted observation of the floral and faunal assemblage. These data form the basis of any well and surface exposure based sequence analysis, into which litho- and chronostratigraphic data is tied. Over the last 25 years BP has built up a very comprehensive, high quality specialist dataset for the northern England Carboniferous. The integration of high quality biostratigraphy is stressed because without a very detailed, robust and trustworthy biozonation scheme it would not be possible to confidently correlate sequences between individual half-graben.

Until relatively recently, Carboniferous biostratigraphy of the British Isles was based almost exclusively on the success of faunal zonation using corals and brachiopods. Most notable was the work of Vaughan (1905) in the Bristol area and Garwood (1913) in northern England. Subsequent work on goniatites (Bisat 1928, Earp et al. 1961 and references therein), conodonts (see discussion in Varker \& Sevastopulo 1985), spores 
(Neves et al. 1972, Clayton et al. 1977) and foraminifers and algae (Conil et al. 1979, Strank 1981) has provided further control on the dating and correlation of Carboniferous rocks within this coral, brachiopod and goniatite framework.

Hedberg (1976) stated that chronostratigraphical classification should encompass all rocks formed within a certain time span and utilise information available from all kinds of stratigraphical classification. With respect to the Carboniferous of northern England, the availability of high resolution, reflection, seismic data has provided a further tool for stratigraphical classification, in addition to the traditional use of lithostratigraphy and biostratigraphy. Vail \& Mitchum (1977) have suggested that a seismic reflection is generated by a time synchronous stratal surface (bedding plane) which may pass through all facies belts. Seismic data, therefore, can potentially identify chronostratigraphical units. This principle provides the basis for the sequence stratigraphic subdivision of the Carboniferous presented herein.

The development of sequence stratigraphy over the past 15 years has contributed greatly to our understanding of basin fill processes, particularly in marginal marine settings where conventional lithostratigraphy has effectively been rendered obsolete. Sequence stratigraphic models have mainly evolved from the analysis of sedimentary basins with relatively simple subsidence histories, such as post-rift successions of passive continental margins and intra-cratonic basins (Vail and Mitchum 1977, Galloway 1989; Figs $1.2 \& 1.3$ ). However, there has always remained a question mark over the applicability of such techniques to tectonically active settings such as the Carboniferous of northern England. In order to address this, several factors need to be considered including rift history, causality (ie. the tectonic versus eustatic origin of sequence boundaries) and sediment/sea-level interplay during rifting. Given the availability of good bio- and lithostratigraphic control from both well and surface exposure, the northern England Carboniferous provides a well calibrated marine rift basin in which to study the relative impact of these factors. 


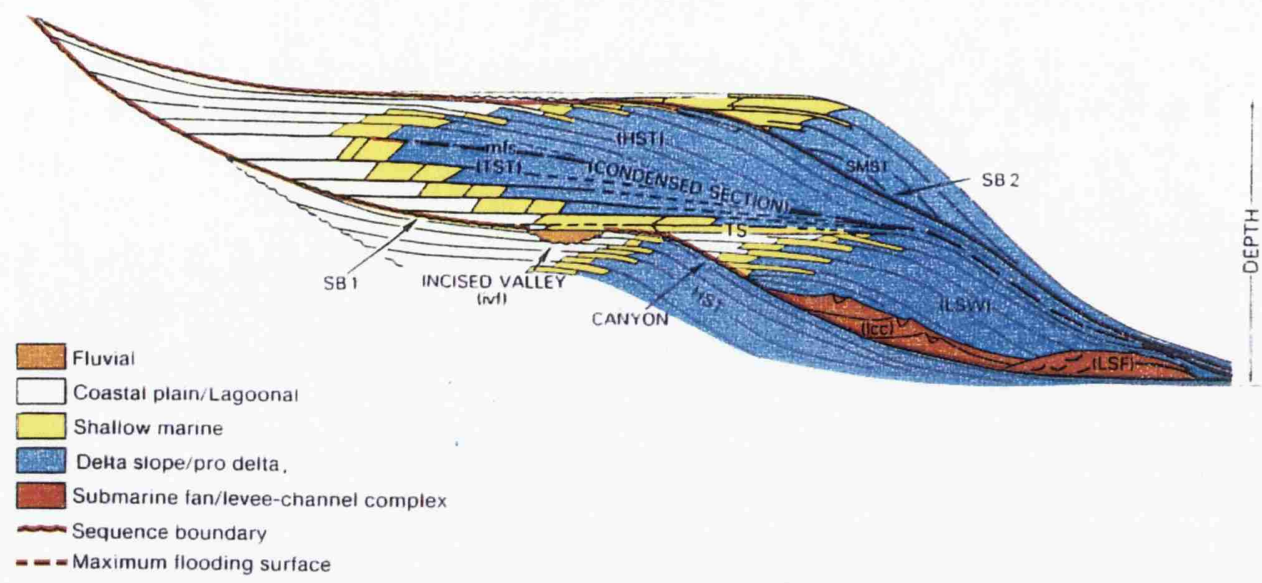

Figure 1.2 Depth cross-section of an 'Exxon-type' conceptional depositional sequence. (After Van Wagoner et al. 1988).
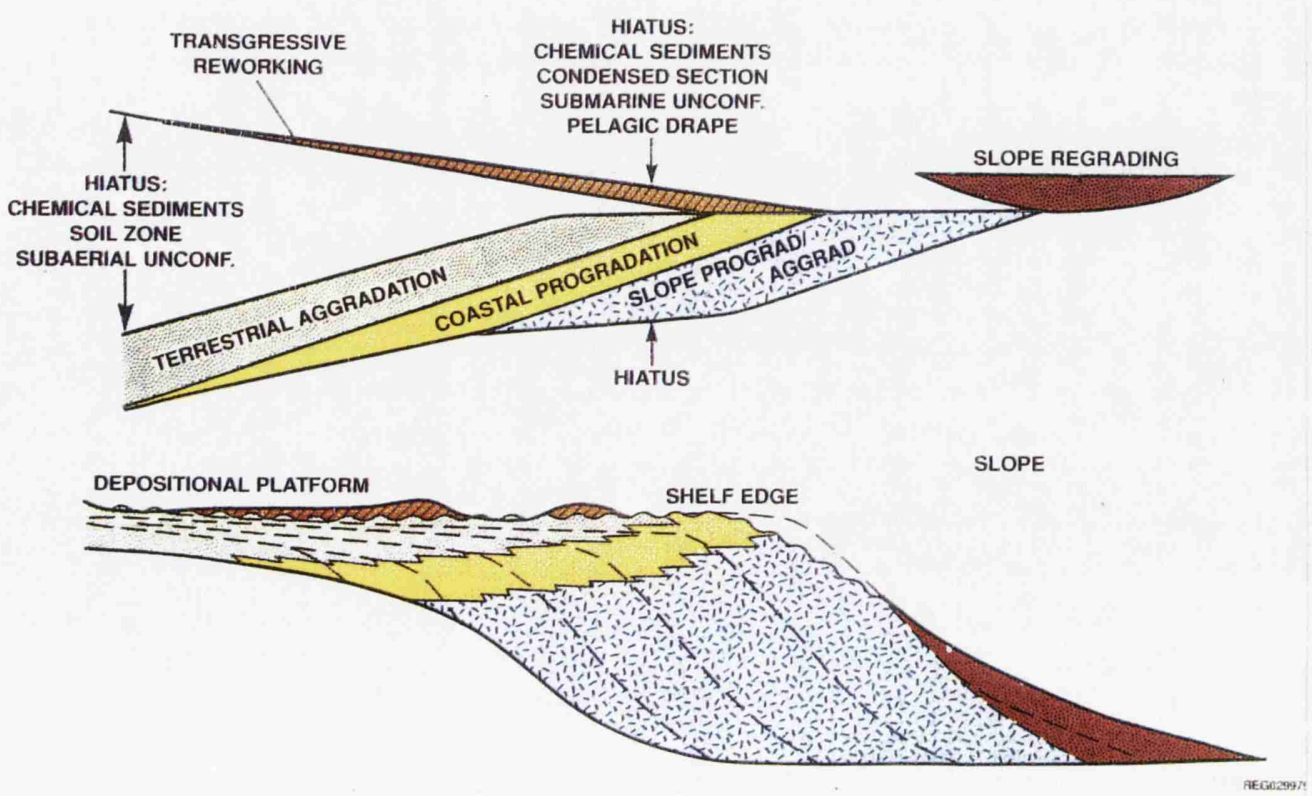

Figure 1.3 Cross sections of a 'genetic' depositional sequence. (After Galloway 1989). 
Recently, several papers have attempted to apply the concepts of sequence and tectonostratigraphy to the Carboniferous in northern England (Gawthorpe 1987a, Gawthorpe et al. 1989, Fraser et al. 1990, Fraser and Gawthorpe 1990, Kimbell et al. 1989, Ebdon et al. 1990). These authors have made varying use of new techniques such as seismic stratigraphy (Vail and Mitchum 1977, Galloway 1989), tectono-stratigraphy (Hubbard et al. 1985a \& b) and sequence stratigraphy (Van Wagoner et al. 1988 \& 1990).

Recent sequence stratigraphic studies of the northern England Carboniferous have concentrated on subsurface (seismic/borehole, eg. Ebdon et al. 1990) or surface exposure, (eg. Read 1991, Maynard \& Leeder 1992) data to construct a sequence stratigraphic scheme. The approach described in this thesis adopts the tectonostratigraphic methodology of Hubbard et al. (1985a \& b) utilising outcrop, well and seismic data to construct an integrated sequence stratigraphy for the Carboniferous of northern England. This provides a consistent stratigraphic framework within which to constrain the structural and stratigraphic evolution of the basin and to assess the hydrocarbon habitat.

An ideal stratigraphic framework for correlation would divide the stratigraphy into its component systems tracts separated by sequence boundaries, transgressive surfaces, maximum flooding surfaces and their correlative condensed intervals (Van Wagoner et al. 1988 \& 1990; Fig. 1.2). Given sufficient well and seismic resolution this is relatively straightforward and the resultant systems tracts can be considered the fundamental units for stratigraphic correlation within which lithofacies are relatively continuous and predictable. In the northern England Carboniferous, however, the systems tracts are often below seismic resolution and a complete breakdown of the stratigraphy in this manner is impractical.

Where detailed well data are available such as for the Namurian-Westphalian 'A' interval of the East Midlands, a more detailed subdivision of the stratigraphy has been attempted. 
Maximum flooding surfaces, such as the late Carboniferous goniatite rich marine bands, are used to integrate specialist stratigraphic data into a predictive regionally correlatable 'genetic' sequence stratigraphy based on the methodology of Galloway (1989), (Fig. 1.3). Maximum flooding surfaces are most easily recognised on wireline logs by their distinctive high gamma ray response representing periods of clastic starvation at times of maximum transgression of the shoreline. They represent the boundary between an overall upward increasing gamma ray signature (retrogradational, deepening unit) and an overlying upward decreasing gamma ray profile (prograding, shallowing unit). On seismic data a maximum flooding surface is recognised as a marine onlap horizon or a downlap surface to an overlying set of prograding clinoforms (Posamentier et al. 1988).

\subsubsection{Petroleum habitat}

A cursory inspection of the number of tests and hydrocarbon shows in the Carboniferous of northern England would suggest that plays with Carboniferous targets had been extensively explored. By 1989, some 280 exploration wells had been drilled to test the Carboniferous (Fig. 1.1), of which almost $60 \%$ had encountered shows. On closer inspection, however, the number of valid tests (ie. trap-reservoir-charge-seal all present) was substantially fewer. For plays within the Carboniferous these were concentrated in the East Midlands, with as little as a dozen valid tests outside this area, and none of commercial significance (Plate 1.2).

The lack of success outside the East Midlands (Fig. 1.4) requires some explanation, particularly given the widespread distribution throughout northern England of both surface hydrocarbons (Plate 1.3) and Carboniferous basins apparently similar to those of the East Midlands (Plate 2.4). Given evidence from major oil provinces around the world (eg. Middle East), it is somewhat unusual for there to be such a poor correlation between the surface and subsurface distribution of hydrocarbons. This fundamentally important observation merits some analysis. Either (i) basins outside the East Midlands 
have been poorly explored and the present distribution of oil and gas fields is merely a reflection of the level of exploration drilling activity to date or, (ii) there exist significant and fundamental geological differences between the individual Carboniferous basins of northern England.

(a)

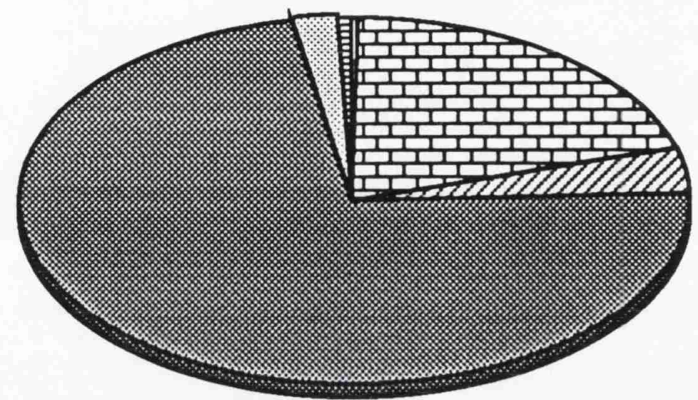

- Welbeck Low (0.17\%)

ㅁ. East Midlands Shelf $(20.38 \%)$

ש. Widmerpool Gulf (3.83\%)

. Gainsborough Trough (72.70\%)

Cleveland Basin (2.23\%)

Goyt Trough $(0.08 \%)$

$\boxminus$ Humberside Shelf $(0.60 \%)$

(b)

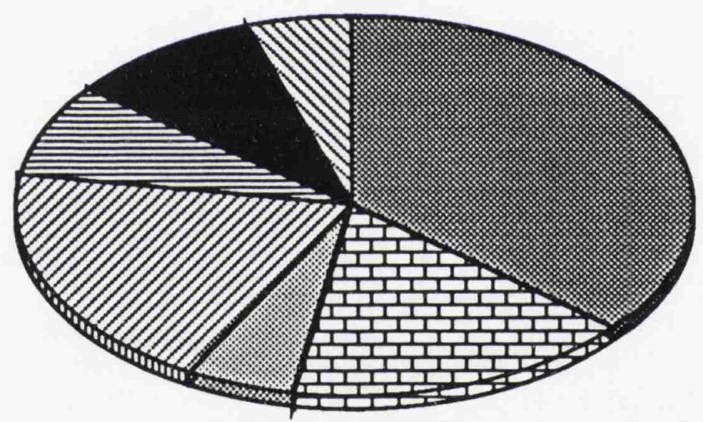

Gainsborough Trough (36.19\%)

ㅁ. East Midlands Shelf (16.67\%)

Cleveland Basin (5.26\%)

U. Widmerpool Gulf (19.67\%)

曰 Humberside Shelf $(7.66 \%)$

- Welbeck Low (9.31\%)

Goyt Trough (5.26\%)

Figure 1.4 Northern England Carboniferous : Distribution of (a) recoverable hydrocarbons and (b) number of fields by province. The Gainsborough Trough in the East Midlands accounts for over $70 \%$ of the discovered reserves in northern England. Basins outside the East Midlands (eg. Cleveland and Humberside) account for only $3 \%$ of the total. Distribution of fields throughout the East Midlands basins is less biased towards the Gainsborough Trough reflecting the dominance of the Welton field over the reserves distribution. See Plates $1.4 \& 2.4$ for basin locations. (Data compiled from in-house BP files). 
A key objective of this thesis has therefore been to attempt to answer the question: "Is the East Midlands unique as an oil province in northern England?" To achieve this, data from an extensive inventory of 'successful' intra-Carboniferous tests has been synthesized and used to identify and calibrate the key factors controlling the specific hydrocarbon environments. These factors have in turn been used to assess the remaining 10-15 sub-basins in northern England where Carboniferous sediments were deposited and where the play may be potentially developed; a technique refered to as play fairway analysis.

\subsection{THESIS OUTLINE}

The basic building blocks of play fairway analysis are a series of regional palaeogeographic and depth isopach maps for the key sequences. Their compilation requires a detailed analysis of both the structural and stratigraphic evolution of the basin. In chapter 2, the structural setting of the northern England Carboniferous is placed in its regional plate tectonic context in order to constrain the external controls on basin development. The structure is seen to be dominated by a series of opposing NE and SW trending listric and sub-planar extensional faults with prominent inversion anticlines developed during the late Carboniferous, particularly on the NE trending fault set.

Having established how and when the basins were formed, chapter 3 describes the stratigraphic fill of the depocentres with reference to a series of interpreted regional seismic profiles, tied to available well and surface geological control, from across the province. These indicate that the early syn-rift fill of the basins in the Upper DevonianLower Carboniferous was characterised by fault scarp alluvial fans which developed into deep water mudstone basins flanked by carbonate ramps and high angle by-pass margins through the Lower Carboniferous. Rifting ceased during the late Dinantian, allowing the rapid southward progradation of a major siliciclastic delta system which dominated the

post-rift, Upper Carboniferous fill of the northern England basins. The late 
Carboniferous Variscan inversion saw, for the first time, a major northwards influx of clastic sediment from the evolving Variscan mountain front located some $500 \mathrm{~km}$ to the south.

The sequence stratigraphic framework established in chapter 3 provides the basis for the generation of the palaeogeography maps which are described in chapter 4 . The maps commence with the late Devonian-Dinantian (syn-rift), through the Silesian (post-rift) and culminate with the major Variscan inversion from Westphalian ' $\mathrm{C}$ ' times. The palaeogeographies have been compiled using a combination of borehole and outcrop information combined with published and BP in-house literature and structural, seismic, gravity and magnetic data. The datasets are correlated using a mixture of proprietary BP and published biostratigraphic data; the glue! It has been important to incorporate as much biostratigraphic control as possible for each palaeogeographic interval as it has been critical in correlation between isolated Carboniferous rift basins.

The detail and quality of the palaeogeographies varies according to the availability of bioand litho-stratigraphic data. For example, the late Devonian map is very poorly constrained whereas the database for the late Carboniferous reconstructions is vast by comparison. Similarly, more prolific subsurface data are available for the East Midlands than for basins to the north and west. This introduces varying degrees of confidence in interpretation both within and between maps.

Discussions with co-workers in the field allowed considerable refinement of the maps. John Hurst (BP Basin Studies Group), Angela Strank (BP Stratigraphic Branch) and sedimentologists Rob Gawthorpe (Manchester), Peter Gutteridge (Cambridge) and Andrew Horbury (BP) have made important contributions in this area. Field work by the author in the Derbyshire Dome, Bowland Basin and Cumbria has provided critical surface geological control for the facies models developed essentially from subsurface seismic and well control. These field areas were identified as particularly good examples 
of exposed Carboniferous sediments. The Derbyshire Dome provides a direct analogy for the depositional environments which prevailed over the East Midlands and other Dinantian carbonate shelf systems. The Bowland Basin is perhaps more significant in that it represents the only exposed example of the deep basinal settings thought to exist in the Gainsborough, Edale and Widmerpool half-graben. The results of the field work have been fully integrated into the study and examples of of the outcrop geology are included as text figures, with the co-ordinates of the key exposures identified in the text and figure captions.

Ultimately the palaeogeographic maps are used in chapter 5 to constrain the regional development of potential reservoir, source and seal facies with time. Trap timing and burial histories are assessed with reference to a series of restored depth isopach maps for the major sequences. Individual play fairways are defined largely on the basis of the presence of potential reservoir rocks on the facies maps eg. the Clastic delta play fairway or the Carbonate shelf margin play fairway. Further analysis of these play fairways involves the incorporation of drilling statistics in order to evaluate and constrain remaining resource potential and distribution.

\subsection{DATABASE}

\subsubsection{Limits of the study}

The study area for this thesis was chosen to incorporate all the half-graben lying in the northern England, Carboniferous rift system (Plate 2.4). Although part of the same province, the older Midland Valley and Culm rifts to the north and south are only briefly discussed. Hence, the Early Palaeozoic Southern Uplands and Wales-Brabant Massif represent the northern and southern geological limits of the study respectively. The western and eastern boundaries of the study extend into the Irish Sea and southern North 
Sea. However, detailed mapping does not extend far beyond the present coastline due to lack of well and seismic penetration of the Carboniferous offshore.

The co-ordinates of the study are therefore as follows (Plate 1.5):-

$270,000 \mathrm{~N} 200,000 \mathrm{E}$

$270,000 \mathrm{~N} 600,000 \mathrm{E}$

$655,000 \mathrm{~N} 600,000 \mathrm{E}$

$655,000 \mathrm{~N} 200,000 \mathrm{E}$
Projection: Transverse Mercator

Zone: OSGB National Grid

Grid Unit: International Metre

Spheroid: Airy 1838

\subsubsection{Well Control}

The well data base consulted for this study is shown on Plates $1.6 \&$ 1.7. and fully detailed in Appendix A. A total of 270 key wells which have penetrated Lower Carboniferous strata in northern England have been incorporated. The wells have been used to control palaeogeography maps, generate isopachs and as fence posts in seismostratigraphic work in the Widmerpool Gulf and Gainsborough Trough. Additional biostratigraphic studies were carried out on key wells, such as Hathern-1, which proved to be critical in the dating and correlation of sequence boundaries between half-graben and with the numerous outcrop based studies that exist in the literature for the Carboniferous. Much of this well data, including summary biostratigraphic data, is now in the public domain and can be accessed from the BGS Hydrocarbons Unit, Murchison House, West Mains Road, Edinburgh via the Department of Trade and Industry.

A summary of the extensive BP in-house geochemical database, consulted in compilation of this thesis, is provided in Appendix C. This data, while not generally in the public domain, can be accessed on request from BP Exploration, Farburn Industrial Estate, Dyce, Aberdeen. This is also the case for the detailed, individual well biostratigraphic reports which have been consulted for correlation purposes. 


\subsubsection{Seismic}

For the first time, use has been made in a regional study of BP's extensive modern reflection seismic database in northern England (Plate 1.8). The seismic has been used in structural, sequence stratigraphic and facies interpretations. Regional seismic lines and isopach maps derived from the seismic and well database have also been used in the compilation of this thesis.

\subsubsection{Surface Geology}

Surface geological control has been provided by BGS 1 inch to the mile or 1:50,000 geological maps. Much of this data is summarised on the more practical 1;500,000 and 1:625,000 regional maps. Fieldwork in Derbyshire, Bowland, Stainmore and the Lancaster Fells is also incorporated. Stratigraphic details have been taken from BGS memoirs which are not referenced individually here.

\subsubsection{Gravity and Magnetics}

A series of BP in-house contoured Bouguer anomaly and first derivative gravity maps (Plates $1.9 \& 1.10$ ) and the regional aeromagnetic map at 1:500,000 scale (BGS 1965; Plate 1.11) were used to constrain fault trends and the location of Dinantian carbonate shelf margins on the palaeogeographic reconstructions. A more detailed analysis of the application of gravity data to early Carboniferous structural mapping is provided by Lee (1988). 


\subsection{EXPLORATION HISTORY}

Over 70 years of petroleum exploration in the Carboniferous of northern England has resulted in the discovery of recoverable reserves totalling 75 million barrels of oil (equivalent to a small North Sea field such as Buchan) and 27 billion cubic feet of gas (insignificant by North Sea standards) contained in 36 oil and gas fields (Plate $1.2 \&$ Fig. 1.5). In general field sizes have been small (Fig. 1.6) with a mean of around 2 million barrels and at a historical finding rate of 1 discovery for every 4 exploration wells.

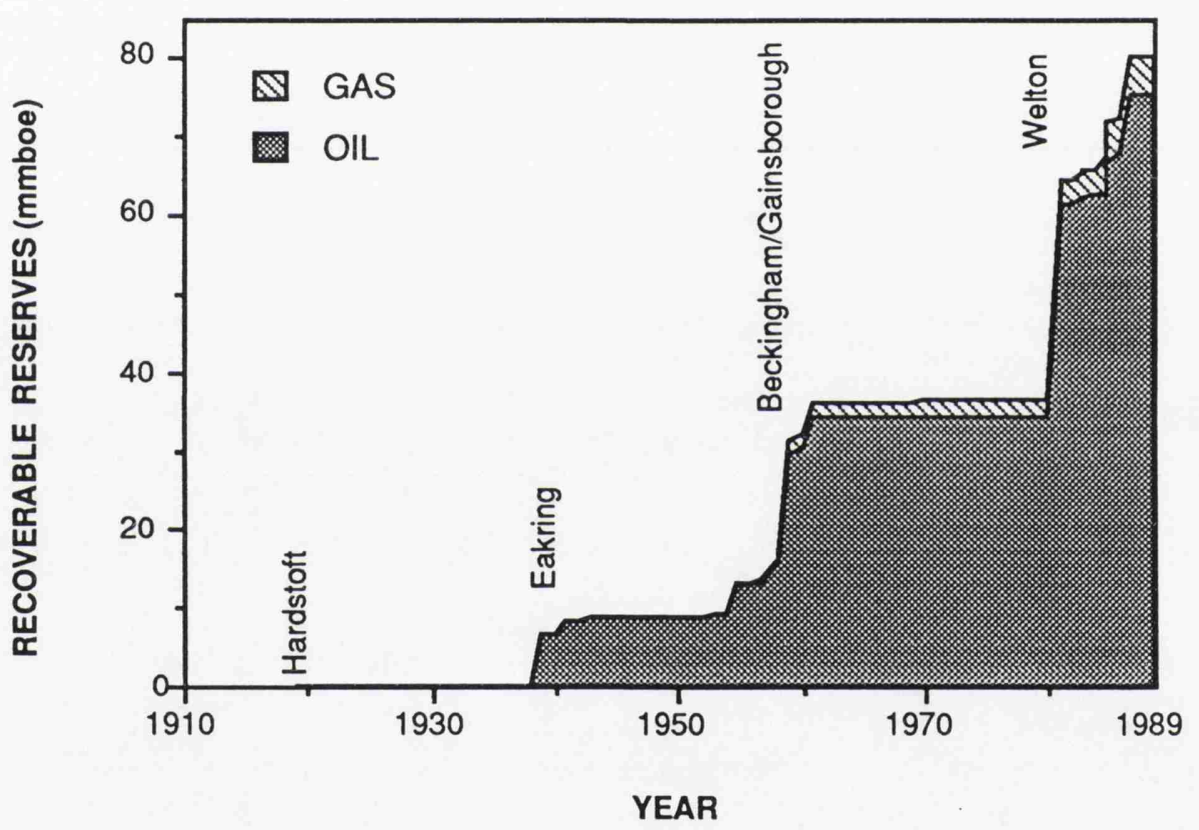

Figure 1.5 Northern England Carboniferous : Cumulative recoverable reserves. Following the initial discovery at Hardstoft in 1919, there were three major increases in the discoveries inventory. The Eakring structure was identified mainly from Coal Board mapping supplemented by seismic refraction techniques. The next significant discovery at Beckingham/Gainsborough was as a result of the evolution of the seismic reflection method. The advent of modern multifold seismic reflection data in the 70's finally led to the Welton discovery in 1981. Several small field additions have been made since Welton, all in the East Midlands. Attempts to extend Carboniferous exploration into other northern England basins during the 1980's have proven largely unsuccessful. (Data compiled from in-house BP files). 
The Kelham borehole, located near Newark in Nottinghamshire was probably the first to be drilled on a potential oilfield. The well was originally drilled to investigate coal prospects in the Kelham area. A 4 metre thick coarse grained oil sand was penetrated at a depth of $743 \mathrm{~m}$. Crude oil was first produced on August 21st 1911 at an estimated flow rate of between 5 and 8 gallons per day. However another 18 years elapsed before the D'Arcy Exploration company (eventually to become BP) confirmed the discovery of the Kelham Hills oilfield (Plate 1.4).

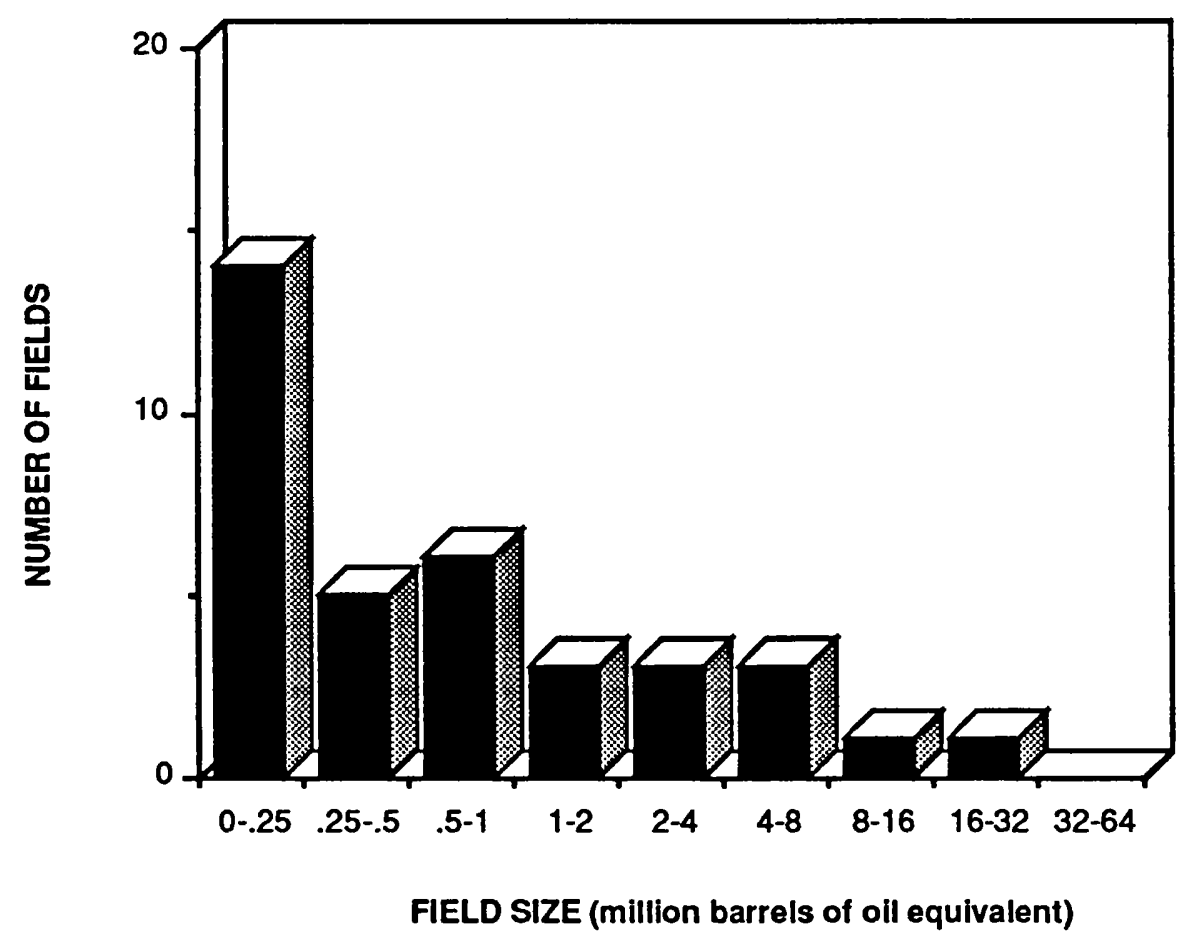

Figure 1.6 Northem England Carboniferous : Field size distribution. In general field sizes have been small with a mean of around 2 million barrels and at a historical finding rate of 1 discovery for every 4 exploration wells. However, low development and production costs have continued to make exploration of the Carboniferous onshore an attractive commercial proposition. (Data compiled from in-house BP files). 
The impetus for the first dedicated search for indigenous petroleum was provided by the first World War. By the spring of 1918 the supply of petroleum products for the war effort had become a serious national problem. Geologists with oilfield experience pointed out that despite the many thousands of boreholes that had been drilled in the UK in the search for coal, water, etc., few of these wells had been located in areas favourable to the accumulation of petroleum deposits, nor had the wells been drilled to a sufficient depth to penetrate possible reservoir rocks.

Sir John Cadman, Deputy Chairman of the Anglo-Persian Oil company (later to become BP) and Lord Cowdray proposed that an immediate exploration drilling programme be implemented on a large scale, in view of the need to find indigenous sources of petroleum. Lord Cowdray placed at the disposal of the government the initial results of an investigation undertaken by his geologists which highlighted the best potential oil prospects. The government accepted Lord Cowdray's offer and allocated a sum of

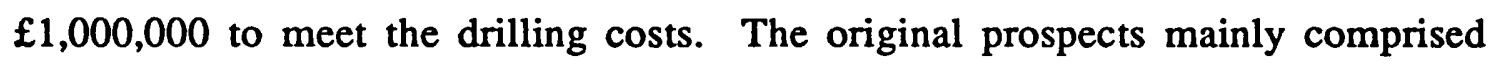
Carboniferous limestone reservoirs in tightly folded anticlinal traps on the flanks of the Pennines. By the time drilling commenced the war was nearly over, but operations continued up to 1922 .

A total of 11 wells were drilled as a result of the government's 1918-1922 exploration programme. Seven wells were located in Derbyshire, two in Staffordshire and a further two in the Lothians of Scotland. Crude oil discoveries were made in only two of the wells namely in the Hardstoft well near Chesterfield in Derbyshire and the D'Arcy well near Dalkeith in the Midland Valley of Scotland, both in reservoirs of Carboniferous age.

The initial discovery at Hardstoft in 1919 (Lees \& Cox 1937) was in shelf carbonates of Dinantian age in a tight anticlinal structure (Plate 1.4). The field produced some 32,000 barrels of crude oil from the fractured top of the Dinantian over a period of 25 years. 
Drilling subsided in the inter war years and it was not until September 1937 that D'Arcy Exploration spudded the well Cousland-1 to test the Lower Carboniferous Oil Shale group on a well defined north-easterly trending anticline some 9 miles southeast of Edinburgh. The well was completed in September 1938 at a depth of $890 \mathrm{~m}$ having encountered gas at two levels within the Lower Carboniferous. Subsequent drilling down flank failed to prove an oil leg and D'Arcy Exploration eventually signed over the rights to the discovery to the Gas Council.

However, a year later in 1939 the first significant onshore UK oil discovery was made at Eakring in Nottinghamshire (Fig. 1.7 \& Plate 1.4). Given the long history of oil seepages in the East Midlands, particularly from the Coal Measures, attention had focussed on more deeply buried anticlines to the east of Hardstoft in Nottinghamshire. The initial objective of the renewed exploration programme was not the Coal Measures, in which mine seepage rates had proven very limited, but the Lower Carboniferous limestone, a reservoir analogous to the great carbonate reservoirs being exploited at that time in the Middle East. It is easy to understand the logic behind this approach, given the many surface bitumen occurrences in the limestone and the earlier success at Hardstoft. Exploration techniques in the late 1930's involved compilation of structural maps mainly from Coal Board data, augmented by limited seismic refraction data around potential anticlinal features. One of the larger prospects identified applying this technique lay under the village of Eakring in Nottinghamshire (Fig. 1.7).

The Eakring No. 1 well was drilled in 1939 and led to the production of over two million barrels of oil from the Midlands Carboniferous during the war years (Fig. 1.8). Outstep drilling from the Eakring field led to the discovery of the larger Dukes Wood accumulation in 1941. Seismic refraction work identified other anticlines and led to the discovery of the nearby Caunton and Kelham Hills fields. 
The original Lower Carboniferous limestone objective at Eakring (and elsewhere) proved to contain only minor quantities of oil. The main oil pool was reservoired in Namurian delta top channel sandstones (Millstone Grit) and in similar facies in the overlying Westphalian 'A' (Coal Measures) with recoverable reserves totalling 7 million barrels in multiple reservoir horizons (Storey \& Nash 1993).

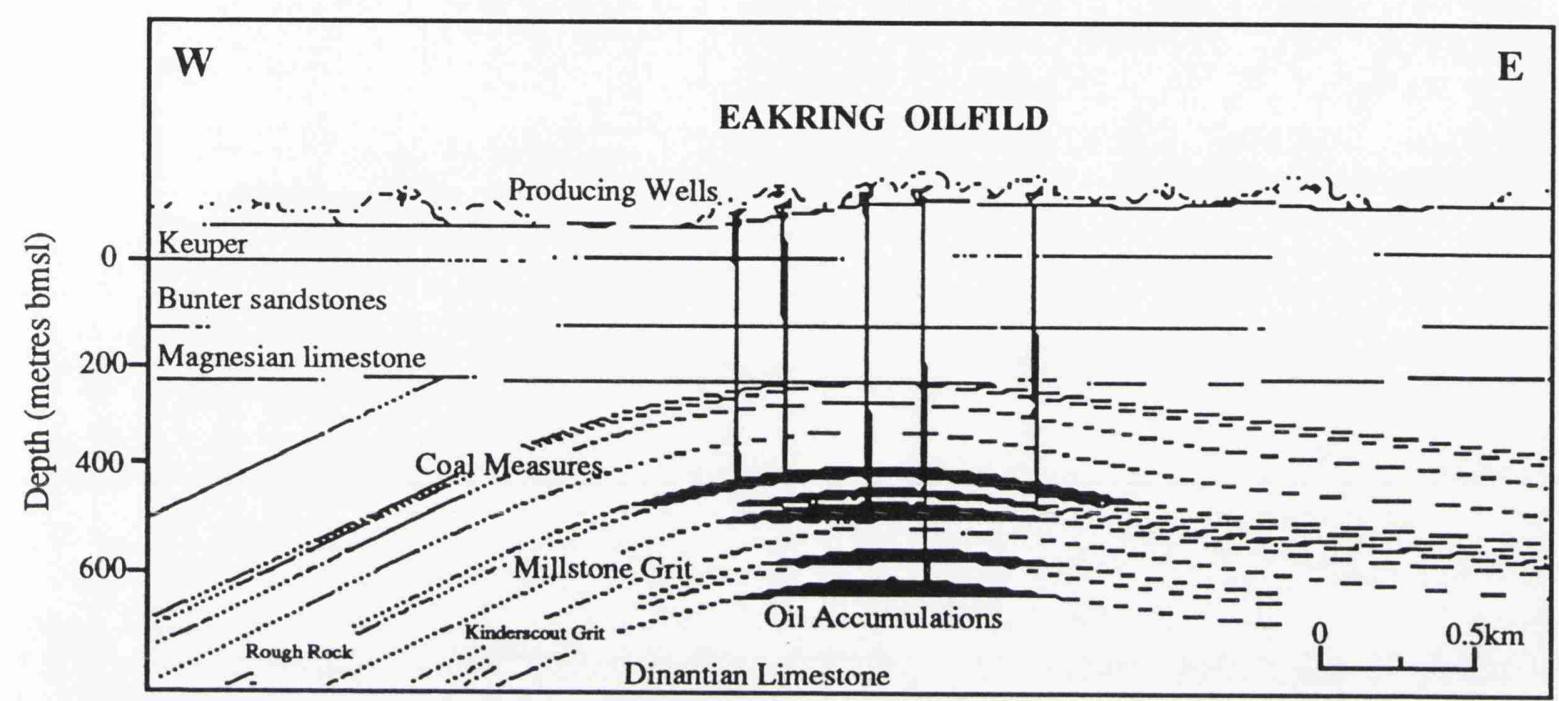

Figure 1.7 Example of early mapping of the Eakring oilfield based on Coal Board and production well data. Compare this with the interpretation based on modern multi-fold seismic (Plate 3.6) which confirms the structure as an inversion anticline.

The wartime discoveries in the Midlands were followed initially by a series of dry holes as exploration progressed over a large area of Lincolnshire to the east. Some of the wells found oil in sub-commercial quantities. Reservoirs were generally poor and seismic definition of these deeper buried structures (thicker Mesozoic) was less than adequate (Kent 1985).

The improvement of the seismic method in the 1950 's provided new and more accurate imaging of the subsurface and an arc of discoveries were made by D'Arcy Exploration to the north of Eakring. These included the Bothamsall, Egmanton and South Leverton fields in Nottinghamshire and the Beckingham/Gainsborough field (13 million barrels of 
oil; 6.5 billion cubic feet of gas) in 1959 in north Lincolnshire (Plate 1.4). The more easterly of these fields included productive reservoirs relatively high in the section in the Middle Coal Measures.

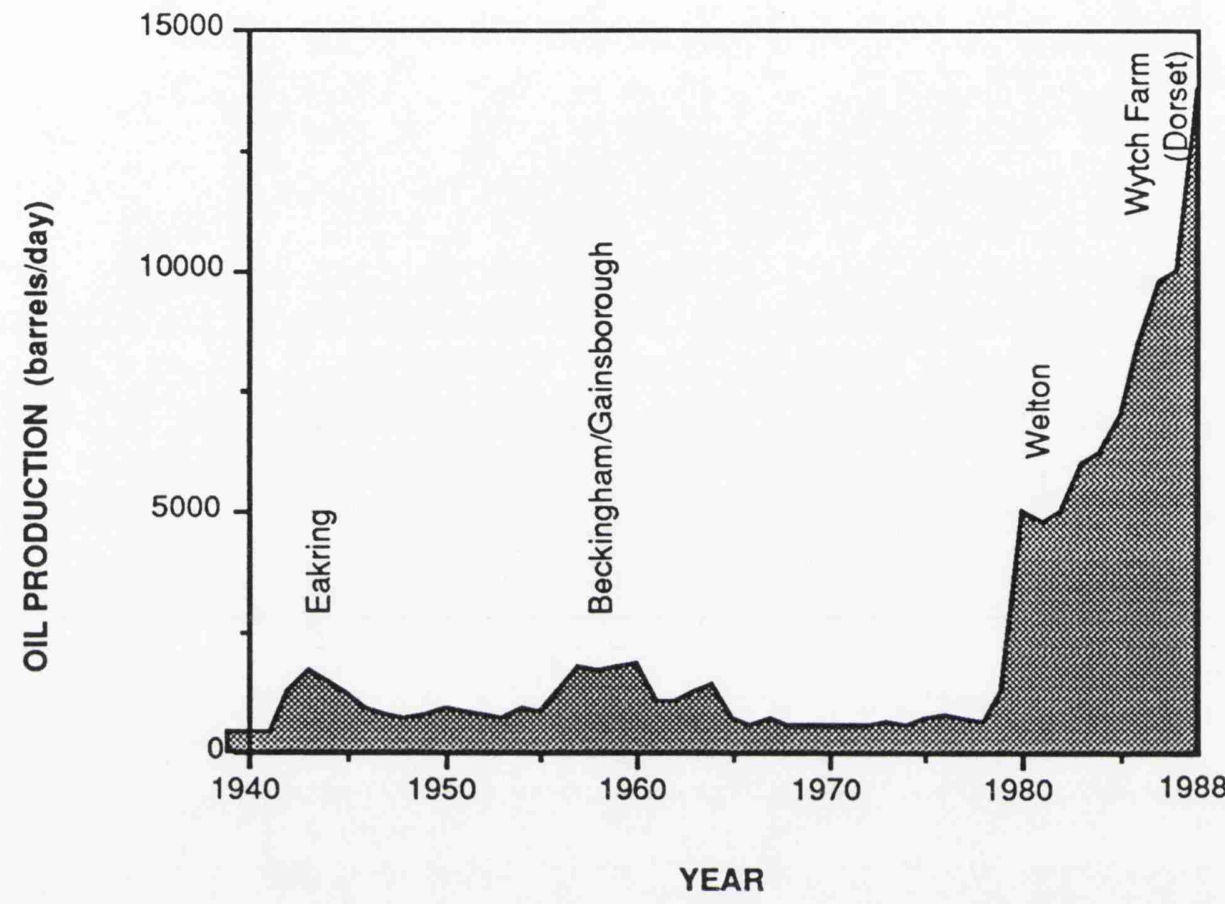

Figure 1.8 BP onshore UK oil production : 1940-1988. Production has averaged around 1000 barrels of oil per day for the majority of its history. Welton at around 3000 barrels per day increased the contribution of the Carboniferous to around 5000 barrels per day. The marked increase in BP's onshore oil production over the last 10 years is as a result of the production from Triassic and Jurassic reservoirs in the Wytch Farm field in Dorset. By comparison, production from the offshore Forties field alone reached 500,000 barrels of oil per day. (Data compiled from in-house BP files).

Over the period from 1946 to 1964, an active exploration and development programme was pursued in the East Midlands and Cleveland, almost exclusively, by D'Arcy Exploration (Fig. 1.9). However, at the end of 1964, the government terminated the remission of duty afforded to indigenous hydrocarbon production, which left UK oil non-competitive with cheap imports from the Middle East and led to the cessation of nearly all onshore UK exploration and development activities. The foundations had, 
however, been laid for the future and when the 1973 oil crisis caused escalation of oil prices, the renewed commercial viability of the UK onshore industry attracted new competition for undrilled acreage.

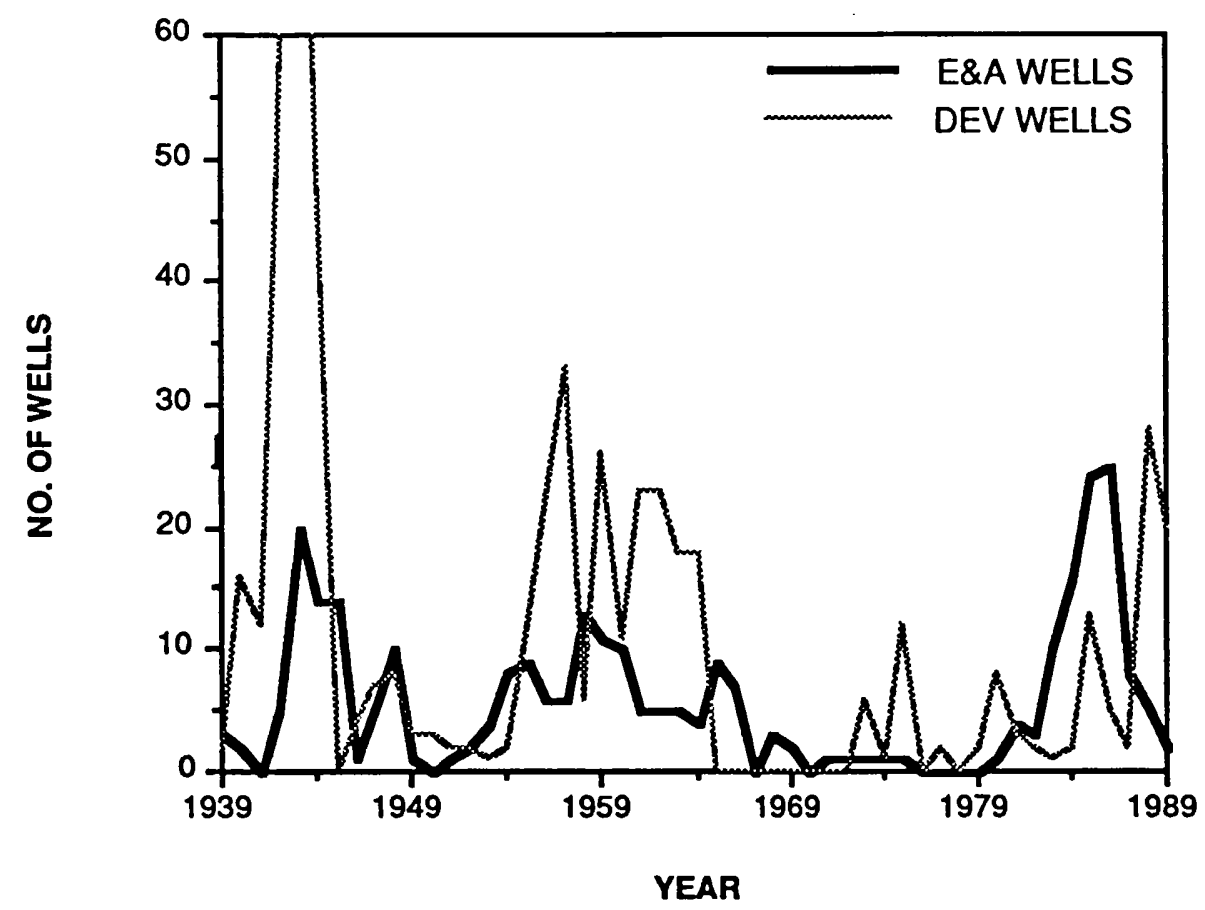

Figure 1.9 BP operated onshore UK wells : 1939-1989. The initial peak during WWII years (128 wells drilled in 1943) results from the Eakring discovery and development and subsequent nearby exploration. Drilling activity was rejuvenated in the 1950's leading to the Beckingham/Gainsborough discovery and in the 80's following the Welton success. Note the slump in activity during the 1970's as a result of government tax legislation. (Data compiled from in-house BP files).

The advent of modern multifold seismic data in the 1970's permitted more detailed mapping of the subsurface under the thicker Mesozoic cover in Lincolnshire. This resulted in the identification of a NW-SE trending anticlinal structure several miles to the north-east of Lincoln. The Welton field was discovered in May 1981 by the Welton No. 1 well (Plate 1.4). The primary objective was the Namurian R2 Chatsworth Grit. However, the main oil bearing reservoir proved to be a 68 metre thick Westphalian ' $A$ ' sandstone lying unconformably on Dinantian limestone. Initial mapping of the prospect 
suggested recoverable reserves in the region of 10 million barrels of oil (Rothwell \& Quinn 1987). However, recent infill development drilling and new seismic has allowed reserves to be upgraded to over 20 million barrels of oil, confirming Welton as the largest oilfield in the northern England Carboniferous, and the most significant in terms of producible hydrocarbon volumes (Plate 1.2). The most recent significant discovery was made by Enterprise Oil and partners at West Firsby in 1987. This field is located some 20 miles northwest of Welton (Plate 1.4) and contains estimated recoverable reserves of 7 million barrels of oil (Plate 1.2).

The removal of North Sea production related PRT (Petroleum Revenue Tax) relief for onshore exploration drilling by the Government in 1987 has seen the withdrawal of large multinational companies from onshore UK Carboniferous exploration and the increasing impact of small independent exploration companies pursuing small-scale gas extraction from the Coal Measures. Ironically, it would seem that the industry has turned full circle with a return to the stratigraphic interval, which through Coal Board activity, first attracted the interest of oil explorers to the Carboniferous back in the 1920's.

The geological review by the author for BP, expanded and detailed in this thesis, formed the basis of a major re-evaluation of the hydrocarbon exploration and economic potential of the northern England Carboniferous. In the past, as outlined above, new techniques and approaches had led to the identification of new and successful hydrocarbon targets. On this occasion, the new technique, exemplified by the seismic sequence stratigraphic approach, did not yield new large prospects, but confirmed that existing exploration had accounted for most of the likely hydrocarbon traps in the area. On this basis, BP made the decision to withdraw from further hydrocarbon exploration in the Carboniferous of the onshore UK. 


\section{CHAPTER 2 REGIONAL STRUCTURAL FRAMEWORK}

\subsection{INTRODUCTION}

The basis for understanding the present day distribution of hydrocarbons in the Carboniferous of northern England is to be found in an interpretation of the complex geological history which the area has undergone in Phanerozoic times (Leeder 1976, 1982, 1987, Zeigler 1978, 1982, 1986, Anderton et al. 1979, Dewey 1982; Thorpe et al. 1984, Whittaker 1985; Andre et al. 1986, Matte 1986). Four important tectonic phases are recognised, each of which fundamentally influences the processes which shape the hydrocarbon environment.

Early Palaeozoic: Caledonian continental collision and suturing

Late Palaeozoic: Variscan back-arc extension, dextral shear and inversion

Mesozoic: Boreal and Atlantic rifting

Cenozoic: North Atlantic spreading and Alpine collision

These are separated by major phases of orogeny, inversion, transgression and thermal uplift which were caused by major plate margin reorganisation events.

Many of the studies cited above have relied on a synthesis of outcrop studies suplemented by gravity and limited seismic reflection and refraction techniques to reconstruct the tectonic development of northern England. In this thesis I have been able to incorporate new data from abundant high quality reflection seismic data and deep exploration boreholes in order to both test existing models and rationalise tectonic history. The seismic and wellbore data also brings a high degree of stratigraphic, facies and thickness detail for basin evolution interpretations, previously unavailable outwith oil company archives. This has been used to better constrain subsidence and thermal 
histories particularly in the Carboniferous where there has been much debate and controversy.

During this study it became apparent that the pre-Carboniferous basement structures had exerted a fundamental control on the development of the later tectonic structures of the area. Hence, some emphasis has been placed on reviewing the Caledonian tectonic structures which outcrop in Wales, the Lake District and the Ingleton and Charnwood Forest inliers and subsurface penetrations in the numerous exploration boreholes of the East Midlands. I will then discuss the controversial issue of the origins of the northern England rift system by reviewing i) the plate tectonic setting of the Variscan Orogeny, and ii) the subsurface evidence from northern England (based on the recent borehole and seismic data) in order to set in context, both geographically and structurally, the models to be discussed towards the end of the chapter. Finally a brief review of Permian and later tectonic events is included as they are considered to have exerted a fundamental control on the hydrocarbon habitat within the Carboniferous.

\subsection{TECTONIC PROVINCES}

The pre-Permian geology of northern England and Wales (Wills 1973, 1978, Whittaker 1985, BGS 1985) is divided by major lineaments and faults into a series of major terranes (Fig. 2.1). The boundaries are largely based on the work of Turner (1949) and Wills $(1973,1978)$. Both realised that old Caledonian faults had exerted considerable influence on the geometry and orientation of subsequent tectonic features. Both authors recognised the presence of a triangular shaped platform underlying the English Midlands which was covered by a thin, flatlying undeformed Palaeozoic cover. The platform is bounded on its southern side by the Variscan thrust front, on its northwestern side by the Longmynd fault and to the northeast by a NW-SE trending lineament which Turner (1949) and Wills (1973) placed in different locations. The Longmynd fault, in the 
northwest, separates the the platform from the deformed and cleaved Palaeozoic sediments of the Welsh Caledonides. The northeast boundary represents a major lineament which separates the platform from a hidden East Midlands Caledonide belt, again with deformed and cleaved Lower Palaeozoic sediments. In this thesis, the boundary of Turner (1949) was found to be the most appropriate. This triangular platform is now refered to as the Midlands microcraton (Pharoah et al. 1987).

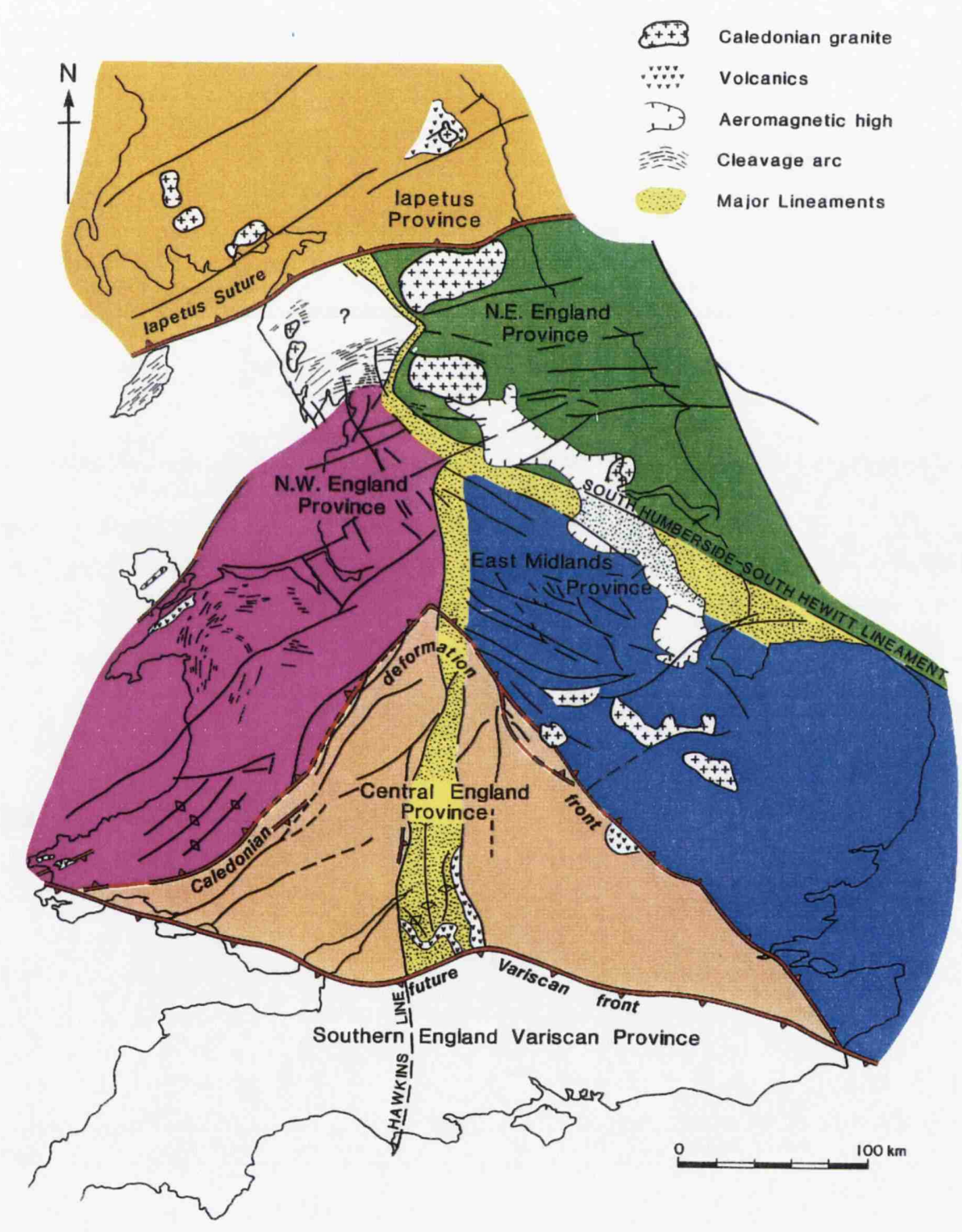

Figure 2.1 Caledonian tectonic provinces of England and Wales (after Fraser $e t$ al. 1990; based on data from Turner 1949, Soper et al. 1987 and Pharoah et al. 1987). 
Turner (1949) compared the northern triangular apex of the microcraton with the Hindu Kush and suggested that the northeast Caledonian trend in Wales could be traced in an arc around the apex into the East Midlands Caledonides (Fig 2.1). This outer arc continues northwards as far as the Iapetus suture which separates the Welsh and East Midlands Caledonides from the Laurentian Caledonides of Scotland and Ireland. The Iapetus suture was located using the positions suggested by Dewey $(1971,1982)$, Soper \& Hutton (1984), Beamish \& Smythe (1986) and Klemperer \& Matthews (1987).

One other major fault boundary is significant. This is the Malvern fault which runs north-south through the microcraton into the apex (Fig. 2.1). It may continue to the north within the Caledonides following the Pennine-Dent fault zone. Wills $(1973,1978)$ also suggested that the Malvern fault continues south of the Variscan thrust front along the 'Hawkins Line'.

On the basis of the major Caledonide tectonic trends, sutures and fault zones, five tectonic provinces can be recognized (Fig. 2.1).

The Central England Province. A triangular, fault-bounded basement area with a thin, weakly deformed covering of lower Palaeozoic sediments, terminated to the south by the Variscan front. Geodynamically the feature is interpreted as a microcraton indentor that collided and joined with other crustal fragments during the closing of the Iapetus ocean in early Palaeozoic times (Soper \& Hutton 1984, Andre et al. 1986, Pharaoh et al. 1987, Soper et al. 1987).

The East Midlands Province. This exhibits a pronounced NW-SE (so-called Charnoid) trend, which can be identified both in the basement areas to the southeast and in the post Caledonian sedimentary cover to the northwest (Turner 1949, Kent 1968, Le Bas 1972, Wills 1973, Evans 1979, Bott 1987). The same trend is typical of the Caledonian grain as far east as the Tornquist line in mainland Europe (Ziegler 1982). The province is 
bounded to the north by the Craven-South Humberside-Hewitt line, to the east by the Pennine-Dent-Malvern line and to the south by the northeastern margin of the Midlands microcraton.

The Northeast England Province. This occurs to the north of the Craven-South Humberside-Hewitt line, and is bounded to the west by the Pennine-Dent line and to the north by the Iapetus suture. The eastern boundary is not clear, it may extend as a distinct block into the Mid North Sea High or be truncated by the precursor of the Dowsing fault zone. Within the province the dominant tectonic trends are east-west and most of the areas which remained positive during subsequent subsidence phases are cored with granites of late Caledonian age (Bott 1967).

The Northwest England Province. On the opposite side of the Pennine-Dent line, the Caledonian grain assumes the more familiar NE-SW trend of the Scottish Caledonides. Basement faults in the Welsh Massif active prior to collision (Coward \& Siddans 1979) can be traced into northwest England where they are truncated by the Pennine-DentMalvern line. The boundary of the indentor (Pontesford-Church Stretton fault) forms the southeastern margin, but the northern boundary is poorly constrained; whether the Lake District should be counted as part of the Northwest England province, or whether it represents a separate distinctive block (microcraton) is not clear.

The Iapetus Province. Finally, overlying the site of the Iapetus suture (Dewey 1971, 1982, Soper \& Hutton 1984, Beamish \& Smythe 1986, Klemperer \& Matthews 1987) encompassing the Northumberland/Solway basin, a narrow province is identified where the Caledonian structure trends strongly ENE-WSW.

The fundamental tectonic grain of northern England and Wales was therefore in place by the end of the Caledonian orogeny. The subsequent late Palaeozoic and Mesozoic 
tectonic history of the region has been one of continued reactivation of these fundamental trends in extensional, compressional and strike slip tectonic regimes.

\subsection{PRE-CALEDONIAN HISTORY}

Pre-Caledonian rocks form the basement to northern England and Wales. The oldest known rocks are the volcanics of the Uriconian, Wrekin and Charnwood Forest areas. They have associated sedimentary rocks generally known as the Longmyndian and Charnian sediments. All have late Proterozoic radiometric ages of $700 \mathrm{Ma}$ (Thorpe et al, 1984). These rocks probably form the basement, hidden beneath the Midlands microcraton. Rocks of similar ages also occur in isolated fault-bounded exposures in the Malvern Hills (Warren House Volcanics), the Church Stretton area (Stanmer House Volcanics) and the Gwna Group of Anglesey (Thorpe et al. 1984, Patchett et al. 1980). All these latter rocks are oceanic tholeiites which could represent the ophiolitic remnants of oceanic crust, most of which was subducted southeastwards beneath the microcraton. Thorpe et al. (1984) postulate that the oldest rocks which exist in the microcraton are no

older than 900 Ma old. Palaeomagnetic poles from the late Proterozoic of England and Wales place the Midlands microcraton on the northern edge of Gondwanaland, close to Arabia (Thorpe et al. 1984). The lithospheric plate which contains the Midlands microcraton is generally named the Cadomian plate (McKerrow \& Cocks 1986). However, by the early Cambrian, the microplate had split away from Gondwanaland and commenced its drift northwards towards Iapetus. During this drift, the Caledonian sediments were deposited on the microcraton. 


\subsection{CALEDONIAN INHERITANCE}

\subsubsection{Caledonide Microplate Collisions}

The Caledonian orogenic belt extended from northern Norway to the Gulf of Mexico and is diachronous in age. It is generally accepted that Caledonian structures throughout northwest Europe formed as a result of continued northwards acretion of continental fragments and magmatic arcs onto Laurentia, the Proterozoic North Atlantic craton (Soper \& Hutton 1984, McKerrow \& Cocks 1986).

Caledonian sediments were deposited unconformably on the Upper Proterozoic rocks described in section 2.3. The interval consists of sediments and volcanics of Cambrian to early Devonian age. During this time period northern England and Wales formed a separate Cadomian plate which was drifting northwards and converging with the Laurentian plate of North America and the separate Baltica plate of Scandinavia (Cocks \& Fortey 1982, Thorpe et al. 1984, Soper \& Hutton 1984, Perroud et al. 1984, McKerrow \& Cocks 1986, Andre et al. 1986) (Fig.2.2). Avalonia, which now forms SE Newfoundland, may have been attached to the Cadomian plate or formed a completely separate terrane. Southward directed subduction was likely beneath the northern margin of Cadomia to form a volcanic arc with a back-arc basin behind in the area of present day Wales (Woodcock 1984). The arc related calc-alkaline volcanics form the present day volcanic outcrops of North Wales and the Lake District. The eastern margin of Cadomia, which faced Baltica during the Ordovician and Silurian (Fig.2.2), is a more enigmatic zone because it is now buried beneath younger sediments. It may have formed an extended passive margin, with a trend at right angles to the Welsh-Lake District volcanic arc; or more likely have itself formed a volcanic back-arc basin (Andre et al. 1986) (Fig.2.2). 


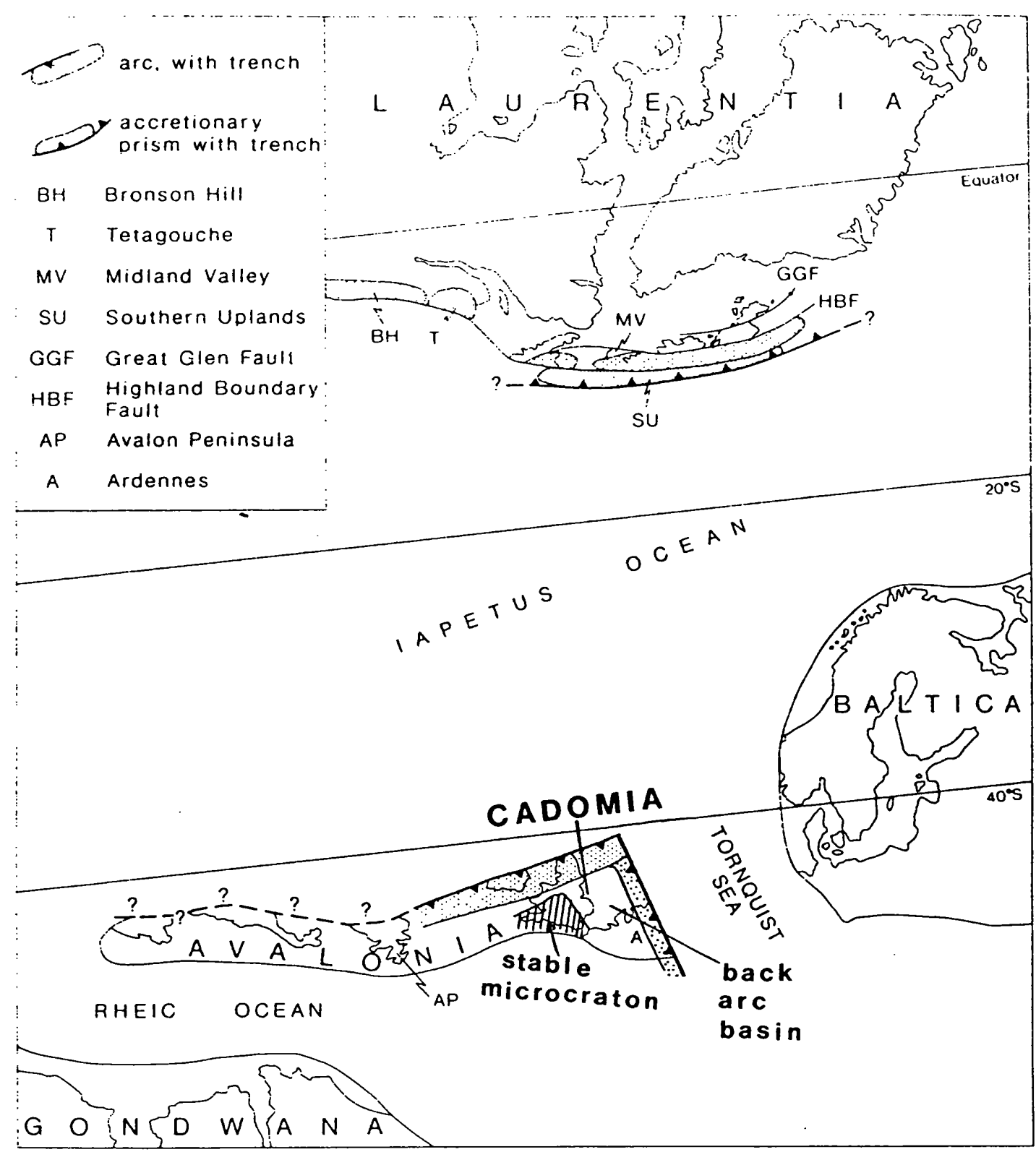

Figure 2.2 Caradoc palaeogeography of Cadomia, Baltica, Laurentia and Avalonia (after McKerrow \& Cocks 1986).

Collision occurred between Baltica and Laurentia by the mid Ordovician and continued until the mid Silurian (Soper \& Hutton 1984). The Southern Uplands accretionary prism appears to have collided with Laurentia in the Caradocian in the area of the present day Newfoundland and then became transported towards its present day position by leftlateral strike slip motion along the Iapetus suture. 
Southward directed subduction beneath the northern edge of the Cadomian plate ended by the late Ordovician (Soper \& Hutton 1984) and continued movement towards Laurentia by Cadomia continued by subduction beneath the Iapetus suture. During its movement the Midlands microcraton represented a stable platform area and the Welsh and East Midlands areas represent the thinned and stretched continental crust of the backarc basin, lying outboard from the craton.

Collision of Cadomia and Laurentia occurred during the Wenlock when northerly derived sediments first appear on the northern margin of Cadomia in the Lake District. Continued collision produced contraction between Cadomia and Lauretia which was accompanied by sinistral transpression in the Welsh Caledonides (Soper et al. 1987).

Finally Cadomia and Baltica collided in the late Silurian along the Tornquist line when faunas were eventually able to migrate and mix across the suture zone (Cocks \& Fortey 1982, Soper \& Hutton 1984, McKerrow \& Cocks 1986). The deformation across the Tornquist line at this time had a component of dextral transpression on the eastern margin of Cadomia. Final closure across the Iapetus and Tornquist sutures was accomplished by the early Devonian (Soper \& Hutton 1984).

Armorica, which now forms Britanny, probably formed a completely separate microplate that collided with the trailing edge of Cadomia in the end Silurian across the Mid European Caledonides (Houchen 1988). Hence by the early Devonian, the complete Northwest European platform had been assembled from a series of minor plates which had sutured along the British, North German-Polish and Mid-European Caledonides as a result of three separate collision events (Fig. 2.3). 


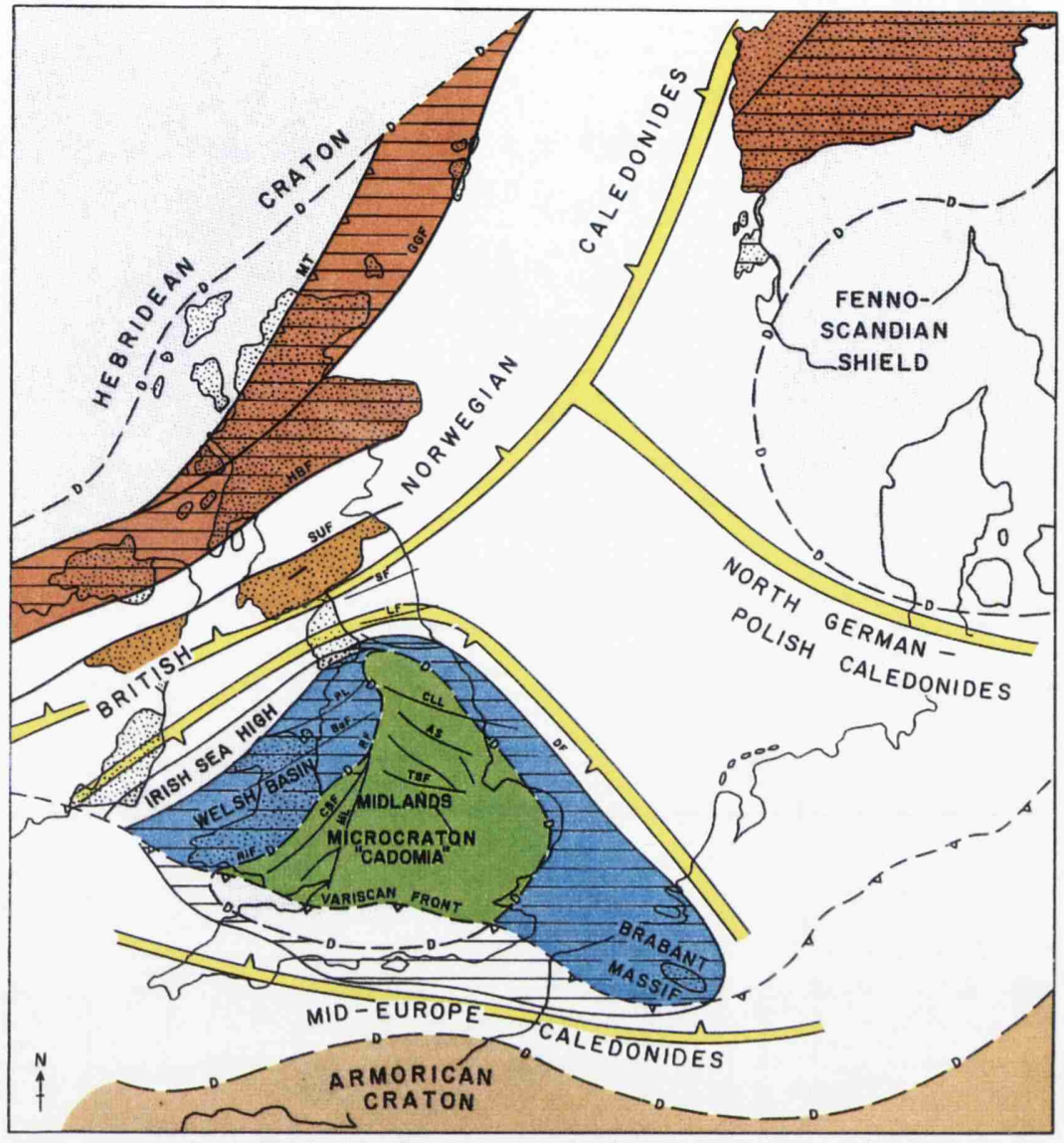

Modified after Andrē et al (1986), Soper \& Hutton (1984), Ziegler (1986)
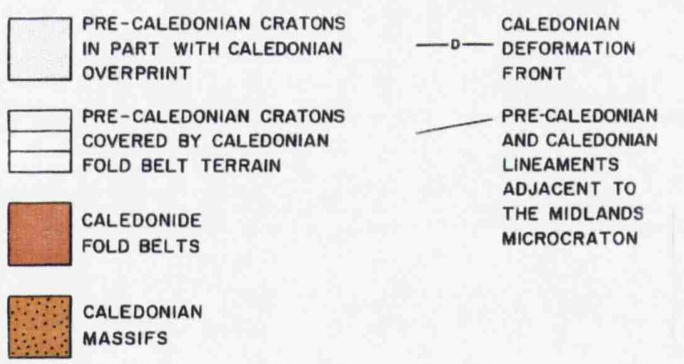

MT = MOINE THRUST

GGF = GREAT GLEN FAULT

SUF = SOUTHERN UPLANDS FAULT

MASSIFS

Figure 2.3 Sketch map of N.W. Europe showing major Pre-Cambrian cratons, foldbelts and sutures. Modified after Andre et al. (1986), Soper \& Hutton (1984) and Zeigler (1986). $\quad$ MT = Moine Thrust, GGF = Great Glen Fault, HBF = Highland Boundary Fault, SUF = Southern Uplands Fault, SF = Stublick Fault, LF = Lunedale Fault, $\mathrm{PL}=$ Pendle Line, $\mathrm{BaF}=\mathrm{Bala}$ Fault, $\mathrm{RF}=$ Red Rock Fault, RiF $=$ Ritel Fault, CLL $=$ Craven-Lincoln Line, AS = Askern-Spital Fault, TSF = Thringstone-Sileby Fault. 


\subsubsection{The Caledonides of northern England}

Plate 2.1 plots the major Caledonian faults of northern England and Wales. The Welsh Caledonides exhibit a strong NE-SW structural grain as evidenced by the trend of the Dinorwic, Bala, Pontesford and Church Stretton faults. Many cover anticlines and synclines run parallel to these faults. These however, curve in an arc, along with the associated cleavage, into an east-west trend where the Caledonian rocks plunge eastwards beneath younger cover sediments. Shackleton (1954) describes stratigraphic variations in facies and thickness in the Cambro-Silurian in terms of a horst and graben model. Coward and Siddans (1979) interpret the structure as a thin skinned thrust belt. The latter model fails to fully explain the marked stratigraphic variations across the main faults. A modification of the Shackleton model is offered here as a more up to date view. The block and basin structure is explained by half-graben geometry with down to the SE boundary faults. The surface folds and thrusts can be explained in terms of end Caledonian inversion of these half-graben.

The buried Caledonian of the East Midlands is interpreted to have a strong NW-SE trend (Plate 2.1). Several authors have described the presence of pre-Carboniferous Caledonian rocks buried at depth beneath the East Midlands (Turner 1949, Bott 1966, Kent 1968, Le Bas 1972, Wills 1973, 1978, Evans 1979, Watson 1980, Pharoah et al. 1987), which have influenced the deposition of the overlying sediments. Several exploration boreholes have encountered pre-Carboniferous basement which is typically composed of Silurian phillites or Ordovician-Silurian volcanics and granites (Falcon \& Kent 1960, Le Bas 1972). Also late Pre-Cambrian sediments and volcanics are exposed in Charnwood Forest. The gravity and aeromagnetic maps of the region (Plates 1.9, 1.10 and 1.11 ) show important anomalies which outline the NW-SE trend of this hidden Caledonian system. It is suggested in this thesis that many of the Carboniferous and younger faults, which follow the same NW-SE trend, represent rejuvenated Caledonian faults. As many of the rocks penetrated by the deep wells are steeply dipping and 
cleaved it is likely that the buried fault system has largely a contractional geometry. This interpretation is followed on Plate 2.1. Most of the known Carboniferous faults dip to the NE suggesting that the Caledonian contractional faults also dipped in this direction. Examples of rejuvenated Caledonian thrust faults are believed to be structures such as the Hoton, Cinderhill, Eakring and Askern-Spital faults. Plate 2.1 also highlights the aeromagnetic anomalies (Plate 1.11) which are also thought to represent deeply buried Caledonian structures. However, not all the structures run in this NW-SE trend. There are two important cross-trending faults through the Wash and also localised structures such as the Don monocline with NE-SW trends. These cross cutting structures probably represent old Caledonian lateral ramps and transfer zones; structures typical of thrust fold belt terranes.

A cleavage front has recently been recognised (Pharoah et al. 1987). Working on basement core material provided by BP from deep exploration boreholes in the East Midlands, Pharoah et al. (1987) have highlighted a N-NNW trending lineament corresponding to the subsurface expression of the Eakring-Foston fault zone (Plate 2.1). It separates Palaeozoic rocks in subcrop and outcrop with steep dips and slatey cleavage from those of the Midlands microcraton which are gently dipping and uncleaved. This front marks the edge of the microcraton as displayed by Turner (1949).

The Lake District provides the link between the Welsh and East Midlands Caledonides. Both Turner (1949) and Soper et al. (1987) believe that the Lake District contains an arcuate structure that completely links the East Midlands-Welsh Caledonides into a single belt. The link is mainly in the form of a cleavage arc (Plate 2.1). In the southwest of the Lake District the late Caledonian cleavage has a NE-SW trend. It curves round continuously into an east-west trend where it is cut-off against the Dent fault (Moseley 1972). East of the fault, the Palaeozoic rocks reappear in the Craven inlier where the cleavage has a ESE trend. From here this trend passes into the East Midlands aeromagnetic anomalies and presumed NW-SE Caledonide trend. 


\subsubsection{Caledonian granites}

The Caledonian orogenic cycle was brought to an end by the final collision of the Cadomian microplate to form the Iapetus suture. Collision across this suture ended by the Gedinnian (410Ma). This produced the important regional unconformity in Scotland, England and Wales between the Lower and Upper Devonian rocks. The collision also marked the final emplacement of Caledonian igneous rocks. Late Caledonian granites exist at outcrop in the Southern Uplands, the Lake District and are also known in the subsurface in deep boreholes in Weardale and Wensleydale (Bott 1967). They were intruded at 390Ma, slightly post-dating the time of final closure. Granites also exist further south around Charnwood Forest (Le Bas 1972) where they have older $540 \mathrm{Ma}$ radiometric ages.

There has always been a problem explaining these late Caledonian intrusives in terms of Iapetus subduction because they occur on both sides of the suture zone. Subduction related volcanics should only occur on the subducted side of a Benioff zone. However, with the recognition of the Mid European Caledonides (Ziegler 1982) these northern England Caledonian intrusives can easily have been generated by a northwards dipping subduction zone which extended from the Mid European Caledonides underneath the Midlands microcraton.

The granites also had a significant impact on the style and location of subsequent tectonics because they formed isostatically bouyant areas which generally form the footwalls to subsequent extensional faults (Bott 1967, Leeder 1982). 


\subsection{VARISCAN PLATE CYCLE}

A general consensus seems to exist regarding the Caledonian tectonic development of northern England. However, this is not the case with the origin of the northern England extensional basins, which is the subject of some controversy. There has been considerable debate regarding the regional controls on Variscan extension and inversion tectonics as evidenced from surface exposure, unconformities in boreholes and more recently modern multifold seismic data as presented in this thesis.

There are at least four models currently in circulation attempting to explain the origin of the northern England late Devonian-early Carboniferous extensional basins and their subsequent inversion during the late Carboniferous;

i) The dextral megashear model; this model, first outlined by Arthaud and Matte (1977) and later developed by Ziegler (1981), Dewey (1982), Johnson (1982), Badham (1982) and Arthurton (1983), suggests that a wide zone of right lateral shear affected Europe, particularly during the Carboniferous as Gondwana docked with Laurasia. The northern England extensional basins are interpreted as being formed by rifting associated with pull-apart basins in an east-west oriented zone of dextral megashear, which linked the Alleghenides in North America to the Urals in Russia. The inversion events which punctuate Carboniferous rifting are interpreted as reflecting the evolution of the shear zone through a 'big bend' of the type evidenced along the San Andreas fault system in California.

ii) Back-arc extension generated by northwards subduction of the Rheic Ocean; this model suggests that extension was driven by ductile creep of the lower crust towards a Rheic subduction zone (Leeder 1976), and as a result of back-arc extension from a northwards dipping subduction zone in southern France (Leeder 1982, 1987). The northern England rift system is interpreted within this setting as essentially back-arc in 
nature with the inversion events linked to initial pulses of the Variscan orogeny which intensified towards final collision in the late Carboniferous-early Permian.

iii) East-west extension derived from southwards propagation of the Boreal rift; this model with its origins based on observations in the Midland Valley of Scotland suggests that progressive southwards propagation of the Boreal rift during the Carboniferous resulted in east-west extension generating crustal thinning, basin formation, syn-tectonic ore deposition and volcanicity eventually leading to the generation of oceanic crust in the region of the present day Rockall Trough, towards the end of the Carboniferous (Haszeldine 1984, 1988 \& 1989, Haszeldine \& Russell 1987).

\section{iv) Lateral expulsion of the English-North Sea-Baltica Block away from an Acadian} indentor; this hypothesis proposes that Devonian and early Carboniferous tectonics in N.W. Europe can be explained in terms of a continuum of Caledonian events. Continued northwards movement of an Acadian indentor is interpreted as causing the eastwards extrusion of a triangular shaped block comprising northern England, the North Sea and Baltica. During the early Carboniferous, the block expanded NW-SE as it was released from the indentor into space created by back-arc extension. As in the wrench model, pull-apart basins formed along the shear systems. Closure of the Ural ocean and subsequent Ural plate collision during the late Carboniferous, reversed the sense of shear along the block margins and the wedge shaped block was pushed back between the Acadian collision zones causing inversion of the pull-apart and extensional basins in northern England (Coward 1993).

In order to evaluate these apparently contradictory models, it is necessary to step back from local detail (principally outcrop and borehole studies), to analyse the plate tectonic processes at a regional scale and attempt to rationalise the numerous field and seismic based observations within this framework. This type of approach has successfully been applied recently by Knott et al. (1993) in an analysis of the Mesozoic evolution of the 
northern Atlantic continental margins and its subsequent impact on the evolution of the Northern North Sea Basin.

\subsubsection{Regional Variscan Tectonics}

This section is designed to provide an outline of the plate tectonic setting of the Variscan orogeny and to set in context, both geographically and structurally, the models to be discussed later. Given this objective, it is necessary to describe the major crustal elements and their relative motions throughout the period from end Caledonian to end Variscan. The end Caledonian plate configuration was established in the previous section. Figure 2.3 shows a sketch map of Northwest Europe and illustrates the three Caledonian fold belts which surround the Cadomian plate with the Midlands microcraton at its centre. These are;

i) Cadomia - Laurentia (Iapetus) Suture - collision end Wenlock

ii) Cadomia - Baltica (Tornquist) Suture - collision late Silurian

iii) Cadomia - Armorica Suture - collision end Silurian

Thus the early Devonian structural framework reflects the end Caledonian configuration and is the result of three separate collision events.

\subsubsection{Variscan plate reconstruction}

The plate reconstruction presented for the late Devonian-Carboniferous was developed as the 'end point' in the series of maps presented in the Knott $e t$ al. study (Plate 2.2). Knott and his co-authors had the benefit of Bathonian to Recent magnetic anomaly data as an external constraint on the relative motions of the plates. In attempting to construct a plate restoration for the late Palaeozoic access is lost to the constraints of the magnetic anomaly data prior to the Mid Jurassic and more reliance has to be placed on palaeomagnetic and 
regional tectono-stratigraphic data such as the presence of plate margin volcanics, abrupt changes in basement lithologies, deformation zones and regional unconformities. The reconstruction describes the northwards movement of Gondwana throughout the mid to late Devonian progressively closing the Rheic and Rheno-Hercynian oceanic basins. Also captured in the reconstruction are the early attempts of the Boreal rift to propagate southwards along the line of the Caledonian collision zone between Norway and Greenland.

The plate reconstruction provides us with several key insights as to the origins of the Variscan controversy. It is evident that at least two plate margin processes were prevalent in late Devonian-Carboniferous times; an extensional system propagating southwards from the northern Boreal ocean and a dominantly contractional system encroaching northwards on southern Britain. It is reasonable to conclude that these events will appear to have varying significance depending on where they are being observed from. Carboniferous tectonic studies using field evidence from the Midland Valley of Scotland and Northumberland are likely to interpret the Boreal system and associated north-south orientated faults as a key control, whereas studies in southern Britain are likely to conclude that the continued development of extension and compressional (inversion) tectonics are occurring within a back-arc system dominated by north-south directed plate collision with variable amounts of dextral shear. Both are acceptable models given the local field observations and more importantly within the context of the Carboniferous plate reconstruction (Plate 2.2) both are compatible and potentially valid.

\subsubsection{Variscan extension}

Although the relative importance of north-south extension versus dextral shear is still uncertain, rifting was affecting the northern margins of the Rheno-Hercynian Basin (Plate 2.3) by the early-mid Devonian (Sellwood \& Thomas 1986) and the cause of this 
is believed to have been back-arc subduction related to the north-westward subduction of the Rheic Ocean beneath the Armorican microcraton (Burg and Matte 1978, Leeder 1987a, 1988).

In the interval 420-370Ma (late Silurian-late Devonian) major thrust tectonics occurred in the orogen, accompanied by the formation of nappes which verge towards the concave sides of the Ibero-Armorican arc and to the south of the Massif Central. The overthrusts are considered to have been on the same scale as the more recent Alpine and Himalyan features. The sense of thrusting and presence of nappes and the southward migration of deformation within the Massif Central (Burg and Matte 1978) is taken to imply continental lithospheric collision of a southern plate which progressively underthrust Laurasia.

The presence of a subduction zone to the south of the South Armorican Shear zone is supported by dismembered ophiolitic material thrust southwards in the Massif Central on the south side of the suture (Burg \& Matte 1978). Further evidence for subduction includes the presence of blue schists on the Ile de Groix and further west in the Vendee (Guiraud et al. 1987) and the associated high temperature/low pressure assemblages in Brittany (Lefort 1979).

The back-arc origin of the Rheno-Hercynian basin is supported by the chemistry of tholeiitic basalts in Cornwall (Floyd 1982) and also by the association of 'oceanic' volcanic rocks with thick greywackes (Matte 1986).

Early (Lower-Middle Devonian) extension within this back-arc setting was dominantly north-south oriented (eg. Benton and Ritec faults in South Wales, Houchen 1988). Sellwood and Thomas (1986) have suggested that the basins on the northern margin of the rift in Devon and Cornwall developed as a series of half-graben controlled by a set of down to the south listric faults (Plate 2.3) as evidenced by the formation of the Trevone 
and South Devon basins in the region. It has been suggested (Chandler and Issac 1982) that the South Devon basin has certain oceanic affinities and the crustal scale cross section interprets the zone as lying very near to the continent-ocean transition after breakup (Plate 2.3). The Upper Devonian to Lower Carboniferous facies in the half-graben trend from clastics in the early syn-rift to reefal and pelagic carbonates with black shale/cherts towards the end of the rift phase. The reefs typically develop on the footwalls of the rotated fault blocks (Plate 2.3). There are clearly similarities here with the Mesozoic Biscay margin where Kimmeridgian reefs developed on tilted footwall blocks prior to break-up (Montadert et al. 1977). Important slivers of MORB basalts under the Giessen/Selke nappe (Wederpohl et al. 1983) is further evidence that late Devonian oceanic crust was generated in the Rheno-Hercynian basin. The age of final break-up when the rift became oceanic is thought to be late Givetian (375ma).

As the crust thinned, a renewed period of rifting in the Frasnian was combined with a possible change in plate motions with some of the dextral shear that was being applied to the southern margin of the Armorican microcraton (a result of oblique subduction of the Rheic Ocean) was transferred to the centre of the Rheno-Hercynian basin (Houchen, 1988). In the Gramscatho basin in southern Cornwall, stretching at a right-handed offset in the resulting dextral transform system increased extension to the point at which dyke intrusion began and finally led to the generation of the Lizard ophiolite complex. Palaeomagnetic data suggest a spreading axis oriented NNW (Hailwood et al. 1984, Barnes \& Andrews 1986). This presents a problem as this observation is largely incompatible with north-south extension unless the oceanic crust was generated along a leaky transform system linking actively spreading segments of the main back-arc system.

Recent isotopic studies of the Lizard ophiolite complex in western Rheno-Hercynia suggest oceanic crust generation at $375 \mathrm{Ma}$ followed by obduction between 370 and $355 \mathrm{Ma}$ (Davies 1984). However, older dates of up to $400 \mathrm{Ma}$ (Halliday \& Mitchell 1976, Styles and Rundle 1984) would place its generation during the earlier Lower 
Table 2.1 Development of the Variscan Orogeny in Northwest Europe:

Timing of key events

$\begin{array}{ll}\text { Mid-Late Devonian } & \text { Subduction of Rheic ocean northwards in the } \\ \text { (390-375Ma) } & \text { Iberian-Armorican-Massif Central region. } \\ & \text { - drives back arc rifting in Rheno Hercynia } \\ & \text { (including Culm province). }\end{array}$

Givetian

(375Ma)
Rheno-Hercynian break-up unconfomity

-syn-rift/post-rift boundary in Rheno-Hercynia

continued subduction of Rheic ocean generates

oceanic crust in Rheno Hercynian back-arc basins.

Thermal subsidence of Rheno-Hercynian passive margin.

\section{Frasnian-Famennian Onset of subduction of Rheno-Hercynian oceanic (?370-365Ma) crust - ?northwards.}

$\begin{array}{ll}\text { Fammenian-Courceyan } & \begin{array}{l}\text { Onset of rifting in northern England resulting } \\ \text { from northwards subduction of Rheno-Hercynian }\end{array} \\ \text { oceanic crust and dextral shear. } \\ \text { Thermal subsidence of Rheno-Hercynian passive } \\ \text { margin. }\end{array}$

Mid Brigantian

(335Ma)
Final closure of Rheno-Hercynian back-arc basin. Nappe formation in Culm province; inversion event in northern England.

Thermal subsidence in northern England with superimposed.dextral shear causing minor fault reactivation through to end Westphalian ' $A$ '.
Namurian-

Westphalian ' $C$ '

(335Ma-300Ma)
Culmination of Variscan orogeny in Northwest Europe. Large scale thrust emplacement and crustal shortening in S. England. Major inversion in northern England accompanied by widespread molasse deposition. 
Devonian normal extension. While timing is therefore uncertain, the younger age is preferred as it places the complexes generation within the later period of basin development.

Lying to the north of the Midlands microcraton, the northern England rift system was in a comparatively external position. It developed in response to the final stages of subduction and back-arc spreading towards the end of the Devonian and involved the negative inversion (normal extension on older thrust faults) of the inherited Caledonian fault system.

\subsubsection{Variscan compression}

The timing of the transition between overall extension and overall compression (from subduction and back-arc spreading to collision) is unsure. Burg and Matte (1978) consider the Rheic Ocean to have closed towards the end of the Devonian, whereas Leeder (1987a) argues for continued subduction and associated back-arc extension throughout the early Carboniferous in order to explain early Dinantian rifting in northern England. Early thrusting, marked by the obduction of the Lizard complex in the early Carboniferous (Barnes \& Andrews 1986) (365-345Ma Famennian-Chadian, Dodson \& Rex 1971) suggests that the change from dextral transtension to dextral transpression in the south of the British Isles probably took place in the late Tournaisian or early Visean. The associated deformation migrated northwards with the western parts of the South Devon and Trevone basins inverting in the late Visean (Sellwood \& Thomas 1986) and the East Midlands basins at end Brigantian (Fraser et al. 1990).

In common with the late extensional history, there appears to be an important component of dextral shear. Sanderson (1984) considers that compression took place in a dextral transpression regime. There are several major faults which exhibit Variscan dextral shear, principally the Bray Fault (Matte et al. 1986) and the North and South Armorican 
Shear Zones (Cogne 1960, Chauris 1969, Watts and Williams 1979, Jegouzo 1981). In South-West England, Coward and Smallwood (1984) also cite the obliquity of thrust transport directions to the Variscan Front to suggest a component of dextral displacement.

A summarised section through the British Variscides is shown in Plate 2.3.

2.5.2 Variscan structural development of northern England.

\subsubsection{Major trends}

The main Carboniferous structural elements of northern England are illustrated in map view on Plate 2.4 and in cross-section on Plate 2.5. Surface structural trends taken from BGS 1:500,000 and 1:625,000 geological maps, have been combined with subsurface trends mapped from seismic, gravity and aeromagnetic data (Plates 1.8, 1.9, 1.10 \& 1.11). The structures illustrated on Plates $2.4 \& 2.5$ are those which significantly affect Carboniferous strata, although many of the lineaments present are believed to have an early Palaeozoic origin and a structural history which extends well into the Tertiary.

In the north, the Northumberland-Solway trough follows the ENE-WSW trend of the Iapetus suture which underlies it. The main boundary fault lies on the north side of the basin with down to the south extension. On the southern margin there are two important east-west trending antithetic faults which downthrow northwards away from the Alston block. These are the Stublick and Ninety-Fathom faults. They die out westwards towards the NNW-SSE trending Eden-Pennine fault..

East-west fault trends are also evident in the Stainmore Trough which is bounded to the north by the en echelon Lunedale, Wigglesworth and Butterknowle faults. This trough separates the Askrigg and Alston blocks. The latter is bounded to the west by the Dent 
fault and on the south side by the Craven fault. Both the Alston and Askrigg blocks form the footwalls to significant half-graben and both blocks are known to have been intruded by Lower Devonian granite plutons. The isostatic buoyancy of these grantes explains the locations of the footwalls here (Bott 1961, 1964, 1967, 1974, Bott \& Masson-Smith 1957a, 1957b, 1960). The east-west block structure extends as far as the Southern North Sea where NW-SE structural trends become apparent. Only the North Craven fault can be shown to link into the offshore trends via the Gilling and Barton fault trends (Fig. 2.4). It is likely that the Southern North Sea faults also follow the trend of older Caledonian thrusts.

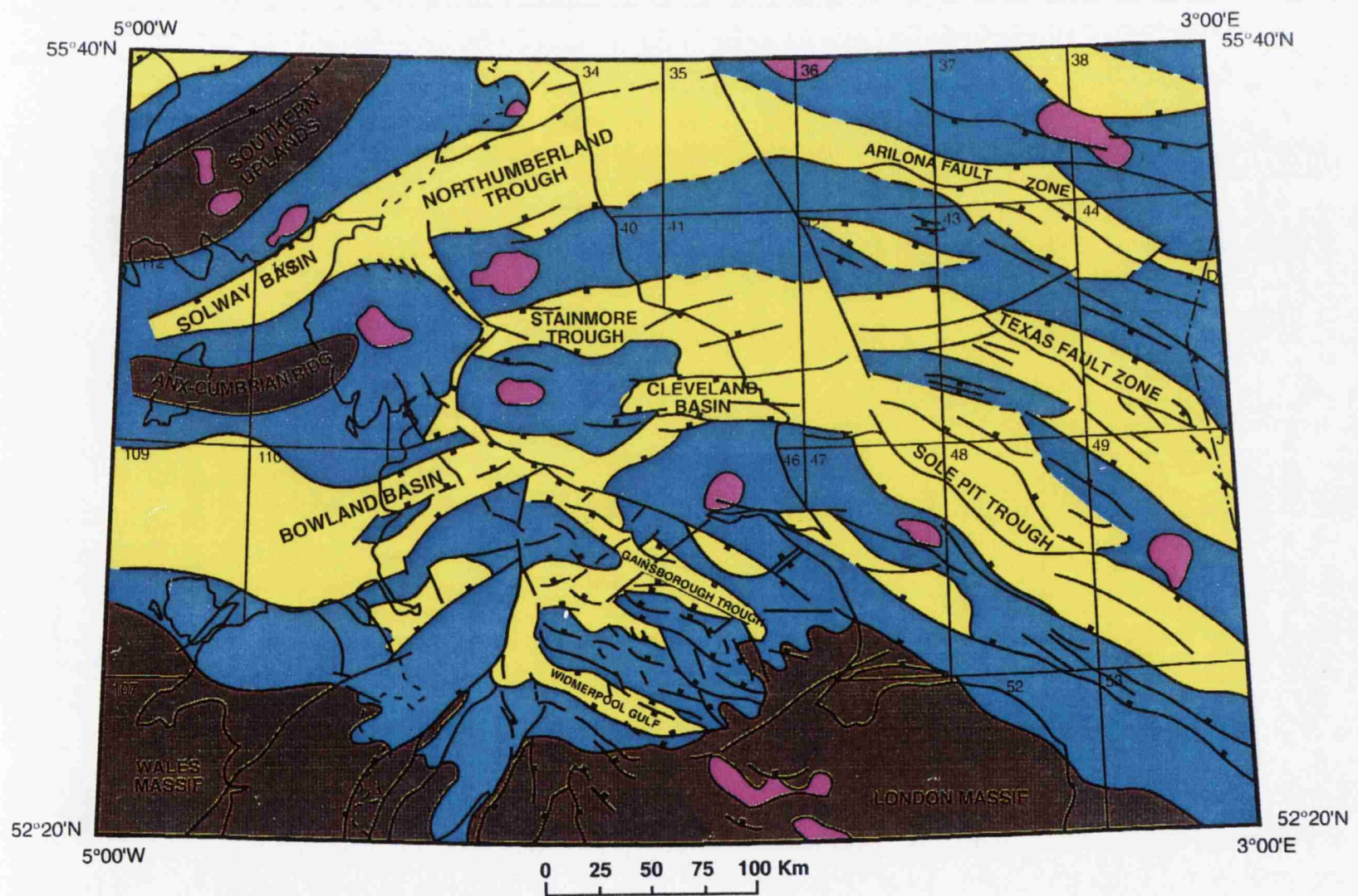

Figure 2.4 Carboniferous structural elements: northern England and the Southern North Sea. 
West of the Pennine-Dent-Craven system, the early Carboniferous extensional faults have NE-SW trends, following the strike of the underlying Welsh Caledonides. The Pendle fault defines the southern margin of the Bowland Basin. This is postulated to follow the surface monocline on the south side of the basin and has down to the north displacement. The monocline, and the fault, die out north of the Mersey estuary. Here the Pendle fault has been linked in Plate 2.4, via a lateral ramp fault, up to the faults which cross Anglesey. The position of the lateral ramp was drawn parallel to prePermian folds known from this area (Colter \& Barr 1975). Note that northeast of the lateral ramp, the main half-graben of the Bowland Basin has down to the NW extension. However, on the other side of the ramp, some of the older Caledonian faults were probably still active in the Carboniferous (eg. Church Stretton, Pontesford and Prees faults). Dinantian movement is inferred on the Bala and Llanelidan faults to explain stratigraphic thickness changes across the fault zone (George 1958) and the presence of the Widnes Basin (Plate 2.4). The Clwyd fault was also active, linking the Berw and Llanelidan faults. There is a small Dinantian half-graben on the southwest side of the Clwyd fault which is inferred to form the western extension of the Widnes Basin. This half-graben demonstrates a component of NE-SW extension which probably caused strike-slip motion on the Bala and Berw faults.

In the East Midlands, the dominant trend of structures (usually faults associated with folds) is NW-SE. Along this trend, a parallel series of faults lie bounded to the north by the Craven-Lincoln line and its eastward extension, the Brigg fault, and to the south by the Hoton fault. To the south of the Hoton fault, the major boundary faults between the East Midlands basins and the London-Brabant Massif trend NW-SE to east-west (the Thringstone and Sileby faults). Between these lines, fault trends such as the MoreleyCampsell, Askern-Spital, Egmanton, Bakewell-Ladybrook, Cronkston-Bonsall and Cinderhill faults form major lineaments extending across the East Midlands platform. Towards the Humberside area, this dominant trend swings into an east-west direction. 
The major basins in the East Midlands are controlled by the NW-SE (eg. Askern-Spital) trend of faults which throw down to the NE and SW. Basins such as the Gainsborough Trough and Widmerpool Gulf are essentially half-graben bounded by these faults. Plate 3.2 is a NNE-SSW section across the East Midlands which illustrates the nature of these basins. The NW-SE trend extends westwards into the Derbyshire Dome area, where it again forms the bounding faults for the half-graben (Smith et al. 1985, Gutteridge, 1987). Superimposed on the NW-SE trend are two further trends; NNW-SSE and NESW (Plate 2.4). The NNW-SSE trend of faults and folds are generally limited in length and can be seen to be confined to blocks defined by the NW-SE trend and often branch off them. Structures such as the Ironville, Calow, Hardstoft, Eakring-Foston and Nocton faults lie in this category. The faults of this trend predominantly throw down to the northeast and are associated with small, tightly folded hangingwall anticlines.

There appear to be fundamental differences between the two more prevalent trends, NWSE (eg. Askern-Spital) and NNW-SSE (eg. Eakring-Foston), which are reflected in the type of structure and its development through time. Most significant is the depth to detachment of the NW-SE trending half-graben bounding faults to the Widmerpool Gulf (Hoton fault) and the Gainsborough Trough (Askern-Spital fault), when compared to that of the NNW-SSE (eg. Eakring-Foston) faults. From the depth converted reflection seismic data (Plate 3.2), the NW-SE border faults appear as planar in section with detachments probably at mid crustal levels (below $12 \mathrm{~km}$ ) and have similar geometries to major border faults in areas of active extension such as the Aegean and Basin and Range (eg. Jackson 1987, Stein and Barientos 1985). By comparison, the NNW-SSE faults are markedly listric in nature and sole out at depths of around $2-3 \mathrm{~km}$.

Towards the western end of the Derbyshire Dome area, the dominant NW-SE trend also swings into a NNW-SSE trend merging with the Pennine axis. Here surface folds and folds have north-south trends and well information defines a deep basin, the Goyt Trough, along the axis. A north-south extension fault has been postulated to explain the 
location of the trough. This has been placed on the western side of the Goyt trough, with down to the east displacement, following the Pennine axis. Southwards, the postulated fault can be traced into the Malvern Line and also splaying into the BoothorpeThringstone trend. There are present day surface folds in south Derbyshire which define the arc into the Thringstone trend. To the north, the Goyt Trough boundary fault probably swings round to join the South Craven fault, following the trend of the large surface anticline here.

The NE-SW trend of faults which dominates most of the northern and western areas of northern England is of limited areal extent and influence in the East Midlands. This trend has been extrapolated from surface geology and gravity modelling (Plate 1.10) in an area of Mesozoic cover in the northwest of the East Midlands province and appears to affect the subsurface structure, particularly at the NW and SE limits of the Gainsborough Trough. The Sheffield-Doncaster lineament lies on this trend (Plate 2.4).

\subsubsection{Late Devonian-Dinantian rifting}

Throughout most of England and Wales, the Upper Devonian sits unconformably on folded Lower Devonian (Wills 1973, 1978) which was deformed by the closure of the Iapetus Ocean. Above the unconformity, the rocks were deposited in a different extensional tectonic regime. Upper Devonian sediments began to accumulate in riftbounded half-graben which followed the trends of older Caledonian structures. The main evidence for this is the sequence of late Devonian-early Dinantian (?Courceyan) clastic sediments penetrated in boreholes such as Eakring-146 in the hangingwalls of the half-graben bounding faults (Plate 2.6). Upper Devonian sandstones are also known from outcrop in the Northumberland Trough, Lancashire Shelf, Derbyshire Dome and East Anglia. It is suggested that this sequence represents local syn-rift continental alluvial fill to the newly active basins. 
Apart from Eakring-146, there is little evidence elsewhere in the East Midlands for clastics of the type and age encountered in Eakring-146. By inference, the wedge shaped sequences at the base of the rift fill, lying adjacent to faults such as the Hoton fault, Askern-Spital fault, and Egmanton fault, all contain syn-rift clastic wedges above the lower Palaeozoic surface. The sites for the clastic wedges will occur where the top basement surface is faulted to produce isolated syn-rift half-graben. Examples of the this are the Goyt Trough, the Widmerpool Gulf and the Gainsborough Trough (Plate 2.4).

The subsurface borehole and seismic reflection data suggest that pulsed rifting continued in northern England into the early Brigantian (Fraser et al. 1990). There is growing evidence for invoking two additional phases of extension and an early Variscan precursor inversion event during the later Dinantian (Chadian-Brigantian). Two phases of movement have been described from the Bowland Basin (Gawthorpe 1987a, Gawthorpe et al. 1989; Plate 2.7). Recently reviewed field evidence for these movements suggests that during the late Chadian-early Arundian and mid-late Asbian, renewed extension occurred on major faults in both the Bowland Basin and Derbyshire Dome areas. These two extensional events are marked by footwall erosion and the development of boulder beds and slumps in the hangingwall (Gawthorpe 1986).

On seismic data these events are marked by footwall rotation causing uplift and erosion followed by onlap of the overlying sequence. The late Chadian/Arundian extensional event is evidenced on seismic in both the Cleveland and Northumberland basins by the development of roll-over anticlines against the main basin bounding faults (Plates 3.16 \& 3.20). From seismic data in the East Midlands, the Chadian/Arundian and Asbian/Brigantian phases of extension can be observed on the Thrinston-Sileby and Hoton faults (Plate 3.4). Within the tilt-block bounded by these faults, the Dinantian sequence thickens to the south into the Thrinston-Sileby fault. From borehole evidence at Hathern, an early Dinantian continental evaporite sequence is overlain by later Dinantian marine shelf carbonates and later still by basinal mudstone sediments on the 
Hathern Shelf (Falcon \& Kent 1960). Adjacent to the Hoton fault, seismic data shows the footwall to have been eroded, and onlapped by a late Dinantian (Brigantian) sequence. It appears that the Hathern Shelf has been back-rotated during both the Chadian and Asbian extensional events such that the footwall was elevated above base level and the northern edge eroded as a consequence. The extension event is also reflected in the onlap of Brigantian onto Asbian shelf margins in the hangingwalls of the main faults and the drowning and onlap of possible Chadian mud mounds by sediments of Arundian and Holkerian age (Plate 3.2).

\subsubsection{Intra-Dinantian inversion}

Intra-Dinantian inversion events have been postulated to have occurred in the Ribblesdale fold belt in the Bowland Basin (Arthurton 1983, 1984). The evidence is based on unconformities and stratigraphic overstep which later became folded by the Ribblesdale folds. A phase of pre-unconformity folding was postulated to explain the unconformity and this older fold event was explained by dextral transpression. However, the same effects could equally be explained by footwall erosion on pre-unconformity intra-basinal extensional faults generating the debris flow deposits described by Gawthorpe \& Clemmey (1985). Hence a pre-Ribblesdale foldlng or intra-Dinantian fold event is still not proven in the Bowland Basin. Chadian, Arundian and Pendleian erosion surfaces have been described from different folds in the belt. If there was an early phase of inversion, it would seem to have been long lived.

There is better evidence for inversion in the East Midlands during the late Dinantian. A proposed mid-Brigantian inversion event has been identified mainly from recent seismic and borehole derived biostratigraphic data over the East Midlands platform (Strank, 1987). Isopach mapping in the Widmerpool Gulf shows that whereas the Dinantian thickens into the main southern bounding fault the Namurian is thickest along the axis of the basin (i.e. onlaps both the hanging and footwalls of the graben bounding faults). 
Perhaps the most convincing evidence for this inversion occurs on seismic line BP84-12 (Fig. 2.5) in the southwest of the Widmerpool Gulf and Hathern Shelf. Here it appears that the hangingwalls of both the Hoton and Sileby faults have been inverted to create a pre-Namurian topography. Subsequent late Brigantian and Namurian events passively onlap this topography. The main effects of this event are seen in the south and east, adjacent to the London-Brabant Massif, where there is pronounced subcrop of preBrigantian strata by erosion and thining, and by onlap of post-Brigantian events. The continued effects of the inversion can be inferred from the regional uplift of the AubournBassingham and Nocton highs where Namurian and later sediments onlap progressively older Dinantian sediments to the east (Strank 1987). This relationship is explained in terms of progressively deeper erosion of the Dinantian surface following the inversion event as it becomes more pronounced towards the east of the East Midlands platform and the south Humberside shelf (see also map on Plate 5.9).
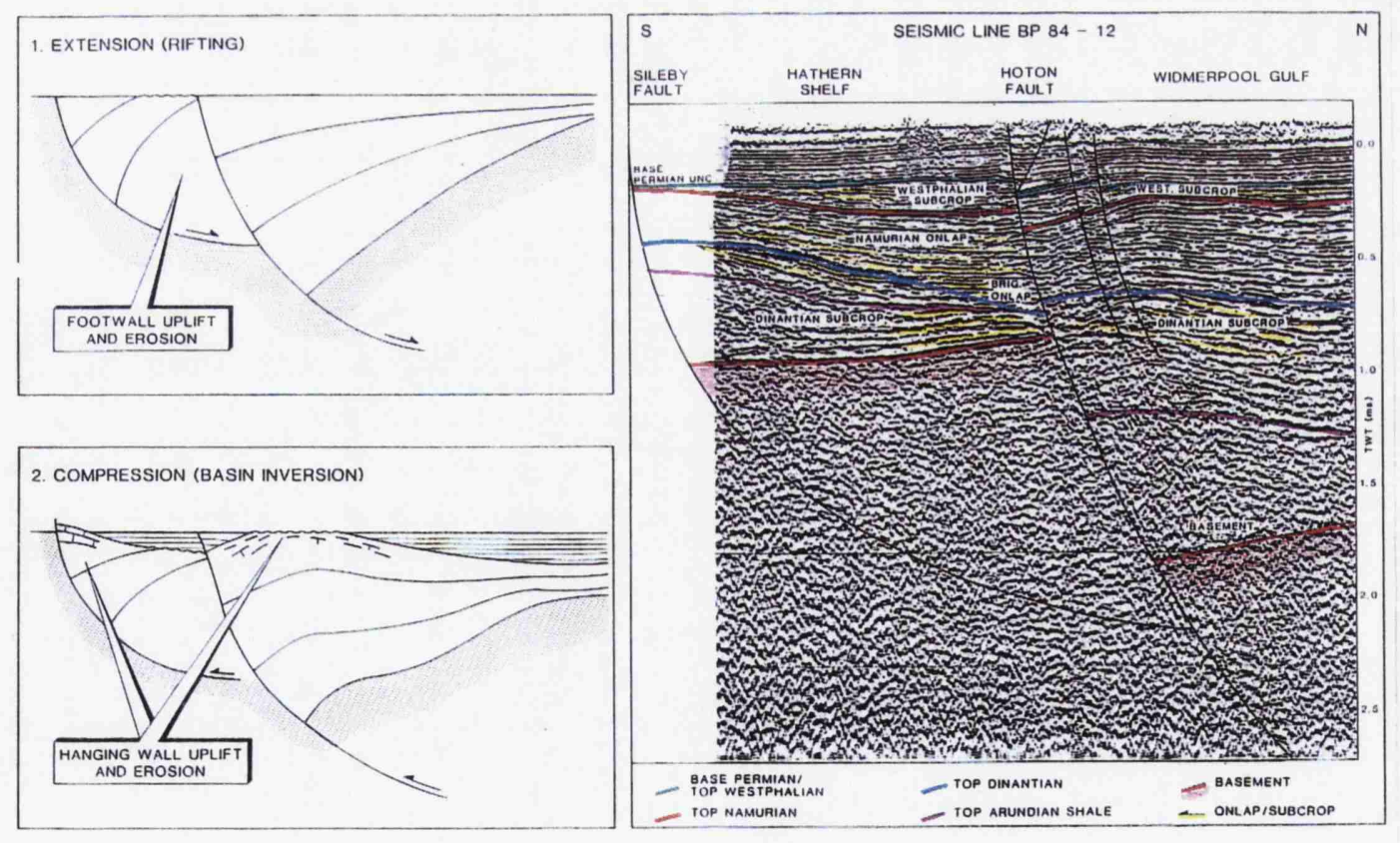

Figure 2.5 Northern England Dinantian tectonics: Schematic models for the development of intra-Dinantian unconformities and their seismic expression. 
The mid-Brigantian inversion event is presumed to have regional significance in northern England. The event appears to correlate with the proposed final closure of the RhenoHercynian back-arc basin (Leeder 1982) and nappe emplacement in the Culm province in Southern England (Sellwood \& Thomas 1986) (Table 2.1). Unfortunately the later, stronger, Variscan inversion pulses of Westphalian 'C', Stephanian and Early Permian age has reactivated, to varying extent, the same basin bounding faults making identification of the earlier (late Dinantian) phase problematic. However, it may be significant that the main evidence for a late Dinantian inversion event occurs on faults of the NW-SE trend, suggesting a NE-SW directed stress field.

\subsubsection{Silesian extension}

Within the context of the Variscan Orogeny, the late Brigantian inversion was relatively minor. Significantly, it corresponds to the switchover from active rifting to thermally induced 'sag' subsidence in northern England. It would seem likely that this event disabled the subduction which controlled back-arc spreading in the Variscan domain to the south, leading to the termination of active rifting in northern England. This switch in subsidence patterns is particularly well demonstrated by comparison of the restored syn and post-rift isopachs over northern England (Plates $2.9 \& 2.10$ ). The early Carboniferous (syn-rift) isopach shows deposition essentially confined to isolated fault bounded half-graben. In contrast, the post rift isopach (Namurian-Westphalian 'B'; Table 2.1) displays a pattern normally associated with thermally driven, broad regional subsidence. Over $3.5 \mathrm{~km}$ of sediments were deposited during the post-rift phase with subsidence centred in the southwest of the study area. A similar pattern of sag-type thermal subsidence has been identified in the offshore domain (Leeder \& Hardman 1990), (Fig 2.6).

Seismic data shows that the early Namurian sequences in the East Midlands onlap the Dinantian surface at the margins of the Widmerpool Gulf and Gainsborough Trough. 


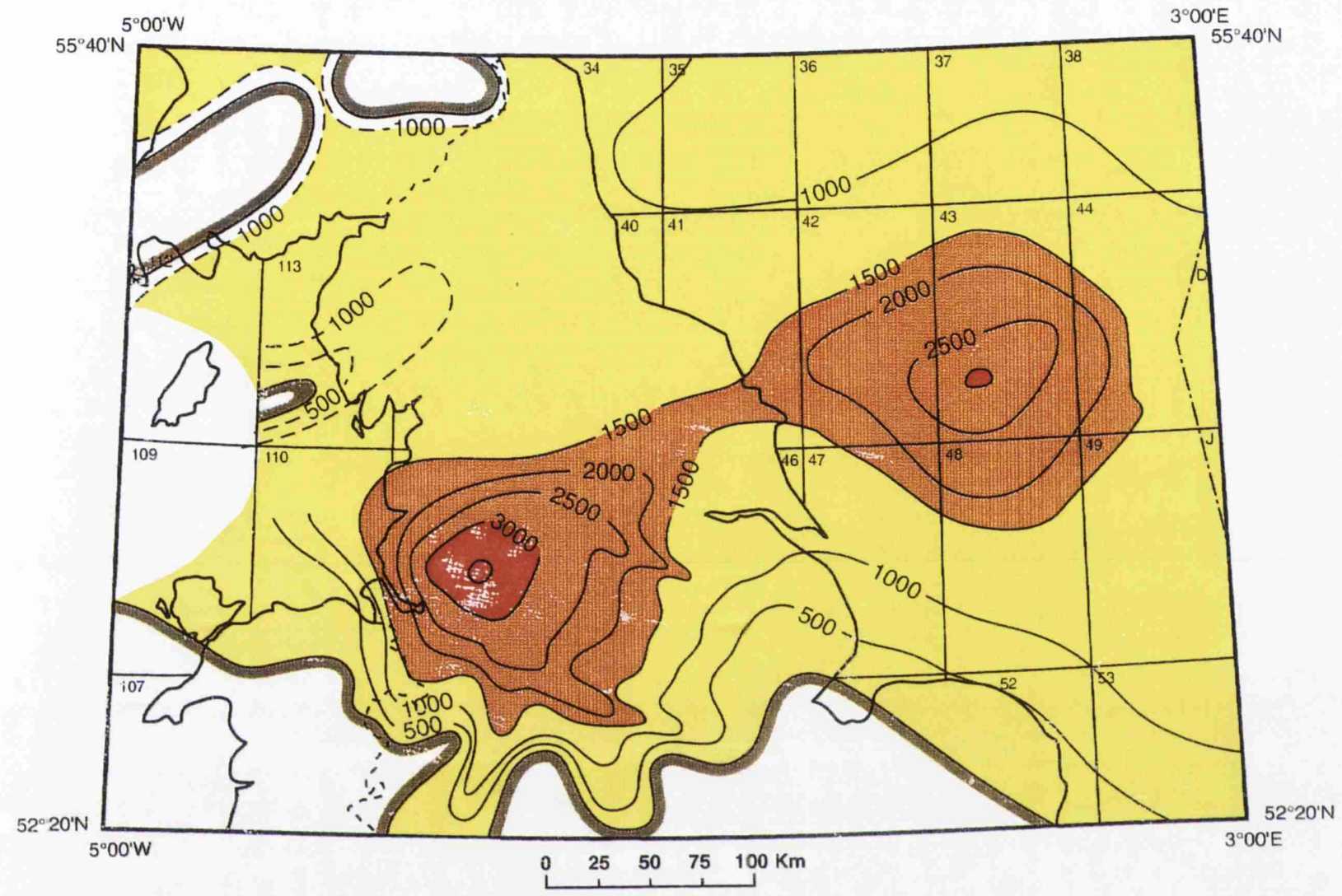

Figure 2.6 Restored isopachs (metres) for post rift sequences LC1-LC2 (NamurianWestphalian 'C') for northern England and the Southern North Sea. (Data from Wills 1951, Kent 1966, Calver 1968, Leeder 1982, Guion \& Fielding 1988, Leeder \& Hardman 1990).

Although Silesian deposition was controlled by regional thermal subsidence, continued extension on the main NW-SE trending half-graben bounding faults to the Widmerpool and Gainsborough basins up to end Westphalian 'A' times was responsible for the great thicknesses now preserved in these areas. However, there are some important differences between the extension during the Silesian to that in the Dinantian, and also between individual basins. 
On the basis of preserved sediment thicknesses, the Widmerpool Gulf apparently subsided to a greater extent $(>1 \mathrm{~km})$ than any other basin (evidence from Namurian thicknesses only) the Westphalian sequence has been for the most part eroded due to Variscan inversion). However, much of the additional sediment thickness can be accounted for by the infill of a previously sediment starved deep water basin (Plate 2.8). The major controlling faults were, as in Dinantian times, the Hoton and Thrinston-Sileby faults. To the north of the Widmerpool Gulf, minor growth occurred across antithetic faults (eg. the Cinderhill Fault system, Plate 3.4), but the Namurian sequence generally thins northwards onto the Rushcliffe High. In contrast, the main bounding fault of the Gainsborough Trough, the Askern-Spital Fault, apparently did not control the thickness of sediment during the Silesian. The Namurian rocks in the Gainsborough Trough are thickest towards the south, and it is the down-to-the-north antithetic faults over which the Namurian sequence grows in thickness (Plate 3.6). Hence in the Gainsborough Trough, the locus of subsidence apparently switched from the northern to southern margins of the half-graben from Dinantian to Namurian times.

The Westphalian sequence in general does not show the same degree of growth across faults into the main basins. Although much has been removed due to later inversion, particularly in the south of the East Midlands, the Westphalian sequence is generally of constant thickness throughout the area, with only minor thickening into the Gainsborough Trough across faults such as the Beckingham fault (Plate 3.6). Thus the Westphalian appears to represent more of a 'post-rift' thermal subsidence phase rather than a more localised syn-rift extension phase.

Minor unconformities identified during mid Westphalian ' $C$ ' and ' $D$ ' on seismic lines associated with major erosional folding at end Westphalian 'C' and early 'D' (eg. southeast margin of the Gainsborough Trough; Plate 3.7), indicate that at the time of deposition the first affects of Variscan compression were being exerted on sedimentation rates, and regional subsidence was being temporarily halted. 


\subsubsection{Variscan compression}

Most of the inversion features observed in the pre-Permian sequence in northern England are interpreted as the product of the Variscan closure of the Rheic Ocean and subsequent collision. The dominant effect of this compressional event was to invert most extensional faults of all three major trends described; NW-SE, NNW-SSE and NE-SW. The style of inversion along these faults does not depend, however, solely on the trend, but on their geometry, and geographical position with respect to the origin of maximum horizontal compression which initiated the inversion.

\section{First Variscan inversion}

During Westphalian 'C' times, Wills (1956) identified a phase of folding and uplift which could be traced throughout south Wales, the Midlands and northern England. This event occurred between the Anthraconauta phillipsi and A. tenuis zones of the late Westphalian. Uplifts produced gentle flexures which became eroded to provide debris for deposition in the intervening depressions. Wills (1956) realised that the uplifts and anticlines were related to fault movement and he was able to identify some of the faults which moved at this time.

The best structural explanation for the formation of the anticlines and uplifts is to utilise the inversion model of Bally (1984). In this model, the uplift and expulsion of the halfgraben infill is produced by slip reversal on the older fault. An anticlinal uplift is generated adjacent to the graben boundary fault. In the northern England examples, the Dinantian rift phase half-graben (Plates $2.4 \& 2.9$ ) can be identified as the precursors of the Westphalian ' $\mathrm{C}$ ' inversion structures (Plate 2.11).

Starting in the north, the northern basin bounding fault of the Northumberland-Solway basin probably reversed slip with an up to the north sense of displacement. Several 
anticlines were formed in the hangingwall close to the boundary fault. Two anticlines were also formed on the footwall side with east-west and north-south trends respectively. The Lunedale-Butterknowle fault also inverted by up to the north slip reversal generating the large Richmond anticline on the southern side of the fault zone. A large depression formed between the inverted Northumberland and Butterknowle faults which accumulated Westphalian ' $\mathrm{C}$ ' deposits, probably eroded from the crests of the inversions. The Eden and Dent faults inverted by reversal to up to the east displacement. This inversion probably produced the deposition of the Lake District and Ingleton red beds.

The en-echelon Ribblesdale fold belt may have formed at this time but earlier inversion events have been postulated here (Arthurton 1983, 1984). The folds are associated with the underlying Pendle fault and their en-echelon offsets and proximity to the fault suggests dextral transpression. The fold belt ends abruptly against the South Craven fault which must have acted as a transfer zone. Other en-echelon folds, formed by the inversion, lie to the north of the South Craven fault. Similarly the North Craven fault probably inverted with an up to the north movement. The inverted fault can be traced out eastwards to the Market Weighton axis. Offshore from here, the Carboniferous is folded by a set of NW curved structures which curve round into the Weighton trend (Fig 2.4). Westphalian ' $\mathrm{C}$ ' deposition in the Southern North Sea suggests that the Dowsing fault may also have been active at this time.

In the East Midlands, the Gainsborough, Eakring and Widmerpool half-graben all inverted during the Westphalian ' $\mathrm{C}$ '. Also the Nocton High could have suffered elevation at this time. Westphalian ' $\mathrm{C}$ ' sediments became deposited in the troughs between the inversion anticlines. All of the East Midlands inversions and associated faults probably extended northwest into the main Pennine axis. Inversion above the east dipping fault beneath the Goyt Trough is postulated to partly explain the deposition of thick red beds to the west in the Cheshire basin. 
The Malvern line was also active at this time. The east-dipping Malvern fault underwent slip reversal so that the hangingwall moved back up the fault. This hangingwall became partially expelled on to the footwall to form the present day Malvern hills structure. Westwards of the Seven Estuary, the Usk and Swansea-Neath disturbances inverted with back up to the west slip reversal. The rising Usk anticline shed debris westwards into the south Wales foredeep. Movement on the Bala-Llanelidan fault produced uplift on the Hope Mountain anticline which shed debris westwards and eastwards back into the Cheshire basin. It is believed that the Dinorwic and Berw faults of Anglesey could have moved at this time. Up to the west movement on these faults probably exposed pre-Carboniferous basement rocks in the hangingwalls and preserved the present outcrops of Carboniferous in the footwalls of these faults.

Movement on the Longmynd and Church Stretton faults produced inversion uplifts in the Longmynd-Market Drayton axes. Similarly the Wyre Forest was uplifted by up to the NW slip reversal. The Walsall area underwent inversion. Uplift on all these Welsh and Central Pennine axes during Westphalian ' $C$ ' produced the deposition of extensive red beds and "Espleys" in the South Midlands and Cheshire basins.

\section{Second Variscan Inversion}

A second phase of Variscan inversion occurred in the Stephanian, following a passive subsidence phase during which the post $A$. phillipsi Westphalian Coal Measures were deposited. By this time, the Variscan thrust front had reached the Bristol-South Wales area. Again Wills (1956) has documented the various uplifts which were formed at this time. These can be dated by the occurrence of coarse clastic sediments close to the sites of active uplift. Unfortunately the Stephanian record is patchy and it is not possible to recognise all the faults that inverted during this event. However Wills (1956) suggests that uplifts on the Malvern and Usk faults indicate that they were still active. Uplift on the Usk axis shed Upper Pennant sandstones to the west into south Wales. Movement 
and continuing inversion on the Malvern fault produced local Stephanian deposition north of the Abberly Hills. Similarly the NE-SW trending Walsall line continued to invert.

Deposition of Stephanian sediments in the Cheshire basin suggests that the surrounding faults were still undergoing slip reversal. Probably the main Pennine axis fault was moving with an up to the west sense of slip. The Pendle fault may have still been overthrusting towards the south and the Bala-Llanelidian and Church Stretton faults were probably still active.

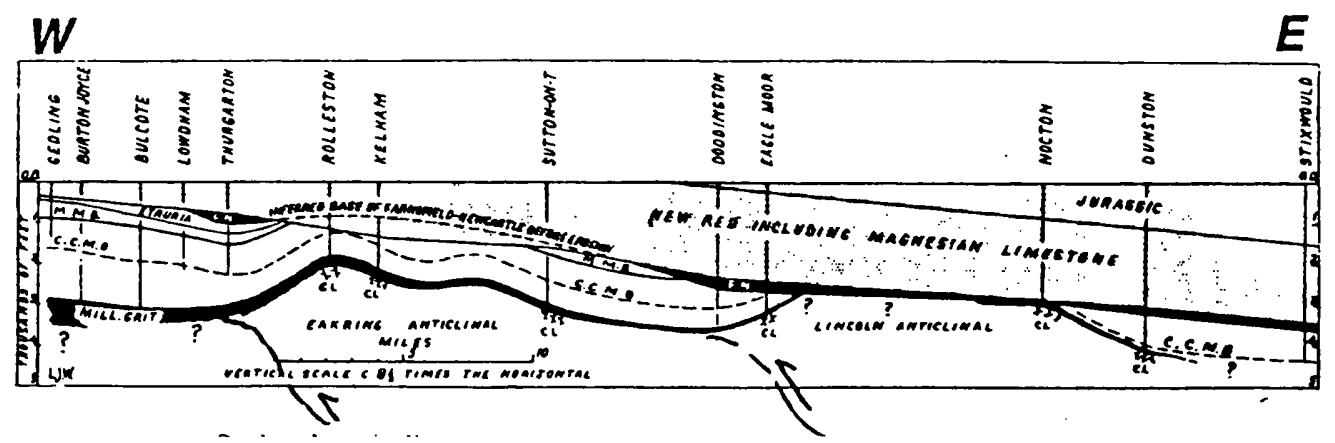

Figure 2.7 Late Carboniferous inversion structures in the East Midlands (after Wills 1956). C.C.M.B. = Clay Cross Marine Band, C.L. $=$ Carboniferous Limestone, F.N. = Farnsfield-Newcastle Group, MMB = Mansfield Marine Band.

Finally, the faults of the East Midlands were still probably inverting with a component of overthrusting to the southwest. A detailed cross section based on BP borehole data from Nottingham to Lincoln, presented by Wills (1956) demonstrates two phases of inversion (Fig. 2.7). The section shows a main phase of uplift, post dating the Mansfield marine band (pre-Etruria) which is cut by a base Farnsfield-Newcastle Group unconformity. This unconformity is further folded by a pre-Permian (?Stephanian) phase of folding. Both fold phases are inversion effects and indicate rejuvenation throughout much of the East Midlands during the Stephanian. 
Inversion styles

The main styles of inverted faults seen on seismic data in northern England (Plates 3.23.20) are summarised on Fig. 2.8. Pre-existing listric extension faults have been inverted such that the hangingwalls have been brought above their regional datum by varying amounts. Of the NW-SE trending major half-graben bounding faults, maximum inversion is seen on the southern margin of the Widmerpool Gulf, adjacent to the Mercian Massif (Plate 3.4). To the north, the inversion on similar trending faults bounding the Gainsborough Trough appears much less pronounced (Plates 3.6 \& 3.8). However, not all faults are inverted, eg. the Cinderhill Fault on the northern margin of the Widmerpool Gulf. Inversion on the main half-graben bounding faults, which sole out deeper than most faults at around $10 \mathrm{~km}$, tends to be recorded by significant hangingwall uplift and accentuation of previous rollover structures. Significant erosion of the Silesian occurs over such zones such as the Hoton and Askern-Spital Faults (Plates $3.4 \& 3.6$ ). However, the amount of inversion along such faults can vary greatly along strike (compare the northern margin of the Gainsborough Trough on Plates 3.6 \& 3.7).

Most other types of inversion occur on faults which sole out at or near the Lower Palaeozoic 'basement' surface, such as the Eakring, Ladybrook and Egmanton Faults. As a consequence of fault geometries, the folds developed on these faults can be interpreted as hangingwall ramp-anticlines, which would have accentuated any previous rollover on the listric fault. The inversion on these faults with relatively shallow detachment surfaces produces small cuspate features in map view and tightly folded anticlines on seismic data (eg. the Brimington anticline; Plate 3.11). 
S

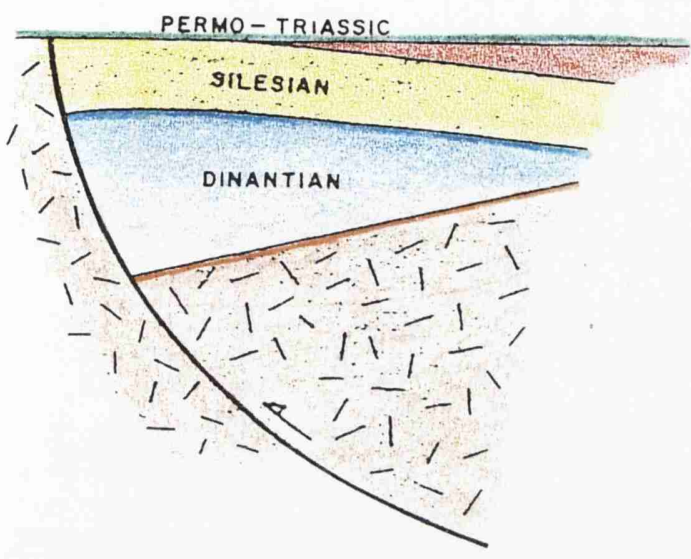

W

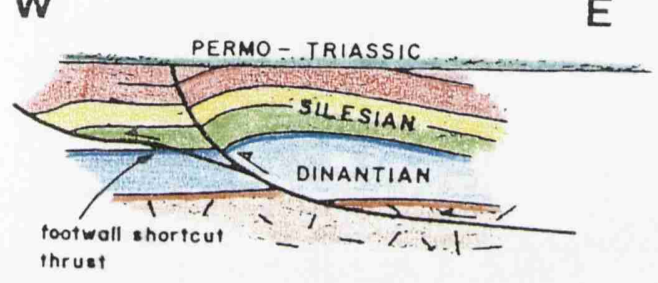

S

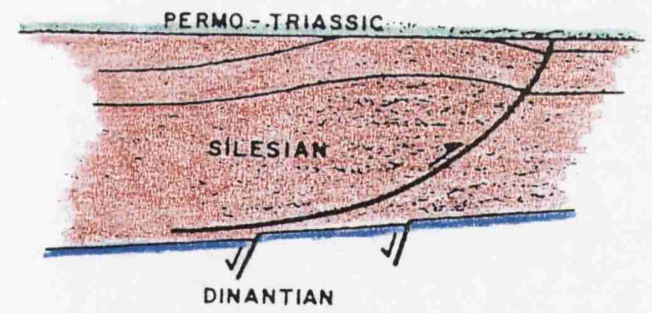

W

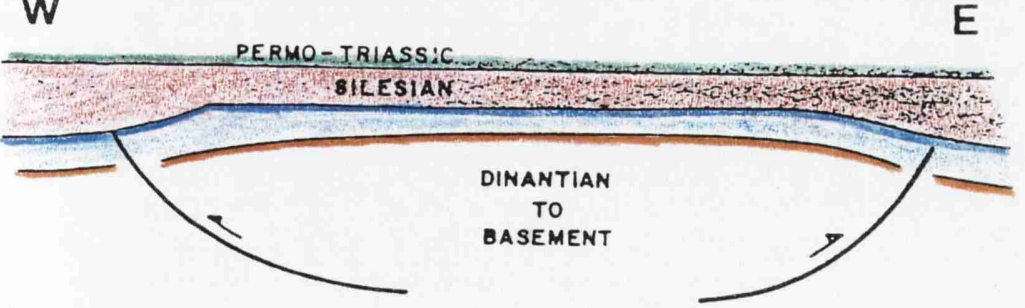

Major half-graben bounding-fault soling out at about $10 \mathrm{~km}$.

e.g. Hoton Fault

Thringstone-Sileby Fault Askern-Spital Fault
Listric fault soling out at about $2-3 \mathrm{~km}$, near top basement.

\section{e.g: Eakring Fault \\ Egmanton Fault \\ Ladybrook Fault}

and other structures such as Ironville, Calow, Hardstoft, etc.
Listric fault soling out above Dinantian surface.

e.g. Humberside area, Broomfleet.

Opposing listric faults soling out at about $2-3 \mathrm{~km}$ inverting block as a 'pop-up'.

e.g Nocton, Aubourn-Bassingham.

Figure 2.8 Inversion styles in northern England. 
At Eakring (Plate 3.9) there is evidence for the development of a footwall short-cut thrust if the small flexure in the footwall is interpreted as a ramp-anticline. Such thrusts are common features in inverted terranes, and form as a consequence of it being mechanically 'easier' to create a new low angle surface during thrusting, rather than follow steeper pre-existing surfaces.

\subsubsection{Geodynamic Interpretation}

\subsubsection{Late Devonian-Dinantian rifting}

In simple terms the Dinantian of northern England can be modelled as a long lived extensional rift event (late Devonian-Dinantian) punctuated by periods of non-extension and inversion. Isopachs for the Chadian-Brigantian syn-rift in northern England (Plate 2.9) suggest that extension factors were roughly the same on either side of the northsouth Pennine divide. Detailed backstripping and thermal modelling of the Widmerpool Gulf using high resolution biostratigraphic and facies data from the Ratcliffe-on-Soar borehole (Plate 2.8 \& Fig.2.9) indicates a stretching factor (ß) of 1.5, consistent with the values obtained elsewhere in northern England by Leeder and MacMahon (1988) and Kimbell et al. (1989) for basins on either side of the Pennines. Given that relatively few north-south oriented faults, compared to east-west trending faults, controlled basin development, the simplest explanation is that rifting was generated by a roughly northsouth oriented extensional stress field. This is further supported by the rift architecture illustrated on Plate 2.4, (compiled from BP's extensive in-house regional seismic database), which suggests that all the shelfal areas (blocks) could be palinspastically restored by a simple north-south translation. It is difficult to conceive how else this could have been accomplished other than by simple north-south extension acting on zones of earlier Caledonian structural weakness (cf. Plates 2.1 and 24 ). The implication of this model is that the NW-SE trending basins to the east of the Pennines opened as sinistral pull-aparts and the NE-SW trending basins to the west of the Pennines opened 
as dextral pull-aparts. It could be argued that the activity on the north-south trending Pennine-Dent line and western bounding fault of the Goyt Trough provides evidence for Boreal events effecting the early Carboniferous development of northern England. This is rejected as the structure and isopach maps clearly indicate that north-south elements exerted little control on basin formation and acted largely as transfer faults offsetting the main extensional systems. Given the strong evidence discussed earlier for the Caledonian origin of the structural grain in northern England it is deduced that the main movements on the north-south fault trends was during an earlier tectonic phase.

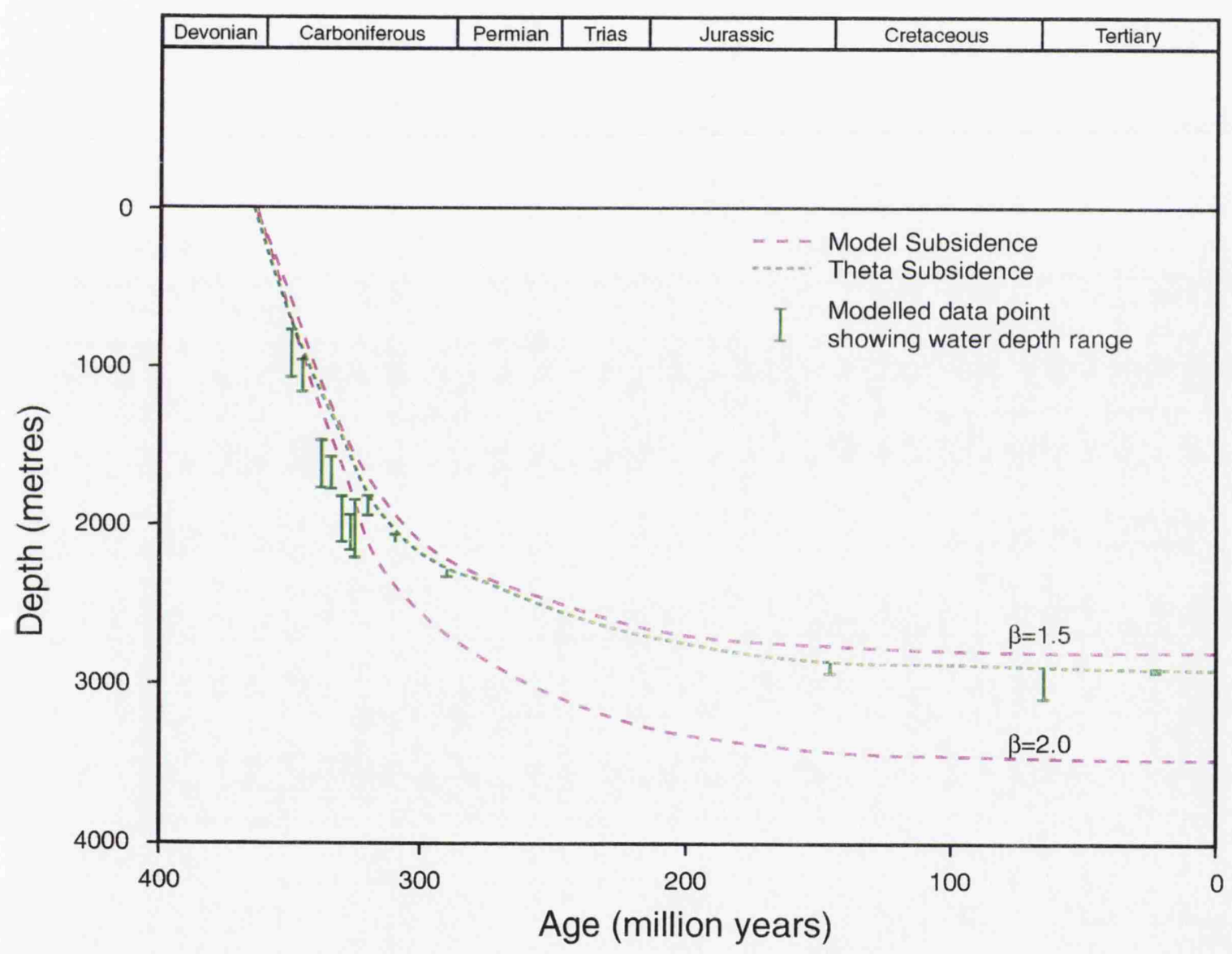

Figure 2.9 Decompacted, sediment-loaded basement subsidence plot for the Ratcliffeon-Soar borehole, Widmerpool Gulf; modelled using the THETA program (Appendix D). 
The model proposed by Leeder $(1982,1987$ a $\& 1988)$ where subsidence of the northern England basins is controlled by plate subduction and back-arc spreading provides a tectonic setting in which north-south extension punctuated by increasingly intense pulses of north-south to NW-SE directed compression can be explained by a single plate margin process. A back-arc system is one in which rapid changes between extensional and contractional tectonics are compatible as back-arc basins are generated and closed. Leeder's model also provides a suitable tectonic regime to explain the extensive intracontinental volcanism. The widespread occurrence of Lower Carboniferous basalts in both Rheno-Hercynia and northern England suggests extension was locally of sufficient magnitude to decompressively melt the asthenosphere upwelling under an extending back-arc. However, there is little evidence for continued back-arc extension in RhenoHercynia younger than the late Devonian-early Dinantian. Burg and Matte (1978) consider the Rheic Ocean to have closed towards the end of the Devonian. Whereas back-arc extension can be invoked as the most plausible explanation for the initiation of the northern England rift system in the late Devonian, there are clearly problems in proposing continued back-arc extension into the later Dinantian to explain the Chadian/Arundian and Asbian/Brigantian rift phases observed on seismic throughout northern England and at outcrop in the Bowland Basin. A further mechanism has to be called on to generate the later rift pulses in the mid-late Dinantian.

There is compelling regional evidence that the north-south extension was combined with a component of east-west dextral shearing, throughout the orogeny, which linked the Alleghenides in North America to the Urals in Russia (Dewey 1982, Badham 1982). Coward's (1993) moving indentor model supports the view that the late Devonian-early Carboniferous rifting in northern England was driven by back-arc extension related to Variscan subduction coupled with right-lateral shear in northern England. Indeed his model of the reactivation of a large Caledonian triangular block extending eastwards to the Urals has some merit. However, evidence from the rift architecture in the southern North Sea (Fig 2.4), based on modern seismic and borehole data introduces some major 
problems with this interpretation. Here the basins continue to sweep in a NW-SE trend paralleling the East Midlands rift system suggesting that the Midlands microcraton was the major control and one need only invoke reactivation of this pre-existing Caledonian block to explain the observed extension and compression geometries in northern England. Furthermore, it is difficult to rationalise the east-west compression required by Coward (resulting from the Ural plate collision in the late Carboniferous) with the intense inversion seen along NE-SW, E-W and NW-SE trending faults in northern England. Haszeldine $(1984,1988 \& 1989)$ favours a purely rifting model of east-west directed extension acting on a series of north-south lineaments rather than shear for the Upper Palaeozoic of Northwest Europe; although his discussion contains several references to dextral shear along the rift and fold belt. However, as discussed previously, it is difficult to rationalise the observed rift architecture in northern England with an east-west oriented extensional stress field.

Fig. 2.10 illustrates the possible effect of north-south directed extension coupled with east-west regional dextral shearing on the pre-existing Caledonian lineaments in England and Wales. In N.W. England and Wales, NE-SW trending lineaments are reactivated as reverse faults with a dextral component of shear. Thus the hangingwall of the basinbounding Pendle Fault could have acted intermittently as a high during extension, and the Ribblesdale Foldbelt, described by Arthurton (1984) as a Dinantian-Namurian feature, would also have developed in this system.

In the East Midlands, the major NW-SE and subsidiary NNW-SSE trending lineaments would have been reactivated as normal faults with a synthetic dextral shear component and normal faults with an antithetic sinistral shear component, respectively. Thus, major basins such as the Gainsborough Trough and Widmerpool Gulf would have been initiated as local pull-apart half-graben in the late Devonian-early Carboniferous period. NNW-trending faults would also form local pull-apart features (Fig. 2.10). The pullapart half-graben may have been bounded by NE-SW trending zones which would have 
acted as highs or transfer zones between rifts; for example between the Gainsborough

Trough and Nocton High (Plate 3.4).
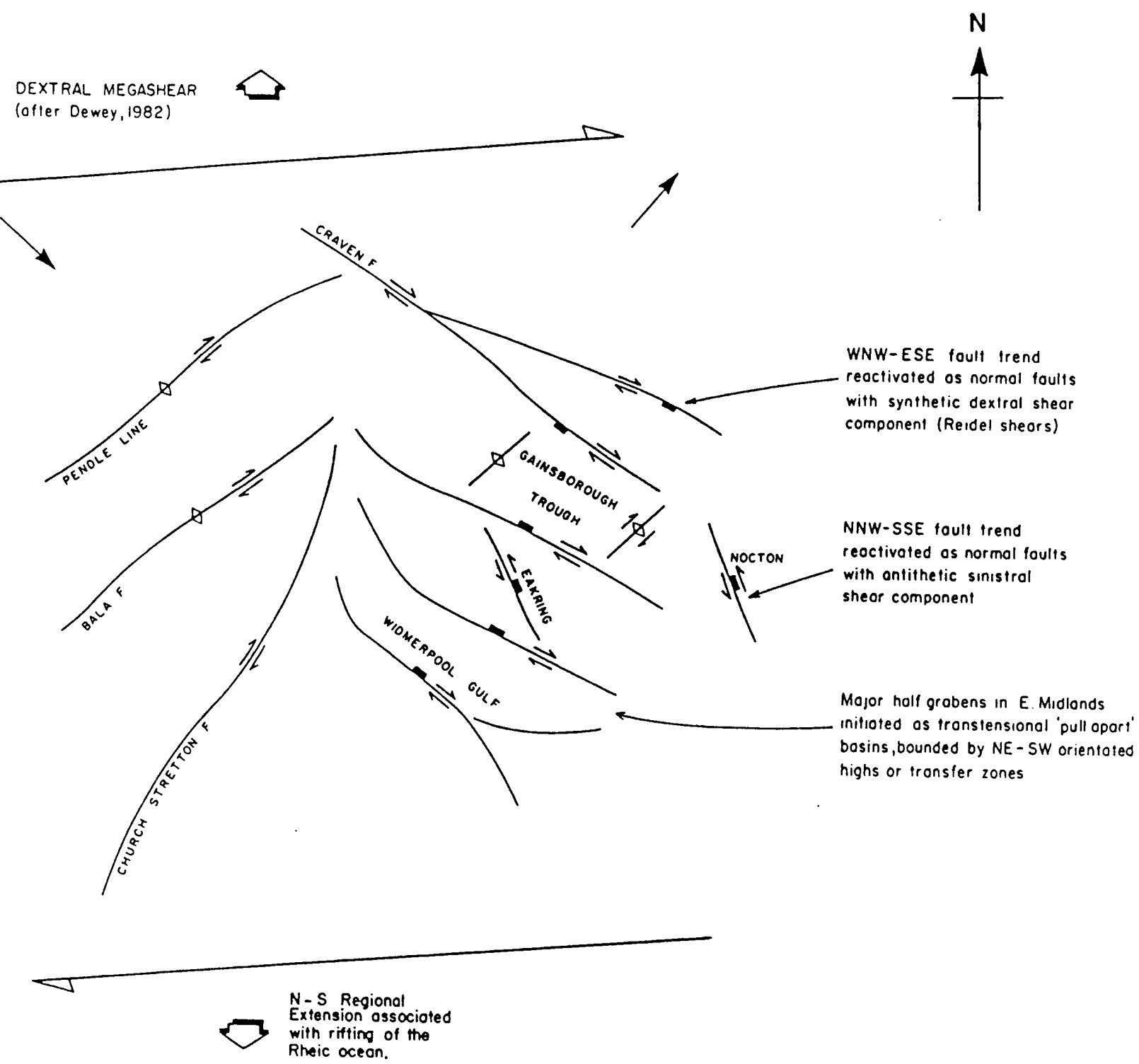

Figure 2.10 Model for late Devonian-Carboniferous tectonics in northern England. 
With the rift system fully developed in northern England by the early Dinantian, it is suggested that later extensional phases during the end Chadian and end Asbian were driven solely by the right lateral shear system, thus removing the need for continued back-arc extension younger than the late Devonian.

Although the regional dextral shear versus north-south normal extension controversy is not yet fully resolved, the above model provides an elegant explanation for the observed extensional fault trends and honours the previously discussed regional data. Superimposing north-south extension upon a dextral strike-slip system (transtension) would increase the ratio of normal to strike-slip motion and honours both the regional evidence for dextral shear and the seismic and borehole data which requires north-south extension.

\subsubsection{Late Dinantian and Silesian tectonics}

The change from transtension to transpression in northern England is marked by the midBrigantian inversion. The inversion event is explained in terms of the dextral megashear model by evolution of the shear zone through a 'big-bend' similar to the type seen along the San Andreas system in California. This process can produce a phase of shortening, within a regional extension regime, in order to accommodate movement around an arcuate zone. This model would also imply that big-bends of lesser significance were encountered in the Chadian and Asbian.

An alternative explanation, and one which is also consistent with the tectonic model presented earlier, requires continued creation and destruction of back-arc type basins on the Rheic oceanic margin throughout the Dinantian. Equally plausible is Leeder's model of continued platelet collision to the south evidenced by the Sudetic deformation fronts moving slowly northwards throughout the Dinantian-early Namurian (Leeder 1987a). 
Whatever their origin, these periods of non-extension/inversion in the Chadian, Asbian and Brigantian are significant in exploration terms in that they allow the development of rimmed carbonate shelves. These high energy shelf margin environments present the best potential for Dinantian reservoir development.

Subsidence during Namurian and Westphalian times was broadly regional and essentially thermally driven within a mild, but increasingly transpressional stress field. Areas further south were undergoing strong deformation with uplift and development of an extensive foreland basin (Houchen, 1988). However, some fault reactivation did occur during the early Namurian particularly on the Craven fault system (Bowland Basin) and the Askern-Spital fault (Gainsborough Trough). In the East Midlands, minor extension continued during the Silesian on the NW-SE trending faults, and upon antithetic faults, such as in the Gainsborough Trough where a polarity change of the rifting is seen between Dinantian and Silesian times (Plate 3.6). However, growth faulting appears to have been mainly achieved on NW-SE faults, with NNW-faults such as the Eakring Fault, having little or no effect on sediment thickness.

\subsubsection{Variscan Inversion}

The final closure of the Rheic ocean culminated in the Variscan orogeny from Westphalian ' $\mathrm{C}$ ' to Stephanian times. The result of the orogeny was large scale thrust and nappe emplacement in northern France, southern Belgium and southern England with corresponding crustal shortening on a regional scale. In northern England this was translated into inversion of pre-existing Dinantian extensional faults which resulted in the uplift and erosion of significant amounts of Carboniferous sediments. The dominant horizontal compressional vector in the Variscan foldbelt was towards the northwest (Sanderson 1984), paralleling the Bray fault trend in northern France. The effect of this was to re-indent the Midlands microcraton, and to develop a conjugate shear system along the major NE-SW and NW-SE trending faults around it (Fig. 2.11). 


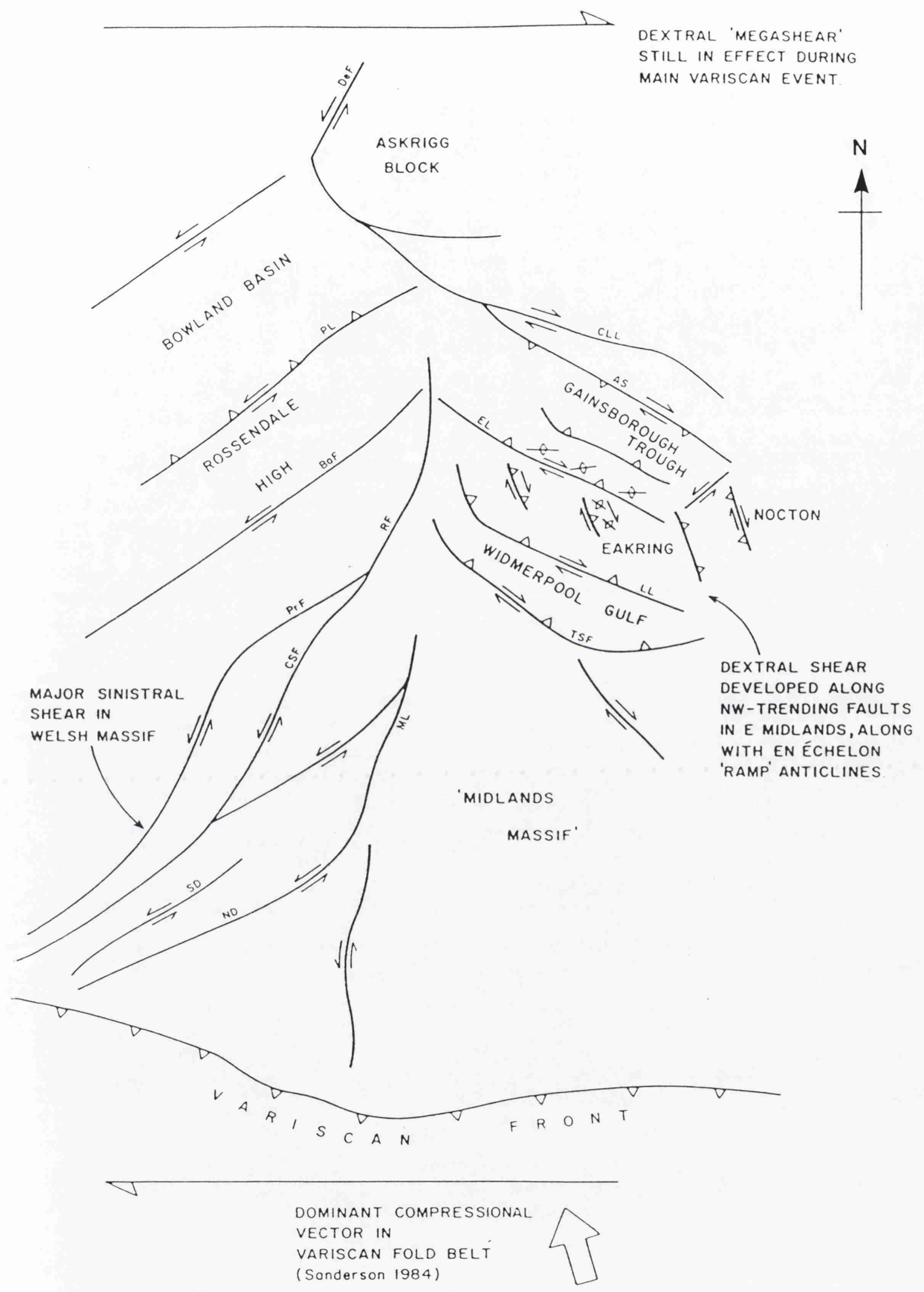

Figure 2.11 Model for Variscan compression and inversion in northern England. DeF $=$ Dent Fault, $\mathrm{PL}=$ Pendle Line, $\mathrm{BaF}=$ Bala Fault, $\mathrm{PrF}=$ Prees Fault, RF $=$ Red Rock Fault, $\mathrm{CSF}=$ Church Stretton Fault, $\mathrm{SD}=$ Swansea Disturbance, ND $=$ Neath Disturbance, $\mathrm{CLL}=$ Craven-Lincoln Line, AS $=$ Askern-Spital Fault, LL $=$ Ladybrook Fault, TSF $=$ Thringstone-Sileby Fault. 
In Wales and N.W. England, NE-trending lineaments became major sinistral strike slip faults and/or reverse faults. In this system, the Bowland Basin inverted along the Pendle and Craven fault systems. In the East Midlands the major NW-SE lineaments inverted by reverse movement with a component of dextral shear. The fact that the degree of inversion increases southwards in the East Midlands is perhaps indicative of a southerly origin for the horizontal compression.

\subsubsection{Summary}

In common with structures developed throughout the Carboniferous, the Variscan history and geometry of structures developed in northern England suggest an important element of dextral shear.

In the early Carboniferous this was combined with a component of extension related to the final stages of back-arc extension associated with the closure of the Rheic Ocean (Fig. 2.12). In the late Carboniferous the dextral shear had an ever increasing component of compression related to the evolving Variscan foldbelt to the south of the Midlands microcraton. Thus the movement vector of the Midlands microcraton describes a smooth progression; initial extension (late Devonian-early Dinantian), succeeded by simple shear with decreasing extension (mid-late Dinantian) and finally increasing compression (Namurian-Stephanian). 


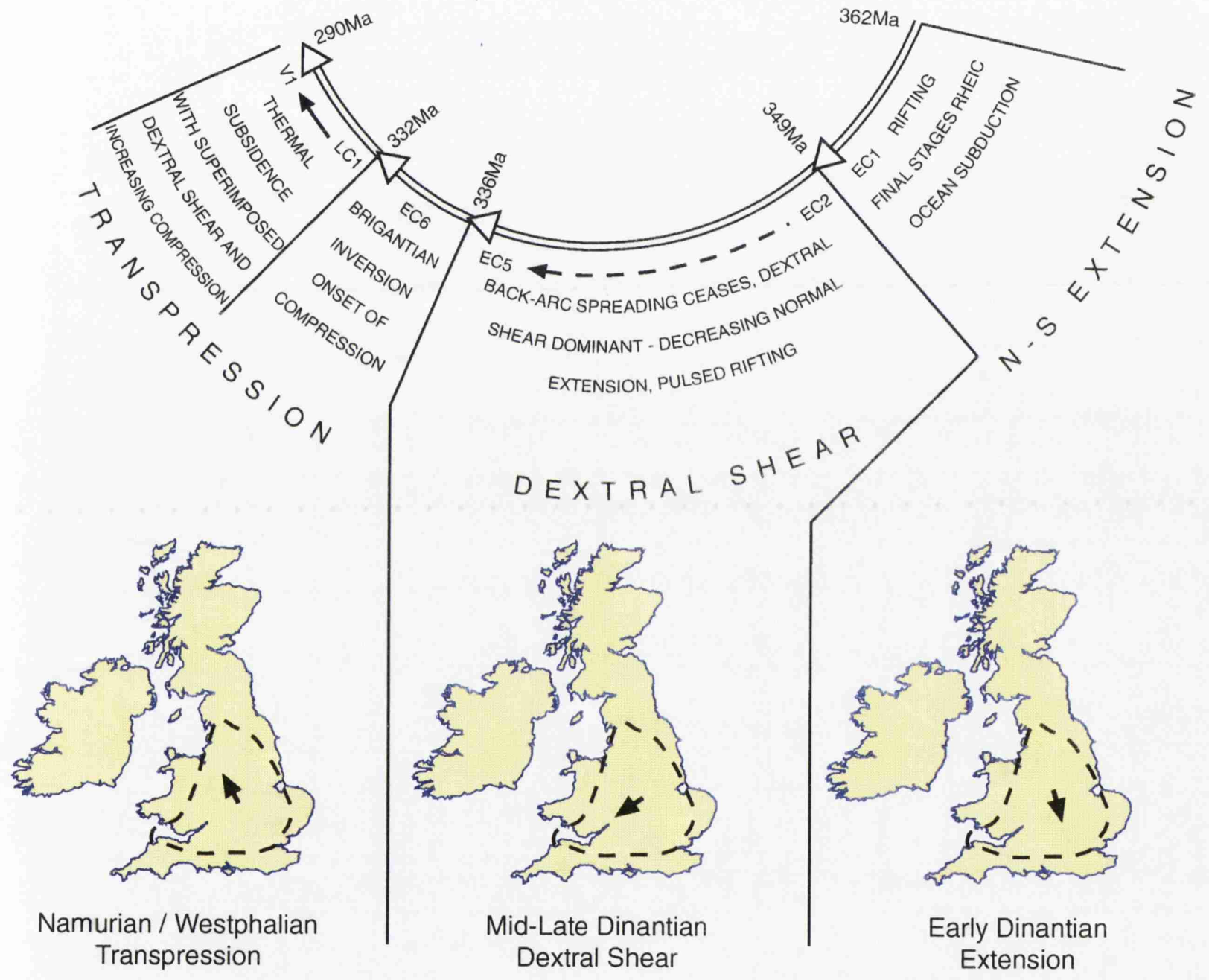

Figure 2.12 Schematic displacement vector for the Midlands microcraton during the Late Devonian-Carboniferous 


\subsection{POST-CARBONIFEROUS TECTONICS}

Post-Carboniferous tectonic events in northern England also have to be addressed because of their perceived influence on the hydrocarbon habitat of the Carboniferous. Permian and Mesozoic extension associated with rifting in the Atlantic and Tethyan provinces modified hydrocarbon trapping geometries and controlled the distribution of source rock maturation subsequent to Variscan trap formation. Tertiary uplift and erosion had the effect of freezing source rock generation and caused minor trap modification.

\subsubsection{Permo-Triassic events}

By late Permian times a new tectonic regime had become established over N.W. Europe, with widespread regional subsidence in the area of the North Sea where the east-west trending Southern Permian Basin formed (Ziegler 1978). To the west, incipient rifts, once again reactivating the NE-SW Caledonian trends, formed the Rockall, Celtic Sea and Western Approaches rift systems (Ziegler 1981).

Northern England straddled these two provinces with the subsequent evolution of the hydrocarbon environment in each province profoundly controlled by this differentiation. Whereas the basins to the west were repeatedly extended and tectonically reactivated to form the Cheshire, Manx-Furness and Vale of Eden basins, the East Midlands and northeast England provinces were located on a gently dipping rift shoulder with little differential subsidence or thickness variation (Fig.2.13).

\subsubsection{Later Mesozoic events}

An accurate reconstruction of the Jurassic and Cretaceous history of northern England is hampered by the widespread erosion of Mesozoic sediments in Cenozoic times. 
Early Cretaceous

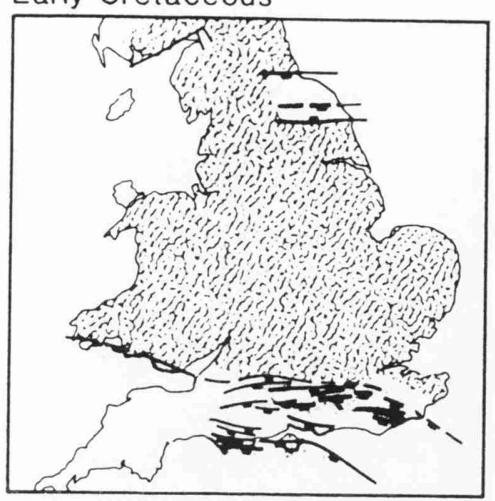

Trias

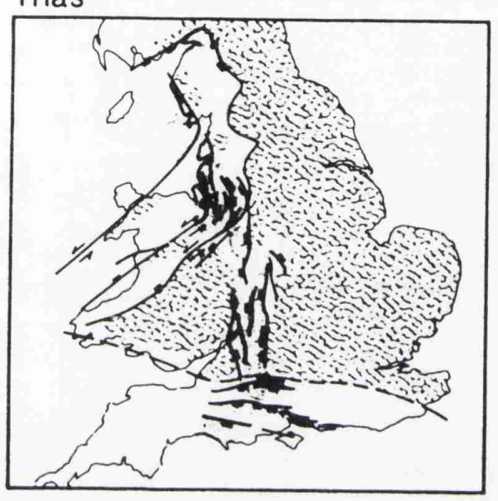

Lias

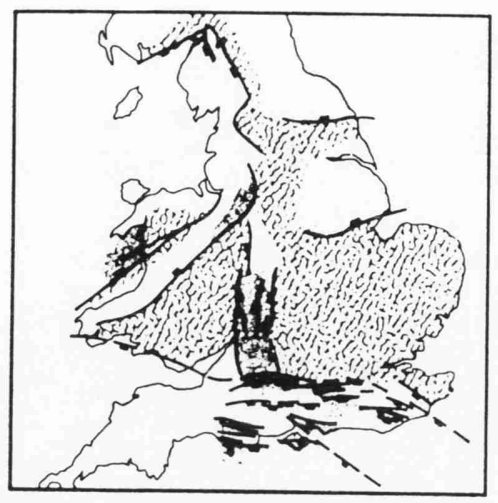

Permian

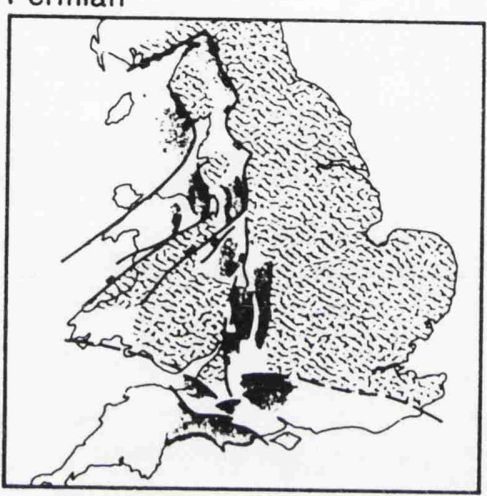

Highs

Grabens

Figure 2.13 Permian-early Cretaceous rift systems of England and Wales (after Fraser et al. 1990).

Fission track analysis (Green 1986), vitrinite reflectance data, shale velocity plots and conodont colour data have all been used in an attempt to deduce the likely post-Triassic overburden. Thick Jurassic and Cretaceous sediments have been penetrated offshore in the Southern North Sea Basin (Plate 3.3). These thin markedly towards the Pennine High which remained a positive feature for much of the remainder of geological time (Plate 2.12). In northwest England, continued subsidence can be inferred from the rift histories derived from the offshore extensions of the basins. However, the profound event, in terms of the hydrocarbon habitat, occurred on the eastern side of the Pennine High where extension and inversion events related to the evolving Sole Pit Trough (Kent 1975; Glennie \& Boegner 1981; Van Hoorn 1987), disrupted the passive subsidence and quiescent setting of the northeast England province (Plate 2.12). This rifting of early 
Jurassic and early Cretaceous age locally induced exceptional burial and was followed by successive phases of basin inversion in the Cleveland and Stainmore Basins during the Cretaceous-Tertiary (Plate 3.16). In stark contrast, the East Midlands province escaped these movements except for minor activity on the southern bounding faults of the Widmerpool Gulf (Kent 1966).

\subsubsection{Cenozoic events}

Fission track analyses in northern England (Green 1986) show that regional uplift began around $60 \mathrm{Ma}$, with up to $3 \mathrm{~km}$ of overburden removed during the Palaeogene in the Lake District area. Plate 2.13 suggests that the uplift in the Lake District could have been achieved by slip reversal on the Eden and Dent faults. Early Tertiary inversions are also known from the Southern North Sea on the Dowsing fault (Plate 3.3) and onshore in the Cleveland Basin (Glennie and Boegner 1981). Here 1200-1800 m of uplift of Mesozoic rocks have been documented to the northeast of the Dowsing Fault zone. In Central England, early Tertiary fault movement has been proven in the Mochras borehole (Kent 1975) where there is over $600 \mathrm{~m}$ of Oligocene sediments in the bay deposited against a west dipping fault which parallels the coast line. The fault appears to link into the offshore extension of the Bala Fault which would have been re-activated in a sinistral strike-slip sense to accommodate the early Tertiary extension.

There is virtually no stratigraphic record of the Neogene onshore except for isolated fissure and pocket deposits (Walsh et al. 1972). Some of these are fossiliferous and bedded and are of late Miocene-early Pliocene age. Elsewhere, evidence exists for weathered zones of this age. Walsh et al. (1972) correlate the base Neogene weathering zone and sediment surface with an important highlevel erosion platform in the Pennines (the Holme Moss bench) described by Sissons (1954). This occurs at over $550 \mathrm{~m}$ above sea level and represents a bench which truncates the geological dip. Sissons has dated this surface as late Miocene. By analogy, a similar surface to the Holme Moss bench has 
been identified in the Lake District and another high Neogene bench occurs in Wales (Holingworth 1938) which has solution and weathering effects on it.

Plate 2.13 is a contour map of proposed Neogene and Quaternary uplift. This is based on the assumption that the dipping base Neogene surface in the Southern North Sea Basin (Plate 3.3) can be correlated with the base Neogene sediment surface and high level Miocene erosion surfaces observed in northern England. In the Irish Sea and the Southern North Sea the base Neogene surface lies at 240 to $250 \mathrm{~m}$ subsea. The surface rises smoothly from the North Sea into onshore northern England (Plate 3.3) and rises up to reach a peak at over $550 \mathrm{~m}$ OD in the Pennines and Lake District (Plate 2.13).

A southeasterly tilt of eastern England during Cenozoic times of between $1^{\circ}$ and $2^{\circ}$ is recorded which has implications for hydrocarbon retention and aquifer characteristics in the region. Tilted palaeo oil/water contacts have been observed in several East Midlands oilfields corresponding to this Cenozoic tilt.

\subsection{SUMMARY}

The late Palaeozoic to Tertiary structure of northern England has been one of repeated extensional and compressional events acting on the inherited Caledonian structural grain of the underlying basement. This basement consists of the triangular shaped Midlands microcraton which is surrounded by three Caledonian fold and fault belts. These are;
i) Cadomia - Laurentia (Iapetus) Suture - collision end Wenlock
ii) Cadomia - Baltica (Tornquist) Suture - collision late Silurian
iii) Cadomia - Armorica Suture - collision end Silurian 
Back-arc extension caused by NW-directed subduction of the Rheic Ocean to the south of the Armorican Massif was affecting the southern margin of the Midlands microcraton by the early Devonian. By the late Devonian, as the subduction drew to a close, the crustal thinning had extended to the north and the northern England rift system developed. A series of interlocked half-graben were formed by reactivation of the earlier Caledonian trends. This led to the accumulation of thick Dinantian sediments in gulfs and troughs throughout northern England.

The transition from extension to compression is poorly dated but dextral transpression appears to have commenced in the early-mid Dinantian as subduction ceased and collision started. Deformation migrated northwards, reaching the East Midlands by the late Dinantian, and is marked by a mid-Brigantian inversion event. The onset of thermal subsidence associated with rifting obscures the continuing effects of dextral transpression during the Namurian and early Westphalian. However, by end Westphalian times, the influence of the Variscan thrust belt began to be felt as contraction and strike-slip transpression effects were transferred into northern England. These produced widespread inversion folding, uplift and erosion of the Carboniferous halfgraben.

It is argued that the evolution of Carboniferous structures in northern England can be explained by the movement vector of the Midlands microcraton which describes a smooth progression from initial extension (late Devonian-early Dinantian), succeeded by simple shear with decreasing extension (mid-late Dinantian) and finally increasing compression (Namurian-Stephanian).

Renewed rifting during the Permo-Triassic, Jurassic and early Cretaceous produced further deposition in northern England, burying the earlier Carboniferous inversion structures. The region suffered $2-3 \mathrm{~km}$ of Tertiary uplift which caused between $1^{\circ}$ and $2^{\circ}$ 
of southeasterly tilt in eastern England and stripped off most of the Mesozoic cover from the central Pennines. 


\section{CHAPTER 3 TECTONO-STRATIGRAPHIC DEVELOPMENT}

The tectonic evolution of the northern England rift system described in the previous chapter, introduced the concept of the Variscan plate cycle which can be divided into a late Devonian-Dinantian rift phase, a Namurian-Westphalian thermal subsidence phase and a late Westphalian to early Permian inversion or foreland basin phase; each different phase or megasequence represents an individual basin forming process, although all were ultimately controlled and driven by the evolving Variscan orogeny to the south. In this chapter, the tectonic framework is used as the basis for the seismo-stratigraphic interpretation of a series of regional seismic traverses across the northern England province (Plates 3.2-3.20 \& Enclosure 1). The tectono-stratigraphic subdivisions for different basins are established by means of criteria from regional seismic lines, integrated whenever possible with information from boreholes (Appendix $\mathrm{H}$ ), or from exposures. A type sequence of tectono-stratigraphic units is erected in the Widmerpool Gulf, and these criteria are then applied to each of the other basins in the study area. The results of this analysis and the wider implications for chronostratigraphical subdivision of the Carboniferous in northern England are discussed.

\subsection{INTRODUCTION}

The development of seismic stratigraphy in the late seventies and sequence stratigraphy in the late eighties has contributed greatly to our understanding of basin fill processes. Sequence stratigraphic models have mainly been constructed from the analysis of sedimentary basins with relatively simple subsidence histories, such as post-rift successions of passive continental margins and intra-cratonic basins. These models have proven applicable to the prediction of reservoir, source and seal facies on a field and basin scale in both modern and ancient passive tectonic settings However, there is currently considerable debate regarding the origin of sequence boundaries. 
Vail and Mitchum (1977) have emphasised the importance of eustatic sea level changes as the major control on sequence development. More recently, Hubbard (1988) comparing the ages of sequence boundaries from a number of Jurassic-early Cretaceous passive margins has dismissed eustatic sea level changes as a primary control and argued that tectonics and more specifically plate margin processes play the most important role. The cyclic nature of the Carboniferous in northern England has prompted equally active debate along similar lines (see for example Bott \& Johnson 1967, Ramsbottom 1973, 1977 \& 1981, George 1978). The problem is essentially one of scale. Boundaries that are likely to have been produced by eustatic sea level changes (eg. carbonate shelf cycles, Yoredale cycles and Upper Carboniferous goniatite bearing, marine bands) are typically small scale (4th and 5th order Vail cycles) and can only be delineated at the subsequence level. These events generally occur below seismic resolution for the northern England Carboniferous. The broader scale tectonic events generate regional angular unconformities which can be readily identified on reflection seismic data and observed in boreholes and at outcrop (3rd order Vailian cycles).

Recent work on both modern and ancient extensional sedimentary basins (eg. Partington et al. (1993) in the North Sea Jurassic and Gawthorpe et al. (1994) from the modern Aegean) suggests it is not possible to directly apply extant sequence stratigraphic models to tectonically active settings such as the northern England Carboniferous. Since a large proportion of the world's sedimentary basins exhibit at least one tectonically active phase in their evolution, this can lead to an incomplete and biased view of basin fill history and erroneous prediction of facies relationships in the subsurface. Analyses of Neotectonic basins from the Aegean and Basin and Range province, USA, allow quantification of the rates of processes (tectonic, sedimentary and glacio-eustatic) that are important in controlling sequence development in active extensional settings (Gawthorpe et al. 1994). The key observation from these analyses is that eustacy is not always the overriding controlling mechanism on sequence development; tectonic deformation along half-graben border faults may operate at a similar rate to eustatic sea-level change. 
Most extensional basins can be classified in terms of three tectonostratigraphic units (Hubbard et al. 1985a \& 1985b); a pre-rift, syn-rift and post rift megasequence. This level of breakdown is acceptable for broad regional tectonic studies. However, to fully understand the evolution of basin fill processes and the temporal and spatial distribution of facies belts a more rigorous subdivision is required. Delta systems located in passive tectonic settings such as the Tertiary of the North Sea and Gulf of Mexico lend themselves to a classic seismo-stratigraphic analysis (Fig 3.1). Modern multifold reflection seismic data allows resolution down to Vail 3rd order cycle level (c 1-5Ma). However, in syn and pre-rift settings depth of burial and the additional complexity introduced by varying rates of tectonic subsidence generally render conventional seismostratigraphic schemes obsolete. Borehole and outcrop control can often provide a solution, and these types of study have led to the development of high resolution sequence stratigraphy (Van Wagoner et al. 1990).

High resolution sequence stratigraphy is based on our ability to identify and correlate maximum flooding surfaces in marine environments between shelfal and basinal settings (Fig 3.1). Maximum flooding surfaces manifest themselves on wireline log data as high radioactive spikes on the gamma log. The high levels of radioactivity are thought to result from the concentration of radioactive isotopes of Uranium by organic material in these highly condensed intervals; see for example Maynard (1992) and Church \& Gawthorpe (1994), who have successfully applied this technique in detailed subdivision of the Upper Carboniferous of northern England using widespread marine bands. These intervals also correspond biostratigraphically to species acme, allowing correlation between individual boreholes and more importantly individual, isolated depocentres and basins. In tectonically active settings these events can be correlated from footwall to hangingwall settings and provide a consistent stratigraphic framework within which to date movement of faults and sedimentation rates and to predict sediment dispersal patterns. The latter are of major importance in oilfield exploration and development. 
Much of the pioneering work on this aspect of the science has taken place in the North Sea Jurassic (eg. Partington et al. 1993, Milton 1993 and Underhill \& Partington 1993).

Having established a consistent tectonic framework using the genetic sequence stratigraphic approach (sensu Galloway 1989), Exxon type sequence boundaries representing downwards shifts in coastal onlap can be identified and mapped. These are inherently more predictive for the explorer as they represent periods of sub-aerial exposure of the shelf accompanied by erosion and transport of coarse clastic sediments from the shelf to the basin generating low stand submarine fan reservoirs (Fig 3.1).

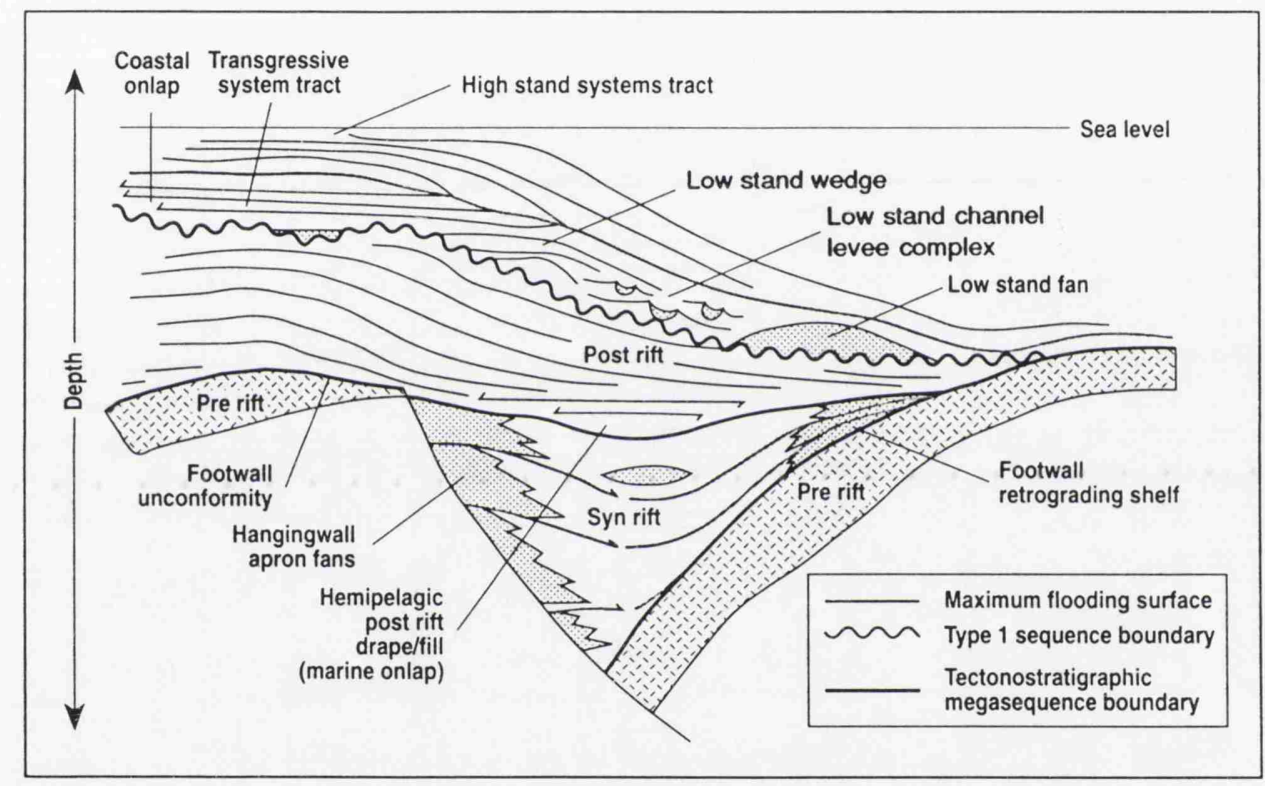

Figure 3.1 Northern England Carboniferous: model for the seismo-stratigraphic evolution of an extensional basin.

\subsection{CARBONIFEROUS TECTONO-STRATIGRAPHY OF NORTHERN ENGLAND}

The object of this section is to evaluate the Carboniferous stratigraphy of northern England in the light of the new subsurface data presented in this thesis. The advent of high quality, modern, multifold seismic reflection data in northern England has allowed the identification of a series of megasequences and their constituent sequences which range from late Devonian to Stephanian in age (Plate 3.21 \& Table 3.1). 
Table 3.1. Tectono-stratigraphy of the northern England Carboniferous

\begin{tabular}{lll} 
Megasequence Sequence & Age \\
\hline Inversion & V1 & $\begin{array}{l}\text { Late Westphalian C- } \\
\text { Stephanian }\end{array}$ \\
& & \\
\hline LC2 & $\begin{array}{l}\text { Early Westphalian A- } \\
\text { Late Westphalian C }\end{array}$
\end{tabular}

Tectonics/Facies Description
Strong uplift and erosion of syn-rift depocentres. Accumulation of barren red beds, coarse pebbly sands and fanglomerates in internally drained molasse basins .

\begin{tabular}{|c|c|c|c|}
\hline \multirow{2}{*}{ Post-rift } & & & $\begin{array}{l}\text { Pennine delta southwards across Wales- } \\
\text { Brabant massif. }\end{array}$ \\
\hline & LCI & $\begin{array}{l}\text { Late Brigantian- } \\
\text { Early Westphalian A }\end{array}$ & $\begin{array}{l}\text { Onset of post-rift thermal subsidence. } \\
\text { Drowning of shelf margins and development } \\
\text { of intra-shelf basins (see Gutteridge 1987) } \\
\text { following marine transgression over inverted } \\
\text { topography. Progressive advance of deltaic } \\
\text { systems from northeast drowning carbonate } \\
\text { platforms. }\end{array}$ \\
\hline
\end{tabular}
Thermal subsidence. Establishment of upper delta plain, coal swamp conditions over much of Northem England. Progradation of Pennine delta southwards across Wales- Brabant massif.

\begin{tabular}{|c|c|c|c|}
\hline & EC6 & Early-Mid Brigantian & $\begin{array}{l}\text { Basin inversion event resulting in a } \\
\text { regressive phase. Carbonate ramp to rimmed } \\
\text { shelf development in the East Midlands with } \\
\text { margins both aggradational and } \\
\text { progradational . }\end{array}$ \\
\hline III & EC5 & $\begin{array}{l}\text { Late Asbian- } \\
\text { Early Brigantian }\end{array}$ & $\begin{array}{l}\text { Reactivation of extensional fault regime with } \\
\text { significant back-stepping of fault system in } \\
\text { Widmerpool Gulf (Fig. 6). Renewed } \\
\text { footwall rotation and erosion and } \\
\text { development of boulder beds and slumps } \\
\text { basinward of drowned margins. }\end{array}$ \\
\hline \multirow{4}{*}{ Syn-rift } & EC4 & $\begin{array}{l}\text { Late Holkerian- } \\
\text { Mid Asbian }\end{array}$ & $\begin{array}{l}\text { Stillstand or regressive phase. Carbonate } \\
\text { ramp to rimmed shelf development with } \\
\text { margins both aggradational and } \\
\text { progradational. }\end{array}$ \\
\hline & $\mathrm{EC} 3$ & $\begin{array}{l}\text { Late Chadian-Late } \\
\text { Holkerian }\end{array}$ & $\begin{array}{l}\text { Rejuvenation of extensional faults causing } \\
\text { rotation of fault blocks and significant } \\
\text { footwall erosion. Development of boulder } \\
\text { beds and slumps (see Gawthorpe 1987) and } \\
\text { drowning of carbonate shelf margins. }\end{array}$ \\
\hline & $\mathrm{EC} 2$ & Chadian & $\begin{array}{l}\text { Stillstand or regressive phase. Carbonate } \\
\text { ramp to rimmed shelf development with the } \\
\text { growth of Waulsortian-type mud mounds on } \\
\text { the upper part of ramp. }\end{array}$ \\
\hline & $\mathrm{ECI}$ & $\begin{array}{l}\text { Late Devonian- } \\
\text { Courceyan }\end{array}$ & $\begin{array}{l}\text { Initial development of half-graben. } \\
\text { Downlapping subaerial fan sequence } \\
\text { developing into Old Red Sandstone fluvial } \\
\text { plain deposits. Marine transgression marked } \\
\text { by progressive onlap of basement by } \\
\text { carbonate slope deposits. }\end{array}$ \\
\hline
\end{tabular}

Pre-rift Pz Pre-Late Devonian

Caledonian granite and folded lower Palaeozoic basement complex. 
The sequences identified are individual stratigraphical units each composed of a relatively conformable succession of genetically related strata which are bounded at their top and base by unconformities or their correlative conformities (Mitchum et al. 1977). The development of these sequences is discussed with particular reference to the Widmerpool Gulf in the East Midlands. A series of representative regional seismic lines tied to well and outcrop control and depth converted geological interpretations ${ }^{1}$ for each of the individual half-graben in the Carboniferous of northern England are presented to illustrate the development of these sequences across the province (Plates 3.2-3.20). The location of these lines is shown on Plate 3.1.

A more detailed subdivision based on maximum flooding surfaces has been possible in the post-rift Namurian-early Westphalian succession. This has been applied in the preparation of the detailed palaeofacies maps used for reservoir facies analysis of this interval in the East Midlands (see Chapters 4 \& 5). Unfortunately, the lack of deep borehole penetrations and consistent, high quality biostratigraphic data for the basinal Dinantian successions in northern England precludes any further breakdown of the synrift interval, beyond the tectono-stratigraphic scale, at present. Hence, the sequence stratigraphic scheme proposed herein for the northern England Carboniferous, is essentially a tectono-stratigraphic analysis of regional seismic and borehole data adopting the methodology of Hubbard et al. (1985a and 1985b).

Correlation of these sequences with the regional stages of the Carboniferous has proven problematical, particularly in the case of those proposed by George et al. (1976) for the syn-rift Dinantian.

1 The depth converted geological interpretations are based on corrected sonic logs taken from nearby boreholes, where available. Elsewhere, and for the deeper Dinantian section on most lines, seismic stacking velocities have been applied. The errors inherent in this latter method could result in errors in the depth section of as much as $+/-10 \%$. Typical velocities used in the depth conversion of the Northumberland Trough and the Eakring and Welton sections in the East Midlands are shown in Appendix B. 
Until relatively recently, the Dinantian stratigraphy of the onshore UK was based almost exclusively on the success of faunal zonation using corals and brachiopods. Most notable was the work of Vaughan (1905) in the Bristol area and Garwood (1913) in northern England. Subsequent work on goniatites (Bisat 1928, Earp et al. 1961), conodonts (Varker \& Sevastopulo 1985), spores (Neves et al. 1972, Clayton et al. 1977) and foraminifers and algae (Conil et al. 1979, Strank 1981) has provided further control on the dating and correlation of Dinantian rocks within this framework.

Ramsbottom (1973) proposed that the Dinantian northern England contained six eustatically controlled major cycles or groups of cycles. The identification of these maior cycles, which are correlated on their fossil content, proved a potential chronostratigraphical subdivision of the Dinantian. George et al. (1976) formally subdivided the British Dinantian into six regional chronostratigraphical divisions or stages. The stages proposed approximately coincide with the major cycles suggested by Ramsbottom (1973), since each major transgression was accompanied by the migratory faunas that are used to recognise the different stages.

Each of the stages proposed by George et al. (1976) has a standard boundary stratotype section at which the base is defined. The top of each stage is defined by the base of the overlying stage. In selecting boundary stratotype sections George et al. (1976) made use of sections in which the succession appears most complete. An attempt was, therefore, made to locate boundary stratotypes in the thicker successions, since the thinner shelf successions often contain hiatuses at the relevant levels (Ramsbottom 1973).

Recognition of the stage boundaries in the subsurface is dependent on the identification of key zonal fossils and, in some cases, associated lithological changes. This has proven difficult and occasionally impossible in the subsurface due to extreme facies variations within the Dinantian, faunal provincialism, and the difficulty of identifying certain fossil groups in borehole samples. Furthermore, recent macro and micropalaeontological and 
microfloral studies have modified the ranges of certain key fossil species and brought into question the criteria for recognising some of the Dinantian stages (Ebdon et al. 1990).

\subsubsection{Tectono-stratigraphic evolution of the Widmerpool Gulf}

The Widmerpool Gulf is typical of the many fault-bounded Carboniferous basins of northern England (Plate 2.4). It is bounded to the south by the Hoton fault (the major basin boundary fault) and to the north by the Cinderhill fault. The Hathern shelf and the East Midlands platform lie on the respective footwalls of these faults (Fig. 3.2). The characteristic form of the Widmerpool Gulf is that of a strongly asymmetric graben which has been inverted along its southern bounding fault at the culmination of the Variscan orogeny in the late Carboniferous (Plate 3.4).

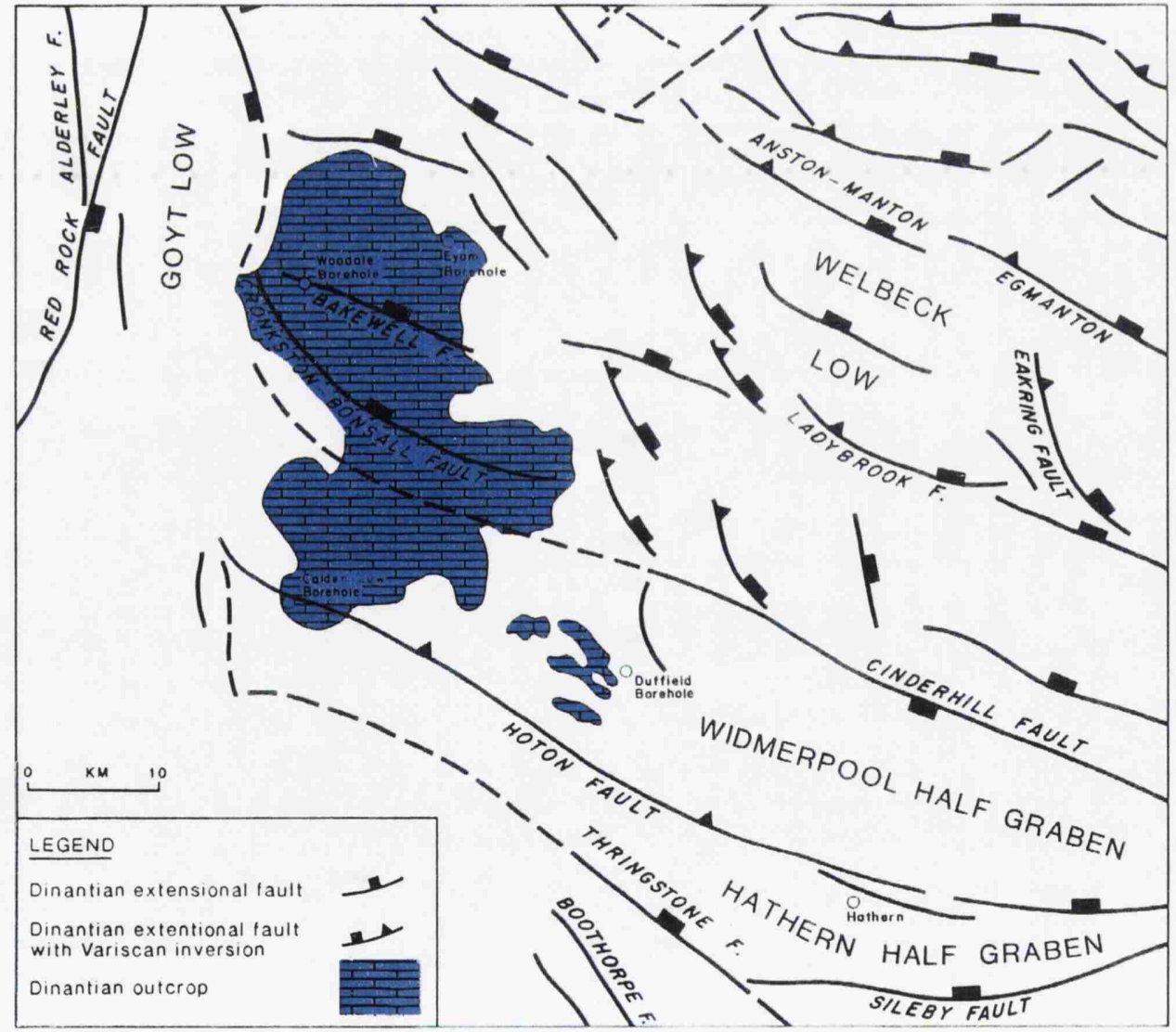

Figure 3.2 Structural setting of the western Widmerpool Gulf. 
Recent work by Gawthorpe (1987a) and Gawthorpe et al. (1989), based on the record of thickness and facies variations, event deposits and the identification of local unconformities within basins of northern England (notably the Bowland Basin), defines four main phases of syn-sedimentary faulting (Plate 2.7). Dating and correlation of these phases of tectonism is hampered by the paucity of biostratigraphically controlled time lines, as a result of facies variation both within and between basins. As discussed in the previous chapter, the four main phases of tectonism are recorded as (i) late Devonianearly Courceyan, (ii) late Chadian/early Arundian, (iii) mid/late Asbian and (iv) Brigantian. These tectonically active phases are punctuated by periods of relative tectonic quiescence. Seismic reflection and borehole evidence (Plates $3.4 \& 3.5$ ) indicates that the Widmerpool Gulf was periodically tectonically active during the Dinantian. Within this syn-rift phase of basin evolution six major seismic sequences have been identified (Fig. 3.3).

The seismostratigraphy presented herein is based on the integration of approximately 200 km of high quality, multifold, seismic reflection data, well data (from which lithological and biostratigraphical data have been obtained), and the correlation of outcrop data from the nearby Derbyshire Dome (Fig. 3.2). Observations from other northern England Carboniferous basins (notably those of Gawthorpe et al. 1989) are also included. Each seismic package is described below from oldest to youngest.

\section{Pre-rift}

Seismic character. The top of the pre-rift is marked by a high amplitude reflector which is laterally continuous on the basin margins, becoming discontinuous and of lower amplitude into the basin. Internally the pre-rift is characterless (Plate 3.4).

Facies. Where penetrated the pre-rift megasequence is composed of metasediments or intrusives. 


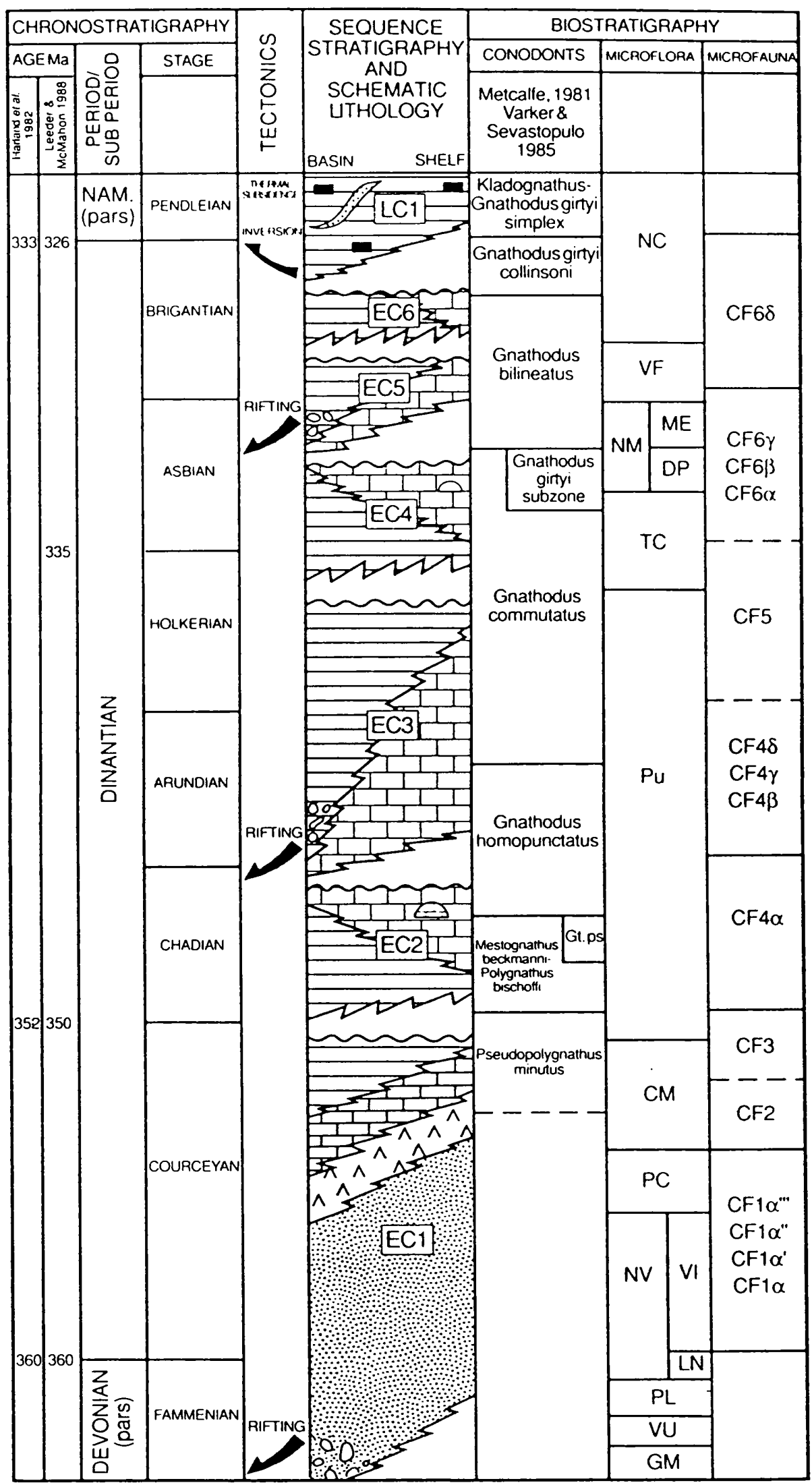

Figure 3.3 Dinantian-early Namurian seismo-stratigraphy of the Widmerpool Gulf. Gt ps, Gnathodus pseudosemiglabar Subzone. 
Interpretation. The pre-rift megasequence represents Caledonian basement.

Age. The metasediments of the hangingwall are of undefined Palaeozoic age. Granodiorite from the footwall has been dated as Caledonian, possibly Silurian in age.

Correlation. South of the Widmerpool Gulf, on the London-Brabant Massif, Charnian (Pre-Cambrian) metasediments and igneous rocks outcrop. To the northwest, on the Derbyshire Dome, the Eyam and Woo Dale boreholes penetrated pre-Dinantian volcanic rocks and Lower Palaeozoic rocks respectively (Cope 1973, Dunham 1973, Strank 1985, 1986). To the northeast, in the East Midlands, a number of boreholes have penetrated pre-Dinantian basement composed of metasedimentary and intrusive rocks (Pharaoh et al. 1987).

\section{ECI sequence}

Seismic character. The sequence thickens into the Hoton fault and ultimately the Thringstone-Sileby fault which was the major basin bounding fault at this time (Plate 3.4) and thins northwards onto the hangingwall dipslope. The base shows a suggestion of progressive northwards onlap onto the pre-rift megasequence in the hangingwall. The top of the sequence is marked by a high amplitude, laterally continuous reflector. Internally the sequence is characterized by low amplitude, high frequency, laterally discontinuous events (Plate 34 ).

Facies and biostratigraphy. Sequence $\mathrm{ECl}$ has not been penetrated by a borehole in the Widmerpool Gulf.

Interpretation. The marked thickening of the $\mathrm{ECl}$ sequence into the major basin bounding faults (the Hoton and Thrinstone-Sileby faults) indicates that deposition of the sequence was tectonically driven. This early phase of faulting represents the initial 
development of the half-graben. A downlapping subaerial fan sequence, similar to that penetrated in the hangingwall of the Eakring/Foston fault (Eakring-146, Plate 3.9), is envisaged adjacent to both the Hoton and Sileby faults. These are interpreted as developing into fluvial plain deposits of Old Red Sandstone facies towards the basin centre and hangingwall dipslope. A marine transgression is marked by the progressive onlap of the basement by carbonate slope deposits.

Age. Late Devonian-Courceyan: The age is based on borehole data from the Hathern shelf and regional correlation (see below).

Correlation. Sediments of the $\mathrm{ECl}$ sequence have been penetrated to the south of the Widmerpool Gulf by the Hathern-1 borehole. At the base of Hathern-1 anhydrites were encountered (Falcon \& Kent 1960, Llewellyn \& Stabbins 1968, 1970). This indicates that there was restricted marine influence by this time in the half-graben. Palynological analysis (Llewellyn et al. 1969) indicates a Courceyan age equivalent to the CM Zone of Clayton et al. (1977). Elsewhere in the East Midlands, ECl is confined to incipient halfgraben, and has only been encountered in the subsurface in a small inverted half-graben (Eakring 146) and on the footwall of the Widmerpool Gulf (Caldon Low borehole; Institute of Geological Sciences 1978, Welsh \& Owens 1983). In both locations ECl consists of red continental conglomeratic sandstones, which are inferred to be of late Devonian-Courceyan age, resting on basement.

Direct comparison with outcrop from the Derbyshire Dome is not possible as the complete Dinantian section is not exposed. The Eyam borehole (Dunham 1973, Strank 1985), however, revealed Courceyan evaporites overlying Ordovician sediments. 
Seismic character. Sequence EC2 comprises high amplitude, laterally continuous reflectors in the basin centre which diverge and thicken along the hangingwall dipslope, where hummocky downlapping clinoforms are tentatively identified. The base of the sequence is marked by a high amplitude, laterally continuous reflector (top ECl). The top of the sequence is marked by onlap of the overlying sequence (Plate 3.4).

Facies and biostratigraphy. The EC2 sequence has not been penetrated by a borehole in the Widmerpool Gulf. The upper part of the sequence was penetrated on the southern margin of the gulf in the Strelley-1 borehole. Here the interval is represented by a series of shelf margin, carbonate grainstones.

Interpretation. EC2 is interpreted as a stillstand or regressive phase. This allowed the development of carbonate ramp to rimmed shelves which were both aggradational and progradational. This interpretation is based on the thickening of EC2 across the hangingwall dipslope and the tentative identification of hummocky downlapping clinoforms. Below wave base the typical packstone/wackestone/mudstone facies association predominated. The high amplitude, laterally continuous reflectors in the basin are believed to represent carbonates.

Age. Chadian, possibly as old as late Courceyan, based on correlation with outcrop and well data.

Correlation. Sediments of the EC2 Sequence have been penetrated at Hathern-1 on the footwall of the Hoton fault. Here the sequence is developed as shelf limestones (Llewellyn \& Stabbins 1968, 1970) which are dated as no older than the CF4 Zone of Conil et al. (1979). On the adjacent East Midlands platform EC2 is the oldest of the 
Dinantian sequences preserved, and is developed as shelf limestones. Strank (1987) indicated that EC2 is no older than late Courceyan in the shelf setting.

At Dovedale, on the Derbyshire Dome along strike from the Widmerpool Gulf, an elongate Waulsortian mud mound complex is reported by Bridges \& Chapman (1988). The mud mound complex developed on a ramp to the southwest of an evolving carbonate platform during Chadian times.

\section{EC3 sequence}

Seismic character. The EC3 sequence thickens significantly into the Hoton fault and thins progressively northwards onto the hangingwall dipslope. At the base of the sequence there is progressive onlap onto the underlying EC2 sequence. The upper limit of the sequence is marked by the truncation of reflectors (Plate 3.4). Internally the sequence consists of low amplitude, high frequency, laterally discontinuous events which progressively onlap onto the hangingwall dipslope (Plate 3.4).

Facies. Where penetrated in the basin the sequence comprises a monotonous series of variably calcareous, carbonaceous, pyritic, dark grey mudstones thinly interbedded with grey, dolomitic limestones. The seismic character of EC3 exhibits no lateral variation and the sediment package is envisaged to show no change in character across the Widmerpool Gulf. On the adjacent East Midlands shelf the sequence is represented by shelf limestones.

Biostratigraphy. Only the top part of the sequence has been penetrated by boreholes in the basin. Miospore assemblages recovered from the sequence include abundant Lycospora pusilla in association with Schulzospora campyloptera, Stenozonotriletes coronatus, V. baccatus, C. aculeata, P. tesselatus and Waltzispora planiangulata (Ebdon et al. 1990). The miospore assemblages recovered from the upper part of the interval are 
broadly equivalent to the TC Zone of Neves et al. (1972). Although conodont analysis has been undertaken no significant assemblages have been recovered.

Interpretation. The geometry of the sequence (ie. significant thickening into the Hoton fault) indicates that deposition of EC3 was initiated by rejuvenation of the major basin bounding fault. This phase of extension is associated with rotation of the fault blocks and significant footwall erosion. Carbonate shelf margins which developed during EC2 on the footwall margins were eroded, those on the hangingwall margin were drowned.

Age. Late Chadian-late Holkerian. The lower age limit is based on analogy with sections in the Bowland Basin (Gawthorpe 1987a). The upper age limit is defined by the identification of the TC Zone of Neves et al. (1972). The TC Zone has a base in the late Holkerian (Ebdon et al. 1990).

Correlation. In the Bowland basin a period of enhanced tectonic activity is noted during the late Chadian-early Arundian (Gawthorpe 1987a). At outcrop this is marked by horizons of debris flow, carbonate breccias and sedimentary slides which unconformably overlie calciturbidites of the preceding EC2 sequence (Plate 2.7). This is believed to correlate with the onset of the EC3 rifting in the Widmerpool Gulf. On the East Midlands shelf a widespread Arundian shale horizon marks a cessation of carbonate growth within the platform and is believed to represent the maximum extent of the EC3 transgression. Previous attempts at seismic interpretation in the southern East Midlands (BP in-house studies) erroneously correlated this high amplitude event with the EC2 basinal carbonate reflector the Widmerpool Gulf.

\section{EC4 sequence}

Seismic character. The sequence is thickest at the margins of the basin, along the Hoton and Cinderhill fault systems, and thins into the basin (Plate 3.4, Fig. 3.4). 


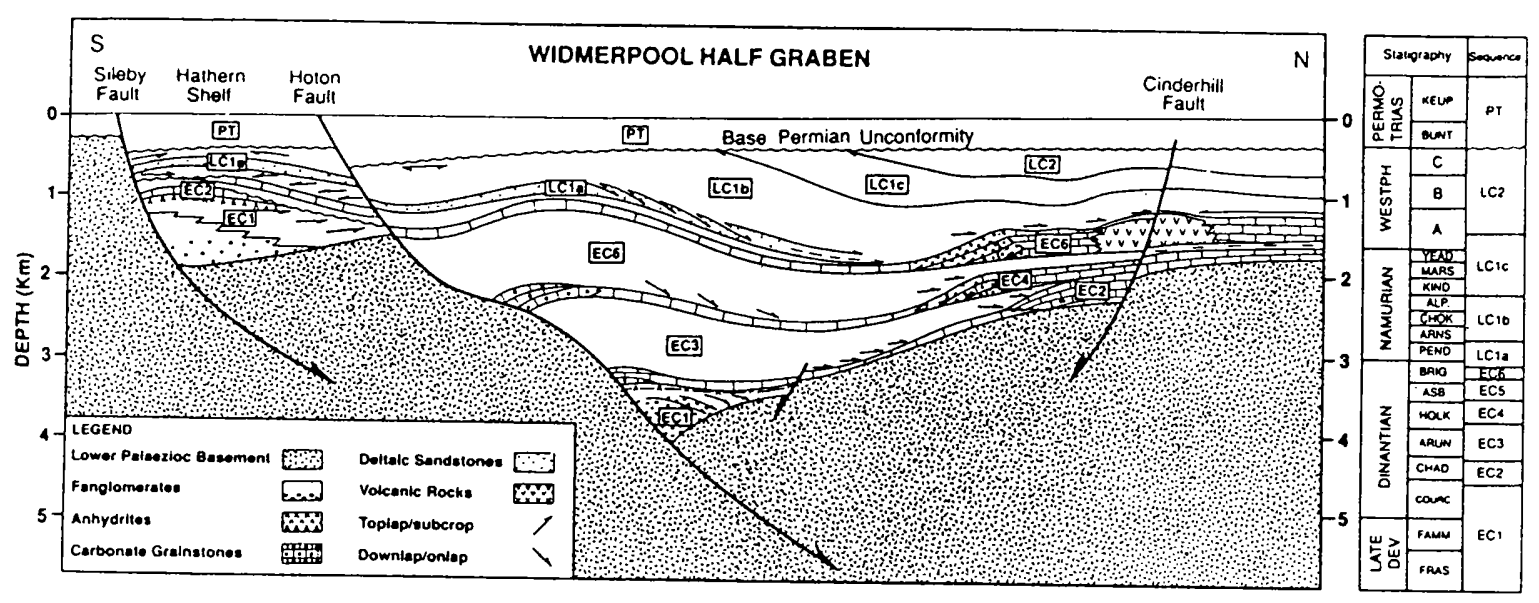

Figure 3.4 Composite sketch of seismo-stratigraphic interpretation, western Widmerpool Gulf.

The base of the sequence shows downlap onto the underlying EC3 sequence along the hangingwall dipslope, becoming subparallel with EC3 towards the basin centre. There is also some evidence of subcrop to the base of EC4 within the basin. The top is marked by progressive onlap of the overlying sequence (Plate 3.5). Internally, in the basin, the sequence comprises high amplitude, low frequency, laterally continuous reflectors. Along the Hoton fault EC4 comprises high amplitude, low frequency, subtle high angle reflectors which represent vertically and laterally accreting clinoforms that prograde northwards into the basin (Fig. 3.5). Along the hangingwall dipslope the sequence is largely characterless but in places high amplitude, low frequency, downlapping hummocky clinoforms are interpreted prograding southwards onto EC3.

Facies. In the basinal setting the high amplitude reflectors recorded on seismic sections represent an increase in carbonate within an otherwise monotonous sequence of mudstones and interbedded limestones. The progradational and aggradational features identified on the basin margins, none of which have been penetrated by wells, are believed to represent the development of carbonate ramp to rimmed shelf facies. Shelfward of these features, and confirmed by borehole data (eg. Ironville-5; Plate 3.5), shallow marine limestones accumulated. 
Biostratigraphy. The sequence is well controlled biostratigraphically by borehole data tied to seismic sections. Diverse conodont faunas include Paragnathodus commutatus, Gnathodus homopunctatus, Gnathodus girtyi girtyi, Cavusgnathus unicornis and Apatognathus sp. in association with bivalve spat, ostracods and brachiopod spines (Ebdon et al. 1990). The sequence equates to the $G$. girtyi Subzone of the $P$. commutatus Zone (Metcalfe 1981). The upper boundary of the sequence is well calibrated, coinciding with the boundary between the $G$. bilineatus and $P$. commutatus Zones (Metcalfe 1981). Palynofloras are broadly equivalent to the NM Zone and the upper part of the TC Zone (Neves et al. 1972).
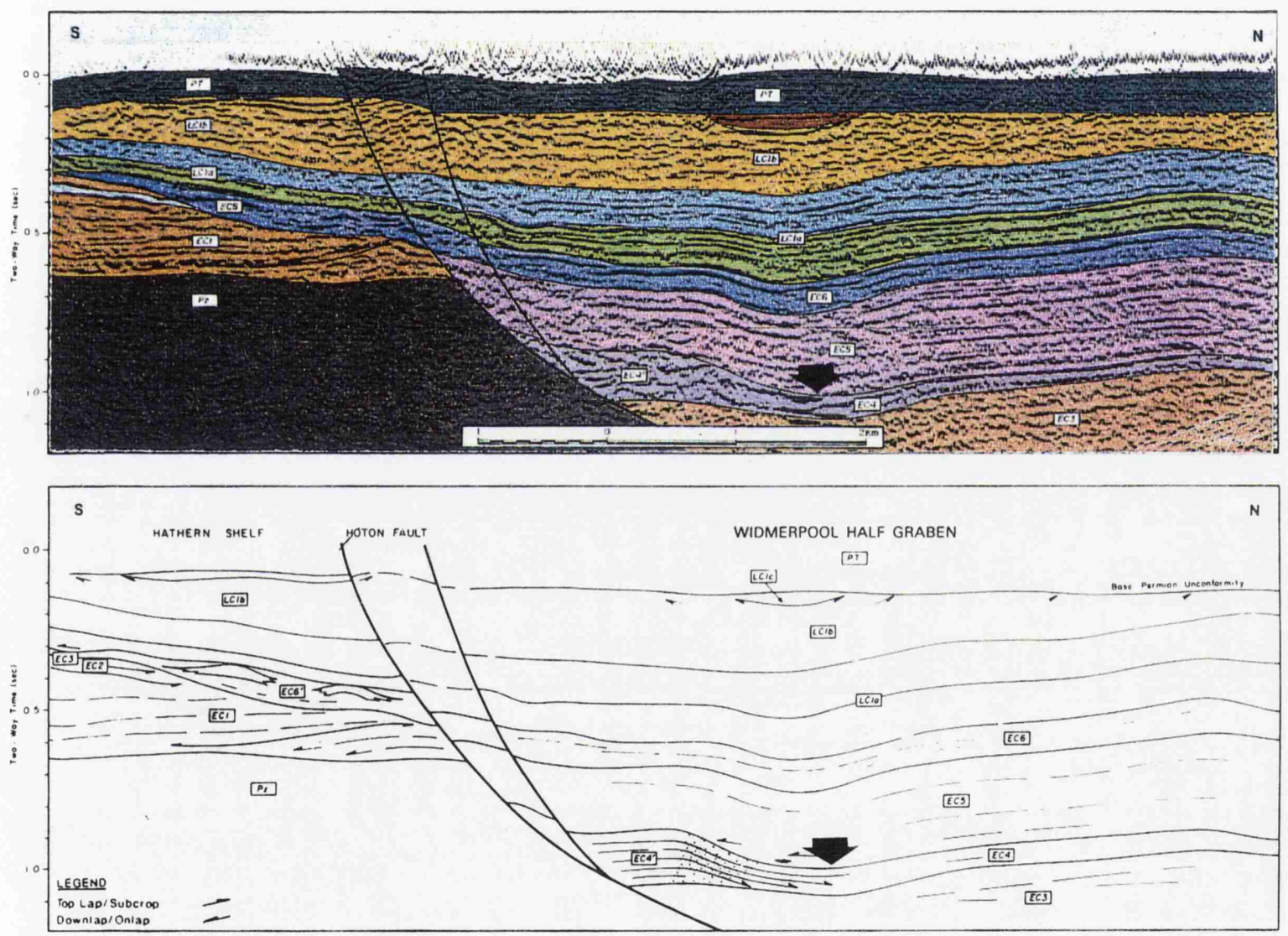

Figure 3.5 Sequence architecture, southern margin of the Widmerpool Gulf, East Midlands showing development of EC4 footwall margin. Bold arrow shows position of EC4/EC5 sequence boundary exposed at Green Pike (Fig 3.25). LC1c delta slope: LC1b prodelta turbidites; LC1a distal prodelta; EC6' shelf carbonates and mudstones; EC6 basinal calciturbidites; EC5 basinal mudstones; EC4' carbonate rimmed shelf margin; EC4 basinal calciturbidites; EC3 basinal carbonate and mudstone; EC2 shelf carbonate; EC1 evaporite/carbonate slope deposits; Pz Basement; PT Permo-Triassic. 
Interpretation. Sequence EC4 is interpreted as having developed during a stillstand or regressive phase. In the Widmerpool Gulf carbonate deposition was re-established along the basin margins and low rates of subsidence prevailed. This enabled the carbonate ramp to prograde both southward and northward from the hangingwall and footwall margins respectively. The strong parallel reflectors in the basinal section link the two prograding ramps.

Age. Late Holkerian to mid-Asbian. The lower age limit is defined by the presence of the TC Zone (Neves et al. 1972) at the base of EC4. The upper age limit is defined by the top of the G. girtyi Subzone, P. commutatus Zone of Metcalfe (1981).

Correlation. An Asbian grainstone footwall shelf margin which progrades towards the basin centre is preserved on the nearby Derbyshire Dome at Castleton. The increased carbonate production at this time (Gawthorpe 1986; Gutteridge 1987) created a gradient at the shelf margin. This lead to carbonate debris flows and sedimentary slides as described from the Bowland Basin (Gawthorpe 1987a). Gutteridge (1987) concluded that in the region of the present day Derbyshire Dome a major carbonate shelf developed across earlier basement topography. The strong parallel reflectors seen across the Widmerpool Gulf in sequence EC4 are believed to represent carbonate debris flows and calciturbidites deposited basinward of the evolving carbonate shelf margins (Plate 3.4).

\section{EC5 sequence}

Seismic character. The EC5 sequence, like the ECl and EC3 sequences, thickens into the Hoton Fault and thins northwards onto the hangingwall dipslope (Plate 3.4 \& Fig 3.4). The base of the sequence shows progressive onlap onto EC4 (Fig. 3.5). Internally the sequence consists of low amplitude, high frequency, laterally continuous parallel events which progressively onlap the hangingwall dipslope (Plate 3.4). 
Facies. In the basinal setting borehole evidence indicates that EC5 consists of a monotonous series of calcareous mudstones and thin dolomitic limestones. Shallow marine shelf limestones accumulated on the East Midlands platform and Hathern shelf. Volcanic centres along the Cinderhill fault system were active during EC5 times (Strelley-1 borehole, Plate 3.5).

Biostratigraphy. Conodont faunas are rich and diverse at the top of the sequence, becoming progressively more impoverished towards the base where assemblages are indeterminate. In boreholes, the top of EC5 occurs within the G. bilineatus Zone (Metcalfe 1981). Assemblages are characterized by G. bilineatus, G. homopunctatus, $P$. commutatus and G. girtyi (Ebdon et al. 1990). Mestognathids, including Mestognathus beckmanni, characteristically occur at the top of the sequence and indicate a shallowing of the system with time. Towards the base of the sequence the indeterminate faunas include fragmented conodonts, foraminiferal casts, isolated brachiopod spines and goniatite spat. Mixing of assemblages during deposition is suggested.

Palynofloral assemblages from the sequence can be assigned to the VF zone of Neves $e t$ al. (1972). Assemblages typically contain species of Lycospora and Densosporites which are common, in association with Schulzospora species, Spelaeotriletes arenaceous, Raistrickia nigra and Remysporites magnificus (Ebdon et al. 1990). A number of taxa appear for the first time within the sequence, including Diatomozonotriletes saetosus, Diatomozonotriutes cervicornutus, Crassispora maculosa, $T$. vetustus, $T$. trivalvis, $R$. fracta, $R$. knoxii, G. spinosa and S. nux. P. tesellatus, Murospora parthenopia, Murospora margodentata, V. baccatus, Chaetosphaerites pollenisimilis and C. aculeata become extinct within the sequence.

Interpretation. The pronounced thickening of the sequence into the major basin bounding fault (the Hoton fault) indicates that EC5 is a tectonically driven sequence. It was initiated by reactivation of the extensional fault regime and significant backstepping 
of the fault system in the Widmerpool Gulf (Fig. 3.5). This was accompanied by footwall rotation generating both uplift and erosion. Contemporaneous volcanic rocks were extruded from centres of igneous activity aligned along the Cinderhill fault zone. Microfaunal evidence indicates that initially EC5 consists of sediments from a mixed source, suggesting sediment slumps and slides or turbidity flow into the basin from the drowned or emergent carbonate shelf margins. By the end of EC5 times shallow water conditions were developed across the Widmerpool Gulf as sedimentation exceeded subsidence.

Age. Late Asbian-early Brigantian. The lower age limit of the sequence is well constrained by the upper age limit of the underlying EC4 sequence. The record of palynofloras belonging to the NM Zone (Neves et al. 1972), ME Subzone (Clayton et al. 1977), is consistent with the late Asbian age assigned to the base of the sequence. The upper age limit is less well constrained, being approximately equivalent to the VF-NC miospore Zone boundary of Neves et al. (1972). Clayton et al. (1977) equate the base of the NC Zone to a position within the $\mathrm{P} 2$ goniatite Zone.

Correlation. Sequence EC5 ties in well with a late Asbian-early Brigantian phase of tectonic activity observed in the Bowland Basin (Gawthorpe 1986,1987a). Basaltic lavas on the Derbyshire Dome, (the Lower and Upper Miller's Dale Lavas) lie along strike from, and are stratigraphically equivalent to, the volcanic centres developed along the hangingwall margin of the Widmerpool Gulf (Macdonald et al. 1984). This volcanism is related to reactivation of extensional faults. Gutteridge (1987) records two periods of emergence and karstic erosion on the Derbyshire Dome in the late Asbian and early Brigantian. These are believed to correspond to two pulses of extension in the area during EC5 times, leading to footwall uplift and erosion. Horizons of debris flows, carbonate breccias and sedimentary slides occur in the Bowland Basin associated with this tectonism as with earlier phases (Plate 2.7). During EC5 times fine terrigenous clastics related to the advancement of major delta systems from the north reached the 
In addition mounded features of up to $0.5 \mathrm{~km}$ across have been mapped on the Hathern shelf (Fig. 3.7).

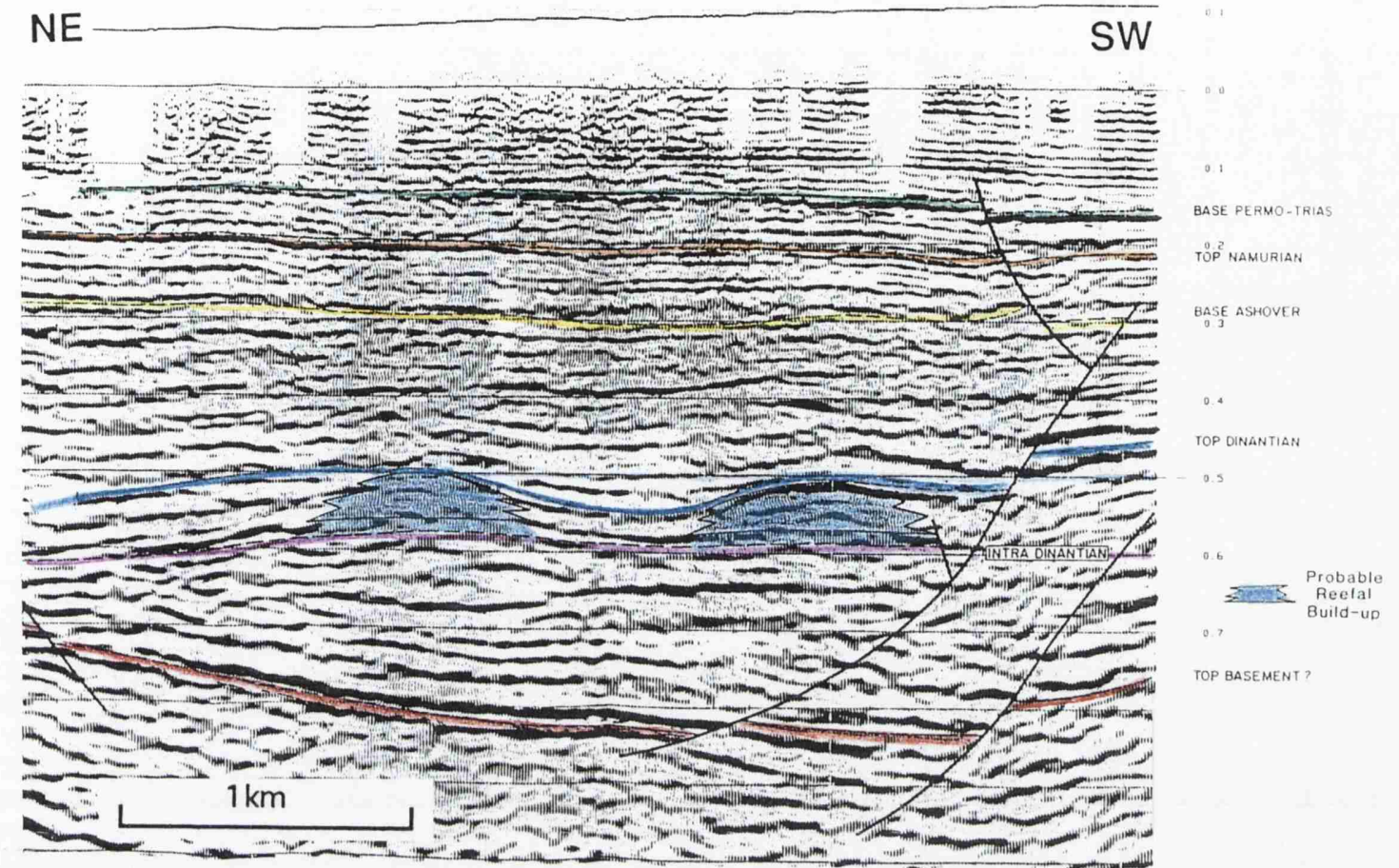

Figure 3.7 Seismic line BP-85-31. Development of carbonate mudmounds within seismic sequence EC6 on the Hathern shelf.

Facies. In the basin EC6 comprises a monotonous series of thinly bedded, dark grey, calcareous mudstones and brown, dolomitic, muddy limestones. Volcanic centres along the Cinderhill fault continued to be active during EC6 times as evidenced by the basalts and tuffs penetrated in the Strelley-1 borehole (Plates $3.4 \& 3.5$ ).

Biostratigraphy. The top of the sequence is well constrained by the top of the $G$. bilineatus conodont Zone of Metcalfe (1981). Conodont assemblages are rich and diverse throughout and resemble those present in the underlying sequence. $G$. bilineatus, G. homopunctatus, G. girtyi and $P$. commutatus continue to typify the microfauna, in association with Neoprioniodus scitulus, Neoprioniodus singularis, Hibbardella milleri and Ozarkodina delicatula (Ebdon et al. 1990). The EC5/EC6 seismic sequence boundary is approximately coincident to the VF/NC miospore Zone boundary of Neves et al. 1972). The base of the NC Zone (Neves et al. 1972) is marked by the appearance of a number of taxa including Bellespores nitidius, Reticulatisporites 
carnosus, Convolutisporites varicosus and Schopfipollenites ellipsoides. Assemblages continue to be characterized by elements consistently recorded in the underlying sequence, namely L. pusilla, $R$. nigra, $R$. magnificus, $R$. fracta, $R$. knoxii, S. nux, Triquitrites marginatus, T. trivalvis and species of Schukospora (Ebdon et al. 1990). The EC6 sequence belongs exclusively to the NC Zone (Neves et al. 1972), the top of the sequence falling within the biozone.

Interpretation. Close to the hangingwall dipslope EC6 is considered to comprise carbonate grainstones. In the Widmerpool Gulf it is proposed that low rates of subsidence (and/or small rises in sea level) were established by the end of EC5. Carbonate production was re-established and a carbonate ramp prograded southward into the basin from the hangingwall dipslope (Fig. 3.8). An increase in subsidence (and/or rise in sea level) resulted in the evolution of a carbonate grainstone rimmed shelf margin from the carbonate ramp. This is indicated by the laterally and vertically accreting clinoforms observed along the proposed shelf margin. The prograding shelf edge would have been at or just below sea level, and the depth of the water in the basin at the time would have been in the order of $300 \mathrm{~m}$.

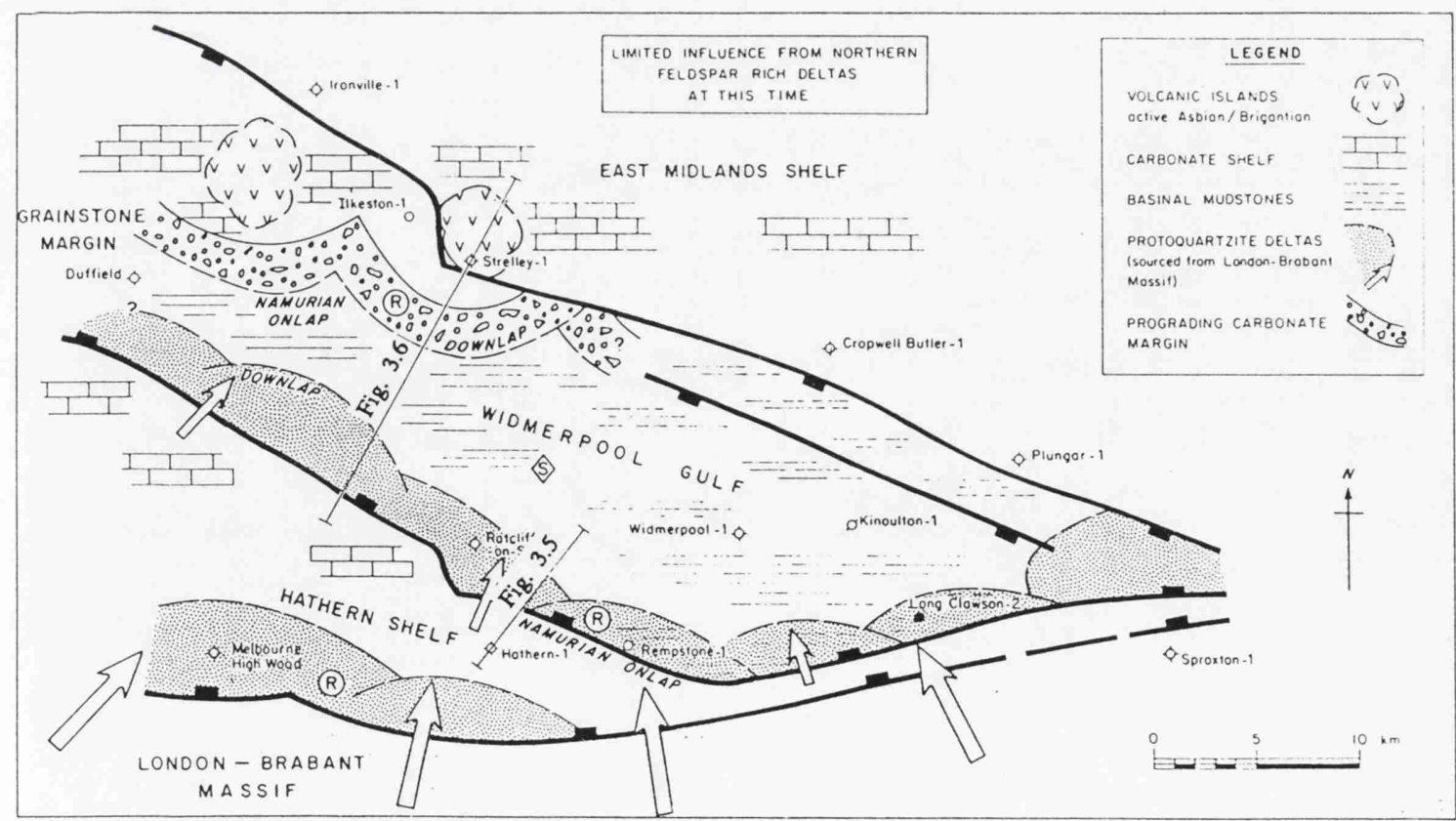

Figure 3.8 EC6-LC1a (Brigantian-Pendleian) seismic facies analysis in the Widmerpool Gulf. Map highlights key boreholes and seismic lines used in the interpretation. 
This interpretation is further supported by conodont faunas recorded from the basinal sediments. The margins have not been penetrated by wells.

Volcanic rocks, of EC5 and EC6 age, extend out into the basin as lava flows. They are believed to have concentrated wave energy which would have enhanced development of the grainstone margin (Fig 3.8), and are represented seismically by very high amplitude, low frequency, laterally continuous reflectors.

Age. Early to mid-Brigantian. The top and base of the sequence are well constrained biostratigraphically. Clayton et al. (1977) correlated the base of the NC Zone (Neves et al. 1972) to the middle of the P2 goniatite Zone (Bisat 1928). The top of the $G$. bilineatus conodont Zone is placed by Metcalfe (1981) within the P2b goniatite Subzone (Prentice \& Thomas 1965).

Correlation. The carbonate grainstone shelf margin interpreted along the hangingwall dipslope in the subsurface of the Widmerpool Gulf lies along strike from the Wirksworth carbonate grainstone margin (Walkden 1982) on the Derbyshire Dome (Fig. 3.9).

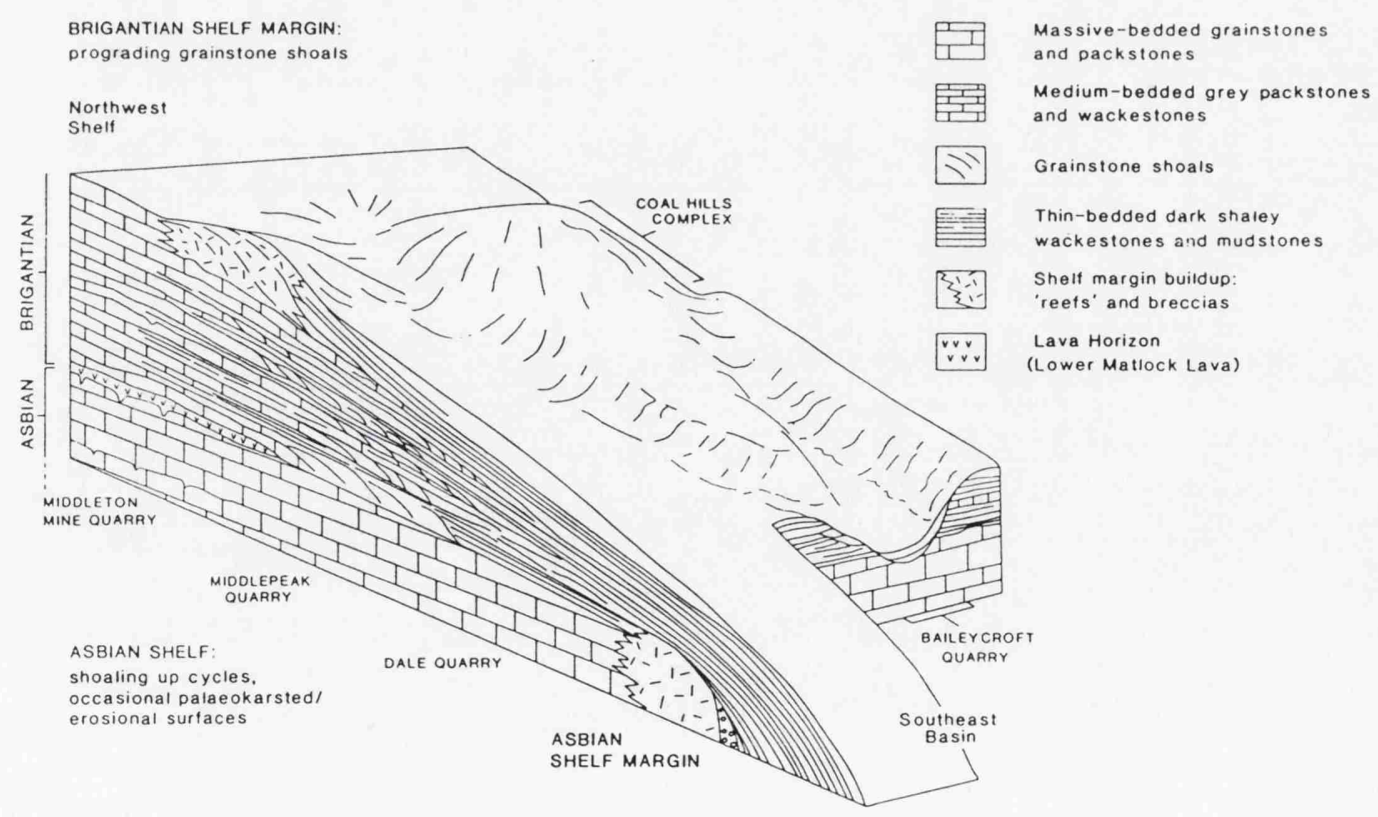

Figure 3.9 Middleton-Wirksworth area south Derbyshire Dome. Asbian-Brigantian shelf margins (sequences EC4 \& EC6). 
The Wirksworth grainstone shelf margin lies above a volcanic horizon, the Lower Matlock Lava, which is believed to be of early Brigantian age (Walkden 1982). The grainstone margin/volcanic rock association on the northern margin of the Widmerpool Gulf adds further credibility to the interpretation made from the seismic data. Mounded features mapped on the Hathern shelf are analogous to the mud mounds of the Coalhills complex in Derbyshire (Walkden 1982).

\section{LC1 sequence}

Seismic character. The LC1 sequence is thickest within the basin just north of the Hoton fault and thins northward and southward onto the hangingwall and footwall margins respectively (Plate 3.4). The lower part of the $\mathrm{LC1}$ sequence internally comprises high amplitude, high frequency, continuous parallel reflectors which downlap onto EC6 within the basin and onlap onto the submerged margins (Fig 3.8).

Facies. The lower part of the sequence comprises interbedded dark grey, pyritic, carbonaceous mudstones and sandstones. Thin tuffaceous units occur sporadically towards the base of the unit. The upper part of the sequence is represented by a series of shallowing upwards cycles consisting of interbedded sands and grey mudstones, which become progressively sandier towards the top (Plate 3.5).

Biostratigraphy. The boundary between the LC1 sequence and the underlying EC6 sequence equates to the boundary between the G. girtyi collinsoni Zone (Varker \& Sevastopulo 1985) and the G. bilineatus Zone (Metcalfe 1981). The base of the G. girtyi collinsoni Zone is marked by the inception of the eponymous taxon. Conodont faunas from the lower part of the LC1 sequence are diverse, and as well as G. girtyi collinsoni include G. girtyi intermedius, G. bilineatus bilineatus, Neoprionoidus spathatus subsp. A, N. scitulus, Cavusgnathus naviculus and P. commutatus (Ebdon et al. 1990). At the base of the sequence brachiopod spines and the internal casts of foraminifers are 
important accessories to the microfauna. Palynofloras remain unchanged from the underlying sequence, being assignable at the base of LC1 to the NC Zone (Neves et al. 1972).

Interpretation. Post EC6 there was a minor inversion event, with maximum inversion concentrated along the NNW-SSE fault trend. Both the Hathern shelf and, to a lesser extent, the Widmerpool Gulf were inverted. Evidence of inversion within the Widmerpool Gulf is provided by the northward offset from the Hoton fault of the thickest part of the $\mathrm{LCl}$ sequence which onlaps onto EC6 (Plate 3.4). $\mathrm{LC1}$ is divisible into subsequences on seismic evidence (Plate 3.4) and high resolution genetic sequences based on borehole data (Plate 3.5). The sediments of LC1 are not generally fault controlled and represent a regressive downlapping sediment package deposited during the thermal subsidence phase which followed Dinantian rifting. The earliest sediments of $\mathrm{LC} 1$ are distal prodelta mudstones of the advancing Silesian delta system which had already filled basins to the north by this time (Fraser et al. 1990). The advancing delta system built out into the existing fault-produced topography. Backstripped seismic data suggests a water depth of about $300 \mathrm{~m}$ in the basin (Plate 2.8). Conodont faunas are characterized by deep water forms and confirm this interpretation. For most of the late Carboniferous, northern England comprised a broad, low angle delta plain with little diversification into clear shelf and basinal environments. The entire seismic dataset for the East Midlands provides only one example of a delta system prograding into a deep water environment (Fig. 3.10). This NW-SE trending line runs along the axis of the Widmerpool Gulf and shows the Ashover delta (LC1c) advancing along the axis of the gulf into water depths of some 150 metres (height of the clinoforms), as predicted from borehole and outcrop studies by Jones (1980).

Age. No older than late Brigantian. The base of the $\mathrm{LCl}$ sequence is no older than the G. girtyi collinsoni Zone. Regional evidence indicates that the sequence ranges into the early Westphalian 'A'. 
Correlation. The inversion noted at the end of EC6 is recorded at outcrop on the nearby Derbyshire Dome. This inversion led to the creation of late Brigantian intrashelf basins of which the Welbeck Low (Fig. 3.2) is considered to be an example. The Welbeck intrashelf basin formed between the Anston-Manton, Ladybrook and Eakring inversion anticlines present along the north, south and eastern margins respectively. An easterly dipping carbonate ramp developed in response to the inversion, in the resultant low, onto which sub wave-base basinal carbonates accumulated during the early part of LC1. Similar intrashelf basins are described from outcrop in Derbyshire (Gutteridge 1987). Elsewhere, over the majority of the East Midlands platform, shelf carbonates continued to accumulate during late Brigantian times. The overlying clastic sequences represent the progressive infill of the basin by the deposits of increasingly shallower water delta systems (eg. Kinderscout, Ashover and Pennine deltas).
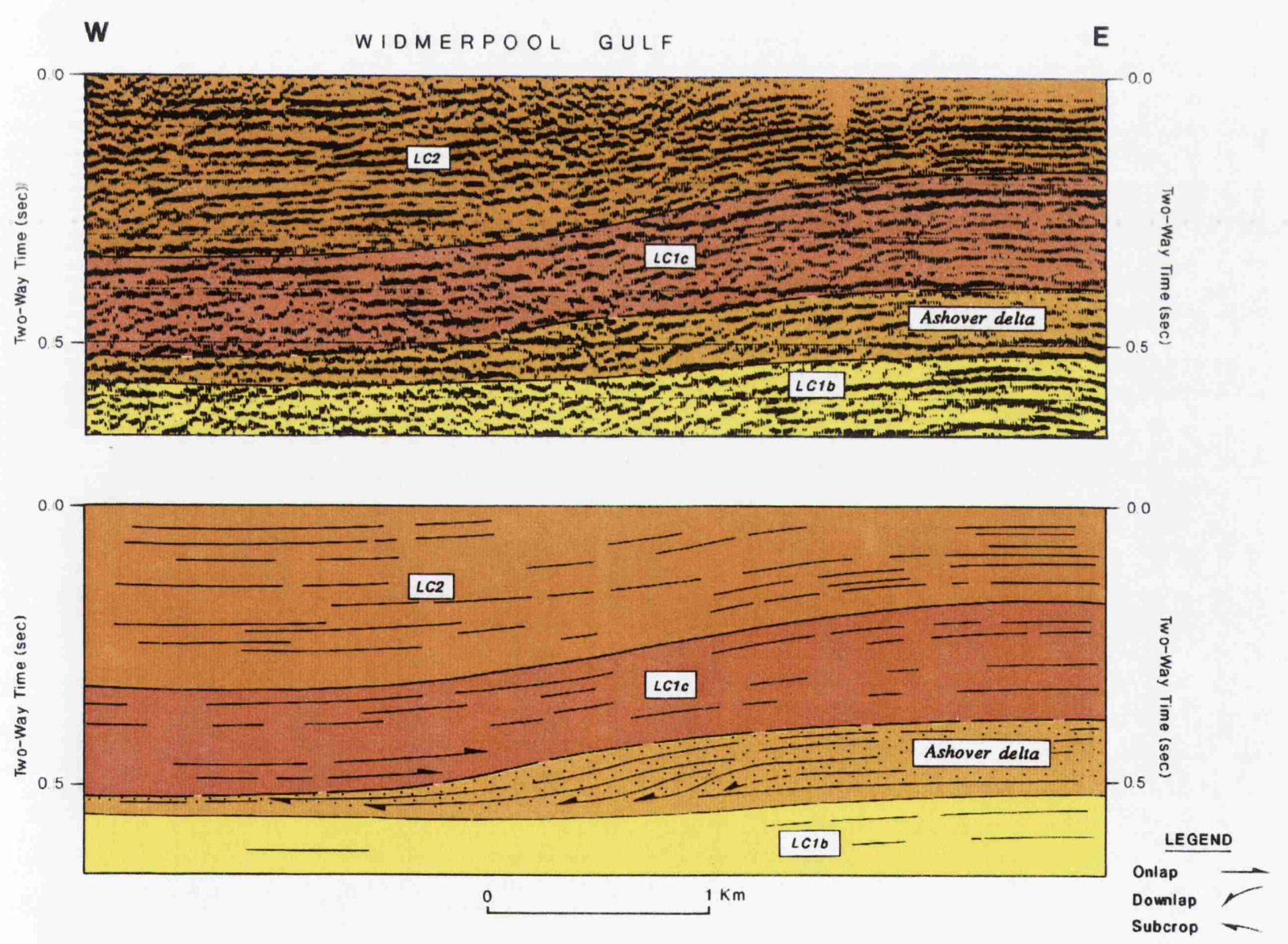

Figure 3.10 East west seismic line along the axis of the Widmerpool Gulf showing the westerly progradation (and eventual abandonment) of the Namurian Ashover delta (sequence LClc). 


\section{LC2 sequence}

Seismic character. The LC2 sequence is thickest on the northern and southern margins of the Widmerpool Gulf. It is absent, by erosion, over much of the central part of the basin due to inversion and uplift and in late Carboniferous times (Plate 3.4). The sequence is characterised by laterally persistent, high amplitude reflectors which overlie the delta plain deposits of $\mathrm{LC} 1$ with subtle onlap.

Facies. The sequence comprises interbedded grey carbonaceous mudstones and sandstones with common coal seams (Plate 3.5).

Biostratigraphy. The boundary between the LC2 sequence and the underlying LC1 sequence is marked by a pronounced 'bulge' on the sonic log equating to the amaliae marine band in the Strelley, Ilkeston and Ironville-5 boreholes and correlates with the boundary between the Bo and DI biozones (Fig 3.11).

Interpretation. By end LC1 times shallow water deltaic conditions were prevalent over the entire Widmerpool Gulf. The LC1/LC2 boundary is picked at a marked change in depositional facies from lower delta plain to upper delta plain conditions observed in the above boreholes. The continuous high amplitude reflectors are generated by the many coal seams developed throughout sequence LC2.

Age. No older than late Westphalian 'C'. Regional evidence indicates that the sequence ranges into the Westphalian ' $\mathrm{C}$ ' where it is terminated by the onset of the Variscan orogeny. The initial phase of folding and uplift of the Variscan is interpreted to have occurred between the Anthraconauta phillipsi and A. tenuis zones of the Upper Carboniferous (Wills 1956). The base of the LC2 sequence lies within the early Westphalian 'A'. 
Ilkeston-1

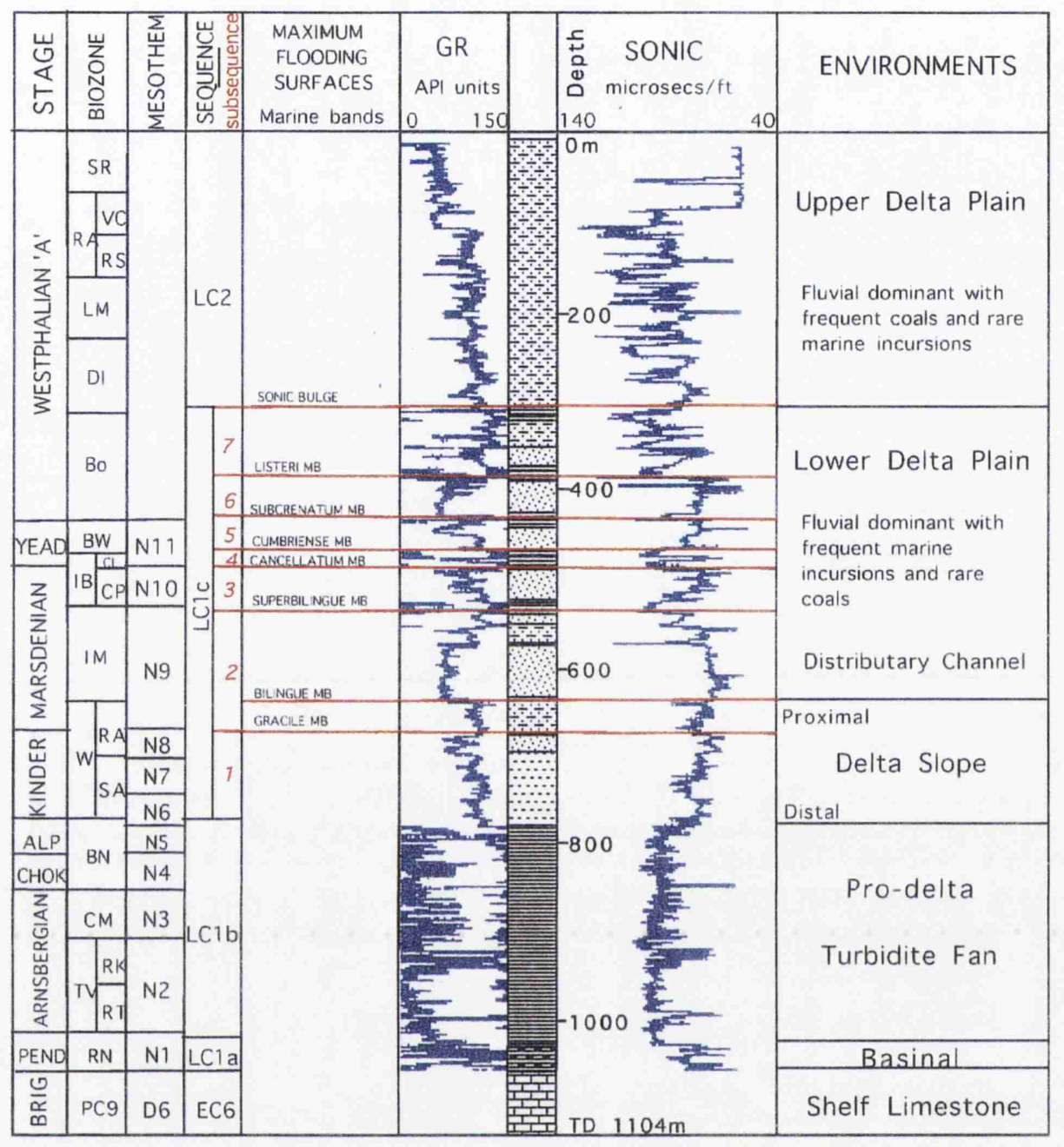

Figure 3.11 Sequence stratigraphy and sedimentary facies analysis for the Ilkeston-1 borehole, East Midlands showing marine band based genetic sequence stratigraphy for seismic sequence LClc.

Correlation. A major shift from lower delta plain to upper delta plain conditions throughout the northern England Pennine basin, approximating to the amaliae marine band, has been described by Guion and Fielding (1988). This event is thought to have regional significance throughout northern England. The periodic tectonic activity evidenced on several of the major basin bounding faults during the early part of the post- 
rift had almost ceased by early Westphalian 'A' times. This also coincided approximately with the cessation of igneous activity in the East Midlands (Kirton 1984). During LC2, upper delta plain, coal swamp conditions were established over most of northern England forming an internally drained basin north of the Wales-Brabant Massif (Guion \& Fielding 1988).

\subsubsection{Tectono-stratigraphic evolution of the Gainsborough Trough}

The Gainsborough Trough forms the northern of the two main depocentres that comprise the East Midlands province (Plate 2.4). It comprises a major half-graben controlled by the major Askern-Spital fault in the north which downthrows the Dinantian section to the south (Plate 3.6). A four-fold increase in thickness of the Dinantian section (EC1-EC6) is evidenced across the fault. The Gainsborough Trough contains a more complete Silesian section compared to the Widmerpool Gulf to the south. Within the depocentre there are no borehole penetrations below the top Dinantian (EC6). The major control on the stratigraphy is provided by the Grove-3 borehole, which penetrated a complete (but condensed) Dinantian section sitting above ?Charnian metamorphic basement on the southern flank of the half-graben.

Major rifting is evidenced in the Gainsborough Trough during EC1 (late DevonianCourceyan) and EC3 (Arundian-early Holkerian) times. However, unlike the Widmerpool Gulf there is very little evidence for a well developed EC5 (late Asbian-early Brigantian) rift. Both the EC1 and EC3 sequences exhibit classic wedge shaped geometries, typical of syn-rift sedimentation, described from the Widmerpool Gulf. The present deep burial of the early syn-rift sediments of late Devonian-Courceyan age in northern England generally preclude any valid seismic facies analysis interpretation. However, the regional seismic lines compiled for the East Midlands and Gainsborough Trough, do give some indication of the nature of the sediment package (Plates $3.2 \&$ 3.6). The hangingwall of the Beckingham fault contains a series of broadly 
progradational downlapping reflectors interpreted as a sub-aerial apron fan system prograding into a lake or early marginal marine gulf. These probably form part of a series of similar coalescing apron fans, sourced from the footwall extending some 4-5 $\mathrm{km}$ into the basin (Plate 3.2), which would have rimmed this and other rift depressions at this time.

The seismic data shows good evidence for a major backstepping of the southern bounding fault of the basin between EC1 and EC3 rifting; control shifting southwards some $7 \mathrm{kms}$ from the Beckingham Fault to the Clarborough Fault at the onset of EC3 rifting. This is a common occurrence in evolving rift basins and has been particularly well demonstrated from the East African rift valley by Rosendahl et al. (1986). Also of note on the section is the shallow set of late Carboniferous listric extensional faults which detach on the top Dinantian surface (base of the Namurian shales).

The Dinantian facies shown on the geological interpretation are largely inferred from seismic character eg. the grainstone margins in sequences EC6 and EC4. The northern margin of the Widmerpool Gulf provides a good seismic example of a hangingwall margin. However, the corresponding footwall margin on the southern flank of the gulf appears to be absent following late Dinantian erosion. In the Gainsborough Trough both hangingwall and footwall margins are developed along the Askern-Spital and corresponding antithetic faults. The seismic data indicates the development of shelf margin complexes during the Chadian (EC2), late Holkerian-mid Asbian (EC4) and Brigantian (EC6). Transgressive facies showing onlapping relationships are represented by the Arundian-Holkerian (EC3) a very thin late Brigantian-early Pendleian (LC1a) and the overlying late Pendleian-Arnsbergian (sequence LC1b). Chadian (EC2) mud mounds are developed on the footwall controlled by the Craven-Lincoln fault lying to the northeast of the Gainsborough Trough (Fig. 3.12). 
LINE BP-85-162(MIG)

NW

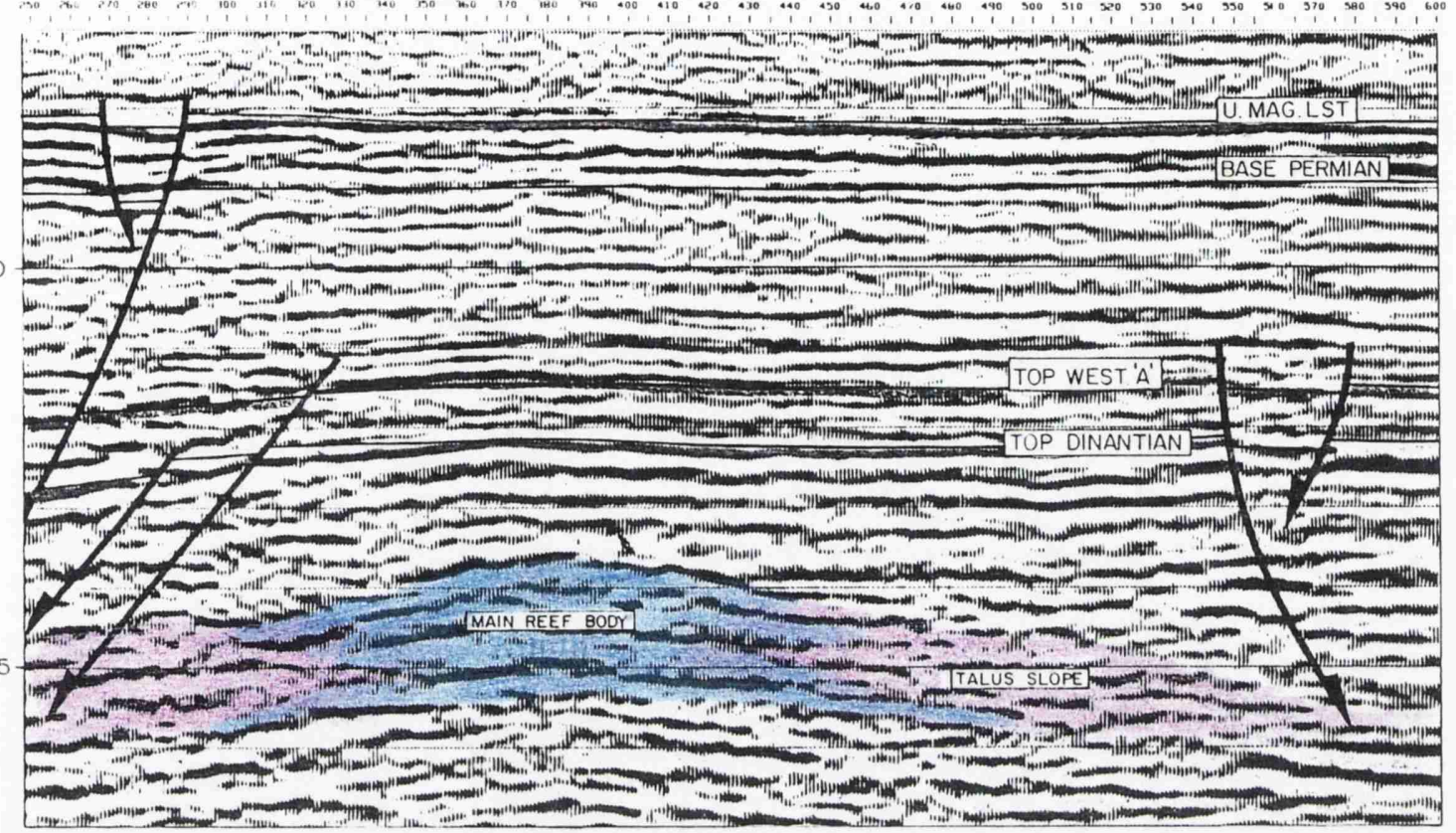

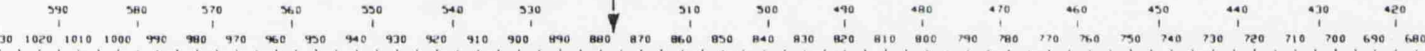

- M M

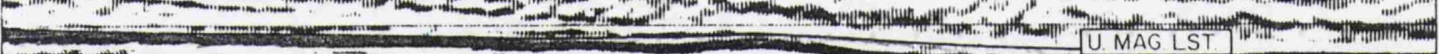
$-1$ -

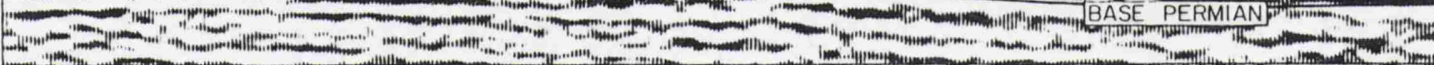
$0=1-1=-1$ Find - -

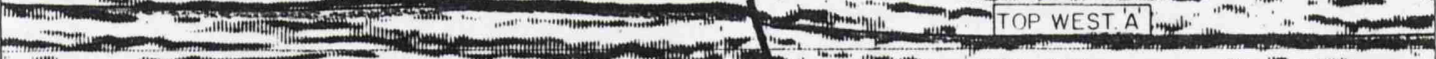
C. -

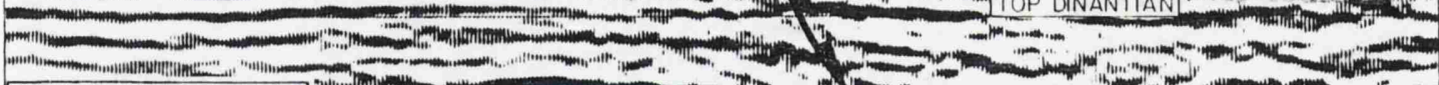

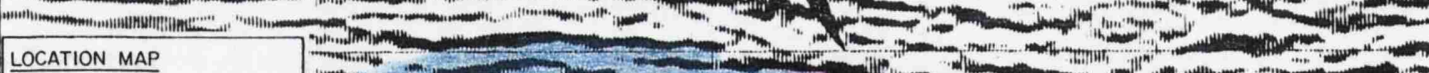
LOCATION MAP $\quad=-1$

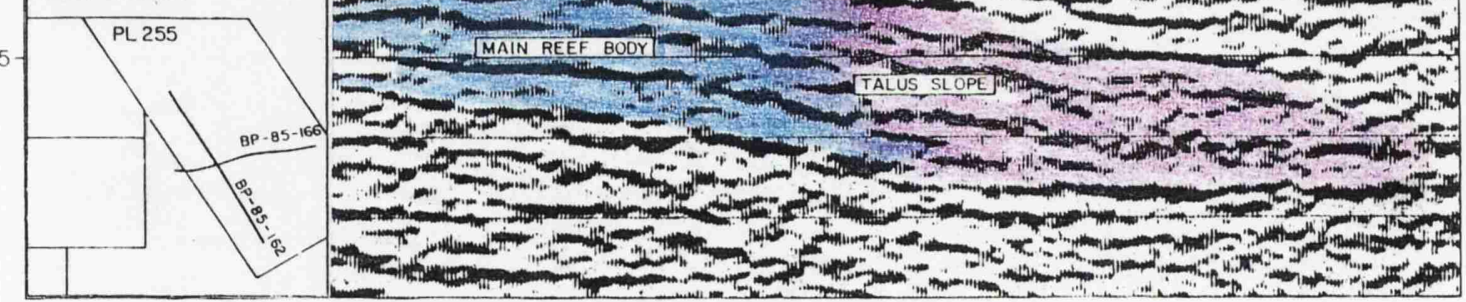

Figure 3.12 Seismic lines BP-85-162 and BP-85-166 showing the development of Chadian (EC2) mud mounds on the hangingwall of the Askern-Spital fault, northern margin of the Gainsborough Trough. 
The overlying post-rift infill of Silesian sediments (LC1-LC2) has been described in detail by Steele (1988). The thickening of the Namurian sequence into the Gainsborough Trough is ascribed to three processes; the infill of existing pre-Namurian bathymetry, differential compaction, and Namurian tectonic activity. The earliest Namurian sediments deposited in the half-graben were carbonaceous mudstones deposited in relatively deep water. Steele estimates some $300 \mathrm{~m}$ of bathymetry existed at the end Dinantian and this has been confirmed by backstripping work carried out for this thesis.

In the late Namurian (LC1c), mild reactivation of extensional faults occurred particularly in the eastern Gainsborough Trough where some $200 \mathrm{~m}$ of relief developed on the NESW trending Scampton fault (Plate 3.7) establishing a strong footwall unconformity in the area and the thick $(150 \mathrm{~m})$ development of Rough Rock equivalent sandstones in the hangingwall. The subsequent fill of the basin has been one of progressive advance of the Kinderscout, Ashover and Chatsworth-Crawshaw shallower water delta systems which infilled the trough from the north (Steele 1988). The culmination of this process was the deposition of extensive coal deposits in the Westphalian which are evidenced on seismic data by strong, laterally continuous high amplitude reflectors (Plates $3.2,3.6$ \& 3.7).

Localised inversion features are recorded along the Askern-Spital and Nettleham faults (Plates $3.7 \& 3.8$ ) forming the West Firsby, Glentworth, Nettleham and Welton oilfields (Plate 1.4). In the West Firsby area, where a thick LC2 (Westphalian A/B) sequence is preserved, and intra-LC2 tectonic event is evidenced by folding of the pre-LC2a sequence and onlap of the subsequent deposits (LC2b) in the hangingwall of the AskernSpital Fault (Plate 3.7). This may represent either an early compressive pulse of the Variscan orogeny or more likely a late (?east-west) extensional phase contemporaneous with the late Carboniferous listric extensional faulting evidenced in the Beckingham area (Plate 3.6). 


\subsubsection{Tectono-stratigraphic evolution of the Edale Gulf}

The Edale Gulf forms the third of the major half-graben which comprise the East Midlands province. It lies to the north of the Derbyshire carbonate platform and is buried beneath the Upper Carboniferous of the central Pennine Basin (Plate 2.4). The basin was originally thought to be part of a large Dinantian basin which extended northwards to the Askrigg Block and was connected to the Bowland Basin (George 1958, Ramsbottom 1969). More recently, Lee (1988) using 3-D, 2-D and residual gravity modelling and Smith et al. (1985), have suggested that the Edale Gulf comprises an individual half-graben controlled by a major east-west trending fault which underlies the northern margin of the Derbyshire carbonate platform. The exact position of this fault is poorly constrained by gravity data and it is only with the aid of modern reflection seismic data that its exact position can be determined (Plate 3.12). Lee (1988) also identified a residual gravity high underlying the Holme area some $15 \mathrm{kms}$ to the north of this fault. The regional seismic profile (Plate 3.12) confirms the Edale Gulf to comprise a halfgraben with the main bounding fault underlying the northern margin of the Derbyshire carbonate platform. The hangingwall dipslope rises northwards towards a footwall crest underlying the Holme area.

The Alport and Edale boreholes are the main currently released data on Dinantian sedimentation in the Edale basin. These were drilled on the Alport and Edale anticlines lying some $12 \mathrm{~km}$ and $3 \mathrm{~km}$ north of the Derbyshire carbonate platform. The Dinantian stratigraphy of these boreholes has been described by Hudson and Cotton (1945a \& b). More recently the Wessenden borehole has become available. It is located on the crest of the residual gravity high which marks the northern limit of the Edale Gulf. The Alport borehole was drilled on the southern flank of this anomaly and the Edale borehole occupies a location close to the footwall on which the Derbyshire carbonate platform is located. The Eyam borehole (Strank 1985) provides important control on the Dinantian stratigraphy on the southern footwall to the basin. 
During the Arundian to early Asbian (EC3/EC4), deposition within the Edale Gulf was on a carbonate ramp, dipping southwards towards the Derbyshire carbonate platform. Sedimentation was mainly by resedimented shallow water carbonates shed off the southern footwall and northern dipslope with the occasional deposition of peri-platform carbonates, basinal shales and volcaniclastic sediments. Carbonate mudmounds developed on the northern margin in the Chadian-early Holkerian (EC2). Sediments older than EC2 are interpreted to lie at the base of the Edale Gulf by analogy with other basins in northern England and the presence of EC1 continental facies in the Eyam borehole on the footwall to the gulf (Plate 3.12).

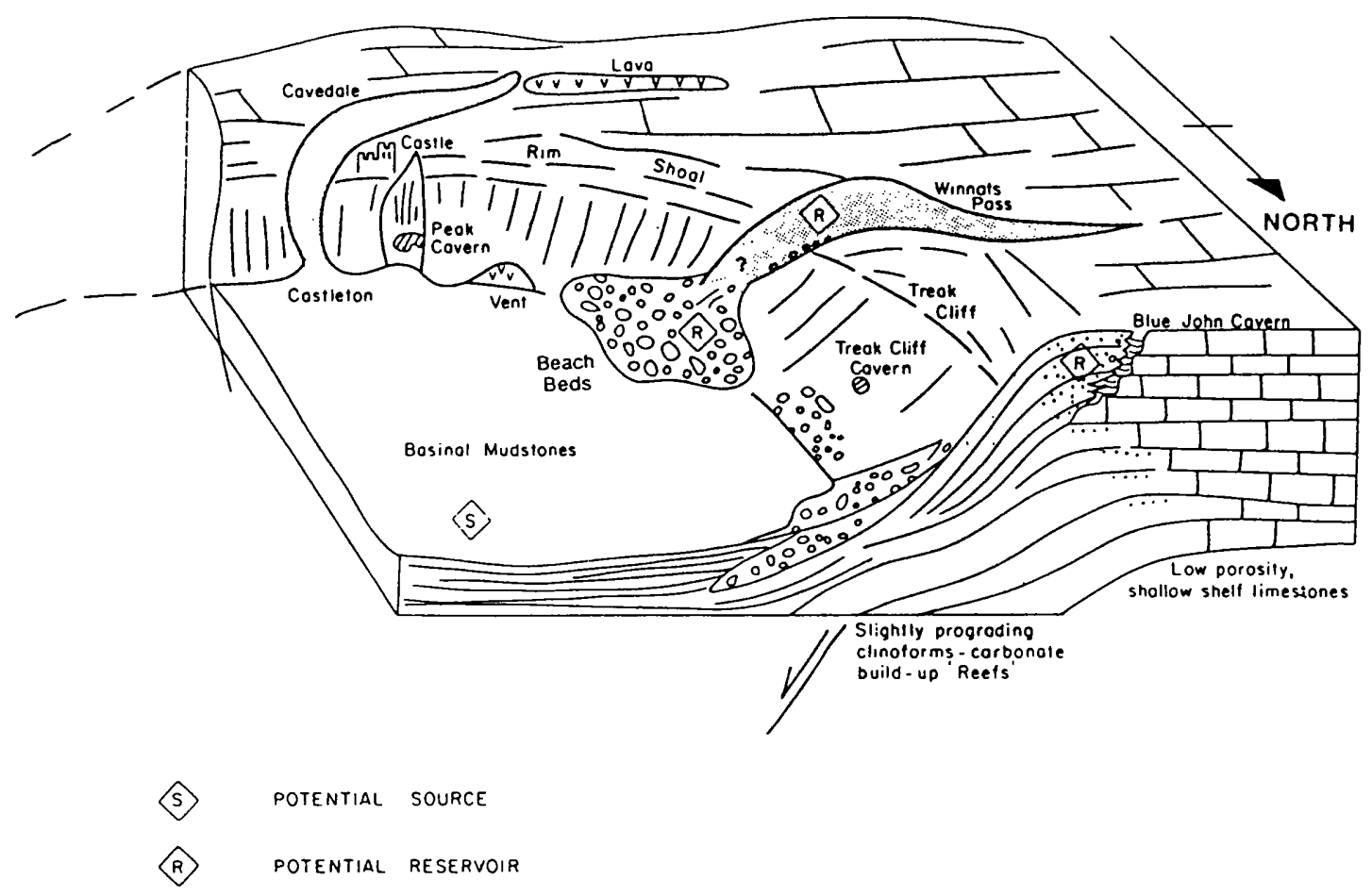

Figure 3.13 Example of an Asbian (EC4) rimmed shelf margin at Castleton, north Derbyshire Dome. 
The nearest Dinantian outcrop to the Edale Gulf is the Derbyshire carbonate platform, whose northern margin is exposed a few kilometres to the west of the regional seismic profile (Fig. 3.13). The evolution of the basin margin facies during the late Dinantian provides the context in which to evaluate the tectono-stratigraphic development of the Edale Gulf.

During the Asbian (EC4), the carbonate platform was fringed to the north by a high angle margin with depositional dips of up to 30 degrees towards the basin (Stevenson \& Gaunt 1971, Broadhurst and Simpson 1967, 1973). In the late Asbian and early Brigantian (EC5) a complex of coarse bioclastic grainstone shoals developed in association with the platform margin (Eden et al. 1964, Stevenson \& Gaunt 1971). These shoals comprise stacked large scale bedforms (Fig. 3.14) which prograded basinward in response to a rise in sea-level of some 20-25 metres at the onset of EC5 rifting (Gawthorpe and Gutteridge 1990). The presence of an angular unconformity in the late Asbian-early Brigantian of the Alport borehole suggests that the southern bounding fault of the Edale Gulf was active during EC5 rifting.

The 'Beach Beds' forms a distinctive unit of coarse bioclastic grainstone containing disarticulated and rounded carbonate debris onlapping the Asbian shelf margin at the base of Winnat's Pass near Castleton (Fig. 3.13) (Eden et al 1964, Stevenson and Gaunt 1971). Evidence from the Castleton borehole shows that the Beach Beds interfinger with and are overlain by basinal sediments (Stevenson and Gaunt 1971). Sedimentary structures within the Beach Beds suggest that they represent redeposited bioclastic limestones which were deposited as turbidites (Sadler 1964). The stratigraphic position of the Beach Beds suggests that they may be basinal equivalents of the late Asbian-early Brigantian (EC5) shelf margin bioclastic grainstone shoals encountered at the top of Winnat's Pass (Fig. 3.14). The Derbyshire carbonate platform was finally onlapped in the late Brigantian-early Namurian (LC1a) by basal sediments consisting of pro-delta Edale shales (Fig. 3.13). 


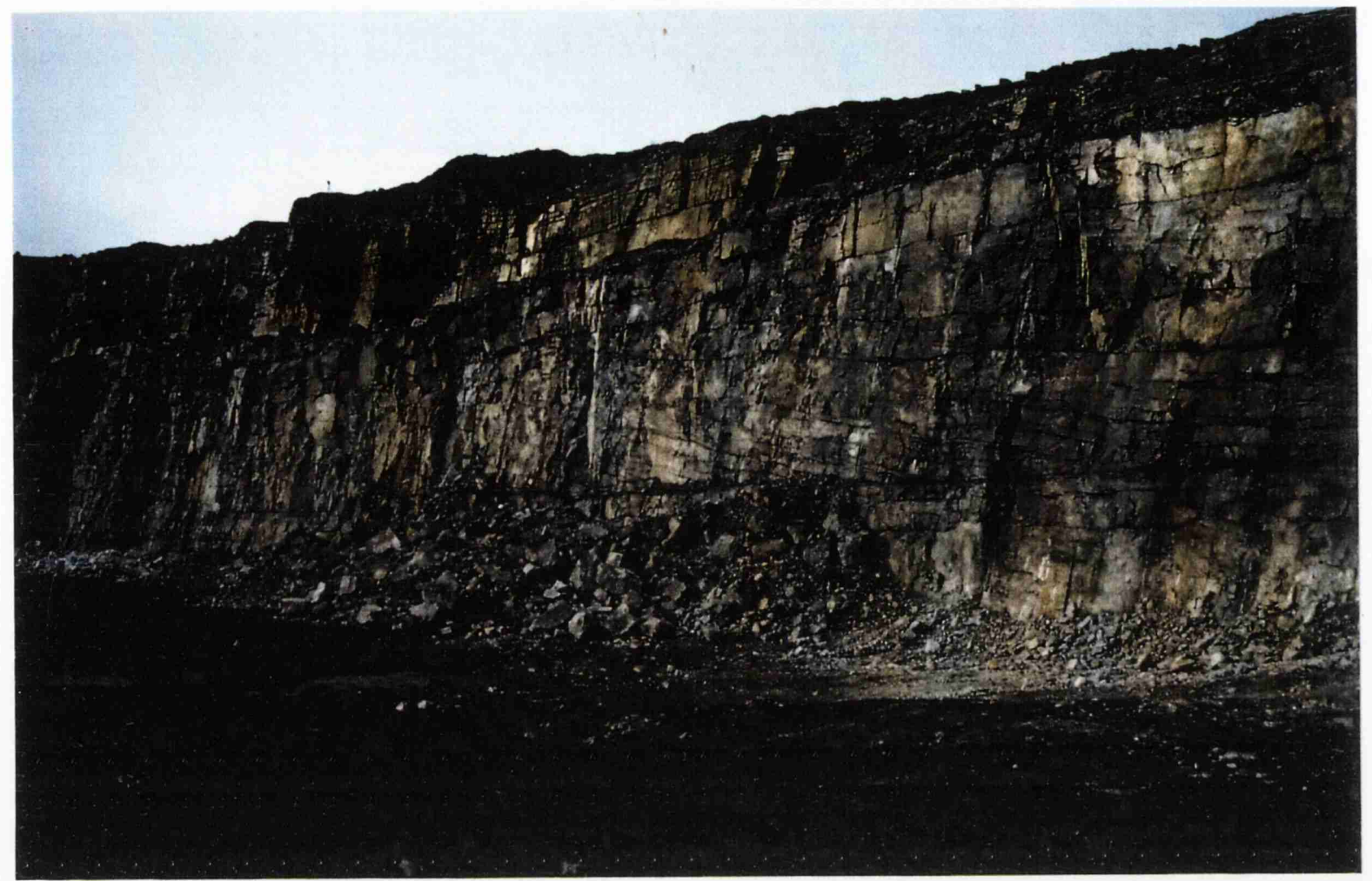

Figure 3.14. Northwest face of Hope Cement Works Quarry, Derbyshire (SK 159 820) showing progradational character of late Asbian-Brigantian (EC5) shoaling sequence. The series of convex-up clinoforms dip to the right (north) and downlap onto the underlying sequence, indicating northwards progradation towards the Edale Gulf. Height of clinoforms c. 10 metres.

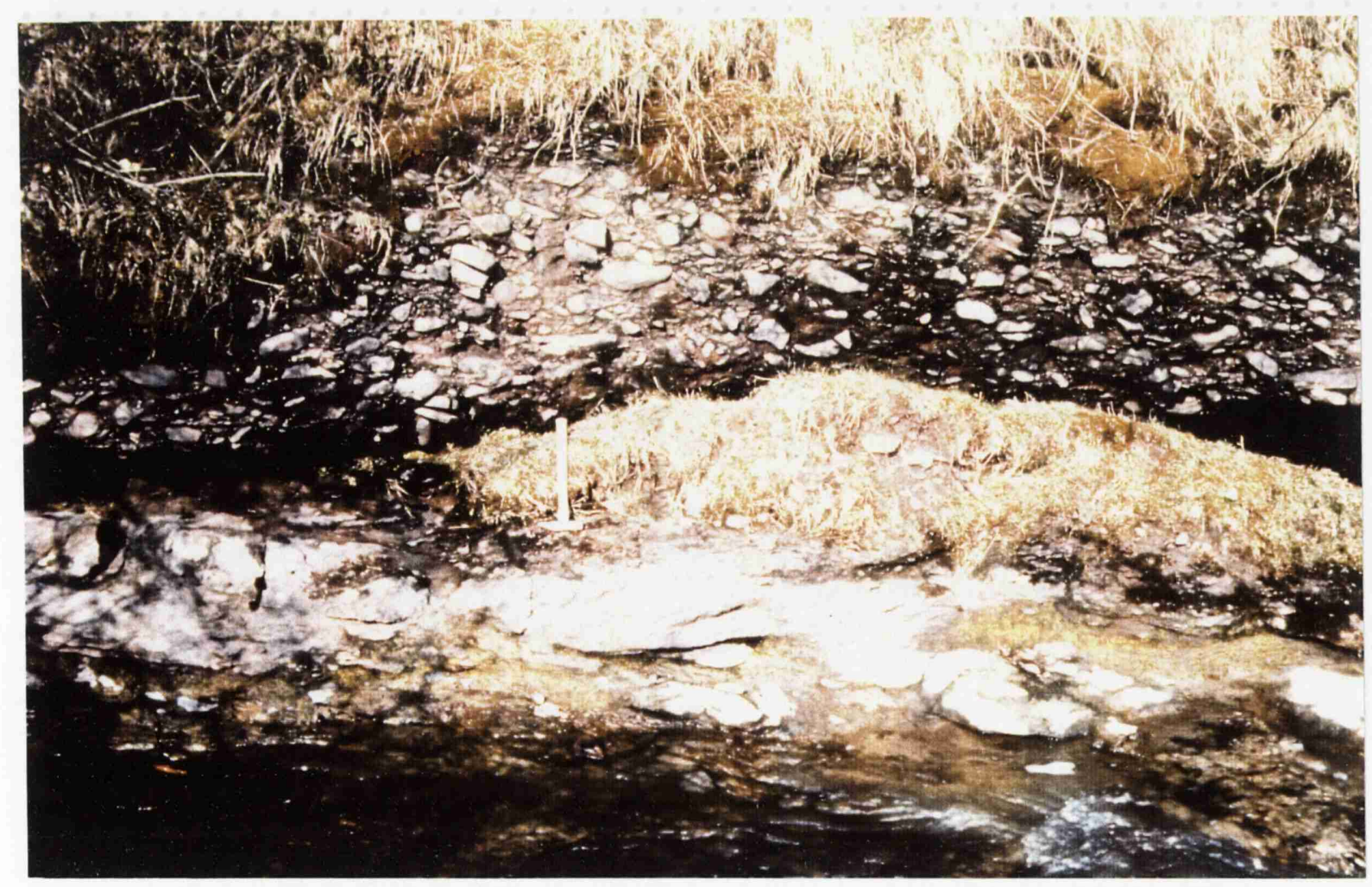

Figure 3.15. Early syn-rift conglomerates from the Cross Fell inlier (NY 753 214), western Stainmore (sequence EC1a). Hammer for scale. 
3.2.4 Tectono-stratigraphic evolution of the Bowland Basin

The Bowland Basin comprises a major NE-SW trending Dinantian half-graben. The basin underwent intense folding and uplift during the late Carboniferous Variscan inversion such that sediments of Courceyan age (EC1) are exposed at surface along the axis of the basin (Plate 3.14). More than $4 \mathrm{~km}$ of Dinantian sediments are indicated from the seismo-stratigraphic interpretation (Plates $3.13 \& 3.14$ ) and gravity modelling (Lee 1988). This contrasts with $500 \mathrm{~m}$ of shallow water carbonates proven by the Holme Chapel borehole on the footwall to the south (Ramsbottom 1974, Miller and Grayson 1982). These facies and thickness variations indicate a southern fault bounded basin margin situated at depth below the inversion related Pendle monocline (Plate 3.14). The northern margin of the basin is marked by facies and thickness changes on to the Bowland High (Lawrence et al. 1987) and the Askrigg Block (Tiddeman 1889, Hudson 1930).

Within the basin, basement has not been penetrated by any borehole to date, the oldest proven sediments being of Courceyan age (EC1b). These were penetrated by the Swinden borehole and comprise sub-wavebase argillaceous packstones deposited on the distal portion of a carbonate ramp (Gawthorpe et al. 1989). This general style of sedimentation continued into the Chadian (EC2; Chatburn and Thornton limestones). Thickness and facies variations indicate some degree of structural control which was inherited from earlier late Devonian-Courceyan (EC1) rifting. Waulsortian carbonate build-ups are often associated with the flanks of intra-basinal fault blocks (Miller and Grayson 1982, Lees and Miller 1985) which later formed the sites of major inversion features exposed at surface (eg. Clitheroe, Hetton-Eshton and Slaidburn anticlines (Harrison 1982, Arthurton 1984)).

As previously noted, the late Chadian-Holkerian (EC3) was marked by the rapid development of sea-floor topography indicated by thickness and facies differentiation 
across the basin (Gawthorpe 1987). These were associated with reactivation of the existing extensional faults and the development of local unconformities on the footwall crests of intra-basinal faults. The succession in the basin became dominated by mudstones (Worston Shales) with local developments of siliciclastic turbidites and sedimentary slides (Gawthorpe and Clemmey 1986). In addition $\mathrm{Pb}-\mathrm{Zn}$ mineralisation is associated with these events (Gawthorpe et al. 1989). The succeeding late Arundian to early Asbian sediments (EC4) show a progressive increase in carbonate sedimentation, culminating in the development of carbonate rimmed shelves on the Bowland High and Askrigg Block along the northern margin of the basin.

A further phase of tectonism occurred during the late Asbian to early Brigantian (EC5) (Gawthorpe 1986). This phase, which comprised several events, is characterised by major units of resedimented carbonate conglomerate, the common occurrence of soft sediment deformation features and major facies and thickness variations within the basin and across the northern basin margin. Background sedimentation became dominated by deep marine mudstone deposition (Bowland Shales) with influxes of coarse grained siliciclastic turbidites (mid-Brigantian Pendleside Sandstone). Facies distributions and thickness variations indicate southerly downthrow on the Middle Craven fault. However, slip reversal along this fault in the Brigantian is indicated by uplift and erosion of the carbonate mud mounds in the hangingwall depositional sequence (Mundy 1980).

Namurian and Westphalian strata are some $2 \mathrm{~km}$ thick in the syncline which separates the Pendle monocline from the Rosendale High (Lancashire coalfield) and about $1500 \mathrm{~m}$ in the Holme Chapel and Boulsworth boreholes (Plate 3.14). There is no direct evidence for original thicknesses over the central part of the basin, however it must have been in excess of the $2 \mathrm{~km}$ preserved in the Pendle monocline. Facies are typical Millstone Grits and Coal Measures pervasive over this part of the central Pennine Basin (see Chapter 4). 
To the west of the Bowland Basin later faulting has buried the Carboniferous under the Permo-Triassic cover of the Manx-Furness Basin (Plate 3.13). Nevertheless Carboniferous inversion and half-graben geometries are well imaged below a marked base Permian unconformity. The Permian rifting was effected on a series of new northsouth faults which were offset along the existing NE-SW faults which controlled the Dinantian infill of the basin. These NW-SE faults acted as transfer faults and moved in a sinistral strike slip sense forming large intra-basinal 'flower structures'(Plate 3.13).

\subsubsection{Tectono-stratigraphic evolution of the Leeds Basin}

The Leeds Basin (not previously described) forms a relatively minor, NE-SW trending half-graben which links the Edale Gulf and Cleveland Basin (Plates $2.4 \& 3.15$ ). The regional seismic profile (Plate 3.15) shows evidence of some $3 \mathrm{~km}$ of ?Upper Devonian and Dinantian sediments preserved in the basin. There is also evidence for a major intraDinantian unconformity in the area of the Aldfield borehole which may be related to either inversion or more probably footwall erosion in late Chadian-Holkerian (EC3) times as extension migrated to the northwest.

There is little borehole control on facies. The Aldfield borehole only penetrated the uppermost part of the late Dinantian (EC6) carbonates. Facies and stratigraphy have been interpreted by regional analogy and from seismic facies analysis, therefore a degree of uncertainty exists with the detail in the geological interpretation presented in Plate 3.13 .

\subsubsection{Tectono-stratigraphic evolution of the Cleveland Basin}

Moving north within the northern England rift system, seismo-stratigraphic interpretation becomes more problematic. Borehole and outcrop data indicate that, even in the

Dinantian, these basins are dominantly clastic filled. Clastics do not respond as well as 
the carbonates encountered to the south as 'thermometers' of the prevailing tectonic conditions. Equally, the syn-rift delta systems do not lend themselves to a simple seismo-stratigraphic interpretation. In the Cleveland Basin, which has been subjected to extensive Variscan inversion and wrench faulting, interpretation of the stratigraphy and facies would have been impossible in the absence of biostratigraphically calibrated recent borehole data.

The Cleveland Basin trends east-west (Plate 2.4) and is overlain for the most part by a thick Permian and Mesozoic cover which represents the onshore extension of the Sole Pit Trough (Kent 1975, Glennie and Boegner 1981, Van Hoorn 1987). The basin takes the form of two half-graben trends offset by a major intra-basinal transfer system (Plate 3.16). These transfer faults have been reactivated to form the loci for the later Mesozoic listric extensional faults which sole out within Permian Zechstein evaporites and laterally equivalent shales.

Up to $4 \mathrm{~km}$ of Dinantian strata are preserved in the basin. The early syn-rift fill (EC1) has not been penetrated by a borehole in the basin. Wedge shaped geometries are observed on seismic and deposition is interpreted as alluvial fan and fan-delta by analogy with contemporaneous rift systems elsewhere in northern England. In the deeper parts of the basin a major angular unconformity is observed, overlying the wedge shaped EC1 sequence, which may represent either the EC1/EC2 or EC2/EC3 sequence boundary (Plate 3.16).

The oldest Dinantian strata penetrated in two deep boreholes in the basin, High Hutton and Kirby Misperton-1, are of Holkerian age (EC3) and represent the deposits of deepwater clastic delta systems which progressively infilled the basin from the north throughout the later part of the Dinantian (Plate 2.6). 
Intense inversion and erosion in late Carboniferous, Variscan times has removed most of the Namurian and Westphalian sediments from the central part of the basin north of the Barton Fault forming a marked base Permian unconformity (Plate 3.16). Where preserved on the footwall of the Barton Fault, these deposits are up to $2500 \mathrm{~m}$ thick and are typical Millstone Grit and Coal Measures facies characteristic of the shallow water clastic delta systems encountered throughout the central Pennine Basin. The 2500 metres of Silesian sediments identified on the footwall represents a lower limit for the original thickness of Silesian post rift sediments which must have been deposited over the Cleveland Basin.

\subsubsection{Tectono-stratigraphic evolution of the Stainmore Trough}

The Stainmore Trough is a major east-west trending half-graben lying to the north of the Cleveland Basin. In the west it is separated from the Cleveland Basin by the eastwards extension of the Askrigg Block but probably merges with the Cleveland Basin towards the east to form a single basin in the offshore domain (Fig. 2.4). The major basin bounding faults in the north are the en echelon Lunedale, Wigglesworth and Butterknowle faults (Plates $3.17 \& 3.18$ ). The southern margin of the basin, which is not represented on the regional seismic data, must be fault bounded, probably along the line of the Stockdale disturbance (Collier 1989), because the northwards extrapolation of the sedimentary dips on the Askrigg Block fails to accommodate the thickness of Dinantian strata evidenced on the seismic to the north.

Previously published interpretations of the Stainmore Trough (George et al. 1976, Burgess and Holliday 1979) have been based on outcrop and shallow borehole data. The total thickness of Dinantian sediments has been consistently underestimated at 1.5 $\mathrm{km}$ (Johnson 1982) and $2.5 \mathrm{~km}$ (Bott et al. 1984) on the basis of outcrop and seismic refraction studies respectively. The availability of modern seismic data (Plates 3.17 and 3.18) has greatly improved our ability to interpret the scale and style of Dinantian 
sedimentation within the Stainmore Trough. The geological interpretation of the seismic data has been constrained by cross-ties to surface outcrop and the deep Seal Sands borehole.

To the south of the Lunedale-Wigglesworth-Butterknowle faulted margin up to about 6 $\mathrm{km}$ of Dinantian sediment are evidenced on regional seismic sections (Plates 3.17 and 3.18). There is no well penetration beneath the Chadian/Arundian (EC3). The timing of rift initiation can therefore be estimated only from the regional setting of the basin. By analogy with neighbouring rift basins such as the Northumberland Trough (Leeder 1974) and the Bowland Basin (Gawthorpe 1986) the age of the earliest basin-fill sediments is interpreted to be late Devonian-Courceyan. (Plate 2.7) The nearest outcrops of early Dinantian strata occur around Ravenstonedale to the west. The basement Beds are locally derived fluvial siliciclastic facies (Kimber \& Johnston 1986). Rapid local thickness changes and facies variations are related to local valley-fill processes and to movements on growth faults such as the Swindale Beck Fault (Burgess \& Harrison 1967, Burgess \& Holliday 1979). At Ravenstonedale the Pinskey Gill Formation (Courceyan) which was deposited in a nearshore environment, rests directly upon the Lower Palaeozoic basement and is overlain by coarse siliciclastics of alluvial fan origin (Gawthorpe et al. 1989).

An early Courceyan-Arundian (EC1-EC3) rift sequence is picked from 1.3-2.5 seconds two-way-travel time, which converts to a sedimentary thickness of about $4000 \mathrm{~m}$. The lower part of the sequence (EC1) includes downlapping clinoforms located against the northern basin bounding faults. The clinoforms are imaged on adjacent seismic lines and describe fan bodies of up to $4 \mathrm{~km}$ in diameter. These are interpreted as representing footwall-derived alluvial fan, fan delta or possibly submarine fan coarse clastic bodies, probably onlapped by marine and/or lacustrine fines. The onlap of these features by several seismic reflectors suggests that the depositional height (top set to bottom set) of some of these bodies may have been as much as $500 \mathrm{~m}$. Active rifting is therefore 
inferred to have taken place during late Devonian-Couceyan (EC1) times to generate the fault scarp and basin topography necessary to accommodate fan geometries of this scale. Within the basinal sediments of this suspected early rift sequence a number of continuous high amplitude reflectors are observed (Plate 3.18). These may represent reflections from high velocity units such as carbonates, volcanics or evaporites. Data from outcrop on the Ravenstonedale Shelf to the west where shallow water carbonates such as the Scandal Beck Limestones are encountered suggest that the high amplitude reflectors most likely represent the basinal equivalent of these carbonates. An alternative interpretation based on analogy with the Northumberland Basin to the north, where basal, early rift volcanic rocks are seen at outcrop (Gawthorpe et al. 1989), could suggest that the strong seismic events represent a limited input of early, syn-rift volcanics to the basin.

Shallow water carbonates dominate the Arundian to early Asbian (EC3 sequence) on the Ravenstonedale and Askrigg highs to the west and south. These carbonates are interbedded with limited thicknesses (about $15 \mathrm{~m}$ ) of fluvio-deltaic and shallow marine Ashfell Sandstones. Within the Stainmore Trough, the seismic character of the basinal equivalents of the Ashfell Sandstone and the upper parts of the Ravenstonedale Limestone show reflectors of varying continuity and amplitude. Up to $2.5 \mathrm{~km}$ of mudstones and sandstones with occasional thin carbonates are ascribed to this stratigraphic interval in the basin, similar to the succession penetrated between $2000 \mathrm{~m}$ and TD $(4170 \mathrm{~m})$ in the Seal Sands borehole. There appears to have been only minor onlap of the Ashfell Sandstones onto the Askrigg block and the Ravenstonedale Shelf suggesting that a subsidence differential between the basin and surrounding footwall blocks continued through this episode of deposition, ie. rifting was active throughout the late Chadian-Holkerian (EC3) in the Stainmore Trough.

Close inspection of the seismic data (Plate 3.18) indicates the presence of sigmoidal clinoforms which appear to prograde southwards from the northern basin margin within the Ashfell equivalent depositional sequence (EC3). Collier (1991) has interpreted these 
reflectors as representing a carbonate-rimmed shelf development. However, as we have seen in the Widmerpool Gulf and Gainsborough Trough, carbonate margins associated with active footwalls are characterised by high-angle clinoforms. The low-angle clinoforms observed in the hangingwall of the Wigglesworth Fault are more likely to represent clastic delta progradation, as the Ashfell Delta infilled bathymetric relief within the Stainmore Trough.

Faulting during EC3 produced tilting and onlap geometries onto intra-basinal fault blocks. The subsequent unconformities, imaged in seismic sections, are overlain by the Holkerian Hillbeck Limestone formation equivalents. This interval is characterised by a package of laterally extensive high-amplitude reflectors (Plates 3.17 and 3.18). These are interpreted as a kilometre-thick interval of inter-bedded carbonates and shales, a hypothesis confirmed by borehole data from Seal Sands-1. This substantial thickness of Holkerian strata in the basin compares to only $30 \mathrm{~m}$ on the Alston Block to the north, supporting the seismic observation of active extensional faulting continuing during the latter part of the EC3 sequence.

The EC3/EC4 sequence boundary is marked in the Stainmore Trough by an angular unconformity in the hangingwall of the main basin-bounding fault (Plate 3.18) This unconformity may be indicative of a previously unrecognised late Holkerian basin inversion event which coincides with the cessation of EC3 rifting. Holkerian-lower Asbian siltstones with occasional limestones and sandstone bodies are recorded around the EC3/EC4 sequence boundary in the Seal Sands-1 borehole. Thin coal seams are also recorded within this sequence, suggesting a similar facies association to the time equivalent Scremerston coal group in the Northumberland Basin (Fowler 1926). In contrast, no terrigenous Scremerston equivalents have been identified on the highs around the Stainmore Trough. This anomaly seems to coincide with the apparent absence of the early Asbian on the Alston Block (Burgess \& Holliday 1979). The equivalent basinal sequence reaches $300 \mathrm{~m}$ in thickness and onlaps and pinches out onto 
the erosional unconformity which forms the EC3/EC4 boundary along the northern margin of the basin (Plate 3.18). This is interpreted as further evidence of structural inversion (tectonic uplift) of the Alston block and northern parts of the Stainmore Trough at the end of EC3.

The late Holkerian-mid Asbian (EC4) sequence is marked by the continuous and widespread Melmerby Scar/Great Scar Limestone and its southerly equivalents (Burgess and Mitchell 1976, Wilson \& Cornwell 1982). This limestone marks a regional transgression over both the basin and surrounding footwall blocks. A regional relative base-level rise is indicated resulting from thermal subsidence in a period of rift inactivity and low sediment influx, following late Holkerian (end EC3) uplift. There is a variation in seismic facies of the Melmerby/Great Scar reflector across the Alston Block margin into the basin (Plates 3.17 \& 3.18). The thick $(35-50 \mathrm{~m}$ ) limestone over the Alston Block, confirmed in outcrop and in boreholes (Woolacott 1923, Dunham et al. 1965), is interpreted to thin into the basin south and east of the Butterknowle and Wigglesworth faults, where it is represented by single high amplitude event. Over intra-basinal highs, stacked high amplitude events are evidence of the sequence thickening in these areas. These reflectors onlap and overlie the previously rotated EC3 tilt block structures (Plates $3.17 \& 3.18)$.

The late Asbian-Brigantian Alston group (sequence EC5), which overlies the Great Scar Limestone, increases in thickness into the basin from $450 \mathrm{~m}$ to $700 \mathrm{~m}$ across the Wigglesworth fault. These deposits are widely exposed in the western parts of Stainmore and form the Yoredale shallow marine to fluvio-deltaic cyclothems (Burgess and Mitchell 1976, Leeder \& Strudwick 1987). Renewed tectonic subsidence during EC5 is invoked to explain this southwards thickening.

The late Asbian-Brigantian Yoredale sequence (Plate 2.7) includes a variety of fluviodeltaic and shallow marine sandstone bodies (Strudwick 1987). Individual Yoredale 
cyclothems are too thin to be resolved as separate reflections or packets of reflections on the regional seismic data. The overlying Namurian and Westphalian sediments, exposed at surface and encountered in boreholes such as Seal Sands-1, comprise a typical sequence of shallow water clastic delta deposits with increasing coal seams towards the top.

\subsubsection{Tectono-stratigraphic evolution of the Northumberland Trough-Solway Basin}

The Northumberland Trough-Solway Basin forms a major NE-SW trending half-graben bounded to the north by the Southern Uplands and to the south by the Alston Block and Lake District Massif (Plates 3.19 and 3.20). Geological relationships (Johnson 1984) and Bouguer anomaly data (Plate 1.9) suggest that a basement high partly separates the western end of the Northumberland Trough from the Solway Basin, across which the basin appears to flip polarity.

The Northumberland Trough is controlled by a major boundary fault in the south defined by the surface expression of the Stublick-Ninety Fathom fault (Plate 2.4). The Solway Basin is controlled in the north by the major fault separating it from the Southern Uplands (Tarras fault and equivalents, Johnson 1984). Comparison of the successions in the Northumberland and Solway basins suggests that subsidence and sedimentation were largely synchronous at least during the Dinantian (Johnson 1984). The exposed sequences are very similar between the two basins except for facies changes associated with better developed marine conditions towards the south-west. Lack of exposure of the lower part of the Dinantian sequence in the centre of each basin previously prevented a full comparison of the thickness of Dinantian strata. The regional seismic data confirms that both basins underwent similar amounts of Dinantian extension with some 4-5 km of early Carboniferous sediments deposited in the central parts of the basins (Plates $3.19 \& 3.20)$. 
Although the simple view of the basin as a half-graben (Leeder 1974,1982) has been confirmed by seismic reflection data (Plate 3.20) it should be noted that the inferred southern bounding extensional faults evidenced at surface are Permian or younger in origin (Leeder et al. 1989). They are believed to overlie, or nucleate upon buried syndepositional structures present at depth below the post-rift thermal subsidence fill, similar to structures noted in the Cleveland basin to the south.

Rifting began during the late Devonian-Courceyan (EC1) with the eruption of the alkaline basaltic Birrenswark/Kelso/Cockermouth lavas, represented by a series of high amplitude reflectors on the regional seismic profile (Plate 3.20 ). Early syn-rift sedimentation was dominated by influxes of mature fluvial siliciclastic detritus from the Southern Uplands interbedded with the widespread Cementstone facies of fluviolacustrine origin (Leeder 1974) forming the Lower Border Group and its correlatives. Regional seismic reflection data across the Northumberland Trough indicates an extremely thick Lower Border Group (EC1 sequence) in the hangingwall of the StublickNinety Fathom fault system (Plate 3.20).

The Courceyan-Chadian (EC1/EC2) Lower Border Group of Bewcastle and Liddesdale comprises numerous peritidal carbonate and clastic deltaic cycles formed by the periodic advance of constructive lobate deltas from the northeast (Leeder 1974, Leeder et al. 1989). On regional seismic data these facies are represented by a series of stacked, laterally continuous, high amplitude reflectors, thought to reflect the interbedded nature of the interval (Plate 3.20).

The diachronous advance of a major axial braided fluvial system, also from the northeast, is recorded in the Arundian to Holkerian Middle Border Group (Sequence EC3). On seismic data the sequence has a characteristic wedge shaped geometry, thickening to the north in the Northumberland Trough suggesting that basin polarity switched between EC1 and EC3 rifting (Plate 3.20). Conversely the EC3 sequence appears to thicken into 
the southern bounding fault of the Solway Basin (Plate 3.19). Outcrop studies confirm the presence of syn-depositional tectonic controls on the alluvial architecture in the central intra-basin lows defined by the Antonstown and Beckhead/Binky Linns faults (Day 1970, Leeder 1987b). The resulting multi-storey sand body (Hodgson 1978) splits and intercalates with marine facies to the southwest (Day 1970), although the Thirlstane Sandstone, a suspected correlative to the southwest, retains its fluvial signature into the Solway Basin (Ord et al. 1988).

The Asbian Upper Border Group (Sequence EC5) is composed of Yoredale-type cycles in south-western areas (Lumsden et al. 1967) but in the central intra-basin lows around Bewcastle and Bellingham (Day 1970, Frost \& Holliday 1980) an abnormal thickness of some $2000 \mathrm{~m}$ comprising clastic deltaic facies is found, again deposited as axial drainage systems derived from the northeast (Leeder 1987b, Leeder et al. 1989). In Berwickshire and northeast Northumberland the equivalent Scremerston Coal Group is very much thinner and largely composed of delta top of fluviatile facies with numerous thick coals generating some of the high amplitude reflectors evidenced on the seismic data. There is little evidence for this late Dinantian (EC5) rifting event on the regional seismic data for the Northumberland-Solway Basin (Plates 3.19 and 3.20).

During the late Asbian, deltaic cycles of Yoredale type were deposited over the whole basin. These conditions continued into the Brigantian (EC5-EC6) when some increase of cycle thickness from the Alston footwall into the basin suggests continued differential subsidence during EC5 times. However, this is relatively minor and is insufficient to be recognised clearly on the regional seismic data.

The Namurian-Westphalian (LC1-LC2) post-rift fill of the basin was characterised by further Yoredale type, Millstone Grit and Coal Measures sedimentation; the latter described by Haszeldine (1981). The Upper Carboniferous succession shows marked differences between the Northumberland and Solway Basins. Not only are there marked 
changes in the thickness of deposits but there appear to have been differences in the duration of phases of subsidence and inversion/erosion (Johnson 1984). Slower subsidence and deposition in the Solway Basin as compared to the Northumberland Trough in the Namurian was compensated by continued subsidence well into the Westphalian ' $D$ ' (sequence V1) with the formation of a thick red-beds succession

The basin was subject to intense inversion in the late Carboniferous (Robson 1980). This has resulted in the removal of Upper Carboniferous sediments from most of the Northumberland Trough (Plate 3.20) and the generation of a marked angular unconformity at the base of the Permian in the Solway Basin (Plate 3.19). Central and south-eastern parts of the basin are characterised by open folds striking approximately north-south. Around the northern and western margins asymmetric anticlines with steep west-facing limbs are often reverse faulted eg. the Bewcastle anticline. Normal displacements of Permian strata on faults such as the Ninety Fathom reflect renewed extensional faulting in the Permo-Triassic (Plate 3.19).

\subsection{TECTONO-STRATIGRAPHIC SUMMARY}

The Variscan plate cycle can be divided into syn-rift, post-rift and inversion megasequences (Plate 3.21). These describe a late Devonian-Dinantian rift controlled subsidence, a Namurian-Westphalian thermally driven subsidence and a late Westphalian to early Permian inversion or foreland basin phase. These can in turn be broken down into a series of depositional cycles or tectono-sequences which describe the late Devonian-Carboniferous fill of the basins. 


\subsubsection{Syn-rift megasequence (late Devonian - early Brigantian)}

The syn-rift megasequence exhibits a characteristic wedge shaped geometry which is exemplified by a four-fold increase in sediment thickness across the major basin bounding faults of half-graben such as the Gainsborough Trough, Bowland Basin and Stainmore Trough (Plates 3.6, $3.14 \&$ 3.17). Isopachs for the upper part of this megasequence show the thickest sections to be confined to the individual fault bounded half-graben (Plate 2.9).

Two main syn-rift depositional systems can be identified (Plate 2.7); i) clastic fluviodeltaic and ii) carbonate platforms. During the syn-rift phase, tectonic subsidence generally exceeded the rate of sediment supply to the basins and the clastic deltas remained confined to the north of the region. As a consequence, the south of the area became sediment starved and carbonates accumulated on the platform areas with the development of carbonate rimmed shelf margins on both the footwall crests and hangingwall dipslopes of the deeper basinal areas (Fig. 3.4) The half-graben were themselves infilled by predominantly fine grained, hemipelagic, clastic deposits.

Sequence EC1 (late Devonian-early Chadian). Syn-rift I. This sequence is typified by fault controlled subsidence and represents the initial development of rifted half-graben in northern England. The sequence shows a characteristic wedge shaped geometry thickening into border faults. Poor seismic resolution precludes the identification of rotated onlaps which would confirm the active syn-rift origin of this sequence. The base shows a progressive onlap onto Lower Palaeozoic basement of the hangingwall dipslope. The top of the sequence is marked by a laterally continuous high-amplitude reflector. The internal character is typically low amplitude, laterally discontinuous events. 
The initial syn-rift clastics ('Old Red Sandstone' facies) are poorly exposed at surface and are generally of local derivation, related to valley-fill processes (Fig. 3.15). By analogy with other desert rift basins (Leeder \& Gawthorpe 1987) downlapping alluvial fan and fan-delta depositional systems are likely to be derived laterally from the footwall and hangingwall basin margins. The early syn-rift clastics proven by the Eakring-146 well (Falcon \& Kent 1960) and the Whita and Annan Sandstones in the Northumberland Basin (Leeder 1974) represent examples of localised footwall-derived, and more sheetlike hangingwall-derived fan systems respectively .

The upper part of the sequence is characterised by onlap of the pre-rift sediments by carbonates and evaporites following the initial marine transgression into the rift system during the Courceyan (Fig. 3.16). The sparse well penetration and poor seismic resolution of this sequence precludes any further breakdown of this interval at present.

Sequence EC2 (mid-late Chadian). Post-rift I. This sequence is represented by a still stand or regressive phase characterised by carbonate ramp to rimmed shelf development typified by the presence of shallow water carbonate grainstone shoals (Fig. 3.17). The sequence comprises high amplitude, laterally persistent reflectors which thicken up-dip along the hangingwall dipslope where hummocky downlapping clinoforms are identified (eg. Plate 3.4). In the Bowland Basin, the sediment fill at this time is dominated by clean carbonate facies with shallow ramp grainstone shoals high on the hangingwall dipslope passing southward into deeper water wackestones/packstones towards the Pendle fault. Waulsortian build-ups are well developed in these deeper ramp environments. The grainstone shoals developed in this sequence may constitute viable reservoir targets when affected by burial dolomitisation and dissolution (Fig. 3.18).

Sequence EC3 (Arundian-early Holkerian). Syn-rift II. This sequence is characterised by the reactivation of extensional faults causing fault block rotation and significant footwall erosion. The onset of the sequence is marked by the development of boulder 


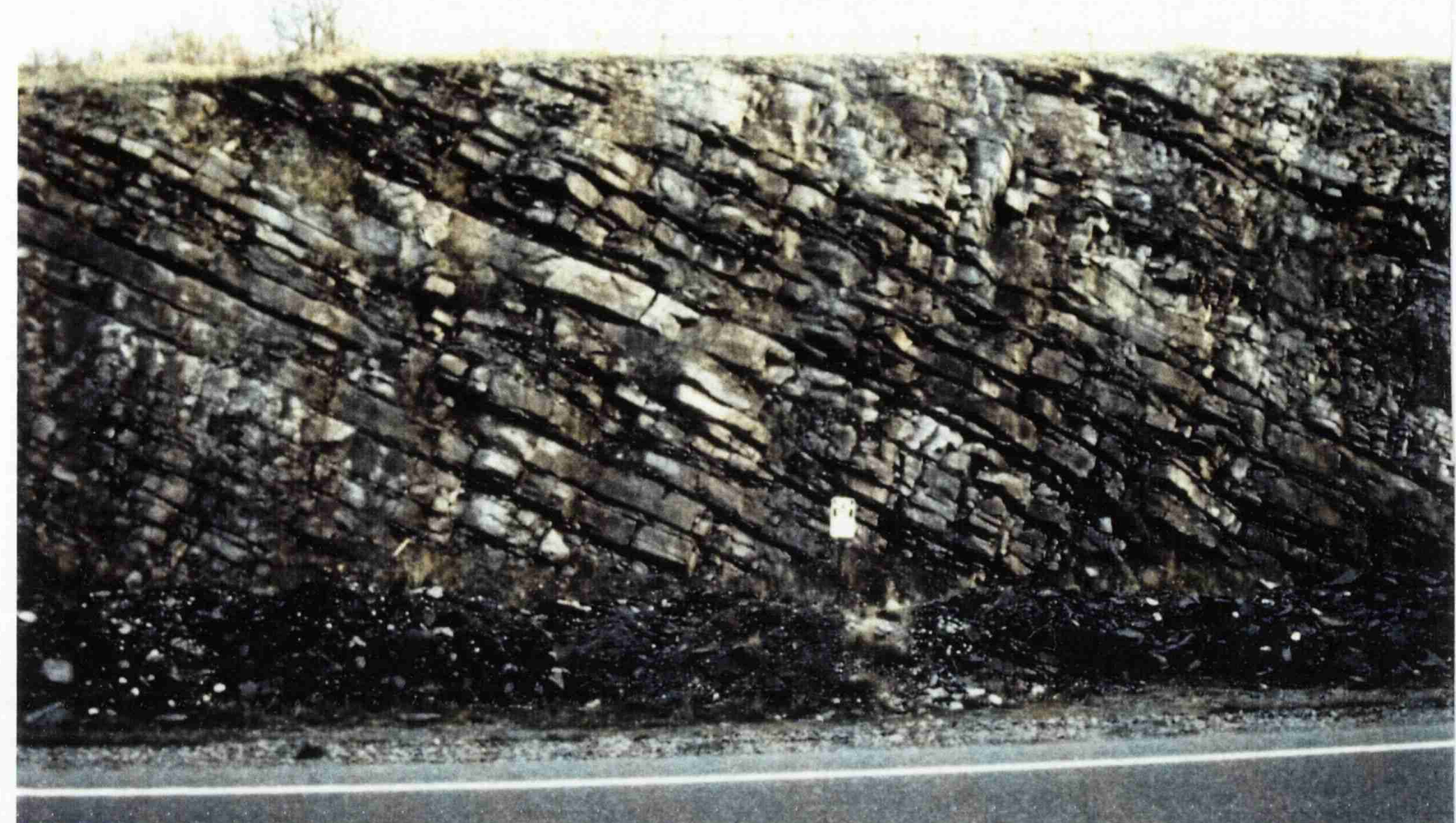

Figure 3.16. Chatburn Limestone (sequence EC1b), Chatburn road cut on the A59

(SD 774 442). Example of ramp carbonates developed following the initial marine transgression into the syn-rift. Exposure is c. 10 metres in height.

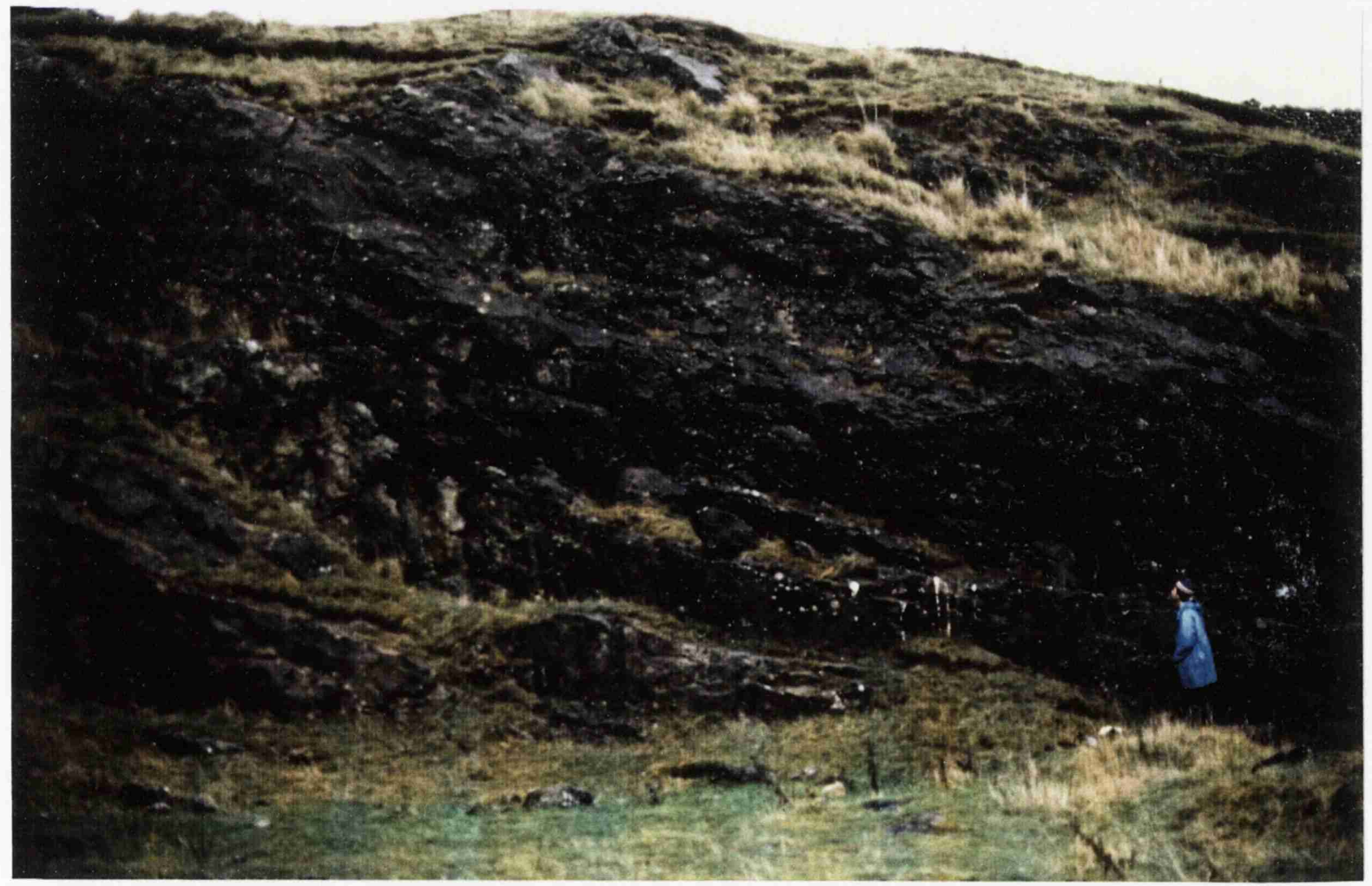

Figure 3.17. Thornton Limestone (sequence EC2), Scrosthorpe Lane Quarry (SD 890 598). Shallow ramp grainstone shoals developed on the upper part of the hangingwall dipslope. Person for scale. 
beds and slumps (event deposits; see Gawthorpe and Clemmey 1985, Gawthorpe et al. 1989) in the hangingwall and the rapid drowning of carbonate shelf margins in the East Midlands and Bowland as carbonate production was unable to keep pace with sea level rise. In the north of the province the Fell and Ashfell fluvio-deltaic systems were deposited in the Northumberland Basin and Stainmore Trough respectively during this period. The progressive onlap of the pre-Arundian topography culminated in the maximum transgression of carbonate platforms in northem England during the Holkerian (Strank 1987). The sequence shows a characteristic wedge shaped geometry and represents the most significant rift pulse, in terms of time and thickness, developed during the syn-rift megasequence. The base of the sequence typically shows a progressive onlap onto the underlying EC2 sequence.

Figure 3.19 shows large boulders of proximal ramp and Waulsortian carbonates derived from footwall erosion of the South Craven fault system at the onset of EC3 rifting. These were deposited contemporaneously with and overlain by the Worston Shale Formation, a predominantly mud and silt grade clastic deposit with thinly interbedded hemipelagics and distal calciturbidites, which forms EC3 in the Bowland Basin (Fig. 3.20). During the rifting phase periodic instability of the hangingwall dipslope led to the generation of syn-sedimentary slumps and slides in sediments of EC3 age (Fig. 3.21).

Sequence EC4 (late Holkerian - mid Asbian). Post rift II. This second still stand or regressive phase is characterised by carbonate ramp to rimmed shelf development in the East Midlands and Bowland basin. Here the sequence shows a marked thickening onto shelf areas (Plates $3.2 \&$ 3.14). On seismic data, EC4 comprises high-amplitude, lowfrequency laterally continuous reflectors in the basinal setting. Along fault scarps the sequence comprises high-amplitude, low-frequency, high angle reflectors which represent vertically and laterally accreting clinoforms. Along the hangingwall dipslope the sequence is largely characterless but in places high-amplitude, low-frequency downlapping clinoforms are identified prograding basinwards onto EC3. A sub-EC4 


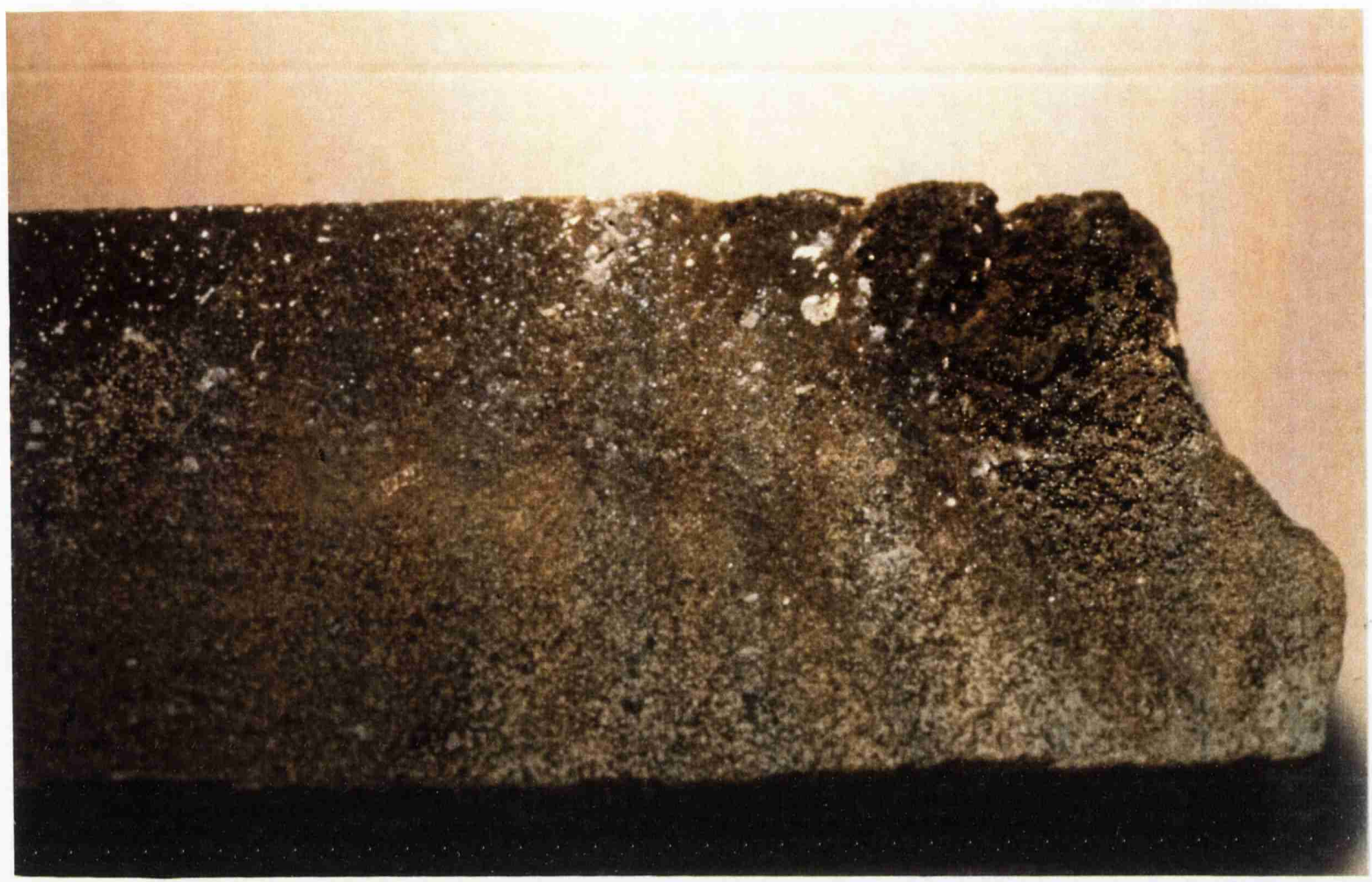

Figure 3.18. Thornton Limestone (sequence EC2) from the High Ings Barn borehole (SD 8867 6031), Airton anticline, Bowland Basin. Porosity development in grainstone facies following burial dolomitisation and dissolution. An excellent reservoir facies seldom considered as an exploration target in the Carboniferous of northern England. Core diameter is $5 \mathrm{~cm}$.

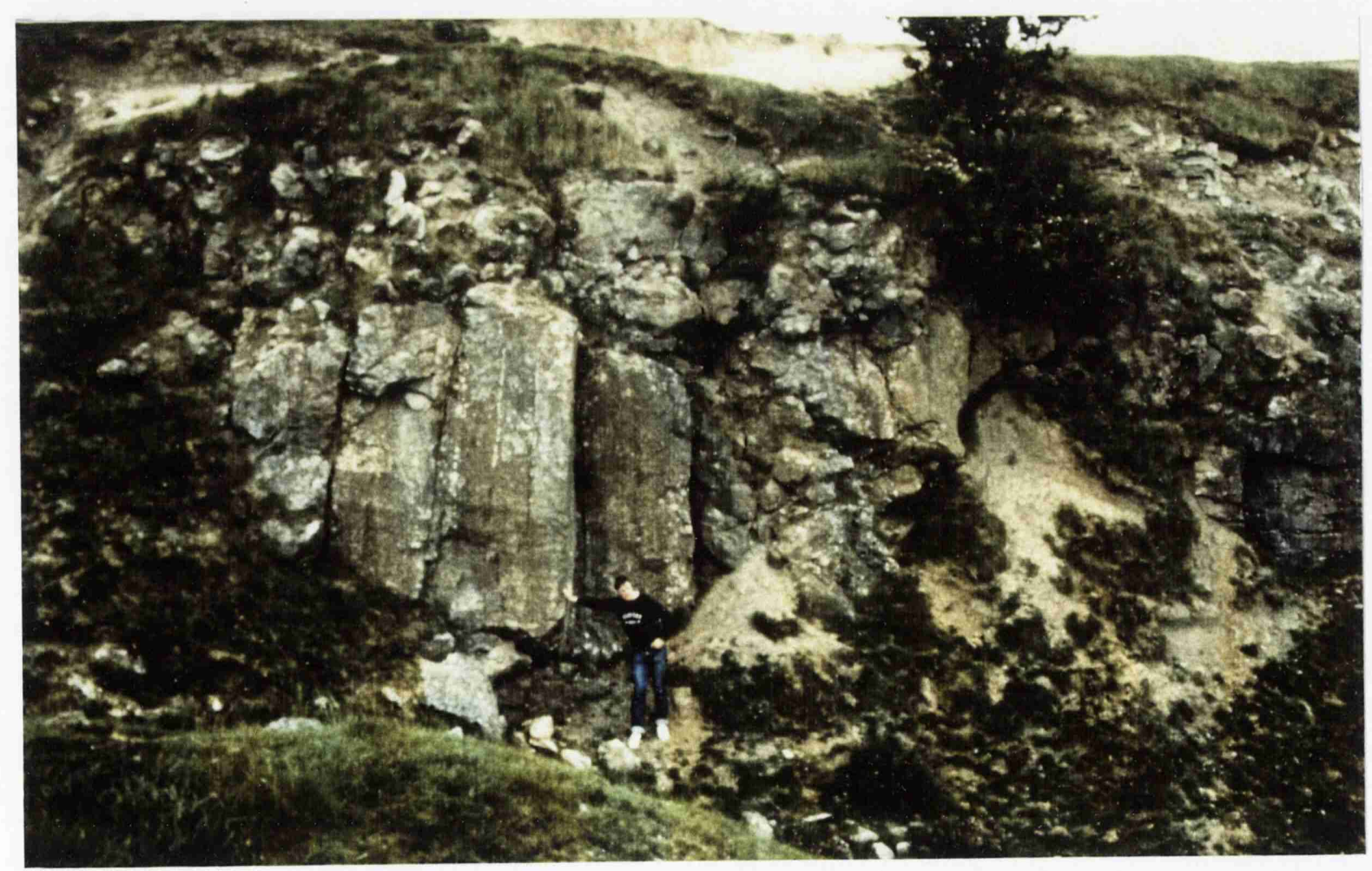

Figure 3.19. Haw Crag (sequence EC3) northern Bowland (SD 914 564); Boulders of proximal ramp and Waulsortian mud mound carbonates derived from footwall erosion along the south Craven fault system at the onset of EC3 rifting. Person for scale. 


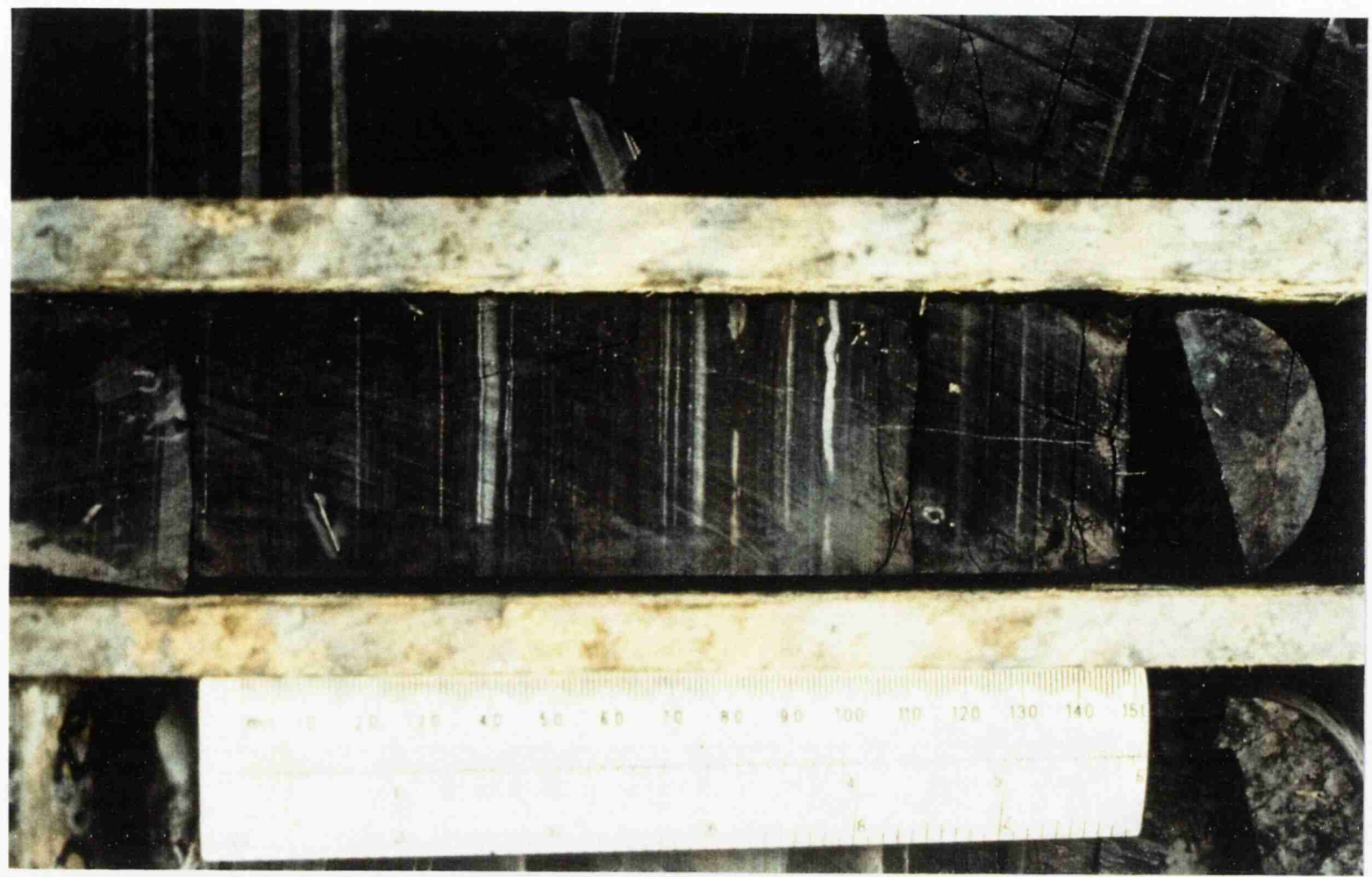

Figure 3.20. Worston Shale, BP Minerals borehole MHD-3 (SD 683 462), southern

Bowland High (sequence EC3). Typical syn-rift basinal deposits comprising thinly bedded hemipelagic mudstones and distal calciturbidites.

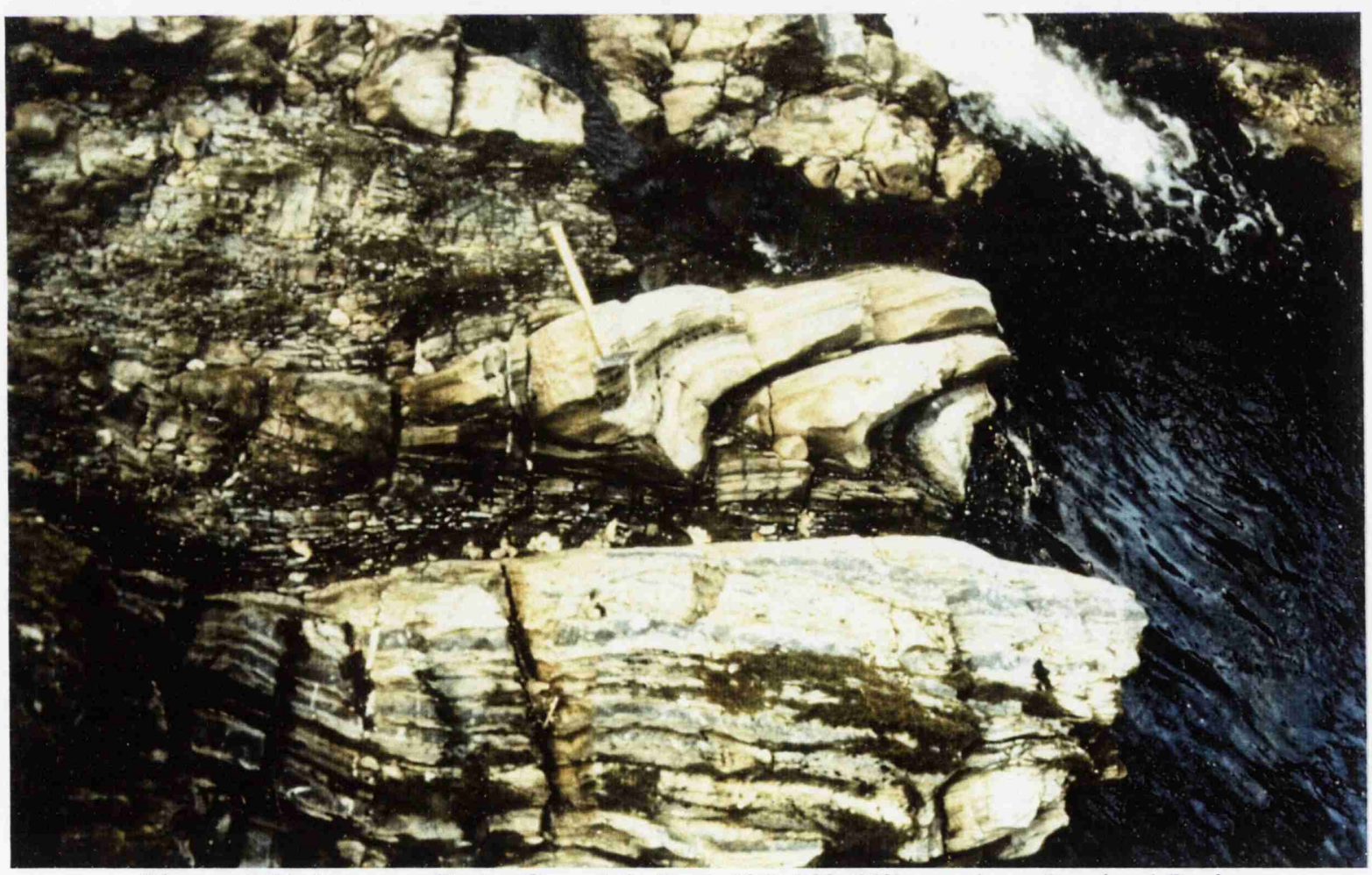

Figure 3.21. Worston Shale Croasdale Beck (SD 702 550), northern Bowland Basin

(sequence EC3). Syn-sedimentary slumps and folds in interbedded hemipelagics and distal calciturbidites generated by slope instability during EC3 rifting. Hammer for scale. 
unconformity evidenced on seismic in Stainmore may be indicative of a late Holkerian basin inversion event perhaps coincident with the cessation of EC3 rifting. A similar angular unconformity has also been identified in the Widmerpool Gulf. Backstripping of the Widmerpool Gulf regional section suggests the development of a long wavelength basin scale inversion at this time (Plate 2.8).

In areas of shallow water, starved of siliciclastic sediment, shoaling upward cyclic shelf carbonates were deposited; for example the Great Scar Limestone and equivalents in western Stainmore and on the Alston and Askrigg blocks (Fig. 3.22). In the East Midlands and Bowland, these shelf carbonates pass basinwards through platform margin facies (Fig. 3.23) into hemipelagic lime mudstones and calciturbidites of the foreslope (Fig. 3.24). This carbonate slope facies association shows a coarsening upward trend reflecting progradation of the rimmed shelf.

Sequence EC5 (late Asbian - early Brigantian). Syn-rift III. This sequence is characterised by reactivation of the extensional fault regime with significant backstepping of the fault system in the Widmerpool Gulf where sequence EC5 is well developed. By comparison, extension was milder during this phase in the Gainsborough Trough (compare Plates 3.4 and 3.6). Elsewhere in the East Midlands and Bowland the extensive EC4 carbonate margins were drowned. Renewed footwall rotation resulted in strong erosional unconformities on the footwalls of the Hoton fault (Widmerpool Gulf) and Craven fault (Bowland Basin) and the development of boulder beds and slumps in hangingwall settings. On seismic, the sequence exhibits the characteristic wedge-shaped geometry typical of syn-rift packages. Internally the sequence comprises low-amplitude, high-frequency reflectors which progressively onlap the hangingwall dipslope.

Volcanics related to the renewed extensional activity during EC5 (late Asbian to earliest Brigantian age) have been described from outcrop in Derbyshire; Lower and Upper Millers Dale lavas (Walkden 1977, Walters \& Ineson 1981, Macdonald et al, 1984). 


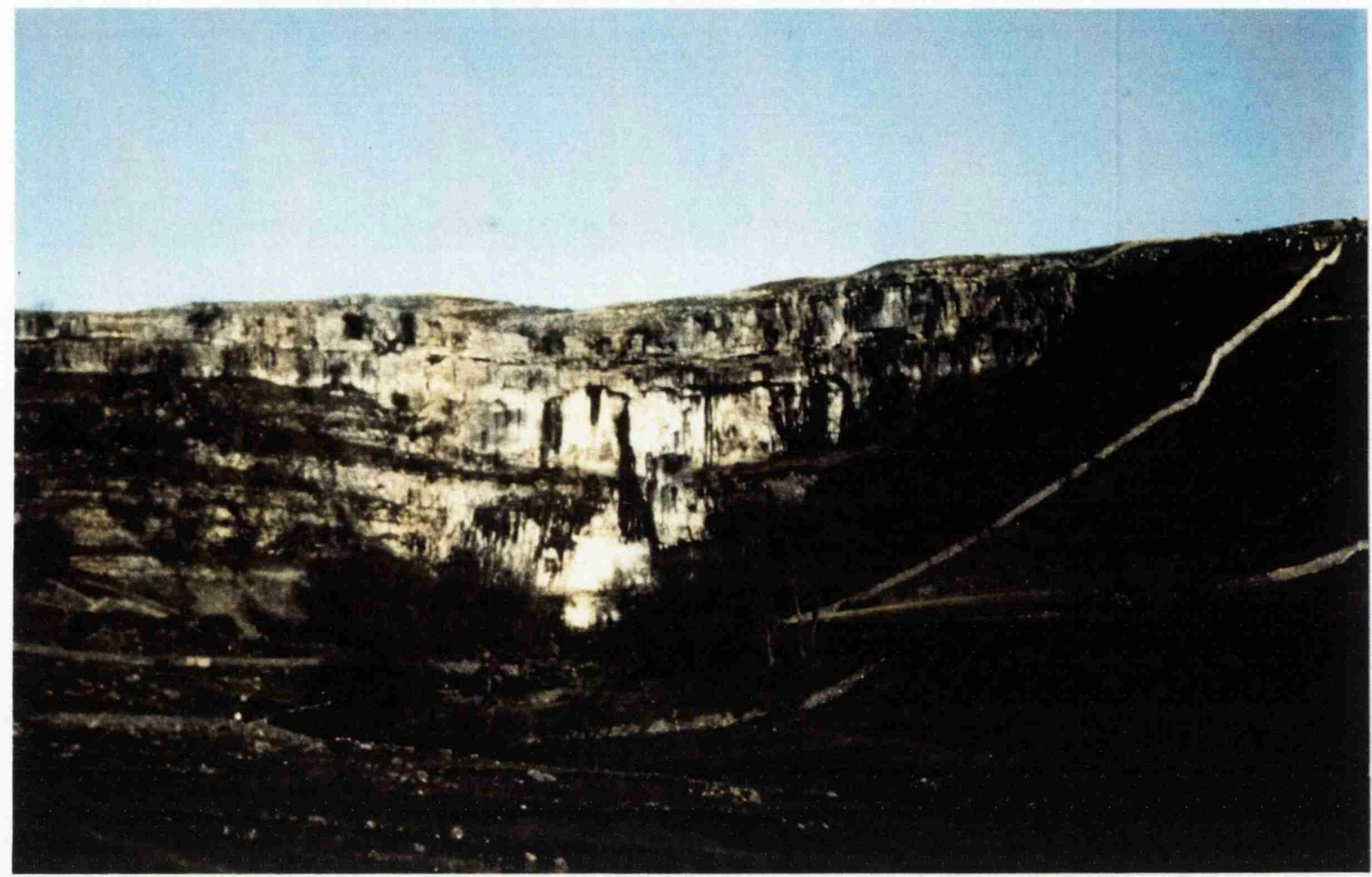

Figure 3.22. Great Scar Limestone; Malham Formation (sequence EC4) at Malham Cove (SD 896 642).

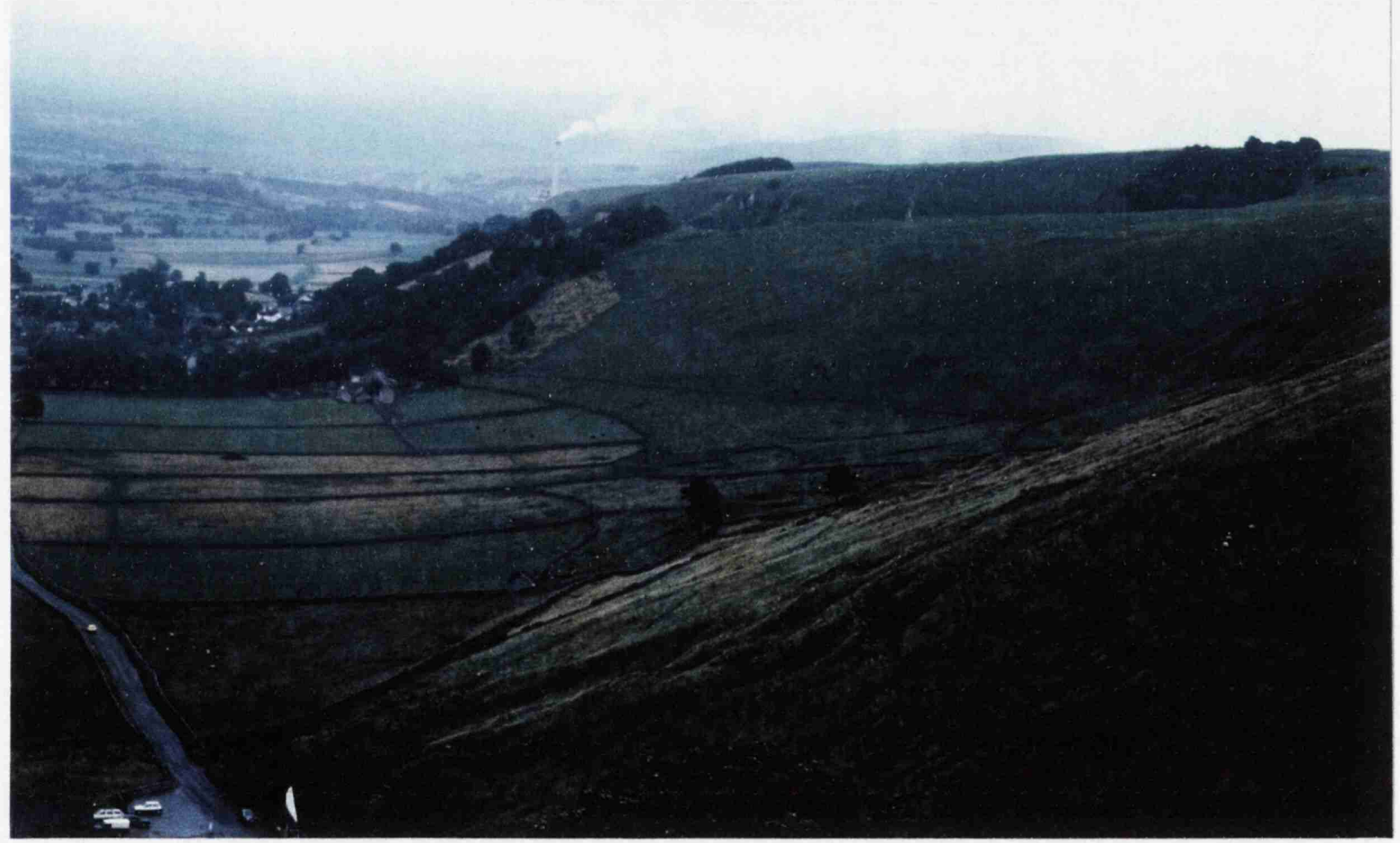

Figure 3.23. Castleton, Derbyshire, southern margin of the Edale Gulf. Present day topography picks out the exhumed EC4 shelf margin. The slopes shown in the photograph represent true depositional topography of up to 30 degrees on the shelf margin (Broadhurst \& Simpson 1967). 
These basalts are associated with extensional activity on a series of NW-SE trending faults (Cinderhill fault system) which bound the northern margin of the Widmerpool Gulf. Basaltic lavas and tuffaceous horizons of similar age have been encountered in exploration boreholes in the East Midlands along the same trend (eg. Strelley-1).

Regional stratigraphic correlation demonstrates considerable facies variations between the individual half-graben during EC5 (Plate 2.7). The Widmerpool and Gainsborough basins were receiving fine-grained clastic material and distal calciturbidites. The sequence in Bowland is dominated by the incoming distal prodelta facies from the north (Lower Bowland Shale). In Stainmore, where shallower water conditions prevailed close to the clastic source, the onset of cyclic Yoredale sedimentation is apparent (Johnson 1960).

The EC4/EC5 sequence boundary can be observed at outcrop in the northern part of the Bowland Basin (Fig. 3.24). As a means of demonstrating the link between the outcrop and seismic expression of sequence boundaries, the equivalent location on the Widmerpool Gulf seismic line is highlighted on Fig. 3.5. Strong erosional truncation on the footwall of the Hoton fault has resulted in a marked angular unconformity on the Hathern Shelf between sequences EC1 and EC6 due to footwall uplift and erosion as a result of EC5 rifting. The erosional debris of this event (presumably shelf derived carbonates as in Figs. $3.24 \& 3.25$ ) is represented by discontinuous high-amplitude, low-frequency events at the base of the EC5 sequence within the hangingwall (Fig. 3.5). These are overlain by hemipelagic lime mudstones comprising the remainder of the EC5 sequence, which has generated the observed seismic impedance contrast. These boulder beds may have some significance as potential reservoirs due to secondary porosity generation during burial diagenesis (Gawthorpe 1987b). This secondary porosity development can often be associated with hydrocarbons (Figs $3.26 \& 3.27$ ). 


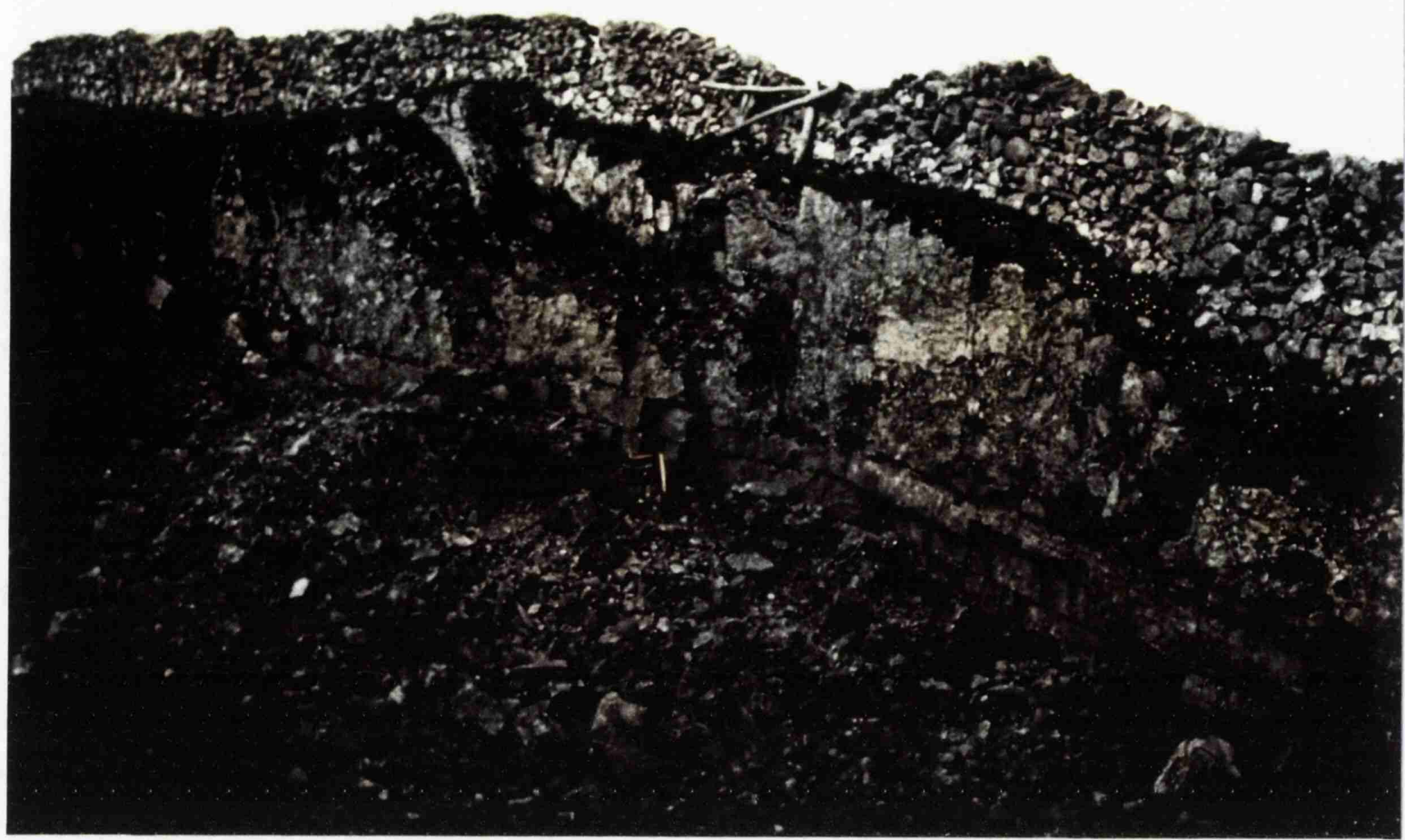

Figure 3.24. Pendleside Limestone (EC4/EC5 sequence boundary), Green Pike, Slaidburn (SD 729 586). An excellent example of a major sequence boundary occurring in the middle of a lithostratigraphic unit. The bedded limestone units in the lower part of the picture are foreslope calciturbidites belonging to the EC4 sequence. These are unconformably overlain by erosional, shelf derived debris from the footwall of the nearby Bowland High at the onset of EC5 rifting; a classic event deposit. Hammer for scale.

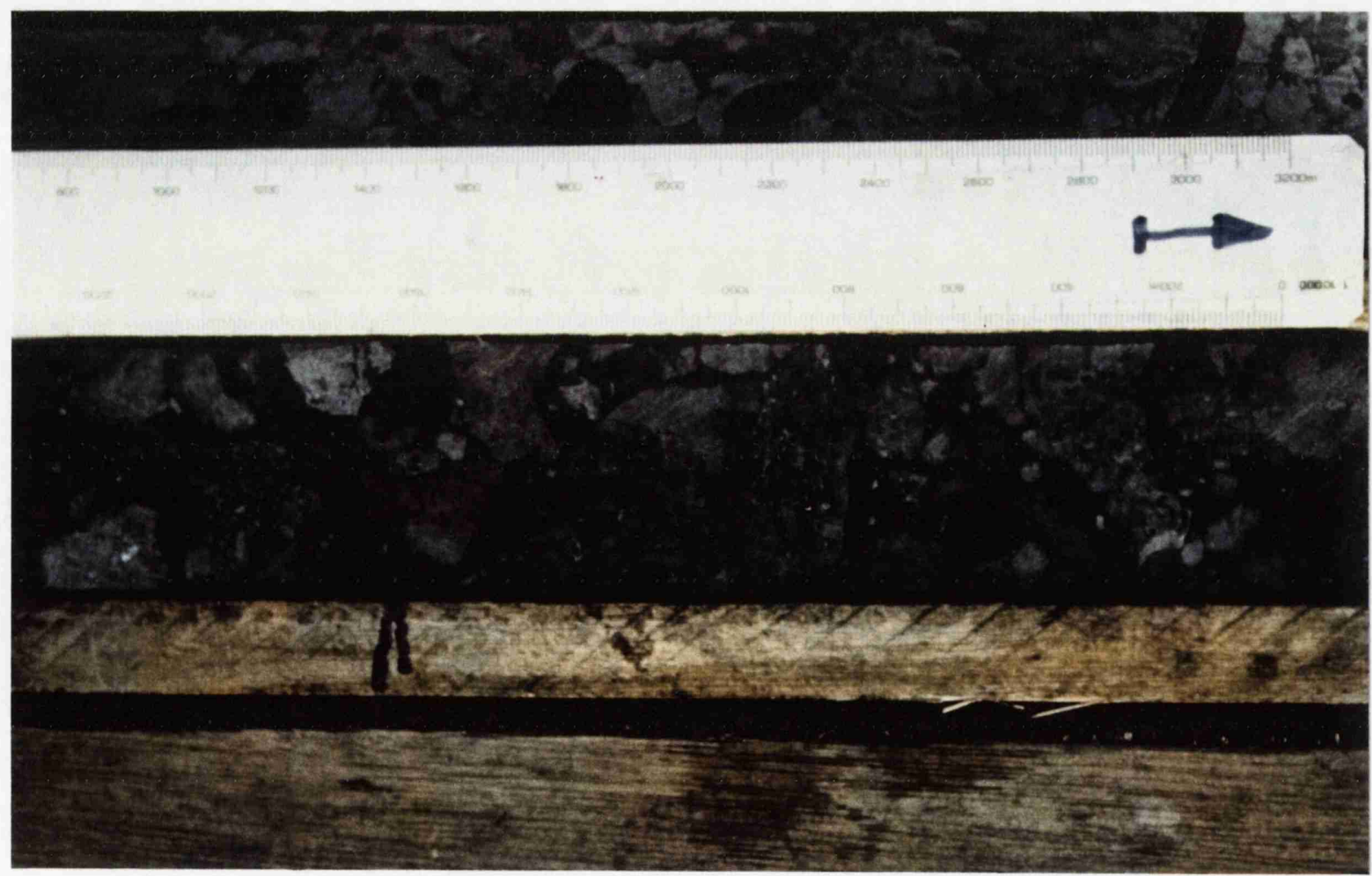

Figure 3.25. Pendleside Limestone (sequence EC5) BP minerals borehole BHD-11 (SD 694 543), Sykes anticline, southern Bowland High. Debris flow deposits from footwall uplift of the Bowland High during EC5 rifting. 


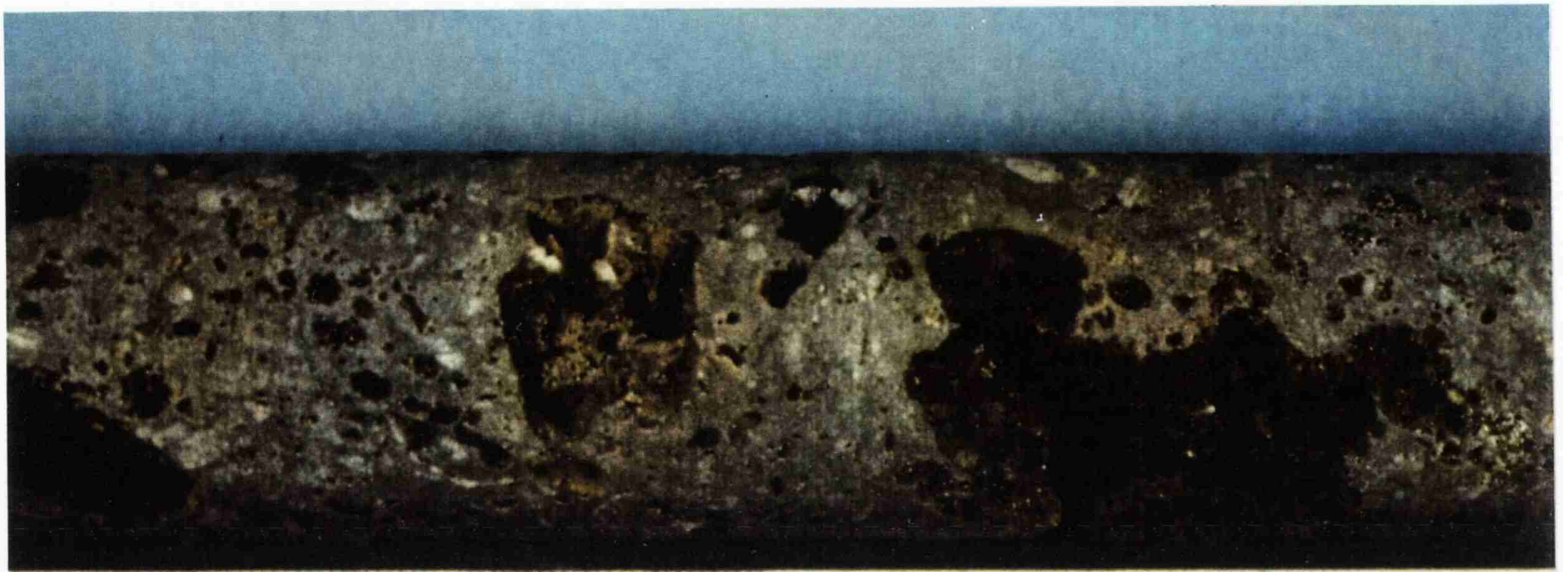

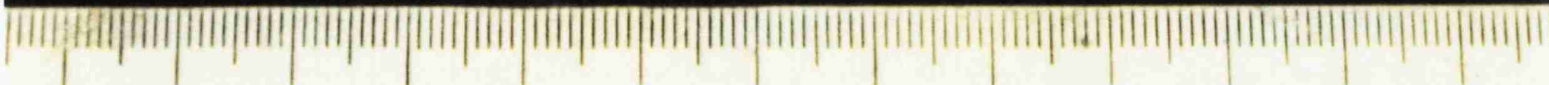

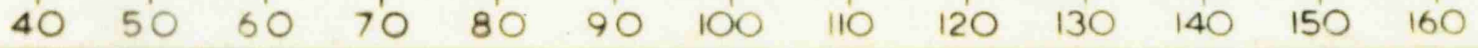

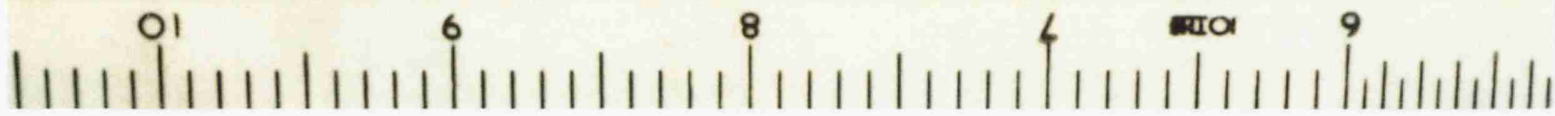

Figure 3.26. Pendleside Limestone (sequence EC5) BP Minerals borehole BHW-4 (SD 647 545), Sykes anticline, southern Bowland High. Secondary porosity development in boulder bed facies.

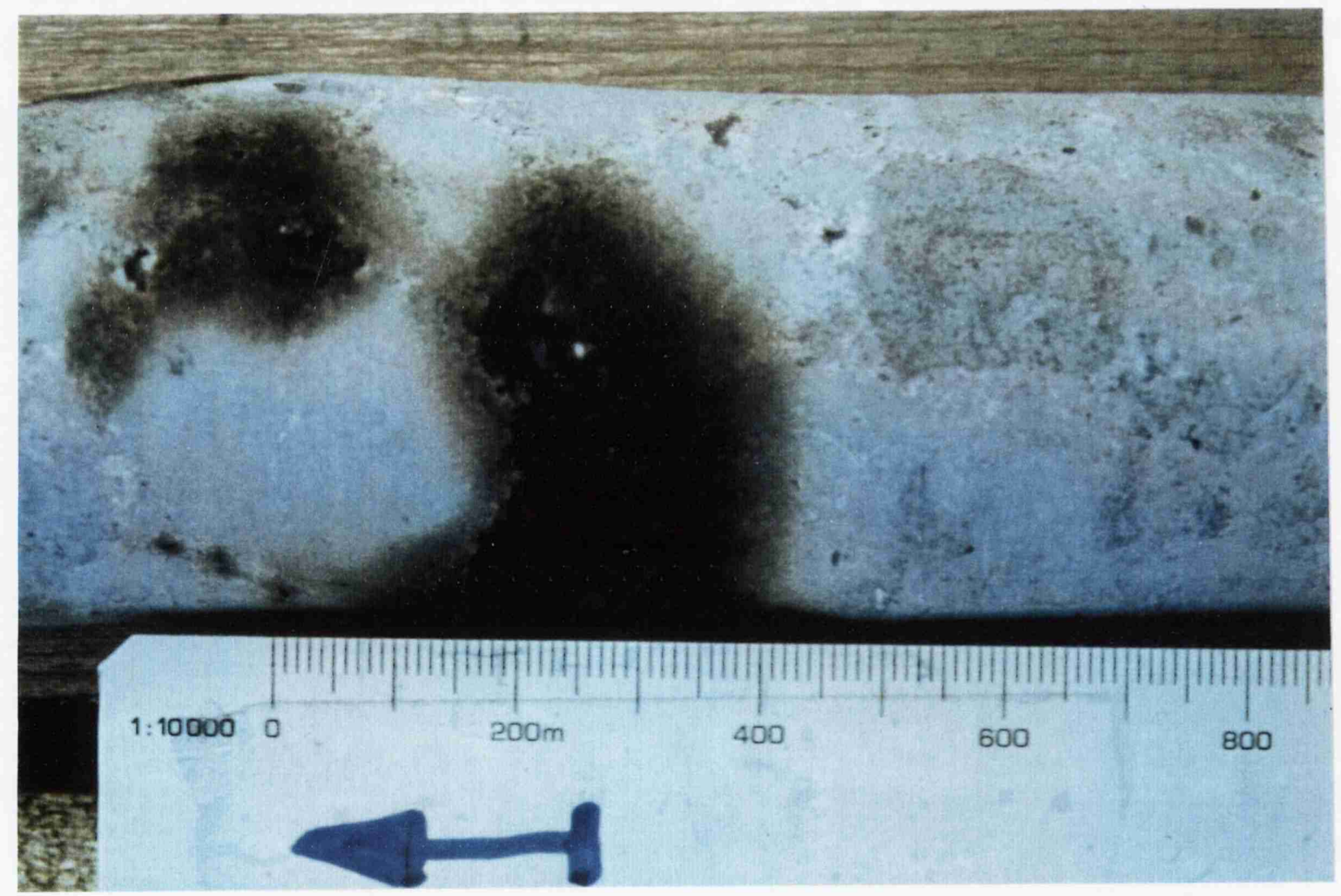

Figure 3.27. Pendleside Limestone (sequence EC5) BP Minerals borehole BHD-11 (SD 641 544), Sykes anticline, southern Bowland High. Vuggy porosity in boulder beds associated with hydrocarbons. 
Sequence EC6 (early to mid Brigantian). Post-rift III. The onset of this sequence is marked by a significant regressive phase over northern England. Seismic data from the Egmanton oilfield in the East Midlands (Plate 3.10) shows evidence for an erosional unconformity in the hangingwall of the fault controlling structure. This is interpreted as inversion of the original listric normal fault in the early Brigantian. This suggests that the initial pulses of the late Dinantian inversion (which culminated in the mid-Brigantian) may have reached northern England by the early Brigantian thus disabling EC5 extensional activity. The unconformity is elegantly demonstrated at outcrop in Derbyshire by the marked disconformity between the Upper Monsal Dale Beds (early Brigantian) and the Eyam Limestones (late Brigantian) in Bradwell Dale (Fig. 3.28).

The sequence is characterised by carbonate ramp to rimmed shelf development in the Widmerpool Gulf, Gainsborough Trough and Edale Gulf where water depth differences of up to $300 \mathrm{~m}$ were established between shelf and basin. The sequence thickens markedly onto shelfal areas. On seismic, the base of the sequence exhibits downlap onto EC5 along the hangingwall dipslope, becoming sub-parallel with EC5 into the basin (Plate 3.4). Internally the EC6 shelf margins are composed of complex oblique-sigmoid, high-amplitude, low-frequency clinoforms which pass basinwards into high-frequency parallel events (Fig. 3.6). The northern hangingwall carbonate margin of the Widmerpool Gulf is exposed at surface at Wirksworth in Derbyshire some $35 \mathrm{~km}$ to the west (Walkden 1982). Over a distance of roughly $1 \mathrm{~km}$ shelf grainstones, packstones and wackestones at Middle Peak (Fig. 3.29) pass southwards through stacked grainstone shoal complexes, into slumps and slides associated with the carbonate shelf margin (Fig. 3.30).

Mounded features up to $0.5 \mathrm{~km}$ across have been observed on the Hathern Shelf (Fig. 3.7). These are probably analogous to the Brigantian mudmounds of the Coalhills complex in Derbyshire (Fig 3. 31) (Walkden 1982). Although these features often have hydrocarbons associated with them, they are small with porosity developed as a series of 

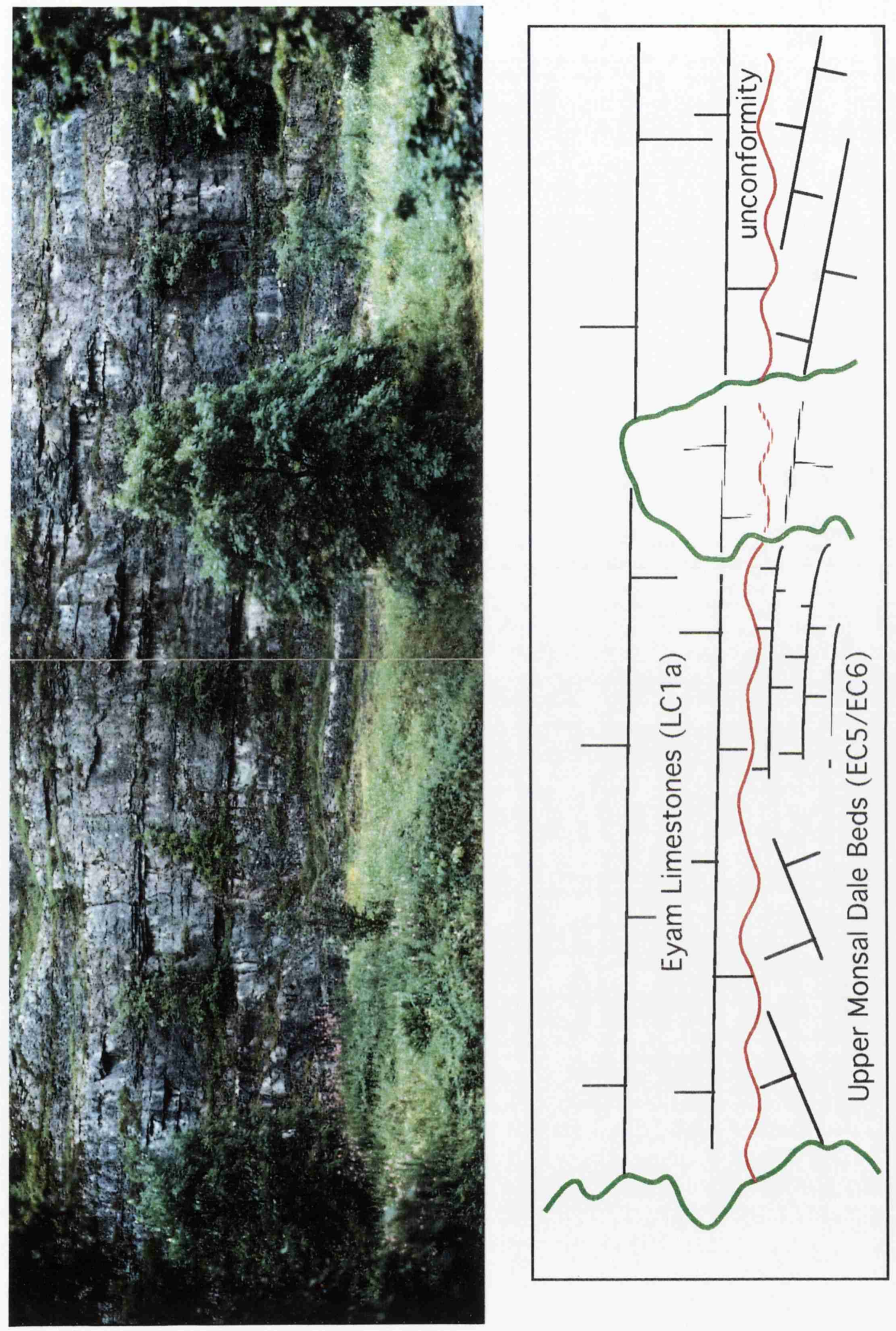

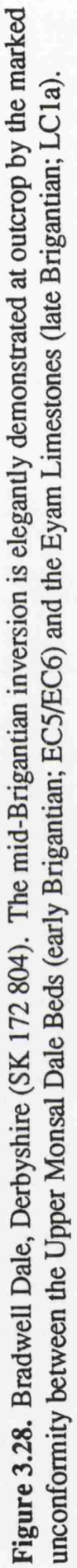




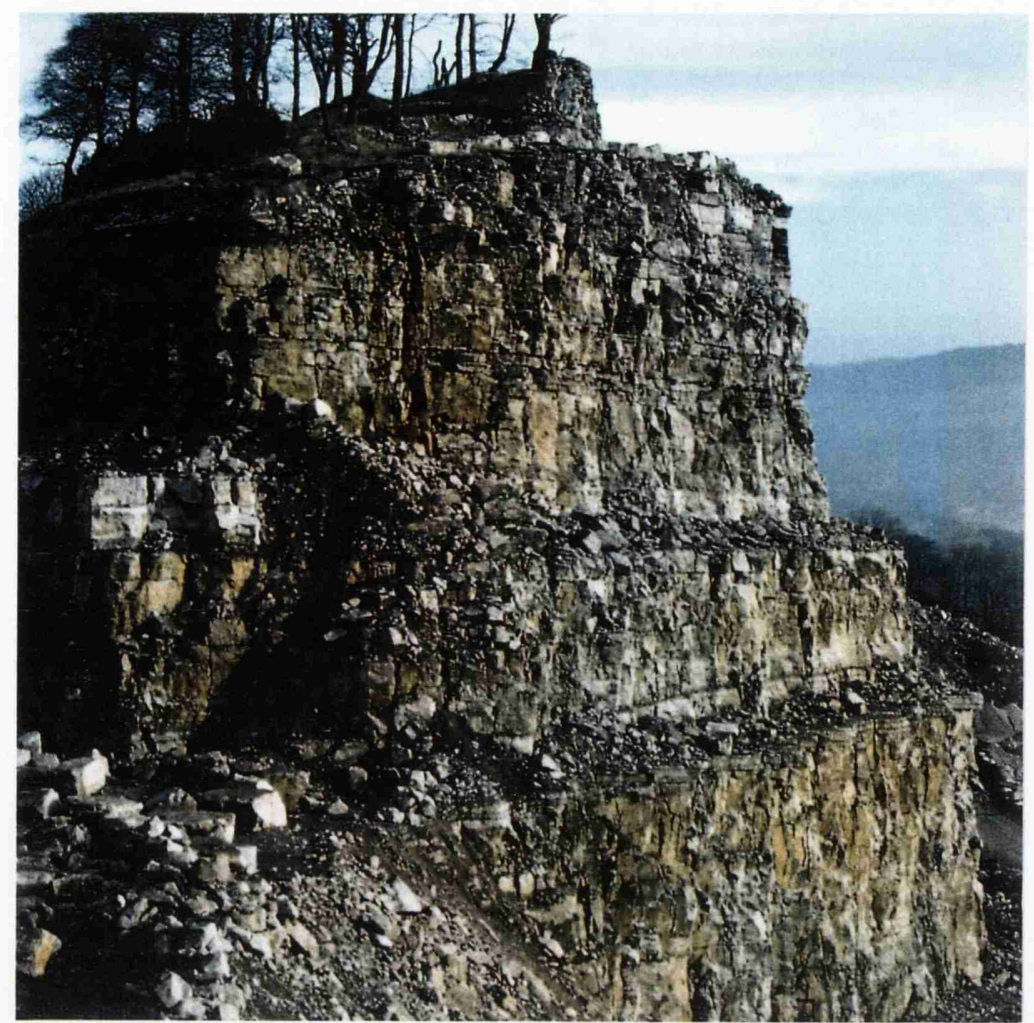

Figure 3.29. Middle Peak, Wirksworth, Derbyshire (SK 278 552). Metre scale cyclic sequence of shelf grainstones, packstones and wackestones. Outcrop lies c. $1 \mathrm{~km}$ north of the EC6 shelf margin shown in Fig. 3.30.

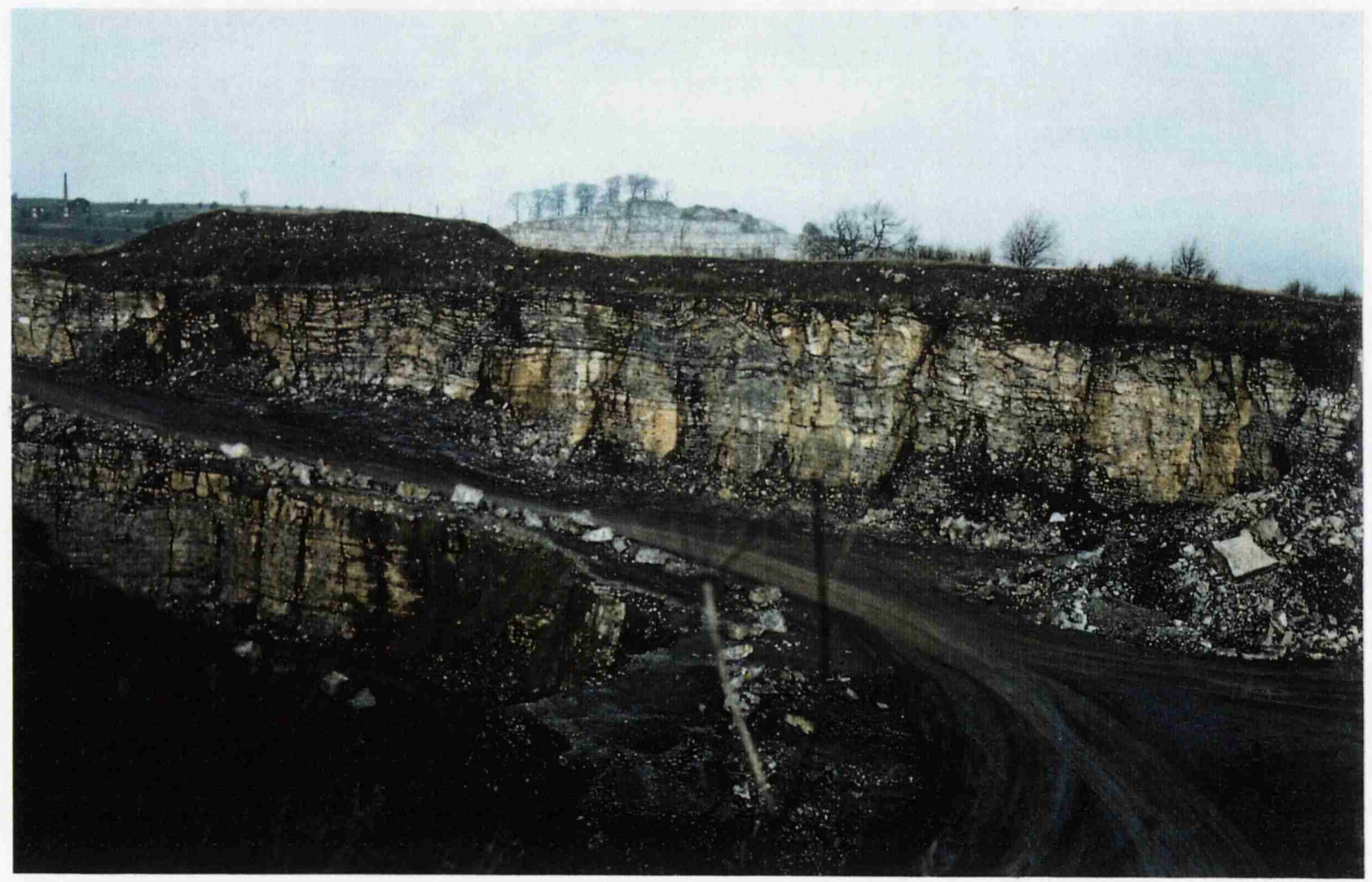

Figure 3.30. Dale Quarry, Wirksworth, Derbyshire (SK 283 548). Hangingwall carbonate margin (EC6). The hill in the background (Middle Peak) comprises a monotonous cyclic sequence of shelf carbonates. These pass southwards through stacked grainstone shoal complexes into slumps and slides evidenced in the quarry in the foreground. 
largely unconnected vugs (Fig. 3.32). Consequently, these mudmounds are considered unlikely to represent viable exploration targets in the East Midlands.

During EC6 the Pendle delta system prograded southwards resulting in the deposition of siliciclastic turbidites (Pendleside Sandstone) in Bowland, effectively precluding further carbonate production in the basin. Cyclic shallow marine Yoredale sedimentation continued in Stainmore. The disconformity between individual Yoredale cycles can be observed at outcrop but as they occur at a frequency below seismic resolution the regional significance of the individual events cannot be assessed.

\subsubsection{Post-rift megasequence (late Brigantian - late Westphalian C)}

Seismic data shows the post-rift megasequence to have been deposited regionally across northern England (eg. Plate 3.2). Isopachs for the post-rift section exhibit a classic bullseye pattern interpreted by Leeder (1982) as resulting from a phase of passive thermal subsidence (Plate 2.10). A similar thermal sag has been identified further east in the Southern North Sea (Leeder \& Hardman, 1990).

During the early post-rift, sediment supply overtook subsidence for the first time allowing the rapid southward progradation of the clastic fluvio-deltaic system which had, until this time, been restricted to the north of the study area. This resulted in the burial of the last vestiges of the northern England carbonate system in the late Brigantian-early Pendleian and the infill of the rifts with deltaic sediments. The backstripped seismic profile of the top syn-rift reflector in the Widmerpool Gulf (Plate 2.8) indicates water depths of around $300 \mathrm{~m}$ for the sediment starved half-graben between shelf and basin at this time; the position of the shelf and basin being well constrained by borehole and seismic facies data. The observed thickening of the Namurian and Westphalian (postrift) isopachs into the Widmerpool Gulf (Kent, 1966) can partly be explained in terms of progressive fill of the starved rifts by progressively shallower water deltaic systems. 


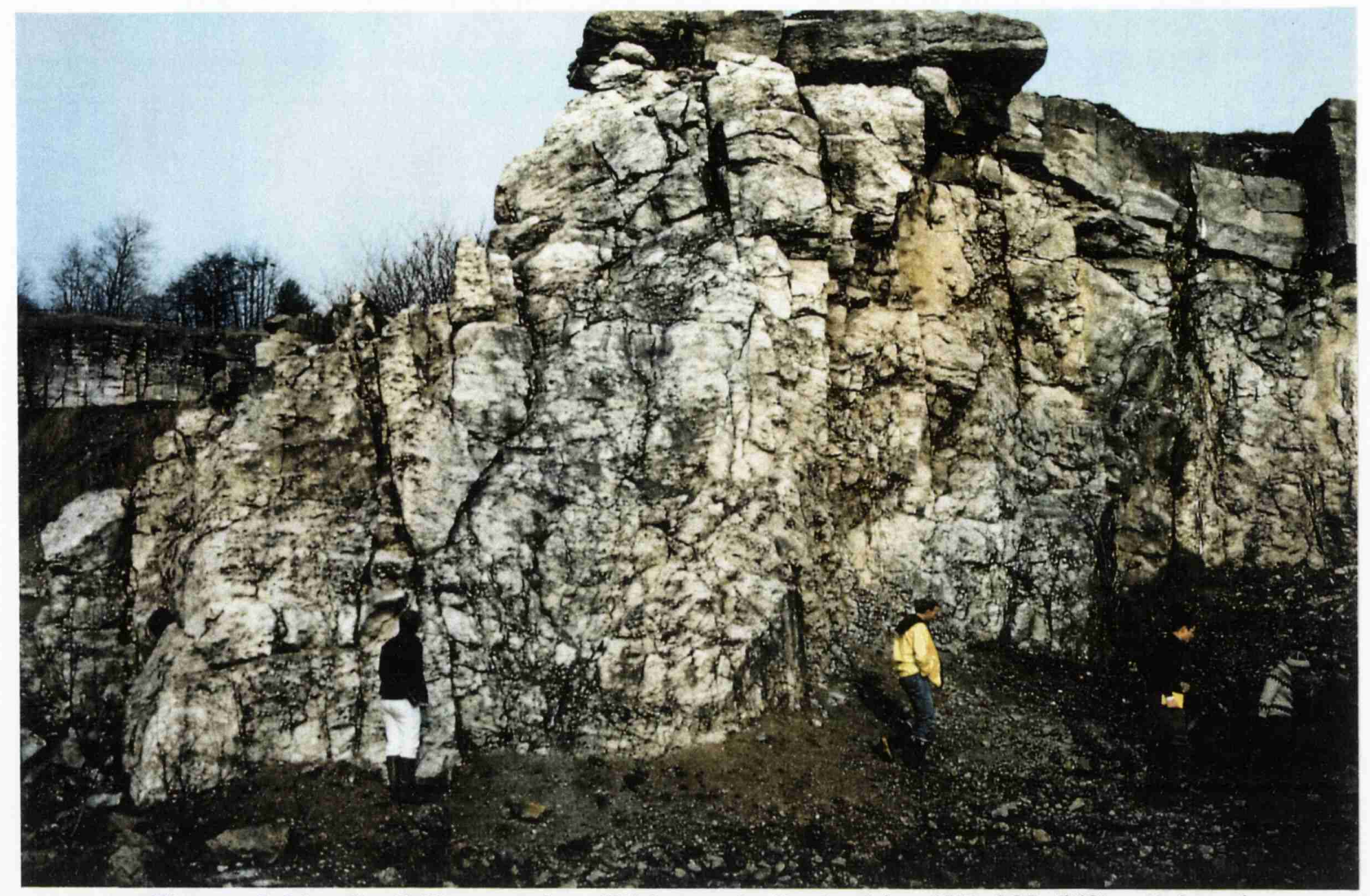

Figure 3.31. Coalhills complex, Wirksworth, Derbyshire (SK 288 553). Brigantian (EC6) mudmounds developed on the hangingwall dipslope of the western Widmerpool Gulf.

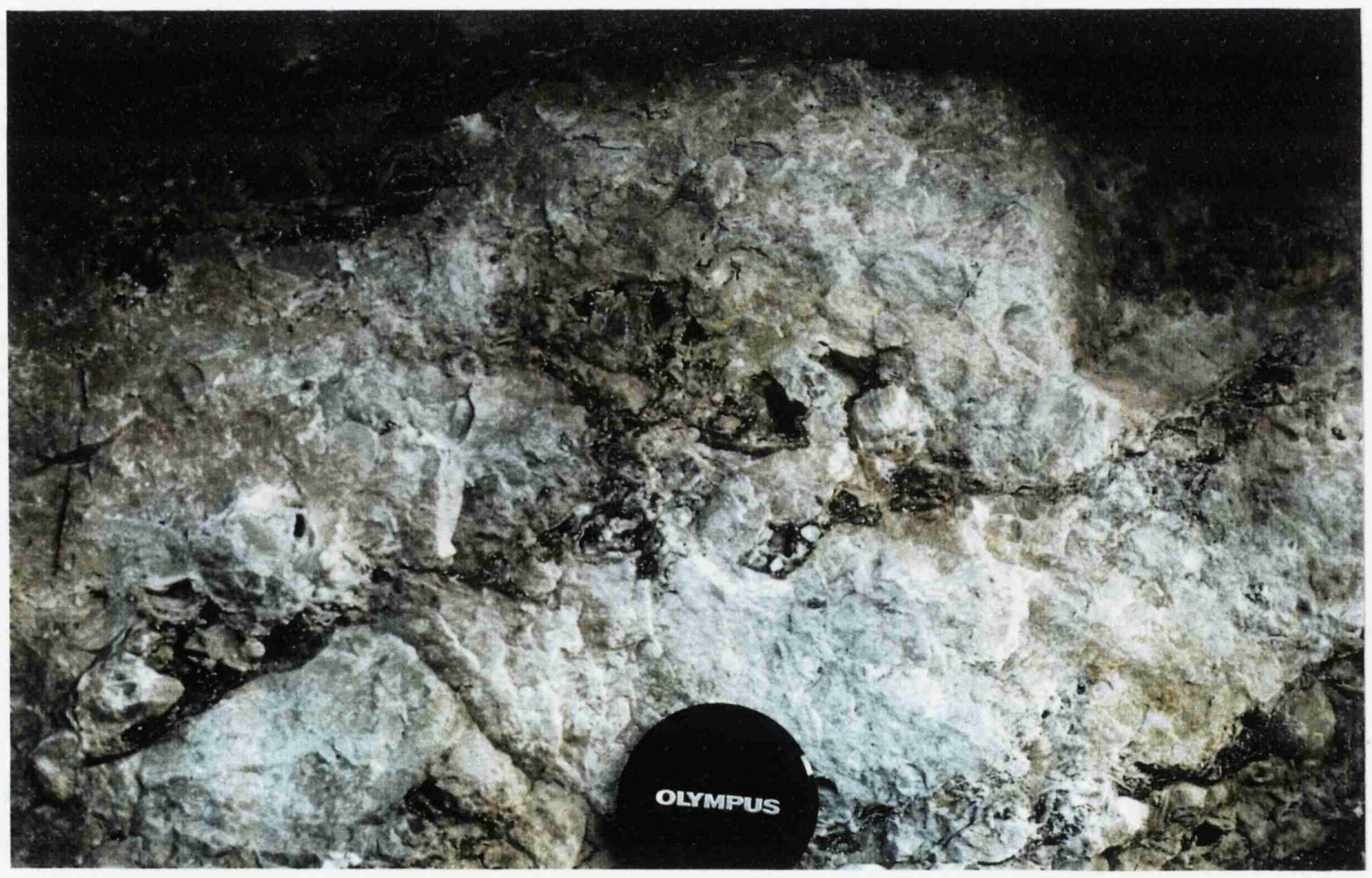

Figure 3.32. Coalhills complex, Wirksworth, Derbyshire (SK 288 553). Brigantian (EC6) mudmound, showing detail of poorly connected vuggy, interparticle porosity developed within brachiopod rich zones. These cavities are rimmed with Fluorite (Blue John) and bitumen stain. 
Sequence LCla (late Brigantian to late Pendleian). The mid-Brigantian inversion heralded the onset of the post-rift thermal subsidence phase in northern England. The last vestiges of the carbonate system in the East Midlands were drowned and intra-shelf basins were developed following marine transgression over the post EC6 inversion topography (Gutteridge 1987,1989). The Pendle delta system (Fig 3.33) advanced from the northeast with relatively deep water $(300 \mathrm{~m})$, distal pro-delta, organic rich shales ponded in the starved Bowland, Edale, Gainsborough and Widmerpool basins (Upper Bowland and Edale shales). The sequence is thickest within the individual half-graben, thinning progressively onto the hangingwall and footwall carbonate margins of the underlying sequence where it is extremely condensed. On seismic reflection data, the sequence is characterised by high-amplitude, high-frequency, laterally continuous parallel reflectors which downlap onto EC6 within the basin and passively onlap the submerged margins (eg. Plate 3.2).

Figure 3.34, a regional view of the Castleton area in Derbyshire, illustrates the Edale Shales (LC1a) ponded in the basinal area in the centre of the photograph. Detail of the outcrop is shown in Figure 3.35. The shales onlap the now exhumed EC4 carbonate margin on the right-hand side of the picture. The delta top mouth bar and channel sands exposed on the hills to the left belong to the succeeding LC1b and LC1c sequences.

Sequence LCIb (late Pendleian-Alportian). Minor reactivation of extensional faults occurred on the Craven fault system (Bowland Basin) and the Askern-Spital fault (Gainsborough Trough). These fault movements are manifested in the pre-Grassington Grit unconformity on the Askrigg block (Arthurton et al. 1988; Dunham and Wilson 1985) and vertical offset of the Dinantian and lowermost Namurian on the northern margin of the Gainsborough Trough (Plate 3.6). Coarse siliciclastics progressively infilled the Bowland Basin with pro-delta organic rich shales deposited contemporaneously in the more distal Gainsborough Trough (Steele 1988) and Widmerpool Gulf (Gamma active shales, Fraser et al. 1990). Sequence LC1b is 


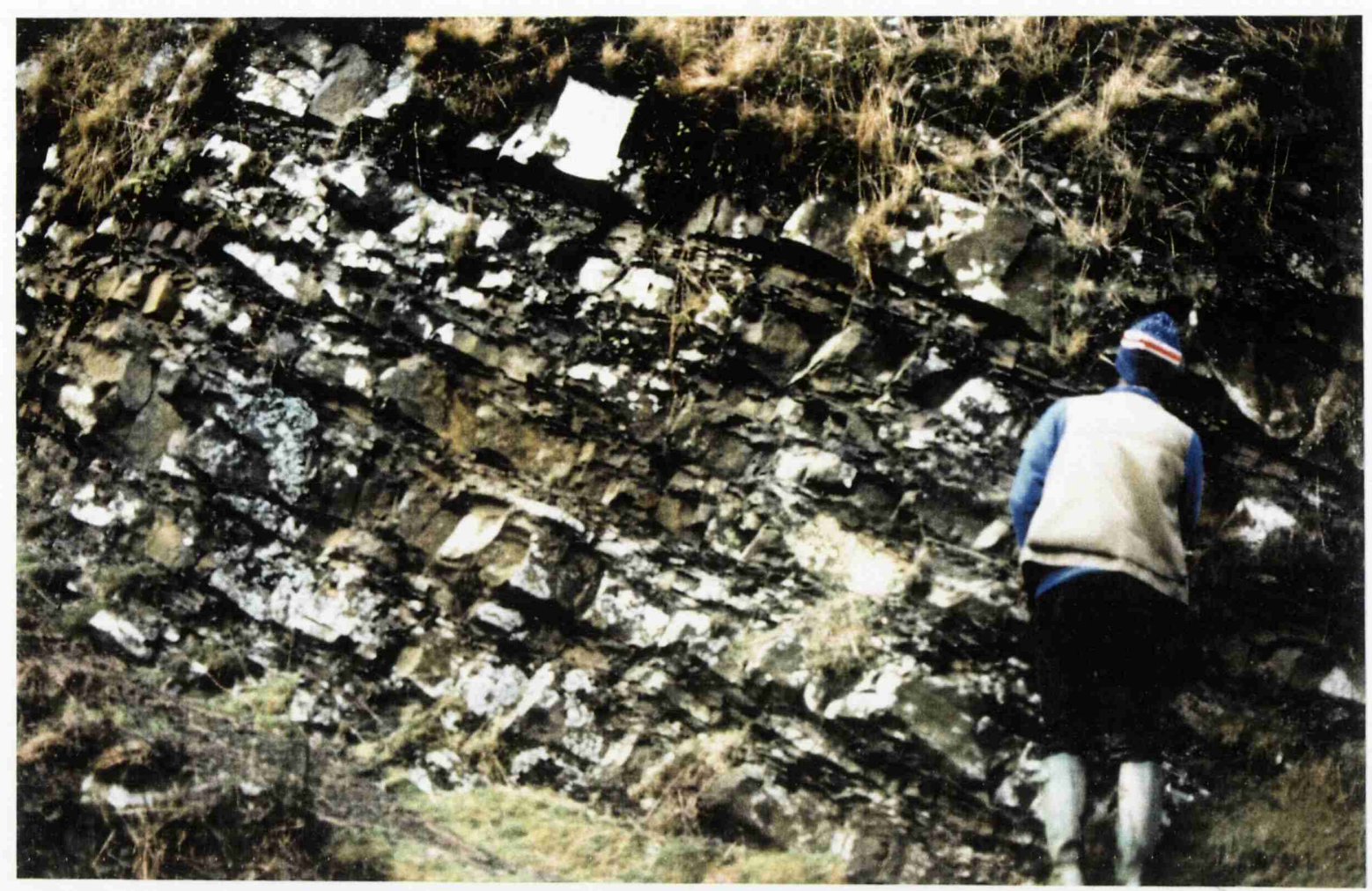

Figure 3.33. Pendle Grit turbidites (sequence LC1a), Trough of Bowland (SD 625 528). These deposits represent the first major influx of the coarse clastics from the northern Dinantian delta systems which prograded southwards into the Bowland Basin during the Pendleian.

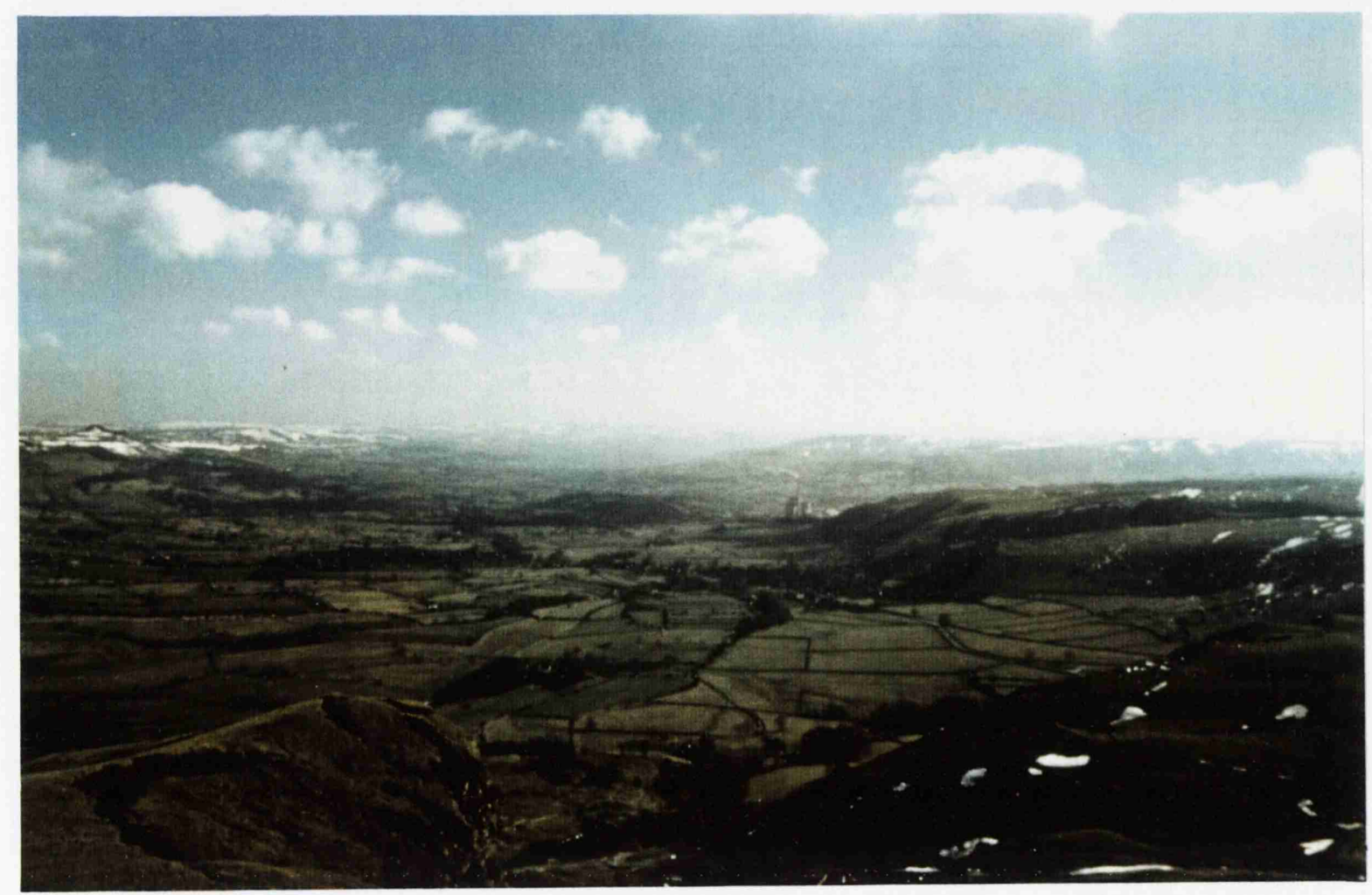

Figure 3.34. A regional view of the Castleton area in Derbyshire, illustrating the Edale Shales (LC1a) ponded in the basinal area in the centre of the photograph. Detail of the outcrop is shown in Figure 3.35. The shales onlap the now exhumed EC4 carbonate margin on the right-hand side of the picture. The delta top mouth bar and channel sands exposed on the hills to the left belong to the succeeding LC1b and LC1c sequences.. 


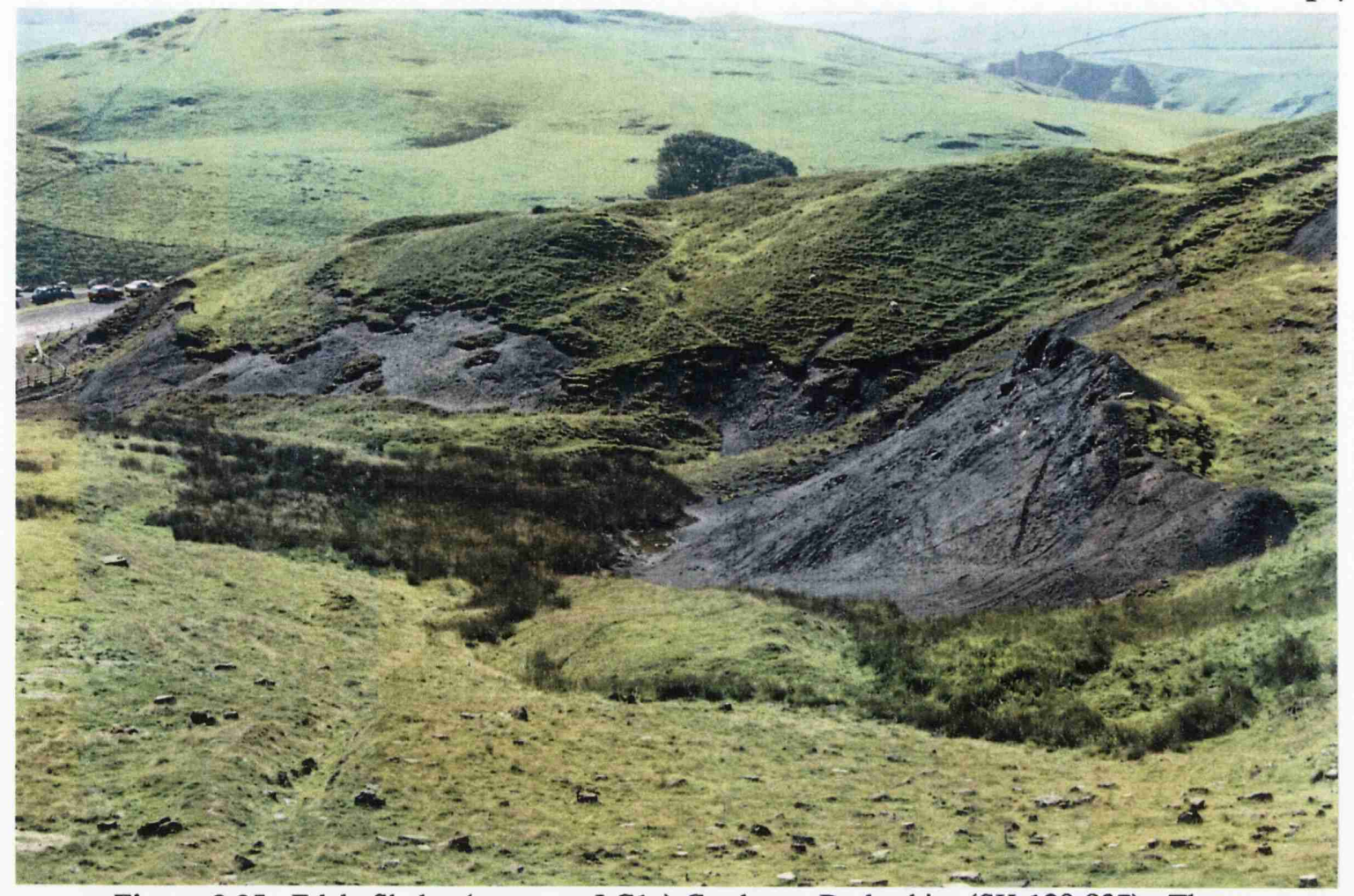

Figure 3.35. Edale Shales (sequence LC1a) Castleton, Derbyshire (SK 129 837). These organic rich black shales were deposited in an oxygen depleted distal pro-delta environment. The time equivalents of these shales (Gamma Active shales) represent the main hydrocarbon source rocks in the East Midlands province to the east.

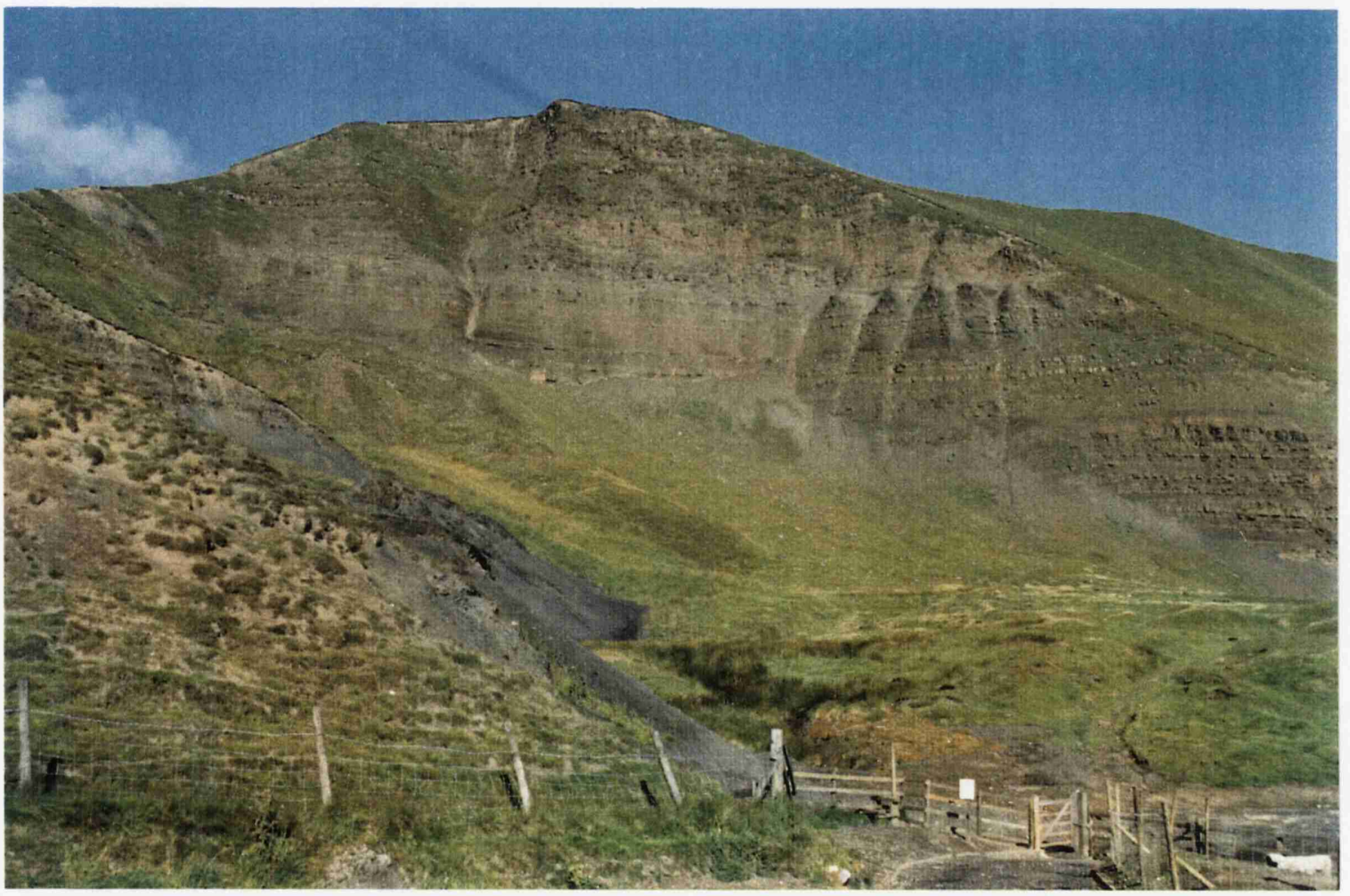

Figure 3.36. Mam Tor, Derbyshire (SK 129 837). The succession at Mam Tor contains basinal pro-delta mudstones (in the foreground) and delta front turbidites associated with the Kinderscout delta system (main cliff). A variety of turbidity current styles are evidenced, ranging from dilute turbidity flows to transitional slumps/viscous flows. The succession is poorly fossiliferous indicating abnormal salinities; true marine conditions were only established where marine bands are present higher up the succession. The abnormal salinities were probably the result of the high meteoric water influx from the Kinderscout delta system.. 
represented on seismic data by high-amplitude, high-frequency discontinuous events. The base of the sequence shows subtle downlap onto LCla in basinal areas and oversteps the remnant carbonate shelves where it onlaps earlier syn-rift (typically EC6) sediments.

Seismic data (presented herein) and confidential biostratigraphic studies (BP Exploration) show sequence LC1b to be condensed over the East Midlands shelf and probably throughout northern England. This may reflect large-scale switching of delta lobes into the Southern North Sea Basin or more regional changes in climate and/or sediment supply in the hinterland to the north.

Sequence LCIC (Kinderscoutian-late Westphalian A). Mild reactivation of extensional faults occurred particularly in the eastern Gainsborough Trough where some $200 \mathrm{~m}$ of relief developed on the NE-SW trending Scampton fault (Plate 3.7) establishing a strong footwall unconformity in the area. The sequence is characterised by the continued and widespread progradation of the Kinderscout, Ashover and Chatsworth-Crawshaw delta systems infilling the central Pennine Basin (Figs 3.36. 3.37 \& 3.38). The Ashover delta filled the Widmerpool Gulf longitudinally in a SE to NW direction following the inherited Dinantian structural grain (Fig. 3.10). As a consequence, the sequence is thickest and best developed in the previously sediment-starved Widmerpool Gulf. The seismic character of sequence LClc consists of high-amplitude, low-frequency events which can be traced onto the shelf areas where the sequence is generally well developed. Lower delta plain conditions were widespread throughout northern England by the end of this interval (Guion \& Fielding 1988).

The wealth of outcrop and subsurface well data available for this interval permits further breakdown of this sequence. Maximum flooding surfaces (marine bands) can be identified and correlated using a combination of log character, goniatite stratigraphy and palynology (Fig 3.11). These events represent sea level highstands which punctuate 

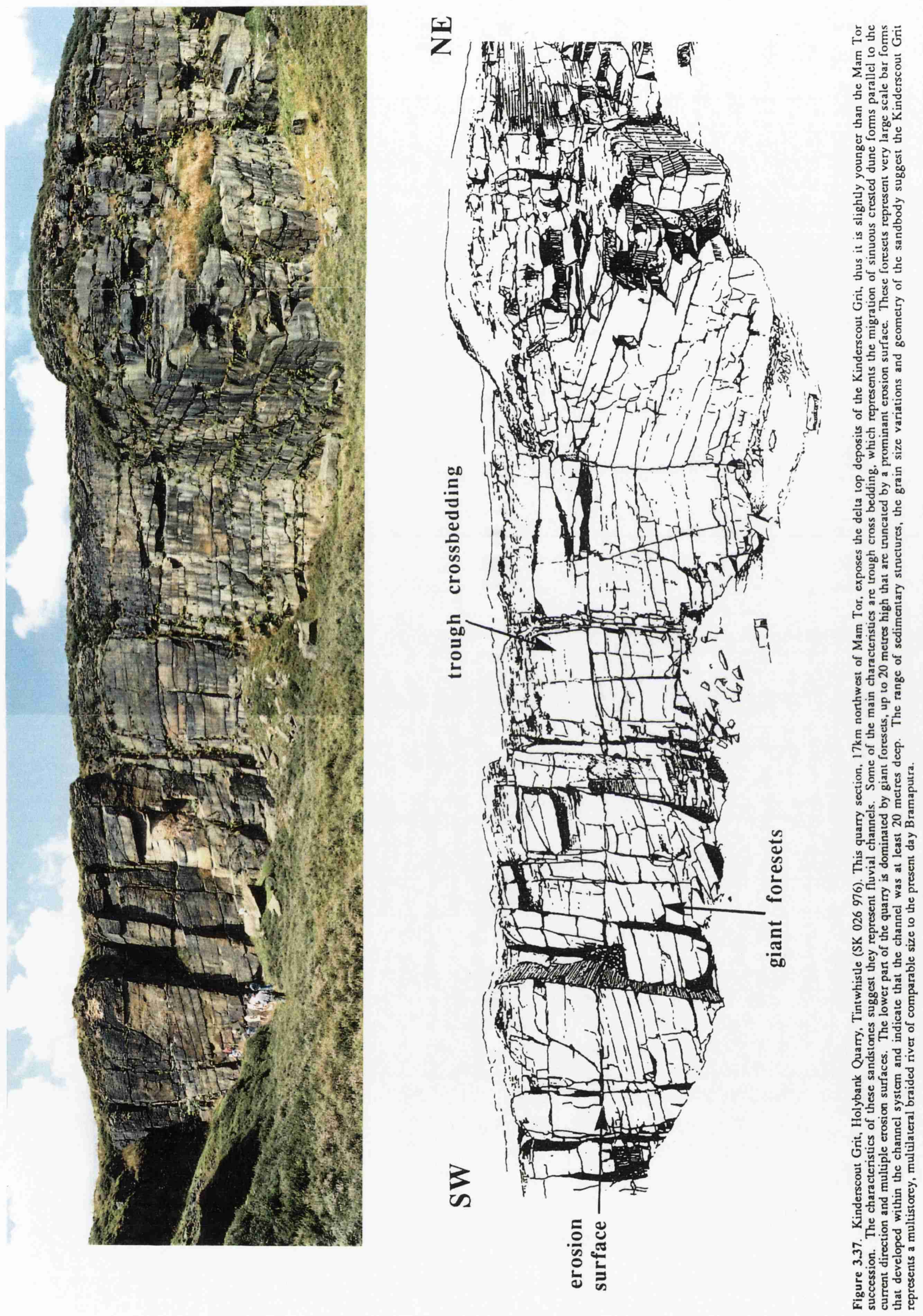
periods of progressive delta plain progradation. In the case of the East Midlands this permits a high resolution facies analysis of what is the main reservoir interval (Fig 3.11) (see also Steele 1988).

Sequence LC2 (late Westphalian A-Westphalian C). The periodic tectonic activity evidenced on several of the major basin bounding faults during the early part of the postrift had almost ceased by late Westphalian A times. This also coincided approximately with the cessation of igneous activity in the East Midlands (Kirton 1984). During LC2, upper delta plain, coal swamp conditions were established over most of northern England (Fig. 3.39), forming an internally drained basin north of the Wales-Brabant Massif (Guion \& Fielding 1988). However, erosion following the Variscan inversion, particularly in hangingwall settings, has resulted in a patchy present day preservation of the sequence. The sequence is characterised by laterally persistent very high-amplitude parallel reflectors which are generated by the many coal seams developed throughout LC2 (Plate 3.2)

\subsubsection{Inversion Megasequence (Late Westphalian 'C'-early Permian)}

The effects of the Variscan orogeny are evidenced on reflection seismic data by the presence of large scale inversion anticlines in the hangingwalls of the existing basin bounding faults (eg Plate 3.14). Early Permian peneplanation of these anticlines is marked by a pronounced subcrop to the base Permian throughout northern England (eg. Plate 3.4). The degree of uplift and subsequent erosion of syn and post-rift Carboniferous sediments (Plate 2.11) has been estimated from extrapolation of regional stratigraphic thickness and palaeoburial studies (mainly vitrinite reflectance analysis). The map highlights the extent to which basins such as Bowland and Northumberland, which are interpreted as lying orthogonal to the NW-SE direction of maximum compressive stress, were inverted during the Variscan. The inversion megasequence is characterised by the accumulation of continental red beds and molasse in intermontane 


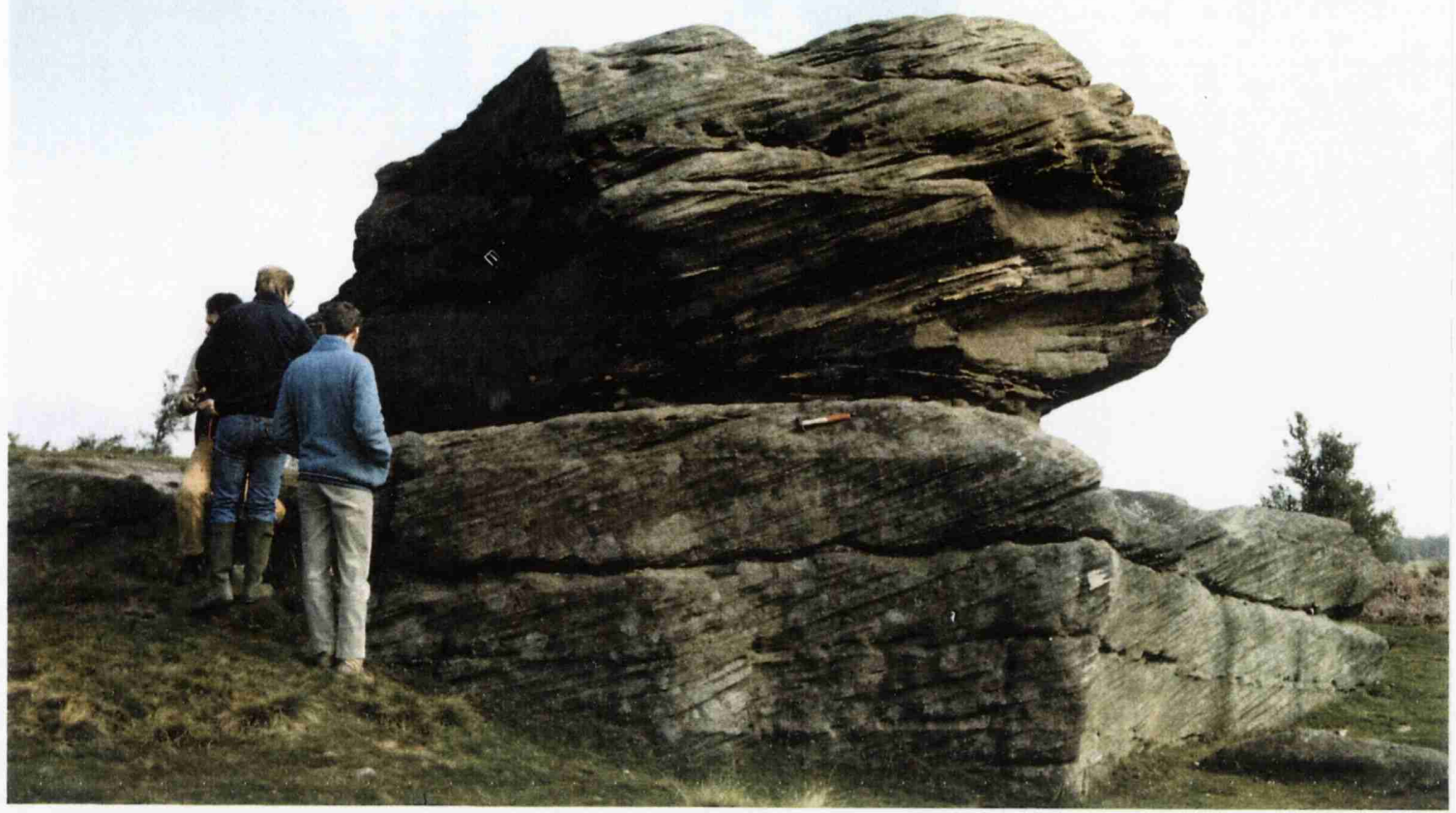

Figure 3.38. Birchen Edge, Derbyshire (SK 280 728). Distributary channel sands, Crawshaw sandstone (sequence LC1c). The dominant sedimentary structures are planar cross-bedding to broad trough cross-bedding. The rock is generally coarse, kaolinitic sandstone with horizons of quartz pebble conglomerates. These are interpreted as the deposits of low sinuosity rivers (Guion 1971).

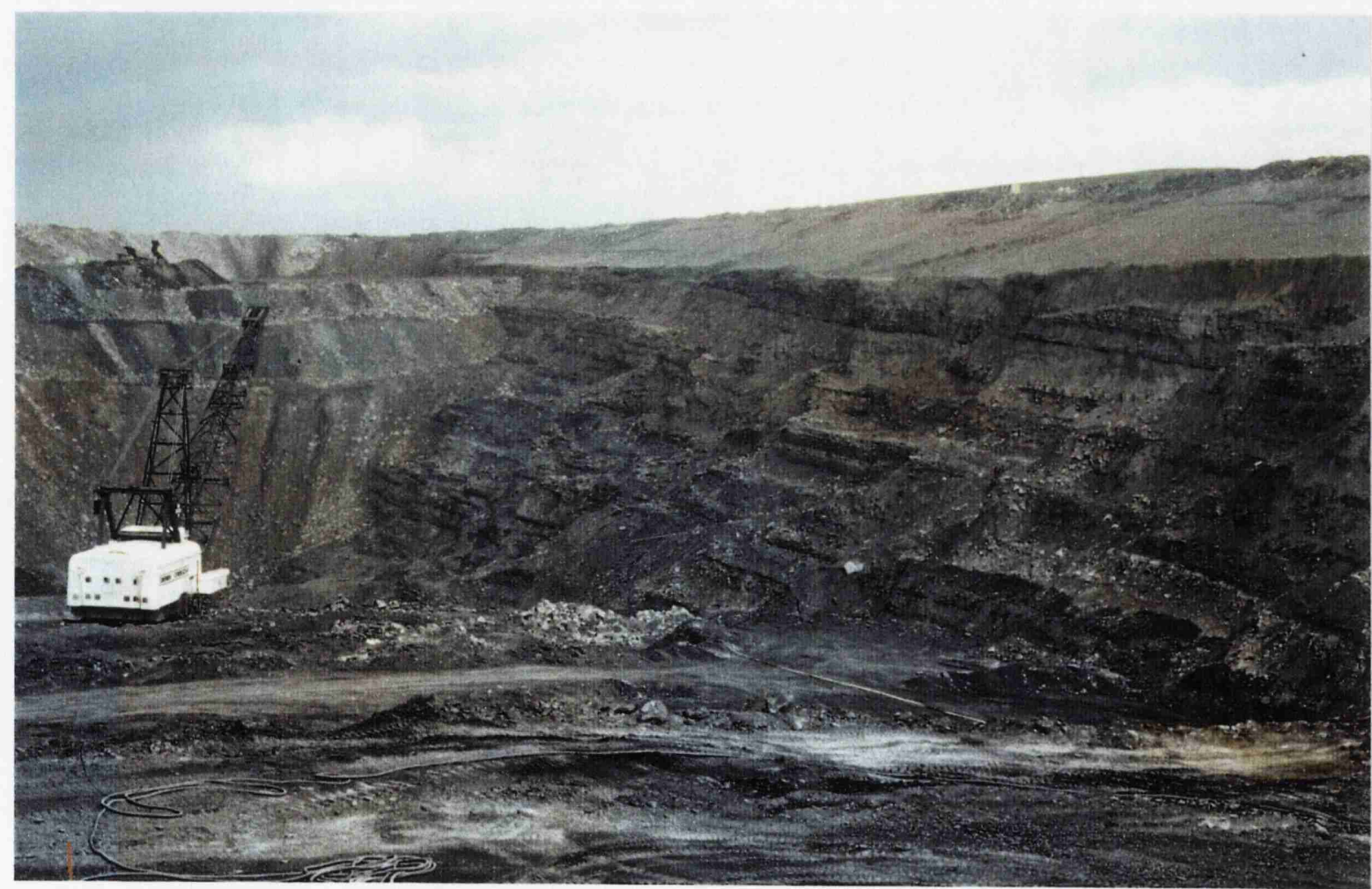

Figure 3.39. Butterwell opencast site, near Morpeth, Northumberland (NZ 190 860), showing Upper Westphalian 'A'-Westphalian 'B' coal measures (sequence LC2). The succession here is mud dominated with prominent coals and minor fluvial sand bodies.. 


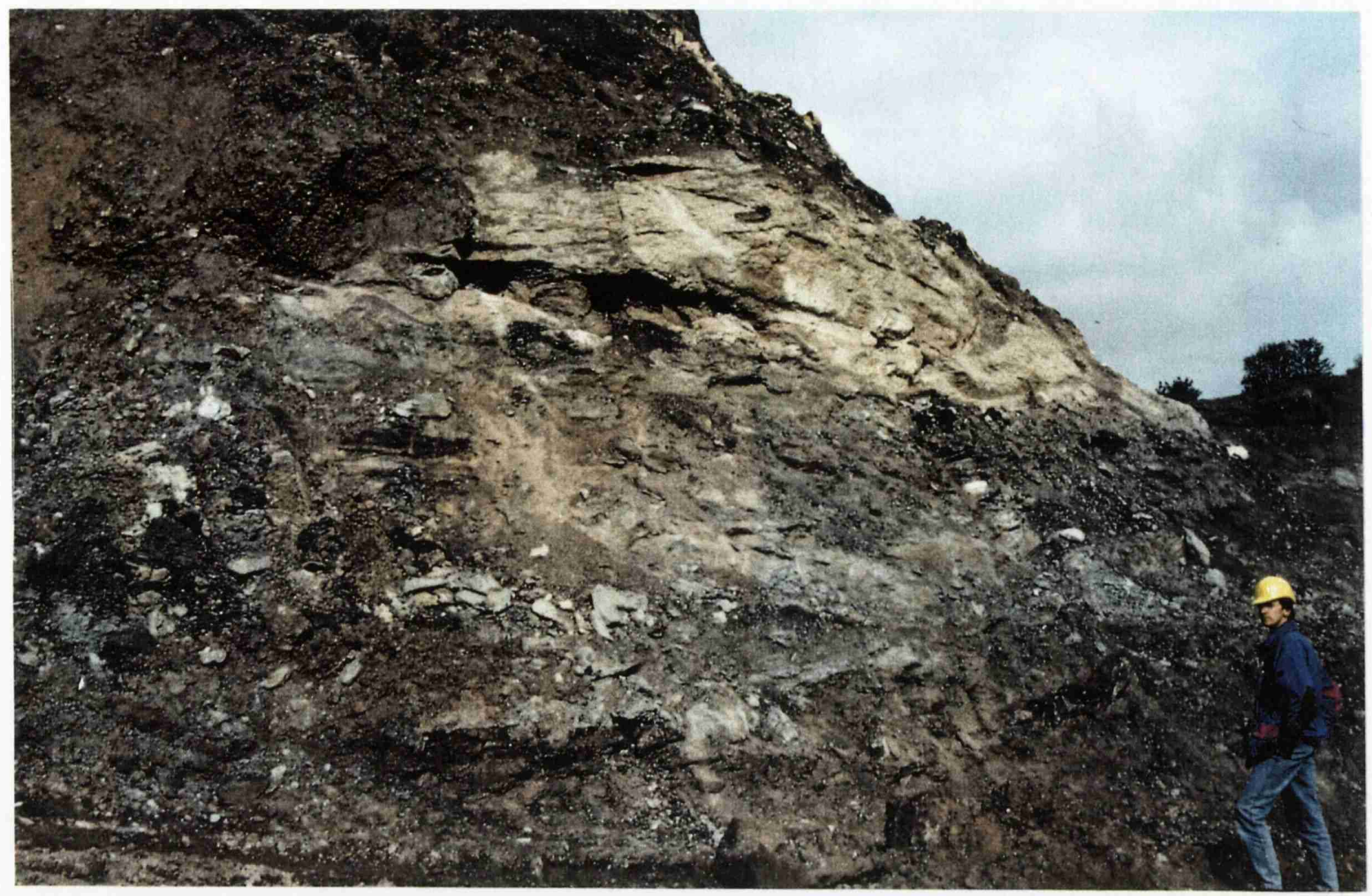

Figure 3.40. Blockley's Quarry, Hadley (SJ 683 118). Barren Measures, alluvial fan red beds, Etruria Formation (sequence V1). The exposure illustrates a range of well drained alluvial facies characteristic of areas proximal to sediment source. This facies association interfingers with the productive coal measures further north. The sequence is mud-dominated with sandstones and conglomerates forming less than $50 \%$ of the succession. Besly (1988) interprets the succession to represent small mud dominated fans derived from erosion of the Wales Brabant massif and other local horsts lying to the south.

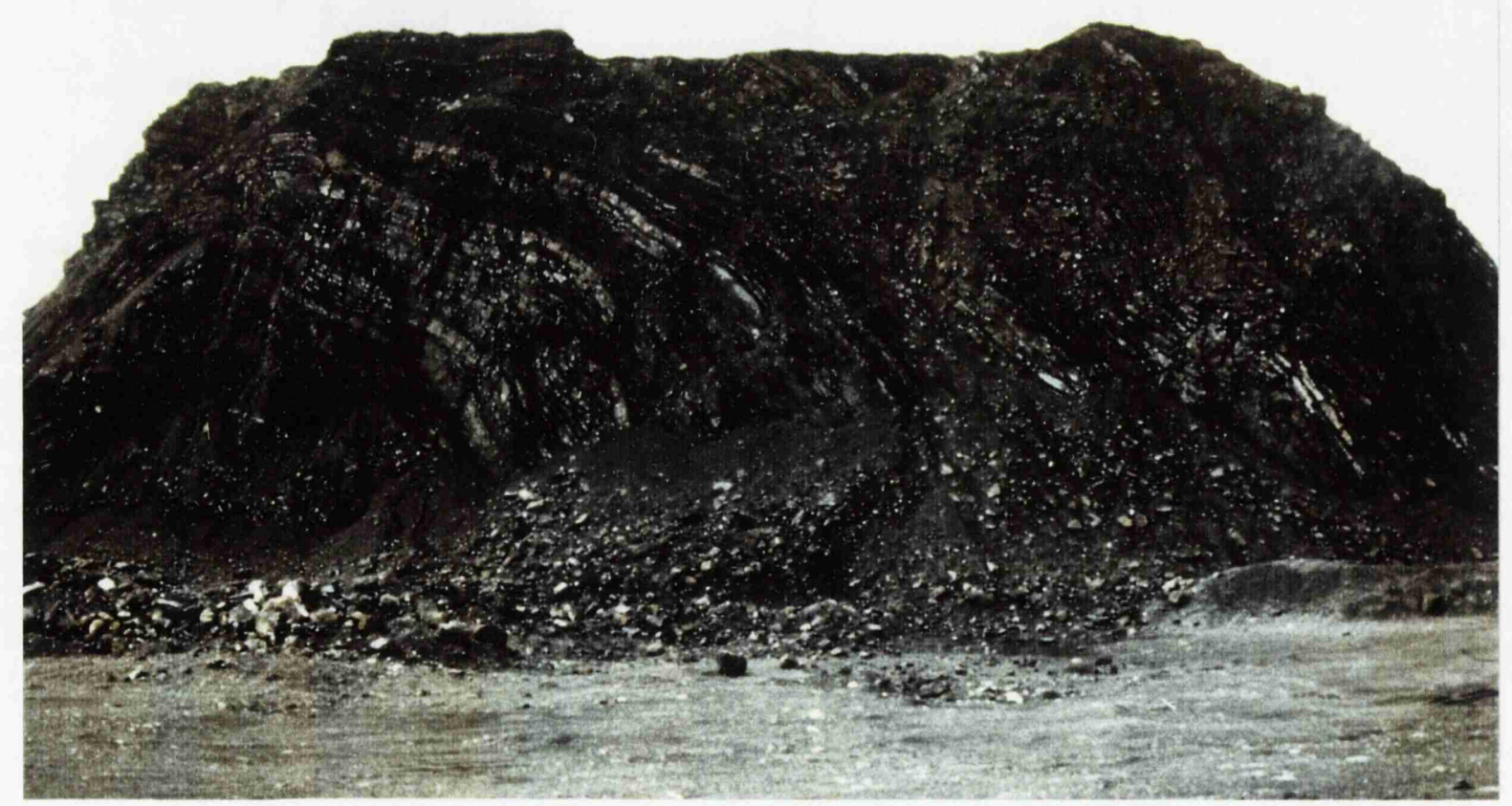

Figure 3.41. Skipton anticline, Central Bowland (SE 014 530). Tightly folded lower Carboniferous (sequence EC1) carbonates deformed during the late carboniferous-early Permian, Variscan inversion event. 
troughs throughout northern England. These sediments display an important component of southerly derived material from the evolving Variscan mountain front in southern England (Besly 1988).

The nature and intensity of the inversion in northern England varies in a predictable sense with respect to fault trend and depth to detachment. NE-SW trending faults such as the Pendle fault (Bowland basin) underwent strong inversion (Plate 3.14). These are interpreted to have been normal to the implied direction of maximum compressive stress. In contrast, NW-SE trending faults, such as the Askern-Spital fault (Gainsborough Trough), moved in a dextral strike slip sense with minimal vertical fault displacement (Plate 3.6). The major basin bounding faults (NW-SE) display broad, long wavelength, inversion anticlines such as demonstrated on seismic data in the Widmerpool Gulf (Plate 3.4). These rarely show four-way dip closures and hence are seldom associated with hydrocarbon accumulations. In contrast the NNW-SSE faults with shallow detachments form tightly folded, closed, inversion anticlines which constitute the major hydrocarbon bearing traps in the East Midlands. Good examples of this style of inversion are seen in the Eakring, Welton and Calow fields as discussed later in chapter 5.

Sequence VI (Westphalian C-Westphalian D). This sequence records the initial Variscan inversion event involving the formation of a series of broad inversion anticlines and the widespread uplift and erosion of the original syn-rift depocentres. The sequence records the first major input of southerly derived sediments with barren red beds and coarse pebbly sands and conglomerates (Fig. 3.40) accumulating in the distal part of the evolving Variscan foreland (Besly 1988). Sequence V1 is poorly represented on seismic data in northern England as a result of widespread erosion below the base Permian unconformity. The sequence can be identified by basal onlap onto inversion anticlines in the hangingwalls of the major faults and is thickest in the synclinal areas between the inversion axes. 
Sequence V2 (Westphalian D-early Permian). The onset of this, the second and strongest pulse of the Variscan orogeny, is dated as Westphalian ' $\mathrm{D}$ '; largely from subsurface evidence in the West Midlands and Southern North Sea basins. Its effect has been to strongly invert all major half-graben in northern England (eg. Widmerpool Gulf and Bowland Basin, (Plates $3.4 \&$ 3.14). The event is probably a series of compressive pulses initiated in Westphalian 'D' times. However, lack of preserved section of this age precludes any further breakdown. The inversion can be demonstrated at outcrop by the tightly folded Lower Carboniferous deposits in the Ribblesdale fold belt in the Bowland Basin (Fig. 3.41). The sequence is characterised by continued uplift and erosion of Dinantian syn-rift basins and accumulation of molasse deposits in small intermontane troughs within an evolving foreland.

\subsection{CONCLUSIONS}

It is suggested that the seismic sequence stratigraphy erected herein may provide a more applicable chronostratigraphical subdivision of the Carboniferous strata of the East Midlands and throughout northern England. Further field and subsurface analysis is necessary to confirm these observations, and may provide the basis for redefinition of the existing stages; particularly in the Dinantian where there is little relationship between the current stages and basin evolution and fill history. 


\section{CHAPTER 4 PALAEOGEOGRAPHY AND FACIES EVOLUTION}

\subsection{INTRODUCTION}

Having established a tectono-stratigraphic framework that can be applied throughout the northern England province to link outcrop, borehole and seismic facies data, it is then possible to construct a series of regional palaeofacies maps for each of the seismically defined sequences. This is of immense value, in terms of an assessment of the hydrocarbon prospectivity of northern England, as it permits an analysis of the regional distribution of the key elements of the hydrocarbon system; ie. reservoir, source and seal facies. This will be discussed in chapter 5 .

Previous palaeogeographic reconstructions for the northern England Carboniferous have relied heavily on surface outcrop mapping supplemented by shallow borehole and gravity data (eg. Wills 1951, George 1958, Johnson 1960, Kent 1966, Leeder 1974, Miller \& Grayson 1982, Gawthorpe 1987a, Gutteridge 1987, Guion \& Fielding 1988, Cope et al. 1992) This thesis has been able to significantly improve on these previous studies with the addition of subsurface information from BP's extensive regional seismic and borehole database. The borehole data has provided the main control on subsurface depositional facies, however, seismic facies analysis has proven invaluable in facies interpretation in areas where there are few deep well penetrations (see previous chapter). The seismic has also provided a hitherto unattainable insight to the Carboniferous basin geometries. The earlier loose structural interpretation of 'gulfs' and 'blocks' with poorly constrained basin margins (Kent 1966), has now been pulled together into a coherent structural framework.

The stratigraphic breakdown of the Dinantian has been achieved by the use of tectonostratigraphy, integrating data from seismic facies, boreholes and surface exposures linked with good quality biostratigraphic data where available. A more detailed 
breakdown of the Namurian and early Westphalian has been permitted using genetic sequence stratigraphy (Galloway 1989). This period in the Carboniferous is characterised by widespread cyclicity; the pattern of thick Millstone Grit sandstones alternating with siltstones and thin marine shales occurs over most of northern England. Given that most of the rifting had ceased by end Dinantian, it seams probable that this cyclicity is glacio-eustatic in origin (Heckel 1990). Ramsbottom (1977) used the broad regional extent of the cycles to define a 'mesothem' stratigraphy (Fig. 3.11). Maynard \& Leeder (1992) have estimated sea-level changes of around 45 metres with a periodicity approaching $100 \mathrm{ka}$. These are not as great as the magnitudes recorded during the Pleistocene of c. 130 metres with a dominant frequency of $100 \mathrm{ka}$ (Gawthorpe et al. 1994). Nevertheless, the consequent changes in palaeogeography were extensive as a result of the flat lying delta plain topography. During regressive phases of eustatic cycles (high stand systems tract of Van Wagoner et al. 1988), fluvio-deltaic sandstones prograded basinwards to fill the accommodation space generated on the shelves by the preceding marine incursion. Coal swamps developed extensively on the upper delta plain but these are rarely of regional stratigraphic significance due to their origin in both eustatic and autocyclic (delta lobe switching) processes. Transgressions (transgressive systems tract) are characterised by thin siltstones and black shales immediately overlying a seatearth and show a succession of faunas corresponding to rapidly increasing marine influence (Ramsbottom 1969). The transgressive acme (maximum flooding surface) is often represented by a thick, black, laminated, organic rich shale with abundant thick shelled goniatites and pectinoid bivalves. In marginal settings, brachiopod-crinoidmollusc communities are developed. Goniatites are rarely recovered from oil exploration boreholes, however palynomorphs are abundant and can be related to the classic goniatite stratigraphy (Ramsbottom et al. 1978 and various BP propriety studies), to permit correlation between outcrop and the subsurface (Fig. 3.11). 


\subsection{REGIONAL PALAEOGEOGRAPHIC SETTING}

By early Devonian times, the Iapetus ocean had finally closed (ca. 400Ma). Postcollision, subduction-related granitoid intrusions were emplaced which considerably influenced subsequent basin geometry and facies development in the northern part of the study area. Although deformation had largely ceased by mid Devonian times, the Caledonian structures acted as both major loci for subsequent tectonic activity and important local sediment sources. Rapid uplift and erosion of the Old Red Sandstone Continent ensued. Sedimentation occurred in internal molasse basins (Lower Old Red Sandstone) under a prevalent arid climate. The northward drift of European Pangea during the Dinantian (Plate 2.2) led to a change to humid climatic conditions by the late Dinantian (Duff 1980). There is general agreement that northern Britain was equatorial during the Namurian (Smith et al. 1981, Scotese et al. 1979). The occurrence of coal and bauxitic soil horizons in Scotland indicates a humid, tropical climate (Cope et al. 1992). The increasing rainfall may in part be responsible for the rapid progradation from the north in earliest Namurian times of a delta system of Brahmaputra scale. The mineralogy of these delta systems suggests a provenance in the Scottish/Scandinavian Caledonides (Gilligan 1920, Leeder 1988) and transportation is thought to have been via braided river systems flowing generally from NNE to SSW. Namurian sedimentation was initially controlled by the inherited Dinantian rift topography. However, this was infilled giving way to a broad thermal sag and thick, more uniform sequences of delta top sediments accumulated over most of northern England through to Westphalian ' $C$ ' times. At this time, the thermal subsidence regime was modified by inversion tectonics related to the progressive northwards movement of the Variscan deformation front. Continued northwards drift of Pangea led to a return to arid conditions by late Westphalian times. Sedimentation was initially confined to internally drained molasse basins which were eventually swamped by increasing amounts of material shed northwards from the evolving Variscan mountain front, lying to the south. 


\subsection{LATE DEVONIAN (Plate 4.1) Sequence ECla - early syn-rift I.}

There are very few data to constrain the palaeogeography of northern England during the late Devonian. By this time, the mountainous topography of the Old Red Sandstone continent, particularly over northern Britain, was much subdued. Fanglomerate deposition developed along newly active fault-scarps, such as the Gamblesby-MelmerbyOusby fans along the Deep Slack, Fellside and Swindle Beck faults (Fig 3.15) and the Mell Fell 'Polygenetic' (= polymict) Conglomerate, in East Cumbria (Plate 4.1). The Whita and Annan Sandstones in the Northumberland basin (Leeder 1974) are interpreted as examples of more sheet-like hangingwall derived fan systems.

Approximately 275 metres of coarse breccias, consisting of pebbles of quartzite, metasediments and igneous rocks, rest on Lower Palaeozoic phyllites in Eakring-146. This is interpreted as deposition in close proximity to an active fault-scarp (Plate 3.9). Other boreholes penetrating siliciclastic rocks of probable late Devonian age are Caldon Low (c. $170 \mathrm{~m}$ red-brown pebbly sandstone) situated on the footwall of the (Widmerpool Gulf) and Whittington Heath (c. 1m pebbly sandstone) in the hanging wall of the Birmingham fault.

Further interpretive evidence for early syn-rift sedimentation in the East Midlands area is obtained from gravity and seismic data. Late Devonian sedimentary basins may be localised around gravity lows eg. the Eakring-Foston and Gainsborough troughs (Plate 4.1).

4.4 COURCEYAN (Plate 4.2) Sequence EC1b - late syn-rift I.

A marine transgression occurred across much of northern England during the Courceyan. Basinal areas such as Northumberland, Cleveland-Stainmore, BowlandCraven, were already subsiding and receiving siliciclastic mudstones and some alluvial 
sands. Main areas of upland e.g. Southern Uplands, Manx-Cumbria-Alston-Askrigg ridge and Mercian Massif, remained emergent and in some cases persisted as highs throughout the Dinantian.

Coastal sabkhas developed around the northern margin of the Mercian Massif. Over 99 metres of anhydrite and dolomite were proven in Hathern-l (Falcon \& Kent 1960, Llewellyn \& Stabbins 1968, 1970). This indicates that there was restricted marine influence by this time in the half-graben. Palynological analysis (Llewellyn et al. 1969) indicates a Courceyan age equivalent to the CM Zone of Clayton et al. (1977). Similar, thicker evaporitic deposits are extrapolated for the Widmerpool Gulf. Thin (c. 80 metres) transgressive siliciclastic sediments were encountered in the Eyam borehole in Derbyshire (Dunham 1973, Strank 1985). Other wells such as Caldon Low (Institute of Geological Sciences 1978, Welsh \& Owens 1983) and Eakring-146 encountered nearshore or alluvial braid plain siliciclastics. Dolomitic carbonates with subordinate siltstone-mudstones in Grove-3, Caldon Low, Welton-A1 and Gun Hill-1 represent the initial stage of a widespread carbonate ramp development in northern England.

Sabkha evaporites accumulated along the northern flank of the Bowland Basin (Gawthorpe 1987a) and in the Northumberland Trough (Johnson 1984). Elsewhere, evaporites and restricted-shelf carbonates are proposed for near-shore environments, such as would have been developed in the Stainmore Trough. The Courceyan sediments, tentatively identified at the base of the Seal Sands-l borehole in the eastern Stainmore Trough, comprised siliciclastic sediments, possibly derived from the emergent Alston Block to the west.

Alluvial, piedmont fans were developed in fault-bounded lows within the ManxCumbria-Alston-Askrigg Ridge. An example of this facies are the Shap Red Beds (Kimber 1984). They include conglomerates derived from the Silurian greywackes to the south and southwest, grading up into cross-bedded sandstones. Similar red 
conglomerates at Sedbergh to the south were probably derived from the northwestern side of the Askrigg Block.

Cementstone-type facies were established during the early Dinantian in the Scottish Borders in fluvio-lacustrine and hypersaline lake environments. Vigorous drainage from the Southern Upland Massif provided coarse siliciclastic sediments to the basin e.g. Rerrick, Annan and Whita alluvial systems (Leeder 1974, Johnson 1984). These may have been the precursors of the large delta systems which were advancing from the north east. In Kirkudbrightshire, the northem Solway fault was active and the Criffel Granite unroofed, causing considerable erosion and sedimentation. By the end Courceyan, marine basin 'gulf' facies and faunas were prevalent in the Northumberland Basin.

The subsidence of the Northumberland basin was accompanied by extensive alkaline fissure basalts (Birrenswark/Kelso/Cockermouth Lavas) along its northern bounding fault (Gawthorpe et al. 1989). Igneous activity was also evident from tuffaceous sediments of Courceyan age encountered in Welton-Al and Grove-3 in the East Midlands.

\subsection{CHADIAN (Plate 4.3) Sequence EC2 - post rift I (regression)}

During Chadian times, a low angle carbonate ramp developed peripheral to the Mercian Massif and along the southern margin of the Manx-Cumbrian Ridge. The lower part of the ramp comprises interbedded mudstone and limestone, gradational basinwards into mudstone dominated deeper water facies. The shallower section of the ramp consists predominantly of shelf limestone. Sediments of the EC2 Sequence have been penetrated at Hathern on the footwall of the Hoton fault. Here the sequence is developed as shelf limestones (Llewellyn \& Stabbins 1968, 1970) which are dated as no older than the CF4 Zone of Conil et al. (1979). On the adjacent East Midlands platform EC2 is the oldest of 
the Dinantian sequences preserved, and is developed as shelf limestones. Strank (1987) indicated that EC2 is no older than late Courceyan in the shelf setting.

Gawthorpe (1987a) proposed that the Chatburn and Thornton Limestones, exposed in the Bowland Basin, reflect deposition on a carbonate ramp and that during the early-late Chadian, passive subsidence of the basin led to the development of a rimmed shelf along the hangingwall dipslope, where carbonate grainstone shoals were concentrated above wave base, as observed in outcrops in the Bowland Basin (e.g. Scrosthrop Lane Quarry; Fig. 3.17). The age of this sequence, however, is uncertain. Fewtrell \& Smith (1978) indicated that an age as old as late Courceyan may be possible. The succession is believed to be equivalent to sequence EC2. This correlation is based on limited biostratigraphic data, and comparison of seismic and outcrop facies.

At Dovedale, on the Derbyshire Dome along strike from the Widmerpool Gulf, an elongate Waulsortian mud mound complex is reported by Bridges \& Chapman (1988). The mud mound complex developed on a ramp to the southwest of an evolving carbonate platform during Chadian times. Grayson \& Oldham (1987) report similar facies of Chadian age from the Bowland Basin.

Waulsortian build-ups developed below wave base, on the lower part of the carbonate ramps, as they evolved towards rimmed shelves. These build-ups are peculiar to Dinantian strata and notably to the Chadian. They comprise steep-sided mudstone mounds, around 200 to $300 \mathrm{~m}$ in height, originally deposited as a biogenic, mucilagenous ooze, with a sparse shelly fauna and sometimes including filamentous algae or bryozoa (Bridges \& Chapman 1988). Occasionally, stromatotactis banding and geopetally-filled vugs are observed at outcrop. Overall, the mounds exhibit evidence of early cementation and very poor poroperm. Flanking the mounds are carbonate grainstones derived from crinoidal colonies which colonised the top of the build-ups. These grainstones possess reworked material providing better reservoir characteristics 
but are laterally restricted. Different sub-facies of Waulsortian mud mounds have been defined, dependent on water depth and light penetration (Lees \& Miller 1985). It is considered that these build-ups, as observed in the field at Dovedale, Derbyshire (Fig. 4.1) or Hall Hill, Bowland Basin (Miller \& Grayson 1982) are of the deep water type. These features probably represent the mounded facies (Fig. 3.12) previously identified as Dinantian reefs on seismic data by various oil company interpreters (BP in-house reports).

Figure 4.1. Dovedale Derbyshire (SK 146 550). Chadian (EC2) Waulsortian build-up. These build-ups are peculiar to Dinantian strata and notably to the Chadian. They comprise steep-sided mudstone mounds, around 200 to $300 \mathrm{~m}$ in height, originally deposited as a biogenic, mucilagenous ooze, with a sparse shelly fauna and sometimes including filamentous algae or bryozoa (Bridges \& Chapman 1988). Flanking the mounds are carbonate grainstones derived from crinoidal colonies which colonised the top of the build-ups.

Near-shore siliciclastic rocks and dolomitic carbonates of Chadian age are encountered in the East Midlands area (eg. Bardney-1, NCB Bassingham, Hathern-1, Eakring-146, Eyam BH, Ironville-5, Strelley-1 \& Grove-3) and in outcrops peripheral to the non- 
depositional upland areas of the Southern Uplands and Manx-Cumbrian-Alston ridge in the north. The topographic highs of Sproxton, Stixwould, Nocton, Foston and Woo Dale received no Chadian sediments. The lowermost Dinantian sediments in the boreholes Holme Chapel-l and Boulsworth-l are carbonates of probable Chadian age.

Marine pro-delta mudstones accumulated in the Northumberland, Cleveland and Bowland basins with some alluvial to deltaic influence, notably in the northeastern part of the area where the Fell delta system had established itself. Restricted basinal facies are interpreted for the Widmerpool Gulf and Gainsborough Trough half-graben.

\subsection{LATE CHADIAN - ARUNDIAN (Plate 4.4) Sequence EC3 - early syn-rift II (transgressive)}

The Arundian-Holkerian, sequence EC3, follows the Chadian (sequence EC2) with a strong onlap relationship and comprises a series of carbonate ramps with associated basinal mudstones. Intermittent mudstone horizons extend across the carbonate shelf area of the East Midlands, notably the Arundian shale interval, the only previously recognised intra-Dinantian seismic reflector.

Renewed extensional tectonic activity at the end of the Chadian is indicated by boulder beds and slumping (olistrostromes) observed in outcrops in the Bowland Basin (eg. Haw Crag (Fig. 3.19). The boulder beds are commonly vuggy with patchy diagenetic dolomitisation redeveloping the high primary porosity. Bitumen occurs rimming fractures and vugs and has been post-dated by hydrothermal $\mathrm{Pb}-\mathrm{Zn}-\mathrm{Ba}$ mineralization. Fig 3.19 shows boulders of proximal ramp and Waulsortian carbonates derived from footwall erosion of the South Craven fault system at the onset of EC3 rifting. In the Bowland basin EC3 is represented by the Worston Shale, predominantly mud and silt grained clastic deposits with thinly bedded hemi-pelagics and calciturbidites (Fig. 3.20). 
During the rifting phase periodic instability of the hangingwall dipslope led to the generation of syn-sedimentary slumps and slides in sediments of EC3 age (Fig. 3.21). The tectonism also caused drowning of the carbonate shelf by mudstones and was accompanied by some alkali volcanism, e.g the Cockermouth Lavas in West and North Cumbria (Johnson 1984).

The palaeofacies map for the late Chadian-Arundian (Plate 4.4) shows clear evidence of a major transgression from the west. Both the Alston and Askrigg blocks were increasingly subject to marine incursions. The conodont fossils recorded from Ravenstondale (Higgins \& Varker 1982) indicate increasing water depths during the Arundian, consistent with an interpretation of regional transgression following the renewed rifting. During this important transgressive phase extensive carbonate shelf areas developed and onlapped upland areas. The Manx-Cumbrian Ridge was apparently separated by shallow shelf seas from the Alston and Askrigg 'islands'. Nondepositional highs persisted to some extent in the East Midlands, but the Woo Dale high in Derbyshire was finally submerged (Woo Dale borehole; Cope 1973).

Basement beds and near-shore sediments of Arundian age outcrop in the Mold District of North Wales (Somerville \& Strank 1984). Elsewhere, Arundian limestones onlap earlier Carboniferous sequences and in places overstep onto the northern Lower Palaeozoic margin of the Wales-Brabant High.

To the southwest of the Askrigg block, calci-turbidities accumulated in the deeper basinal areas of Bowland. Delta top siliciclastics and thin coals of the Ashfell delta on encroached the eastern Northumberland Trough and northern Cleveland Basin (Seal Sands-1). 


\subsection{HOLKERIAN (Plate 4.5) Sequence EC3 - late syn-rift II (transgressive)}

There was no major tectono-stratigraphic break between the Holkerian and Arundian with a continuation of carbonate ramp development and progressive onlap. This interval marked the maximum extent of the Dinantian transgression. Shelf limestones were more extensive during the Holkerian than at any other period in the Dinantian. Correspondingly the Fell clastic delta system in the Northumberland and Cleveland basins retreated back towards the northeast. Carbonates with minor siliciclastic sediments accumulated across the East Midlands, and the Nocton, Foston, Stixwold and Askern-Spital highs were all submerged (Strank 1987). Shelf-ramp carbonates extended northward beyond the Alport-1 borehole in the Edale Gulf. Basal beds of alluvial and near-shore siliciclastic facies are of Holkerian age in North Wales and Anglesey (Strank 1986). Coal and cannel coal are recorded from the Holkerian of the Egmanton-68 borehole representing a mid-shelf swamp.

In places, on the Derbyshire Dome, the Holkerian is thin or absent, representing local emergence or non-deposition (eg. Dovedale). Highly porous dolomitised shelf limestones (Woo Dale Limestone) have been described by Schofield and Adams (1985) who interpreted the environment of deposition as a shallow subtidal carbonate shelf which experienced varying degrees of restriction from open marine conditions. Carbonate shelf environments persisted around the islands and uplands to the north. Despite its retreat, the Fell clastic delta system still covered most of the Northumberland and Cleveland basins. Coal swamps developed on the upper delta plain. These provided structured woody plant material to the pro-delta organic mudstone facies, deposited in the southern Cleveland and Solway basins. 


\subsection{ASBIAN (Plate 4.6) Sequence EC4 - post rift II (regressive)}

Considerably more data is available to control the Asbian palaeogeography-facies distribution. Over 200 boreholes penetrate Asbian strata and outcrops occur of shelf, shelf margin and basinal facies in the Derbyshire Dome, Bowland Basin, North Wales, Cumbria and across the Alston and Askrigg blocks. In the East Midlands rimmed shelf margins are visible on some better quality seismic lines (see chapter 3). In the basinal setting the high amplitude reflectors recorded on seismic sections represent an increase in carbonate within an otherwise monotonous sequence of mudstones and interbedded limestones. The progradational and aggradational features identified on the basin margins, none of which have been penetrated by wells, are believed to represent the development of carbonate ramp to rimmed shelf facies. Shelfward of these features, and confirmed by well data, shallow marine shelf, carbonate grainstones accumulated.

The Asbian-Holkerian (EC3/EC4) boundary is poorly defined biostratigraphically but can be observed seismically as strong downlap of the prograding shelf margin sequence. The faunal assemblage for the early Asbian type section at Little Asby Scar (NY 698 082; George et al. 1976) is considered atypical and is not regionally developed (Ebdon et al. 1990).

By Asbian times, the extensive Arundian-Holkerian shelf-ramp had evolved into a series of rimmed shelves (Plate 4.6). In areas of shallow water, starved of clastic sediment, shoaling-upward cyclic shelf carbonates were deposited; for example the Great Scar Limestone and equivalents in western Stainmore and on the Alston and Askrigg blocks (Fig. 3.22). In the East Midlands and Bowland, these shelf carbonates pass basinwards through platform margin facies into hemipelagic lime mudstones and calciturbidites of the foreslope. This carbonate slope facies association shows a coarsening upward trend reflecting progradation of the rimmed shelf. Shelf margin complexes are exposed in the Derbyshire Dome, Bowland Basin and N. Wales. There was an absence of framework 
building organisms during the Dinantian and boundstone reefs were not usually formed.

Little Orme, N. Wales, is one rare example as is the Dunhald Mill quarry section in Cumbria (Fig. 4.2). Elsewhere the rimmed shelf comprised bioclastic carbonate buildups with abundant fauna including crinoids, productids and other brachiopods and solitary corals.

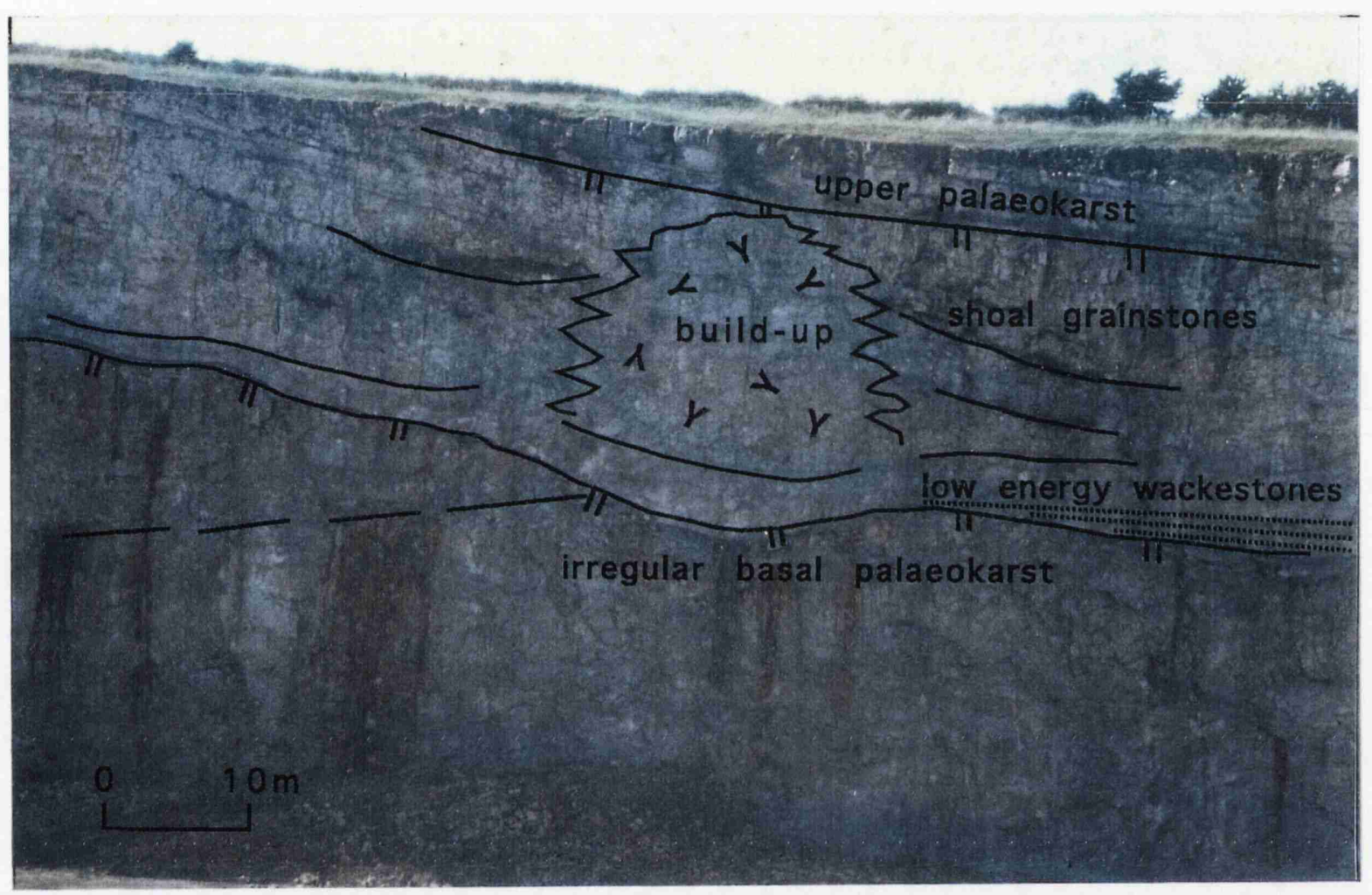

Figure 4.2. Dunald Mill Quarry, near Carnforth, Lancashire (SD 482 808). This locality comprises late Asbian (EC5) shelf grainstones situated on the northern margin of the Lancaster Fells Basin. A small palaeoberesellid build-up is is exposed in the western face of the quarry. The build-up comprises a loose framework of the alga Kamaenella and early marine peloidal cements (Horbury 1992). The build-up is flanked to the north (shelfward) by crinoidal-bryozoan grainstones and packstones. The prominent palaeokarst emergent surface, onto which the build-up has seeded, is of mid-late Asbian age and marks the onset of EC5 tectonic subsidence.

At Castleton (footwall margin), the depositional talus slope attained angles of upto $30^{\circ}$

(Fig.3.23). These steep angles would have been maintained by early biogenic cementation. This footwall margin was weakly progradational, but not sufficiently so as to extend beyond the controlling fault. The form and location of the rimmed shelf 
complexes was largely controlled by faulting and a belt of carbonate build-ups may be extrapolated around the fault-controlled East Midlands basins (Widmerpool Gulf, Edale Gulf and Gainsborough Trough). The angle of slope and amount of progradation would have been greatly affected by the amount of throw on the fault or whether the shelf margin developed on the footwall or hangingwall rollover.

An apron of shelf debris forming coarse grainstones may develop on the shelf front. These beds are likely to have possessed high primary, vuggy porosities, eg. Pendleside Limestone, Bowland Basin (Fig. 3.24). In some of these localities secondary porosity has been generated by dolomitisation. The marginal facies were also controlled by climatic conditions as recognised in the Derbyshire Dome (Schofield 1982), with grainstone facies apparently developed on the northern facing windward margins. Oil seeps are known from the shelf margin facies, eg. Windy Knoll, in Derbyshire (Fig. 4.3). Bitumen staining is common, associated with and predating hydrothermal $\mathrm{Pb}-\mathrm{Zn}$ $\mathrm{Ba}$ or fluorite mineralization. The fluorite at Castleton is thought to derive its famous Blue John colouration from numerous microscopic hydrocarbon inclusions in the crystal lattice (Ford 1969). The peritidal shelf limestones flanking the rim complexes are typically mudstones-wackestones with poor porosity and permeability characteristics. The Bowland and East Midlands basinal areas received calcareous turbidites and hemipelagic mudstones.

Deltaic conditions prevailed to the northeast with the development of the Yoredale delta system. Associated pro-delta mudstones provided some potential hydrocarbon source rock in the Northumberland/Solway and Cleveland basins. Cyclical shelf carbonates and near-shore siliciclastics accumulated in North Wales, related to episodic emergence and karstification (Walkden and Davies 1983). This is also recognised from outcrops in the Derbyshire Dome (eg. Hartington Station Quarry; SK 129 615). Fossil tree fragments and subaerially weathered limestones are described from Guides Farm (SD 402 764) in the Lancaster Fells Basin (Adams \& Horbury 1990). The delta system had advanced 
considerably southwards, filling much of the Northumberland and Cleveland basins with cyclical deltaic silicicalastics, with minor coals and interbedded marine limestones and mudstones.

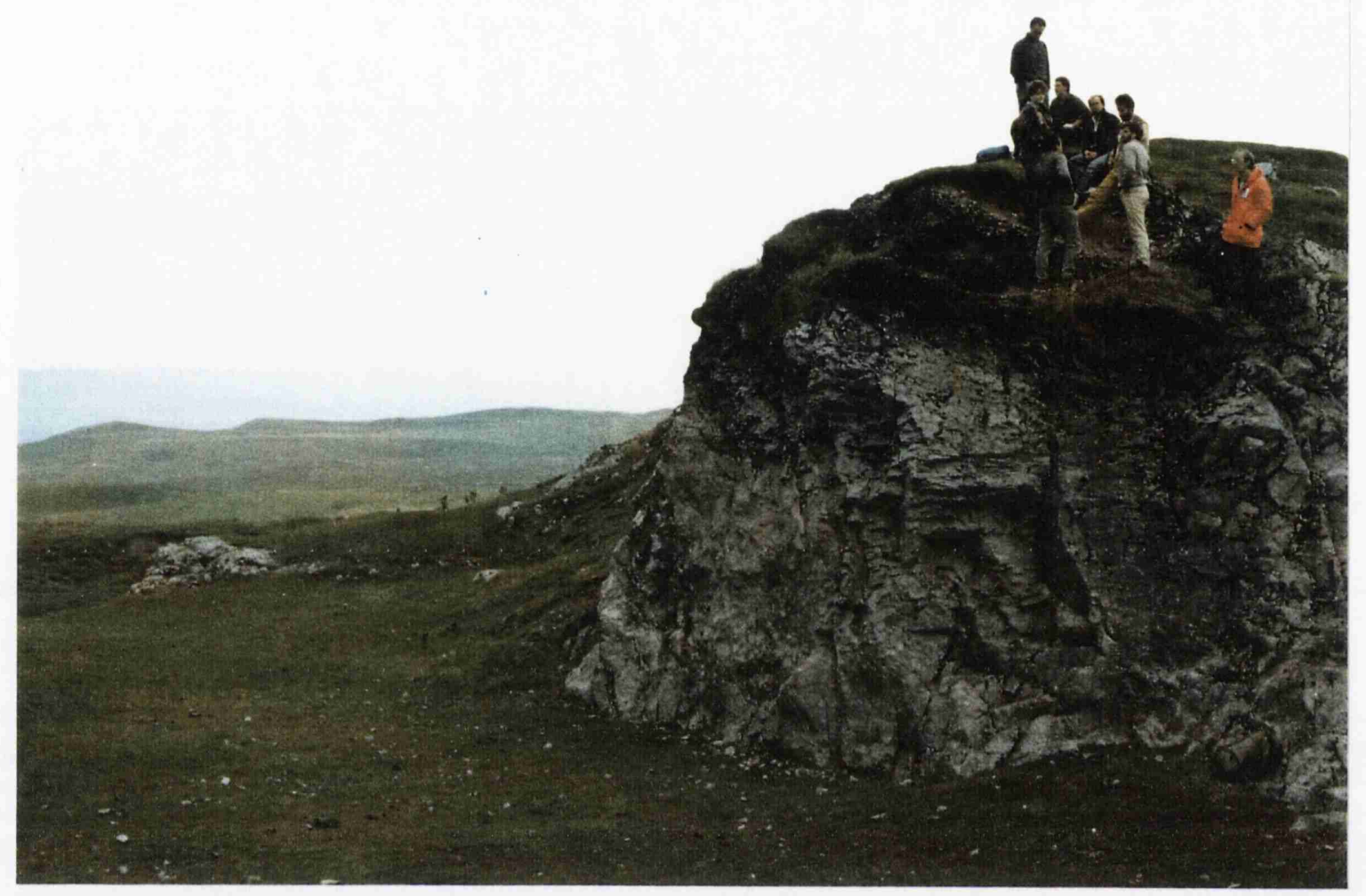

Figure 4.3. Windy Knoll, Castleton, Derbyshire (SK 413 381). Fissure fills and hydrocarbons in shelf carbonates. The Windy Knoll exposures are of Asbian (EC4) age and represent the crest of a small breached oilfield. Hydrocarbons at this locality are severely biodegraded, infilling remnant primary, secondary and fracture porosity. The Edale Shales which onlapped the carbonate platform during the early Namurian form both the seal and hydrocarbon source rocks for this structure. Lithologies are primarily grainstones. Neptunian dykes in the massive face of the outcrop are of Brigantian (EC6) age, at which time this part of the margin was emergent and rifting/slope instability resulted in fracturing of the partially cemented carbonates near the shelf/slope break.

\subsection{LATE ASBIAN - EARLY BRIGANTIAN (Plate 4.7) Sequence EC5}

- syn rift III (transgressive)

Renewed tectonic activity in late Asbian times, again reactivated and rotated fault blocks causing inundation of the shelf margins, footwall erosion and slumping and boulder bed deposition in hangingwall settings. The exact timing of this end Asbian event is difficult to ascertain due to rapid facies related faunal variations. The record of palynofloras 
belonging to the NM Zone (Neves et al. 1972), ME Subzone (Clayton et al. 1977), is consistent with the late Asbian age assigned to the base of the sequence (Ebdon et al. 1990).

Shallow marine shelf limestones accumulated on the East Midlands platform and Hathern shelf. In the basinal setting borehole evidence (Ratcliffe-on-Soar-1; Plate 3.5) indicates that EC5 consists of a monotonous series of calcareous mudstones and thin dolomitic limestones. Volcanic centres as evidenced by basalts and tuffs in the Strelley-1 borehole (Plate 3.5) were active along the Cinderhill fault system during EC5 times (Plate 4.7).

Sequence EC5 ties in well with a late Asbian-early Brigantian phase of tectonic activity in northern England (Gawthorpe 1986, 1987a). Basaltic lavas on the Derbyshire Dome, (the Lower and Upper Miller's Dale Lavas) lie along strike from, and are stratigraphically equivalent to, the volcanic centres developed along the hangingwall margin of the Widmerpool Gulf (Macdonald et al. 1984). This volcanism is related to reactivation of extensional faults. Gutteridge (1987) records two periods of emergence and karstic erosion on the Derbyshire Dome in the late Asbian and early Brigantian. These are believed to correspond to two pulses of extension in the area during EC5 times, leading to footwall uplift and erosion. As with earlier phases, horizons of debris flows, carbonate breccias and sedimentary slides occur in the Bowland Basin associated with this tectonism (Fig. 3.25). During EC5 times fine terrigenous clastics related to the continued advance of major delta systems from the north reached the Bowland Basin for the first time forming the Lower Bowland Shale. In the Widmerpool Gulf, carbonate production ceased either as the EC5 transgression inundated the shelf margins or the marginal platforms became emergent.

In Stainmore and the Alston and Askrigg blocks, where shallower water conditions prevailed close to the clastic source, the onset of cyclic Yoredale sedimentation is apparent (Johnson 1960). This facies association comprises repetative cyclothems, each 
beginning with a marine limestone followed by a coarsening-upwards succession of shale-siltstone-sandstone indicative of delta progradation and ending with delta top formation of a thin coal. Leeder \& Strudwick (1987) have discussed the origin of the Yoredale cyclicity and suggested that a combination of tectonic and purely sedimentary (autocyclic) processes were involved which locally subdued the influence of glacioeustatic sea-level changes. The Yoredale facies also accumulated over a large area of the Southern North Sea (Fig 4.4).

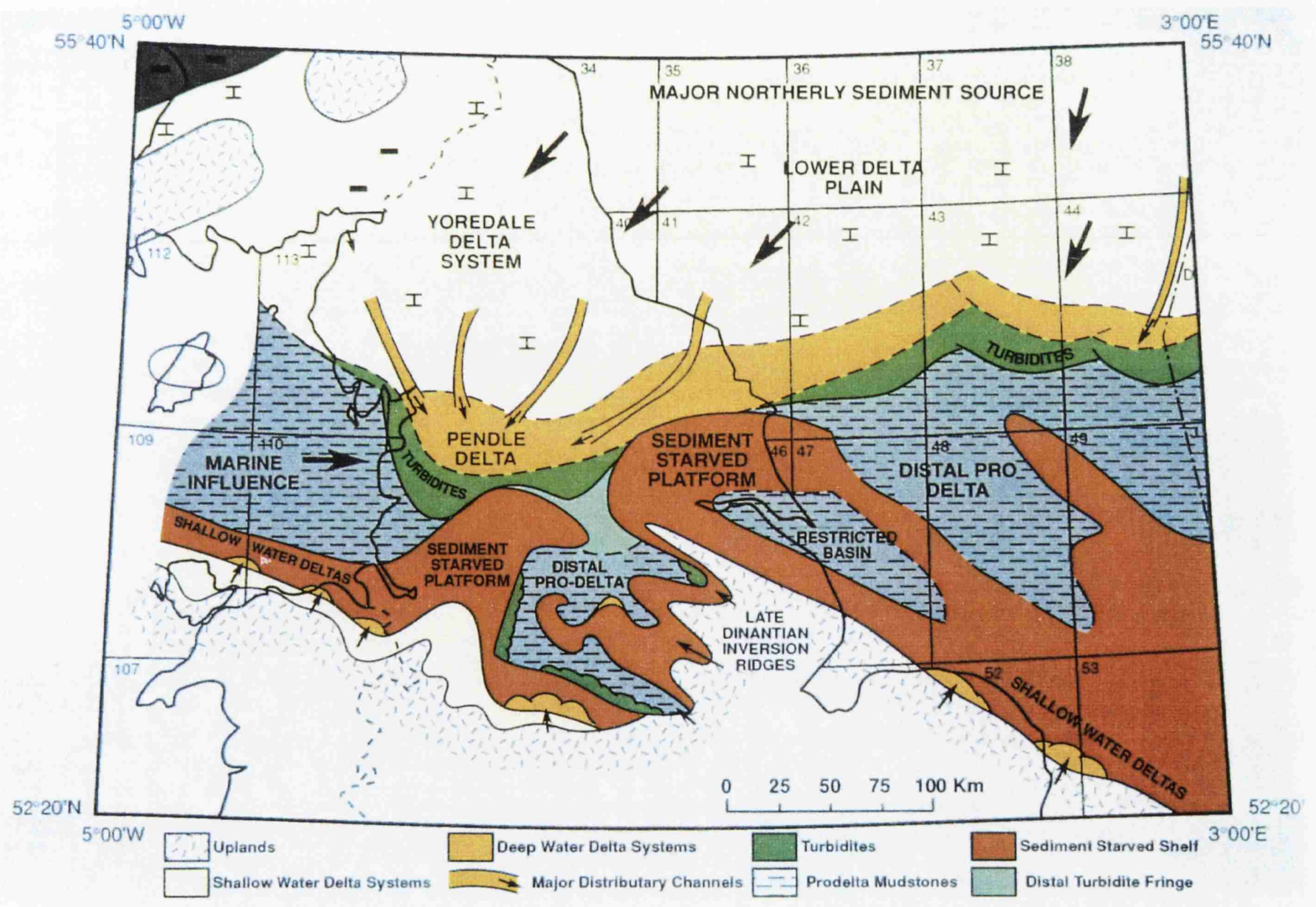

Figure 4.4 Schematic palaeogeography for the late Dinantian-early Namurian, showing the extent of Yoredale facies deposition over northern England and the Southern North Sea. Offshore data extracted from confidential oil company records.

Alkaline fissure basalts and tuffs related to the tectonic activity occur in boreholes and outcrops. Volcanics related to the renewed extensional activity during EC5 (late Asbian 
to earliest Brigantian age) have been described from outcrop in Derbyshire; Lower and Upper Millers Dale lavas (Walkden 1977, Walters \& Ineson 1981, Macdonald et al. 1984). These basalts are associated with a series of NW-SE trending faults (Cinderhill fault system) which bound the northern margin of the Widmerpool Gulf. Basaltic lavas and tuffaceous horizons of similar age have been encountered in exploration boreholes in the East Midlands along the same trend (Strelley-1; Plate 3.5). Walkden (1977) suggested that this volcanism could be temporally related to periods of uplift and emergence as indicated by karst surfaces developed in shelfal limestones. The volcanics are interpreted as resulting from renewed extensional activity along the Cinderhill fault system during early Asbian rifting. The karst limestone/volcanics association suggested by Walkden (1977) can thus be explained in terms of footwall uplift during extension resulting in erosion and karstification rather than sea-level changes from glacio-eustatic effects as later suggested by Walkden (1987).

\subsection{EARLY-MID BRIGANTIAN (Plate 4.8) Sequence EC6 - post rift III (regressive)}

By Brigantian times it seems likely that basinal sedimentation was continuous from the Dublin Basin to the Bowland Basin and eastwards to the Widmerpool and Gainsborough basins. Shelf limestone facies were now widespread across the East Midlands (Strank 1987). The top of the sequence is well constrained by the top of the G. bilineatus conodont Zone of Metcalfe (1981). Conodont assemblages are rich and diverse throughout and resemble those present in the underlying EC5 sequence. The EC6 sequence belongs exclusively to the NC palynomorph Zone (Neves et al. 1972), the top of the sequence falling within the biozone.

The interval is characterised by carbonate ramp to rimmed shelf development in the Widmerpool Gulf and Gainsborough Trough where water depth differences of up to 300 metres were established between shelf and basin. In the basin the interval comprises a 
monotonous series of thinly bedded, dark grey, calcareous mudstones and brown, dolomitic, muddy limestones. In Derbyshire 'reefs' were developed within the carbonate platform. The hangingwall margin formed on the north of the Widmerpool Gulf at this time is exposed at surface at Wirksworth in Derbyshire some $35 \mathrm{kms}$ along strike to the west (Walkden 1982). Over a distance of roughly $1 \mathrm{~km}$ away from the fault shelf grainstones, packstones and wackestones pass southwards through stacked grainstone shoal complexes and into slumps and slides associated with the rimmed shelf margin (Fig. 3.30).

The presence of a barrier to the south is suggested by evidence from the Whittington Heath borehole with only $0.75 \mathrm{~m}$ of Brigantian rocks and the Rotherwood borehole with Brigantian anhydrites indicating marginal conditions. Alkaline fissure basalts and tuffs are recorded at this time in the Isle of Man, the Derbyshire Dome and the Little Wenlock area of Shropshire.

The Brigantian shelf margins developed shelfwards of the Asbian margins, and similarly prograded basinwards. Bioclastic grainstone shoals formed as low amplitude clinoforms. This facies has been mapped in surface outcrops by the Geological Survey as 'flat reefs' (eg. Bradwell Dale, Derbyshire; Fig. 3.28).

During this period, the Pendle delta system prograded southwards from the NE and NW resulting in the deposition of siliciclastic turbidites (Pendleside Sandstone) in Bowland, effectively precluding further carbonate production in the basin (Fig. 4.4). Cyclic shallow marine Yoredale sedimentation continued in Stainmore and across the Alston and Askrigg blocks.

In north Wales, the Brigantian contains cherty horizons and in the Llangollen and Oswestry areas sandstones are developed within the limestone succession (Cope et al. 1992). 


\subsection{LATE BRIGANTIAN (Plate 4.9) Sequence LC1a - post rift}

Renewed subsidence, following shortly after the early-mid Brigantian inversion event, caused inundation of the shelf margins and development of new intrashelf basins, such as the Welbeck Low (Fig. 3.2) and across the Derbyshire Dome (Gutteridge 1987). Bituminous carbonates and mudstones accumulated in these highly isolated, anoxic basins (eg. Litton Mills Railway cutting; SK 160 729). Slumping and debris flows were associated with fault movements eg. Bottoms Beck, Bowland Basin (SD 745 567).

Brigantian strata belonging to sequences EC6 and LC1a are not encountered on the palaeotopographic highs of Nocton, Foston and Stixwold. This is interpreted as nondeposition due to uplift related to the earlier mid-Brigantian inversion event. This may also be the case in the Widmerpool Gulf where the Brigantian is absent over large parts of the basin where the inversion is thought to have been strongest.

At Welton in the East Midlands, the top Dinantian includes quartzose channel sands, with a probable southeasterly provenance. These low sinuosity channels are considered analogous to outcrops in Anglesey (Walkden \& Davies, 1983). Oil was produced from the Upper Brigantian sands in the Welton oilfield.

Calcareous turbidites accumulated in the basinal areas to the south of the advancing Yoredale delta. More proximal quartz-rich turbidite sands derived from the LondonBrabant Massif are evident in several Goyt Trough and Widmerpool Gulf boreholes (eg. Bosley, Nooks Farm-1A, Widmerpool-1 \& Duffield). These sands may form prospective reservoir horizons. Gas has been tested from these quartz-rich turbidite sands in the Nooks Farm-1A and Widmerpool-1 boreholes. 
Towards the end of the Brigantian the deltaic influence covered most of northern England. Distal pro-delta mudstones accumulated as the Upper Bowland Shale providing a potentially rich, oil prone source rock.

Over most of the northern province, Yoredale facies prevailed. This was a cyclic, delta top system developed across a flat, low-lying delta plain, episodically breached by marine incursions. The complex transgressive/regressive regimes of the Brigantian encompassing the sequences (EC5-LCla) is reflected in the cyclic nature of the Yoredale deposition.

\subsection{EARLY PENDLEIAN (Plate 4.10) Sequence LCla - post rift}

By the end of the Dinantian, the last vestiges of a once extensive carbonate platform were disappearing. The earliest Namurian (Pendleian) was characterised by the southward progradation of successive deltaic lobes beyond the Craven Fault Zone. North of this zone, cyclical Yoredale facies continued, dissected presumably by some major distributary channels, which are either not recognised or not preserved. The earliest delta lobe, was the deep water, stacked turbidites of the Pendle Grit. This extended south and southwestwards across the Bowland Basin, possibly channeled through a graben structure, across the Cleveland Basin from the north and northeast. After Pendle Grit deposition, shallower-water, deltaic deposits accumulated, especially in the south and west Yorkshire area - the Grassington, Skipton Moor, Warley Wise and Beamsley Grits.

These lobes prograded westwards from Cleveland and southwards across Cumbria into the Bowland Basin, the sands interdigitated with the pro-delta mudstones forming the Upper Bowland shales. These basinal mudstones, rich in terrigenous plant debris, accumulated southwards towards the Edale Gulf and Gainsborough Trough (eg. Edale Shales) and to a lesser extent across depositionally lower parts of the Humberside area 
(thin Gamma-active shales, Fraser et al. 1990). These mudstones are proven rich potential hydrocarbon source rocks (Fig. 3.35).

The main delta advance was prevented from entering the East Midlands area by a structurally controlled topographic barrier, the Pennine High (Plate 4.10). Southerlyderived, proximal turbidites, with quartzitic petrography, continued to accumulate at the head of the Gainsborough Trough and Widmerpool Gulf, with only minor distal turbidites entering from the north. Proximal turbidite fans and minor slumps developed around the margins of the East Midland basins, perhaps indicating some renewed extensional fault movements in the Pendleian. The Dinantian shelf areas became sediment-starved platforms with only thin shallow-water sandstone or limestone deposition. Minor quartzose deltas formed on the shallow shelf areas along the Mercian Massif shoreline.

\subsection{LATE PENDLEIAN-ARNSBERGIAN (Plate 4.11) Sequence LC1b - post rift}

After the major turbidite-fronted delta advance across the Craven-Bowland Basin during the early Pendleian (LC1a), the Arnsbergian was a time of turbidite sandstone and mudstone deposition over much of the southern province. Coarse grained, feldspathic deltaic sediments did not extend far south of the Craven Fault zone. Interbedded sandstone and mudstones of the Roeburndale Grit Group were deposited in the Lancaster Fells (Moseley 1972) with minor coal development. The Silsden Moor Grits spilled southwards from the Askrigg Block in the Leeds-Bradford district. To the south and west the Lower Sabden Shales deposition was predominant, as encountered in outcrops and also in boreholes (eg. Croxteth, Upholland, Heywood, Fletcher Bank and Holme Chapel). 
Across the Northumberland Basin and Alston/Askrigg block areas, north of the Craven fault zone, Yoredale-type, cyclical sedimentation persisted throughout the Arnsbergian. Sedimentation kept pace with subsidence in the Stainmore Trough as evidenced from increased thickness (100-200 $\mathrm{m}$ ) in the absence of any facies variation. Various 'grits' (eg. Thornborough, Grindstone, Botany, Red Scar) are interbedded with very shallow marine mudstones and limestones, developed during intervals of non-clastic input on the shallow water delta top. Downcutting channels have been interpreted from geological cross sections in survey sheet Memoirs (eg. Nos. 31/25, 30). Interdistributary facies include seatearth and coal development (eg. Tan Hill and Yoredale Coals). On the southern margin of the Askrigg Block the sequence includes very shallow-water limestones. The Cumbrian non-depositional/erosional high was onlapped by thin or condensed marine mudstones and interbedded deltaic siliciclastics of the Upper Hensingham Group.

Across the East Midlands area non-depositional or erosional shelf areas of Dinantian limestone persisted, such as the Askern-Spital high, where no pre-Kinderscoutian sediments are proven. Thin, condensed mudstone siltstone sequences onlap these shelf areas. The thickest Arnsbergian sedimentation occurred in the previously starved and thermally subsiding Gainsborough Trough, Edale Gulf, Widmerpool Gulf and Goyt Trough depocentres. Turbidites and siliciclastics derived from the exposed granitic and Lower Palaeozoic/Precambrian basement of the Mercian Massif to the south, were channeled longitudinally along the gulf areas (Rempstone-1 and Duffield). These pass laterally into open marine, basinal mudstones of the Lower Churnet Shales, Sabden Shale and equivalents.

In the East Midlands, rich oil and gas prone pro-delta source rocks of Arnsbergian age are proven from the Widmerpool Gulf. These are the major source of the Widmerpool Gulf oils in fields such as Rempstone and Long Clawson. 
The exact form of the North Wales Massif shoreline is uncertain. Minor shallow-water deltas of southerly-derived quartzitic sandstones (eg. Cefn-y-fedw) flanked the massif.

\subsection{CHOKIERIAN - ALPORTIAN (Plate 4.12) Sequence LC1b - post rift.}

These stages are treated together as they are both poorly represented across most of northern England. Over most of the area the main sedimentation is of mudstone - part of the Sabden Shales. Only very minor sandstone input occurred throughout this interval. There is no evidence for Chokierian/Alportian sedimentation in the Midland Valley of Scotland. Across the Northumberland Basin, and the Askrigg-Alston Blocks, westwards to Cumbria and southwards to the Craven faults, Chokierian/Alportian sediments comprise thin mudstones or are absent or unrecognised. In Yorkshire, these stages are represented by less than 30 m of mudstones and siltstones in the Cowling area and slightly thicker at Wharfedale (Plate 4.12). In the latter, fluviatile sands of the Upper Follifoot Grit up to $18 \mathrm{~m}$ thick occur at the top of the succession heralding the earliest approach of the Kinderscout delta system. Similar sands have been identified in boreholes in the Cleveland Basin (Kirby Misperton-1). In the Colsterdale district, this interval is represented by beds of ganister, often with rootlets and at least one coal. Minor marine limestones and calcareous mudstones are also present indicating alternating delta plain/shallow marine conditions. The Brocka Bank and Middleton Grits occur in South Yorkshire near Leeds.

Similarly, diagnostic Chokierian-Alportian fauna are not recognised over the North Wales Shelf area.

Mudstone-siltstone, sometimes calcareous, deposition dominated in the North Staffordshire, Derbyshire and East Midlands area, eg. Lower and Middle Churnet Shales, Sabden Shale and equivalents. Minor sandstones (eg. Lum Edge Sandstone (N. 
Staffordshire) occur which may be of turbidite origin. There is no evidence for turbidites of Alportian age in the Duffield borehole in the Widmerpool Gulf.

Where present, Chokierian-Alportian sedimentation is thin and condensed over the East Midlands area. Thickest sequences are reported from the central Gainsborough Trough (c. $280 \mathrm{~m}$ from Scaftworth-2) and Goyt Trough (up to $200 \mathrm{~m}$ ). Minor volcanism and tuffs may be of Chokierian-Alportian age in the vicinity of the Long Clawson-1 borehole in the Widmerpool Gulf.

The most likely explanation for the minor sedimentation and striking lack of coarse clastics during this interval would be if the whole delta system switched. Consequently, the coarse clastics would have been diverted to another area (ie. the Southern North Sea). An alternative hypothesis envisages broader scale changes in climate/sediment supply in the Fenno-Scandian hinterland.

\subsection{KINDERSCOUTIAN (Plates 4.13 \& 4.14) Sequence LClc - post rift.}

After the quiescent episode of Sabden Shale deposition, influx of coarse, deltaic detritus from the north recommenced some time during the early to mid Kinderscoutian (Plate 4.13). The deposition of Yoredale-type facies persisted in the Northumberland-Alston area, whereas the earliest 'true Millstone Grit' appeared across the Askrigg Block; fluviatile sands of the Libishaw and First Brimham Grits. These prograded over the Craven Fault zone as various deltaic lobes: Cobden, Todmorden, Addlethorpe and Caley Grits of the Lancaster Fells and south Yorkshire (Ramsbottom 1974). On the southern edge of the Alston Block in the Wharfedale-Nidderdale area, there are several notable shell beds, eg Cayton Gill Shell Bed. These are usually quartzose sandstones with brachiopods and shelly fauna indicative of very shallow water, which is consistent with the underlying Arnsbergian limestones. 
Mudstone deposition persisted with the Upper Sabden and Upper Churnet shales across most of the Pennine Basin from Lancashire to East Midlands. Minor, shallower-water, coarsening upward deltaic cycles of deposition, with no major channels, occurred across the Gainsborough Trough area throughout the Kinderscoutian (Steele 1988).

During Kinderscoutian times, shallow-water quartzose delta sands, fronted by minor turbidites have been identified in the south Derbyshire/north Staffordshire area (Blackstone Edge Sandstone) probably derived from the Mercian Massif. Such sedimentation continued in this area into late Kinderscoutian times with the Longnor Sandstone.

Thin, condensed sediments of minor, shallow water sandstone and thin mudstone typify the entire Kinderscoutian of North Wales and the Lancashire Shelf area.

By later Kinderscoutian times (Plate 4.14), the southward advance of a major delta from the north dominated northern England. The Kinderscout delta was fronted and preceded by turbidites of the Mam Tor Sandstone (Fig. 3.36) and Shale Grit and equivalents. Mam Tor (SK 129 837) is an excellent exposure in which to study the process by which the turbidites infilled remnant syn-rift topography. Palaeocurrent indicators such as flute casts and tool marks indicate an east-west transport direction for the initial thin turbidites which reached the basin.(ie. along the strike of the Edale Gulf). These rest directly on dark marine shales (Edale Shales). The thickness of individual turbidite bodies and the percentage of sandstone increases up stratigraphy. This suggests that the turbidites were becoming increasingly proximal in nature with time. In the upper part of the cliff section, current indicators suggest a southerly transport direction, orthogonal to the structural grain and parallel to the main transport direction of sediments across the delta plain (Fig. 4.5). 


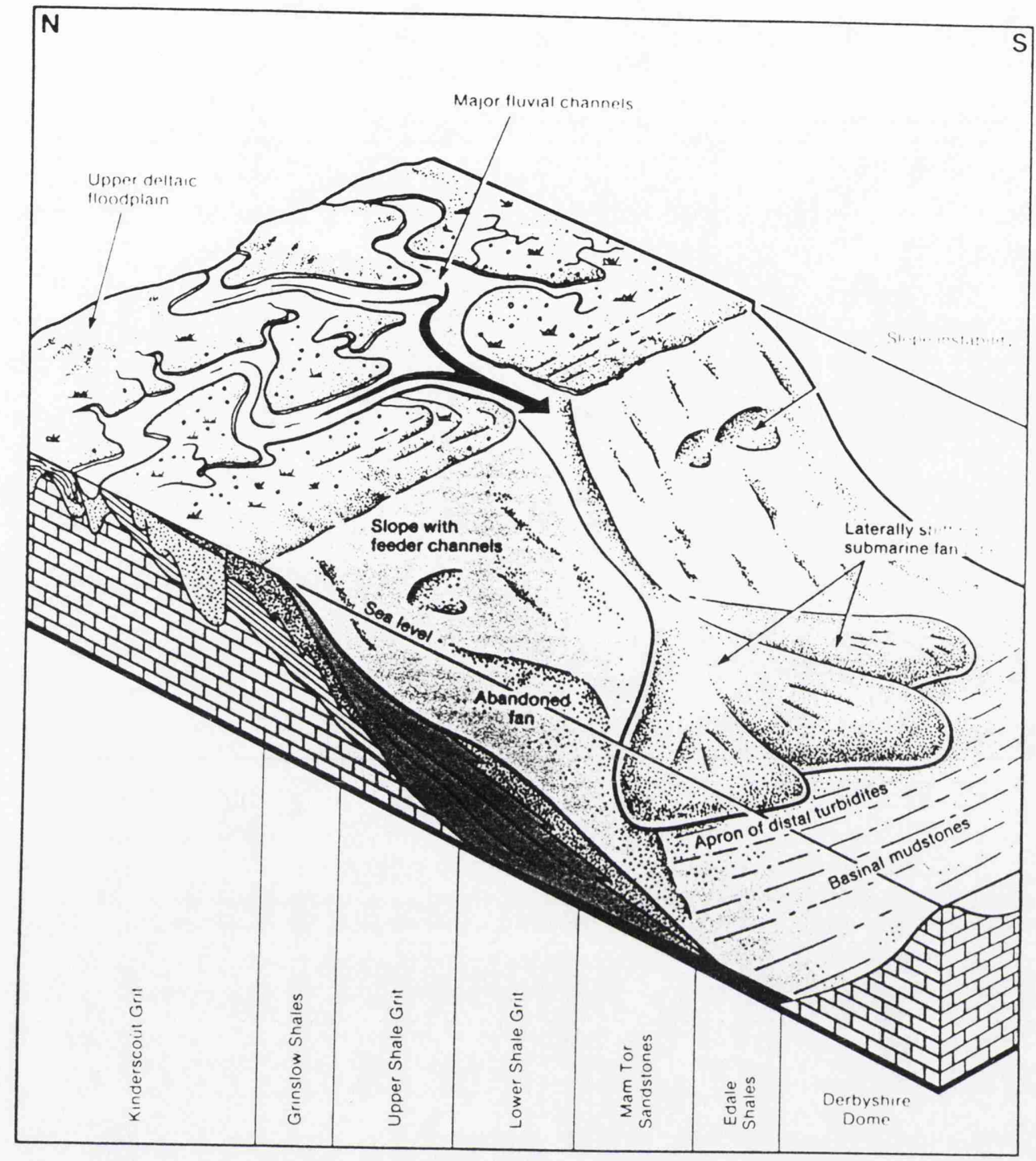

Figure 4.5. Schematic depositional model for the Kinderscout delta system (modified after Reading 1964). The model is based on the observation of Vail \& Mitchum (1977) that coarse clastic sediments are transported into the basin as submarine turbidite fans during sea-level lowstands on the shelf.

The overall pattern of sedimentation at Mam Tor, highlights the reduction in structural control as topography is progressively infilled. The turbidites were followed by slope deposits of the Grindslow and Todmorden Shales which are coarse siltstones and sands (eg. McCabe 1978). The Lower Kinderscout Grit is up to $300 \mathrm{~m}$ thick in north Derbyshire and comprises fluviatile sands deposited from major distributary channels (Fig. 3.37) with larger scale channels with erosive bases. 
McCabe (1978) interprets the Upper Kinderscout Grit as a deltaic sheet sand, deposited following a short lived abandonment, represented by the Butterfly marine band. The Upper Kinderscout Grit may be traced northwards into the Upper Brimham Grits.

The earliest 'true' Millstone Grit facies of the Northumberland-Alston Block area are probably of late Kinderscoutian age; the First Grit, which thickens progressively southwards. The whole Kinderscoutian stage exceeds $500 \mathrm{~m}$ in north Derbyshire thinning to a mere $30 \mathrm{~m}$ in the Woodland borehole, Co Durham. Shallow-water bivalve rich shell beds (eg. Sharnberry Shell Bed) are of Kinderscoutian age in the Barnard Castle Area.

The vast lobe of the Kinderscout Grits effectively filled the Pennine and other Central Province basins by the end of the Kinderscoutian resulting in widespread delta-top conditions in these areas. The remaining topographic lows to be infilled following the deposition of the Kinderscout delta lay to the south in Derbyshire, north Staffordshire and the East Midlands.

\subsection{MARSDENIAN (Plates $4.15 \& 4.16$ ) Sequence LC1c - post rift.}

By Early Marsdenian times, the Kinderscout delta lobe was effectively abandoned. Sediments of Marsdenian age are poorly represented to the north of the Craven Fault zone. Major channel systems were established from the east and north-east across the East Midlands area by the mid Marsdenian comprising the Ashover delta (Plate 4.15). The sedimentary facies have been studied in detail over the East Midlands area with specific reference to reservoir distribution and quality. The Ashover delta represents the last deep water turbidite-fronted system across northern England. The Ashover Grit fills the Widmerpool Gulf longitudinally (Fig. 3.10) and it attains its greatest thickness $(>300$ m near Duffield). It comprises coarse, pebbly sands deposited by low sinuosity 
channels. The Roaches Grit of north Staffordshire represents the corresponding turbidite deposits on the delta front in the deep Goyt Trough (Jones 1980). The main sediment transport direction was from the east and south-east along the Widmerpool Gulf.

Across the Gainsborough Trough, Ashover Grit equivalents included coarse pebbly channel sands (eg. Trumfleet Grit) with sedimentation dominated by shallow-water delta deposition (Steele 1988). The East Midlands platform received thinner sediments with overbank deposits grading westwards into pro-delta mudstones and siltstones.

The Ashover Grit occurs between the Bilinguites bilinque marine band (below) and the B. superbilinque marine band (above). The former is not easily recognised in the subsurface but the $B$. gracile is a good marker, although slightly lower, and defines the base of the Middle Grit Group (Fig. 3.11).

The Middle Grit Group across Lancashire and south Yorkshire comprises several delta 'lobes' including pebbly grits. These represent shallow-water fluvio-deltaic sediments, with a general southwesterly direction of sediment transport and thickening (Collinson et al. 1977).

By late Marsdenian times shallow-water delta top conditions were established across most of northern England. Channels with coarse pebbly grits and interdistributary deposits of the Chatsworth delta system accumulated across the East Midlands area. Minor coals (eg. Ringinglow, Simmondsley and Baslow Coals) developed. Similar depositional environments extended across the West Midlands area, with the Holcombe Brook and Brooks Bottom Grits. Delta front turbidites and pro-delta mudstones are predicted in the Manx Furness basin to the west. There was local basic volcanism in the East Midlands (Kirton 1984). 
The major sediment transport direction was from the northeast. Sediments thicken southwards across the Craven Fault zone, but less drastically than during previous stages. The Second Grit (Alston, Block and Northumberland) and Wandley Gill Grit (Askrigg Block) were deposited to the north. In the Kirby Misperton-1 borehole, Upper Marsdenian strata are represented by less than 10 metres of mudstone with Lingula fragments. In south Yorkshire around 30 metres of shallow-water deltaic sediments accumulated (Huddersfield White Rock). Marsdenian sedimentation was minor in the North Wales area.

\subsection{YEADONIAN (Plates $4.17 \& 4.18$ ) Sequence LC1c - post rift}

The pervasive Marsdenian channel systems of the East Midlands flowing from the east and northeast were abandoned by early Yeadonian times. Thin mudstone-siltstone sedimentation developed across most of northern England. In the Northumberland Trough/Alston Block area, upper delta plain facies continued (Second Grit) which presumably fed channel sands southwards.

In the West Midlands, the Lower and Upper Haslingden Flags were deposited. These have a generally east-west trend with a sediment transport direction towards the east. The Haslingden Flags are interpreted as mouth bar finger sands (Collinson and Banks, 1975); marine influence reworking sediments in the mouth of a major channel system, probably fed from the north.

Later in the Yeadonian, northern England was dominated by Rough Rock deposition. The Rough Rock, sheet sand sedimentation, covers an area of over 10000 sq kms with relatively constant thickness (c. $30 \mathrm{~m}$ ). The major sediment transport direction was again from the north and the facies extends southwards into the north Wales area as the Aqueduct Grit. Apart from the southeastern margin of the Gainsborough Trough, the 
Rough Rock is poorly developed in the East Midlands area, with only minor channels, mouth bars 'flags' and crevasse splays developed.

\subsection{EARLY WESTPHALIAN 'A' (Plate 4.19) Sequence LC1c - post rift.}

By Westphalian ' $\mathrm{A}$ ' times, the Namurian deltas had produced a low lying paralic plain with swamps and brackish and fresh water lagoons where mudstone, siltstone and coals accumulated. Deltaic sands and grits were introduced by migratory, distributary channels. The 'Coal Measures' show a cyclicity with black and dark grey mudstones coarsening upwards into silts and sands generally with the development of a seatearth and coal at the top. The thin marine bands are important for correlation with the widespread $G$. subcrenatum marine band taken as the internationally accepted Westphalian base. Stratigraphically the G. subcrenatum marine band is arbitrary in Britain as sedimentary conditions were similarly fluvio-deltaic as during the Namurian.

The Crawshaw shallow water delta (including the Sub Alton and Basal Sand intervals) dominated the East Midlands and Derbyshire during early Westphalian 'A' times (Fig. 3.38). Major channels were supplied by a generally north to northeasterly source. The Crawshaw channels flowed westwards across the East Midlands either reflecting controls by a persisting underlying palaeotopography or constraints imposed by the Wales-Brabant Massif to the south forcing the rivers to drain into the remaining depocentre in the Irish Sea to the west.

The thickest depocentre for the entire Westphalian ' $\mathrm{A}$ ' is around the Goyt Trough to Rossendale High (Central Pennine Basin). This appears to be the focus of all channel systems draining across northern England at this time. Outside of the East Midlands/Derbyshire area, facies analysis is limited. South of the Craven Fault system 
the facies is dominated by shallow water, lower delta plain environments. Northwards this grades into the upper delta plain.

The Nocton and Aubourn-Bassingham highs persisted in the East Midlands, but these became swamped by later Westphalian sediments.

\subsection{LATE WESTPHALIAN 'A'- WESTPHALIAN 'C' (Plate 4.20)}

Sequence LC2 - post rift

The depositional environment of the upper part of the Westphalian ' $\mathrm{A}$ ' of most of the exposed coalfield areas of of Britain, north of the Variscan Front, has generally been interpreted in terms of upper delta plain environments with low gradient alluvial systems (Kelling 1974, Heward 1976, Guion 1978, 1984, 1987, Kirk 1983, 1989, Fielding 1984a \& b, 1986, Fulton \& Williams 1988, Guion \& Fielding 1988, Read 1988). Important elements of the depositional environment include distributary channels and shallow fresh to brackish lakes that were filled by lacustrine deltas, crevasse splays and overbank deposition. Gradients were low and thus palaeocurrent directions in many cases represent local depositional conditions rather than regional palaeoslopes (Cope $e t$ al. 1992). However, in certain ares minor contemporaneous tectonic activity did influence the pattern of sedimentation. Fielding (1984a), Fielding \& Johnson (1987) and Guion \& Fielding (1988) showed that a number of faults, including the Ninety Fathom, Butterknowle and Morely-Campsall faults continued to be active during sedimentation.

The amount of data available for the Westphalian is immense as a result of the extensive coal mining activity. Thicknesses of up to $3 \mathrm{~km}$ sediment are estimated for the Lancashire coalfield. Local lithostratigraphic nomenclature for coals, sands and marine bands seriously hinders regional correlation. Distributary channels were of a highly migratory nature and splitting, pinching-out or washing-out of the multitudinous, 
generally thin coal seams is common. These factors render construction of a single detailed Westphalian palaeogeography virtually impossible. A sensible and reasonably satisfactory solution has been provided by Guion and Fielding (1988), and it is an adaption of their somewhat diagramatic palaogeography for this interval that is presented here (Plate 4.20). Shorter time intervals and in depth research of outcrop, borehole and mining data would be required to provide more detailed synthesis. To a large extent this has already been accomplished by Wills (1956) and it is difficult to imagine improving on this excellent study.

After the early Westphalian fluvial-dominated delta systems, typical 'Coal Measure' facies (Fig. 3.39) were established across the entire northern England area. The intermittent marine bands are still of importance for correlation, but non-marine bivalves and fish beds become increasingly abundant with time. The area was dominated by coal swamps with migratory river channels. Sedimentation was less controlled by structure, and the ancient basins such as the Widmerpool Gulf and Gainsborough Trough ceased to be the focus for major distributary channels. However, differential subsidence on early Variscan inversion structures resulted in some sediment thickness variations as evidenced in the SE Gainsborough Trough (Plate 3.7).

As the Westphalian progressed conditions became increasingly non-marine, evolving into an internally drained basin. Alluvial red beds were deposited in south Anglesey and Wyre-Clee Hills districts from the early Westphalian. Red beds became more prominent in later Westphalian times, partly due to the approaching Variscan front cutting off marine access, partly due to movement towards more arid climatic conditions and partly due to the basin being filled in. 


\subsection{LATE WESTPHALIAN 'C' - EARLY PERMIAN (VARISCAN) (Plate 4.21)}

Sequence V - inversion.

During mid-late Westphalian 'C' times, a major inversion event commenced which radically changed the sedimentary depocentres and facies patterns across northern England. The major loci of uplift are shown on Plate 4.21. Dinantian and Namurian basinal sediments were exhumed and these areas became highs. The effects of the inversion are demonstrated at outcrop by tight folding of Lower Carboniferous (EC1) deposits, for example in the Skipton anticline, Central Bowland (Fig. 3.41).

Slight tectonic 'nudges' as precursors to the major Variscan collision event may have affected subsidence as early as Westphalian 'B' times. This is suggested by decreased sedimentary thickness of c.50 m from Welton to Nettleham and North Greetwell. Seismic evidence for an intra-Westphalian ' $B$ ' precursor inversion is also provided from the same area (Plate 3.7). Differential thicknesses across the Pendle Line are also evident from vitrinite reflectance data in the West Midlands area and during much of the Westphalian the Bowland Basin was apparently a positive feature receiving less sediments than in the Ingleton or Lancashire coalfields to the south (Plate 3.14). By analogy with more recent fold belts (eg. Alpine and Himalayan forelands), a foreland bulge lying to the north of the Variscan mountain front is expected to have been present across central England. This would have caused gentle regional uplift prior to the inversions and may have resulted in rejuvenation of the Mercian Massif and greater input of sediment from the south into the northern England area.

The major inversion during Westphalian 'C' times has been described by Wills (1956) and later by Besly (1988). The climate had become increasingly arid with accumulation of Barren Red Measures succeeding the grey or productive 'Coal Measures' in several areas. It is envisaged that sandy lithic detritus was shed from the Variscan mountain front and travelled in a northerly direction through the Oxfordshire region (Besly 1988, 
Foster et al. 1989). This sandy detritus is represented by the sandstones of the Halesowen Formation, which occurs near to the base of the Westphalian 'D' in the Midlands. However, the southerly derived lithic detritus does not appear to have been transported further north than Warwickshire, south Staffordshire and Nottinghamshire. Following the inversion, isolated internal molasse basins with fresh to brackish water lakes (depositing Spirorbis limestones), fluviatile and semi-arid flats red beds were established, eg. the Newcastle and Farnsfield Formations across the East Midlands and the Ruabon, Keele and Etruria Marl Beds (Fig. 3.40) across the North Wales-West Midlands area. Sandstones in the Keele Formation, which overlies the Halesowen Formation in the Midlands, are petrographically different from those of the Halesowen Formation. This, together with limited palaeocurrent evidence, suggests that the Keele Formation may have been of northerly provenance (Besly 1988, 1990).

Very coarse, pebbly sands and fanglomerates (eg. Espley Conglomerate) were deposited in the most actively subsiding basins. The thickest post-Variscan sedimentary pile accumulated in the Cheshire Basin (North Wales/Lancaster Shelf area) and into Coalbrook Dale, Warwickshire, south Staffordshire and Cannock.

Very few younger Carboniferous sediments have been preserved. It is probable that the Westphalian ' $D$ ' was more extensive and that a thick Stephanian was deposited. Thermal modelling of the Ratcliffe-on-Soar borehole (Fig. 2.9) requires the deposition and erosion of some $600 \mathrm{~m}$ of post-Westphalian 'B' sediments prior to basal Permian sedimentation, in order to match the theoretical thermal subsidence curves (Appendix D). However, the base Permian unconformity has cut across the late Carboniferous stratigraphy of northern England and much of the evidence for the deposition of these sediments has been removed. 


\section{CHAPTER 5 HYDROCARBON GEOLOGY}

The importance of the preceding events on the evolution of the hydrocarbon environment of intra-Carboniferous plays will be discussed in this chapter. In order to make a confident assessment of the play fairways it is necessary to analyse the key elements of the play system on a regional basis. The following section discusses the key factors controlling hydrocarbon occurrence in the Carboniferous of northern England and the Southern North Sea under the headings of reservoir, seal and charge.

\subsection{RESERVOIR, SEAL AND SOURCE DISTRIBUTION}

The value in producing a series of palaeogeography maps by time slice for the Carboniferous of northern England is that they permit a detailed analysis of the distribution of reservoir, seal and source facies with time. The following sections present an analysis of the regional distribution of these three key stratigraphic elements of the hydrocarbon system.

\subsubsection{Reservoir}

Three main reservoir systems have been identified from the regional tectono-stratigraphic analysis of the Carboniferous (Plate 5.1):-

\footnotetext{
* syn-rift alluvial fans and fan deltas

* carbonate rimmed shelves

* clastic delta systems -delta top channel and mouth bar sands -basin floor and slope turbidites
}

Establishing the presence and effectiveness of the above systems represents the first phase in the analysis of the Carboniferous play fairways presented herein. 


\subsubsection{Syn-rift alluvial fans and fan deltas}

Syn-rift fanglomerates and fluvial sandstones form a potential reservoir facies in the rift basins throughout northern England and the Southern North Sea (Fig. 5.1).

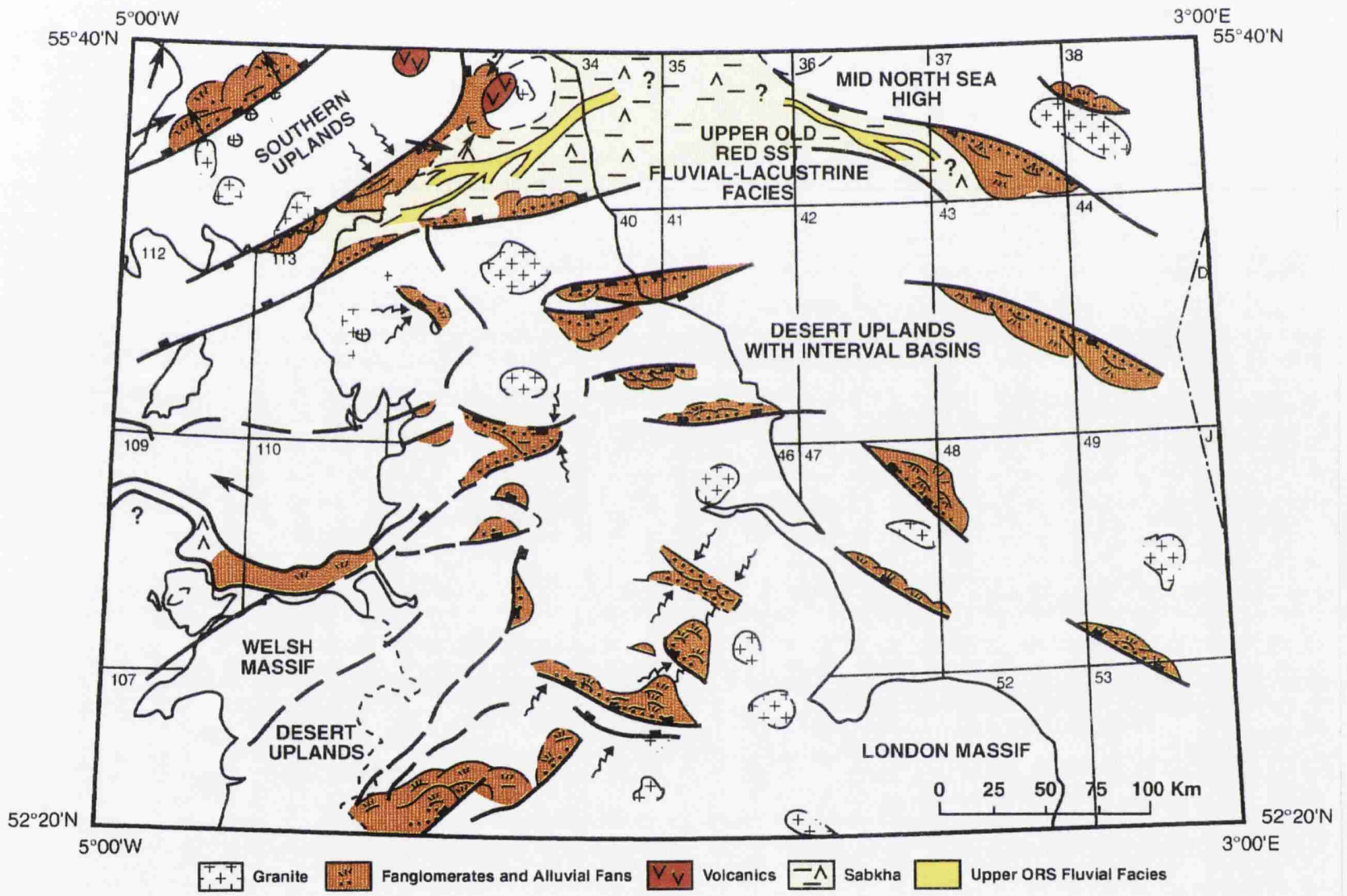

Figure 5.1. Schematic palaeogeography for the late Devonian syn-rift of northern England and the Southern North Sea. Data from a number of sources including Leeder (1974) and Leeder \& Hardman (1990).

Two main settings of early syn-rift clastics can be identified (Leeder and Gawthorpe 1987). Firstly, a narrow zone a few kilometres wide adjacent to the border fault zone 
dominated by downlapping alluvial fan depositional systems derived laterally from the footwall particularly at fault transfer zones. The early syn-rift clastics proven by the Eakring-146 borehole (Falcon \& Kent 1960) and the Caldon Low borehole (Institute of Geological Sciences 1978) are probably examples of this setting. Secondly, a broader zone along the margins of the hangingwall dipslope characterised by fan delta deposits derived from the hangingwall margin. The Whita and Annan sandstones in the Northumberland Trough (Plate 4.2; Leeder 1974) are examples of the more sheet-like hangingwall derived fans.

These sediments now lie at the base of the rift systems and have subsided to present day burial depths of over 4000 metres. This renders poroperm largely ineffective for hydrocarbon production; in Eakring-146 the sands are described as polymict, poorly sorted, immature, oxidised and well cemented. (Falcon \& Kent 1960). The key to identifying effective reservoir in this facies is to identify areas of shallow burial such as on the footwall of later syn-rift border faults. The regional seismic section from the East Midlands (Plate 3.2) shows the case in point, where a wedge of early syn-rift clastics has been 'stranded' on the footwall of the Widmerpool Gulf by Arundian (EC3) rifting.

\subsubsection{Carbonate margins \& associated facies}

The most prospective reservoir facies for the carbonate margin play are the rimmed shelf complexes comprising grainstone shoals, build-ups and boulder beds. Peritidal and shallow shelf limestones lying landwards of the margin commonly exhibit a mudstonewackestone texture with low primary porosity which only produce hydrocarbons when fractured in tightly folded Variscan anticlines (e.g., the Eakring and Hardstoft oilfields). High-energy environments near wavebase may have enabled the development of grainstone shoals behind the shelf margin towards palaeo-shorelines, but these are very difficult to predict in the subsurface. Original porosity is unlikely to be preserved but by 
diagenetic processes of dissolution and replacement, predominantly dolomitisation and dedolomitisation, some of the primary porosity may be restored.

Dolomitisation does not necessarily produce porous rocks and may be patchy and unpredictable (Schofield \& Adams 1985, Gawthorpe 1987b). Early dolomites associated with sabkha environments (eg. Courceyan, Chadian) are generally finely crystalline with poor poroperm. Coarser crystalline dolomite is more typical of deeper burial diagenesis and favourable poroperm properties have been demonstrated by drill stem test flow rates in wells such as Esso's Milton Green-1 (1915bwpd) or Brimington-1 (2500bwpd). These and other tests (Appendix A), which gave high water production rates, also clearly demonstrate that these dolomites however porous were not in communication with source rocks.

Palaeokarstification is not usually associated with enhancing poroperm unless preferential dissolution occurs. Cavity infills are usually fine grained and may include calcrete precipitates and early marine cements.

Preferential dissolution features associated with emergence are observed in the Nettleham-2 borehole. Vadose diagenetic dissolution and recrystallisation of an AsbianHolkerian bioclastic grainstone produced around $17 \%$ core porosity and $1.79 \mathrm{mD}$ permeability. Due to poor hole conditions the best reservoir potential was not tested (the 'Chalky Limestone member' $1265-1300 \mathrm{mbrt})$. DST 1 flowed $12.9 \mathrm{bpd}$ oil from the limestone.

As a general rule the most prospective carbonate reservoirs are restricted to the Chadian, Asbian and early-mid Brigantian (sequences EC2, EC4 and EC6) when rimmed shelves were able to develop in periods of reduced tectonic activity. These facies are areally restricted to basins within the central England rift system around basins such as the Widmerpool Gulf, Goyt Trough, Edale Gulf, Gainsborough Trough and Bowland Basin 
(Fig. 5.2). This is a result of the preclusion of growth of the carbonate system north of a line from Cleveland to the Isle of Man by the presence of an extensive siliciclastic delta system (Fig. 5.2).

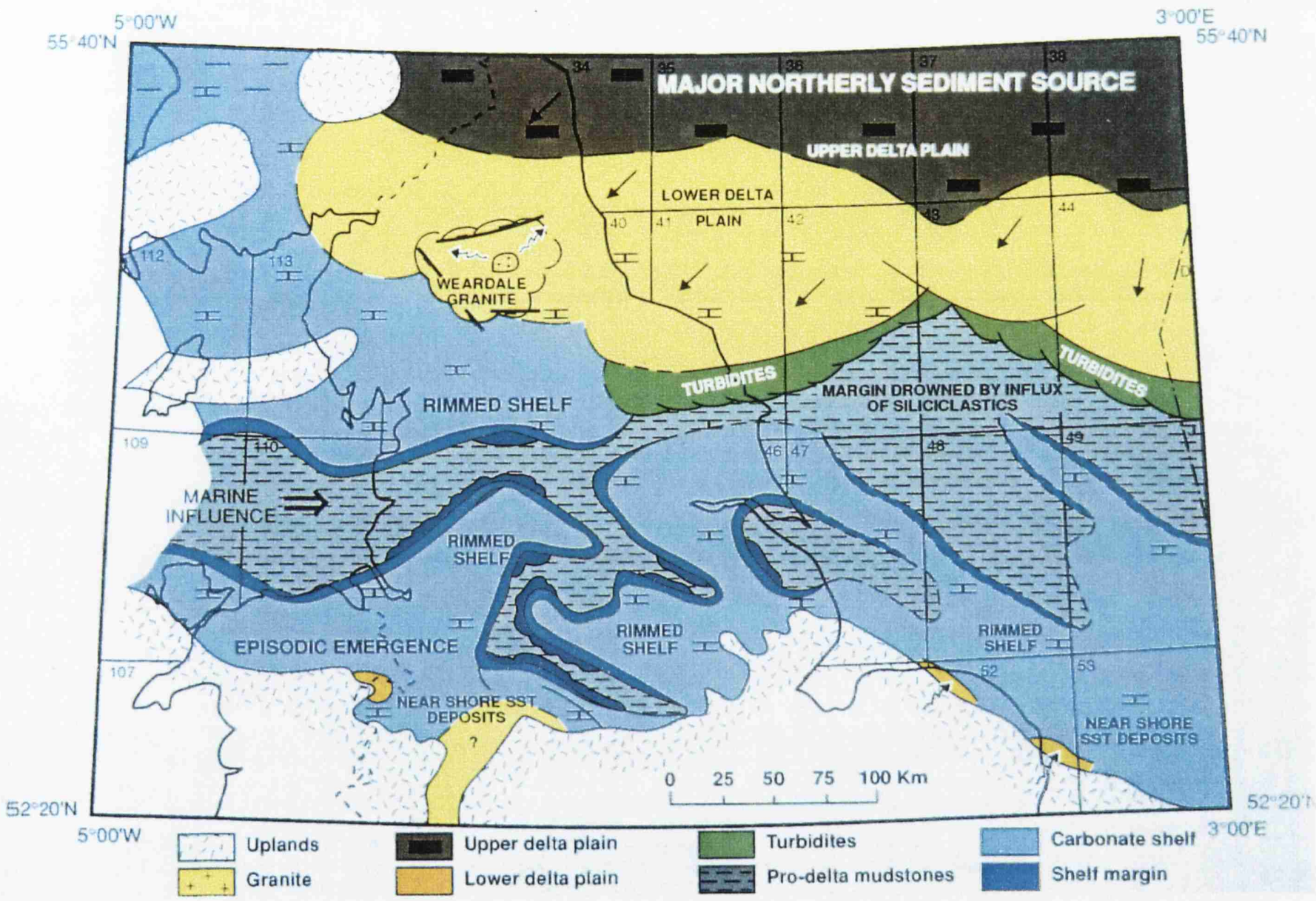

Figure 5.2. Schematic palaeogeography for the late Dinantian of northern England and the Southern North Sea. Incorporates data from Stevenson \& Gaunt 1971, Leeder 1974, Miller \& Grayson 1982, Smith et al. 1985, Aikenhead et al. 1985; Gawthorpe 1987a, Grayson \& Oldham 1987. Offshore data extracted from confidential oil company records. 
The shelf margin carbonate shoals represent a narrow play fairway which is often associated with onlapping basinal shales with source rock potential (Plate 5.1) These basinal mudstones may also provide the dolomitising fluids which produce secondary porosity in the shelf margin complexes ie. in facies such as boulder beds, shelf apron deposits and grainstone shoals. The hydrothermal dolomitising fluids may be closely related to and followed by migrating hydrocarbons, analogous to the Nisku reef belt in Alberta Canada (J. Hurst, pers. comm.). High porosity, dolomitised grainstone shoals have been identified in outcrop at Scosthrop Lane in the Bowland Basin (Fig. 3.19). In the Bowland Basin and Derbyshire Dome, $\mathrm{Pb}-\mathrm{Zn}-\mathrm{Cu}-\mathrm{Ba}-\mathrm{F}$ mineralization associated with remnant hydrocarbons is often observed (eg.Windy Knoll, Castleton; Fig. 4.3).

Asbian and Brigantian shelf margin complexes ('reefs') have been recognised from outcrop (eg. Little Orme, Prestatyn, Castleton), boreholes (eg. Croxteth-1, Whitmoor-1) and from seismic data (eg. Plate 3.2). A Dinantian shelf margin target was drilled on the margins of the Widmerpool Gulf (Strelley-1) but the well encountered volcanic rocks and failed to penetrate the margin complex by several kilometres (Plate 3.2). The volcanic rocks in Strelley-1, significantly, did carry some heavy oil stain as did the underlying Chadian carbonate margin. Croxteth-1 (southern margin of the Bowland Basin) flowed $14 \mathrm{bpd}$ oil and $285 \mathrm{bpd}$ formation water from 'reefal' shelf margin carbonates. Quintana's Holme Chapel-1 (Rossendale high) was drilled on a 'reef' prospect. No 'reefal' facies were encountered although ?Chadian porous dolomites flowed water.

Vuggy, porous boulder beds formed on shelf margins at the end Chadian (EC3) and Asbian-early Brigantian (EC5) associated with slope instability caused by renewed extensional tectonic activity at this time. These boulder beds are observed in outcrop and BP Minerals boreholes in the Bowland Basin (Gawthorpe 1987b), where they are dolomitised with minor bitumen stain and mineralization eg. Haw Crag (Fig. 3.19), Crimpton Pit (SD 679 467), Sykes Quarry (SD 627519) and Green Pike (Fig. 3.25). 
The Waulsortian mud mounds, predominantly of Chadian (EC2) and Brigantian (EC6) age are recognisable on seismic (eg. Figs. $3.7 \& 3.12$ ). The mudmounds themselves are considered non-prospective, although in places the build-ups may be brecciated and dolomitised with well developed vuggy porosity often associated with brachiopod rich zones (Fig. 3.32). In many cases, crinoidal grainstones flank the mud mounds and these may be more prospective. Miller \& Grayson (1982) argue for the Waulsortian play, largely using analogies with Waulsortian facies of Texas, which hosts many oilfields. However, different facies according to photic conditions and water depth are proposed (Lees and Miller 1985) with the northern England variety falling into the deep water, low prospectivity category.

\subsubsection{Clastic delta systems}

The most prospective siliciclastic reservoir rocks, throughout the Carboniferous of northern England, comprise deltaic and associated alluvial sands. The facies which exhibit the most favourable reservoir characteristics are channel and mouth bar sands on the delta top and turbidite sands in the proximal pro-delta. The distribution of the former in the Carboniferous is extensive both laterally and vertically. As the palaeofacies maps indicate, potential reservoir sands occur in the shallow water Dinantian delta systems in the north of the area and in the deeper water early Namurian and shallow water late Namurian-Westphalian ' $A$ ' deltas deposited in the central England rifts. The trunk channels forming the distributary network are commonly medium to coarse grained with a moderate feldspar content. Sands in the late post-rift, LC2 sequence are similarly feldspathic but generally fine to medium grained. Quartz rich sands, probably sourced from the Wales-Brabant Massif to the south and east, are also observed in parts of the East Midlands following the mid-Brigantian inversion. 
The earliest onset of deltaic sedimentation occurred in the north-east of the province in the Northumberland Trough. Fluvially dominated deltas developed around the upland areas surrounding the basin. Episodically, siliciclastic wedges accumulated in the Solway-Northumberland basin derived, along active scarps, from the Southern Uplands. The clastic contribution from the Cumbrian Massif was insignificant. The Whita sandstone (Courceyan) is a good potential reservoir horizon in the north of the basin. It ranges up to $300 \mathrm{~m}$ thick with no significant shale breaks and good visible porosity. Sandstone interbeds are frequent in the Lower Lynebank Beds (Chadian) and rarer in the Upper Lynebank Beds, in which one sandstone exhibited microbotryoidal hydrocarbon. Deltaic sands are intermittent throughout the Arundian-Holkerian around Solway. Asbian sands comprise $30 \%$ of the Upper Border Group and six significant fluviatile sand intervals are described which are poorly cemented with good visible porosity. Similar sands of Brigantian age occur in the Archerbeck borehole where "oozing oil" was described from the Upper Liddesdale Group. Deltaic sedimentation prevailed in the Cleveland Basin from Chadian times. By late Asbian deltaic influence was prevalent across most of northern England. Between 30 and 60\% of the Upper Alston Group comprise siliciclastic deposits. Petrographic examination shows visible porosities of around $10 \%$. Potential reservoir sands are abundant, but their distribution tends to be unpredictable and laterally restricted.

The Pendleside Sandstone represents the earliest deltaic sand body to enter the Bowland Basin. It is a multiple sand body of overlapping $\mathrm{N}$ and ENE derived distal, turbidite fans interdigitating with the Lower Bowland Shales. The sands are fine-grained and exhibit typical turbidite features including grading, load casts, mudflake breccia and soft sediment deformation with slumps. Unfortunately samples that have been examined from both outcrop and wells have shown little reservoir potential due to extensive burial diagenesis. 
Deltaic sands did not prograde southwestwards to cover the Lancashire Shelf and East Midlands areas until the early Namurian. Locally sourced turbidite sands developed around gulf areas during the Brigantian and Pendleian, such as the Onecote sandstone, which is exposed at outcrop in North Staffordshire and in several boreholes in the Goyt Trough eg. Gun Hill-1. The pro-delta turbidite reservoirs are typical low stand deposits and confined to the evolving half-graben or sediment starved basins following the cessation of rifting. These sands form the producing interval in the Rempstone field (Duffield turbidites) where they attain a thickness of $20 \mathrm{~m}$ and on production test delivered 2 million standard cubic feet of gas per day. The sands are interleaved with basinal distal pro-delta organic rich mudstones.

Fluviatile and shallow water, near-shore sands are common throughout the HolkerianBrigantian along the North Wales Mercian Massif shoreline. The sands are developed in a series of cyclical shallowing-up sequences. These near-shore sands are generally poor reservoirs due to early cementation and there is little evidence for secondary porosity enhancement.

Welton oilfield appraisal wells A-2 and A-4 encountered quartz-rich Brigantian fluvial channel sands. These channel sands possess excellent reservoir characteristics and are oil-bearing in Welton A-4. The channel formed in a deeply incised (palaeokarst) Asbian carbonate platform and the quartzose and lithic detritus was probably derived from the Mercian Massif to the south. Analysis of the core data from the Welton wells suggests that the channel is of a low sinuosity type, in the order of 20 metres thick and a few hundred metres in width. A tentative N-S to NNW-SSE trend for the channel system is suggested from the palaeogeographic interpretation (Plate 4.10). Quartzose sands of similar provenance were encountered in several of the Eakring/Dukes Wood wells (Storey \& Nash 1993). Similar channel sands are also described from outcrops in North Wales (Walkden \& Davies 1983). 
The main reservoirs in the northern England Carboniferous are the shallow water delta top facies of late Namurian and Westphalian 'A' age (sequence LC1c; Fig 5.3). These sands comprise the reservoirs for the existing hydrocarbon accumulations in the East Midlands, often in a complex series of stacked reservoir/seal pairs, and an extensive database of borehole derived log, core and production data exists in-house within BP, with which to study the main controls on reservoir presence and effectiveness.

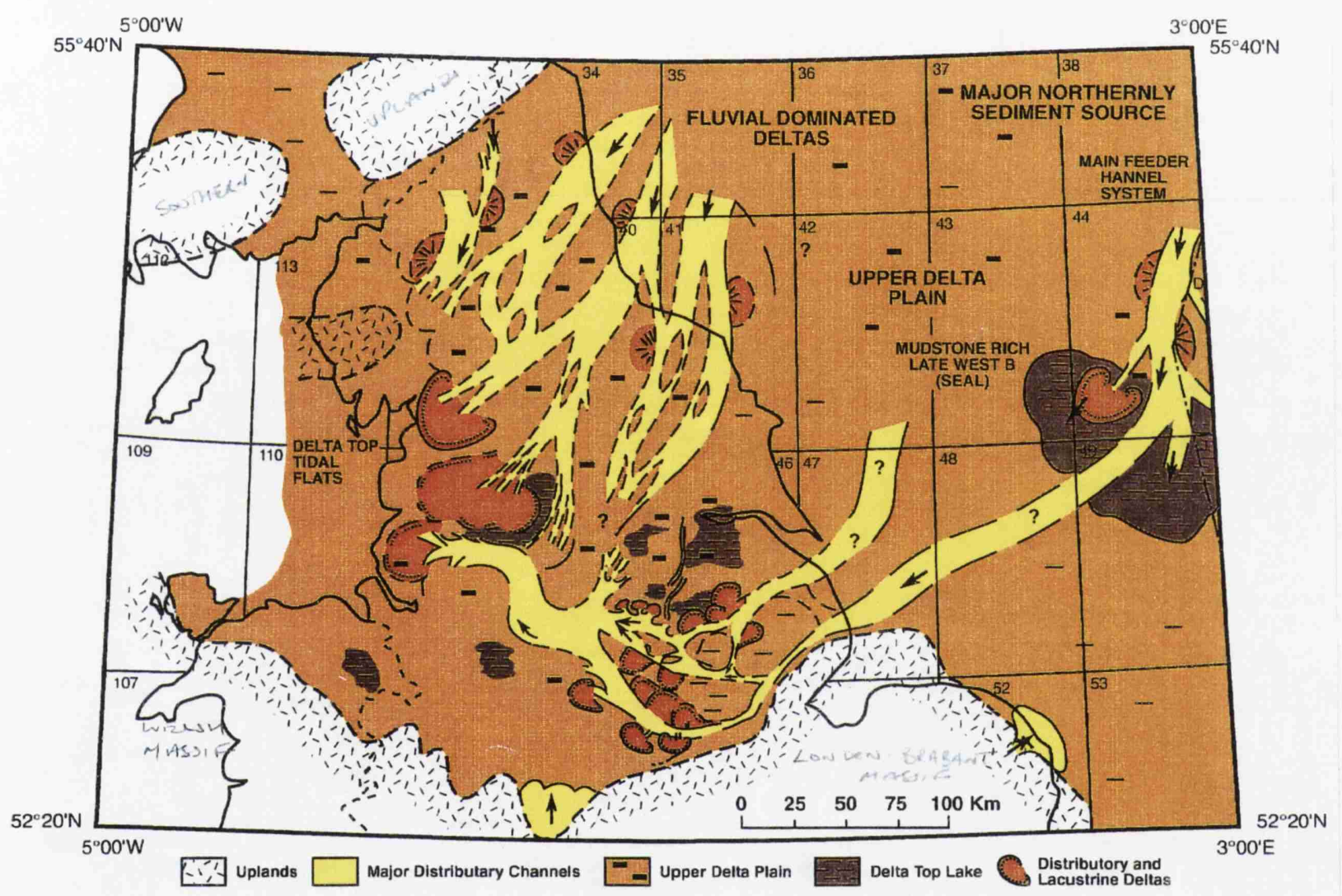

Figure 5.3. Schematic palaeogeography for the late Namurian-early Westphalian of northern England and the Southern North Sea. Onshore data from Collinson et al. 1977, Reading 1964, Guion \& Fielding 1988. Offshore data extracted from confidential oil company records. 
Detailed studies on the Namurian-Westphalian 'A' sandstones of the East Midlands have been based on a high resolution sequence stratigraphic scheme which relies on the presence of maximum flooding surfaces or marine bands. These events represent geologically instantaneous transgressive surfaces forming thin but widespread radioactive shale horizons which periodically flooded the delta top. Within this 'genetic' sequence stratigraphic framework individual sandstone reservoirs can be correlated with some confidence. The sequence stratigraphic framework is supported by a palynozonation scheme linked to existing goniatite stratigraphy that aids correlation in areas where marine bands cannot be identified from their electric log profiles alone.

Each sequence was isopached to determine sediment transport directions and to help constrain facies interpretation. The Namurian isopach shows that the major depocentres are located over the original Dinantian syn-rift half-graben; largely a reflection of existing palaeo-bathymetry persisting into the earlier parts of the Namurian coupled with a degree of differential compaction of the shales filling the basinal areas (Fig. 5.4). The interpretation for sediment transport from this map is that the sediments entered from the north and east and flowed laterally along the half-graben to fill the central Pennine Basin in the west.

A series of detailed facies maps for the East Midlands have been constructed for the main reservoir intervals defined by the 'genetic' sequences. Unfortunately, core data is typically limited to the oil bearing intervals which requires a scheme whereby log data is tied to core material and log motifs used to interpret depositional environment on the delta top. The technique of subsurface facies analysis is a common interpretive tool used by the oil industry (eg. Steele 1988, Collinson et al. 1993). Fortunately a good correlation was obtained between the gamma log motif and facies. The main distributary channels show a cylindrical log motif, typically 20-30 metres thick and a medium to coarse grain size profile (Fig. 5.5). The mouth bar reservoirs are characterised by a cleaning upwards profile (decreasing gamma radiation) 20 -30 metres thick with a very fine to fine grain 


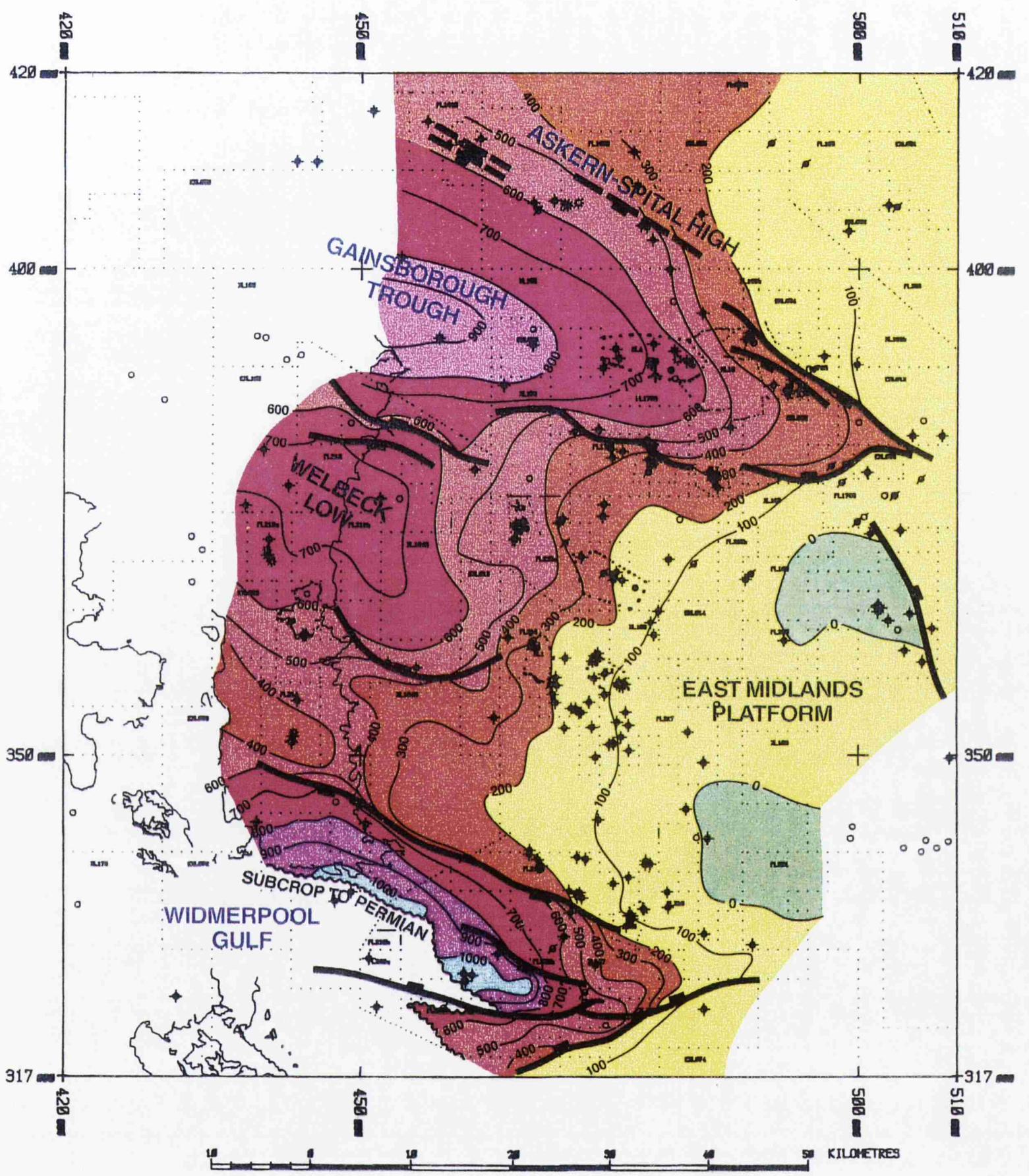

Figure 5.4. Simplified Namurian isopachs (metres) for the East Midlands based on borehole and seismic data. 


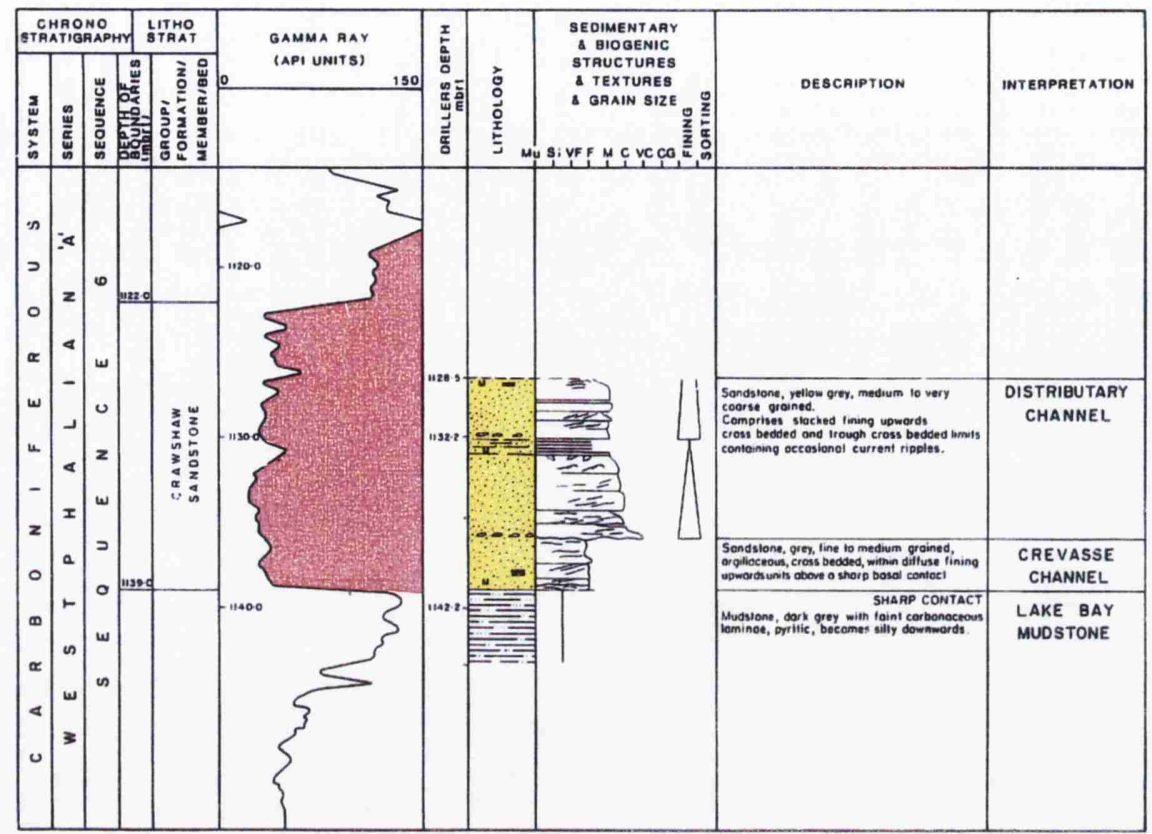

Figure 5.5. Distributary channel facies. Gamma-ray log profile and core sedimentological interpretation (Askham-1).

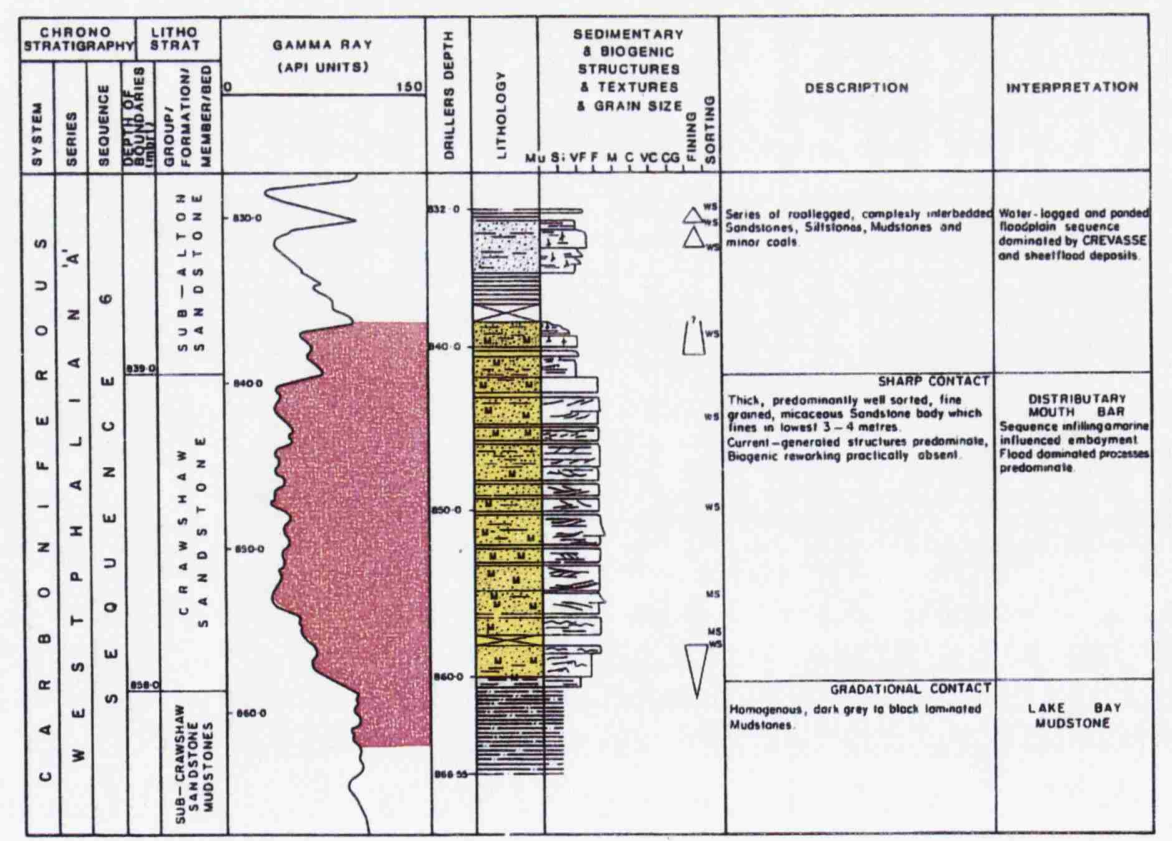

Figure 5.6. Distributary mouth bar/crevasse splay facies. Gamma-ray log profile and core sedimentological interpretation (Cropwell Butler-2). 


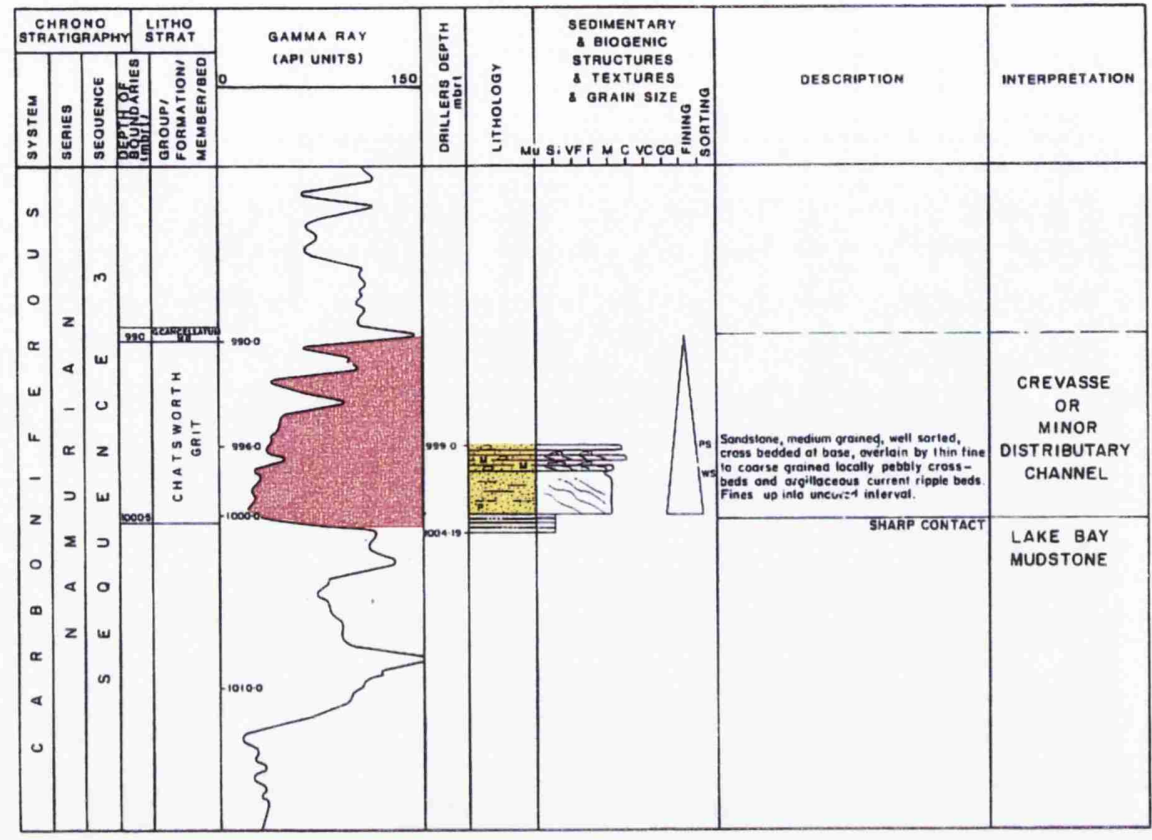

Figure 5.7. Crevasse channel facies. Gamma-ray log profile and core sedimentological interpretation (Fiskerton-1).

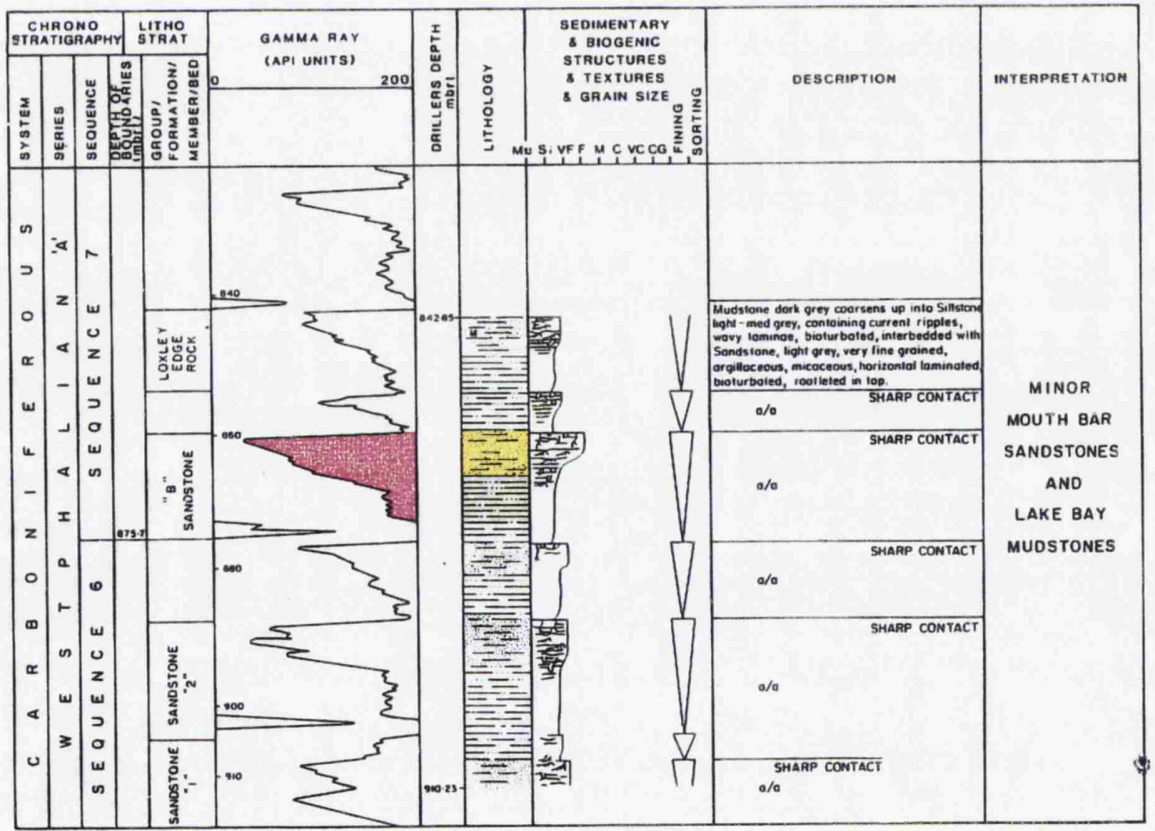

Figure 5.8. Minor distributary mouth bar facies. Gamma-ray log profile and core sedimentological interpretation (Ladybrook-1). 
size (Figs. 5.6 \& 5.7). These represent the main reservoir units in the East Midlands. The grain size comparison is fundamental to an interpretation of the large amount of pre1960 (no gamma log) wells. Other log motifs used in the construction of the palaeofacies maps are crevasse channels typically 5-10 metres in thickness ranging from fine to coarse grained (Fig. 5.8) and crevasse splay and interdistributary bay fines typically 5-10 metres thick and very fine to medium grained (Fig. 5.6).

The 'genetic' sequence stratigraphic scheme for seismic sequence LC1c is detailed on Fig 3.11; a summarised log from the Ilkeston-1 borehole on the northern margin of the Widmerpool Gulf. The log profile for the Namurian and Westphalian 'A' indicates four main gross depositional environments;

i) Pro-delta as the first clastic material reached the previously sediment starved rifts

ii) Delta-slope as the initial progradation of the Kinderscout/Ashover deltas reached the basin

iii) Lower delta plain with stacked channel sands and extensive marine band seals

iv) Upper delta plain representing the periodic abandonment of the delta system with extensive coals

The sonic marker noted in the early part of the Westphalian ' $\mathrm{A}$ ' corresponding to the approximate level of the amaliae marine band seems to be a regionally significant event which can be identified and mapped across the East Midlands. As discussed earlier, it represents the transition from lower delta plain to upper delta plain conditions across the East Midlands province. It is considered to mark the end of local subsidence in the halfgraben, perhaps related to an early phase of Variscan compression, during which time the delta systems continued to prograde westwards to infill the central Pennine Basin.

Detailed palaeofacies maps have been constructed for the Ashover, Chatsworth and Crawshaw reservoir systems (Figs 5.9, $5.10 \& 5.11$ ). These maps define the presence 


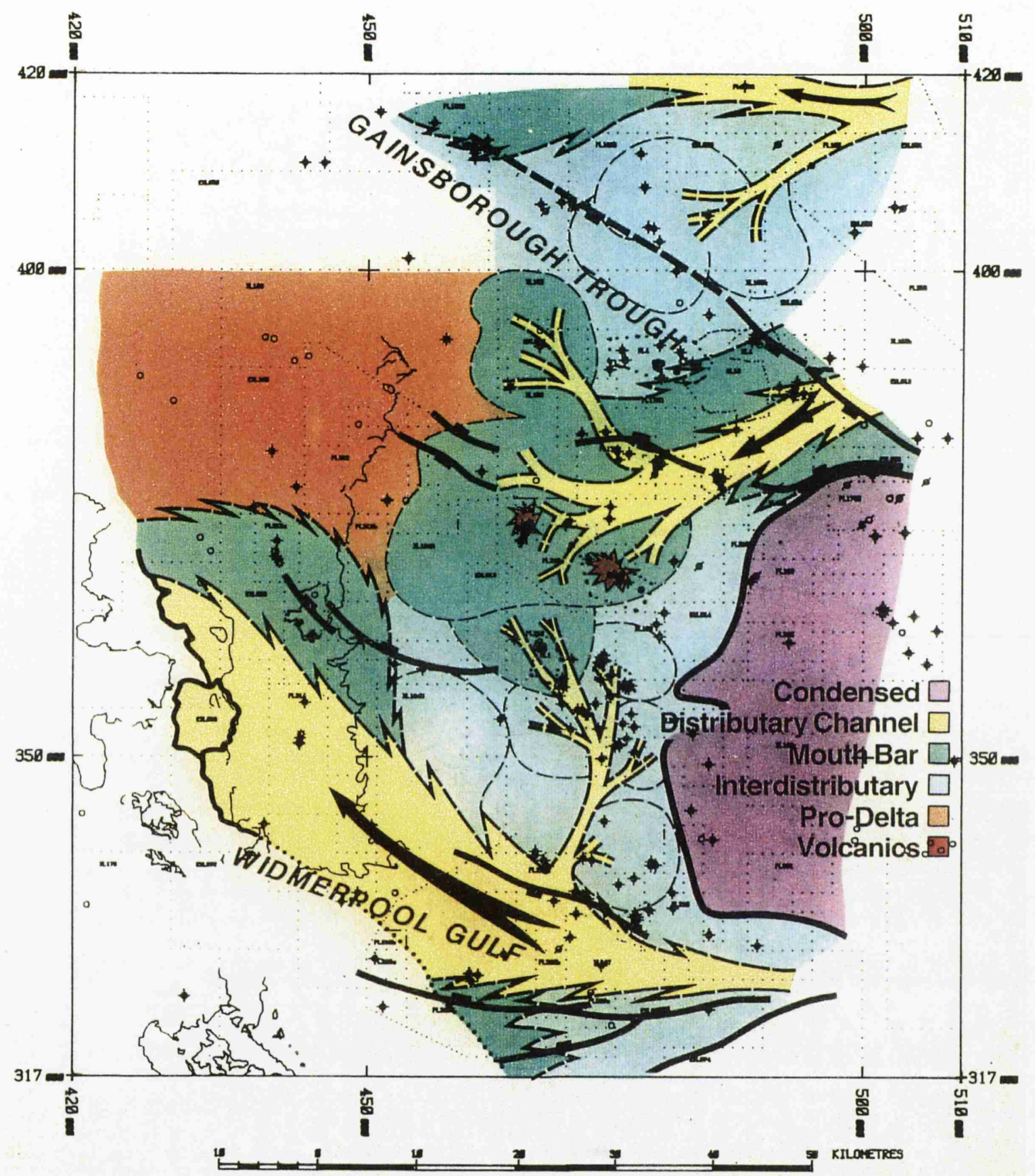

Figure 5.9. Palaeofacies map for the Ashover delta in the East Midlands (genetic sequence 2; $R$ Gracile MB to $R$. Superbilingue MB). The Ashover sandstone comprises the main reservoir interval developed within genetic sequence 2. A major distributary channel system can be mapped along the axis of the Widmerpool Gulf (see also Fig. 3.10) This sandstone represents a major phase of basin infill in the Widmerpool Gulf and this delta system fronted by turbidite fans prograded into the deeper water central Pennine Basin to the west (Jones 1980). 


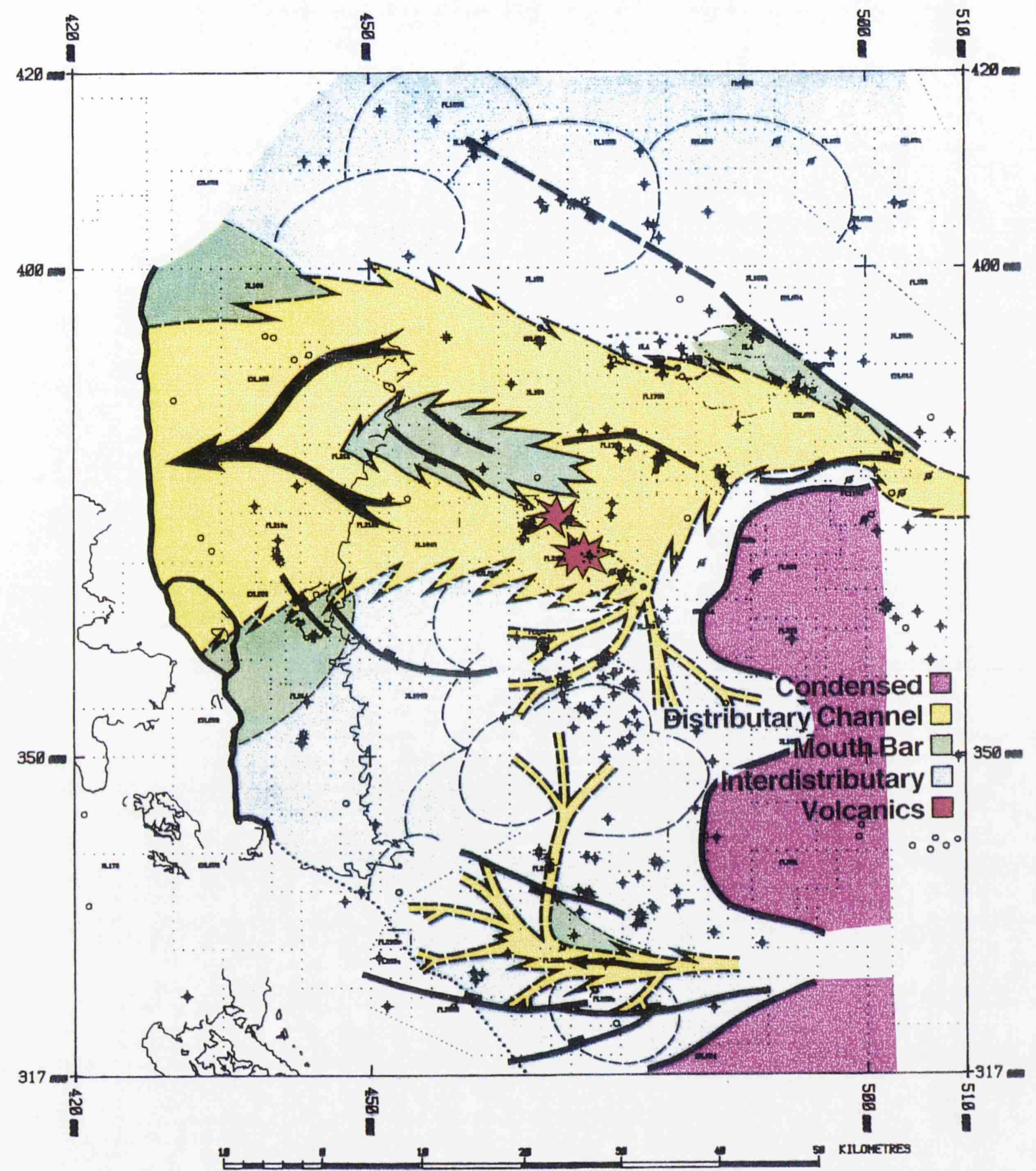

Figure 5.10. Palaeofacies map for the Chatsworth delta in the East Midlands (genetic sequence $3 ; R$. Superbilingue MB to base $G$. Cancellatum MB). A distributary channel system continued to prograde westwards along the axis of the Widmerpool Gulf, but was not as laterally extensive as the preceding sequence 2 Ashover channel belt. To the north a more extensive channel belt was developing within the Welbeck Low largely fed by sediment from the Gainsborough Trough area. Palaeocurrents measured at outcrop by Mayhew (1978) confirm the westwards continuation of the Welbeck channel system into the central Pennine Basin. 


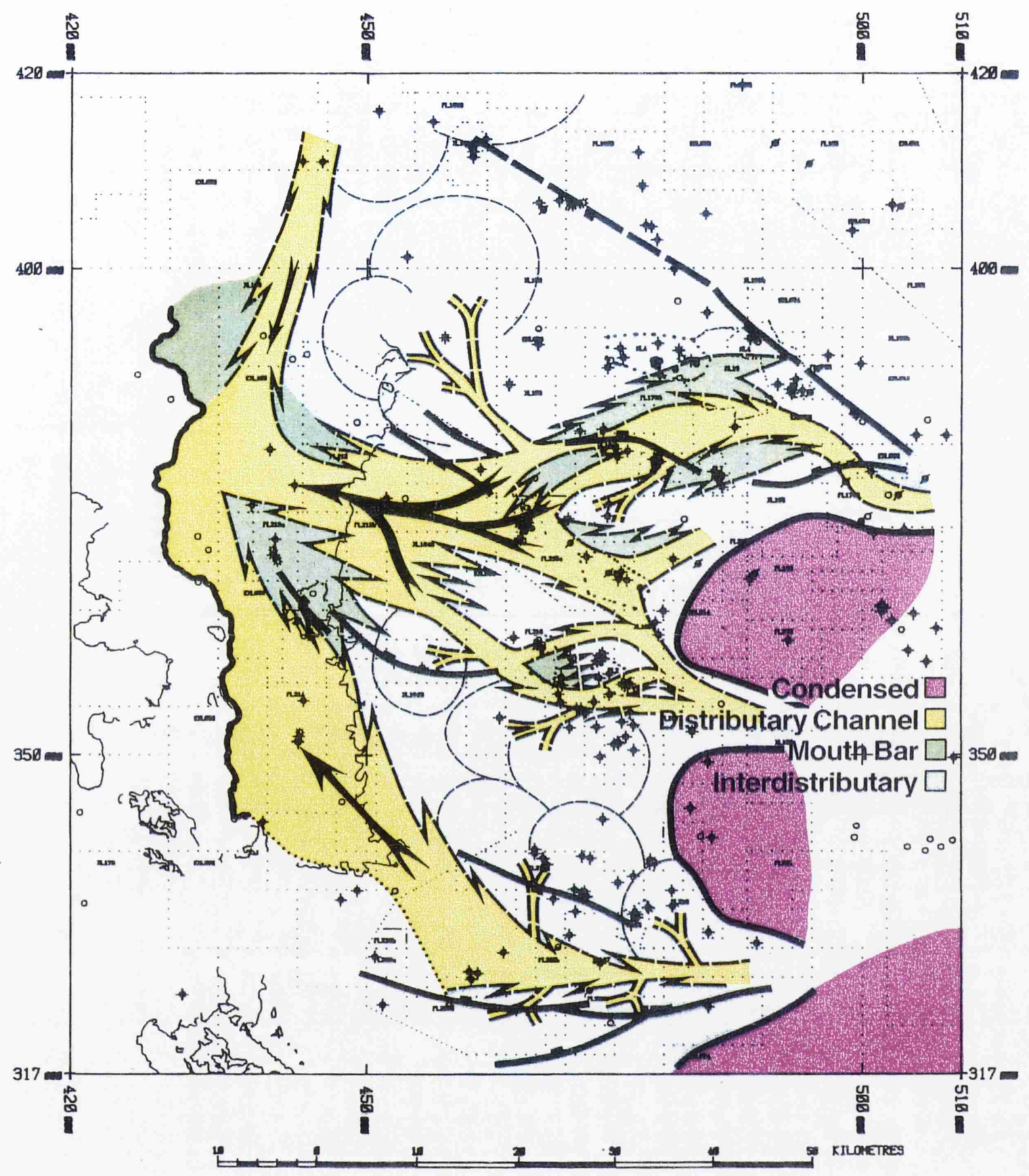

Figure 5.11. Palaeofacies map for the Crawshaw delta in the East Midlands (genetic sequence 6; G. Subcrenatum MB to base G. Listeri MB). Following periods of low clastic input to the east Midlands during sequences 4 and 5, major distributary channel belts were re-established in the Widmerpool Gulf and Welbeck Low areas during sequence 6; Crawshaw and Sub Alton sandstones. 
of the main reservoir facies and its distribution in the main distributary channel belts. In general, the upper Namurian trunk channels forming the distributary network are commonly medium to coarse grained with a moderate feldspar content. Sands of Westphalian ' $\mathrm{A}$ ' age are similarly feldspathic but generally fine to medium grained. In general, however, the maps illustrate the widespread distribution of late NamurianWestphalian ' $A$ ' reservoir facies throughout the East Midlands province.

Burial diagenesis is the key post-depositional process controlling poroperm development in the deltaic clastic reservoirs. The major features are a progressive quartz-clay diagenesis that occludes primary porosity and the leaching of feldspars to create secondary porosity. The destruction of primary porosity is the more important in restricting permeability and is the principal limiting factor on reservoir quality. The depth of burial and timing of maximum depth of burial were determined from vitrinite reflectance against depth plots (Figs. $5.12 \& 5.13$ ).

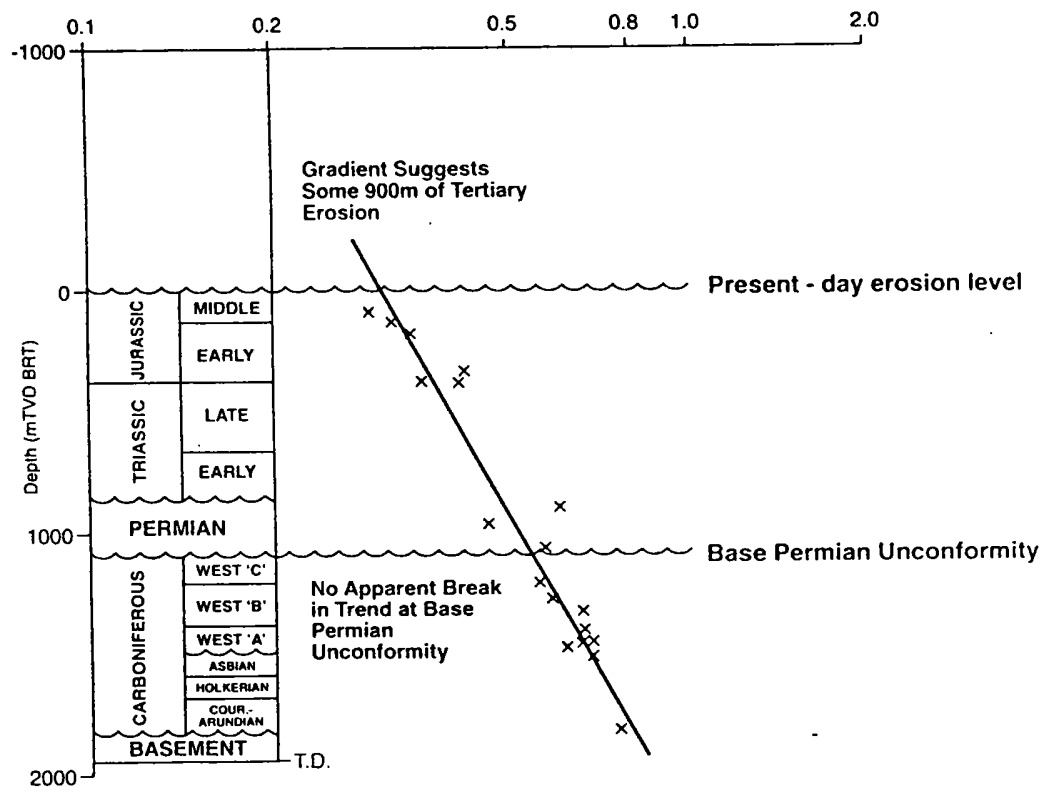

Figure 5.12. Maturity against depth profile for the Bardney-1 borehole in the East Midlands based on vitrinite reflectance data. 
The reflectance value of certain types of organic matter reflects temperature and hence in most cases increased temperature with increased depth of burial. The plot for the Bardney-1 well in the East Midlands (Fig. 5.12) extended to a surface Ro\% value of $0.2 \%$ suggests some 900 metres of post Jurassic erosion with no offset at the base Permian unconformity indicating that the Carboniferous in this borehole attained its maximum depth of burial in the Mesozoic. This well is typical of the burial history of the majority of the East Midlands. In contrast, well 39/9-1 from the Southern North Sea Basin (Fig 5.13) shows a continuous unbroken trend from top Carboniferous to the Pleistocene at the seabed indicating that the Carboniferous burial is maximum at the present day.

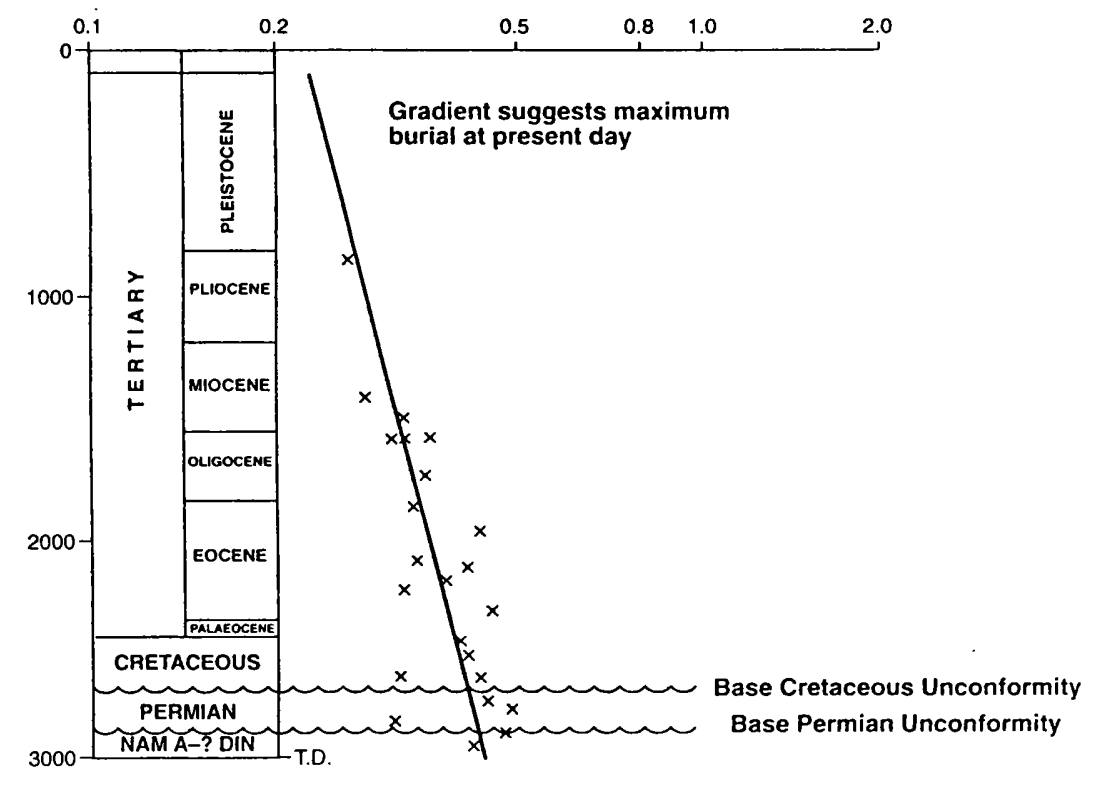

Figure 5.13. Maturity against depth profile for the well $39 / 9-1$ in the Southern North Sea Basin based on vitrinite reflectance data.

The next step in estimating reservoir effectiveness on a regional scale is to identify a relationship between maximum burial depth and porosity. From production test data from a number of fields in the East Midlands a cut-off for oil production has been established at $1 \mathrm{mD}$ permeability. 

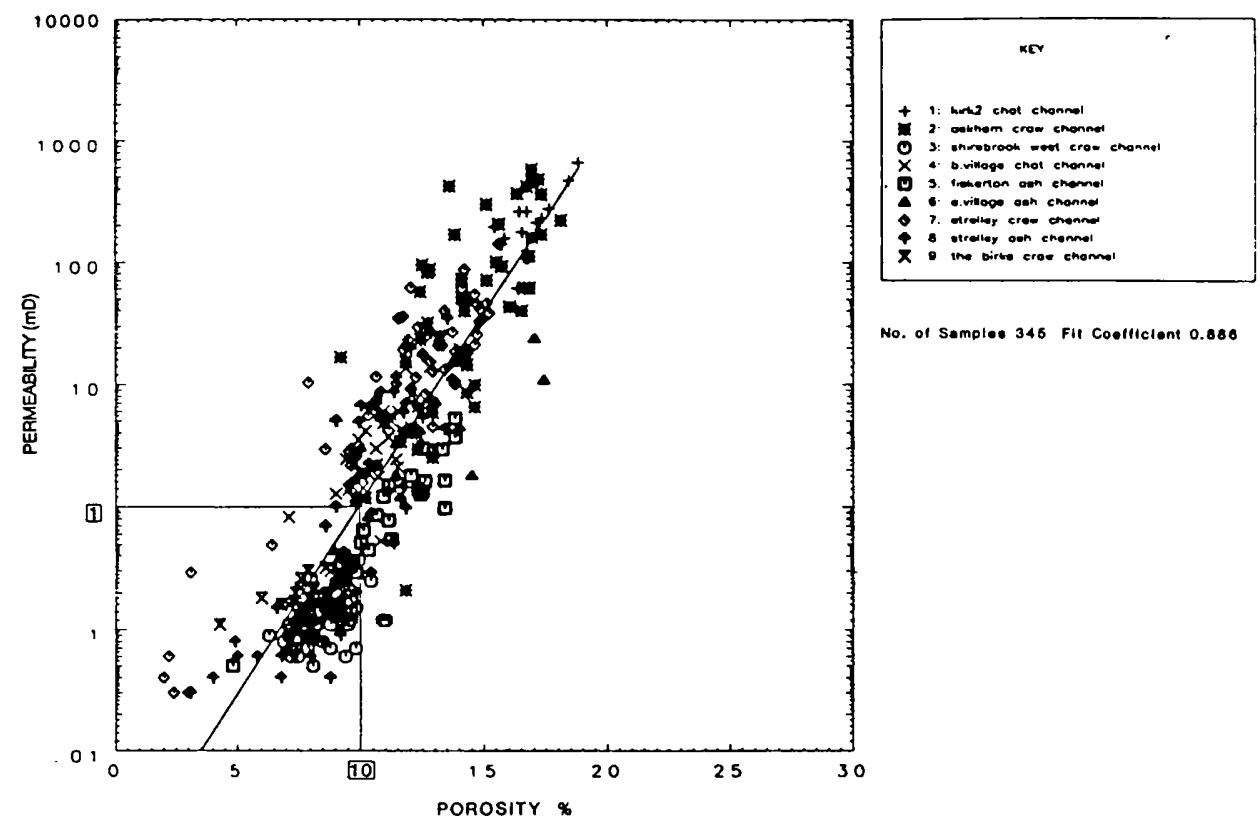

No. ol Somptee 346 Fil Coeflictent 0.880

Figure 5.14. Porosity $v$ permeability plot for late Namurian-Westphalian ' $A$ ' channel sandstone facies based on core analysis data from boreholes in the East Midlands.

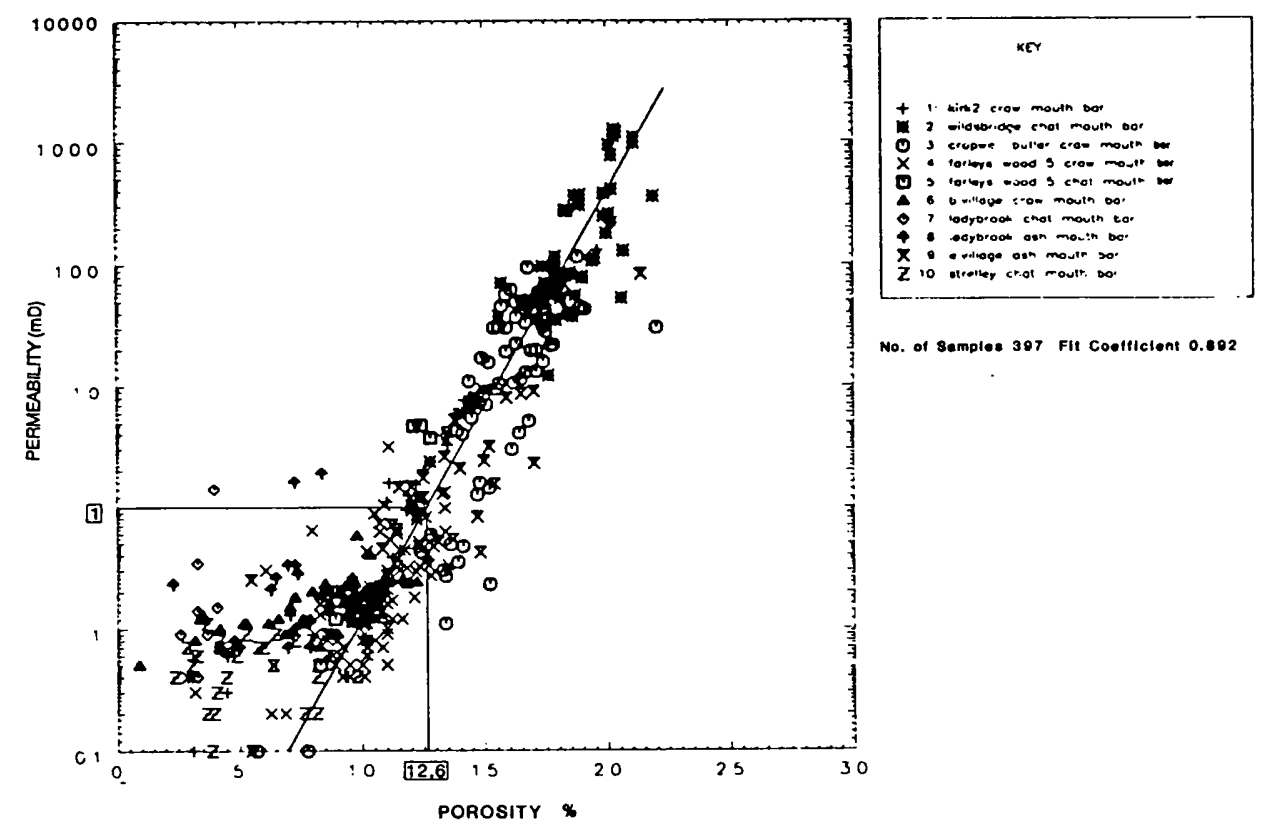

Figure 5.15. Porosity $v$ permeability plot for late Namurian-Westphalian ' $A$ ' mouth bar sandstone facies based on core analysis data from boreholes in the East Midlands. 
A cross plot of porosity vs permeability based on over $1.5 \mathrm{~km}$ of core data from East Midlands wells suggests a $10 \%$ porosity cut off for channel sandstones (Fig. 5.14) and $13 \%$ for mouth bar sands (Fig 5.15). This corresponds to a depth cut of for effective reservoir in channel sands of c. $2550+/-200$ metres and in mouth bar sands of c. 2350 +/- 200 metres (Fig. 5.16). These values can be input to a map showing maximum depth of burial and areas of relative high and low risk for effective oil production can be identified for the East Midlands (Fig. 5.17) and by extension the entire north of England (Plate 5.2).

In summary the principal controls on reservoir distribution for the NamurianWestphalian 'A' deltaics are environment of deposition and maximum depth of burial.

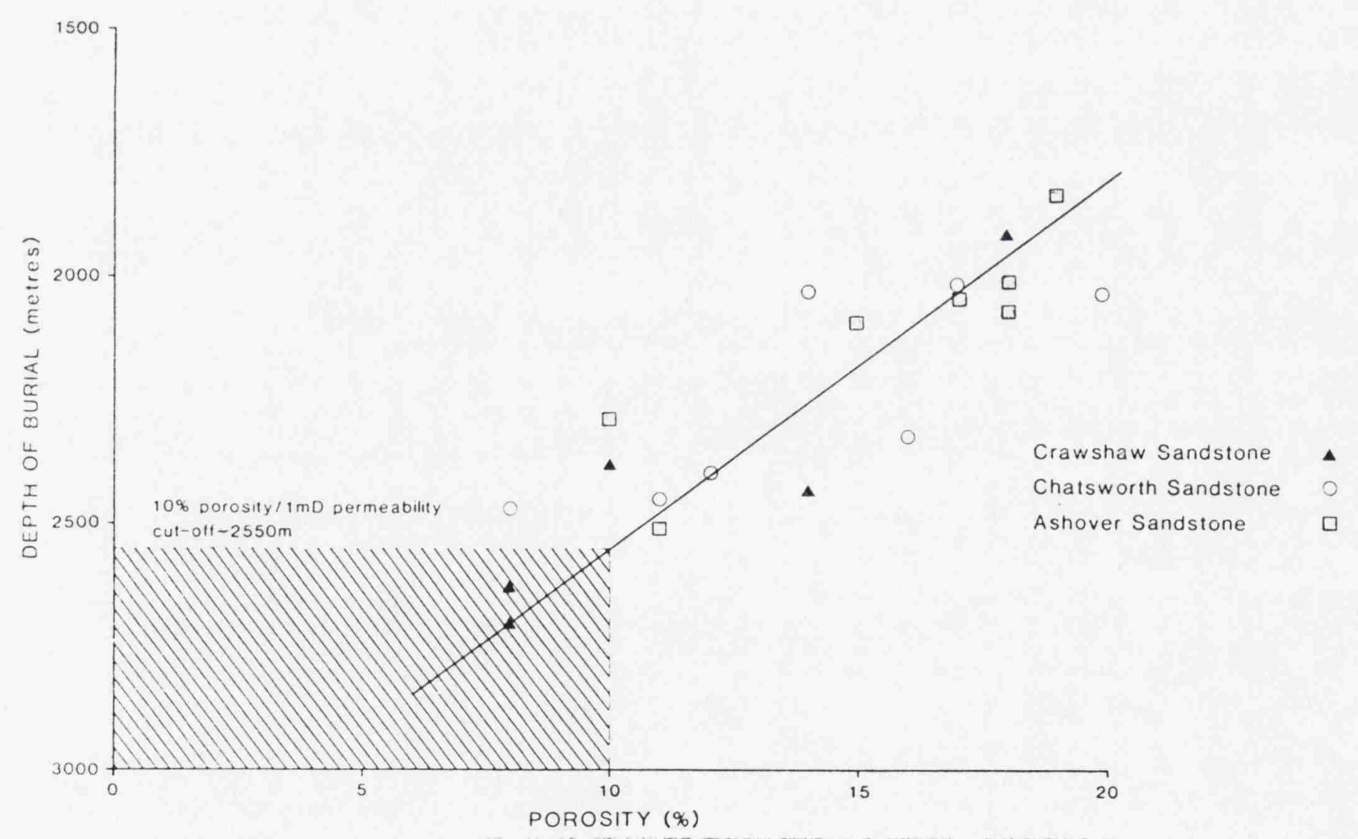

Figure 5.16. Porosity $v$ depth plot for late Namurian-Westphalian ' $A$ ' channel sandstone facies based on core analysis data from boreholes in the East Midlands. 


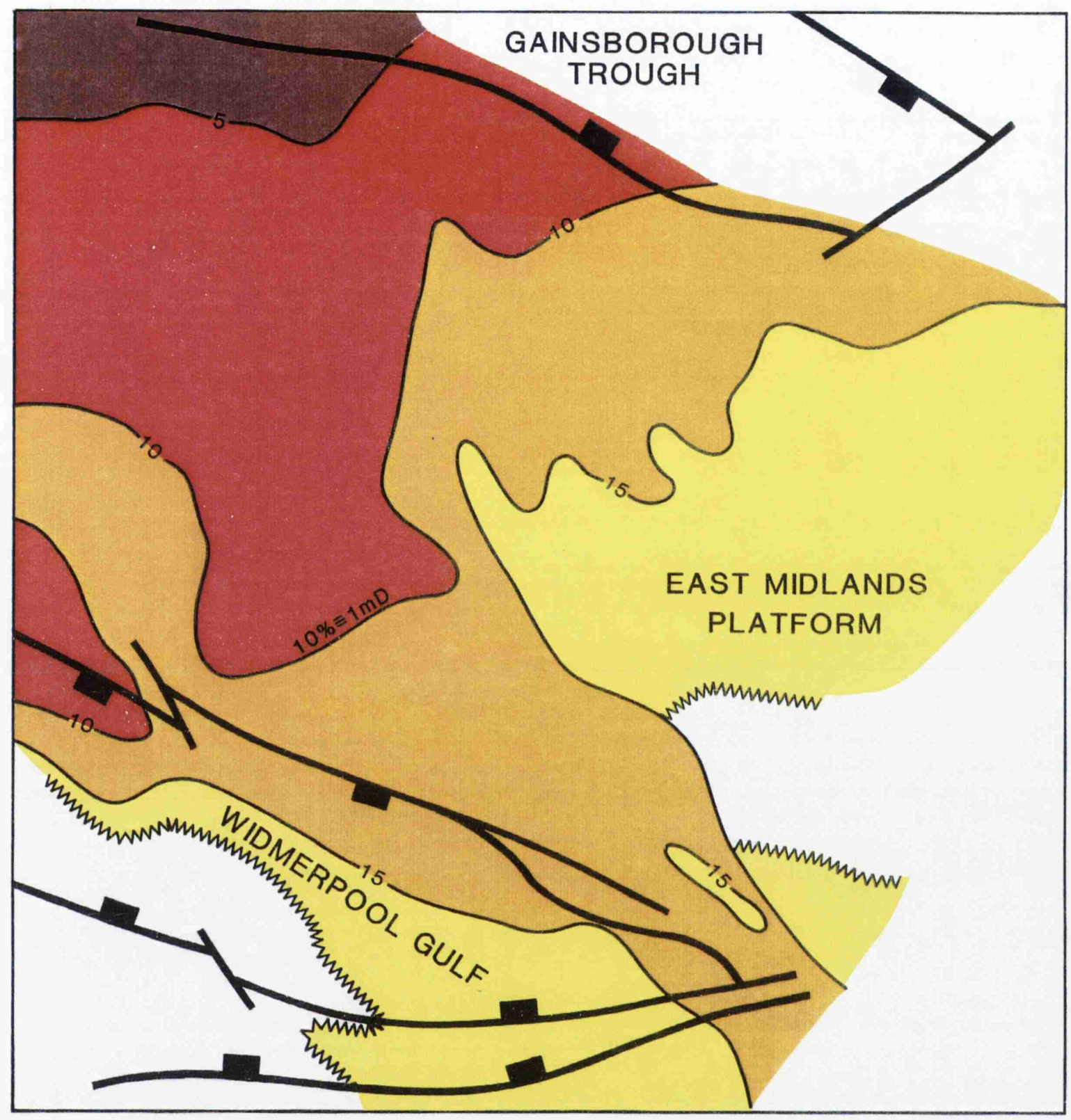

Average Porosity

$$
\begin{aligned}
& 0-5 \% \\
& 5-10 \% \\
& 10-15 \% \\
& >15 \%
\end{aligned}
$$

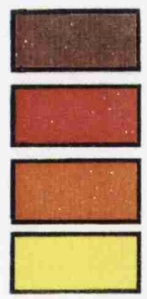

Figure 5.17. Crawshaw sandstone isoporosity map for the East Midlands. 


\subsubsection{Retaining hydrocarbons}

Retaining includes two aspects of the hydrocarbon environment: seal capacity/extent and trap occurrence/integrity.

\subsubsection{Seal Capacity and Extent.}

This aspect of the hydrocarbon system in northern England is important, particularly for gas, but extremely difficult to quantify. The two most common reservoir-seal pairs in the Carboniferous delta environment are delta-top sands sealed by marine bands or interdistributary muds and turbidites encased in pro-delta shales. The marine bands of the late Carboniferous of northern England are highly effective regionally distributed seals (Fig. 5.18) with a thickness and distribution controlled by post-rift thermal sag subsidence (Plate 2.10).
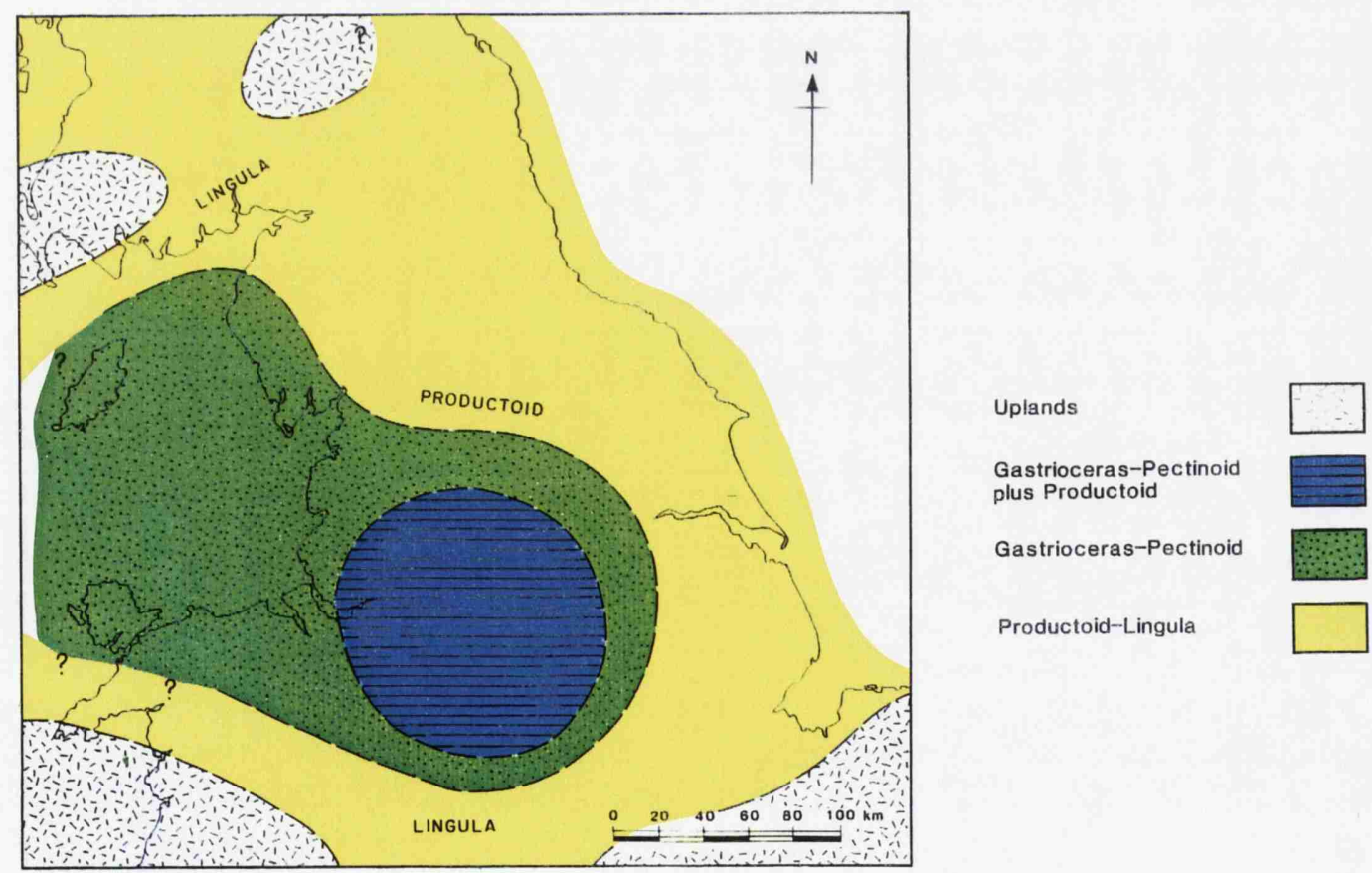

Figure 5.18. Faunal facies at the maximum transgression of the Gastrioceras Subcranatum Marine Band marking the Namurian/Westphalian boundary (after Calver 1968). Note correlation with the Namurian-early Westphalian isopach pattern shown on Plate 2.10. 
These marine shales have negligible sand/silt contents as reflected by their overall gamma-ray log response. Such marine band shales are rarely in excess of 1-2 m thick in the East Midlands, but where unfaulted can support oil columns of 40-50 m. Although the marine bands are thin but extensive (Calver 1968), the interdistributary shales may locally be relatively thick (10-15 $\mathrm{m}$ in the East Midlands fields). However, these interdistributary shales are likely to be less effective due to their limited extent and relatively high silt content. The sealing mechanism developed by an interdistributary shale may be quite complex and not involve a single stratigraphic layer but a 3dimentionally interdigitating network of shales.

Seal capacity for gas has only been measured with any degree of confidence on one structure; Calow, a dip-closed, inversion anticline in the East Midlands (Fig. 5.19). Gas columns of 30-40 m are sealed at two separate reservoir levels by delta top shale and argillaceous sandstone where structural closure is in excess of $100 \mathrm{~m}$.
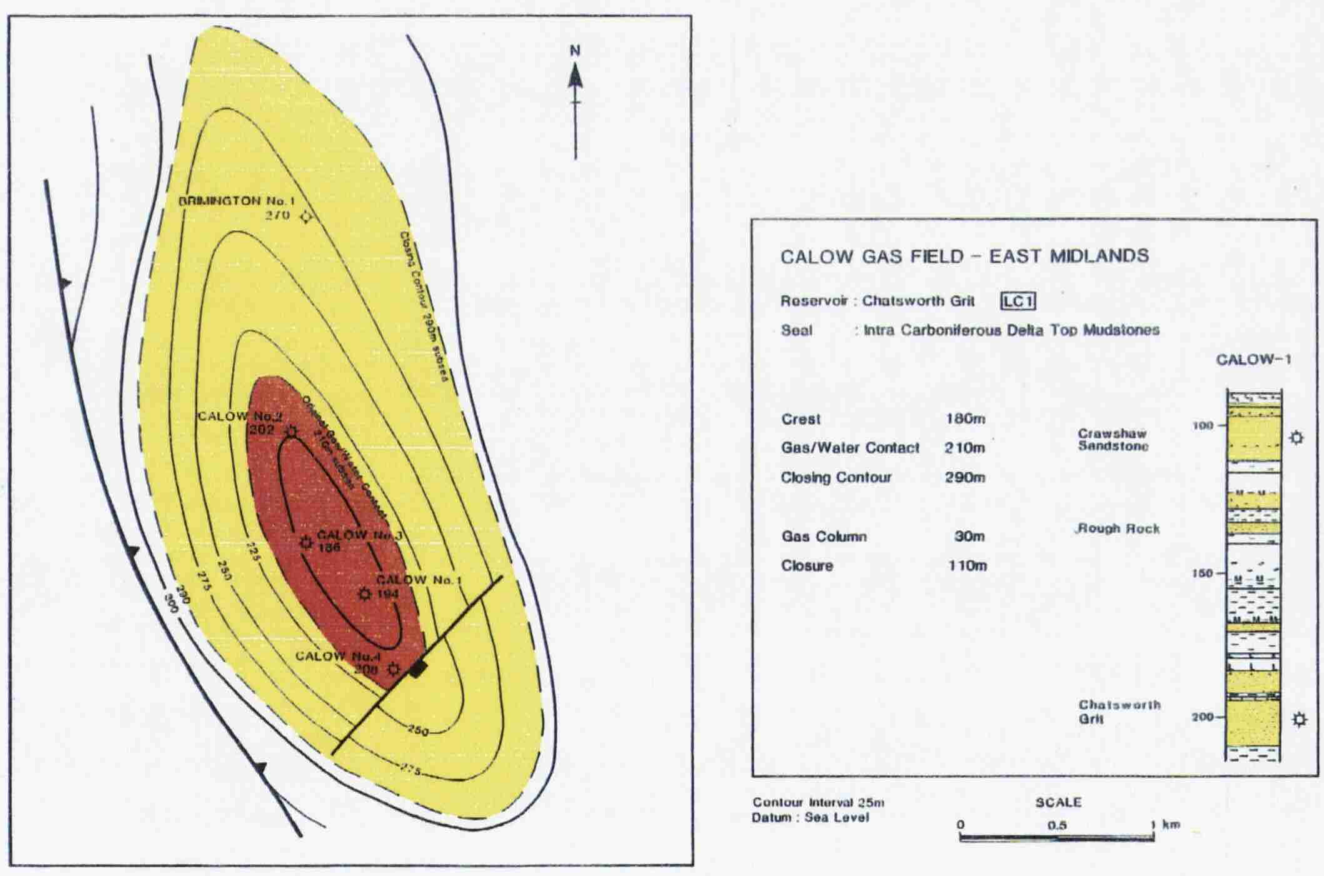

Figure 5.19. Depth to top Chatsworth grit reservoir (metres) in the Calow gas field, East Midlands. The map highlights the discrepancy between the observed gas/water contact at 210 metres sub sea-level reference and the mapped structural spill point at 290 metres subsea. 
Hydrocarbon generation from source rocks was effectively 'frozen' in the early Tertiary following regional uplift. Consequently seals are required to have maintained their integrity for up to $60 \mathrm{Ma}$. This is extremely unlikely as mudstones still have small vertical permeabilities and rarely form 'perfect' seals over geological time. The difference in mapped structural closure and column height in the Calow Field may therefore reflect the extent of gas seepage that has taken place post-late Cretaceous uplift. As a result significant gas accumulations can only survive in northern England where Permo-Triassic evaporite seals overlie the Upper Carboniferous such as in the Cleveland Basin and offshore in the Southern North Sea (Fig. 5.20). Seal capacities for mudstones in parts of the offshore Carboniferous are not as critical as in the East Midlands due to continuing hydrocarbon generation from the source rocks to the present day (Fig. 5.13).

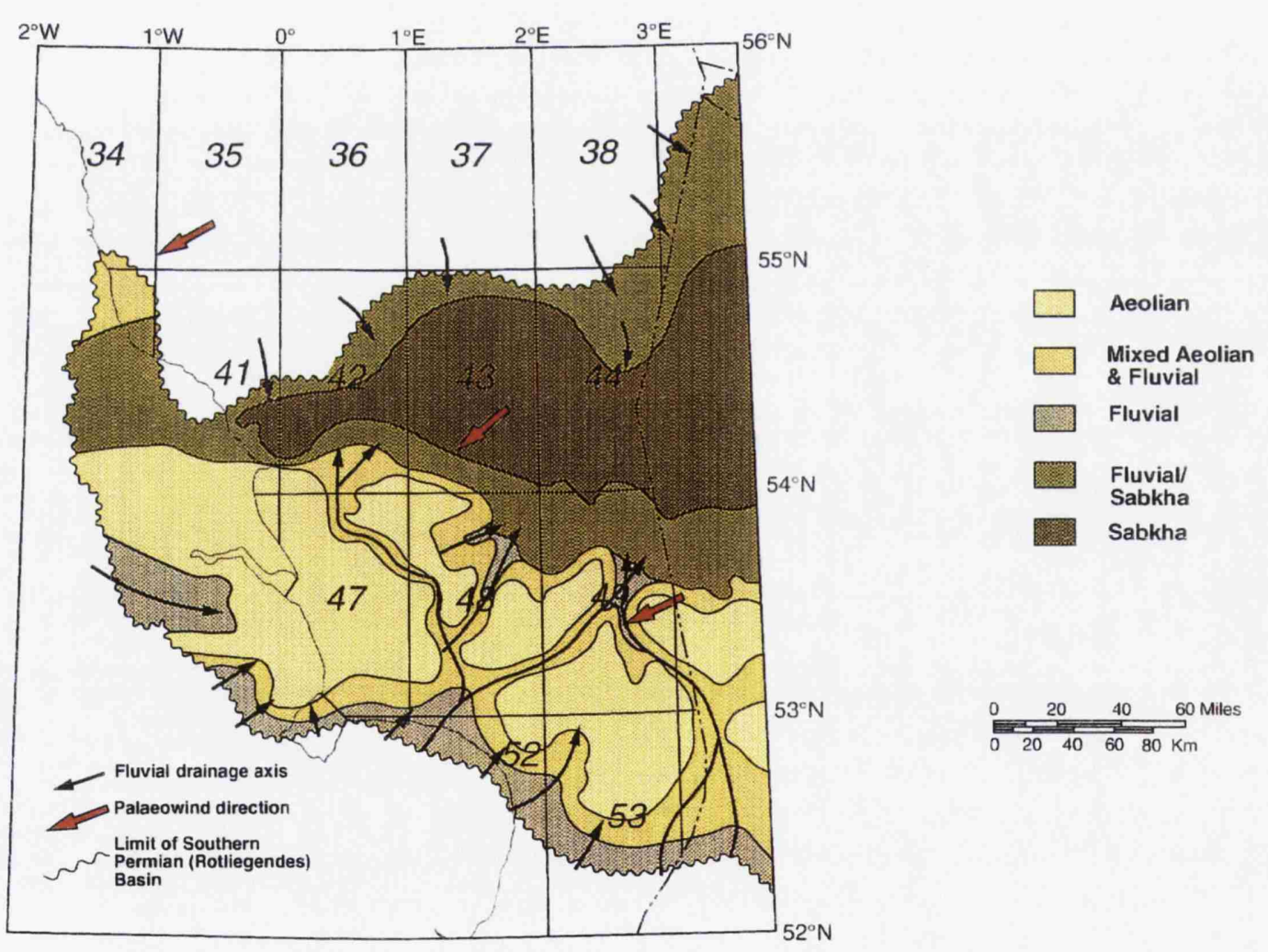

Figure 5.20. Sketch of the early Permian palaeogeography of eastern England and the Southern North Sea showing the extent of base Permian Rotliegend and Zechstein evaporite seals (Sabkha facies). 


\subsubsection{Trap occurrence and integrity.}

Trap occurrence is not thought to be a limiting factor on the hydrocarbon environment of northern England. The Variscan orogeny was pervasive and created an extensive array of variably faulted, inversion anticlines of which the Eakring Field is a typical example (Fig. 5. 21). Each of the 36 oil and gas fields discovered to date in the Carboniferous of northern England display some component of Variscan deformation in their geometry. Taking the East Midlands as an example, it can be seen that the oil and gas fields show a close relationship with the major fault trends (Plate 1.4). Inspection of a depth converted regional seismic line across the province shows the major fields to lie in the hangingwalls of faults active during the Dinantian rift phase (Plate 3.2).

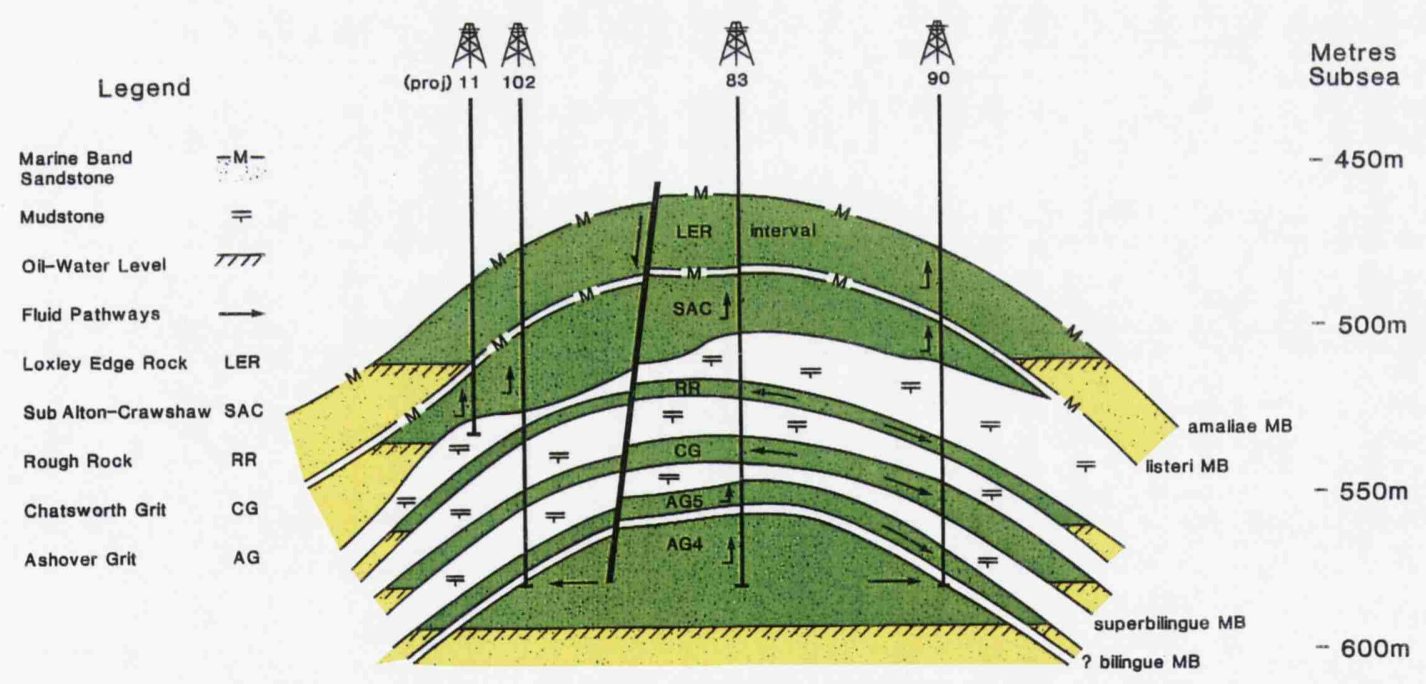

Figure 5.21. East-west scale cross section of the Eakring oilfield in the East Midlands highlighting the stacked nature of the reservoir channel and mouth bar sand bodies. 
The amplitude and wavelength of the structures was determined by the relative orientations of the controlling faults to the northwesterly directed compression. Only in northwest England is the presence of Variscan closures difficult to demonstrate. Here post-trap faulting, associated particularly with Permo-Triassic rifting, has fragmented and severely modified earlier Variscan structures. In sharp contrast, traps in the East Midlands province are almost entirely Variscan in origin with only Tertiary tilting significantly disturbing accumulations. The latter is reflected throughout the East Midlands by the prominence of transition zones and residual oil columns, which if reconstructed within a pre-Tertiary structural setting may be found to correspond to structural spill point. The Cleveland Basin was subject to a more profound phase of late Cretaceous-Tertiary trap tilting and inversion which has considerably modified earlier Variscan structures.

Structures reliant on some element of fault seal for closure are rarely successful exploration targets in the Upper Carboniferous as the thin mudstones interbedded with the reservoir sandstones seem incapable of providing effective juxtaposition seals across fault planes.

\subsubsection{Source rock distribution.}

In this section the distribution and character of potential Carboniferous source rocks across northern England are summarised.

The quantity and quality of geochemical data is variable across the study area, with the best coverage available for the East Midlands (various BP proprietary borehole geochemistry reports). Several confidential regional reports compiled by BP's Sunbury Research Centre which have been available as background data to this thesis, provide a good basis for the larger scale understanding of source rock distribution in northern England. 
Geochemical data and references are summarised in Appendix C. Outcrop and borehole sample locations are shown on Plate 5.3. Source rock distribution and richness are summarised in Plate 5.4.

The key control on the Carboniferous play system in northern England is the presence of delta top coal, and and pro-delta mudstone source rocks. This section analyses the presence of such deposits for the major provinces in the study area.

\section{Northumberland Trough}

Potentially organic rich pro-delta mudstones and delta top coals would have reached the Northumberland Trough earlier than the rest of the northern England study area. However, the organic richness of Courceyan sediments (Lower Border Group from Alwinton, Liddlewater, Kirkcambeck and Lemmington) is poor, with TOC values variable between 0.04 and 1.98 wt. \%. The basal Cementstones show little or no hydrocarbon source potential with TOC values rarely exceeding $1 \%$ and the kerogen type often dominated by inertinite. Kerogen examination showed these sediments to be predominantly gas prone with a high proportion of terrestrial, woody plant material.

The Arundian/Chadian aged Middle Border Group is represented by samples from the Stonehaugh borehole and outcrops at Kingwater and Craigburn. Vitrinite reflectance data indicate that sediments are mature for oil and gas generation, with locally high Ro due to igneous intrusions. TOC's for sediments from the Stonehaugh borehole ranged from 0.63 to $29.69 \mathrm{wt} \%$, and $>50 \%$ for coals. Potential hydrocarbon yields were poor to good (2-12 kg tonne-1). The kerogen types are mixed, with a large terrestrial plant input and again predominantly gas prone.

Asbian/Holkerian Upper Border Group sediments (Scremerston Coal Group equivalents) from the Stonehaugh, Ferney Rigg, Tarry and Ridsdale boreholes and outcrops from 
North Rothbury, Irthing, Thirlwall, Bearsmouth, Redesdale and Hareshaw Burn, are generally immature, but approaching oil generation threshold (Ro $0.55 \%$ ). Locally higher maturities are associated with igneous intrusions. Most sediments analysed were rich in organic matter, being nearly all above $3.0 \%$ and ranging up to $40 \%$ in the coals. Pyrolysis-gas chromatography analysis shows the presence of a significant waxy, oil prone component and these shales and coals represent moderate to good mixed oil and gas sources. Biomarker ratios show a marine background shale with a variable terrestrial input.

Oil shales have been reported from several localities in and around the Northumberland Trough during the Asbian. These oil shales are analogues of the thick oil shale deposits of the Midland Valley of Scotland which were deposited in tectonically and volcanically active basins. Studies on the Scottish Oil Shale group suggest that they accumulated in an internally drained system of freshwater lakes sustained by continual run-off in a wet tropical climate. Such conditions apparently did not persist for long over the Northumberland Trough and it is considered unlikely that the shales were widespread over the basin. They are characterised by high organic carbon contents (10-30\%). Chemically, these source rocks are seen to have a high wax content, typical of land plant sourced kerogen.

Towards the late Asbian the onset of Yoredale sedimentation is marked by the Lower Liddesdale group. Upwards the limestones become thicker and more persistent and were deposited in increasingly open marine conditions. This resulted in a reduction in source rock quality, partly because of the increase in oxygenation of the depositional environment. These sediments show moderate to good TOC's ( 0.81 to $18.23 \%)$ with coals upto 78.0wt \%, from the Ferney Rigg borehole, and Tipalt Burn and Four Laws outcrops. Moderate to good potentials at present day are indicated by potential hydrocarbon yields of between 2 and $40 \mathrm{~kg}$ tonne-1. Mixed kerogen types are assessed from the Ferney Rigg borehole samples as more gas than oil prone. 
Brigantian Upper Liddesdale Group samples from Steel Rigg, Ferney Rigg and South Acton boreholes as well as Frankham Fell and Tyne Bottom outcrops show maturity levels below the gas generation threshold. TOC and hydrocarbon yield values show variably poor to good source potential; being highest in coals. Terrestrial woody plant material deposited under brackish water conditions, was identified. The shale and coal beds may constitute up to half of the thickness of any one Yoredale cycle and are good to excellent gas prone source rocks and occasionally moderate oil prone source rocks.

Early Namurian sediments are represented by a continuation of the Yoredale cyclothemic sequence. Grey shales and canneloid coals were sampled from the East Coldside and Steel Rigg boreholes and Boulmer, Haltwhistle Burn and Great Limestone outcrops. Maturity levels exceed oil generation threshold in most cases. This higher than average maturity level is related in most cases to the intrusion of the Whin Sill. High terrestrial plant input from the prevalent deltaic environment is consistent with the regional setting. Organic rich mudstones have TOC's of between 1.6 and $9.54 \%$ and coals TOC's ranging up to $78.85 \%$. Apart from the high potential yields from the coals, other sediments have poor to moderate residual potential partly due to high inertinite content. Kerogen type from visual examination suggests predominantly gas prone source potential.

In the Northumberland Trough, methane gas is common in coal mines, but this is probably locally derived from the Coal Measures. Several occurrences of bitumen are recorded from fractures in the Great Limestone at Shellbracs (NZ 001 719), Kirkheaton (NZ 018 773) and Capheaton (NZ 016 787) (Creaney et al. 1980). These indicate important terrestrial input and generally high maturities especially at Capheaton where a heating event is evident post-dating emplacement and solidification. GCMS fingerprinting of the Moot Law bitumen suggests a Brigantian (Upper Liddesdale Group) source. 
In summary oil and gas prone source rocks have been observed within all the Carboniferous strata encountered within the Northumberland Trough with the exception of the Courceyan. Pyrolysis yield values range from $2-12 \mathrm{~kg}$ tonne-1. The most prolific source horizon lies within the Asbian. These source rocks comprise generally thin coals and organically rich lacustrine shales with a high wax content.

\section{Solway Basin}

The Solway Basin forms the westerly extension of the Northumberland Trough, but is likely to exhibit better source rock potential as a result of the more temporally persistent pro-delta environments during the Dinantian and Namurian.

Thin mudstone beds from the Arundian Thirlstane Sandstone Group show some residual potential with potential hydrocarbon yield values of up to $14.8 \mathrm{~kg}$ tonne-1. These sediments are oil prone despite a high terrigenous plant component. A coal sample from the Asbian Powillimount beds (equivalent to the Scremerston Coals of Northumberland) proved to have restricted oil and gas potential. The Asbian Throssburnfott Coal (sample from Irthing) is predominantly gas prone. Brigantian and Pendleian sediments show generally poor source potential, with TOC's typically below $5.0 \%$ and potential yield values below $2 \mathrm{~kg}$ tonne-1 for mudstones. Coals from Penton and Bedlam (Pendleian) have higher TOC and pyrolysis values and are interpreted as both oil and gas prone.

\section{Alston and Askrigg Blocks}

Potential oil source rock beds are poorly developed across these granite cored persistent highs. These areas were never subject to deep burial either during or after the Carboniferous. However, anomalously high maturity levels are recorded by vitrinite reflectance data, due to the very high temperature gradient associated with greater thermal conductivity of the underlying granite (Plate 5.3). 
Pendleian mudstone samples from Eggleston Burn gave potential hydrocarbon yield values of up to $1.2 \mathrm{~kg}$ tonne $\mathrm{e}^{-1}$ corresponding to a maximum TOC of $6.8 \%$. The organic matter comprises largely structured woody plant material with traces of amorphous algal kerogen. Vitrinite reflectance values range up to $1.28 \%$. Yoredale facies samples of Asbian-Brigantian age from the Raydale borehole show little significant potential, with highest TOC's measured for coals. Vitrinite reflectance values range from 1.19 to 2.58\%. Gigglewick outcrop samples are less mature and show moderate potential for gas.

Stainmore Trough

Various Brigantian outcrop samples from the Stainmore Trough show poor to good source potential, being best for coals. Asbian-Brigantian, Yoredale delta top coals and organic rich shales have been identified as the only significant source rocks in the basin. Gas-prone and mixed kerogen types are reported, with abundant woody, terrestrial plant material. Vitrinite reflectance values show the sediments to be mature, at least to the oil generation threshold, and locally much higher due to high basal heat flows, as confirmed by base-metal mineralisation.

\section{Cleveland Basin}

Very few data are available to evaluate the source rock potential of the Dinantian-early Namurian strata of the Cleveland Basin.

The presence of a number of gas accumulations along with numerous gas shows within wells drilled in the basin indicates the presence of an effective and mature gas prone source rock. This is confirmed by the limited geochemical data available for evaluation. In general source rocks are now mature to post mature for both oil and gas generation. 
Under these conditions rock-eval pyrolysis does not give a reliable guide to the original source rock potential.

Geochemical analyses of the Seal Sands-1 borehole provides the major data source for Courceyan to Brigantian sediments in the basin. Limited data is also available for undifferentiated Dinantian (Chadian-Asbian) sediments in Kirkleatham-l and the offshore borehole 41/20-1. The Seal Sands-1 samples show no significant oil source potential with minor gas prone, dark grey mudstones and coals at present day maturities which are too high to enable characterisation of the organic matter (TOC's up to $4 \%$ with a considerable inertinite component). Siltstones and mudstones from 41/20-1 are also highly mature (Ro>2\%) and would only be capable of generating methane. Similarly Visean sediments from Kirkleatham-l are considered to have only limited residual gas potential.

Holkerian shales and thin sands associated with the Fell delta give average TOC's of $2.3 \%$ at a maturity of $1.5 \%$ Ro in the Seal Sands well. This figure probably represents half of the original TOC value. Asbian shales in Seal Sands-l gave similar values to the Holkerian with TOC's averaging 3.5\%. The Brigantian (Yoredale facies) in Seal Sands and Harlsey-l showed higher than average TOC's of between $2.16 \%$ and $1.32 \%$. The organic matter type is consistently dominated by vitrinite and minor amounts of amorphous sapropelic organic matter.

The Kirby Misperton-1 borehole encountered Dinantian and lower Namurian sediments (Holkerian to Arnsbergian age). These showed little or no source potential except for the basal Namurian, Sabden Shales which showed good potential for gas and the BrigantianPendleian, Bowland shales which, despite high maturities, showed moderate gas potential. Silesian sediments from Egton Moor-1 and Lockton-7 are also overmature but identified as gas prone. 
Although largely absent due to uplift and erosion in late Carboniferous-early Permian times, sediments of Westphalian age show fair to good oil and gas potential when preserved. Oil source rocks have been observed in coals and associated shales throughout the Westphalian 'A', 'B' and ' $\mathrm{C}$ ' on the flanks of the basin. Geochemically they are characterised by a dominantly land plant derived component with high organic carbon values and moderate to high hydrogen indices (a measure of oil proneness).

\section{Manx-Furness Basin}

The Manx-Furness Basin is a proven hydrocarbon province which contains the Morecambe Gas Field containing 5tcf of recoverable reserves in sands of Keuper age (Ebbern 1981). Several minor onshore discoveries notably at Formby and Croxteth and the presence of numerous seeps in outcrops on the basin flanks (Plate 1.3), enhance prospectivity.

Along the southern margin of the basin, the Holywell Shale (Dinantian-Namurian boundary) is shown to have oil and gas potential in the Abbey Mills-2 borehole, with potential hydrocarbon yields of between 4.3 and $10.5 \mathrm{~kg}^{-1}$ tonne ${ }^{-1}$. Promising, mixed gas/oil prone source rocks of Namurian age are also identified in Abbey Mills-l with pyrolysis yields of $11.2 \mathrm{~kg}$ tonne $\mathrm{e}^{-1}$ and TOC $=5.5 \mathrm{wt} \%$. Dinantian strata generally have poor potential. For example, Dinantian mudstone and limestone samples from outcrop at Great Orme and Halkyn (North Wales) have pyrolysis yield values of between 2.5 and $7.1 \mathrm{~kg}$ tonne-1 respectively at a maturity level equivalent to the oil generation threshold; both are gas prone.

The Dinantian around the eastern margin exhibits poor to moderate potential. A Roosecote borehole sample provided values of TOC $=4.0 \mathrm{wt} \%$ and pyrolysis yields of between 7 and $9 \mathrm{~kg}$ tonne-1. The Dinantian on the northern margin of the basin is represented by outcrops along the south of the Isle of Man, where samples have high 
maturities all beyond the oil floor with values of between $2 \%$ and $4 \%$ Ro. High geothermal gradients related to plutonism and associated with $\mathrm{Pb}-\mathrm{Zn}-\mathrm{Cu}$ mineralisation, account for the high sediment maturity.

Good source potential in the east of the basin is proven for Namurian pro-deltaic Bowland Shales from Roosecote-1 and Formby-1. Pyrolysis values range from 2.9 to $14.3 \mathrm{~kg}$ tonne $\mathrm{e}^{-1}$ (average 5.4 for Roosecote samples). Bowland Shale samples from the Formby-1 borehole, which are approaching oil floor at $1.3 \%$ Ro, have lower pyrolysis yields of around $2 \mathrm{~kg}$ tonne-1.

The basin centre is represented by several offshore wells eg. 112/25A-1 where Namurian and Dinantian sediments have high maturities due to significant Mesozoic burial. Namurian sediments $(112 / 30-1)$ have TOC's of up to $2.6 \%$ but largely comprise inertinite. Lower Carboniferous samples from 112/25A-1 have maximum potential hydrocarbon yields of $0.9 \mathrm{~kg}$ tonne-1.

\section{Bowland Basin}

The Bowland Basin is essentially the onshore, eastward extension of the Manx-Furness Basin. Outcrop and borehole sample analyses show the richest source rocks to be the Brigantian-Pendleian Bowland Shales. The first deltaic siliciclastic influx to prograde southwards over the Craven Faults into the basin was the Pendleside Sandstone during the Brigantian. The associated pro-deltaic Bowland Shales contain abundant terrigenous plant material. Values of TOC and pyrolysis yield commonly exceed $10.0 \mathrm{wt} \%$ and $5.0 \mathrm{~kg}$ tonne $\mathrm{e}^{-1}$ respectively. Measured thickness of Bowland Shale ranges from $70 \mathrm{~m}$ to in excess of $300 \mathrm{~m}$ in the basin depocentre. The Bowland Shales are mixed oil and gas prone. Present day maturities are high, eg. in the Holme Chapel borehole, where a vitrinite reflectance value of $2.5 \%$ Ro was achieved by burial prior to end Carboniferous. 
The overlying Sabden Shales have patchy oil source potential with typically high inertinite contents. Humic coal horizons from the Warleywise Grit have excellent hydrocarbon potential.

The Dinantian sediments in the Bowland Basin have generally poorer source potential than the overlying Upper Brigantian-Lower Namurian section. Samples of argillaceous Pendleside Limestone (Asbian) from Harclough have TOC values ranging up to $3.5 \mathrm{wt} \%$ and maximum pyrolysis yields of around $5.0 \mathrm{~kg}$ tonne-1.

The Asbian-Holkerian Worston Shales typically have poor source potential with TOC $<$ $2.3 \mathrm{wt} \%$ and pyrolysis yields of $<1.5 \mathrm{~kg}$ tonne $\mathrm{e}^{-1}$. Older sediments have even lower organic carbon contents. The Clitheroe Limestone (Chadian-Arundian) sampled from outcrop at Slaidburn has poor residual potential (TOC c. 1.0\%). Courceyan sediments from the Swinden-1 borehole have moderately good gas and light oil source potential, comprising predominantly woody organic matter, although around $60 \%$ of the measured $3 \%$ TOC comprises inertinite.

Dinantian (Brigantian-?Chadian) dark grey, calcareous mudstones from Weeton-l contain moderate amounts of organic carbon (TOC $=0.6$ to $2.0 \mathrm{wt} \%$ ) but are over mature (Ro > $1.3 \%$ ) at present day for any residual potential. It is suggested that these sediments may have been originally gas prone.

Oils from the Bickershaw Colliery and the BP Minerals borehole Marl Hill-II indicate more than one source, with the light oil component suggesting a Bowland Shale origin.

In summary, the best oil and gas source rocks in the Bowland Basin are the pro-deltaic Bowland Shales of Brigantian-Pendleian age (P2 5-14kg tonne-1), with some significant gas source potential in Pendleian coal horizons. Asbian and older sediments are 
predominantly marine basinal mudstones with some terrigenous plant input, but little source potential.

\section{North Wales Shelf Area}

Although mudstone-siltstone horizons are present in the cyclical Holkerian-Brigantian near-shore sediments, no source rocks have been identified in this area. Shelf margin localities, such as Great Orme and Halkyn, have some source potential (see ManxFurness and Bowland Basins, above). High porosity dolomite eg. in Milton Green-1 with minor hydrocarbon shows, require further examination before the prospectivity and source potential of this area can be downgraded. Recent results from the well Erbistock-1 concur with this analysis suggesting that source potential in the Dinantian-basal Namurian is restricted to occasional thin mudstones. All samples were mature with Ro ranging from $0.7 \%$ to $1.0 \%$.

\section{East Midlands}

Source rock distribution Early Dinantian (Courceyan-Chadian) dolomite and anhydrite deposits typified by sections in the Eyam and Hathern-l boreholes show no hydrocarbon source potential in these hypersaline environments. The Eakring-146 section of thick red conglomerates and breccias with thin limestones also shows no hydrocarbon source potential as would be expected in this environment.

However, the Gun Hill-1 and Caldon Low wells, which are dominated by a basinal lacustrine mudstone sequence, are reported to show the development of good oil and gas prone source rocks. It is suggested that during this early syn-rift phase, a series of restricted basins were developed. In the deeper water areas, beyond the influence of syn-tectonic breccias, source rock development is likely with the preservation of oilprone, algal organic matter. Source characteristics are expected to be similar to the 
lacustrine shales encountered in the mid-Devonian of the Orcadian Basin in northeast Scotland. Here TOC's range from $5 \%$ to $20 \%$.

Sediments of Arundian age in the East Midlands are dominated by a series of shelf limestones. They exhibit little or no source potential for either oil or gas. The surprising absence of source potential from the carbonate rocks in the Dinantian of northern England is widespread. One explanation for this may be the dilution of organic carbon material by excess carbonate transported into the basin.

Oil source rocks are present in Holkerian black shales and very occasionally as brown limestones such as in Stixwould-1. These sediments represent moderate to good quality oil source rocks and good to very good gas sources. Elsewhere the Holkerian on the East Midlands shelf is represented by a series of thick shelf carbonates with no source potential. The development of a basinal clastic facies is limited, with thin intervals observed in Alport-1, Gun Hill-1 and Eakring-146. These constitute moderate to good gas source rocks.

The only significant oil source rock of Asbian age in the region is to be found in dark, fissile, pelagic shales of the Mixon Limestone Shales as described by Aitkenhead et al. (1985). These are present in the New Mixon Hay-2 and Gun Hill-1 boreholes. These mudstones which are interbedded with turbidites show moderate to good mixed oil and gas source potential.

The East Midlands basins (Widmerpool Gulf, Goyt Trough, Edale Gulf, Welbeck Low and Gainsborough Trough) which evolved during the Dinantian, acted as the depocentres for the major Brigantian-Arnsbergian oil prone source rocks in the area. The advancing delta lobes prograding from the north were prevented from entering these basins by a series of topographic barriers until the Arnsbergian or later. Fine grained terrigenous plant material did, however, reach the basins as early as the Brigantian to mix with algal 
material which was already present. The richest source rocks in the Gainsborough Trough are Pendleian (?Brigantian) as is the case in the Edale Gulf (Edale-l, Alport-l) and the Goyt Trough (Gun Hill-1). In the more isolated Widmerpool Gulf the richest source rocks are of Pendleian-Amsbergian age.

Brigantian-Arnsbergian sediments (Edale shales and equivalent) are typically black, pyritous, organic rich pro-delta mudstones. They are referred to as the 'Gamma-active shales' (Fraser et al. 1990) where encountered in the subsurface, as a result of their high radioactive log signature. The shales have average TOC contents of about $3.5 \%$ and commonly in excess of $5.0 \%$. Corresponding pyrolysis yields average some $15 \mathrm{~kg}$ tonne-1 in wells such as Rempstone on the southern margin of the Widmerpool Gulf. In the Gainsborough Trough pyrolysis yields are of the order of $10-12 \mathrm{~kg}$ tonne-1 dropping to around 8-9kg tonne-1 in the Welbeck Low (extension to the Edale Gulf formed in the late Brigantian as an intra-shelf basin). In these latter areas the 'Gamma-active' shales are of late Brigantian-Pendleian age.

These mudstones are predominantly oil prone. Biomarker studies and carbon isotope values clearly indicate a mixed marine/terrestrial derived kerogen. This is entirely consistent with a distal pro-delta environment of deposition. The source facies has concentrated in the remnant half-graben and intra-shelf basinal areas more-or-less bypassing the East Midlands Shelf. Biostratigraphic studies have shown that late Arnsbergian or condensed Alportian-Chokierian sediments rest directly on Dinantian carbonates on the platforms.

In the north of the East Midlands province oil and gas prone source rocks of Westphalian age have been encountered in several of boreholes eg. Stixwould-1, Beckingham-1, Trumfleet-1 and Tetney Lock-1. These source facies are generally coals and carbonaceous mudstones probably associated with the development of local lake sites within an upper delta plain environment. They are characterised by very high organic 
carbon content and high pyrolysis yields. Average TOC values of about $60 \%$ and hydrogen indices of 300-400 (indicating oil as well as gas potential) are typical. Elsewhere in the East Midlands, coals are largely gas prone.

In summary, oil-source rock correlations in the East Midlands confirm the late Brigantian-Arnsbergian pro-delta mudstones as the main source intervals for oils discovered in the province (Fig. 5.22).

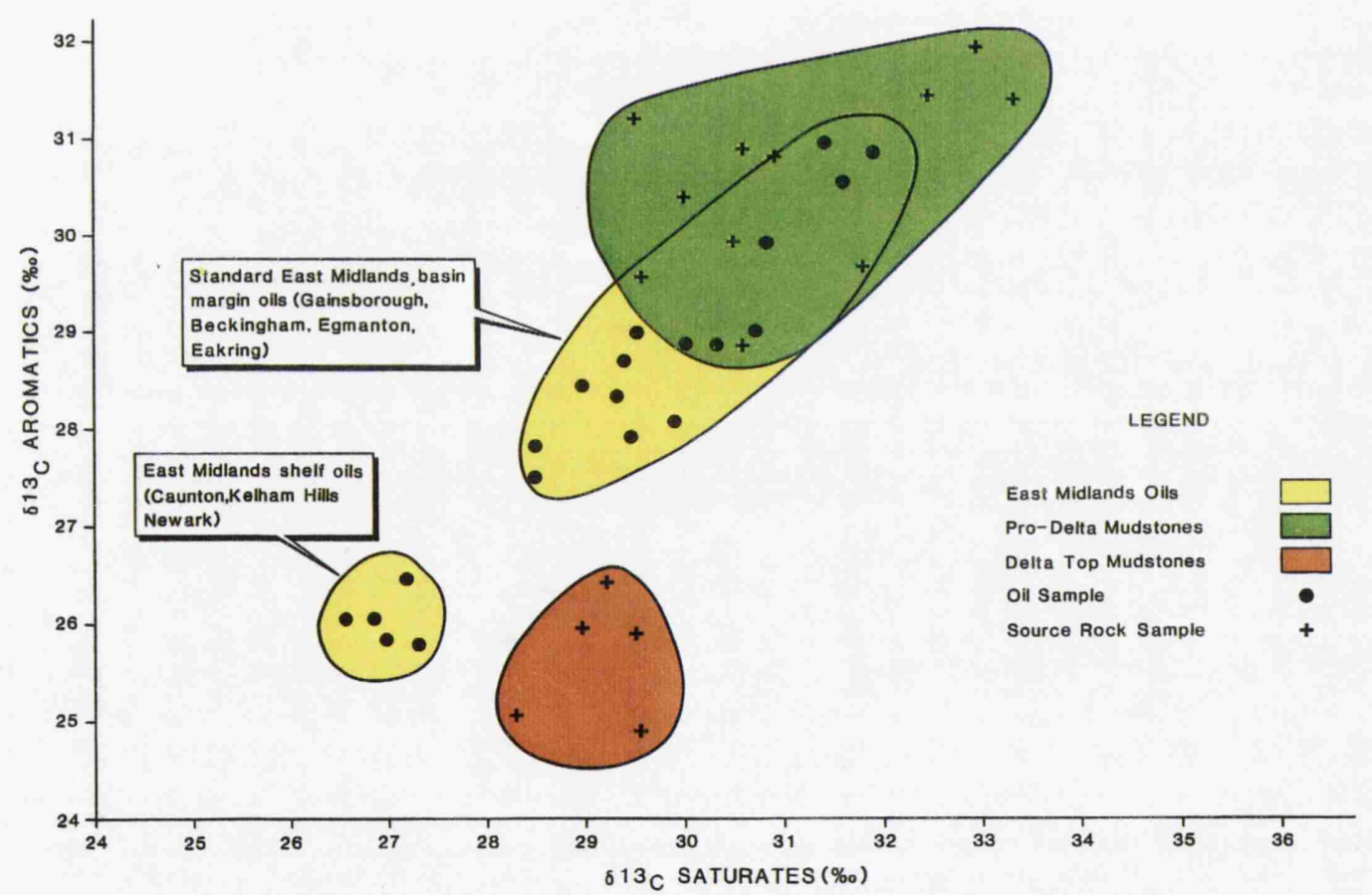

Figure 5.22. Oil/source rock correlation based on carbon isotope analyses of East Midlands source rock and oil samples. 
However, alternative source facies have been identified, notably in delta top environments, where marine bands, coals and interdistributary mudstones can form local sourcing mechanisms (e.g., Caunton \& Kelham Hills Fields, Fig. 5.22). None of these are regarded as having significantly contributed to the hydrocarbon budget in the East Midlands; however, all are areally extensive and in the case of the marine bands, locally give high yields (7-10 kg tonne-1 is not unusual). Coals in the late Namurian and Westphalian are ubiquitous and rich but largely gas prone and requiring significant burial. Offshore in the Southern North Sea Basin, where deeply buried by thick Mesozoic cover, similar coals are the source for some 2 trillion cubic feet of gas reserves.

Oil Characteristics. The characteristics of the different East Midlands oils and source rocks are illustrated on saturates against aromatic residue plots for some 20 sample points in the East Midlands (Fig. 5.22). The oils can be grouped into two main types based on their carbon isotope values. Typical East Midlands crudes reservoired on the margins of the major basinal areas form the largest group. These oils are principally sourced from the distal pro-delta 'Gamma-active' shales. An isotopically heavier suite of oils occurring more distally from the basinal areas (Kelham and Caunton fields) reflect increased contributions from marine bands, interdistributary mudstones and coals. Oil quality is not regarded as a critical factor, except for the occasional occurrence of sour crudes (Welton) and wax contents which tend to be high (10-20\%) due to the contribution from cuticular wax from land plants.

\subsubsection{Source rock distribution summary}

In general terms the source rocks in northern England young southwards in step with the southward progradation of the clastic delta systems throughout the Carboniferous (Fig. 5.23 \& Plate 5.4). This is consistent with biomarker and isotope studies which clearly 
indicate a mixed marine/terrestrial derived kerogen content. The most likely explanation for the relationship between the deltas and the source facies is one involving the introduction of fresh water from the delta top to the isolated fault bounded half-graben causing stratification of the waters and resultant regional anoxia below the pycnocline. The depositional environment and hence source rock development were influenced by changes in the salinity, nutrient supply and degree of anoxicity within the individual basinal areas.
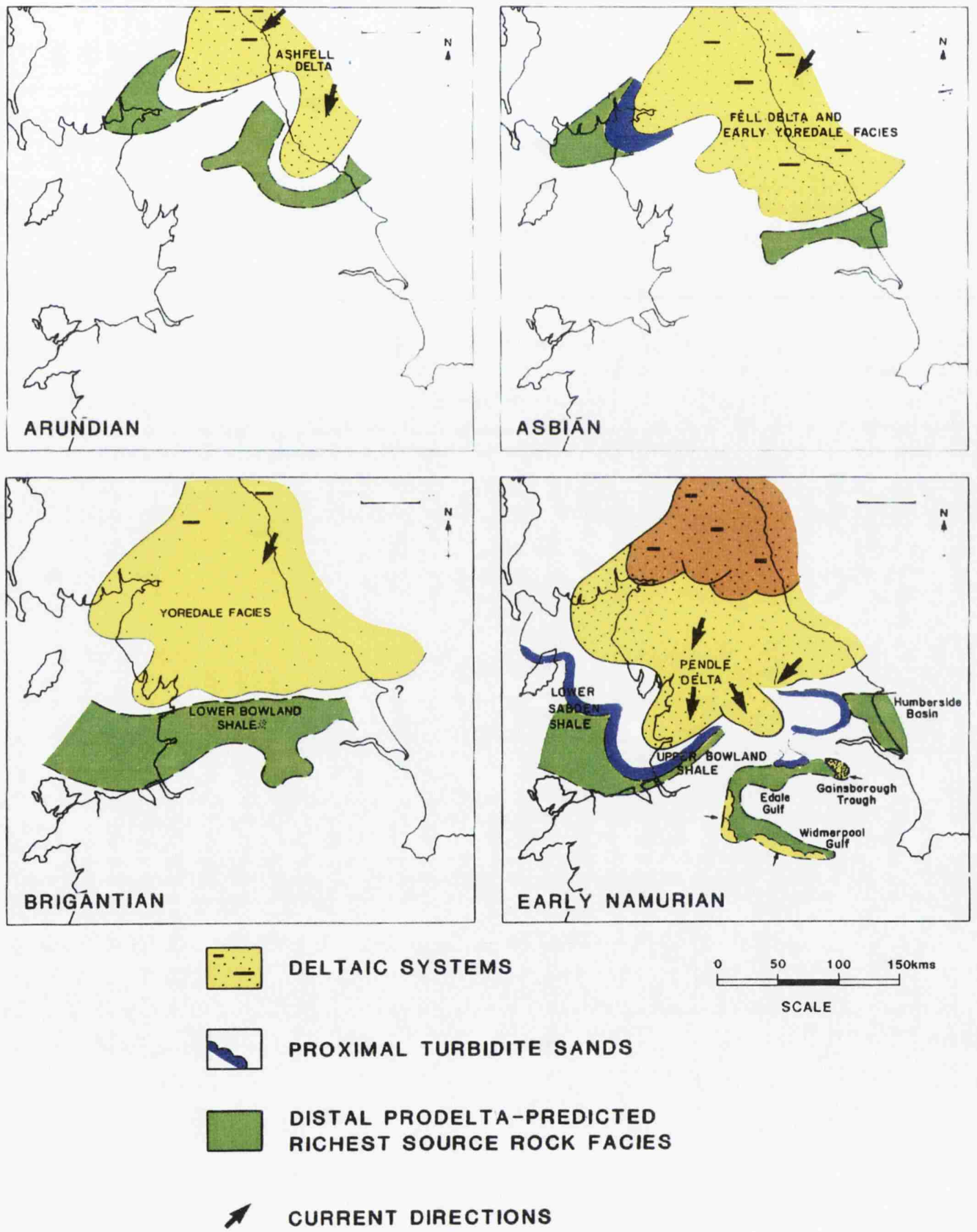

Figure 5.23. Delta advance during the middle to late syn-rift and early post-rift and its relationship with source rock distribution and age in northem England. 
The best quality oil prone source rocks were deposited in the central England rift basins in the south of the study area. These source rocks are associated with the distal pro-delta of relatively deep water (200-300 m) delta systems and correspond to the Bowland, Edale and Sabden shales and equivalents (Fig. 5.24). These exhibit gross thicknesses of around $100 \mathrm{~m}$ with yields of up to $14 \mathrm{~kg}$ tonne-1. Shallower water deltas $(50-150 \mathrm{~m})$ which were established in basins such as Northumberland, Solway and Stainmore during the early Carboniferous are characterised by thinner, poorer quality source rock intervals (Plate 5.4).

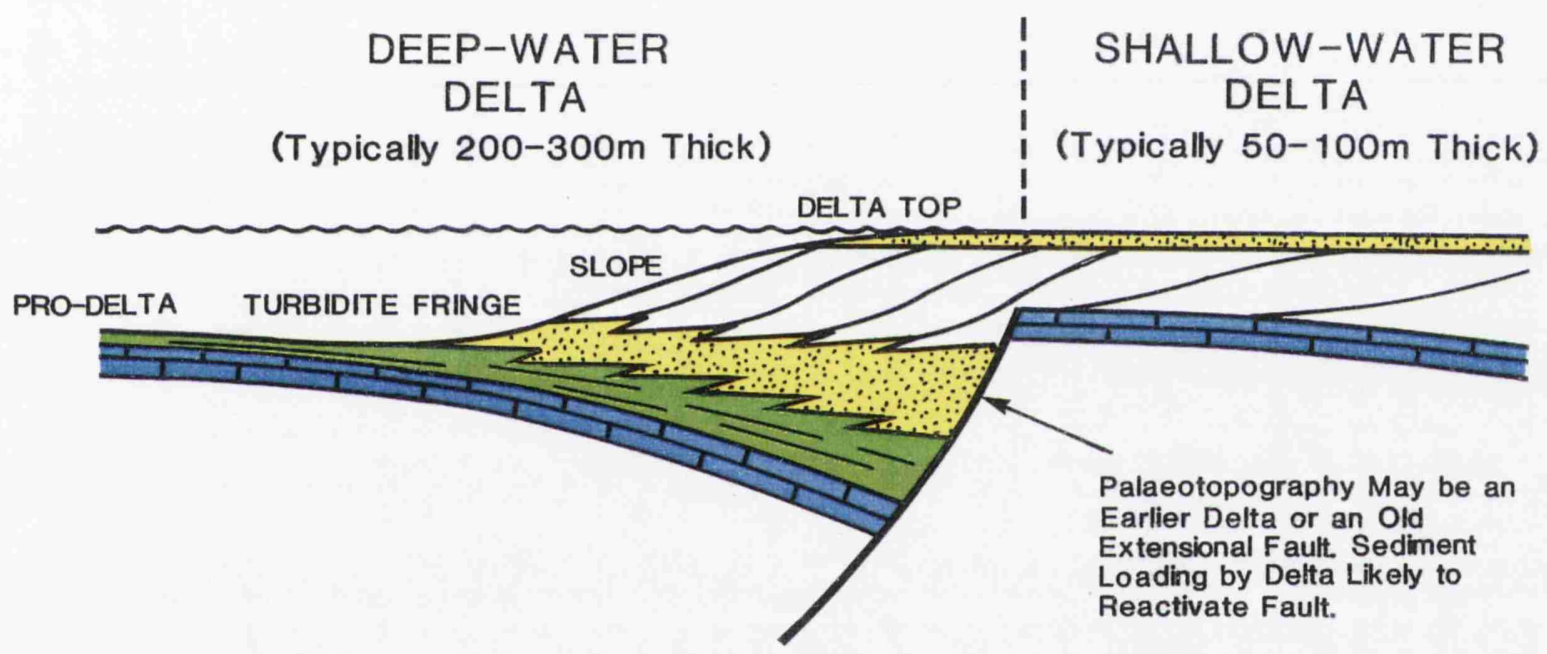

Figure 5.24. Model for the evolution of the late Dinantian-Namurian deep water deltas in the rift basins in the south of the study area from the shallow water systems in the north.

In climatic terms the best source rocks occur around times of transition from semi-arid to humid and vice-versa. During the Carboniferous, northern England drifted northwards as part of Pangea from southern equatorial latitudes to around $20^{\circ} \mathrm{N}$. The climate at the outset appears to have been at least semi-arid as indicated by the Courceyan evaporites from Derbyshire and minor anhydrites and evaporite pseudomorphs throughout northern 
England. By the end of the Dinantian humid, possibly monsoonal, conditions are suggested by palaeolatitudes and the development of large scale fluvial systems. This is significantly the period of best source rock development in northern England. Continued northwards drift of Pangea during the late Carboniferous re-introduced semi-arid conditions in the late Westphalian.

The 'factory' which supplied organic matter to the distal pro-delta was the upper delta plain coal swamps. Within these delta top swamps, the accumulating carbohydrate and lignins were reduced to the vitrinite precursor huminite under wet conditions and oxidised to inertinite under drier conditions. Lipid components were relatively stable. If water tables were consistently low on the delta top (ie. during arid conditions) oxidation was likely to destroy the organic matter. This explanation elegantly accounts for the concentration of good quality source rocks deposited during the humid conditions which prevailed around the Dinantian-Namurian boundary.

The main points relating to Carboniferous source rock analysis are outlined below:

i. The richest source rocks are distal pro-delta facies which contain a high proportion of terrigenous plant material. These generally accumulated in the basinal areas.

ii. The source facies young southward reflecting the southward progradation of major clastic delta systems.

iii. Both oil and gas prone source rocks are recorded. The gas prone sources tend to be associated with more oxic delta front and delta top environments.

iv. Some oil prone source potential has been recorded from coals deposited in delta top swamp conditions. 


\subsection{TECTONO-SEDIMENTARY CONTROLS ON THE HYDROCARBON HABITAT}

The major tectonic controls on the hydrocarbon distribution in the Carboniferous of northern England are discussed in terms of trap formation and source rock burial history. The analysis of play fairway development considers the more subtle controls exerted by tectonic activity on the regional distribution of reservoir, source and seal facies.

\subsubsection{Trap Formation}

Each of the 36 oil and gas fields discovered to date in the Carboniferous of northern England display some component of Variscan deformation in their geometry. Taking the East Midlands as an example, it can be seen that the oil and gas fields show a close relationship with the major fault trends (Plate 1.4). Inspection of a depth converted regional seismic line across the province shows the major fields to lie in the hangingwalls of faults active during the Dinantian rift phase (Plate 3.2). Sub-regional seismic lines with depth conversions are presented for several of the key East Midlands fields to illustrate the structural style associated with the trapping geometry. For the location of the individual fields refer to Plate 1.4.

Beckingham/Gainsborough (Plate 3.6). The Beckingham/Gainsborough Field was discovered by BP in 1959 in a complexly faulted series of stacked reservoirs of Namurian and Westphalian age (sequences LC1c/LC2). Recoverable reserves from the field are assessed at 13 million barrels of oil plus an additional 6.5 billion cubic feet of associated gas. The complexly faulted anticlinal structure was apparently formed by inversion on a series of early syn-rift faults lying at depth within the Gainsborough Trough. Closure is complicated by the presence of shallow, listric faults which apparently sole out on Upper Dinantian basinal carbonates. 
Welton (Plate 3.8). Discovered in 1981, Welton is, to date, the largest hydrocarbon accumulation in northern England. Reserves are now assessed at well over 20 million barrels. Production is mainly from delta top channel sands within sequence $\mathrm{LClc}$ (Rothwell and Quinn 1987). Seismic shows the field to again result from Variscan compressional tectonics.

Eakring-Dukes Wood (Plate 3.9). The field occurs as a series of en-echelon inversion anticlines adjacent to the NNW-SSE trending Eakring-Foston fault (Storey \& Nash 1993). Ultimate recoverable reserves are assessed at 7 million barrels of oil, mainly reservoired in a stacked series of delta top channel and mouth bar sands of Namurian early Westphalian age (Sequence LC1c).

Egmanton (Plate 3.10). The Egmanton Field is an inversion anticline formed on a NWSE trending fault to the south of the Gainsborough Trough (Plate 1.4). The field was discovered in 1955 and recoverable reserves are assessed at 3.5 million barrels. The main component of trap formation was again the late Carboniferous, Variscan inversion, as evidenced by the strong subcrop to the base Permian unconformity (Plate 3.10). However, the suggestion on seismic of subcropping Dinantian events at the base of the LC1 sequence may indicate hangingwall uplift predating the main Variscan inversion event.

Calow (Plate 3.11). The Brimington anticline is perhaps the best example of a tight inversion fold in the East Midlands. The structure is that of a ramp anticline formed on a shallow detachment within the Dinantian. The Calow Field is a small gas accumulation ( 0.5 billion cubic feet) residing in channel and mouth bar sands in sequence LC1c. 


\subsubsection{Burial History and Hydrocarbon Generation}

The main hydrocarbon traps identified in the northern England Carboniferous are of Variscan origin having formed at the end of the Carboniferous. Therefore, it is imperative to determine whether hydrocarbon generation occurred during Carboniferous or Mesozoic burial. In order to achieve this aim, the burial history of the late Dinantianearly Namurian source rocks must be resolved and estimates made of the geothermal gradient (or heat flow) acting on the source rocks during burial. Hence, the timing and limits of generation can be determined and thus the distribution of maturity at base Namurian across the study area. Estimates of burial and heat flow history can be made with reference to the observed maturity data from borehole and outcrop samples.

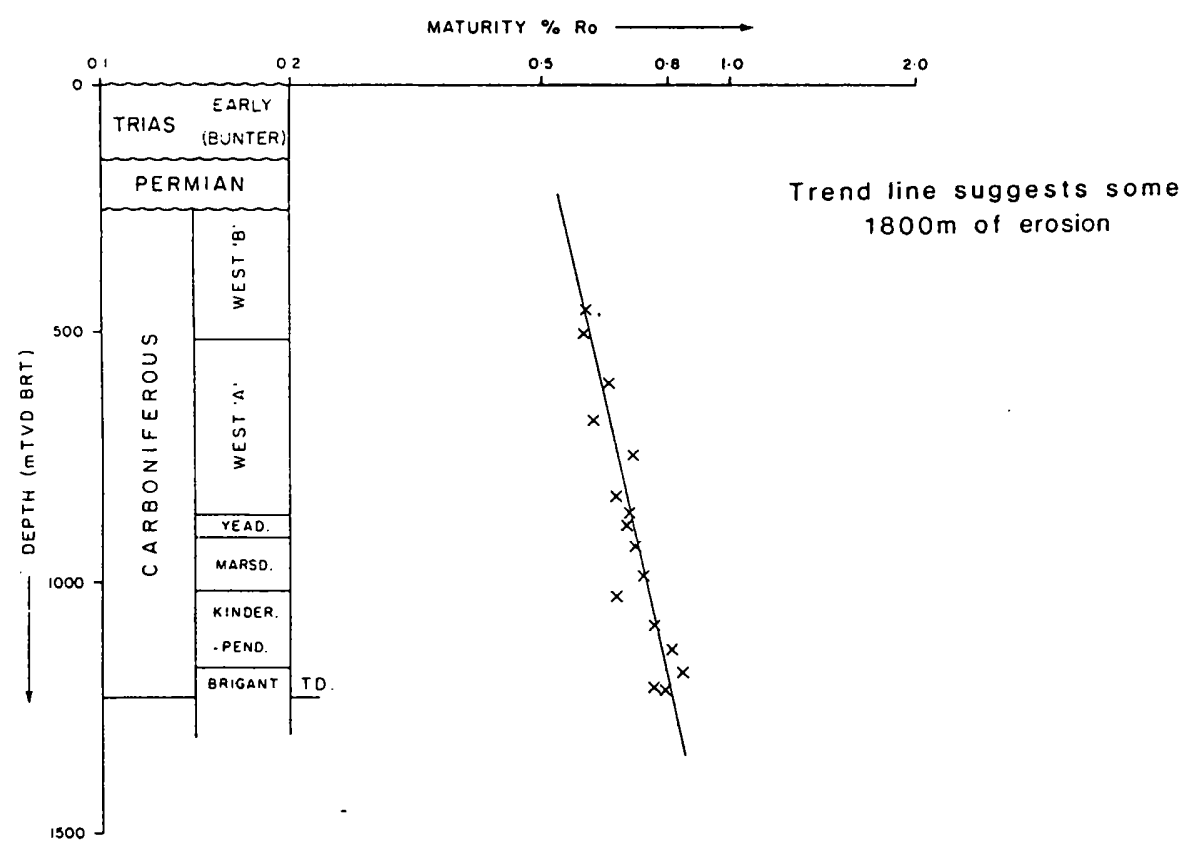

Figure 5.25. Maturity against depth profile for the Rufford-1 borehole in the East Midlands based on vitrinite reflectance data. 
Some 40 key wells with maturity data (i.e. vitrinite and spore colour) from the Central England rift basins have been analysed and compared to interpret maturity thresholds in late Dinantian-Silesian source rock facies. The maturity of basal Namurian/top Dinantian sediments based on vitrinite reflectance data across northern England is shown on Plate 5.3. Insufficient data exist for the late Devonian-early Dinantian sequences in this area to draw any firm conclusions.

Over most of the East Midlands and Southern North Sea, maturity/depth trends based on vitrinite reflectance show little variation in gradient between the pre and post Variscan section suggesting that post-Carboniferous burial has overprinted any signature of end Carboniferous erosion. (Figs. 5.12, $5.13 \&$ 5.25).

In order to determine the post-Carboniferous burial history of the pro-delta source rocks the following methods have been employed;

i) extrapolation of vitrinite reflectance data

ii) shale velocity curves

iii) isopach extrapolation from well data

Vitrinite reflectance method. At surface, vitrinite has a reflectance of about $0.2 \%$ Ro. Therefore, under continuous sedimentation there should be a straight line relationship between increasing depth of burial and log reflectivity, with the origin at zero depth and $0.2 \%$ Ro. The gradient of the trend line depends on the overall heat flow acting through the sediment pile during burial and the rate of burial. The accuracy of this method depends mainly on the confidence of the trend line and therefore the quality of the data. The error associated with the trends for the northern England Carboniferous is estimated at about 200 metres in every 1000 metres. 
In northern England there have been two major phases of uplift; late Carboniferous and late Cretaceous. Over much of the East Midlands province the degree of uplift during the late Carboniferous was not excessive with estimates varying from c. 200 metres in the Gainsborough Trough and Welbeck Low to between 600 and 1500 metres in the Widmerpool Gulf (Plate 2.11). Estimates of Tertiary uplift are generally much greater. Extrapolation of the late Carboniferous vitrinite data back through the present day unconformity to intersect the $0.2 \%$ Ro line for the Bardney-1 borehole suggests that some 900 metres of erosion has occurred (Fig 5.12). A similar plot for the Rufford-1 borehole some $50 \mathrm{~km}$ to the west, suggests 1800 metres of uplift and erosion (Fig. $5.25)$.

The shale velocity curve method. The method of determining the degree of uplift and erosion from shale velocity curves has been described by Marie (1975) for the Lower Bunter Shales section (late Permian) of the Southern North Sea. The principle involved relies on the observed increase in sonic velocity through shales with increasing depth of burial. This method has been applied to the Permian lower Bunter shale and the Triassic Mercia Mudstone for some 12 boreholes in the East Midlands (Fig. 5.26). The accuracy of this method is heavily reliant on how the average interval transit time is picked from sonic logs over the relevant section and errors of up to $+/-300$ m may occur.

The plot suggests similar amounts of Tertiary uplift to those derived from vitrinite reflectance data. It also highlights the increasing degree of Tertiary uplift and erosion from east to west across the East Midlands.

Reconstructed isopach maps. The two methods described above have provided an estimate of the variation in total Tertiary uplift across the study area. By using this data and the available stratigraphic data from boreholes throughout northern England it is possible to reconstruct restored isopachs for the post Variscan section (Plate 2.12). 


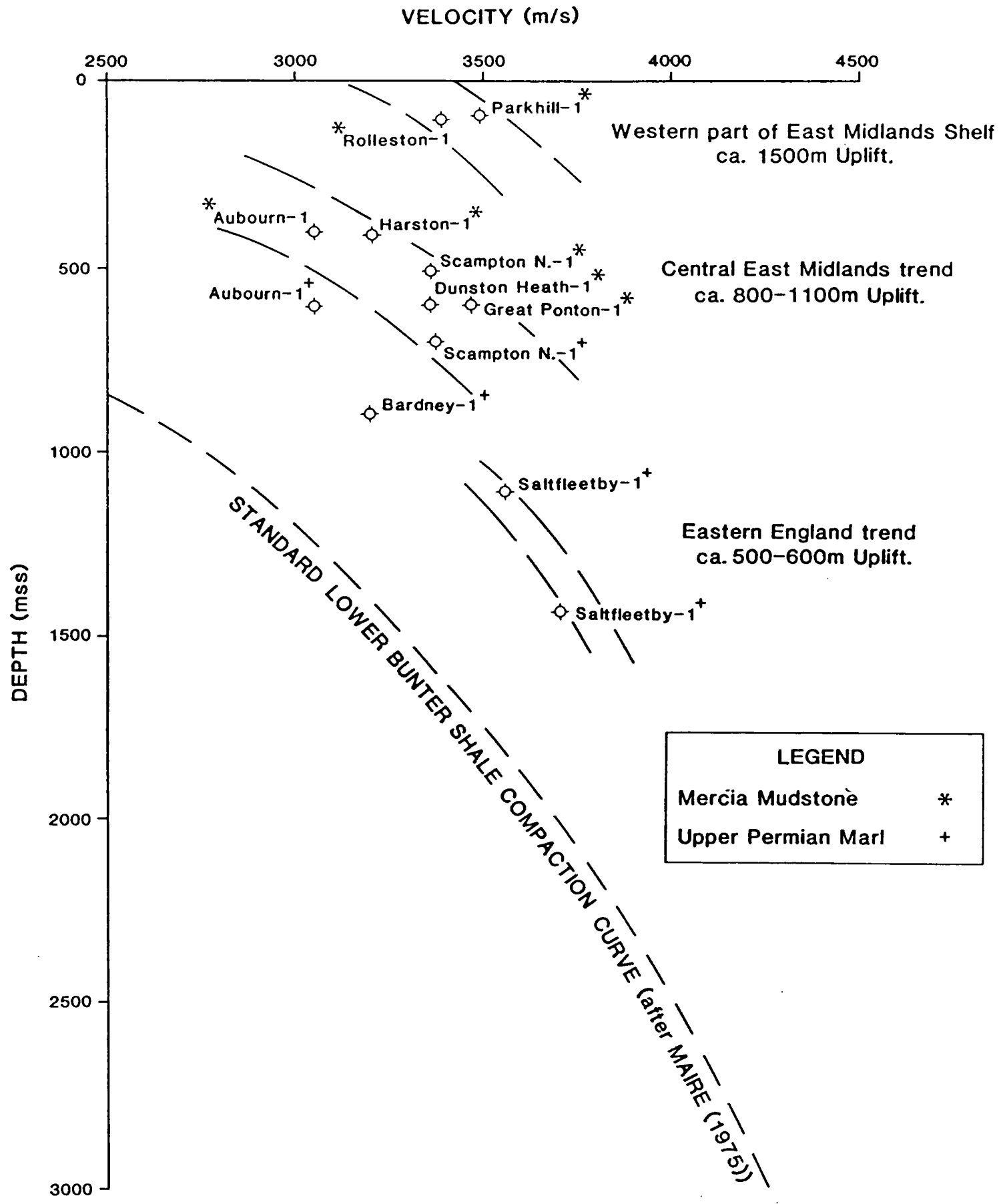

Figure 5.26. Plot of Lower Bunter Shale and Mercia Mudstone velocities from boreholes in the East Midlands against the standard Lower Bunter Shale compaction curve presented by Marie (1975). 
Geothermal gradients and heat flow. Basal heat flow and the resulting temperature gradient through the sediment pile during burial is the major factor controlling the maturation of Carboniferous source rocks. The rate of maturation of any source rock can be closely compared to the reaction rate equation proposed by Arrhenius ie;

$$
\mathrm{K}=\mathrm{Ae}-\mathrm{E}-\mathrm{ERT}
$$

where $\mathrm{K}=$ reaction rate, $\mathrm{T}=$ absolute temperature, $\mathrm{A}=$ the frequency factor, $\mathrm{E}=$ the activation energy and $R=$ the universal gas constant (Tissot and Welte 1984). The reaction rate is therefore strongly controlled by temperature and to a lesser extent by time.

The 'THETA' thermal modelling programme uses the parameter $\mathrm{P}$ as an indicator of the thermal maturity of a source rock. Its derivation closely approximates the Arrhenius equation (Appendix D).

Leeder and McMahon (1988) estimate the geothermal gradient acting on the sediment pile during the Carboniferous was in the order of $40-50^{\circ} \mathrm{C} / \mathrm{km}$ falling to some $30^{\circ} \mathrm{C} / \mathrm{km}$ during the Mesozoic. This seems reasonable given that the present day geothermal gradient over the major part of the study area is about $25-35^{\circ} \mathrm{C} / \mathrm{km}$ (Wheildon \& Rollin 1986) and that during the early Carboniferous major rifting and crustal extension was occurring producing a high heat flow from the crust into the sediment pile. Recent work by Green (1989) using Apatite Fission Track analysis also suggests that the palaeogeothermal gradient during the Mesozoic would have been between $20-35^{\circ} \mathrm{C} / \mathrm{km}$.

By applying these estimates of geothermal gradient to those of Carboniferous and postCarboniferous burial then estimates of the average heating rate can be made. These data can now be incorporated into the 'THETA' modelling programme to provide a more detailed breakdown of the exact timing of generation. A modelled subsidence history curve and source rock maturity timing plot is presented for the Rufford-1 borehole in the 
East Midlands (Fig. 5.27). The subsidence history has been estimated from the rate of sedimentation and the relevant lithofacies. The heat flow variation through time is applied using the McKenzie (1981) stretching curve. Superimposed on the time/depth burial curves are the calculated maturities and the change in maturity through time dependent on the variation in heat flow, depth of burial and thermal conductivity of the sediments.

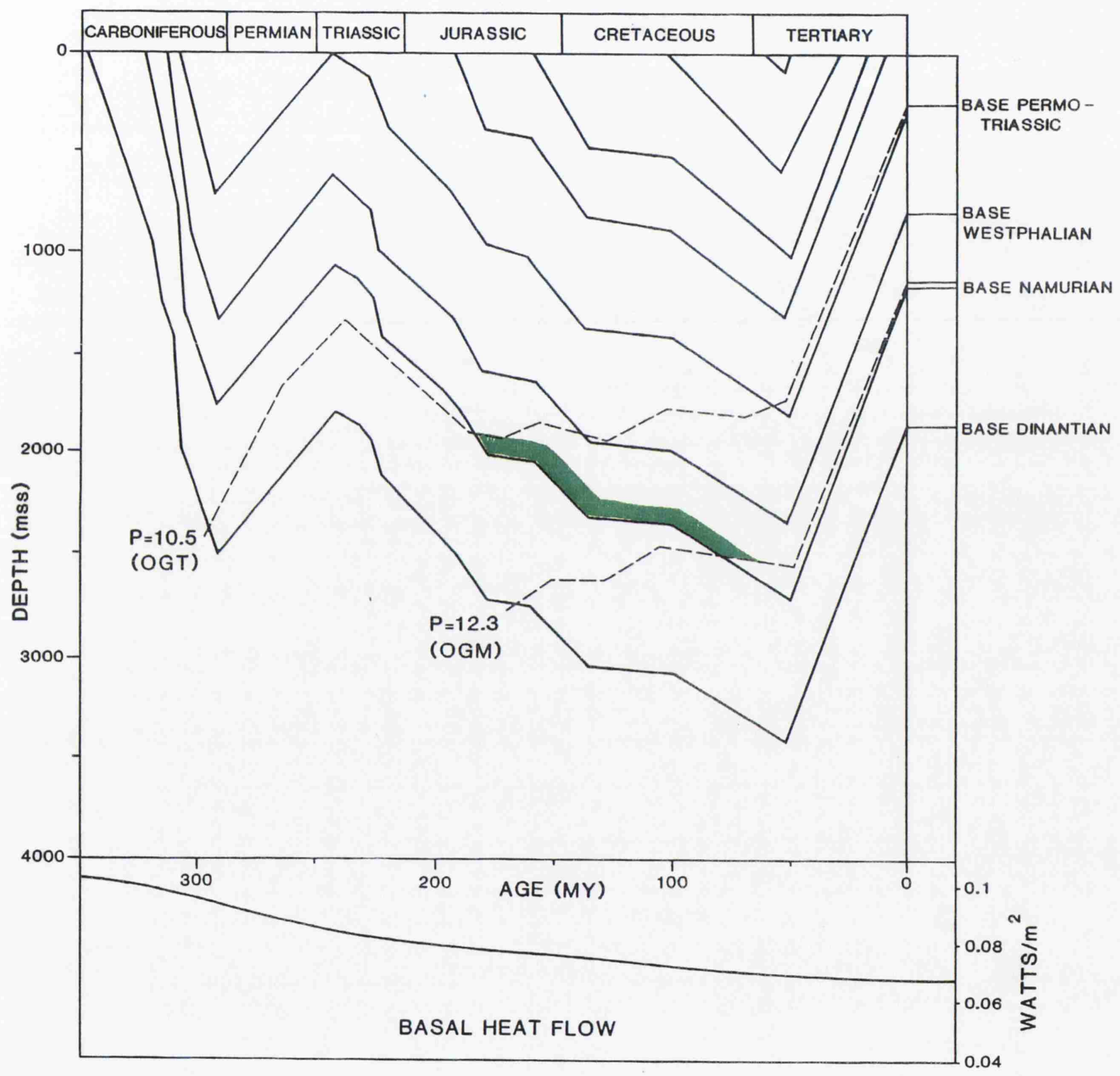

Figure 5.27. Subsidence history and source rock maturity for the Rufford-1 borehole in the East Midlands modelled using the 'THETA' programme (see Appendix D). Thermal maturity parameters indicate that oil generation commenced in the early Jurassic, peaking in the late Cretaceous. 
The oil generation threshold, corresponding to a maturity parameter $(\mathrm{P})$ value of 10.5 , was attained at Rufford during the early Jurassic with peak generation $(\mathrm{P}=12.3)$ occuring in the late Cretaceous. This result and the base and top Namurian value for $\mathrm{P}$ equates very closely with the observed vitrinite reflectance trend from the well (Fig. 5.25).

This modelling has been used to estimate maturity thresholds for oil and gas generation throughout northern England. Approximate figures used for the top and base of the oil window are $1900 \mathrm{~m}$ and $3600 \mathrm{~m}$ with a maximum at around $2700 \mathrm{~m}+/-200 \mathrm{~m}$. The gas generation maximum is assessed at around $3450 \mathrm{~m}+/-200 \mathrm{~m}$.

The presence of vein mineralisation in several areas may indicate that potential source rocks have been 'over cooked' with respect to the above analysis (eg. S. Isle of Man and Alston-Askrigg-Stainmore). Anomalously high local geothermal gradients during the late Carboniferous-early Permian (up to $100^{\circ} \mathrm{C} / \mathrm{km}$ ) are indicated by metallic sulphide $\left(80-150^{\circ} \mathrm{C}\right)$ and quartz-vein $\left(200-300^{\circ} \mathrm{C}\right)$ mineralisation. Locally, high heat flow also occurred in the Derbyshire Dome and Bowland Basin areas associated with $\mathrm{Pb}-\mathrm{Zn}-\mathrm{Cu}-\mathrm{F}-$ Ba hydrothermal mineralisation.

Persistent subsidence of basinal areas during the Dinantian enabled thick sediment accumulation. By the end of the Dinantian, basal Dinantian sediments may have already attained the oil generation threshold, as indicated by Visean isopachs (Plate 2.9). The Visean deposition was controlled by extensional, rift tectonics. The half-graben basins persisted into the Silesian as loci for sedimentation, but restored isopachs for Namurian and Westphalian A/B sediments (Plate 2.10) suggest a dominant thermal subsidence control, with northern 'block' areas apparently buoyed-up by granitic plutons. The thickest Silesian developed in the Lancashire shelf coalfield area as the Namurian delta systems infilled the last remaining starved Dinantian basins. 
Towards the end of the Westphalian, local unconformities occurred heralding the onset of the Variscan inversion. This effectively 'froze' the maturation of Carboniferous source rocks and in order to realise their potential a second stage of burial was required to charge the large number of traps formed during the late Carboniferous-early Permian Variscan event.

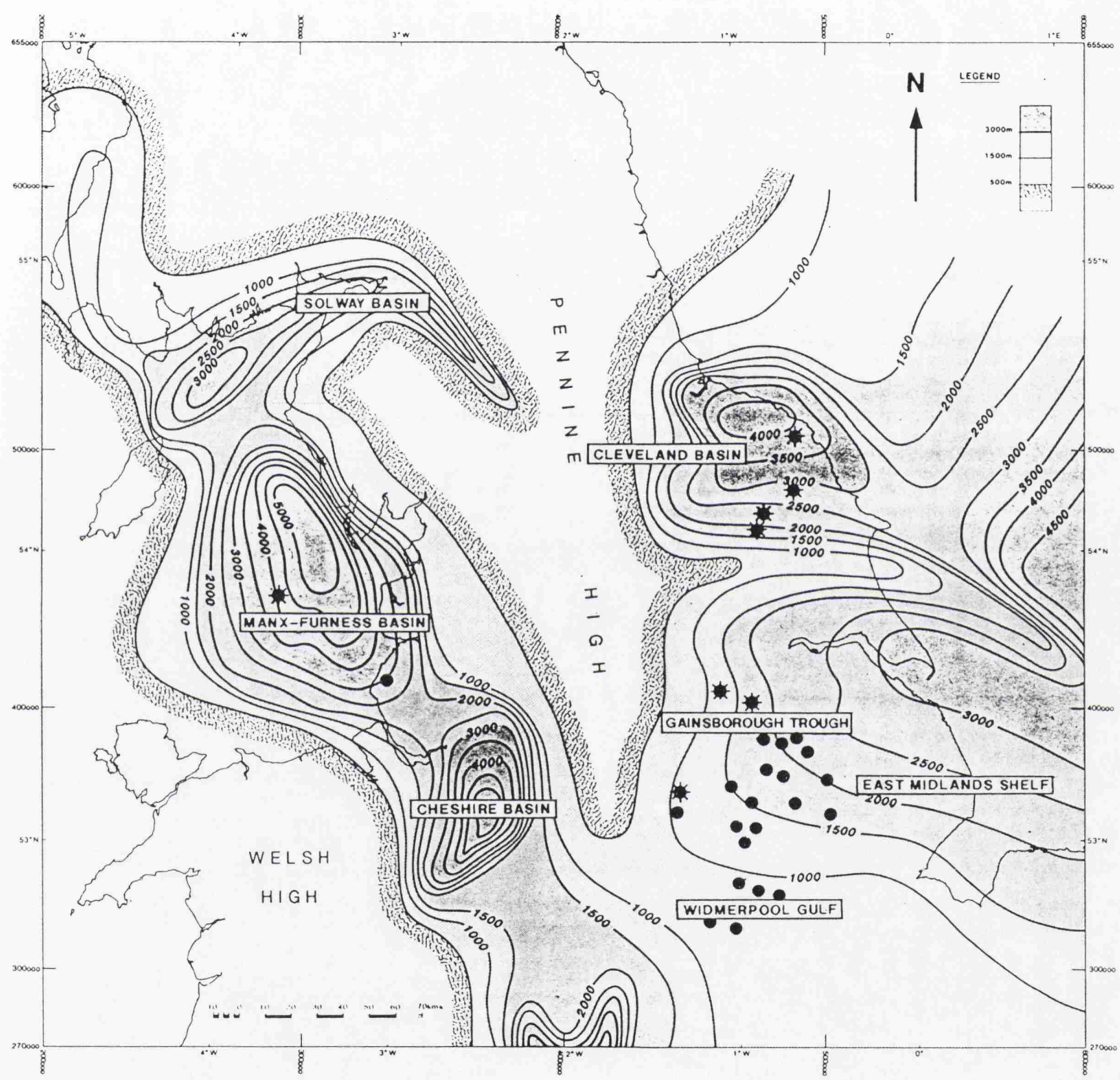

Figure 5.28. Restored post-Carboniferous isopachs in metres and the location of the major hydrocarbon discoveries in northern England. Data from a number of sources including Whittaker (1985) and vitrinite/fission track studies. Note that gas is the main hydrocarbon phase in regions subject to over $3000 \mathrm{~m}$ of post Carboniferous burial and the East Midlands oilfields are concentrated in an area of moderate burial. There are no hydrocarbon discoveries along the axis of the Pennine high where Mesozoic burial has been negligible. 
Subsidence associated with Permo-Triassic, Liassic and late Jurassic/early Cretaceous rifting enabled further maturation of Carboniferous source rocks. In the deepest parts of the superimposed rift systems (Fig. 5.28) there are offshore gas fields; Morecambe Bay, in the Manx-Furness Basin and Amethyst, Rough and West Sole in the Southern North Sea. Recent gas discoveries eg. Kirby Misperton, show the high maturity attained by Carboniferous source rocks in the Cleveland Basin. Moderate sedimentary cover across the East Midlands enabled oil generation from early Namurian pro-delta shales in the Gainsborough-Widmerpool-Edale basins.

Burial of the Dinantian-Lower Namurian source rocks during the late Carboniferous will have matured sediments in certain areas up to and beyond the oil generation threshold prior to the Variscan orogeny (late Carboniferous-early Permian). The identification of these regions is based on restored isopachs, regional maturity data, the results of limited fission track data (Green 1986 \& 1989) and geothermal modelling.

\subsubsection{Late Carboniferous Generation}

Generation and migration of hydrocarbons during the late Carboniferous is considered to have taken place in the following areas:

Northumberland-Solway Basin, Alston Block. Structural/maturity profiles in the Northumberland and Alston Block areas demonstrate that most, if not all, of the observed maturity was developed during the Carboniferous. Restored isopachs of the Dinantian and Silesian sediments in these areas also point to early generation in the Solway Basin.

Manx-Furness (including Formby-Fylde), Bowland and Cheshire. This area is isolated from the Northumberland-Solway Basin by the Manx-Cumbrian ridge, which remained as a high with little sedimentation throughout the Carboniferous. High maturities in the 
Irish Sea coupled with substantial maturity changes across the Pendle Monocline, high maturity gradients in boreholes such as Boulsworth-1 and fission track analyses in the Formby-Fylde area (Lewis et al. 1992), point to early generation of hydrocarbons. Over a substantial part of this area, the only phase of hydrocarbon generation occurred during the Carboniferous, Mesozoic burial not being sufficient to approach the maximum temperatures attained during earlier burial. The notable exceptions to this are the northern part of the Cheshire Basin and parts of the Manx-Furness basin.

Central Pennines, Derbyshire Dome, East Midlands and Humber Basin. These areas were very much on the limit of Carboniferous generation. Maturities were much lower and the quantity of hydrocarbons generated during the Carboniferous would have been considerably less than in the areas described above. The boundary of the zone where hydrocarbons were generated during the Carboniferous roughly corresponds to the present day outcrop of the Permian with important extensions into the Widmerpool Gulf and Gainsborough Trough. The Humber basin, if present, would have represented an isolated pocket of Carboniferous generation quantitatively insignificant on a regional scale.

Cleveland Basin. Limited geothermal modelling has suggested that most of the oil potential of the source rocks present within this area would have been realised by end Carboniferous. The exception may have been the southern margin of the basin, adjacent to the Barton Fault.

\subsubsection{Mesozoic Generation}

As discussed earlier, the main trap forming event in northern England was the late Carboniferous-early Permian Variscan orogeny which created inversion anticlines in the hangingwalls of the major half graben border faults. The considerable uplift and erosion which resulted from this event led to the effective 'freezing' of source rock generation 
and migration. Therefore, Mesozoic burial leading to renewed generation from the source rocks, post dating this trap forming event, is critical to the success of northern England as a hydrocarbon province. Several key areas of Mesozoic hydrocarbon generation have been identified (Plate 5.5).

East Midlands. The dominant phase of generation in the East Midlands province occurred during Mesozoic times (Fig.5.28). This has been confirmed by recent burial studies (eg. Green 1989). Restored, pre-Tertiary uplift maps indicate that the basal Namurian pro-delta shales would have been generating liquid hydrocarbons over most of the area by late Cretaceous times. Gas generation is likely to have been short lived and restricted to the deeper parts of the Gainsborough Trough and Widmerpool Gulf. All hydrocarbon generation was 'frozen' in the Tertiary by an estimated 200-1800 metres of regional uplift and erosion. A degree of remigration of hydrocarbons took place in the late Tertiary as a result of a regional eastwards tilting of the basin by about $2^{\circ}$ towards the Southern North Sea Basin (Fraser et al. 1990).

Humber Basin. Oil generation may have occurred to a minor extent in this area during the late Carboniferous. Regional isopach and maturity studies suggest that if the Humber basin is present, significant oil generation would have commenced in the late Jurassicearly Cretaceous. Gas generation would only be important in the offshore continuation of the basin into the Southern North Sea (Fig. 5.28).

Cleveland Basin. The Cleveland basin is characterised by superimposed Carboniferous and late Jurassic-Cretaceous rift systems. The Carboniferous rift event formed the 'kitchens' for the deposition of the source facies. Late Jurassic-early Cretaceous extension matured the sediments through the oil window and into the gas zone by the mid-Cretaceous. Generation peaked during the late Cretaceous and ceased during Oligocene basin inversion. Estimates of Tertiary uplift from vitrinite and shale velocity 
studies range from 1800 metres in the south of the basin to over 3000 metres in the north.

Manx-Furness. The important part of the burial in this area is related to the rapid subsidence of the basin during Permo-Triassic extension. The onset of oil generation is taken as the mid Triassic, with peak oil generation by the late Triassic and gas generation occurring from mid-late Jurassic through to the early Tertiary. This important phase of Mesozoic generation sourced the Morecambe gas field (5 trillion cubic feet reserves) in the offshore part of the basin (Ebbern 1981). This phase of generation was 'frozen' during the early Tertiary by up to $2 \mathrm{~km}$ of uplift and erosion (Lewis et al. 1992) probably related to rifting between Europe and Greenland.

Cheshire Basin. An important area of implied Mesozoic maturation and generation occurs in the Cheshire basin. Most of the subsidence in this area is of Permo-Triassic age with further passive infill of the basin in the Jurassic and Cretaceous. The excessive Mesozoic burial suggests that gas is the only hydrocarbon phase likely to be encountered in the basin. However, the absence of a regional evaporite seal is likely to preclude the existence of large gas accumulations. This area was also affected by considerable uplift and erosion (c.1000 metres) in the Tertiary.

Solway Basin Burial studies around the Lake District (Green 1986 \& Lewis et al. 1992) and isopach mapping (Plate 2.12) suggest that this basin attained maximum generation during the Mesozoic. The greater part of the subsidence in this area is related to PermoTriassic rifting. Onset of oil generation is thought to be in the late Triassic-early Jurassic with peak generation in the late Cretaceous. The basin has probably been subject to some 500 metres of late Tertiary uplift (Fraser et al. 1990).

Vitrinite reflectance and fission track data indicate that areas such as the central Pennines and the Northumberland and Stainmore Troughs reached maximum burial during the late 
Carboniferous. Significantly, this was prior to the trap forming Variscan inversion event; the only remnants of this earlier phase of generation being the widespread and well documented surface bitumen occurrences in the region (Lees \& Cox 1937).

\subsection{PLAYFAIRWAY ANALYSIS}

The sequence stratigraphic analysis of the Carboniferous described earlier represents a powerful tool with which to analyse the hydrocarbon system by constraining the regional distribution of reservoir, source and seal facies. This is used to develop a play fairway analysis for the Carboniferous. The initial phase in any such analysis is to define a number of play fairways based on some easily mapable parameter. Typically this is done on the basis of the regional distribution of a particular reservoir facies (eg. the Carbonate Margin play), however this need not always be the case; play fairways based on the regional extent of a source system or particular structural style are equally valid. Play fairway analysis is essentially an assessment of exploration risk at a basin scale. In the past the hydrocarbon industry has applied the concept of risk mainly on a prospect specific level. Extending this concept to the fairway level in frontier basins permits a focussing of exploration effort into the most prospective parts of the basin. In more mature areas, the technique can highlight new play fairways in under explored parts of the basin or equally provide an indication that the basin has very little remaining prospectivity and that it may be time to withdraw.

Plate 5.1 from Fraser et al. (1990) shows an idealised model of the potential Carboniferous plays recognised in northern England. The key elements of the model are elegantly displayed at outcrop in the Castleton area of Derbyshire (Fig. 3.34). The photo of the Edale Gulf shows the exhumed rimmed shelf margin of Asbian and Brigantian age on the right. The shelf margin shows depositional angles of up to $35^{\circ}$ (Broadhurst $\&$ Simpson 1967) and was probably situated over a major east-west trending basin 
boundary fault throwing to the north. The carbonates exhibit a grainstone texture with the major components being crinoid ossicles and brachiopod valves. Initial depositional porosity must have been significant, however late stage diagenesis has destroyed most of this. The margin is noted for the many Blue John (fluorspar) deposits located in the hillside in the foreground. It is believed that the distinctive blue/yellow banding in the Blue John results from the fluorspar being injected into a hydrocarbon bearing carbonate reservoir (Ford 1969). In the foreground of the photograph, forming the valley fill, are the distal pro-delta, organic rich Edale Shales. These are of early Namurian age and preceded the southward progradation of the main delta systems. These marine shales are considered to be the source for the hydrocarbons encountered along the shelf margin and most obviously at Windy Knoll (Fig. 4.3) to the west of the carbonate margin on the right of the photograph. The snow capped hills on the left of the photograph represent the delta top environments of the Kinderscout and Shale Grit delta systems following their advance in the late Namurian (see chapter 4). The deep water delta fill of the basin is poorly represented on the photo which was taken from Mam Tor (Fig. 3.36). This hill represents a coarsening up series of progressively shallower water turbidites which comprise the fill of the Edale Gulf. The continental clastics identified in the early syn-rift are rarely seen at outcrop and these are predicted to be present from borehole evidence elsewhere in the East Midlands.

In the offshore domain one further play system is present; the molasse/red bed sequence of the late Westphalian-Stephanian (Fig 5.29). As discussed earlier these sands were deposited primarily in intermontane troughs following the Variscan inversion and form the principal reservoirs in offshore Southern North Sea Carboniferous gas fields. However, due to poor preservation of this sequence below the base Permian unconformity in northern England, this play is not considered further in this analysis. 


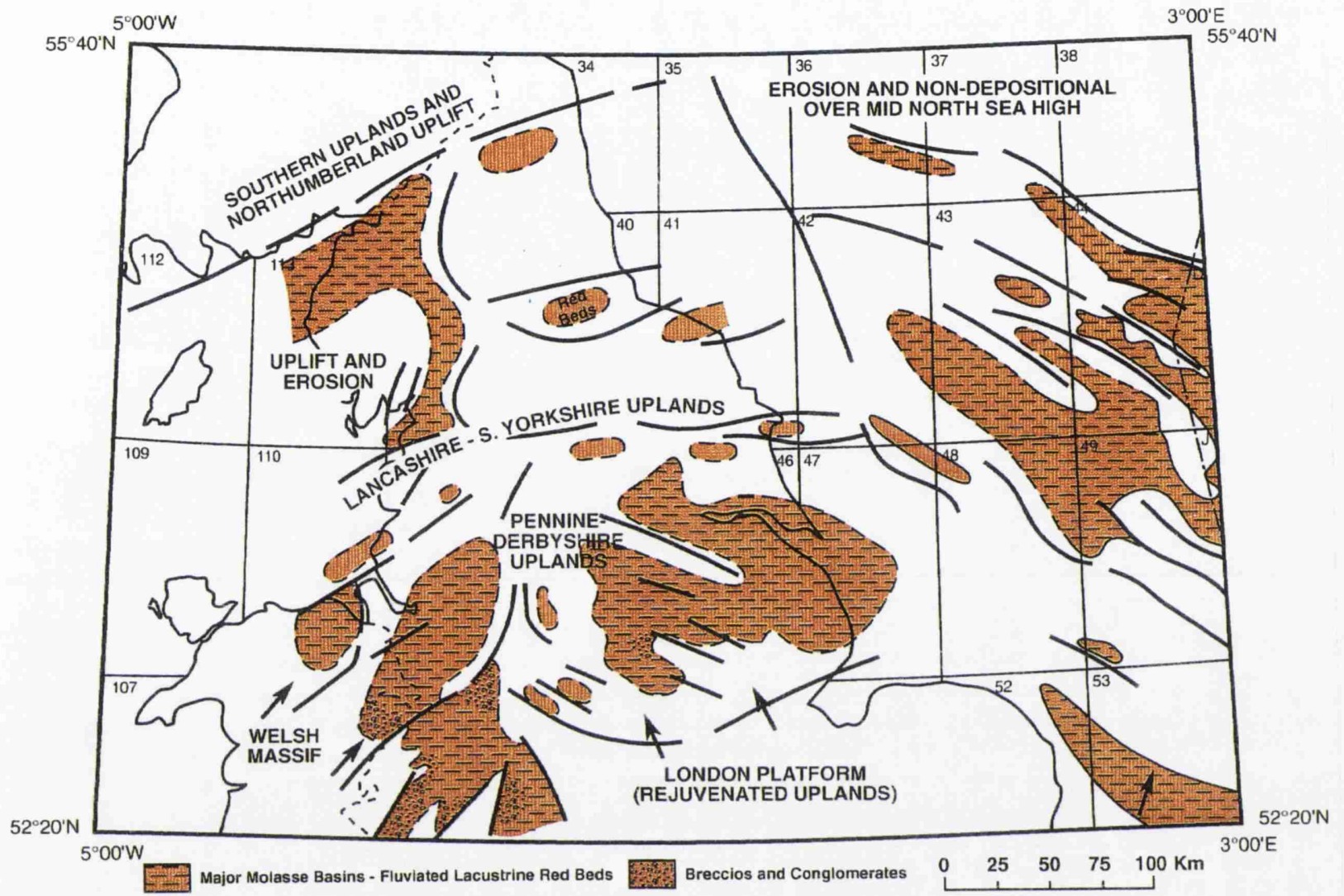

Figure 5.29. Schematic palaeogeography for the late Westphalian of northern England and the Southern North Sea. Onshore interpretation from borehole and seismic data, Wills (1951) and Besly (1988). Offshore data extracted from confidential oil company records.

\subsubsection{Syn-rift clastics (Plate 5.6)}

Late Devonian-Courceyan syn-rift fanglomerates and fluvial clastics of 'Old Red Sandstone' facies form a potential play in the rifted half-graben throughout northern England (Plate 5.6). Well data, for example Caldon Low (Institute of Geologicial Sciences 1978), and Hathern-1 (Falcon \& Kent 1960, Llewellyn \& Stabbins 1968, 1970) suggest that sands of this age should be sealed by overlying Courceyan evaporites 
associated with an early marine transgression into the basins. The early rifts may contain lacustrine source rocks such as have been tentatively identified in the Gun Hill-1 well in the Goyt Trough (Lees \& Tait 1945). In deep basinal settings, hydrocarbon prospectivity is reduced by the depth of burial of the reservoir facies and the consequent overmaturity of source rock facies.

The key to this play is the identification of the reservoir facies preserved in the footwall of syn-rift border faults where burial depths are minimal. The seismic example from the Widmerpool Gulf (Plate 3.2) shows the case in point, where a wedge of early syn-rift clastics (EC1) has been preserved on the footwall, apparently not affected by extensive post-rift burial and in juxtaposition with basal Namurian oil-prone source facies.

The most prospective areas for this play are interpreted as follows:

(i) Southern Margin Widmerpool Gulf.

(ii) Northern Margin Gainsborough Trough.

(iii) Margins of the Cleveland Basin.

The lack of reservoir development in this facies in the well Eakring-146 (hangingwall location) seriously downgrades the intra-basinal setting as a target for this play.

\subsubsection{Carbonate Shelf Margins (Plate 5.7)}

Outcrop studies in Derbyshire and the Bowland Basin have suggested that Dinantian carbonate reservoirs are most likely to be found in the regressive Chadian (EC2), Asbian (EC4) and Brigantian (EC6) sequences when rimmed shelves were developed around the margins of the major rifts. These grainstone margins are restricted to the central England rift system around half-graben such as the Widmerpool Gulf, Goyt Trough, Edale Gulf, Gainsborough Trough and Bowland Basin (Plate 5.7). 
The internal facies of the margins comprise carbonate shoals, mounds, peri-platform talus, debris flows and turbidites: all potential reservoir facies. Boulder beds were developed on the shelf margins at the end Chadian (EC3) and late Asbian (EC5), associated with slope instability caused by renewed extensional tectonic activity (Gawthorpe 1987a). These debris flows are seen at outcrop and in mineral exploration boreholes in the Bowland Basin, where they exhibit up to $30 \%$ secondary porosity where dolomitised and show minor bitumen stain and mineralisation.

The grainstone margins can also be identified in the subsurface on modern, high quality reflection seismic data (eg. Plate 3.2). The margins are characterised by a progradational sequence of laterally and vertically accreting clinoforms. These change character along the hangingwall dipslope into hummocky clinoforms and pass basinwards into a series of parallel reflections which are associated with distal calciturbidite sedimentary facies. The areal distribution of the carbonate margin play is thus limited to a 0.5 to $2 \mathrm{~km}$ wide fairway which rims the margins of the deeper half-graben (Plate 5.7). The narrowness of the play fairway highlights the need to identify the margins on seismic, since present well control is of insufficient density to map the extent of the rimmed shelves in the subsurface.

The key to this play is the presence of onlapping Upper Brigantian-Lower Namurian prodelta mudstones which provide both top seal and source. They should also contribute dolomitising and corrosive fluids on compaction to enhance porosities in the grainstones. The importance of this late stage dolomitising and leaching event cannot be stressed too strongly as field and core petrophysical studies have pointed to an early calcite cement virtually occluding all primary pore space (Walkden 1987). The arrival of the dolomitising and leaching fluids prior to both phases of hydrocarbon generation and migration in northern England is particularly timely. Similar dolomitisation fronts as precursors to hydrocarbon migration have been described from the Nisku reef province 
in Alberta. Evidence for this porosity enhancing event in northern England has been described by Gawthorpe (1987b) and Schofield and Adams (1985).

The reservoir quality of rimmed shelves can also be influenced by their degree of exposure to the prevailing winds. Windward facing margins are the turbulent sides of carbonate platforms and are winnowed free of fine sediment leaving a cleaner grainstone facies. Leeward margins represent lower energy conditions where wide belts of grainstone/packstone shoals can develop. In the late Dinantian, northern England was drifting northwards as part of European Pangea through equatorial zones making interpretation of palaeo wind directions very difficult. Evidence from the Derbyshire Dome (Schofield, 1984) has suggested that northern facing margins were windward at end Dinantian and hence should exhibit the better reservoir potential.

Success of this play requires lateral seal to be provided by the facies change from the high energy shelf margin grainstones into low poroperm peritidal micrites developed shorewards of the margin. Faulting of the margin against basal Namurian or Holkerian mudstone facies would also validate the play.

Mesozoic generation is perhaps not as critical for a stratigraphic play where late Carboniferous charge may have been preserved in the trap. However, areas where Mesozoic generation has additionally occurred, will carry a considerably reduced risk.

The most prospective areas for this play are therefore where Upper Dinantian-Lower Namurian source rocks, matured during the Mesozoic, directly onlap dolomitised Dinantian grainstone margins (Plate 5.10). These areas have been identified as follows;

(i) Widmerpool Gulf (northern margin) - seismic and outcrop data has highlighted the presence of Asbian/Brigantian hangingwall margins along the northern rim of the Widmerpool Gulf (Plate 3.4 \& Fig 3.30). 
(ii) Gainsborough Trough (north and south margins) - seismic and well data has confirmed the presence of grainstone margins of Asbian and Brigantian age in both footwall and hangingwall settings (Plate 3.6).

(iii) Edale Gulf - field and seismic evidence suggests the presence of well developed Asbian/Brigantian margins surrounding the Edale Gulf (Plate 3.12, Fig. 3.23). The Blue John deposits at Treak Cliff cavern (SK 135 831) near Castleton (southern footwall margin) are thought to have been injected into a hydrocarbon bearing margin of this type.

(iv) Manx-Furness Basin (including Formby-Fylde) - the presence of rimmed shelves developed to the north and south of the western Bowland Basin (ie. Manx-Furness) is inferred mainly from outcrop in the south of the Askrigg Block and boreholes such as Croxteth and Formby. Residual hydrocarbons were encountered in a BP Minerals borehole in this facies on the northern margin of the Bowland Basin (Fig. 3.27).

Other areas which may retain some potential are the Goyt Trough, Bowland Basin, Derbyshire Dome, Humber Basin and the margins of the Pennine-Leeds basins.

\subsubsection{Secondary Carbonate Plays}

\subsubsection{Waulsortian Mudmounds}

The facies which forms these deepwater mudmounds is tight porcelainous micrite displaying poor poroperm characteristics. However, marginal facies developed on the flanks of the build-ups do show some potential. Mound growth from the sea bed to heights of some 10 's to 100 's of metres encouraged the development of crinoid colonies on the surface of the mounds. The crinoids formed a carbonate 'factory' which on erosion by-passed the mound slopes to be deposited as crinoidal grainstones on the basinward margins of the mudmounds (Fig. 3.12). 
These features appear to have been prolific in shelf margin locations during the Chadian and this forms the main play fairway for this facies. Here basinal transgressive mudstones of Arundian age are relied upon to provide top seal with the low poroperm mudmound facies providing lateral seal. Source rocks are a major problem given the lack of potential source rock development in the overlying Arundian (see previous section).

Field evidence from the south of the Derbyshire Dome (Coalhills; Fig. 3.31) has shown that similar mud mound features were developed in the Brigantian. Here early vadose dissolution has formed cavities often lined with residual hydrocarbons and showing evidence of $\mathrm{Pb}-\mathrm{Zn}$ mineralisation (Fig. 3.32). Reservoir potential, if it exists, will be the flanking grainstone facies. These Brigantian features should be capped by overlying and onlapping Upper Brigantian/Lower Namurian organic rich shales to provide both seal and source.

Mounded "reef like" facies described previously from seismic and drilled as reef prospects are now considered to be Dinantian mudmounds e.g. Grove (Plate 3.2), North Willingham (Fig. 3.12) and Wessenden (Plate 3.12).

The mudmound play fairway is thought to be prospective in off shelf locations in the Widmerpool Gulf, Hathern Shelf, Edale Gulf, Gainsborough Trough and Humber Basin. The majority of these areas have had access to both Carboniferous and Mesozoic oil generation.

Parts of the Bowland Basin and Goyt Trough may still retain some potential but these areas rely solely on Carboniferous generation and were subject to large amounts of uplift in both the late Carboniferous-early Permian and Tertiary. 
As a result of the major source problem with Chadian build-ups, the Brigantian features are thought to be the more prospective.

\subsubsection{Chadian Grainstone Shoals}

Chadian grainstone shoals developed shelfwards of the mudmound facies and exhibit the best reservoir characteristics identified in the Dinantian carbonates of northern England. The best example comes from a BP Minerals borehole from the north of the Bowland Basin (Fig. 3.18). Similar facies can also be observed at outcrop in Bowland at Scrosthorpe Lane Quarry (Fig. 3.17) and were encountered, oil bearing, in Strelley-1 in the Widmerpool Gulf.

This facies was developed close to the Chadian shoreline perhaps around local highs. When dolomitised the grainstones are of reservoir quality with moderate to good visible porosity. Onlapping Arundian basinal mudstones and lateral facies changes into low poroperm peritidal carbonates should provide both top and lateral seal. Sourcing this intra-Dinantian play fairway is a major problem. However, fault juxtaposition with the Carbonate Margin play fairway in Strelley-l has proven to be an effective migration path from the basal Namurian shales (Plate 3.2).

The major problem with the Chadian grainstone play fairway is in predicting its presence. Outcrop and well data suggest a very restricted fairway both in terms of its shoreline location and its apparent reliance on the development of local highs (fault footwalls).

The best potential for developing the fairway will be in the Widmerpool and Gainsborough Troughs. The facies is not identifiable on seismic and strong emphasis will have to be placed on mapping facies-structural relationships around the basin margins. 


\subsubsection{Shelf Carbonates}

As already discussed in this thesis, the onshelf carbonates in the Dinantian display little primary porosity and patchy, unpredictable secondary porosity. When porosity is developed it is generally poorly located with respect to source rocks to receive a hydrocarbon charge. Nevertheless, the relatively high density of on-shelf drilling in the East Midlands has identified certain circumstances under which hydrocarbons can be reservoired and trapped in this facies.

Fractured shelf carbonates associated with Variscan folding have produced some 32,000 bbls of oil in Hardstoft in the East Midlands (Plate 5.10). Dolomitised limestones tend to be developed almost randomly within the shelf carbonate section and are therefore rarely in communication with basinal source facies. Data from the well Brimington-1 (Appendix A) indicates that some 2400 bbls of water per day were produced on test from Dinantian dolomites.

\subsubsection{Clastic delta systems (Plates 5.8 \& 5.9)}

\subsubsection{Description}

This play is by far the most important in the Carboniferous of northern England and contains the majority of the reserves discovered to date in the province (Plate 1.2).

Reservoirs are developed in both shallow water delta top and deep water environments

(Plate 5.8). Channel and mouth bar sands form the main producing reservoir facies associated with the delta top of the major southerly prograding Carboniferous delta systems, with the channel sands exhibiting the more favourable reservoir characteristics. Antecedent rift bathymetry exerted a significant control on the distribution of reservoir 
sands (eg. Fig. 5.9); with delta top and mouth bar reservoirs being best developed where they axially infill remnant rift bathymetry.

Turbidite sands derived from the main delta systems from the north and the WalesBrabant Massif in the south also form potential reservoirs in the pro-delta setting. However, these turbidite sands occur as thin bedded sheets separated by muds, rather than channels and are unlikely to have poroperm comparable to the channel and mouth bar facies on the delta top and will be considerably less predictable in the subsurface.

Additional important reservoirs are provided by southerly derived, quartzose fluvial sands which accumulated in channels incised into Dinantian carbonate platforms and abandoned delta plains during major lowstands, such as during the mid-late Brigantian (Plate 5.9). This play is particularly well developed in the late-Brigantian following the regional uplift and inversion event (Sequence LC1a). Oil bearing sands of this age have been encountered, in both Welton and Eakring/Dukes Wood. The Welton-A4 well flowed at a rate of $570 \mathrm{bbls}$ of oil per day from this interval. These sands are predictable on a regional scale in terms of the palaeotopography being controlled by the underlying structural grain (Plate 5.9). However, having identified the palaeo valleys, prediction of the location of the individual channels is problematical. At present these sands which can range up to 35 metres in thickness are seismically unresolvable.

Regional sealing facies on the delta top is provided by marine bands deposited during maximum flooding events. As discussed by Heckel (1990) the marine bands are likely to have been glacio-eustatically controlled. The thin marine bands which overstep delta top environments have been shown to be adequate seals for oil accumulations, but are unreliable for gas (eg. Calow example). In the pro-delta, shale rich environment, marine mudstones provide excellent seals for turbidite sandstone reservoirs. 
The richest hydrocarbon source rocks identified are interpreted as distal pro-delta mudstones which were deposited in advance of the southerly prograding delta systems (Fig. 5.23). In the East Midlands the pro-delta source rocks (Gamma-active shales) are well developed in the basinal areas but are poorly represented on the East Midlands shelf. The pro-delta source facies are predominantly oil prone. Biomarker studies and carbon isotope analyses clearly indicate a mixed marine/terrestrial derived kerogen.

Both the pro-delta and delta-top reservoir systems prograde across the distal pro-delta source rocks forming hydrocarbon migration pathways. Delta top coal swamps, developed regionally during the Westphalian (sequence LC2) over northern England and the Southern North Sea, provide gas and occasional oil prone source rocks which are likely to be in good communication with the delta top channel and mouth bar reservoirs.

\subsubsection{Assessment of the Clastic delta play in northern England}

\section{Summary of critical factors}

The critical factors which can be quantified and are amenable to an assessment of the Clastic delta play of northern England are:

(i) maximum burial depth for preservation of reservoir quality (c. $2550 \mathrm{~m}$ ).

(ii) critical burial depth range for the oil window $(1900-3600 \mathrm{~m})$.

(iii) distribution of good quality basinal pro-delta source rocks.

(iv) minor degree of post-Variscan trap modification.

Application of these risk elements to the clastic delta play allows the potential importance of the various northern England basins to be assessed and the 'uniqueness' of the East Midlands examined. 
Post-rift Carboniferous Events. Two key events critically affect the potential of the intraCarboniferous play at this time.

(i) Restricted distribution of basinal shales. The data from the East Midlands demonstrate the volumetric importance of the lower Namurian shales as source rocks and hence the necessity to have available the distal pro-delta shales within an effective kitchen. This generally limits the play fairway to within a few kilometres of the early Carboniferous depocentres. In the East Midlands the maximum horizontal migration distance from this source is $12 \mathrm{~km}$; the average is $5 \mathrm{~km}$. As discussed previously, source rock quality in the pro-delta varies across northern England with the central England rifts displaying the greater potential (Plate 5.4).

(ii) Location of the Silesian depocentre. As Plate 2.10 shows, the basinal shales located in the central Pennine Basin and the Northwest England province were probably mature and producing hydrocarbons during the late Carboniferous, thereby reducing oil potential in this area prior to Variscan trap formation. Dinantian and Lower Namurian reservoir quality would also have been adversely affected at this time.

End Carboniferous Variscan inversion. The Variscan inversion has been identified as the dominant trap-forming event in northern England. The uplift associated with the Variscan unfortunately also led to the 'freezing' of oil generation from source rocks throughout the province. The hydrocarbon system was essentially reset at this time necessitating a second, Mesozoic, phase of burial and source rock generation post-dating the formation of Variscan traps. Areas where significant post-Carboniferous hydrocarbon generation occurred are highlighted in Plate 5.5.

Plate 5.2 shows the areas where the main deltaic clastic target was removed by end Carboniferous erosion related to Variscan uplift and erosion. This includes the Derbyshire Dome, parts of the Bowland Basin and extends along the Pennine-Dent line 
into the Northumberland Trough where the removal of the deltaic clastic sequence is only partial.

Permo-Triassic Extension. The distinct burial and tectonic evolution in Permo-Triassic times substantially downgraded the hydrocarbon potential of basins on the western side of the Pennine High. The critical effects on the intra-Carboniferous play are;

(i) In the major Permo-Triassic depocentres (Cheshire Basin and parts of Manx-Furness) maximum burial cut-offs for both reservoir quality and oil generation were exceeded (Plate 5.2).

(ii) Pervasive and repeated rifting throughout the period fragmented earlier traps and reactivated trap bounding faults. Examples of trap modifications at this time occur in the Formby-Fylde area (onshore Manx-Furness) and in parts of the Cheshire Basin (Fig. 2.13).

Gas generation commenced in the major depocentres towards the end of the Triassic, but repeated faulting of marine band seals and trap modification make prospects in basins lying in the Northwest England province unsuitable for gas retention. With continued gas generation, flushing of oil accumulations becomes an additional risk.

In contrast, basins lying east of the Pennine High, in both geological provinces, underwent gradual burial at this time with renewed oil generation in the basinal areas and little trap modification.

Jurassic-Cretaceous Subsidence and Local Inversion. The later Mesozoic history of the Northwest England province is highly conjectural but it has been shown from fission track analysis that some 1-1.5 km of Jurassic and Cretaceous sediments were deposited. This continued burial left only minor onshore areas in the south of the Formby-Fylde 
above the oil maximum for basal Namurian shales. Gas generation from Westphalian coals, where preserved following Variscan uplift and erosion, was widespread, particularly in the Cheshire Basin (Plate 5.5).

Prior to early Jurassic times the hydrocarbon environments of the intra-Carboniferous basins lying in the Northeast England and East Midland provinces (and their offshore extensions into the Southern North Sea) had been subject to a remarkably similar burial and thermal history. Both provinces had been strongly structured in late Variscan times, forming an array of anticlinal and fault-related traps and had been subject to gentle regional subsidence during the Permo-Triassic. The contrast between basins of the Northeast England and East Midlands provinces commenced in early Jurassic times and continued into the Tertiary as the Cleveland and Stainmore basins became involved in rifting and inversion related to the Sole Pit fault system in the Southern North Sea (Glennie \& Boegner 1981). This had essentially two effects:

(i) Widespread disruption of traps due to localised fault movements and successive phases of basin inversion in the late Cretaceous-Tertiary .

(ii) Localised deep burial, principally as a product of early Cretaceous rifting in northern Cleveland and the Southern North Sea. This event dropped most of the basin into a gas generation depth (Plate 5.5) with consequent flushing of liquid hydrocarbons from existing traps.

Cenozoic Uplift and Erosion. From the end of late Cretaceous chalk deposition onwards, the northern England basins experienced strong uplift and erosion with a consequent 'freezing' of hydrocarbon generation. Offshore in the Southern North Sea, basins have experienced continued subsidence and hydrocarbon generation to the present day (Fig. 5.13). A regional heating event which has elevated present day geothermal gradients in parts of Northwest England and the East Midlands (Wheildon \& Rollin 
1986; Fig. 5.30) may have been associated with early Tertiary volcanism in the North Atlantic province.

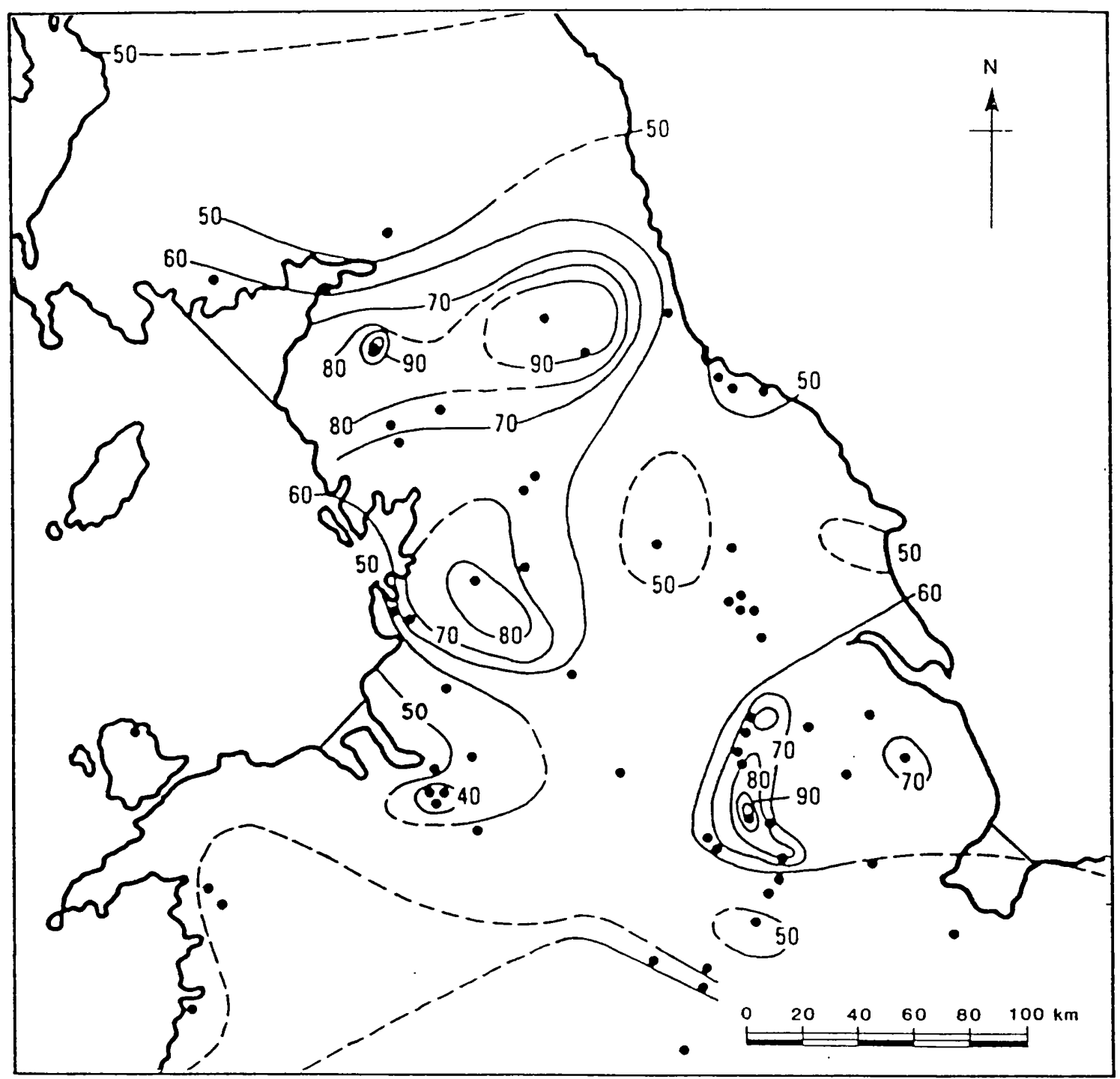

Figure 5.30. Present day heat flow map for northern England. Units are $\mathrm{mW} / \mathrm{m}^{2}$. Borehole locations where heat flow has been measured are indicated. After Wheildon and Rollin (1986).

However, these elevated heat flows are unlikely to have significantly retriggered generation from source rocks in these areas, which were already in an advanced stage of maturity. Regional estimates of uplift and erosion range from $1100-3000 \mathrm{~m}$ in the Northwest England province to 1000-2000 m in the East Midlands (Fraser et al. 1990). 
The effects of uplift and tilting on existing accumulations is well demonstrated in many of the East Midlands fields, where palaeo-oil columns can be related back to pre-tilt closures. Surface and shallow seeps (Plate 1.3) still give a fair indication of the pre-tilt distribution of subsurface accumulations.

\section{Play assessment}

An assessment of the deltaic clastics play in the northern England Carboniferous is illustrated on Plates 5.11 \& 5.12. From the point of view of the evolution of the hydrocarbon system described above, it is clear that the geological history of the East Midlands province is somewhat unique. The area works as a successful oil environment because of the following.

(i) It includes several isolated early Carboniferous rift basins containing thick basal Namurian source rocks which are encountered at several levels providing source 'back-up'.

(ii) Except in areas to the west of the province, maturation occurred in Mesozoic times after Variscan trap formation.

(iii) There is an abundance of reservoir-seal pairs providing reservoir-seal 'back-up' with burial depths over most of the area shallower than the critical threshold for commercial oil production.

(iv) The area was tectonically quiescent following Variscan trap formation with passive burial accompanied by a mild easterly tilting. 
The burial data provided here suggests that the East Midlands (in a fairly restricted fairway surrounding the basinal areas) is the only oil province likely to be developed today in the intra-Carboniferous of northern England (Plate 5.11). However, drilling statistics in this province do not give much encouragement for future significant discoveries. .The 'creaming curve' (Fig. 1.1) indicates that recent discoveries in the intra-Carboniferous play have been small suggesting only limited remaining potential in the East Midlands. The shape of the graph is typical of a mature play fairway.

In contrast the intra-Carboniferous gas play is likely to be more extensive, particularly in Northeast England and the offshore Southern North Sea. However, gas potential may be hampered by poor reservoir quality and, particularly in the Northwest England province, by contemporaneous trap reactivation and the increased need for an effective sealing facies.

Elsewhere, several factors have contributed to the lack of success in this play fairway.

(i) Deep burial - excessive burial of Dinantian sediments has resulted in loss of reservoir quality beyond depths of around $2500 \mathrm{~m}$.

(ii) Dinantian pro-delta source - not as rich its the basal Namurian equivalent and tends to be gas prone.

(iii) Delta top seals - these are poor, especially in terms of trapping gas.

(iv) Relative lack of Mesozoic generation-little Mesozoic subsidence in the north of the study area where these deltas were developed.

(v) Lack of exploration - northern basins containing Clastic delta plays are either immature or unexplored. 
Outside the East Midlands, the most prospective areas for this play fairway are in the Solway, southern Manx-Furness and Cleveland and Southern North Sea basins. These areas are likely to have reasonable Dinantian-early Namurian pro-delta and Westphalian delta top coal source rocks combined with the presence of clastic reservoirs distributed throughout the Carboniferous. Traps formed during Carboniferous extension, Variscan inversion and Mesozoic extension structures will have been charged by late Mesozoic hydrocarbon generation. Perhaps the only barrier to success in the play is the excessive depths of burial the reservoirs been subjected to in these basins. This is likely to result in poor reservoir quality, gas as the main hydrocarbon phase and hence reliance on intraCarboniferous mudstone and basal Permian evaporite seals. 


\section{CHAPTER 6 CONCLUSIONS}

The structures which controlled the Carboniferous tectonic and stratigraphic development of northern England were inherited from the earlier Caledonian orogeny. These events imparted a strong NW-SE and NE-SW tectonic grain which is evidenced on surface and subsurface data throughout northern England. The subsequent Variscan plate cycle, which involved the closure of the Rheic and Rheno-Hercynian oceans, controlled the development of syn-rift, post-rift and inversion megasequences from late Devonian to early Permian times. Sequences developed within the Carboniferous are seen to be controlled by episodic rifting and periodic fault reactivation, with eustatic sea level changes providing only minor control and that only at the subsequence level. A revised tectono-stratigraphic scheme has been proposed for the northern England Carboniferous which is considered to provide a more applicable stratigraphic template with equal validity for seismic, borehole and outcrop analyses.

In the south of the province during the Dinantian, carbonate environments were extensively developed in syn-rift basins starved of terrigenous clastics. The north of the region was dominated from early Dinantian times onward by a southward prograding terrigenous clastic delta system. The carbonate environments in the south were finally drowned in the early post-rift (Pendleian) when the supply of terrigenous clastic sediments outpaced subsidence for the first time. Following this rapid southward progradation of the delta systems occurred.

Over 70 years of exploration in northern England has resulted in the discovery of 75 million barrels of recoverable reserves. Average field size is assessed at 2 million barrels at a historical finding rate of 1 discovery in 4 exploration wells. All hydrocarbon discoveries to date within the Carboniferous have shown some element of Variscan deformation in their geometry (Fig. 6.1). Tectonics have also exerted a subtle, but important control on play fairway evolution. The main source rocks, developed in distal 
1. Pre-Variscan, and Westphalian 'B':- maximum source rock burial pre-Variscan trap formation

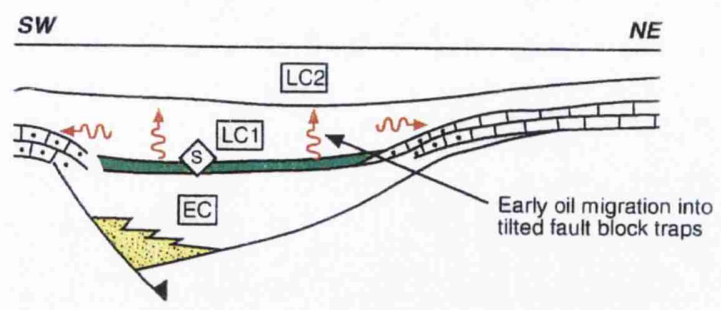

2. End Carboniferous, Variscan inversion and erosion - trap formation

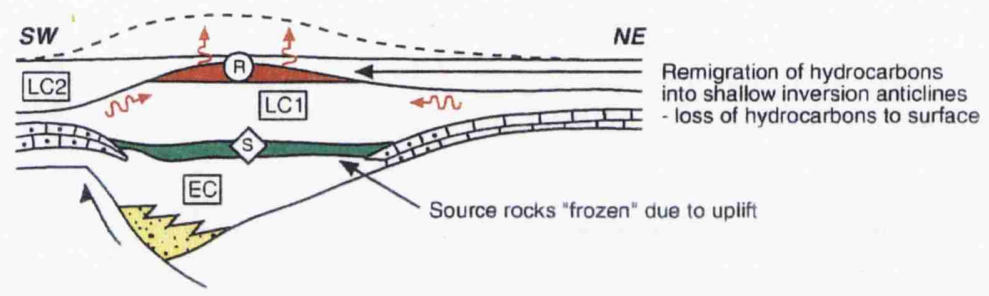

3. Mesozoic burial - maximum burial of source rocks

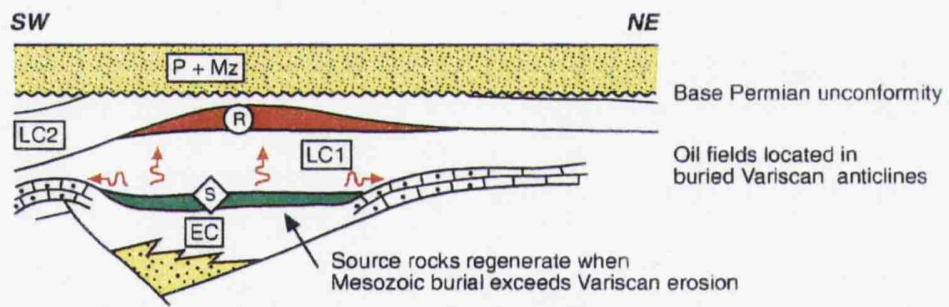

4. Tertiary tilting and remigration of hydrocarbons

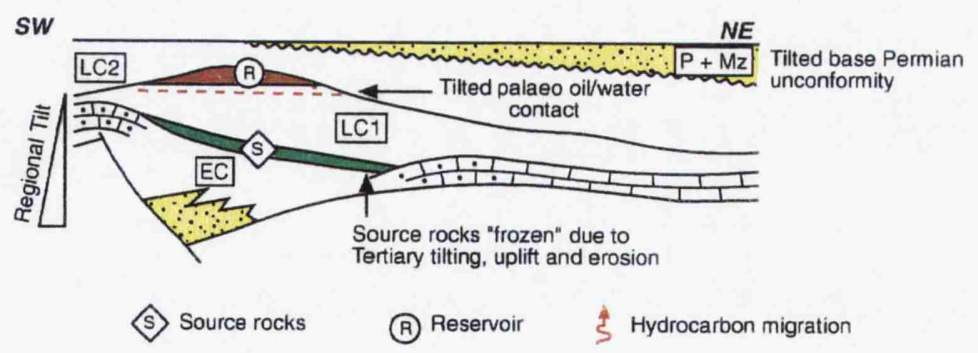

Figure 6.1 Evolution of the hydrocarbon system in the Carboniferous of the East Midlands. 
pro-delta environments, are restricted to the syn-rift depocentres. Syn-rift siliciclastic reservoirs, associated with the early rift phase are located within the isolated, rifted, halfgraben. Carbonate grainstone reservoirs are controlled by the rift topography and rim the margins of the deeper half-graben in the south of the province. Delta top channel and mouth bar reservoirs are best developed where they axially infill remnant rift bathymetry.

Mesozoic burial ensuring hydrocarbon generation post-dating Variscan trap formation, is considered to be the main control on the present day distribution of hydrocarbons in northern England (Fig. 6.1). Areas such as the central Pennines and Northumberland and Stainmore basins which received limited Mesozoic burial are considered to have poor hydrocarbon potential. The Cleveland, Manx-Furness and Cheshire basins where Mesozoic burial was excessive have gas as the major hydrocarbon phase. The East Midlands, where Mesozoic burial and post Variscan trap modification have been moderate, has therefore emerged as the most successful oil province in northern England.

This thesis began with a question concerning the uniqueness of the East Midlands in terms of the intra-Carboniferous plays of northern England. It would seem that even with a small data set of fully tested targets there exists sufficient evidence from the reconstructed hydrocarbon environment to suggest that the East Midlands is geologically a unique setting and is most probably the only northern England province where commercial oil accumulations will be found 


\section{REFERENCES}

ADAMS, A.E \& HORBURY, A.D. 1990. Tree root structures on a Dinantian palaeokarst, Urswick Limestone, south Cumbria. Proceedings of the Yorkshire Geologists Association, 101, 19-30.

AITKENHEAD, N \& CHISHOLM, J.I. \& STEVENSON, I.P. 1985. Geology of the country around Buxton, Leek and Bakewell. Memoir of the British Geological Survey. H.M.S.O., London

ANDERTON, R., BRIDGES, P. H., LEEDER, M. R. \& SELLWOOD, B. W. 1979. A dynamic stratigraphy of the British Isles. A study in crustal evolution. Allen \& Unwin.

ANDRE, L., HERTOGEN, J. \& DEUTSCH, S. 1986. Ordovician - Silurian magmatic provinces in Belgium and the Caledonian orogeny in Middle Europe. Geology, 14, 879882.

ARTHAUD, F. and MATTE, P. 1977. Late Palaeozoic strike-slip faulting in southern Europe and northern Africa: result of a right-lateral shear zone between the Appalachians and the Urals. Bulletin of the Geological Society of America, 88, 1305-1320.

ARTHURTON, R.S., 1983. The Skipton Rock Fault an Hercynian wrench fault associated with the Skipton Anticline, northwest England. Geological Journal, 18, 105114.

ARTHURTON, R. S. 1984. The Ribblesdale fold belt, NW England - a Dinantian-Early Namurian dextral shear zone. In: HUTTON, D. H. W. \& SANDERSON, D. J. (eds). Variscan Tectonics of the North Atlantic Region. Geological Society, London, Special Publication, 14, 131-138. 
ARTHURTON, R.S., JOHNSON, E.W.\& MUNDY, D.J.C. 1988. Geology of the country around Settle. Memoir of the British Geological Survey. H.M.S.O., London.

BRITISH GEOLOGICAL SURVEY, 1965. Aeromagnetic maps of the United Kingdom Scale 1:500,000. H.M.S.O., London.

BRITISH GEOLOGICAL SURVEY, 1985. Pre-Permian Geological map of the United Kingdom (South) Map 1. Contours on the top of the Pre-Permian surface of the United Kingdom (South). Map 2. Scale 1:1,000,000. H.M.S.O., London.

BADHAM, J.P.N. 1982. Strike-slip orogens - an explanation for the Hercynides. Journal of the Geological Society London, 139, 495-506.

BALLY, A.W. 1984 Tectogenese et sismique reflections. Bull. Soc. Geol. France, 7 , XIV (2), 279-285.

BARNES, R.P. \& ANDREW, J.R. 1986. Upper Palaeozoic ophiolite generation and obduction in North Cornwall. Journal of the Geological Society London, 143, 117-124.

BEAMISH, D. \& SMYTHE, D. K. 1986. Geophysical images of the deep crust: the Iapetus suture. Journal of the Geological Society London, 143, 489-497.

BESLY, B. M. 1988. Palaeogeographic implications of late Westphalian to early Permian red beds, Central England. In: BESLY, B. M. \& KELLING, G. (eds). Sedimentation in a synorogenic basin complex: The Carboniferous of north west Europe. Blackie, Glasgow, 200-221.

BESLY, B.M. 1990. Carboniferous. In: Glennie, K.W. (ed) Introduction to the Petroleum Geology of the North Sea. Blackwell, Oxford, 90-119. 
BISAT, W. S. 1928. The Carboniferous goniatite zones of England and their continental equivalents. Compte rendue Congres Stratigraphie Carbonifere, Heerlen, 117-133.

BOTT, M.H.P., 1961. Geological interpretation of magnetic anomalies over the Askrigg Block. Quarterly Journal of the Geological Society London, 117 (4). 481-495.

BOTT, M.H.P. 1964. Formation of sedimentary basins by ductile flow of isostatic origin in the upper mantle. Nature, 201, 1082-1082.

BOTT, M. H. P. 1967. Geophysical investigations of the Northern Pennine basement rocks. Proceedings of the Yorkshire Geological Society, 36, 139-168.

BOTT, M.H.P. 1974. The geological interpretation of a gravity survey of the English Lake District and Vale of Eden. Journal of the Geological Society London, 130, 309331.

BOTT, M.H.P. 1987. Subsidence mechanisms of Carboniferous basins in Northern England. In: MILLER, J., ADAMS, A. E. \& WRIGHT, V. P. (eds). European Dinantian Environments. John Wiley, Chichester, 21-32.

BOTT, M.H.P. \& JOHNSON, G.A.L. 1967. The controlling mechanism of Carboniferous cyclic sedimentation. Quarterly Journal of the Geological Society, London, 122, 421-441.

BOTT, M.H.P. \& MASSON SMITH, D.J., 1957a. The geological interpretation of a gravity survey of the Alston Block and the Durham Coalfield. Quarterly Journal of the Geological Society London, 113, 93-117. 
BOTT, M.H.P. \& MASSON SMITH, D.J., 1957b. Interpretation of a vertical field magnetic survey in North-East England. Quarterly Journal of the Geological Society London, 113, 119-136.

BOTT, M.H.P. and MASSON SMITH, D.J., 1960. A gravity survey of the Criffell Granodiorite and the New Red Sandstone deposits near Dumfries. Proceedings of the Yorkshire Geological Society, 32, 317-332.

BOTT, M.H.P., SWINBURN,P.M. \& LONG, R.E. 1984. Deep structure and origin of the Northumberland and Stainmore troughs. Proceedings of the Yorkshire Geological Society, 44, 479-495.

BRIDGES, P. H. \& CHAPMAN, A. J. 1988. The anatomy of a deep water mud-mound complex to the southwest of the Dinantian platform in Derbyshire, UK. Sedimentology, $35,139-162$.

BROADHURST, F.M. \& SIMPSON, I.M. 1967. Sedimentary infillings of fossils and cavities in limestone at Treak Cliff, Derbyshire. Geological Magazine, 104, 443-448.

BROADHURST, F.M. and SIMPSON, I.P.1973. Bathymetry on a Carboniferous reef. Lethaia , 6, 367-381.

BURG, J. P. \& MATTE, P.. 1978, A cross section through the French Massif Central and the scope of its Variscan geodynamic evolution. Z Deutsch. Geol. Gesell., 129, 429-460.

BURGESS, I.C. \& HARRISON, R.K. 1967. Carboniferous Basement Beds in the Roman Fell district, Westmorland. Proceedings of the Yorkshire Geological Society, 36, 203-225. 
BURGESS, I. C. \& MITCHELL, M. 1976. Visean lower Yoredale limestones on the Alston and Askrigg blocks and the base of the D2 Zone in Northern England. Proceedings of the Yorkshire Geological Society, 40, 613-630.

BURGESS, I.C. \& HOLLIDAY, D.W. 1979. Geology of the country around BroughUnder-Stainmore. Memoir of the British Geological Survey. H.M.S.O., London

CALVER, M. A. 1968. The distribution of the Westphalian marine faunas in northern England and adjoining areas. Proceedings of the Yorkshire Geological Society, 37, 172.

CHANDLER, P \& ISAAC K.P. 1982. The geological setting, geochemistry and significance of lower Carboniferous basic volcanic rocks in central south-west England. Proceedings of the Usher Society, 5, 279-288.

CHAURIS, L. 1969. Sur un important accident structural dans le nord-ouest de l'Armorique. C. r. hebd. Seanc. Acad. Sci., Paris, 268, 2859-61.

CHURCH, K.D. \& GAWTHORPE, R.L. 1994. High resolution sequence stratigraphy of the late Namurian in the Widmerpool Gulf (East Midlands, UK). Marine and Petroleum Geology, 11/5, 528-544.

CLAYTON, G., HIGGS, K., GUEINN, K. J. \& VAN GELDER, A. 1974. Palynological correlations in the Cork Beds (Upper Devonian-? Upper Carboniferous) of southern Ireland. Proceedings of the Royal Irish Academy, 74, 145-155.

CLAYTON, G., COOUEL, R., DOUBINGER, J., GUEINN, K. J., LOBOZIAIC, S., OWENS, B. \& STREEL, M. 1977. Carboniferous miospores of western Europe; illustration and zonation. Mededelingen rijk Geologische Dienst, 29, 1-171. 
COCKS, L.R.M. and FORTEY, R.A., 1982. Faunal evidence for oceanic separations in the Palaeozoic of Britain. Journal of the Geological Society London. 134, 465-478.

COGNE, J. 1960. Schistes cristallins et granites en Bretagne meridionale. Le domaine de l'Anticlinal de Cornouaille. Mem. Serv. Carte. Geol. Fr. 1-382

COLLIER, R.E.LL. 1989. Tectonic evolution of the Northumberland Basin; the effects of renewed extension upon an inverted extensional basin. Journal of the Geological Society London, 146, 981-989.

COLLIER, R.E.LL. 1991. The Lower Carboniferous Stainmore Basin, N. England: extensional basin tectonics and sedimentation. Journal of the Geological Society London, 148, 379-390.

COLLINSON, J.D. and BANKS, 1975. The Haslingden Flags (Namurian G1) of south east Lancashire: bar finger sands in the Pennine Basin. Proceedings of the Yorkshire Geological Society, 40, 431.

COLLINSON, J.D., JONES, C.M. \& WILSON, A.A. 1977. The Marsdenian (Namurian R2) succession West of Blackburn: Implications for the evolution of Pennine delta systems. Geological Journal, 12, 59-76.

COLLINSON, J.D., JONES, C.M., BLACKBOURN, G.A., BESLY, B.M., ARCHARD, G.M. \& MCMAHON, A.H. 1993. Carboniferous depositional systems of the Southern North Sea. In: PARKER, J.R. (ed) Petroleum Geology of Northwest Europe: Proceedings of the 4th Conference. Geological Society of London. 677-687. 
COLTER, V.S. and BARR, K.W. 1975. Recent developments in the geology of the Irish Sea and Cheshire basin. In WOODLAND A.W. (ed.) "Petroleum and the continental shelf of north west Europe". Applied Science Publ. 61-75.

CONIL, R., LONGERSTAEY, P. J. \& RAMSBOTTOM, W. H. C. 1979. Materiaux pour l'etude micropaleontolgique du Dinantian de Grande-Bretagne. Memoire Institue Geologie, Louuain, 30, 1-187.

COPE, F. W. 1973 Woo Dale Borehole near Buxton, Derbyshire. Nature, 243, 29-30.

COPE, J.C.W., INGHAM, J.K. \& RAWSON, P.F. (eds.) 1992. Atlas of palaeogeography and lithofacies. Geological Society, London, Memoir, 13.

COWARD, M.P. 1993. The effect of Late Caledonian and Variscan continental escape tectonics on basement structure, Palaeozoic basin kinematics and subsequent Mesozoic basin development in NW Europe. In: PARKER, J.R. (ed) Petroleum Geology of Northwest Europe: Proceedings of the 4th Conference. Geological Society, London, 1095-1108.

COWARD, M. P. \& SIDDANS, A. W. B. 1979. The tectonic evolution of the Welsh Caledonides. In: HARRIS, A. L., HOLLAND, C. H. \& LEAKE, B. E. (eds). Caledonides of the British Isles-reviewed . Geological Society of London Special Publication, 8, 187-198.

COWARD, M.P. \& SMALLWOOD S. 1984. An interpretation of the Variscan tectonics of SW Britain. In: HUTTON, D.H.W. \& SANDERSON, D.J. (eds) Variscan tectonics of the North Atlantic region. Geological Society of London Special Publication, 14, 139-146. 
DAVIES, G.R. 1984. Isotopic evolution of the Lizard Complex. Journal of the Geological Society London, 141, 3-14.

DAY, J.B.W. 1970. Geology of the country around Bewcastle. Memoir of the Geological Survey of Great Britain. H.M.S.O., London.

DEWEY, J. F. 1971. A model for the Lower Palaeozoic evolution of the southern margin of the early Caledonides of Scotland and Ireland. Scottish Journal of Geology, 7, 219-240.

DEWEY, J. F. 1982. Plate tectonics and the evolution of the British Isles. Journal of the Geological Society of London, 139, 371-412.

DODSON, M.H. \& REX, D.C. 1971. Potassium-argon ages of the slates and phyllites from south west England. Quarterly Journal of the Geological Society London., 126, 465-499.

DUFF, B. 1980. The palaeomagnetism of Jersey volcanics and dykes, and the Lower Palaeozoic apparent polar wander path for Europe. Geophysical Journal of the Royal Astrological Society, 60, 355-375.

DUNHAM, K. C. 1973. A recent deep borehole near Eyam in Derbyshire. Nature, 241, 84-85.

DUNHAM, K.C. \& WILSON, A.A. 1985. Geology of the Northern Pennine orefield: Volume 2 Stainmore to Craven. Economic Memoir of the British Geological Survey. Her Majesty's Stationary Office, London. 
DUNHAM, K.C., DUNHAM, A.C., HODGE, B.L. \& JOHNSON, G.A.L. 1965. Granite beneath Visean sediments with mineralization at Rookhope, northern Pennines. Quarterly Journal of the Geological Society, London, 121, 383-417.

EARP, J. R., MAGRAW, D., POOLE, E. G., LAND, D. H. \& WHITEMAN, A. J. 1961. Geology of the country around Clitheroe and Nelson. Memoirs of the Geological Survey of Great Britain, sheet 68. H.M.S.O., London.

EBBERN, J. 1981. The geology of the Morecambe gas field. In: ILLING, L.V. \& HOBSON, G.D. (eds). Petroleum geology of the Continental Shelf of north-west Europe, Institute of Petroleum, London, 485-493.

EBDON, C.C., FRASER, A.J., HIGGINS, A.C., MITCHENER, B.C. \& STRANK, A.R.E. 1990. The Dinantian Stratigraphy of the East Midlands: A seismostratigraphic approach. Journal of the Geological Society, London, 147, 519-536.

EDEN, R.A., ORME, G.R., MITCHELL, M \& SHIRLEY J. 1964. A study of part of the Carboniferous Limestone "Massif" in the Pin Dale area of Derbyshire. Bulletin of the Geological Survey G.B., 21, 73-118.

EVANS, A. M. 1979. The East Midlands Aulacogen of Caledonian age. Mercian Geologist, 7, 31-42.

FALCON, N. L. \& KENT, P. E. 1960. Geological results of petroleum exploration in Britain 1945-1957. Geological Society, London, Memoir 2.

FEWTRELL, M. D. \& SMITH, D. G. 1978. Stratigraphic significance of calcareous microfossils from the Lower Carboniferous rocks of the Skipton area, Yorkshire. Geological Magazine, 115, 255-271. 
FIELDING, C.R. 1984a. A coal depositional model for the Durham Coal Measures of N.E. England, Journal of the Geological Society London, 141, 919-931.

FIELDING, C.R. 1984b. Upper delta-plain lacustrine and fluviolacustrine facies from the Westphalian of the Durham Coalfield. Sedimentology , 31, 547-567.

FIELDING, C.R. 1986. Fluvial channel and overbank deposits from the Westphalian of the Durham Coalfield, N.E. England. Sedimentology, 33, 119-140.

FIELDING, C.R. \& JOHNSON, G.A.L.. 1987. Sedimentary structures associated with extensional fault movement from the Westphalian of N.E. England. In: COWARD, M.P., DEWEY, J.F. \& HANCOCK P.L.,(eds.) Continental Extensional Tectonics . Special Publication of the Geological Society London, 28.

FLOYD, P.A. 1982. Chemical variation in Hercynian basalts relative to plate tectonics. Journal of the Geological Society London ,134, 505-520.

FORD, T.D. 1969. The Blue John fluorspar deposits of Treak Cliff in relation to the boulder bed. Proceedings of the Yorkshire Geological Society, 37, 153-158.

FOSTER, D., HOLLIDAY, D.W., JONES, C.M., OWENS, B. \& WELSH, A. 1989. The concealed Upper Palaeozoic rocks of Berkshire and South Oxfordshire. Proceedings of the Geologists' Association, 100, 395-407.

FOWLER, A. 1926. The geology of Berwick-on-Tweed, Norham and Scremerston. Memoir of the Geological Survey of Great Britain, 1, 2. H.M.S.O., London. 
FRASER, A.J. \& GAWTHORPE ,R.L. 1990. Tectono-stratigraphic development and hydrocarbon habitat of the Carboniferous in northern England. In: HARDMAN, R.F.P. \& BROOKS, J. (eds). Tectonic Events Responsible for Britain's Oil and Gas Reserves, Geological Society Special Publication, 55, 49-86.

FRASER, A.J., NASH, D.F., STEELE, R.P. \& EBDON, C.C. 1990. A regional assessment of the intra-Carboniferous play of northern England. In: BROOKS, J. (ed). Classic Petroleum Provinces. Geological Society, London, Special Publication, 50, 417-440.

FROST, D.V. \& HOLLIDAY, D.W. 1980. Geology of the Bellingham district. Memoir of the Geological Survey of Great Britain. H.M.S.O., London

FULTON, I.M. \& WILLIAMS, H. 1988. Palaeogeographical change and controls of Namurian and Westphalian A/B sedimentation at the Southern margin of the Pennine Basin. In: BESLY, B.M. \& KELLING, G (eds) Sedimentation in a Synorogenic Basin Complex: the Upper Carboniferous of Northwest Europe Blackie, Glasgow and London, 178-199.

GALLOWAY W.E. 1989. Genetic stratigraphic sequences in basin analysis: I. Architecture and genesis of flooding-surface bounded depositional units. Bulletin of the American Association of Petroleum Geologists , 73, 125-142.

GARWOOD, E. J. 1913. The Lower Carboniferous succession in the north-west of England. Quarterly Journal of the Geological Society, of London, 68, 449-596.

GAWTHORPE, R. L. 1986. Sedimentation during carbonate ramp-to-slope evolution in a tectonically active area: Bowland Basin (Dinantian), N. England. Sedimentology, 33, $185-2116$. 
GAWTHORPE, R.L. 1987a. Tectono-sedimentary evolution of the Bowland Basin, Northern England, during the Dinantian. Journal of the Geological Society, London, 144, 59-71.

GAWTHORPE, R.L. 1987b. Burial dolomitization and porosity development in a mixed carbonate-siliciclastic sequence: an example from the Bowland Basin, northern England. Sedimentology, 34, 555-565.

GAWTHORPE R.L. \& CLEMMEY H. 1985. Geometry of submarine slides in the Bowland Basin (Dinantian) and their relation to debris flows. Journal of the Geological Society London ,142, 555-565.

GAWTHORPE, R.L., GUTTERIDGE, P. \& LEEDER, M.R. 1989. Late Devonian and Dinantian basin evolution in Northern England and North Wales. In: ARTHURTON, R.S., GUTTERIDGE, P. \& NOLAN, S.C. (eds). The role of tectonics in Devonian and Carboniferous sedimentation in the British Isles. Yorkshire Geological Society (Occasional Publication No.6), 1-23.

GAWTHORPE, R.L. \& GUTTERIDGE, P. 1990. Geometry and evolution of platformmargin bioclastic shoals, late Dinantian (Mississippian), Derbyshire, U.K. In: TUCKER, M.E. (ed.), Carbonate Platforms. Special Publication International Association of Sedimentology, 9, 39-54.

GAWTHORPE, R.L., FRASER, A.J. \& COLLIER, R.E.Ll. 1994. Sequence stratigraphy in active extensional basins: implications for the interpretation of ancient basin-fills. Marine and Petroleum Geology, 11/6, 642-658.

GEORGE, T.N. 1958. Lower Carboniferous palaeogeography of the British Isles. Proceedings of the Yorkshire Geological Society, 31, 227-318. 
GEORGE, T.N. 1978. Eustacy and tectonics: Sedimentary rhythms and stratigraphic units in British Dinantian correlation. Proceedings of the Yorkshire Geological Society, 42, 229-262.

GEORGE, T. N., JOHNSON, G. A. L., MITCHELl, M., PRENTICE, J. E. RAMSBOTTOM, W. H. C., SEVASTOPULO, G. D. \& WILSON, R. B. 1976. A correlation of Dinantian rocks in the British Isles. Geological Society of London Special Report, 7.

GILLIGAN, A. 1920. The petrography of the Millstone Grit of Yorkshire. Quarterly Journal of the Geological Society London., 75, 251-94.

GLENNIE, K. W. \& BOEGNER, P. L. F. 1981. Sole Pit Inversion tectonics. In: ILLING, L. V. \& HOBSON, G. D. (eds). Petroleum geology of the continental shelf of North-West Europe. Institute of Petroleum, London 110-120.

GRAYSON, R.F., \& OLDHAM, L. 1987. A new structural framework for the northern British Dinantian as a basis for oil, gas and mineral exploration. In MILLER, J., ADAMS, A.E. \& WRIGHT, V.P. (eds). European Dinantian Environments. John Wiley and Sons, Chichester, 33-59.

GREEN, P. F. 1986. On the thermo-tectonic evolution of Northern England: Evidence from fission track analysis. Geological Magazine, 123, 493-506.

GREEN, P. F. 1989. Thermal and tectonic history of the East Midlands Shelf (onshore UK), and surrounding regions assessed by Apatite Fission Track Analysis. Journal of the Geological Society, London, 146, 755-773. 
GUION, P.D. 1971. A sedimentological study of the Crawshaw Sandstone(Westphalian A) in the East Midlands Coalfields area. Unpublished Ph.D thesis, University of Keele.

GUION, P.D. 1978. Sedimentation of interseam strata and some relationships with coal seams in the East Midlands Coalfield. Unpublished Ph.D. thesis , Council of National Academic Awards.

GUION, P.D. 1984. Crevasse splay deposits and roof-rock quality in the Threequarters seam (Carboniferous) in the East Midlands Coalfield, U.K. In: RAHMANI, R.A. \& FLORES, R.M. (eds.) Sedimentology of Coal and Coal-Bearing Strata, Special Publication of the International Association of Sedimentology, 7, 291-308.

GUION, P.D. 1987. Palaeochannels in mine workings in the High Hazles Coal (Westphalian B), Nottinghamshire Coalfield, England. Journal of the Geological Society London, 144, 471-488.

GUION, P.D. 1987. Westphalian A palaeogeography. Palaeogeographical Atlas, Geological Society of London.

GUION, P.D. \& FIELDING, C.R. 1988. Westphalian A and B sedimentation in the Pennine basin, UK. In: BESLY, B.M. \& KELLING, G (eds). Sedimentation in a synorogenic basin complex: The Carboniferous of northwest Europe. Blackie \& Sons, Glasgow, 153-177.

GUIRAUD, M., BURG, J.P.\& POWELL, R. 1987. Evidence for a Variscan suture zone in the Vendee, France; a petrological study of the blueschist facies rocks from the Bois de Cene. Journal of Metamorphic Geology, 5, 225-237. 
GUTTERIDGE, P. 1987. Dinantian sedimentation and basement structure of the Derbyshire Dome. Geological Journal , 22, 25-41.

GUTTERIDGE, P. 1989. Controls on carbonate sedimentation in a Brigantian intrashelf basin, Derbyshire. In: ARTHURTON, R.S. GUTTERIDGE, P. \& NOLAN, S.C. (eds). The role of tectonics in Devonian and Carboniferous sedimentation in the British Isles. Yorkshire Geological Society (Occasional Publication No.6), 171-187.

HAILWOOD, E.A., GASH, P.J.R., ANDERSON, P.C. \& BADHAM, J.P.N. 1984. Palaeomagnetism of the Lizard Complex. Journal of the Geological Society London, 141, 27-33.

HALLIDAY, A.N. \& MITCHELL, J.G. 1976. Structural K-Ar and 40Ar-39Ar age studies of adularia K-feldspars from the Lizard Complex, England. Earth and Planetary Science Letters, 29, 227-237

HARLAND, W. B., COX, A. V., LLEWELlYN, P. G., PICKTON, C. A. G., SMITH, A. G. \& WALTERS, R. 1982. A geologic time scale. Cambridge University Press, Cambridge.

HASZELDINE, R.S. 1981. Westphalian B coalfield sedimentology in north-east England and its regional setting. Unpublished Ph.D. thesis, University of Strathclyde.

HASZELDINE, R. S. 1984. Carboniferous North Atlantic palaeogeography: stratigraphic evidence for rifting, not megashear or subduction. Geological Magazine, 121, 443-463. 
HASZELDINE, R. S. 1988. Crustal lineaments in the British Isles: their relationship to Carboniferous basins. In: BESLY, B. M. \& KELLING, G. (eds). Sedimentation in a synorogenic basin complex: The Carboniferous of north west Europe. Blackie, Glasgow, 53-83.

HASZELDINE, R.S. 1989. Evidence against crustal stretching, north-south tension and Hercynian collision, forming British Carboniferous basins. In: ARTHURTON, R.S. GUTTERIDGE, P. \& NOLAN, S.C. (eds). The role of tectonics in Devonian and Carboniferous sedimentation in the British Isles. Yorkshire Geological Society (Occasional Publication No.6), 25-33.

HASZELDINE, R.S. \& RUSSELL M.J. 1987. The late Carboniferous northern North Atlantic ocean: implications for hydrocarbon exploration from Britain to the Arctic. In: BROOKS, J. \& GLENNIE, K. (eds) Petroleum geology of NW Europe. Graham \& Trotman, London.

HECKEL, P.H. 1990. Evidence for global controls (glacial-eustatic) over Upper Carboniferous (Pennysylvanian) Cyclothems. In: HARDMAN, R.P. (ed). Tectonic events responsible for Britain's oil and gas reserves. Geological Society, London, Special Publication 55, 35-47.

HEDBERG, H. D. 1976. International stratigraphic guide, Wiley, New York.

HEWARD, A. 1976. Sedimentation patterns in coal bearing strata, northern Spain and Great Britain. Unpublished D. Phil. thesis. University of Oxford.

HOLLINGWORTH, S.E., 1938. The recognition and correlation of high-level erosion surfaces in Britain: a statistical study. Quarterly Journal of the Geological Society London, 94, 55-84. 
HORBURY, A.D. 1992. A Late Dinantian peloid cementstone-palaeoberesellid buildup from North Lancashire, England. Sedimentary Geology, 79, 117-137.

HOUCHEN, M.A. 1988. Structural modelling of the external Variscides of France and Belgium. Unpublished Ph.D. thesis. National University of Ireland.

HUBBARD, R.J. 1988. Age and significance of sequence boundaries on Jurassic and early Cretaceous rifted continental margins. American Association of Petroleum Geologists Bulletin, 72, 49-72.

HUBBARD, R.J., PAPE, J. \& ROBERTS, D.G. 1985a. Depositional sequence mapping as a technique to establish tectonic and stratigraphic framework and evaluate hydrocarbon potential on a passive continental margin. In: BERG, O.R. \& WOOLVERTON, D.G. (eds). Seismic Stratigraphy II, American Association of Petroleum Geologists Memoir, 39, 79-92.

HUBBARD, R.J., PAPE, J. \& ROBERTS, D.G. 1985b. Depositional sequence mapping to illustrate the evolution of a passive continental margin. In: BERG, O.R. \& WOOLVERTON, D.G. (eds). Seismic Stratigraphy II, American Association of Petroleum Geologists Memoir, 39, 93-115.

HUDSON, R.G.S. \& COTTON G. 1945a. The Lower Carboniferous in a boring at Alport, Derbyshire. Proceedings of the Yorkshire Geological Society, 25, 254-330.

HUDSON, R.G.S. \& COTTON, G. 1945b The Carboniferous rocks of the Edale Anticline, Derbyshire. Quarterly Journal of the Geological Society London, 101, 1-36.

INSTITUTE OF GEOLOGICAL SCIENCES. 1978. IGS Boreholes 1977. Report of the Institute of Geological Sciences, 78/21, 1-24. 
JACKSON, J.A. 1987. Active normal faulting and crustal extension. In: COWARD, M.P. \& DEWEY, J.F. \& HANCOCK, P.L. (eds). Continental Extensional Tectonics. Geological Society London, Special Publication, 28, 3-17.

JEGOUZO, P. 1981. The South Armorican Shear Zone. Journal of Structural Geology, 2, 39-47.

JOHNSON, G. A. L. 1960. Palaeogeography of the northern Pennines and part of NE England during deposition of the Carboniferous cyclothemic deposits. International Geological Congress XXI Session Norden, 12, 118-128.

JOHNSON, G.A.L. 1982. Geographical change in Britain during the Carboniferous period. Proceedings of the Yorkshire Geological Society , 44, 181-203.

JOHNSON, G.A.L. 1984. Subsidence and sedimentation in the Northumberland Trough. Proceedings of the Yorkshire Geological Society , 45, 71-83.

JONES, C.M. 1980. Deltaic sedimentation in the Roaches Grit and associated sediments (Namurian R2b) in the SW Pennines. Proceedings of the Yorkshire Geological Society, $43,39-67$.

KELLING, G. 1974. Upper Carboniferous sedimentation in South Wales. In: Owen, T.R. (ed). The Upper Palaeozoic and Post-Palaeozoic rocks of Wales. University of Wales Press, Cardiff, 185-224.

KENT, P.E. 1966. Structure of the concealed Carboniferous rocks of NE England. Proceedings of the Yorkshire Geological Society, 35, 323-352. 
KENT, P.E. 1968. The buried floor of Eastern England. In: SYLVESTER-BRADLEY, P. C. \& FORD, T. D. (eds). The Geology of the East Midlands. Leicester University Press, 138-148.

KENT, P.E. 1975. The tectonic development of Britain and surrounding seas. In: WOODLAND, A. W. (ed.). Petroleum and the continental shelf of North West Europe. Vol. 1 Geology. Applied Science Publishers. 3-28.

KENT, P.E. 1985. UK Onshore Oil Exploration, 1930-1964. Marine and Petroleum Geology, 2, 56-64.

KIMBELL, G.S., CHADWICK, R.A., HOLLIDAY, D.W. \& WERNGREN, O.C. 1989. The structure and evolution of the Northumberland Trough from new seismic reflection data and its bearing on modes of continental extension. Journal of the Geological Society, London, 146, 775-787.

KIMBER, R. 1984. Clastic deposition between the lowermost Carboniferous limestones of north-west England. European Dinantian Environments 1st Meeting, Manchester, Abstracts, Department of Earth Sciences, Open University.

KIMBER, R.N. \& JOHNSON, G.A.L. 1986. Lake District Highlands and Islands during the Upper Palaeozoic. Proceedings of the Cumberland Geological Society, 4, 377-390.

KIRK, M. 1983. Sedimentology and palaeoecology in the Westphalian A and B Coalfields of Scotland. Unpublished Ph.D. Thesis University of Strathclyde.

KIRK, M. 1989. Westphalian alluvial plain sedimentation, Isle of Arran, Scotland. Geological Magazine, 126, 407-421. 
KIRTON, S.R. 1984. Carboniferous volcanicity in England with special reference to the Westphalian of E and W Midlands. Journal of the Geological Society London. 141, 161-78.

KLEMPERER, S. \& MATTHEWS, D. 1987. Iapetus suture located beneath the North Sea by BIRPS deep seismic reflection profiling. Geology, 15, 195- 198.

KNOTT, S.D., BURCHELL, M.T., JOLLEY, E.J. \& FRASER, A..J. 1993. Mesozoic to Cenozoic plate reconstructions of the North Atlantic and hydrocarbon plays of the Atlantic margins. In: PARKER, J.R. (ed) Petroleum Geology of Northwest Europe: Proceedings of the 4th Conference. Geological Society, London, 953-974.

LAWRENCE, S.R., COSTER, P. \& IRELAND, R.J. 1987. Structural development and petroleum potential of the northern flank of the Craven Basin (Carboniferous) northwest England. In: BROOKS, J. \& GLENNIE, K. (eds) Petroleum Geology of Northwest Europe. 95-107.

LE BAS, M. J. 1972. Caledonian igneous rocks beneath central and eastern England. Proceedings of the Yorkshire Geological Society, 39, 71-86.

LEE, A. G. 1988. Carboniferous basin configuration of Central England, modelled using gravity. In: BESLY, B. M. \& KELLING, G. (eds). Sedimentation in a Synorogenic basin complex: The upper Carboniferous of north west Europe. Blackie, Glasgow, 69-84.

LEEDER, M.R. 1974. Lower Border Group (Tournasian) fluvio-deltaic sedimentation and the palaeogeography of the Northumberland Basin. Proceedings of the Yorkshire Geological Society, 40, 129-180. 
LEEDER, M. R. 1976. Sedimentary facies and origins of basin subsidence along the northern margin of the supposed Hercynian ocean. Tectonophysics, 36, 167-179.

LEEDER, M. R. 1982. Upper Palaeozoic basins of the British Isles - Caledonide inheritance versus Hercynian plate margin processes. Journal of the Geological Society, London, 139, 479-491.

LEEDER, M. R. 1987a. Tectonic and palaeogeographic models for Lower Carboniferous Europe. In MILLER, J., ADAMS, A.E. \& WRIGHT, V.P. (eds). European Dinantian Environments, John Wiley and Sons Chichester, 1-19.

LEEDER, M.R. 1987b. Sediment deformation structures and Palaeo-tectonic analysis of extensional sedimentary basins. In: JONES, M. and PRESTON, R.M.F. (eds) Deformation of Sediments and Sedimentary Rocks. Special Publication of the Geological Society, 29, 137-146.

LEEDER, M. R. 1988. Recent developments in Carboniferous geology: A critical review with implications for the British Isles and NW Europe. Proceedings of the Geologists' Association, 99, 73-100.

LEEDER, M. R. \& GAWTHORPE, R.L. 1987. Sedimentary models for extensional tilt-block/half-graben basins. In: COWARD, M.P., DEWEY, J.F. \& HANCOCK, P.L. (eds). Continental extensional tectonics. Geological Society of London, Special Publication, 28, 139-152.

LEEDER, M. R. \& MCMAHON, A.H. 1988. Upper Carboniferous (Silesian) basin subsidence in northern Britain. In: BESLY, B.M. \& KELLING, G. (eds). Sedimentation in a synorogenic basin complex: The Carboniferous of northwest Europe. Blackie \& Sons, Glasgow, 43-52. 
LEEDER, M. R., FAIRHEAD, D., LEE, A. G., STUART, G., CLEMMEY, H., GREEN, C. \& AL-HADDEH, B. 1989. The Northumberland Basin: an inverted Carboniferous extensional basin. In: GUTTERIDGE $P$., ARTHURTON, R. S. \& NOLAN, S. C. (eds) The role of tectonics in Devonian and Carboniferous sedimentation in the British Isles. Yorkshire Geological Society (Occasional Publication No. 6) 207223.

LEEDER, M. R. \& HARDMAN, M. 1990. Palaeozoic Controls on Southern North Sea Carboniferous Prospectivity. In: HARDMAN, R.P. (ed). Tectonic events responsible for Britain's oil and gas reserves. Geological Society, London, Special Publication, 55, 87-105.

LEEDER, M.R. \& STRUDWICK, A.S. 1987. Delta-marine interactions: a discussion of sedimentary models for Yoredale-type cyclicity in the Dinantian of northern Endland. In: ADAMS, A. E., MILLER, J. \& WRIGHT, V. P. (eds). European Dinantian Environments. John Wiley, Chichester, 139-152.

LEFORT, J.P. 1979. Iberian-Armorican arc and Hercynian Orogeny in Western Europe. Geology, 1, 384-388.

LEES, G. M. \& Cox, P. T. 1937. The geological results of the present search for oil in Great Britain by the D'Arcy Exploration Company Ltd. Quarterly Journal of the Geological Society, 93, 156- 194.

LEES, A \& MILLER J. 1985. Facies variation in Waulsortian buildups, Part 2: Mid Dinantian buildups from Europe and North America. Geological Journal, 20, 159-180.

LEES, G. M. \& TAITT, A.H. 1945. The geological results of the search for oilfields in Great Britain. Quarterly Journal of the Geological Society, London, 101, 255-317. 
LEWIS, C.L.E., GREEN, P.F., CARTER, A. \& HURFORD, A.J. 1992. Elevated K/T palaeotemperatures throughout Northwest England: three kilometres of Tertiary erosion? Earth and Planetary Science Letters, 112, 131-145.

LLEWELLYN, P.G. \& STABBINS, R. 1968. Demonstration: Core material from the Anhydrite series, Carboniferous Limestone, Hathern Borehole, Leicestershire. Proceedings of the Geological Society, London, 1650, 171-186.

LLEWELLYN, P. G., BACKHOUSE, J. \& HOSKIN, I. R. 1969. Lower-Middle Tournasian miospores from the Hathern Anhydrite Series, Carboniferous Limestone, Leicestershire. Proceedings of the Geological Society, London, 1655, 85-91.

LLEWELLYN, P.G. \& STABBINS, R. 1970. The Hathern Anhydrite Series, Lower Carboniferous, Leicestershire, England. Transactions of the Institution of Mining and Metallurgy, 79B, B1-15.

LUMSDEN, G.I., TULLOCH, W., HOWELLS, M.F. \& DAVIES, A. 1967. The geology of the neighbourhood of Langholm. Memoir of the Geological Survey of Great Britain. H.M.S.O., London.

MCCABE, P.J. 1978. The Kinderscoutian Delta (Carboniferous) of northern England: a slope influenced by density currents. In: STANLEY, D.J. \& KELLING, G. (eds) Sedimentation in submarine canyons, fans, and trenches. 116-126.

MACDONALD, R., GASS, K. N., THORPE, R. S. \& GASS, I. G. 1984. Geochemistry and petrogenesis of the Derbyshire Carboniferous basalts. Journal of the Geological Society, London, 141, 159. 
MCKENZIE, D.P. 1981. The variation of temperature with time and hydrocarbon maturation in sedimentary basins formed by extension. Earth and Planetary Science Letters, 55, 87-98.

McKERROW, W.S. and COCKS, L.R.M., 1986. Oceans, island arcs and olistostromes: the use of fossils in distinguishing sutures, terranes and environments around the Iapetus ocean. Journal of the Geological Society London, 143, 185-191.

MARIE, J.P.P. 1975. Rotliegendes stratigraphy and diagenesis. In: The continental shelf of North West Europe. Volume. 1: Geology. Applied Science Publishers.

MATTE, P. 1986. Tectonics and plate tectonics model for the Variscan belt of Europe. Tectonophysics, 126, 329-374.

MAYHEW, R.W. 1978. A sedimentological investigation of the Marsdenian Grits and associated measures in North-east Derbyshire. Unpublished Ph.D. thesis, University of Sheffield.

MAYNARD, J.R. 1992. Sequence stratigraphy of the Upper Yeadonian of northern England. Marine and Petroleum Geology, 9, 197-207.

MAYNARD, J.R. \& LEEDER, M.R. 1992. On the periodicity and magnitude of Late Carboniferous glacio-eustatic sea-level changes. Journal of the Geological Society London, 149, 303-311.

METCALFE, 1. 1981. Conodont zonation and correlation of the Dinantian and Early Namurian strata of the Craven Lowlands of northern England. Report of the Institute of Geological Sciences, 80/10. 
MILLER, J. \& GRAYSON, R. F. 1982. The regional context of Waulsortian facies in N. England. In: BOLTON, K., LANE, H. R. \& LEMONE, D. V. (eds). Symposium on the Environmental Setting and Distribution of the Waulsortian facies. The El Paso Geological Society and University of Texas at El Paso, 17-33.

MILTON, N.J. 1993. Evolving depositional geometries in the North Sea Jurassic rift. In: PARKER, J.R. (ed) Petroleum Geology of Northwest Europe: Proceedings of the 4th Conference. Geological Society, London, 953-974.

MITCHUM, R.U., VAIL, P.R. \& THOMPSON, S. 1977. The depositional sequence as a base unit for stratigraphic analysis. In: PAYTON, C.E. (ed). Seismic stratigraphy applications to hydrocarbon exploration. American Association of Petroleum Geologists Memoir, 26, 53-62.

MONTADERT, L., ROBERTS, D.G., AUFFRET, G.A., BOCK, W., DAPEUBLE, P.A., HAILWOOD, E.A., HARRISON, W., KAGAMI, H., LUMSDEN, D.N., MULLER, C., SCHNITKER, D., THOMPSON, R.W., THOMPSON, T.I. \& TIMOFEEV, P.P. 1977. Rifting and subsidence on passive continental margins in the North East Atlantic. Nature, 268, 305-309.

MOSELEY, F. 1962 The structure of the south-western part of the Sykes anticline, Bowland, Yorkshire. Proceedings of the Yorkshire Geological Society, 33, 287-315.

MOSELEY, F., 1972. A tectonic history of northwest England. Journal of the Geological Society of London, 128, 561-594.

MUNDY, D.J.C. 1980. Aspects of the Palaeoecology of the Craven Reef Belt (Dinantian) of North Yorkshire. Unpublished Ph.D. thesis, University of Manchester. 
NEVES, R., GUEINN, K. J., CLAYTON, G., IOANNIDES, N. \& NEVILLE, R. S. W. 1972. A scheme of miospore zones for the British Dinantian. Compte Rendue $7 m e$. Congres International Stratigraphie Geologie Carbononifere, Krefield, 1, 347-353.

ORD, D.M., CLEMMEY, H. \& LEEDER M.R. 1988. Palaeotectonic analysis of faults in the Carboniferous Solway Basin, SW Scotland. Journal of the Geological Society London 145, 249-259.

PARTINGTON, M.A., MITCHENER, B.C., MILTON, N.J. \& FRASER, A.J. 1993. Genetic sequence stratigraphy for the North Sea Late Jurassic and Early Cretaceous: distribution and prediction of Kimmeridgian-Late Ryazanian reservoirs in the North Sea and adjacent areas. In: PARKER, J.R. (ed) Petroleum Geology of Northwest Europe: Proceedings of the 4th Conference. Geological Society, London, 953-974.

PATCHETT, J.P., GALE, N.H., GOODWYN, R. and HUMM, M.J., 1980. Rb-Sr whole-rock isochron ages of Late Pre-Cambrian to Cambrian igneous rocks

PERROUD, H, VAN DER VOO, R. and BONHOMMET, N., 1984. Palaeozoic evolution of the Armorican plate on the basis of Palaeomagnetic data. Geology, 2, 579582.

PHAROAH, T. C., MERRIMAN, R. J., WEBB, P. C. \& BECKINSDALE, R. D. 1987. The concealed Caledonides of eastern England: preliminary results of a multidisciplinary study. Proceedings of the Yorkshire Geological Society, 46, 355-369. 
POSAMENTIER, H.W., JERVEY M.T. \& VAIL, P.R.. 1988. Eustatic controls on clastic deposition 1-conceptual framework. In: WILGUS, B.J., HASTINGS, J. POSAMENTIER, H., VAN WAGONER, J.C., ROSS, C.A. \& KENDALL, C.G.ST C.(eds) Sea-level Change - an Integrated Approach, Special Publication of the Economic Society of Palaeontologists and Mineralogists, 42, 109-124.

PRENTICE, J. E. \& THOMAS, J. M. 1965. Prolecanhna from the Carboniferous rocks of north Devon. Proceedings of the Yorkshire Geological Society, 35, 33-46.

RAMSBOTTON, W.H.C. 1969. The Namurian of Britain. G.R. 6th Cong. Int. Strat. Geol. Carb., Sheffield 1967, 1, 219-232.

RAMSBOTTOM, W. H. C. 1973. Transgressions and regressions in the Dinantian: a new synthesis of British Dinantian stratigraphy. Proceedings of the Yorkshire Geological Society, 39, 567-607.

RAMSBOTTOM, W.H.C. 1974. Dinantian. In: RAYNER, D. H. \& HEMMINGWAY, J. E. (eds) The geological and mineral resources of Yorkshire. Yorkshire Geological Society, 47-73.

RAMSBOTTOM, W. H. C. 1977. Major cycles of transgression and regression (mesothems) in the Namurian. Proceedings of the Yorkshire Geological Society, 41, 261-291.

RAMSBOTTOM, W. H. C. 1981. Eustacy, sea level and local tectonics, with examples from the British Carboniferous. Proceedings of the Yorkshire Geological Society, 43, 473-482. 
RAMSBOTTOM, W. H. C., CALVER, M. A., EAGAR, R. M. C., HODSON, E., HOLLIDAY, D., STUBBLEFIELD, C. J. \& WILSON, R. B. 1978. A correlation of Silesian rocks in the British Isles. Geological Society, London, Special Report 10.

READ, W.A. 1988. Controls on Silesian sedimentation in the Midland valley of Scotland. In: BESLY, B.M.\& KELLING, G. (eds) Sedimentation in Synorogenic Basin complex: the Upper Carboniferous of Northwest Europe. Blackie, Glasgow. 222-241.

READ, W.A. 1991. The Millstone Grit (Namurian) of the southern Pennines viewed in the light of eustatically controlled sequence stratigraphy. Geological Journal , 26, 157165.

READING, H.G. 1964. A review of the factors affecting the sedimentation of the Millstone Grit (Namurian) in the Central Pennines. In: VAN STRAATEN, L.M.J.U., (ed). Deltaic and Shallow Marine Deposits. Elsevier, Amsterdam.

ROSENDAHL, B.R., REYNOLDS, D.J., LORBER, P.M., BURGESS, C.F., MCGILL, J., SCOTT, D., LAMBIASE, J. \& DERKSEN, S.J. 1986. Structural expressions of rifting: lessons from Lake Tanganyika, Africa. In: FROSTICK, L.E., RENTANT, R.W., REID, I. \& TIERCELIN, J.J. (eds) Sedimentation in the African Rifts. Geological Society of London Special Publication, 25, 29-44.

ROTHWELL, N.R. \& QUINN, P. 1987. The Welton Oilfield. In: BROOKS, J. \& GLENNIE, K. (eds). Petroleum Geology of North West Europe. Graham and Trotman, London. 181-189.

SADLER, H.E. 1964. The origin of the 'Beach Beds' in the Lower Carboniferous of Castleton, Derbyshire. Geological Magazine, 101, 360-372. 
SANDERSON, D.J. 1984. Structural variations across the northern margins of the Variscides in NW Europe. In: HUTTON, D.H.W. \& SANDERSON, D.J. (eds) Variscan tectonics of the North Atlantic region. Geological Society London Special Publication, 14, 149-165.

SCHOFIELD, K. 1982. Sedimentology of the Woo Dale Limestone Formation, Derbyshire. Unpublished Ph.D. thesis. University of Manchester.

SCHOFIELD, K. \& ADAMS, A.E. 1985. Stratigraphy and depositional environments of the Woo Dale Limestones Formation (Dinantian), Derbyshire. Proceedings of the Yorkshire Geological Society, 45, 225-233.

SCOTESE, C., BAMBACH, R.F., BARTON, C., VAN DER VOO, R \& ZIEGLER, A. 1979. Palaeozoic base maps. Journal of Geology , 87, 217-278.

SELLWOOD, E.B. \& THOMAS, J.M. 1986. Variscan facies and structure in central SW England. Journal of the Geological Society, London, 143, 199-207.

SHACKLETON, R.M., 1954. The structural evolution of North Wales. Liverpool and Manchester Geological Journal, 1, 261-297.

SISSONS, J. B. 1954. The erosion surfaces and drainage system of S. W. Yorkshire. Proceedings of the Yorkshire Geological Society, 29, 305-342.

SMITH, A.G., HURLEY, A.M. \& BRIDEN, J.C. 1981. Phanerozoic Palaeocontinental World maps. Cambridge University Press. Cambridge.

SMITH, K., SMITH, N.J.P. \& HOLLIDAY, D. 1985. The deep structure of Derbyshire. Geological Journal, 20, 215-225. 
SOMERVILLE, I. D. \& STRANK, A. R. E. 1984. Discovery of Arundian and Holkerian faunas from a Dinantian platform succession in North Wales. Geological Journal, 19, 85-104.

SOPER, N.J. \& HUTTON, D.H.W. 1984. Late Caledonian sinistral displacements in Britain: Implications for a three plate collision model. Tectonics, 3, 781-794.

SOPER, N.J., WEBB, B.C. \& WOODCOCK, N.H. 1987. Late Caledonian (Acadian) transpression in North West England: timing, geometry and geotectonic significance. Proceedings of the Yorkshire Geological Society, 46, 175-192.

STEELE, R.P. 1988. The Namurian sedimentary history of the Gainsborough Trough. In: BESLY, B.M. \& KELLING, G.(eds) Sedimentation in a Synorogenic Basin Complex: the Upper Carboniferous of Northwest Europe Blackie, Glasgow \& London, 102-113.

STEIN, R.S. \& BARIENTOS, S.E. 1985. Planer high angle faulting in the Basin and Range: Geodetic analysis of the 1983 Borah Peak, Idaho, earthquake. Journal of Geophysical Research, 90, 11355-11366.

STEVENSON, I.P. \& GAUNT, G.D. 1971. Geology of the country around Chapelen-le-Frith. Memoir of the British Geological Survey. 99, H.M.S.O., London.

STOREY, M.W. \& NASH, F.W. 1983. The Eakring Dukeswood oil field: an unconventional technique to describe a field's geology. In: PARKER, J.R. (ed) Petroleum Geology of Northwest Europe: Proceedings of the 4th Conference, Geological Society of London, 1527-1537. 
STRANK, A. R. E. 1981. Foraminiferal biostratigraphy of the Holkerian. Asbian and Brigantian stages of the British Lower Carboniferous. Unpublished Ph.D. Thesis, University of Manchester.

STRANK, A. R. E.1985. The Dinantian biostratigraphy of a deep borehole near Eyam, Derbyshire. Geological Journal, 20, 227-237.

STRANK, A. R. E. 1986. Foraminiferal biostratigraphy of the Woo Dale borehole, Derbyshire and the age of the Dinantian-Basement unconformity. Journal of Micropalaeontology, 5, 1-4.

STRANK, A. R. E. 1987. The stratigraphy and structure of Dinantian strata in the East Midlands, UK. In: ADAMS, A. E., MILLER, J. \& WRIGHT, V. P. (eds). European Dinantian Environments. John Wiley, Chichester, 157-175.

STRUDWICK, A.E. 1987. A study of delta-marine interactions with particular reference to the Carboniferous. Unpublished Ph. D. thesis, University of Leeds.

STYLES, M.T. \& RUNDLE, C.C. 1984. The Rb-Sr isochron age of the Kennack Gneiss and its bearing on the age of the Lizard Complex, Cornwall. Journal of the Geological Society London, 141, 15-19.

THORPE, R. S., BECKINSDALE, R. D., PATCHELT, P. J., PIPER, J. D. A., DAVIES, G. R. \& EVANS, J. A. 1984. Crustal growth and Late Precambrian-Early Palaeozoic plate tectonic evolution of England and Wales. Journal of the Geological Society, 141, 521-536.

TISSOT, B.P. \& WELTE, D.A. 1984. Petroleum formation and occurrence. (second edition). Springer Verlag. 
TURNER, J.S. 1949. The deeper structure of Central and northern England. Proceedings of the Yorkshire Geological Society, 27, 280-297.

UNDERHILL, R. \& PARTINGTON M.A. 1993. Jurassic thermal doming and deflation in the North Sea: implications of the sequence stratigraphic evidence. In: PARKER, J.R. (ed) Petroleum Geology of Northwest Europe. Proceedings of the 4th Conference. Geological Society, London, 337-345.

VAN HOORN, B. 1987. Structural evolution, timing and tectonic style of the Sole Pit inversion. Tectonophysics, 137, 239-284.

VAIL, P.R. \& MITCHUM, R.M. 1977. Seismic stratigraphy and global changes of sea level, Part 1: overview. In: PAYTON, C.E. (ed). Seismic stratigraphy - applications to hydrocarbon exploration, American Association of Petroleum Geologists, Memoir 26, $51-52$.

VAN WAGONER, J.C., MITCHUM, R.M., VAIL P.R., SARG, J.F., LOUTIT,T.S. \& HARDENBOL, J. 1988. An overview of the fundamentals of sequence stratigraphy and key definitions. In: WILGUS, B.J., HASTINGS, J. POSAMENTIER, H., VAN WAGONER, J.C., ROSS, C.A. \& KENDALL, C.G.ST C. (eds) Sea-level Change - an Integrated Approach, Special Publication of the Economic Society of Palaeontologists and Mineralogists, 42, 39-45.

VAN WAGONER, J.C., MITCHUM, R.M.,CAMPION R.M. \& RAHMANIAN, V.D. 1990. Siliciclastic sequence stratigraphy in well logs, cores and outcrops. American Association of Petroleum Geologists. Methods in Exploration Series. 7. 
VARKER, W. J. \& SEVASTOPULO, G. D. 1985. The Carboniferous System, Part 1Conodonts of the Dinantian Subsystems from Great Britain and Ireland, In: HIGGINS, A. C. \& AUSTIN, R. L. (eds) A stratigraphical index of conodonts. British Micropalaeontological Society Series, Ellis Horwood, Chichester, 167-209.

VAUGHAN, A. 1905. The palaeontological sequence in the Carboniferous Limestone of the Bristol area. Quarterly Journal of the Geological Society of London, 61, 181-307.

WALKDEN, G. M. 1977. Volcanic and erosive events on an Upper Visean carbonate platform, north Derbyshire. Proceedings of the Yorkshire Geological Society, 41, 347367.

WALKDEN, G.M. 1987. Sedimentation and diagenetic style in the late Dinantian carbonates of Britain. In: MILLER, J., ADAMS, A.E.\& WRIGHT V.P. (eds) European Carbonate Environments, Wiley, Chichester, 131-156.

WALKDEN, G. M. 1982. Field guide to the Lower Carboniferous rocks of the south east margin of the Derbyshire Block: Wirksworth to Grangemill. Publication of the Department of Geology and Mineralogy, University of Aberdeen.

WALKDEN, G.M. \& DAVIES J. 1983. Polyphase erosion of subaerial omission surfaces in the late Dinantian of Anglesey, North Wales. Sedimentology, 30, 861-878.

WALSH, P. T., BOULTER, M. C., IJTABA, M. \& URBAN, D. M. 1972. The preservation of the Neogene Brassington formation of the Southern Pennines and its bearing on the evolution of Upland Britain. Journal of the Geological Society, 128, 519559. 
WALTERS, S.G. \& INESON, P.R. 1981. A review of the distribution and correlation of igneous rocks in Derbyshire, England. Mercian Geologist , 8, 81-132.

WATSON, J. 1980. Flaws in the continental crust. Mercian Geologist, 8, 1-10.

WATTS, M.J. \& WILLIAMS, G.D. 1979. Fault Rocks as indicators of progressive shear deformation in the Guingamp region, Brittany. Journal of Structural Geology, 1, 323-332.

WEDERPOHL, K.H., MEYER, K. \& MUCKE, C.K. 1983. Chemical composition and genetic relations of meta-volcanic rocks from the Rhenohercynian belt of northwest Germany. In: MARTIN, H \& EDER, F.W. (eds) Intracontinental fold belts, case studies in the Variscan Belt of Europe and the Damara Belt in Namibia. Springer-Verlag, Berlin. 231-256.

WELSH, A. \& OWENS, B. 1983. Early Dinantian miospore assemblages from the Caldon Low Borehole, Stratfordshire, England. Pollen et Spora, 25, 253-264.

WHEILDON, J. \& ROLLIN, K. E. 1986. Heat flow. In: DOWNING, R. A. \& GRAY, D. A. (eds). Geothermal Energy - The Potential in the United Kingdom, H.M.S.O., London, 8-20.

WHITTAKER, A. (ed). 1985. Atlas of onshore sedimentary basins in England and Wales: Post Carboniferous tectonics and stratigraphy. Blackie, Glasgow.

WILLS, L.J. 1951. A palaeographical atlas of the British Isles and adjacent parts of Europe. Blackie and Son Ltd, London. 
WILLS, L.J., 1956. Concealed Coalfields. A palaeogeographic study of the stratigraphy and tectonics of Mid-England in relation to coal reserves. Blackie \& Sons Glasgow .

WILLS, L. J. 1973. A palaeogeographical map of the Palaeozoic floor beneath the Permian and Mesozoic formations in England and Wales. Memoir of the Geological Society of London, 7.

WILLS, L. J. 1978. A palaeogeographic map of the Lower Palaeozoic floor below the cover of Upper Devonian, Carboniferous and later formations. Memoir of the Geological Society, London, 8.

WILSON, A.A. and CORNWELL, J.D. 1982. The Institute of Geological Sciences borehole at Beckermonds Scar, North Yorkshire. Proceedings of the Yorkshire Geological Society, 44, 59-88.

WOODCOCK, N.H., 1984. Early Palaeozoic sedimentation and tectonics in Wales. Proceedings of the Geological Association, 95, 323-335.

WOOLACOTT, D. 1923. On a boring at Roddymoor Colliery, near Crook, County Durham. Geological Magazine, 60, 50-62.

ZIEGLER, P. A. 1978. North-Western Europe: tectonics and basin development. Geologie en Mijnbouw, 57, 589-626.

ZIEGLER, P. A. 1981. Evolution of sedimentary basins in northwest Europe. In: ILLING, L. V. \& HOBSON, G. D. (eds). Petroleum geology of the Continental Shelf of North-West Europe, Heyden, London, 3-39. 
ZIEGLER, P. A. 1982. Geological Atlas of Western and Central Europe. Shell International Petroleum Maatschappij B. V., The Hague.

ZIEGLER, P. A. 1986. Geodynamic model for the Palaeozoic crustal consolidation of Western and Central Europe. Tectonophysics, 126, 303-328. 
Appendix A

Northern England Carboniferous

Borehole data base with Dinantian facies \& Carbonate reservoir production data. 


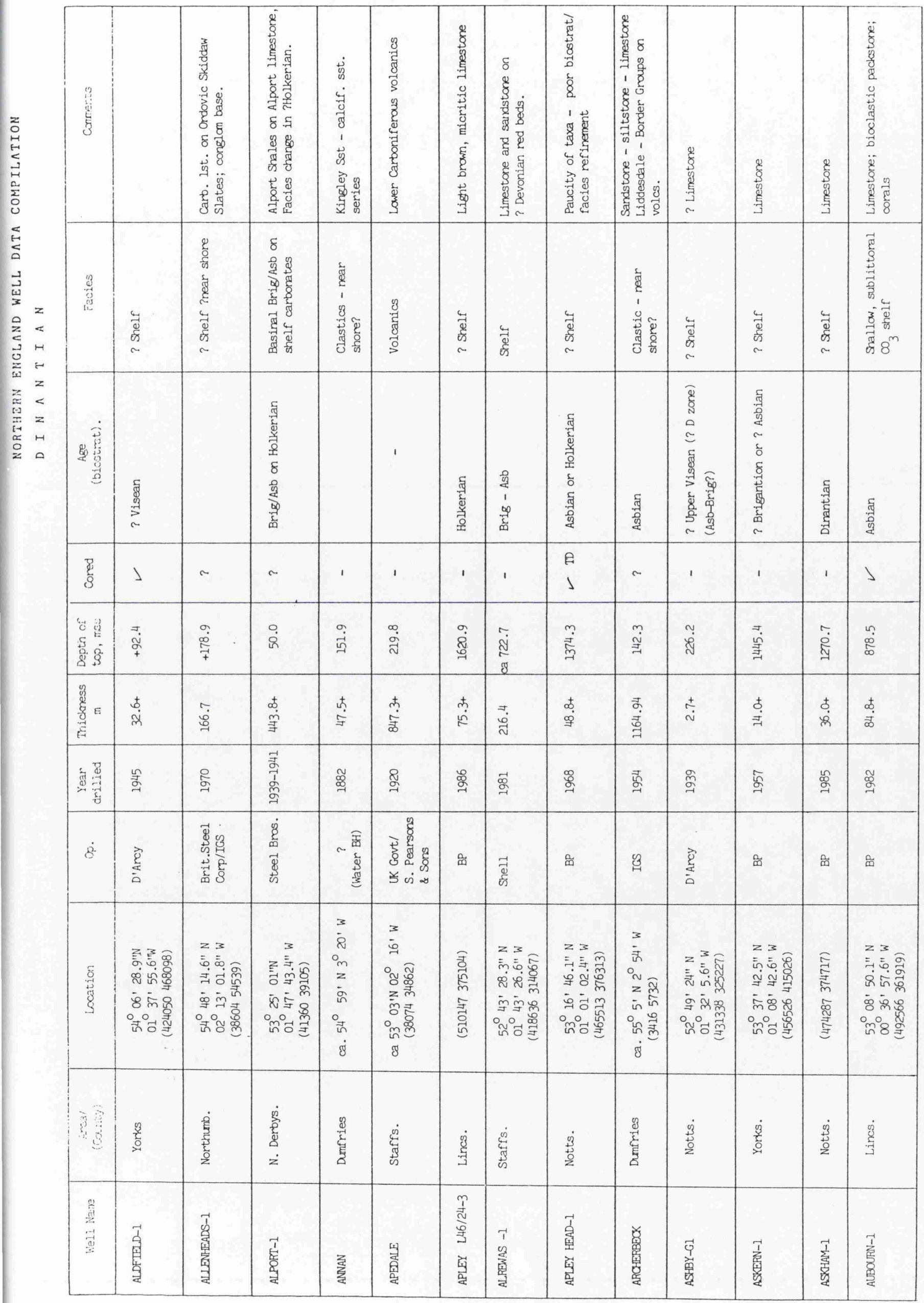




\begin{tabular}{|c|c|c|c|c|c|c|c|c|c|c|c|}
\hline $\begin{array}{l}3 \\
\text { 蓝 } \\
3\end{array}$ & 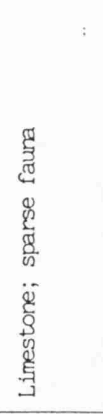 & 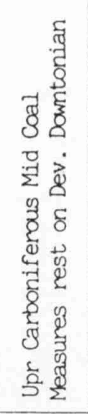 & 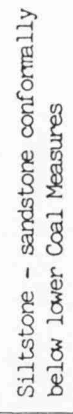 & 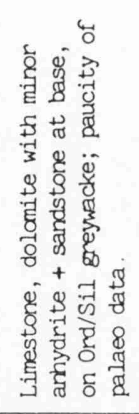 & 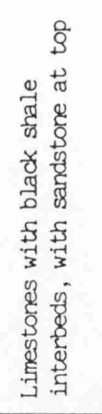 & 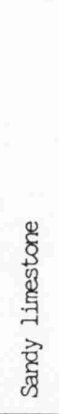 & 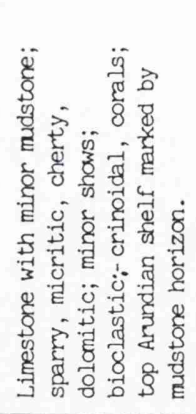 & 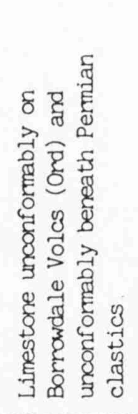 & 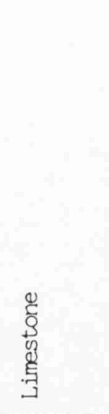 & 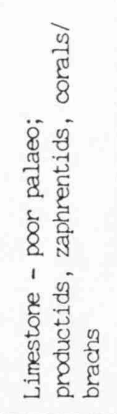 & $\begin{array}{l}\frac{3}{3} \\
\pi \\
8 \\
8 \\
\frac{\pi}{8} \\
8 \\
8 \\
8 \\
8 \\
0 \\
0 \\
\frac{5}{9}\end{array}$ \\
\hline 量 & 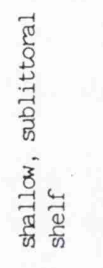 & 1 & 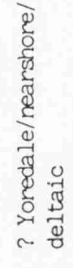 & $\begin{array}{l}\breve{~} \\
\dot{\tilde{\xi}}\end{array}$ & 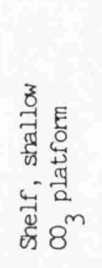 & $\begin{array}{l}\breve{\mathscr{\varpi}} \\
\text { है }\end{array}$ & $\begin{array}{l}\breve{\varpi} \\
\text { है }\end{array}$ & $\begin{array}{l}\text { पू } \\
\text { है } \\
\text { के }\end{array}$ & 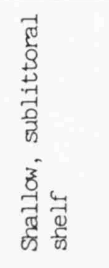 & $\begin{array}{l}\breve{\widetilde{J}} \\
\ddot{\sigma}\end{array}$ & 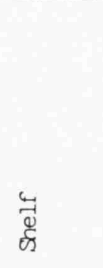 \\
\hline 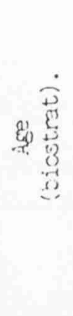 & $\begin{array}{l}\text { 䒜 } \\
08 \\
9 \\
9 \\
9\end{array}$ & 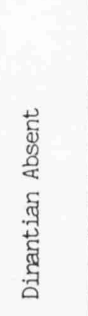 & 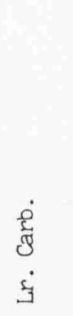 & 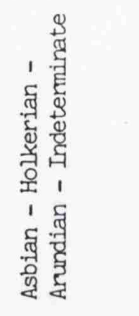 & 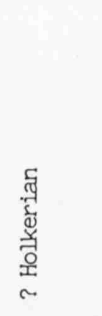 & $\begin{array}{l}\text { 蛋 } \\
\text { 忽 } \\
\text { 至 }\end{array}$ & 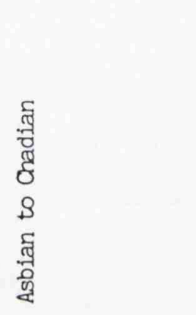 & 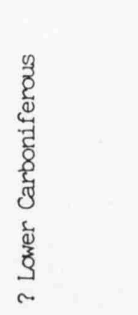 & 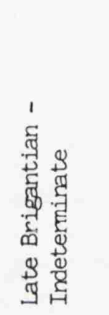 & 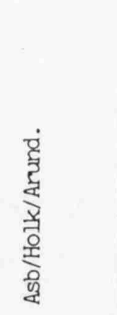 & 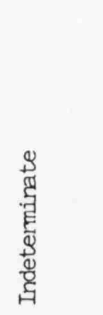 \\
\hline $\begin{array}{l}3 \\
3 \\
3\end{array}$ & $\stackrel{1}{a}$ & & $\sim$ & 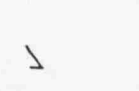 & $>$ & $\omega$ & $>$ & 1 & $\lambda$ & $\Delta$ & 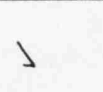 \\
\hline 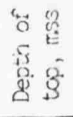 & $\stackrel{m}{\vec{B}}$ & $\circ$ & $\begin{array}{l}\text { 吕 } \\
\text { 离 }\end{array}$ & 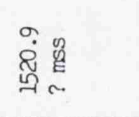 & $\begin{array}{l}\text { บุ } \\
\stackrel{3}{3}\end{array}$ & 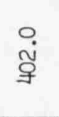 & ங் & 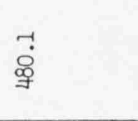 & 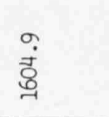 & $\underset{m}{\stackrel{m}{\tilde{5}}}$ & †ే \\
\hline 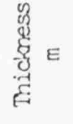 & ڤ્ & ○ & $\begin{array}{l}\text { 表 } \\
\text { 弯 }\end{array}$ & 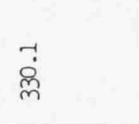 & & 志 & $\begin{array}{l} \pm \\
\text { 寺 } \\
\text { g }\end{array}$ & 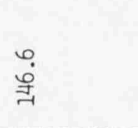 & 孛 & $\begin{array}{l}\stackrel{d}{.} \\
\dot{d}\end{array}$ & $\begin{array}{l}+ \\
\stackrel{+}{+} \\
\stackrel{9}{-1}\end{array}$ \\
\hline 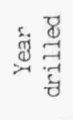 & F & 荅 & $\stackrel{8}{్}$ & \& & 举 & 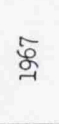 & $\underset{G}{\mathbb{G}}$ & $\omega$ & ま & ळ్తి & \& \\
\hline$\dot{8}$ & 衰 & $\begin{array}{l}\text { च. } \\
\text { है }\end{array}$ & 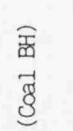 & 嵒 & $\begin{array}{l}\vec{y} \\
\text { 产 } \\
\dot{a}\end{array}$ & $\underset{G}{\mathscr{G}}$ & $\begin{array}{l}\text { 商 } \\
\text { 是 }\end{array}$ & 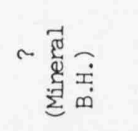 & 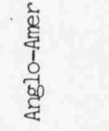 & 苗 & 㽞 \\
\hline 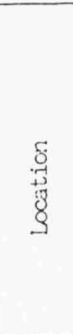 & 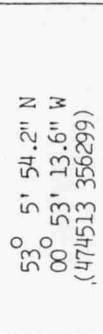 & 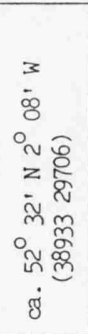 & 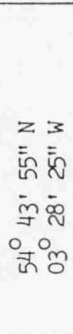 & 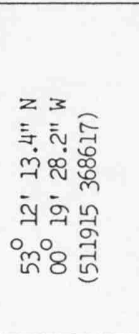 & 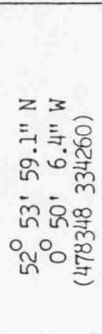 & 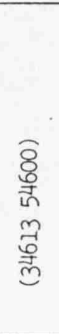 & 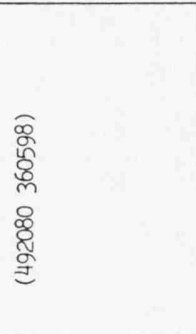 & 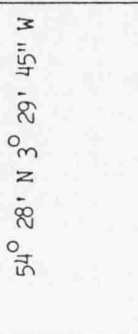 & 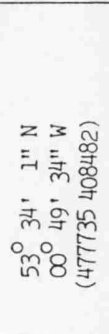 & 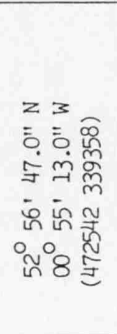 & 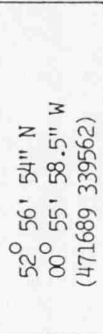 \\
\hline 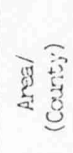 & 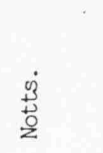 & 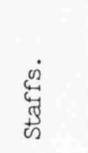 & 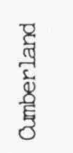 & \&్ & 官 & 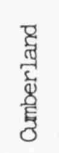 & 宅 & 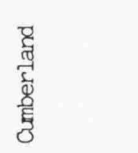 & $\begin{array}{l}\dot{\xi} \\
\dot{y}\end{array}$ & $\begin{array}{l}\dot{3} \\
\text { 䓂 }\end{array}$ & $\begin{array}{l}\dot{y} \\
\stackrel{3}{3} \\
\stackrel{2}{z}\end{array}$ \\
\hline 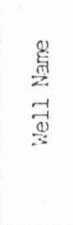 & 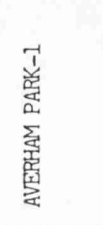 & 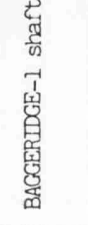 & 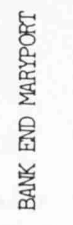 & 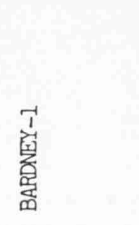 & 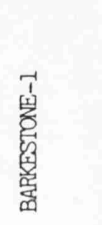 & 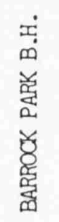 & 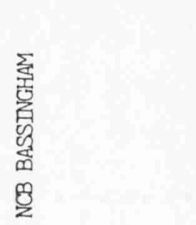 & 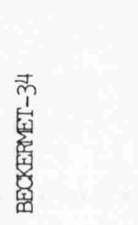 & 章 & $\begin{array}{l}\text { 窔 } \\
\text { 空 } \\
\text { 音 }\end{array}$ & $\begin{array}{l}\text { 紊 } \\
\text { 空 } \\
\text { 竞 }\end{array}$ \\
\hline
\end{tabular}




\begin{tabular}{|c|c|c|c|c|c|c|c|c|c|c|c|c|c|}
\hline 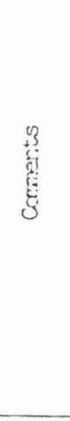 & 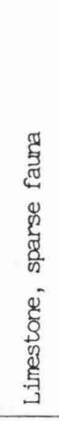 & 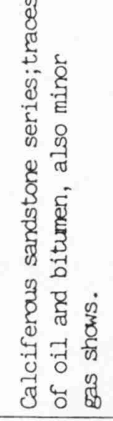 & 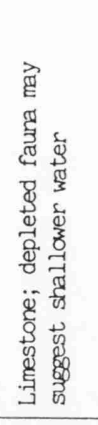 & 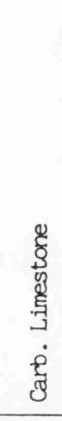 & 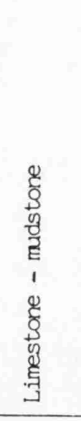 & 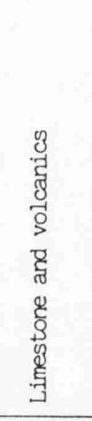 & 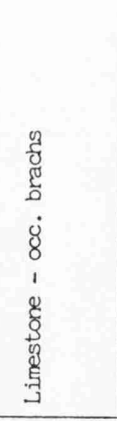 & 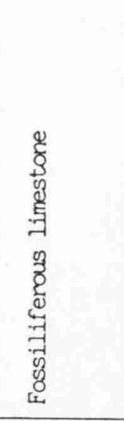 & & $\begin{array}{l}\frac{\pi}{3} \\
\frac{7}{3} \\
8 \\
\frac{\pi}{2} \\
8 \\
2 \\
\end{array}$ & 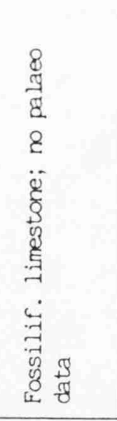 & 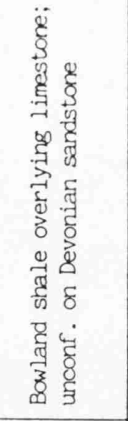 & 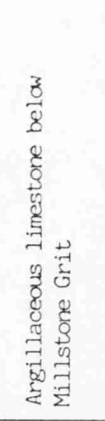 \\
\hline 造 & 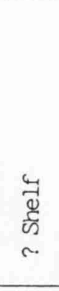 & 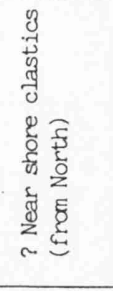 & $\begin{array}{l}y \\
\frac{y}{5} \\
\frac{5}{5} \\
\frac{9}{3} \\
\frac{3}{3} \\
\frac{\pi}{2}\end{array}$ & 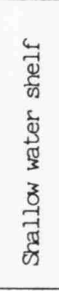 & 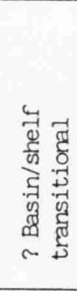 & 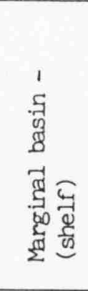 & 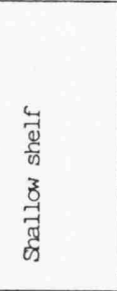 & 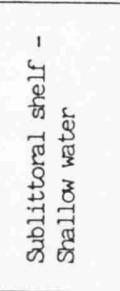 & $\begin{array}{l}\text { 乌్ } \\
\text { ळू }\end{array}$ & 1 & $\begin{array}{l}\stackrel{\breve{\Xi}}{~} \\
\text { ตे }\end{array}$ & 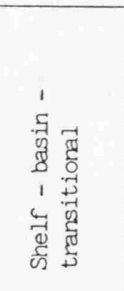 & 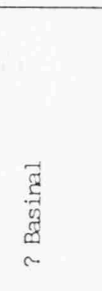 \\
\hline 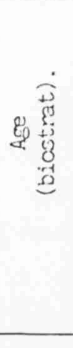 & 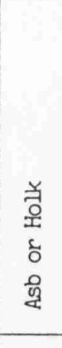 & & 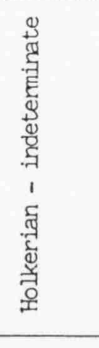 & $\sim$ & & 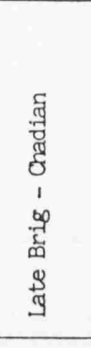 & 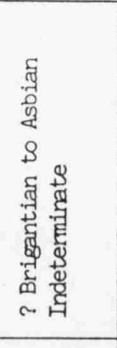 & 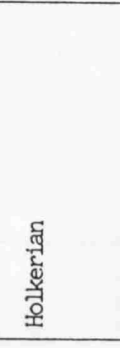 & 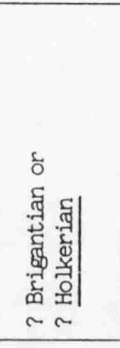 & 1 & 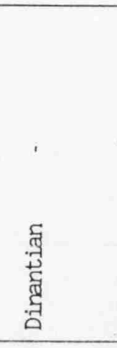 & 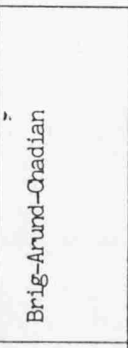 & $\begin{array}{l}\text { है } \\
\text { है } \\
5 \\
\end{array}$ \\
\hline $\begin{array}{l}8 \\
8 \\
8\end{array}$ & $>$ & & & , & 1 & . & 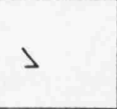 & & $\lambda$ & 1 & 1 & 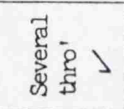 & , \\
\hline 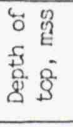 & 莣 & †े & †̆ & $\begin{array}{l}\stackrel{m}{\mathcal{D}} \\
\stackrel{\infty}{\infty}\end{array}$ & 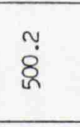 & $\begin{array}{l}\text { के } \\
\dot{\phi} \\
\dot{q}\end{array}$ & 욝 & $\begin{array}{l}\text { Pे } \\
\text { まे }\end{array}$ & $\begin{array}{l}\text { జे } \\
\tilde{\tilde{~}}\end{array}$ & $\begin{array}{l}\stackrel{\circ}{\dot{d}} \\
\stackrel{\text { g }}{ }\end{array}$ & 형 & $\begin{array}{l}\infty \\
\text { జू. } \\
\text { On }\end{array}$ & $\begin{array}{l}\dot{\infty} \\
\dot{\infty}\end{array}$ \\
\hline 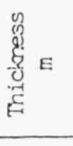 & $\begin{array}{l}\stackrel{+}{+} \\
\text { 足 }\end{array}$ & $\stackrel{+}{\stackrel{+}{*}}$ & $\stackrel{+}{\stackrel{\varpi}{m}}$ & $\underset{\sim}{+}$ & $\begin{array}{l}+ \\
\text { 岁 } \\
\text { \& }\end{array}$ & 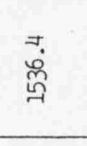 & $\begin{array}{l}+ \\
\dot{8} \\
\dot{8}\end{array}$ & $\stackrel{+}{\stackrel{+}{ే}}$ & $\begin{array}{l}+ \\
\stackrel{+}{\circ} \\
\stackrel{-1}{2}\end{array}$ & $\underset{\text { m. }}{+⿱ 乛 龰}$ & $\stackrel{ \pm}{\stackrel{ \pm}{\oplus}}$ & 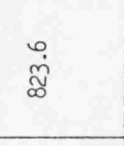 & $\begin{array}{l}+ \\
0 \\
\infty \\
2\end{array}$ \\
\hline 过苛 & $\underset{\sim}{\stackrel{్}{\sigma}}$ & き & 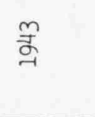 & 券 & c. & $\underset{\Im}{\mathscr{\Im}}$ & 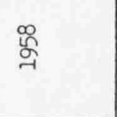 & 巻 & 旁 & 番 & 䒯 & $\underset{\mathscr{q}}{\mathscr{q}}$ & $\stackrel{\aleph}{\alpha}$ \\
\hline$\dot{8}$ & 嵒 & 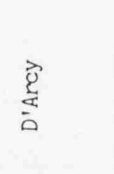 & 產 & 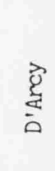 & $\cdots$ & 奠 & 茴 & 衰 & 衰 & 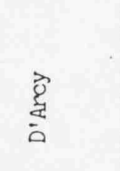 & 衰 & 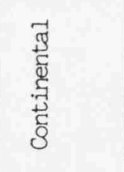 & $\frac{8}{2}$ \\
\hline 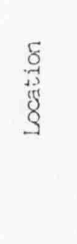 & 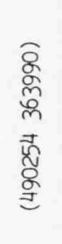 & 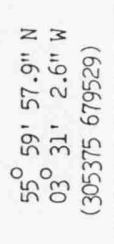 & 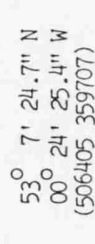 & 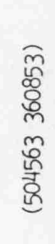 & 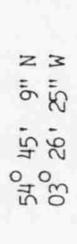 & 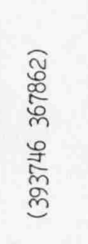 & 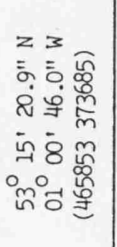 & 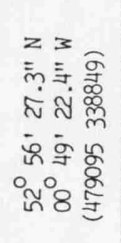 & 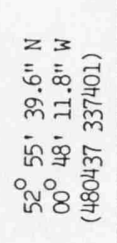 & 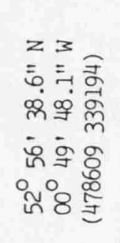 & 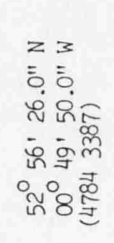 & 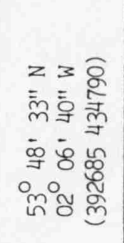 & 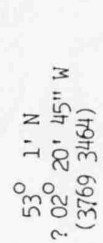 \\
\hline 施离 & $\begin{array}{l}\dot{\xi} \\
\dot{y} \\
\end{array}$ & 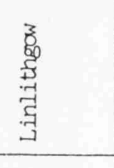 & छ் & 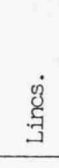 & 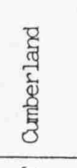 & 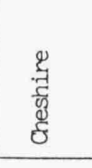 & $\begin{array}{l}\dot{3} \\
+1 \\
2 \\
2\end{array}$ & $\begin{array}{l}\dot{y} \\
\dot{3}\end{array}$ & $\begin{array}{l}\ddot{g} \\
\dot{9} \\
\dot{9}\end{array}$ & $\begin{array}{l}0 \\
9 \\
9\end{array}$ & $\begin{array}{l}\dot{g} \\
\dot{\Xi} \\
\end{array}$ & $\begin{array}{l}\dot{y} \\
\text { छ़ } \\
\end{array}$ & 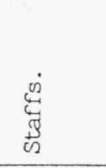 \\
\hline 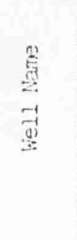 & 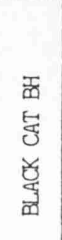 & 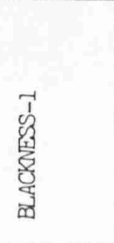 & $\begin{array}{l}\overrightarrow{1} \\
\text { 禀 } \\
\text { 产 }\end{array}$ & 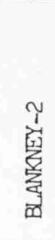 & 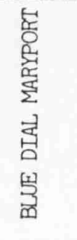 & 竞 & 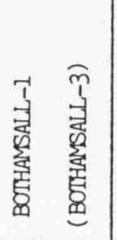 & $\begin{array}{l}\overrightarrow{1} \\
\text { 兽 } \\
\text { 赛 }\end{array}$ & 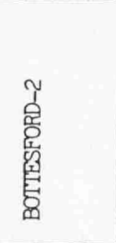 & 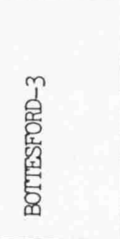 & 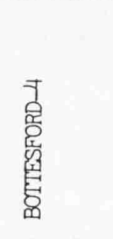 & 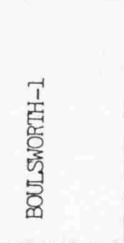 & 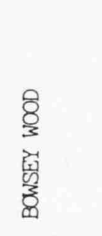 \\
\hline
\end{tabular}




\begin{tabular}{|c|c|c|c|c|c|c|c|c|c|c|c|c|c|}
\hline 量 & 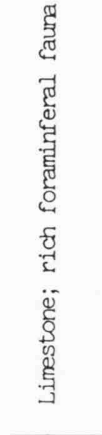 & 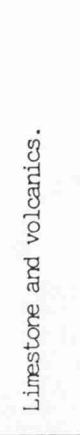 & 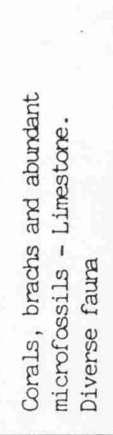 & $\begin{array}{l}8 \\
5 \\
0 \\
\text { 量 } \\
\end{array}$ & 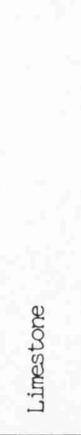 & 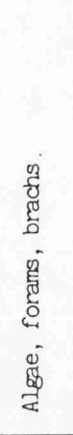 & 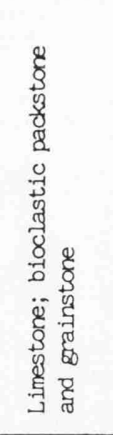 & 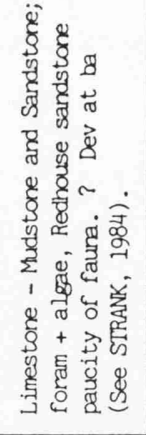 & 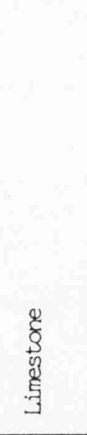 & 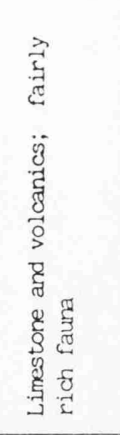 & 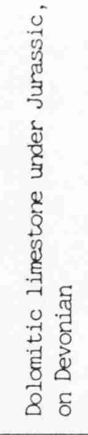 & 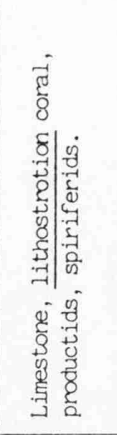 & 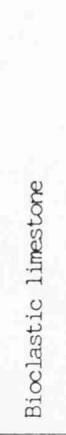 \\
\hline 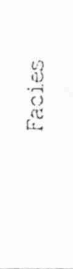 & $\begin{array}{l}\frac{y}{y} \\
\frac{y}{w} \\
\frac{z}{7} \\
\text { क्ष }\end{array}$ & 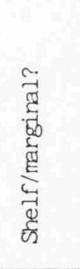 & 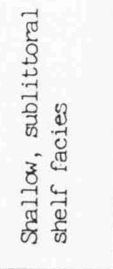 & 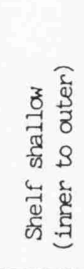 & 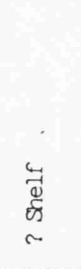 & 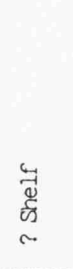 & 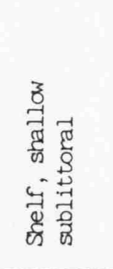 & 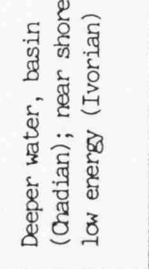 & 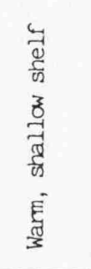 & 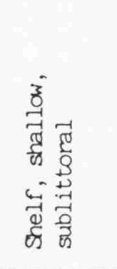 & $\begin{array}{l}\frac{4}{7} \\
\text { के } \\
\text { के }\end{array}$ & 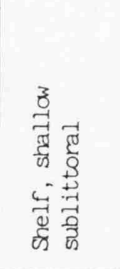 & 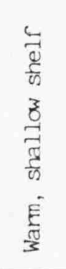 \\
\hline 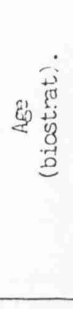 & 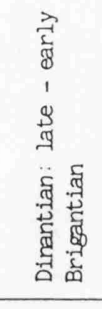 & 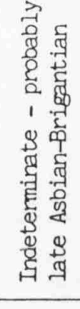 & 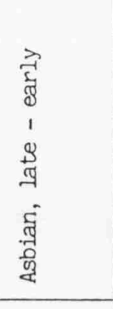 & 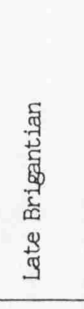 & 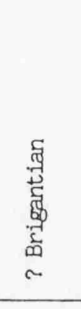 & 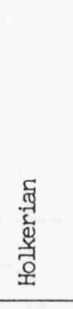 & 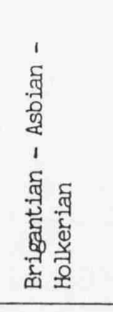 & 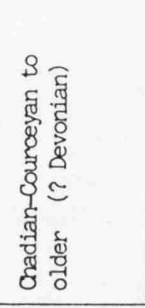 & 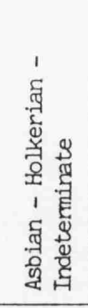 & 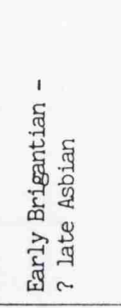 & 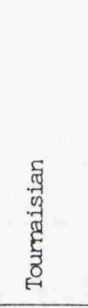 & 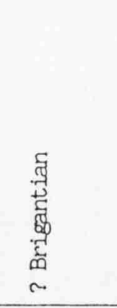 & 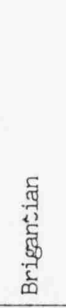 \\
\hline 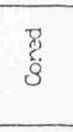 & 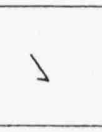 & ' & 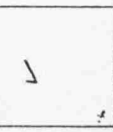 & 1 & ' & & 1 & 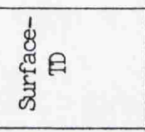 & 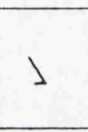 & 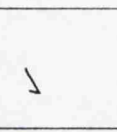 & 1 & 1 & 1 \\
\hline 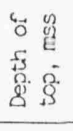 & $\begin{array}{l}0 \\
\stackrel{0}{0} \\
\infty \\
\infty\end{array}$ & 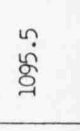 & 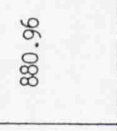 & & 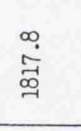 & 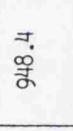 & 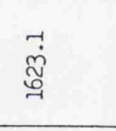 & 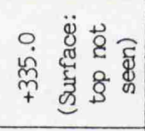 & 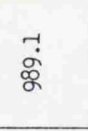 & 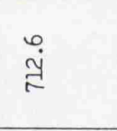 & ֻั & 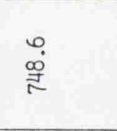 & †े \\
\hline $\begin{array}{l}\text { on } \\
\text { 量 } \mathrm{E} \\
\text { है }\end{array}$ & $\stackrel{+}{\stackrel{+}{q}}$ & $\begin{array}{l}+ \\
\stackrel{0}{m} \\
\text {. }\end{array}$ & 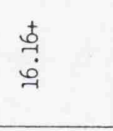 & & 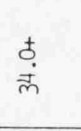 & $\begin{array}{l}+ \\
\stackrel{0}{-} \\
\stackrel{-}{7}\end{array}$ & $\stackrel{+}{\stackrel{\leftrightarrow}{\sim}}$ & 青 & 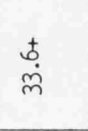 & 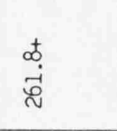 & 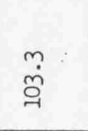 & $\begin{array}{l}\text { ț. } \\
\text { के }\end{array}$ & $\begin{array}{l}\stackrel{+}{+} \\
\ddot{\sim}\end{array}$ \\
\hline 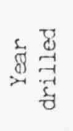 & $\overrightarrow{\stackrel{\Xi}{\sigma}}$ & 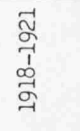 & 志 & 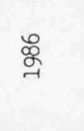 & 㞼 & 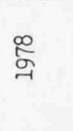 & 怘 & స్త్ & 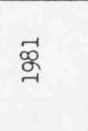 & 条 & $\alpha$ & 亭 & 表 \\
\hline$\dot{8}$ & 藏 & $\begin{array}{l}\vec{\xi} \\
\overrightarrow{0}\end{array}$ & & 무 & 嵒 & $\underset{Z}{\mathscr{O}}$ & 吕 & ב్고 & $\frac{Q}{z}$ & 范 & $\dot{8}$ & 褰 & \\
\hline 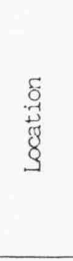 & 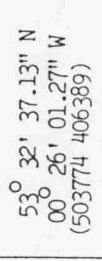 & 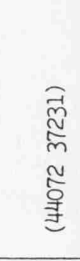 & 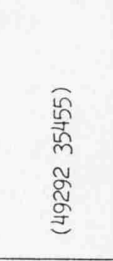 & 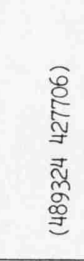 & 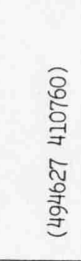 & 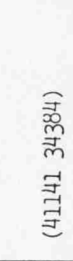 & 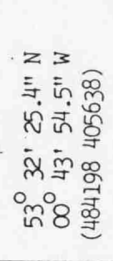 & 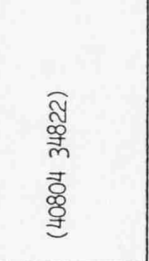 & 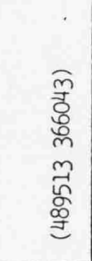 & 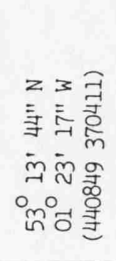 & 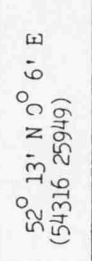 & 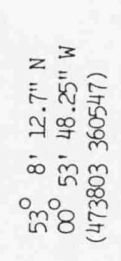 & 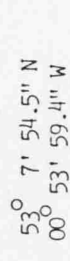 \\
\hline 害产 & 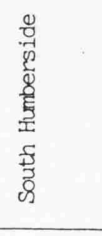 & 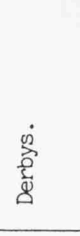 & 宅 & 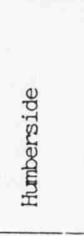 & 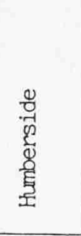 & $\begin{array}{l}\dot{y} \\
\dot{y}\end{array}$ & 宓 & 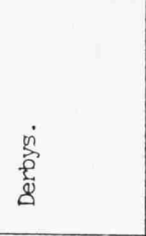 & $\begin{array}{l}\dot{\xi} \\
\dot{y}\end{array}$ & $\begin{array}{l}\text { 离 } \\
\text { 要 }\end{array}$ & 屌 & $\begin{array}{l}\dot{3} \\
+3 \\
\dot{0} \\
z\end{array}$ & 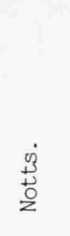 \\
\hline 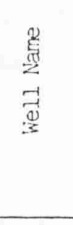 & $\begin{array}{l}\overrightarrow{1} \\
\text { ch } \\
\text { 畐 }\end{array}$ & 音 & 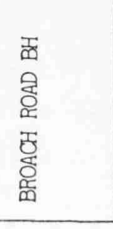 & 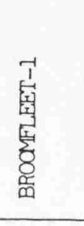 & 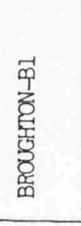 & 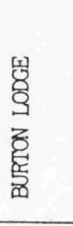 & 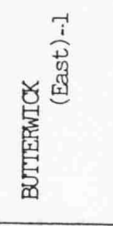 & 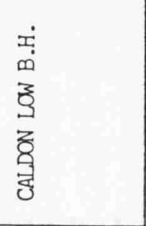 & 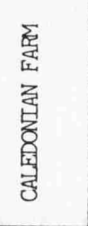 & క్త్రీ & 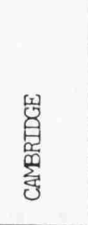 & 紊 & 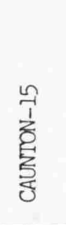 \\
\hline
\end{tabular}




\begin{tabular}{|c|c|c|c|c|c|c|c|c|c|c|c|c|}
\hline 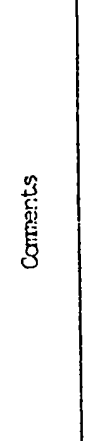 & 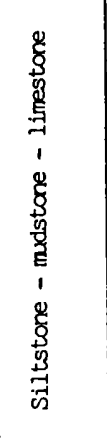 & 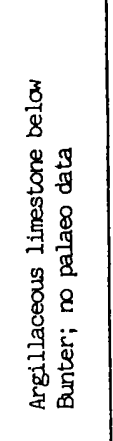 & 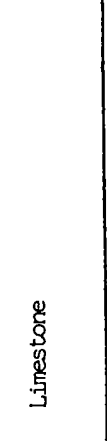 & 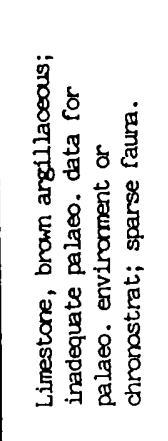 & 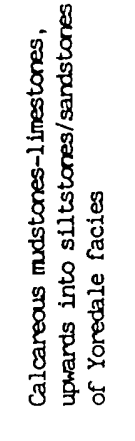 & 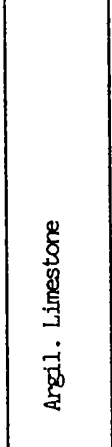 & 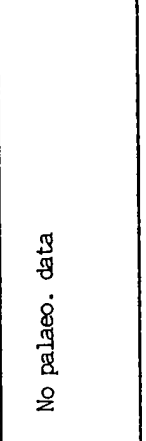 & 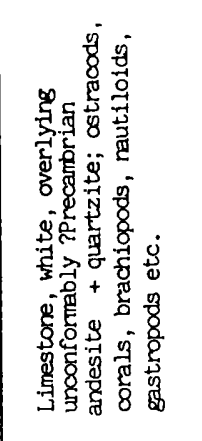 & 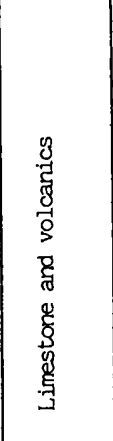 & 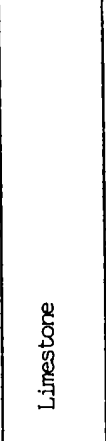 & 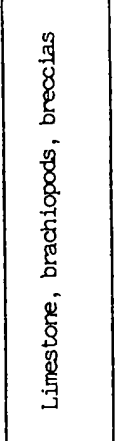 & 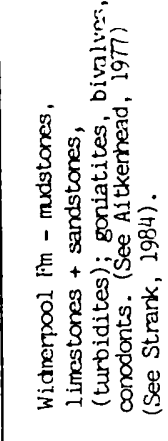 \\
\hline 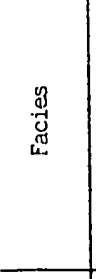 & 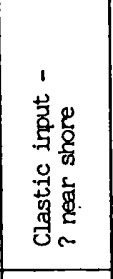 & 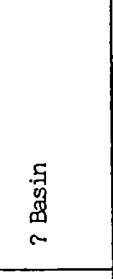 & 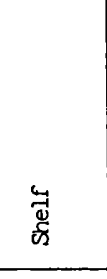 & 育 & 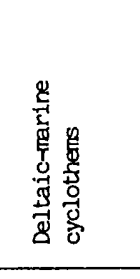 & 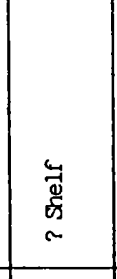 & 参 & 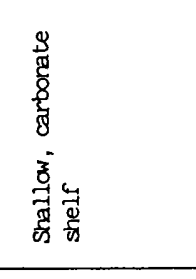 & 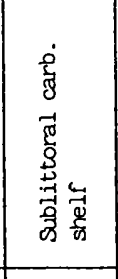 & 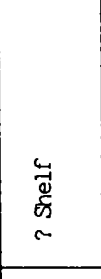 & 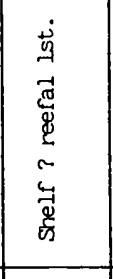 & 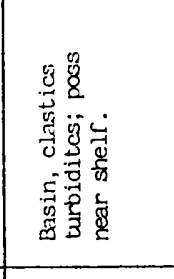 \\
\hline 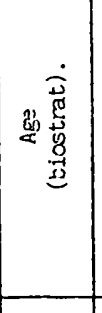 & $\underline{g}$ & 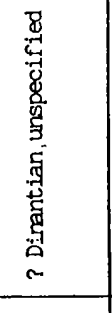 & $\begin{array}{l}\frac{5}{3} \\
\frac{3}{2} \\
\frac{2}{4} \\
\frac{1}{2} \\
\frac{1}{2}\end{array}$ & 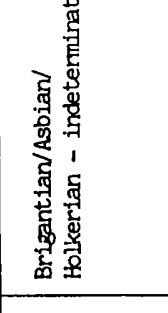 & 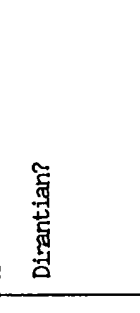 & 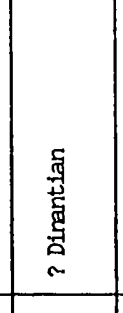 & $\begin{array}{l}\text { 离 } \\
\text { 蹇 } \\
\end{array}$ & 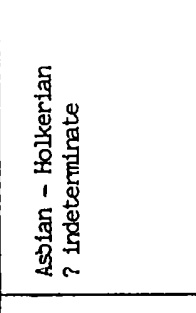 & 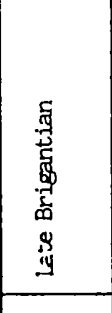 & 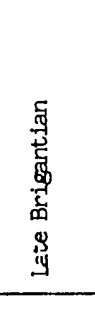 & 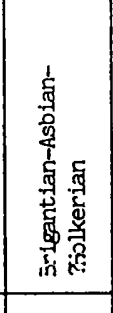 & 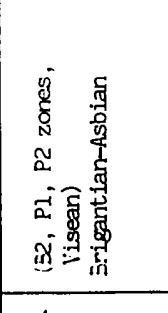 \\
\hline$\frac{\pi}{8}$ & $\sim$ & ' & $د$ & ' & 1 & 1 & ' & $د$ & $>$ & ' & $د$ & 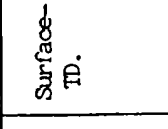 \\
\hline 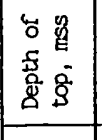 & $\stackrel{\frac{n}{p}}{\vec{p}}$ & 总 & 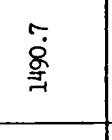 & 兽 & $\overrightarrow{\overrightarrow{\tilde{\sigma}}}$ & 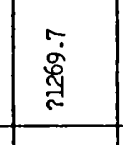 & 范 & $\widetilde{\overline{9}}$ & 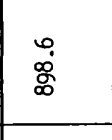 & 总 & 产 & 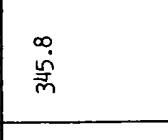 \\
\hline 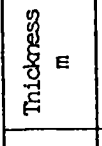 & 㕝 & 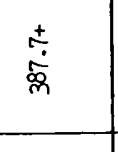 & 奔 & 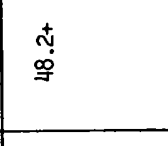 & 呄 & $\stackrel{+}{\stackrel{\$}{g}}$ & $\underset{m}{\stackrel{ \pm}{n}}$ & $\tilde{\mathscr{B}}$ & 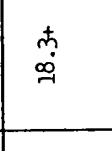 & 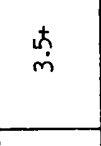 & 志 & $\begin{array}{l}\text { क } \\
\text { 辛 }\end{array}$ \\
\hline 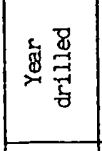 & 㖺 & 离 & 裈 & 第 & 吾 & 㽜 & 番 & $\stackrel{n}{g}$ & 惫 & 番 & $\$$ & 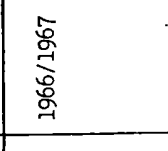 \\
\hline$\dot{8}$ & $\underline{\underline{Q}}$ & 装 & æ & 亳 & ) & ๘ & 兽 & 是 & . ஐ & 面 & $\begin{array}{l}\vec{s} 8 \\
\end{array}$ & 名 \\
\hline 总 & 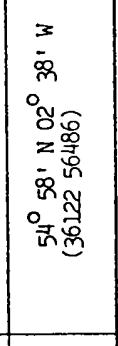 & 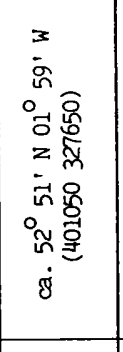 & 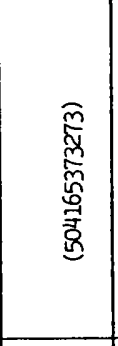 & 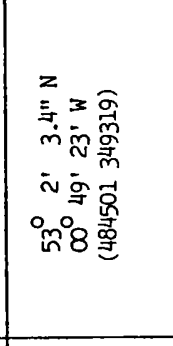 & 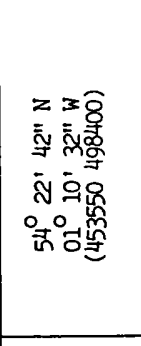 & 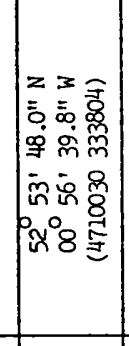 & 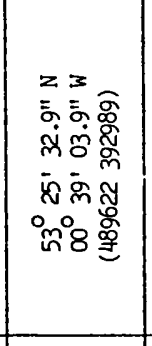 & 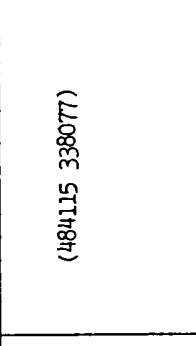 & 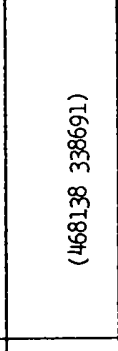 & 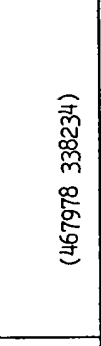 & 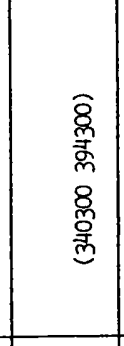 & 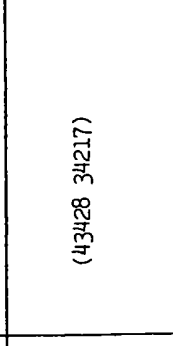 \\
\hline 要变豪 & 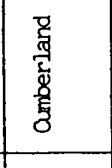 & $\begin{array}{l}\text { 离 } \\
\text { s. } \\
\end{array}$ & 婂 & $\frac{\dot{s}}{\underline{z}}$ & 㝘 & $\begin{array}{l}\dot{s} \\
\end{array}$ & 客 & 富 & $\begin{array}{l}\frac{\dot{s}}{8} \\
\end{array}$ & $\begin{array}{r}\frac{\dot{g}}{3} \\
\end{array}$ & 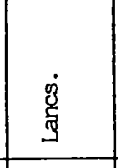 & $\begin{array}{l}\frac{8}{8} \\
\end{array}$ \\
\hline 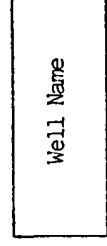 & 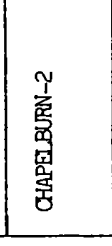 & 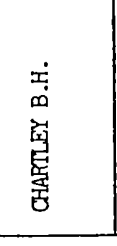 & 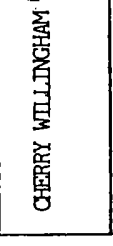 & 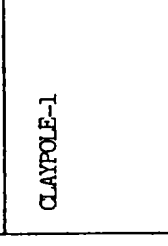 & $\begin{array}{l}\text { 置 } \\
\text { 赛 } \\
\end{array}$ & 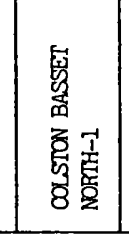 & 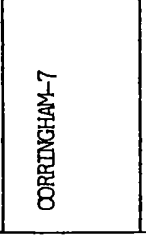 & 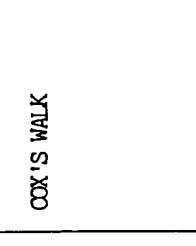 & 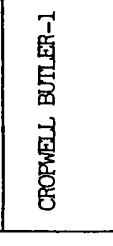 & 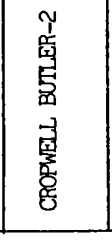 & 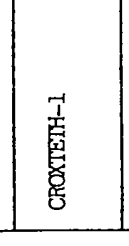 & 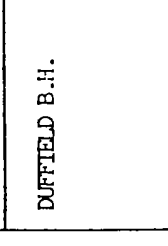 \\
\hline
\end{tabular}




\begin{tabular}{|c|c|c|c|c|c|c|c|c|c|c|c|c|}
\hline 量 & 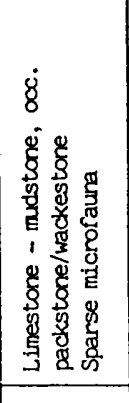 & 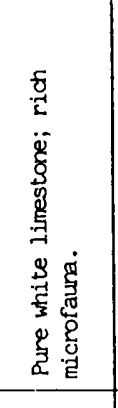 & 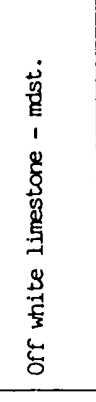 & 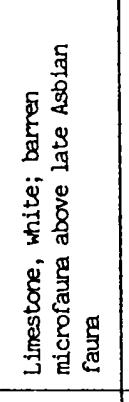 & 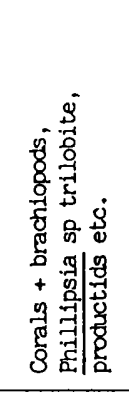 & 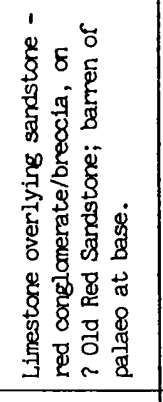 & 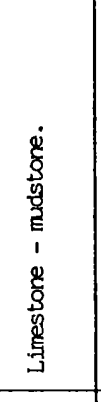 & 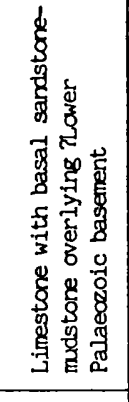 & 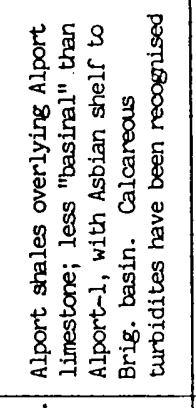 & 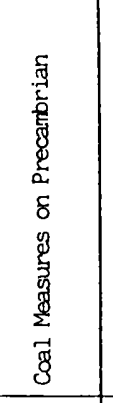 & 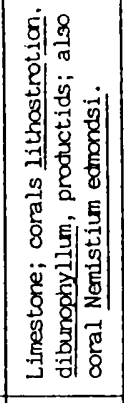 & 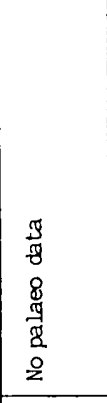 \\
\hline 量 & 衰 & 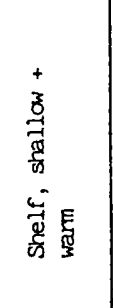 & 参 & 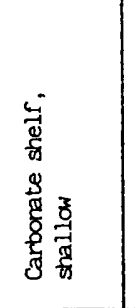 & 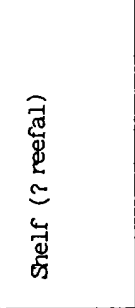 & 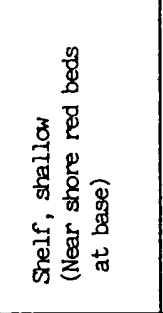 & 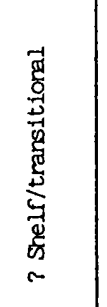 & 参 & 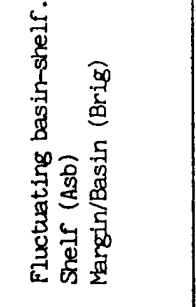 & . & 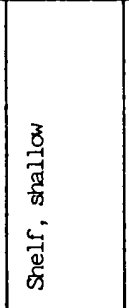 & 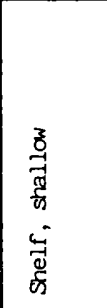 \\
\hline 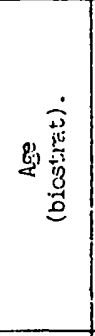 & 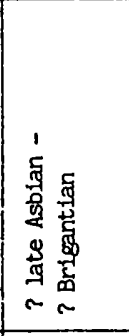 & 量 & 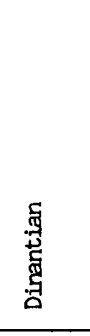 & 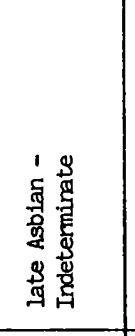 & 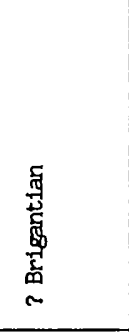 & 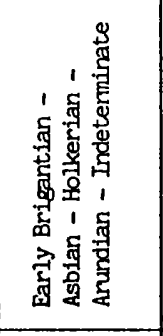 & 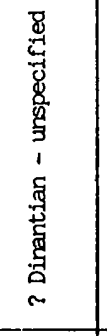 & 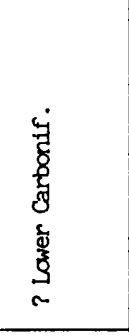 & 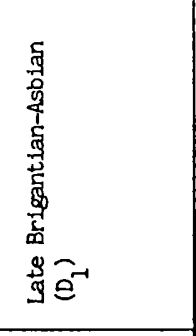 & 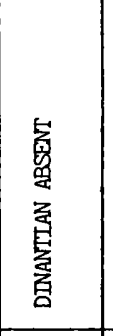 & & 㝵 \\
\hline$\frac{\pi}{3}$ & ' & ( & & 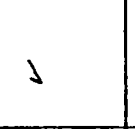 & & 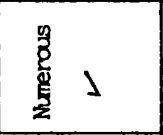 & , & ح & 悹焉 & & $\lambda$ & \\
\hline 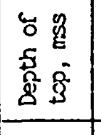 & 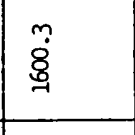 & 安 & 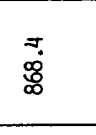 & 芯 & $\overrightarrow{\underline{g}}$ & $\overrightarrow{\mathrm{g}}$ & 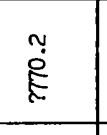 & 荌 & 足 & $\circ$ & 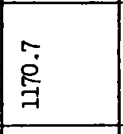 & 苞 \\
\hline 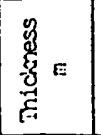 & 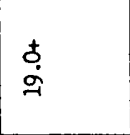 & 春 & $\underset{\dot{f}}{\stackrel{t}{q}}$ & $\stackrel{\mathbb{\Xi}}{\mathbb{J}}$ & 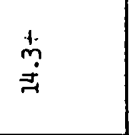 & s & 蒿 & 莥 & 志 & 。 & 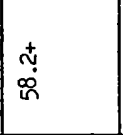 & 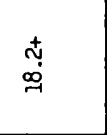 \\
\hline 要 & $\mathscr{g}_{g}$ & 㱏 & 丞 & 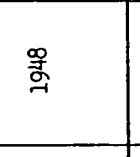 & $\begin{array}{l}\text { 亭 } \\
\text { 首 } \\
\end{array}$ & 杽 & $\dddot{g}$ & $\vec{g}$ & 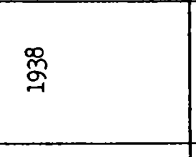 & $\sim$ & 染 & 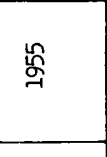 \\
\hline$\dot{8}$ & 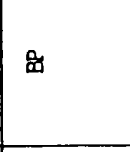 & 婄 & $\approx$ & 搒 & 衰 & 害 & 略矛 & 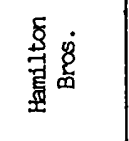 & 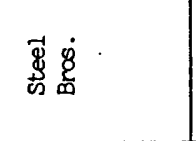 & $\cdots$ & 衰 & 衰 \\
\hline $\begin{array}{l}8 \\
8 \\
3 \\
9\end{array}$ & 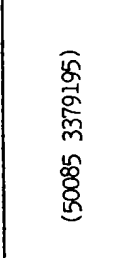 & 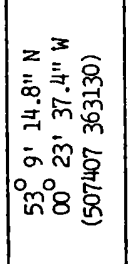 & 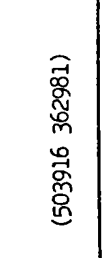 & 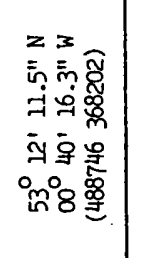 & 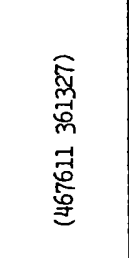 & 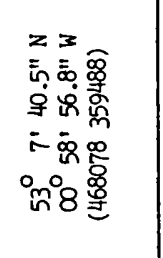 & 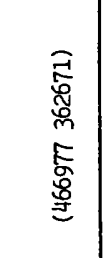 & 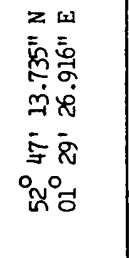 & 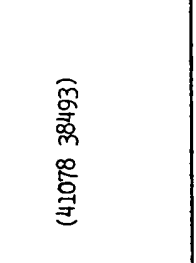 & 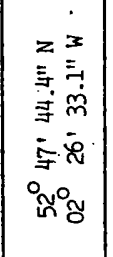 & 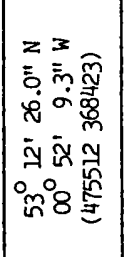 & 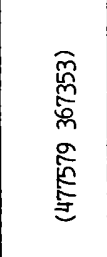 \\
\hline 要变 & $\dot{g}$ & 藓 & 安 & 它 & $\frac{\dot{s}}{\frac{s}{2}}$ & 菨 & $\frac{\dot{s}}{3}$ & 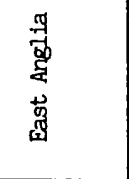 & $\frac{1}{8}$ & $\begin{array}{l}\dot{6} \\
\dot{\xi} \\
\dot{\bar{n}}\end{array}$ & 童 & $\frac{\dot{s}}{\frac{3}{2}}$ \\
\hline 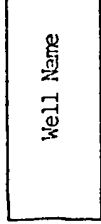 & $\begin{array}{l}1 \\
\text { 喜 } \\
\end{array}$ & $\begin{array}{l}\vec{t} \\
\text { 意 } \\
\end{array}$ & $\begin{array}{l}\frac{1}{1} \\
\text { 童 } \\
\text { 寒 } \\
\end{array}$ & 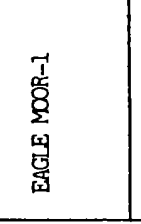 & 意 & 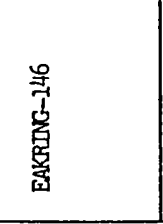 & 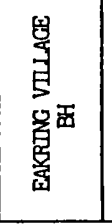 & 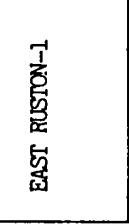 & 薯 & \begin{tabular}{|l|}
$\overrightarrow{1}$ \\
窗 \\
\end{tabular} & 意 & 咅 \\
\hline
\end{tabular}




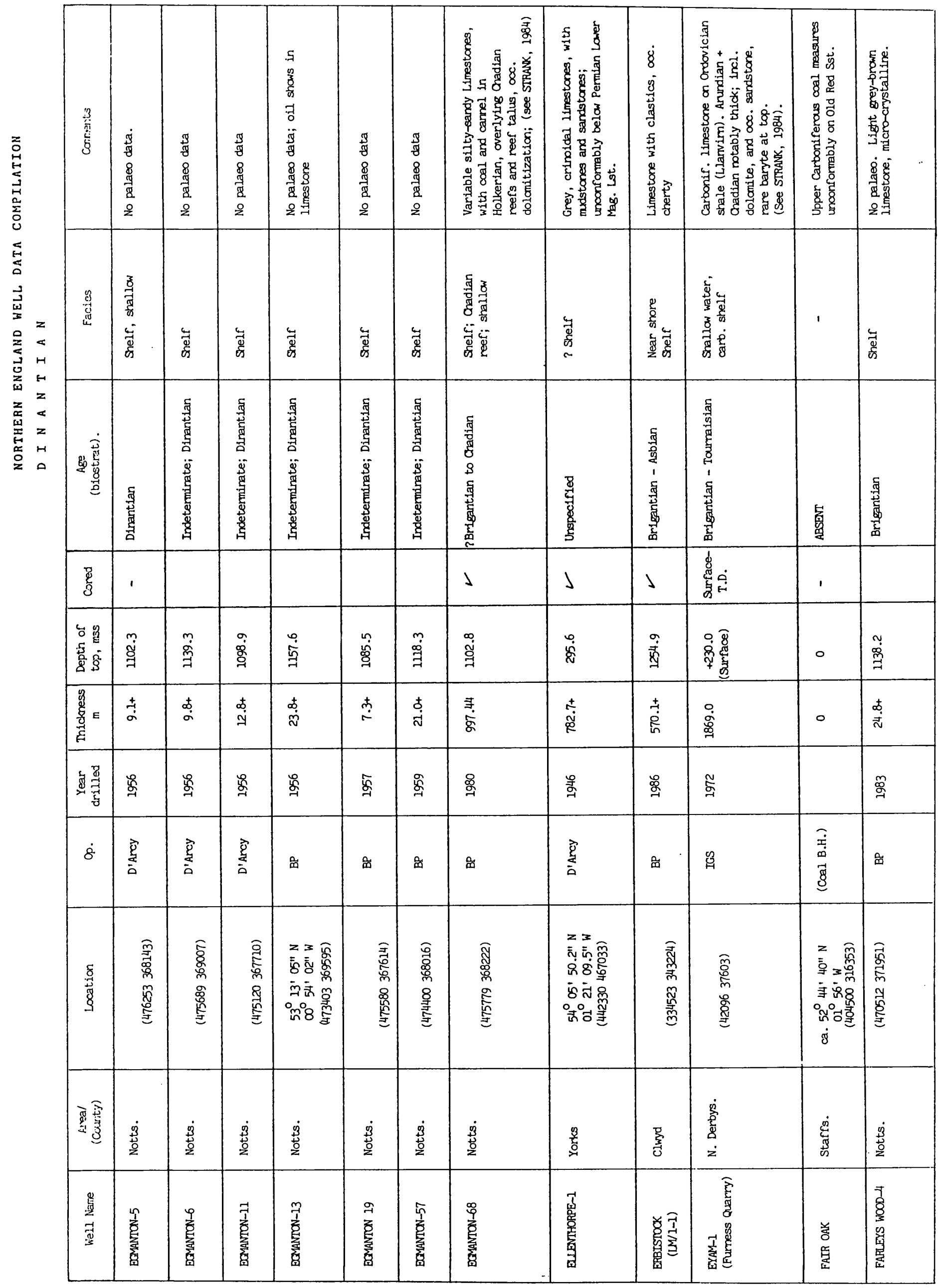




\begin{tabular}{|c|c|c|c|c|c|c|c|c|c|c|c|c|}
\hline $\begin{array}{l}3 \\
\frac{3}{2}\end{array}$ & 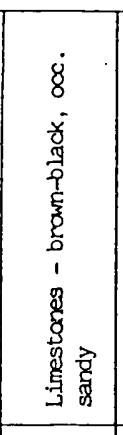 & 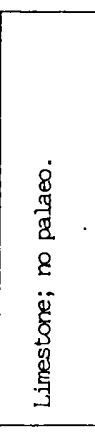 & 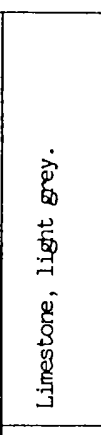 & 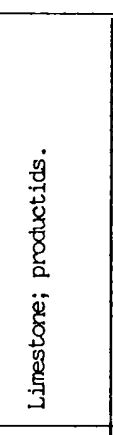 & 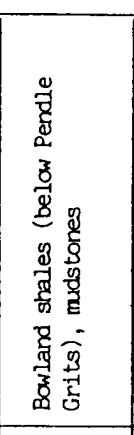 & 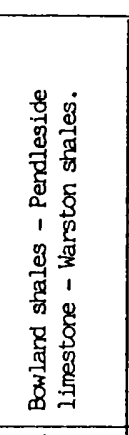 & 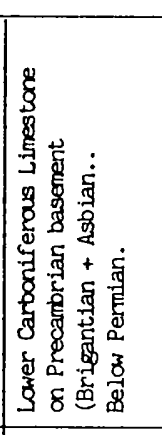 & & 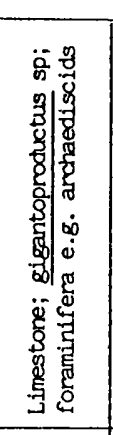 & 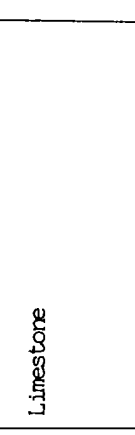 & 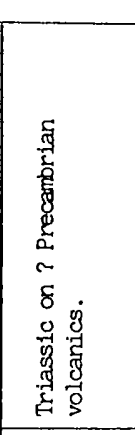 & 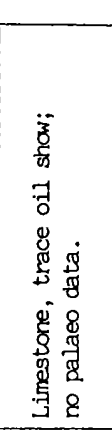 \\
\hline 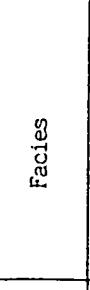 & 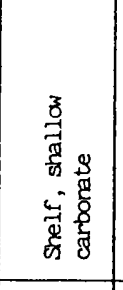 & 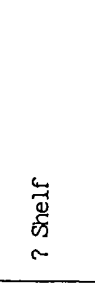 & 高 & 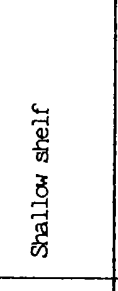 & 噁 & 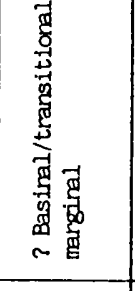 & 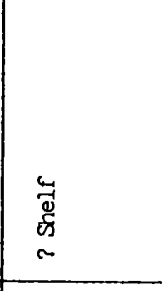 & & 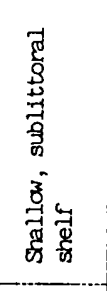 & \begin{tabular}{l}
$\frac{\breve{s}}{5}$ \\
\multirow{5}{5}{}
\end{tabular} & & 善 \\
\hline 竞离 & 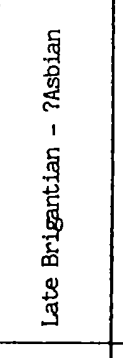 & 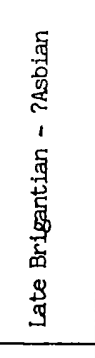 & 量 & 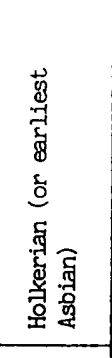 & $\begin{array}{l}\text { 量 } \\
\text { 焉 } \\
\end{array}$ & 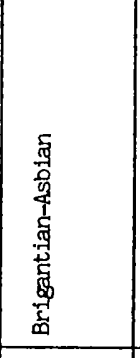 & 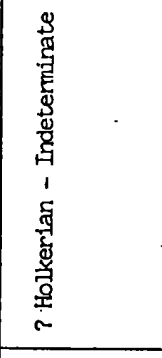 & 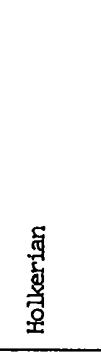 & 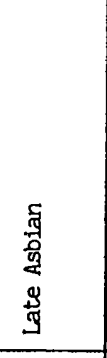 & 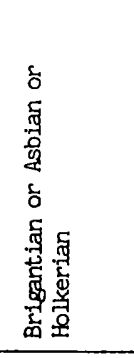 & 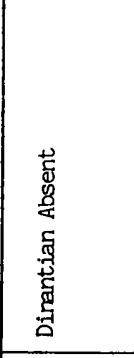 & 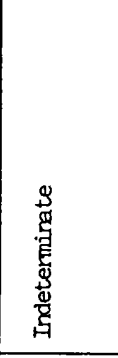 \\
\hline$\frac{8}{8}$ & 1 & . & ' & a & ' & 1 & 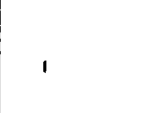 & 1 & 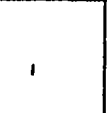 & $\jmath$ & , & $د$ \\
\hline 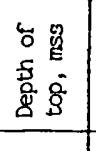 & 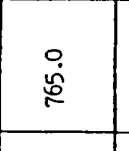 & 锒 & 产 & 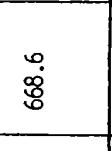 & $\frac{8}{2}$ & 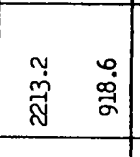 & \begin{tabular}{|l} 
离 \\
要
\end{tabular} & 安 & ָั & 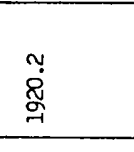 & $\circ$ & 菩 \\
\hline 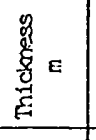 & 呄 & $\stackrel{+}{\sim}$ & 索 & 蒿 & $\begin{array}{r}+ \\
2 \\
2 \\
\end{array}$ & 夺 & $\stackrel{\infty}{\stackrel{\infty}{*}}$ & $\underset{\mathscr{g}}{\stackrel{\Delta}{g}}$ & 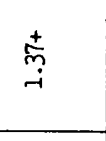 & 声 & 。 & 志 \\
\hline 畓 & 琒 & 睪 & 号 & $\stackrel{2}{5}$ & 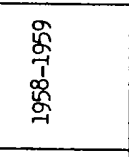 & 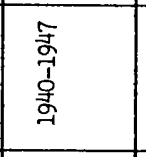 & 年 & E & $\stackrel{\mathscr{g}}{\mathrm{g}}$ & 志 & 䚄 & 索 \\
\hline$\dot{8}$ & 衰 & 案 & 品 & $\underline{\theta}$ & 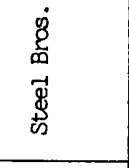 & \& $\approx$ & 害 & $\underline{\theta}$ & $\frac{\mathscr{B}}{2}$ & 苗 & 吕 & 㐔 \\
\hline$\frac{8}{3}$ & 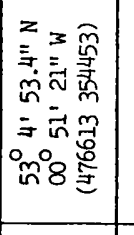 & 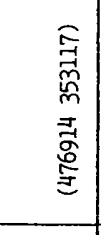 & 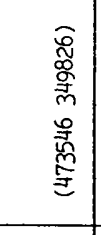 & 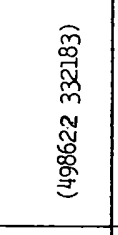 & 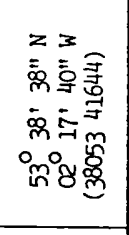 & 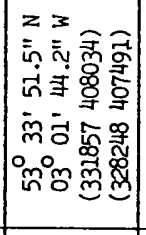 & 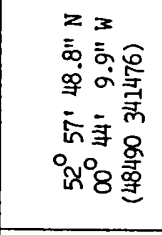 & 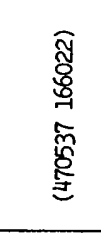 & $\begin{array}{l}\text { 羉 } \\
\text { 罍 }\end{array}$ & 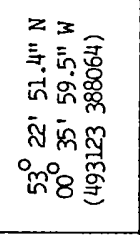 & 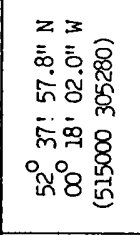 & 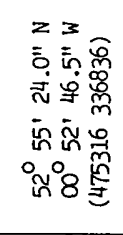 \\
\hline 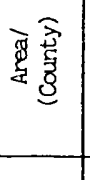 & $\frac{\dot{s}}{\frac{g}{2}}$ & $\frac{\dot{s}}{\frac{3}{2}}$ & $\begin{array}{l}\frac{\dot{s}}{3} \\
\end{array}$ & 婂 & 密 & 窎 & 宴 & $\begin{array}{l}\dot{s} \\
\end{array}$ & 窨 & 窨 & 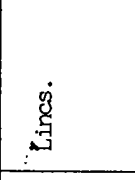 & $\begin{array}{l}\dot{3} \\
\frac{3}{2} \\
\end{array}$ \\
\hline 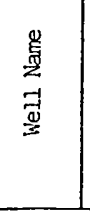 & 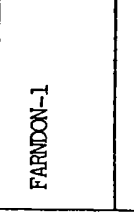 & 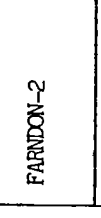 & 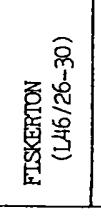 & 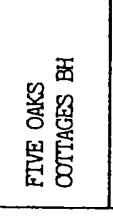 & 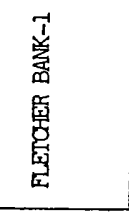 & 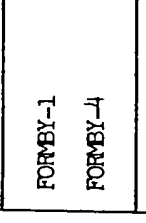 & 稁 & 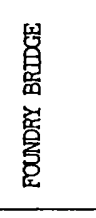 & 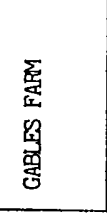 & 晨 & 意 & 章 \\
\hline
\end{tabular}




\begin{tabular}{|c|c|c|c|c|c|c|c|c|c|c|}
\hline 急 & 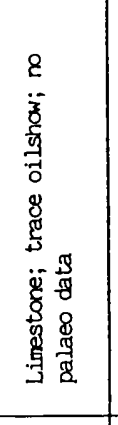 & 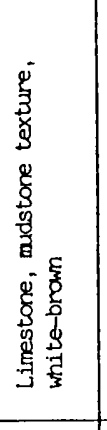 & 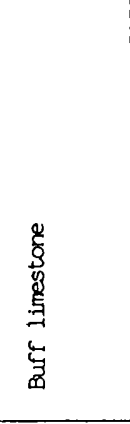 & 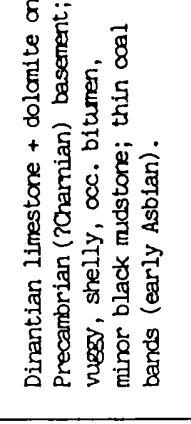 & 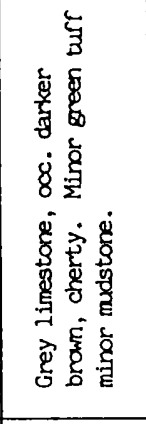 & 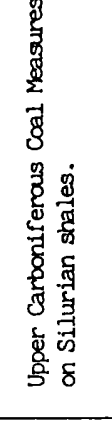 & 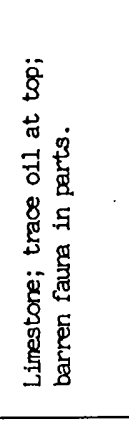 & 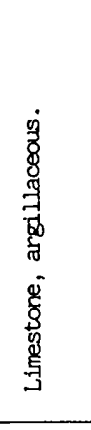 & 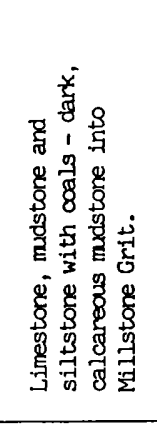 & 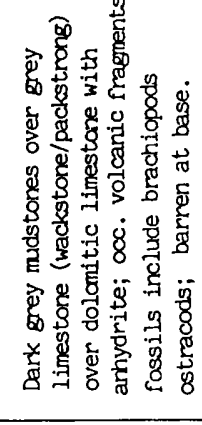 \\
\hline 焉 & 喜 & 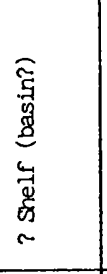 & 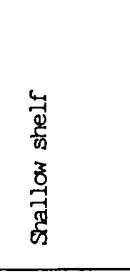 & 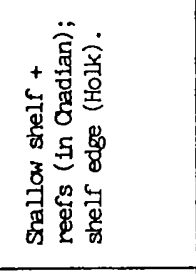 & 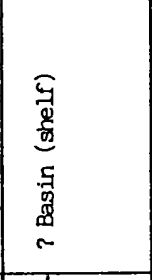 & , & 蓑 & 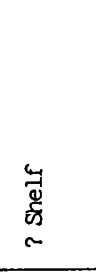 & 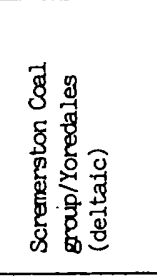 & 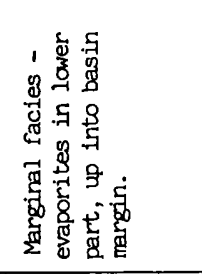 \\
\hline 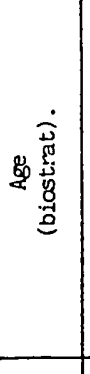 & $\begin{array}{l}\text { s. } \\
\text { 憘 } \\
\text { 咅 } \\
\end{array}$ & & 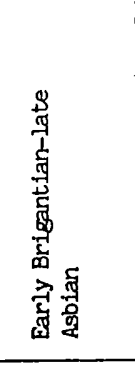 & 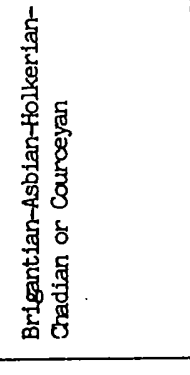 & 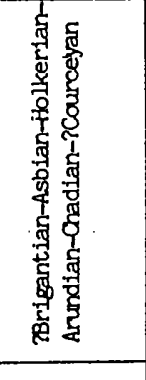 & 脂 & 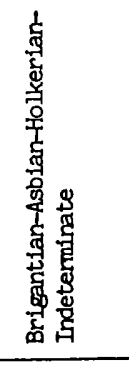 & 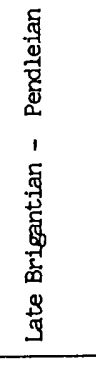 & 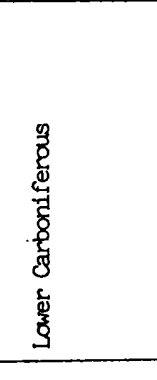 & 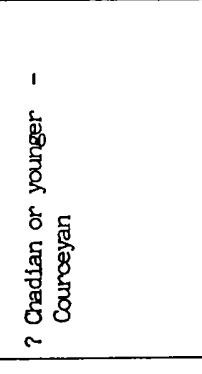 \\
\hline$\frac{\pi}{8}$ & ' & & $د$ & 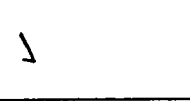 & $د$ & 1 & , & . & 1 & 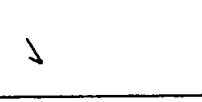 \\
\hline 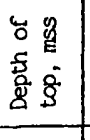 & 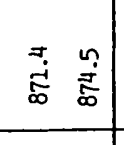 & $\tilde{\dot{s}}$ & 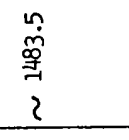 & 宔 & $\begin{array}{l}\infty \\
g \\
g\end{array}$ & $\circ$ & 号 & 总 & 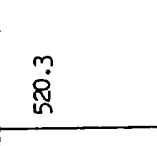 & 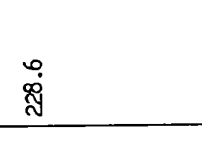 \\
\hline 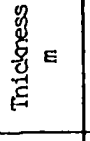 & 青 & 志 & $\stackrel{+}{\vec{J}}$ & 怘 & 苦 & $\circ$ & 卖 & 亭 & 壳 & 卷 \\
\hline 敢莄 & s. & 兽 & 8 & $\overrightarrow{\mathrm{g}}$ & g్ & 嗠 & 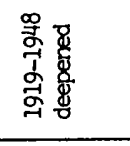 & $\stackrel{\$}{g}$ & : & 壱 \\
\hline$\dot{8}$ & 衰 & 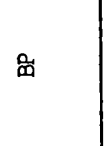 & 亩 & 占 & 衰 & $\frac{\mathscr{g}}{2}$ & 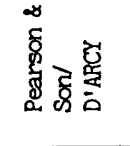 & ळ & 苗 & 褰 \\
\hline 曾 & 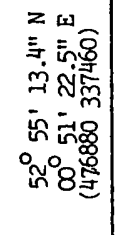 & 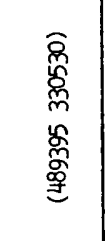 & 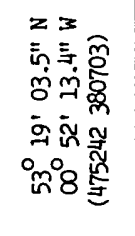 & 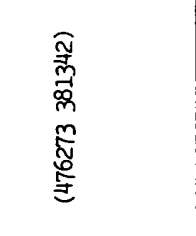 & 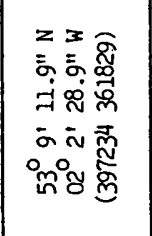 & 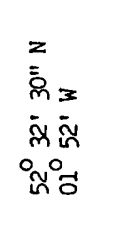 & 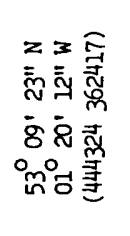 & 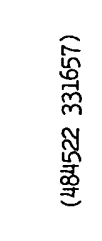 & 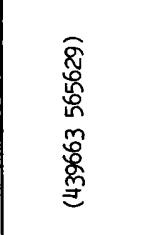 & 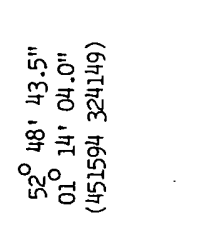 \\
\hline 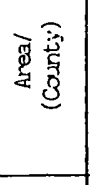 & $\frac{\dot{s}}{\frac{3}{2}}$ & $\frac{3}{\frac{3}{2}}$ & $\frac{\dot{s}}{\underline{\underline{s}}}$ & 章 & $\frac{5}{3}$ & 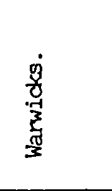 & $\frac{m}{\frac{m}{2}}$ & 客 & 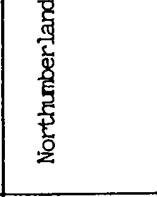 & $\frac{\dot{g}}{9}$ \\
\hline 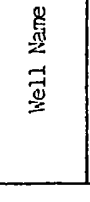 & $\begin{array}{l}\frac{y}{1} \\
\frac{1}{3} \\
\end{array}$ & 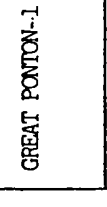 & 要 & $\begin{array}{l}\text { 蓉 } \\
\end{array}$ & 窅 & 飬 & $\begin{array}{l}\text { 壳 } \\
\text { 案 } \\
\end{array}$ & $\begin{array}{l}\text { 前 } \\
\text { 空 }\end{array}$ & $\begin{array}{l}\text { 意 } \\
\text { 至 }\end{array}$ & $\begin{array}{l}\frac{1}{1} \\
\text { 咅 } \\
\end{array}$ \\
\hline
\end{tabular}




\begin{tabular}{|c|c|c|c|c|c|c|c|c|c|c|c|}
\hline 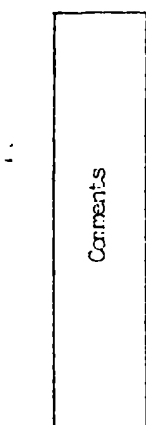 & 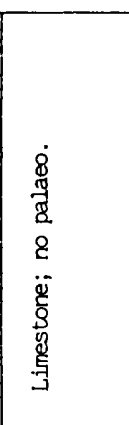 & 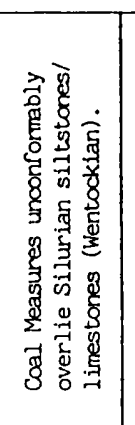 & 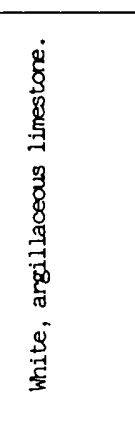 & 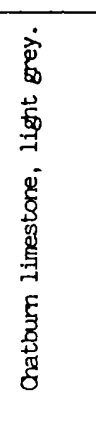 & 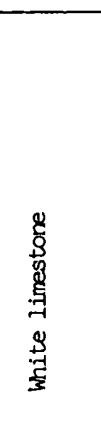 & 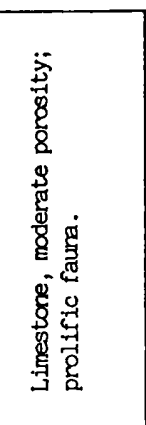 & 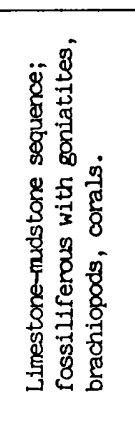 & 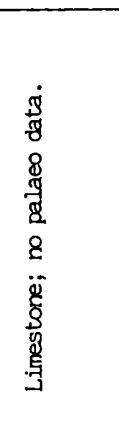 & 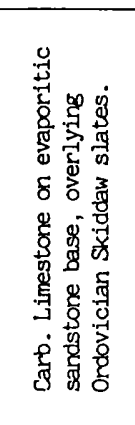 & 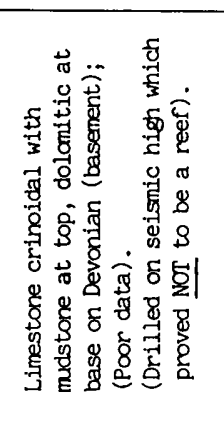 & 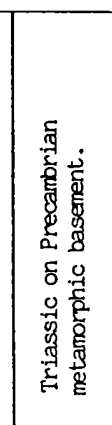 \\
\hline 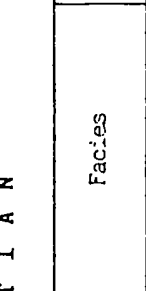 & & & 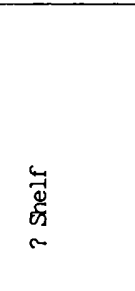 & 壳 & 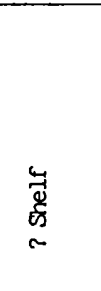 & 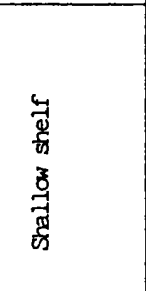 & 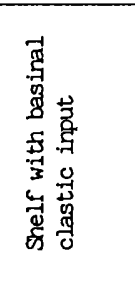 & 育 & 参 & 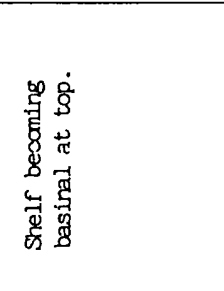 & \\
\hline 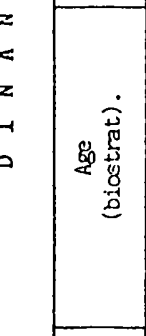 & 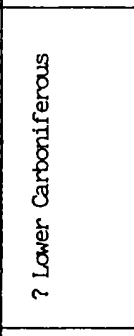 & 旨 & 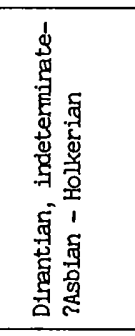 & 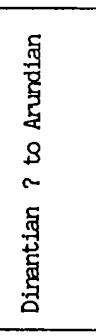 & & 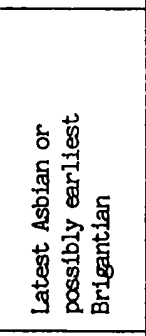 & 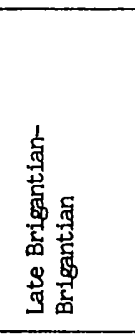 & 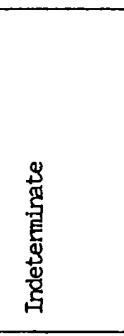 & & 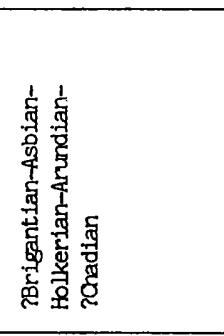 & 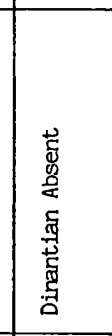 \\
\hline$\frac{1}{8}$ & $\approx$ & , & , & $د$ & , & 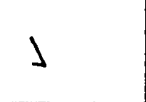 & 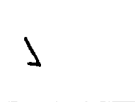 & . & a & $\cdots$ & ' \\
\hline 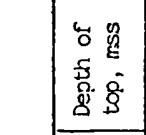 & \begin{tabular}{|l}
$\overrightarrow{\sigma_{g}}$ \\
\end{tabular} & $\circ$ & 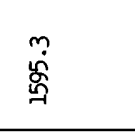 & $\stackrel{n}{g}$ & 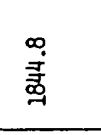 & 产 & $\stackrel{\bar{j}}{\bar{q}}$ & $\stackrel{\widetilde{E}}{\tilde{E}}$ & $\frac{\dddot{y}}{2}$ & 迥 & ० \\
\hline 鹖 & 表 & 。 & $\stackrel{+}{\stackrel{5}{8}}$ & 熟 & $\stackrel{t}{*}$ & 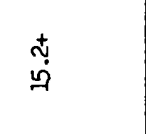 & $\stackrel{\Delta}{\mathscr{E}}$ & 志 & $\begin{array}{l}n \\
\vdots \\
\vdots\end{array}$ & $\stackrel{\widetilde{\tilde{g}}}{\dot{q}}$ & $\circ$ \\
\hline 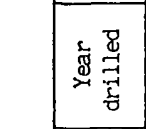 & $\underset{\tilde{g}}{\tilde{g}}$ & 丞 & $\stackrel{\mathscr{g}}{\mathscr{g}}$ & 丞 & 㞼 & 兽 & 萝 & 嗐 & $\begin{array}{l}\frac{2}{9} \\
\text { ? }\end{array}$ & 䓫 & $\stackrel{g}{g}$ \\
\hline$\dot{8}$ & 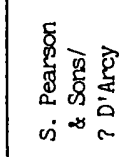 & 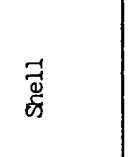 & 总 & 吕 & 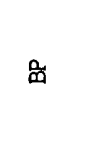 & 品 & $\mathscr{g}$ & 婄 & $\therefore$ & 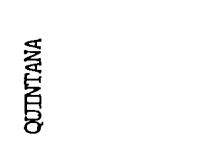 & 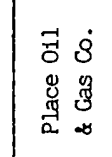 \\
\hline 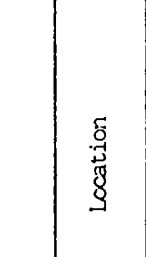 & 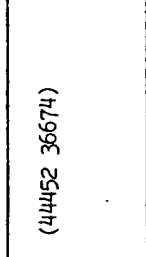 & 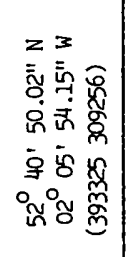 & 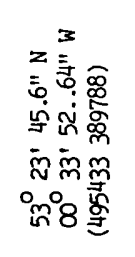 & 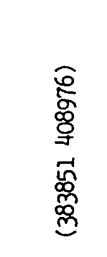 & 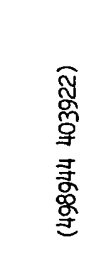 & 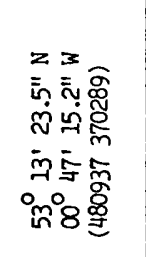 & $\begin{array}{l}\text { 営 } \\
\text { 爱 }\end{array}$ & 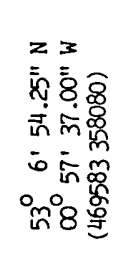 & 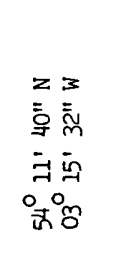 & 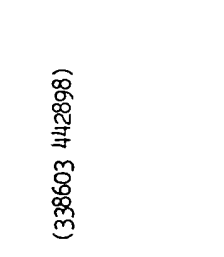 & 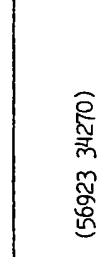 \\
\hline 要獣 & $\begin{array}{l}\dot{0} \\
\frac{2}{8} \\
\frac{8}{8}\end{array}$ & 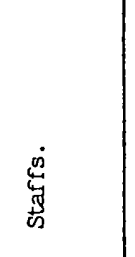 & $\dot{y}$ & 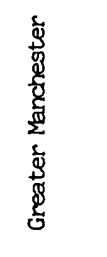 & 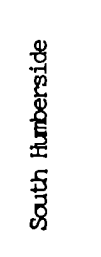 & $\frac{\dot{3}}{\vec{z}}$ & 兽 & 竞 & 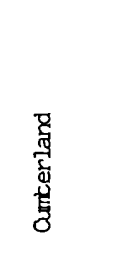 & $\begin{array}{l}\dot{g} \\
\dot{g}\end{array}$ & 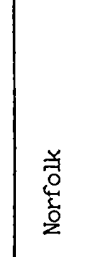 \\
\hline 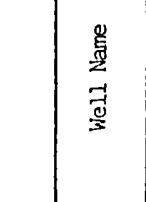 & 喜 & 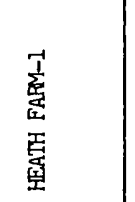 & $\overrightarrow{\mid \overrightarrow{1}}$ & 案 & 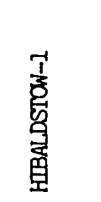 & 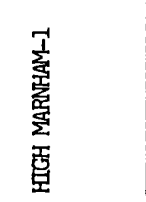 & $\begin{array}{l}\text { 贾 } \\
\text { 基 } \\
\text { 夏 }\end{array}$ & 誉 & 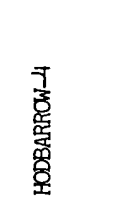 & 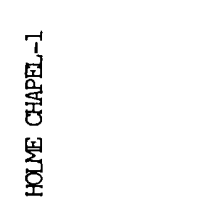 & 章 \\
\hline
\end{tabular}




\begin{tabular}{|c|c|c|c|c|c|c|c|c|c|c|}
\hline $\begin{array}{l}3 \\
\vdots \\
5\end{array}$ & 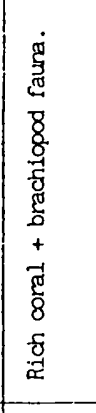 & 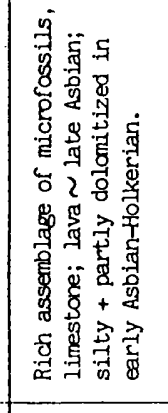 & & 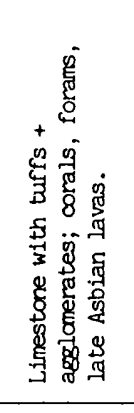 & 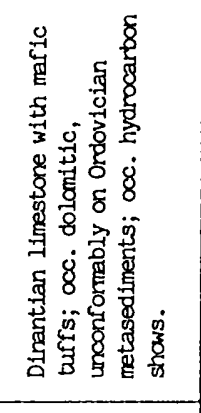 & 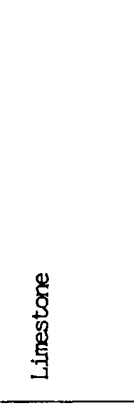 & 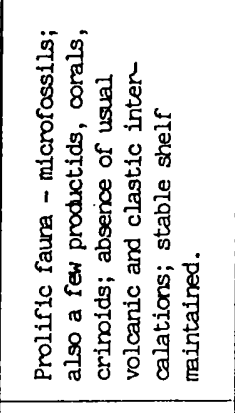 & 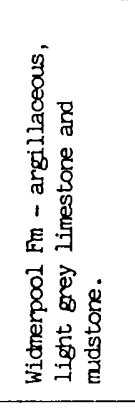 & 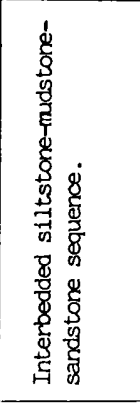 & 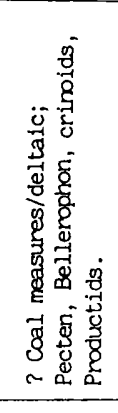 \\
\hline 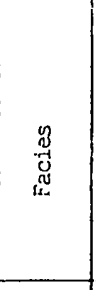 & 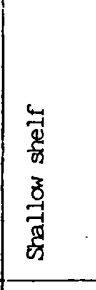 & 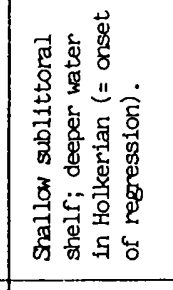 & $\begin{array}{l}\text { 嘉 } \\
\text { 量 } \\
\frac{5}{5} \\
\end{array}$ & 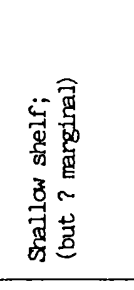 & 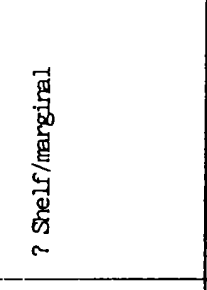 & 参 & 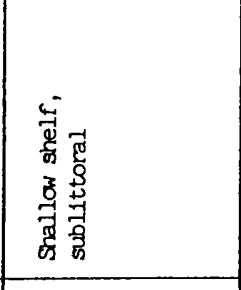 & 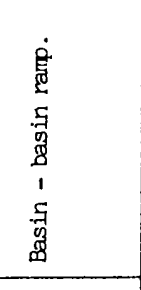 & 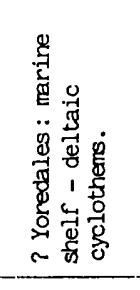 & \\
\hline 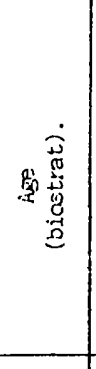 & \begin{tabular}{|l} 
\\
\\
$\frac{5}{9}$ \\
$\frac{9}{2}$ \\
$\frac{8}{9}$ \\
9
\end{tabular} & 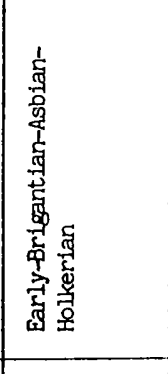 & 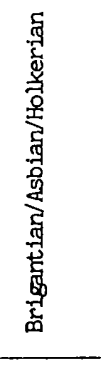 & 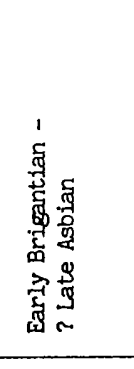 & 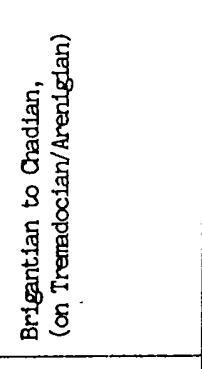 & & 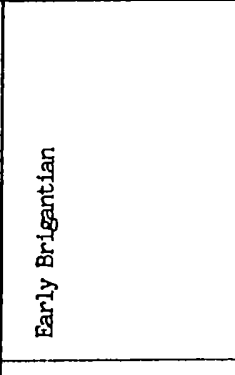 & 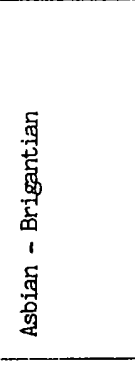 & 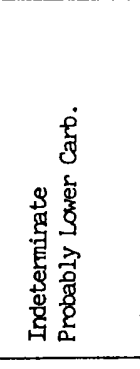 & $\sim$ \\
\hline$\frac{2}{8}$ & , & . & , & 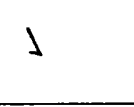 & 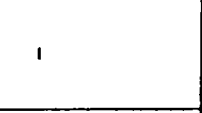 & , & $\downarrow$ & \lrcorner & \lrcorner & ' \\
\hline 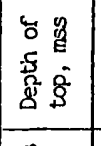 & $\overrightarrow{6}$ & 号 & $\overrightarrow{\tilde{\Sigma}}$ & 品 & 㒸 & $\ddot{\ddot{g}}$ & 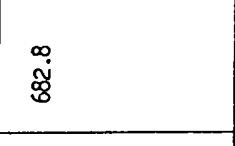 & $\overrightarrow{0}$ & 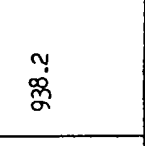 & 离 \\
\hline 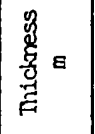 & 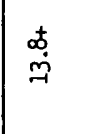 & 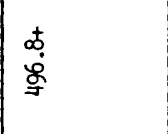 & 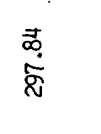 & 梞 & $\stackrel{n}{\tilde{\Xi}}$ & 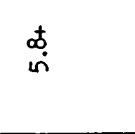 & $\underset{\mathcal{W}}{\mathcal{W}}$ & 芯 & 青 & 走 \\
\hline 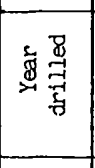 & $\underset{g}{g}$ & $\stackrel{\mathscr{Z}}{\mathrm{g}}$ & 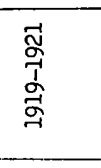 & 驾 & 㬝 & 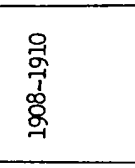 & $\begin{array}{l}\text { 塝 } \\
\text { 毫 }\end{array}$ & $\dddot{\dddot{m}}$ & 等 & 费 \\
\hline$\dot{8}$ & $\underline{\underline{B}}$ & 㝘 & 衰 & జ & 酋 & 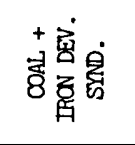 & 衰 & 品 & 离 & 害 \\
\hline 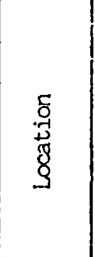 & 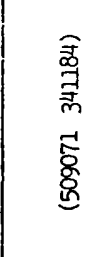 & 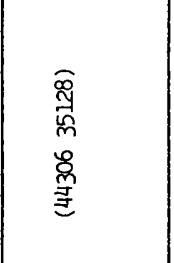 & 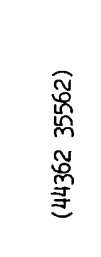 & 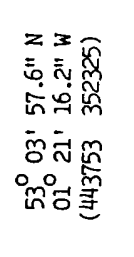 & 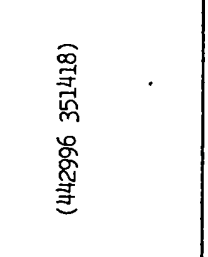 & $\begin{array}{l}\text { 贾 } \\
\text { 总 } \\
\text { 焉 }\end{array}$ & 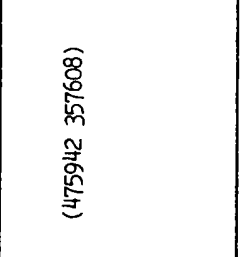 & 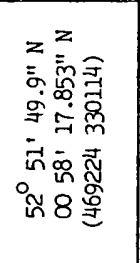 & 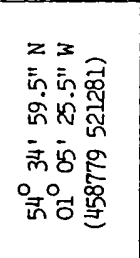 & 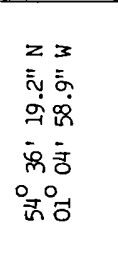 \\
\hline 要意 & 䇋 & 章 & 噌 & $\begin{array}{l}\text { 离 } \\
\text { 害 }\end{array}$ & 害 & $\frac{\dot{g}}{\frac{3}{2}}$ & 䇋 & 竞 & 寗 & 害 \\
\hline 产 & $\begin{array}{l}\text { 筫 } \\
8 \\
\text { 曾 } \\
\end{array}$ & 泀 & 曾 & 睍 & 算 & 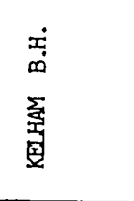 & $\begin{array}{l}\text { 焉 } \\
\text { 虽 } \\
\text { 等 }\end{array}$ & 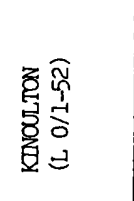 & 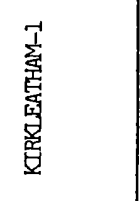 & 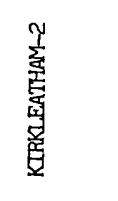 \\
\hline
\end{tabular}




\begin{tabular}{|c|c|c|c|c|c|c|c|c|c|c|c|}
\hline 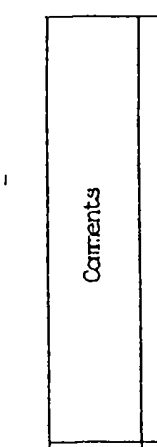 & 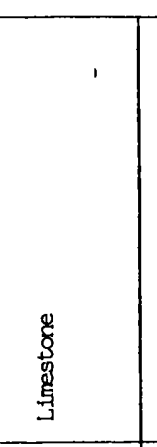 & 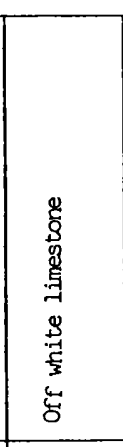 & 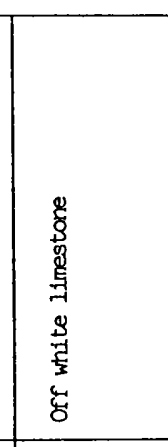 & 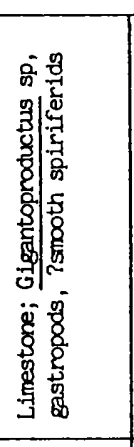 & 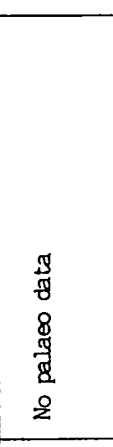 & 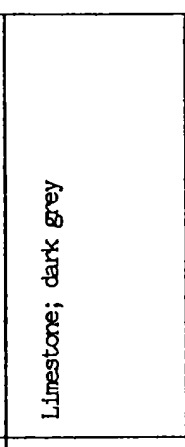 & 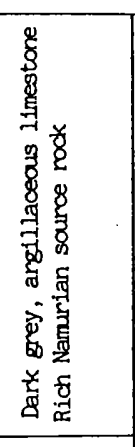 & 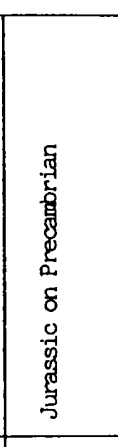 & 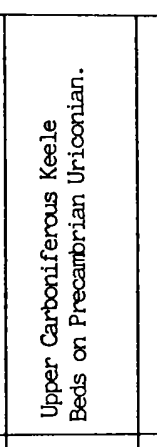 & 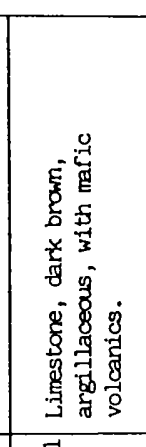 & 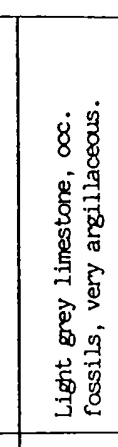 \\
\hline$\frac{8}{8}$ & 亮 & 喜 & 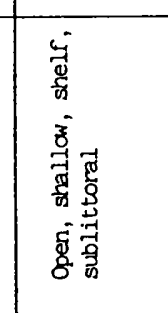 & ॅू & 参 & 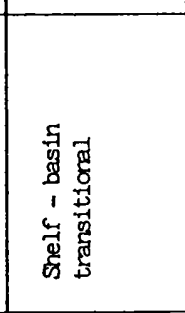 & 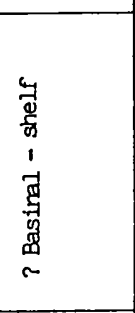 & & & 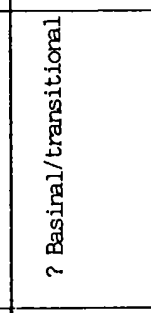 & 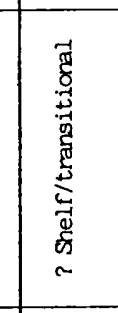 \\
\hline 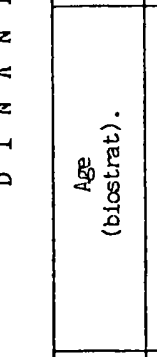 & 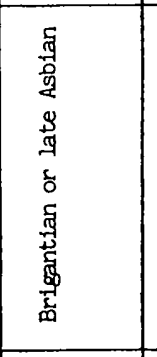 & 喜 & 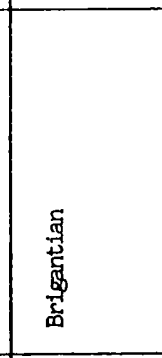 & 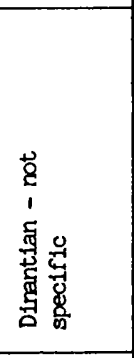 & $\begin{array}{l}\text { 量 } \\
\text { 僦 }\end{array}$ & 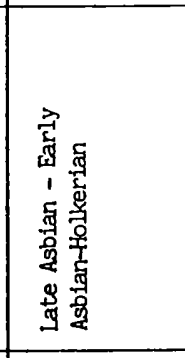 & 意 & 霆 & $\begin{array}{l}\text { 惹 } \\
\text { 龺 }\end{array}$ & 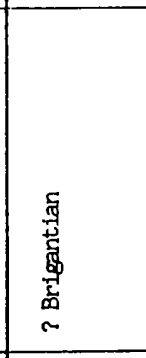 & 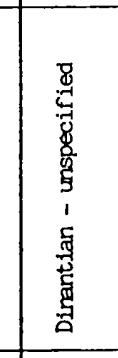 \\
\hline$\frac{8}{8}$ & 1 & , & & 1 & & $د$ & 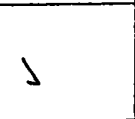 & 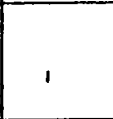 & . & $\lambda$ & \\
\hline 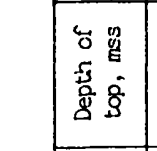 & $\begin{array}{l}\infty \\
\stackrel{\infty}{\infty} \\
\end{array}$ & 怘 & 兽 & 疍 & 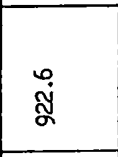 & 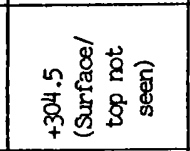 & 迅 & $\circ$ & $\circ$ & $\overline{\tilde{y}}$ & $\overrightarrow{\underline{J}}$ \\
\hline 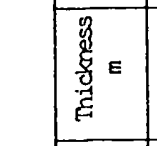 & $\stackrel{+}{j}$ & 胥 & 志 & 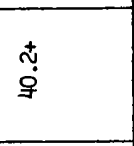 & 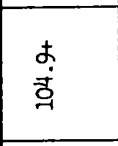 & $\begin{array}{l} \\
\\
\dot{8} \\
\dot{8} \\
\end{array}$ & 孛 & 。 & $\circ$ & 节 & 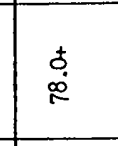 \\
\hline 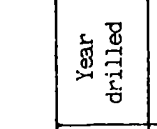 & $\frac{o}{2}$ & 然 & 욱 & 5 & 密 & E & $\underset{g}{E}$ & $\overrightarrow{\mathrm{I}}$ & $\overrightarrow{\mathrm{s}}$ & \% & $\stackrel{8}{\%}$ \\
\hline$\dot{8}$ & 衰 & щ & 兽 & 首 & 嚍 & $g$ & $\dddot{m}$ & $\begin{array}{l}\frac{9}{8} \dot{8} \\
\frac{E}{2}\end{array}$ & 绐 & æ & 嵒 \\
\hline 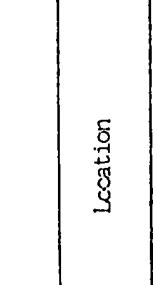 & 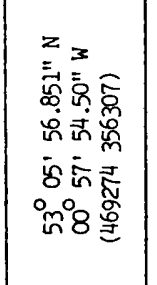 & 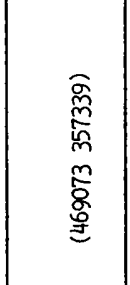 & 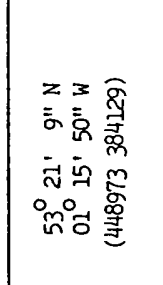 & 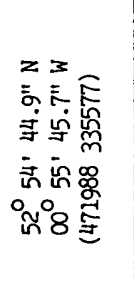 & 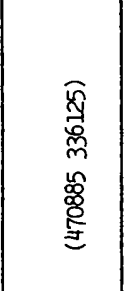 & 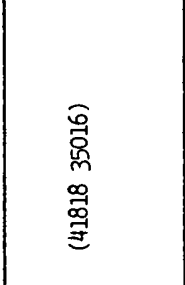 & 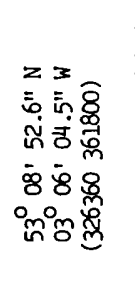 & 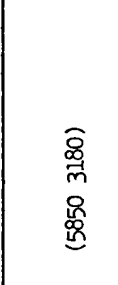 & 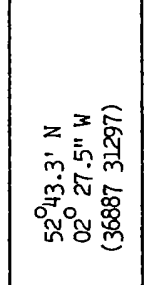 & 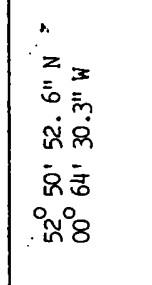 & 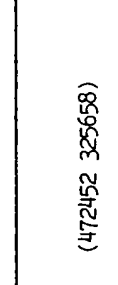 \\
\hline 要票 & 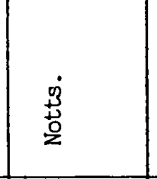 & $\frac{\frac{9}{2}}{\frac{8}{2}}$ & 焉 & $\frac{\dot{g}}{\vec{z}}$ & $\frac{\dot{s}}{\underline{z}}$ & $\begin{array}{l}\dot{2} \\
\text { 量 }\end{array}$ & 害 & 誉 & 容 & 宮 & $\dot{s}$ \\
\hline 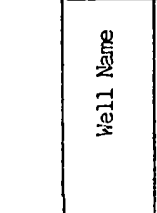 & \begin{tabular}{|l} 
喜 \\
毫 \\
夏
\end{tabular} & $\begin{array}{l}\text { 套 } \\
\text { 害 }\end{array}$ & 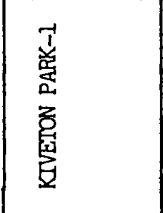 & 竞 & 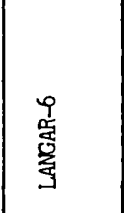 & $\begin{array}{l}\text { 盖 } \\
\text { 首 }\end{array}$ & 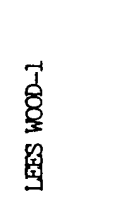 & $\overrightarrow{\text { 壘 }}$ & $\begin{array}{l}\text { 要 } \\
\text { 罗 }\end{array}$ & 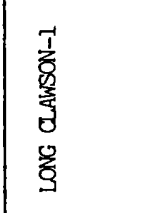 & 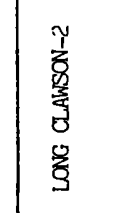 \\
\hline
\end{tabular}




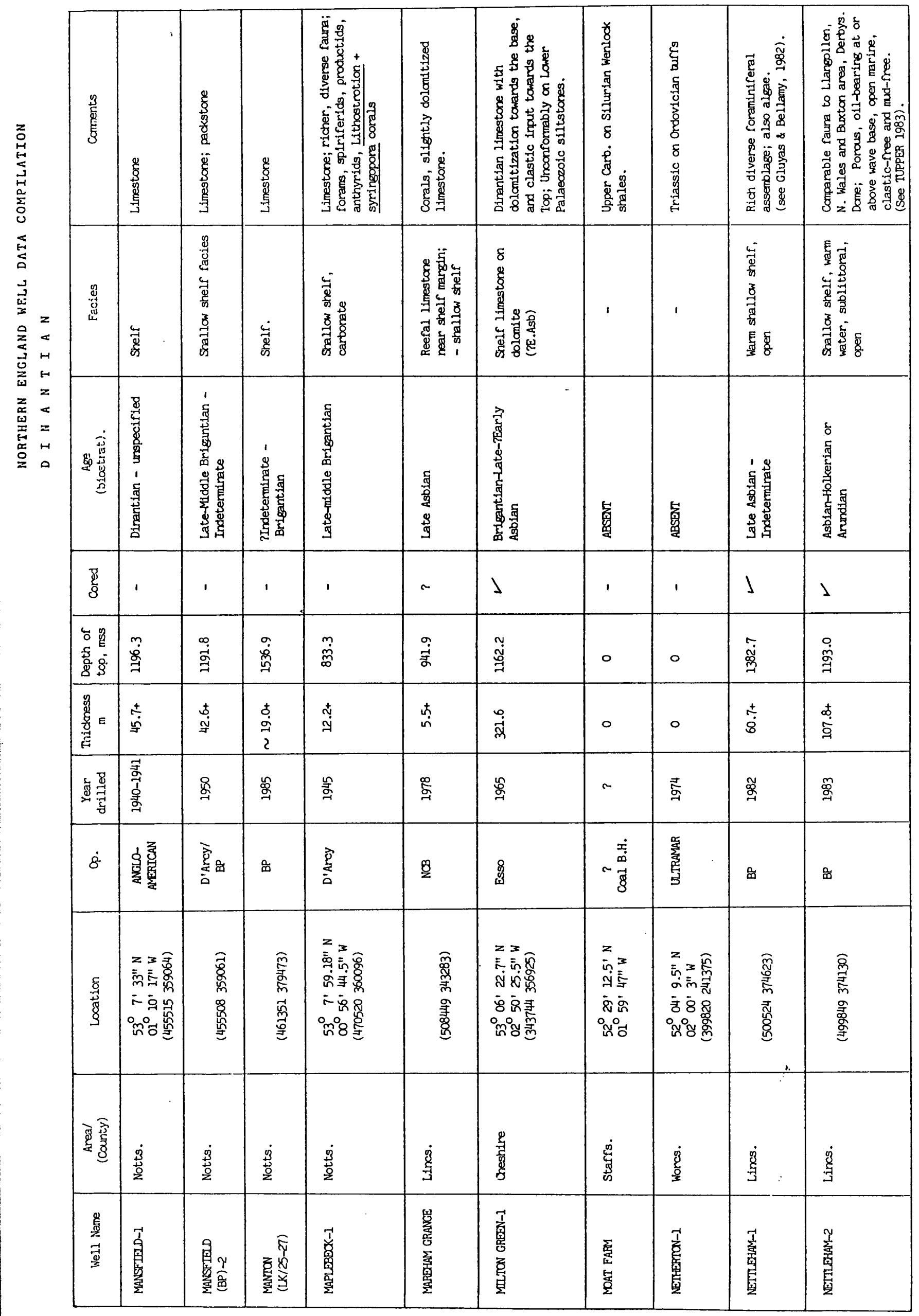




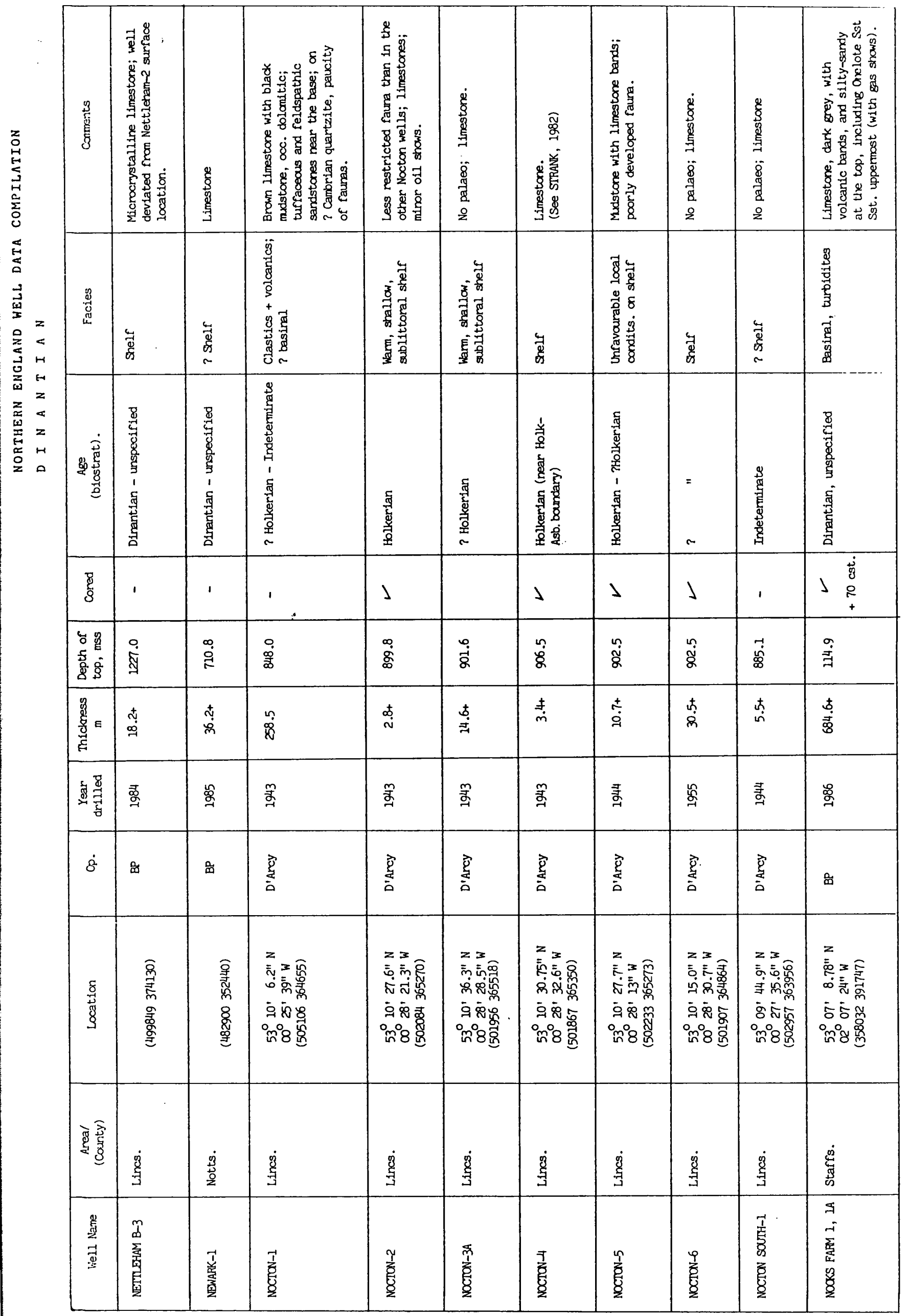




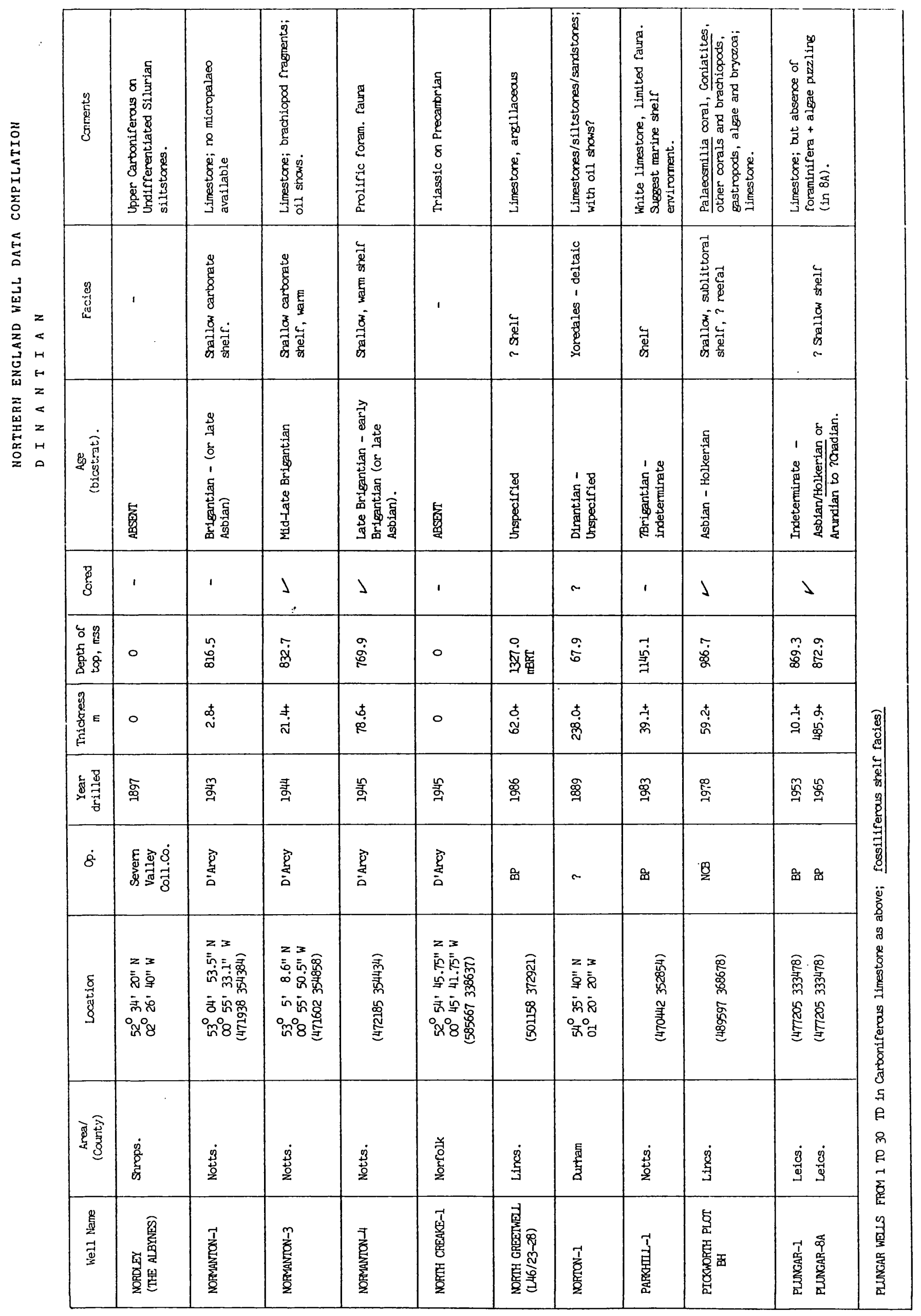




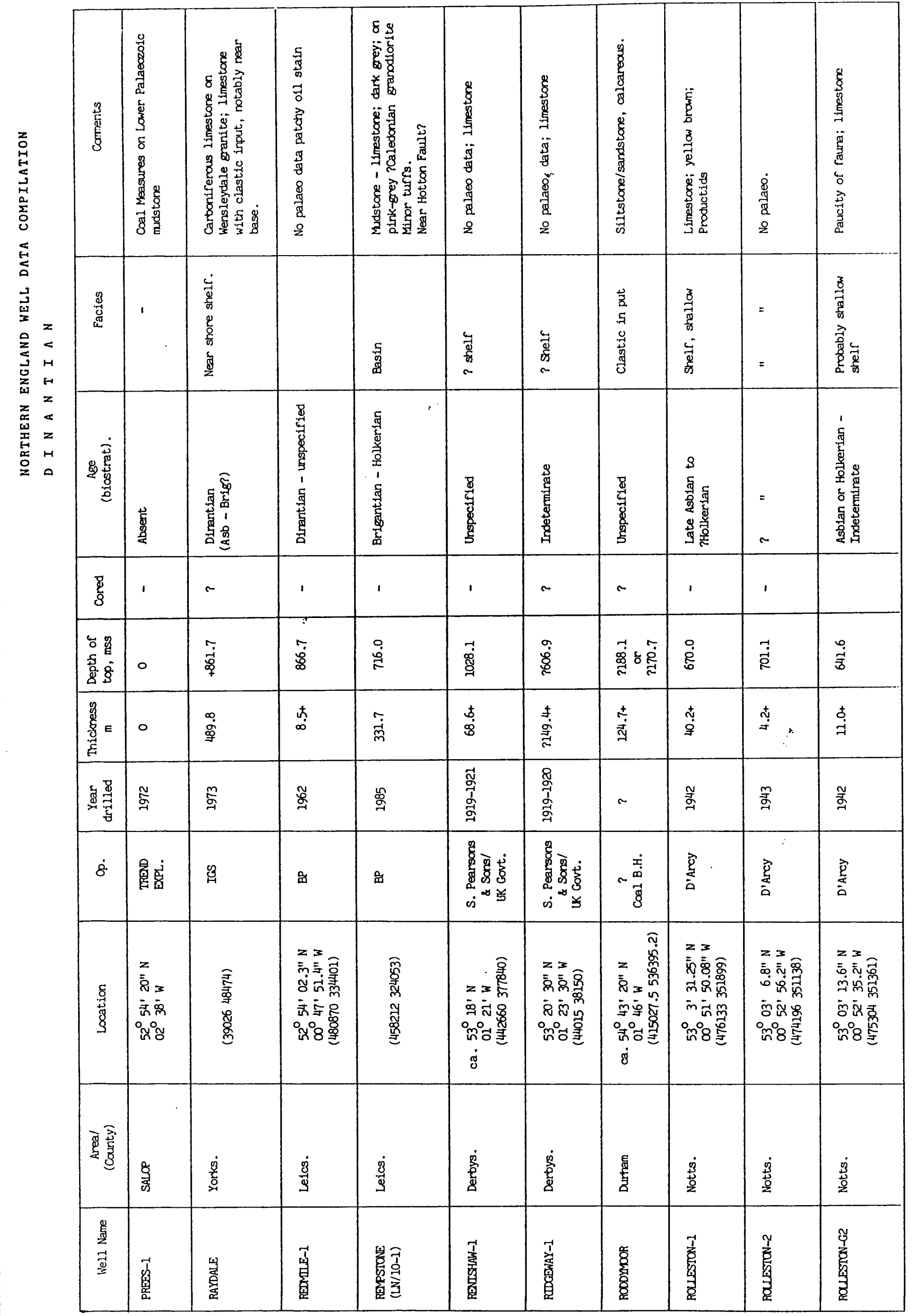




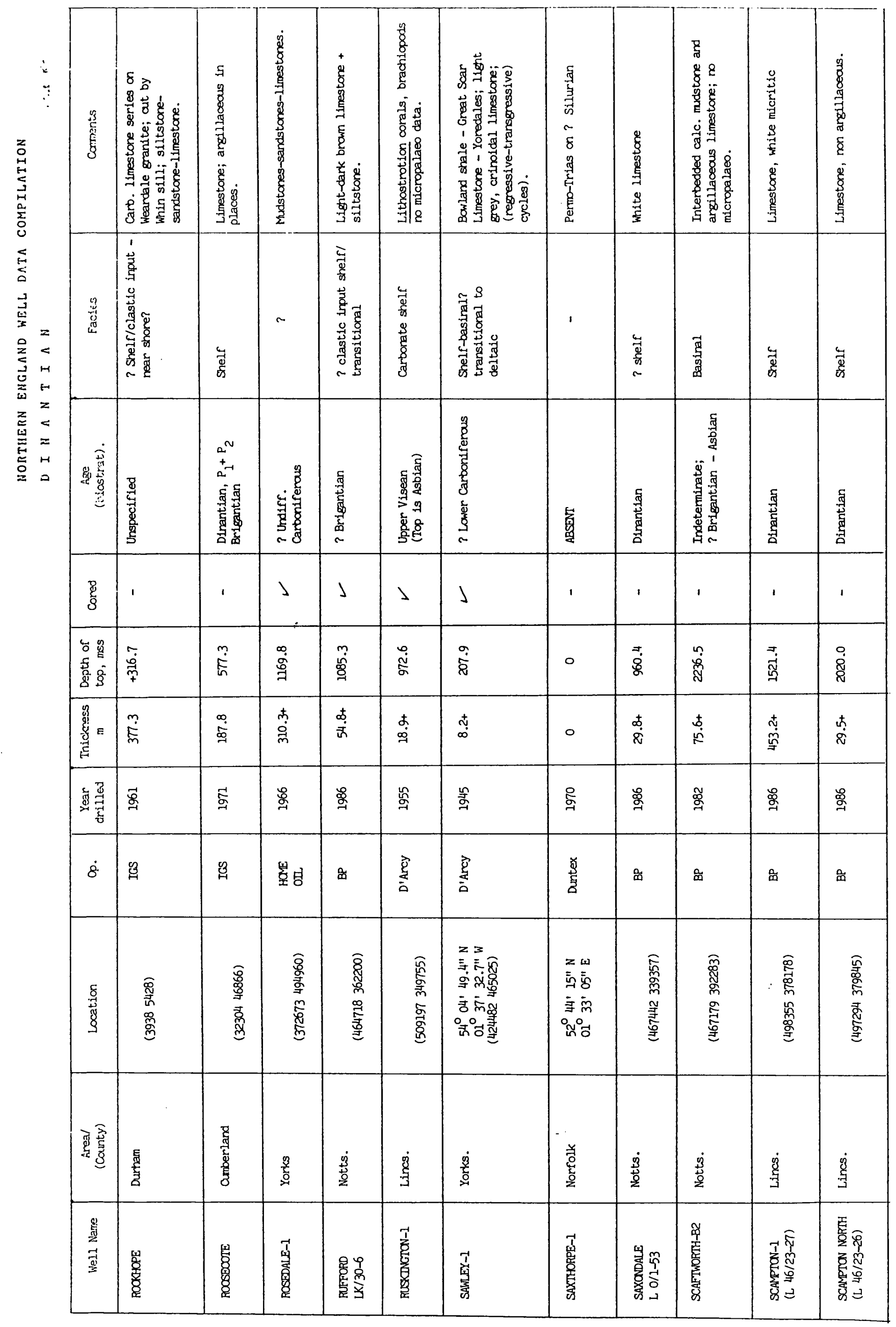




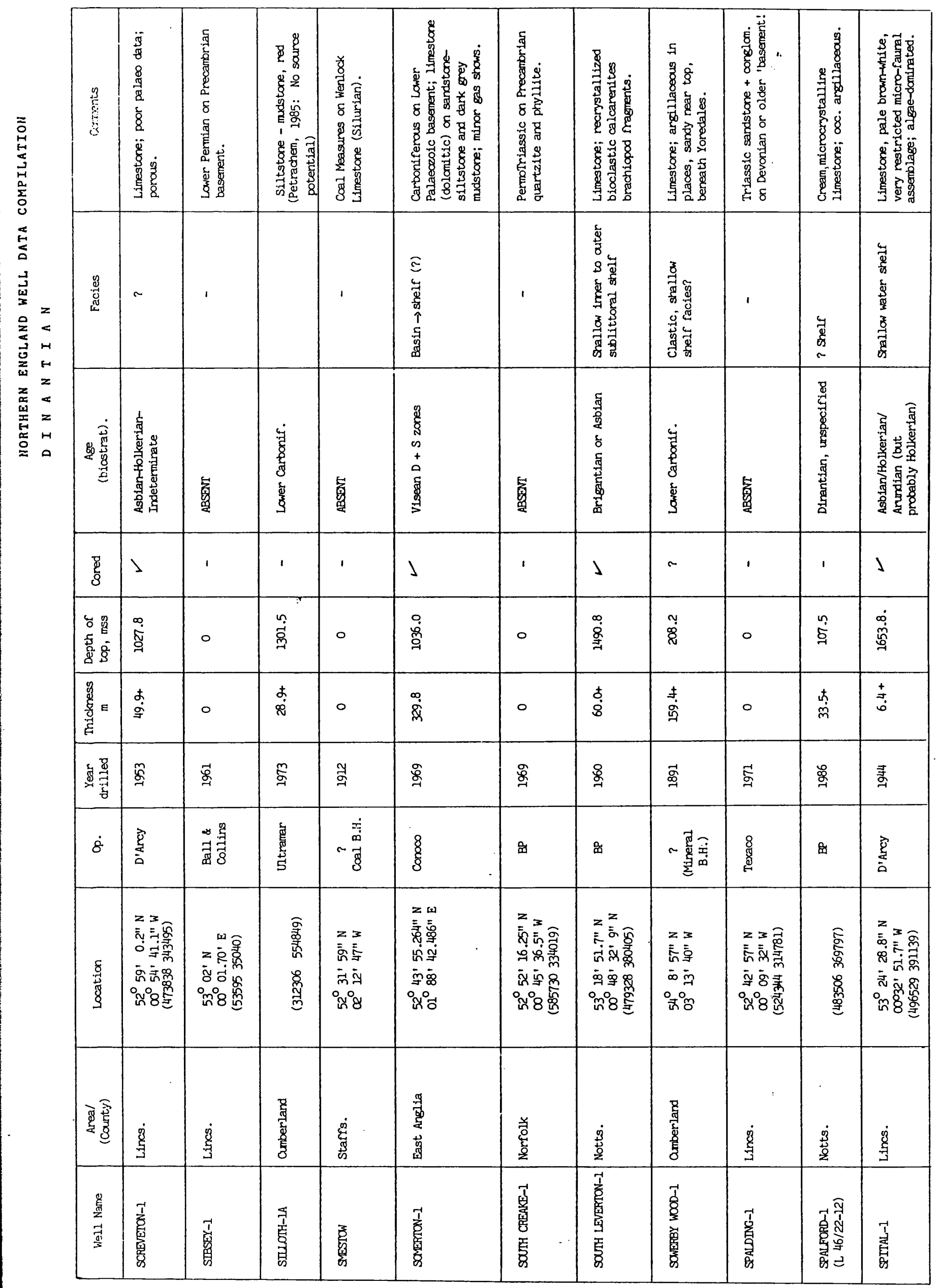




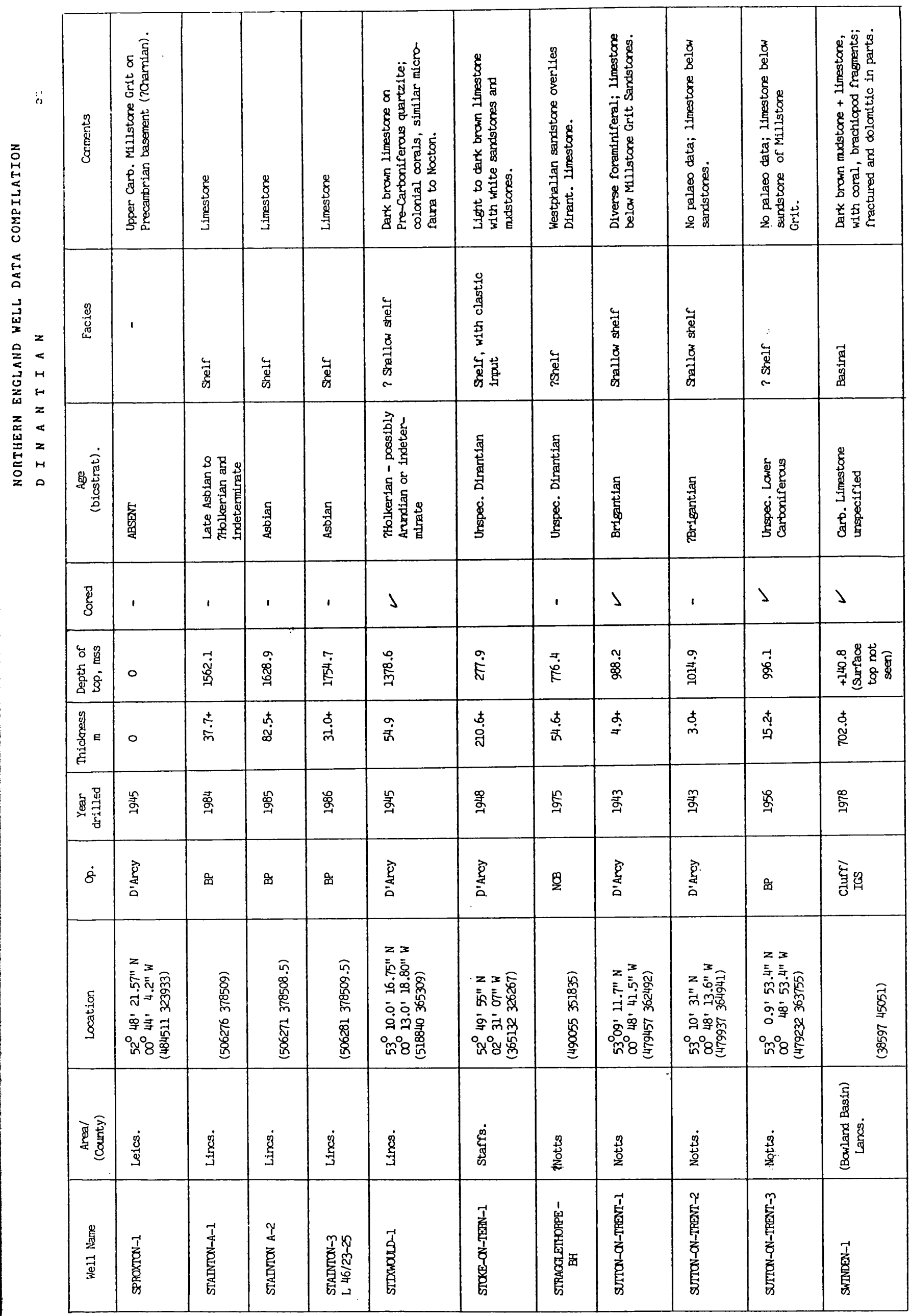




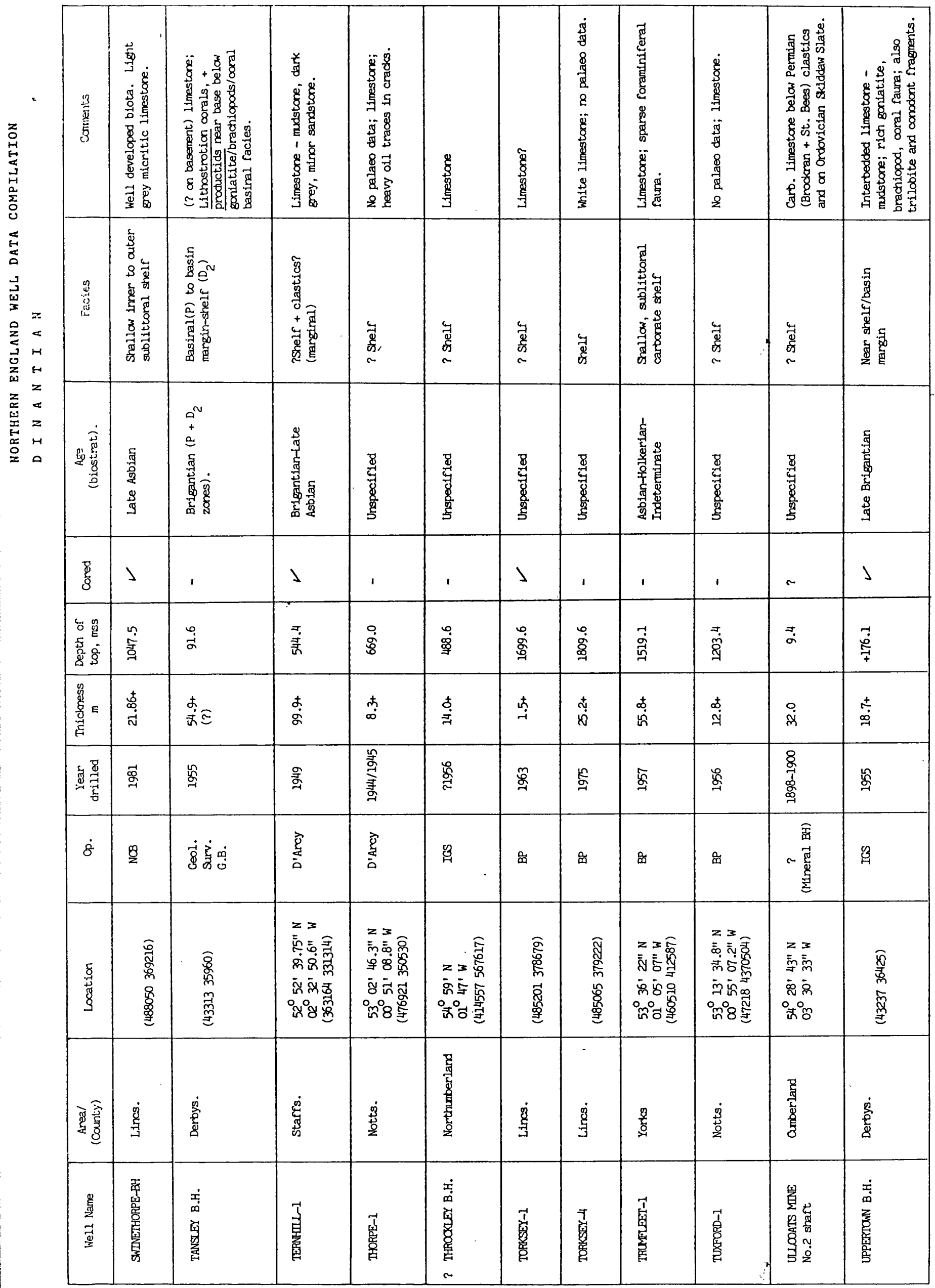




\begin{tabular}{|c|c|c|c|c|c|c|c|c|c|c|c|}
\hline 亳 & 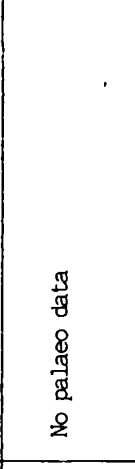 & 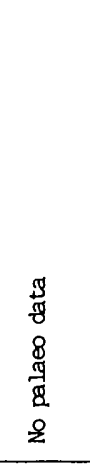 & 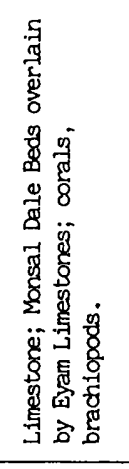 & 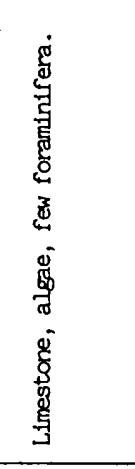 & 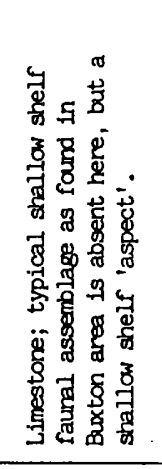 & 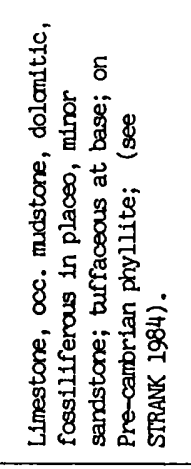 & 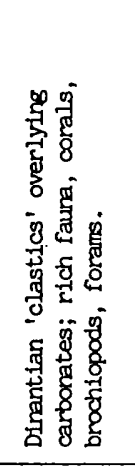 & 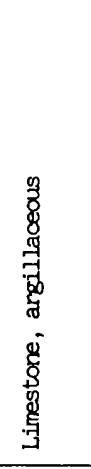 & 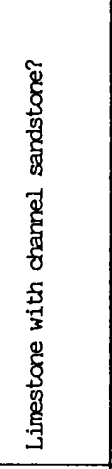 & 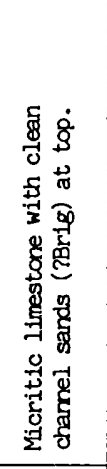 & 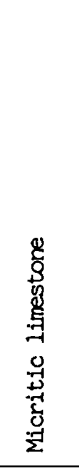 \\
\hline 第 & 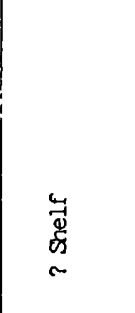 & $\begin{array}{l}\stackrel{y}{z} \\
\bar{x} \\
\sim\end{array}$ & 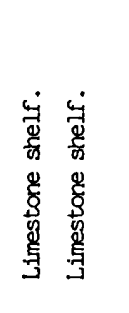 & 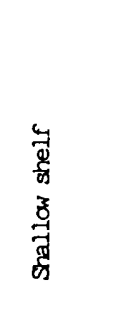 & 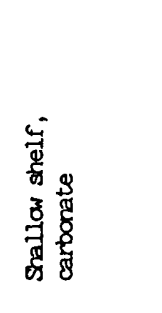 & 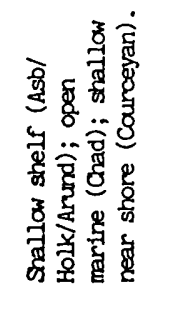 & 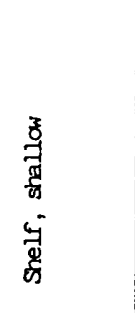 & 参 & 参 & 参 & 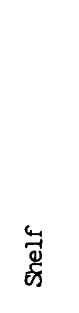 \\
\hline 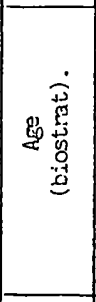 & 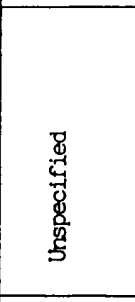 & 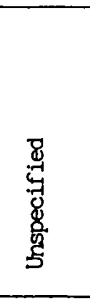 & 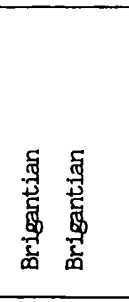 & 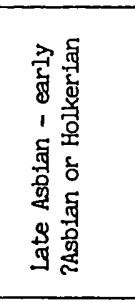 & 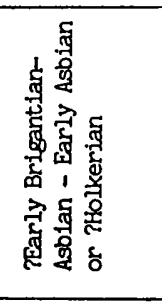 & 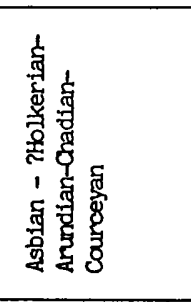 & 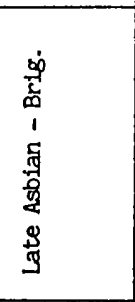 & 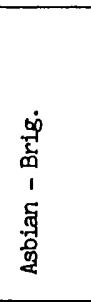 & 量 & 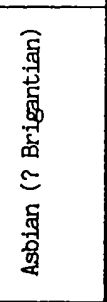 & 重 \\
\hline$\frac{\pi}{3}$ & $د$ & $د$ & $\lambda$ & 1 & 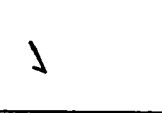 & \lrcorner & $د$ & &. & 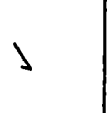 & $د$ \\
\hline 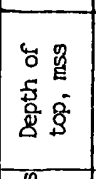 & 官 & $\tilde{\dot{\ddot{g}}}$ & 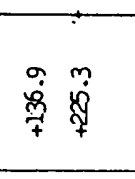 & 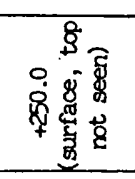 & 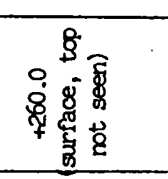 & $\overrightarrow{\underline{*}}$ & 曾 & 总 & 羍 & ्ְञ & 㪯 \\
\hline 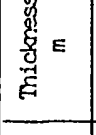 & 茟 & 志 & 索䯨 & 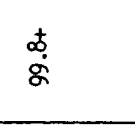 & 常 & æ. & 声 & 㺼 & $\stackrel{\vdots}{\$}$ & 芯 & 畜 \\
\hline 急总 & 算 & 焘 & ఫ్త & $\underset{g}{E}$ & E & $\overrightarrow{\mathrm{g}}$ & 㞼 & 帝 & 丞 & $\dddot{g}$ & $\dddot{\dddot{g}}$ \\
\hline$\dot{8}$ & 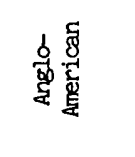 & 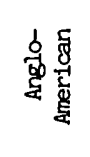 & 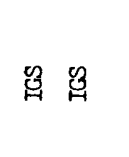 & $\mathscr{2}$ & $\mathscr{g}$ & 8 & $\approx$ & a & 吕 & هั & 뭄 \\
\hline $\begin{array}{l}8 \\
3 \\
3\end{array}$ & 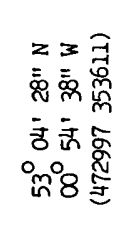 & 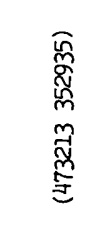 & 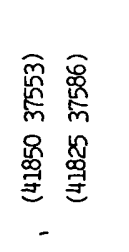 & 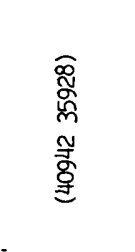 & 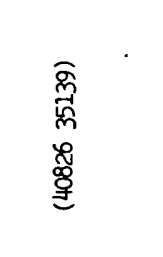 & 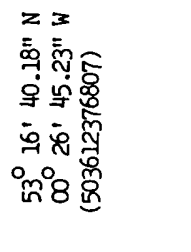 & 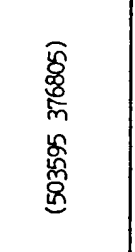 & 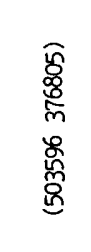 & 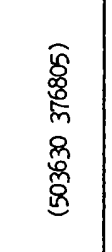 & 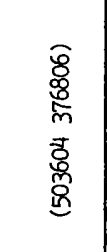 & 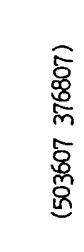 \\
\hline 要意 & $\frac{\dot{s}}{\frac{8}{2}}$ & $\frac{\dot{s}}{\underline{z}}$ & 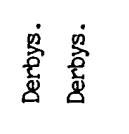 & 害 & 离 & 害 & 莺 & 路 & 曾 & 鹭 & 产 \\
\hline 量 & 竞 & 意 & 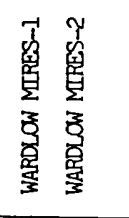 & 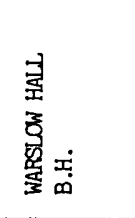 & 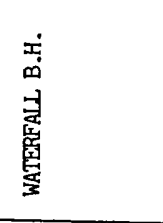 & 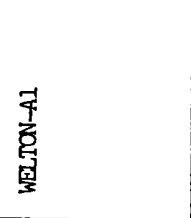 & 秚 & 鿷 & 熟 & 唯 & 量 \\
\hline
\end{tabular}




\begin{tabular}{|c|c|c|c|c|c|c|c|c|c|c|c|}
\hline $\begin{array}{l}\frac{3}{3} \\
\frac{1}{3}\end{array}$ & 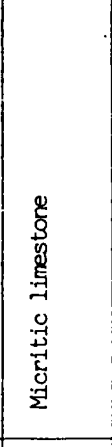 & 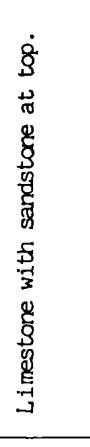 & 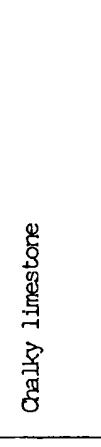 & & 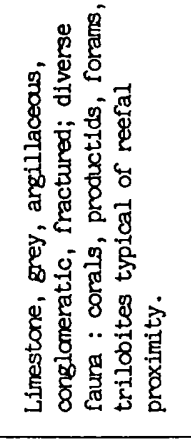 & 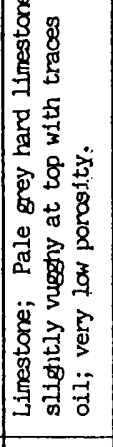 & 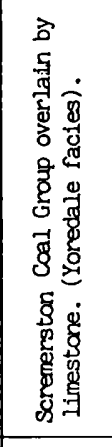 & 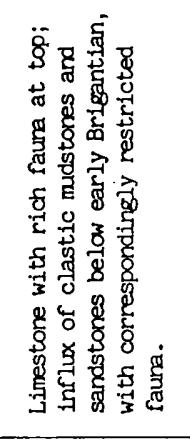 & 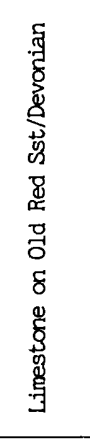 & 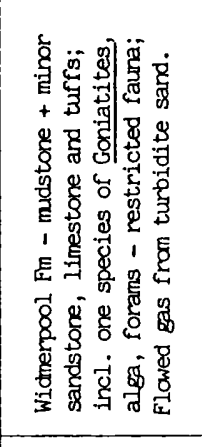 & 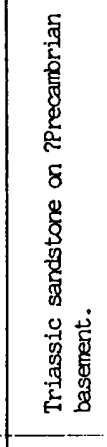 \\
\hline 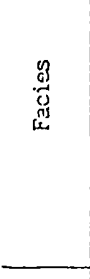 & 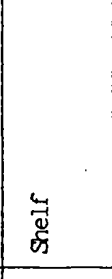 & 参 & 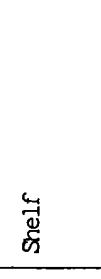 & & $\begin{array}{l}\text { 参 } \\
\text { 兽 } \\
\end{array}$ & 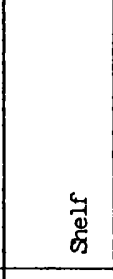 & 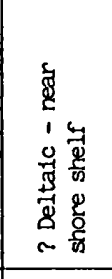 & 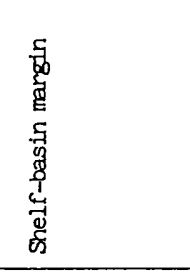 & 歖 & 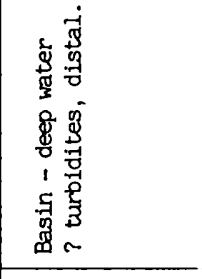 & 1 \\
\hline 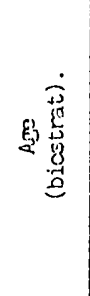 & 量 & 章 & 意 & & 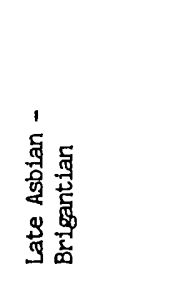 & 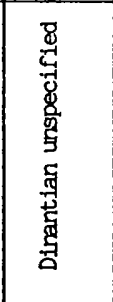 & 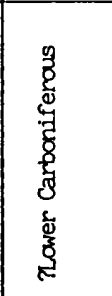 & 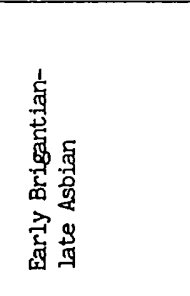 & 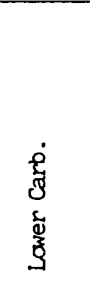 & 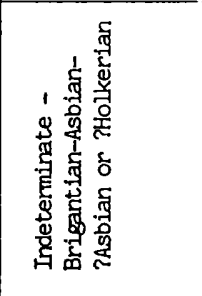 & 萈 \\
\hline$\frac{\mathbb{Z}}{3}$ & ' & 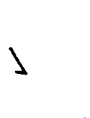 & ' & & 1 & $د$ & $\jmath$ & ' & a & $\jmath$ & , \\
\hline 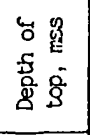 & 曾 & 市 & 尊 & & 䓵 & 字 & 胥 & $\overline{\dot{B}}$ & $\widetilde{\tilde{g}}$ & 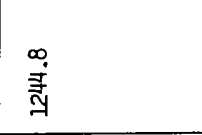 & 。 \\
\hline 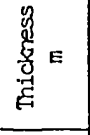 & \begin{tabular}{|l}
$\neq$ \\
毒
\end{tabular} & $\underset{8}{\alpha}$ & 莣 & & 壳 & 表 & 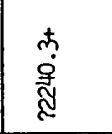 & 雍 & g. & 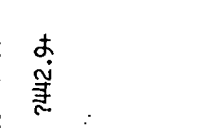 & 。 \\
\hline 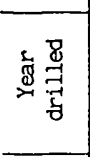 & 谷 & $\stackrel{\dddot{g}}{g}$ & $\stackrel{\leftrightarrow}{g}$ & $\overline{\mathrm{g}}$ & 呂 & ఖ & $\overline{8}$ & 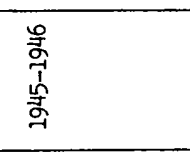 & 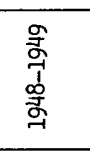 & 䂹 & $\vec{G}$ \\
\hline$\dot{8}$ & 品 & 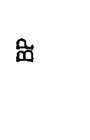 & 品 & 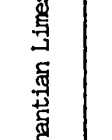 & $\frac{\mathscr{O}}{2}$ & 和咅 & 鹃 & 衰 & 㲅. & 害 & 总 \\
\hline $\begin{array}{l}8 \\
\frac{8}{3} \\
\frac{1}{3}\end{array}$ & 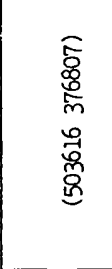 & 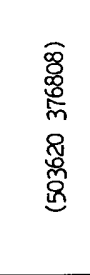 & 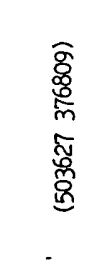 & 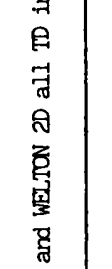 & 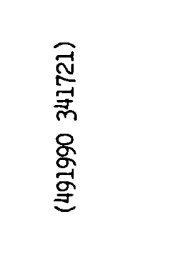 & 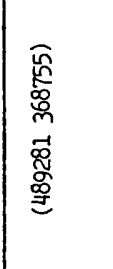 & 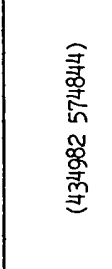 & 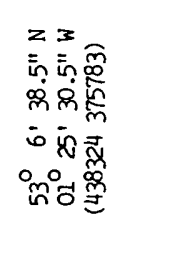 & $\begin{array}{l}\text { 兽 } \\
\text { 急 }\end{array}$ & 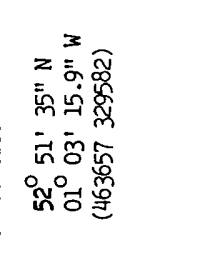 & 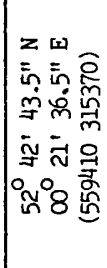 \\
\hline 焉要 & 然 & 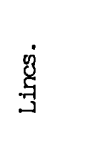 & 姁 & 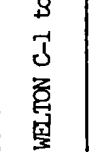 & 客 & 客 & 宰 & $\frac{8}{8}$ & 岛 & $\frac{\dot{s}}{\frac{3}{2}}$ & $\begin{array}{l}\text { 总 } \\
\text { 案 }\end{array}$ \\
\hline 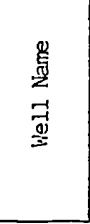 & 譩 & 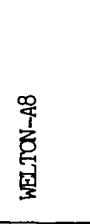 & 喜 & 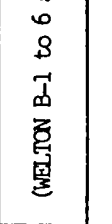 & 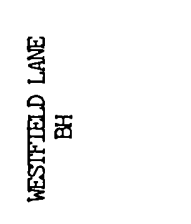 & 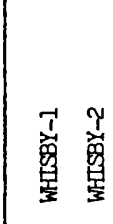 & 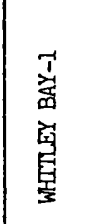 & 喜 & 辠 & 案 & 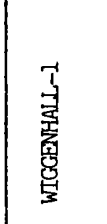 \\
\hline
\end{tabular}




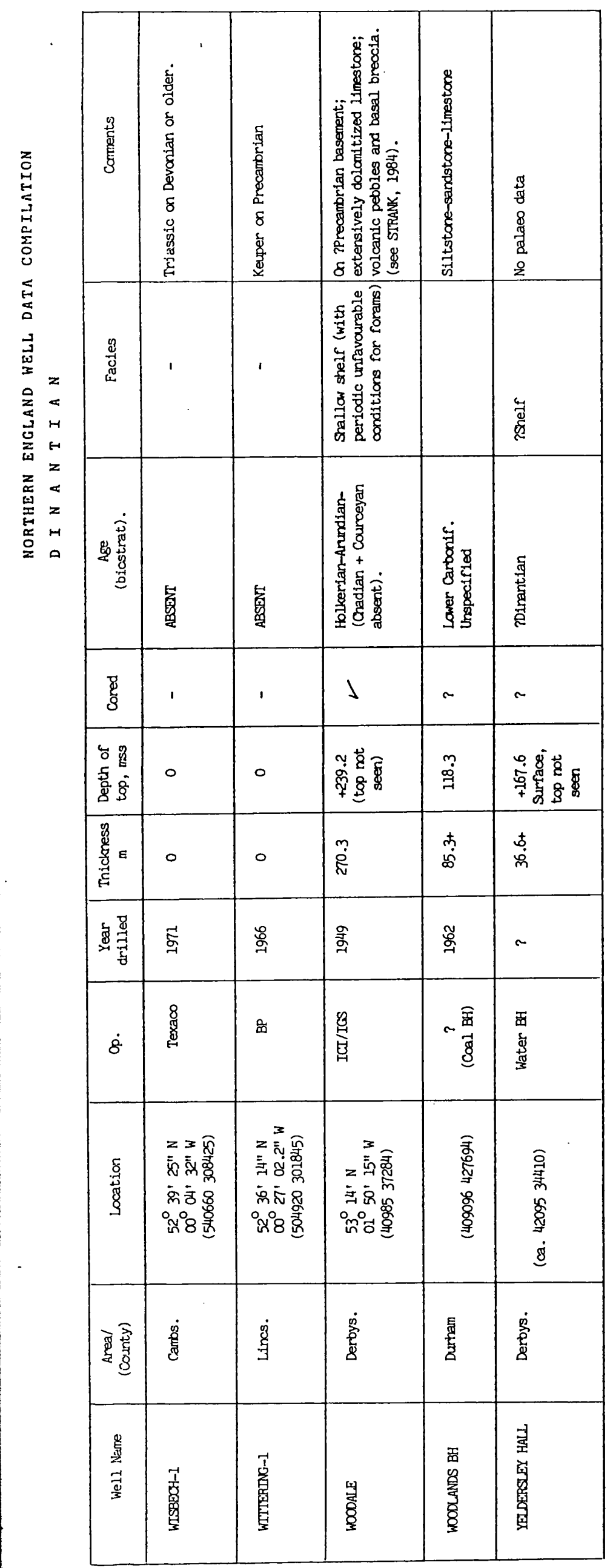




\begin{tabular}{|c|c|c|c|c|c|c|c|c|c|c|c|c|c|c|}
\hline $\begin{array}{l}\text { 量 } \\
\text { 尊 }\end{array}$ & 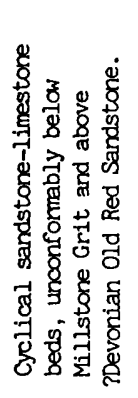 & 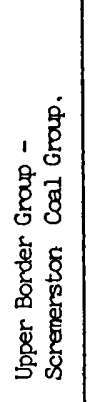 & 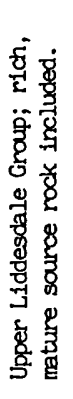 & 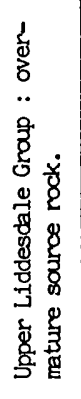 & 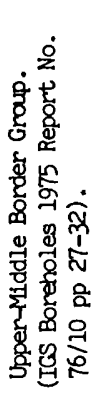 & 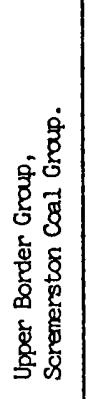 & 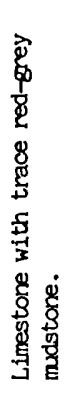 & 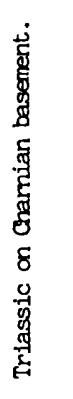 & 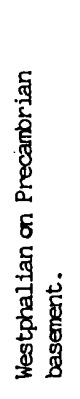 & 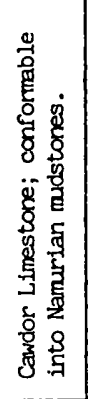 & 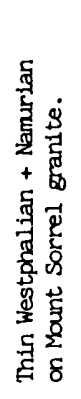 & 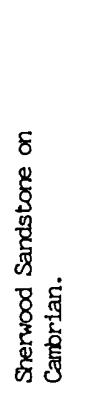 & 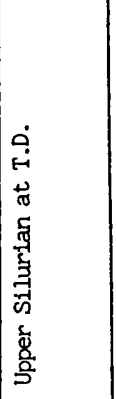 & 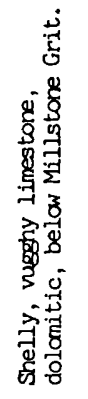 \\
\hline 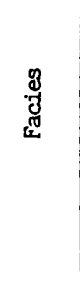 & 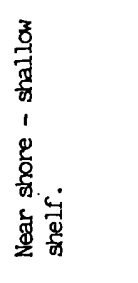 & 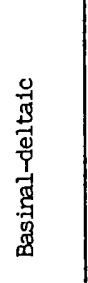 & $\frac{0}{3}$ & $\frac{0}{3}$ & 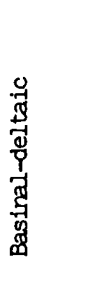 & $\frac{0}{\frac{3}{8}}$ & 岁 & 1 & $\omega$ & 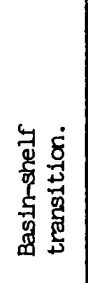 & I & ' & 1 & 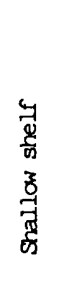 \\
\hline 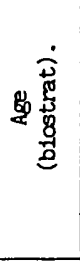 & 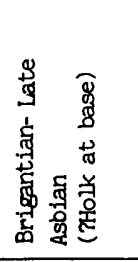 & 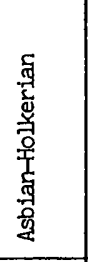 & 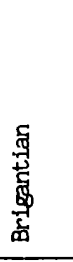 & 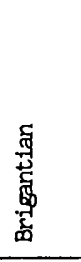 & 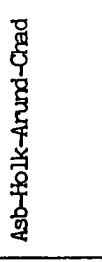 & $\begin{array}{l}\text { 羊 } \\
\text { 总 } \\
\text { 曾 }\end{array}$ & 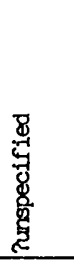 & 䉥 & 㽚 & 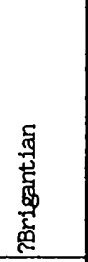 & 薑 & 窗 & 掏 & 薆 \\
\hline$\frac{7}{8}$ & & 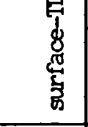 & & & & ' & 1 & & & & 1 & ' & 1 & \\
\hline 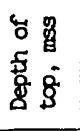 & 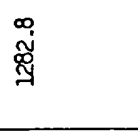 & $\cdots$ & $\sim$ & $\sim$ & 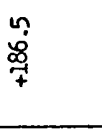 & 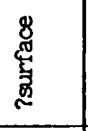 & 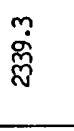 & 0 & $\circ$ & 官 & 0 & 0 & $\circ$ & ğ \\
\hline $\begin{array}{l}\text { g } \\
\frac{8}{8} \\
\text { है }\end{array}$ & $\stackrel{\sim}{\stackrel{n}{\tilde{m}}}$ & $\infty$ & $\sim$ & 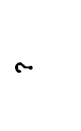 & $\begin{array}{l}+ \\
\\
8\end{array}$ & $\sim$ & $\stackrel{t}{5}$ & 0 & 0 & $\sim$ & 0 & 0 & $\circ$ & $\begin{array}{l}\text { ま } \\
\text { ம் }\end{array}$ \\
\hline 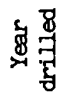 & 㞼 & 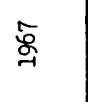 & $\sim$ & $\cdots$ & $\stackrel{m}{\mathscr{G}}$ & 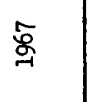 & $\underset{G}{\mathscr{G}}$ & 号 & E్ & $\omega$ & $\stackrel{\text { L }}{g}$ & 鸹 & స్త్య & \& \\
\hline$\dot{8}$ & $\begin{array}{l}\vec{\Xi} \\
\dot{\tilde{x}}\end{array}$ & 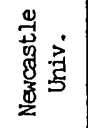 & : & ஜ్ర & z⿺辶 & 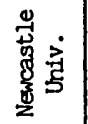 & 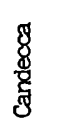 & $\frac{B}{Z}$ & $\underset{Z}{Z}$ & $\frac{8}{2}$ & $\frac{B}{2}$ & $\frac{B}{z}$ & $y$ & ; \\
\hline 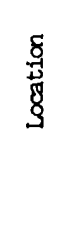 & 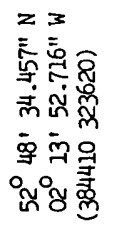 & 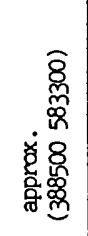 & 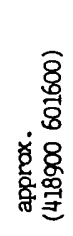 & 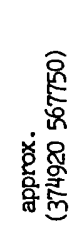 & 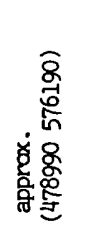 & 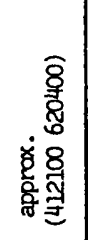 & 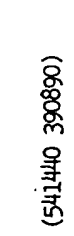 & 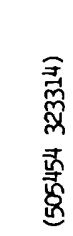 & 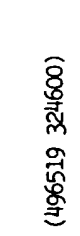 & 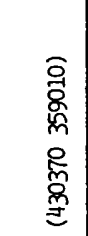 & 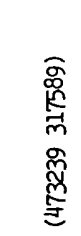 & 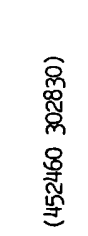 & 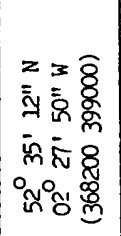 & 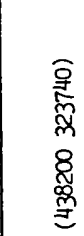 \\
\hline 零 & $\begin{array}{l}\dot{8} \\
\dot{c} \\
\dot{c}\end{array}$ & 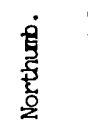 & $\begin{array}{l}\frac{1}{5} \\
\frac{5}{5} \\
\frac{5}{2}\end{array}$ & $\begin{array}{l}\dot{1} \\
\text { 蒠 } \\
\text { 尊 }\end{array}$ & $\begin{array}{l}\dot{\gamma} \\
\text { 害 } \\
\text { 尊 }\end{array}$ & 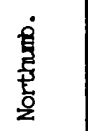 & $\dot{8}$ & $\dot{g}$ & $\dot{\dot{g}}$ & $\begin{array}{l}\dot{8} \\
\frac{\operatorname{sen}}{8}\end{array}$ & छ் & $\dot{3}$ & $\begin{array}{l}\dot{0} \\
\text { छे } \\
\dot{\xi}\end{array}$ & $\begin{array}{l}\dot{3} \\
\stackrel{3}{0} \\
z\end{array}$ \\
\hline 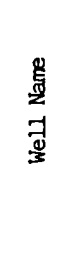 & 音 & $\begin{array}{l}\text { 品 } \\
\text { 㥯 } \\
\text { 息 }\end{array}$ & 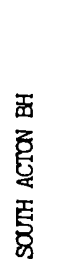 & $\begin{array}{l}\text { 覀 } \\
\text { 总 } \\
\text { 国 }\end{array}$ & 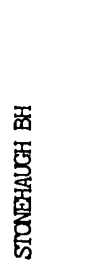 & 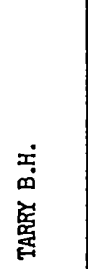 & 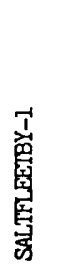 & $\begin{array}{l}\text { 覃 } \\
\text { 筫 } \\
\text { 穿 } \\
\text { 宩 }\end{array}$ & 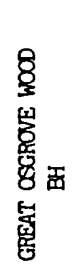 & 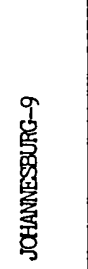 & 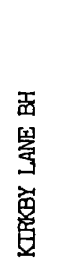 & 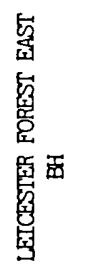 & 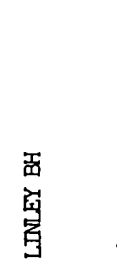 & 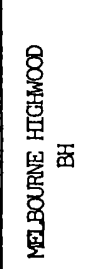 \\
\hline
\end{tabular}




\begin{tabular}{|c|c|c|c|c|c|c|c|c|c|c|c|}
\hline 照 & 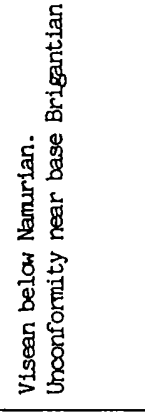 & 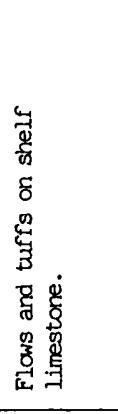 & 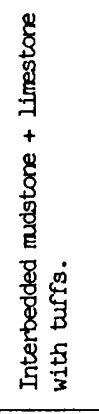 & 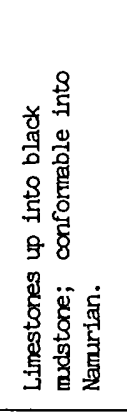 & 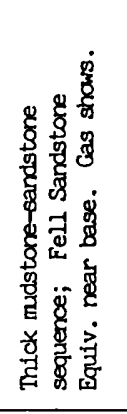 & 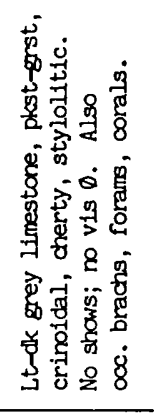 & 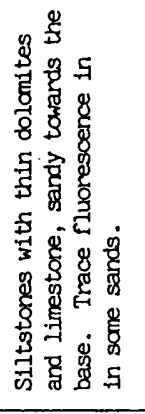 & 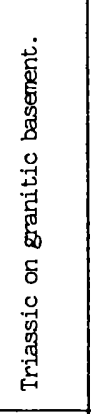 & 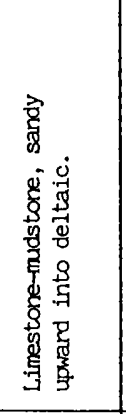 & 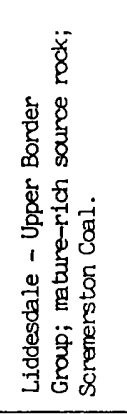 & 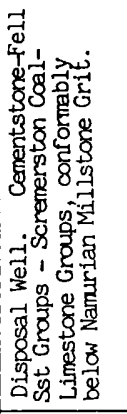 \\
\hline 䄈 & 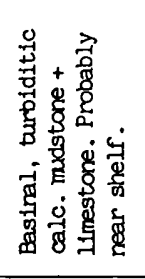 & 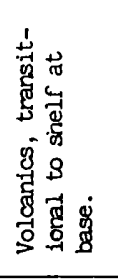 & 鴶 & 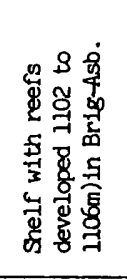 & 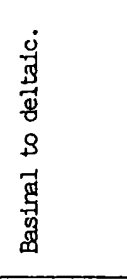 & 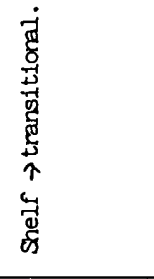 & 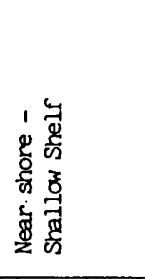 & & 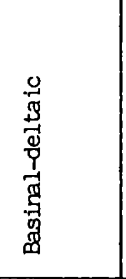 & $\frac{0}{3}$ & 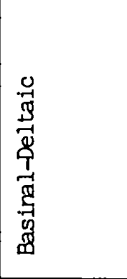 \\
\hline 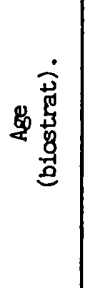 & 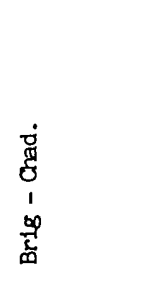 & 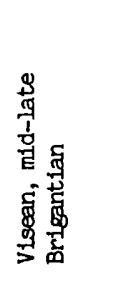 & 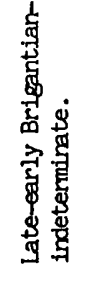 & 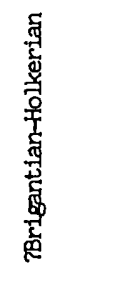 & 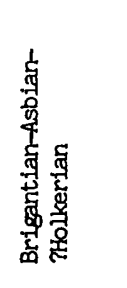 & 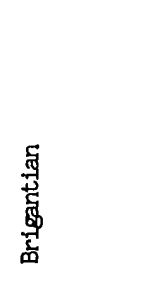 & 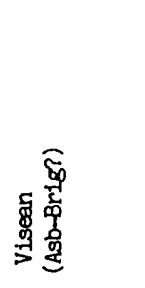 & 瓷 & 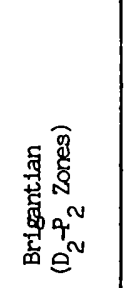 & 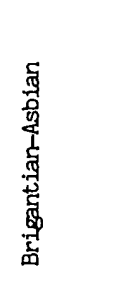 & 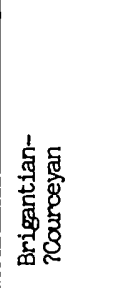 \\
\hline 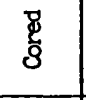 & 1 & & & ' & & $د$ & ' & & & 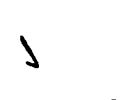 & $\lambda$ \\
\hline 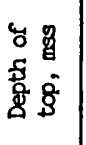 & 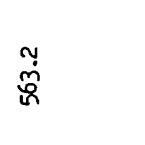 & 产 & 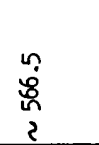 & $\begin{array}{l}\text { 蒿 } \\
\text { 兽 }\end{array}$ & 足 & 芯 & ঙ્. & 0 & 总 & 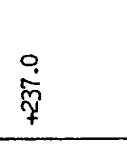 & $\vec{E}$ \\
\hline 量 & 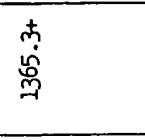 & 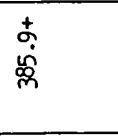 & 志 & 壳 & 亳 & 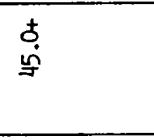 & 晜 & $\circ$ & 志 & $\stackrel{n}{5}$ & 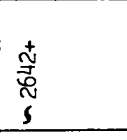 \\
\hline 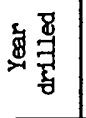 & 帝 & 品 & 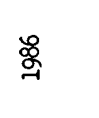 & ‡ & 惫 & 罒 & 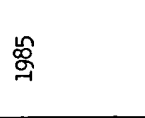 & 怘 & 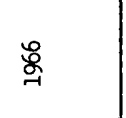 & 壳 & 等 \\
\hline$\dot{8}$ & 볼 & 囬 & 뭄 & $\frac{8}{2}$ & 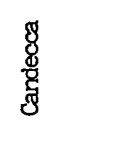 & 볼 & $\begin{array}{l}\overrightarrow{\mathrm{g}} \\
\frac{5}{n}\end{array}$ & $\begin{array}{l}8 \\
8 \\
\frac{8}{8}\end{array}$ & 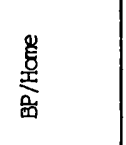 & g్ & 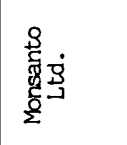 \\
\hline 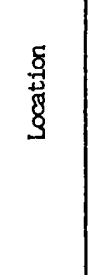 & 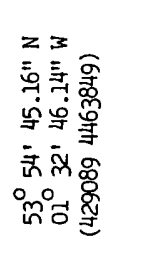 & 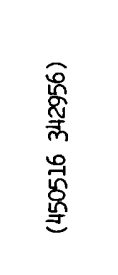 & 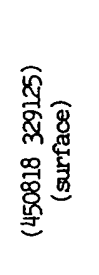 & 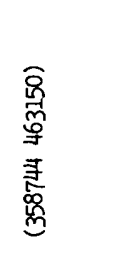 & 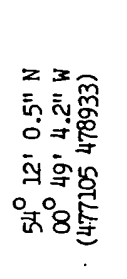 & 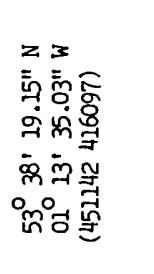 & 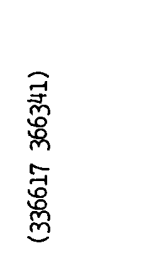 & 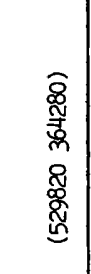 & 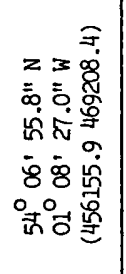 & 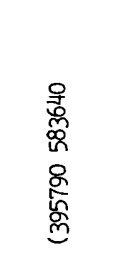 & 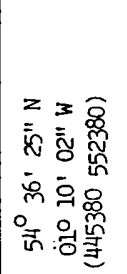 \\
\hline 要变 & 啶 & $\begin{array}{l}\frac{9}{3} \\
\frac{3}{2}\end{array}$ & $\frac{g}{2}$ & $\begin{array}{l}\dot{g} \\
\frac{\operatorname{g}}{\mathrm{g}}\end{array}$ & 密 & 旁 & 毒 & $\frac{g}{3}$ & 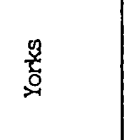 & 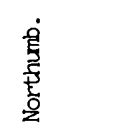 & 哭 \\
\hline 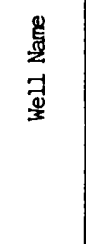 & 章 & 䰛产 & 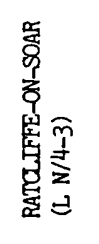 & 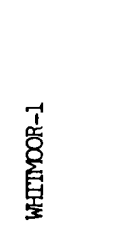 & 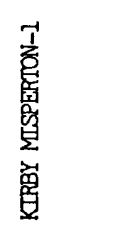 & 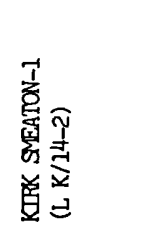 & 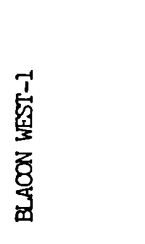 & $\begin{array}{l}\frac{1}{1} \\
\frac{1}{y} \\
\end{array}$ & 㢺 & 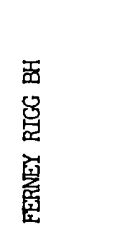 & 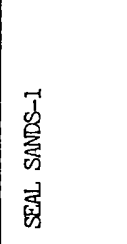 \\
\hline
\end{tabular}




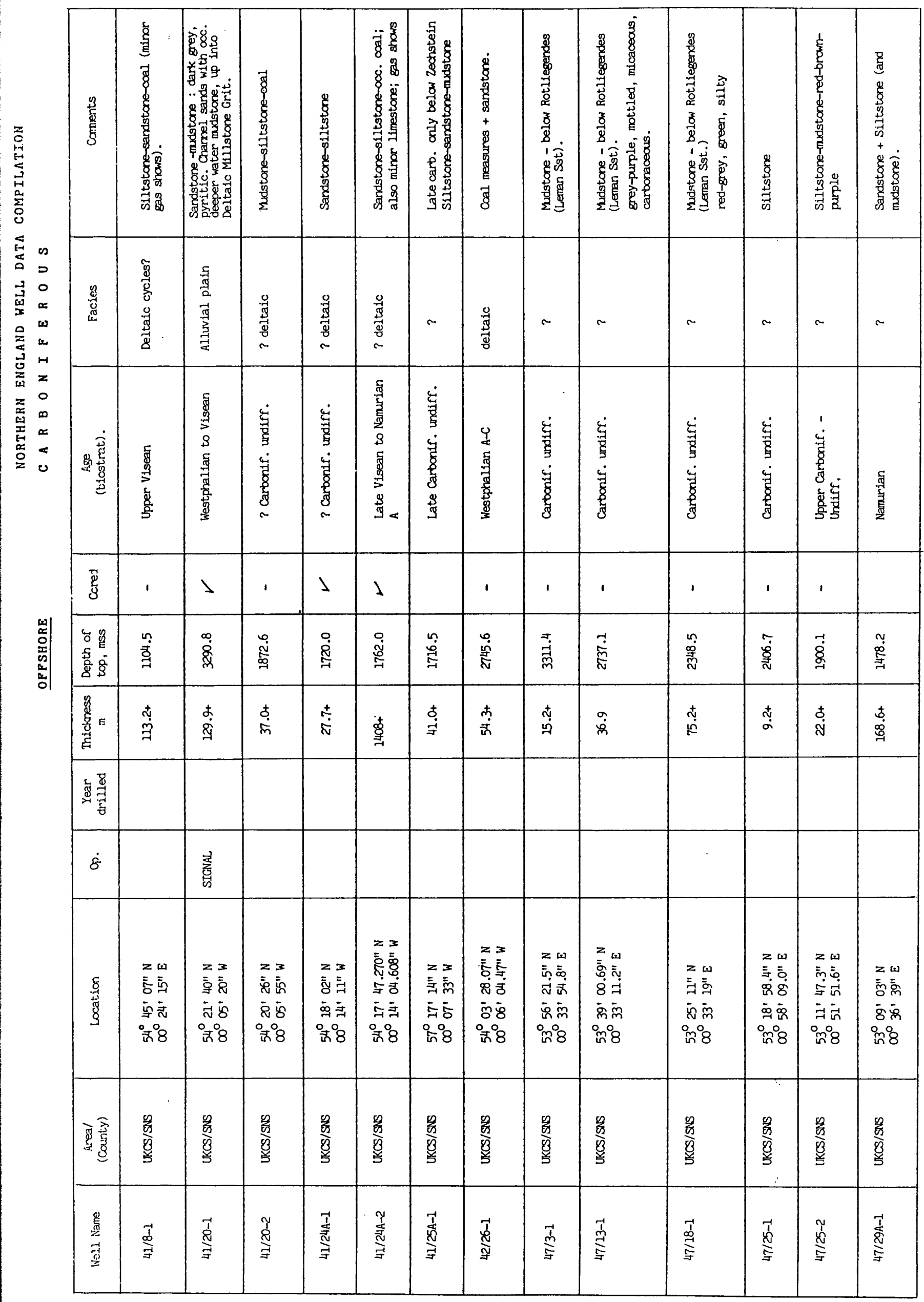




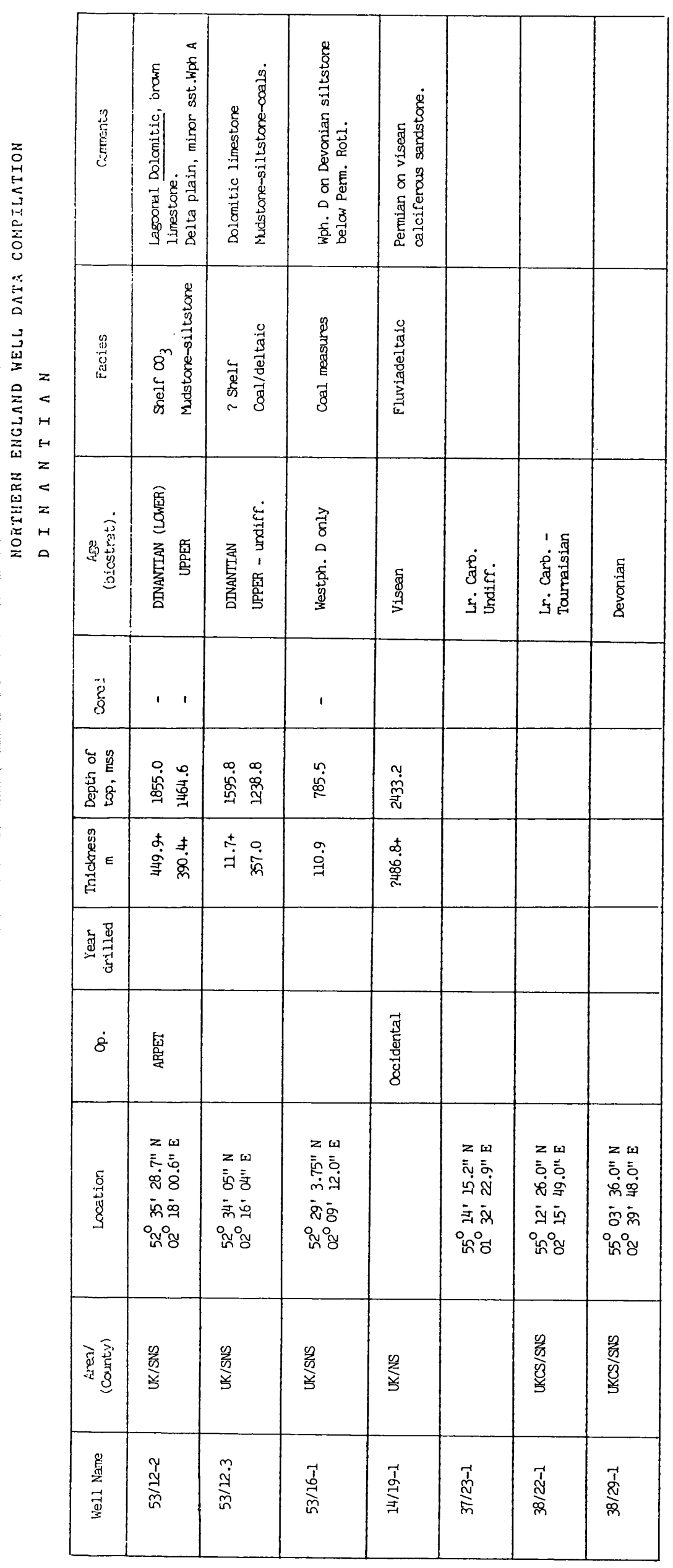




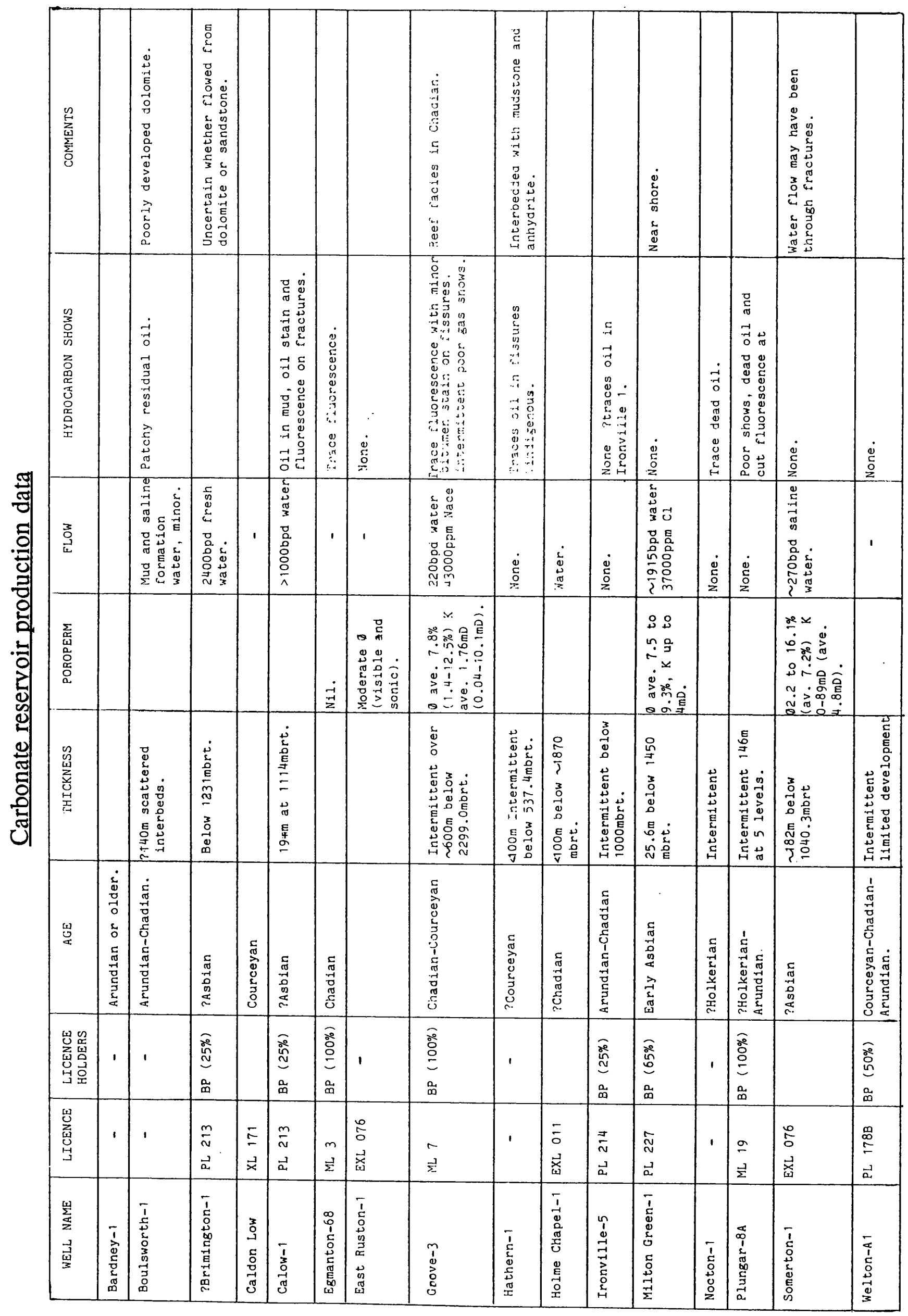


Appendix B

Northern England Carboniferous

Depth conversion of regional seismic profiles 
Example velocities used in depth conversion of the regional seismic profiles derived from borehole velocity analysis and seismic stacking velocities over the Eakring and Welton oilfields and the Northumberland Trough (Plates 3.8, 3.9 \& 3.20).

Welton

Jurassic

$2450 \mathrm{~m} / \mathrm{sec}$

Triassic(Sherwood Sandstone)

$3290 \mathrm{~m} / \mathrm{sec}$

Permian (Magnesian Limestone)

$3470 \mathrm{~m} / \mathrm{sec}$

Late Westphalian (Variscan)

$3700 \mathrm{~m} / \mathrm{sec}$

Westphalian (Coal Measures)

$3450 \mathrm{~m} / \mathrm{sec}$

Namurian (Millstone Grit)

$3700 \mathrm{~m} / \mathrm{sec}$

Dinantian (EC6)

$5350 \mathrm{~m} / \mathrm{sec}$

EC5

$5600 \mathrm{~m} / \mathrm{sec}$

EC4

$5650 \mathrm{~m} / \mathrm{sec}$

EC3

$5700 \mathrm{~m} / \mathrm{sec}$

EC2

$5750 \mathrm{~m} / \mathrm{sec}$

EC1

$5500 \mathrm{~m} / \mathrm{sec}$

Palaeozoic basement

$7000 \mathrm{~m} / \mathrm{sec}$

Eakring

Triassic(Sherwood Sandstone)

$2700 \mathrm{~m} / \mathrm{sec}$

Permian (Magnesian Limestone)

$3730 \mathrm{~m} / \mathrm{sec}$

Westphalian (Coal Measures)

$3100 \mathrm{~m} / \mathrm{sec}$

Namurian (Millstone Grit)

$3300 \mathrm{~m} / \mathrm{sec}$

Dinantian (EC6)

$5000 \mathrm{~m} / \mathrm{sec}$

EC5

$5350 \mathrm{~m} / \mathrm{sec}$

EC4

$5400 \mathrm{~m} / \mathrm{sec}$ 
EC3

EC2

EC1

Palaeozoic basement
$5500 \mathrm{~m} / \mathrm{sec}$

$5700 \mathrm{~m} / \mathrm{sec}$

$5500 \mathrm{~m} / \mathrm{sec}$

$7000 \mathrm{~m} / \mathrm{sec}$

Northumberland Trough (Kimbell et al. 1989)

Stainmore Group (LC1)

Liddlesdale Group (EC4-EC6)

Upper Border Group (EC3)

Cambeck Beds (EC2)

Lower Border Group (EC1)
$3600 \mathrm{~m} / \mathrm{sec}$

$3980 \mathrm{~m} / \mathrm{sec}$

$4130 \mathrm{~m} / \mathrm{sec}$

$4780 \mathrm{~m} / \mathrm{sec}$

$5500 \mathrm{~m} / \mathrm{sec}$ 
Appendix C

Northern England Carboniferous

Geochemical data, reports \& sample locations 
Source Rock Data

Area: East Midlands (1)

\begin{tabular}{|c|c|c|c|c|c|c|c|c|}
\hline SAMPLE & AGE & $\begin{array}{l}\text { FOPPATTON } \\
\text { LTPHOCOGY }\end{array}$ & FACIES & $\underset{\text { ROR }}{\text { MATURIY }}$ & $\begin{array}{l}\mathrm{Kg}_{2} \\
\mathrm{P}_{2}{ }^{\mathrm{RICH}}-1\end{array}$ & Toc & KEROCEN TYPE & COMPNIS, REFERENCES \\
\hline \multirow{2}{*}{$\begin{array}{l}\text { BORGHOLES - CAD } \\
\text { Scaftworth-2 }\end{array}$} & INSBOROUCH & Trouct & & & & & & CURRAN 1983; \\
\hline & $\begin{array}{l}\text { Pendleian- } \\
\text { Brigantian- } \\
\text { Asbian }\end{array}$ & $\begin{array}{c}\text { Mudstonet } \\
\text { limestone }\end{array}$ & $\begin{array}{l}\text { Basinal-? } \\
\text { prodelta }\end{array}$ & $\mid \begin{array}{l}>1.3 \\
\text { over } \\
\text { mature }\end{array}$ & $0-0.03$ & 2.7 & $\begin{array}{l}\text { Terrigenous input } \\
\text { Gas }+\infty \text { ondensate }\end{array}$ & $\begin{array}{l}\text { 1986; TAYLR, } 1987 \\
\text { No residual potential } \\
\text { 3some original } \\
\text { potential. }\end{array}$ \\
\hline Gainsborough-2 & Pendleian & $\begin{array}{l}\text { Gamma } \\
\text { Active } \\
\text { Shales }\end{array}$ & $\begin{array}{l}\text { Prodelta - } \\
\text { basin }\end{array}$ & $0.7-0.8$ & $\begin{array}{l}1.0-2.0 \\
\text { (13.9 max) }\end{array}$ & $3.0-7.0$ & $\begin{array}{l}\text { Mixed: Gas + oil } \\
\text { prone }\end{array}$ & $\begin{array}{l}\text { oil + gas prone } \\
100-200 \mathrm{~m} \text { thick }\end{array}$ \\
\hline \multirow[b]{2}{*}{ Edale-1 } & $L E$ GLF & & & & & & & \\
\hline & $\begin{array}{l}\text { Brigantian- } \\
\text { Asbian }\end{array}$ & \begin{tabular}{|l|} 
Alport/ \\
Edale \\
Shales \\
(minor \\
limestone)
\end{tabular} & $\begin{array}{l}\text { Basinal - } \\
\text { (prodelta) }\end{array}$ & $>1.3$ & - & 8.0 & Mixed & $\begin{array}{l}\text { No residual source } \\
\text { but? gas + condensate } \\
\text { prone original } \\
\text { potential }\end{array}$ \\
\hline Alport-1 & $\begin{array}{l}\text { Pendleian- } \\
\text { Brigantian }\end{array}$ & - & & $>1.3$ & $1.9-3.0$ & & Gas prone & $\begin{array}{l}\text { Predicted original } P_{2} \\
38-60 \mathrm{~kg} \text { tonne } \\
\text { Pendleian richer than } \\
\text { Brigantian }\end{array}$ \\
\hline \multirow{3}{*}{ Gun Hill-1 } & TROUGH & & & & & & & \\
\hline & Pend-Asb & $\begin{array}{c}\text { Mudstone } \\
(+ \text { tolcanic })\end{array}$ & Basinal & 1.0 & Ave. 1.8 & Ave. 1.3 & $\begin{array}{l}\text { Gas + condensate } \\
\text { prone. } \\
\text { Vascular plant, } \\
\text { minor algae. }\end{array}$ & $\begin{array}{l}\text { Moderate - good source } \\
\text { potential predicted } \\
\text { original p } \mathrm{P}_{2}<15.0 \mathrm{~kg} \\
\text { tonne }\end{array}$ \\
\hline & Holk-Courc. & $\left|\begin{array}{c}\text { Mudstone } \\
(+ \text { volcanic })\end{array}\right|$ & Basinal & $>1.0$ & & & $\begin{array}{l}\text { Gas + condensate } \\
\text { prone. } \\
\text { Vascuiar plant. } \\
\text { mi nor algae. }\end{array}$ & Poor source potential \\
\hline \multicolumn{2}{|c|}{ WIIMERPOOL GIIF } & & & & & & & \\
\hline \multirow{2}{*}{ Widmerpool-1 } & Pendleian & & $\begin{array}{l}\text { Basin + } \\
\text { proximal } \\
\text { turbidite }\end{array}$ & $<0.7$ & 5.0 ave & - & $\begin{array}{l}\text { Oil + gas prone } \\
\text { terrigenous }\end{array}$ & $\begin{array}{l}\text { Predicted original } \\
\mathrm{P}_{2}=6.7 \mathrm{~kg} \text { tonne }\end{array}$ \\
\hline & Brigantian & $\begin{array}{l}\text { Widmerpool } \\
\text { Fm. }\end{array}$ & Basin & $0.7-0.85$ & 5.6 ave & - & $\begin{array}{l}\text { ofl }+ \text { gas prone } \\
\text { terrigenous }\end{array}$ & $\begin{array}{l}\text { Predicted original } \\
\mathrm{P}_{2}=11.2 \mathrm{~kg} \text { tonne }\end{array}$ \\
\hline \multirow{3}{*}{ Duffield B.H. } & Pendleian & $\begin{array}{l}\text { Mudstone + } \\
\text { sandstone }\end{array}$ & $\begin{array}{l}\text { Restricted } \\
\text { marine basin }\end{array}$ & $0.6-0.7$ & 11.9 ave & $>2.0$ & $\begin{array}{l}\text { Terrigenous } \\
\text { input. Mixed; } \\
\text { oil + gas prone }\end{array}$ & $\begin{array}{l}\text { Predicted original } \\
\mathrm{P}_{2}=15.9 \mathrm{~kg} \text { tonne }\end{array}$ \\
\hline & Brigantian & Mudstone & $\begin{array}{l}\text { Restricted } \\
\text { marine basin }\end{array}$ & $\mathrm{ca} 0.8$ & - & $1.2-6.1$ & $\begin{array}{l}\text { Mixed; oil }+ \\
\text { gas prone }\end{array}$ & $\begin{array}{l}\text { Predicted origina } f \\
\mathrm{P}_{2} 12.3 \mathrm{~kg} \text { tonne-f }\end{array}$ \\
\hline & Asbian & $\begin{array}{l}\text { Mudstone + } \\
\text { igneous } \\
\text { rocks }\end{array}$ & $\begin{array}{l}\text { Restricted } \\
\text { marine basin }\end{array}$ & $\mid \begin{array}{c}>1.3 \\
\text { (intru- } \\
\text { sives) }\end{array}$ & & $0.5-4.4$ & Mixed & $\begin{array}{l}\text { PETRACHEM } 1985 \\
-\end{array}$ \\
\hline Werdlow Mires-2 & Brigantian & $\begin{array}{l}\text { Mudstone+ } \\
\text { limestone }\end{array}$ & Basin-shelf & 1.04 & $0.5-1.4$ & $0.6-4.6$ & $\begin{array}{l}\text { Structured } \\
\text { terrigenous } \\
\text { plant + a amorphous } \\
\text { algal. - MIXED }\end{array}$ & $\begin{array}{l}\text { Wet gas only at presen } \\
\text { day maturity level }\end{array}$ \\
\hline Ilkeston-1 & E. Namurian & $\begin{array}{l}\text { Gamma- } \\
\text { Active } \\
\text { Shales }\end{array}$ & $\begin{array}{l}\text { Prodelta to } \\
\text { open marine }\end{array}$ & 0.8 & - & - & & TAYIOR, 1986 \\
\hline
\end{tabular}


Source Rock Data

Area: East Midlands (2)

\begin{tabular}{|c|c|c|c|c|c|c|c|c|}
\hline SAMPLE & AGE & $\begin{array}{l}\text { FORMATTON } \\
\text { LITHOLOGY }\end{array}$ & PACIES & $\underset{\text { Rof }}{\text { MATURTY }}$ & Kg tornne- & SS & KEROCPN TYPE & COMMPNIS, REFERPNCES \\
\hline \multirow{3}{*}{ Rempstone-1 } & $\begin{array}{l}\text { L. } \\
\text { Dinantian }\end{array}$ & Mudstone & Marine & & $1.9-9.7$ & 1.03 .6 & & $\begin{array}{l}\mathrm{P}_{2} \text { values given are } \\
\text { predicted original }\end{array}$ \\
\hline & Pendleian & Mudstones & $\begin{array}{l}\text { Prodelta/ } \\
\text { Marine }\end{array}$ & & $2.1-10.1$ & $0.5-3.8$ & & \\
\hline & $\begin{array}{l}\text { Arnsbergian- } \\
\text { ?Chokierian }\end{array}$ & Mudstones & Prodelta & & $5.9-19.5$ & $3.2-4.8$ & & \\
\hline \multirow{2}{*}{ Rufford-1 } & Dinantian & Mudstones & Marine & & 2.2 & 0.5 & & \\
\hline & E. Namurian & Mudstones & Prodelta & & $2.3-8.1$ & $0.8-2.7$ & & \\
\hline \multirow{3}{*}{ Kinoulton-1 } & L.Dinantian & Mudstones & Marine & & $2.8-3.2$ & $1.4-1.6$ & & \\
\hline & Pendleian & Mudstones & $\begin{array}{l}\text { Prodelta/ } \\
\text { marine }\end{array}$ & & $2.8-9.0$ & $1.1-3.5$ & & \\
\hline & Arnsbergian & Mudstones & Prodelta & & $7.9-14.7$ & $2.8-4.6$ & & $\begin{array}{l}\text { Potential destroyed by } \\
\text { dolerite sill }\end{array}$ \\
\hline \multicolumn{2}{|c|}{ "SHETP" AREAS } & & & & & & & CURRAN, 1983 \\
\hline Eakring-146 & Visean & $\begin{array}{l}\text { Mudstone/ } \\
\text { siltstone }\end{array}$ & Marino-shelf & $>0.6$ & & 2.6 & - & Possibly migrated oil \\
\hline Welton-Al & $\begin{array}{l}\text { Asblan- } \\
\text { courceyan }\end{array}$ & $\begin{array}{l}\text { Limestonet } \\
\text { minor } \\
\text { mudstone }\end{array}$ & Shelf & $\begin{array}{l}\text { Over- } \\
\text { mature }\end{array}$ & $\begin{array}{l}0.5-1.0 \\
\max \text { in } \\
\text { Chad/Courc }\end{array}$ & 0.45 ave. & $\begin{array}{l}\text { Gas + condensate } \\
\text { prone }\end{array}$ & $\begin{array}{l}\text { Fow intervals of } \\
\text { interest for source } \\
\text { potential - only } \\
\text { poor - moderate at } \\
\text { best. Thin horizons }\end{array}$ \\
\hline Egnanton-68 & PBrig-Chad & $\begin{array}{l}\text { Limestonet } \\
\text { minor } \\
\text { mudstone }\end{array}$ & $\begin{array}{l}\text { Shelf with } \\
\text { Chadian } \\
\text { 'reef' } \text {; coals } \\
\text { in Holkerian }\end{array}$ & & 0.2 ave & 0.5 ave & $\begin{array}{l}\text { Gas + condensate } \\
\text { prone }\end{array}$ & $\begin{array}{l}\text { Richest in Holkerian } \\
\text { but no significant } \\
\text { source potential; } \\
\text { some migrated oi i } \\
\text { traces }\end{array}$ \\
\hline Grove-3 & Brig-Courc. & $\begin{array}{l}\text { Dolanitet } \\
\text { limestone }\end{array}$ & Shelf & & 0 predam. & 0.19 ave & - & $\begin{array}{l}\text { No signi ficant } \\
\text { potential }\end{array}$ \\
\hline Eyam & Chad-Courc & $\begin{array}{l}\text { Domanitet } \\
\text { limestone }\end{array}$ & Shelf & $\begin{array}{l}7.13 \\
\text { (near } \\
\text { lgneous } \\
\text { rocks) }\end{array}$ & - & - & - & No potential \\
\hline Black Cat BH & 3Asb/Holk. & $\begin{array}{l}\text { Mudstone/ } \\
\text { limestone }\end{array}$ & Shelf & & 0.2 ave. & 2.0 ave. & $\begin{array}{l}\text { Gas + gas/oil } \\
\text { prone }\end{array}$ & Poor potential \\
\hline Trumfleet-1 & Asbian & Limestone & Shelf & - & - & $5.0 \max$ & & \\
\hline Hathern-1 & & & & & & & & $\begin{array}{l}\text { ROEERTSONS RESEARCH } \\
1986 \text { a }\end{array}$ \\
\hline \multirow{3}{*}{ Caldon Low } & Chadian & Dolanite & Shallow Shelf & 6.09 & - & - & - & \\
\hline & Courceyan & $\begin{array}{l}\text { Dolanite/ } \\
\text { mudstone }\end{array}$ & $\begin{array}{l}\text { Near shore/ } \\
\text { shelf }\end{array}$ & $0.5-1.3$ & $0.5-12.5$ & $<2.0$ ave & $\begin{array}{l}\text { Up to } 608 \\
\text { inertinite }\end{array}$ & No source potential \\
\hline & ?Devonian & $\begin{array}{l}\text { Mudstone/ } \\
\text { sandstone }\end{array}$ & $\begin{array}{l}\text { Near shore/ } \\
\text { alluvial }\end{array}$ & 1.7 & - & & $\begin{array}{l}\text { Up to } 908 \\
\text { inertinite }\end{array}$ & No source potential \\
\hline
\end{tabular}


Source Rock Data

Area: East Midlands (3)

\begin{tabular}{|c|c|c|c|c|c|c|c|c|}
\hline SAMPLE & AGE & $\begin{array}{l}\text { POFPATION } \\
\text { LITHOLOGY }\end{array}$ & FACIES & $\begin{array}{l}\text { MATURTTY } \\
\text { ROA }\end{array}$ & $\mathrm{Kg} \stackrel{\mathrm{P}}{\mathrm{P}}_{\mathrm{Rnne-}}^{\mathrm{RICW}}$ & $\begin{array}{l}\text { SSS } \\
\text { Toc } \\
\text { int }\end{array}$ & KEPOGEN TYPE & COMMENIS, REFERENCES \\
\hline \multirow{2}{*}{ Kirklington-2 } & L.Dinantian & Mudstones & Marine & & 1.1 & 0.9 & & TAYLOR, 1986 \\
\hline & E. Namurian & Mudstones & $\begin{array}{l}\text { Prodelta, } \\
\text { condensed } \\
\text { sequence }\end{array}$ & & $2.3-11.2$ & $0.8-3.5$ & & \\
\hline Manton-1 & E. Namurian & Mudstones & $\begin{array}{l}\text { Prodelta, } \\
\text { gamma active } \\
\text { shales }\end{array}$ & ca. 1.0 & - & - & & \\
\hline$\frac{\text { OuTcrops }}{\text { Widmerpool Gulf }}$ & $\begin{array}{l}\text { Pendleian- } \\
\text { Brigantian }\end{array}$ & Mudstone & Basin & $0.4-0.6$ & $7.8-18.5$ & & $\begin{array}{l}\text { Oil prone, oil } \\
+ \text { gas prone }\end{array}$ & 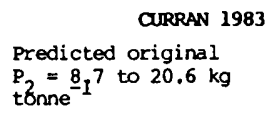 \\
\hline Goyt Trough & Pendleian & Mudstone & Basin & $0.6-0.8$ & 11.0 & & Oil gas prone & $\begin{array}{l}\text { Predicted original } \\
P_{2}=16.4 \mathrm{~kg} \text { tonne }\end{array}$ \\
\hline Edale Gulf & Pendleian & Mudstone & Basin & $0.8-1.0$ & 2.5 & & oil gas; oil & $\begin{array}{l}\text { Predicted original } \\
P_{2}=7.4 \mathrm{~kg}_{\text {tonne }}-1\end{array}$ \\
\hline $\begin{array}{l}\text { DERBYSSIRE DOME } \\
\text { South West D.D. }\end{array}$ & $\begin{array}{l}\text { Courceyan/ } \\
\text { Chadian }\end{array}$ & $\begin{array}{l}\text { Mudstone/ } \\
\text { limestone }\end{array}$ & $\begin{array}{l}\text { Basin/shelf } \\
\text { (reef) }\end{array}$ & - & - & - & - & No potential source \\
\hline $\begin{array}{l}\text { Windy Knoll, } \\
\text { Little Longstone }\end{array}$ & Brigantian & $\begin{array}{l}\text { Bituminous } \\
\text { mudstone }\end{array}$ & Basin & & & & Cas + oil prone & $\begin{array}{l}\text { Oil seep; mod-v. good } \\
\text { potent1al. coGl }= \\
0.29-0.41\end{array}$ \\
\hline $\begin{array}{l}\text { Caldon Low } \\
\text { Quarry } \\
\text { (4080 3405) }\end{array}$ & Chadian & Limestone & Shelf/Basin & 0.58 & - & 0.23 & 908 vitrinite & $\begin{array}{r}\text { ROBERTSONS RESEARCH } \\
1986 a\end{array}$ \\
\hline $\begin{array}{l}\text { Lee House } \\
\text { Quarry } \\
\text { (4092 3502) }\end{array}$ & & Limestone & Shelf/Basin & 0.81 & - & $0.4-0.5$ & 908 vitrinite & (preliminary results) \\
\hline $\begin{array}{l}\text { Borron Pits } \\
(42473516)\end{array}$ & & Mudstone & Shelf/Basin & $0.3-0.8$ & 8.5 & 3.9 & 80 vitrinite & \\
\hline $\begin{array}{l}\text { Milldale } \\
\text { (4143 3533) }\end{array}$ & & Limestone & Shelf/Basin & - & 0.46 & 1.77 & & \\
\hline $\begin{array}{l}\text { Castleton } \\
\text { (4150 3828) }\end{array}$ & & $\begin{array}{l}\text { Mudstone/ } \\
\text { limestone }\end{array}$ & $\begin{array}{l}\text { Shelf/Basin } \\
\text { ind. reef }\end{array}$ & & $\begin{array}{l}<9.1 \\
\text { (mudstone) }\end{array}$ & $<4.0$ & & \\
\hline $\begin{array}{l}\text { Matlock } \\
\left(\begin{array}{ll}4077 & 3794) \\
(4285 & 3606) \\
(4284 & 3545) \\
(4285 & 3544) \\
(4281 & 3548\end{array}\right)\end{array}$ & & $\begin{array}{l}\text { Mudstone/ } \\
\text { limestone }\end{array}$ & & $<0.9$ & $\begin{array}{l}1.3-9.8 \\
\text { mudstone }\end{array}$ & & & \\
\hline
\end{tabular}


Source Rock Data

Area: Bowland/Manx Furness Basin (West Midlands) (1)

\begin{tabular}{|c|c|c|c|c|c|c|c|c|}
\hline SAMPLE & $A C E$ & $\begin{array}{l}\text { FOPAATION } \\
\text { LITLOLOGY }\end{array}$ & FACIES & $\begin{array}{l}\text { MATURTTY } \\
\text { ROA }\end{array}$ & Kg tónnol & SS Toc & KEROCEN TYPE & COMENTS, REFERENCES \\
\hline Boreholes & & & & & & & & $\begin{array}{r}\text { (CURRAN, 1983; } \\
\text { PETRACHDL1983; } \\
\text { ROBERTSONS RESEARCH; } \\
\text { 1986a) }\end{array}$ \\
\hline \multirow{3}{*}{ Holme Chapel-1 } & Pendleian & $\begin{array}{l}\text { Upper } \\
\text { Bowland } \\
\text { Shale }\end{array}$ & $\begin{array}{l}\text { Basinal- } \\
\text { prodelta }\end{array}$ & $\begin{array}{l}2.31-2.44 \\
\text { over- } \\
\text { mature }\end{array}$ & $0.15-0.6$ & $1.8-2.9$ & $\begin{array}{l}\text { Marine with } \\
\text { terrigenous input }\end{array}$ & $\begin{array}{l}\text { Peak oil generation } \\
\text { exceeded. Originally- } \\
\text { good source potential }\end{array}$ \\
\hline & Brigantian & $\begin{array}{l}\text { Lower } \\
\text { Bowland } \\
\text { Shale }\end{array}$ & & $>2.5$ & $0.24-0.39$ & $2.53-4.14$ & $\begin{array}{l}\text { Marine with } \\
\text { terrigenous input }\end{array}$ & $\begin{array}{l}\text { Oil prone source } \\
\text { originally }\end{array}$ \\
\hline & $\begin{array}{l}\text { Courceyan- } \\
\text { Asbian }\end{array}$ & $\begin{array}{l}\text { Various } \\
\text { mudstonet } \\
\text { limestone }\end{array}$ & $\begin{array}{l}\text { Basinal, } \\
\text { carbonate } \\
\text { ramp }\end{array}$ & $>2.6$ & $0.16-0.39$ & $1.31-2.62$ & $\begin{array}{l}\text { Marine with scme } \\
\text { terrigenous input }\end{array}$ & $\begin{array}{l}\text { oil prone source at } \\
\text { top originally }\end{array}$ \\
\hline & Pendleian & $\begin{array}{l}\text { Upper } \\
\text { Bowland } \\
\text { Shale }\end{array}$ & $\begin{array}{l}\text { Basinal- } \\
\text { prodelta }\end{array}$ & & & $0.7-1.4$ & $\begin{array}{l}\text { Terrigenous + } \\
\text { marine }\end{array}$ & \\
\hline Formby-1 & Brigantian & $\begin{array}{l}\text { Lower } \\
\text { Bowland } \\
\text { Shale }\end{array}$ & $\begin{array}{l}\text { Basinal- } \\
\text { prodelta }\end{array}$ & & & 1.85 & $\begin{array}{l}\text { Terrigenous + } \\
\text { marine }\end{array}$ & \\
\hline Ternhill-1 & Asb-Brig & Mudstone & Basinal & & & 1.70 & $\begin{array}{l}\text { Terrigenous + } \\
\text { marine }\end{array}$ & \\
\hline Roosecote-BH & $\begin{array}{l}\text { Pendleian- } \\
\text { Brigantian }\end{array}$ & $\begin{array}{l}\text { Bowland } \\
\text { Shales }\end{array}$ & $\begin{array}{l}\text { Basinal- } \\
\text { prodelta }\end{array}$ & $\mathrm{ca} \cdot 0.70$ & $>2.0$ & $>2.0$ & $\begin{array}{l}\text { Mixed, } \\
\text { terrigenous input }\end{array}$ & Rich source rock \\
\hline Swinden-1 & Courceyan & $\begin{array}{l}\text { Mudstone+ } \\
\text { limestone }\end{array}$ & Basinal & $>1.0$ & $1.18-3.2$ & $1.18-3.2$ & $\begin{array}{l}\text { Inert } 10-608 \\
\text { vit. } 90-408\end{array}$ & $\begin{array}{r}\text { FoBerTsons RESEARCH } \\
1986 a\end{array}$ \\
\hline \multirow{2}{*}{ Neeton-1 } & Pendleian & $\begin{array}{l}\text { Bowland } \\
\text { Shales }\end{array}$ & Prodelta & \begin{tabular}{|l}
$<1.3$ \\
(max gas \\
generation \\
+ oil \\
floor)
\end{tabular} & $0.77-1.87$ & $0.71-3.69$ & $\begin{array}{l}\text { Terrigenous input } \\
\text { prdom }\end{array}$ & PEIRACAFY 1985C \\
\hline & $\begin{array}{l}\text { Brigantian- } \\
\text { ?Chadian }\end{array}$ & $\begin{array}{l}\text { Various } \\
\text { mudstone- } \\
\text { limestone }\end{array}$ & Basin-shelf & $\begin{array}{l}>1.3 \\
\text { Over } \\
\text { mature }\end{array}$ & $0.049-0.85$ & $0.09-2.23$ & $\begin{array}{l}\text { Marine- } \\
\text { Terrigenous }\end{array}$ & $\begin{array}{l}\text { No residual potention; } \\
\text { some original gas } \\
\text { service? }\end{array}$ \\
\hline $\begin{array}{l}\text { OUTCROPS } \\
\begin{array}{l}\text { Sowland Basin } \\
\text { (various) }\end{array}\end{array}$ & Brigantian & $\begin{array}{l}\text { Lower } \\
\text { Bowland } \\
\text { Shale }\end{array}$ & $\begin{array}{l}\text { Basin- } \\
\text { prodelta }\end{array}$ & $0.5-0.9$ & ave. 5.0 & $>5.0$ & $\begin{array}{l}\text { Terrigenous- } \\
\text { rich }\end{array}$ & $\begin{array}{l}\text { Mnsow \& JACKSaN, } 1981 \\
\text { Mod-good source } \\
\text { potential }\end{array}$ \\
\hline $\begin{array}{l}\text { 3owland Basin } \\
\text { (various) }\end{array}$ & Brigantian & $\begin{array}{l}\text { Lower } \\
\text { Bowland } \\
\text { Shale }\end{array}$ & $\begin{array}{l}\text { Basin- } \\
\text { prodelta } \\
\text { (+ turbidites) }\end{array}$ & $<1.3$ & 7.2 & calo.0 & $\begin{array}{l}\text { Terrigenous- } \\
\text { rich }\end{array}$ & $\begin{array}{l}\text { ROBERTSONS RESEARCH } \\
\text { 1986a } \\
\text { Rich source. } \\
70-100 \mathrm{~m} \text { thick; } \\
\text { Up to }>300 \mathrm{~m}\end{array}$ \\
\hline $\begin{array}{l}\text { NORUH LANCASHIRE } \\
\text { ross O'Greet }\end{array}$ & Pendleian & $\begin{array}{l}\text { Bowland } \\
\text { Shale + } \\
\text { Pendle } \\
\text { Grit }\end{array}$ & $\begin{array}{l}\text { Delta + } \\
\text { prodelta }\end{array}$ & & $0.23-0.74$ & $2.02-2.44$ & & Significant potential \\
\hline $\begin{array}{l}\text { Trough of } \\
\text { 3owland }\end{array}$ & Brigantian & $\begin{array}{l}\text { Bowland } \\
\text { Shale }\end{array}$ & $\begin{array}{l}\text { Prodelta }+ \\
\text { basin }\end{array}$ & & $3.72-8.28$ & $3.72-4.06$ & & Significant potential \\
\hline Hare Clough & Asbian & $\begin{array}{l}\text { Pendleside } \\
\text { Limestone }\end{array}$ & $\begin{array}{l}\text { Shelf/basin } \\
\text { margin }+ \\
\text { reefs }\end{array}$ & & $4.56-5.3$ & $0.12-3.46$ & & Significant potential \\
\hline
\end{tabular}


Source Rock Data

Area: Bowland/Manx Furness Basin (West Midlands) (2)

\begin{tabular}{|c|c|c|c|c|c|c|c|c|}
\hline \multirow{2}{*}{ SAMPLE } & \multirow{2}{*}{ ACE } & \multirow{2}{*}{$\begin{array}{l}\text { POPEATTION } \\
\text { LTHAOCGY }\end{array}$} & \multirow{2}{*}{ FACIES } & \multirow{2}{*}{$\begin{array}{c}\text { MATURrTY } \\
\text { Rot }\end{array}$} & \multicolumn{2}{|c|}{ RTONNESS } & \multirow{2}{*}{ KEROCEN TYPE } & \multirow{2}{*}{ COMEIENIS, REFERENCES } \\
\hline & & & & & $\mathrm{kg}$ tónne-1 $^{\mathrm{P}}$ & wt & & \\
\hline $\begin{array}{l}\text { Bottans Beck } \\
\text { Crossdale Beck }\end{array}$ & $\begin{array}{l}\text { Asbian- } \\
\text { Holkerian }\end{array}$ & $\begin{array}{l}\text { Worston } \\
\text { Shale + } \\
\text { Pendleside } \\
\text { Lst. }\end{array}$ & Shelf/bas in & & $0.2-0.9$ & $0.22-2.21$ & & $\begin{array}{l}\text { Poor to moderate } \\
\text { potential }\end{array}$ \\
\hline Sykes quarry & Holkerian & $\begin{array}{l}\text { Worston } \\
\text { Shale }\end{array}$ & Basinal & & $0.41-1.45$ & $0.99-2.27$ & & $\begin{array}{l}\text { Poor to moderate } \\
\text { potential }\end{array}$ \\
\hline Foredale Quarry & Holkerian & $\begin{array}{l}\text { Horton } \\
\text { Limestone }\end{array}$ & $\begin{array}{l}\text { Basinal/ } \\
\text { shelf }\end{array}$ & & - & 0.15 & & $\begin{array}{l}\text { No significant } \\
\text { potential. }\end{array}$ \\
\hline Slaidburn & $\begin{array}{l}\text { Chadian- } \\
\text { Arundian }\end{array}$ & $\begin{array}{l}\text { Clitheroe } \\
\text { Limestone }\end{array}$ & $\begin{array}{l}\text { Basinal + } \\
\text { 'mud mound' } \\
\text { reefs }\end{array}$ & & $0.7-1.7$ & $1.0-1.3$ & & $\begin{array}{l}\text { Poor to moderate } \\
\text { potential }\end{array}$ \\
\hline $\begin{array}{l}\text { Marl Hill - } 11 \\
\text { BP MIL Borehole }\end{array}$ & Brigantian & $\begin{array}{l}\text { Bowland } \\
\text { shale + } \\
\text { Worston } \\
\text { Shale }\end{array}$ & $\begin{array}{l}\text { Basinal- } \\
\text { prodelta }\end{array}$ & $0.74-0.84$ & $2.8-5.7$ & & Gas predorn. & $\begin{array}{l}\text { HEFPESRUN + MASON, } 198 \\
\text { COG1 } 0.42-0.55\end{array}$ \\
\hline $\begin{array}{l}\text { Alum Crag } \\
(37634651) \\
(36364281)\end{array}$ & Dinantian & Mudstone & " & $\begin{array}{l}0.62 \\
0.37-0.71\end{array}$ & $\begin{array}{l}2.01 \\
1.37\end{array}$ & $\begin{array}{l}3.15 \\
1.2-2.6\end{array}$ & & $\begin{array}{l}\text { ROBERCSONS RESEARCH, } \\
1986 a\end{array}$ \\
\hline $\begin{array}{l}\text { Various } \\
\text { boreholes/ } \\
\text { outcrops }\end{array}$ & $\begin{array}{l}\text { Pendleian- } \\
\text { Brigantian }\end{array}$ & & $\begin{array}{l}\text { Basinal- } \\
\text { prodelto }\end{array}$ & $\begin{array}{l}>1.3 \text { on } \\
\text { North } \\
\text { Margin, } \\
\text { cao.7 on } \\
\text { South } \\
\text { margin }\end{array}$ & & & oil + gas prone & $\begin{array}{l}\text { HEFFERENAN, 1983; } \\
\text { HEFFEPAN \& MASON, } \\
\text { 1984 } \\
\text { Good to excellent } \\
\text { source }\end{array}$ \\
\hline
\end{tabular}


Source Rock Data

Area: Northumberland-Solway Basin (1)

\begin{tabular}{|c|c|c|c|c|c|c|c|c|}
\hline SAMPLE & ACE & $\begin{array}{l}\text { FORPATTON } \\
\text { LTILOLOGY }\end{array}$ & PACIES & $\begin{array}{l}\text { MATURITY } \\
\text { ROA }\end{array}$ & Kg tónne-1 & $\begin{array}{l}\text { TOC } \\
\text { wt } 8\end{array}$ & KEROGEN TYPE & COMENIS, REFERENCES \\
\hline \multicolumn{2}{|c|}{ Boperous - Northumberland } & & & & & & & ROBETRISONS RESEARCH, \\
\hline Ridsdale & $\begin{array}{l}\text { Late } \\
\text { Asbian - } \\
\text { Holkerian }\end{array}$ & $\begin{array}{l}\text { Upper } \\
\text { Borden } \\
\text { Group }\end{array}$ & $\begin{array}{l}\text { Deltaic- } \\
\text { marine } \\
\text { cyclotherms }\end{array}$ & $0.57-1.3$ & $0.4-18.0$ & cal.0-8.0 & Mixed & $\begin{array}{l}\text { Higher values of } \mathrm{T} \propto+ \\
\mathrm{P}_{2} \text { for } \infty \text { cals }\end{array}$ \\
\hline Steel Rigg & Asbian-Holk & $\begin{array}{l}\text { Upper } \\
\text { Border } \\
\text { Group } \\
\text { Mudstones }\end{array}$ & $\begin{array}{l}\text { Deltaic-marine } \\
\text { cyclotherns }\end{array}$ & $\begin{array}{l}>1.4 \\
\text { over } \\
\text { mature }\end{array}$ & ca.0.5-1.3 & $\mathrm{ca} 2.0$ & $\begin{array}{l}\text { Gas prone in } \\
\text { thin coals. }\end{array}$ & $\begin{array}{l}\text { PETRACHFM, 1985b } \\
\text { No residual source } \\
\text { potential }\end{array}$ \\
\hline \multirow{3}{*}{ Ferney Rigg } & Brigantian & $\begin{array}{l}\text { Upper } \\
\text { Liddesdale } \\
\text { Gp. }\end{array}$ & $\begin{array}{l}\text { Deltaic-marine } \\
\text { cyclothems }\end{array}$ & $0.58-0.62$ & - & - & $\begin{array}{l}\text { Gas prone in } \\
\text { coals }\end{array}$ & Significant potential \\
\hline & Late Asbian & $\begin{array}{l}\text { Lower } \\
\text { Liddesdale } \\
\text { G. }\end{array}$ & $\begin{array}{l}\text { Deltaic-marine } \\
\text { cyclothems }\end{array}$ & $0.63-0.74$ & $<4.0$ & $<2.0$ & $\begin{array}{l}\text { Gas prone in } \\
\text { coals }\end{array}$ & $\begin{array}{l}\text { Significant potential; } \\
\text { higher in coals }\end{array}$ \\
\hline & $\begin{array}{l}\text { Early } \\
\text { Asbian }\end{array}$ & $\begin{array}{l}\text { Upper } \\
\text { Border } \\
\text { Gp. }\end{array}$ & $\begin{array}{l}\text { Deltaic-marine } \\
\text { cyclothens }\end{array}$ & $0.72-0.79$ & $<4.0$ & $<0.20$ & $\begin{array}{l}\text { Mixed Kerogen. } \\
\text { Terrigenous-rich }\end{array}$ & $\begin{array}{l}\text { Poor potential; } \\
\text { higher in coals }\end{array}$ \\
\hline \multirow{2}{*}{ Stonehaugh } & $\begin{array}{l}\text { Asbian- } \\
\text { Holk }\end{array}$ & $\begin{array}{l}\text { Upper } \\
\text { Border } \\
\text { Gp. }\end{array}$ & $\begin{array}{l}\text { Deltaic-marine } \\
\text { cyclothens }\end{array}$ & $0.41-0.72$ & $>3.0$ & $2.0-10.0$ & & Significant potential \\
\hline & $\begin{array}{l}\text { Holkerian- } \\
\text { Arundian }\end{array}$ & $\begin{array}{l}\text { Middle } \\
\text { Border } \\
\text { Gp. }\end{array}$ & $\begin{array}{l}\text { Deltaic-marine } \\
\text { cyclothems }\end{array}$ & $0.75-1.64$ & $0.4-6.0$ & $<2.0-5.0$ & $\begin{array}{l}\text { Gas + oil prone } \\
\text { in places }\end{array}$ & $\begin{array}{l}\text { Higher } T O C+P_{2} \text { in } \\
\text { coals. Same potential } \\
\text { source }\end{array}$ \\
\hline Tarry & $\begin{array}{l}\text { Asbian- } \\
\text { Holk. }\end{array}$ & $\begin{array}{l}\text { Upper } \\
\text { Border } \\
\text { Group. }\end{array}$ & $\begin{array}{l}\text { Deltaic-marine } \\
\text { cyclothems }\end{array}$ & $0.51-0.55$ & $\begin{array}{l}23.0 \\
(50.0 \text { in } \\
\text { coally } \\
\text { camples) }\end{array}$ & $\begin{array}{l}>3.0 \\
\text { predan }\end{array}$ & $\begin{array}{l}\text { Mixed Kerogen, } \\
\text { Terrigenous-rich, } \\
\text { gas + oil prone } \\
\text { in places. }\end{array}$ & $\begin{array}{l}\text { Higher } T O C+P_{2} \text { in } \\
\text { coals. Some potential } \\
\text { source. }\end{array}$ \\
\hline $37 / 23-1$ & $\begin{array}{l}\text { Dinantian- } \\
\text { undiff }\end{array}$ & $\begin{array}{l}\text { Mid-dark } \\
\text { grey } \\
\text { mudstone }\end{array}$ & $\begin{array}{l}\text { ?Marine } \\
\text { basinal }\end{array}$ & - & $<2 / 8$ & $0.04-5.77$ & & \\
\hline $38 / 22-1$ & Tournaisian & $\begin{array}{l}\text { Mudstone- } \\
\text { siltstone }\end{array}$ & $\begin{array}{l}\text { PMarine } \\
\text { basinal }\end{array}$ & $0.49-5.8$ & - & $0.1-1.17$ & & $\begin{array}{l}\text { No significant } \\
\text { (residual) potential. }\end{array}$ \\
\hline $\begin{array}{l}\text { Harton (Dame) } \\
-1\end{array}$ & $\begin{array}{l}\text { Dinantian } \\
\text { (undiff.) }\end{array}$ & $\begin{array}{l}\text { Siltstone- } \\
\text { mudstone } \\
\text { Scremerston } \\
\text { coal + } \\
\text { Yoredale } \\
\text { facies }\end{array}$ & $\begin{array}{l}\text { Deltaic (+ } \\
\text { marine) }\end{array}$ & $\begin{array}{l}>1.0 \\
\text { predan }\end{array}$ & - & $\begin{array}{l}1.0-3.0 \\
\text { (higher } \\
\text { for } \\
\text { coals }\end{array}$ & $\begin{array}{l}\text { ca308 inertinite } \\
\text { ca708 vitrinite } \\
\text { Structured } \\
\text { terrigenous } \\
\text { plants-rich. }\end{array}$ & $\begin{array}{l}\text { ROBERTSONS RESEARCH, } \\
\text { 1986b } \\
\text { Gas-prone source } \\
\text { originally. No } \\
\text { residual potential. }\end{array}$ \\
\hline \multicolumn{2}{|c|}{ BORBAOLES - Solway Basin } & & & & & & & PETRACHEM, 1985 b \\
\hline Archerbeck & Asbian & \begin{tabular}{|l|} 
Liddesdale- \\
Border \\
Groups
\end{tabular} & $\begin{array}{l}\text { Deltaic } \\
\text { (Yoredales) }\end{array}$ & $0.82-1.02$ & $\begin{array}{l}<1.8 \\
\text { (poor) }\end{array}$ & $\begin{array}{l}0.07-2.3 \\
\text { (poor) }\end{array}$ & $\begin{array}{l}\text { Abundant wood } \\
\text { with minor algal, } \\
\text { mixed. }\end{array}$ & $\begin{array}{l}\text { No significant } \\
\text { potential. }\end{array}$ \\
\hline \multirow[t]{2}{*}{ Barrock Park } & Pendleian & & Yoredales & 0.8 & $177.0 \max$ & $77.0 \mathrm{max}$ & Gas (toil) prone & Coals \\
\hline & Brigantian & $\begin{array}{l}\text { Upper } \\
\text { Liddesdale } \\
\text { Grp. }\end{array}$ & Yoredales & 0.87 & 86.2 & 53.11 & Gas prone & Coals \\
\hline Silloth-1 & $\begin{array}{l}\text { Dinantian- } \\
\text { undiff }\end{array}$ & $\begin{array}{l}\text { Pink } \\
\text { siltsone- } \\
\text { sandstone }\end{array}$ & $\begin{array}{l}\text { Deltaic- } \\
\text { aerobic. }\end{array}$ & - & - & - & - & No potential \\
\hline
\end{tabular}


Source Rock Data

Area: Northumberland-Solway Basin (2)

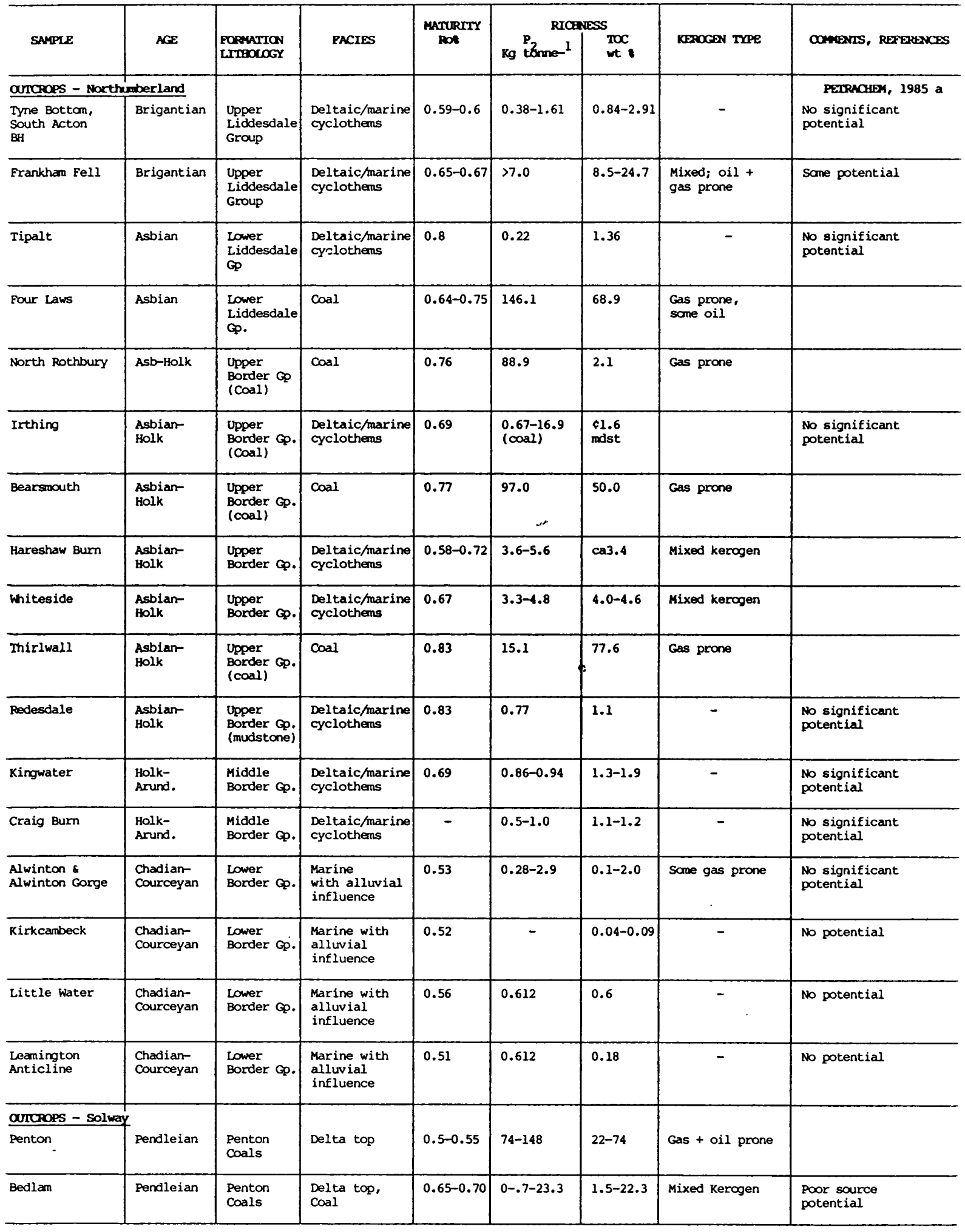


Source Rock Data

Area: Northumberland-Solway Basin (3)

\begin{tabular}{|c|c|c|c|c|c|c|c|c|}
\hline SAMPTE & AGE & $\begin{array}{l}\text { FOPAATION } \\
\text { LTHOOLOGY }\end{array}$ & FACIES & $\begin{array}{c}\text { MATURTTY } \\
\text { Rot }\end{array}$ & Kg torne- ${ }^{P_{2}}$ & $\begin{array}{l}\text { IOSS } \\
\text { wt }\end{array}$ & KEPOCEN TXPE & COMENTS, REFERENCES \\
\hline Snebro & Pendleian & $\begin{array}{l}\text { Hensingham } \\
\text { Gp. incl. } \\
\text { ironstone } \\
\text { nodules }\end{array}$ & Delta top & $0.65-0.83$ & $<2.2$ & $0.9-4.6$ & Mixed kerogen & $\begin{array}{l}\text { No significant } \\
\text { potential }\end{array}$ \\
\hline Wardhall & Brigantian & $\begin{array}{l}\text { Limestone } \\
+ \text { mudstone }\end{array}$ & Yoredales & $1.28-1.33$ & $0.4-1.0$ & $0.2-1.3$ & & $\begin{array}{l}\text { No significant } \\
\text { potential }\end{array}$ \\
\hline Broughton & Brigantian & $\begin{array}{l}\text { Limestone } \\
+ \text { mudstone } \\
\text { (+ cherts) }\end{array}$ & Yoredales & 0.7 & $0.1-1.1$ & $0.3-1.7$ & & $\begin{array}{l}\text { No significant } \\
\text { potential }\end{array}$ \\
\hline Bridge & Brigantian & $\begin{array}{l}\text { Limestone } \\
+ \text { mudstone } \\
\text { (+ cherts) }\end{array}$ & Yoredales & $0.68-0.71$ & $<3.2$ & $1.2-6.5$ & Mixed kerogen & $\begin{array}{l}\text { Some potential } \\
\text { possible. }\end{array}$ \\
\hline Irthing & Asbian & $\begin{array}{l}\text { incl. } \\
\text { Throssburn- } \\
\text { foot coal }\end{array}$ & Yoredales & $0.67-0.69$ & $\begin{array}{l}\max \\
134 \\
\text { (coal) }\end{array}$ & $\begin{array}{l}\max \\
65.2-80.2\end{array}$ & Gas prone/mixed & coals \\
\hline Kingsbridge & Holkerian & $\begin{array}{l}\text { Calc-argil } \\
\text { sandstone }\end{array}$ & Yoredales & $0.62-1.45$ & $<1.3$ & $0.5-1.5$ & $\begin{array}{l}\text { Significant } \\
\text { terrigenous } \\
\text { plants }\end{array}$ & $\begin{array}{l}\text { No significant } \\
\text { potential }\end{array}$ \\
\hline Arbigland & Holkerian & $\begin{array}{l}\text { Calc-argil } \\
\text { sandstone }\end{array}$ & Yoredales & $0.78-1.61$ & $<1.5$ & $0.3-2.2$ & $\begin{array}{l}\text { Significant } \\
\text { terrigenous } \\
\text { plants }\end{array}$ & $\begin{array}{l}\text { No significant } \\
\text { potential }\end{array}$ \\
\hline Powillimount & Arundian & $\begin{array}{l}\text { Thirlstone } \\
\text { Sandstone } \\
\text { Gp \& thin } \\
\text { mudstone } \\
\text { beds }\end{array}$ & $\begin{array}{l}\text { Basinal + } \\
\text { alluvial input }\end{array}$ & $0.86-0.89$ & $0.8-14.8$ & $1.7-6.7$ & $\begin{array}{l}\text { Significant } \\
\text { terrigenous } \\
\text { plants }\end{array}$ & $\begin{array}{l}\text { 3Scme residual } \\
\text { potential }\end{array}$ \\
\hline southerness & Chadian & $\begin{array}{l}\text { Limestone/ } \\
\text { mudstone/ } \\
\text { sandstone }\end{array}$ & $\begin{array}{l}\text { Basinal + } \\
\text { alluvial input }\end{array}$ & $0.7-0.76$ & $0.4-1.1$ & $0.5-1.0$ & $\begin{array}{l}\text { Significant } \\
\text { terrigenous } \\
\text { plants }\end{array}$ & $\begin{array}{l}\text { No significant } \\
\text { potential }\end{array}$ \\
\hline Bolmehead & courceyan & $\begin{array}{l}\text { Bewcastle } \\
\text { Beds }\end{array}$ & Basinal & $0.9-1.07$ & $0.5-0.8$ & $0.8-1.6$ & $\begin{array}{l}\text { Significant } \\
\text { terrigenous } \\
\text { plants }\end{array}$ & $\begin{array}{l}\text { No significant } \\
\text { potential }\end{array}$ \\
\hline Nixonstown & Courceyan & $\begin{array}{l}\text { Lynebank } \\
\text { Beds }\end{array}$ & Basinal & $1.0-1.30$ & $0.18-0.63$ & $0.3-1.7$ & $\begin{array}{l}\text { Significant } \\
\text { terrigenous } \\
\text { plants }\end{array}$ & $\begin{array}{l}\text { No significant } \\
\text { potential }\end{array}$ \\
\hline
\end{tabular}


Source Rock Data

Area: Cleveland Basin \& Stainmore Trough (1)

\begin{tabular}{|c|c|c|c|c|c|c|c|c|}
\hline SAMPLE & ACE & $\begin{array}{l}\text { FOPAATTON } \\
\text { LTHOLOGY }\end{array}$ & FACIES & $\begin{array}{l}\text { MaturTTY } \\
\text { Rot }\end{array}$ & Kg tơnne- & $\begin{array}{l}\text { TOC } \\
\text { wt }\end{array}$ & KEROCEN TYPE & COMBNIS, REFERENCES \\
\hline$\frac{\text { BOPBHOCES }}{41 / 20-1}$ & Dinantian & $\begin{array}{l}\text { Siltsone- } \\
\text { mudstone }\end{array}$ & $\begin{array}{l}\text { Basinal- } \\
\text { deltaic }\end{array}$ & $2.18-2.37$ & $\begin{array}{l}\text { POor } \\
<0.03\end{array}$ & $1.3-3.4$ & $\begin{array}{l}\text { Gas prone- } \\
\text { terrigenous }\end{array}$ & $\begin{array}{l}\quad \text { PETRACHFM, 1986a } \\
\text { Only capable of } \\
\text { generating } \mathrm{CH} \text { at } \\
\text { present day hlgh } \\
\text { maturity. Limited } \\
\text { source potential }\end{array}$ \\
\hline Raydale BH & $\begin{array}{l}\text { Asbian- } \\
\text { Brigantian }\end{array}$ & $\begin{array}{l}\text { Mudstone- } \\
\text { siltsone } \\
\text { coal }\end{array}$ & $\begin{array}{l}\text { Yoredales- } \\
\text { deltaic- } \\
\text { near shore } \\
\text { marine }\end{array}$ & $1.19-2.58$ & $0.04-0.20$ & $0.23-1.04$ & $\begin{array}{l}0-608 \text { inertinite } \\
40-1008 \text { vitrinite } \\
\text { (coals) }\end{array}$ & $\begin{array}{l}\text { No significant source. } \\
\text { TOCs measured for } \\
\text { coals. HI<53. }\end{array}$ \\
\hline \multirow{5}{*}{ Seals Sands-1 } & E. Namurian & $\begin{array}{l}\text { Upper } \\
\text { Limestone } \\
\text { Gp. }\end{array}$ & $\begin{array}{l}\text { Deltaic } \\
\text { (Yoredales) }\end{array}$ & $0.9-1.25$ & cal. 25 & $0.8-3.0$ & $\begin{array}{l}808 \text { inert; } \\
208 \text { vit. }\end{array}$ & \\
\hline & Brigantian & $\begin{array}{l}\text { Mid } \\
\text { Limestone } \\
\text { Gp. }\end{array}$ & $\begin{array}{l}\text { Deltaic/ } \\
\text { Marine }\end{array}$ & $0.87-1.32$ & $0.4-0.65$ & $0.97-1.84$ & $\begin{array}{l}608 \text { inert; } \\
40 \text { vit }\end{array}$ & \\
\hline & $\begin{array}{l}\text { Early } \\
\text { Brig-Late } \\
\text { Asbian }\end{array}$ & $\begin{array}{l}\text { Lower } \\
\text { Limestone } \\
\text { Gp. }\end{array}$ & $\begin{array}{l}\text { Daltaic/ } \\
\text { Marine }\end{array}$ & 1.03 & - & 0.96 & $\begin{array}{l}608 \text { inert; } \\
40 \text { vit }\end{array}$ & \\
\hline & $\begin{array}{l}\text { Asbian- } \\
\text { PChadian }\end{array}$ & $\begin{array}{l}\text { Scremerston } \\
\text { Coal } \\
\text { Group }\end{array}$ & Deltaic & $1.15-1.25$ & $0.3-1.25$ & $0.2-1.66$ & $\begin{array}{l}408 \text { inert; } \\
608 \text { vit }\end{array}$ & \\
\hline & Courceyan & $\begin{array}{l}\text { PCenent- } \\
\text { stone } \\
\text { Group }\end{array}$ & $\begin{array}{l}\text { Marine- } \\
\text { basinal }\end{array}$ & $1.3-2.45$ & $0.3-15.5$ & $0.7-3.95$ & - & \\
\hline Kirkleathan-1 & rvisean & $\begin{array}{l}\text { Mudstone- } \\
\text { siltstone }\end{array}$ & $\begin{array}{l}\text { PBasinal/ } \\
\text { deltaic }\end{array}$ & $1.96-2.08$ & $<0.7$ & $\begin{array}{l}0.6-2.5 \\
\text { predan }\end{array}$ & $\begin{array}{l}60-808 \text { inertinite } \\
\text { gas-prone in } \\
\text { places. }\end{array}$ & $\begin{array}{l}\text { ROBERTSONS RESEARCH } \\
\qquad 1986 \text { a } \\
\text { No significant } \\
\text { oil source } \\
\text { potential, minor } \\
\text { gas prone } \\
\text { sediment/coal. } \\
\\
1986 \text { b }\end{array}$ \\
\hline $\begin{array}{l}\text { OUTCROPS: } \\
\text { CDNIRAL STAIMORE }\end{array}$ & Trough & & & & & & & PEIRACHEM, 1986a \\
\hline $\begin{array}{l}\text { Grassholme } \\
\text { Reservoir, } \\
\text { Deepdale Beck }\end{array}$ & Pendleian & Mudstone & $\begin{array}{l}\text { Marine } \\
\text { incursions } \\
\text { onto delta } \\
\text { plain }\end{array}$ & $0.80-1.2$ & $<2.0$ & $0.73-3.33$ & $\begin{array}{l}\text { Terrigenous, } \\
\text { structured } \\
\text { plants predom. }\end{array}$ & $\begin{array}{l}\text { Gas-prone mainly, } \\
\text { same oil; } \\
\text { poor-moderate } \\
\text { potential }\end{array}$ \\
\hline $\begin{array}{l}\text { Chert Gill, } \\
\text { Greta Bridge }\end{array}$ & Brigantian & $\begin{array}{l}\text { Upper } \\
\text { Alston } \\
\text { Group } \\
\text { mudstone- } \\
\text { limestone- } \\
\text { sandstone }\end{array}$ & $\begin{array}{l}\text { Yoredales- } \\
\text { deltaic }\end{array}$ & $\mid \begin{array}{c}0.79-0.82 \\
\text { mature/ } \\
\text { peak oil } \\
\text { generation } \\
\text { threshold }\end{array}$ & $0.15-6.0$ & $1.69-5.91$ & $\begin{array}{l}\text { Degraded } \\
\text { structured plants } \\
+ \text { lean } \\
\text { amorphous } \\
\text { kerogen. Mixed } \\
\text { oil + gas }\end{array}$ & $\begin{array}{l}\text { Higher for coals (gas } \\
\text { prone). Poor (to } \\
\text { moderate) potential. }\end{array}$ \\
\hline \multicolumn{9}{|l|}{ STAMMORE OUMIER } \\
\hline Mousegill Beck & Pendleian & $\begin{array}{l}\text { Millstone } \\
\text { Grit - } \\
\text { coals- } \\
\text { mudstone }\end{array}$ & Deltaic & $\begin{array}{l}0.78, \\
\text { approach- } \\
\text { ing peak } \\
\text { oil } \\
\text { genera- } \\
\text { tion } \\
\text { threshold }\end{array}$ & $<2.0$ & $0.4-3.87$ & $\begin{array}{l}\text { Structured, } \\
\text { woody plants } \\
\text { with trace } \\
\text { amorphous algal } \\
\text { kerogen }\end{array}$ & $\begin{array}{l}\text { Poor to good } \\
\text { potential. Higher for } \\
\text { coals. }\end{array}$ \\
\hline Augill Beck & Brigantian & $\begin{array}{l}\text { Upper } \\
\text { Alston } \\
\text { Group }\end{array}$ & $\begin{array}{l}\text { Yoredales- } \\
\text { deltaic }\end{array}$ & $0.77-1.28$ & $0.14-2.0$ & $\begin{array}{l}<1.5 \\
\text { predom }\end{array}$ & $\begin{array}{l}\text { Structured, } \\
\text { woody plants } \\
\text { with trace } \\
\text { amorphous algal } \\
\text { kerogen }\end{array}$ & $\begin{array}{l}\text { No significant } \\
\text { potential. }\end{array}$ \\
\hline
\end{tabular}


Source Rock Data

Area: Cleveland Basin \& Stainmore Trough (2)

\begin{tabular}{|c|c|c|c|c|c|c|c|c|}
\hline SAMPLE & AGE & $\begin{array}{l}\text { POPMATION } \\
\text { LTTHOCOGY }\end{array}$ & FACIES & $\begin{array}{l}\text { MATURTTY } \\
\text { Bot }\end{array}$ & ${ }_{\mathrm{Kg}}^{\mathrm{P}_{2}}$ torne- $^{\mathrm{RIO}}$ & TESS & KEROCEN TYPE & COMPNIS, REFERENCES \\
\hline$\frac{\text { ALSTON BLOOX }}{\text { Eggleston Burn }}$ & Pendleian & $\begin{array}{l}\text { Limestone- } \\
\text { mudstone } \\
\text { above } \\
\text { Little } \\
\text { Limestone }\end{array}$ & $\begin{array}{l}\text { Deltaic- } \\
\text { marine } \\
\text { (Yoredales) }\end{array}$ & $\begin{array}{l}\text { 1.02-1.28 } \\
\text { approach- } \\
\text { ing oil- } \\
\text { floor } \\
\text { threshold }\end{array}$ & $0.19-1.2$ & $0.98-6.83$ & $\begin{array}{l}\text { Structured, } \\
\text { woody with trace } \\
\text { amorphous algal } \\
\text { kerogen }\end{array}$ & $\begin{array}{l}\text { No significant } \\
\text { potential }\end{array}$ \\
\hline $\begin{array}{l}\text { ASTRIGG BLOCK } \\
\\
\text { Giggleswick: } \\
(37254655) \\
(37444632)\end{array}$ & & & & $\begin{array}{l}0.53 \\
0.52\end{array}$ & $\begin{array}{l}3.41 \max \\
3.63,10.8 \\
\max \end{array}$ & $\begin{array}{l}0.97-1.76 \\
1.17-3.87\end{array}$ & $\begin{array}{l}\text { Abundant } \\
\text { terrigenous } \\
\text { material }\end{array}$ & $\begin{array}{l}\text { POBERTSONS RESEARCH } \\
\text { 1986a } \\
\text { No to moderate } \\
\text { potential }\end{array}$ \\
\hline
\end{tabular}




\section{EAST MIDLANDS}

\begin{tabular}{|c|c|c|c|}
\hline R.G. Jackson & welton/W25 & $\begin{array}{l}\text { The Geochemistry of sediment } \\
\text { and Extracted Oil Samples fram } \\
\text { the well Welton Al, Lincoln- } \\
\text { shire, England. }\end{array}$ & $-8-81$ \\
\hline P.C. Mason & GL/EK/5191 & $\begin{array}{l}\text { A Geochemical examination of } \\
\text { Carboniferous outcrops from } \\
\text { Derbyshire and core samples } \\
\text { fram IGS boreholes at Duffield, } \\
\text { Eyam and Rotherwood. }\end{array}$ & $-6-82$ \\
\hline P.C. Mason & W28 & $\begin{array}{l}\text { Petroleum Geochemistry of the } \\
\text { well Clarborough-1 (PL 178) } \\
\text { East Midlands, UK Land. }\end{array}$ & $-6-82$ \\
\hline D.B. Swift & GL/EK/5203 & $\begin{array}{l}\text { The Geochemistry of Carbonif- } \\
\text { erous core samples from } 4 \text { NCB } \\
\text { boreholes in the East Midlands. }\end{array}$ & $-7-82$ \\
\hline M.F. Hefferman & W 25 & $\begin{array}{l}\text { Geochemical Analysis of the } \\
\text { well Nettleham-1. }\end{array}$ & $-9-82$ \\
\hline P.C. Mason & W25 & $\begin{array}{l}\text { Petroleum Geochemistry of the } \\
\text { well Scaftworth } 2 \text {. }\end{array}$ & $-8-82$ \\
\hline J. Hefferman & W25.1 & $\begin{array}{l}\text { A Geochemical analysis of two } \\
\text { core extracts from the well } \\
\text { Nettleham-1, UK Midlands. }\end{array}$ & $-9-82$ \\
\hline S.W. Lister & W.25.1 & $\begin{array}{l}\text { Geochemical analysis of a } \\
\text { dinantian core extract from } \\
\text { the well Grove-3. }\end{array}$ & $11-82$ \\
\hline S.W. Lister & W. 25.1 & $\begin{array}{l}\text { Petroleum Geochemistry of the } \\
\text { East Midlands NCB well, Eakring } \\
\text { Village. }\end{array}$ & \\
\hline S. O'Reilly & W25 & $\begin{array}{l}\text { The Geochemistry of sediments } \\
\text { samples from the well Widmer- } \\
\text { pool-1, Nottinghamshire. }\end{array}$ & $-12-82$ \\
\hline S. O'Reilly & W 25 & $\begin{array}{l}\text { The Geochemistry of sediment } \\
\text { Samples from the well Gains- } \\
\text { borough-2, Lincolnshire: }\end{array}$ & $12-82$ \\
\hline $\begin{array}{l}\text { W. Lister } \\
\text { E. Ward }\end{array}$ & Alport-1/W25.1 & $\begin{array}{l}\text { Petroleum Geochemistry of the } \\
\text { East Midlands, wells - Alport-1 } \\
\text { and Gunhill-1. }\end{array}$ & $-1-83$ \\
\hline P.M. Curran & GL/EK/5247 & $\begin{array}{l}\text { A Geochemical Review of the } \\
\text { East Midlands } 2 \text { vols. }\end{array}$ & $-1-83$ \\
\hline
\end{tabular}


1. EAST MIDLANDS CONID.

\begin{tabular}{|c|c|c|c|}
\hline P.M. Curran & W25.1 & $\begin{array}{l}\text { A Geochemical Study of Sediment } \\
\text { Samples and extracted oil shows } \\
\text { fram the well Parkhill-l, East } \\
\text { Midlands. }\end{array}$ & $-1-84$ \\
\hline P.C. Mason & W42 & $\begin{array}{l}\text { Geochemical Analysis of Crude } \\
\text { Oil from the well Welton No. } \\
\text { Al, UK Land, Lincolnshire, } \\
\text { PL } 179 \text {. }\end{array}$ & $-2-82$ \\
\hline P.C. Mason & W25 & $\begin{array}{l}\text { A Geochemical study of NCB } \\
\text { Wilds Bridge, East Midlands. }\end{array}$ & $-10-84$ \\
\hline D. Coombes & W25 & $\begin{array}{l}\text { Geochemical Analysis of the } \\
\text { Stainton-1 oil, East Midlands. }\end{array}$ & $-2-85$ \\
\hline S.W. Lister & W25.1 & $\begin{array}{l}\text { Geochemical Analysis of an oil } \\
\text { fram Cherry Willingham-1, East } \\
\text { Midlands. }\end{array}$ & $-4-85$ \\
\hline D.B. Swift & W25 & $\begin{array}{l}\text { The Geochemistry of the } \\
\text { Cropwell Butler } 2 \text { and Farleys } \\
\text { Wood } 4 \text { and } 5 \text { oils, East } \\
\text { Midlands. }\end{array}$ & $-8-85$ \\
\hline D. Coombes & W25 & $\begin{array}{l}\text { Geochemical Analysis of the } \\
\text { Broughton Bl oil, East Midlands }\end{array}$ & $-2-85$ \\
\hline S. Fry & W25 & $\begin{array}{l}\text { The Geochemistry of the } \\
\text { Dunholme } 1 \text { oil, onshore UK. }\end{array}$ & $-3-84$ \\
\hline $\begin{array}{l}\text { H.E. Ward } \\
\text { S O'Reilly }\end{array}$ & W25 & $\begin{array}{l}\text { A Geochemical Study of Samples } \\
\text { from the well Brigg-1, South } \\
\text { Humberside. }\end{array}$ & $-10-81$ \\
\hline S. O'Reilly & W25 & $\begin{array}{l}\text { A Geochemical Study of the } \\
\text { Tetney Lock-1 well, S. Humb. }\end{array}$ & $-2-85$ \\
\hline Petra-Chem Ltd & GL/EK/5371 & $\begin{array}{l}\text { Geochemical evaluation of an } \\
\text { oil seepage sample collected } \\
\text { from Derbyshire. }\end{array}$ & $-8-83$ \\
\hline Petra-Chem Ltd & GL/EK/5426 & $\begin{array}{l}\text { Geochemical evaluation of } \\
\text { sediments from } 5 \text { boreholes: } \\
\text { Duffield, Wardlow Mines 2, } \\
\text { Knutsford 1, Holme Chapel } 1 \\
\text { and Knott Copy. }\end{array}$ & $-10-83$ \\
\hline
\end{tabular}


1. EAST MIDLANDS CONID.

\begin{tabular}{|l|l|l|l|}
\hline Petra-Chem Ltd & GL/EK/5468 & $\begin{array}{l}\text { Geochemical evolution of oil } \\
\text { stained sandstone from } \\
\text { Derbyshire. }\end{array}$ & $-4-84$ \\
\hline $\begin{array}{l}\text { Robertson } \\
\text { Research }\end{array}$ & GL/EK/5679 & $\begin{array}{l}\text { The Petroleum Geochemistry } \\
\text { of the Carboniferous of } \\
\text { Northern England. Prel im Report }\end{array}$ & $-1-86$ \\
\hline
\end{tabular}




\begin{tabular}{|l|l|l|l|}
\hline $\begin{array}{l}\text { M. Gernon } \\
\text { P.C. Mason }\end{array}$ & W25 & $\begin{array}{l}\text { Petroleum Geochemistry of the } \\
\text { well Fordon-1, Yorkshire. }\end{array}$ & -1-83 \\
\hline Petra-Chem & GL/EK/5522 & $\begin{array}{l}\text { Geochemical evaluation of } \\
\text { potential source rocks of } \\
\text { Carboniferous age from the } \\
\text { Northumberland Trough and } \\
\text { Mid North Sea High. }\end{array}$ & $-7-85$ \\
\hline Petra-Chem & W25 & $\begin{array}{l}\text { Geochemical evaluation of } \\
\text { sediments from Weeton No. 1 } \\
\text { borehole, W. Yorkshire. }\end{array}$ & $-2-85$ \\
\hline $\begin{array}{l}\text { Robertson } \\
\text { Research }\end{array}$ & GL/EK/5679 & $\begin{array}{l}\text { The Petroleum Geochemistry } \\
\text { of the Carboniferous of } \\
\text { N. England (Prelim. Report) . }\end{array}$ & $-1-86$ \\
\hline
\end{tabular}


3. WESTERN ENGLAND (W. Midlands/Cheshire/Manx-Furness Basin)

\begin{tabular}{|l|l|l|l|}
\hline H.E. Ward & GL/EK/5063 & $\begin{array}{l}\text { Geochemical study of samples } \\
\text { from Bickershaw Colliery, west } \\
\text { Midlands. }\end{array}$ & $-6-81$ \\
\hline P.C. Mason & GL/EK/5066 & $\begin{array}{l}\text { A Geochemical study of } \\
\text { Lancashire outcrops of } \\
\text { Carboniferous age. }\end{array}$ & $-10-81$ \\
\hline $\begin{array}{l}\text { M.F. Heffeman } \\
\text { M.F. Heffeman }\end{array}$ & GL/EK/5355 & $\begin{array}{l}\text { A Geochemical Review of the } \\
\text { Manx-Furness Basin, Irish Sea, } \\
\text { part 1. }\end{array}$ & $-6-83$ \\
\hline $\begin{array}{l}\text { Robertson } \\
\text { Research }\end{array}$ & GL/EK/5679 & $\begin{array}{l}\text { A Geochemical study of the } \\
\text { Manx Basin, part II (see also } \\
\text { GL/EK/5355) }\end{array}$ & $-6-84$ \\
\hline $\begin{array}{l}\text { The Petroleum Geochemistry of } \\
\text { the Carboniferous of N. England } \\
\text { (Prel im. Report). }\end{array}$ & $-1-86$ \\
\hline
\end{tabular}


Appendix D

Northern England Carboniferous

The 'THETA' thermal modelling program 


\section{Appendix D}

\section{THE 'THETA' THERMAL MODELLING PROGRAM}

The aim of thermal modelling is to calculate the temperature history of any given sediment unit in an area. Its primary use in petroleum exploration is to interpret and predict the maturity and timing of generation in source rocks given their temperature history. It can also be used to help constrain the timing of diagenetic events in reservoir rocks.

\section{HEATFLOW}

The THETA program has been developed in-house by BP to model the thermal history of a 1-D stratigraphic column. The main component of the thermal history is heat flow. Most of the heat which reaches the surface of the earth is produced by the decay of radioactive elements deep within the earth. Only a small portion comes from residual cooling of the earth following its formation.

The most important parts of the system for the thermal modelling of sedimentary basins are the crust and lithosphere (Fig. 1). The lithosphere is a 'conductive thermal boundary layer' - a region in which heat energy is transferred primarily by conduction. Beneath the lithosphere, the temperatures are high enough such that the asthenosphere behaves as a fluid and convects. Because of the convection, the asthenospheric material becomes well 'mixed' and so the temperatures within the asthenosphere are broadly similar. The lithosphere/asthenosphere boundary can therefore be thought of as a constant temperature surface. In practice, mantle convection occurs for temperatures greater than c. $1300^{\circ} \mathrm{C}$. The base of the 'thermal lithosphere' is defined by the $1333^{\circ} \mathrm{C}$ isotherm. In most continental and old oceanic basins, this temperature corresponds to a depth of about 125 $\mathrm{km}$. The convection in the asthenosphere is 'fuelled' by the heat produced by the decay 
of $\mathrm{U}^{238}, \mathrm{U}^{235}, \mathrm{Th}^{232}$ and $\mathrm{K}^{40}$. Clearly as these isotopes decay their concentration decreases and the amount of heat produced also decreases. However, for the Phanerozoic it has probably decreased by less than $10 \%$.

The top of the crust is defined by another 'fixed temperature' boundary (either the land surface or the sea bed) with the temperatures defined by the annual average surface air temperature or, in the submarine case, the sea bed temperature.

Thus, the heat flow in the crust and lithosphere can be treated as a conductive transfer of energy to the surface with the heat flow determined by the surface and base lithosphere temperatures, and the thickness and thermal conductivity of the crust/ithosphere system. Tectonic models for the evolution of heat flow can be built into this framework. For example, stretching and thinning of the lithosphere brings the $1333{ }^{\circ} \mathrm{C}$ isotherm to a shallower depth, causing a transient increase in heat flow (McKenzie 1978). Through time, the lithosphere re-adjusts to the equilibrium state, with a typical lithospheric thickness of $125 \mathrm{~km}$. From this model, simple calculations allow the prediction of variations in crustal heat flow with time, i.e. the heat flow history.

The main area of interest to the oil industry is the top few kilometres of the crust where oil and gas might be generated; only the very shallowest part of the system shown in Fig. 1. In order to model temperatures over this interval we consider conduction of heat within a column of varying conductivity, with the lower boundary condition described in the model by a heat flow, instead of the constant temperature condition at the base of the lithosphere. By varying the basal heat flow history in the model of the sediment column, tectonic variations in the properties and thickness of the lithosphere and its (constant temperature) lower boundary can be accounted for. The surface temperature remains the upper boundary condition for the model. 

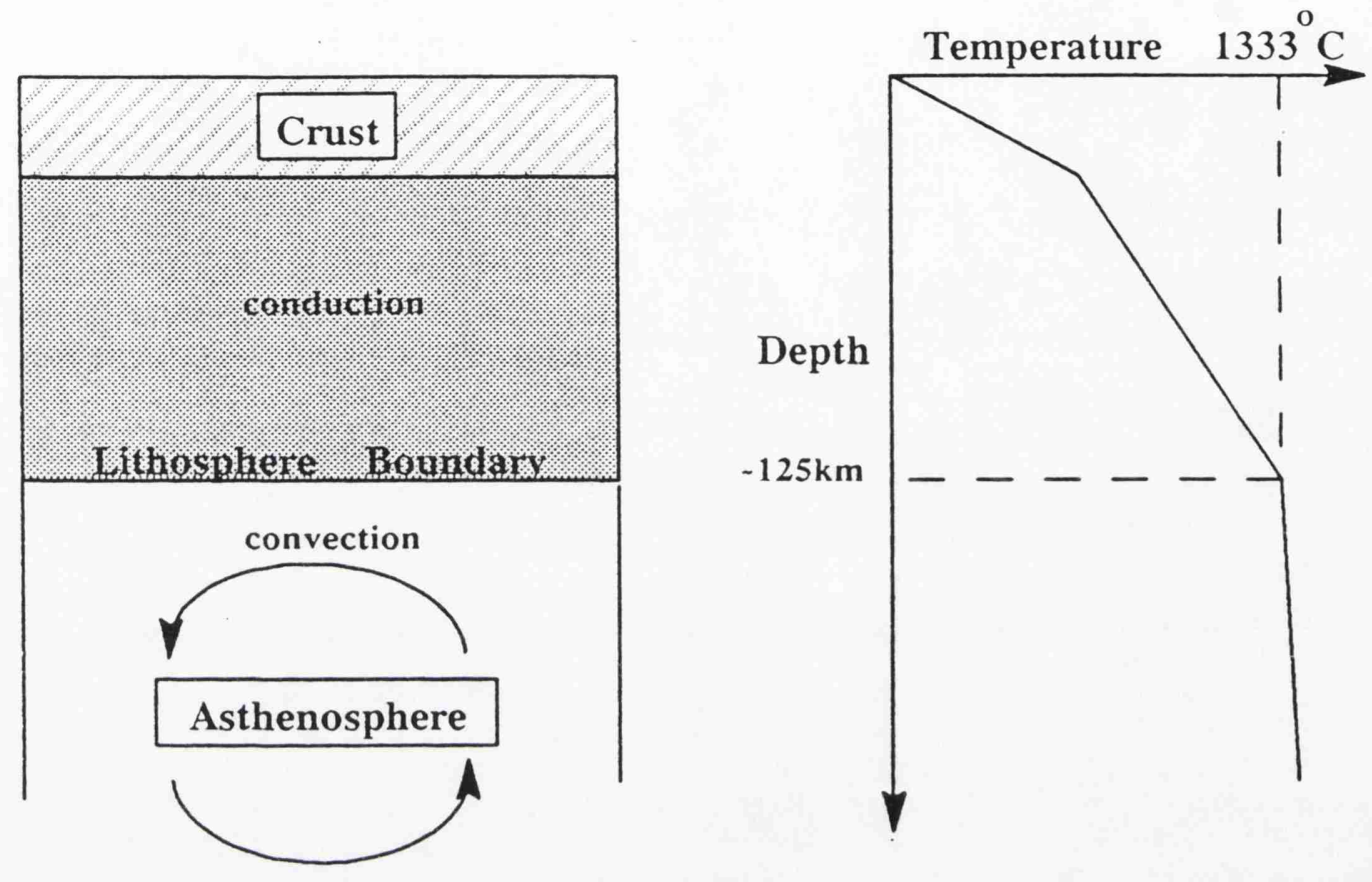

Figure 1 Simplified section through the earth.

As well as the conductive heat flow from the asthenosphere to the Earth's surface, the heat produced within the lithosphere must be accounted for. In practice, heat production is highly concentrated in the uppermost $10-20 \mathrm{~km}$ of continental crust and sediments; oceanic and lower continental crust and sub-crustal lithosphere have very low $\mathrm{U}, \mathrm{Th}$, and $\mathrm{K}$ concentrations. Heat production simply adds to the heat flow so that heat flow increases as the surface is approached: the strict condition of constant heat flow at depth must be relaxed . 
Therefore, the crustal heat flow can be described as follows:
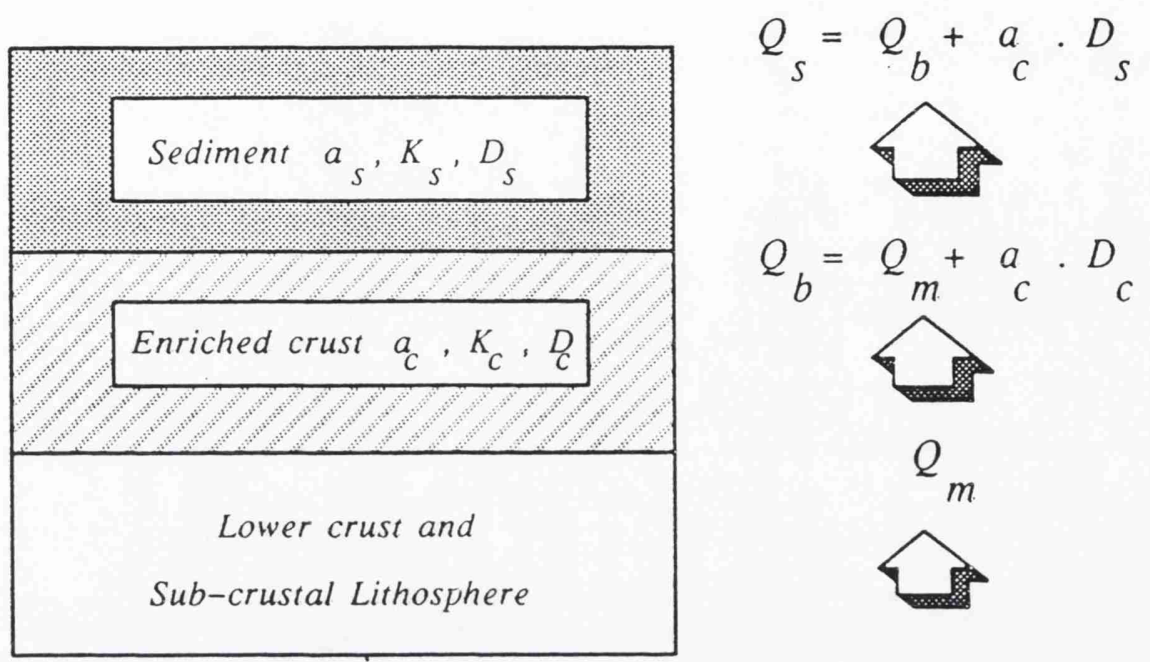

$\begin{array}{ll}\text { Where } & \begin{array}{ll}\mathrm{Q}_{m}= & \text { heat flow in the lower lithosphere } \\ \mathrm{Q}_{b}= & \text { heat flow at the base of the sediments } \\ \mathrm{Q}_{s}= & \text { heat flow at the surface } \\ \mathrm{a}_{c}= & \text { heat production in the enriched crust } \\ \mathrm{a}_{s}= & \text { heat production in the sediments } \\ \mathrm{D}_{c}= & \text { thickness of the enriched crust } \\ \mathrm{D}_{s}= & \text { thickness of the sediments }\end{array}\end{array}$

\section{SOURCE ROCK MATURITY}

Having identified a potential source rock within the sediment column, heat flow modelling can be used to estimate its temperature history. From this, we can go on to estimate the maturation history of the sediment. There are several ways to calculate maturity; the THETA program uses the maturity parameter ' $\mathrm{P}$ ' which is obtained from the following (entirely empirical) time-temperature integral :

$$
P=\ln \left[\int_{t=0} t_{2}(T / 10) d t\right]
$$


The equation shows that $P$ increases with both time $(t)$ and temperature $(T)$; in fact, the temperature dependence is by far the most important. ' $P$ ' has been calibrated in a large number of studies, which indicate that the 'oil window' is characterised by $P$ values in the range of 10 to 14 . In addition, an empirical relationship has been established between $\mathrm{P}$ and vitrinite reflectance, so that modelled P's can be compared directly with reflectances measured in the borehole.

\section{THE THETA PROGRAM}

In the simplest case, a 1-D column is taken to be representative of the thermal history of a single borehole or seismic shot point location in a sedimentary basin. The lithologies forming the sediment column can be input directly from wellbore data or estimated from seismic and regional facies models. Hence the thermal resistivity and heat production at depth can be estimated. Temperatures can be measured at depth and hence estimates of $Q(z)$, the heat flow at depth $z$. , can be made. The surface temperature, $T O$, is generally easily accessible and if the tectonic history of the basin is known, lithospheric models can then be used to predict the heat flow history $Q m(t)$ and $Q b(t)$; the heat flows to the base of the crust and sediment column as a function of time. Given these parameters, the thermal histories for the sediments of interest can be calculated.

Fig. 2 presents simplified flow diagrams of the THETA method. The three major data inputs to the program are;

Stratigraphic data

Lithological data

Temperature data 

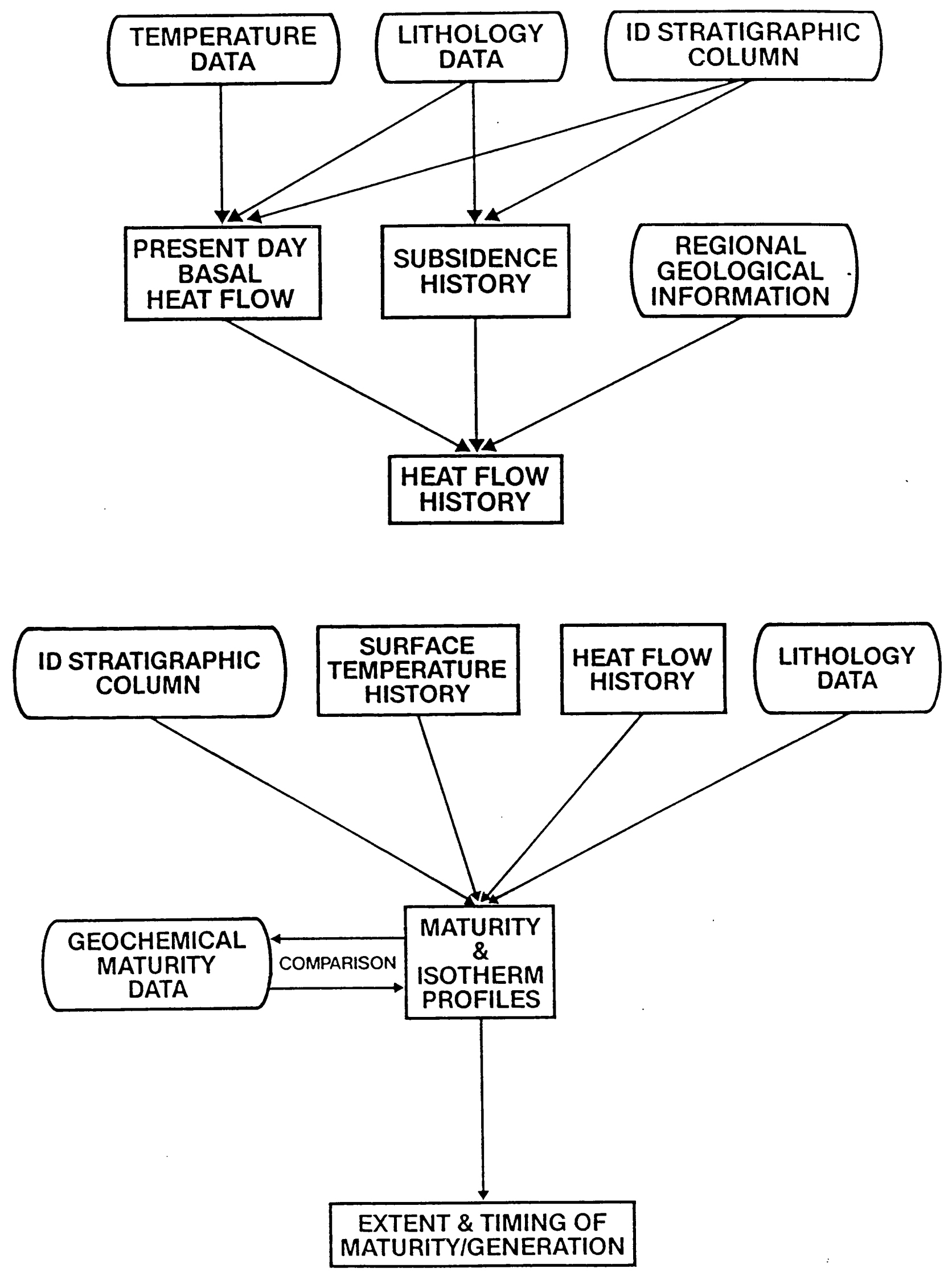

Figure 2. Simplified flow diagrams of the THETA method 
The stratigraphic data is used in the creation of a 1-D column comprising formations each assigned a single lithology (Table 1). Each formation is described by depth and age values supplied for the top and bottom of the formation. These values, therefore, define a depositional history for the column. The lithological data is a description of the physical properties of each formation in the 1-D column.

The temperature data consists mainly of bottom hole temperatures (BHTs) and drill stem test temperatures (DST's) recorded at various depths in the borehole. These temperatures are used to find present day equilibrium formation temperatures.

THETA starts at the oldest age input for the 1-D stratigraphic column. At this age the column consists wholly of basement with none of the input stratigraphy present. The program moves forward in time by one time step. The amount of formation deposited during the time step is calculated and added to the top of the column. The temperature throughout the column is then calculated and the first increment of maturity is recorded. The program then moves forward by the second time step, adds more formation and the calculation of temperature and maturity is repeated. The whole process is repeated over and over until it reaches the present day.

Before running the THETA program, two boundary conditions have to be considered:

(i) the heat input at the bottom of the column (the basal heat flow) and (ii) the surface temperature. These must be defined throughout the whole depositional history of the column.

The basal heat flow history is obtained from 3 sets of data, as shown in Fig. 2.

(i) the present day basal heat flow,

(ii) the subsidence history of the column and

(iii) regional geological information. 
Table 1 Theta modelling - input parameters used to model basin subsidence history for the Ratcliffe-on-Soar borehole location, Widmerpool Gulf.

\begin{tabular}{|c|c|c|c|c|c|c|}
\hline Age Ma & 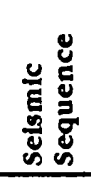 & Lithology & 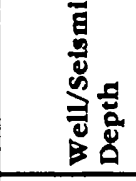 & 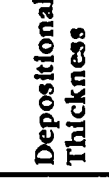 & $\begin{array}{l}\frac{5}{0} \\
0\end{array}$ & $\begin{array}{c}\text { Water depth } \\
\text { range }\end{array}$ \\
\hline 233 & $\mathrm{~T} 2$ & ${ }_{M D S T / S S T} \uparrow$ & & (50) & $\begin{array}{l}50 \mathrm{~m} \\
200 \mathrm{~m}\end{array}$ & $0-20 \mathrm{~mm}$ \\
\hline 65 & $\mathrm{k}=$ & ChaLK $\uparrow$ & & -- & $900 \mathrm{~m}$ & \\
\hline & J & MDST & & $(800)$ & & $0.50 \mathrm{~m}$ \\
\hline 208 & TR & SANDY MDST & -0 & $(500)$ & & $0-5 \mathrm{~m}$ \\
\hline 290 & $\mathbf{P}$ & SST & & 50 & & $0-10 \mathrm{~m}$ \\
\hline 310 & $\mathrm{v}$ & MDST & $\begin{array}{l}-250 \\
-250\end{array}$ & $(600)$ & $1650 \mathrm{~m}$ & $0.5 \mathrm{~m}$ \\
\hline & LC2 & MDST/COAL & & $(500)$ & & $0-10 \mathrm{~m}$ \\
\hline & $\mathrm{LClC}$ & MDST & & (S50) & & $0-20 \mathrm{~m}$ \\
\hline 220 & LC1b & SANDY MDST $\hat{i}$ & -400 & 150 & & $20-150 \mathrm{~m}$ \\
\hline 325 & LC1a & MDST & -350 & 325 & & $150-500 \mathrm{~m}$ \\
\hline 321 & EC6 & IST & $-8 / 3$ & 125 & & $300-500 \mathrm{~m}$ \\
\hline 330 & ECS & MDST & 7000 & 750 & & $200-500 \mathrm{~m}$ \\
\hline נבנו & EC4 & LST & טנוא & 150 & & $200-400 \mathrm{~m}$ \\
\hline 338 & EC3 & MDST & -1900 & 1200 & & $200-500 \mathrm{~m}$ \\
\hline 345 & EC2 & IST & -3100 & 150 & & $200-400 \mathrm{~m}$ \\
\hline 349 & EC1 & SST/SHALE & -3250 & 750 & & $100-400 \mathrm{~m}$ \\
\hline 305 & F $\mathbf{z}$ & BASEMENT & -4000 & & & $0-25 m$ \\
\hline
\end{tabular}

The present day heat flow and subsidence history may be calculated using the program. Regional geological information is used to interpret the tectonic setting in which the sediments where deposited; whether the region is in a compressive, extensive or passive regime and/or whether there has been major tectonic change during the period of interest. 
For example, in calculating the heat flow history for an extensional basin, the model can be divided into three phases: pre, syn and post-rift. In the case of short lived extension, McKenzie's model for instantaneous stretching is used (McKenzie 1978). In this model the lithosphere is stretched over a very short period of time then subsides as it cools and contracts. The THETA program calculates the heat flow resulting from a McKenzie-type stretching event, using current heat flow to constrain the present day state of the model and define the component of crustal heat production. The heat flow history is linked to the amount of extension which can be estimated for the subsidence profile of the basin.

Subsidence of any sedimentary basin is controlled by two processes; tectonic subsidence of the basement (due, for example to the cooling of the underlying lithosphere following a stretching event) and subsidence due to the loading effect of the infilling sediment. In calculating the subsidence history we are not interested in the portion caused by sediment loading. The THETA program calculates the amount of subsidence due to tectonic factors alone. For our extensional basin, the amount of stretching required by the McKenzie model is then calculated from the corrected tectonic subsidence.

Clearly, present day basal heat flow (obtained from temperatures measured in wells) is the strongest constraint we have on heat flow history and in any regional study, such as the northern England Carboniferous, it is important to calculate the basal heat flow in as many wells as possible. It may be found that the regional heat flow is constant, or has a systematic geographical distribution, or is related to the thickness of the sediments. Each of these cases gives us clues as to the likely heat flow history.

For thermal modelling, surface temperature is taken to be the temperature at the sediment/water or sediment/air interface. The present day heat flow calculations are particularly sensitive to the present day surface temperatures when the temperature measurements are at shallow depths $(<1000 \mathrm{~m})$. Ideally, present day surface temperatures should be measured over a yearly period and averaged. Ancient surface 
temperatures can be estimated from palaeo-latitude, palaeo-bathymetry and other palaeoenvironmental data.

\section{CALIBRATION OF THE MODEL}

After the THETA program has calculated the maturity history of the column, the consistency of the calculated parameters has to be calibrated against observed vitrinite reflectance values and Apatite Fission Track data.

Major discrepancies, can result from poor input parameters (including the geochemistry!). If the quality of the data is poor, sensitivity studies are carried out to estimate the possible uncertainty in the final maturity predictions. This involves varying each of the parameters separately to see their effect on parameter P. Fortunately, the modelling carried out for the northern England Carboniferous showed a close relationship between modelled parameters and vitrinite reflectance values in boreholes and sensitivity studies were not required.

\section{REFERENCES}

McKENZIE, D. P., 1978. Some remarks on the development of sedimentary basins. Earth and Planetary Science Letters, 40, 25-32. 


\section{Appendix E}

Copy of: FRASER, A.J., NASH, D.F., STEELE, R.P. \& EBDON, C.C. 1990. A regional assessment of the intra-Carboniferous play of northern England. In: BROOKS, J. (ed). Classic Petroleum Provinces. Geological Society, London, Special Publication, 50, 417-440. 


\title{
A regional assessment of the intra-Carboniferous play of Northern England
}

\author{
A. J. FRASER', D. F. NASH, R. P. STEELE \& C. C. EBDON \\ BP Petroleum Development Lid., Kirklington Rd, Eakring, Newark, \\ Notts NG22 ODA, UK \\ 'Present address: BP Petroleum Development Ltd., 301 St Vincent Street, Glasgow, G25 \\ 2DD, UK
}

\begin{abstract}
Hydrocarbons have been produced from the Carboniferous of the East Midlands since the 1926. Some 30 discoveries have heen made to date and allhough field sizes are gencrally small. the relatively low costs have made exploration and development an attractive commercial proposition. Many of the factors which contribute to sucess in the East Midlands occur in other basins in Northern England but have not produced significant hydrocarbon accumulations. This paper examines the key attributes of the intra-Carboniferous play and through an integrated regional geological framework contrasts the successful East Midlands oil province with the other Carboniferous hasins of Northern England.
\end{abstract}

North of the Variscan front in England, Carboniferous sediments form viable targets for hydrocarbon exploration. The sediments were deposited in a complex network of fault bounded basins which escaped the penetrative deformation and pervasive, low-grade metamorphism that affects much of the Carboniferous further south (see Besly (1988a) for an excellent summary).

Hydrocarbons have been produced from the Carboniferous of Northern England since the 1920s (Fig. 1) (Less \& Cox 1937; Lees \& Taitt 1945; Falcon \& Kent 1960; Kent 1985). Some 30 discoveries have been made to date, the majority in the East Midlands (Fig. 2). Despite field sizes being generally small (typically 1-2 $\mathrm{mm}$ bbls recoverable), the relatively low costs have made exploration and development an attractive commercial proposition.

A cursory inspection of the number of tests and hydrocarbon shows in the Carboniferous of Northern England would suggest that plays with Carboniferous targets had been intensely explored: some 280 exploration wells have been drilled to test the Carboniferous, of which almost 6()$\%$ have encountered shows. On closer inspection, however the number of valid (structure/reservoir-seal present) tests are substantially fewer and for the intra-Carboniferous are concentrated in the East Midlands with as little as a dozen valid tests outside this area, and none of commercial significance. The lack of success outside the East Midlands requires some explanation, particularly given the widespread distribution throughout Northern England of Carbonifcrous sediments and basins apparently similar to the East Midlands (Fig. 3).

The object of this paper is to attempt to answer the question: "Is the East Midlands unique as an oil province in Northern England?' To achieve this, data from an extensive inventory of 'successful' intra-Carboniferous tests has been synthesized and used to identify and calibrate the key factors controlling the specific hydrocarbon environments. These factors have in turn been used to assess the remaining 10-15 sub-basins in Northern England where Carboniferous sediments were deposited and where the play may be potentially developed.

\section{Regional geological model}

The basis for understanding the distribution of hydrocarbons in the intra-Carboniferous of Northern England is to be found in an interpretation of the complex geological history which the arca has undergone in Phanerozoic times (Anderton et al. 1979; Andre et al. 1986; Leeder 1976, 1982. 1987; Matte 1986; Thorpe et al. 1984; Whittaker 1985; Zeigler 1978, 1982, 1986). Four important tectonic phases are recognized, each of which fundamentally influences the processes which shape the hydrocarbon environment. Modern sequence stratigraphic techniques applied to regional seismic lines have been used along with outcrop and well data to provide a consistent interpretational framework, while recent ideas on Caledonian 


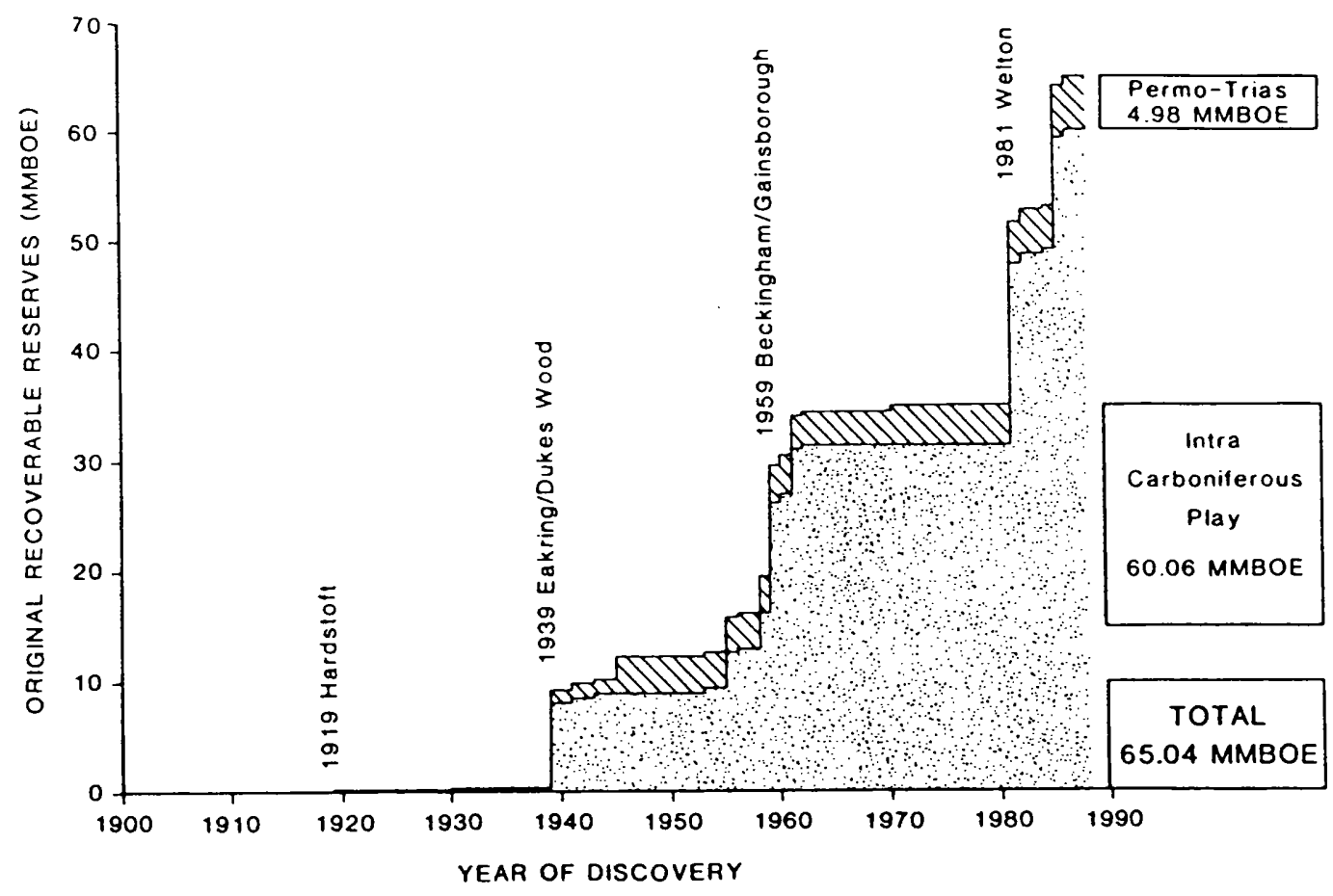

Fig. 1. Northern England - cumulative original recoverable reserves.

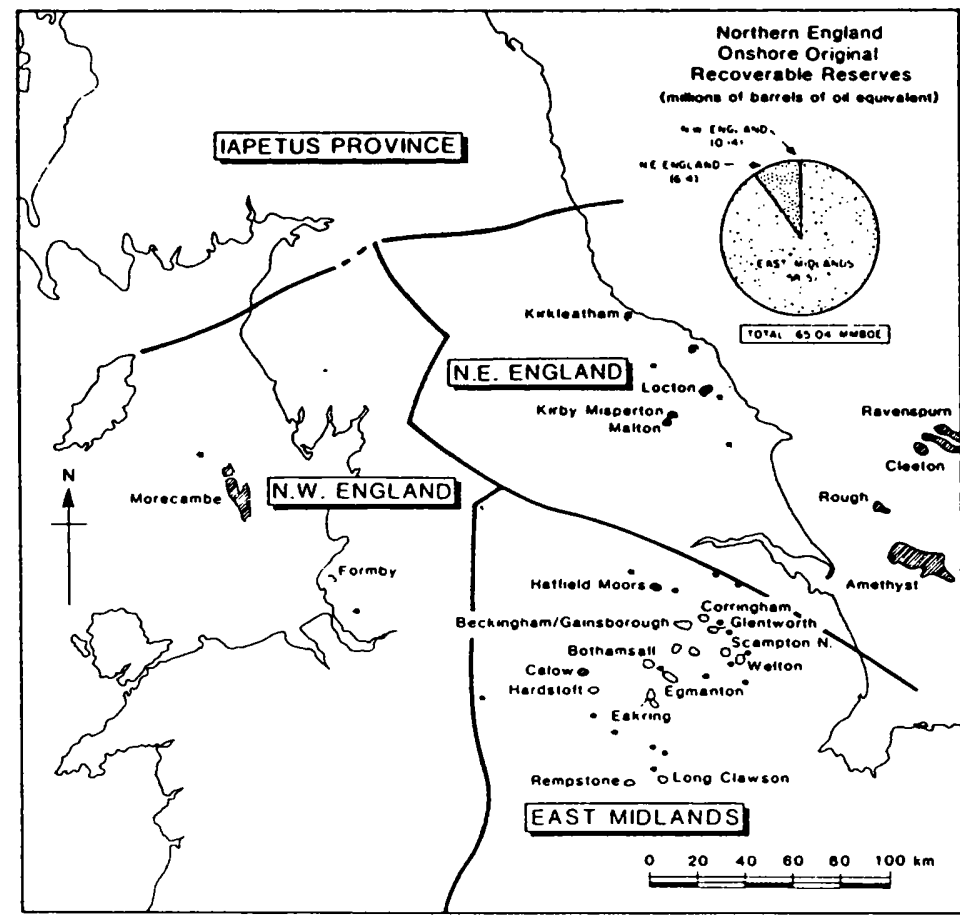

LEGEND

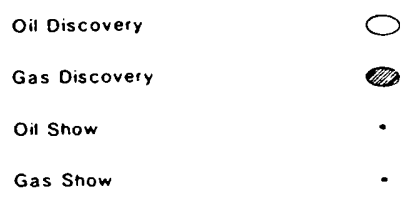

Fig. 2. Study arca showing hydrocarbon discoverics and shows. 


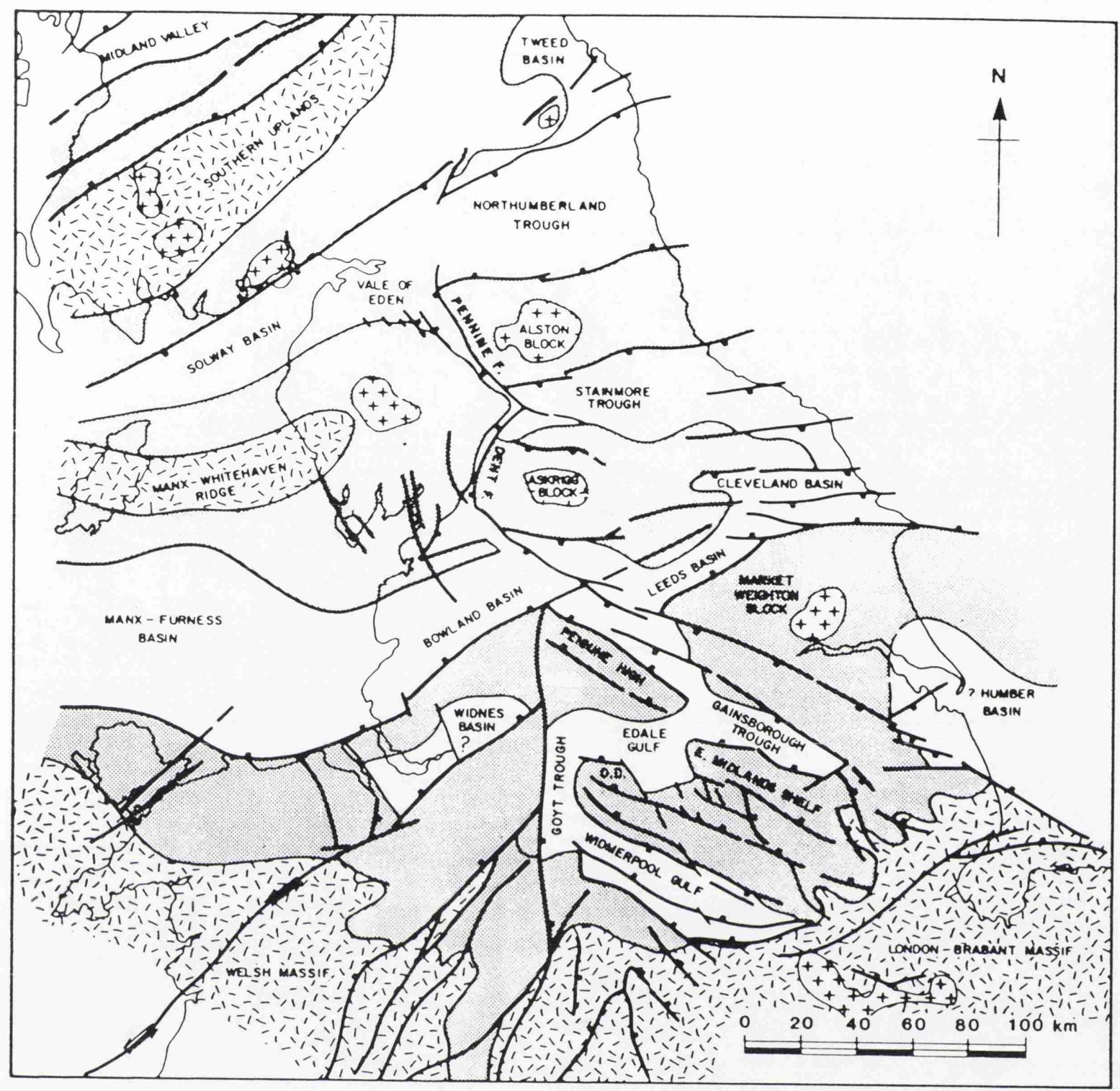

\section{LEGEND}

Basin

Platform

Basement High

Granite

Fig. 3. Earls Carboniferous structural clements.
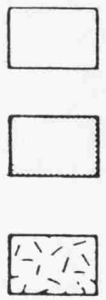

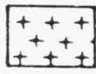


and V'ariscan fectonics have heen incorporated and developed to provide the framework for a regional hasin development model in Northern England.

\section{Caledonian structural framework}

It is widely recognized that the subsidence and inversion patterns which emerged from late Palacozoic times onwards were controlled by the underlying structure of the Caledonian basement (Arthurton 1986; Turner 1949; Wills 1973, 1978). Reconstructing the Caledonian structure and understanding its origin is an important pre-requisite for interpreting later crustal events that controlled basin polarity. subsidence history, depositional patterns, uplift etc.

On the hasis of Caledonide tectonic trends, sutures or major fault zones and other geological features (c.g- proportion of granite), five provinces are recognized (Fig. 4).

The Central England Province. A triangular, fault-bounded basement area with a thin, weakly deformed covering of Lower Palaeozoic

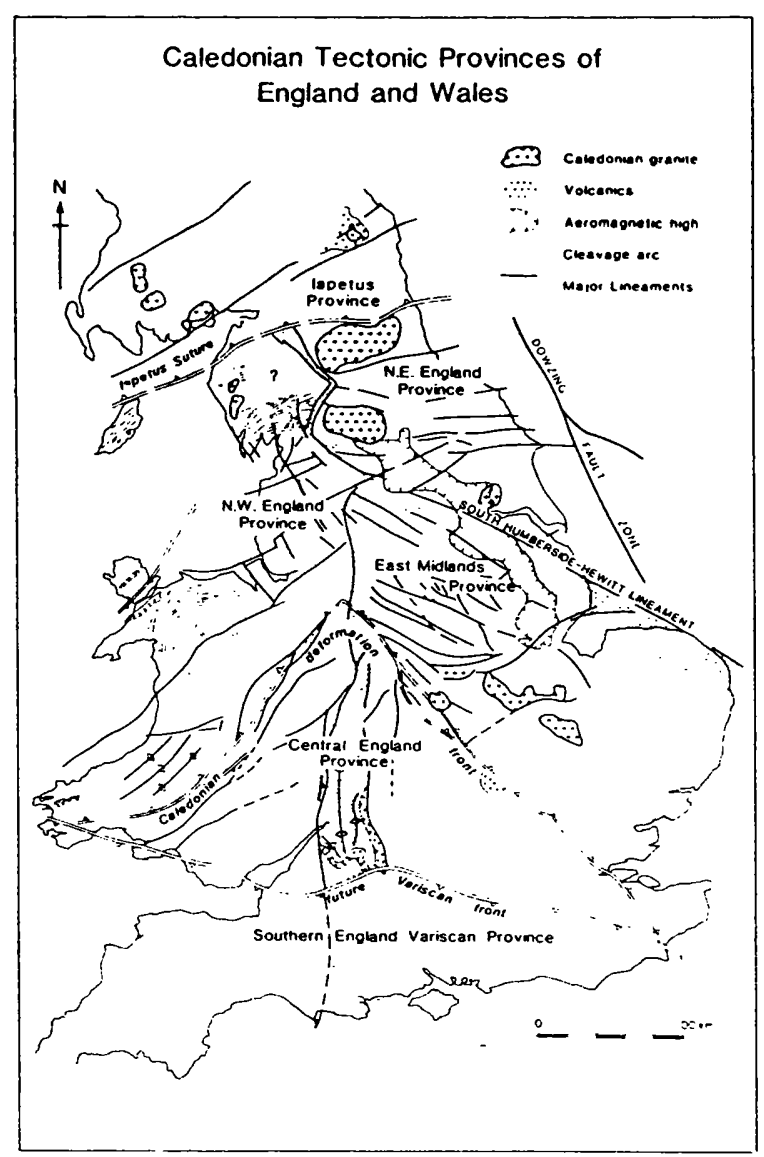

Fig. 4. Caledonian tectonic provinces of England and Walcs. sceliments, terminated to the south by the Variscan front. Geodynamically the feature is interpreted as a microcraton indenter that collided and joined with other crustal fragments during the closing of the lapetus occan in carly Palaeozoic times (Andre et al. 1986. Pharaoh et al. 1987, Soper \& Hutton 1984, Soper et al. 1987).

The East Midlands Province. This exhibits a pronounced NW-SE (so-called Charnoid) trend, which can be identified both in the basement arcas to the southeast and in the postCaledonian sedimentary cover to the northwest (Turner 1949; Kent 1968; Le Bas 1972; Evans 1979; Bott 1987; Wills 1973). The same trend is typical of the Calcdonian grain as far cast as the Tournquist line in mainland Europe (Ziegler 1982). The province is bound to the north by the Craven-South Humberside-Hewitt line, to the east by the Pennine-Dent-Malvern line and to the south by the northeastern margin of the Central England microcraton.

The Northeast England Province. This occurs to the north of the Craven-South HumbersideHewitt line, and is bounded to the west by the Pennine-Dent line and to the north by the lapetus suture. The eastern boundary is not clear: it may extend as a distinct block into the Mid North Sea High or be truncated by the precursor of the Dowsing fault zone. Within the province the dominant tectonic trends are eastwest and most of the areas which remained positive during subsequent subsidence phases are cored with granites of late Caledonian age (Bott 1966).

The Northwest England Province. On the opposite side of the Pennine-Dent line, the Caledonian grain assumes the more familiar NE-SW trend of the Scottish Caledonides. Basement faults in the Welsh Massif active prior to collision (Coward \& Siddans 1979) can be traced into Northwest England where they are truncated by the Pennine-Dent-Malvern line. The boundary of the indenter (PontesfordChurch Stretton fault) forms the southeastern margin, but the northern boundary is poorly constrained: whether the Lake District should be counted as part of the Northivest England province, or whether it represents a separate distinctive block (microcraton) is not clear.

The lapetus Province. Finally, overlying the site of the lapetus suture (Dewey 1971, 1982; Soper \& Hutton 1984, Beamish \& Smythe 1986; Klemperer \& Matthews 1987) encompassing the Northumberland/Solway basin, a narrow province is identified where the Caledonian structure trends strongly ENE-WSW. 


\section{Variscan corck}

Frame'ueste and interpretation. The Variscan Cycle extends from post Caledonian consolidation in late Devonian times to the cessation of inversion in the late Carboniferous - early Permian. Rifting during this period produced a complex scries of basins by extension along the pre-existing Caledonian framework (Fig. 4).

Traditionally the Carboniferous structure and facies of these basins has been interpreted in terms of a series of steep-sided 'blocks' and 'troughs' with shelf carbonates covering the blocks and basinal mudstones accumulating in the troughs (c.g., Kent 1966). Typically 'reefs' were interpreted as flanking the margins of the blocks (Hudson 1930; Parkinson 1957; Miller \& Grayson 1982). More recently tilt block models have become popular to explain the marked asymmetry of the basins revealed by deep drilling and modern multifold seismic (e.g., Grayson \& Oldham 1987; Lec 1988; Leeder 1987: Leeder \& Gawthorpe 1987; Smith et al. 1985). These models typically use straight faults which are associated with folding in the hangingwall. However, this particular geometrical relationship will only occur above curved listric faults.

Seismic data has shown the Carboniferous basins to have a very characteristic form (Figs $5-7)$. They appear as strongly inverted halfgraben with a rollover flexure often associated with antithetic faulting on the shallow side of the basin. This flexure which represents the return to regional in the hangingwall is often associated with the development of rimmed carbonate margins which prograde basin-wards. Similar margins are developed contemporaneously above the footwall scarp of the graben. The hangingwall shows strong inversion with pronounced angular unconformity at the base of the Permian as a result of reactivation of the main boundary faults during the Variscan orogeny (late Carboniferous).

Variscan stratigraphy and palaeofacies interpretation. A chronostratigraphic diagram for the Carboniferous of Northern England has been compiled to illustrate the relationship between conventional Carboniferous stages (George et al. 1976; Ramsbottom 1973; Ramsbottom et al. 1978 ) and the sequence stratigraphy developed from seismic, well control and outcrop studies (Fig. 8). The sequence stratigraphic scheme proposed here for the Carboniferous (Fig. 9) is based mainly on the seismo-stratigraphic interpretation of high-quality, modern multifold reflection seismic lines in Northern England and in particular the East Midlands. These have

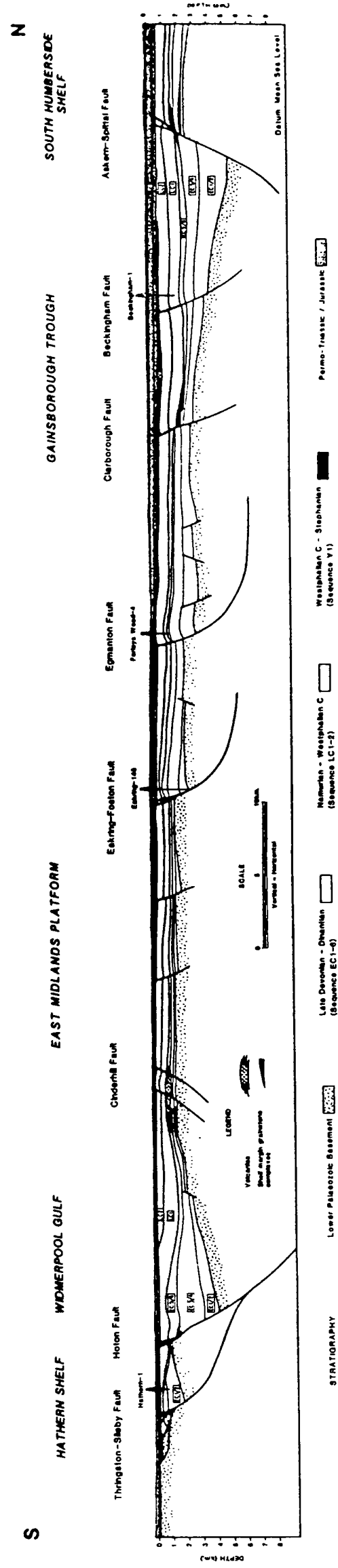

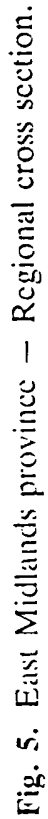



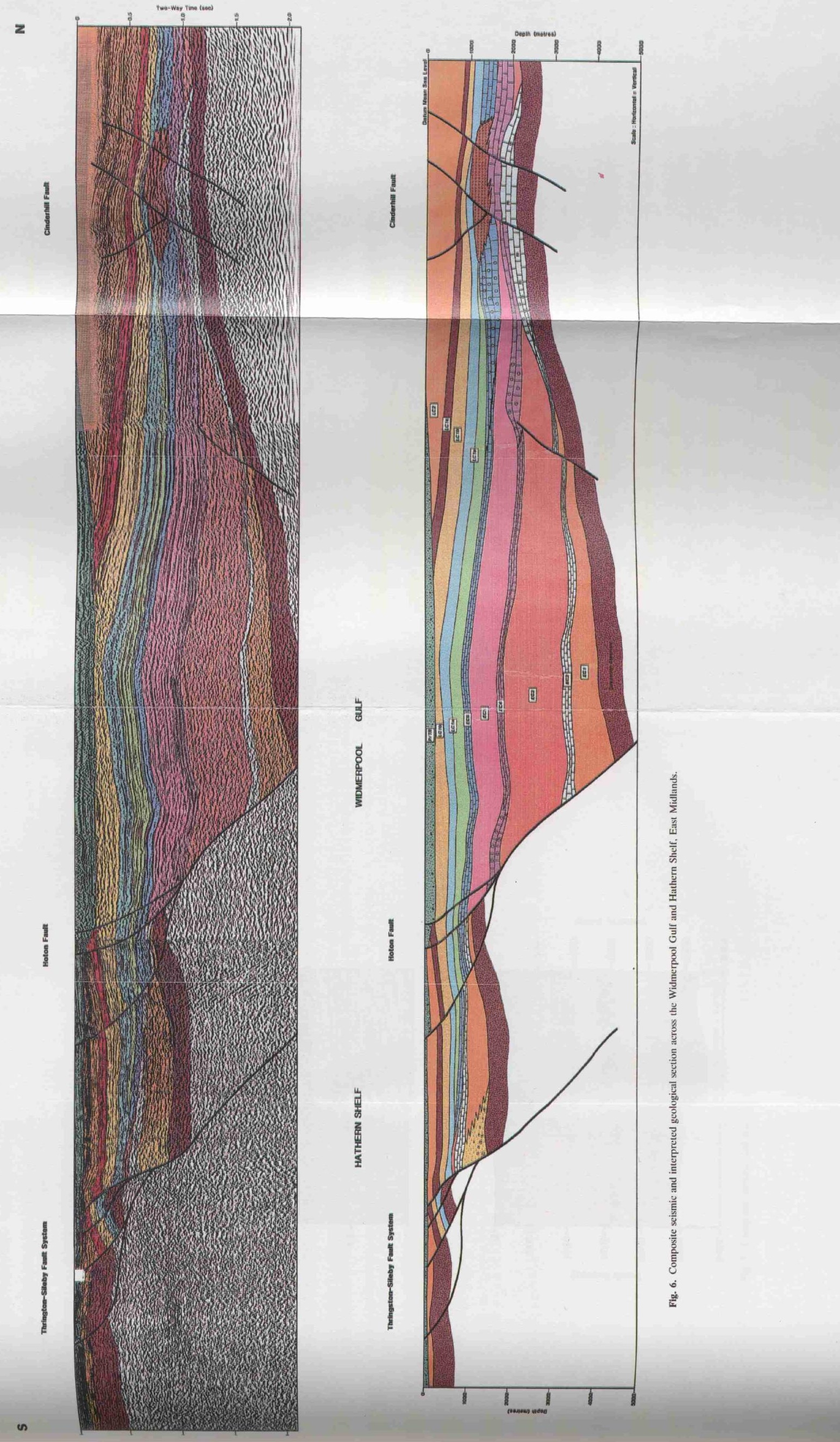

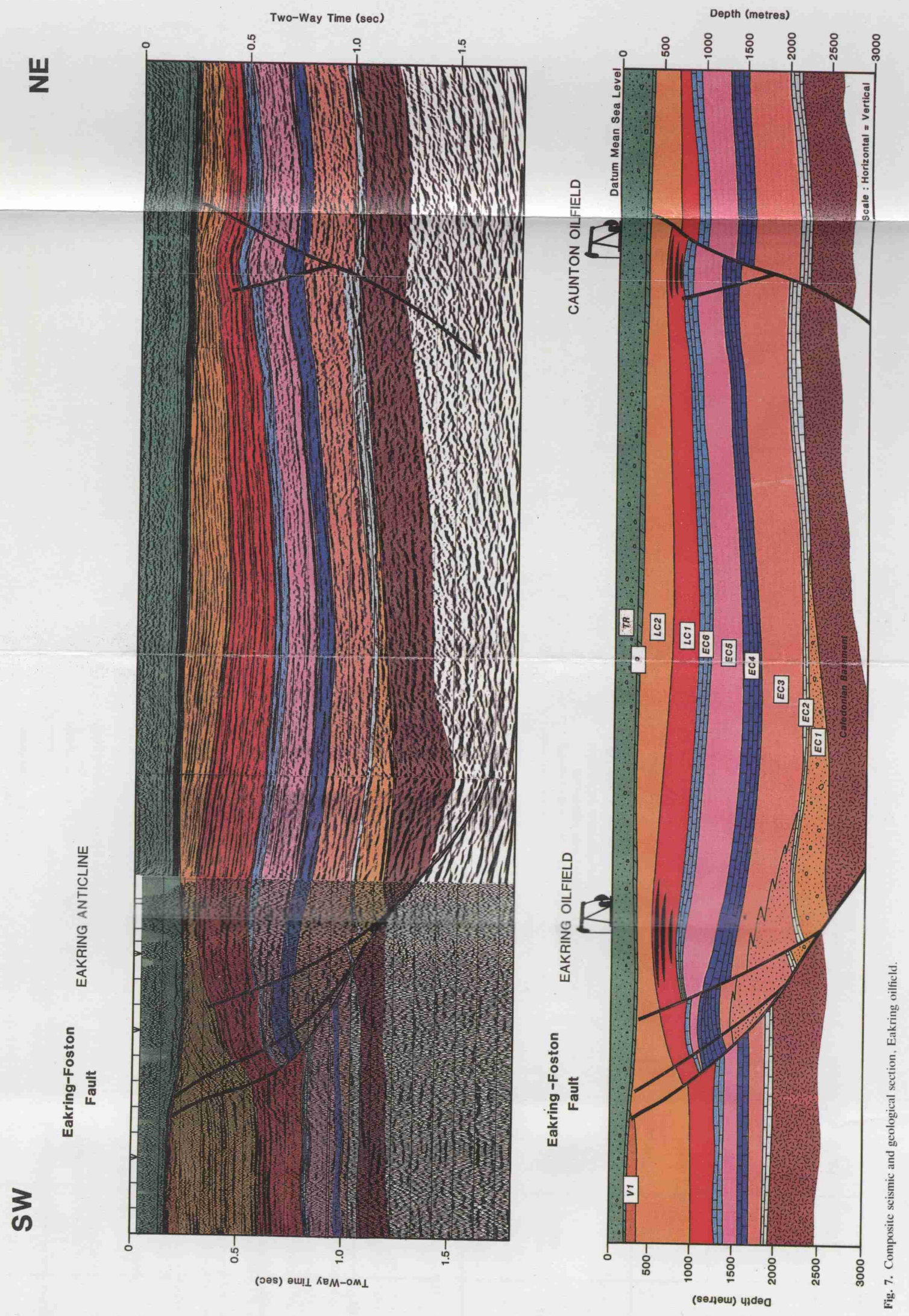
Table I. Sequence stratighaphy of the Variscan cycle in the Central England rift system

\begin{tabular}{|c|c|c|c|c|}
\hline \multicolumn{2}{|c|}{ Megatsequence } & Sequence & Agc & Tectonics/Facies Description \\
\hline \multicolumn{2}{|l|}{ Inversion } & V1 & $\begin{array}{l}\text { Latc Westphalian C- } \\
\text { Stcphanian }\end{array}$ & $\begin{array}{l}\text { Serong uplift and crosion of syn-rift } \\
\text { depocentres. Accumulation of barren red } \\
\text { beds and coarse pebbly sands and } \\
\text { fanglomerates in internally dratined molasse } \\
\text { basins. }\end{array}$ \\
\hline \multirow{2}{*}{\multicolumn{2}{|c|}{ Post-rift }} & LC2 & $\begin{array}{l}\text { Early Westphalian A- } \\
\text { late Westphalian C }\end{array}$ & $\begin{array}{l}\text { Thermal subsidence. Establishment of upper } \\
\text { delta plain, coal swamp conditions over } \\
\text { much of Northern England. Progradation of } \\
\text { Pennine delta southwards across Walcs- } \\
\text { Brabant massif. }\end{array}$ \\
\hline & & LC.1 & $\begin{array}{l}\text { Latc Brigantian- } \\
\text { carly Westphalian A }\end{array}$ & $\begin{array}{l}\text { Oasct of post-rift thermal subsidence. } \\
\text { Drowning of shelf margins and development } \\
\text { of intra-shelf basins (sec Gutteridge 1987) } \\
\text { following marine transgression over inverted } \\
\text { topography. Progressive advance of deltaic } \\
\text { sy'stems from nortlicast drowning carbonatc } \\
\text { platforms. }\end{array}$ \\
\hline \multirow{6}{*}{ Syn-rift } & \multirow{2}{*}{ III } & EC6 & Early-mid Brigantian & $\begin{array}{l}\text { Basin inversion cvent resulting in a } \\
\text { regressive phasc. Carbonate ramp to rimmed } \\
\text { sliclf development in the East Midlands with } \\
\text { margins both aggradational and } \\
\text { progradational. }\end{array}$ \\
\hline & & EC5 & $\begin{array}{l}\text { Latc Asbian- } \\
\text { carly Brigantian }\end{array}$ & $\begin{array}{l}\text { Reactivation of extensional fault regime with } \\
\text { significant back-stcpping of fault systcm in } \\
\text { Widmerpool Gulf (Fig. 6). Rencwed } \\
\text { footwall rotation and crosion and } \\
\text { development of boulder beds and slumps } \\
\text { basinward of drowned margins. }\end{array}$ \\
\hline & \multirow{2}{*}{ II } & EC4 & $\begin{array}{l}\text { Late Holkcrian- } \\
\text { mid Asbian }\end{array}$ & $\begin{array}{l}\text { Stillstand or regressive phase. Carbonate } \\
\text { ramp to rimmed shelf development with } \\
\text { margins both aggradational and } \\
\text { progradational. }\end{array}$ \\
\hline & & EC3 & $\begin{array}{l}\text { Latc Chadian-late } \\
\text { Holkcrian }\end{array}$ & $\begin{array}{l}\text { Rejuvenation of cxtcnsional faults causing } \\
\text { rotation of fault blocks and significant } \\
\text { footwall crosion. Development of boulder } \\
\text { beds and slumps ( } \mathrm{scc} \text { Gawthorpc 1987) and } \\
\text { drowning of carbonate shclf margins. }\end{array}$ \\
\hline & \multirow{2}{*}{ I } & $\mathrm{EC} 2$ & Chadian & $\begin{array}{l}\text { Stillstand or regressive phase. Carbonatc } \\
\text { ramp to rimmed shelf development with the } \\
\text { growth of Waulsortian-type mud mounds on } \\
\text { the upper part of ramp. }\end{array}$ \\
\hline & & $\mathrm{ECl}$ & $\begin{array}{l}\text { Latc Devonian- } \\
\text { Courceyan }\end{array}$ & $\begin{array}{l}\text { Initial development of half graben. } \\
\text { Downlapping subacrial fan sequence } \\
\text { developing into Old Red Sandstone fluvial } \\
\text { plain deposits. Marine transgression marked } \\
\text { by progressive onlap of bascment by } \\
\text { carbonate slope deposits. }\end{array}$ \\
\hline \multicolumn{2}{|l|}{ Pre-rift } & PZ & Prc-late Dcvonian & $\begin{array}{l}\text { Caledonian granite and folded lower } \\
\text { Palacozoic basement complex. }\end{array}$ \\
\hline
\end{tabular}




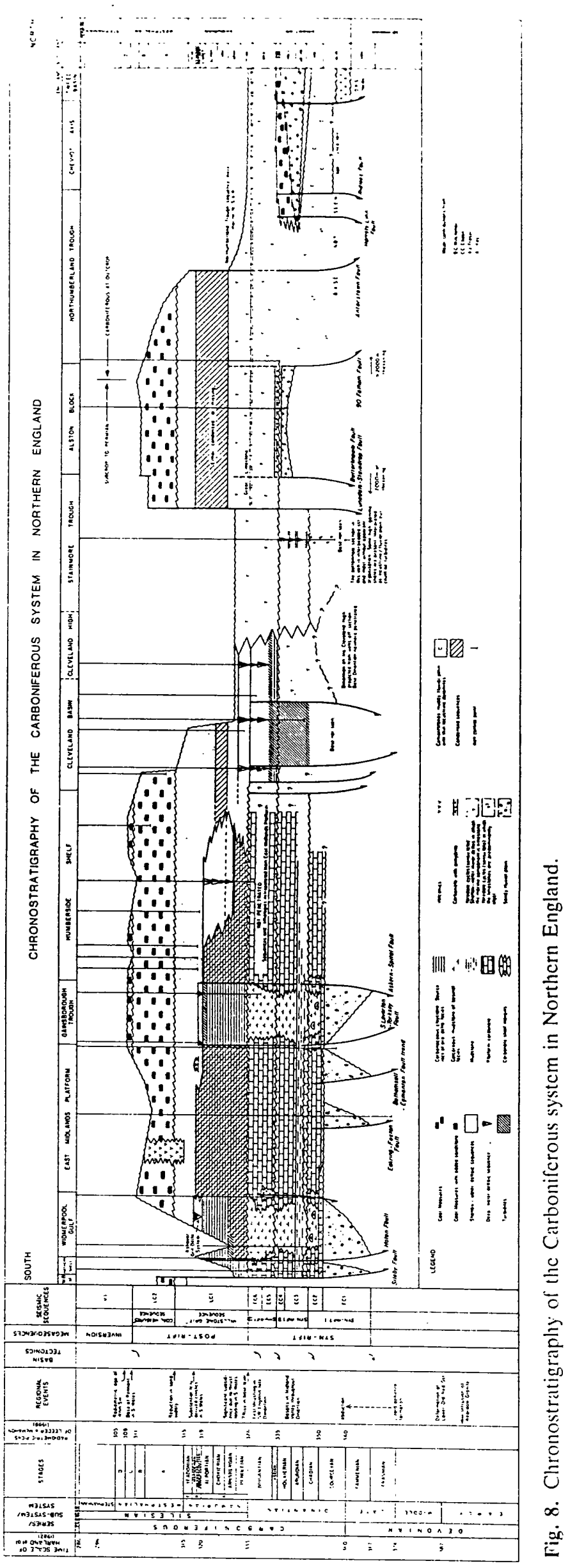




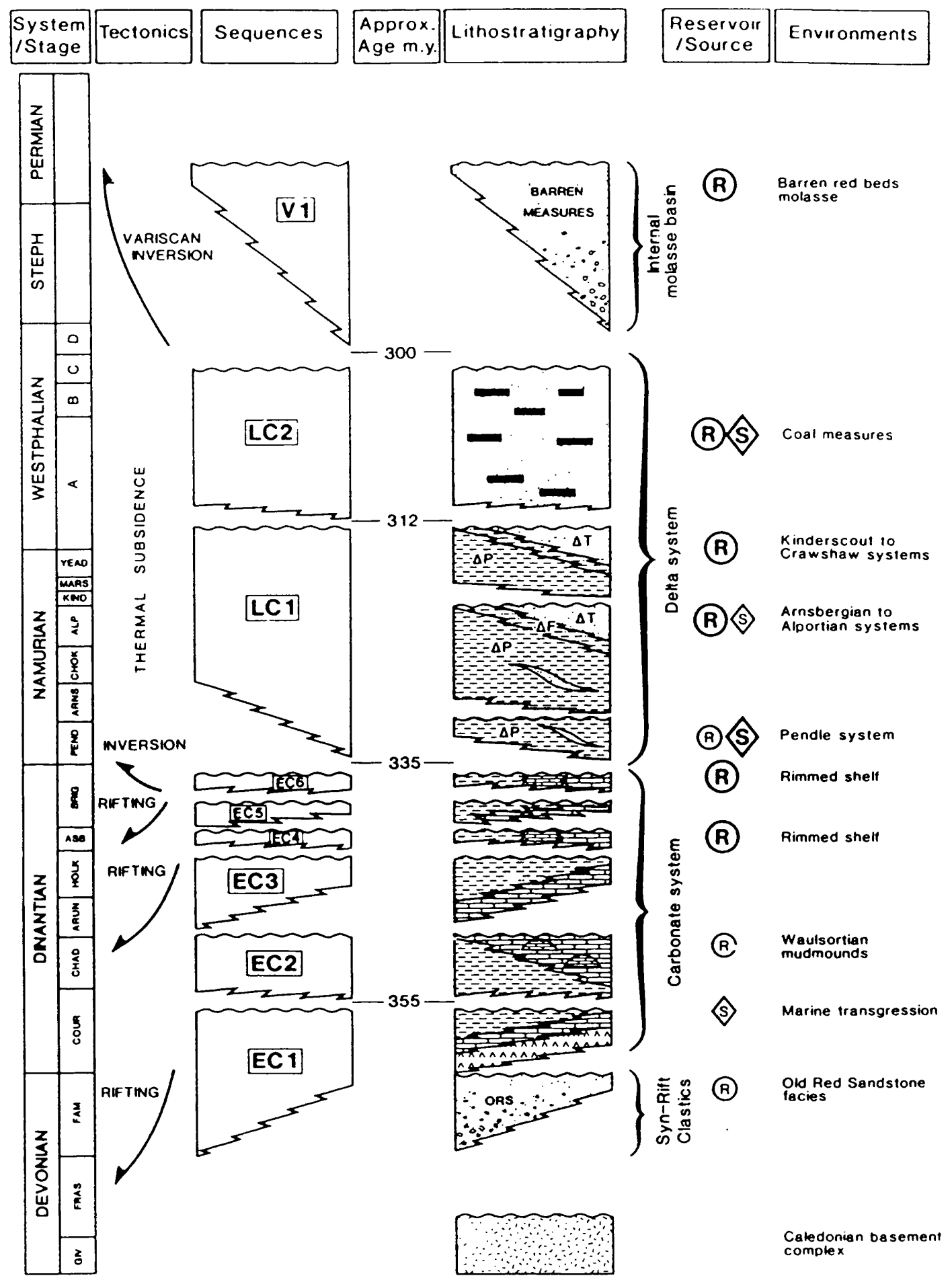

Fig. 9. Summarised stratigraphy of the East Midlands - showing megasequence and sequence stratigraphy.

been rigorously tied to biostratigraphic data from near-by well control and correlated with equivalent sections at outcrop. Table 1 summarizes the sequences presently observed within the Carboniferous of the Bowland Basin. Derbyshire Dome and East Midlands. The sequence stratigraphic approach has been adopted as the basis for compiling a series of twelve palaeofacies maps for the Variscan cycle (Fig. 10). These maps permit an analysis of the evolution of reservoir, seal and source facies by time slice.

The fundamental control on sedimentation in the Northern England Carbonifcrous basins was 

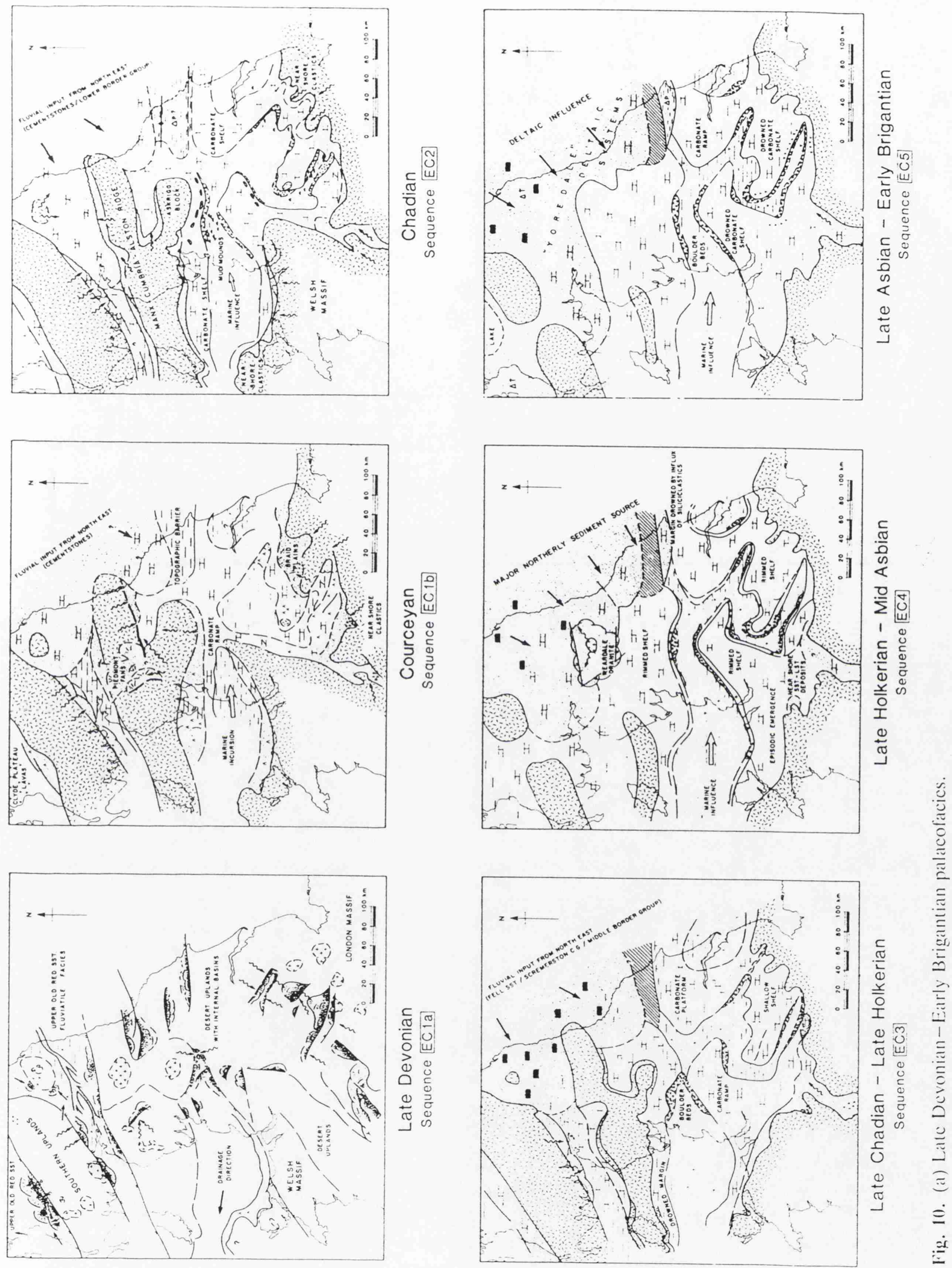

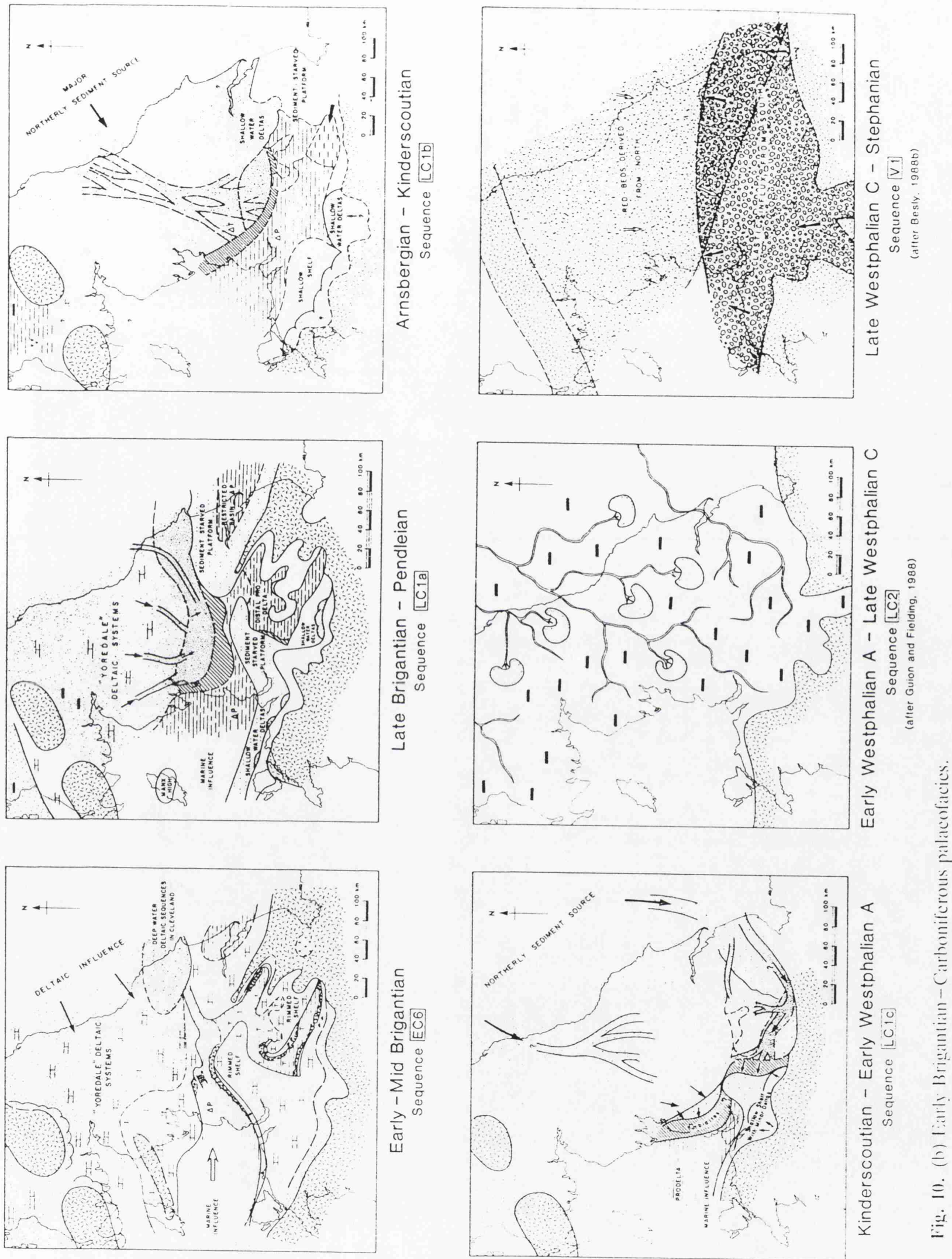
Whe presence of a major clastic source area to the north. Thus the predominant sediment transport direction was from north to south controlled and hindered by the developing rift topography. Whilst clastics were trapped by the more northerly basins, carbonates accumulated in the south. The more southerly basins only received a clastic fill during the post-rift when an inherited sediment-starved topography was rapidly infilled.

Geodynamic interpretation. There is much controversy surrounding the origin of the Northern England extensional basins. Essentially the geodynamic models fall into two categories, with subsidence controlled either by plate subduction and back-arc spreading (Leeder $1982 \&$ 1987) or related to large-scalc transtensional shear (Badham \& Halls 1975; Dewey 1982). A recent model proposed by Haszeldine (1984, 1988) has suggested an alternative mechanism based on east-west extension related to early rifting in the Atlantic province. The work carried out for the study reported here, favours the 'Leeder model' and interprets Northern England rifting south of the Iapetus suture specifically in terms of domal arching followed by incipient north-south directed back-arc spreading centred on Central England. Some evidence for the presence of a thermally driven dome is provided by the widespread development of continental facies at the onset of rifting (Fig. 10), the semi circular southern rim to the rift system formed by the northern margin of the Wales Brabant Massif (Fig. 3) and the 'bulls eye' pattern of the post-rift thermal sag (Fig. 1).

The sequence stratigraphic analysis has suggested that doming and rifting commenced in late Devonian times and continued to the end of the Dinantian, with continental deposition gradually replaced by more marine conditions from the Courceyan as subsidence progressed. The prolific clastic hinterland to the north (Leeder 1987) of the Central England basins, however, did not prograde markedly southwards in the Dinantian, due probably to the very substantial subsidence of the lapetus basins (Midland Valley, Northumberland/Solway) keeping pace with sediment supply but, also, to the barrier formed by the granite-cored Alston and Askrigg blocks (Fig. 3). The palaeofacies shown on Fig. 10 illustrate the isolation of the Central England rifts and the predominance of carbonate over clastic sedimentation at this time.

In late Brigantian times this partitioning of sedimentary facies was terminated by tectonic movements, which are reflected in a widespread early-mid Brigantian inversion in Central
England, that clevalted hasin margins and induced intra-Carboniferous crosion surfaces (Strank 1987). The inversion was relatively minor but corresponds, significantly, to the switchover from active rifting to thermallyinduced 'sag' subsidence. Temporally the inversion correlates with collision events as recorded by nappe emplacement in the Variscan orogenic zone lying to the south (Scllwood \& Thomas 1986). It would seem likely that this event disabled the subduction which controlled backarc spreading leading to the termination of active rifting in Northern England. This switch in subsidence patterns is particularly well demonstrated by comparison of the restored syn and post-rift isopachs over Northern England. (Figs 11 \& 12). The carly Carboniferous (syn-rift) isopach shows deposition essentially confined to isolated fault bounded half-graben. In contrast, the post rift isopach displays a pattern of thermally driven, broad, regional subsidence. Over $3.5 \mathrm{~km}$ of sediments were deposited during the post-rift phase with subsidence centred in the southwest of the study area. The depocentre migrated southwards with time in response to initial phases of basement uplift and breaching of the southern shoulder of the collapsed dome (Wales-Brabant Massif) during the Westphalian (Guion \& Fielding 1988).

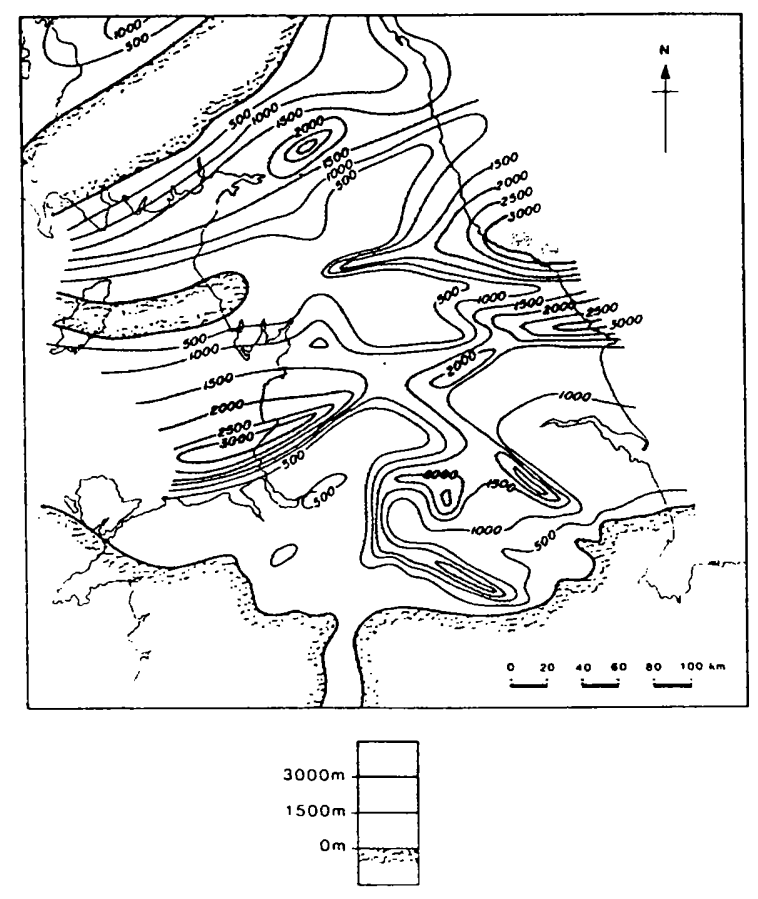

Fig. 11. Restored Chadian-carly Brigantian Isopachs. Syn-rift sequences EC2-EC6. 

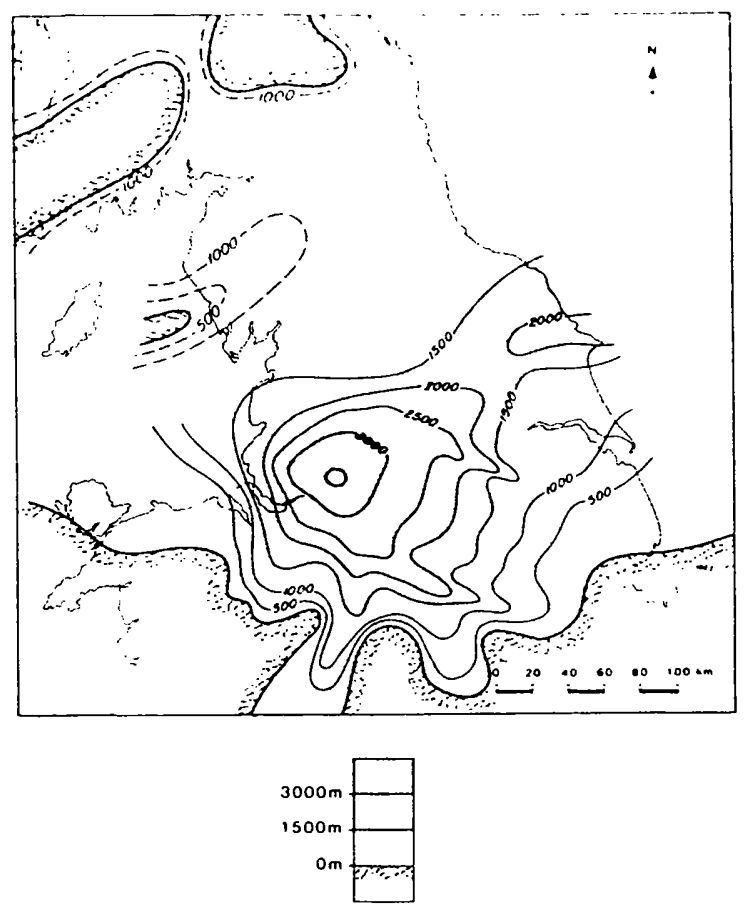

Fig. 12. Restored Namurian-mid-Westphalian C isopachs. Post-rift scquences LC1-LC2.

Late Westphalian, Variscan movements extensively uplifted Northern England (Fig. 13). Faults in Northwest England trending NE-SW and at a high angle to the translation direction of Variscan convergence were massively inverted. Importantly the NW-SE grain in the
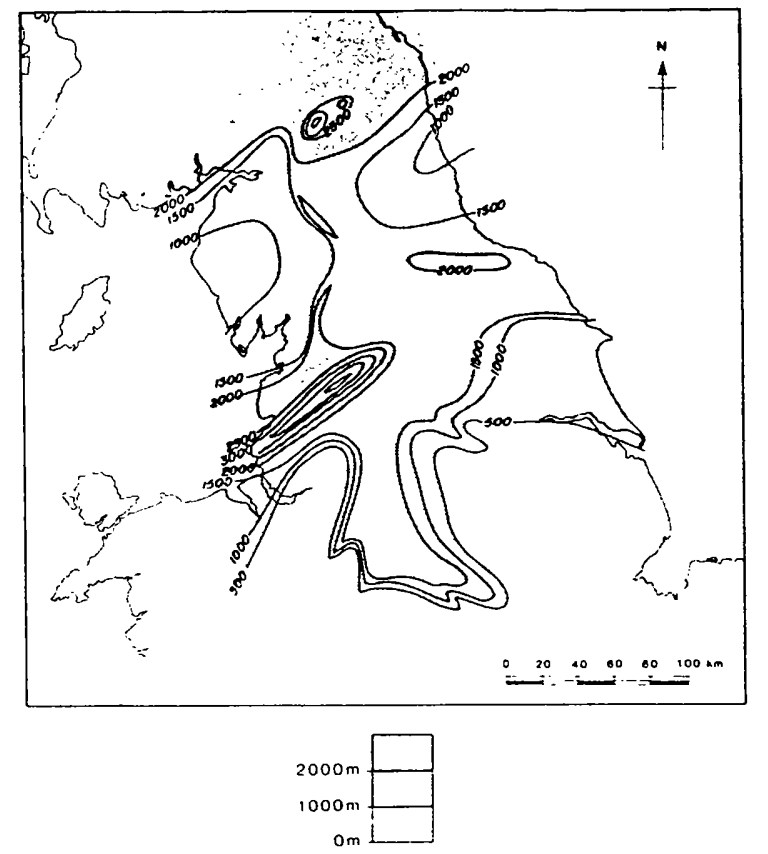

Fig. 13. Estimated Variscan uplift and cresion.
Last Midlands was only mildly inverted with the inversion anticlines often occurring at intersections with NNW-SSE basement lineaments (c.g. Eakring, Hardstoft).

\section{Permo-Trias events}

By late Permian times a new tectonic regime had become established over Northwest Europe, with widespreald regional subsidence in the area of the North Sea where the east-west trending Southern Permian Basin formed (Ziegler 1978). To the west, incipient rifts, once again reactivating the $\mathrm{NE}-\mathrm{SW}$ Caledonian trends, formed the Rockall. Celtic Sea and Western Approaches rift systems (Ziegler $1981)$.

Northern England straddled these two provinces with the subsequent evolution of the hydrocarbon environment in each province profoundly controlled by this differentiation. Whereas the basins to the west were repeatedly extended and tectonically reactivated, the East Midlands and Northeast England provinces were located on a gently dipping rift shoulder with little differential subsidence or thickness variation (Fig. 14).

\section{Later Mesozoic Events}

An accurate reconstruction of the Jurassic and Cretaceous history of Northern England is hampered by the widespread erosion of Mesozoic sediments in Cenozoic times.

Fission track analysis (Green 1986) vitrinite reflectance, shale velocity plots and conodont colour data have all been used in an attempt to deduce the likely post-Triassic overburden. Thick Jurassic and Cretaceous sediments have been penetrated offshore in the Southern North Sea Basin. These thin markedly towards the Pennine High which remained a positive feature for much of the remainder of geological time (Fig. 15). In Northwest England, continued subsidence can be inferred from the rift histories derived from the offshore extensions of the basins. However, the profound event, in terms of the hydrocarbon habitat, occurred on the eastern side of the Pennine High where extension and inversion events related to the evolving Sole Pit Trough (Kent 1975; Glennie \& Boegner 1981; Van Hoorn 1987), - disrupted the passive subsidence and quiescent setting of the Northeast England province (Fig. 14). This rifting of early Jurassic and early Cretaceous age locally induced exceptional burial and was followed by successive phases of basin inversion in the Cleveland and Stainmore Basins during 
Early Cretaceous
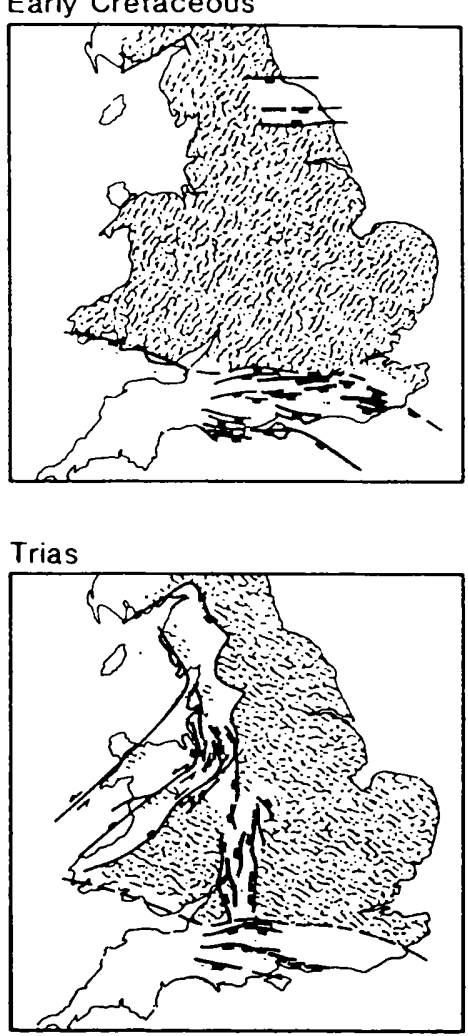

Lias

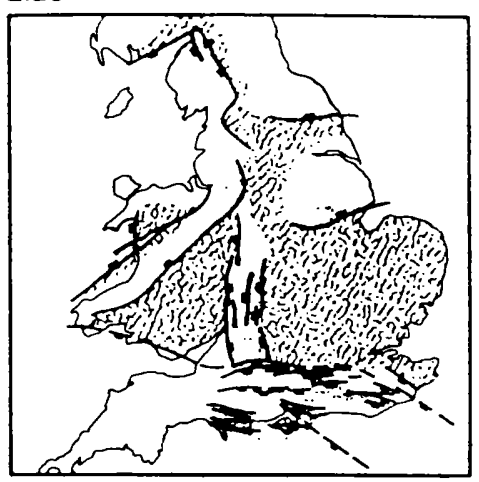

Permian

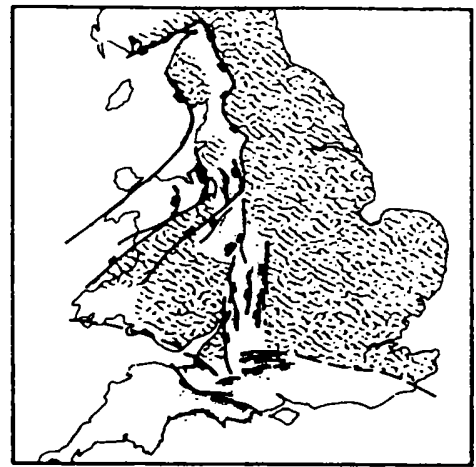

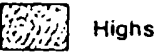

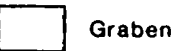

Fig. 14. Permian-early Cretaccous rift systems.
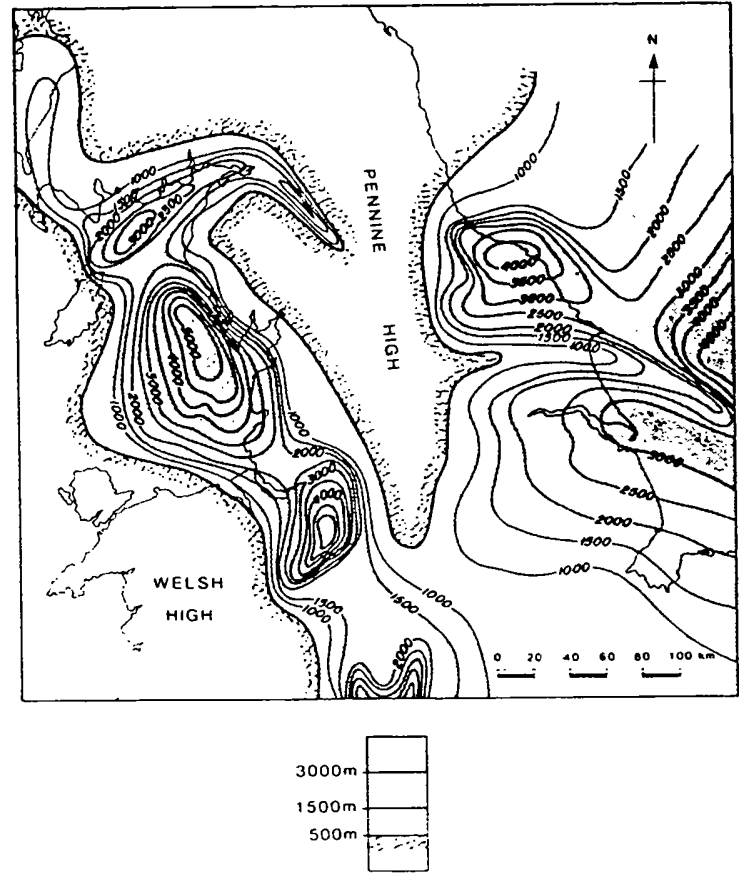

Fig. 15. Restored post-Carboniferous isopachs. the Cretaceous-Tertiary. In stark contrast, the East Midlands province escaped these movements except for minor activity on the southern bounding faults of the Widmerpool Gulf (Kent 1966).

\section{Cenozoic Events}

Recent fission track analyses in Northern England (Green 1986) show that regional uplift began around $60 \mathrm{Ma}$ with up to $3 \mathrm{~km}$ of overburden removed during the Palaeogene in the Lake District area. There is virtually no stratigraphic record of the Neogene onshore except for isolated fissure and pocket deposits (Walsh et al. 1972). Elsewhere evidence exists for weathered zones of this age. Walsh et al. (1972) correlate the base Neogene weathering zone and sediment surface with an important highlevel erosion platform in the Pennines described by Sissons (1954). This occurs at $550 \mathrm{~m}$ above sea level and represents a bench which truncates the geological dip.

Figure 16 is a contour map of proposed Neogene and Quaternary uplift. This is based on the assumption that the base Neogene sediments in the Southern North Sea basin can be 


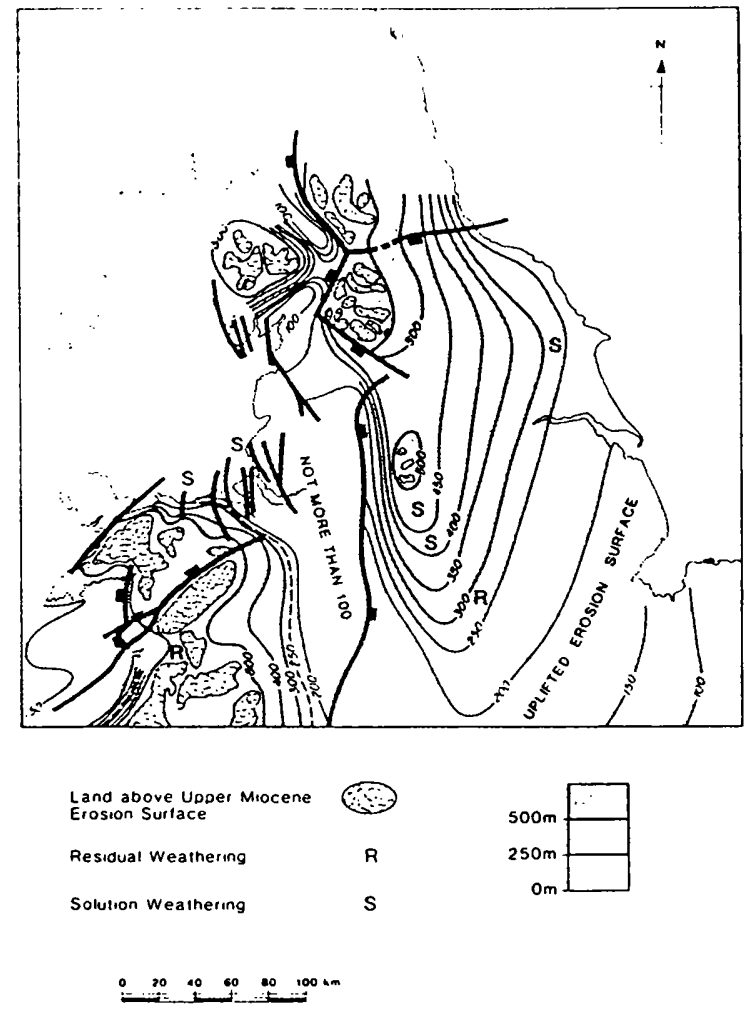

Fig. 16. Neogene and Quaternary uplift of Northern England. correlated with the base Neogenc sediment surface and high level Miocene erosion surfaces observed in Northern England.

A southeasterly tilt of eastern England during Cenozoic times of between 1 and $2^{\circ}$ is recorded which has implications for hydrocarbon retention and aquifer characteristics in the region.

\section{Controls on the hydrocarbon environment}

Figure 17 shows a conceptual model of the potential intra-Carboniferous targets in Northern England. All have been recognized by BP but only the clastic delta play has been extensively explored. The remaining two major plays, the syn-rift clastics and the carbonate shelf margins will therefore only be discussed briefly.

The importance of the preceding events on the evolution of the hydrocarbon environment of intra-Carboniferous plays will be discussed in the following section. In order to make an assessment of the play system the key factors controlling the occurrence and distribution of hydrocarbons will be examined. These factors are discussed under three headings which address reservoiring, retaining and charging.

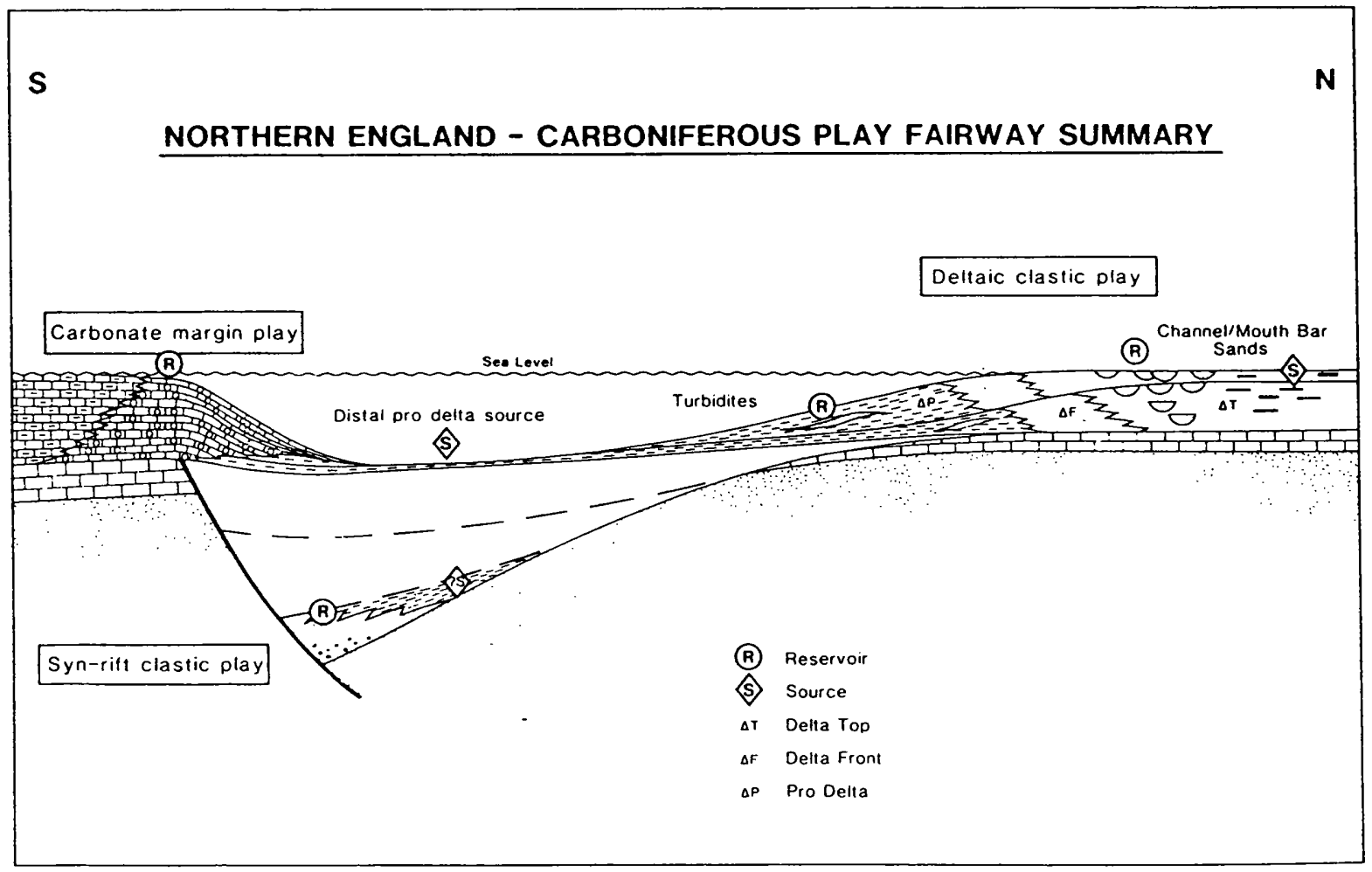

Fig. 17. Intra-Carboniferous play lairway summary. 


\section{Reservoiring}

Distribution of potential reservoir units. The conceptual location of primary reservoir facies is shown in Fig. 17. For the deltaic clastic play these include turbidite sands in the pro-delta basinal setting, but of major importance are delta-top mouthbar and channel sands. The distribution of the latter in the Carboniferous is extensive both laterally and vertically. As palaeofacies maps show, potential reservoir sands occur in the shallow water Dinantian delta systems in the Iapetus province in the north of the area and in the deeper water Silesian deltas deposited in the Central England rifts. The trunk channels forming the distributary network are commonly medium to coarse grained with a moderate feldspar content. Sands in the LC2 sequence are similarly feldspathic but generally fine to medium grained. Quartzrich sands, probably sourced from the WalesBrabant Massif to the south, are also observed in parts of the East Midlands following the mid Brigantian inversion.

The most prospective reservoir facies for the carbonate margin play are the rimmed shelf complexes comprising grainstone shoals, buildups and boulder beds. Peritidal and shallow shelf limestones lying landwards of the margin commonly exhibit a mudstone-wackestone kexture with low primary porosity which only produce hydrocarbons when fractured in tight Variscan anticlines (c.g.. the Eakring and Hardstoft oilficlds). High-energy environments near wavehase may enable the development of grainstone shoals behind the shelf margin towards palaeo-shorelines, but these are very difficult to predict in the subsurface. As a general rule the carbonate reservoirs are restricted to the Chadian, Asbian and early-mid Brigantian (sequences EC2, EC4 and EC6) when rimmed shelves were able to develop in periods of reduced tectonic activity. These facies are areally restricted to basins within the Central England rift system (Fig. 10).

Burial Effects (deltaic clastics). Burial diagenesis is the key post-depositional process controlling poroperm development in the deltaic clastic reservoirs. The major features are a progressive quartz-clay diagenesis that occludes primary porosity and the leaching of feldspars to create secondary porosity. The destruction of primary porosity is the more important in restricting permeability and is the principal limiting factor on reservoir quality.

Figure 18 shows a crossplot of maximum burial depth against core porosities for Namurian channel sands based on over $1.5 \mathrm{~km}$ of core data from a number of East Midlands wells. Relationships between $\log$ and core porosities,

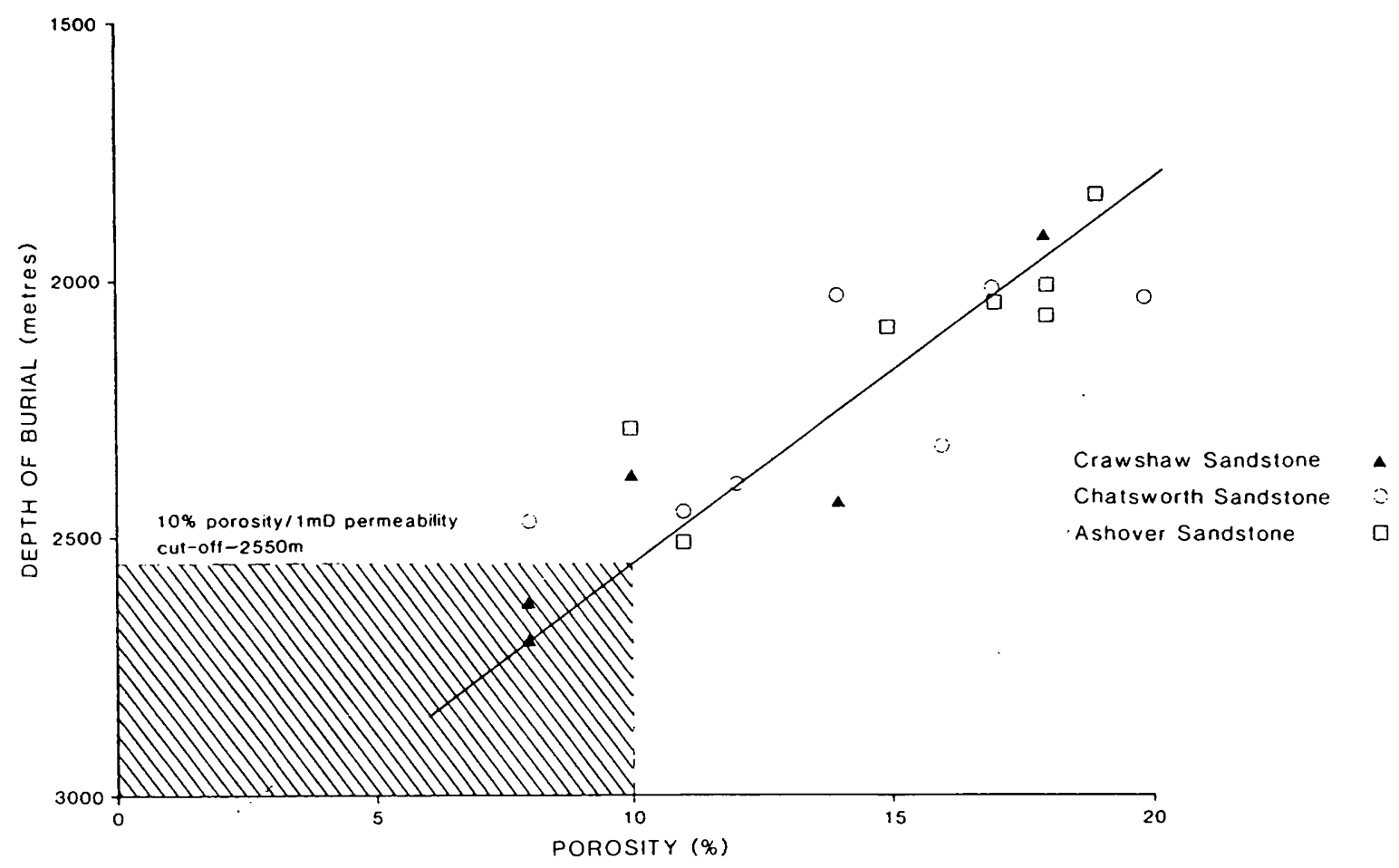

Fig. 18. Porosity against depth plot for Namurian-carly. W'estphalian channel sandstonc facies from wells in the East Midlands. 
and between porosities and permeabilitics permit the prediction of porosity in different sandstone types to within $\mathrm{I}$ or 2 porosity units. For channel sandstones the porosity cut-off for commercially' viable reservoirs $(10 \%=c .1 \mathrm{mD})$ corresponds to a maximum depth of burial of $2550 \mathrm{~m} \pm 200 \mathrm{~m}$.

\section{Retaining}

Retaining includes two aspects of the hydrocarbon environment: seal capacity/extent and trap occurrence/integrity.

Seal Capacity and Extent. This aspect of the hydrocarbon system in Northern England is important. particularly for gas, but extremely difficult to define. The two most common reservoir-seal pairs in the Carboniferous delta environment are delta-top sands sealed by marine bands or interdistributary muds and turbidites encased in pro-delta shales. The marine bands of the East Midlands are highly effective regionally distributed seals with negligible sand/silt contents as reflected by their overall gamma-ray log response. The bands are rarely in excess of $1-2 \mathrm{~m}$ thick in the East Midlands, but where unfaulted can support oil columns of $40-50 \mathrm{~m}$. Whereas the marine bands are thin but extensive (Calver 1968), the interdistributary shales may locally be relatively thick $(10-15 \mathrm{~m}$ in the East Midlands fields). However, the latter are likely to be less effective due to their limited extent and relatively high silt content. The sealing mechanism developed by an interdistributary shale may be quite complex and not involve a single stratigraphic layer but an interdigitating network of shales.

Seal capacity for gas has been measured confidently on only one structure - Calow, a dipclosed, inversion anticline in the East Midlands (Fig. 19). Gas columns of $30-40 \mathrm{~m}$ are sealed at two separate reservoir levels by delta top shale and argillaceous sandstone where structural closure is in excess of $100 \mathrm{~m}$.

With source rock generation frozen in the early Tertiary following regional uplift, seals are required to have remained effective for up to $60 \mathrm{Ma}$. As a result significant gas accumulations can only survive in Northern England where overlying evaportic seals are present in the Permo-Triassic.

Trap occurrence and integrity. Trap occurrence is not thought to be a limiting factor on the hydrocarbon environment of Northern England. The Variscan orogeny was pervasive and created an extensive array of variably faulted, inversion anticlines of which the Eakring Field is a typical example (Fig. 7). The amplitude and wavelength of the structures wals determined by the relative orientations of the controlling faults to the northwesterly directed compression. Only in Northwest England is the presence of Variscan closures difficult to $\mathrm{dem}-$ onstrate. Here post-trap faulting, associatcd particularly with Permo-Triassic rifting, has
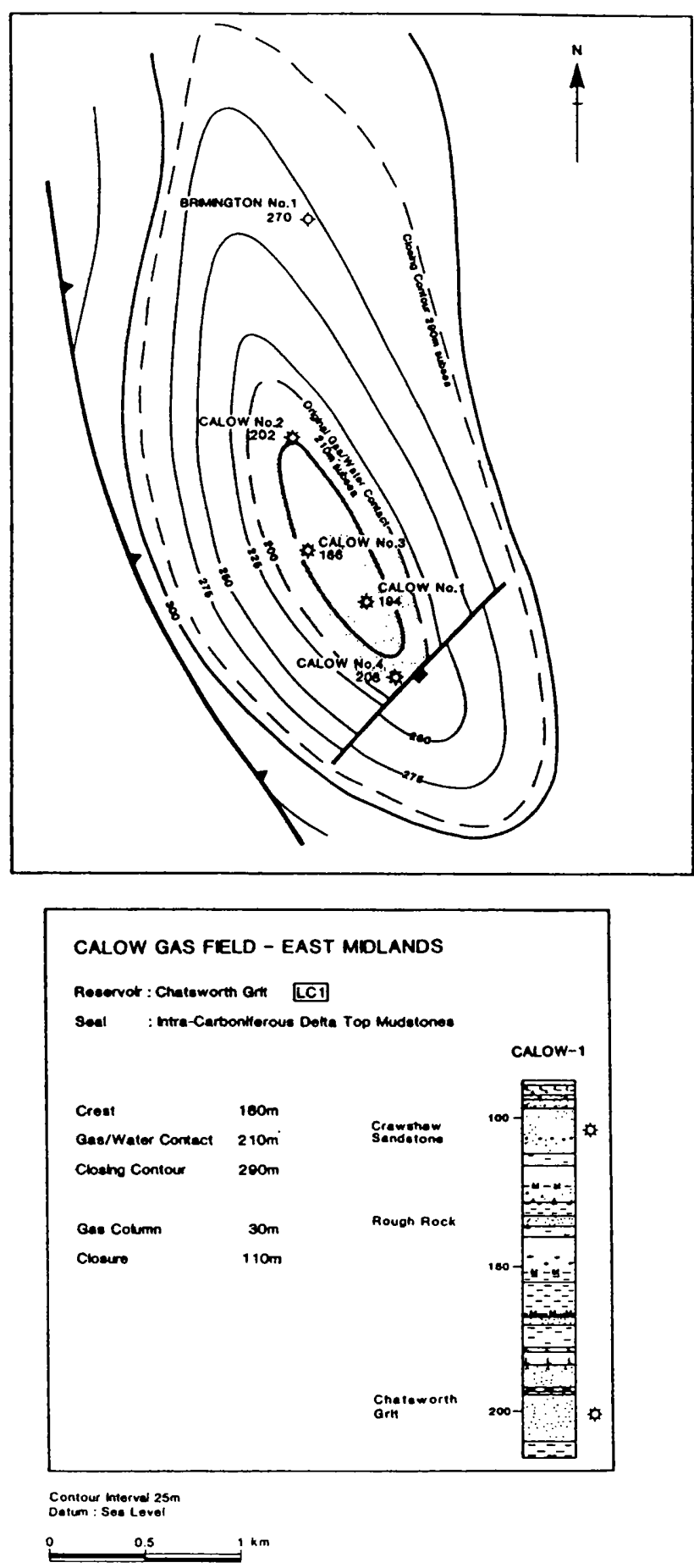

Fig. 19. Calow gas ficld - depth to Chatsworth Grit reservoir. 


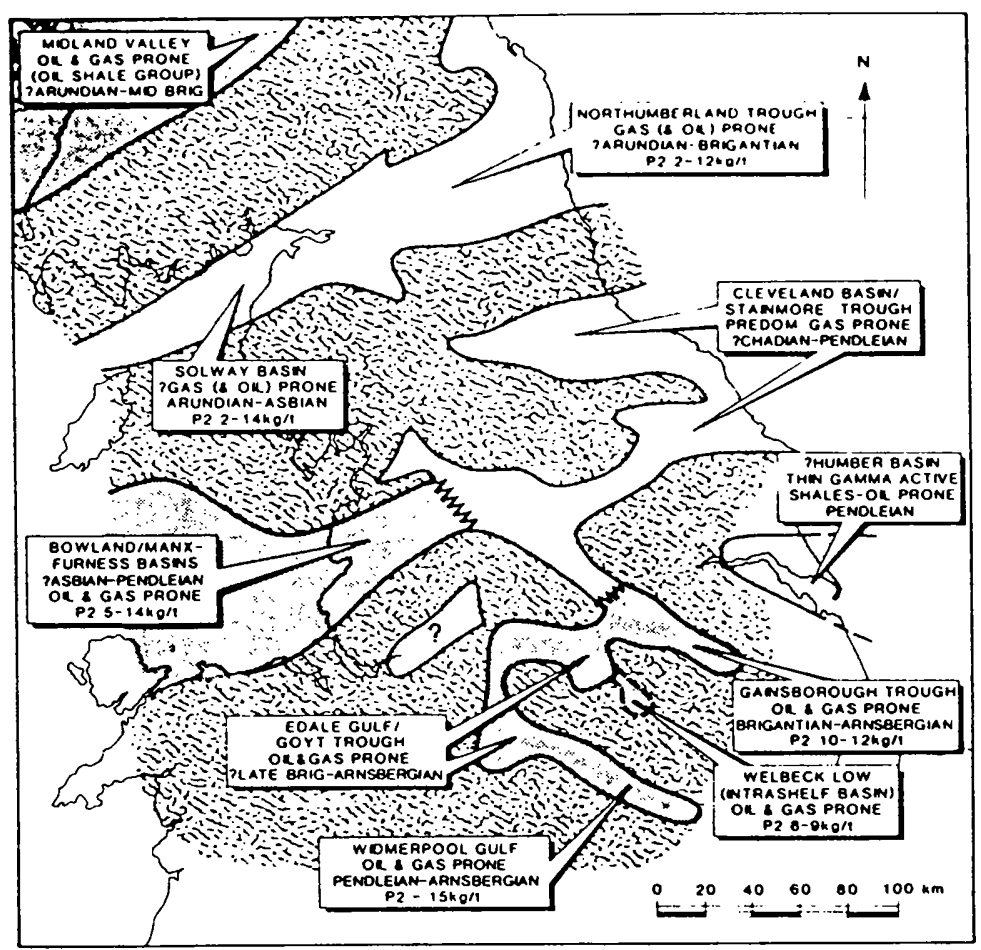

LEGEND
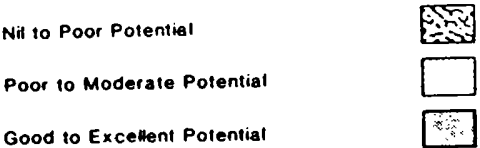

Poor to Moderale Potential

Good to Excellent Potential

Fig. 20. Summary of Dinantian and Namurian (principally pro-delta) source rock distribution and potential.

fragmented and severely modified earlier Variscan structures. In sharp contrast, traps in the East Midlands province are almost entirely Variscan in origin with only Tertiary tilting significantly disturbing accumulations. The latter is reflected throughout the East Midlands by the prominence of transition zones and residual oil columns, which if reconstructed within a pre-Tertiary structural setting may be found to correspond to structural spill point. The Cleveland Basin (Northeast England Province) was subject to a more profound phase of late Cretaceous-Tertiary trap tilting and inversion which has considerably modified earlier Variscan structures.

\section{Charging}

Charging addresses the critical questions of source rock distribution, oil quality and maturity /migration timing.

Source rock distribution. In gencral terms the source rocks in Northern England young south- wards in step with the southward progradation of the clastic delta systems throughout the Carboniferous (Figs $10 \& 2()$ ). The best quality oil prone source rocks were deposited in the Central England rift basins in the south of the study area. These source rocks are associated with the distal pro-delta of relatively deep water $(200-300 \mathrm{~m})$ delta systems and correspond to the Bowland, Edale and Sabden shales. Thesc exhibit gross thicknesses of around $100 \mathrm{~m}$ with yields of up to $14 \mathrm{~kg}$ tonne ${ }^{-1}$. Shallower water deltas $(50-150 \mathrm{~m})$ which were established in basins such as Northumberland, Solway and Stainmore during the early Carboniferous are characterized by thinner, poorer quality source rock intervals (Figure 20).

Oil-source rock correlations in the East Midlands confirm the pro-delta mudstones as the main source intervals for oils discovered in the province (Fig. 21). However, alternative source facies have been identified, notably in delta top environments, where marine bands, coals and interdistributary mudstones can form 


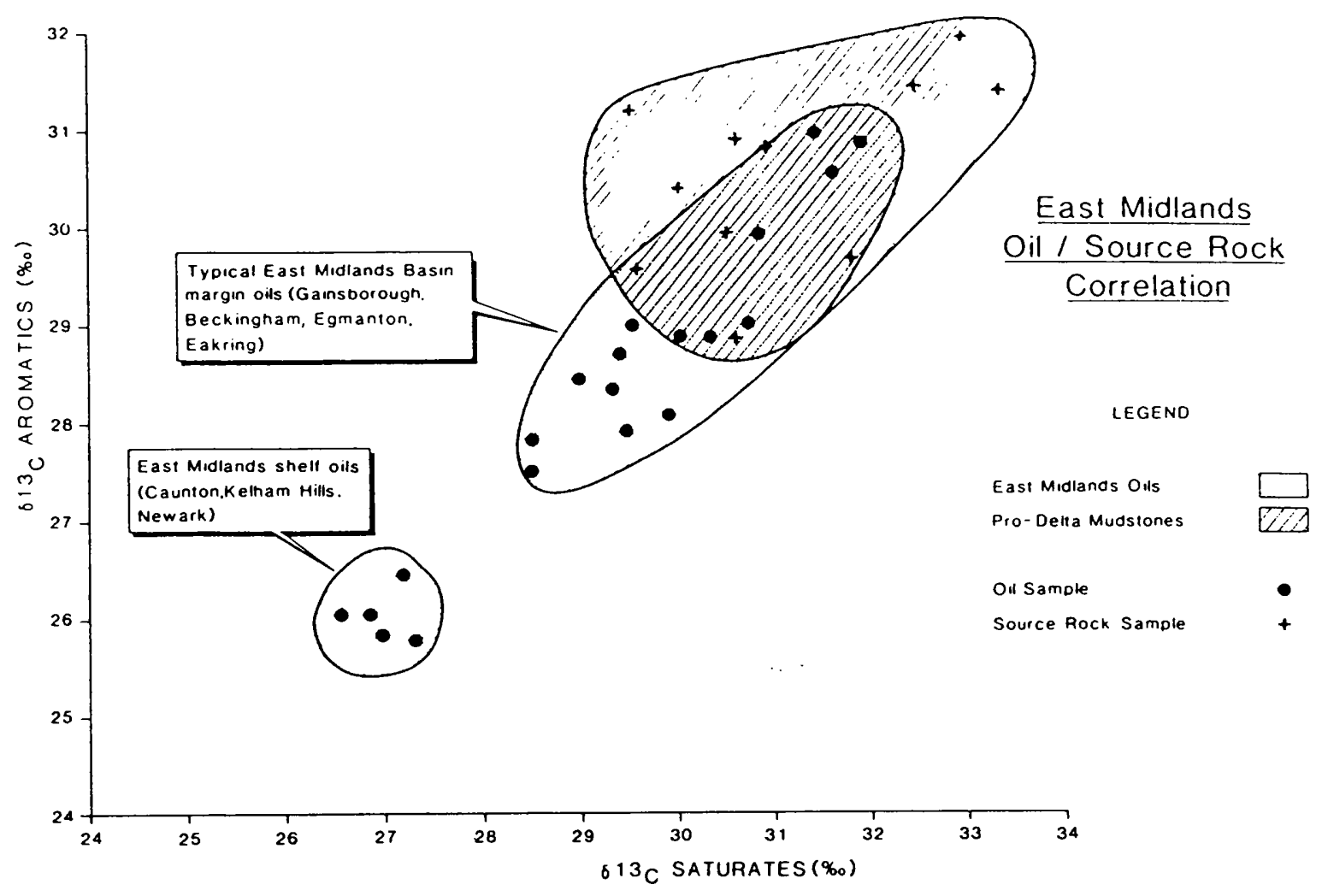

Fig. 21. East Midlands oil/source rock correlation.

local sourcing mechanisms (e.g., Caunton \& Kelham Hills Fields, Fig. 21). None of these are regarded as having significantly contributed to the hydrocarbon budget in the East Midlands; however, all are areally extensive and in the case of the marine bands, locally give high yields $(7-10 \mathrm{~kg} /$ tonne is not unusual). Coals are ubiquitous and rich but wholly gas prone and requiring significant burial.

The optimal development of the prodelta source rock probably occurs in the Gainsborough Trough of the East Midlands where two basin-confined horizons occur with a third, thinner unit extending beyond the basin margins. The lowermost unit is Pendleian in age and comprises a black, pyritous organic rich shale. These 'gamma active' shales have average TOC contents of $3-4 \%$ and hydrocarbon yields of over $15 \mathrm{~kg} /$ tonne $^{-1}$. Gross thickness varies in this lower unit from 80 to $200 \mathrm{~m}$. The middle source unit is Arnsbergian in age and is strictly confined to the Gainsborough, Widmerpool and Welbeck basins (Fig. 20). (The Welbeck basin is unique as a source kitchen in the East Midlands, being initiated as an intrashelf basin following the mid-Brigantian inversion and subsequent thermal subsidence). The main difference when compared with the !ower unit is an increased coarse clastic component which reduces the source potential to $5-10 \mathrm{~kg} /$ tonne $^{-1}$. The upper source unit occurs towards the top of the Arnsbergian and continues into the earliest Marsdenian. It extends onto the East Midlands shelf and includes several major reservoir units. Source quality is considerably poorer than the basin-bound units but it forms the basis of a local source mechanism in the platform areas. Net thicknesses are $5-15 \mathrm{~m}$ with original yields estimated at $5-7 \mathrm{~kg} /$ tonne $^{-1}$.

Oil Characteristics. The characteristics of the different oils and source rocks are illustrated on saturates against aromatic residue plots for some 20 sample points in the East Midlands (Fig. 20). The oils can be grouped into two main types based on their carbon isotope values. Typical East Midlands crudes reservoired on the margins of the major basinal areas form the largest group. These oils are principally sourced from the distal pro-delta 'gamma-active' shales. An isotopically heavier suite of oils occurring more distally from the basinal areas (Kelham and Caunton fields) reflect increased contributions from marine bands and the interdistributary mudstones. Oil quality is not regarded as a critical factor, except for the occasional occurrence of sour crudes (Welton) and wax contents 


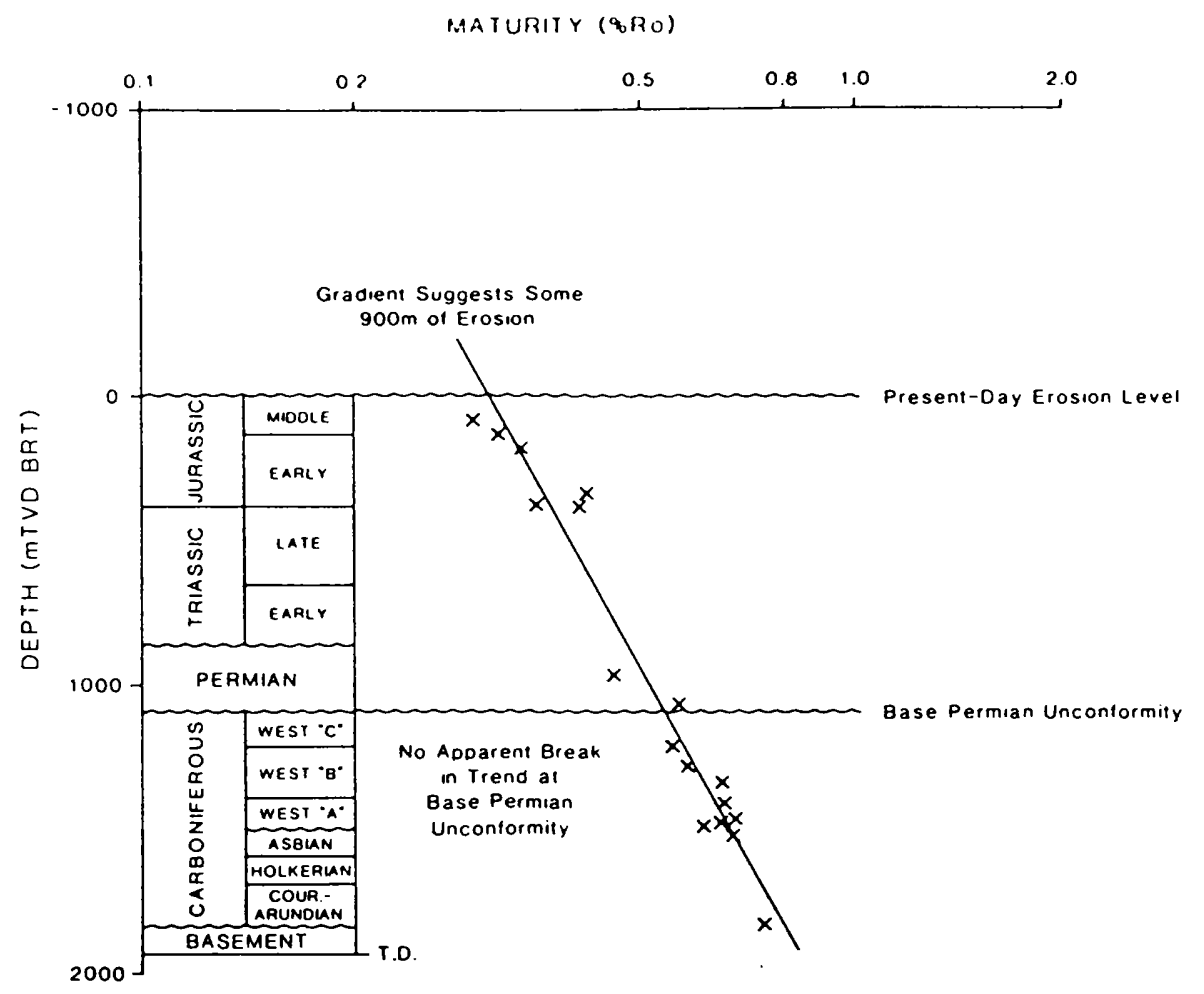

Fig. 22. Maturity against depth profile for the well Bardncy-1 in the East Midlands bascd on vitrinite reflectance data.

which tend to be high $(10-20 \%)$ due to the contribution from cuticular wax from land plants.

Maturity thresholds. Some 40 key wells with maturity data (i.e. vitrinite and spore colour) from the Central England rift basins have been analysed and compared to interpret maturity thresholds in late Dinantian-Silesian source rock types. Insufficient data exist for the late Devonian-Dinantian sequences in this area to draw any firm conclusions. Over most of the East Midlands maturity/depth trends based on vitrinite reflectance show little variation in gradient between the pre and post Variscan section suggesting that post-Carboniferous burial has overprinted any signature of endCarboniferous erosion. (Fig. 22).

Approximate figures used for the top and base of the oil window are $1900 \mathrm{~m}$ and $3600 \mathrm{~m}$ with a maximum at around $2700 \mathrm{~m}+1-200 \mathrm{~m}$. The gas generation maximum is assessed at around $3450 \mathrm{~m}+/-200 \mathrm{~m}$.

\section{Summary of critical factors}

Of the critical factors which can be quantified and are amenable to mapping, the most important for the assessment of the intra-
Carboniferous play of Northern England are:

(i) critical burial depth for preservation of reservoir quality (maximum $2550 \mathrm{~m}$ ).

(ii) critical burial depth for the oil window (1900-3600m).

(iii) distribution of good quality basinal prodelta source rocks

(iv) degree of post-Variscan, trap modification. Application of these to the principal intraCarboniferous play (deltaic clastic) allows the potential importance of the various Northern England basins to be assessed and the 'uniqueness' of the East Midlands examined.

\section{Evolution and assessment of the intra- Carboniferous play in Northern England}

\section{Evolution (Deltaic Clastics)}

Post-rift Carboniferous Events. Two key events critically affect the potential of the intraCarboniferous play at this time.

(i) Restricted distribution of basinal shales. The data from the East Midlands demonstrate the volumetric importance of the lower Namurian shales as source rocks and hence the necessity to have available the distal pro-delta shales within an effec- 

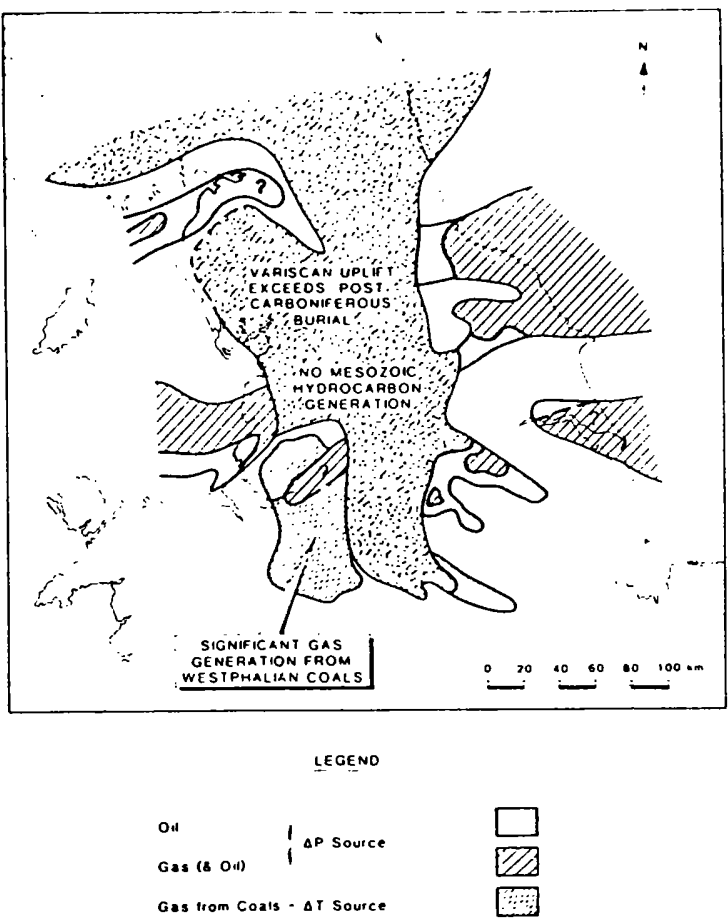

Fig. 23. Summary of Latc Mcsozoic hydrocarbon gencration (post-Variscan trap formation).
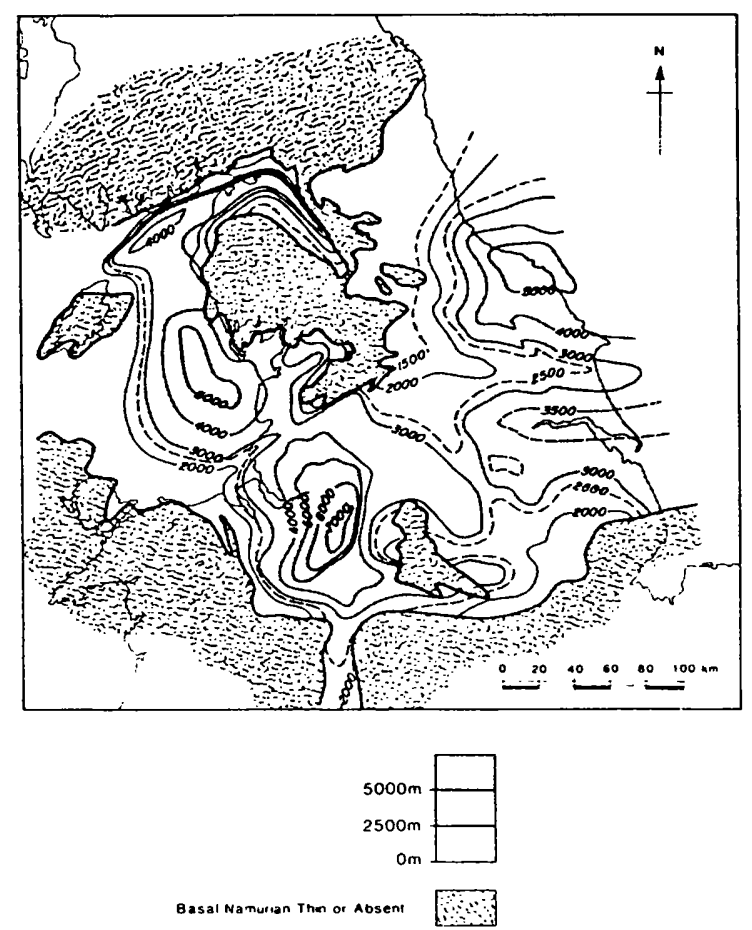

Fig. 24. Estimated maximum palaco burial depths for the basal Namurian rescrvoir and source intervals. dice kitchen. This generolly limus the plas fairway to within a few kilometres of the carly Carboniferous depocenters. In the bast Midlands the maximum horizomal migrattion distance from this source is $12 \mathrm{~km}$ : the average is $5 \mathrm{~km}$. As discussed previously source rock quality in the pro-deltat varies across Northern England with the Contral England rifts displaying the greater potential.

(ii) Location of the Silesian depocentre. As Fig. 12 shows, the basinal shales located in the Northwest England province were prohably mature and producing hydrocarbons cluring the late Carboniferous thereby reducing oil potential in this arca prior to Variscan trap formation. Basal Namurian reservoir quality would also have been adverscly affected.

End Carboniferous Variscan inversion. The Variscan inversion has been identified as the dominant trap-forming event in Northern England. The uplift associated with the Variscan unfortunately also led to the freezing of oil generation from source rocks throughout the province. The hydrocarbon system was essentially reset at this time necessitating a second, Mesozoic, phase of burial and source rock generation post dating the formation of Variscan traps. Areas where significant postCarboniferous hydrocarbon generation occurred are highlighted in Fig. 23.

Figure 24 shows the areas where the main deltaic clastic target was removed by end Carboniferous erosion related to Variscan uplift and erosion. This includes the Derbyshire Dome, parts of the Bowland Basin and extends along the Dent-Pennine line into the Northumberland Trough where the removal of the deltaic clastic sequence is only partial.

Permo-Triassic Extension. The distinct burial and tectonic evolution in Permo-Triassic times substantially downgraded the hydrocarbon potential of basins on the western side of the Pennine High. The critical effects on the intraCarboniferous play are:

(i) In the major Permo-Triassic depocentres (Cheshire Basin and parts of ManxFurness) burial cut-offs for both reservoir quality and oil generation were exceeded (Fig. 24).

(ii) Pervasive and repeated rifting throughout the period fragmented earlier traps and reactivated trap bounding faults. Examples of trap modifications at this time occur in the Formby-Fylde area (onshore ManxFurness) and in parts of the Cheshire Basin (Fig. 14). 
(iats gencration commenced in the major depocentres towards the end of the Triassic, hut repeated faulting of marine band seals and trap modification make prospects in basins lying in the Northwest England Province unsuitable for gas retention. With continued gas generation, flushing of oil accumulations becomes an additional risk.

In contrast, basins lying east of the Pennine High, in both geological provinces, underwent gradual burial at this time with renewed oil generation in the basinal areas and little trap modification.

Jurassic-Cretaceous Subsidence and Local Inversion. The later Mesozoic history of the Northwest England province is highly conjectural but it has been shown from fission track analysis that some $1-1.5 \mathrm{~km}$ of Jurassic and Cretaceous sediments were deposited. This continued burial left only minor onshore areas in the south of the Formby-Fylde below the oil maximum for base Namurian shales. Gas generation from Upper Carboniferous coals, where preserved following Variscan uplift and erosion, was widespread, particularly in the Cheshire Basin (Fig. 23).

Prior to early Jurassic times the hydrocarbon environments of the intra-Carboniferous basins lying in the Northeast England and East Midland provinces had been subject to a remarkably similar burial and thermal history. Both provinces had been strongly structured in late Variscan times, forming an array of anticlinal and fault-related traps and had been subject to gentle regional subsidence during the Permo-Triassic. The contrast between basins of the Northeast and East Midlands provinces commenced in early Jurassic times and continued into the Tertiary as the Cleveland and Stainmore basins became involved in rifting and inversion related to the Sole Pit fault system (Fig. 14). This had essentially two effects:

(i) Widespread disruption of traps due to localized fault movements and successive phases of basin inversion in the late Cretaceous-Tertiary.

(ii) Localized deep burial, principally as a product of early Cretaceous rifting in northern Cleveland. This event pushed most of the basin into gas generating zone (Fig. 23) with consequent flushing of liquid hydrocarbons updip towards the south.

Cenozoic Uplift and Erosion. From the end of late Cretaceous chalk deposition onwards, the Northern England basins experienced strong uplift and erosion with a consequent freezing of hydrocarbon generation. A regional heating event which has elevated present day geothermal gradients in Northern England (Wheildon \& Rollin 1986) may have been associated with Tertiary volcanism. However, these elevated heat flows are unlikely to have significantly retriggered generation from source rocks, which in most areas were already in an advanced stage of maturity. Regional estimates of uplift and erosion range from 110()$-3(1)(0) \mathrm{m}$ in the Northwest England province to $10(0)-20(0) \mathrm{m}$ in the East Midlands. The effects of uplift and tilting on existing accumulations is well demonstrated in many of the East Midlands fields, where palaco-oil columns can be related back to pre-tilt closures. Surface and shallow seeps still give a fair indication of the pre-tilt distribution of subsurface accumulations.

\section{Play assessment}

An assessment of the deltaic clastics play in the Northern England basins is illustrated on Fig. 25. From the point of view of the evolution of the hydrocarbon system described above, it is clear that the geological history of the East Midlands province is somewhat unique. The area works as a successful oil environment because of the following.

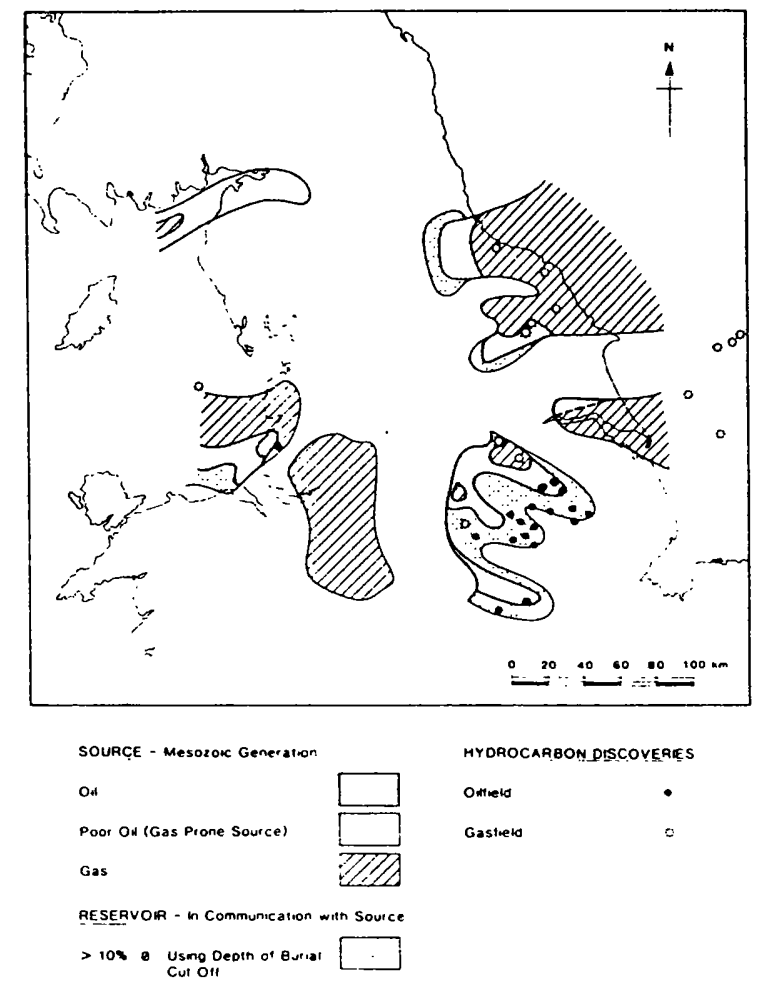

Fig. 25. Clastic delta play assessment. 
(i) It includes several isolated carls (itrboniferous rift basins comtaining thick hasal Namurian source rocks which are encountered at several levels providing source 'back-up'.

(ii) Except in areas to the west of the province, maturation occurred in Mesozoic times after Variscan trap formation.

(iii) There is an abundance of reservoir-seal pairs providing reservoir-scal 'back-up' with burial depths over most of the area above the critical threshold for commercial oil production.

(iv) The area was tectonically quiescent following Variscan trap formation with passive burial accompanicd by a mild easterly tilting.

The burial data provided here suggests that the East Midlands (in a fairly restricted fairway surrounding the basinal areas) is the only oil province likely to be developed in the intraCarboniferous of Northern England. In contrast the intra-Carboniferous gas play is likely to be more extensive, particularly in Northeast England. However, gas potential may be hampered by poor reservoir quality and, particularly in the Northwest England province, by contemporaneous trap reactivation and the increased need for an effective sealing facies.
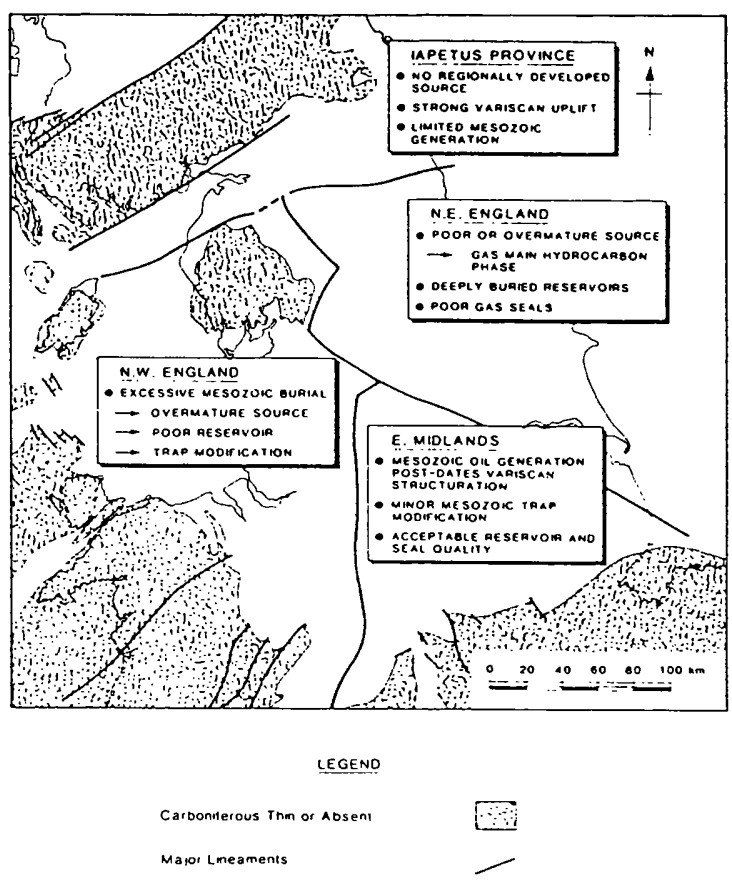

Fig. 26. Intra-Carbonifcrous play summary.

\section{Conclusions}

This paper began with a question concerning the uniqueness of the East Midlands in terms of the intra-Carboniferous plays of Northern England. It would seem that even with a small data set of fully tested targets there exists sufficient cvidence from the reconstructed hydrocarbon environment to suggest that the East Midlands is geologically a very unique setting and most probably the only Northern England province where commercial oil accumulations will be found (Fig. 26).

Permission to publish this paper has been granted by the British Petrolcum Company ple. We are also gratcful to partners. Gas Council (Exploration) and Floyd Oil for permission to publish scismic data from the East Midlands. The authors wish to thank the many BP Eakring gcologists and gcophysicists who have becn involved in this work. In particular we would like to mention Dr A. Kaj, Dr J. Hossack, B. Mitchener, Dr A. Strank. C. Einchcomb and N. Taylor who made important contributions to the study.

\section{References}

Anderton, R., Bridges, P. H., Leeder. M. R. \& SellwoOd, B. W. 1979. A dynamic stratigraphy of the British Isles. A study in crustal evolution. Allen \& Unwin.

Andre, L., Hertogen, J. \& Deutsch, S. 1986. Ordovician-Silurian magmatic provinces in Belgium and the Calcdonian orogeny in Middle Europe. Geology, 14. 879-882.

Arthurton, R. S. 1986. The Ribblesdale fold belt, NW England - a Dinantian-Early Namurian dextral shcar zone. In: Hutron, D. H. W. \& Sanderson, D. J. (cds). Variscan Tectonics of the North Atlantic Region. Geological Socicty, London, Spccial Publication 14, 131-138.

ВАрнлм, J. P. N. \& HAlls, C. 1975. Microplate tectonics, oblique collisions. and the cvolution of the Hercy'nian orogenic sy'stem. Geology, 3 , $373-376$.

Benmish, D. \& Smythe. D. K. 1986. Gcophysical images of the decp crust: the Iapctus suturc. Journal of the Geological Societv, 143. 489-497.

BESLY. B. M. 1988a. Late Carboniferous sedimentation in northwest Europe: an introduction. Im: BesLy, B. M. \& KeLLING. G. (eds). Sedimentation in a synorogenic basin complex: The Carboniferous of north west Europe. Blackic. Glasgow, $1-7$.

1988b. Palacogcographic implications of latc Westphalian to carly Permian red beds. Central England. In: Best.y. B. M. \& Krlling. G. (cds). Sedimentation in a synorogenic basin complex: The Carboniferous of north west Europe. Blackic. Glasgow, 2()()-221

Borr. M. H. P. 1966. Geophysical investigations 
of the Northern Penuine basement rocks. Proceedings of the Yorkshire Geological Society, 36, $139-168$

- 1987. Subsidence mechanisms of Carboniferous basins in Northern England. In: Miller, J., Adnмs, A. E. \& Wright, V. P. (eds). European Dinantian Environments. John Wilcy, Chichester, $21-32$.

Chlver, M. A. 1968. The distribution of the Westphalian marinc faunas in northern England and adjoining arcas. Proceedings of the Yorkshire Geological Society. 37, 1-72.

Cowikd, M. P. \& Siddans, A. W. B. 1979. The tectonic cvolution of the Welsh Calcdonides. In: HARRIS, A. L.. HOlland, C. H. \& LeAKe, B. E. (cds). Caledonides of the British Isles - reviewed. Gcological Socicty, London. Spccial Publication 8. $187-198$.

Dewey. J. F. 1971. A model for the Lower Palacozoic cvolution of the southern margin of the carly Calcdonides of Scotland and Ircland. Scortish Journal of Geology, 7, 219-240.

- 1982. Plate tectonics and the cvolution of the British Islcs. Journal of the Geological Society of London, 139, 371-412.

Evans, A. M. 1979. The East Midlands Aulacogen of Caledonian age. Mercian Geologist, 7, 31-42.

FAlCon, N. L. \& KENT, P. E. 1960. Geological results of petroleum exploration in Britain 1945-1957. Gcological Society, London, Memoir 2.

GNiTHORPE, R. L. 1987. Tectono-sedimentary evolution of the Bowland Basin northern England, during the Dinantian. Journal of the Geological Society, 144, 59-71.

George, T. N., Johnson, G. A. L., Mitchell, M.. Prentice, J. E. Ramsbottom, W. H. C., Sevastopulo, G. D. \& Wilson, R. B. 1976. A correlation of Dinantian rocks in the British Isles. Geological Society. London. Special Report, 7.

Glennie, K. W. \& Boegner, P. L. F. 1981. Sole Pit Inversion tectonics. In: IlliNG, L. V. \& HoBSON, G. D. (cds). Petroleum geology of the continental shelf of North-West Europe. Institute of Petrolcum, London 110-120.

GrAYSON, R. F. \& OldHAM, L. 1987. A ncw structural framework for the northern British Dinantian as a basis for oil, gas and mincral cxploration. In: Miller, J., Adims, A. E. \& Wright, V. P. (cds). European Dinantian Environments. John Wilcy, Chichester. 33-59.

Green, P. F. 1986. On the thermo-tectonic evolution of Northern England: Evidence from fission track analysis. Geological Magazine. 123. 493-506.

Gulon, P. D. Fielding. C. R. 1988. Westphalian A and $B$ scdimcntation in the Pcnninc basin, UK. In: Besly, B. M. \& Kreling. G. (cods). Sedimentation in a svnorogenic hasin complex: The Carboniferous of north west Europe. Blackic. Glasgow. 153-177.

Gutreridge. P. 1987. Dinantian sedimentation and basement structure of the Derbyshire Dome. Geological Journal. 22, 25-41.

Haszeidine, R. S. 1984. Carbonifcrous North Atlantic palacogeography: stratigraphic evidence for rifting, not megashcar or subduction. (ieological Magasinc, 121, 44.3-46.3.

- 1988. Crustal lincaments in the British Isles: their relationship to Carbonifcrous basins. In: BESLY, B. M. \& KELILING, G. (cds). Sedimentation in a synorogenic basin complex: The Carboniferous of north west Europe. Blackic, Glasgow, $53-83$.

Hudson, R. G. S. 1930. The Carboniferous of the Craven Recf Belt: the Namurian unconformity of Scalbcr, near Scttlc. Proceeding of the Geologists' Association. 41, 290-322.

Krint, P. E. 1966. The structure of the concealed Carbonifcrous rocks of NE England. Proceedings of the Yorkshire Geological Sociery, 35, 323-352. 1968. The buricd floor of Eastern England. In: Sylvester-Br.diliy. P. C. \& Ford. T. D. (cds). The Geolog! of the East Midlands. Leicester University Press. 138-148.

- 1975. The tectonic development of Britain and surrounding scas. In: WOODLAND. A. W. (cd.). Petroleum and the continental shelf of North West Europe. Vol. 1 Gcology. Applied Science Publishers. 3-28.

— 1985. UK Onshorc Oil Exploration, 1930-1964. Marine and Perroleum Geology, 2, 56-64.

Klemperer, S. \& M^triews, D. 1987. Iapetus suture located beneath the North Sca by BIRPS deep seismic reflection profiling. Geology, 15, 195-198.

LE BAS, M. J. 1972. Calcdonian igncous rocks bencath central and eastcrn England. Proceedings of the Yorkshire Geological Society, 39, 71-86.

LEE, A. G. 1988. Carboniferous basin configuration of Central England, modclled using gravity. In: Besly, B. M. \& Kelling, G. (eds). Sedimentation in a Synorogenic basin complex: The upper Carboniferous of north west Europe. Blackic, Glasgow, 69-84.

LeEder, M. R. 1976. Scdimentary facics and origins of basin subsidence along the northern margin of the supposed Hercynian ocean. Tectonophysics, 36, $167-179$.

- 1982. Upper Palacozoic basins of the British Isles - Calcdonian inheritance versus Hercynian platc margin processes. Journal of the Geological Society, London, 139, 479-491.

1987. Plate tectonics and sedimentation in Lower Carbonifcrous Europe. In: Ad八MS, A. E., Miller, J. \& Wright, V. P. (cds). European Dinantian Environments. John Wilcy, Chichester, 1-19.

_ \& GAwTHorpe. R. L. 1987. Sedimentary models for cxtcnsional tilt block/half graben basins. In: Coward, M. P.. Dewey, J. F. \& Hancock, P. L. (cds). Continental extensional tectonics. Gcological Socicty. London, Special Publication 28. $139-152$.

\& McMahon. A. H. 1988. Upper Carboniferous (Silcsian) basin subsidence in northern Britain. In: Bresly, B. M. \& Kelling, G. (cds). Sedimentation in a stnorogenic basin complex: The Carboniferous of north west Europe. Blackic, Glasgow, 4.3-52. 
Lies, G. M. \& Cox, P. T. 1937. The geological results of the present scarch for oil in Grat Britain by the D'Arcy Exploration Company Ltd. Quarterly Journal of the Geological Society, 93, $156-194$.

\& TAlT, A. H. 1945. The geological results of the scarch for oilficlds in Great Britain. Quarterly Journal of the Geological Society, 101, 255-317.

MAITE, P. 1986 . Tectonics and plate tectonics model for the Variscan belt of Europc. Tectonophysics, $126,329-374$

Millek, J. \& Grayson, R. F. 1982. The regional contcxt of Waulsortian facics in N. England. In: Bolton, K. LANe, H. R. \& Lemone, D. V. (cds). Symposium on the Environmental Setting and Distribution of the Waulsortian facies. The El Paso Gcological Socicty and University of Texas at El Paso. 17-33.

PARKINSON, D. 1957. Lower Carboniferous recfs of Northern England. Bulletin of the American Association of Perroleum Geologists, 41, 512-537.

Pharoah, T. C.. Merkiman, R. J.. Webb, P. C. \& Beckinsdnle, R. D. 1987. The conccaled Caledonides of eastcrn England: preliminary rcsults of a multidisciplinary study. Proceedings of the Yorkshire Geological Society, 46, 355-369.

Ramsвortom, W. H. C. 1973. Transgressions and regressions in the Dinantian: a new synthesis of British Dinantian stratigraphy. Proceedings of the Yorskhire Geological Society, 39, 567-607.

- Calver, M. A., Eagar, R. M. C., Hodson, E., Holliday, D., Stubblefield, C. J. \& Wilson, R. B. 1978. A correlation of Silesian rocks in the British Isles. Geological Society, London, Spccial Report 10.

Sellwood, E. B. \& Thомлs, J. M. 1986. Variscan facies and structurc in central S.W. England. Journal of the Geological Society, London, 143, 199-207.

Sissons, J. B. 1954. The crosion surfaces and drainage system of S. W. Yorkshire. Proceedings of the Yorkshire Geological Society, 29, 305-342.

Smith, K., Smith, N. J. P. \& Holliday, D. W. 1985. The decp structure of Derbyshire. Geological Journal, 20, 215-225.

Soper, N. J. \& Hutton, D. H. W. 1984. Latc Calcdonian sinistral displacements in Britain: implications for a three platc collision model. Tecronics, 3, 781-794.

-, Webi. B. C. \& Woodcock, N. H. 1987. Latc Calcdonian (Acadian) transgression in North Wcst England: timing, gcometry and gcotectonic significance. Proceedings of the Yorkshire
Geological Socierv, 46, 175-192.

Strank, A. R. E. 1987. The stratigraphy and structurc of Dinantian strata in the East Midlands, UK. In: Ad八ms, A. E., Mill.ek, J. \& Wrichit, V. P. (eds). European Dinantian Enviromments. John Wilcy, Chichester, 157-175.

Thorpe, R. S., Beckinsdnle, R. D., Patchelt, P. J., Piper, J. D. A., Davies, G. R. \& Evans, J. A. 1984. Crustal growth and Latc PrccambrianEarly Palacozoic platc tectonic cvolution of England and Wales. Journal of the Geological Society, 141, 521-536.

Turner, J. S. 1949. The decper structure of Central and Northern England. Proceedings of the Yorkshire Geological Society, 27, 280-297.

VIN Hookn, B. 1987. Structural cvolution, timing and tectonic style of the Solc Pit inversion. Tecionophysics, 137, 239-284.

WALSH, P. T., BOUITER, M. C., IJTABA, M. \& URBAN, D. M. 1972. The preservation of the Neogene Brassington formation of the Southern Pennines and its bearing on the cvolution of Upland Britain. Journal of the Geological Society, 128, $519-559$.

WhEILDON, J. \& Rollin, K. E. 1986. Heat flow. In: Downing, R. A. \& Gray, D. A. (cds). Geothermal Energy - The Potential in the United Kingdom, HMSO, London, 8-20.

WhitrAKer, A. (ed.) 1985. Atlas of onshore sedimentary basins in England and Wales: Post Carboniferous tectonics and stratigraphy. Blackie, Glasgow.

WILLS, L. J. 1973. A palaeogeographical map of the Palaeozoic floor beneath the Permian and Mesozoic formations in England and Wales. Gcological Socicty, London, Mcmoir 7.

- 1978. A palaeogeographical map of the Lower Palaeozoic floor below' the cover of Upper Devonian, Carboniferous and later formations. Gcological Socicty, London, Mcmoir 8.

Ziegler, P. A. 1978. North-Western Europe: tectonics and basin devclopment. Geologie en Mijnbouw', 57, 589-626.

- 1981. Evolution of sedimentary basins in northwest Europc. In: Illing, L. V. \& Hobson, G. D. (cds). Petroleum geology of the Continental Shelf of North-West Europe, Heyden, London, 3-39. 1982. Geological Atlas of Western and central Europe. Shcll International Petrolcum Maatschappij B. V., The Haguc.

1986. Gcodynamic model for the Palacozoic crustal consolidation of Western and Central Europc. Tectonophysics, 126, 303-328. 


\section{Appendix F}

Copy of: EBDON, C.C., FRASER, A.J., HIGGINS, A.C., MITCHENER, B.C. \& STRANK, A.R.E. 1990. The Dinantian Stratigraphy of the East Midlands: A seismostratigraphc approach. Journal of the Geological Society, London, 147, 519536. 


\title{
The Dinantian stratigraphy of the East Midlands: a seismostratigraphic approach
}

\author{
C. C. EBDON, 'A. J. FRASER,' A. C. HIGGINS, ' B. C. MITCHENER' \& \\ A. R. E. STRANK ${ }^{2}$ \\ 'BP Exploration, 301 Vincent Street, Glasgow G2 5DD, UK \\ ${ }^{2} B P$ Research Centre, Chertsey Road, Sunbury-on-Thames TW16 7LN, UK
}

\begin{abstract}
Six tectonically controlled seismic sequences have been identified in the Dinantian succession of the Widmerpool Gulf, East Midlands and they have also been recognized in outcrop sections in Derbyshire and the Bowland Basin. These correlations are made possible by integrating and calibrating sequence boundaries with the biostratigraphical evidence from foraminifers, conodonts and palynomorphs and relating these to the tectonostratigraphical evolution of the basin. It is suggested that the current chronostratigraphical stages of the Dinantian do not always reflect major regional stratigraphical events and that the seismic sequence stratigraphy erected herein may provide a more applicable chronostratigraphical subdivision of the Dinantian of the East Midlands and northern England.
\end{abstract}

The object of this paper is to evaluate the Dinantian stratigraphy of the East Midlands. The advent of high quality, modern, multifold seismic reflection data in northern England, and in particular the East Midlands, has allowed the identification of six seismic sequences in the subsurface which are of approximately early Carboniferous age (Fraser et al. 1990). The sequences identified are individual stratigraphical units each composed of a relatively conformable succession of genetically related strata which are bounded at their top and base by unconformities or their correlative conformities (Mitchum et al. 1977). Correlation of these sequences with the regional stages of the Dinantian proposed by George et al. (1976) has proven problematical.

An historical review of the chronostratigraphical subdivision of the Dinantian is undertaken herein, with particular reference to the definition of the stages and the problems of applying them in the subsurface. The Dinantian seismostratigraphy of the Widmerpool Gulf is presented and integrated with biostratigraphical and lithostratigraphical data from available wells and correlated with nearby outcrop data. The results of this analysis and the wider implications for chronostratigraphical subdivision of the Dinantian in northern England are discussed.

\section{Chronostratigraphical division of the Dinantian}

\section{Background}

Until relatively recently the Dinantian stratigraphy of the British Isles was based almost exclusively on the success of faunal zonation using corals and brachiopods. Most notable was the work of Vaughan (1905) in the Bristol area and Garwood (1913) in northern England. Subsequent work on goniatites (Bisat 1928; Earp et al. 1961 and references therein), conodonts (see discussion in Varker \& Sevastopulo 1985), spores (Neves et al. 1972; Clayton et al. 1977) and foraminifers and algae (Conil et al. 1979; Strank 1981) has provided further control on the dating and correlation of Dinantian rocks within this framework.

Ramsbottom (1973) proposed that the Dinantian of
Great Britain contained six eustatically controlled major cycles or groups of cycles. The identification of these major cycles, which are correlated on their fossil content, provided a potential chronostratigraphical subdivision of the Dinantian. This work inferred the existence of many gaps in the succession in the Bristol area. George et al. (1976) formally subdivided the British Dinantian into six regional chronostratigraphical divisions or stages. The stages proposed approximately coincide with the major cycles suggested by Ramsbottom (1973), since each major transgression was accompanied by the migratory faunas that are used to recognize the different stages (Fig. 1).

Each of the stages proposed by George et al. (1976) has a standard boundary stratotype section at which the base is defined. The top of each stage is defined by the base of the overlying stage. In selecting boundary stratotype sections George et al. (1976) made use of sections in which the succession appears most complete. An attempt was, therefore, made to locate boundary stratotypes in the thicker successions, since the thinner shelf successions often contain hiatuses at the relevant levels (Ramsbottom 1973).

Recognition of the stage boundaries in the subsurface is dependent on the identification of key zonal fossils and, in some cases, associated lithological changes. This has proven difficult and occasionally impossible in the subsurface due to extreme facies variations within the Dinantian, faunal provincialism, and the difficulty of identifying certain fossil groups in borehole samples. Furthermore, recent macroand micropalaeontological (Strank in prep.) and microfloral (BP in-house) studies have modified the ranges of certain key fossil species and brought into question the criteria for recognizing some of the Dinantian stages. Discussion on the definition of each of the stages together with, where appropriate, comments on the recognition of each stage in the subsurface are presented below in ascending stratigraphical order (refer to Fig. 1).

\section{Courceyan Stage}

This stage is broadly equivalent to the Tournasian Series of northwest Europe. The base of the Dinantian Subystem (as 


\section{Discussion}

Almost without exception, the six Dinantian stages erected by George et al. (1976) are difficult to identify accurately in the subsurface and away from the stratotype sections. The bases of both the Courceyan and Arundian Stages can be approximately located using palaeontological criteria. The same, however, is not true for the Chadian, Holkerian, Asbian and Brigantian Stages. Identification of these stages is hampered by the need to clarify the biostratigraphical characteristics of the boundary stratotypes.

Hedberg (1976) stated that chronostratigraphical classification should encompass all rocks formed within a certain time span and utilise information available from all kinds of stratigraphical classification. With respect to the Dinantian of northern England, the availability of high resolution, reflection, seismic data has provided a further tool for stratigraphical classification, in addition to the traditional use of lithostratigraphy and biostratigraphy. Vail \& Mitchum (1977) have suggested that a seismic reflection is generated by a time synchronous stratal surface (bedding plane) which may pass through all facies belts. Seismic data, therefore, potentially identify chronostratigraphical units. This principle provides the basis for the stratigraphical subdivision of the Dinantian presented below.

\section{Sequence stratigraphy of the Widmerpool Half Graben}

\section{Geological setting}

The Widmerpool half graben is typical of the many fault-bounded Carboniferous basins of northern England (Fig. 2). It is bounded to the south by the Hoton fault (the major basin boundary fault) and to the north by the Cinderhill fault. The Hathern half graben and East Midlands platform lie on the respective footwalls of these faults (Fig. 3). Traditionally the structure of the North of England Carboniferous basins has been interpreted as a series of steep sided blocks on which shelf carbonates accumulated, and intervening troughs in which basinal mudstones were deposited. Reefs were interpreted as flanking the blocks (e.g. Kent 1966). Bott and Johnson were amongst the first to suggest that cyclicity in Carboniferous sediments was tectonically controlled (Bott 1967; Bott \& Johnson 1967; Johnson 1967). Seismic data later showed these basins to have marked asymmetry. The identification of tilt blocks (Miller \& Grayson 1982; Smith et al. 1985; Grayson \& Oldham 1987) and half graben (Leeder 1974; Gawthorpe 1987) provided weight to the theory that the Dinantian basins of northern England were formed as a result of lithospheric stretching (Dewey 1982; Leeder; 1982, 1987). The characteristic form of the Widmerpool half graben is that of a strongly asymmetric graben which has been inverted along the major basin bounding fault at the culmination of the Variscan orogeny in the late Carboniferous (Fig. 4).

The Carboniferous fault system, the trend of which was inherited from the Caledonian orogeny (Wills 1973, 1978), was reactivated at the onset of late Devonian-early Carboniferous rifting (Bott 1976, 1978; Leeder 1982, 1987). At this time Great Britain was part of the Rheno-Hercynian foreland (Leeder 1987). Rheno-Hercynian extension in the Lower Carboniferous was initiated by thermal doming and hack-are spreading as a result of plate subductorn (1 eeded 1987; Fraser et al. 1990). Recent work by Gawthorpe (1987) and Gawthorpe et al. (1989), based on the record of thickness and facies variations, event deposits and the identification of local unconformities within basins of northern England (notably the Bowland Basin), defines four main phases of syn-sedimentary faulting (Fig. 5). Dating and correlation of these phases of tectonism is hampered by the paucity of biostratigraphically controlled time lines, as a result of facies variation both within and between basins Nevertheless, the four main phases of tectonism are recorded as (i) late Devonian-early Courceyan, (ii) late Chadian/early Arundian, (iii) mid/late Asbian and (iv) Brigantian. These tectonically active phases are punctuated by periods of relative tectonic quiescence.

Seismic reflection evidence indicates that the Widmerpool half graben was periodically tectonically active during the Dinantian. Within this syn-rift phase of basin evolution six major seismic sequences have been identified (Fig. 4).

The seismostratigraphy presented herein is based on the integration of approximately $200 \mathrm{~km}$ of high quality, multifold, seismic reflection data, well data (from which lithological and biostratigraphical data have been obtained), and the correlation of outcrop data from the nearby Derbyshire dome. Observations from other northern England Carboniferous basins (notably those of Gawthorpe et al. 1989) are also included. Each seismic package is described below from oldest to youngest.

\section{Pre-rift}

Seismic character. The top of the pre-rift is marked by a high amplitude reflector which is laterally continuous on the basin margins, becoming discontinuous and of lower amplitude into the basin. Internally the pre-rift is characterless (Fig. 6).

Facies. Where penetrated the pre-rift megasequence is composed of metasediments or intrusives.

Interpretation. The pre-rift megasequence represents Caledonian basement.

Age. The metasediments of the hangingwall are of undefined Palaeozoic age. Granodiorite from the footwall has been dated as Caledonian, possibly Silurian in age.

Correlation. South of the Widmerpool half graben, on the London-Brabant Massif, Charnian (Pre-Cambrian) metasediments and igneous rocks outcrop. To the northwest, on the Derbyshire Dome, the Eyam and Woo Dale boreholes penetrated pre-Dinantian volcanic rocks and Lower Palaeozoic rocks respectively (Cope 1973; Dunham 1973; Strank 1985, 1986). To the northeast, in the East Midlands, a number of boreholes have penetrated pre-Dinantian basement composed of metasedimentary and intrusive rocks (Pharaoh et al. 1987)

\section{EC1 sequence}

Seismic character. The sequence thickens into the Hoton fault (and ultimately the Sileby fault which was the major basin bounding fault at this time; Fig. 7) and thins northwards onto the hangingwall dipslope. The base shows a 


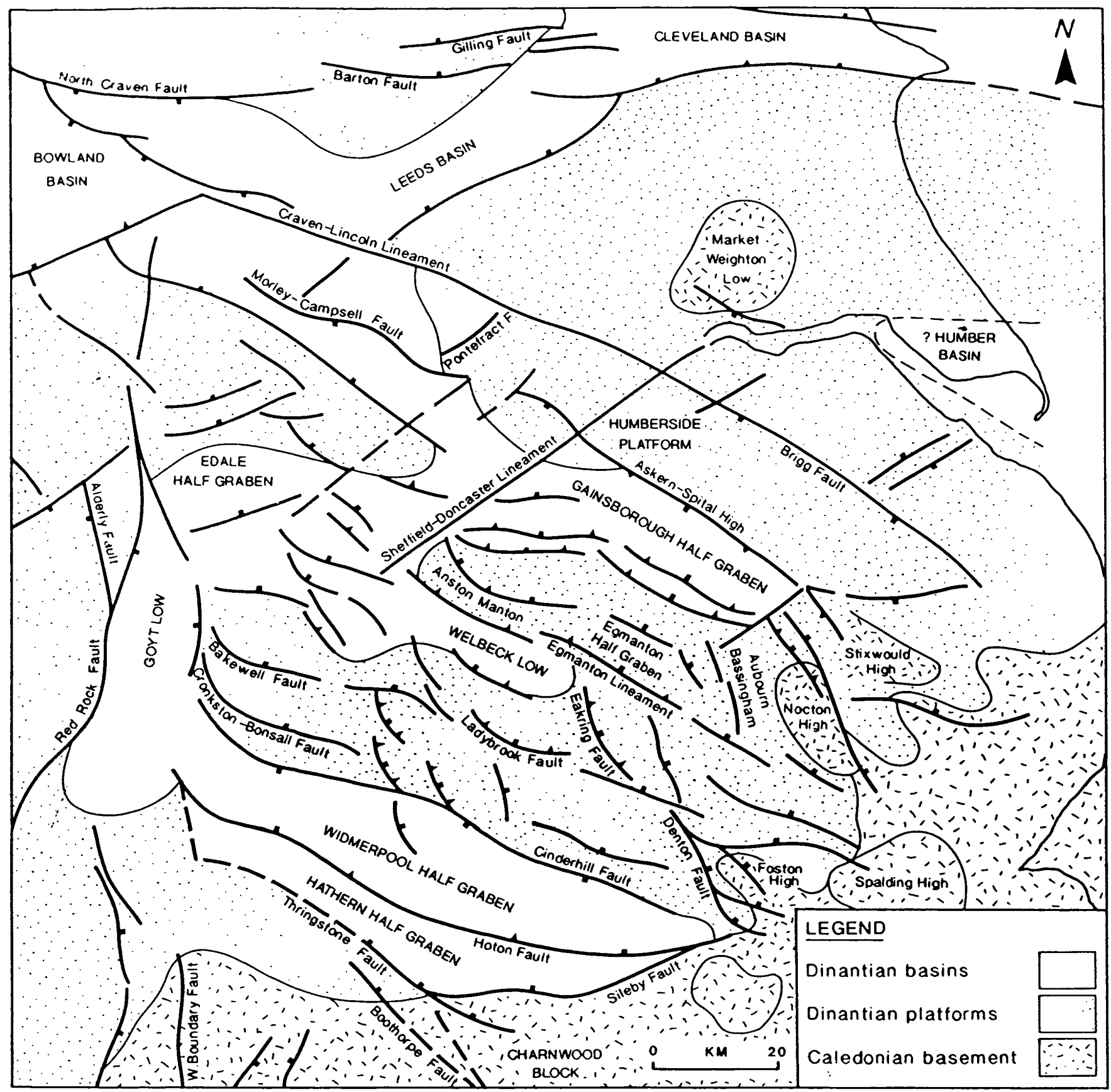

Fig. 2. East Midlands Dinantian structural elements.

suggestion of progressive northwards onlap onto the pre-rift megasequence in the hangingwall. The top of the sequence is marked by a high amplitude, laterally continuous reflector. Internally the sequence is characterized by low amplitude, high frequency, laterally discontinuous events (Fig. 4).

Facies and biostratigraphy. Sequence EC1 has not been penetrated by a borehole in the Widmerpool half graben.

Interpretation. The marked thickening of the EC1 sequence into the major basin bounding faults (the Hoton and Sileby faults) indicates that deposition of the sequence is tectonically driven. This early phase of faulting represents the initial development of the half graben. A downlapping subaerial fan sequnce, similar to that penetrated in the hangingwall of the Eakring/Foston fault (Eakring-146, Fraser et al. 1990), is envisaged adjacent to both the Hoton and Sileby faults. These are interpreted as developing into fluvial plain deposits of Old Red Sandstone facies towards the basin centre and hangingwall dipslope. A marine transgression is marked by the progressive onlap of the basement by carbonate slope deposits.

Age. Late Devonian-Courceyan: The age is based on 


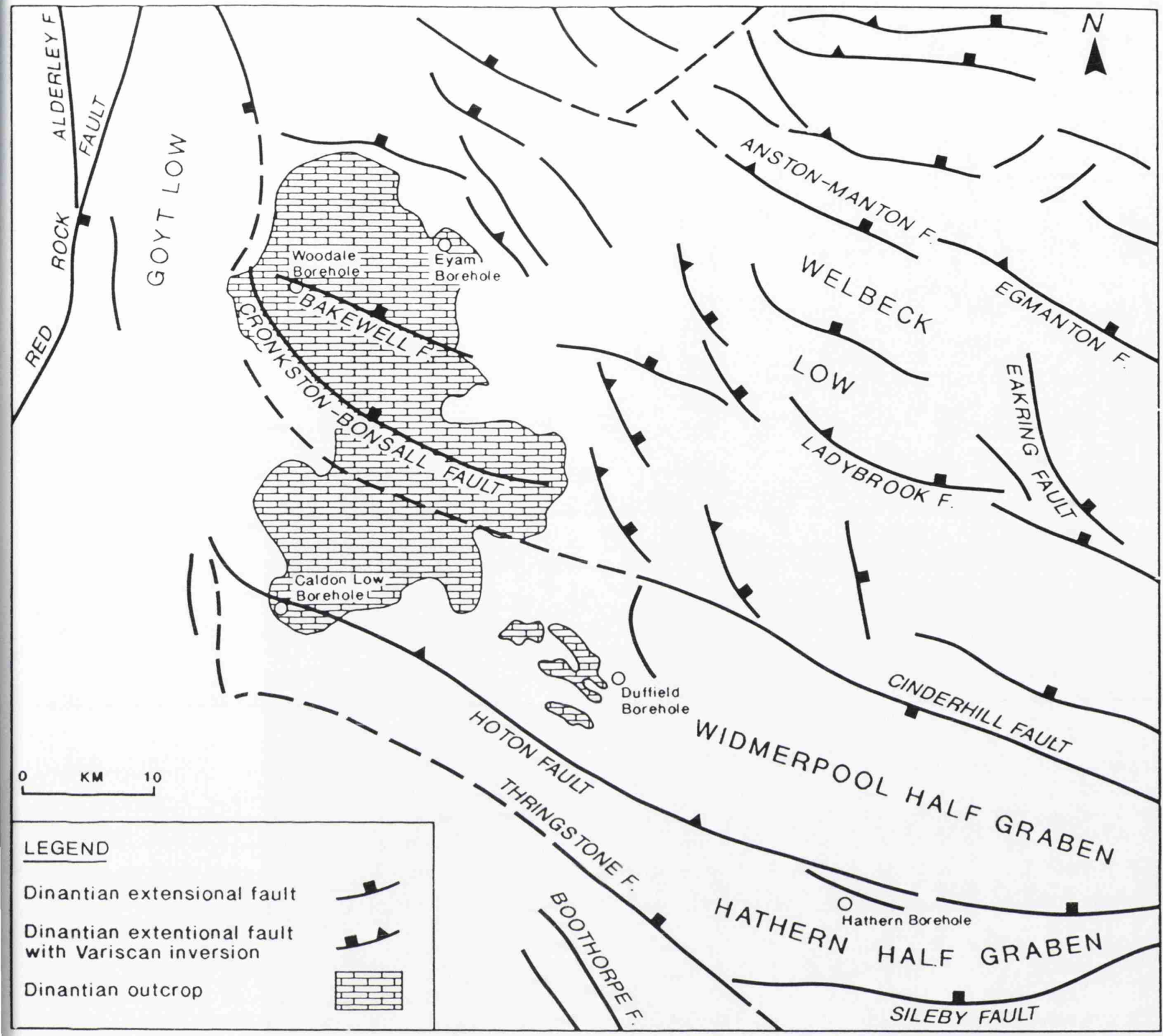

Fig. 3. Structural setting, western Widmerpool half graben.

borehole data from the Hathern half graben and regional correlation (see below).

Correlation. Sediments of the EC1 sequence have been penetrated to the south of the Widmerpool Gulf by the Hathern borehole. At the base of Hathern-1 anhydrites were encountered (Falcon \& Kent 1960; Llewellyn \& Stabbins 1968, 1970). This indicates that there was restricted marine influence by this time in the half graben Palynological analysis (Llewellyn et al. 1969) indicates a Courceyan age equivalent to the CM Zone of Clayton et al. (1977). Elsewhere in the East Midlands EC1 is confined to incipient half graben, and has only been encountered in the subsurface in a small inverted half graben (Eakring 146) and on the footwall of the Widmerpool Half Graben (Caldon Low borehole; Institute of Geological Sciences 1978; Welsh \& Owens 1983). In both locations EC1 consists of red continental conglomeratic sandstones, which are inferred to be of late Devonian-Courceyan age, resting on basement.

Direct comparison with outcrop from the Derbyshire dome is not possible as the complete Dinantian section is not exposed. The Eyam borehole (Dunham 1973; Strank 1985), however, revealed Courceyan evaporites overlying Ordovician sediments. In the Bowland Basin Courceyan conodont assemblages are recorded by Metcalfe (1981). Higgins \& Varker (1982) record Courceyan conodont faunas from sabkha deposits exposed at Ravenstonedale. In the Northumberland Basin rifting is marked by the eruption of the basaltic Birrenswark/Kelso/Cockermouth lavas (Gawthorpe et al. 1989), which are dated as early Courceyan. The subsequent syn-rift sedimentation is dominated by influxes of mature siliciclastic sediments which interdigitate with the cementstone facies of fluvio-lacustrine origin (Leeder 1974; Gawthorpe et al. 1989). 

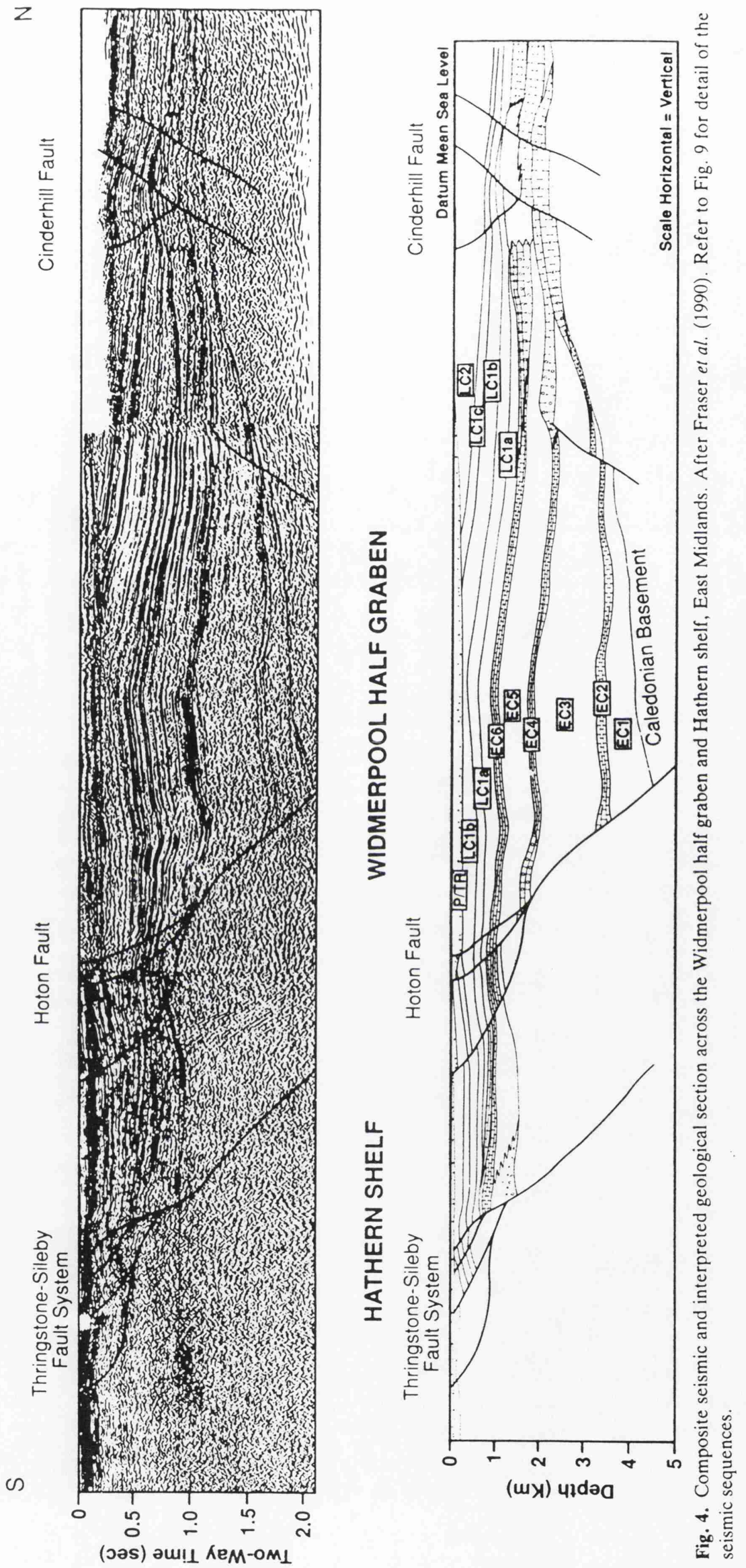


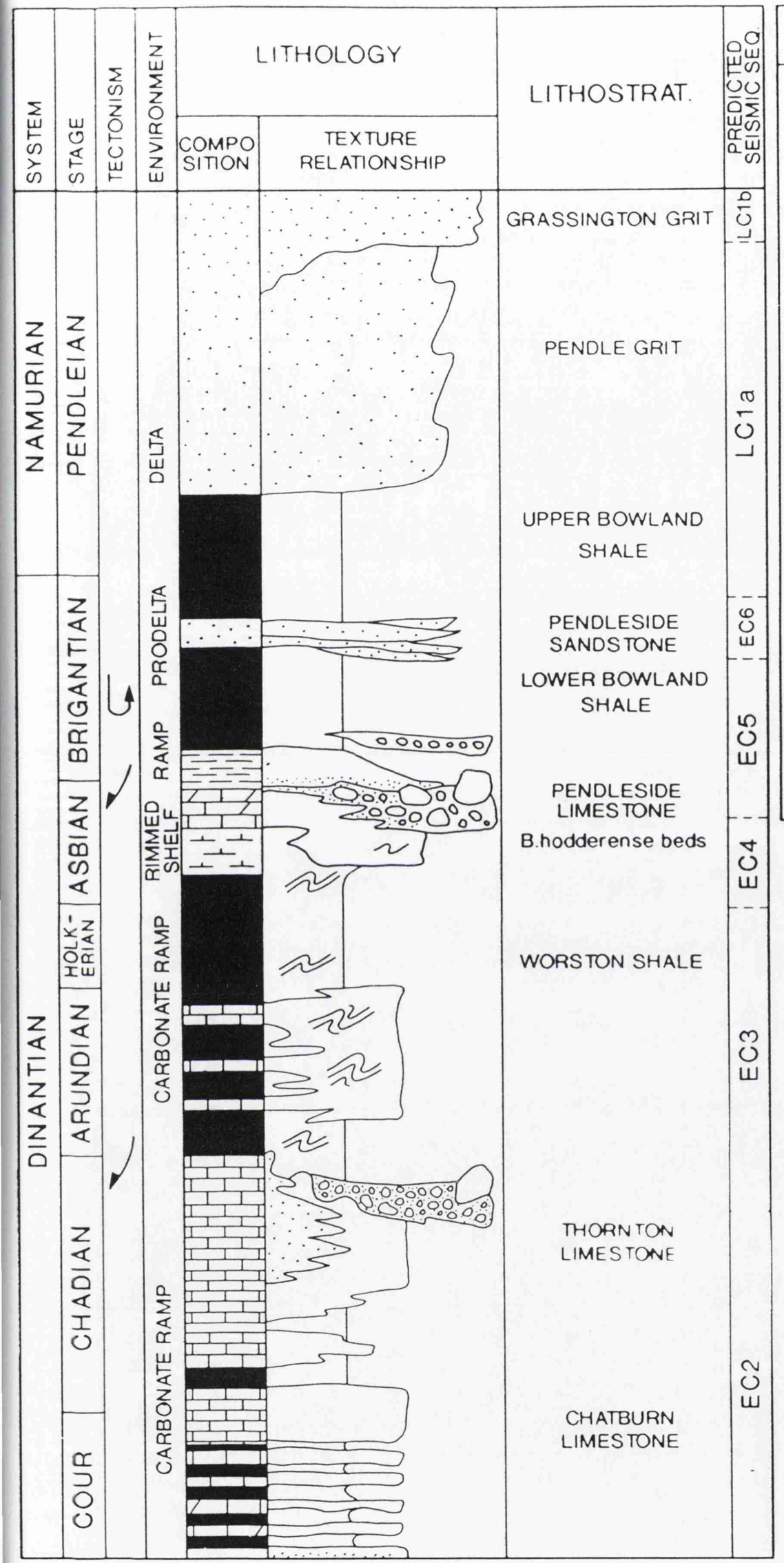

\begin{tabular}{l} 
LEGEND \\
\hline COMPOSITION \\
Coarse siliclastics \\
Mudstone \\
Calcareous mudstone \\
Limestone \\
Dolomitic limestone
\end{tabular}

\section{TEXTURE}

Sandstone. grainstone

Mudstone

Slumps, slides

Breccias

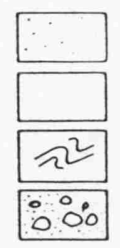

\section{TECTONIC EVENT}

Extensional, rifting

Inversion
ֻุ

Fig. 5. Generalized sedimentary log for the Dinantian of the Bowland Basin with interpreted sequence stratigraphy. After Gawthorpe (1987). 


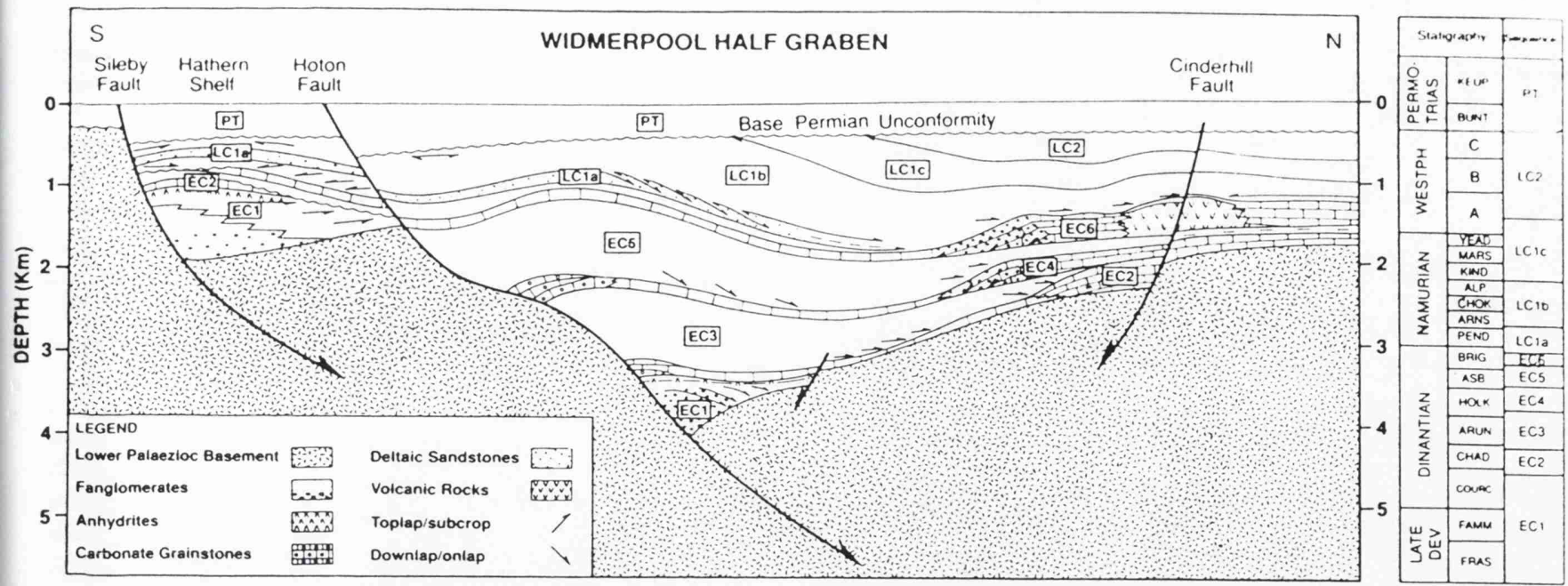

Fig. 7. Composite sketch of seismo-stratigraphic interpretation, western Widmerpool half graben

\section{EC2 sequence}

Seismic character. Sequence EC2 comprises high amplitude, laterally continuous reflectors in the basin centre which diverge and thicken along the hangingwall dipslope, where hummocky downlapping clinoforms are tentatively identified. The base of the sequence is marked by a high amplitude, laterally continuous reflector (top EC1). The top of the sequence is marked by onlap of the overlying sequence (Fig. 4).

Facies and biostratigraphy. The EC2 sequence has not been penetrated by a borehole in the Widmerpool half graben.

Interpretation. EC2 is interpreted as a stillstand or regressive phase. This allowed the development of carbonate ramp to rimmed shelves which were both aggradational and progradational (Fig. 7). This interpretation is based on the thickening of EC2 across the hangingwall dipslope and the tentative identification of hummocky downlapping clinoforms. Below wave base the typical packstone/wackstone/mudstone facies association predominated. The high amplitude, laterally continuous reflectors in the basin are believed to represent carbonates.

Age. Chadian, possibly as old as late Courceyan, based on correlation with outcrop and well data.

Correlation. Sediments of the EC2 Sequence have been penetrated at Hathern on the footwall of the Hoton fault. Here the sequence is developed as shelf limestones (Llewellyn \& Stabbins 1968,1970 ) which are dated as no older than the CF4 Zone of Conil et al. (1979). On the adjacent East Midlands platform EC2 is the oldest of the Dinantian sequences preserved, and is developed as shelf limestones. Strank (1987) indicated that EC2 is no older than late Courceyan in the shelf setting.

Gawthorpe (1987) proposed that the Chatburn and Thornton Limestones, exposed in the Bowland Basin. reflect deposition on a carbonate ramp (Fig. 5) and that during the early-late Chadian, passive subsidence of the basin led to the development of a rimmed shelf along the hangingwall dipslope, where carbonate grainstone shoals were concentrated above wave base. The age of this sequence, however, is uncertain. Fewtrell \& Smith (1978) indicated that an age as old as late Courceyan may be possible. The succession is believed to be equivalent to sequence EC2. This correlation is based on limited biostratigraphic data, and comparison of seismic and outcrop facies.

At Dovedale, on the Derbyshire dome along strike from the Widmerpool half graben, an elongate Waulsortian mud mound complex is reported by Bridges \& Chapman (1988). The mud mound complex developed on a ramp to the southwest of an evolving carbonate platform during Chadian times. Grayson \& Oldham (1987) report similar facies of Chadian age from the Bowland Basin.

In the Northumberland Trough sedimentation is influenced by the advance of deltas from the northeast (Leeder 1974; Fraser et al. 1990; Leeder et al. 1989). Sediments comprise siliciclastic deltaic cycles and peritidal carbonates of the Lower Border Group.

\section{EC3 sequence}

Seismic character. The EC3 sequence thickens significantly into the Hoton fault and thins progressively northwards onto the hangingwall dipslope. At the base of the sequence there is progressive onlap onto the underlying EC2 sequence. The upper limit of the sequence is marked by the truncation of reflectors (Fig. 4). Internally the sequence consists of low amplitude, high frequency, laterally discontinuous events which progressively onlap onto the hangingwall dipslope (Figs 4 \& 7).

Facies. Where penetrated in the basin the sequence comprises a monotonous series of variably calcareous, carbonaceous, pyritic. dark grey mudstones thinly interbedded with grey, dolomitic limestones. The seismic character of EC3 exhibits no lateral variation and the sediment package is envisaged to show no change in character across the Widmerpool half graben. On the adjacent East Midlands shelf the sequence is represented by shelf limestones. 
Biostratigraphy. Only the top part of the sequence has been penetrated by borehole in the basin. Miospore assemblages recovered from the sequence include abundant Lycospora pusilla in association with Schulzospora campyloptera Stenozonotriletes coronatus, $V$. baccatus, $C$. aculeata, $P$. tesselatus and Waltzispora planiangulata. The miospore assemblages recovered from the upper part of the interval are broadly equivalent to the TC Zone of Neves et al. (1972). Although conodont analysis has been undertaken no significant assemblages have been recovered.

Interpretation. The geometry of the sequence (i.e. significant thickening into the Hoton Fault) indicates that deposition of EC3 was initiated by rejuvenation of the major basin bounding fault. This phase of extension is associated with rotation of the fault blocks and significant footwall erosion. Carbonate shelf margins which developed during EC2 on the footwall margins were eroded, those on the hangingwall margin were drowned.

Age. Late Chadian-late Holkerian. The lower age limit is based on analogy with sections in the Bowland Basin (Gawthorpe 1987). The upper age limit is defined by the identification of the TC Zone of Neves et al. (1972). The TC Zone has a base in the late Holkerian (see discussion above).

Correlation. In the Bowland basin a period of enhanced tectonic activity is noted during the late Chadian-early Arundian (Gawthorpe 1987). At outcrop this is marked by horizons of debris flow, carbonate breccias and sedimentary slides which unconformably overlie calciturbidites of the preceding EC2 sequence (Fig. 5). Associated with the tectonism is a cessation of carbonate production and increase in deposition of terrigenous mud. Areas which were carbonate-producing during EC2 were either inundated or became emergent following footwall uplift and erosion. This is believed to correlate with the onset of the EC3 rifting in the Widmerpool half graben. On the East Midlands shelf a widespread Arundian shale horizon marks a cessation of carbonate growth over the platform and is believed to represent the maximum extent of the EC3 transgression.

\section{EC4 sequence}

Seismic character. The sequence is thickest at the margins of the basin, along the Hoton and Cinderhill fault systems, and thins into the basin (Figs $4,6, \& 7$ ). The base of the sequence shows downlap onto the underlying EC3 sequence along the hangingwall dipslope, becoming subparallel with EC3 towards the basin centre. There is also some evidence of subcrop to the base of EC4 within the basin. The top is marked by progressive onlap of the overlying sequence (Figs 6 \& 7). Internally, in the basin, the sequence comprises high amplitude, low frequency, laterally continuous reflectors. Along the Hoton fault EC4 comprises high amplitude, low frequency, subtle high angle reflectors which represent vertically and laterally accreting clinoforms that prograde northwards into the basin (Fig. 6). Along the hangingwall dipslope the sequence is largely characterless but in places high amplitude, low frequency, downlapping hummocky clinoforms are interpreted prograding southwards onto EC3.

Facies. In the basinal setting the high amplitude reflectors recorded on seismic sections represent an increase in carbonate within an otherwise monotonous sequence of mudstones and interbedded limestones. The progradational and aggradational features identified on the basin margins. none of which have been penetrated by wells, are believed to represent the development of carbonate ramp to rimmed shelf facies. Shelfward of these features, and confirmed by well data, shallow marine limestones accumulated.

Biostratigraphy. The sequence is well controlled biostratigraphically by borehole data tied to seismic sections. Diverse conodont faunas include Paragnathodus commutatus, Gnathodus homopunctatus, Gnathodus girtyi girtyi, Cavusgnathus unicornis and Apatognathus sp. in association with bivalve spat, ostracodes and brachiopod spines. The sequence equates to the $G$. girtyi Subzone of the P. commutatus Zone (Metcalfe 1981). The upper boundary of the sequence is well calibrated, coinciding with the boundary between the $G$. bilineatus and $P$. commutatus Zones (Metcalfe 1981). Palynofloras are broadly equivalent to the NM Zone and the upper part of the TC Zone (Neves et al. 1972)

Interpretation. Sequence EC4 is interpreted as having developed during a stillstand or regressive phase. In the Widmerpool half graben carbonate deposition was reestablished along the basin margins and low rates of subsidence prevailed. This enabled the carbonate ramp to prograde both southward and northward from the hangingwall and footwall margins respectively. The strong parallel reflectors in the basinal section link the two prograding ramps.

Age. Late Holkerian to mid-Asbian. The lower age limit is defined by the presence of the TC Zone (Neves et al. 1972) at the base of EC4. The upper age limit is defined by the top of the $G$. girtyi Subzone, $P$. commutatus Zone of Metcalfe (1981).

Correlation. An Asbian grainstone footwall shelf margin which progrades towards the basin centre is preserved on the nearby Derbyshire dome at Castleton. The increased carbonate production at this time (Gawthorpe 1986: Gutteridge 1987) created a gradient at the shelf margin. This lead to carbonate debris flows and sedimentary slides as described from the Bowland Basin (Gawthorpe 1987; Fig 5). Gutteridge (1987) concluded that in the region of the present day Derbyshire dome a major carbonate shelf developed across earlier basement topography. The strong parallel reflectors seen across the Widmerpool Gulf in sequence EC4 are believed to represent calciturbidites deposited basinward of the evolving carbonate shelf margins.

\section{EC5 sequence}

Seismic character. The EC5 sequence, like the EC1 and EC3 sequences, thickens into the Hoton Fault and thins northwards onto the hangingwall dipslope (Figs 4 \& 7). The base of the sequence shows progressive onlap onto EC4 (Fig. 6). Internally the sequence consists of low amplitude. high frequency, laterally continuous parallel events which progressively onlap the hangingwall dipslope (Figs 4 \& 6) 

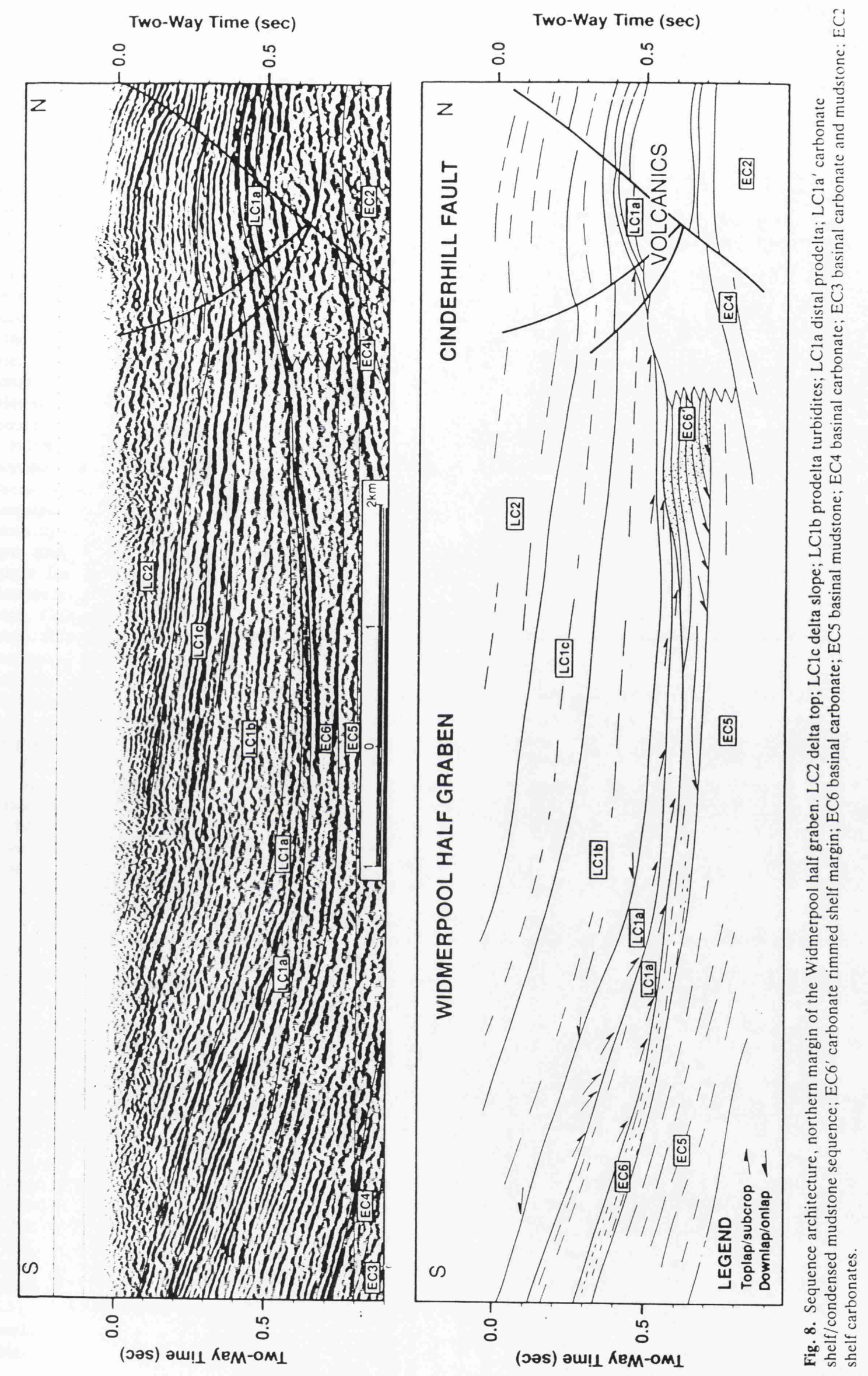
Facies. In the basinal setting borehole evidence indicates that EC5 consists of a monotonous series of calcareous mudstones and thin dolomitic limestones. Shallow marine shelf limestones accumulated on the East Midlands platform and Hathern shelf. Volcanic centres along the Cinderhill fault system were active during EC5 times (Fig. 8)

Biostratigraphy. Conodont faunas are rich and diverse at the top of the sequence, becoming progressively more impoverished towards the base where assemblages are indeterminate. In boreholes the top of EC5 occurs within the $G$. bilineatus Zone (Metcalfe 1981). Assemblages are characterized by $G$. bilineatus, $G$. homopunctatus, $P$. commutatus and $G$. girtyi. Mestognathids, including Mestognathus beckmanni, characteristically occur at the top of the sequence and indicate a shallowing of the system with time. Towards the base of the sequence the indeterminate faunas include fragmented conodonts, foraminiferal casts, isolated brachiopod spines and goniatite spat. Mixing of assemblages during deposition is suggested

Palynofloral assemblages from the sequence can be assigned to the VF Zone of Neves et al. (1972). Assemblages typically contain species of Lycospora and Densosporites which are common, in association with Schulzospora species, Spelaeotriletes arenaceous, Raistrickia nigra and Remysporites magnificus. A number of taxa appear for the first time within the sequence, including Diatomozonotriletes saetosus, Diatomozonotrilites cervicornutus, Crassispora maculosa, T. vetustus, T. trivalvis, $R$. fracta, $R$. knoxii, $G$. spinosa and $S$. nux. $P$. tesellatus, Murospora parthenopia, Murospora margodentata, $V$. baccatus, Chaetosphaerites pollenisimilis and $C$. aculeata become extinct within the sequence.

Interpretation. The pronounced thickening of the sequence into the major basin bounding fault (the Hoton fault) indicates that EC5 is a tectonically driven sequence. It was initiated by reactivation of the extensional fault regime and significant backstepping of the fault system in the Widmerpool half graben (Fig. 6). This was accompanied by footwall rotation generating both uplift and erosion. Contemporaneous volcanic rocks were extruded from centres of igneous activity aligned along the Cinderhill fault zone. Microfaunal evidence indicates that initially EC5 consists of sediments from a mixed source, suggesting sediment slumps and slides or turbidity flow into the basin from the drowned or emergent carbonate shelf margins. By the end of EC5 shallow water conditions were developed across the Widmerpool half graben as sedimentation exceeded subsidence.

Age. Late Asbian-early Brigantian. The lower age limit of the sequence is well constrained by the upper age limit of the underlying EC4 sequence. The record of palynofloras belonging to the NM Zone (Neves et al. 1972), ME Subzone (Clayton et al. 1977), is consistent with the late Asbian age assigned to the base of the sequence. The upper age limit is less well constrained, being approximately equivalent to the VF-NC miospore Zone boundary of Neves et al. (1972) Clayton et al. (1977) equate the base of the NC Zone to a position within the $\mathrm{P} 2$ goniatite Zone

Correlation. Sequence EC5 ties in well with a late Asbian-early Brigantian phase of tectonic activity in northern England (Gawthorpe 1986, 1987). Basaltic lavas on the Derbyshire Dome, (the Lower and Upper Miller's Dale Lavas) lie along strike from, and are stratigraphically equivalent to, the volcanic centres developed along the hangingwall margin of the Widmerpool half graben (Macdonald et al. 1984). This volcanism is related to reactivation of extensional faults. Gutteridge (1987) records two periods of emergence and karstic erosion on the Derbyshire dome in the late Asbian and early Brigantian. These are believed to correspond to two pulses of extension in the area during EC5 times, leading to footwall uplift and erosion. Horizons of debris flows, carbonate breccias and sedimentary slides occur in the Bowland basin associated with this tectonism as with earlier phases (Fig. 5). During EC5 times fine terrigenous clastics related to the advancement of major delta systems from the north reached the Bowland Basin. In the Widmerpool half graben carbonate production ceased as either EC5 inundated the shelf margin areas or the marginal platforms became emergent

\section{EC6 sequence}

Seismic character. EC6 is thickest along the Cinderhill fault system with the shelf margin apparently developing basinward of the EC5 volcanic centres (Figs $4 \& 8$ ). The base of the sequence exhibits downlap onto EC5 along the hangingwall dipslope, becoming sub-parallel with EC5 southward into the basin. The top of the sequence is marked by progressive onlap of the overlying sequence LC1 (Fig. 8) Internally EC6 is a progradational complex of sigmoid oblique, laterally and vertically accreting high amplitude, low frequency clinoforms. These change character along the hangingwall dipslope to hummocky clinoforms on parallel seismic lines, and pass southwards into high amplitude, high frequency parallel events in the basin (Fig. 8). In addition mounded features of up to $0.5 \mathrm{~km}$ across have been mapped on the Hathern shelf (Fig. 6).

Facies. In the basin EC6 comprises a monotonous series of thinly bedded, dark grey, calcareous mudstones and brown, dolomitic, muddy limestones. Volcanic centres along the Cinderhill fault continued to be active during EC6 times (Fig. 8)

Biostratigraphy. The top of the sequence is well constrained by the top of the $G$. bilineatus conodont Zone of Metcalfe (1981). Conodont assemblages are rich and diverse throughout and resemble those present in the underlying sequence. $G$. bilineatus, $G$. homopunctatus, $G$. girtyi and $P$. commutatus continue to typify the microfauna, in association with Neoprioniodus scitulus, Neoprioniodus singularis, Hibbardella milleri and Ozarkodina delicatula. The EC5/EC6 sequence boundary is approximately coincident to the VF/NC miospore Zone boundary of Neves et al. 1972). The base of the NC Zone (Neves et al. 1972) is marked by the appearance of a number of taxa including Bellespores nitidius, Reticulatisporites carnosus, Convolutisporites varicosus and Schopfipollenites ellipsoides. Assemblages continue to be characterized by elements consistently recorded in the underlying sequence, namely $L$. pusilla, $R$. nigra, $R$. magnificus, $R$. fracta, $R$. knoxii, S. nux, Triquitrites marginatus, $T$. trivalvis and species of Schulzospora. The EC6 Sequence belongs exclusively to the 
NC Zone (Neves et al. 1972), the top of the sequence falling within the biozone.

Interpretation. Close to the hangingwall dipslope EC6 is considered to comprise carbonate grainstones. In the Widmerpool half graben it is proposed that low rates of subsidence (and/or small rises in sea level) were established by the end of EC5. Carbonate production was re-established and a carbonate ramp prograded southward into the basin from the hangingwall dipslope. An increase in subsidence (and/or rise in sea level) resulted in the evolution of a carbonate grainstone rimmed shelf margin from the carbonate ramp. This is indicated by the laterally and vertically accreting clinoforms observed along the proposed shelf margin. The prograding shelf edge would have been at or just below sea level, and the depth of the water in the basin at the time would have been about $150 \mathrm{~m}$. This interpretation is further supported by conodont faunas recorded from the basinal sediments. The margins have not been penetrated by wells

Volcanic rocks, of EC5 and EC6 age, extend out into the basin as lava flows. They are believed to have concentrated wave energy which would have enhanced development of the grainstone margin, and are represented seismically by very high amplitude, low frequency, laterally continuous reflectors.

Age. Early to mid-Brigantian. The top and base of the sequence are well constrained biostratigraphically. Clayton et al. (1977) correlated the base of the NC Zone (Neves et al. 1972) to the middle of the P2 goniatite Zone (Bisat 1928). The top of the $G$. bilineatus conodont Zone is placed by Metcalfe (1981) within the P2b goniatite Subzone (Prentice \& Thomas 1965).

Correlation. The carbonate grainstone shelf margin interpreted along the hangingwall dipslope in the subsurface of the Widmerpool half graben lies along strike from the Wirksworth carbonate grainstone margin (Walkden 1982) on the Derbyshire dome. The Wirksworth grainstone shelf margin lies above a volcanic horizon, the Lower Matlock Lava, which is believed to be of early Brigantian age (Walkden 1982). The grainstone margin/volcanic rock association on the northern margin of the Widmerpool half graben adds further credibility to the interpretation made from the seismic data. Mounded features mapped on the Hathern shelf are analogous to the mud mounds of the Coalhills complex in Derbyshire (Walkden 1982).

\section{LC1 sequence}

Seismic character. The LC1 sequence is thickest within the basin just north of the Hoton fault and thins northward and southward onto the hangingwall and footwall margins respectively (Fig. 4). The lower part of the $\mathrm{LC1}$ sequence internally comprises high amplitude, high frequency, continuous parallel reflectors which downlap onto EC6 within the basin and onlap onto the submerged margins (Fig. 8)

Facies. The lower part of the sequence comprises interbedded dark grey, pyritic, carbonaceous mudstones and sandstones. Thin tuffaceous units occur sporadically towards the base of the unit.
Biostratigraphy. The boundary between the 1.C'l sequence and the underlying EC sequence equates to the boundars between the $G$. girtyi collinsoni Zone (Varker \& Sevastopulo 1985) and the $G$. bilineatus Zone (Metcalfe 1981). The base of the $G$. girtyi collinsoni Zone is marked by the inception of the eponymous taxon. Conodont faunas from the lower part of the LCl sequence are diverse, and as well as $G$. girtyi collinsoni include $G$. girtyi intermedius, $G$ bilineatus bilineatus, Neoprionoidus spathatus subsp. A, $N$. scitulus, Cavusgnathus naviculus and P. commutatus. At the base of the sequence brachiopod spines and the internal casts of foraminifers are important accessories to the microfauna. Palynofloras remain unchanged from the underlying sequence, being assignable at the base of LC1 to the NC Zone (Neves et al. 1972)

Interpretation. Post EC6 there was a minor inversion event. with maximum inversion concentrated along the NNW-SSE fault trend. Both the Hathern shelf and, to a lesser extent. the Widmerpool half graben were inverted. Evidence of inversion within the Widmerpool half graben is provided by the northward offset from the Hoton fault of the thickest part of the LC1 sequence which onlaps onto EC6 (Fig. 4) $\mathrm{LC} 1$ is divisible into subsequences on seismic evidence though this subdivision is beyond the scope of the present study. The sediments of LC1 are not generally fault controlled and represent a regressive downlapping sediment package deposited during the thermal subsidence phase which followed Dinantian rifting. The earliest sediments of $\mathrm{LC} 1$ are distal prodelta mudstones of the advancing Silesian delta system which had already filled basins to the north by this time (Fraser et al. 1990). The advancing delta system built out into the existing fault-produced topography. Seismic data suggests a water depth of about $300 \mathrm{~m}$ in the basin. Conodont faunas are characterized by deep water forms and confirm this interpretation.

Age. No older than late Brigantian. The base of the LC1 sequence is no older than the $G$. girtyi collinsoni Zone. Regional evidence indicates that the sequence ranges into the earliest Westphalian A.

Correlation. The inversion noted at the end of EC6 is recorded at outcrop on the nearby Derbyshire Dome. This inversion led to the creation of late Brigantian intrashelf basins of which the Welbeck Low (Fig. 3) is considered to be an example. The Welbeck intrashelf basin formed between the Anston-Manton, Ladybrook and Eakring inversion anticlines present along the north, south and eastern margins respectively. An easterly dipping carbonate ramp developed in response to the inversion, in the resultant low, onto which sub wave-base basinal carbonates accumulated during the early part of LC1. Similar intrashelf basins are described from outcrop in Derbyshire (Gutteridge 1987). Elsewhere, over the majority of the East Midlands platform, shelf carbonates proceeded to accumulate during late Brigantian times.

\section{Discussion}

The seismostratigraphy of the Widmerpool Gulf has revealed that Dinantian sedimentation in the East Midlands is characterized by phases of enhanced tectonism and intervening tectonically quiescent periods. The tectonically 
active periods are characterized by the accumulation of siliciclastics which thicken into the active basin bounding faults and onlap onto the hangingwall dipslope. Tectonically driven sequences (EC1, EC3 and EC5) have a characteristic wedge shaped geometry. Rotation of the fault blocks resulted in the inundation and drowning of hangingwall carbonate margins and the emergence of footwalls. The results of footwall uplift are local unconformities and the development of condensed successions. Tectonically quiescent periods are characterized by increased carbonate production and starved clastic input to the basin. Aggradational and progradational carbonate shelves characterize the hangingwall dipslope margin. Rimmed shelves on the footwall margin are aggradational. Progradation is limited by the greater change in water depth across the major fault zone. Sequences which formed during these tectoncially quiescent periods (EC2, EC4, and EC6) are characteristically thick on the basin margins and thin into the basin centre.

The integration of biostratigraphical data and correlation with outcrop has stratigraphically constrained each of the phases of tectonism and the resulting sequences (Fig. 9). The earliest rifting phase in which the basin was initiated is poorly constrained due to limited exposure and paucity of well data. Initial extension is believed to have occurred during the late Devonian/early Courceyan. Sub-aerial fans developed into an Old Red Sandstone fluvial plain environment at the onset of EC1. A marine transgression later in $\mathrm{ECl}$ times resulted in progressive onlap of the basement and the development of evaporites and carbonates (Fig. 10a).

During ?late Courceyan-Chadian times the Widmerpool half graben was tectonically quiescent. Carbonate ramp to rimmed shelves developed with Waulsortian-type mudmounds being common on the upper part of the ramp (Fig. 10b). Deposition of EC2 was terminated by fault reactivation in the late Chadian. Existing carbonate margins on the hangingwall dipslope were drowned, those on the footwall became emergent. Sequence EC3 accumulated during the late Chadian-late Holkerian phase of renewed faulting and basin subsidence (Fig. 10c).

By late Holkerian times carbonate production had resumed on the basin margins (Fig. 10d). A third phase of fault activity, though much less pronounced than the previous two, drowned the carbonate margins of EC4 (Fig. 10e). Progressive filling of the basin (sequence EC5) during late Asbian-early Brigantian times resulted in the re-establishment of carbonate deposition during the early to mid-Brigantian (Fig. 10f).

The top of sequence EC6 and of the complete syn-rift package is marked by a basin inversion in the midBrigantian. Subsequent Carboniferous sedimentation (for example, sequence LC1) was controlled by thermal subsidence.

The observations made herein with the assistance of seismic data confirm the following field and well observations made by previous workers. The progressive onlap of Dinantian strata onto basement highs has been noted in the East Midlands (Strank 1987), the Craven lowlands and Stainmore trough (Ramsbottom 1974) and the Bowland basin (Tiddeman 1889). The early observation that phases of earth movement occurred during the Dinantian (Hudson \& Turner 1933; Parkinson 1944) is also confirmed. The present study also verifies Gawthorpe's observations

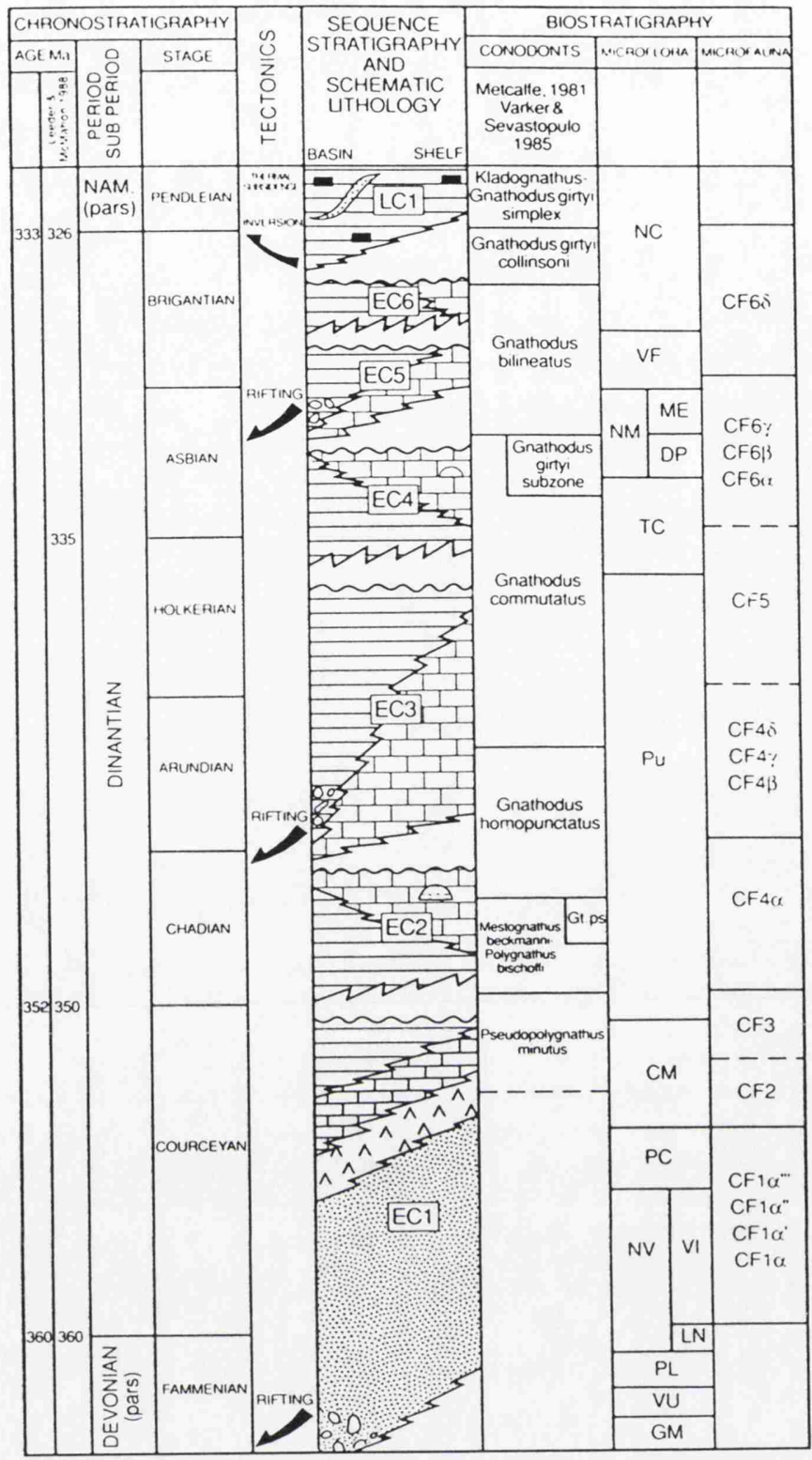

Fig. 9. Dinantian seismo-stratigraphic summary, Widmerpool half graben. Gt ps, Gnathodus texanus pseudosemiglabar Subzone.

that Dinantian basin evolution was pulsed (Gawthorpe 1986 , 1987; Gawthorpe et al. 1989) and suggests that eustasy was not an important factor controlling large scale cyclicity in the Carboniferous.

A preliminary analysis of other Carboniferous basins in northern England (Fraser et al. 1990) has indicated that the three phases of extension noted in the Widmerpool Half Graben are also evident. Though biostratigraphical data are sparse, these tectonic episodes appear to be coeval. Further north, for example in the Northumberland and Cleveland basins (Fig. 2), the tectonically quiescent sequences have a different seismic character due to the proximity of a prevalent clastic source to the north. Carbonate production is completely masked by the build up of deep and shallow water deltas. The six sequences identified herein can, however, be identified on good quality seismic data 
throughout northern England. This suggests fundamental regional tectonic control related to the Variscan orogeny further south.

\section{Conclusions}

The authors suggest that the seismic sequence stratigraphy erected herein may provide a more applicable chronostratigraphical subdivision of the Dinantian strata of the East Midlands and northern England. Further field and subsurface analysis is necessary to confirm these observations in other northern England Carboniferous basins, and may provide the basis for redefinition of the existing stages.

Permission to publish this paper has been granted by the British Petroleum Company plc. We are also grateful to partners, Gas Council (Exploration) and Floyd Oil, for permission to publish seismic data from the East Midlands. Reviews of the manusciipt were provided by $M$. Leeder and $A$. Whittaker. We would also like to thank E. A. Kay, T. P. Bevan, A. Welsh and others who made important contributions to the early part of the study. We also acknowledge helpful discussion with R. Gawthorpe, P. Gutteridge and $\mathrm{A}$. Horbury, who kindly introduced us to their field areas in Derbyshire and the Bowland basin.

\section{References}

BISAT, W. S. 1928. The Carboniferous goniatite zones of England and their continental equivalents. Compte rendue Congres Stratigraphie Carbonifere, Heerlen, 117-133.

Bort, M. H. P. 1967. Geophysical investigations of the northern Pennine basement rocks. Proceedings of the Yorkshire Geological Society, 36, 139-168.

1976. Formation of sedimentary basins of graben type by extension of the continental crust. Tectonophysics, 36, 77-86.

1978. Subsidence mechanisms of Carboniferous basins in northern England. In: MiLer, J., AdAMs, A. E. \& Wrigit, V. P. (eds) European Dinantian environments. John Wiley and Sons, Chichester, 21-32.

- \& Johnson, G. A. L. 1967. The controlling mechanism of Carboniferous cyclic sedimentation. Quarterly Journal of the Geological Society of London, 122, 421-441.

Bridges, P. H. \& Chapman, A. J. 1988. The anatomy of a deep water mud-mound complex to the southwest of the Dinantian platform in Derbyshire, UK. Sedimentology. 35, 139-162.

Burgess, I. C. \& Mrrchell, M. 1976. Visean lower Yoredale limestones on the Alston and Askrigg blocks and the base of the D2 Zone in Northern England. Proceedings of the Yorkshire Geological Society, 40, 613-630.

Cinsilolm, J. E., Mitciell, M., Strank, A. R. E., Cox, F. C. \& Harrison, D. J. 1983. A revision of the stratigraphy of the Asbian and Brigantian limestones of the area west of Mallock, Derbyshire. Report of the Institute of Gcological Sciences, No. 83/10, 17-24.

Clatton, G., Coouel, R., Doubinger, J., Gueinn, K. J., Loboziak, S., OWens, B. \& Streel, M. 1977. Carboniferous miospores of western Europe; illustration and zonation. Mededelingen rijks Geologische Dienst, 29, 1-171.

- Higgs, K., Gueinn, K. J. \& Van Gelder, A. 1974. Palynological correlations in the Cork Beds (Upper Devonian-? Upper Carboniferous) of southem Ireland. Proceedings of the Royal Irish Academy, 74, 145-155.

Conil, R., Longerstaey, P. J. \& Ramsbottom, W. H. C. 1979. Materiaux pour l'ctude micropaleontolgique du Dinantian de Grande-Bretagne. Memoire Institue Geologie, Louvain, 30, 1-187.

COPE, F. W. 1940. Daviesiella llangollensis (Davidson) and related forms. Journal of the Manchester Geological Association, 1, 199-231.

1973. Woo Dale Borehole near Buxton, Derbyshire. Nature, 243, 29-30.

DEWEY, J. F. 1982. Plate tectonics and the evolution of the British Isles. Journal of the Geological Sociery, London, 139, 371-412.

Duniam, K. C. 1973. A recent deep borehole near Eyam in Derbyshire. Nature, 241, 84-85.

\& WILSON. A. A. 1985. Geology of the Northern Pennine Orefield; volume 2. Stainmore to Craven. Memoirs of the Gcological Survey of Grcat Britain. His Majesty's Stationary Office, London.

Earp, J. R., Magraw. D., Poole, E. G.. Lani, D. H. \& Williman, A. J 1961. Geology of the couniry around Clitheroe and Nelson. Memoirs of the Gcological Survey of Great Britain, shect GR. Her Majesty's Stationary Office, London.

FALCON, N. L. \& KENT, P. E. 1960. Geological results of petroleum exploration in Britain 1945-1957. Gcological Socicty, London, Mcmoir. No. 2.

Fewtrell, M. D. \& SMITH, D. G. 1978. Stratigraphic significance of calcareous microfossils from the Lower Carboniferous rocks of the Skipton area, Yorkshire. Geological Magazine, 115, 255-271.

Fraser, A. J., Nash, D. F., Steele, R. P. \& Ebdon, C. C. 1990 . A regional assessment of the intra-Carboniferous play of northern England. In: Brooks, J. (cd.). Classic Petroleum Provinces Geological Socicty, London, Special Publication, 50, 417-439.

GARWOOD, E. J. 1913. The Lower Carboniferous succession in the north-west of England. Quarterly Journal of the Geological Society, of London, 68, 449-596.

GAWTHORPE, R. L. 1986. Sedimentation during carbonate ramp-to-slope evolution in a tectonically active area: Bowland Basin (Dinantian), $\mathrm{N}$. England. Sedimentology, 33, 185-206.

- 1987. Tectono-sedimentary evolution of the Bowland Basin, N. England, during the Dinantian. Journal of the Geological Sociery. London, 144, 59-71.

- Gutteridge, P. \& Leeder, M. R. 1989. Late Devonian and Dinantian basin evolution in northern England and North Wales. In: GurteruDGE, P., Arthurton, R. S. \& Nolan, S. C. (eds) The role of teclonics in Devonian and Carboniferous sedimentation in the British Isles. Yorkshire Geological Society Occasional Publication, 6, 1-23.

George, T. N., Johnson, G. A. L., Mitchel, M., Prentice, J. E., Ramsbottom, W. H. C., Sevastopulo, G. D. \& Wilson, R. B. 1976. A correlation of Dinantian rocks in the British Isles. Geological Society, London, Special Report, No. 7.

Grayson, R. F. \& OLdham, L. 1987. A new structural framework for the northem British Dinantian as a basis for oil, gas and mineral exploration. In: MiLler, J., Adams, A. E. \& Wright, V. P. (eds) European Dinantian Environments. John Wiley and Sons, Chichester, 33-59.

GuTtERIDGE, P. 1987. Dinantian sedimentation and the basement structure of the Derbyshire Dome. Geological Journal, 22, 25-41.

harland, W. B., Cox, A. V., Llewelirn, P. G., Pickton, C. A. G., Smith, A. G. \& WALters, R. 1982. A geologic time scale. Cambridge University Press, Cambridge.

HedberG, H. D. 1976. International stratigraphic guide. Wiley, New York.

Higins, A. C. 1975. Conodont zonation of the late Visean-early Westphalian strata of the south and Central Pennines of Northern England. Bulletin of the Geological Survey of Great Britain, 53, 1-90.

— \& VARKER, W. J. 1982. Lower Carboniferous conodont faunas from Ravenstonedale, Cumbria. Palaeontology, 25, 145-166.

Hudson, R. G. S. \& TuRner, S. 1933. Early and mid-Carboniferous earth movements in Great Britain. Proceedings of the Leeds Philosophcial Society (Science Secrion), 2, 455-466.

Institute of Geological SCiences 1978. IGS Boreholes 1977. Report of the Institute of Gcological Sciences, No. 78/21.

Jolinson, G. A. L. 1967. Bascment control of Carbonifcrous sedimentation in northern England. Proceedings of the Yorkshire Geological Society, 36, 175-194.

KeNT, P. E. 1966. Structure of the concealed Carbonifcrous rocks of NE England. Proceedings of the Yorkshire Geological Society, 35, 323-352.

Leeder, M. R. 1974. Lower Border Group (Tournaisain) fluvio-deltaic sedimentation and the palacogcography of the Northumberland Basin. Proceedings of the Yorkshire Geological Society, 40, 129-180.

- 1982. Upper Palacozoic basins of the British Isles-Caledonide inheritance versus Hercynian plate margin processes. Journal of the Geological Sociery, London, 139, 479-491.

- 1987. Tectonic and palaeogeographic models for Lower Carboniferous Europe. In: Miller, J., Adams, A. E. \& Wrigrt, V. P. (cds) European Dinantian Environments John Wiley and Sons, Chichester, 1-19.

- Falritead, D., Lee, A. G., Stuart, G., Clemmey, H., Green, C. \& AL-HaddeH, B. 1989. The Northumberland Basin: an inverted Carboniferous extensional basin. In: Gutteridge, P., ARTHurton, R. S. \& Nolan, S. C. (eds) The role of tectonics in Devonian and Carboniferous sedimentation in the British Isles. Yorkshire Gcological Socicty Occasional Publication, 6, 207-223

- \& MCMalion, A. H. 1988. Upper Carboniferous (Silesian) basin subsidence in northern Britain. In: BesLY, B. M. \& KELLiNG, G. (eds) Sedimentation in a synorogenic basin complex: The Carboniferous of northwest Europe. Blackic \& sons, Glasgow, 43-52.

Llewellyn, P. G., Backhouse, J. \& Hoskin, I. R. 1969. Lower-Middle 
Tournatian miosperes from the Hathern Anhydrite Series, Carboniferous Limestonc. Leicestershire. Proceedings of the Geological Secierv. London, 1655, 85-91

- \& Siabisins, R. 1968. Demonstration: core material from the Anhydrite Scrics. Carboniferous Limestonc, Hathern Borchole, Leicestershire. Proceedings of the Geological Society. London. 1650, 171-186.

\& Siabins, R. 1970. The Hathern Anhydrite Series, Lower Carboniferous, Lciccstershirc, England. Transactions of the Institution of Mining and Metallurgy. 79B, B1-15.

Macdonald, R., Gass, K. N., Thorpe, R. S. \& Gass, I. G. 1984 Geochemistry and petrogenesis of the Derbyshire Carboniferous basalts Journal of the Geological Society, London, 141, 159.

Metcalfe, I. 1981. Conodont zonation and correlation of the Dinantian and Early Namurian strata of the Craven Lowlands of northern England. Report of the Institute of Gcological Sciences, 80/10.

Miller, J. \& Grayson, R. F. 1982. The regional context of Waulsortian facies in northern England. In: Bolton, K., Lane, H. R. \& Lemone, D. $\mathrm{U}$. (cds) Symposium on the palaeoenvironmental setting and distribution of the Waulsortion facies. The El Paso Geological Society and University of Texas at El Paso, 17-30.

Mitchum, R. M., Vall, P. R. \& Thompson, S. 1977. The depositional sequence as a basic unit for stratigraphic analysis. In: PAYTON, C. E. (cd.) Seismic stratigraphy-applications to hydrocarbon exploration. American Association of Petroleum Geologists Memoir, 26. 53-62.

Neves, R. Gueinn, K. J., Clayton, G., loannides, N. \& Neville, R. S. W. 1972. A scheme of miospore zones for the British Dinantian. Compte Rendue 7me. Congres International Stratigraphie Geologie Carbononifere, Krefield, 1, 347-353.

Parkinson, D. 1944. The origin and structure of the Lower Visean reef-knolls of the Clitheroe district, Lancashire. Quarterly Journal of the Geological Society of London, 99, 155-168.

Pharaoh, T. C. Merriman, R. J., Webi, P. C. \& Beckinsale, R. D. 1987. The concealed Caledonides of eastern England: preliminary results of a multidisciplinary study. Proceedings of the Yorkshire Geological Society, 46, 355-369.

Prentice, J. E. \& Thomas, J. M. 1965. Prolecantina from the Carboniferous rocks of north Devon. Proceedings of the Yorkshire Geological Society, 35, 33-46.

Ramsвotrom, W. H. C. 1973. Transgressions and regressions in the Dinantian: a new synthesis of British Dinantian stratigraphy. Proceedings of the Yorkshire Geological Society, 39, 567-607.

- 1974. Dinantian. In: Rayner, D. H. \& Hemmingway, J. E. (eds) The geological and mineral resources of Yorkshire. Yorkshire Geological Society, 47-73.

- 1981 (ed) Field guide to the boundary stratotypes of the Carboniferous Stages in Britain. Unpublished, Field Guide.

Sмrth, K., Sмгтн, N. J. P. \& Holliday, D. W. 1985. The deep structure of Derbyshire. Geological Journal, 20, 215-225.

SOMERvilie, I. D. \& Strank, A. R. E. 1984a. Discovery of Arundian and
Holkerian faunas from a Dinantian platform succession in North Wales Geological Journal, 19, 85-1(14

- \& Strank, A. R. E. 1984b. Faunal discoveries from Visean limestones of North Wales. Proceedings of the Geological Association, 95, 394-395 - \& Strank, A. R. E. 1984c. The recognition of the Asbian/Brigantian boundary fauna and marker horizons in the Dinantian of North Wales Geological Journal, 19, 227-237.

Strank, A. R. E. 1981. Foraminiferal biostratigraphy of the Holkerian Asbian and Brigantian stages of the British Lower Carboniferous. PhD Thesis, University of Manchester.

- 1985. The Dinantian biostratigraphy of a deep borehole near Eyam. Derbyshire. Geological Journal, 20, 227-237.

- 1986. Foraminiferal biostratigraphy of the Woo Dale borehole. Derbyshire and the age of the Dinantian-Basement unconformity Journal of Micropalaeontology, 5, 1-4

1987. The stratigraphy and structure of Dinantian strata in the East Midlands, UK. In: Miller, J., Adams, A. E. \& Wright, V. P. (eds) British Dinantian Environments John Wiley and Sons. Chichester. 157-175.

Tiddeman, R. H. 1889. On concurrent faulting and deposition in Carboniferous times in Craven, Yorkshire, with a note on Carboniferous reefs. Report of the British Association for the Advancement of Science. Newcastle, 600-603.

VAIL, P. R. \& Mitchum, R. M. 1977. Seismic stratigraphy and global changes of sea level, Part 1: overview. In: Payton, C. E. (ed.) Seismic stratigraphy-applications to hydrocarbon exploration. American Association of Petroleum Geologists Memoir, 26, 51-52.

Varker, W. J. \& Sevastopulo, G. D. 1985. The Carboniferous System, Part 1 - Conodonts of the Dinantian Subsystems from Great Britain and Ireland, In: Higgins, A. C. \& Austin, R. L. (eds) A stratigraphical index of conodonts. British Micropalaeontological Society Series, Ellis Horwood, Chichester, 167-209.

Vaughan, A. 1905. The palaeontological sequence in the Carboniferous Limestone of the Bristol area. Quarterly Journal of the Geological Society of London, 61, 181-307.

WALKDEN, G. M. 1982. Field guide to the Lower Carboniferous rocks of the south east margin of the Derbyshire Block: Wirksworth to Grangemill. Publication of the Department of Geology and Mineralogy, University of Aberdeen.

Welsh, A. \& OWEns, B. 1983. Early Dinantian miospore assemblages from the Caldon Low Borehole, Stratfordshire, England. Pollen et Spores, 25, 253-264.

Wuss, L. J. 1973. A palaeogeographic map of the Palaeozoic floor beneath the Permian and Mesozoic formations in England and Wales. Geological Society, London, Memoir No. 7.

1978. A palaeogeographic map of the Lower Palaeozoic floor below the cover of Upper Devonian Carboniferous and later formations. Geological Society London, Memoir No. 8. 


\section{Appendix G}

Copy of: FRASER, A.J. \& GAWTHORPE ,R.L. 1990. Tectono-stratigraphic development and hydrocarbon habitat of the Carboniferous in northern England. In: HARDMAN, R.F.P. \& BROOKS, J. (eds). Tectonic Events Responsible for Britain's Oil and Gas Reserves, Geological Society Special Publication, 55, 49-86. 


\title{
Tectono-stratigraphic development and hydrocarbon habitat of the Carboniferous in northern England
}

\author{
A. J. FRASER' \& R. L. GAWTHORPE' \\ ${ }^{\prime} B P$ Exploration, 301 St Vincent Street, Glasgow G2 5DD, UK \\ ${ }^{2}$ Department of Geology, The University, Manchester M13 9PL, UK
}

\begin{abstract}
Over 70 ycars of exploration in the Carboniferous of northern England has resulted in the discovery of rather modest recoverable reserves totalling 75 million barrels of oil and 27 billion cubic fect of gas. Nevertheless during this time the petrolcum industry has amassed a substantial quantity of borcholc and scismic information. Integrating this csscntially subsurface databasc with information derived from outcrop studics has permitted a hitherto unachicvable understanding of the Carboniferous in terms of its tectonostratigraphic devclopment and hydrocarbon habitat.

The strong NW-SE and NE-SE structural trends developed in the northern England Carbonifcrous were inherited from the late Palacozoic Calcdonian orogeny. These fault trends were consistently reactivated throughout the Carboniferous in both an extcnsional and compressional sensc. The main influence on Carboniferous basin cvolution in northern England was the Variscan collision-type orogeny. The Variscan plate cycle controlled the development of syn-rift, post-rift and inversion megascquences from late Devonian to early Permian times. Sequences developed within these Carboniferous megasequences are primarily controlled by episodic rifting and periodic fault reactivation with custatic scalevel changes providing only minor control at the subscquence Icvel.

The late Carboniferous-carly Permian culmination of the Variscan orogeny is scen to be the main trap forming event. All hydrocarbon discoveries to date display some clement of Variscan inversion in their geometry. Variscan tectonics have also cxerted a subtle but important control on play fairway cvolution. The main source rocks (pro-dclta shales) arc confined to isolated, syn-rift depocentres. Syn-rift siliciclastic reservoirs are also restricted to the rifted half graben. Carbonate grainstone reservoirs rim the margins of the decper half graben where terrigenous input has becn limited. Delta top channel and mouth bar reservoirs are best developed where they axially infill remnant syn-rift bathymetry.

Mesozoic burial, ensuring hydrocarbon gencration post Variscan trap formation, is, however, the main control on the present day distribution of hydrociarbons in the Carboniferous of northern England. Several key areas where Carboniferous source rocks have gencrated significant hydrocarbons during the Mesozoic have been identified; the East Midlands being the most significant in terms of produced hydrocarbons and perceived future potential.
\end{abstract}

Recent developments in our understanding of the tectono-stratigraphic development of the Carboniferous in northern England (Gawthorpe 1987a, Gawthorpe et al. 1989; Fraser et al. 1990; Kimbell et al. 1989; Ebdon et al. 1990) have been made largely with the use of modern basin analysis techniques, and in particular, the application of sequence stratigraphy. Previous papers have concentrated on subsurface (seis$\mathrm{mic} /$ wells) or surface (outcrop) data to construct a sequence stratigraphic scheme. Our approach integrates outcrop, well and seismic data to produce an integrated sequence stratigraphy for the Carboniferous of northern England. We will argue that the sequences described record tectonic events related to Variscan plate margin processes and that these events exert a fundamental control on the hydrocarbon habitat.

\section{Exploration history}

Over 70 years of petroleum exploration in the Carboniferous of northern England have resulted in the discovery of recoverable reserves totalling $75 \mathrm{mmbbls}$ of oil and $27 \mathrm{bcf}$ of gas. The first discovery was made at Hardstoft in Derbyshire in 1919 (Lees \& Cox 1937) in fractured shelf carbonates of Dinantian age in a tight anticlinal structure. The first significant discovery was made by the D'Arcy Exploration Company in 1939 at Eakring in Namurian delta top channel and mouth bar sandstones with recoverable rescrves of $7 \mathrm{mmbbls}$. Important discoveries have since been made by BP at Beckingham/Gainsborough (13mmbbls oil, 6.5 bcf gas) in 1959 and Welton (over $20 \mathrm{mmbbls}$ oil) in 1981, both in Namurian and carly West- 
phalian A delta top sandstones. In general field sizes have been small with a mean of around 2 mmbbls at a historical finding rate of onc discovery for every four exploration wells. However, low development and production costs continue to make exploration of the Carboniferous onshore an attractive commercial proposition.

\section{Regional structural framework}

\section{Caledonian inheritance}

The structural development of the Carboniferous of northern England has its origins in the Caledonian orogeny (Leeder 1987; Bott 1976; Soper et al. 1987; Coward, this volume). The most recent models tor the ( aledomian orogeny involve a threc platte configuration (Andre e't al. 1986: Soper \& Hutton 1984: Phatroah ef al. 1987). Although the lapetus suture remains the site of the main collision, the Midlands Microcraton has now been re-introduced as a northwards moving indentor which collided with Laurentia during the early Palacozoic.

The Midlands microcraton represents a triangular-shaped terrane comprising relatively undeformed lower Palacozoic platform sediments with the Welsh and East Midlands Caledonides wrapped around the apex (Fig. 1). The strong NE-SE trend of the Church Stretton, Bala and Pendle faults is linked to the underlying grain of the Welsh Caledonides (Fig. 2). The contrasting NW-SE trends, particularly of the Hoton,

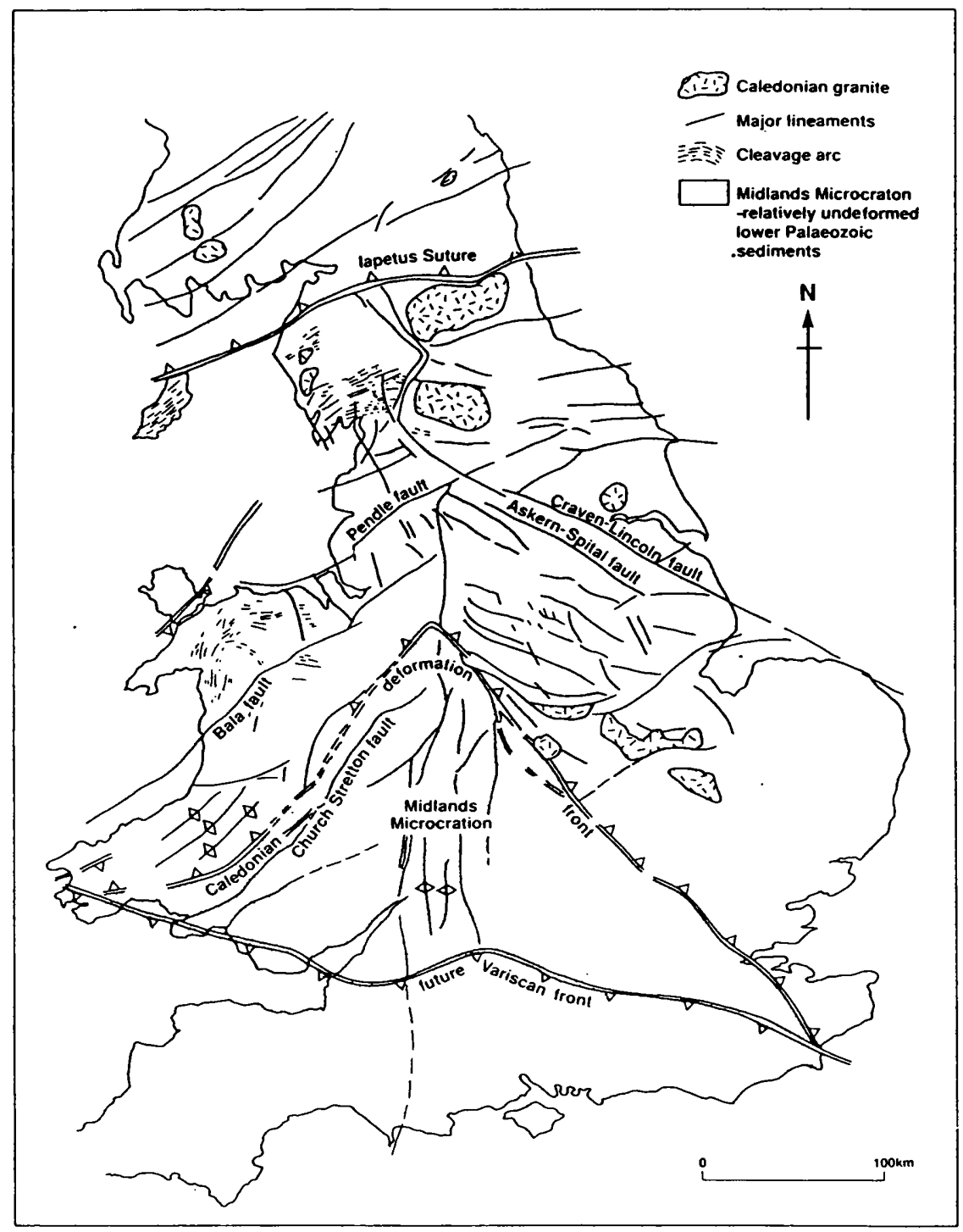

Fig. 1. Calcdonian tectonic provinces of England and Wales (alter Fraser et al. 1990; based on data from Turner 1949. Soper et al. 1987 and Pharoah et al. 1987). 


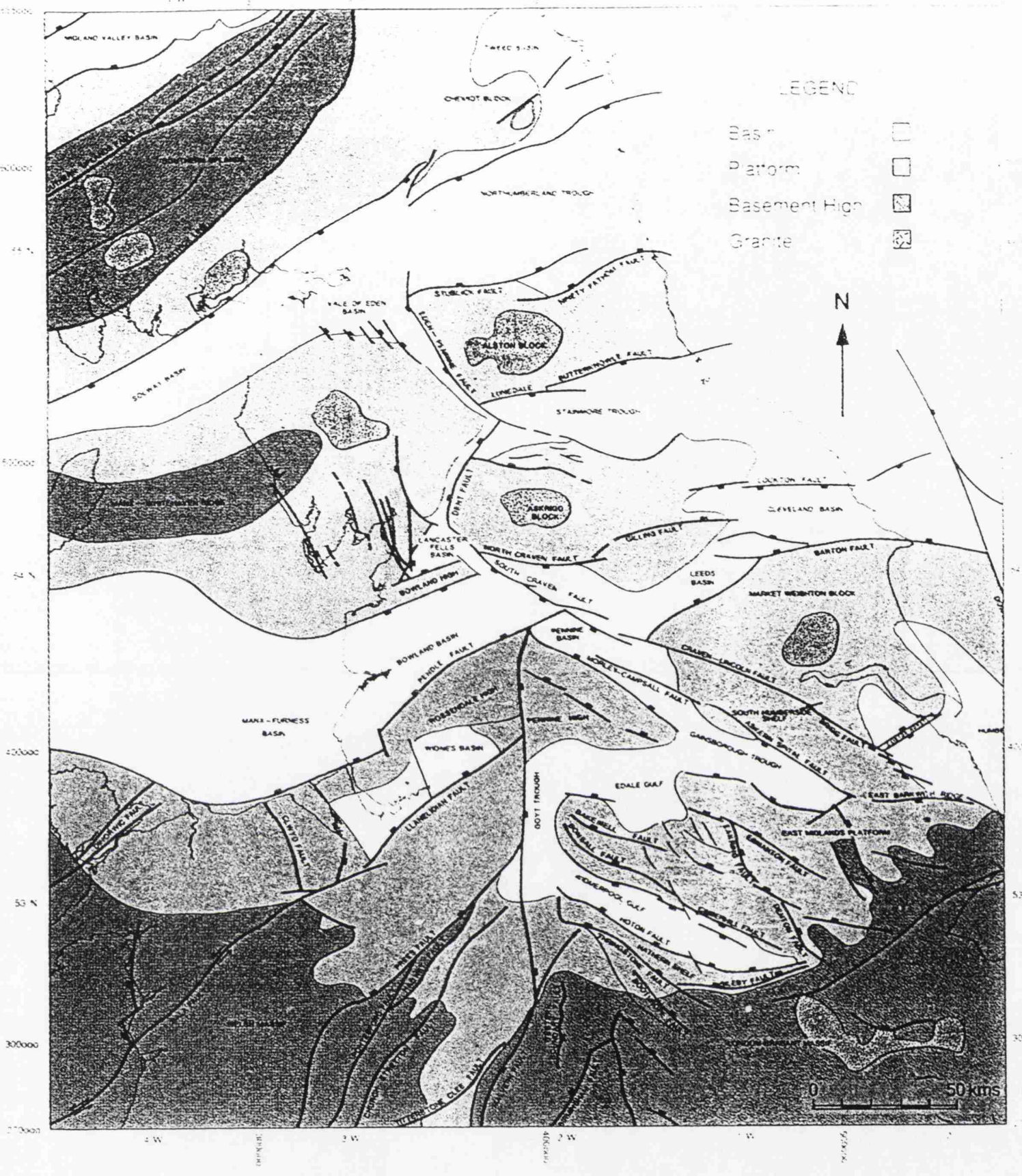

Fig. 2. Dinantian wn-rift structural elements in northern England.

Astern-Spital and (raten-Lincoln fauls in the East Midlands. reflect an underlving deformed Caledonian (Charnian) thrust fold helt (Fig. 2). The tinal clesure of oceans along the lapetus and Tornquist sumes took place in the carly Devonian (Soper et ail lyst). The subsequent late Palaterate and Mesozoce lectonic history of the resion has heen one of continued reactivation of these fundamental facnds in

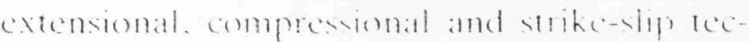
waric resinics
Variscan Plate (irle

The main plate marem process controlling be Carhoniferous struedual development of northern England was the formation of at allision-type orogence hele in the Herian Amori-

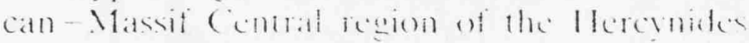
(Lecder 19s7. Mosis). Batch-ate extension was cstathlished to the moth of the orogente bett he

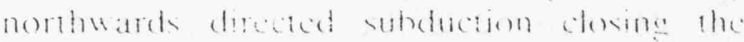
Rhere ()eath. Hithen thes bateare watem. 


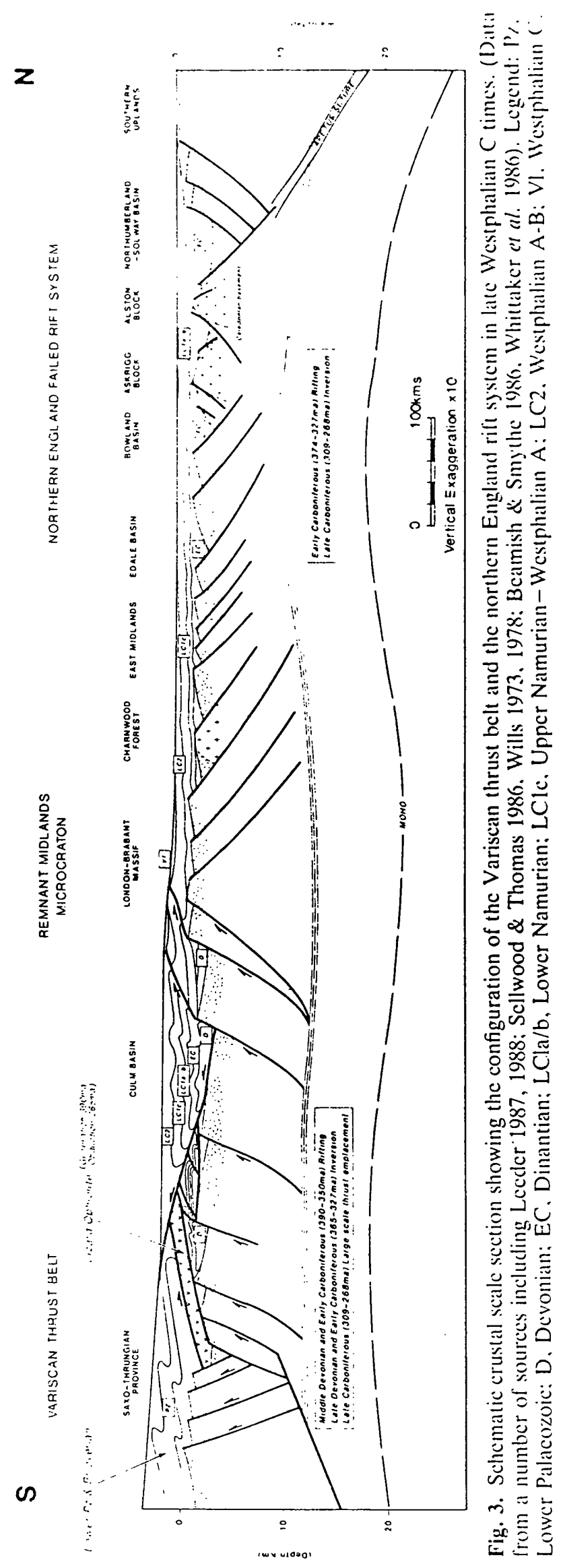




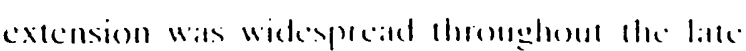
Palacozoic (liag. 3)

The northern England extensional province wals situated some $5(0) \mathrm{km}$ north of the main Rheno-Hercymian hack-arc, separated hy a horst comprising the remnants of the Midlands Microcraton (London-Brabant massif). This province is significantly younger (late Devonian-late Dinantian) than the back-arc basins lying to the south; extension having migrated northwards. possibly subsequent to the onsed of occan foor spreading within the back-are in the late Devonian.

The late Devonian (Frasnian-Fammenian) onset of rifting in northern England initiated a series of linked, half grabens which were the precursors of the Northumberland-Solway. Stainmore. Bowland. Cleveland. Edale. Gainsborogh and Widmerpool basins (Fig. 2). These strongly asymmetric grabens were generated by $\mathrm{N}-\mathrm{S}$ extension acting along a series of $\mathrm{NW}-\mathrm{SE}$ and NE-SW trending faults which were themselves related to zones of earlier Calcdonian structural weakness (cf. Figs $1 \& 2$ ). On depth converted seismic data the border faults appear as planar in section with detachments probably at mid-crustal levels and have similar geometries to major border faults in areas of active extention such as the Aegean and Basin and Range (e.g. Jackson 1987; Stein \& Barientos 1985). Structural wavelength is greater in the NE England structural province where the presence of large Caledonian granitic bodies has maintained regional structural elevation of the Askrigg and Alston blocks (Fig. 2).

Pulsed rifting continued in northern England into the early Brigantian (Fraser et al. 1990) with reactivation of border fault zones of the graben during renewed phases of extension in the late Chadian-early Arundian and mid-late Asbian (Gawthorpe 1987a; Gawthorpe et al. 1989).

Subsidence during the Namurian and Westphalian times was broadly regional and essentially thermally driven. Some fault reactivation did occur during the carly Namurian particularly on the Craven fault system (Bowland Basin) and the Askern-Spital fault (Gainshorough Trough).

The final closure of the Rheic ocean culminated in the Variscan orogeny from Westphalian C to early Permian times. The result of the orogeny was large-scale thrust and nappe emplacement in northern France, southern Belgium and southern England with corresponding crustal shortening on a regional scalc. This shortening must have thickened the Carboniferous lithosphere and crust back up to the

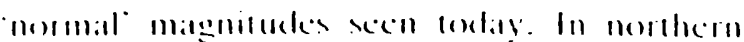
Fengland this wats manstated into inversion of pre-existing Dinantian extensional fatuls which resulted in the crosion of significant amounts of (arhoniferous sediments.

\section{Post-Carboniforous iectonics}

Although not specifically within the remit of this paper, the influence of post-Carboniferous tectonics on the habitat of hydrocarbons within the Carboniferous necds to be addressed. Permian and Mesozoic extension associated with rifting in the Atlantic and Tethyan provinees modified trapping geometrics and controlled the distribution of source rock maturation subsequent to Variscan trap formation. Tertiary uplift and crosion had the effect of freczing source rock generation and caused minor trap modification.

Rifting associated with early attempts to open the north Atlantic throughout the Permian and Triassic generated $E-W$ extension on a series of $\mathrm{N}-\mathrm{S}$ trending faults throughout western England. Existing NE-SW trending Caledonian lineaments were reactivated in a strikeslip sense as transfer faults linking the extensional basin system. Early Jurassic rifting in the Tethyan province resulted in renewed fault movement on NW-SE and $E-W$ trending faults in northern England; for example the Hoton fault (Widmerpool Gulf) and Barton fault (Cleveland Basin) (Fig. 2). North Sea rifting in the late Jurassic and rifting in the Bay of Biscay/Rockall Trough areas in the early Cretaceous led to an important phase of extension throughout southern England which extended as far north as the Cleveland basin. Subsequent late Cretaceous thermal subsidence achieved maximum depths of burial of the Carboniferous over most of northern England.

Regional uplift of the onshore UK as a consequence of rifting between Greenland and Scotland from early Tertiary times induced a $1-2^{\circ}$ easterly tilt on eastern England. An added complication during the Tertiary was the OligoMiocene culmination of the Alpine orogeny, closing the Tethyan ocean. In northern England $E-W$ trending faults such as the Hoton and Barton faults (Fig. 2) were reactivated during this phase of inversion.

\section{Sequence stratigraphic development}

The sequence stratigraphic scheme for the Carboniferous of northern England has been based largely on the interpretation of modern, multifold, reflection seismic data. A threefold sub- 


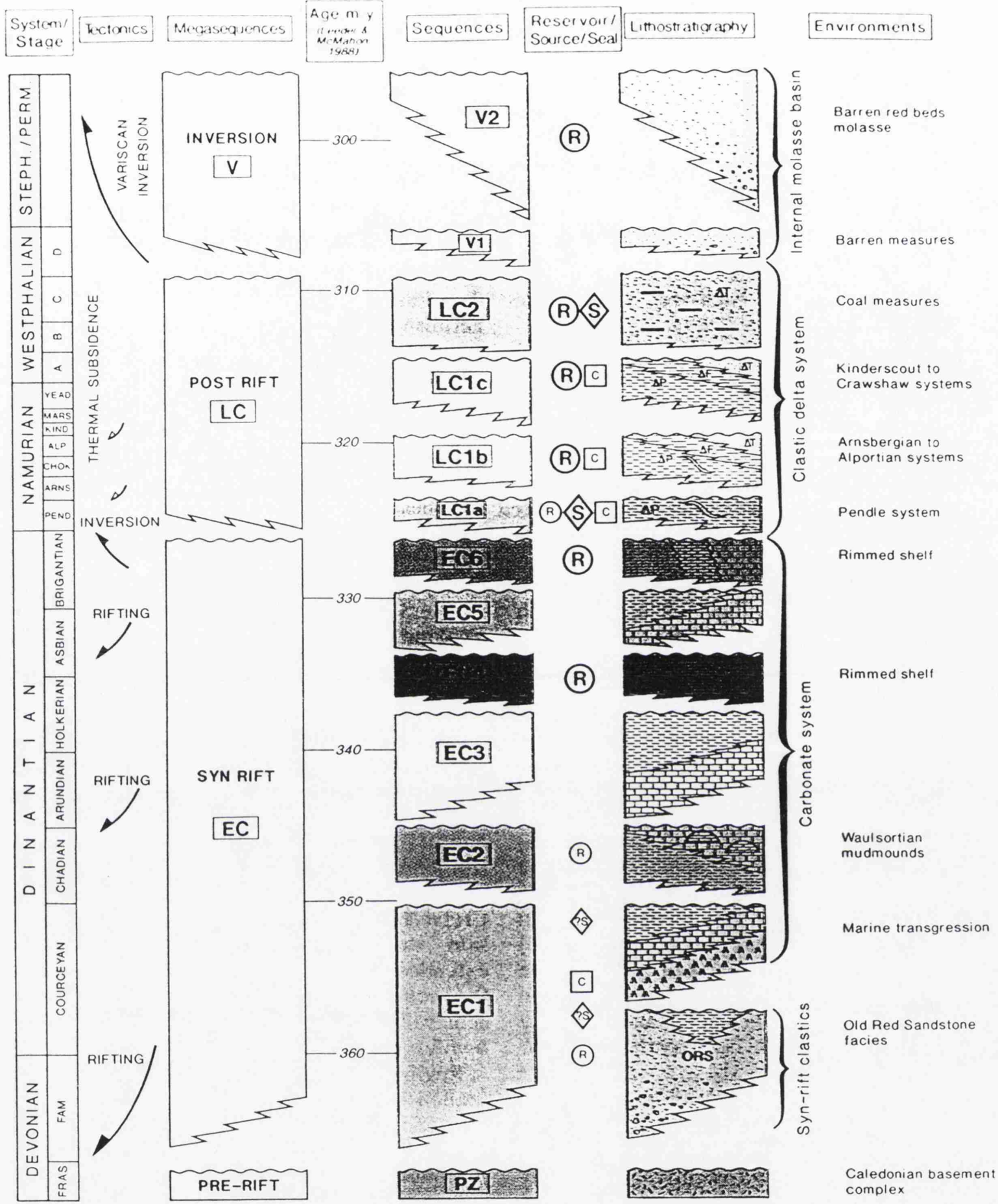

Fig. 4. Summarized stratigraphy of the Variscan plate cycle in the East Midlands showing megasequence and sequence development (modificd from Fraser et al. 1990) $\triangle T=$ delta top. $\Delta F=$ delta front,$\triangle P=$ pro delta

division into plate cycles, megasequences and their constituent sequences is proposed, adapting the methodology of Hubbard et al. (1985a, b). Three megasequences have been identified, which can in turn be broken down into a series of depositional sequences (Fig. 4). These depositional sequences are individual stratigraphic units composed of a relatively conformable succession of genetically related strata and bounded at their top and base by unconformities or their correlative conformities (Mitchum et al. 1977).

There is currently considerable debate regarding the origin of sequence boundaries. Vail \& Mitchum (1977) have emphasized the im- 


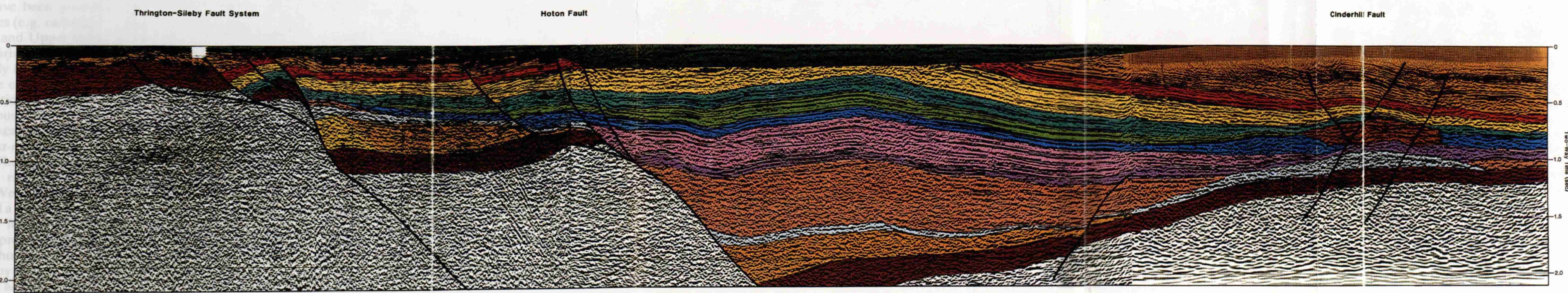

Fig. 5. Composite seismic and interpreted geological section across the Widmerpool Gulf and Hzthern Shelf, East Midlands (after Fraser et al. 1990

W I D M E R P O O

G U L F

A S T

$S$ H E L
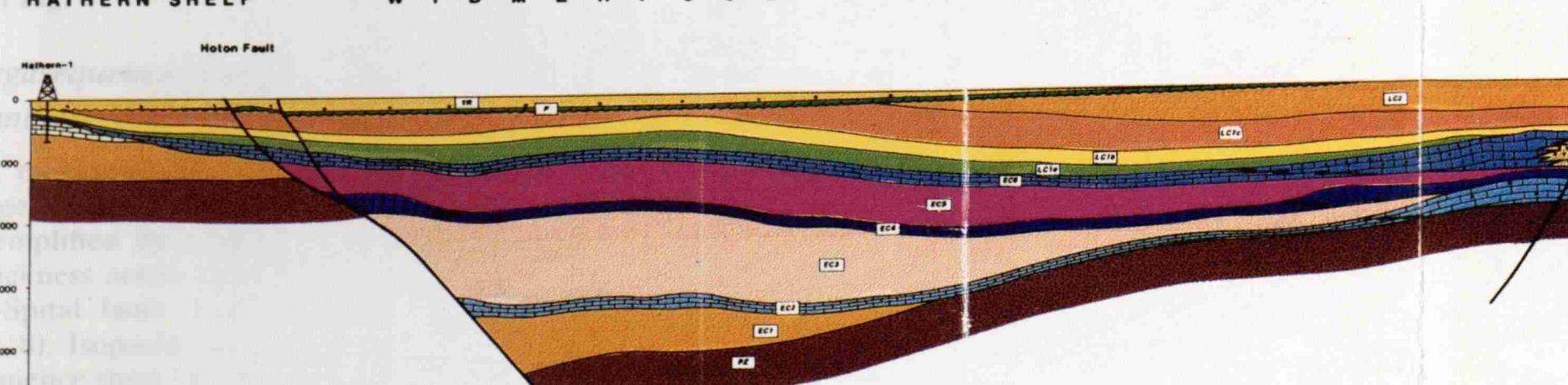

1 7

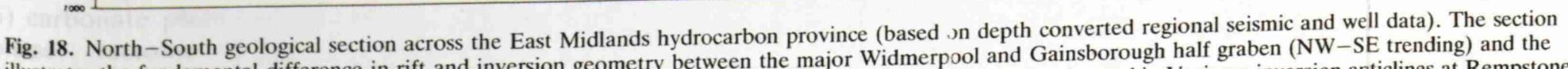

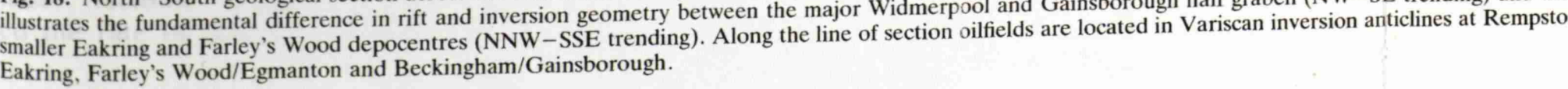


pertance of eustatic seat-level changes as the major control on seyuence development. More recently. Hubbard (19S8) comparing the ages of sequence houndaries from a number of Jurassic-carly Cretaceous passive margins has dismissed eustatic sea-level changes as a primary control and argued that tectonics and more specifically plate margin processes play the most important role. The cyclic nature of the Carhoniferous in northern England has prompted equally active debate along similar lines (see for example Bott \& Johnson 1967; Ramsbottom 1973, 1977, 1981: George 1978). In a sense the problem is one of scale. Boundaries that are likely to have heen produced by eustatic sealevel changes (c.g. carbonate shelf cycles, Yoredale cycles and Upper Carboniferous goniatite bearing, marine bands are typically small scale and can only be delineated at the subsequence level. These events generally occur below seismic resolution for the northern England Carboniferous.

The Variscan plate cycle can be divided into syn-rift, post-rift and inversion megasequences (Fig. 4). These describe: a late DevonianDinantian rift controlled subsidence; a Namurian-Westphalian thermally driven subsidence; and a late Westphalian to early Permian inversion or foreland basin phase. Each megasequence represents an individual basin forming process, although all are ultimately controlled and driven by the evolving Variscan orogeny to the south. The development of the constituent sequences is discussed with particular reference to the Widmerpool Gulf regional seismic section (Fig. 5) and manual backstripping of this line (Fig. 6). A sequence stratigraphic correlation based on generalized sedimentary logs for the East Midlands, Bowland and Stainmore is presented in Fig. 7.

\section{Syn-rift megasequence (late Devonian- early Brigantian)}

The syn-rift megasequence exhibits a characteristic wedge shaped geometry (Figs 5 \& 8) which is exemplified by a fourfold increase in sediment thickness across the northern bounding Askern-Spital fault of the Gainsborough Trough (Fig. 8). Isopachs for the upper part of this megasequence show the thickest sections to be confined to the individual fault bounded half graben (Fig. 9a).

Two main syn-rift depositional systems can be identified (Fig. 9b); (i) clastic fluvio-deltaic and (ii) carbonate platforms. During the synrift phase, tectonic subsidence generally exceeded the rate of sediment supply to the hasins and the elastic dellas remanded eonfined to the north of the region. As a consequence, the south of the areat hecame sediment starved and carbonates accumulated on the platform areas with the development of rimmed shelf margins on both the footwall crests and hangingwall dipslopes of the deeper hasinal areas. The half graben were themselves infilled by predominantly fine grained, hemi-pelagic, clastic deposits.

Sequence ECI (late Devonian-early Chadian). Syn-rift 1 - fault controlled subsidence and initial development of the half graben. The sequence shows a characteristic wedge shaped geometry thickening into the horder faults. The base shows a progressive onlap onto Lower Palacozoic basement of the hangingwall dipslope. The top of the sequence is marked by a laterally continuous, high-amplitude reflector (Figs 5, 8 $\&$ 10). The internal character is of lowamplitude, laterally discontinuous events.

The initial syn-rift clastics ('Old Red Sandstone' facies) are poorly exposed at surface and are generally of local derivation, related to valley-fill processes. By analogy with other desert rift-basins (Leeder \& Gawthorpe 1987) downlapping alluvian fan and fan-delta depositional systems are likely to be derived laterally from the footwall and hangingwall basin margins. The early syn-rift clastics proven by the Eakring-146 well (Falcon \& Kent 1960) and the Whita and Annan Sandstones in the Northumberland Basin (Leeder 1974) represent examples of localized footwall-derived, and more sheetlike hangingwall-derived fan systems respectively.

The upper part of the sequence is characterized by onlap of the pre-rift sediments by carbonates and evaporites following the initial marine transgression into the rift system during the Courceyan. The sparse well penetration and poor seismic resolution of this sequence precludes any further breakdown of this interval at present.

Sequence EC2 (mid-late Chadian). Post-rift I still stand or regressive phase characterized by carbonate ramp to rimmed shelf development. The sequence comprises high amplitude, laterally persistent reflectors which thicken up-dip along the hangingwall dipslope where hummocky downlapping clinoforms are identified (Fig. 5). In the Bowland Basin the sediment fill at this time is dominated by clean carbonate facies with shallow ramp grainstone shoals high on the hangingwall dipslope passing southward into deeper water wackestones/packstones 
Present Day

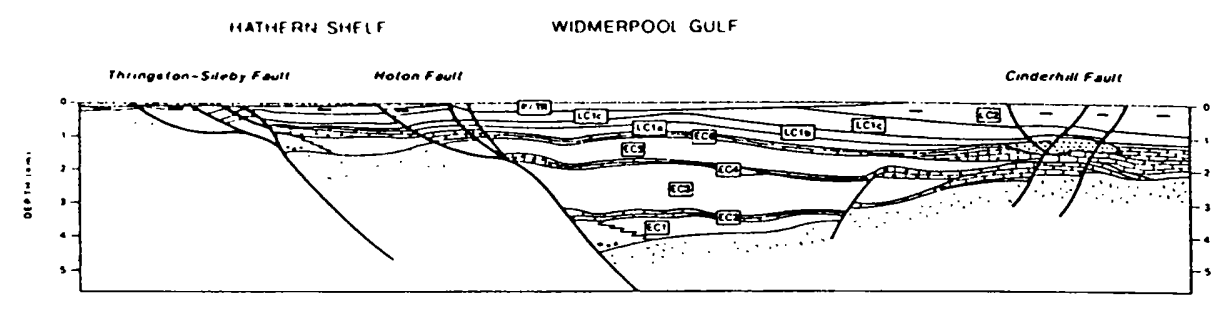

Early Westphalian 'A' - Early Westphaliar: 'C' (LC2) Post-rift II

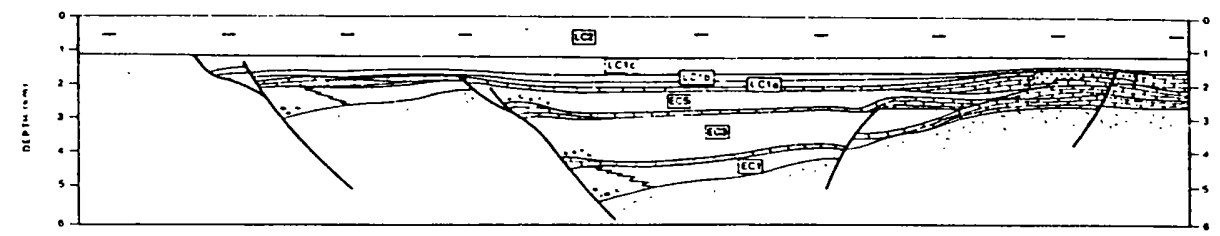

Late Brigantian - Early Westphalian 'A' (LC1) Post-rift I

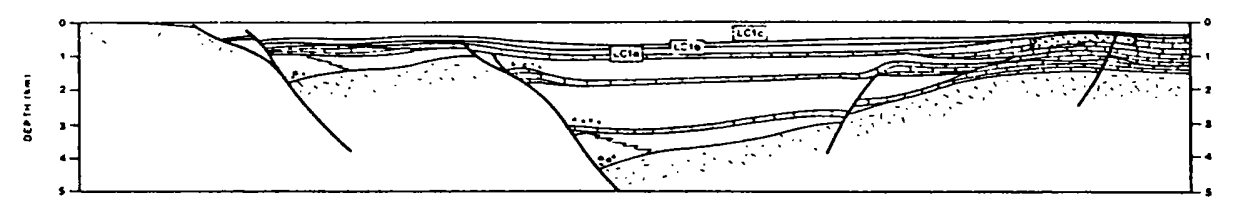

Early - Mid Brigantian (EC6)

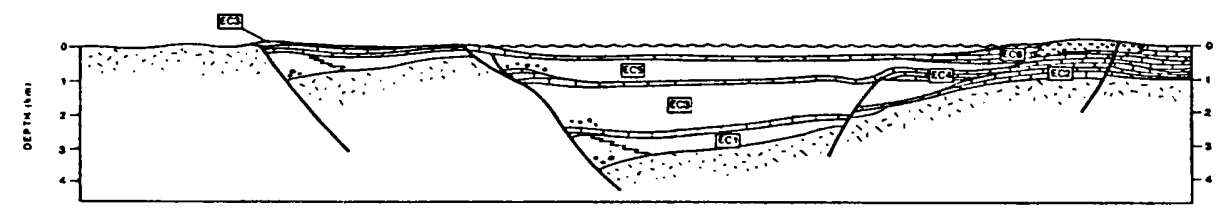

Late Asbian - Early Brigantian (ECS) Syn-rift III

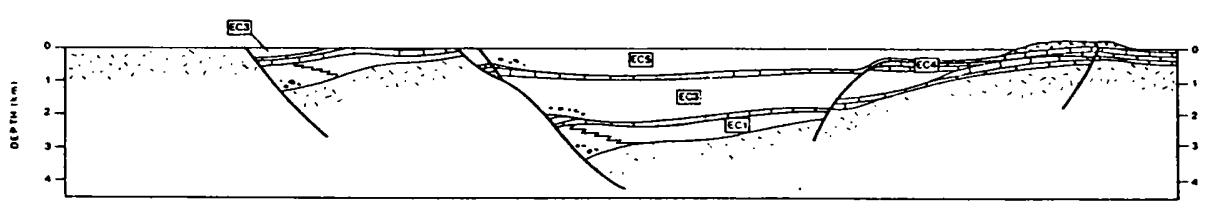

Fig. 6. Devono-Carbonifcrous basin development: Widmerpool Gulf and Hathern shelf. East Midlands (adapted from Ebdon et al. 1990).

towards the Pendle fault. Waulsortian buildups are well developed in these deeper ramp environments.

Sequence EC.3 (Arundian-early Holkerian). Syn-rift II - reactivation of extensional faults causing fault block rotation and significant footwall erosion. The onset of the sequence is characterized by the development of boulder beds and siumps (event deposits; see Gawthorpe \&
Clemmey 1985, Gawthorpe et al. 1989) in the hangingwall and the rapid drowning of carbonate shelf margins in the East Midlands and Bowland as carbonate production was unable to keep pace with sea level rise. In the north of the province the Fell and Ashfell fluvio-deltaic systems were deposited in the Northumberland Basin and Stainmore Trough respectively during this time (Fig. 7). The progressive onlap of the pre-Arundian topography culminated in the 
Late Holkerian - Mid Asbian (EC4)

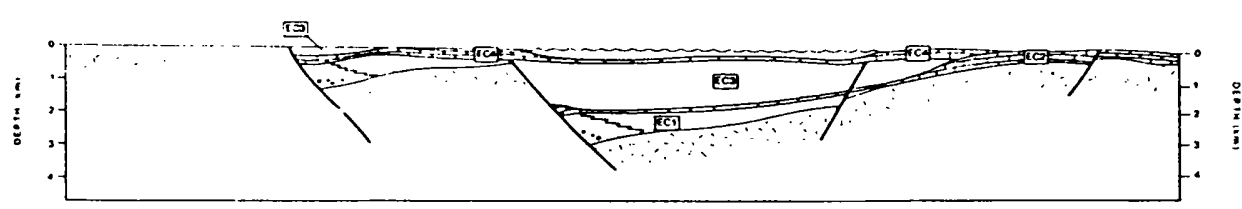

Late Chadian - Late Holkerian (EC3) Syn-rift II

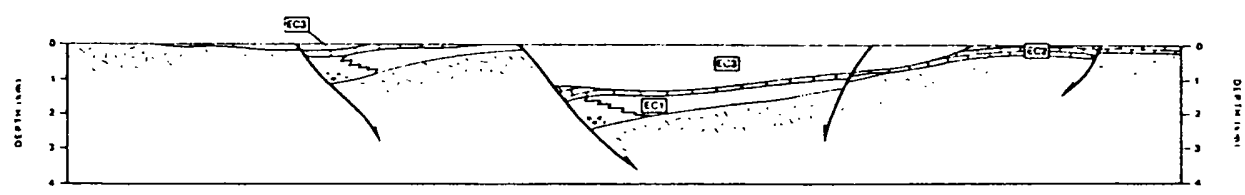

Chadian (EC2)

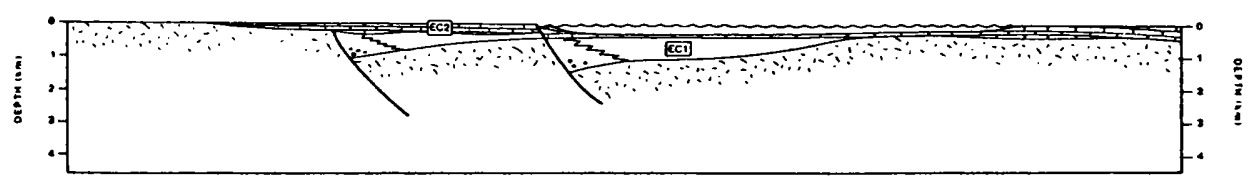

Late Devonian - Courceyan (EC1) Syn-rift I

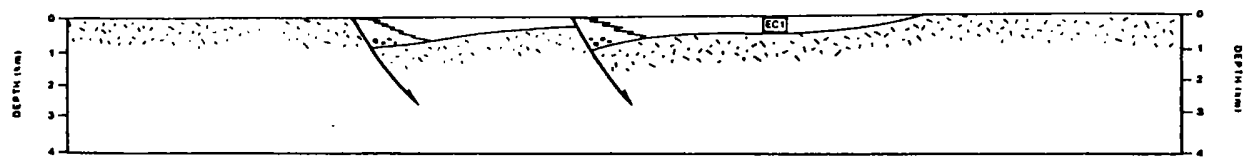

LEGENO

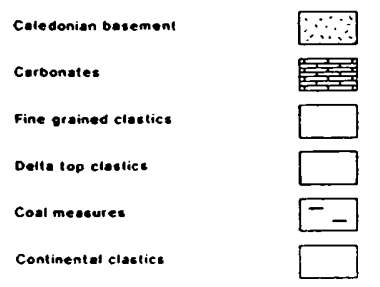

Scale : Morizontsi=verticst

maximum transgression of carbonate platforms in northern England during the Holkerian (Strank 1987). The sequence shows a characteristic wedge shaped geometry and represents the most significant rift pulse, in terms of time and thickness, during the syri-rift megasequence. The hase of the sequence shows a progressive onlap onto the underlying EC.2 sequence (Figs 5, \& \& 10). Internally, the sequence consists of low-amplitude, highfrequency events which progressively onlap the hangingwall dipslope. Figure 11 a shows boulders of proximal ramp and Waulsortian carbonates derived from footwall erosion of the South Craven fault system at the onset of EC3 rifting. These were deposited contemporancously with and overlain by the Worston Shale Formation, a predominantly mud and silt grade clastic 


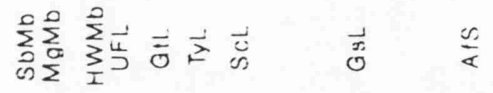

爱

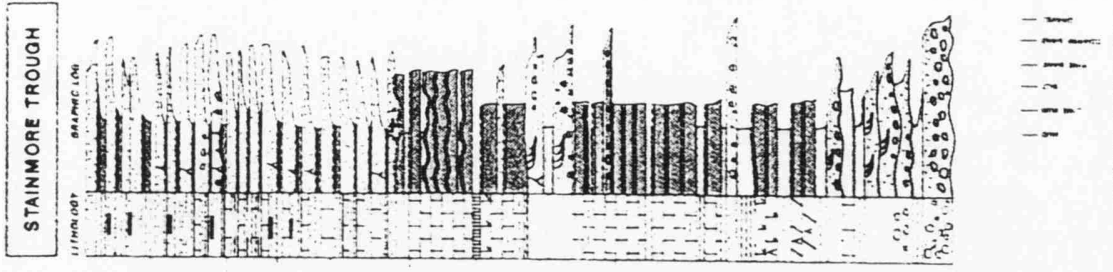

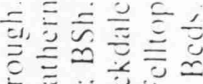

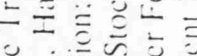

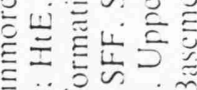

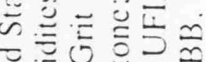

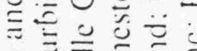

言要要

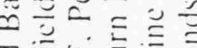

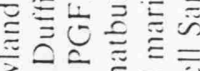

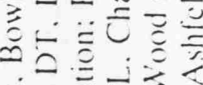

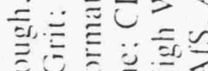

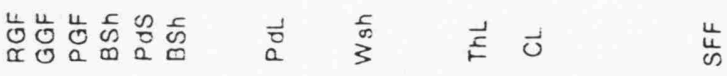
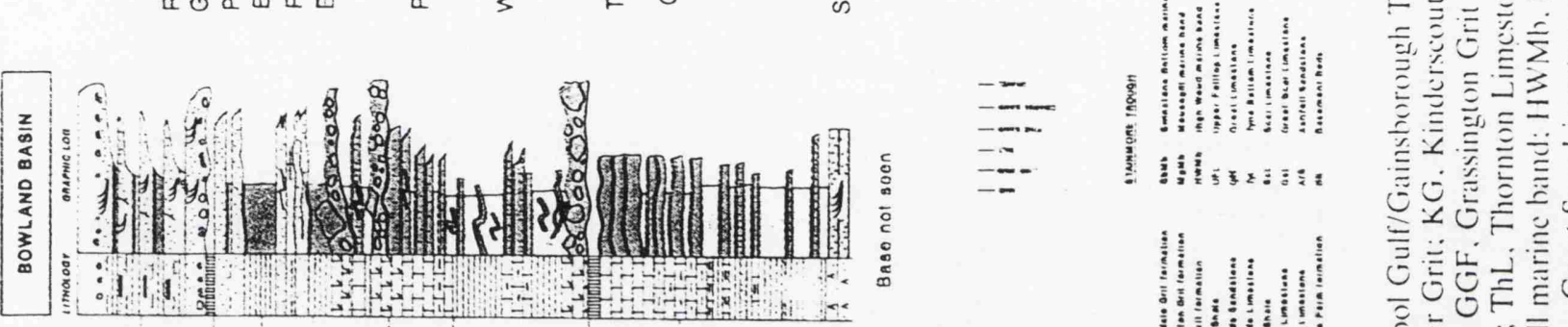

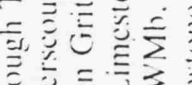

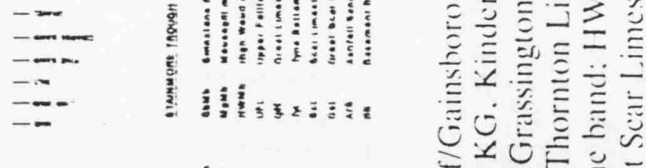

IIIII IIIIII

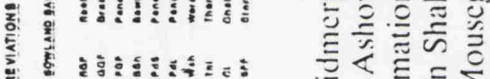
V) 30 远

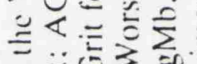

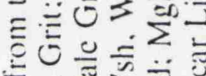

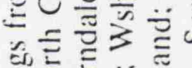
क力

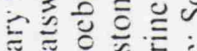

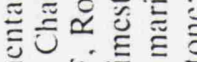
言记它言

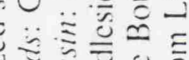

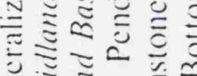

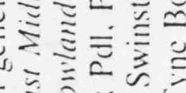

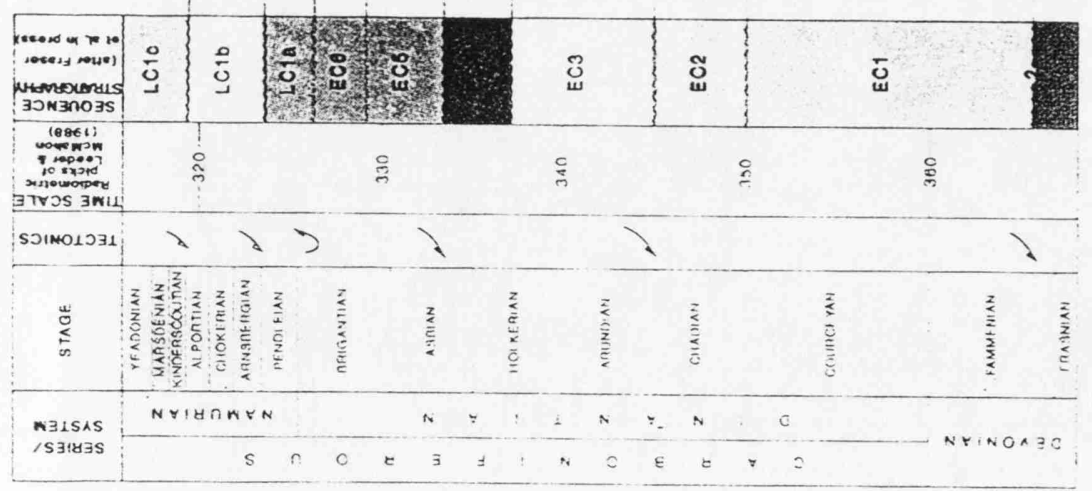



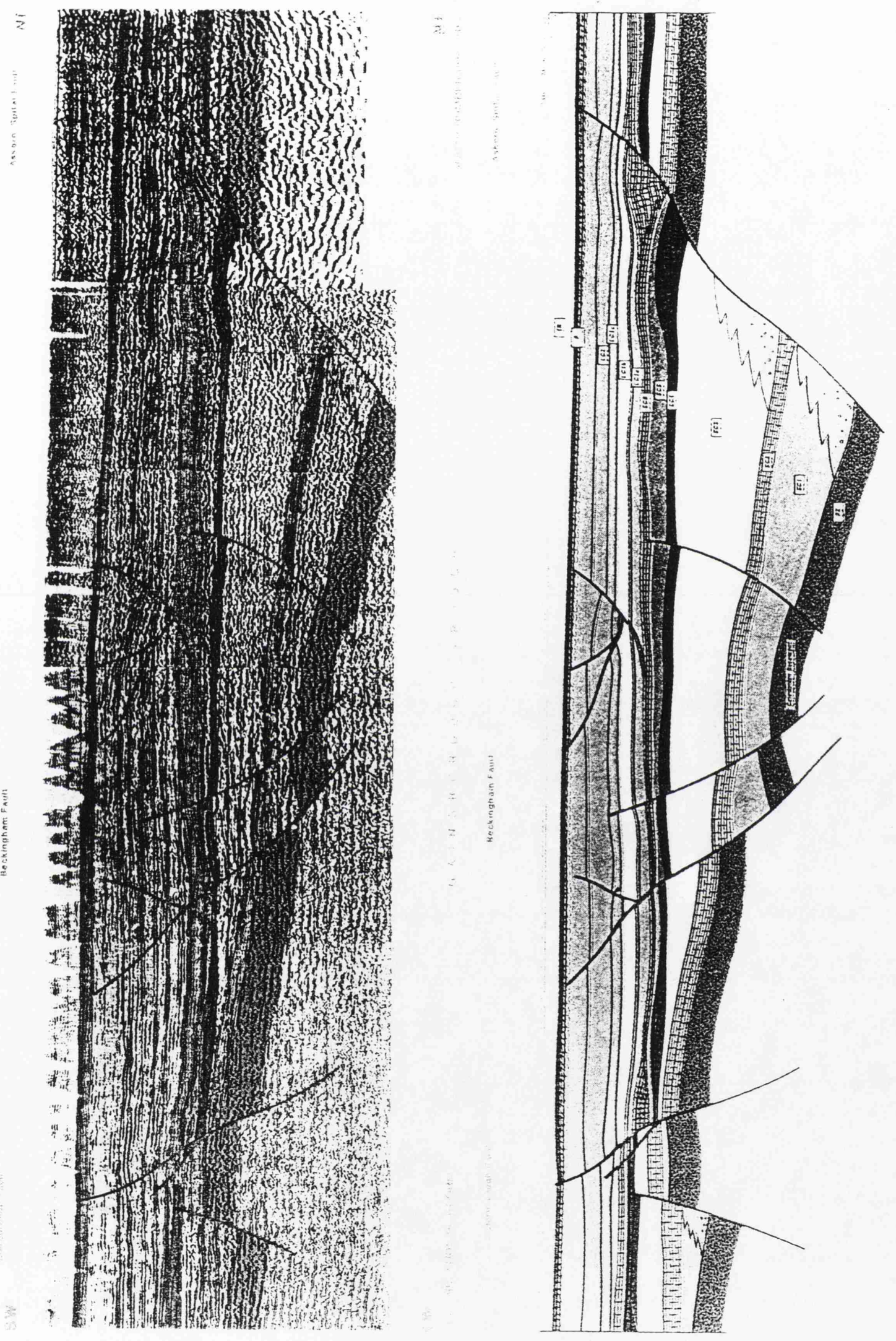


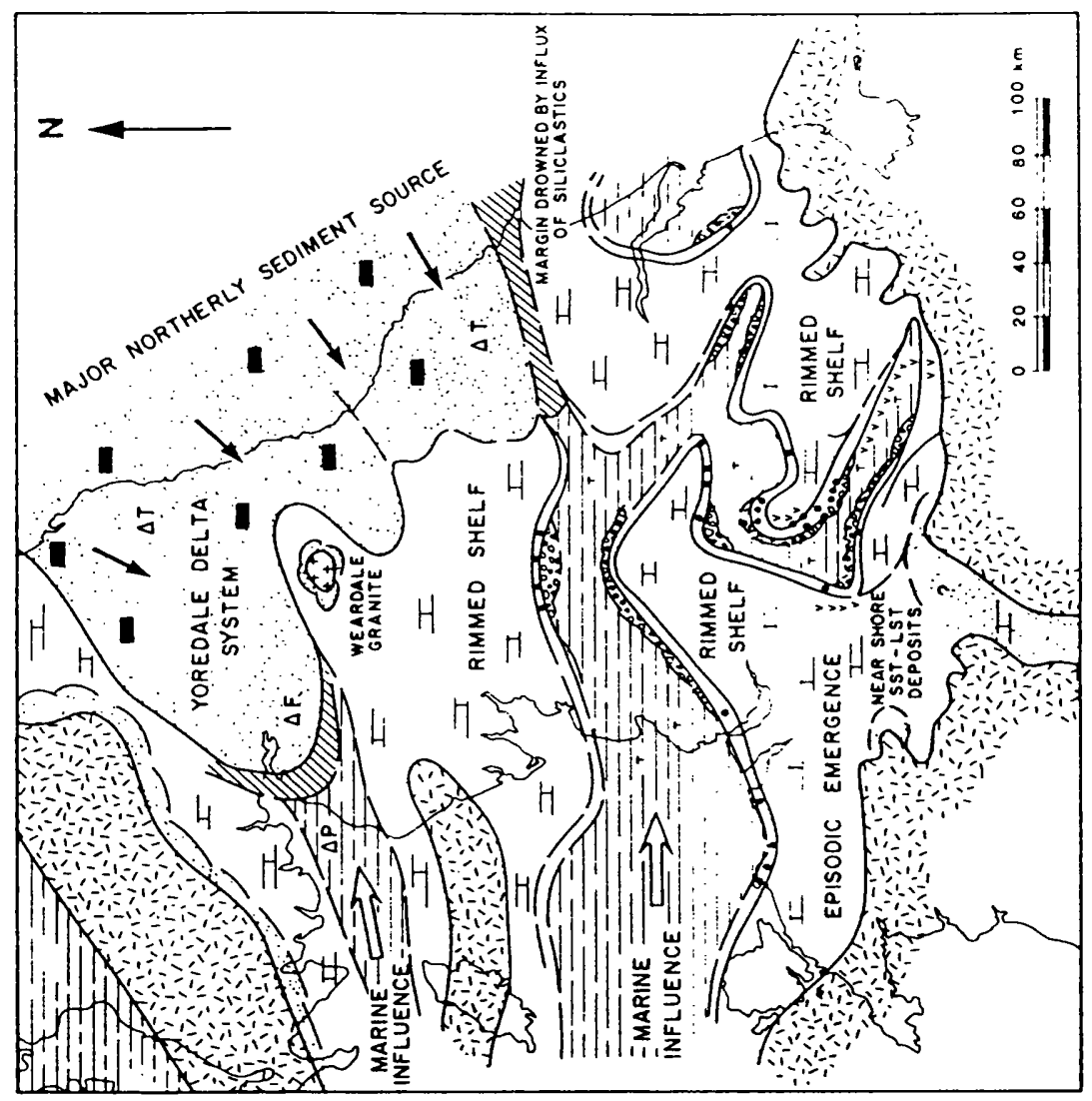

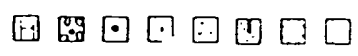
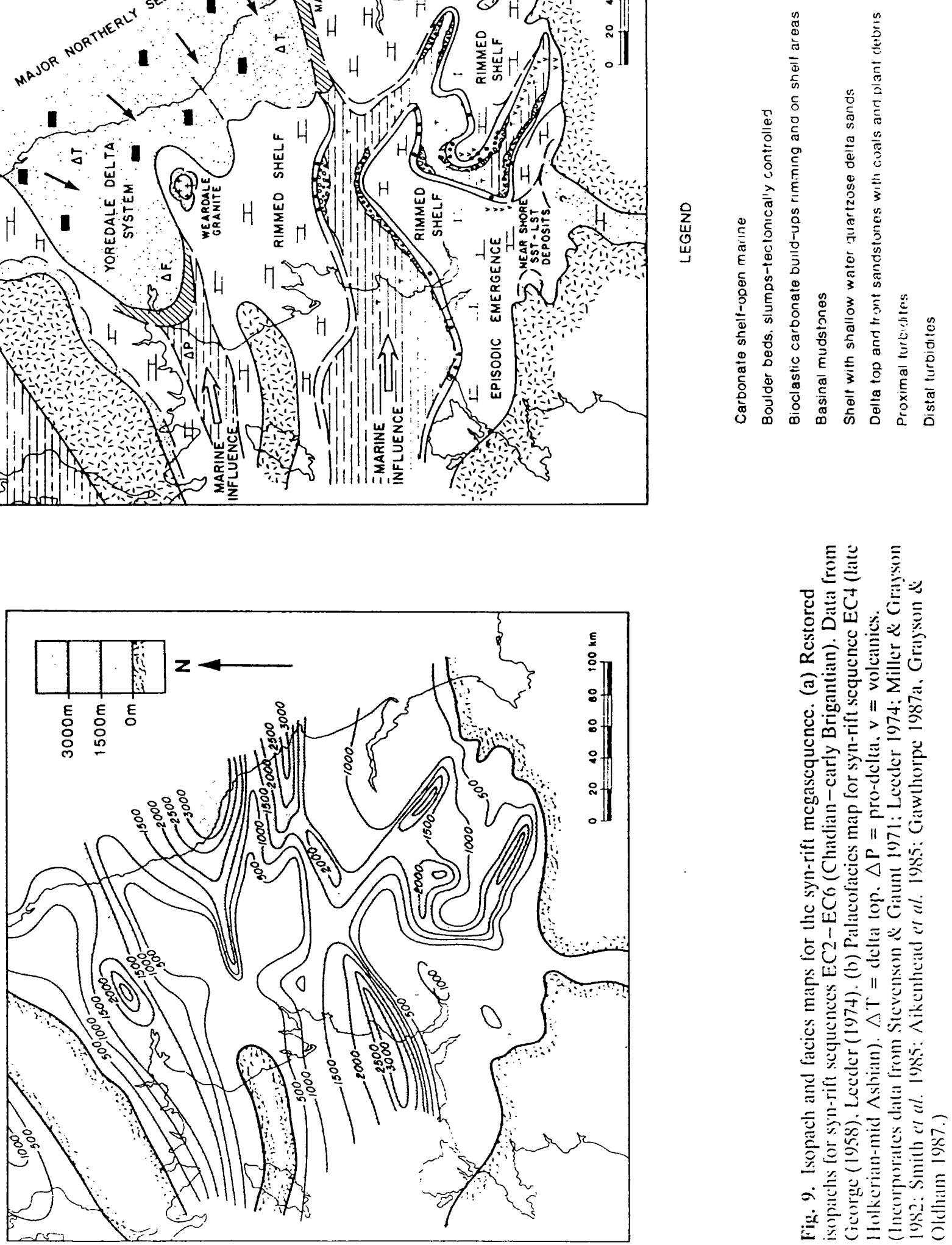
cleposit with thinly interbededed hemipelagics and distal calciturbidites, which forms $\mathrm{FC} \cdot 3$ in the Bowland Basin (Fig. 7). During the rifting phase periodic instability of the hangingwall dipslope led to the generation of syn sedimentary slumps and slides in sediments of EC.3 age (Fig. 11b).

Sequence EC4 (late Holkerian-mid Asbian). Post-rift II - still stand or regressive phase characterised by carbonate ramp to rimmed shelf development in the East Midlands and Bowland. Here the sequence shows a marked thickening onto shelf areas (Fig. 5). In the basinal setting, EC4 comprises high amplitude, low frequency laterally continuous reflectors. Along fault scarps the sequence comprises high amplitude, low-frequency, high-angle reflectors which represent vertically and laterally accreting clinoforms. Along the hangingwall dipslope the sequence is largely characterless but in places high-amplitude, low-frequency downlapping clinoforms are identified prograding hasinwards onto EC3 (Fig. 5). A sub-EC4 unconformity evidenced on seismic in Stainmore may be indicative of a late Holkerian basin inversion event perhaps coincident with the cessation of EC3 rifting (Fig. 10b). A similar angular unconformity can also be identified in the Widmerpool Gulf (Fig. 5).

In areas of shallow water, starved of siliciclastic sediment, shoaling upward cyclic shelf carbonates were deposited; for example the Great Scar Limestone and equivalents in western Stainmore and on the Alston and Askrigg blocks (Fig. 7). In the East Midlands and Bowland, these shelf carbonates pass basinwards through platform margin facies into hemipelagic lime mudstones and calciturbidites of the foreslope. This carbonate slope facies association shows a coarsening upward trend reflecting progradation of the rimmed shelf.

Sequence EC5 (late Asbian-carly Brigantian). Syn-rift III - reactivation of the extensional fault regime with significant backstepping of the fault system in the Widmerpool Gulf where EC5 is well developed. By comparison, extension was milder during this phase in the Gainsborough Trough (cf. Figs 5 and 8). Elsewhere in the East Midlands and Bowland the extensive EC4 carbonate margins ivere drowned. Renewed footwall rotation resulted in strong erosional unconformities on the footwalls of the Hoton fault (Widmerpool Gulf; Fis. 12) and Craver fault (Bowland Basin) and the development of boulder beds and slumps in hanginguall settings. The sequence exhibits the characteris-

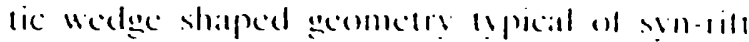
packages. Intemally the seyucnec comprises low-amplitude, high-frequency reflectors which progressively onlap the hangingwall dipslope.

Volcanics related to the rencwed extensional activity during EC.5 (late Ashian to earlicst Brigantian age) have been described from outcrop in Derhyshire; Lower and Upper Millers Dale lavas (Walkden 1977: Walters \& Ineson 1981: MacDonald et al. 1984). These hasalts are associated with a series of NW-SE trending faults (Cinderhill fault system) which bound the northern margin of the Widmerpool Gulf. Basaltic lavas and tuffaceous horizons of similar age have been encountered in exploration horeholes in the East Midlands along the same trend.

Regional stratigraphic correlation demonstrates considerable facies variations between the individual half grabens during EC.5 (Fig. 7). The Widmerpool and Gainshorough Basins were receiving fine-grained clastic material and distal calciturbidites. The sequence in Bowland is dominated by the incoming of distal prodelta facies from the north (Lower Bowland Shale). In Stainmore, where shallower water conditions prevailed close to the clastic source, the onset of cyclic Yoredale sedimentation is apparent (Johnson 1960). The EC4/EC5 sequence boundary can be observed at outcrop in the northern part of the Bowland basin (Fig. 11c). As a means of demonstrating the link between the outcrop and seismic expression of sequence boundaries, the equivalent location on the Widmerpool Gulf regional seismic line is highlighted on Fig. 12. Strong erosional truncation on the footwall of the Hoton fault resulted in a marked angular unconformity on the Hathern shelf between ECl and EC6 due to footwall uplift and erosion as a result of EC5 rifting. The erosional debris of this event (presumably shelf carbonates as in Fig. 11c) is represented by discontinuous high-amplitude, low-frequency events at the base of the EC.5 sequence within the hangingwall (Fig. 12). These are overlain by hemipelagic lime mudstones comprising the remainder of the EC.5 sequence, which has generated the observed seismic irupedance contrast. These boulder beds may have some significance as potential reservoirs due to secondary porosity generation during burial diagenesis (Gawthorpe 1987b). This secondary porosity development can often be associated with hydrocarbons (Fig. 11d).

Sequence ECo (early-mid Brigantian). Post rift III - basin inversion event resulting in a marked regressive phase over northern 
N

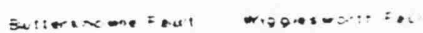

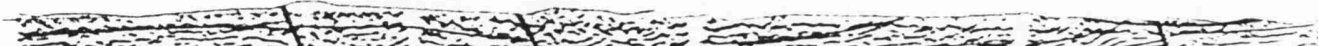
(1)

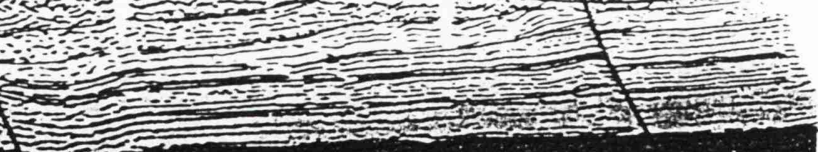

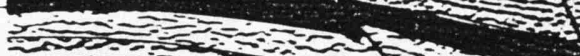

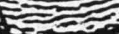
Non
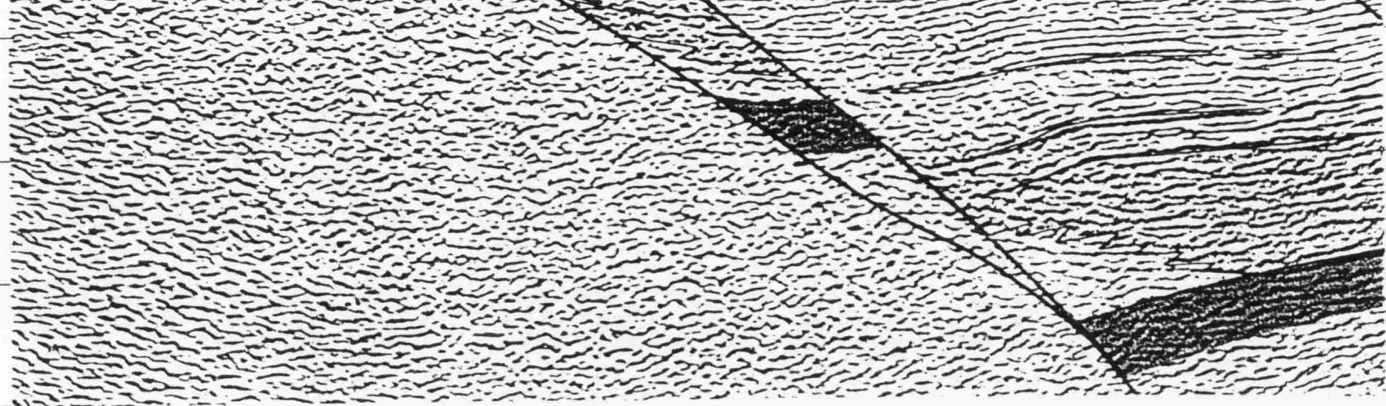

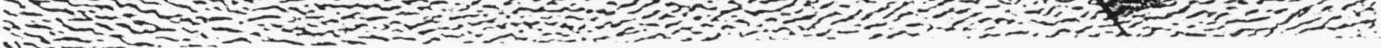

N

ALSTON BLOCK

STANNURE TROUGH

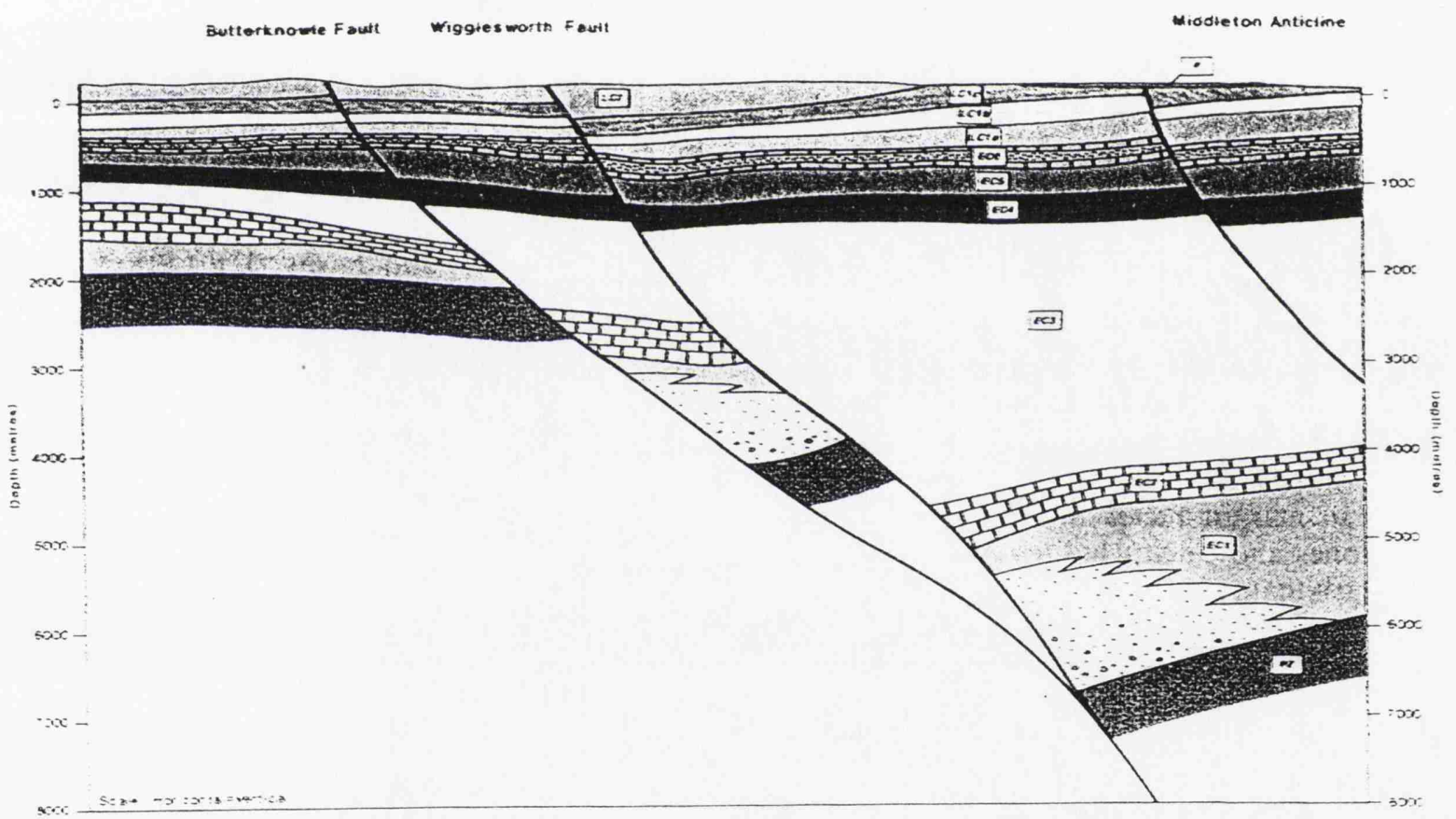

England. Scismic data from the Egmanton oilficld in the East Midlands (Fig. 13) shows an erosional unconformity in the hangingwall of the fault controlling the structure. This is inter preted as inversion of the original listric normal fault in the carly-mid Brigantian and is apparently contemporantous with thrust and nappe emplacement in southwest England (Sellwood \& Thomas 1986). The sequence is characterized bvearhonate ramp to rimmed shelf development in the Widmerpool Ciulf. (iamshorough Trough and Edale (iulf where water depth differences of up to $5(x)$ metres were established between shelf and hasin. The sequence thickens markedIy onte shelf areas. The hase of the sequence exibits downlap onto EC along the hangingwall dipslope, hecoming sub-parallel with EC inte) the hasin (Fie. 5). Internally the E(6 shelf mateins are comprised of complex ohliquesigmoid, high-amplitude, low-frequency clino- 


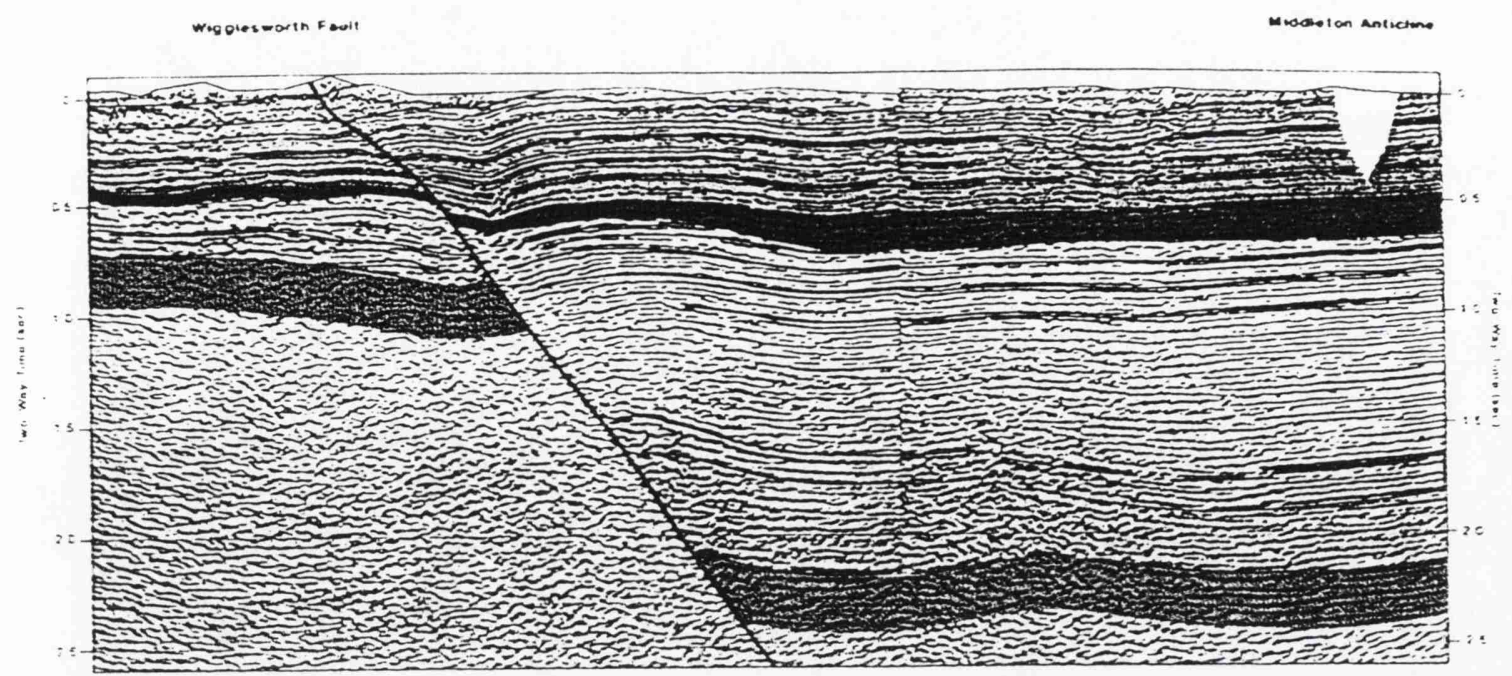

ALSTON BLOCX

SIALNMRE TROUGH

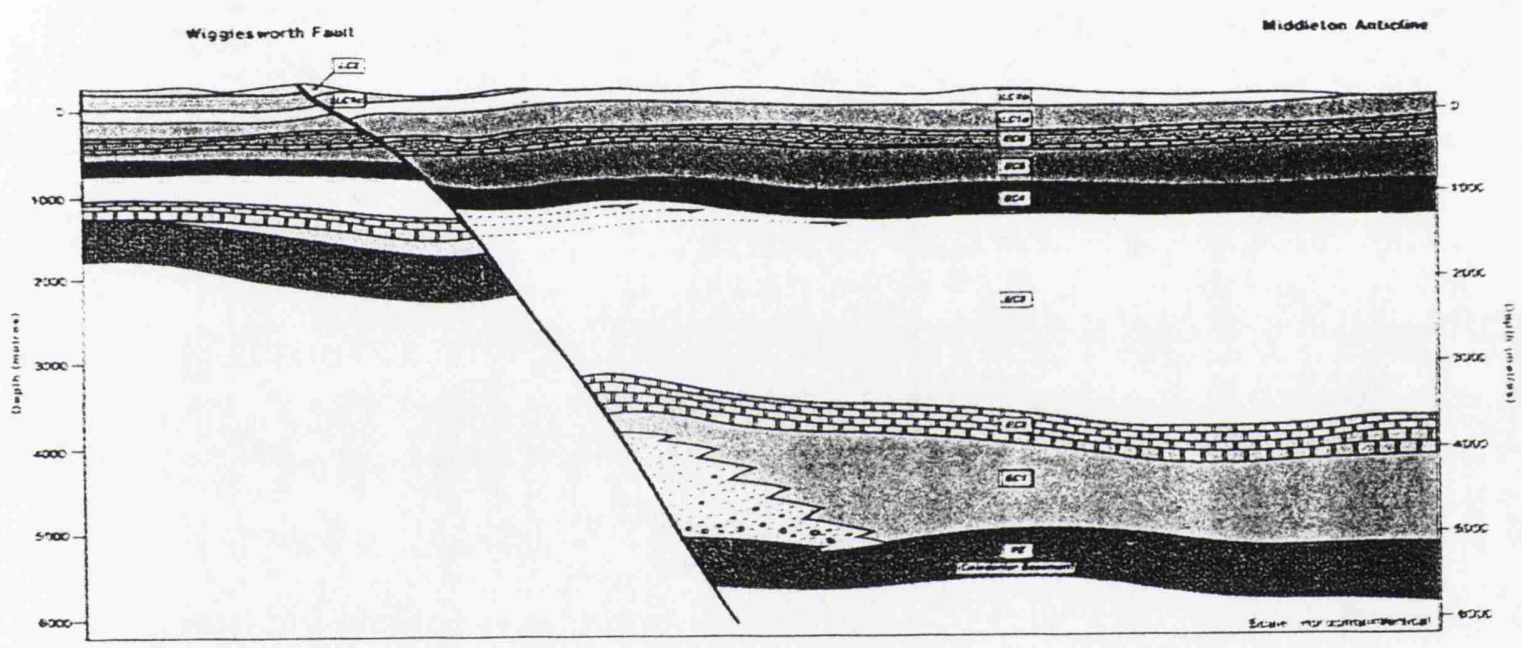

Fig. 10. Composite seismic and interpreted geological sections across western Stainmore. Surface geology based on Mills \& Hull (1976). Burgess \& Holliday (1979) and BGS solid geology sheets 31-Brough-underStainmore and 32-Barnard Castle.

forms (Fig. 5) which pass basinwards into high frequency parallel events. Mounded features up to $0.5 \mathrm{~km}$ across have been ohserved on the Hathern Shelf (Fig. 12). These are prohably analogous to the Brigantian mudmounds of the Coalhills eomplex in Derbyshire (Waltiden 1982).

During EC6 the Pendle delta system prograded southwards resulting in the deposition of siliciclastic turbidites (Pendleside Sandstone) in Bowland, effectively precluding further carbonate production in the basin (Fig. 7). Cyclic, shallow marine Yoredale sedimentation continued in Stainmore. The disconformity between the individual Yoredale cucles can be ohscrved at outcrop but as they occur at a frequency below seismic resolution the regional significance of the individual events cannot be assessed.

\section{Post-rift megasequence llate Brigantian- late Westphalian $C$ )}

Scismic data shows the post-rift megasequence to have been deposited regionally across northern England (Figs 5, \& \& 1(1). Isopachs for the post-rift section exhibit a classic bullseye pattern interpreted by Leeder (1982) as resulting from a phase of passive thermal subsidence (Fig. 14a). 

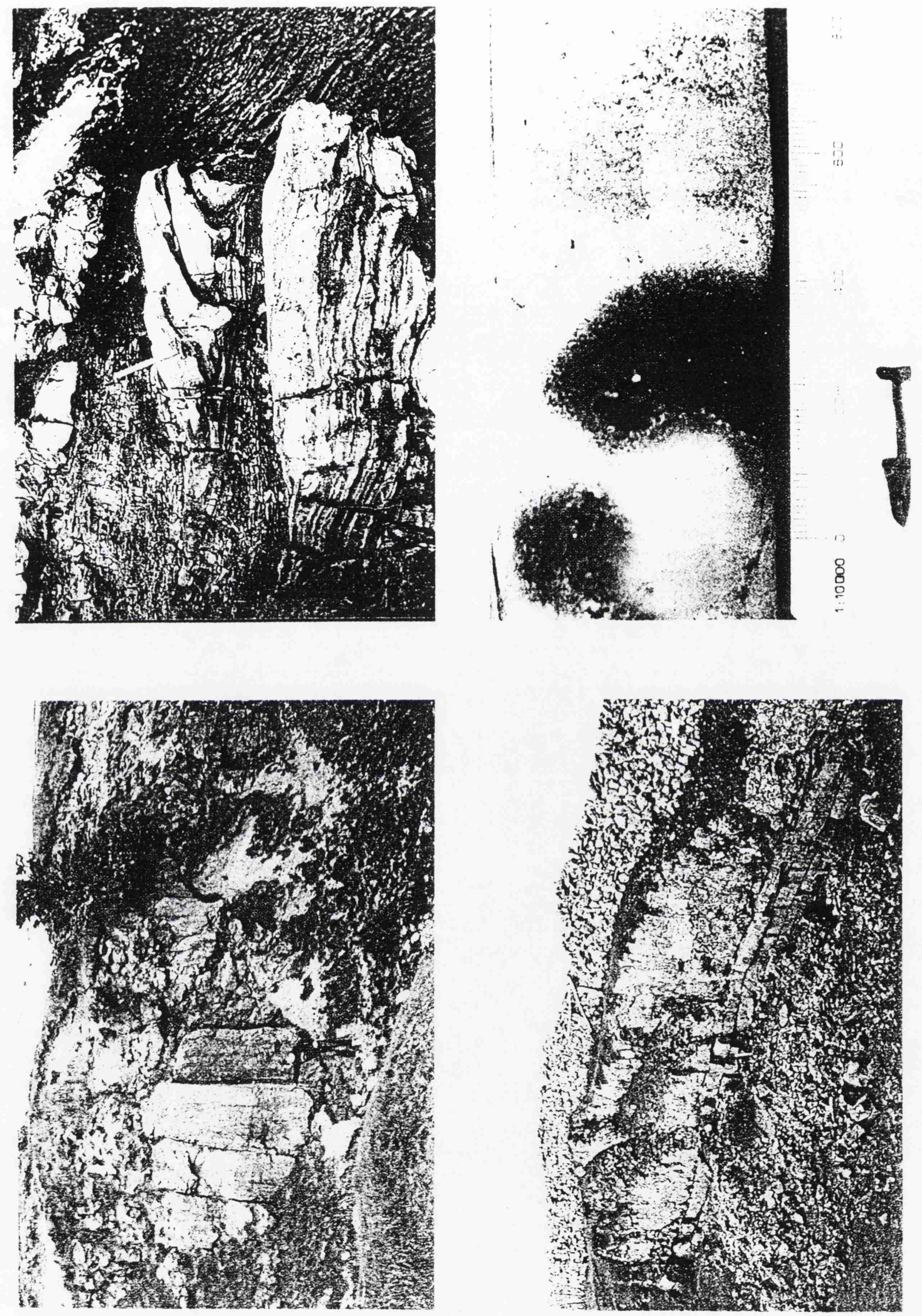

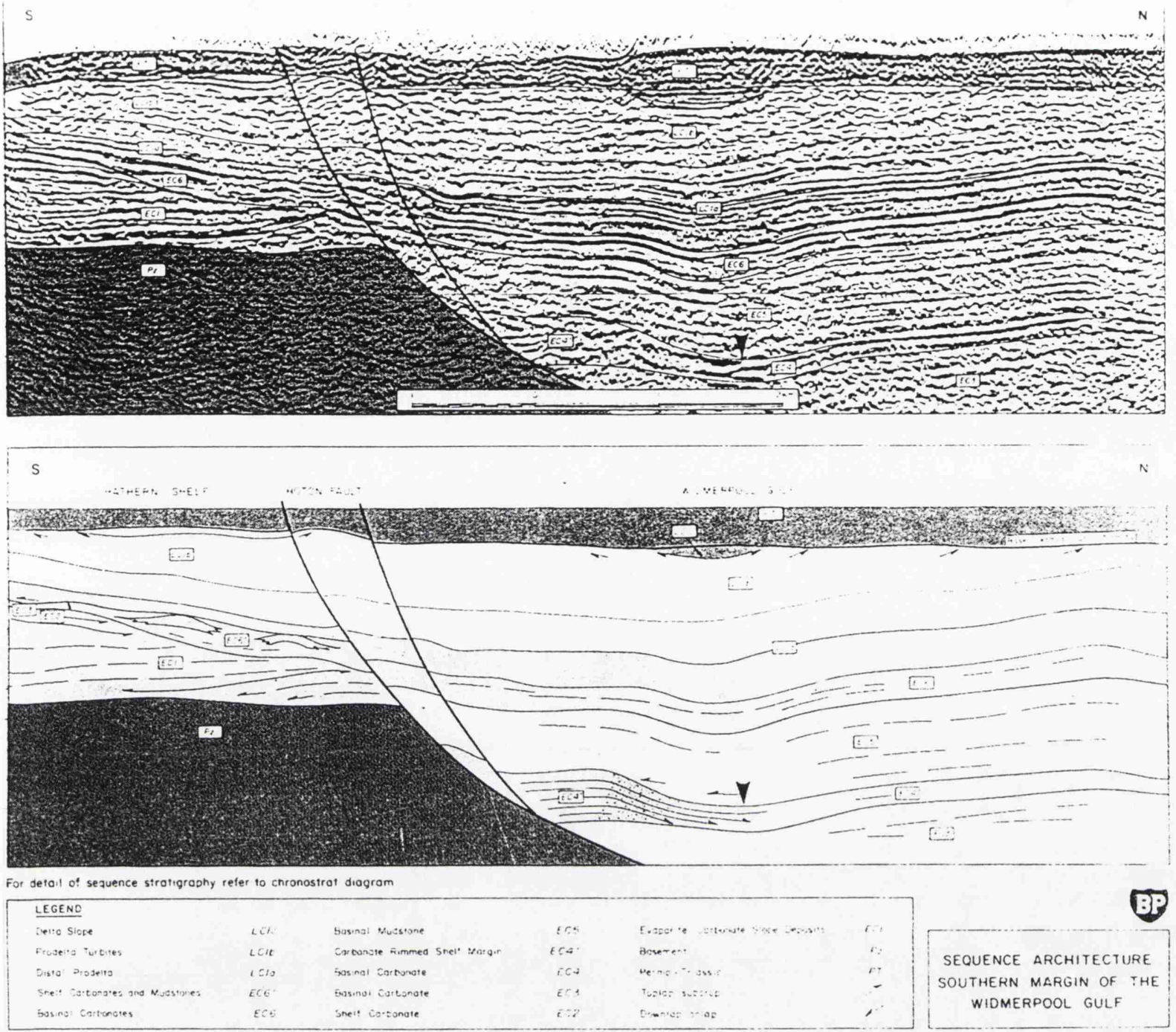

Fig. 12. Sequence architecture, southern margin of the Widmerpool Gulf, East Midlands, showing development of the ECt footwall margin (EC4). Strong high amplitude reflectors at base of EC4 slope (indicated by arrow) are gencrated by boulder beds which represent footwall erosion of the Hathern shelf at the EC4/EC5 scquence boundary (cf. Fig. 11c) (from Ebdon et al. 199())

Fig. 11. (a) Haw Crag (sequence EC 3) northern Bowland: Boulders of proximal ramp and Waulsortian carbonates derived from footwall erosion along the South Craten fault system at the onset of E: 3 rifting. (h) Worston Shale Formation. Croasdate Beck, northern Bowland basin (sequence E( 3). Sin-sedimentary slumps and folds in interbedded hemipelagic mudstones and distal calciturbidites generated by slope instability during EC3 rifting. (c) Pendleside Limestone (EC4/EC5 sequence boundary). Green Pike, Bonbland Basin. An excellent cxample of a major sequence boundary occurring in the midele of a lithestratigraphic unit. The bedded limestonc units in the lower part of the picture are foreskope calciturbidites betonging to the Ec t sequence. These are unconformably overlain by she!f derived debris sourecd from crosion of the footwall of ahe nearby Bowland High at the onset of EC5 rifting (cf. Fig. 12). (d) Pendeside Limsestone (sequence EC (5) mineral exploration borchole, south of Bowland High. Vugge perosits in houlder heds associated with hadrocarbon showe 


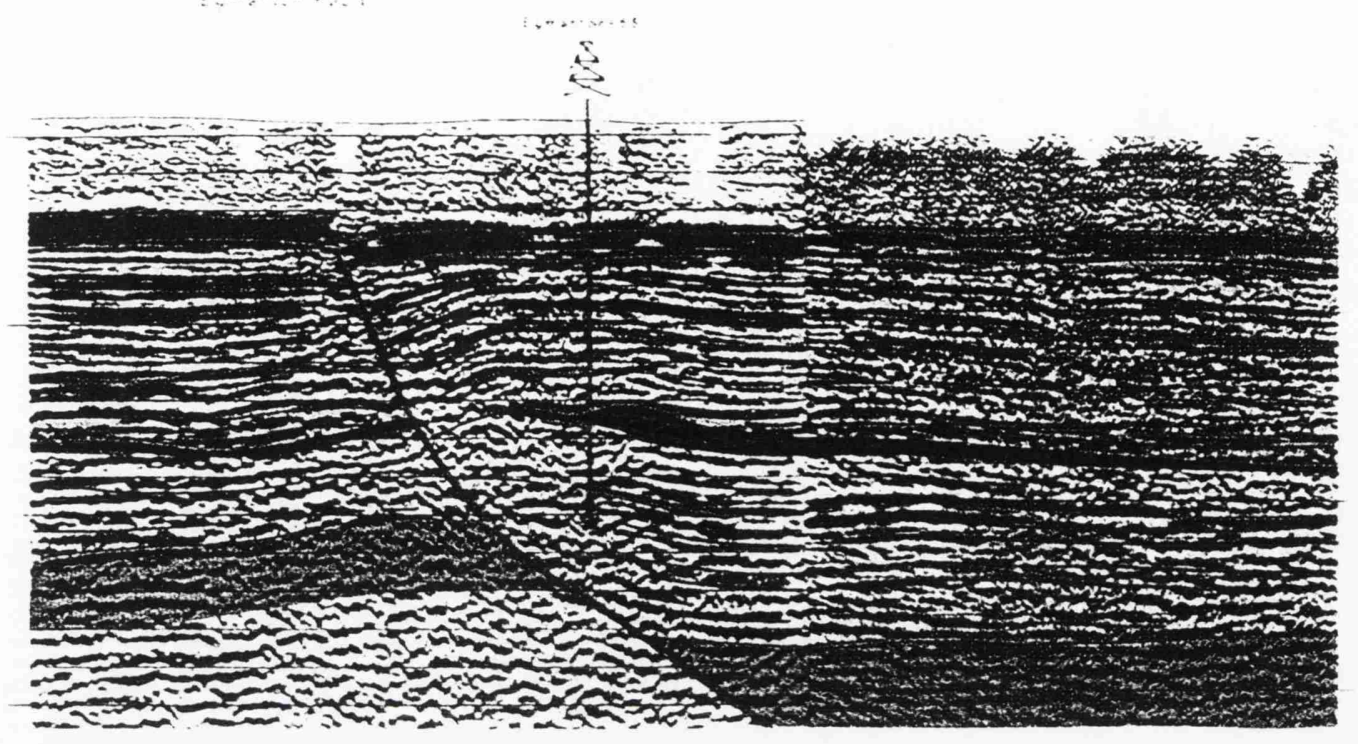

S

$\mathbf{N}$

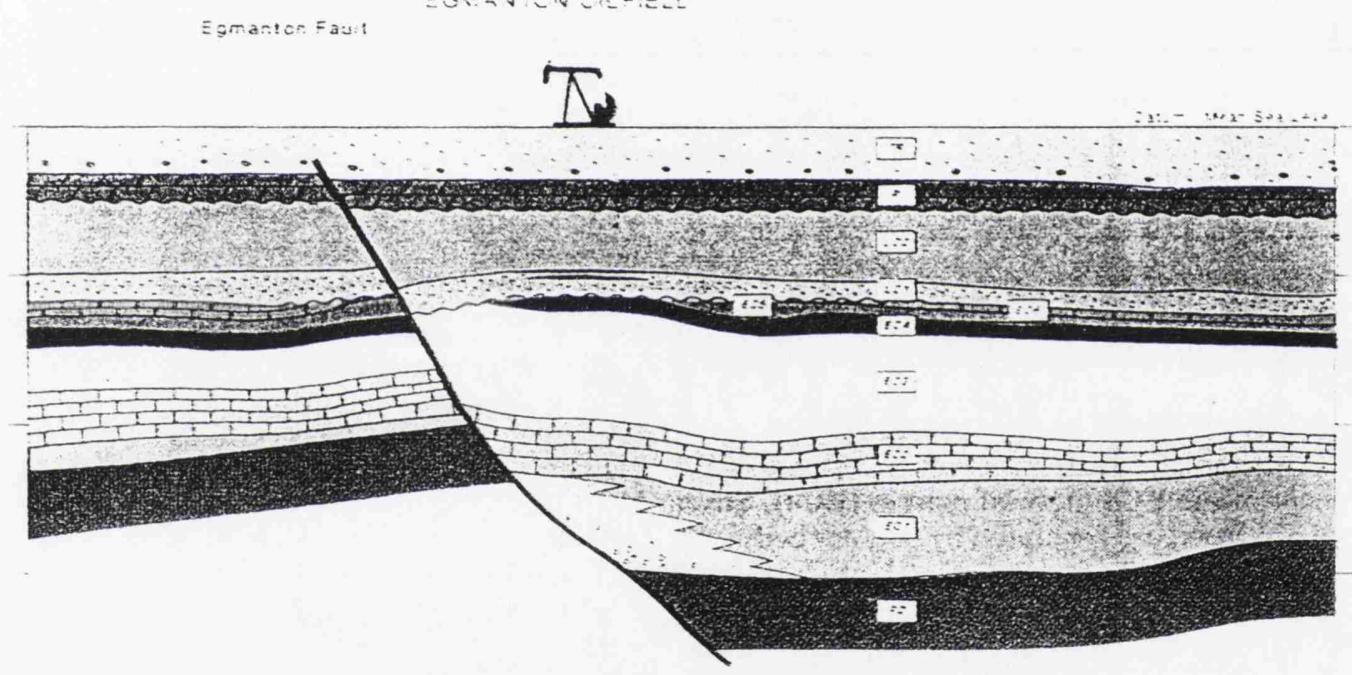

Fig. 13. Composite seismic and interpreted geological section atcross the Egmanton oilficld. East Midlands. Late Dinantian inversion is evidenced by the suggestion of subcropping E C $3-E(6)$ secpuences to the base of the pest-rift (L. (1)

A similat thermal sag hats been identified further east in the Southern North Sea hasin (Lecder d Hardman, this volume). The position of the post-rift depocentre in the south of the study area may restule from a combination of factors: (i) the presence of extensive Calectonian granitoid hodies in the north of the area maintaming crustal huovancy. (ii) the substantial water depthe existing in the south of the areat following the syn-rift phase and (iii) the presence of a thermal anomaly possibly related to an carlier pre-rift thermal hulge in the region. A representatice palacofacies map for the early post-rift (Fig. 14h) shows the southward progradation of the clastic fluvio-delatic system (ct. Fig. 9h) as sediment supply overtook subsidence for the first time. This resulted in the burial of the lase vesties of the northern England car- 


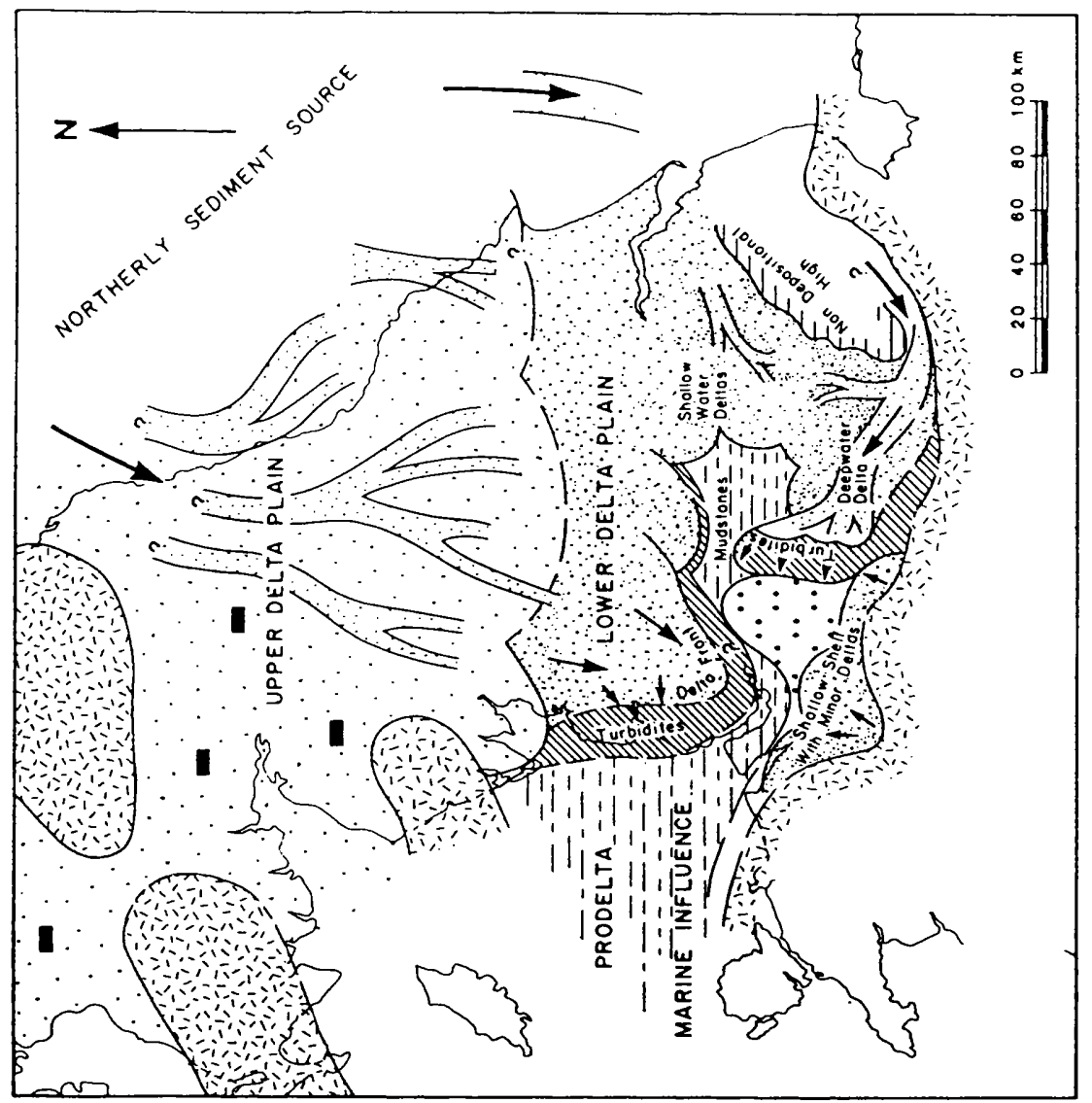

田母母曰
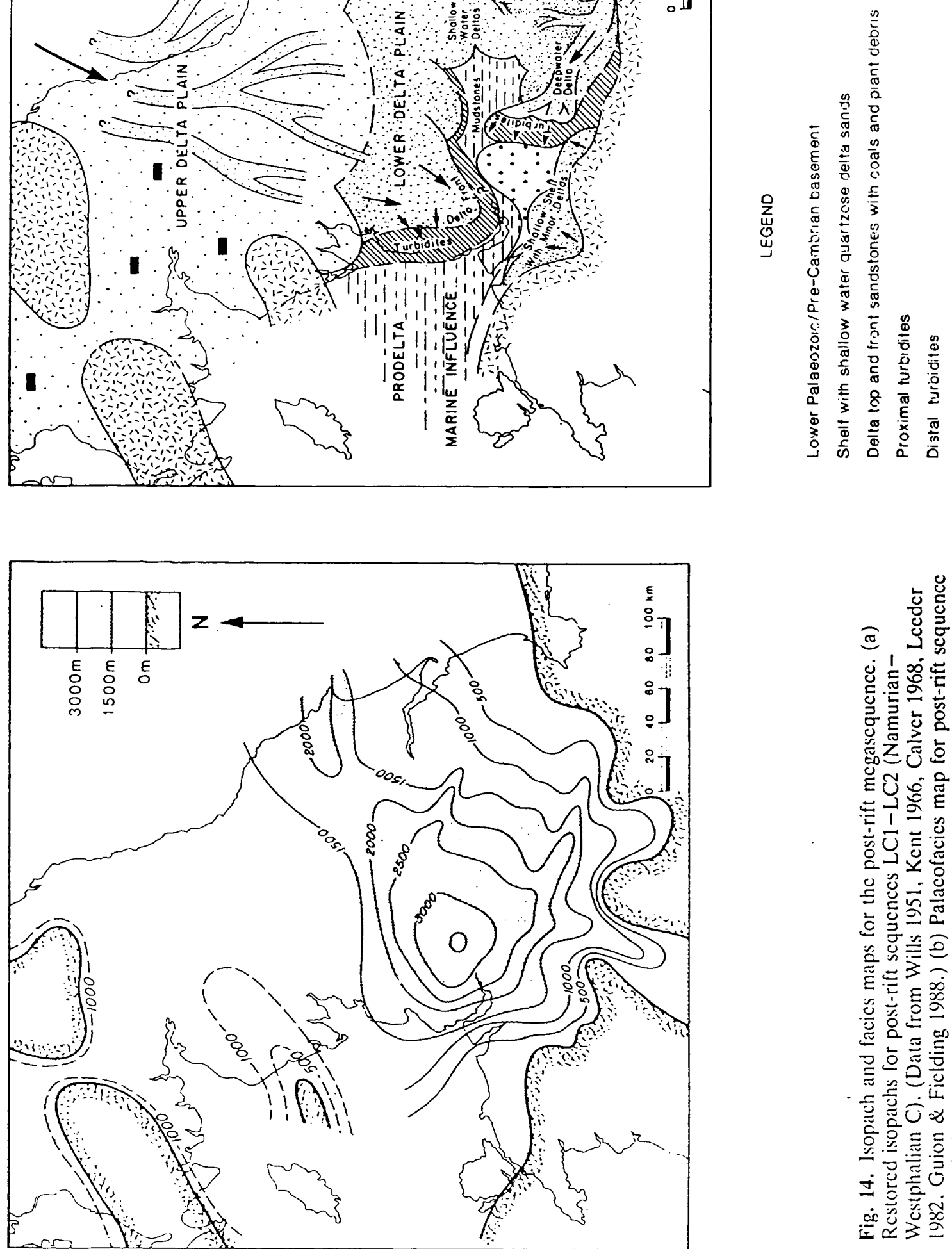

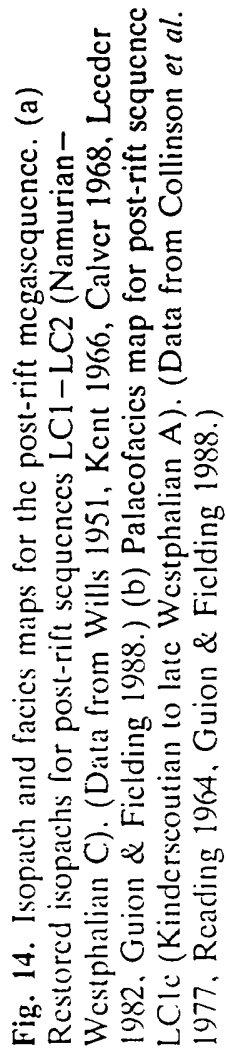


seismic sections by the generation of large-scale inversion anticlines in the hangingwalls of the existing basin bounding faults (c.g. Fig. 5). Early Permian peneplanation of these anticlines is evidenced by a pronounced subcrop to the base Permian throughout northern England. The degree of uplift and subsequent erosion of syn- and post-rift Carboniferous sediments has been estimated from regional stratigraphic (thickness) and vitrinite reflectance (palaeoburial) studies (Fig. 15a). The map highlights the extent to which basins such as Bowland and Northumberland, which are interpreted as lying normal to the NW-SE direction of maximum compressive stress, were inverted during the Variscan. The inversion megasequence (Fig. $15 b$ ) is characterized by the accumulation of continental red beds and molasse in intermontane troughs (essentially the footwalls to the syn-rift half graben) throughout northern England. These sediments are the first to display an important component of southerly derived material from the evolving Variscan mountain front in southern England (Besly 1988).

The nature and intensity of the inversion in northern England varies in a predictable sense with respect to fault trend and depth to detachment. NE-SW trending faults normal to the implied direction of maximum compressive stress such as the Pendle fault (Bowland basin) underwent strong inversion (Fig. 16). In contrast, NW-SE trending faults, such as the AskernSpital fault (Gainsborough Trough), probably moved in a strike-slip sense with minimal vertical fault displacement (Fig. 8). The major basin bounding faults (NW-SE) display broad, long wavelength, inversion anticlines such as demonstrated on seismic in the Widmerpool Gulf (Fig. 5). These rarely show four-way dip closures and hence are seldom associated with hydrocarbon accumulations. In contrast the NNW-SSE faults with shallow detachments form tight, closed, inversion anticlines which constitute the major hydrocarbon-bearing traps in the East Midlands. Good examples of this style of inversion are seen at Eakring, Welton and Calow as discussed below.

Sequence VI (Westphalian C-Westphalian D). This sequence records the initial basinwide Variscan inversion event involving the formation of a series of broad inversion anticlines and the widespread uplift and erosion of original syn-rift depocentres. The sequence records the first major input of southerly derived sediments with barren red heds and coarse pebbly sands and conglomerates accumulating in the distal part of the Variscan foreland (Besly i988).
Sequence VI is poorly represented on seismic data in northern England as a result of widespread erosion below the base Permian unconformity. The sequence can he identified by basal onlap onto inversion anticlincs in the hangingwalls of the major faults and is thickest in the synclinal areas between the inversion axes (Fig. 15b).

Sequence V2 (Westphalian D-carly Permian). The onset of this the second and strongest pulse of the Variscan orogeny is dated as Westphalian D largely from subsurface evidence in the West Midlands. Its effect has been to strongly invert all major half grabens in northern England (c.g. Widmerpool Gulf and Bowland Basin, Figs 5 \& 13). The event is probably a series of compressive pulses initiated in the Westphalian ' $D$ '. However, lack of preserved section of this agc precludes any further breakdown. The inversion can be demonstrated at outcrop by the tightly folded lower Carboniferous deposits in the Ribblesdale fold belt in the Bowland Basin (Gawthorpe 1987a). The sequence is characterized by continued uplift and erosion of Dinantian syn-rift basins and accumulation of molasse deposits in small intermontane troughs within an evolving foreland.

\section{Tectono-sedimentary controls on the hydrocarbon habitat}

The major tectonic controls on the hydrocarbon distribution in the Carboniferous of northern England are discussed in terms of trap formation and Mesozoic burial. The analysis of play fairway development considers the more subtle controls exerted by tectonic activity on the regional distribution of reservoir, source and seal facies.

\section{Trap formation}

All of the 30 or so fields discovered to date in the Carboniferous of northern England display some component of Variscan deformation in their geometry. Taking the East Midlands as an example, it can be seen that the oil and gas fields show a close relationship with the major fault trends (Fig. 17). Inspcction of a depth converted regional seismic line across the province shows the major fields to lie in the hangingwalls of faults active during the Dinantian rift phase (Fig. 18). Sub-regional seismic lines with depth conversions are presented for several of the key East Midlands fields to illustrate the structural style associated with the 

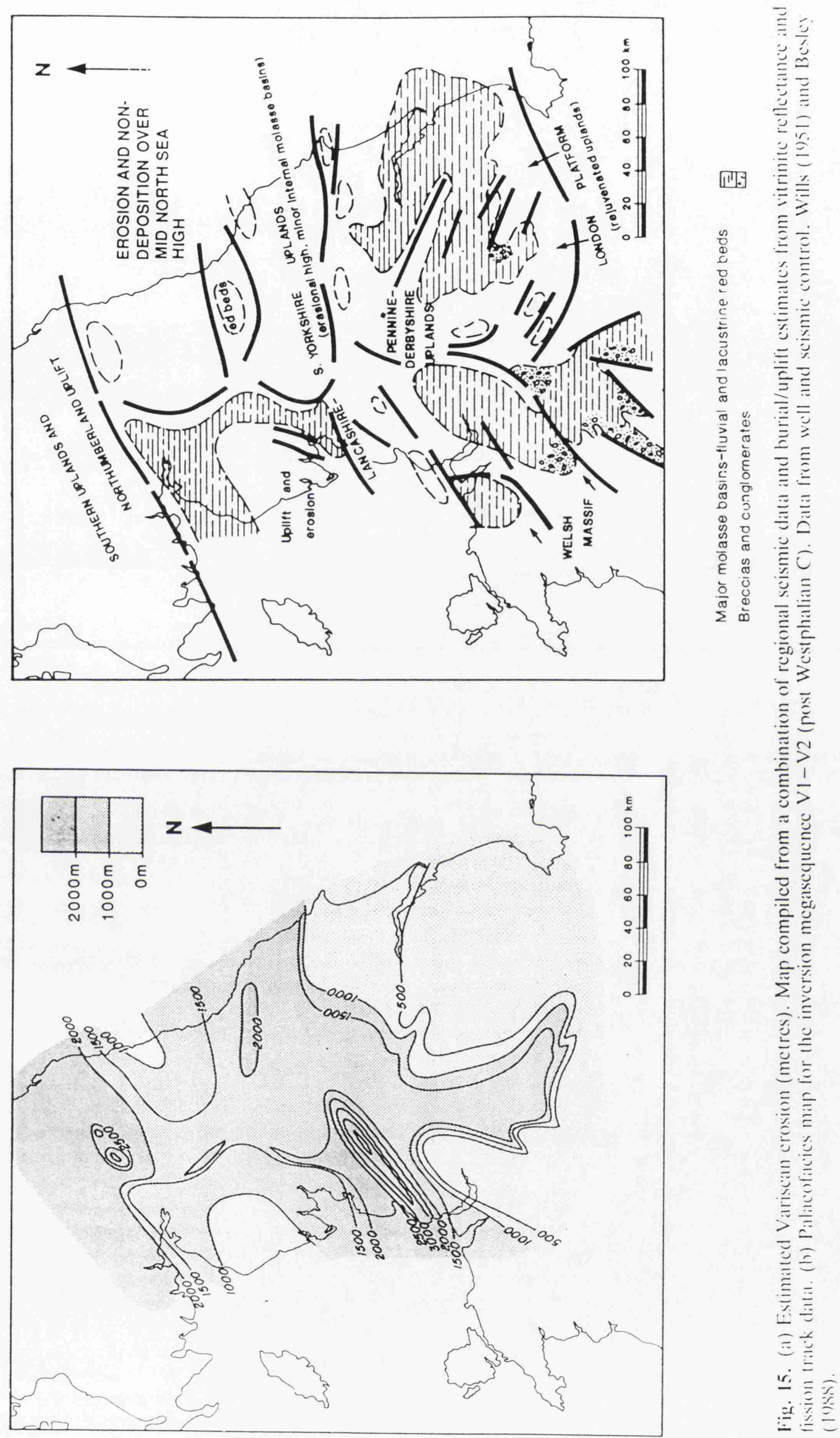


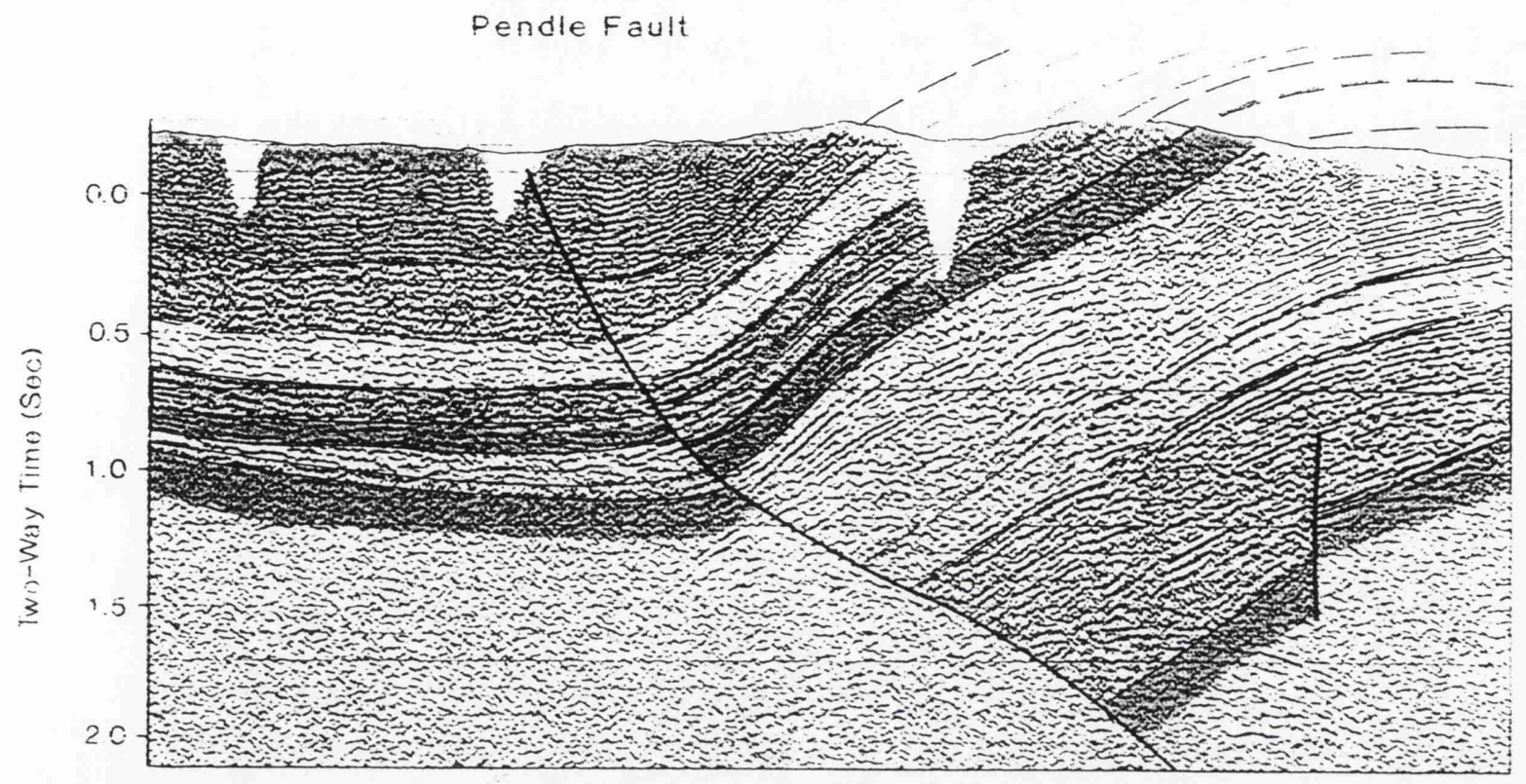

BOWLAND BASIN

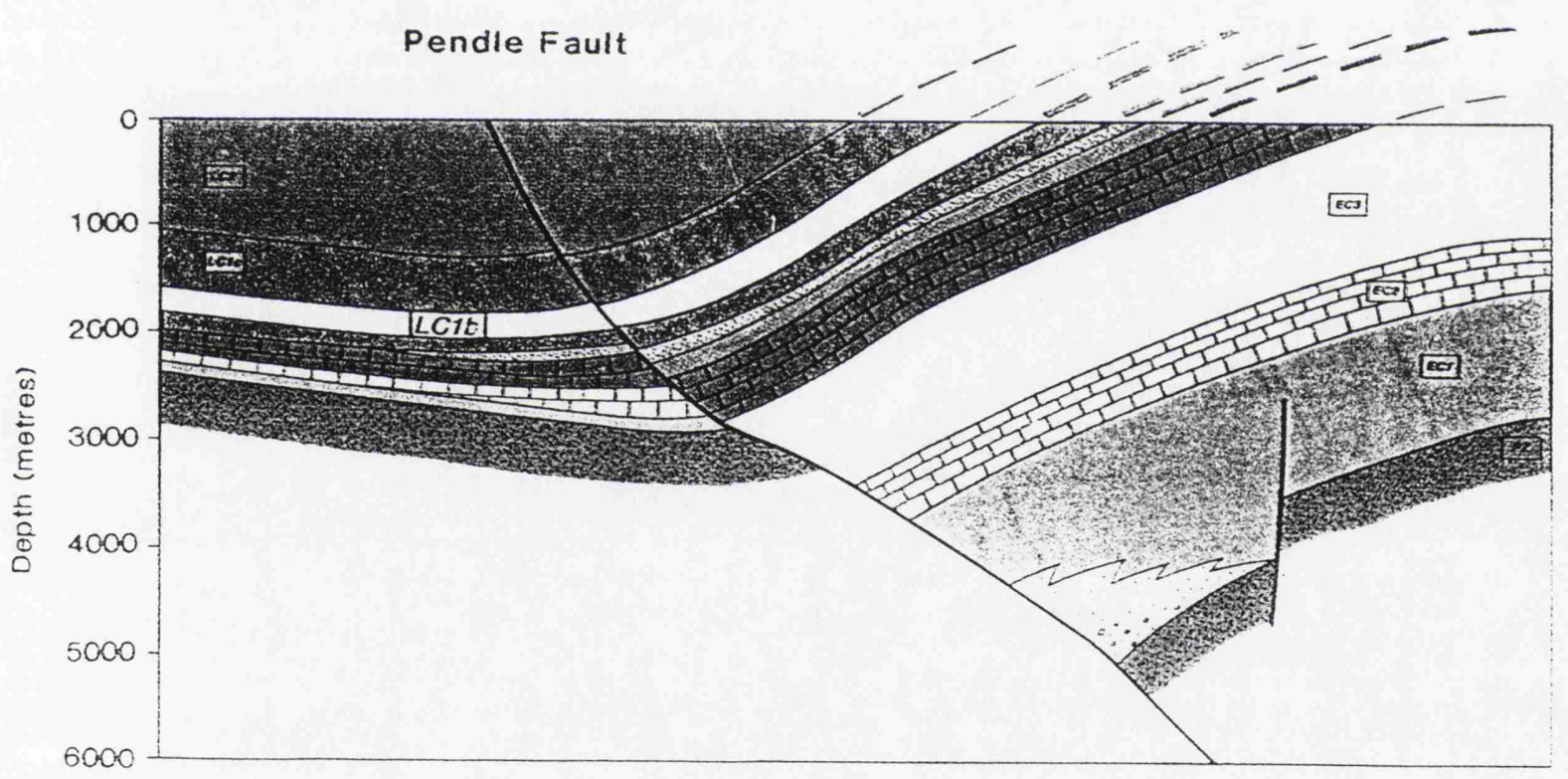

Fig. 16. Scismic and interpeted geological scetion across the Pendle monocline, southern Bowland basin showing strong Variscan inversion along existing southern border faule of the basin. Scismic data reproduced by kind permission of Amoco UK Ltd.

trapping geometry. For the location of the fickds refer to Fig. 17.

Eating-Dukes Wood (Fig. 19). The lickd occurs as a series of en echelon inversion anticlines adjacent to the NNW-SSF rending
Fakring-Foston fault. Ultimate recoverable reserves are assessed at $7 \mathrm{~mm} h \mathrm{mls}$ of oil, mainly reservoired in a stacked series of delta top channel and mouth har sands of Namurian(arly Hestphalian age (Sequence LC lc). 


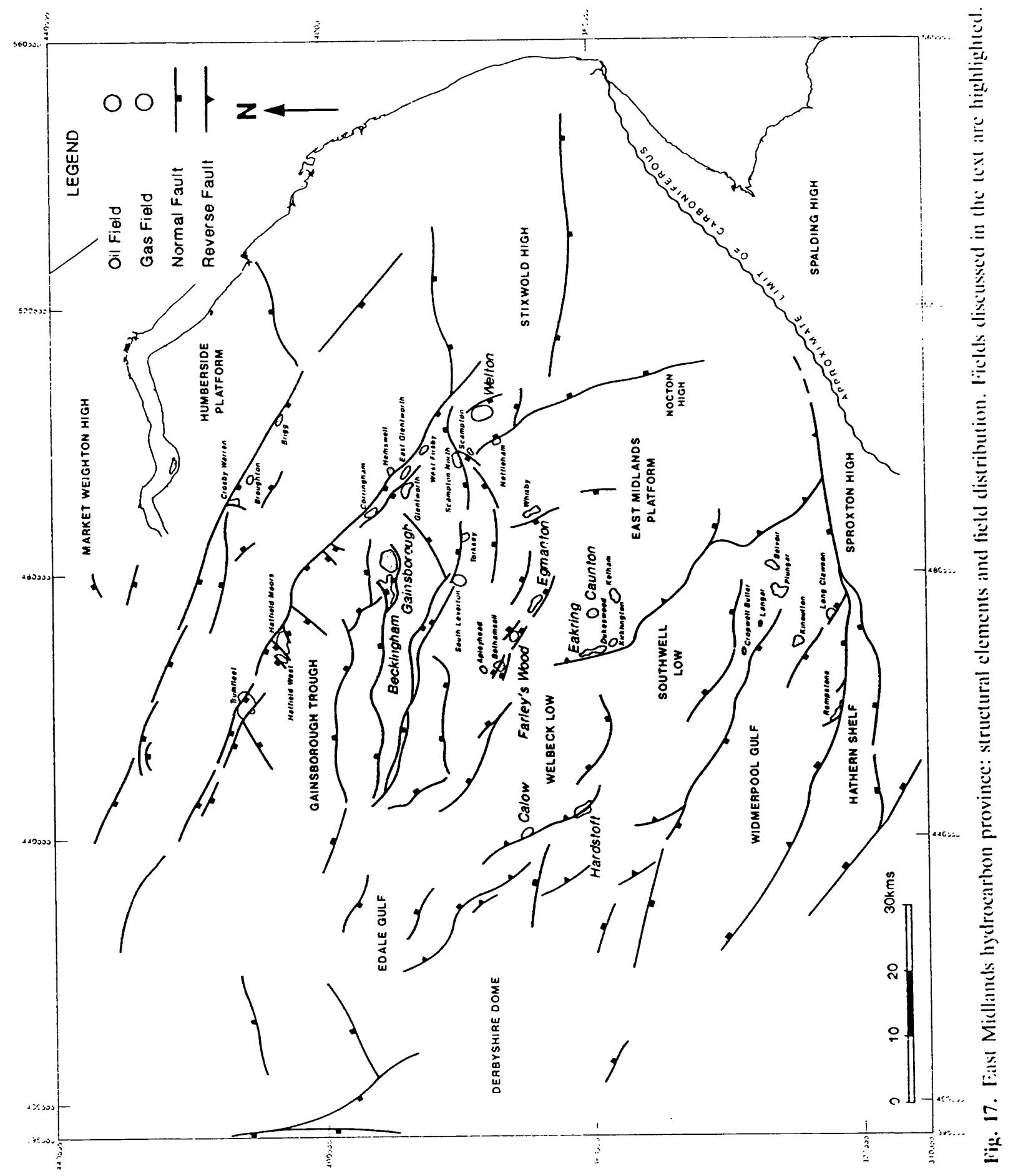



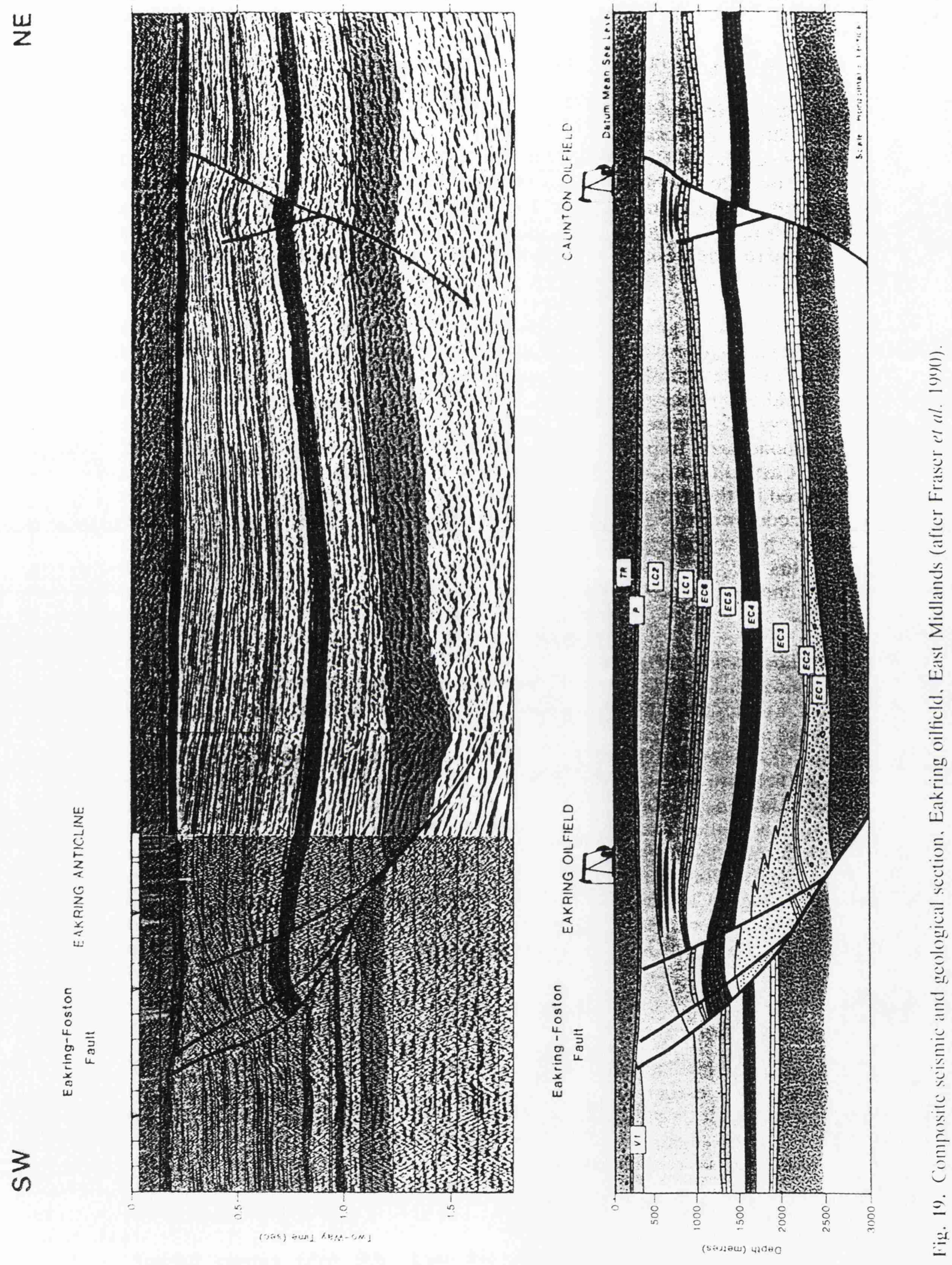
(alow (Fig. 20). The Brimingen anticline is perhaps the hest example of a tight inversion fold in the East Midlands. The structure is that of a ramp anticline formed on a shallow detachment within the Dinantian. The Calow lickl is a small gas accumulation (0.56cf) residing in channel and mouth bar sands in sequence LC Ic.

Welton (Fig. 21). Discovered in 1981. Welton is, to date, the largest hydrocarbon accumulation in northern England. Reserves are now assessed at well over $20 \mathrm{mmbbls}$. Production is mainly from delta top channel sands within scquence Lclc (Rothwell \& Quinn 1988). Seismic shows the field to again result from Variscan compressional tectonics.

Egmanton (Fig. 13). The Egmanton field is an inversion anticline formed on a NW-SE trending fault to the south of the Gainsborough Trough (Fig. 3). The field was discovered in 1955 and recoverable reserves are assessed at $3.5 \mathrm{mmb}$ bls. The main component of trap formation was again the late Carboniferous, Variscan inversion, as evidenced by the strong subcrop to the base Permian unconformity (Fig. 13). However, the suggestion on seismic of subcropping Dinantian events at the base of the LCl sequence may indicate a precursor Variscan inversion event.

Beckingham/Gainsborough (Fig. 8). The Beckingham/Gainsborough field was discovered by BP in 1959 in a complexly faulted series of stacked reservoirs of Namurian and Westphalian age (sequences $\mathrm{LC1c} / \mathrm{LC} 2$ ). Recoverable reserves from the field are assessed at $13 \mathrm{mmbbls}$ of oil plus an additional $6.5 \mathrm{bcf}$ of associated gas. The complexly faulted anticlinal structure was apparently formed by inversion on a series of early syn-rift faults lying at depth within the Gainsborough Trough. Closure is complicated by the presence of shallow, listric faults which apparently sole out on Upper Dinantian (EC6) basinal carbonates.

\section{Carboniferous play fairways}

The sequence stratigraphic analysis of the Carboniferous described earlier represents a powerful tool with which to analyse the hydrocarbon system by constraining the regional distribution of reservoir, source and seal facies. This is used to develop a play fairway analysis for the Carboniferous.

Syn-rift clastics (Fig. 22). Late DevonianCourceyan (EC1) syn-rift conglomerates and

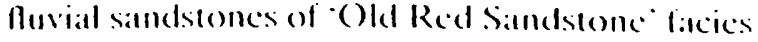
form a potential play in the half sraben throughout northern England. Two main areas of carly syn-rift clastics can be identified (ce. Leceder \& Gawthorpe 19\$7). Firstly, a narrow zonc, a few kilometres wide, adjacent to the border fault zone and, secondly, a wider zonc along the margins of the hangingwall dipslope. Well data, for example Caldon Low (Institutc of Geological Sciences 1978), and Hathern-1 (Falcon \& Kent 1960); Llewellyn \& Stabbins $1968,197())$ suggest that sands of this age could be scaled by overlying Courceyan evaporites associated with an early marine transgression into the half graben. The early rifts may contain lacustrine (?marine) source rocks such as have been tentatively identified in the Gun Hill 1 well in the Goyt Trough (Lees \& Tait 1945). In hangingwall settings, hydrocarbon prospectivity is reduced by the depth of burial of the reservoir facies and the consequent overmaturity of source rock facies.

The key to this play is the identification of the reservoir facies preserved in the footwall of EC3 border faults where burial depths are minimal (Fig. 23). The seismic example from the Widmerpool Gulf (Fig. 12) shows the case in point, where a wedge of $\mathrm{ECl}$ early syn-rift clastics has been preserved on the footwall. Equivalent reservoir facies, the Redhouse sandstones, have been identified some $50 \mathrm{kms}$ along strike in the BGS Caldon Low borehole (Aikenhead \& Chisholm 1982).

Carbonate Shelf Margins (Fig. 23). Outcrop studies in Derbyshire and the Bowland Basin have suggested that Dinantian carbonate reservoirs are most likely to be found in the regressive Chadian (EC2), Asbian (EC4) and Brigantian (EC6) sequences when rimmed shelves were able to develop during periods of reduced tectonic activity. These grainstone margins are restricted to the central England rift system around half grabens such as the Widmerpool Gulf, Goyt Trough, Edale Gulf, Gainsborough Trough and Bowland Basin (Figs $2 \& 9 b)$.

The internal facies of the margins comprise carbonate shoals, build-ups, peri-platform talus. debris flows and turbidites: all potential reservoir facies. Boulder beds were developed on the shelf margins at the end Chadian (EC3) and late Asbian (EC5), associated with slope instability caused by renewed extensional tectonic activity at this time (Gawthorpe 1987a). These debris flows are seen at outcrop and in mineral exploration boreholes in the Bowland Basin, where they exhibit up to $30 \%$ secondary 


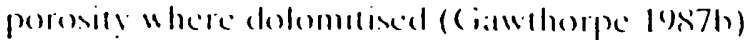
and show minor hifumen stain and mincralizallion (1.ig. 11:1).

The grainstonc mareins can also be identilied in the subsurface on modern, high quality reflection scismic data (17ig. 5). The margins are characterized hy a progradational sequence of laterally and vertically accreting clinoforms. These change character along the hangingwall dipslope into hummocky clinoforms and pass basinwards into a series of parallel reflections which are associated with distal calciturbidite sedimentary facies. The areal distribution of the carbonate margin play is thus limited to a 0.5 to $2 \mathrm{~km}$ wide fairway which rims the margins of the deeper half grahen (Fig. 9b). The narrowness of the play fairway highlights the need to identify the margins on seismic, since present well control is of insufficient density, from an exploration point of view, to map the extent of the rimmed shelves in the subsurface.

In the East Midlands, the Brigantian (EC6) grainstone margin play is considered the most prospective given the presence of onlapping Namurian pro-delta mudstones which should provide both source and top seal (sequence LCla). In the absence of fortuitous structural or fault dependent closure, success of the play requires lateral seal to be provided by the expected change from shelf margin facies into a tightly cemented cyclic shelf carbonate developed shelfwards of the margin. Clastic delta systems (Fig. 24). This play is by far the most important in the Carboniferous of northern England and has been described in some detail by Fraser et al. (1990).

Reservoirs are developed in both the delta top and pro-delta environments. Channel and mouth bar sands form the main producing reservoir facies on the delta top, with channel sands exhibiting the more favourable reservoir characteristics. Turbidite sands also form potential reservoirs in the pro-delta setting. Antecedent rift bathymetry exerted a significant control on the delta systems (Fig. 14b); delta top and mouth bar reservoirs being best developed where they axially infill remnant rift hathymetry.

Regional sealing facies on the delta top is provided by marine bands deposited during maximum flooding events and interdistributary bay fines. As discussed by Heckel (this volume) the marine bands are likely to have been glaciocustatically controlled. The thin marine bands which overstep delta top environments have been shown to be adequate seals for oil accumulations, but are suspect for gas (Fraser et al. $199(0)$. In the pro-delta, shale-rich environment, marime mudstomes provide excelleme seals for turbidile sandstone rescrobirs.

The richest source rocks idemtilied ate interpreted as distal pro-delta mudstones which were deposited in advance of the southerly prograting delta systems (Fig. 25). In the East Midlands the pro-delta source facies (sequence LCla) (Edale shale and equivalents) is well developed in the remnant half graben but is poorly represented on the East Midlands shelf.

The prodelta source facies are predominantly oil prone. Biomarker studies and carbon isotope analyses clearly indicate a mixed marine/terrestrial derived kerogen (Fraser et al. 199(1). One explanation for the relationship between the deltas and the source facies involves the introduction of fresh water from the delta top to the isolated fault bound half graben causing stratification of the waters and resultant regional anoxia below the pycnocline.

Both the pro-delta and delta-top reservoir systems prograde across the distal pro-delta source rocks forming hydrocarbon migration pathways. Delta top coal swamps, developed regionally during the Westphalian (sequence LC2) over northern England, provide gas and occasional oil-prone source rocks which are likely to be in good communication with the delta top channel and mouth bar reservoirs.

\section{Mesozoic burial history and hydrocarbon generation}

As discussed earlier, the main trap forming event in northern England was the late Carboniferous-early Permian Variscan orogeny which created inversion anticlines in the hangingwalls of the major half graben border faults. The considerable uplift and erosion which resulted from this event led to the effective 'freezing' of source rock generation and migration. Therefore, Mesozoic burial leading to renewed generation from the source rocks, post-dating this trap forming event, is critical to the success of northern England as a hydrocarbon province. Several key areas of Mesozoic hydirocarbon generation have been identified (Fig. 26).

East Midlands. The dominant phase of generation in the East Midlands province occurred during Mesozoic times. This has been confirmed by recent fission track studies (Green 1989). Restored, pre-Tertiary uplift maps indicate that the basal Namurian pro-delta shales would have been generating liquid hydrocarbons over most of the area by late Cretaccous times. Gas gen- 


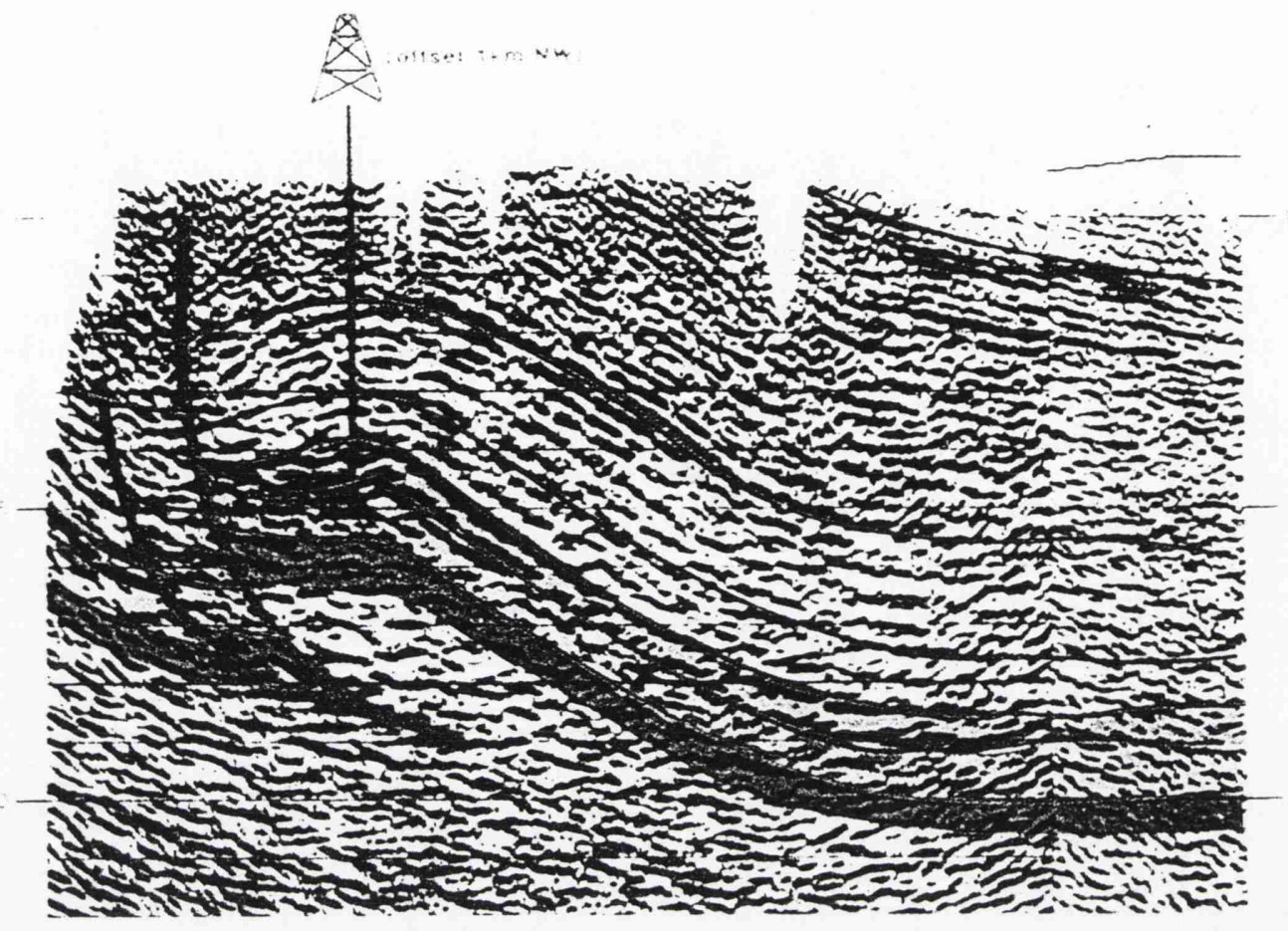

Brimington Anticline

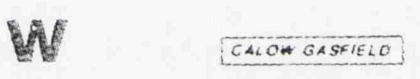

E

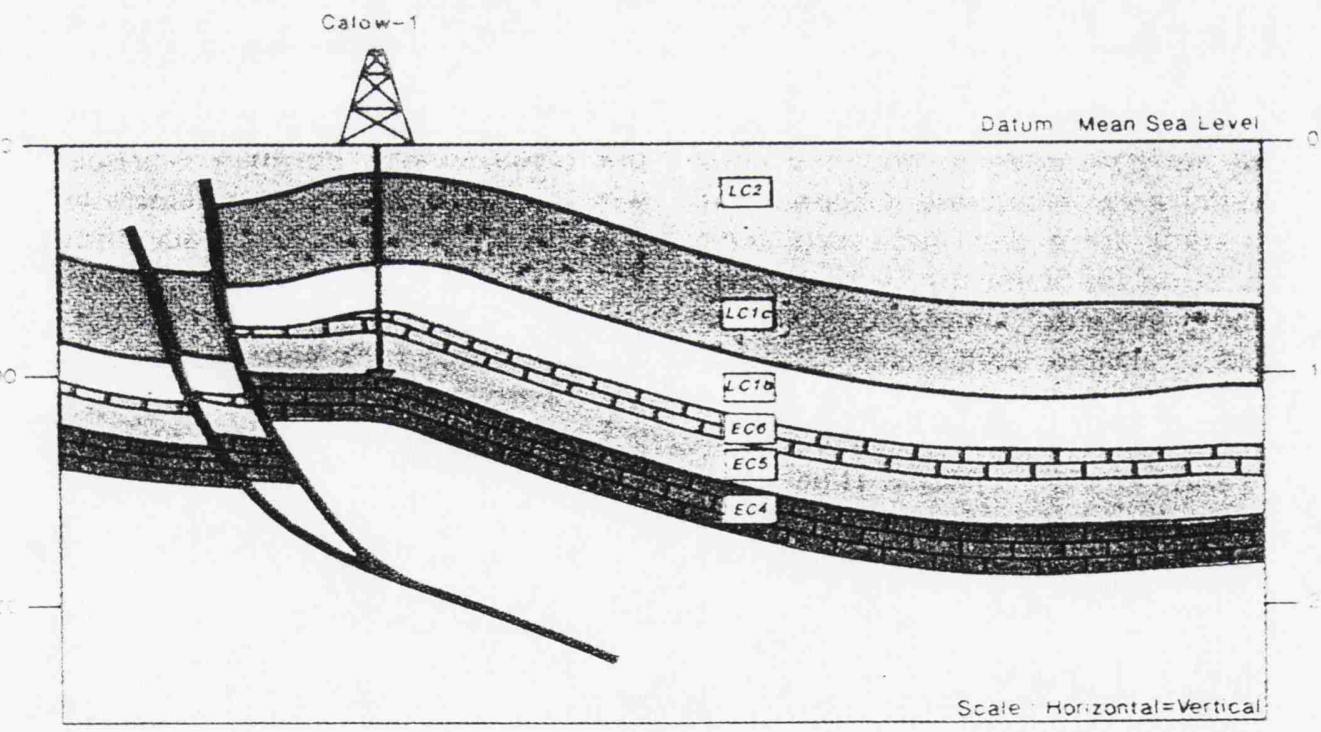

Fig. 20. Composite scismic and interpreted geological section across the Calow gasfictd, East Midlands.

eration is likely to have heen short lived and restricted to the deeper parts of the Gainshorough Trough and Widmerpool (iulf. All hydrocarbon gencration was frozen' in the
Tertiary by some $10(0)$ metres of regional uplifi. A degree of remigration of hydrocarbons look place in the late Tertiary as a result of a aceional castward tilting of the hasin by ahout 


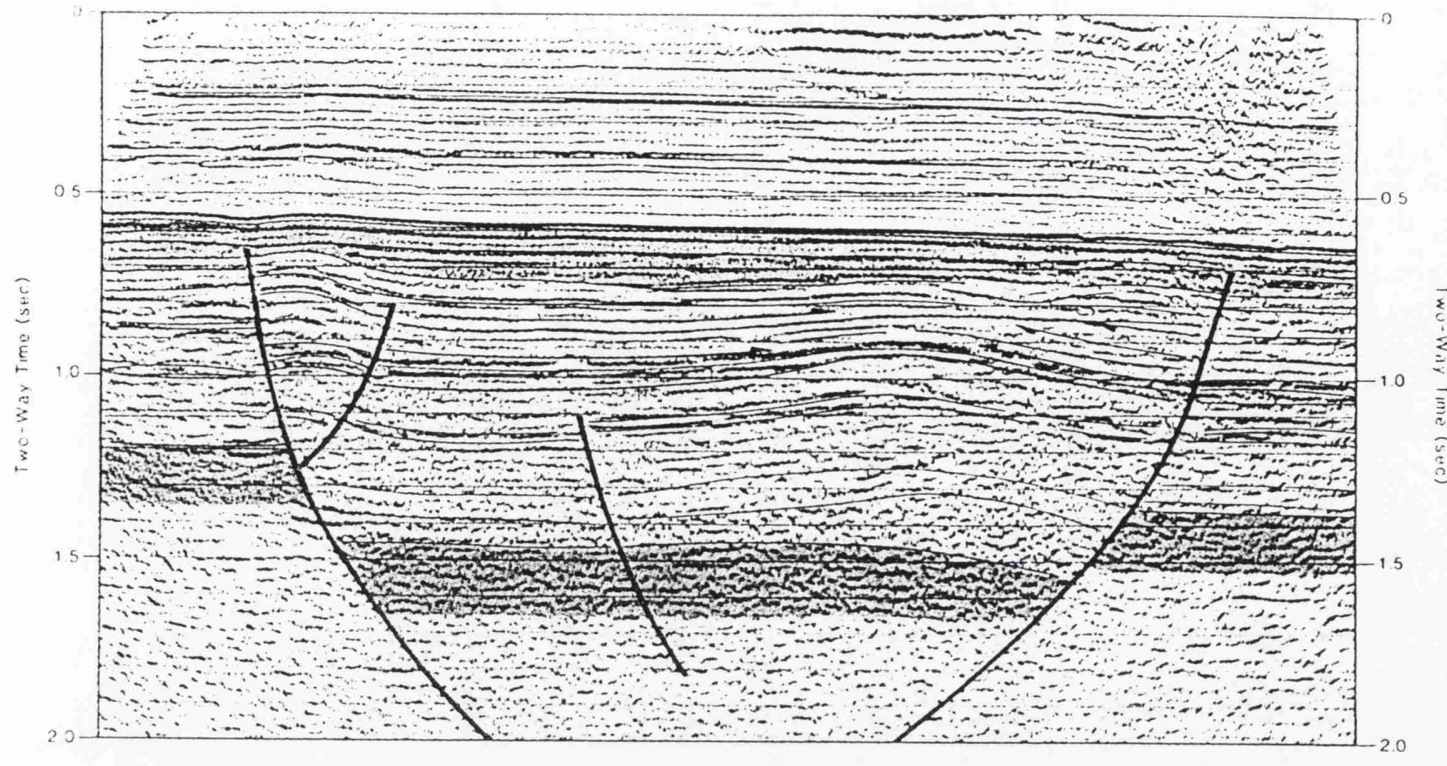

WELTON OILFIELD

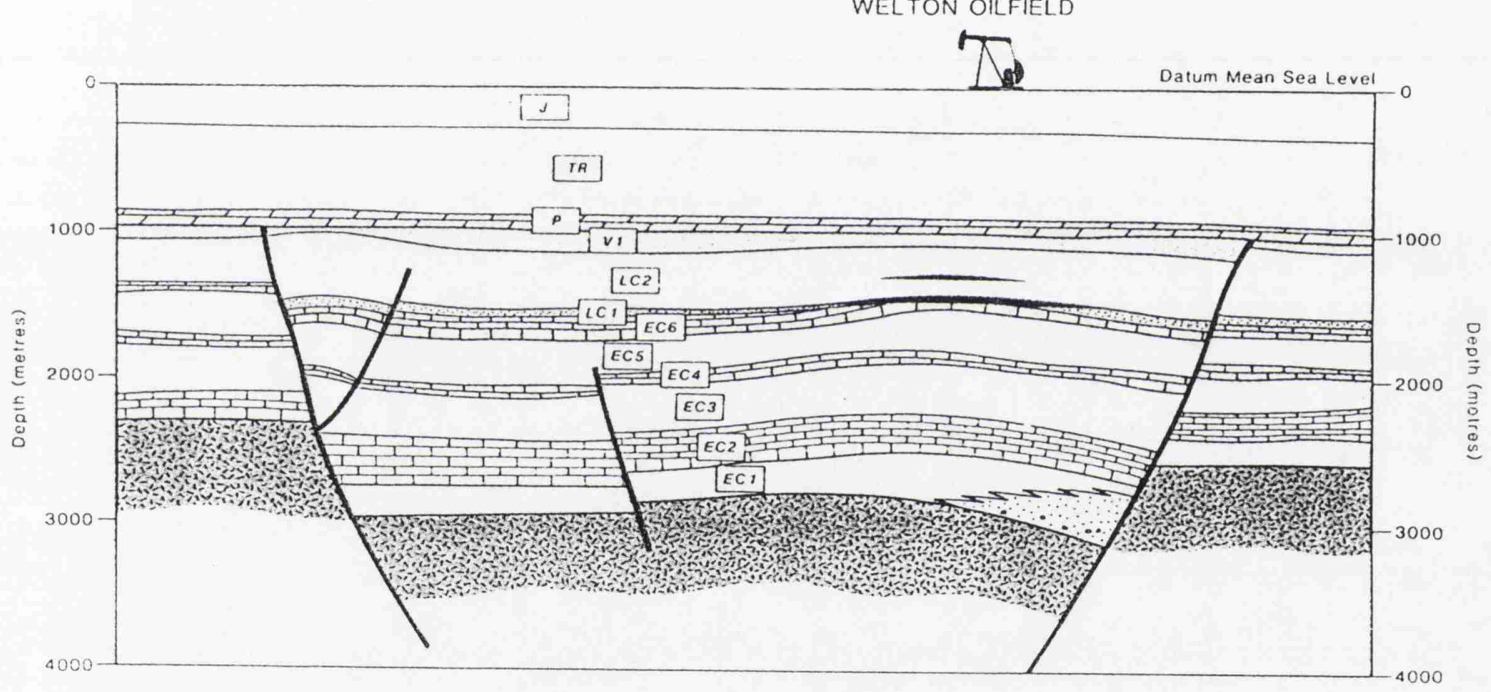

SEISMIC AND GEOLOGICAL SECTION, WELTON

Fig. 21. Scismic and interpreted geological section across the Welton onificld. East Midlands.

2 towards the Southern North Sea Basin (Fraser (') al. 199(1)

Cleveland Basin. The Cleveland Basin is chat racterized by supcrimposed Carboniferous and Cretaceous rift svstems. The Carboniferous rift event formed the kitchens for the deposition of the source facies, whereas bate Jurassic-earls
Cretaceous extension matured the sediments through the oil window and into the gas zone by the mid Cretaceous. Generation peated durins the late Cretaceous and ecased during Oligosene basin inversion. Estimates of Tertiary uplift from sonic velocity and vitrinite data ranec from lse(t) metres in the south of the hasin (Malton) to over 3okt) $\mathrm{m}$ in the north (Estidale) in the hanginewall of the Lenedale tault. 


\section{SYN-RIFT SANDSTONES}

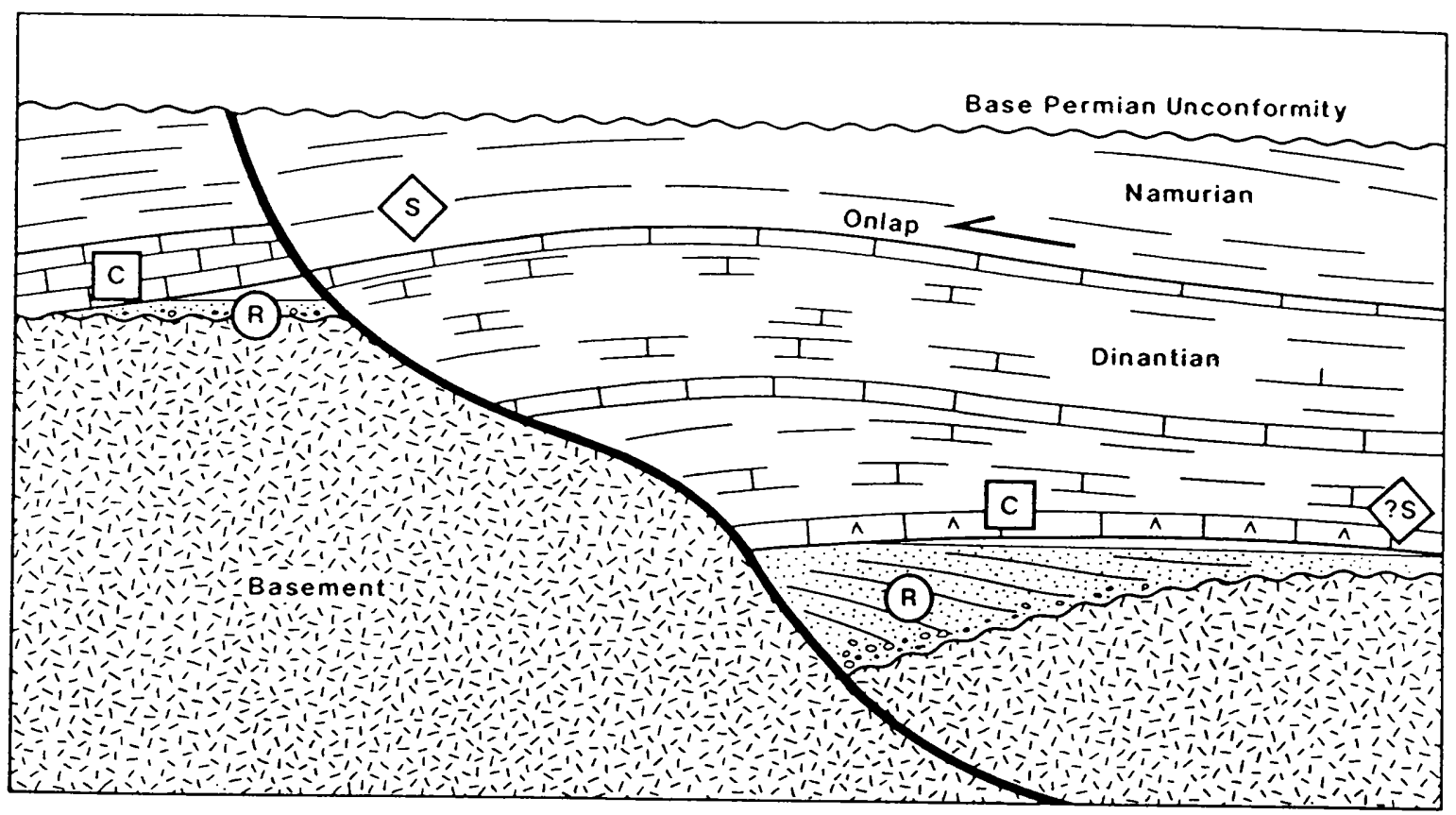

RESERVOIR :

Upper Devonian - Courceyan syn-rift conglomerates and fluvial sandstones

SEAL :

Courceyan evaporites and shales.

SOURCE :

Early syn-rift (Courceyan) basinal shales - not proven.

Cross fault juxtaposition with pro-delta shales.

Carboniferous and Mesozoic charge.

CRITICAL FACTORS: (i) Excessive depths of reservoir burial in hanging wall.

(ii) Limited distribution

(iii) Play relies heavily on unproven early syn-rift source.

Fig. 22. Early syn-rift clastic play fairway summary. $\$=$ source. $Q=$ scal. $(\mathbb{B})=$ rescrvoir

Manx-Furness. The important part of the burial in this area is related to the rapid subsidence of the basin during the Permo-Triassic. The onset of oil generation is taken as the mid-Triassic. with peak oil generation by the late Triassic and gas gencration occurring from mid-late Jurassic through to the early Tertiary. This important phase of Mesozoic generation sourced the Morccambe gas field (5tcf reserves) in the offshore part of the hasin (Ebbern 1981). This 


\section{CARBONATE SHELF MARGINS}

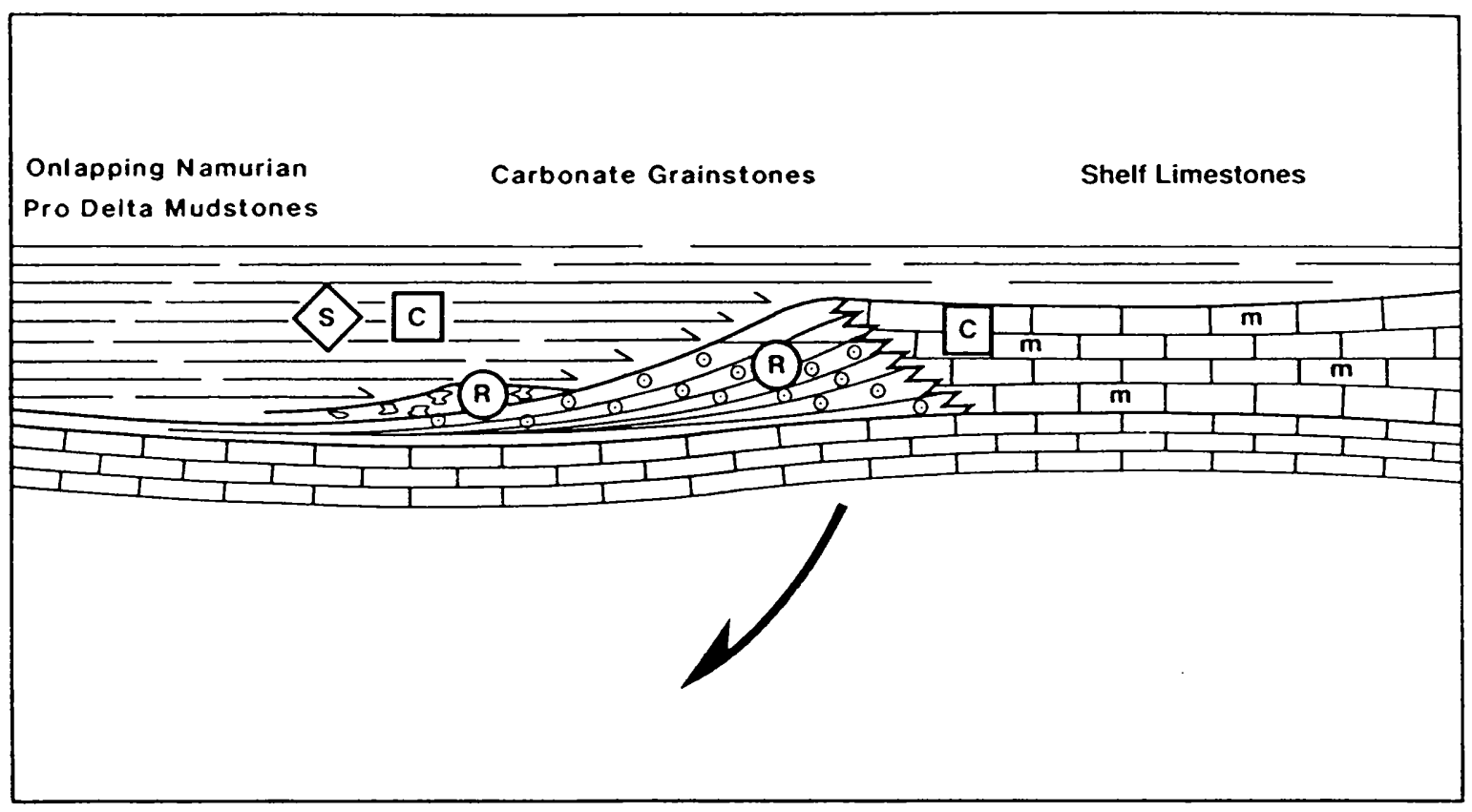

RESERVOIR :

Chadian/late Asbian/early Brigantian grainstones

SEAL :

Onlapping late Dinantian and Namurian pro-delta mudstones Lateral facies change into tight shelfal limestones

SOURCE : Interdigitating and onlapping late Dinantian/early Namurian mudstones (Bowland Shales and equivalents)

\section{CRITICAL FACTORS: (i) Secondary porosity (dolomitisation) required.}

(ii) Lateral seal.

(iii) Narrow belt. difficult to identify.

Fig. 23. Dinantian carbonate shelf margin play fairway summary.

phase of generation was frozen during the early Tertiary by uplift and erosion possibly related to rifting between Europe and Greenland.

Cheshire Basin. An important area of implied Mesozoic maturation and generation occurs in the Cheshire basin. Most of the subsidence in this area is of Permo-Triassic age with further passive infill of the arca in the Jurassic and Cretaceous. The excessive Mesozoic burial suggests that gas is the only hydrocarbon phase likely to be encountered in the basin. This area was also affected by considerable uplift and erosion $(c .1000 \mathrm{~m})$ in the Tertiary. 


\section{CLASTIC DELTA SYSTEMS}

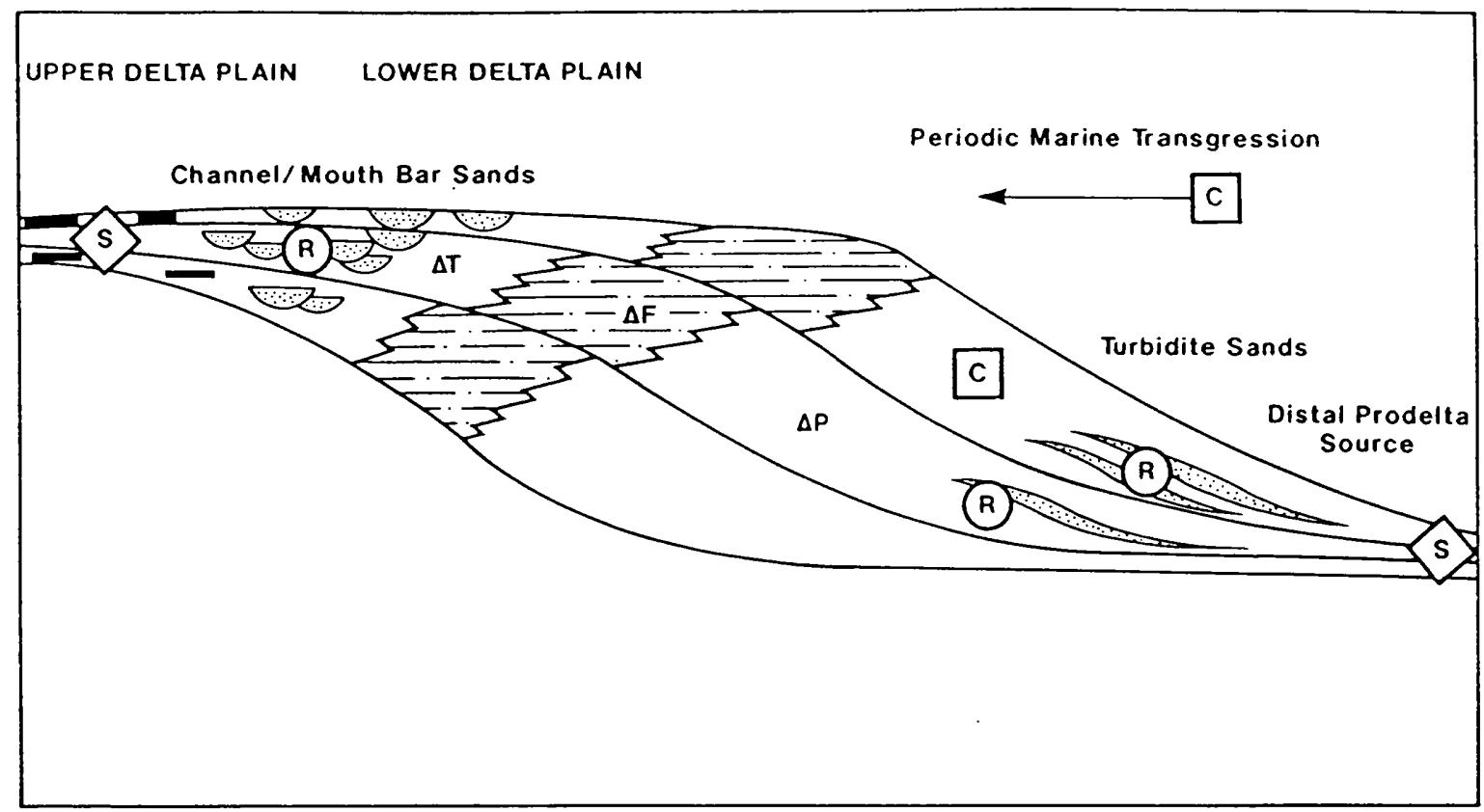

RESERVOIR :

$\Delta T$ channel/mouth bar sands.

$\Delta \mathrm{P}$ turbidite sands.

SEAL :

$\Delta T$ marine bands - good; lacustrine/overbank muds - moderate/poor. $\Delta P$ mudstones - good.

SOURCE :

$\Delta T$ and $\Delta P$ reservoirs prograde over distal pro delta-source rocks.

- Delta top coals.

- Late Carboniferous/Mesozoic charge.

CRITICAL FACTORS: (i) Reservoir quality downgraded beyond $2500 \mathrm{~m}$ burial depths.

(ii) Dinantian pro-delta source tends to be gas prone.

(iii) $\Delta \mathrm{T}$ seals poor for trapping gas.

Fig. 24. Carboniferous clastic delta sy'stem play fairway summary. $\Delta T=$ delta top. $\triangle F=$ delta Front, $\triangle P=$ pro-delta 

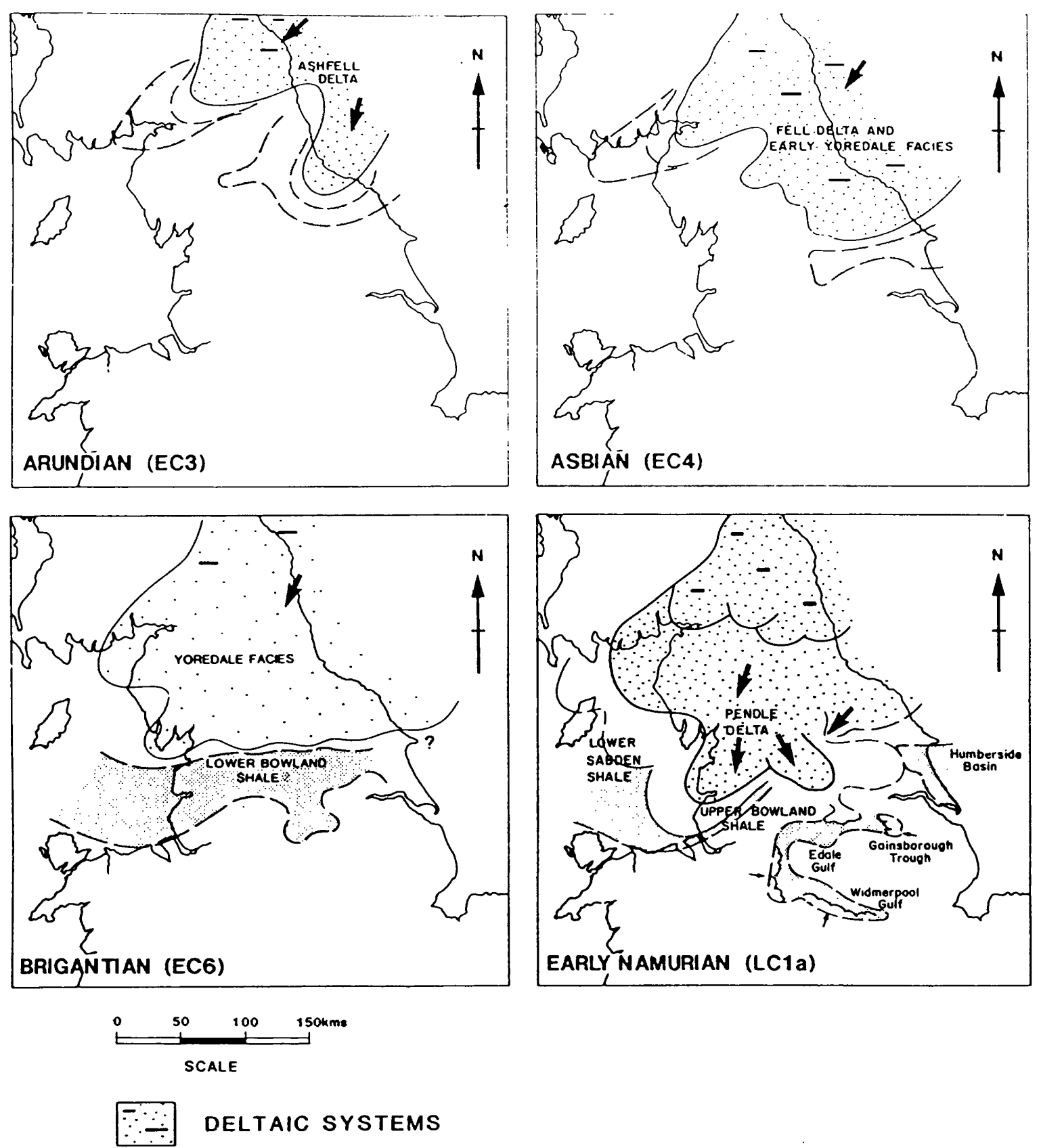

PROXIMAL TURBIDITE SANDS

DISTAL PRO-DELTA: PREDICTED

RICHEST SOURCE ROCK FACIES

\section{$\nearrow$ CURRENT DIRECTIONS}

Fig. 25. Delta advance during the middle to late syn-rift and carly post-rift and its relationship with source rock distribution and age in northern England. 


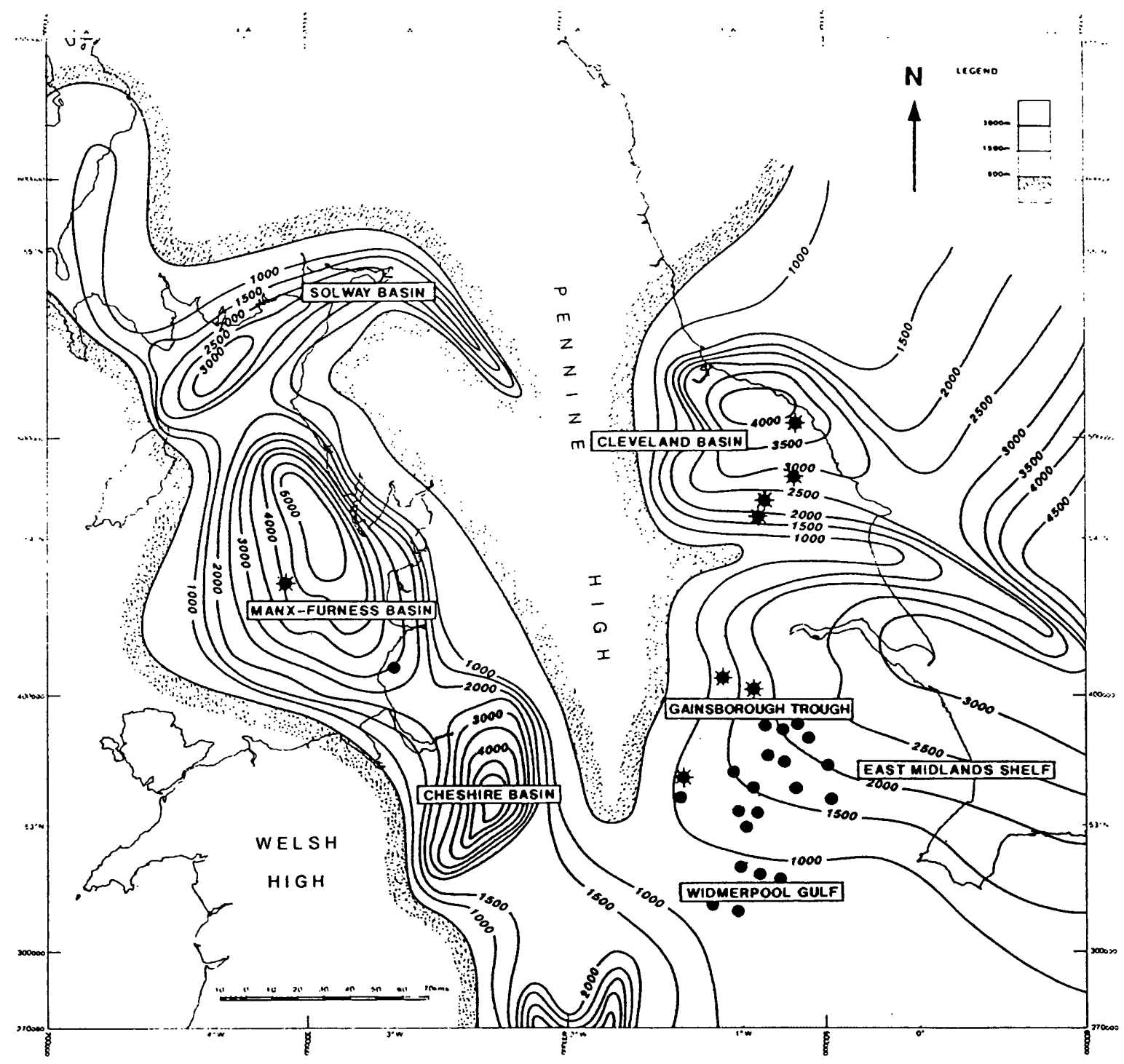

Fig. 26. Restored post-Carbonifcrous isopachs in metres and the location of the major hydrocarbon discoveries in northern England. Data from a number of sources including Whittaker (1985) and vitrinite/ fission track studies. Note that gas is the main hydrocarbon phase in regions subject to over $3000 \mathrm{~m}$ of post Carboniferous burial and the East Midlands oilficlds are concentrated in an area of moderate burial. There are no hydrocarbon discoveries along the axis of the Pennine high where Mesozoic burial has becn negligible.

Solway Basin. Fission track studies around the Lake District (Green 1986) and isopach mapping suggest that this basin attained maximum generation during the Mesozoic. The greater part of the subsidence in this area is related to Permo-Triassic rifting. Onset of oil generation is thought to be in the late Triassic-early Jurassic with peak generation in the late Cretaceous. The basin has probably been subject to some $5(1)$ metres of late Tertiary uplift (Fraser et al. 199()$)$.

Vitrinite reflectance and fission track data indicate that arcas such as the central Pennines and the Northumberland and Stainmore Troughs reached maximum burial during the late Carboniferous. Significantly, this was prior to the trap forming Variscan inversion event: the only remnants of this earlier phase of generation being the widespread and well documented surface bitumen occurences in the region (Lees \& Cox 1937).

\section{Conclusions}

The structures which controlled the Carboniferous tectono-stratigraphic development of 
northern England were inherited from the earlier Caledonian orogeny. These events imparted a strong NW-SE and NE-SW tectonic grain which is evidenced on surface and subsurface data throughout northern England. The subsequent Variscan plate cycle, which involved the closure of the Rheic and Rheno-Hercynian oceans, controlled the development of syn-rift, post-rift and inversion megasequences from latc Devonian to early Permian times. Sequences developed within the Carboniferous are seen to be controlled by episodic rifting and periodic fault reactivation with eustatic sea level changes providing only minor control and only at the sub-sequence level.

In the south of the province during the Dinantian, carbonate environments were extensivly developed in syn-rift basins starved of terrigeneous clastics. The north of the region was dominated from early Dinantian times onward by a southward prograding terrigenous clastic delta system. The carbonate environments in the south were finally drowned in the early post-rift (Pendleian) when the supply of terrigenous clastic sediments outpaced subsidence for the first time, allowing rapid southward progradation of the delta systems.

Over 70 years of exploration in northern England has resulted in the discovery of $75 \mathrm{mmbbl}$ of recoverable reserves. Average field size is assessed at $2 \mathrm{mmbbls}$ at a historical finding rate of one discovery in four exploration wells. All hydrocarbon discoveries to date within the Carboniferous have shown some element of Variscan deformation in their geometry. Tectonics have also exerted a subtle, but important control on play fairway evolution. The main source rocks, developed in distal pro-delta environments, are restricted to the syn-rift depocentres. Syn-rift siliciclastic reservoirs, associated with the early rift phase are located within the isolated, rifted, half-graben. Carbonate grainstone reservoirs are controlled by the rift topography and rim the margins of the deeper half graben in the south of the province. Delta top channel and mouth bar reservoirs are best developed where they axially infill remnant rift bathymetry.

Mesozoic burial, ensuring hydrocarbon generation post-Variscan trap formation, is considered to be the main control on the present day distribution of hydrocarbons in northern England. Areas such as the central Pennines and Northumberland and Solway Basins which received limited Mcsozoic burial are considered to have poor hydrocarbon potential. The Cleveland, Manx-Furness and Cheshire Basins where Mesozoic burial was excessive have gas as the major hydrocallonen phase. The Fast Midlands, where Mesozoic hurial and post Variscan trap modification have been moderate, hats therefore emerged as the most successful oil province in northern England.

Permission to publish this paper has been granted by the British Petrolcum Co ple. We are also grattcful to partners Gas Council (Exploration), Elf Oil and Gas Lid and Blackland Oil for permission to publish scismic data from the East Midlands. Critical readings of the manuscript and many helpful suggestions were provided by R. J. Bailey and M. R. Lecder. Wc would also like to thank E. A. Kay, J. Hossack, S. D. Knott and B. C. Mitchener who made important contributions to the study. We also acknowledge the contributions of Dr G. A. L. Johnson and Dr R. E. LI. Collier to our analysis of the Stainmore Trough. R. L. G. would like to thank the Durham University Rescarch Foundation and the Socicty of Fellows for support whilst he was at the Department of Geological Sciences. University of Durham. Sincere thanks to Paul Batey for the drafting and Lisa Phelan who typed the manuscript.

\section{References}

Aikfenifad, N. \& Cimsiom.m, J. I. 1982. A standard nomenclature for the Dinamian formations of the Peak District of Derbyshire and Staffordshire. Report of the Institutc of Gcological Scicnces, $82 / 8$.

- - \& Stevenson. I. P. 1985. Geology of the country around Buxton, Leek and Bakewell. Memoir of the British Gcological Survey.

Andrf. L., Hetrogen, J. \& Deutsci, S. 1986. Ordovician-Silurian magmatic provinces in Belgium and the Calcdonian orogeny in Middle Europc. Geology, 14, 879-882.

Artiurton, R. S., Joinson, E. W. \& Mundi, D. S. C. 1988. Geology of the country around Settle. Memoir of the British Gcological Survey.

Beamisir, D. \& Smrrire, D. K. 1986. Gcophysical images of the decp crust: The lapetus suture. Journal of the Geological Society. London, 143. $489-497$.

BFsı.Y, B. M. 1988. Palacogeographic implications of late Westphalian to carly Permian red beds. central England. In: Bi:si.Y. B. M. \& KFI.IING; G. (eds). Sedimentation in a Synorogenic Basin Complex: The Carboniferous of Northwest Europe. Blackic, Glasgow, 2()-221.

Bort. M. H. P. 1976. Formation of sedimentary basins of graben type by extension of the conlinental crust. Tectomophysics. 36. 77-86.

— JoInson, G. A. L. 1967. The controlling mechanism of Carboniferous cyclic sedimentation. Quarterly Jomrnal of the Geological Societs. London, 122, +21-441.

Burciess. I. C. \& Hen.tinay. D. W' 1979. Gcology of the country around Brough-Under-Stainmore Memoir of the British Geological Survey. 
(illi:k. M. A. IY)S. The distribution of Westphalian marinc faumas in northern England and adjoining arca. Proceedings of the Yorkshire Ceological Societs. 44. $479-496$.

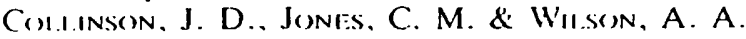
1977. The Marsdenian (Namurian R2) sucecssion West of Blackburn: Implications for the cvolution of Penninc delta systems. Geological Journal, 12 $59-76$.

Dunitam. K. C. \& Wilson, A. A. 1985. Gcology of the Northern Penninc oilficld: Volume 2 Stainmore to Craven. Economic Memoir of the British Geological Survey.

Eibion, C. C.. Fraser, A. J., Hicicins, A. C.. Mitcifiner, B. C. \& Strank, A. R. E. 1990. The Dinantian Stratigraphy of the East Midlands: A scismostratigraphic approach. Journal of the Geological Sociery. London, 147. 519-536.

EmbFrN. J. 1981. The gcology of the Morccambe gas ficld. In: It. Inc; L. V. \& Homson. G. D. (cds). Petroleum Geology of the Continental Shelf of North-West Europe. Institute of Pctrolcum. London, 485-493.

Fraser. A. J.. Nasi, D. F., Stfeif., R. P. \& Ebion, C. C. 1990 . A regional assessment of the intraCarboniferous play of northern England. In: Brooks, J. (cd). Classic Petroleum Provinces. Gcological Society, London, Special Publication 50, $417-440$.

Falcon, N. L. \& Kent, P. E. 1960. Geological results of petroleum exploration in Britain 1945-1957. Meinoir of the Geological Society, London. No. 2.

Gawthorpe. R. L. 1987a. Tectono-sedimentary evolution of the Bowland Basin, N England, during the Dinantian. Journal of the Geological Society. London, 144, 59-71.

1987b. Burial dolomitisation and porosity development in a mixed carbonate - clastic sequence: An example from the Bowland Basin, Northern England. Sedimentology, 34, 533-558.

- \& Clemmey, H. 1985. Gcometry of submarine slides in the Bowland Basin (Dinantian) and their relation to debris flows. Journal of the Geological Society, London, 142, 555-565.

- Gutteridge, P. \& Leeder. M. R. 1989. Late Devonian and Dinantian basin cvolution in Northern England and North Walcs. Im: Artiurtun, R. S., Gutteridge. P. \& Nol.an, S. C. (cds). The role of tectonics in Devonian and Carboniferous sedimentation in the British Isles. Yorkshirc Gcological Socicty (Occasional Publication No. 6), 1-23

Greorcje, T. N. 1958. Lower Carboniferous palacogcography of the British Islcs. Proceedings of the Yorkshire Geological Society, 31, 227-318.

- 1978. Eustacy and tectonics: Scdimentary rhythms and stratigraphic units in British Dinantian corrclation. Proceedings of the Yorkshire Geological Society, 42, 229-262.

Gratson, R. F., \& Olditam, L. 1987. A new structural framework for the northern British Dinantian as a basis for oil, gas and mincral cxploration. In: Milifr, J., Adams, A. E. \& Wricitr. V. P.

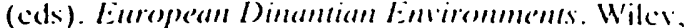
Chichester, 33-59)

Grian. P. F. 1986. On the thermo-tectonic cvolution of northern England: Evidence from fission track analysis. Geological Magazine. 123, 493-5()6.

1989. Thermal and tectonic history of the East Midlands Shelf (onshore UK). and surrounding regions assessed by Apatite Fission Track Analysis. Journal of the Geological Society, London. 146. 75.5-773.

Guion, P. D. \& Fifi.ining. C. R. 1987. Westphalian A and $B$ scdimcntation in the Pcnninc basin, UK. In: Brst.y, B. M. \& KFilung, G. (cds). Sedimentation in a svmorogenic basin complex: The Carboniferous of northwest Europe. Blackic. Glasgow, 153-177.

Gurrtrinc;F, P. 1987. Diantian sedimentation and bascment structure of the Derbyshire Domc. Geological Journal. 22, 25-41.

- 1989. Controls on carbonatc scdimentation in a Brigantian intrashelf basin, Derbyshirc. In: Artiunton, R. S. Gutteridif. P. \& Noi.an, S. C. (eds). The role of tectonics in Devonian and Carboniferous sedimentation in the British Isles. Yorkshirc Gcological Socicty (Occasional Publication No. 6), 171-187.

Hubrard, R. J. 1988. Agc and significance of sequence boundaries on Jurassic and early Cretaceous rifted continental margins. American Association of Petroleum Geologists Bulletin, 72. 49-72.

- Pape, J. \& Roberts. D. G. 1985a. Depositional sequence mapping as a technique to establish tectonic and stratigraphic framework and cvaluate hydrocarbon potential on a passive continental margin. In: BERG, O. R. \& WOOLVERTON, D. G. (eds). Seismic Stratigraphy II, American Association of Petroleum Geologists Memoir. 39. 79-92.

, \& $\&$ 1985b. Depositional sequence mapping to illustrate the evolution of a passive continental margin. In: BERG, O. R. \& WOOLVERTON, D. G. (eds). Seismic Stratigraphy II. Amcrican Association of Pctrolcum Geologists Memoir, 39, pp 93-115.

Institute of Geol.ogical. Scifnces. 1978. IGS Borcholes 1977. Report of the Institute of Geological Sciences, No. 78/21. 1-24.

JACKSON, J. A. 1987. Active normal faulting and crustal extension. In: Cowaris, M. P., DFivfy. J. F. \& Hancoch. P. L. (cds). Continental Ertensional Tectonics. Gcological Socicty, London Spccial Publication. 28. 3-17.

Jomnsox. G. A. L. 1960. Palacogeography of the northern Pennincs and part of NE England during deposition of Carbonifcrous cyclothemic deposits. International Geological Congress XXI Session Norden, 12. 118-128.

KFnT. P. E. 1966. Structurc of the concealed Carboniferous rocks of NE England. Proceedings of the Yorkshire Geological Society, 35, 323-352.

Kimizfi.1. G. S. CinaDWick. R. A., Hoilidar. D. W: \& Wfrengren. O. C. 1989. The structure and cvolution of the Northumberland Trough from 
new scismic reflection data and its bearing on modes of contincontal extension. Iournal of the Goological Sociess. London. 146, 775-787.

KIRToN. S. R. 1984. Carboniferous volcanicity in England with special reference to the Westphalian of the $E$ and $W$ Midlands. Journal of the Geological Society. London, 141. 161-17().

LFEDIER, M. R. 1974. Lower Border Group (Tournasian) fluvio-deltaic sedimentation and the palacogeography of the Northumberland Basin. Proceedings of the Yorkshire Geological Society. 40. $129-180$

1982. Unper Palacozoic basins of the British Isles - Calcdonide inheritance versus Hercynian plate margin processes. Journal of the Geological Society, London, 139, 479-491.

- 1987. Tectonic and palacogcographic models for Lower Carbonifcrous Europe. In: Mil...E. J. Amams. A. E. \& Wricint. V. P. (cds). European Dinantian Environments. Wilcy. Chichester. $1-19$.

- 1988. Recent developments in Carbonifcrous gcology: A critical rcvicw with implications for the British Islcs and NW Europc. Proceedings of the Geologists' Association, 99, 73-100).

_ \& GaWtiorpe, R. L. 1987. Sedimentary models for cxtensional tilt-block/half-graben basins. In: Coward. M. P., Dewey, J. F. \& Hancock, P. L. (cds). Continental Exrensional Tectonics. Gcological Socicty, London, Special Publication, 28. $139-152$.

\& MCMAHON, A. H. 1988. Upper Carboniferous (Silesian) basin subsidence in northern Britain. In: Besi.y, B. M. \& Kel.uing, G. (eds). Sedimentation in a synorogenic basin complex: The Carboniferous of northwest Europe. Blackic, Glasgow, 43-52.

Lefs, G. M. \& Cox, P. T. 1937. The gcological results of the recent scarch for oil in Grcat Britain by the D'Arcy Exploration Company Limited. Quarterly Journal of the Geological Society. London, 93, 156-194.

- \& TAIT, A. H. 1945. The geological results of the scarch for oilficlds in Grcat Britain. Quarterly Journal of the Geological Society, London, 101 . $255-317$.

Lifewfilyn. P. G. \& Stabizins, R. 1968. Demonstration: Corc matcrial from the Anhydrite scrics. Carboniferous Limestonc, Hathern Borcholc, Lciccstershire. Proceedings of the Geological Sociery. London, 1650, 171-186.

- - 1970. The Hathern Anhydrite Scrics. Lower Carboniferous, Lcicestershirc, England. Transactions of the Institution of Mining and Metallurgl. 79b, Bl-15.

Macionnal. R. Gass. K. N., Tilorple, R. S. \& Gass. I. G. 1984. Gcochemistry and petrogenesis of the Derbyshire Carboniferous basalts. Journal of the Geological Society. London, 141, 147-159.

Mili.er, J. \& Grayson, R. F. 1982. The regional context of Waulsortian facies in northern England. In: BOI.TON, K., LaNe, H. R.. \& LEMONE. D. U. (cds). Sympositum on the palaeoenvironmental setring and distribution of the

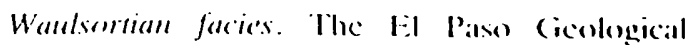
Socicty and University of Texals all lis liaso. $17-30$.

Mit..s. D. A. C. \& Hen.1.J. H. 1976. Geology of the country around Barnard Castle. Memoir of the British (ieological Survey

Mitcuime. R. U., Vall. P. R. \& TIIomipson, S. 1977. The depositional sequence as a basc unit for stratigraphic analysis. In: PAYton. C. E. (ed). Seismic stratigraphy - applications to hydrocarbon exploration. Amcrican Association of PetroIcum Gcologists Mcmoir, 26, 53-62.

Pliaroahi. T. C. Mrekriman, R. J.. Wfibib. D. C. \& Bfackinsidal.f. R. D. 1987. The concealed Calcdonides of castern England: preliminary results of a multidisciplinary study. Proceedings of the Yorkshire Geological Society, 46, 335-369.

Ramshottom. W. H. C. 1973. Transgressions and regressions in the Dinantian: a new synthesis of British Dinantian stratigraphy. Proceedings of the Yorkshire Geological Society, 39. 567-6(1)7.

1977. Major cycles of transgression and regression (mcsotherms) in the Namurian. Proceedings of the Yorkshire Geological Societv. 41, 261-291.

1981. Eustasy, sca level and local tectonics, with cxamples from the British Carbonifcrous. Proceedings of the Yorkshire Geological Society, 43, $473-482$.

RF.ADING. H. G. 1964. A revicw of the factors affecting the scdimentation of the Millstone Grit (Namurian) in the Central Pennines. In: VAN Stranten, L. M. J. U., (cd.). Deltaic and Shallow Marine Deposits, Elscvier, Amsterdam.

Rotimet.l. N. R. \& Quinn, P. 1987. The Welton Oilfield. In: Brooks, J. \& Glennie, K. (eds). Petroleum Geology of North West Europe. Graham \& Trotman, London, 181-189.

Sfli.wood, E. B. \& Thomas, J. M. 1986. Variscan facies and structure in central S.W. England. Journal of the Geological Society, London, 143, 199-207.

Smitiı, K.. Smitil, N. J. P. \& Hol.i.iday, D. 1985. The deep structurc of Derbyshirc. Geological Journal, 20. $215-225$

Soper. N. J. \& Hutron, D. H. W. 1984. Late Calcdonian sinistral displacements in Britain: Implications for a threc plate collision model. Tectonics, 3, 781-794.

—. WFB3, B. C. \& Wooncock, N. H. 1987. Latc Calcdonian (Acadian) transpression in North West England: timing, gcomctry and geotcctonic significance. Proceedings of the Yorkshire Geological Socien. 46, 175-192.

Srefa. R. P. 1988. The Namurian sedimentary history of the Gainsborough Trough. In: Brest.y. B. M. \& KI:I.1.ING. G. (cds). Sedimentation in a swnorogenic basin complex: The Carboniferous of norihwest Europe. Blackic, Glasgow, 101-113.

Strin. R. S. \& Barifntos, S. E. 1985. Planer high angle faulting in the Basin and Range: Geodetic analysis of the 1983 Borah Pcak. Idaho, carthquake. Jommal of Geophysical Research, 90. $1135,5-11366$

Smitisen. I. P. \& Gaunt. G. D. 1971. Geology of 
the country around Chapel-en-le-Frith. Memoir of the British Geological Survey.

Strank, A. R. E. 1987. The stratigraphy and structure of Dinantian strata in the East Midlands, UK. In: Mil...ER, J., Adams, A. E. \& Wright, V. P. (cds). European Dinantian Environments, Wilcy, Chichester, 157-175.

Turner, J. S. 1949. The deeper structure of Central and Northern England. Proceedings of the Yorkshire Geological Societv, 27, 280-297.

VAll, P. R. \& Mircium., R. M. 1977. Seismic stratigraphy and global changes of sea level, Part 1 : overvicw. In: PAyton. C. E. (cd). Seismic stratigraphy - applications to hydrocarbon exploration. Amcrican Association of Petrolcum Gcologists, Memoir 26, 51-52.

WAI.KDF. . G. M. 1977. Volcanic and erosive cvents on an Upper Visean carbonate platform, north Derbyshire. Proceedings of the Yorkshire Geological Society, 41, 347-367.

WALKDEN, G. M. 1982. Ficld guide to the lower Carboniferous rocks of the south cast margin of the Derbyshirc block: Wirksworth to Grangemill. Publication of the Department of Geology and
Mineralogy, University of Aherdeen.

Wal.Ters, S. G. \& InEson, P. R. 1981. A revicw of the distribution and corrclation of igncous rocks in Derbyshirc, England. Mercian Geologist, 8, 81132.

Wiuttaker, A. (cd). 1985. Allas of onshore sedimentary basins in England and Wales: Post Carboniferous tectonics and stratigraphy. Blackic, Glasgow.

, Ciladwick, B. A. \& Penn, I. E. 1986. Decp crustal traverse across southern Britain from seismic reflection profiles. Bulletin of the Geological Society, France, 8, 55-68.

WII.LS, L. J. 1951. A palacogcographical atlas of the British Isles and adjacent parts of Europe. Blackic, London.

1973. A palacogcographic map of the Palacozoic floor bencath the Permian and Mesozoic formations in England and Walcs. Memoir of the Geological Society. London 7.

1978. A palacogcographic map of the Lower Palacozoic floor below the cover of Upper Devonian, Carbonifcrous and Later formations. Memoir of the Geological Society. London, 8. 


\title{
THE TECTONO-STRATIGRAPHIC DEVELOPMENT AND HYDROCARBON HABITAT OF THE CARBONIFEROUS IN NORTHERN ENGLAND
}

\author{
Volume 2 \\ Plates
}

A thesis submitted for the degree of Doctor of Philosophy

by

Alastair James Fraser

Department of Geology and Applied Geology,

University of Glasgow.

January 1995 


\section{CONTENTS VOLUME 2}

\section{PLATES}

1. Exploration history and database

1.01 Licence position March 1989

1.02 Carboniferous oil and gas fields and cumulative reserves

1.03 Reported surface and near surface hydrocarbon occurrences

1.04 East Midlands hydrocarbon province: Structural elements and fields

1.05 Study area showing hydrocarbon discoveries and shows

1.06 Dinantian database map

1.07 NCB Boreholes and upper Carboniferous outcrop

1.08 Seismic database

1.09 Bouguer anomaly

1.10 First order derivative of Bouguer anomaly

1.11 Aeromagnetic survey

\section{Tectono-stratigraphic development}

\subsection{Caledonian structural elements}

2.02 Plate reconstruction for the Early Carboniferous

2.03 Idealised crustal scale sections: Pre and Post Variscan collision

2.04 Dinantian structural elements

2.05 Central England rift system: Regional cross sections

2.06 Chronostratigraphy of the Carboniferous system in Northern England

2.07 Sequence stratigraphy correlation: Widmerpool Gulf-Bowland Basin-

Stainmore Trough

2.08 Basin development: Widmerpool Gulf and Hathern Shelf

2.09 Chadian-Mid Brigantian syn-rift isopachs; sequences EC2-EC6

2.10 Late Brigantian-Westphalian C post-rift isopachs; sequences LC2-LC6

2.11 Variscan uplift and erosion

2.12 Post Variscan isopachs

2.13 Neogene and Quaternary uplift 


\section{Regional seismic and geological interpretation}

3.01 Location of regional seismic profiles and cross sections

$3.02 \mathrm{~N}-\mathrm{S}$ geological section across East Midlands hydrocarbon province

3.03 Regional seismic and depth section across the Southern North Sea Basin

3.04 Composite seismic and interpreted geological section across the Widmerpool Gulf

3.05 Regional well correlation across the Widmerpool Gulf

3.06 Composite seismic and interpreted geological section across the Gainsborough Trough

3.07 Composite seismic and interpreted geological section across the SE Gainsborough Trough

3.08 Composite seismic and interpreted geological section: Welton Oilfield

3.09 Composite seismic and interpreted geological section: Eakring Oilfield

3.10 Composite seismic and interpreted geological section: Egmanton Oilfield

3.11 Composite seismic and interpreted geological section: Calow Gasfield

3.12 Composite seismic and interpreted geological section across the Edale Gulf

3.13 Composite seismic and interpreted geological section across the western Bowland Basin

3.14 Composite seismic and interpreted geological section across the Pendle Monocline \& Bowland Basin

3.15 Composite seismic and interpreted geological section across the Leeds Basin

3.16 Composite seismic and interpreted geological section across the Cleveland Basin

3.17 Composite seismic and interpreted geological section across Western Stainmore

3.18 Composite seismic and interpreted geological section across Western Stainmore

3.19 Composite seismic and interpreted geological section across the Solway Basin

3.20 Composite seismic and interpreted geological section across the Northumberland Basin

3.21 Summarised stratigraphy of the East Midlands showing megasequence and sequence stratigraphy 
$4 \underline{\text { Palaeogeography and facies evolution }}$

4.01 Late Devonian Palaeofacies (EC1a)

4.02 Courceyan Palaeofacies (EC1b)

4.03 Chadian Palaeofacies (EC2)

4.04 Late Chadian - Arundian Palaeofacies (EC3)

4.05 Holkerian Palaeofacies (EC3)

4.06 Late Holkerian - mid Asbian Palaeofacies (EC4)

4.07 Late Asbian - early Brigantian Palaeofacies (EC5)

4.08 Early - mid Brigantian Palaeofacies (EC6)

4.09 Late Brigantian Palaeofacies (LC1a)

4.10 Early Pendleian Palaeofacies (LC1a)

4.11 Late Pendleian - Arnsbergian Palaeofacies (LC1b)

4.12 Chokierian - Alportian Palaeofacies (LC1b)

4.13 Early - mid Kinderscoutian Palaeofacies (LC1c)

4.14 Late Kinderscoutian Palaeofacies (LC1c)

4.15 Middle Marsdenian Palaeofacies (LC1c)

4.16 Late Marsdenian Palaeofacies (LC1c)

4.17 Earliest Yeadonian Palaeofacies (LC1c)

4.18 Yeadonian Palaeofacies (LC1c)

4.19 Earliest Westphalian A Palaeofacies (LC1c)

4.20 Westphalian A - B Palaeofacies (LC2)

4.21 Variscan - Post Westphalian C Inversion Palaeogeography (V1)

5. Hydrocarbon habitat and play fairway analysis

5.01 Northern England Carboniferous play fairway summary

5.02 Maximum Palaeo burial of basal Namurian fluvio-deltaic reservoirs

5.03 Vitrinite reflectance at Top Dinantian

5.04 Summary of Dinantian and Namurian source rock distribution and potential

5.05 Summary of Late Mesozoic Hydrocarbon Generation

5.06 Carboniferous Play Fairways - 1. Syn-rift Sandstones

5.07 Carboniferous Play Fairways - 2. Carbonate Shelf Margins

5.08 Carboniferous Play Fairways - 3. Clastic Delta Systems

5.09 Carboniferous Play Fairways - 4. Quartzose Fluvial Sands

5.10 Carbonate margin play assessment

5.11 Clastic delta play assessment

5.12 Intra-Carboniferous play summary 
APPENDIX H Summarised well logs (1:10,000 scale) of key boreholes used in the regional seismic interpretation (Plates 3.2-3.20) and palaeofacies mapping (Plates 4.1-4.21).

\section{LIST OF BOREHOLES}

Alkborough-1

Aldfield No. 1

Alport-1 (data sheet only)

Axholme No. 1

Barton-1

Beckingham-1

Belton No. 1

Blyton No. 1

Boulsworth-1

Broomfleet-1

Burton upon Stather-1

Butterwick (East) No. 1

Caldon Low borehole

Calow No. 1

Clarborough-1

Cold Hanworth-1

Crowle No. 1

Croxteth No. 1

Dunholme-1

Eakring No. 146

Edale-1

Egmanton-68

Egton High Moor-1

Eskdale-12

Eyam borehole (data sheet only)

Farley's Wood-4

Fletcher Bank-1

Grove-3

Hardstoft-1

Hathern No. 1

Hayton no. 1

Helmswell-1

Heywood-1
High Hutton-1

Holme Chapel-1

Ilkeston-1

Ironville-5

Kirby Misperton-1

Ladybrook-1

Lockton No. 8

Malton-4

Mansfield-1

NCB Kirby Lane

Newton Mulgrave-1

Normanby-1

Oxton No. 1

Ralph Cross No. 1

Ratcliffe-on-Soar-1

Rempstone-1

Rosedale No. 1

Rufford-1

Scaftworth-2

Scampton North-1

Scampton North-2

Seal Sands No. 1

Silloth-1

Southcliffe-1

Strelley-1

Sutton-on-Trent No. 3

Swinden-1

Welton-1

West Drayton No. 2

West Firsby-1

Whenby-1

Whittington-1

Whitwell-on-the-Hill-1 
1. Exploration history and database 


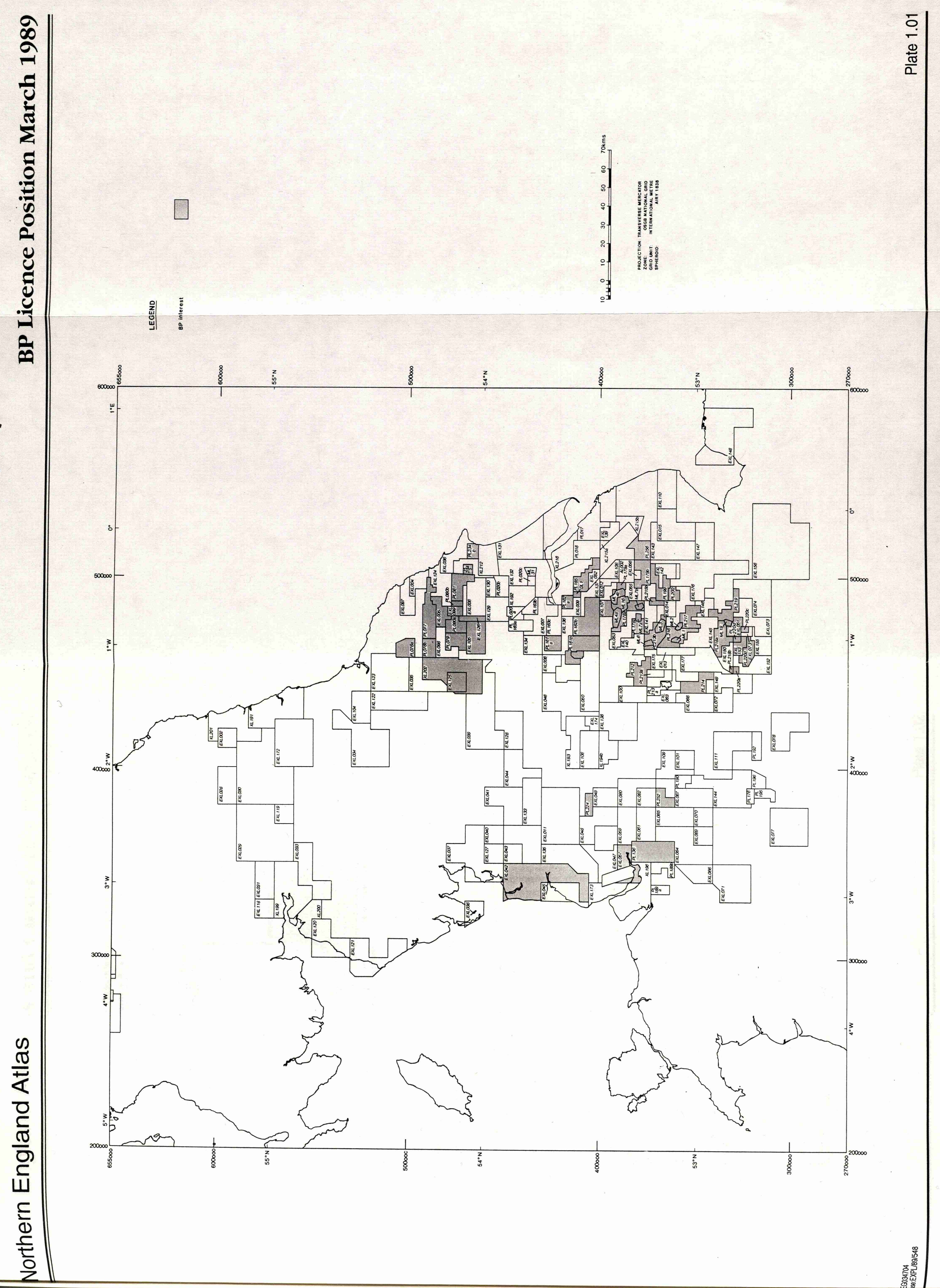



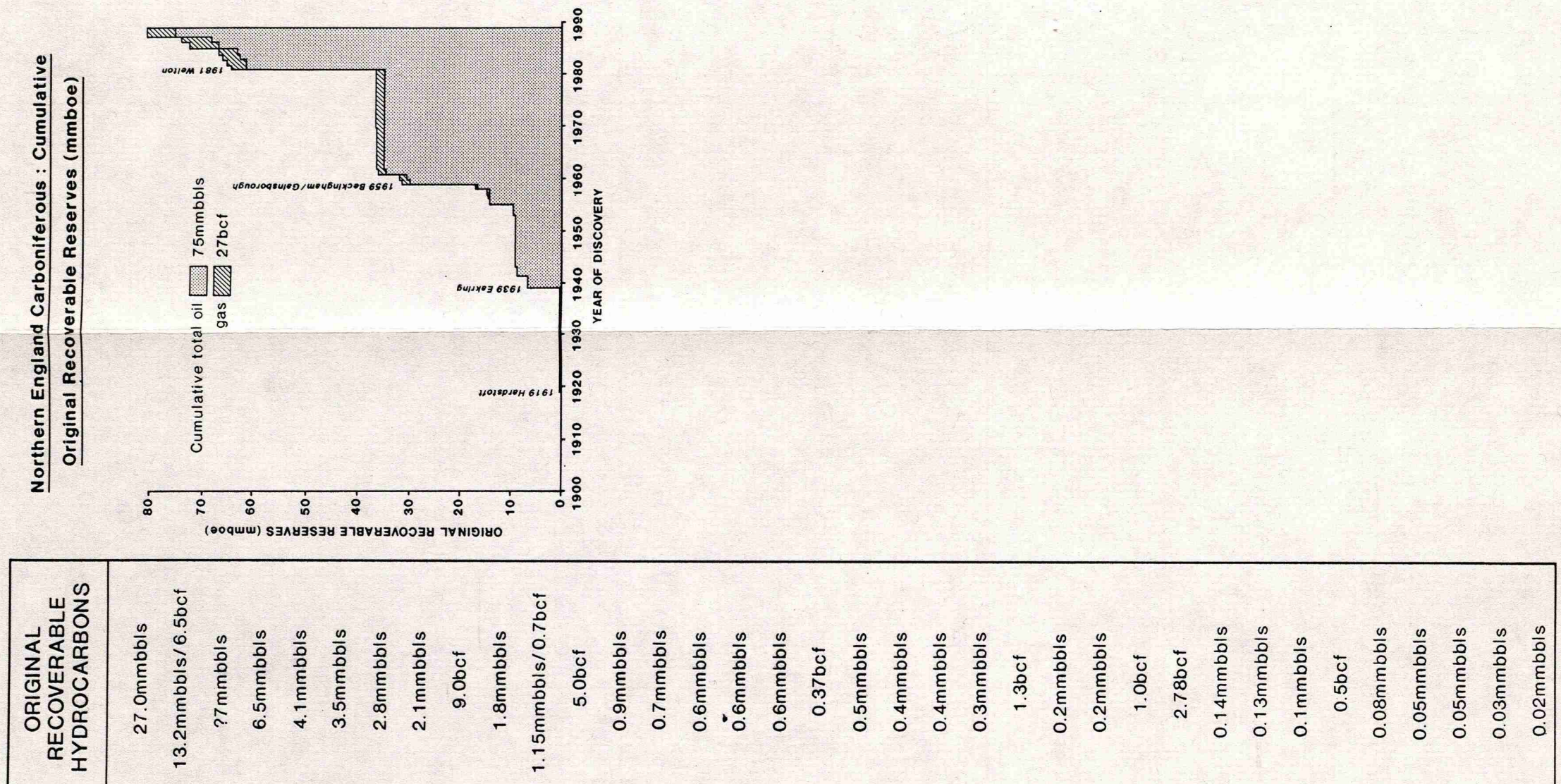

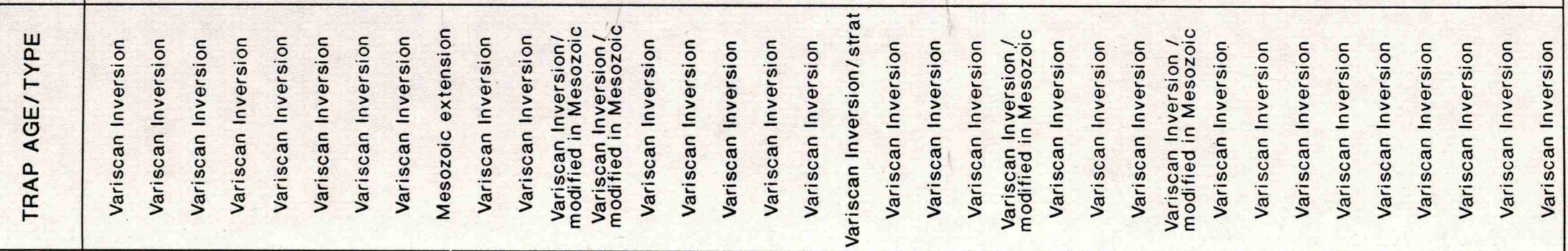
岀

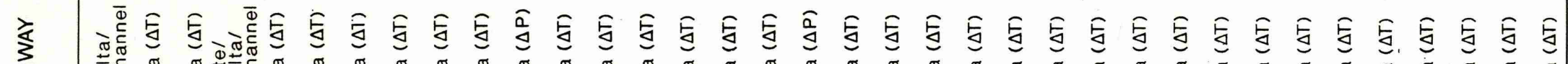

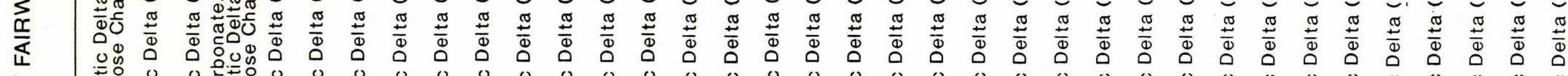

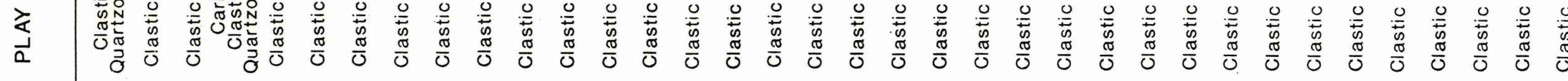

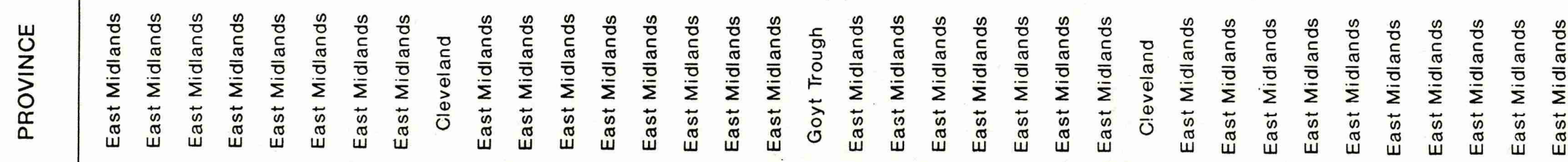

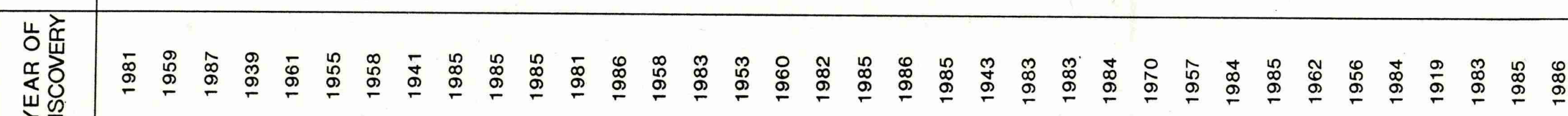

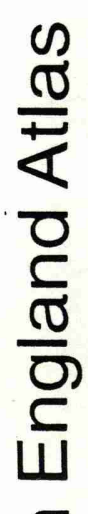

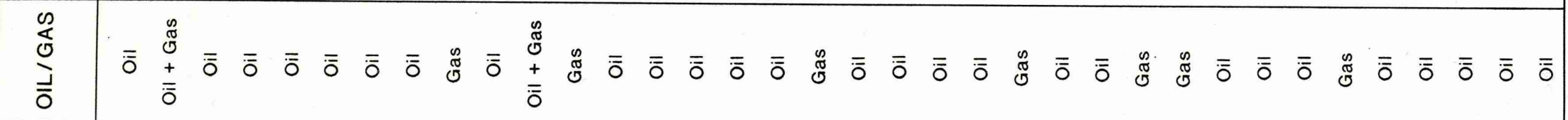

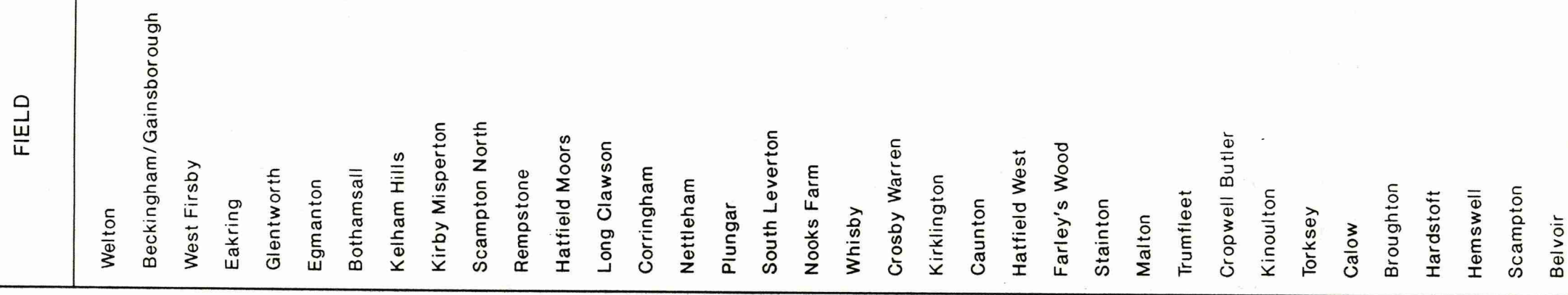
동 


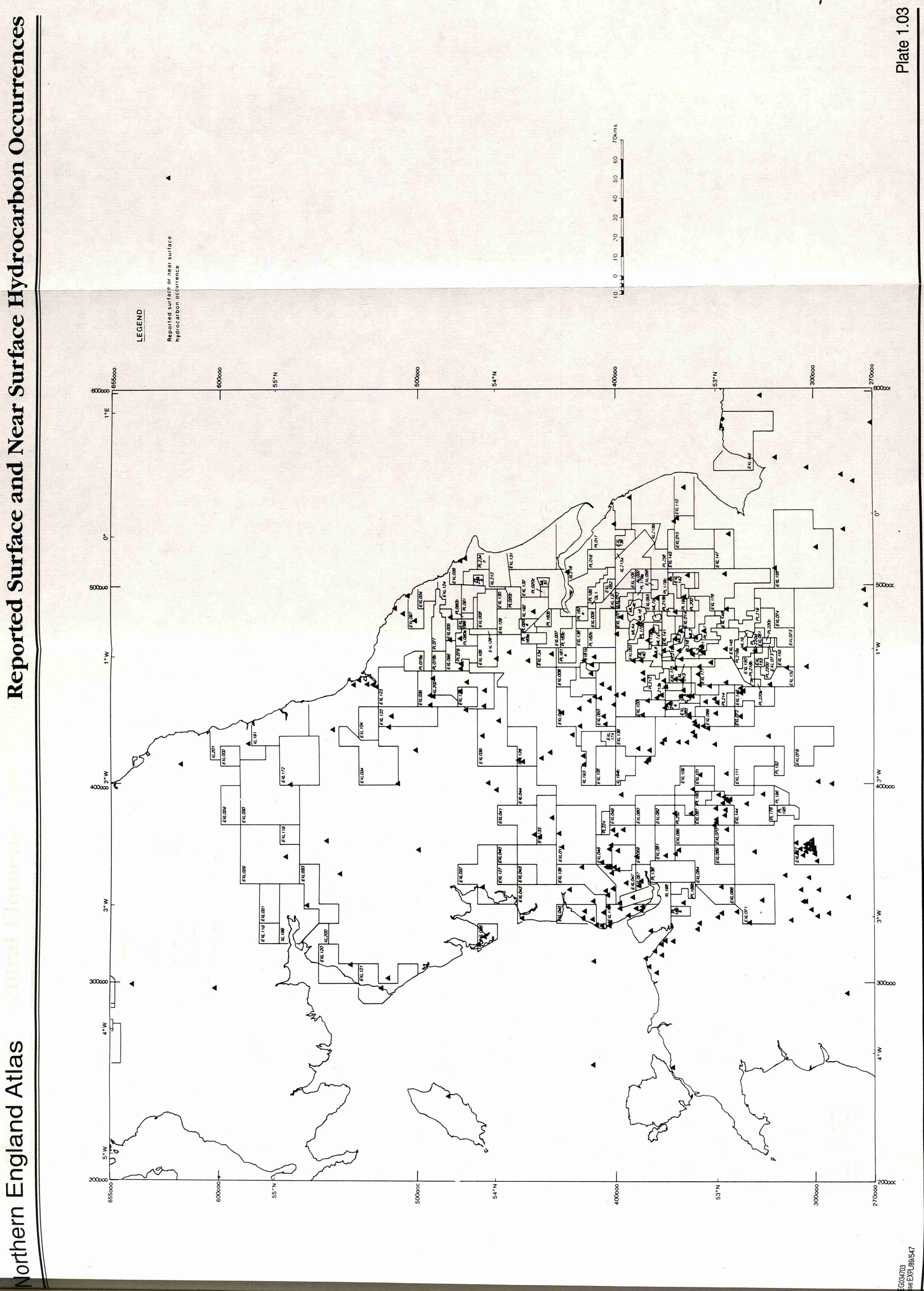




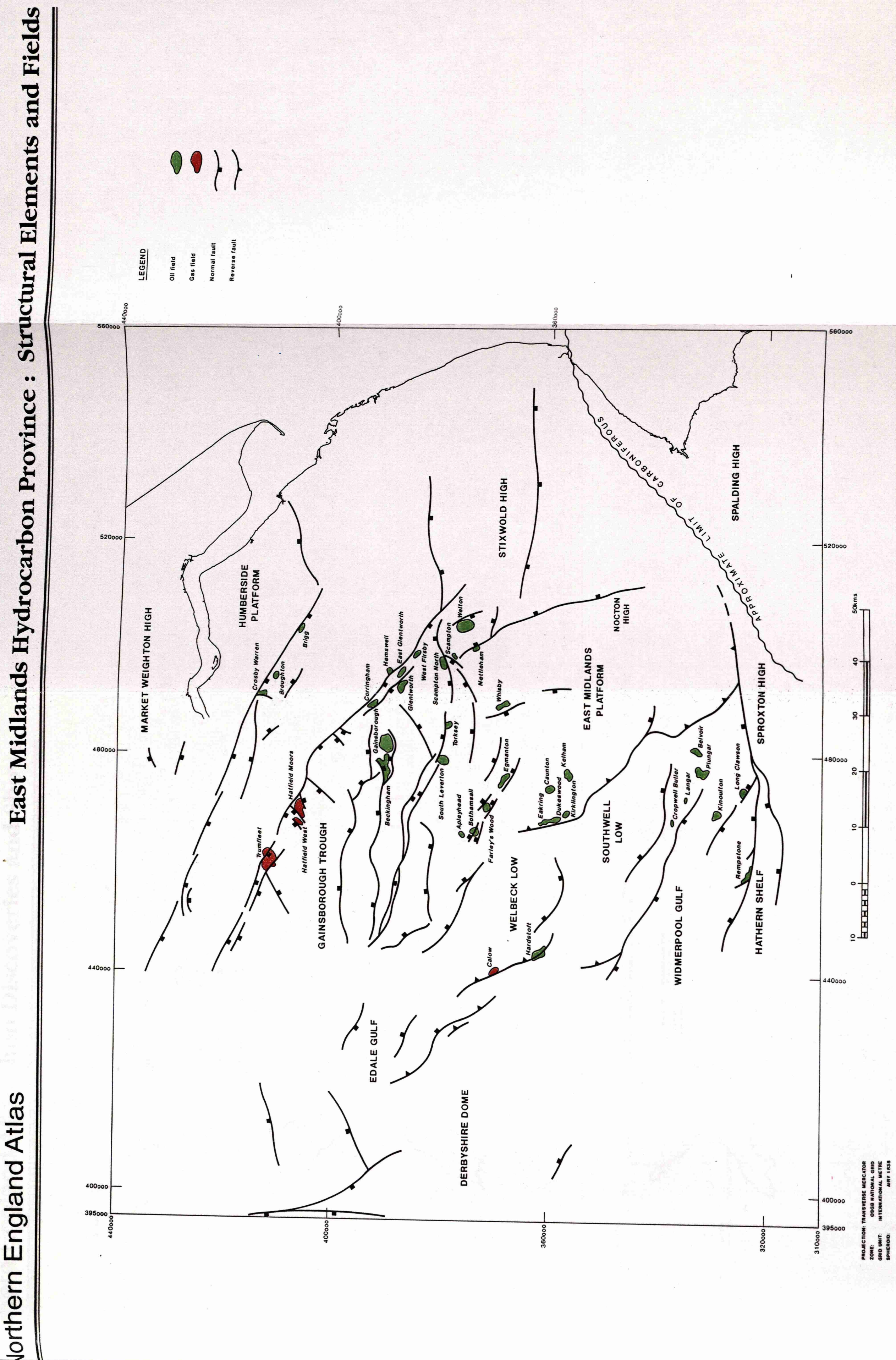




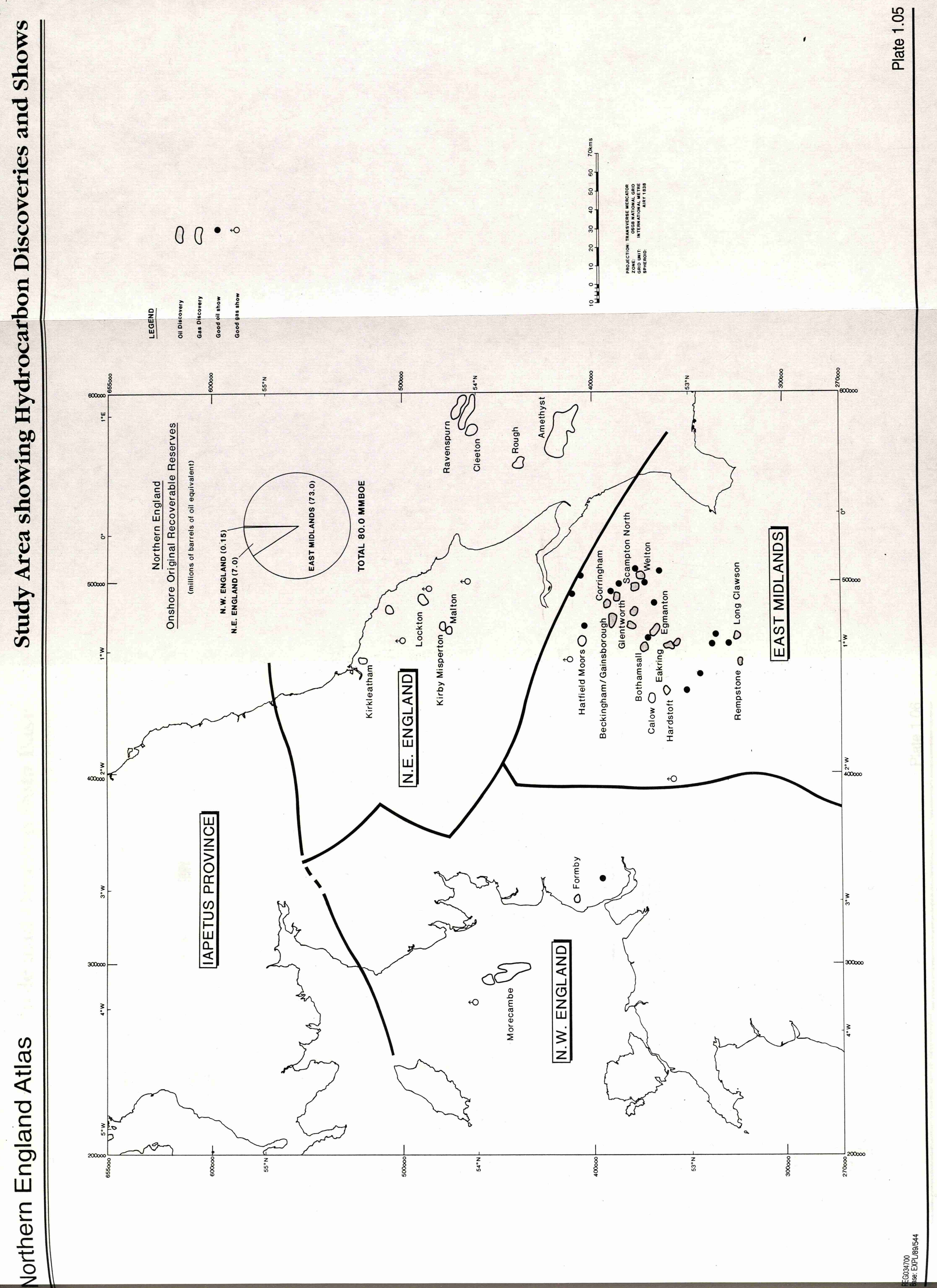




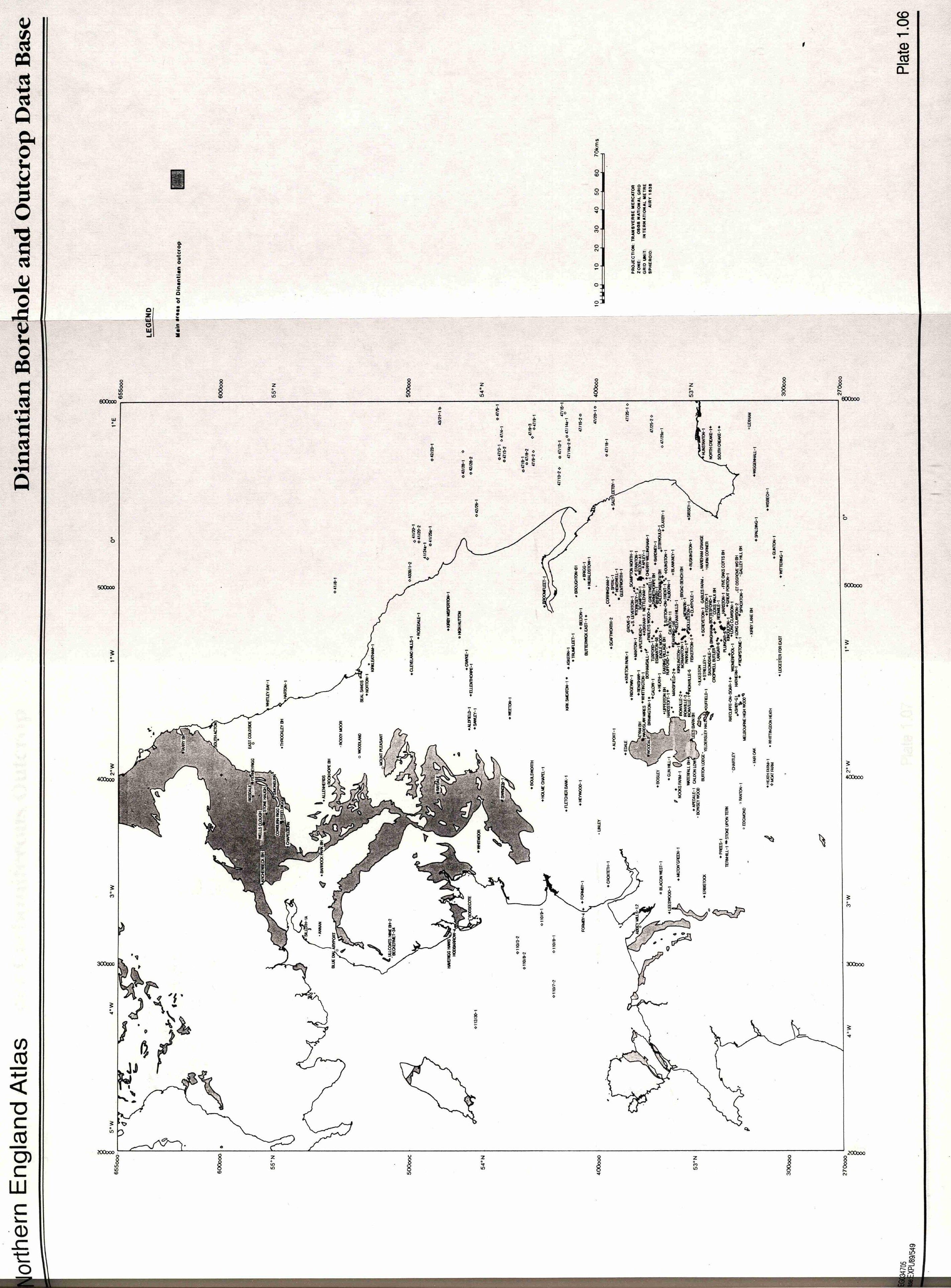




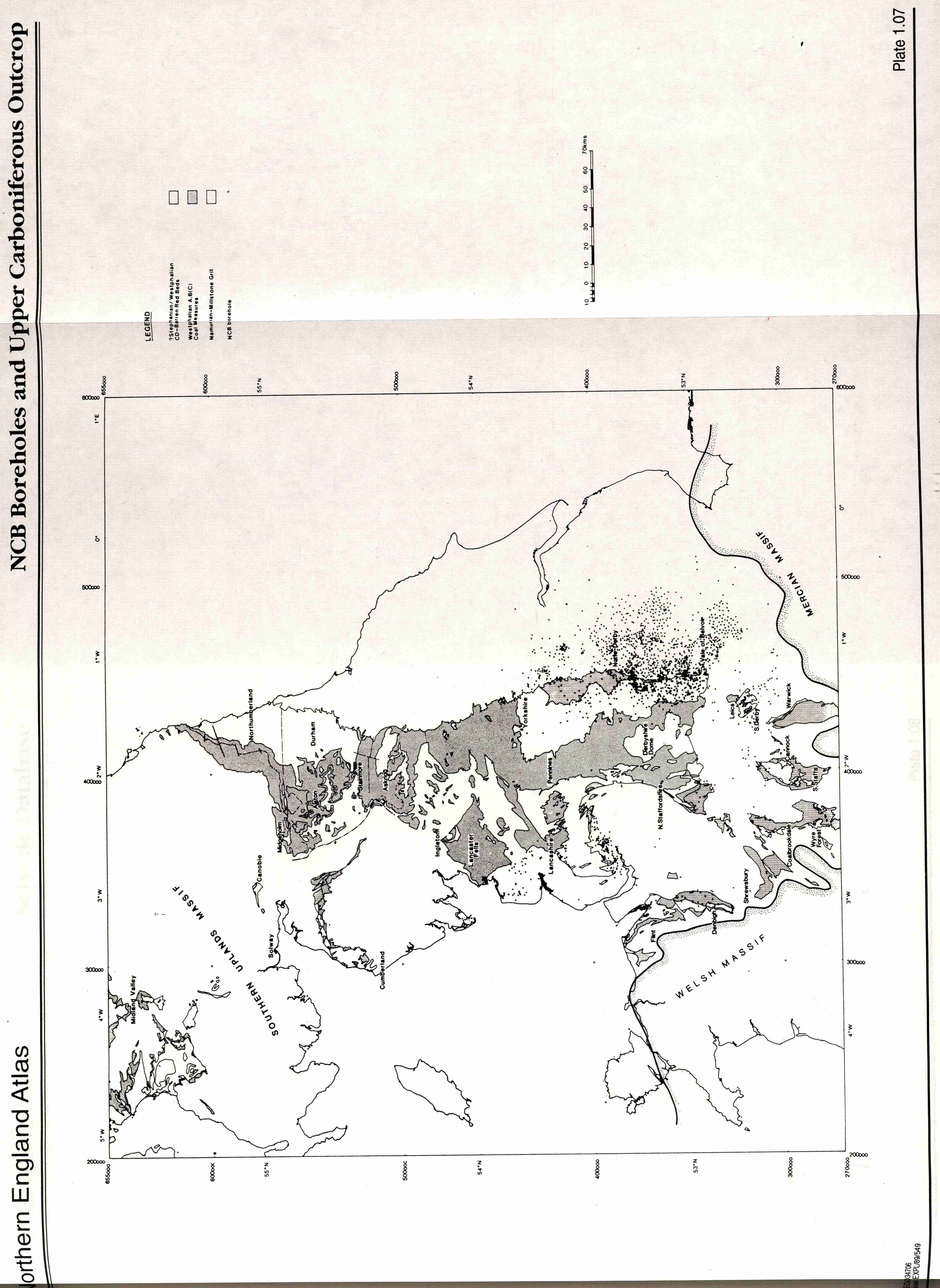



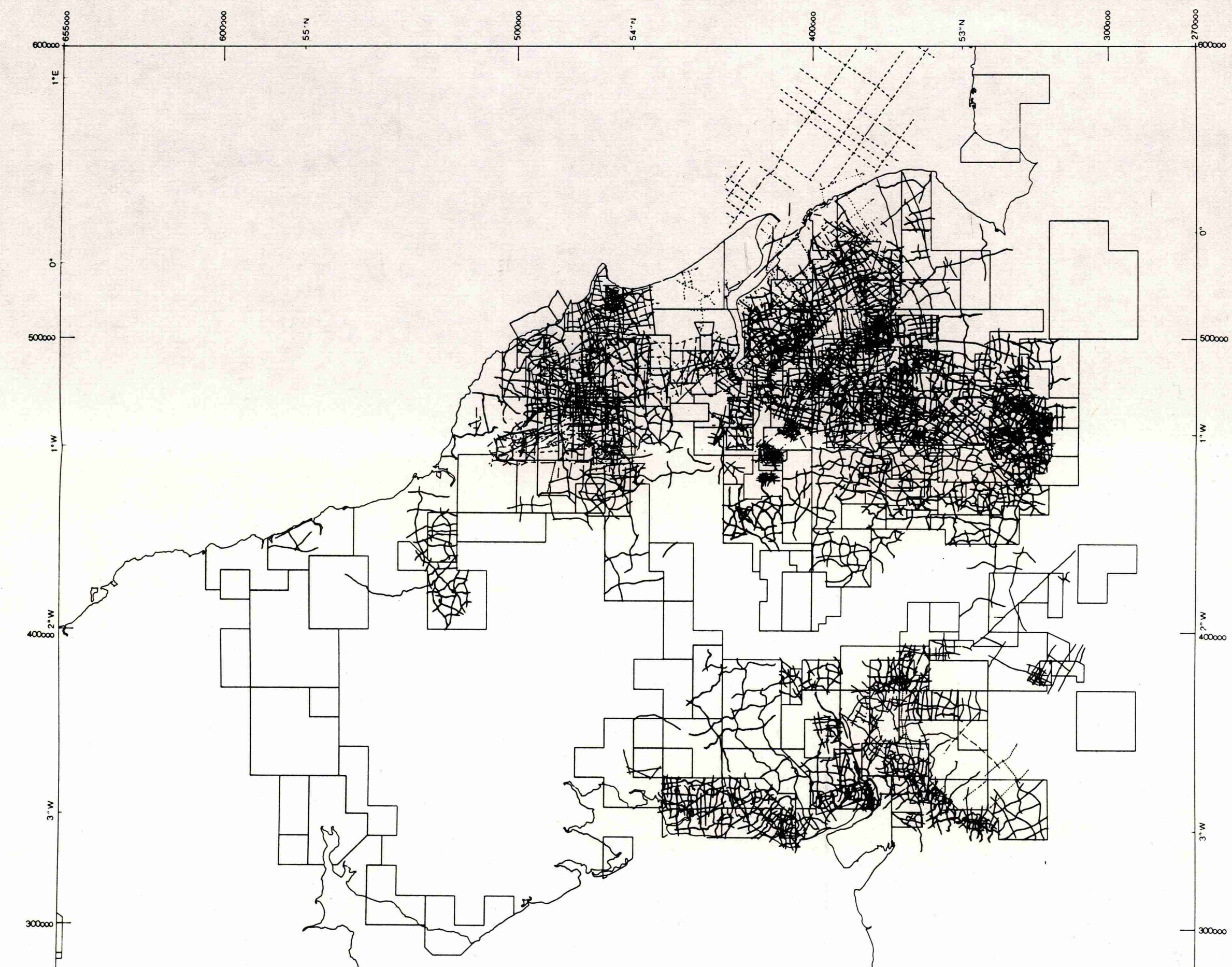

O) 


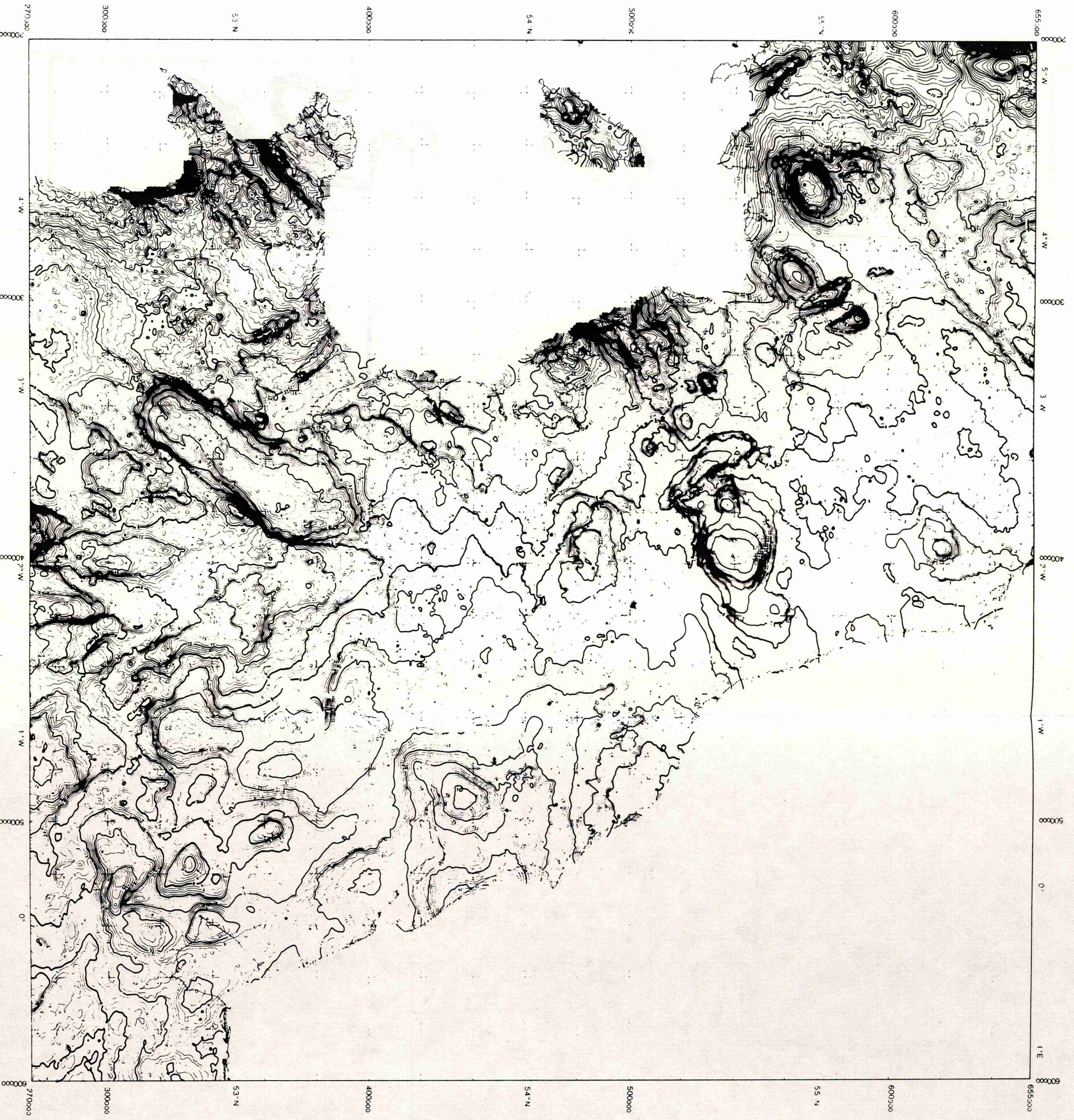

$\frac{0}{20}$
$\frac{0}{0}$
$\frac{0}{8}$ 

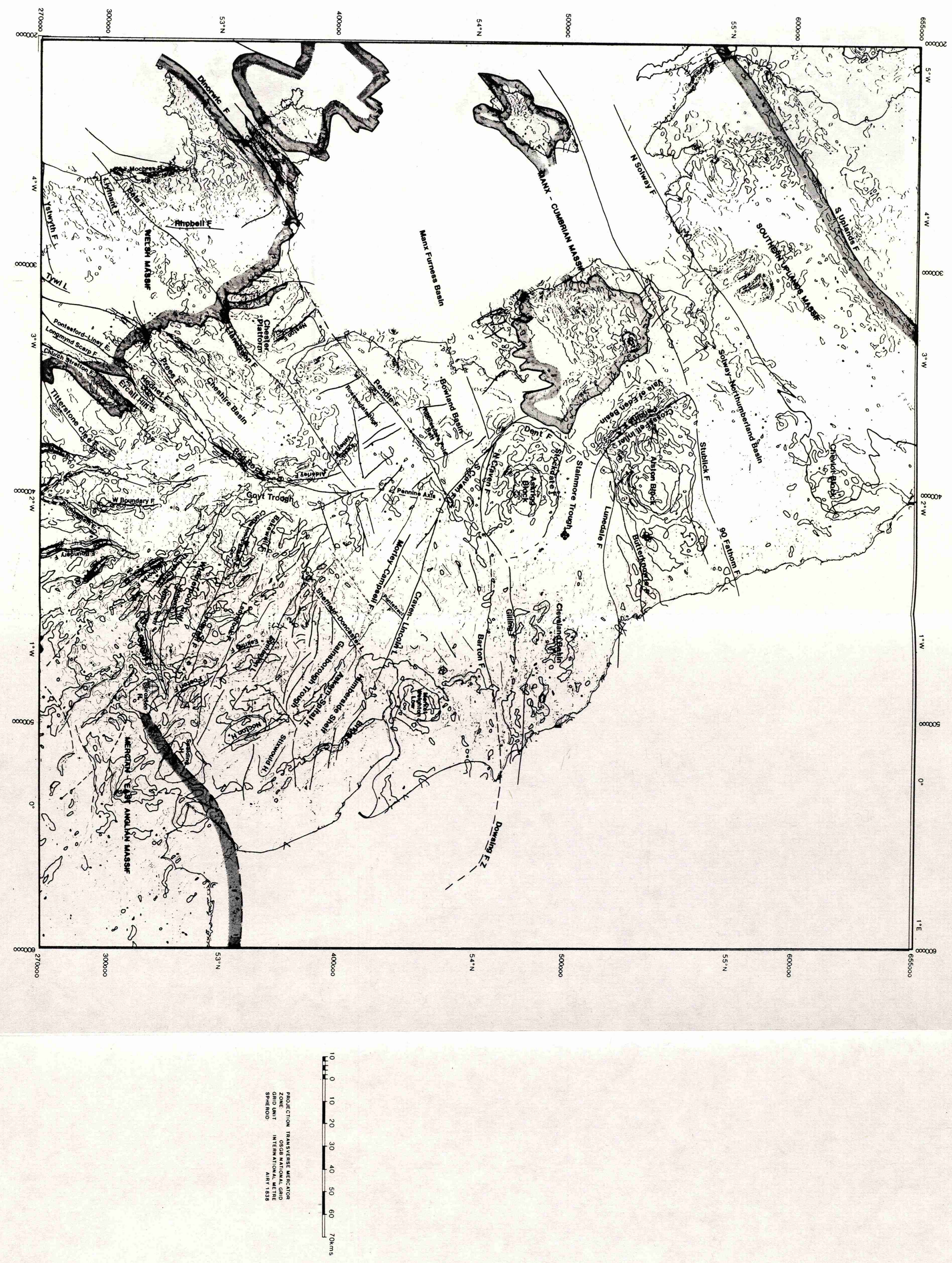

$\frac{0}{\frac{0}{00}}$ 


$$
b^{2}
$$


2. Tectono-stratigraphic development 

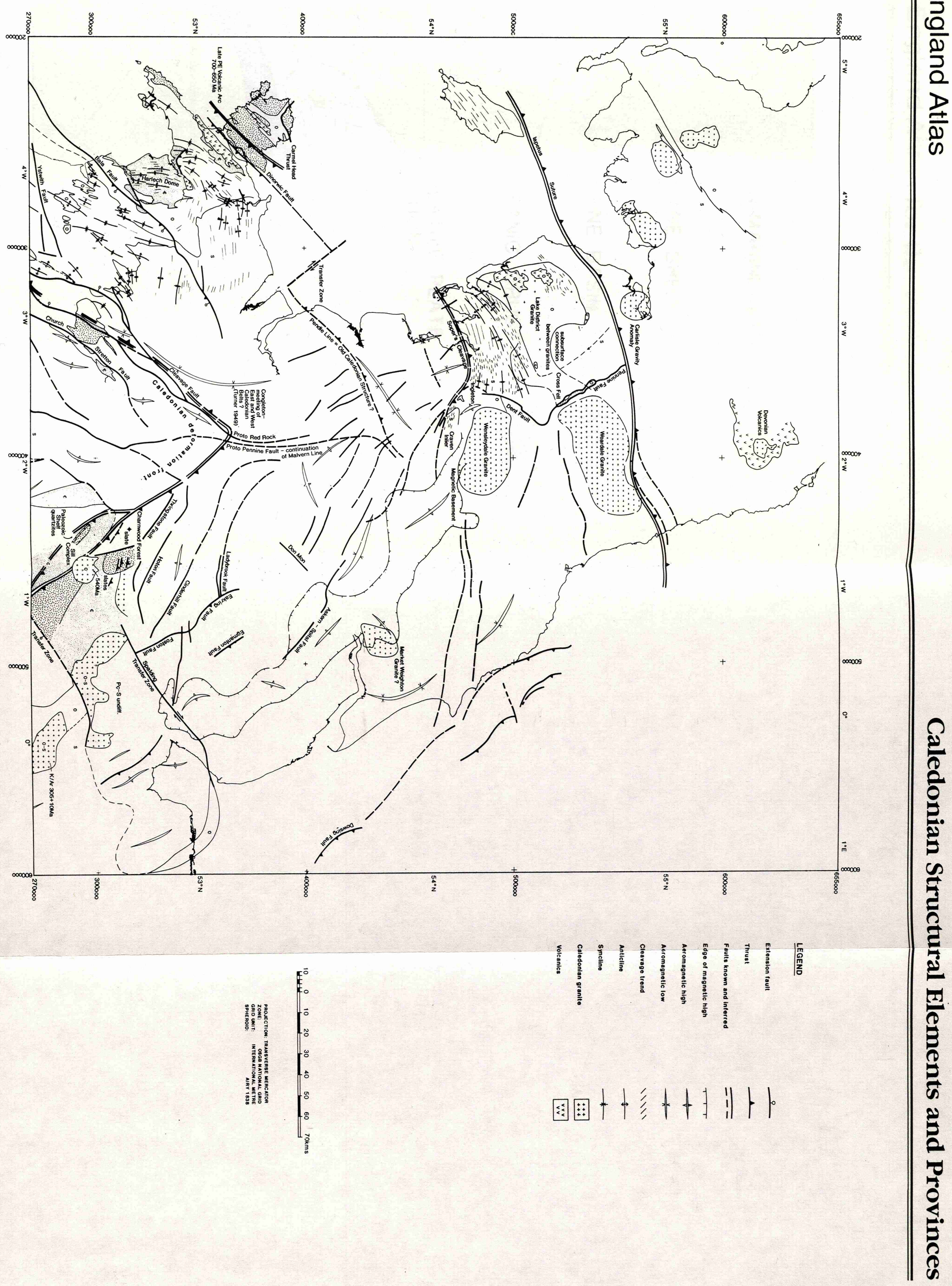


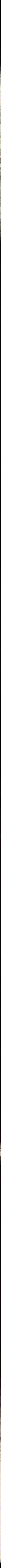




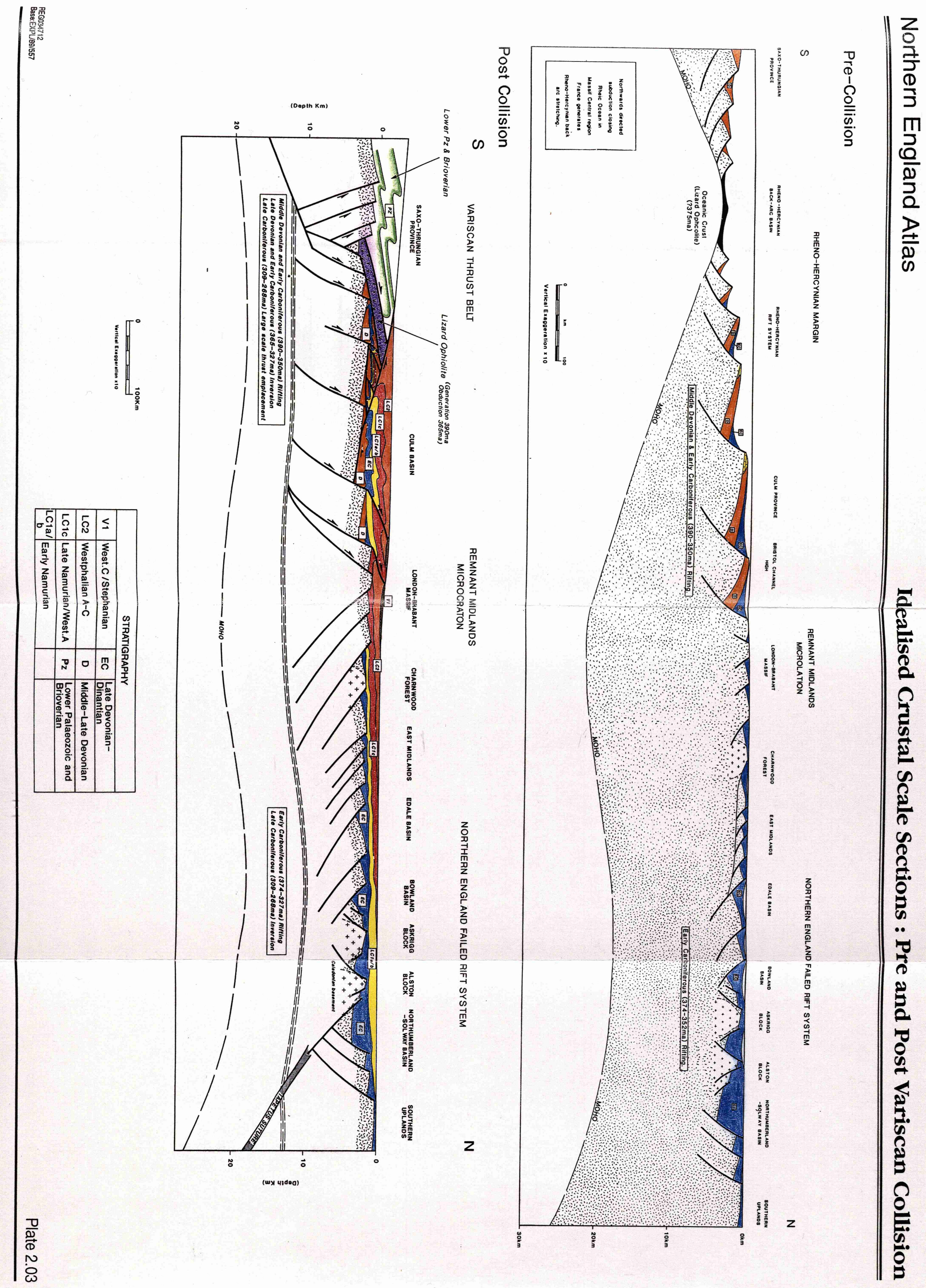




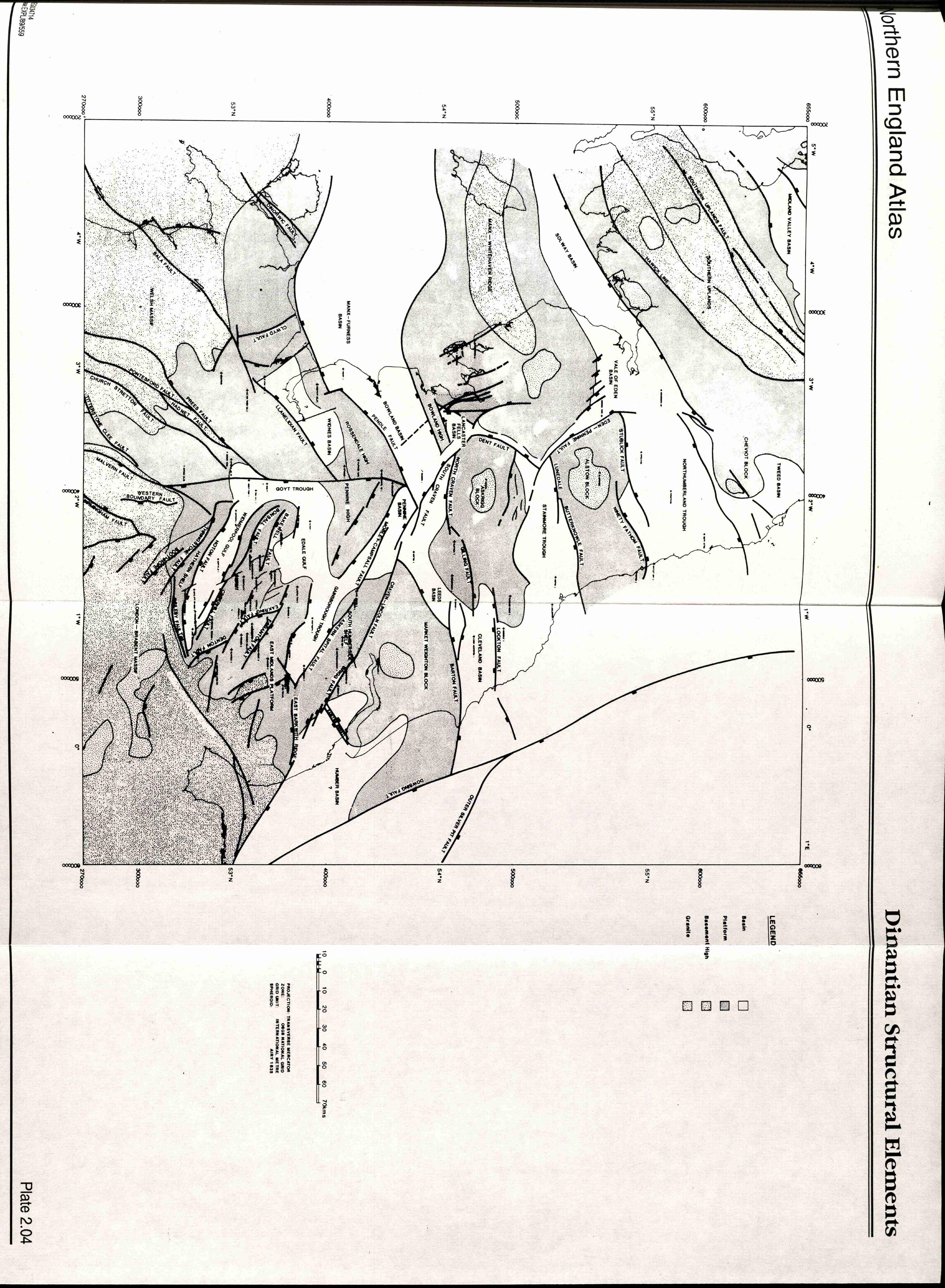




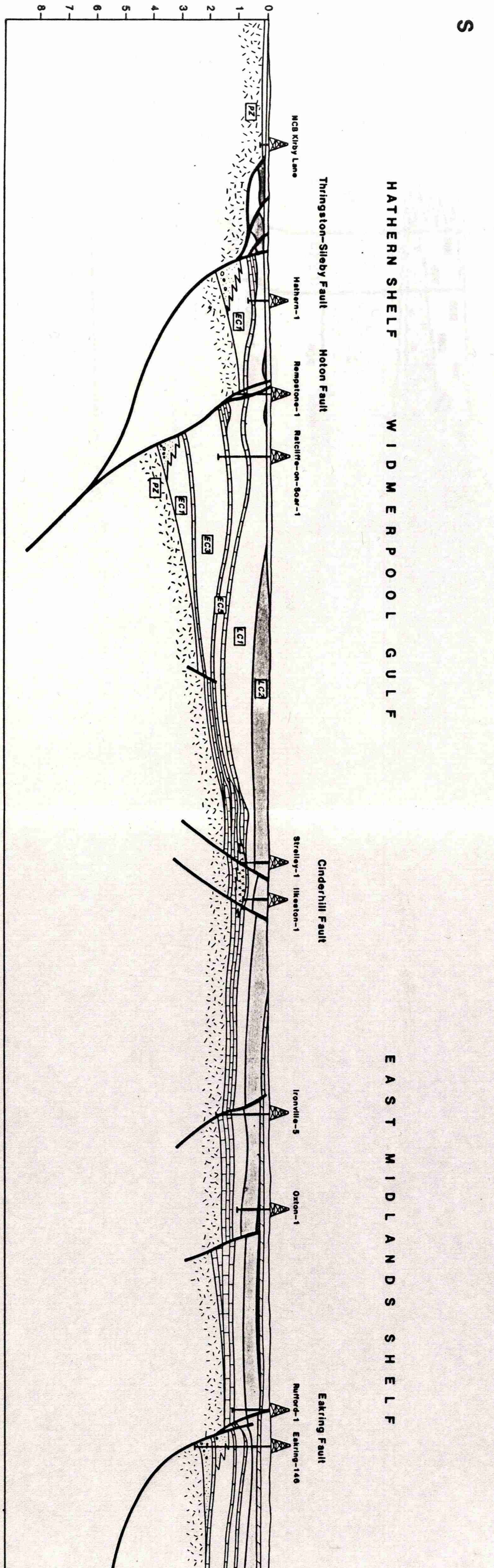

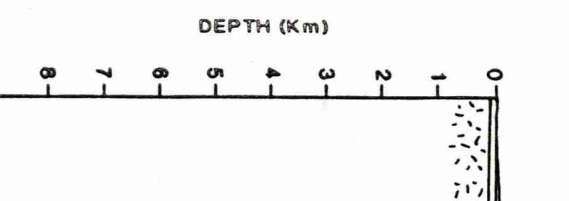

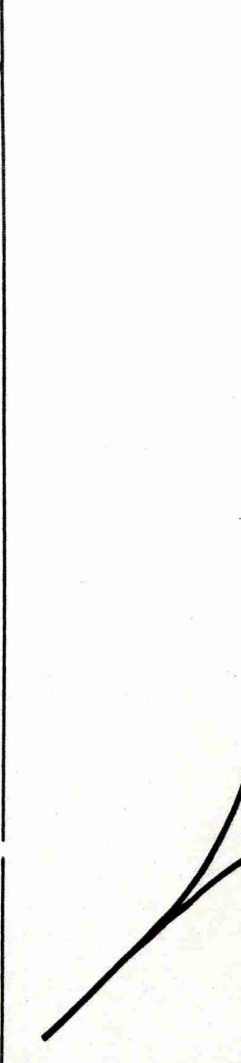

| 


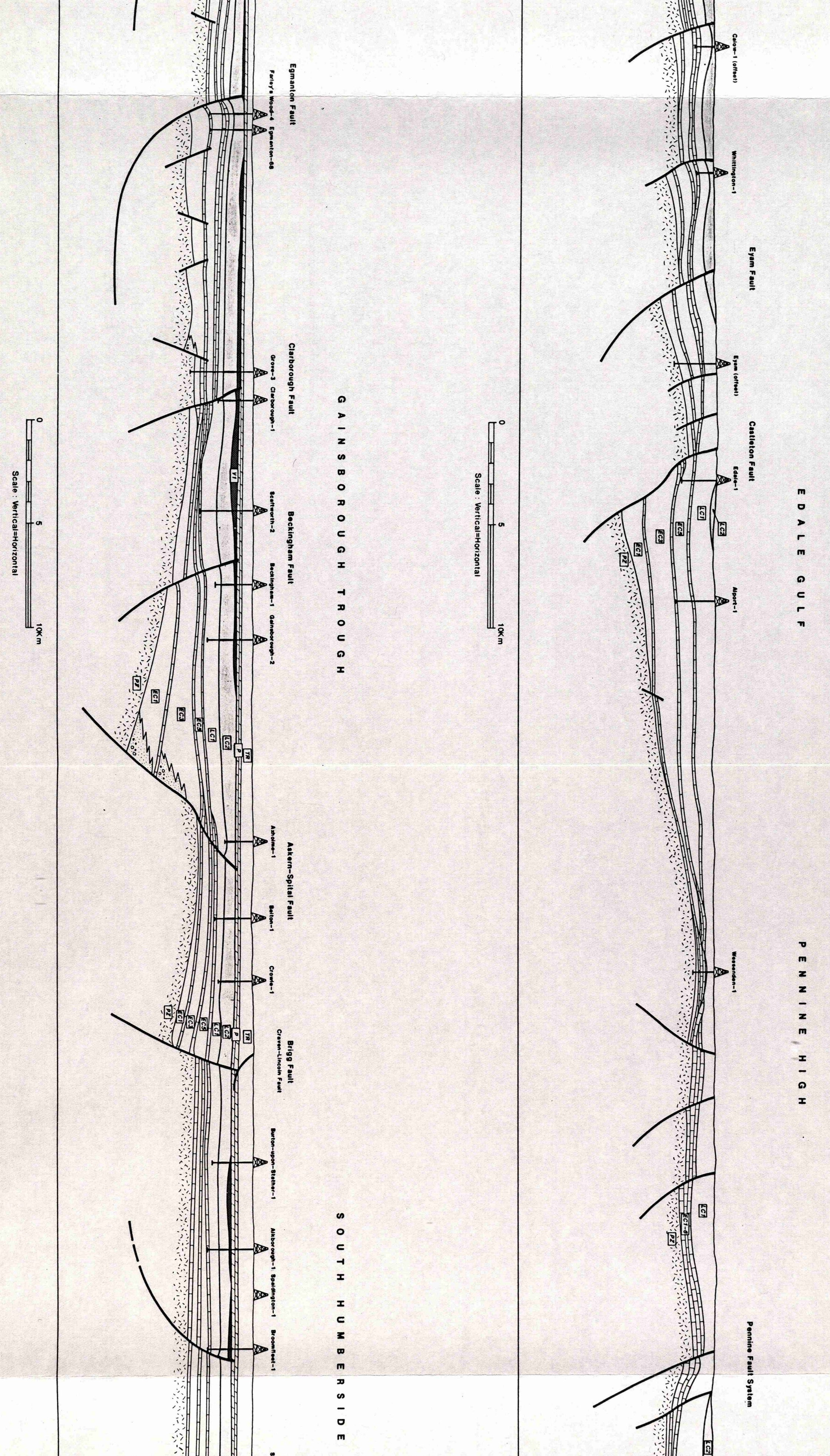


111111

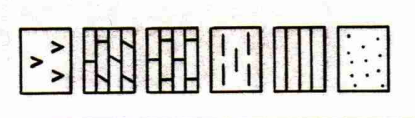

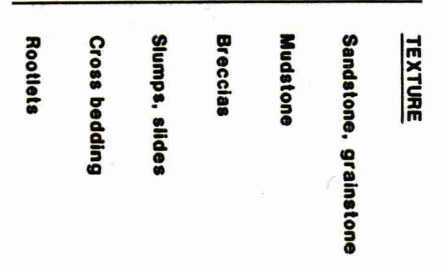

$x k$ \&

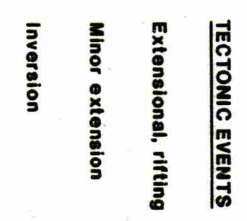

$<1<$

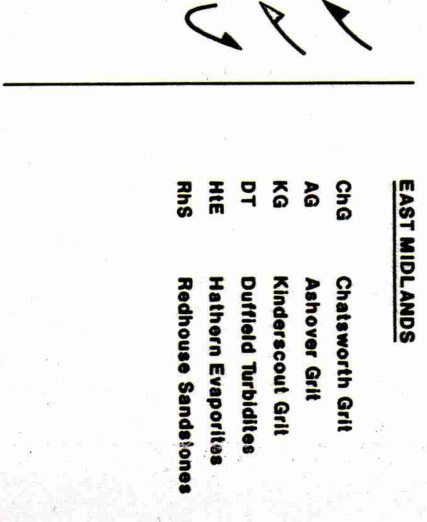

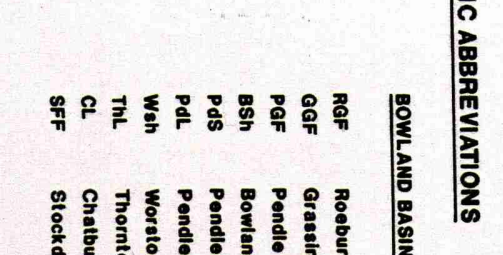

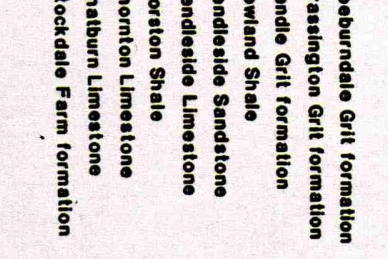

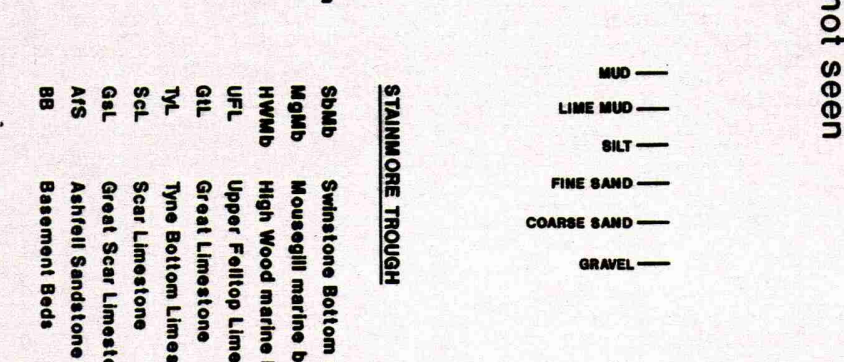

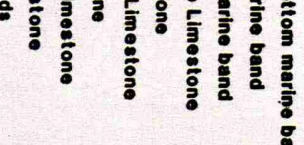

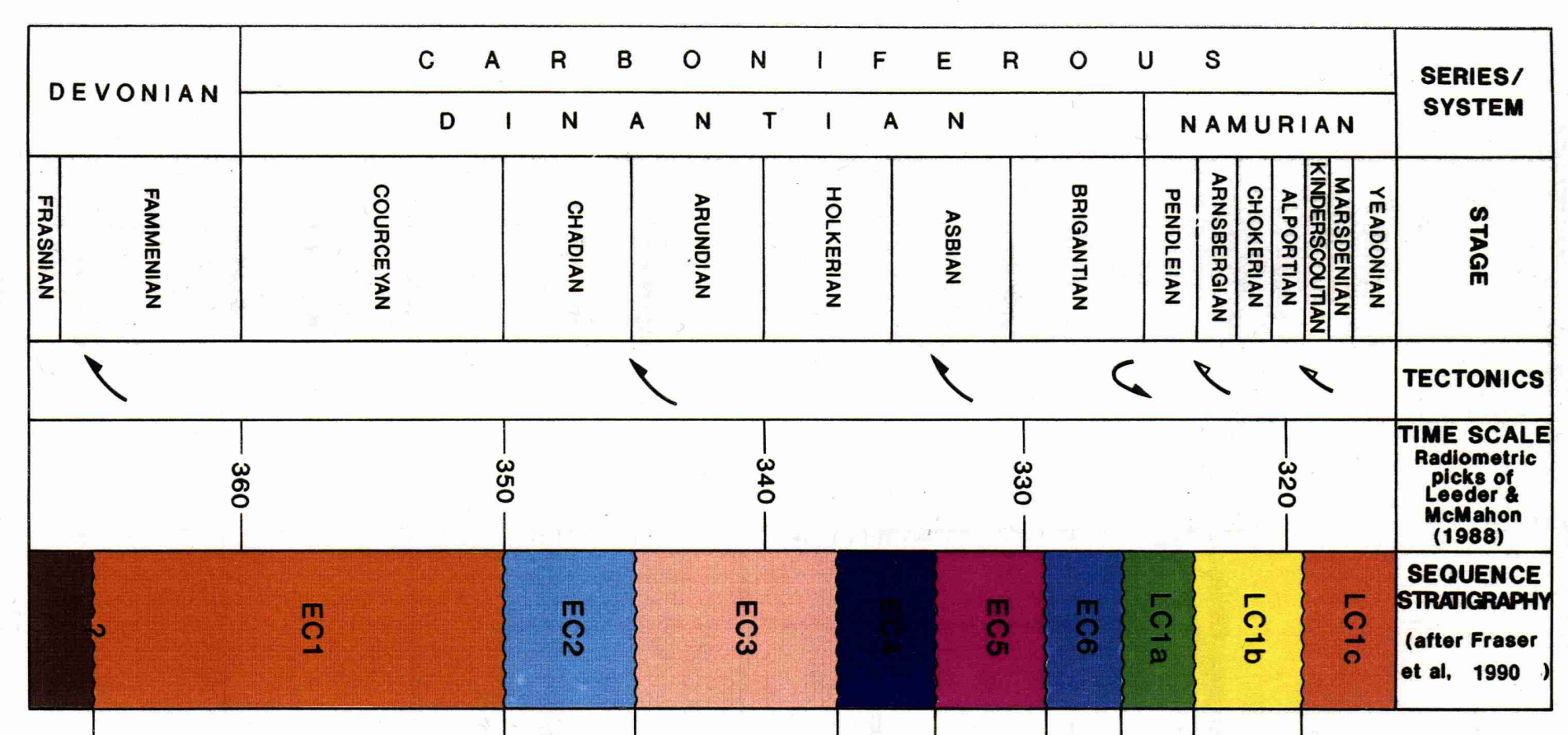
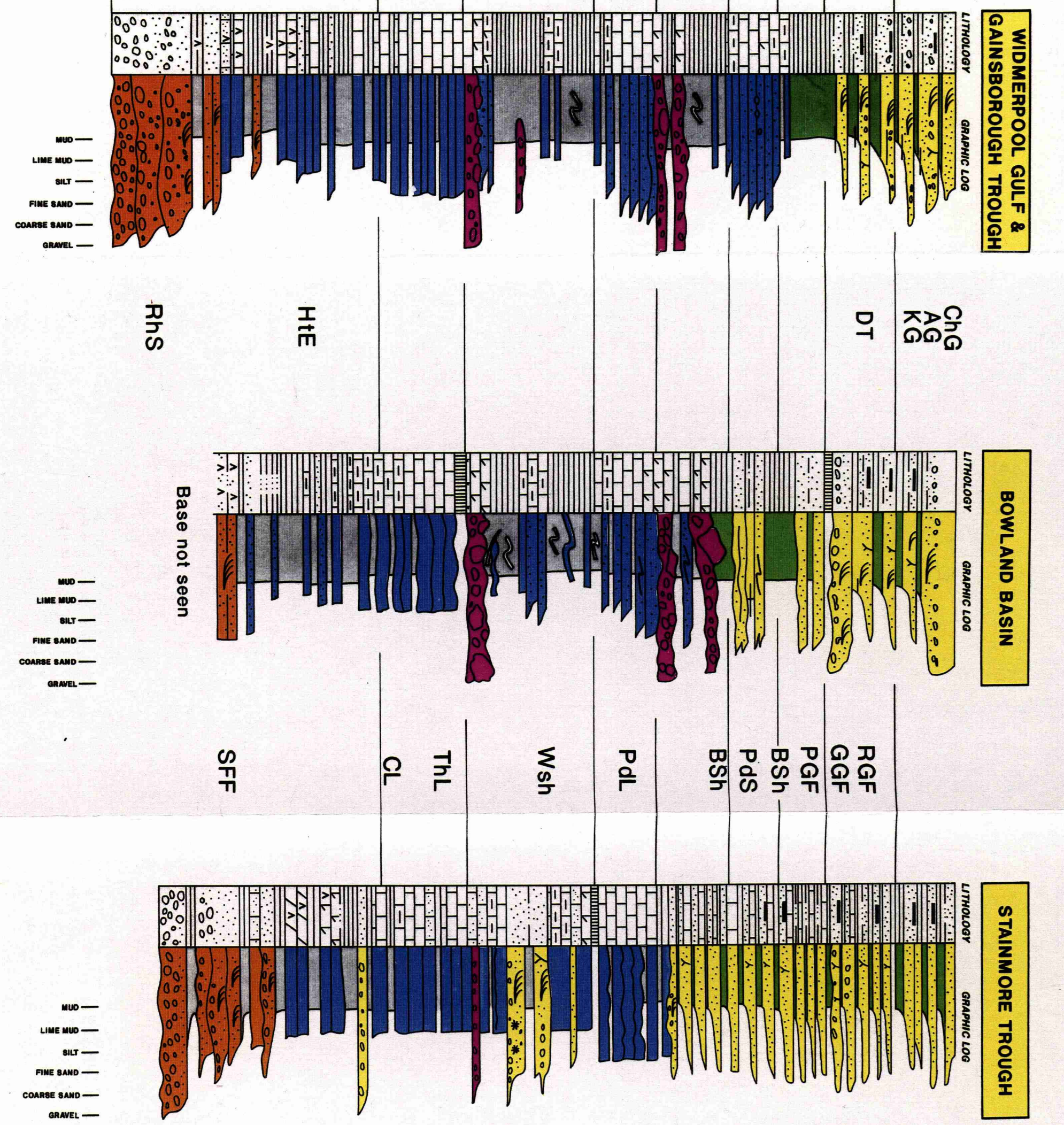

㽚

$11 z$ 


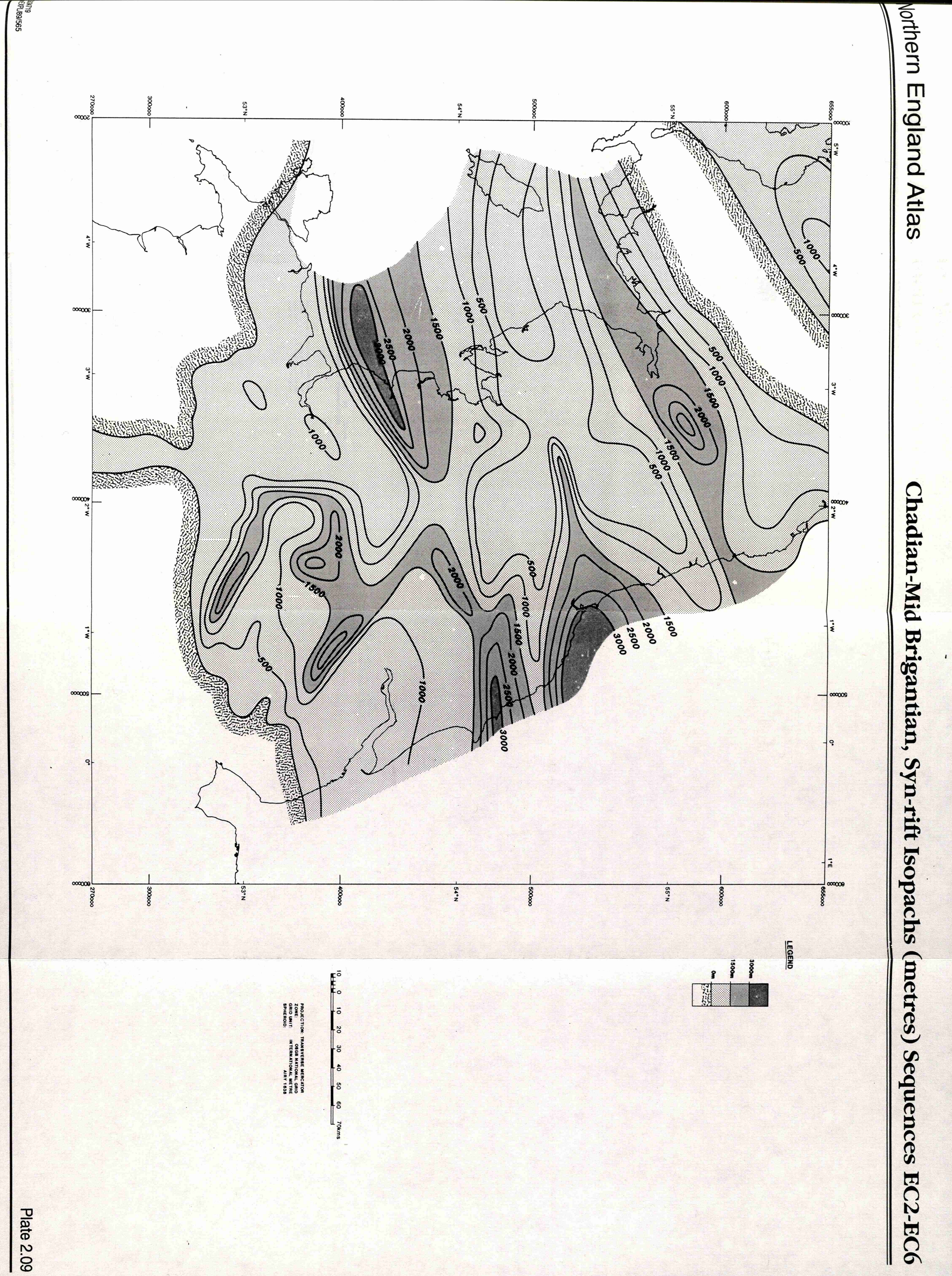




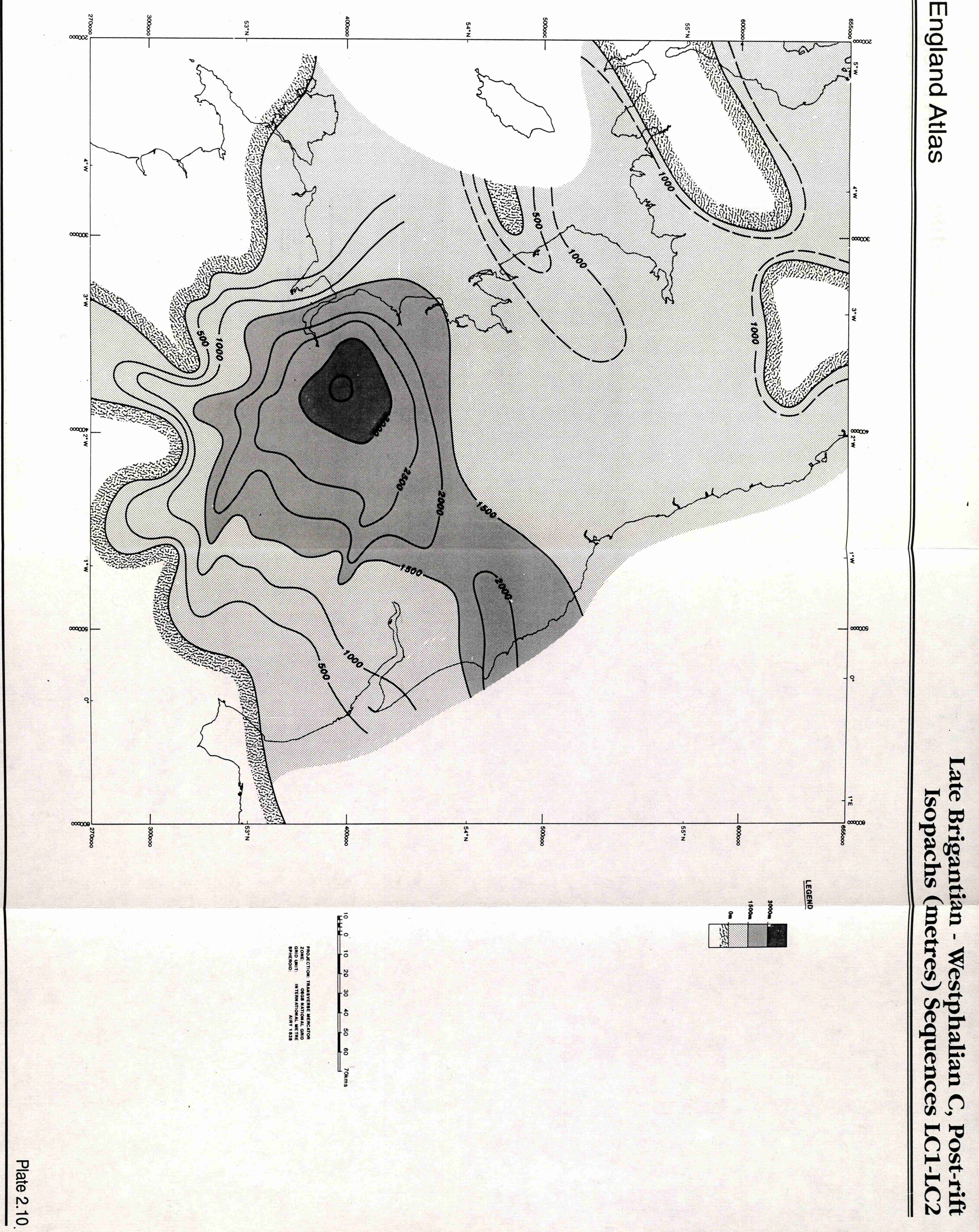

$\frac{\frac{5}{2}}{\frac{D}{3}}$ 


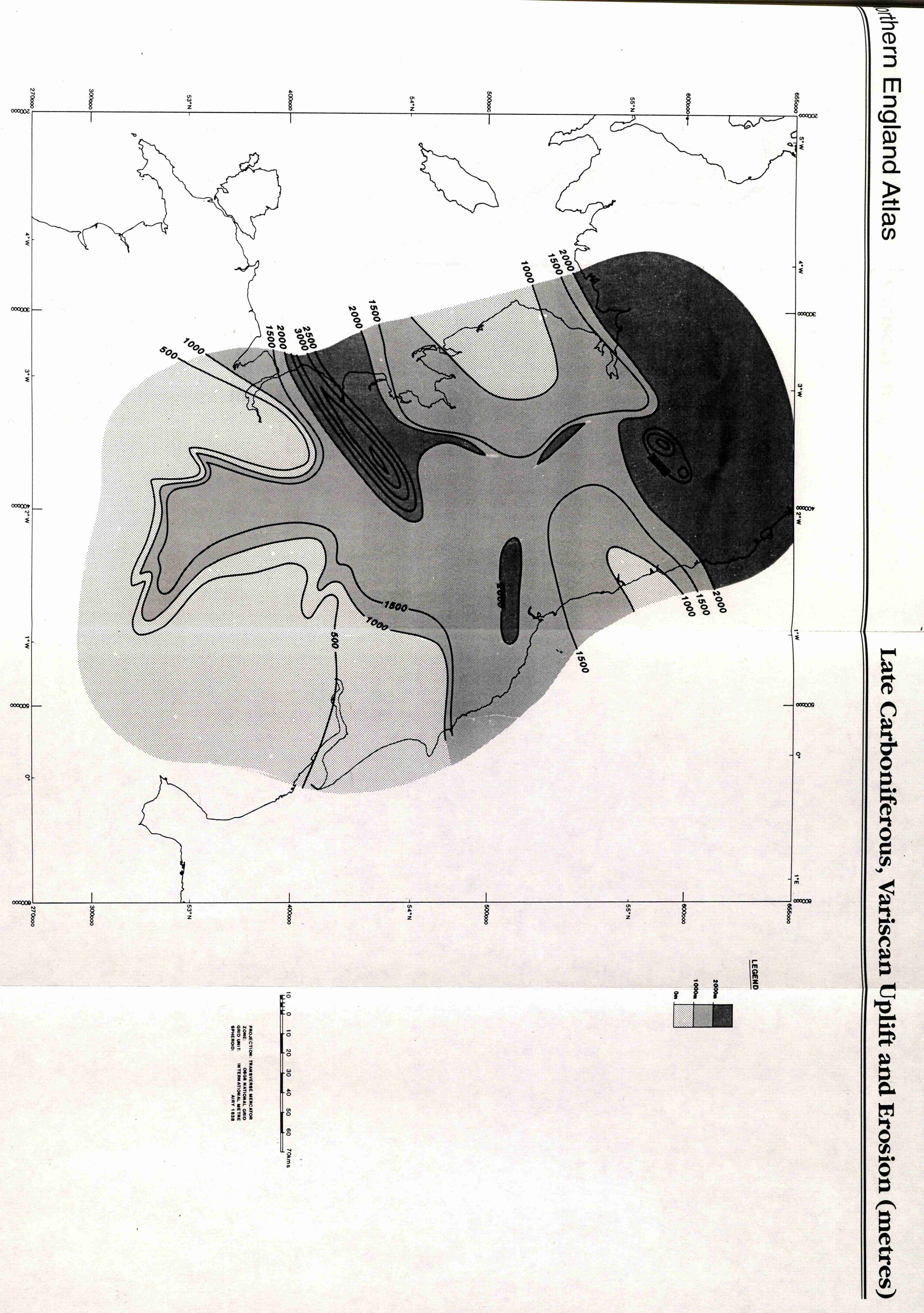



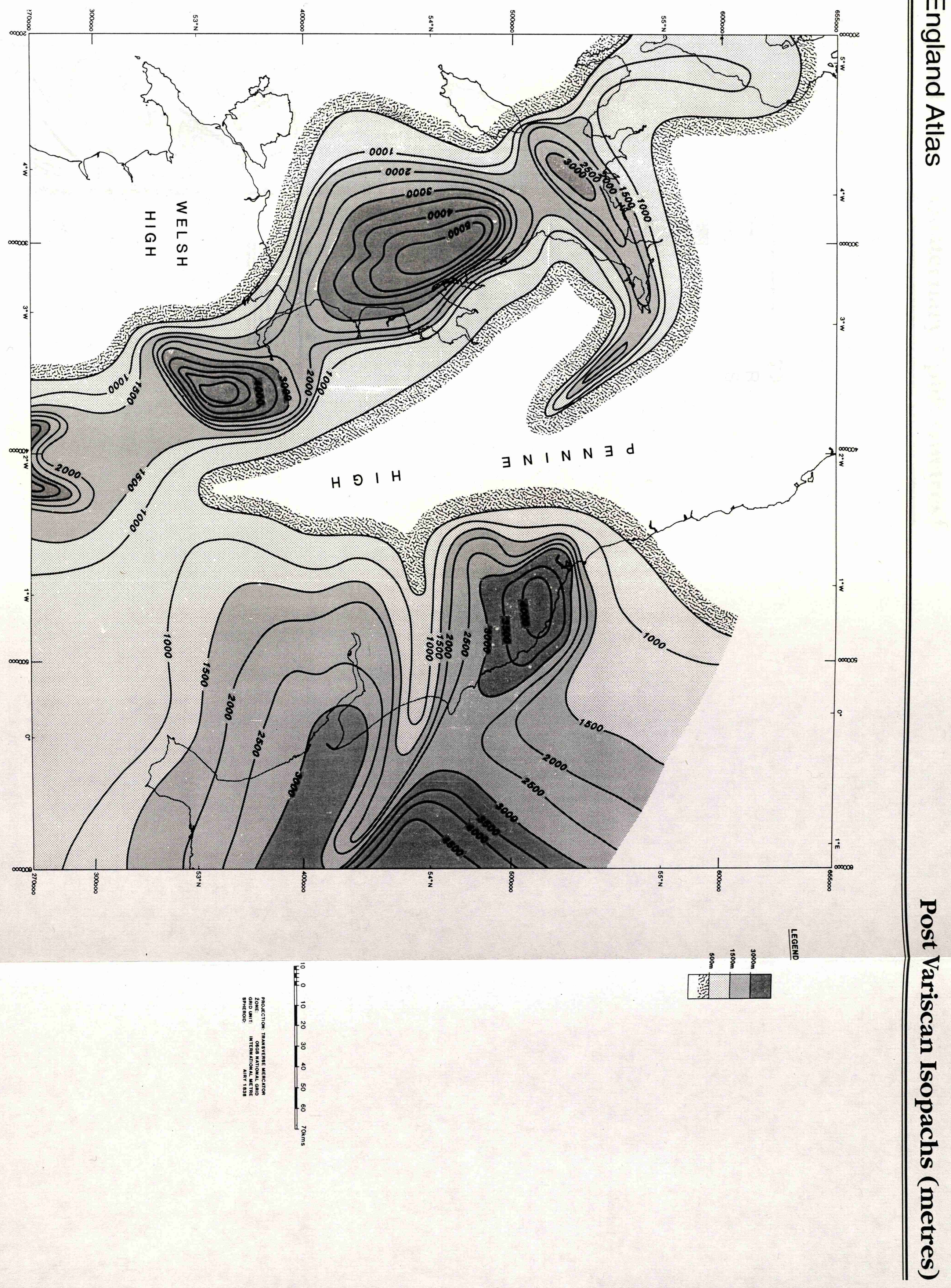
3. Regional seismic and geological interpretation 


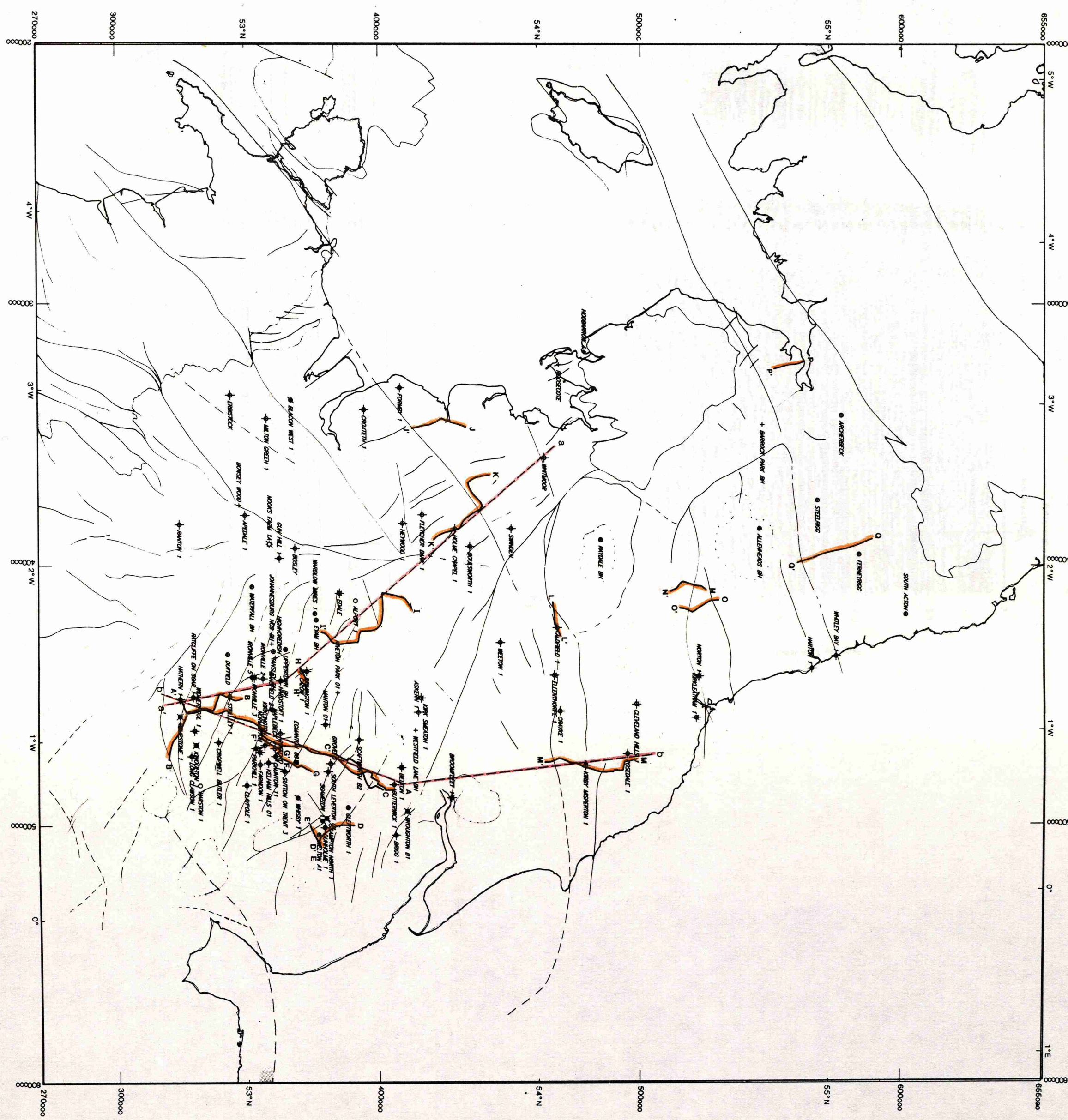

$\frac{1}{2}$
$\frac{0}{2}$
$\frac{2}{2}$
$\frac{2}{2}$
$\frac{2}{0}$
0

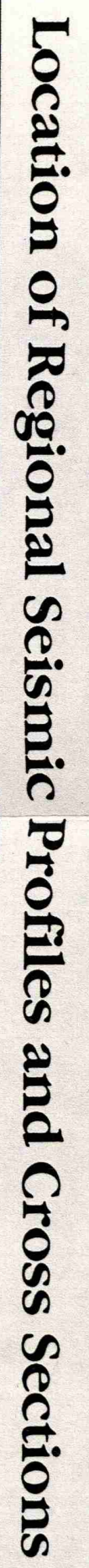





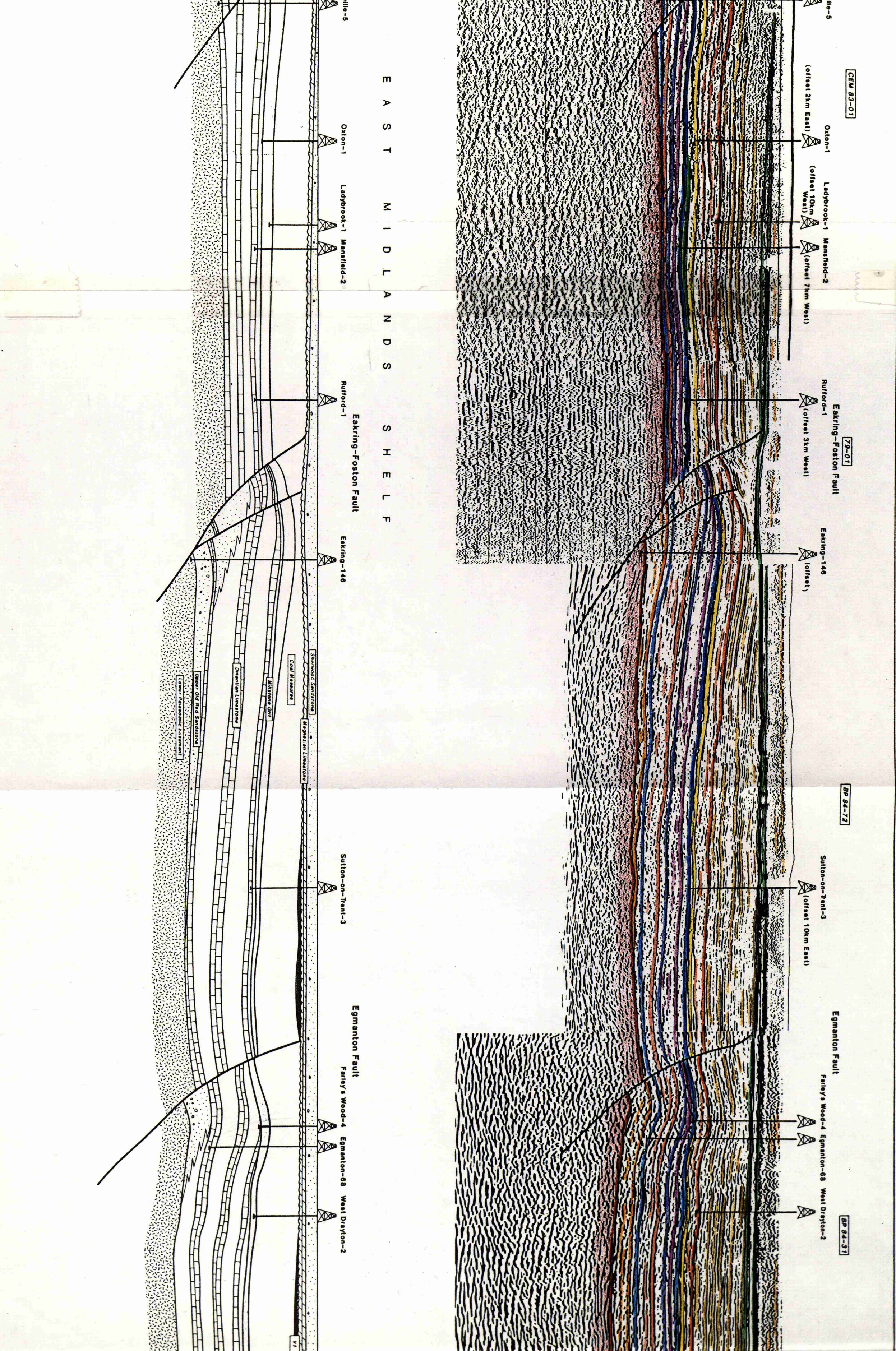




\section{North - South Composite Seismic and Interpreted}

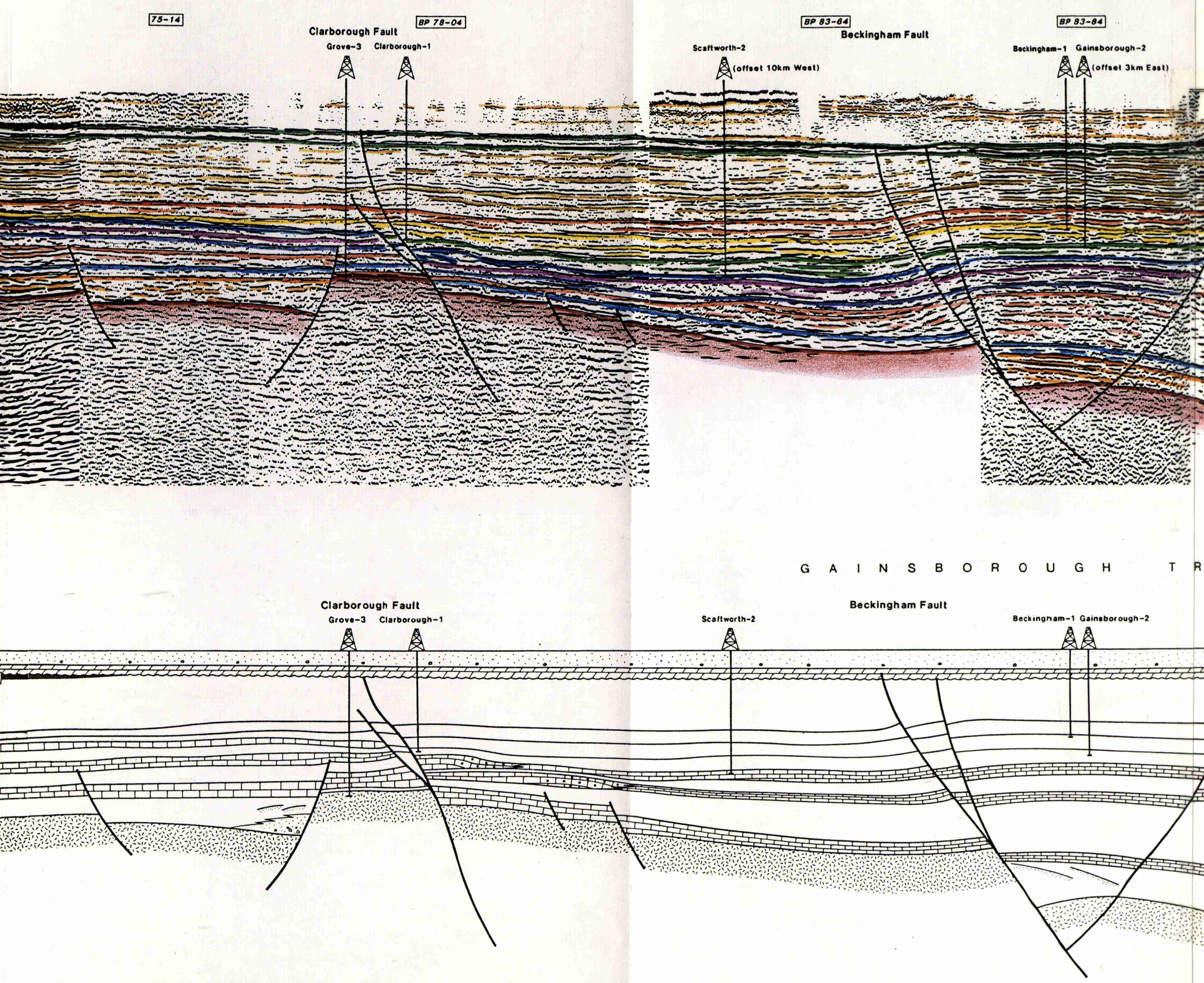




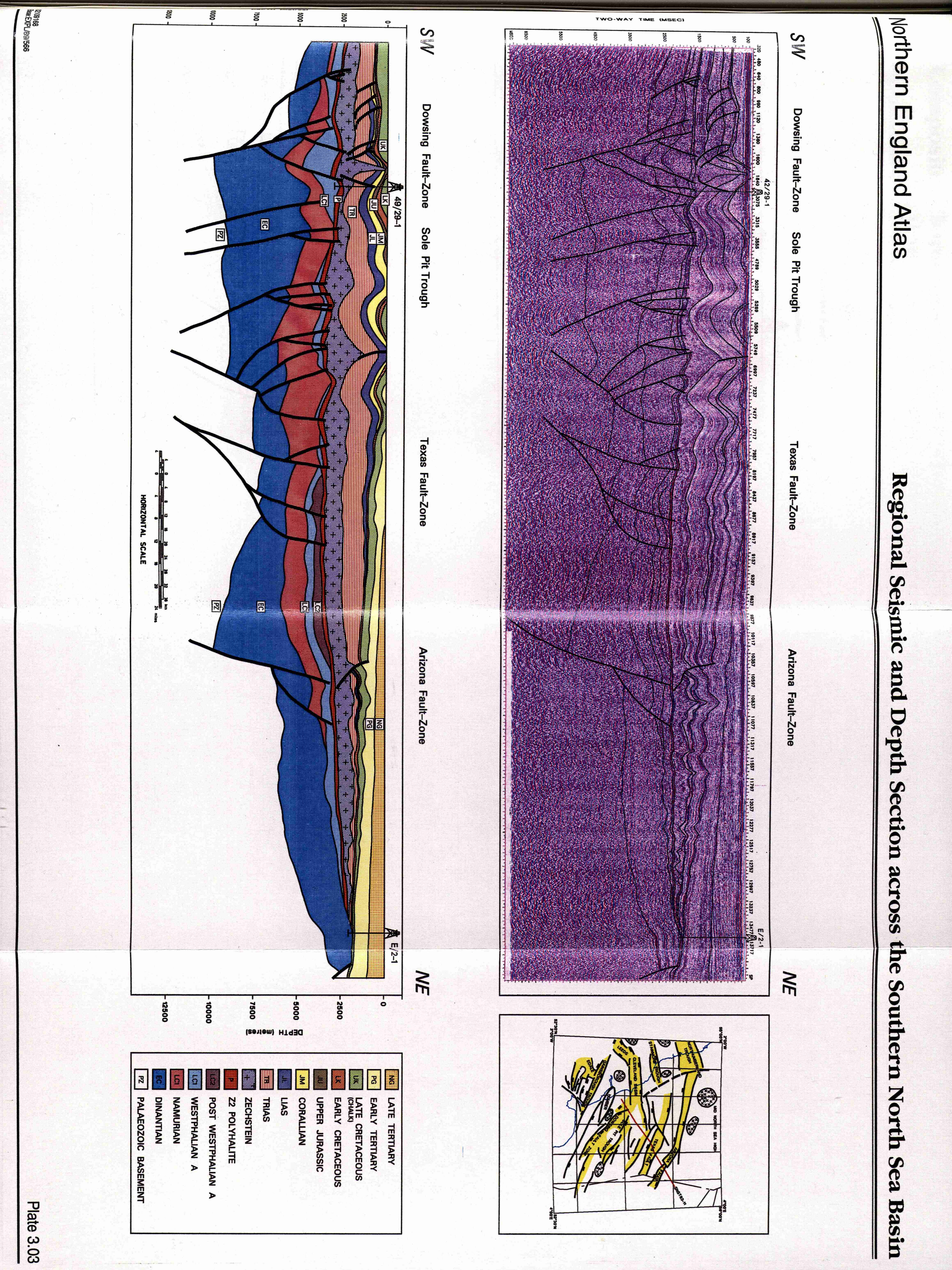




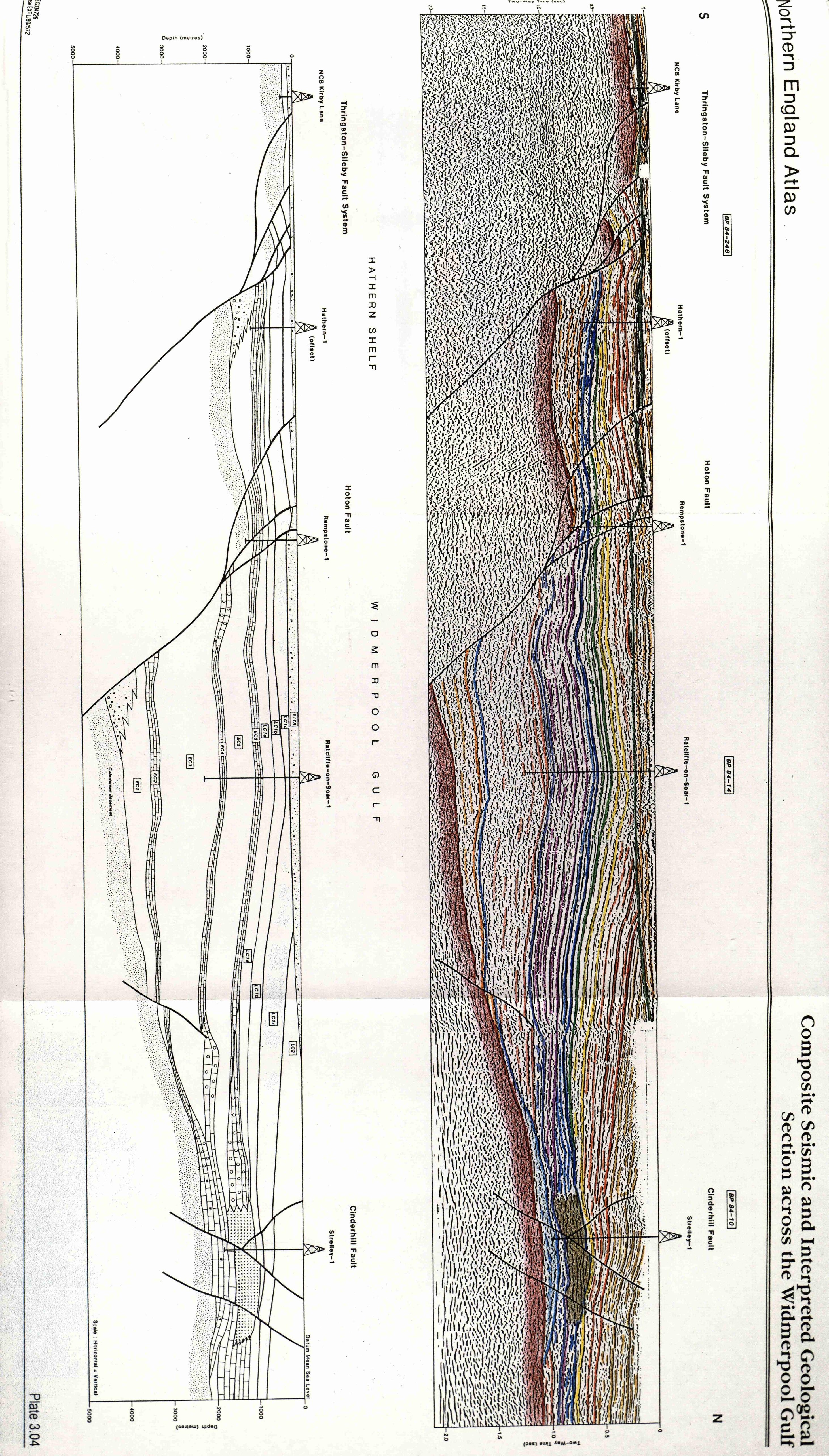




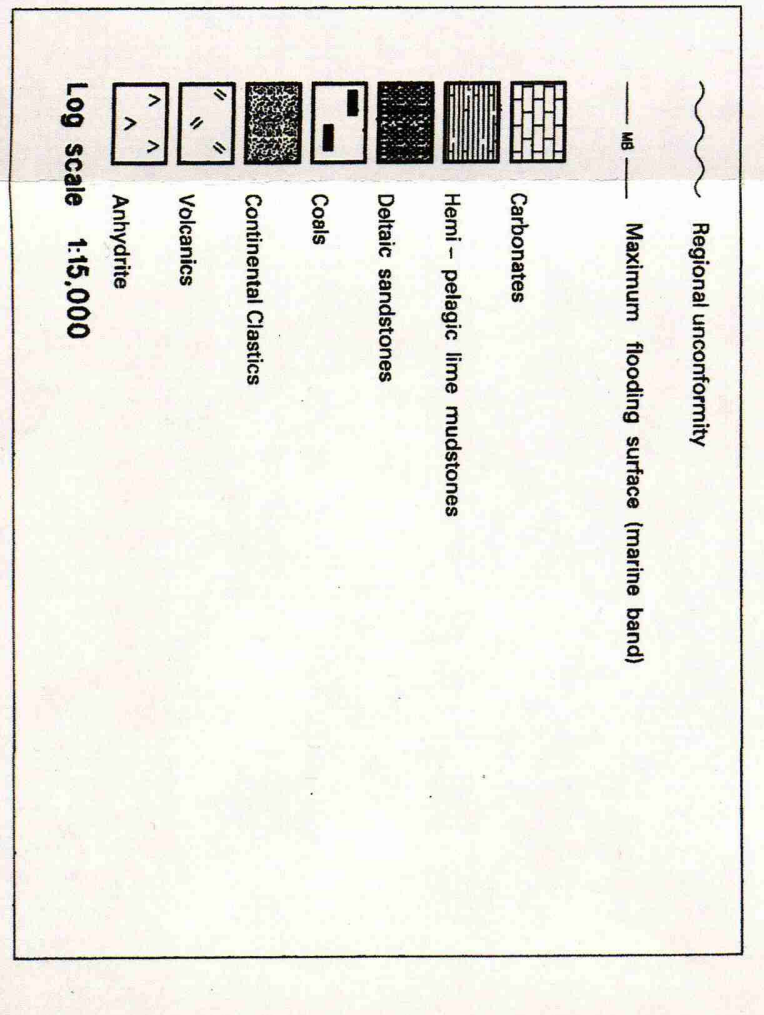

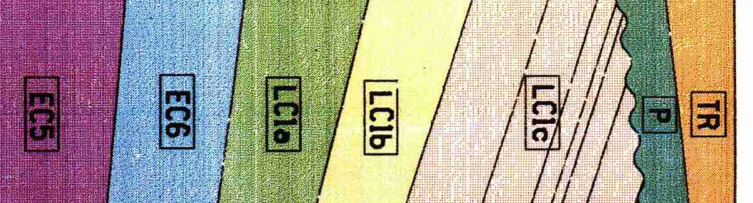
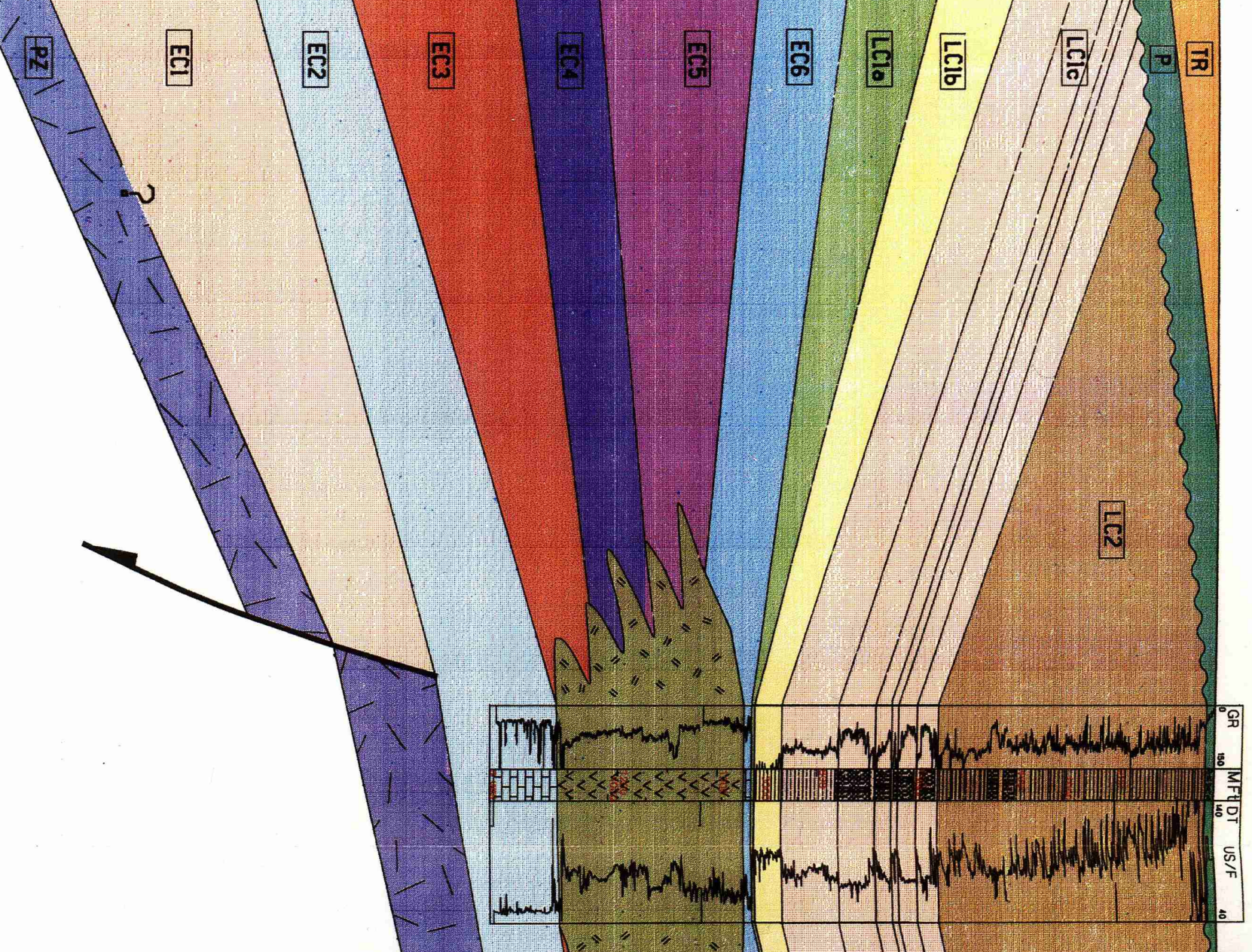

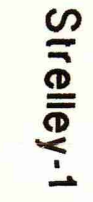






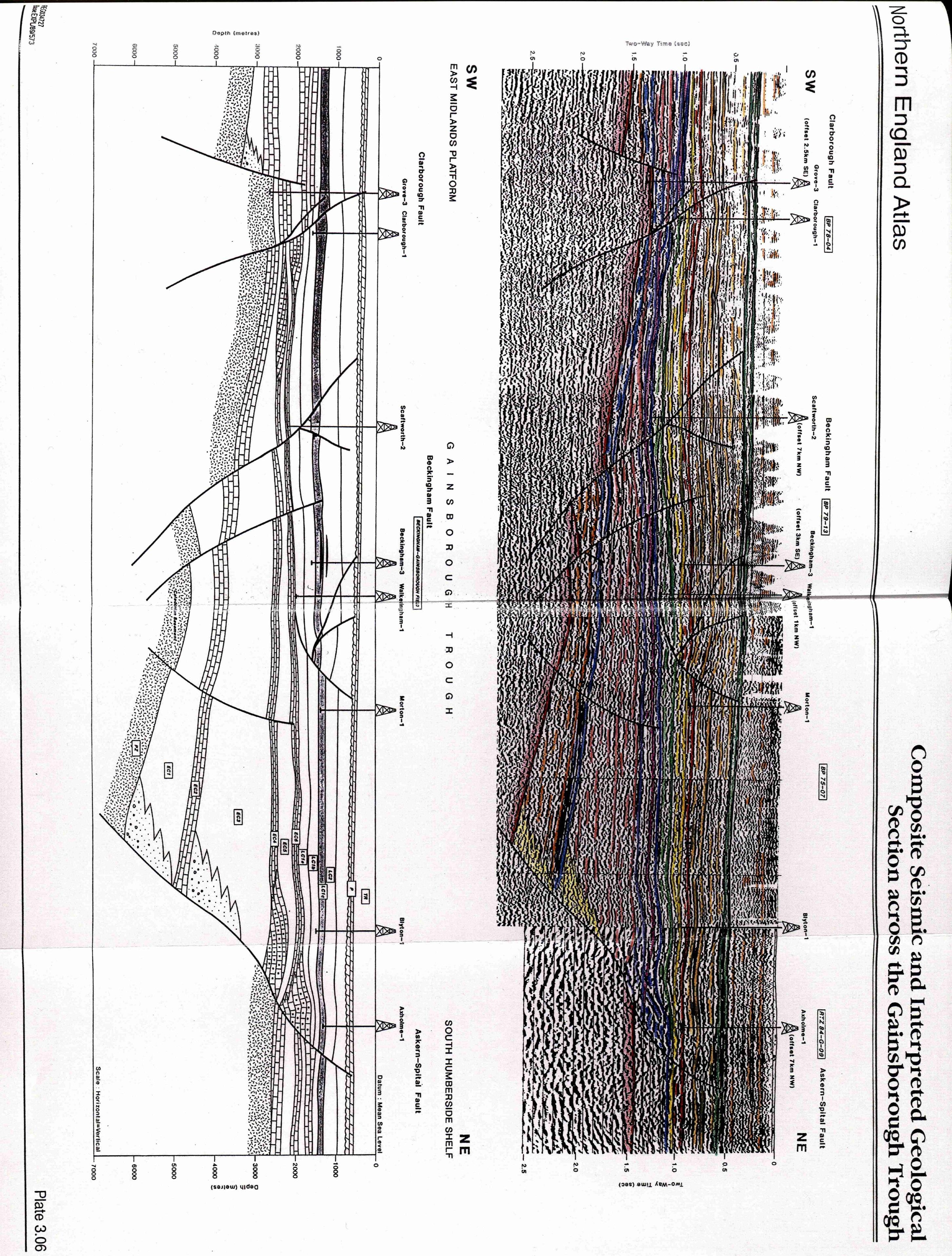


量器

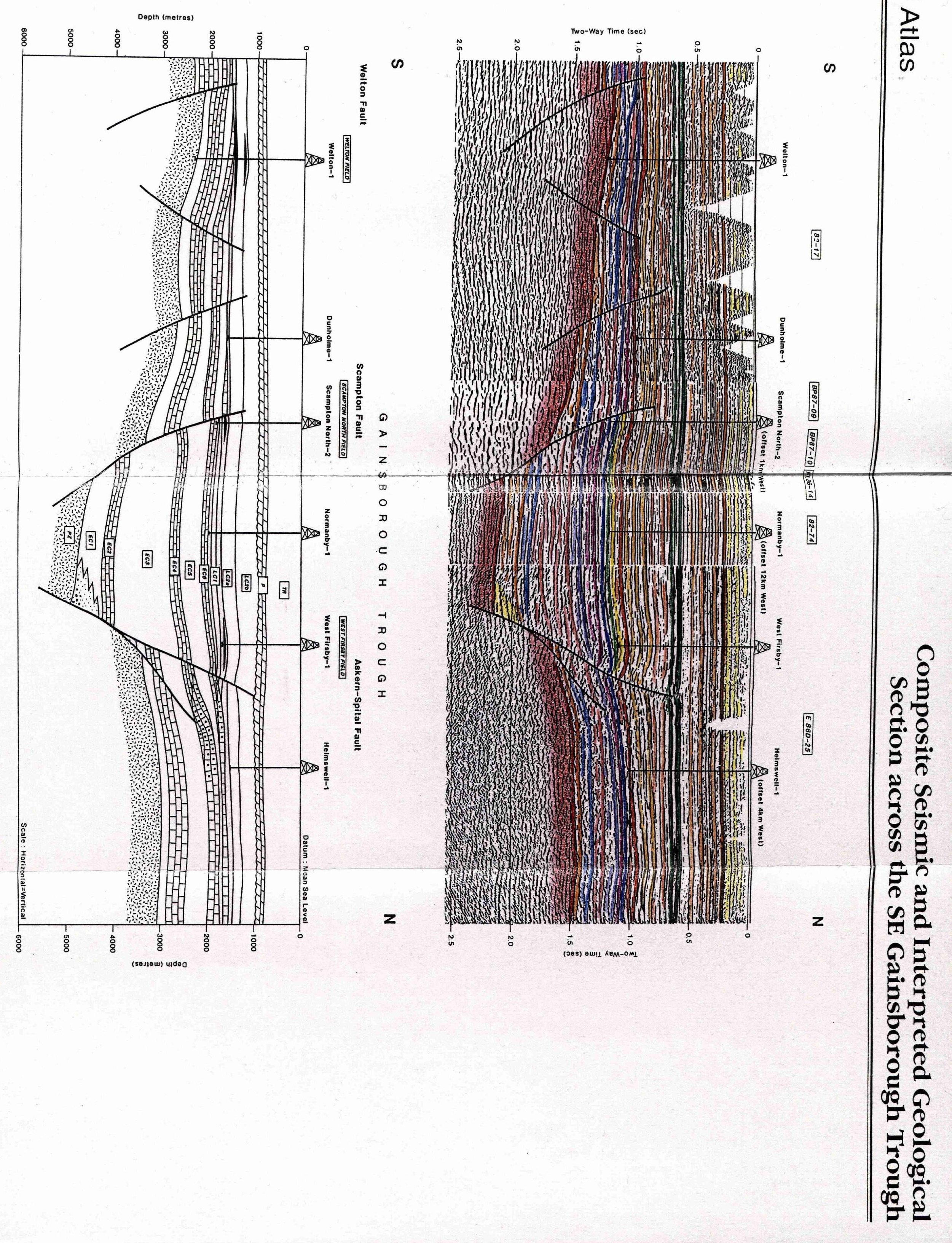




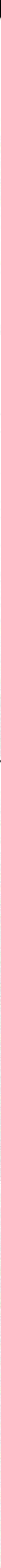




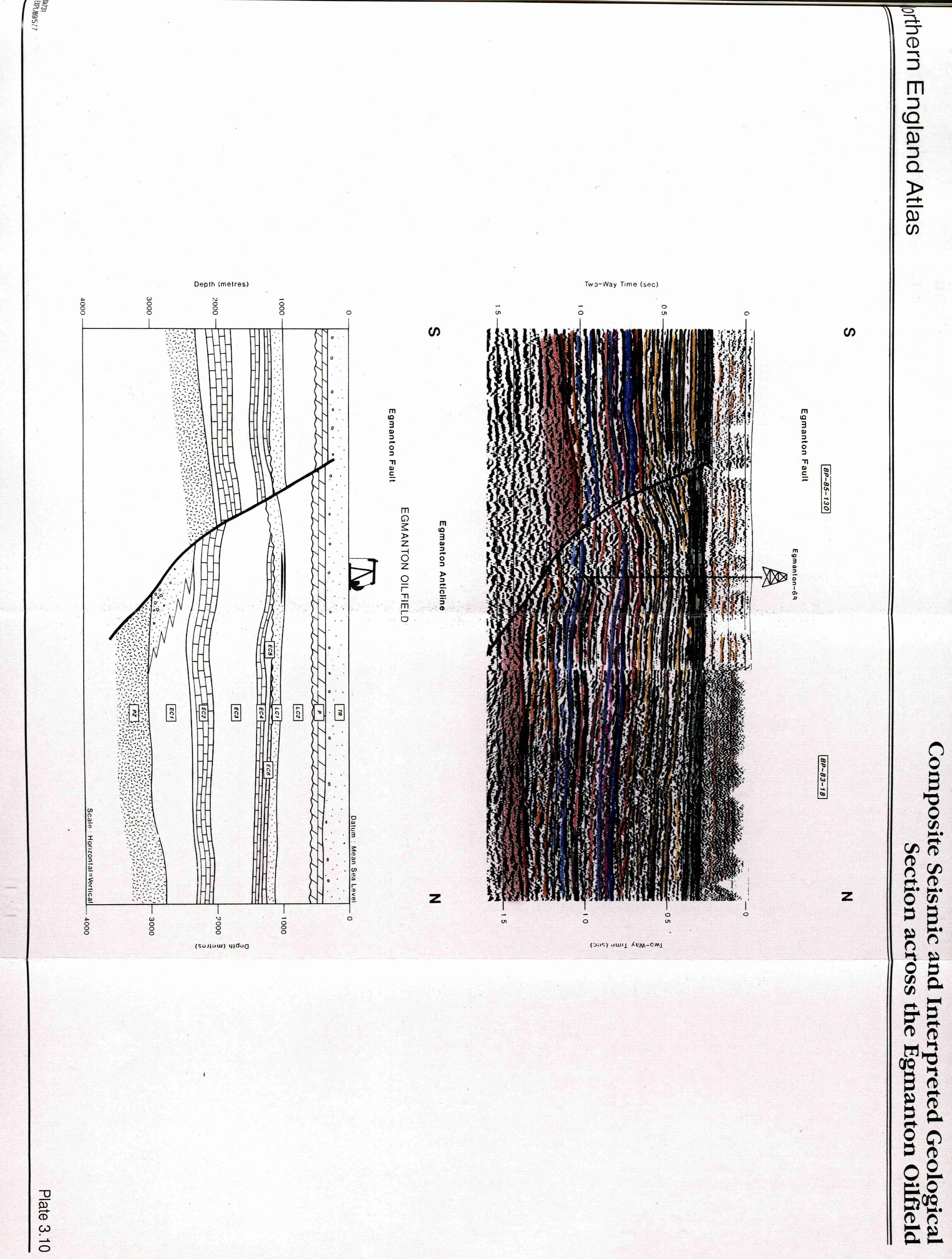




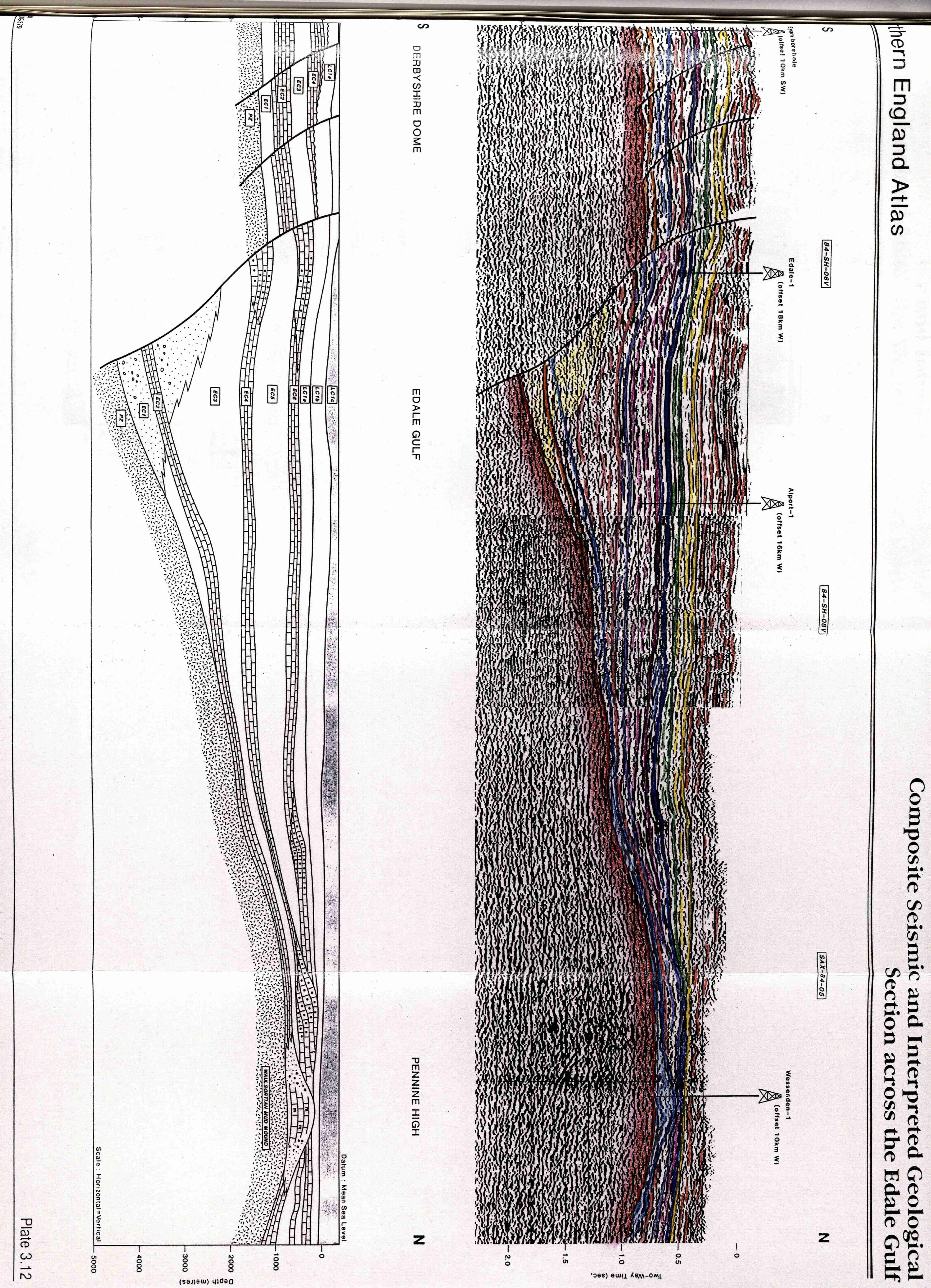




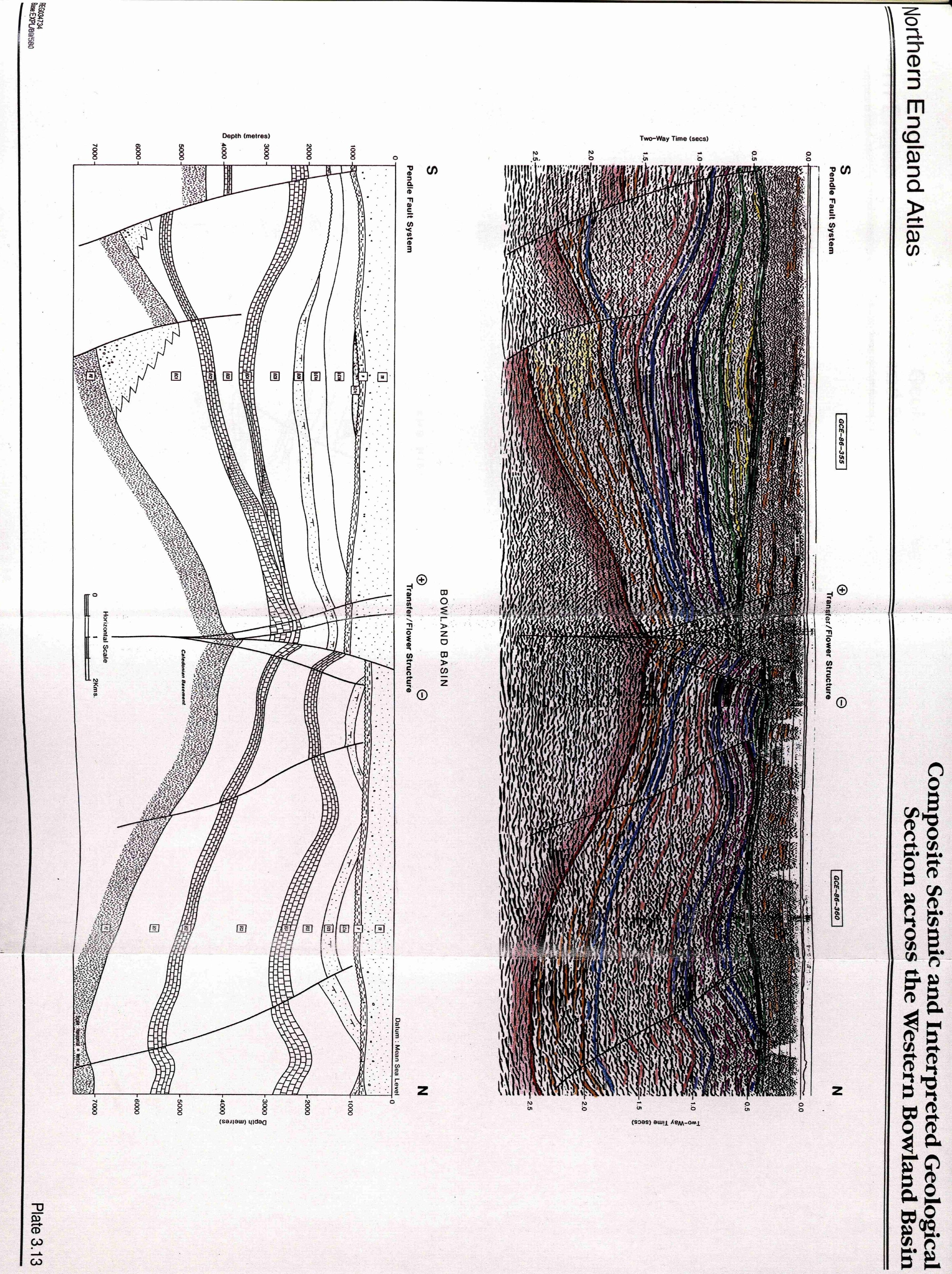




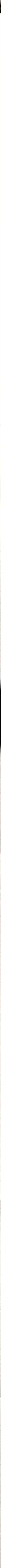





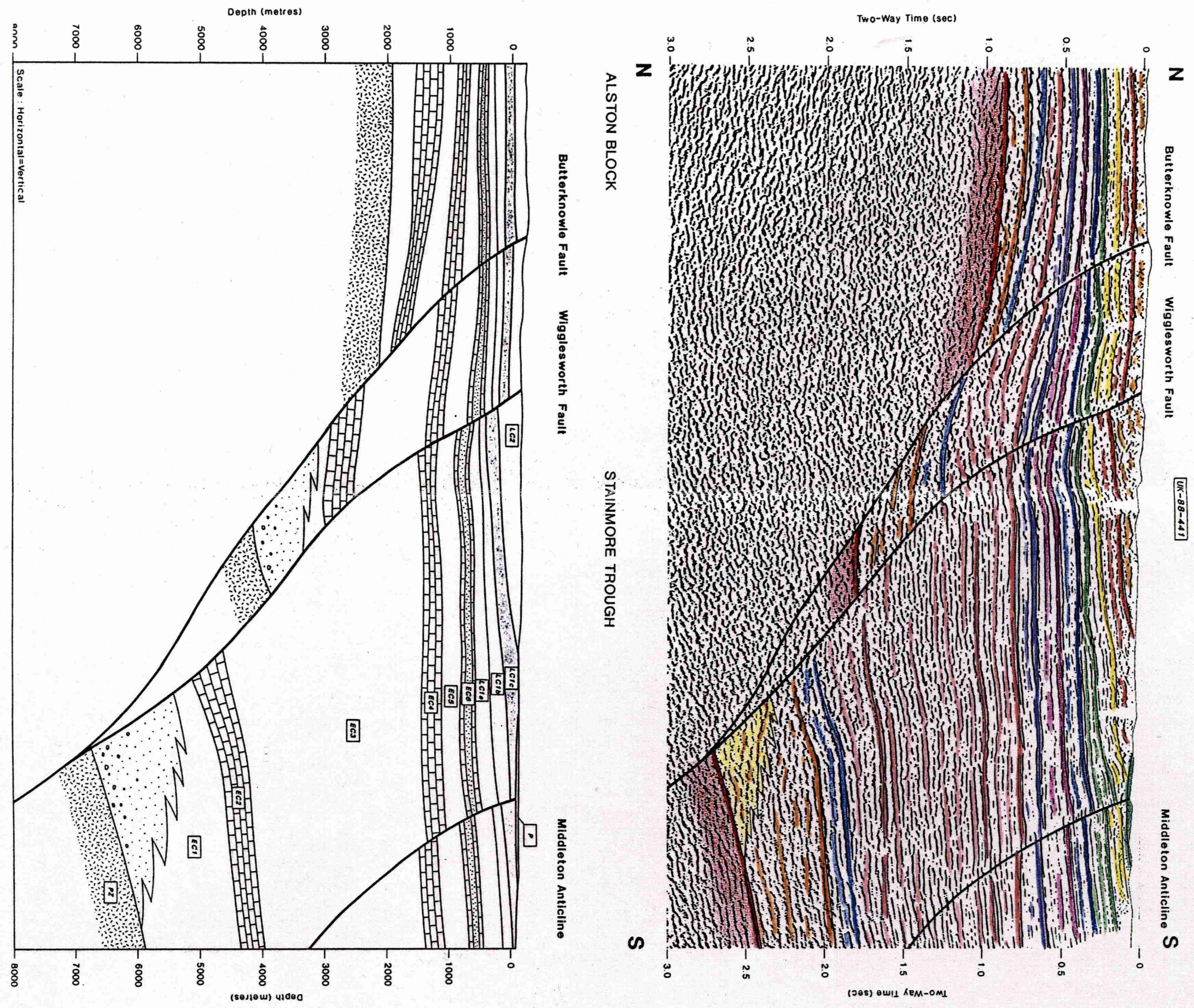

$\frac{0}{0}$
$\frac{0}{0}$
$\omega$
$\vec{v}$ 


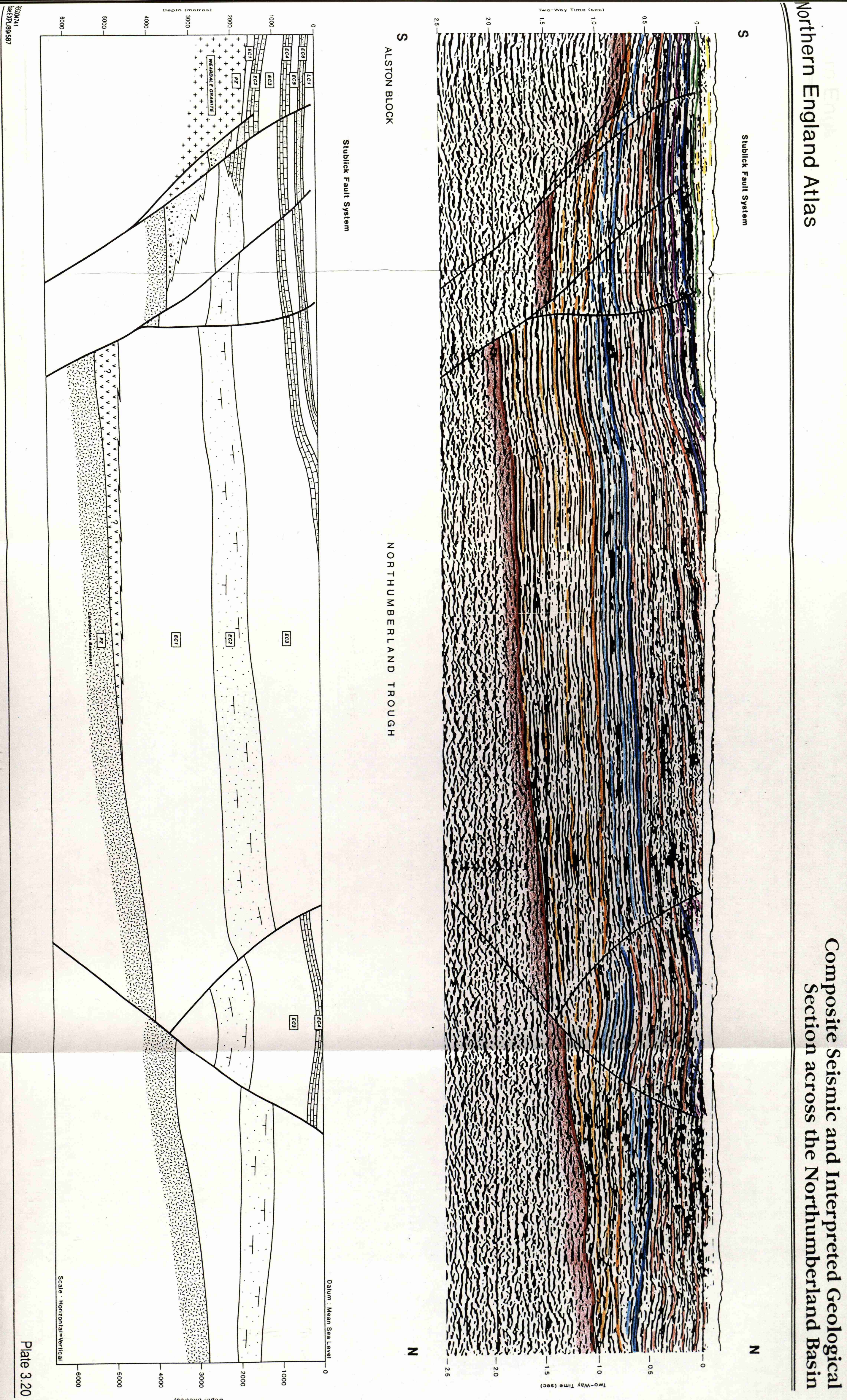




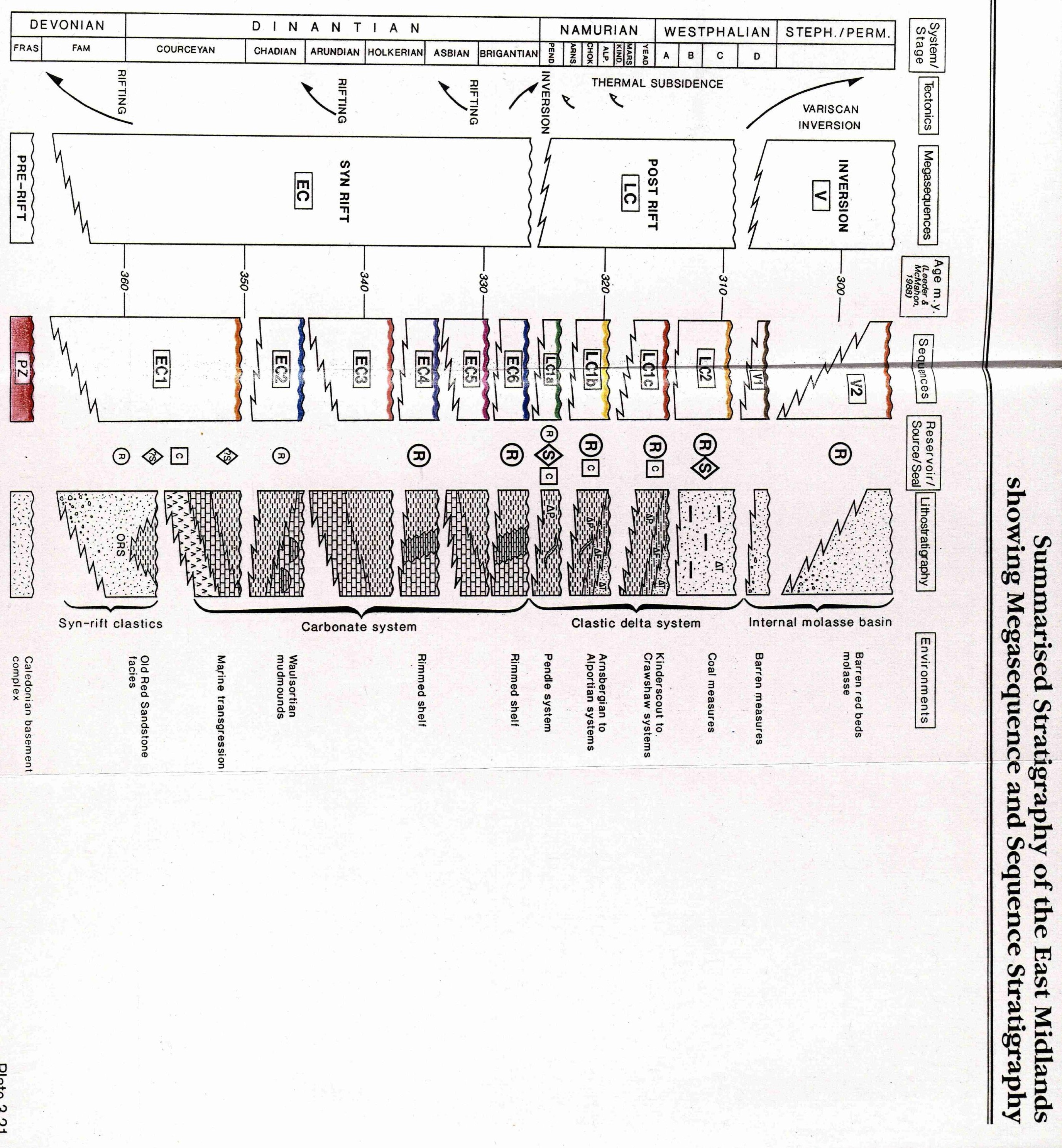


4. Palaeogeography and facies evolution 


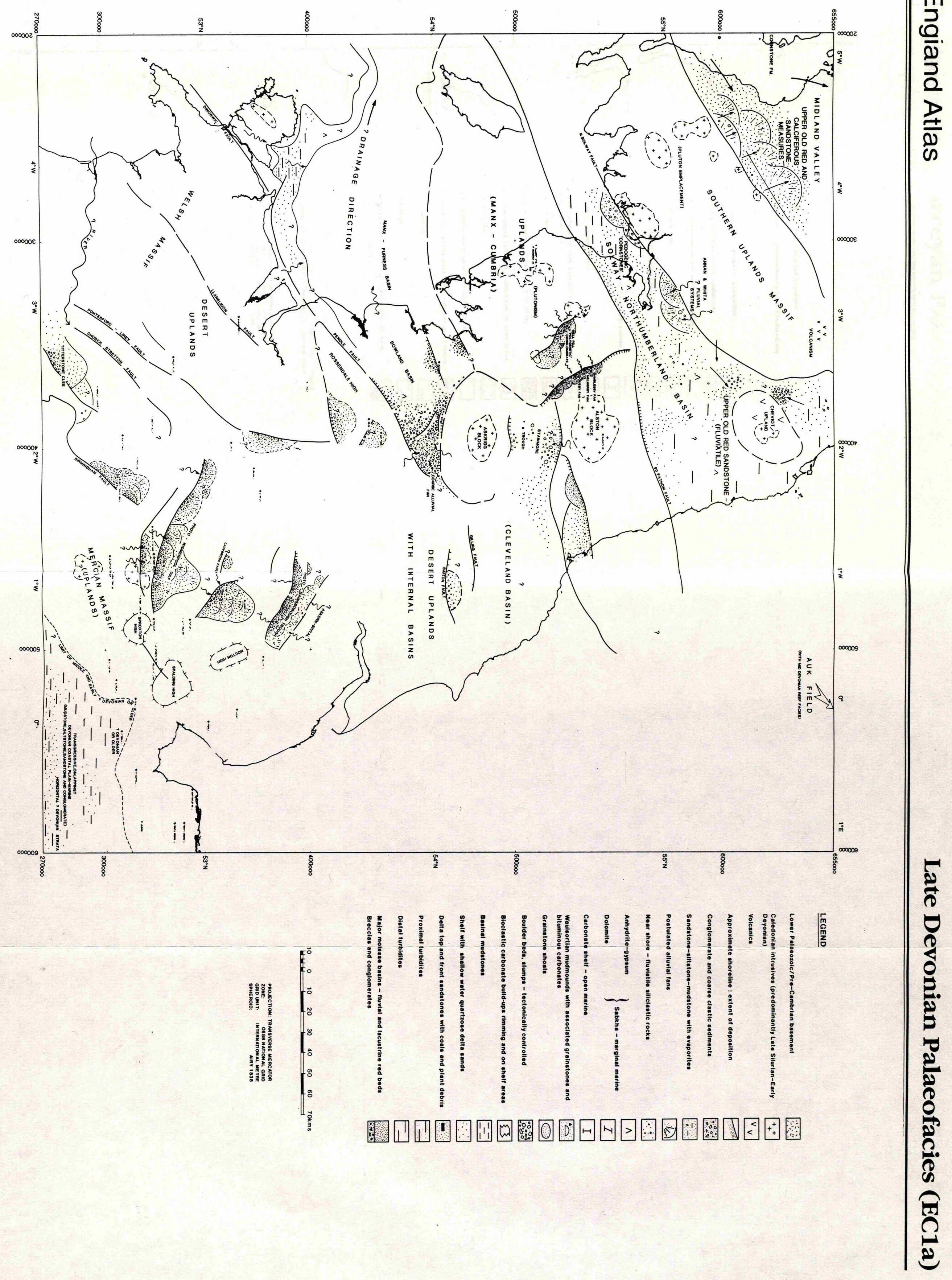



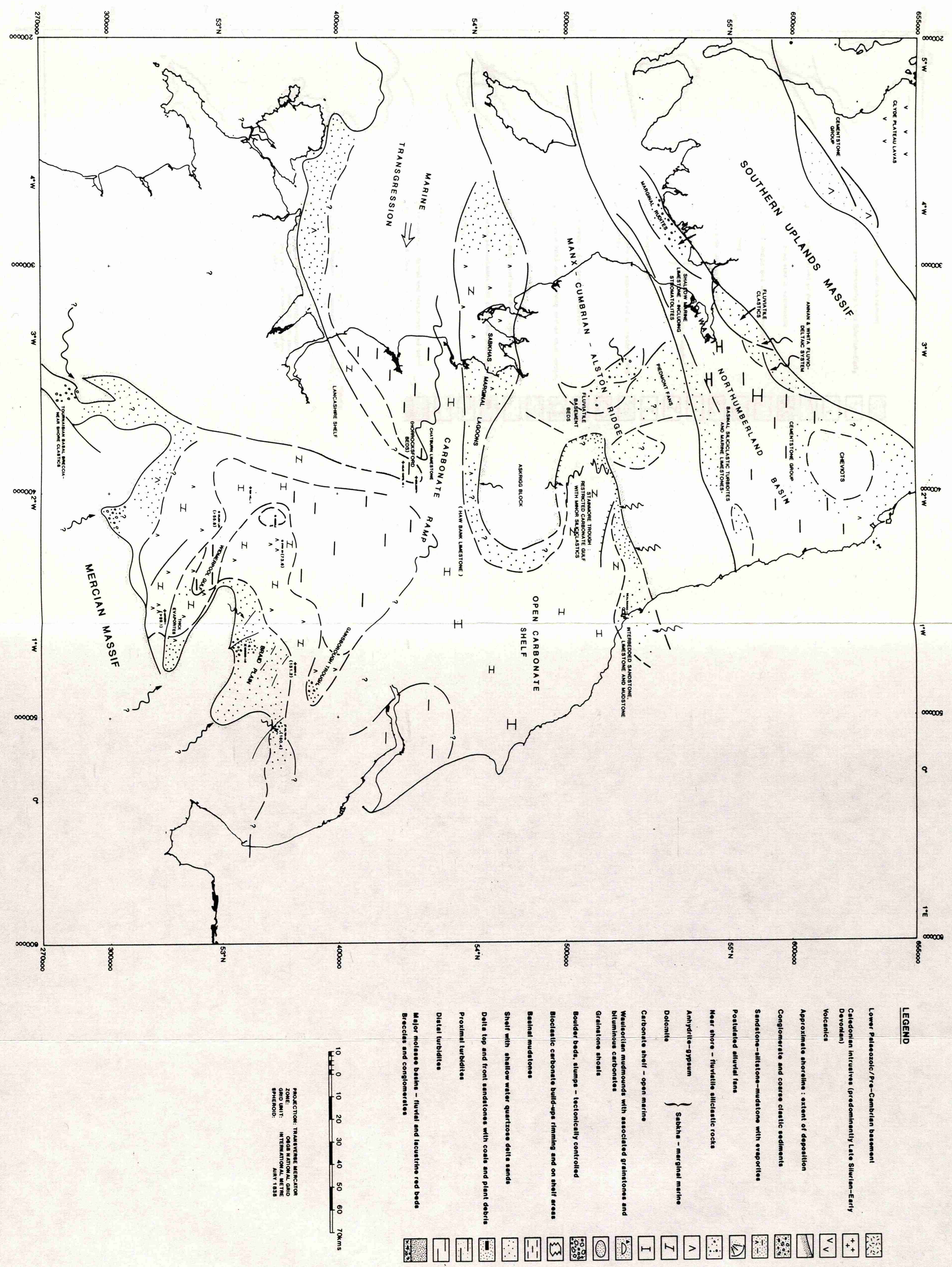

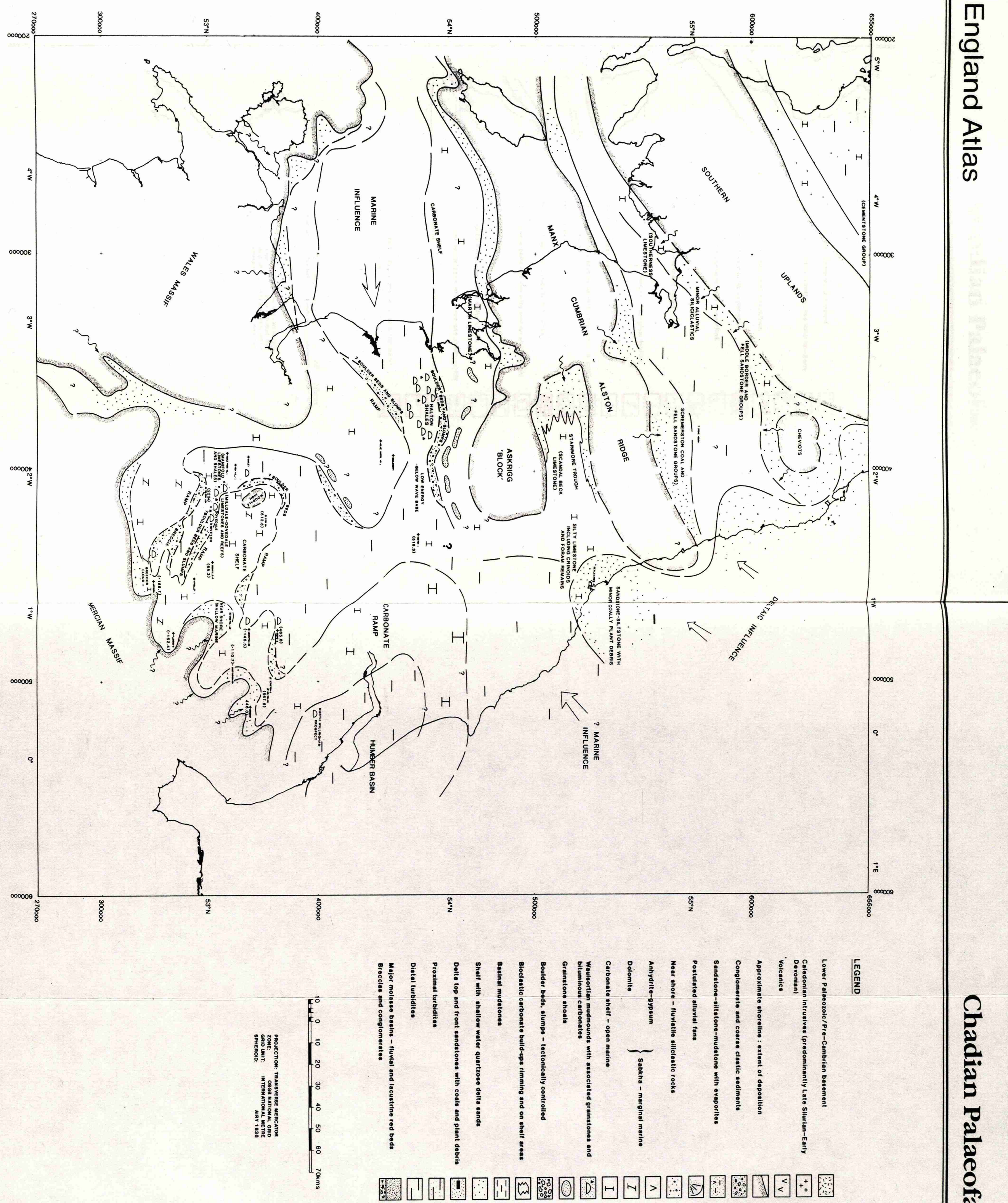


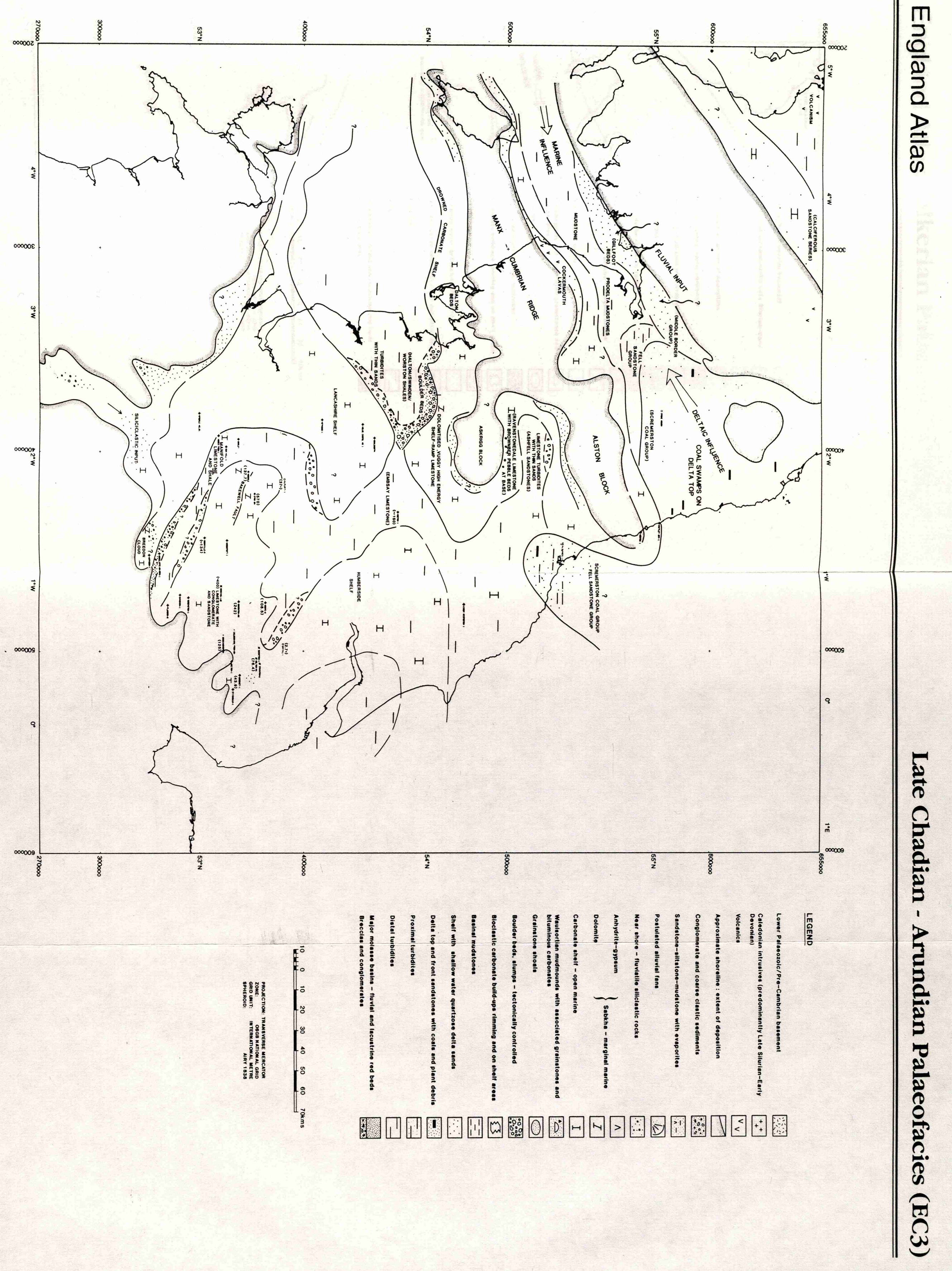



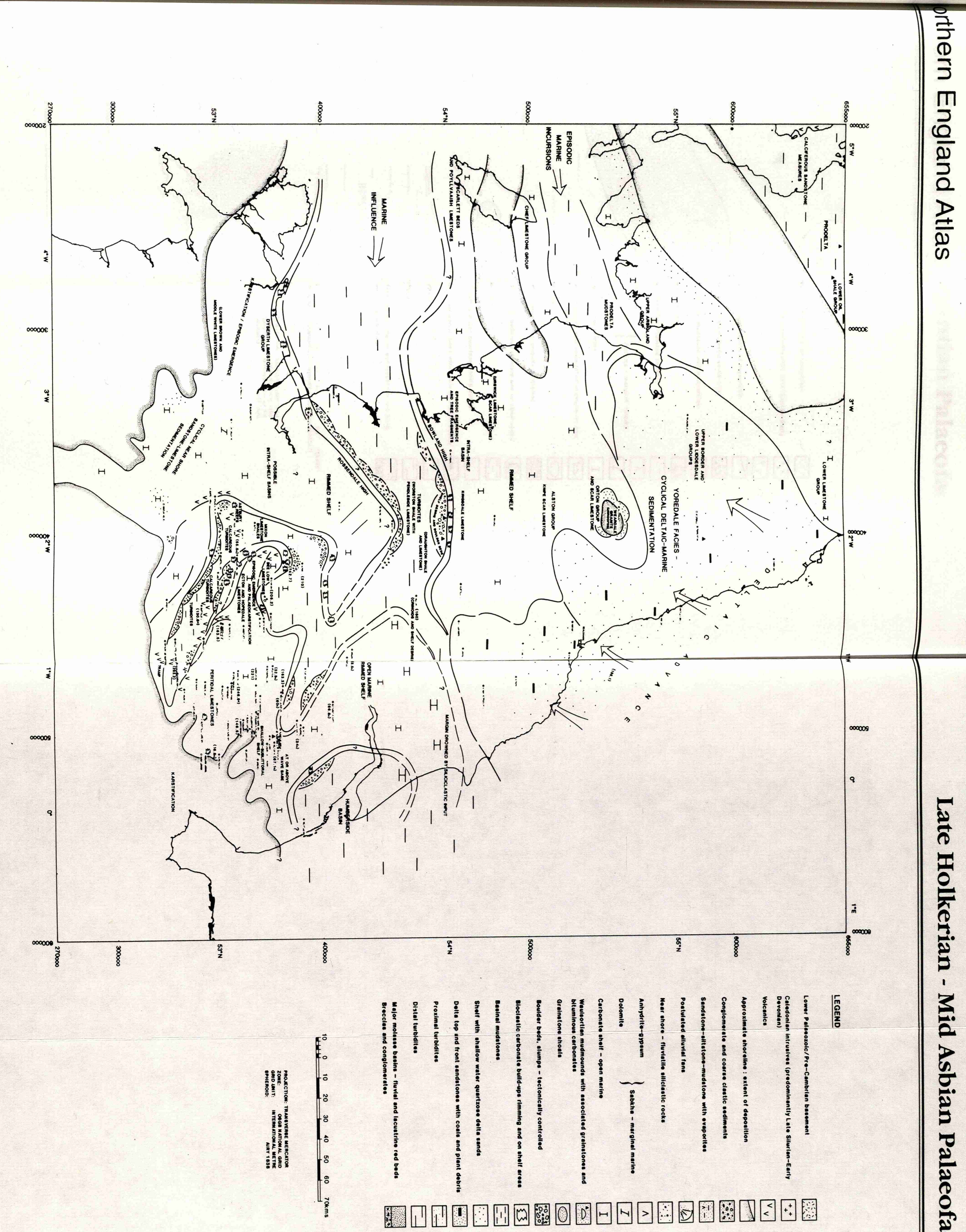


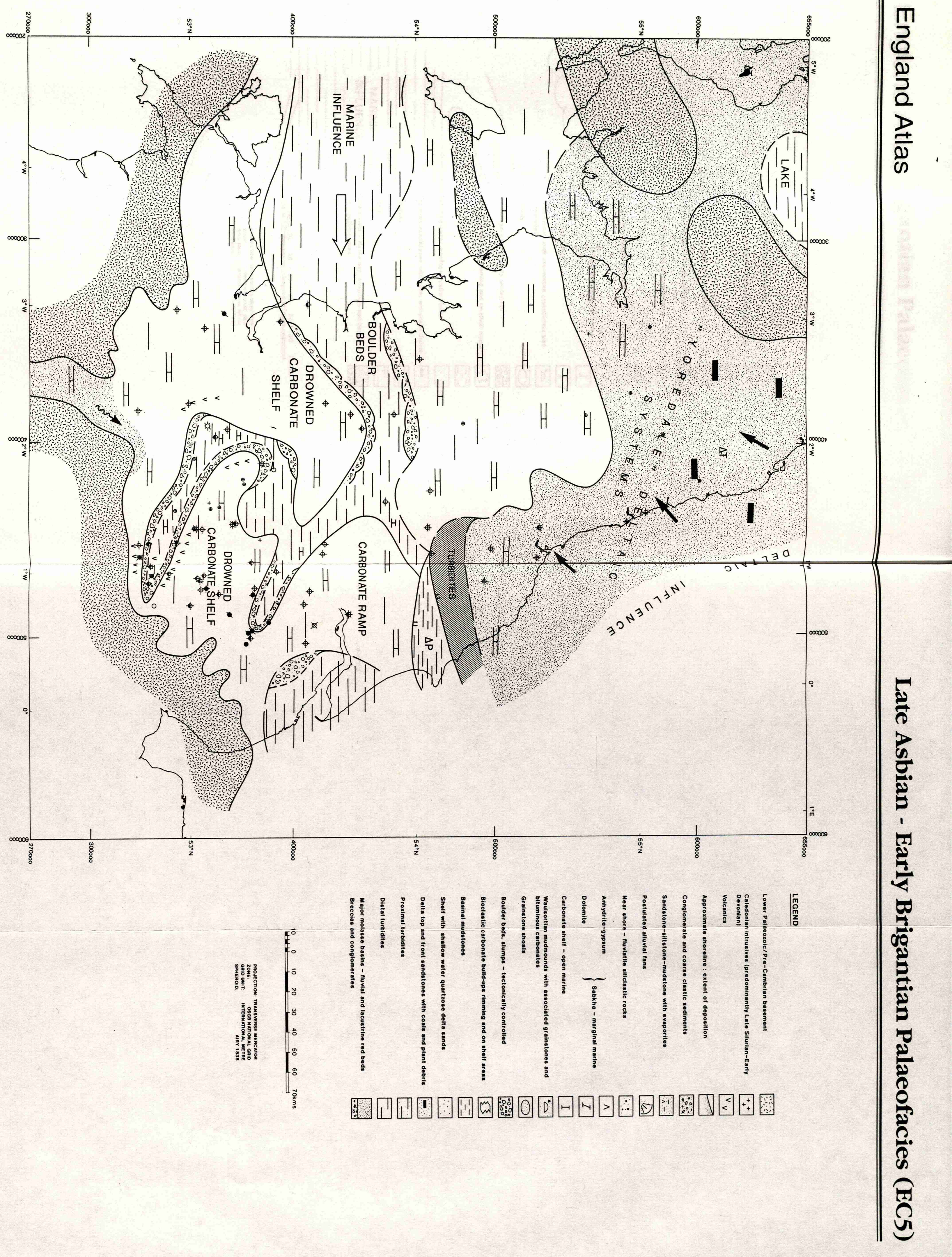



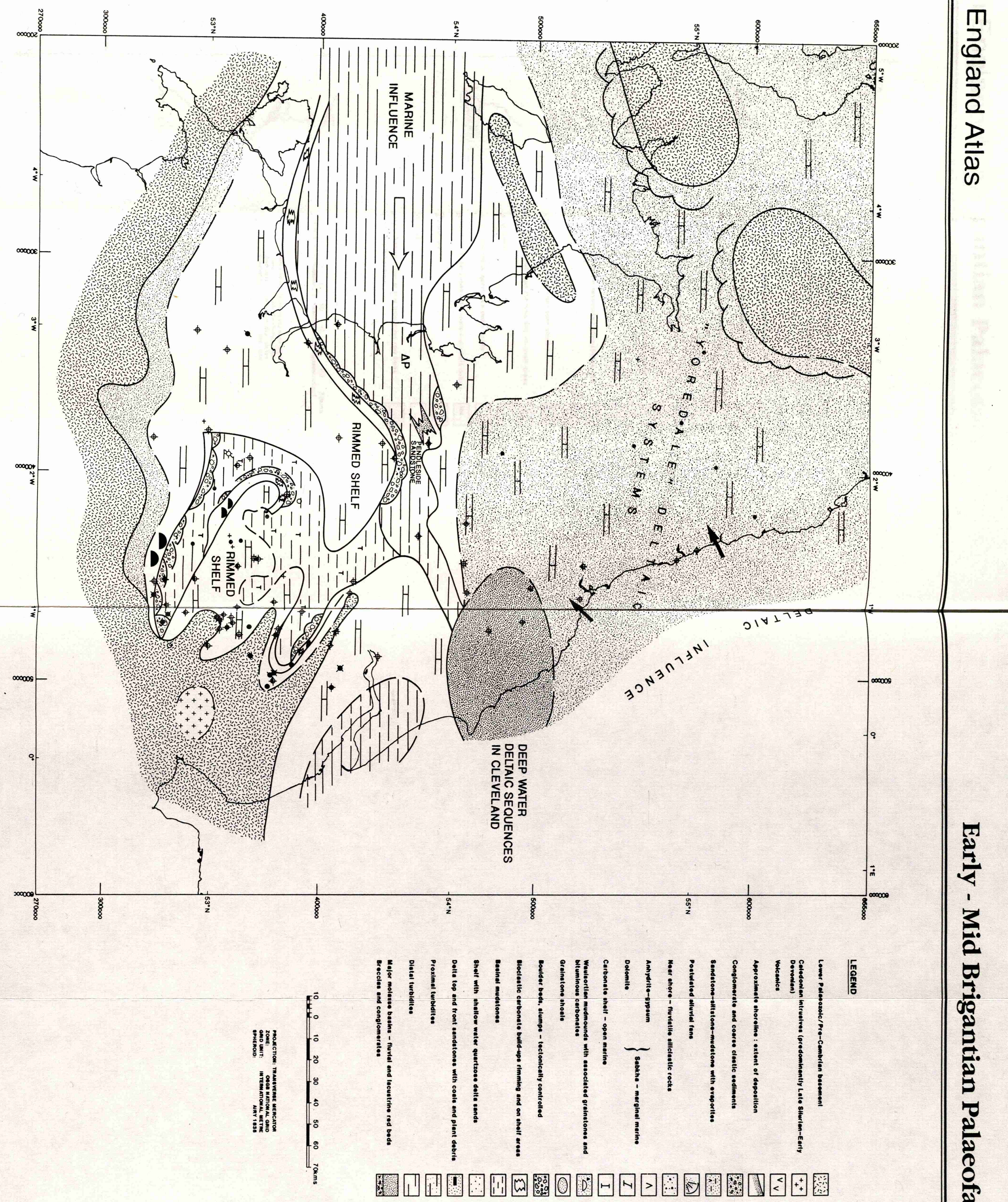

$\frac{0}{00}$
$\stackrel{0}{0}$
+0
$\dot{0}$ 


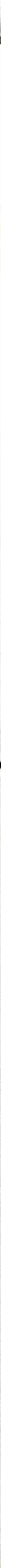




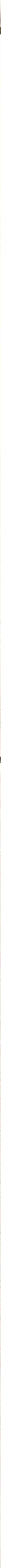




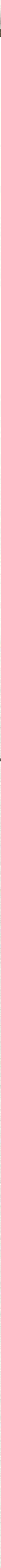



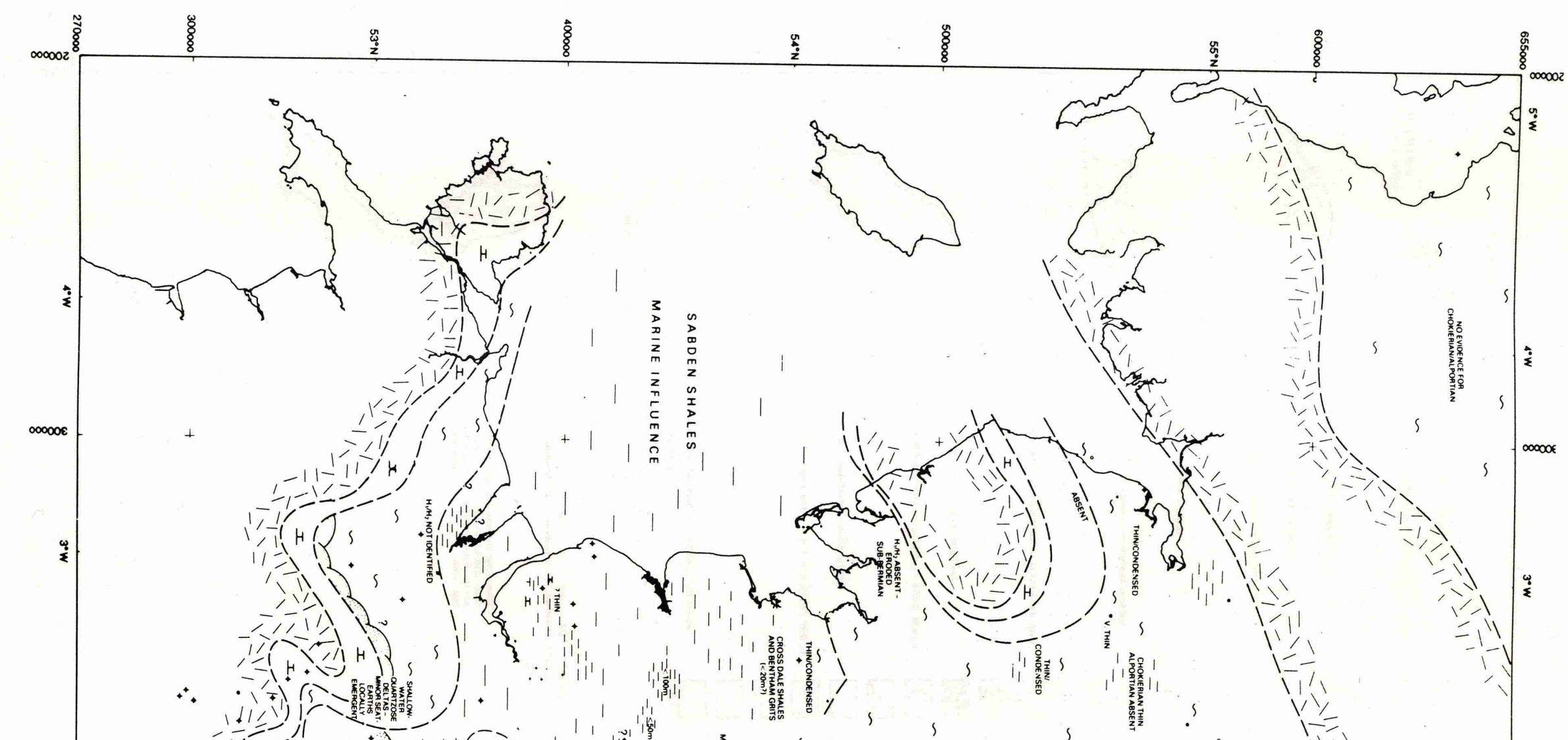

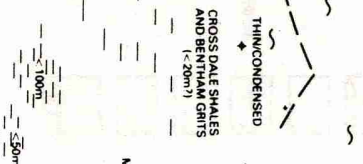

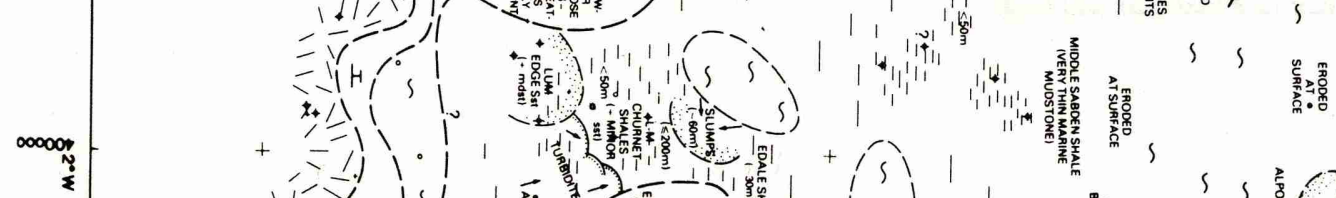

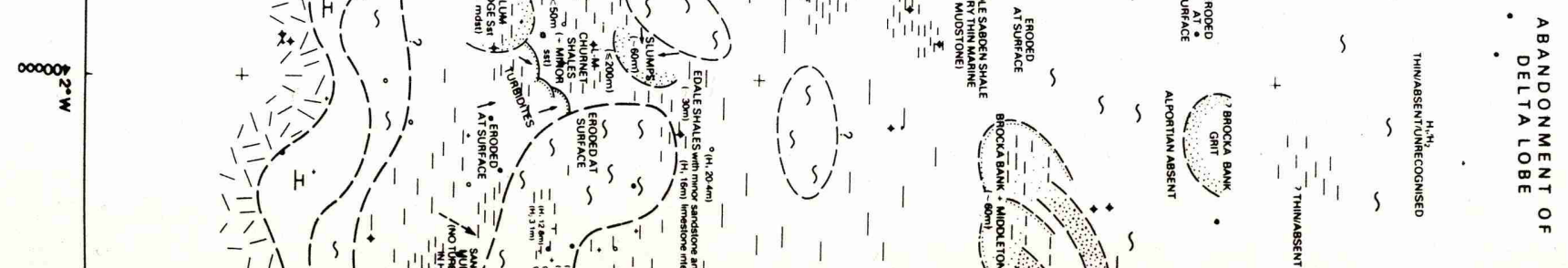
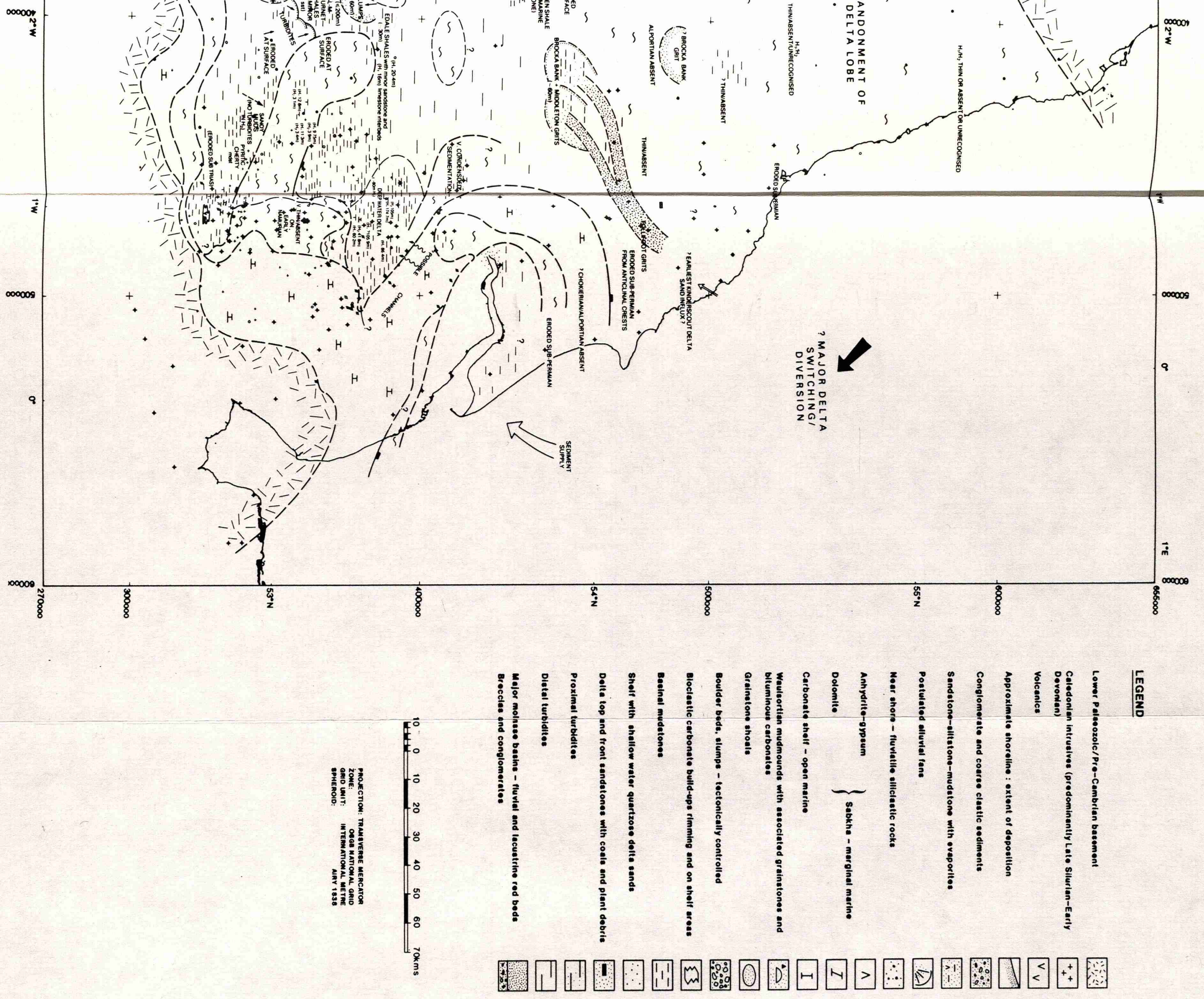

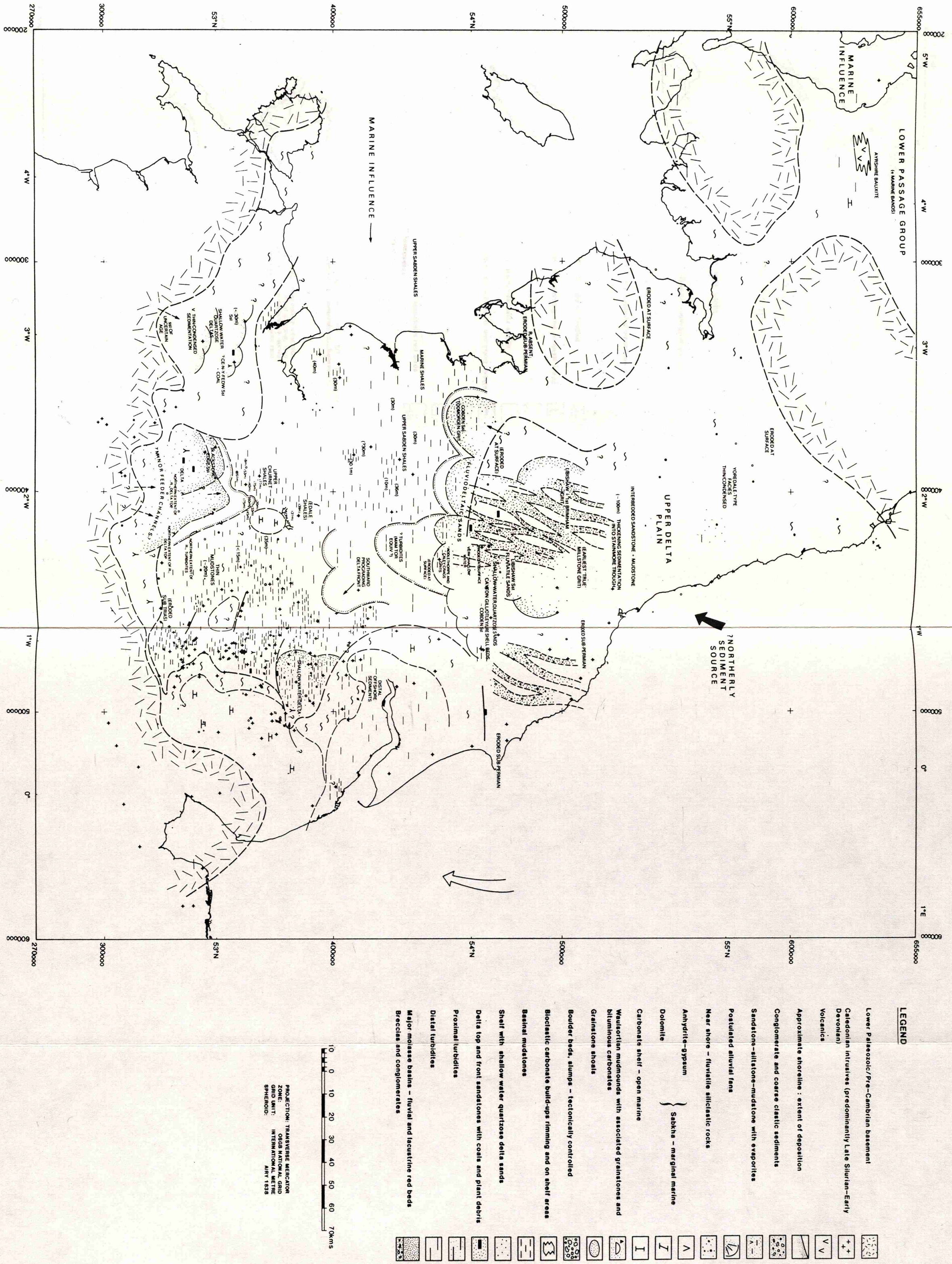


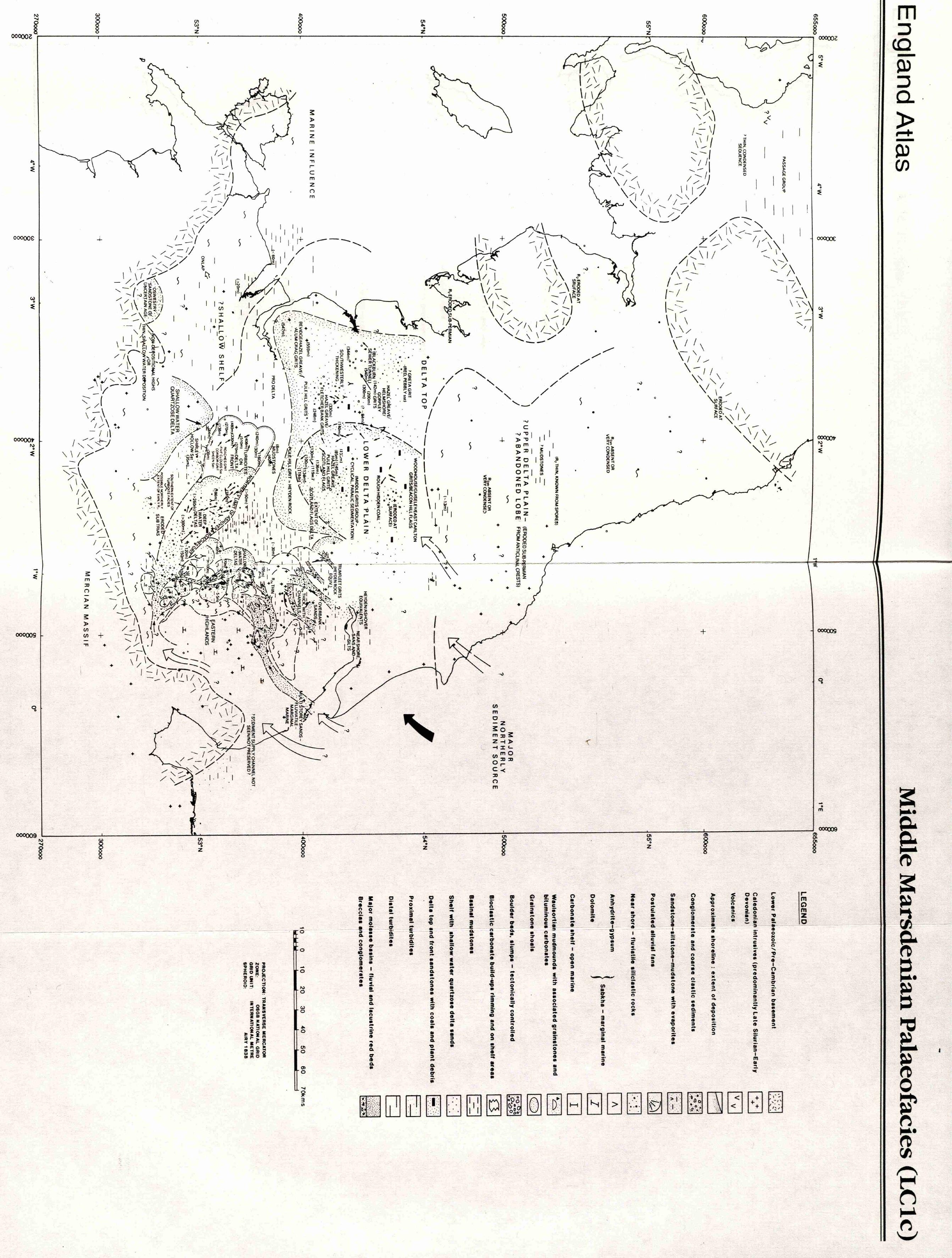




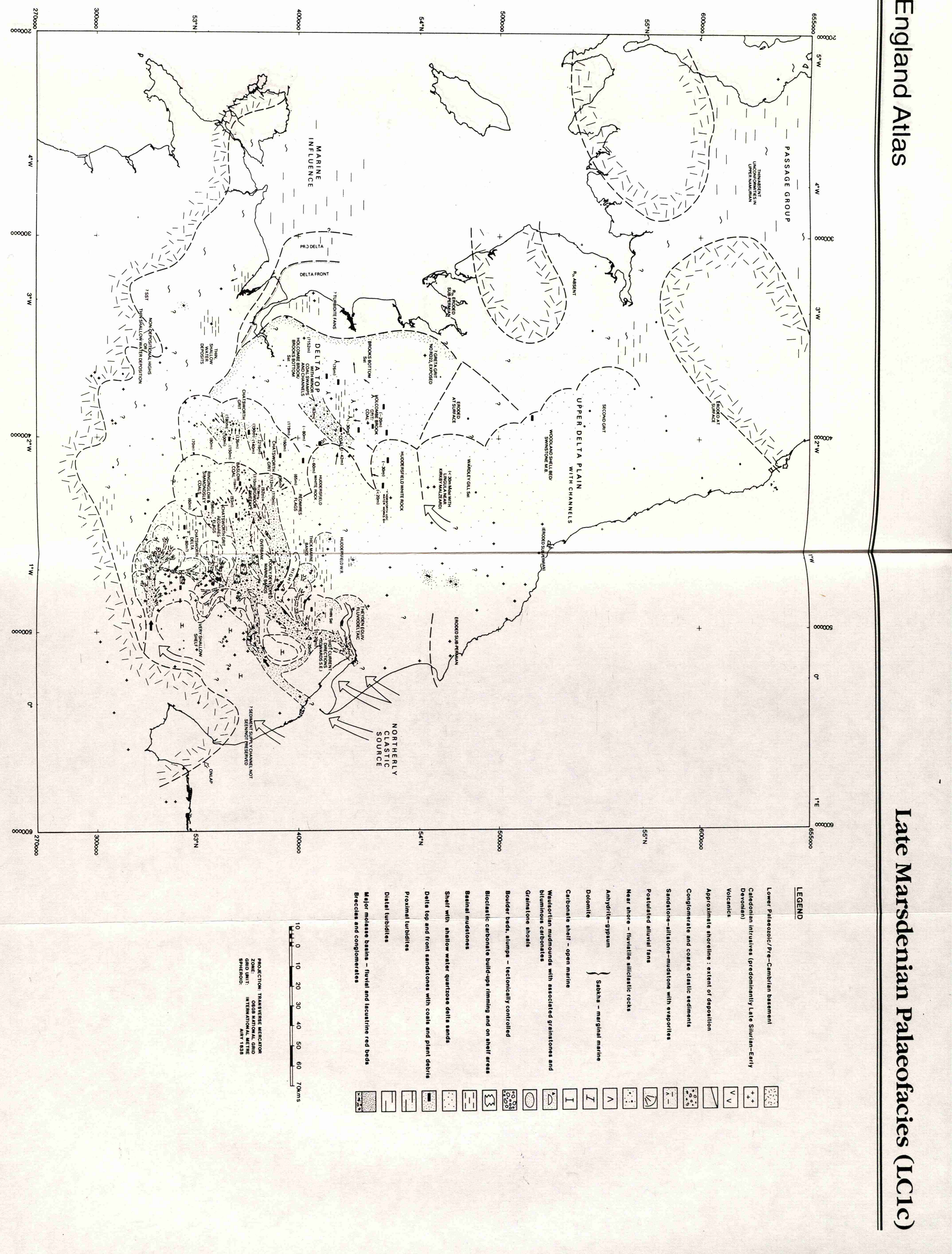




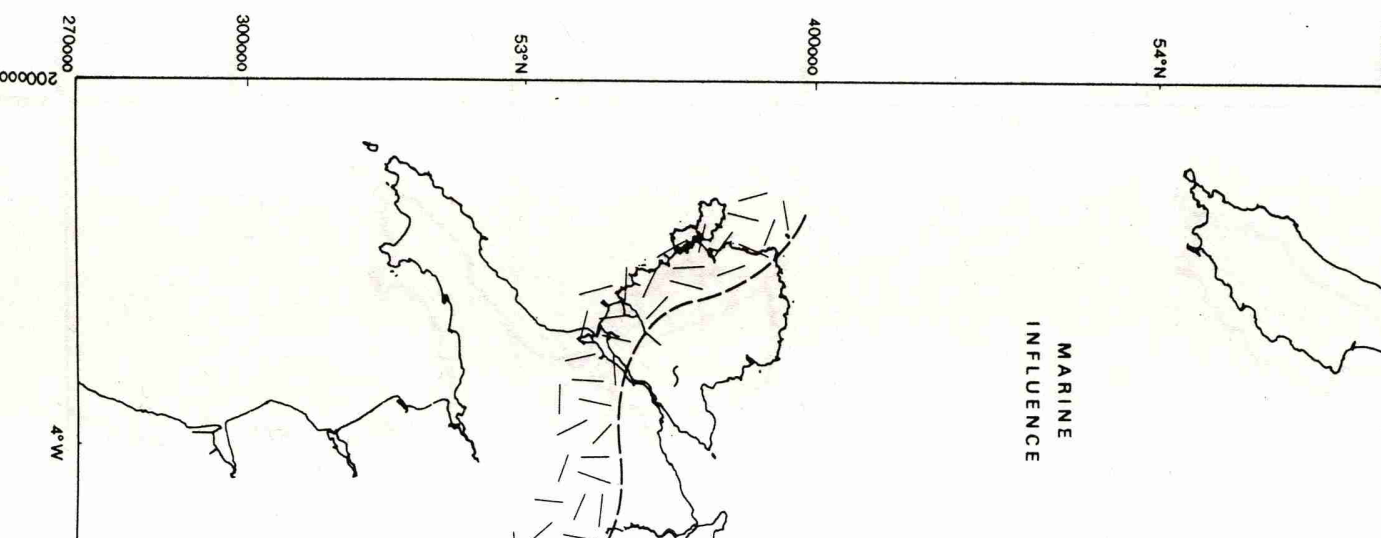

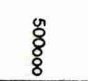

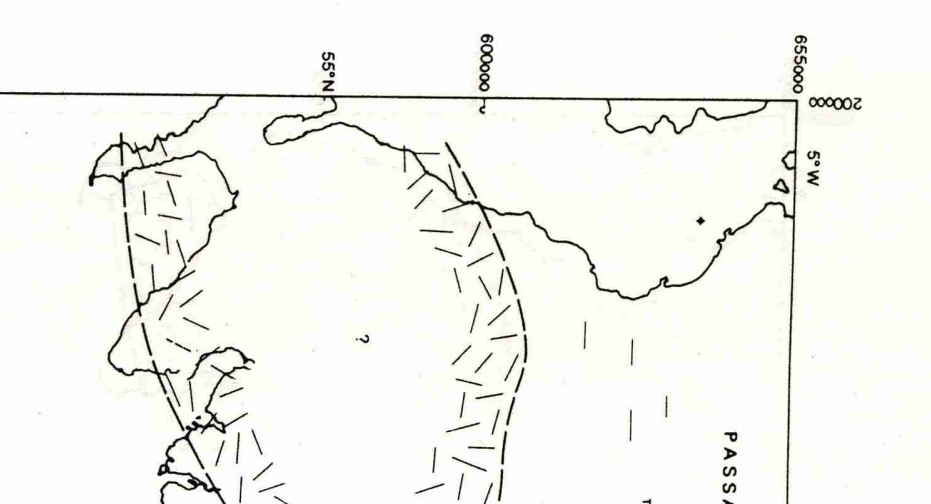

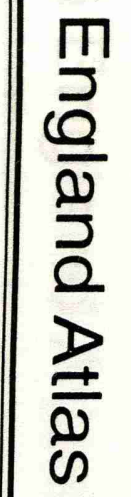
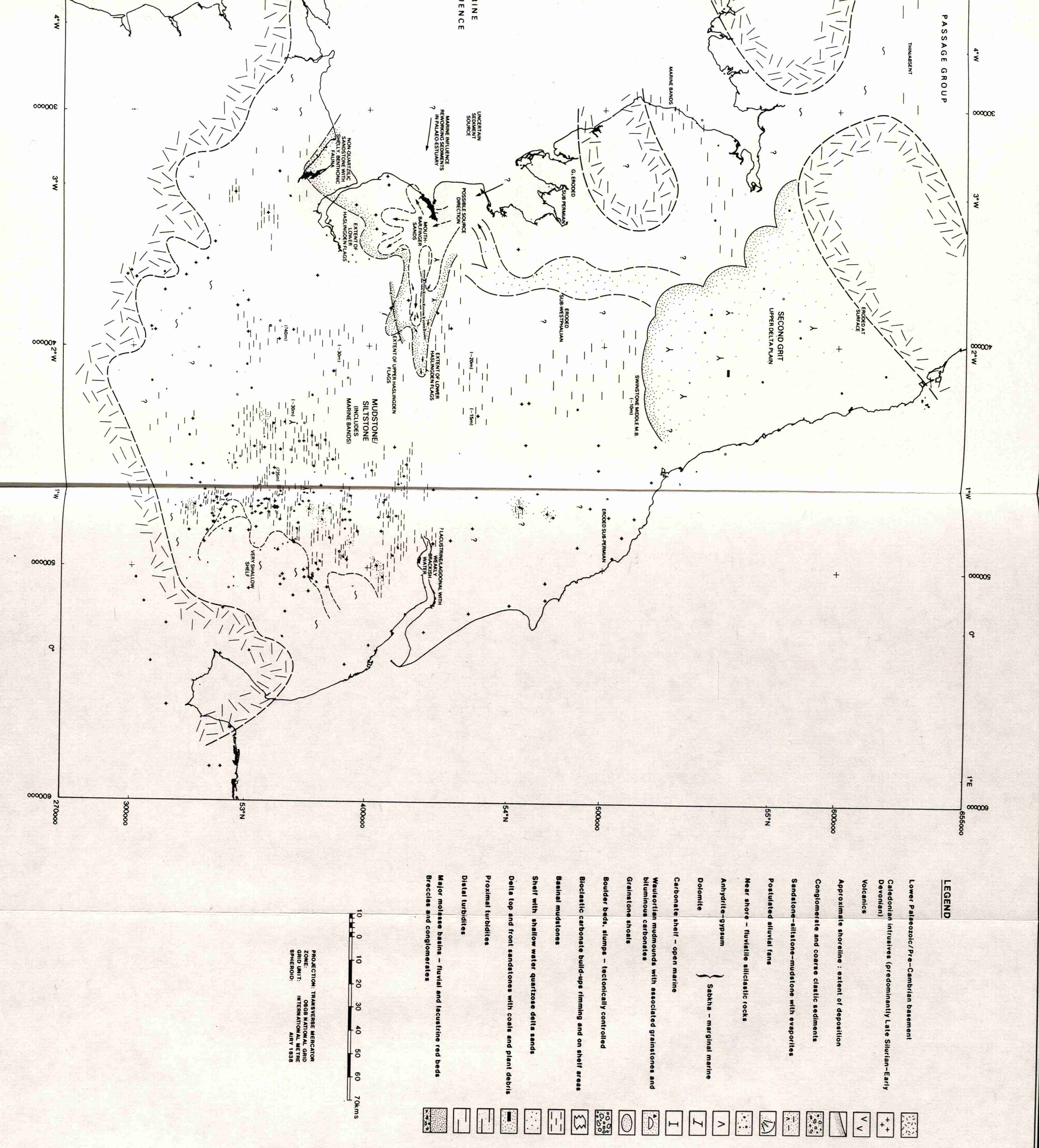

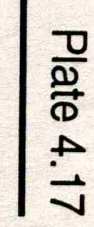




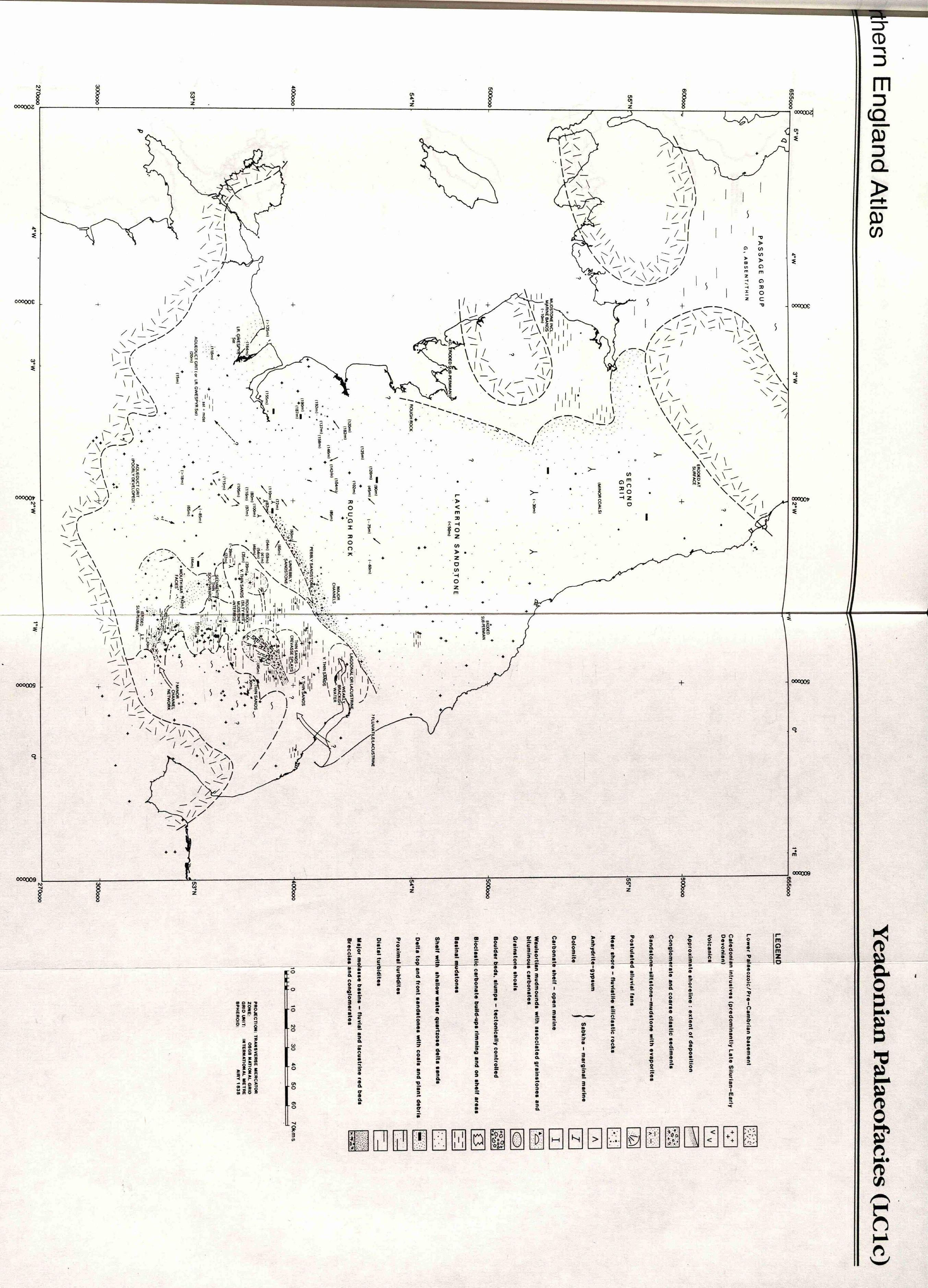



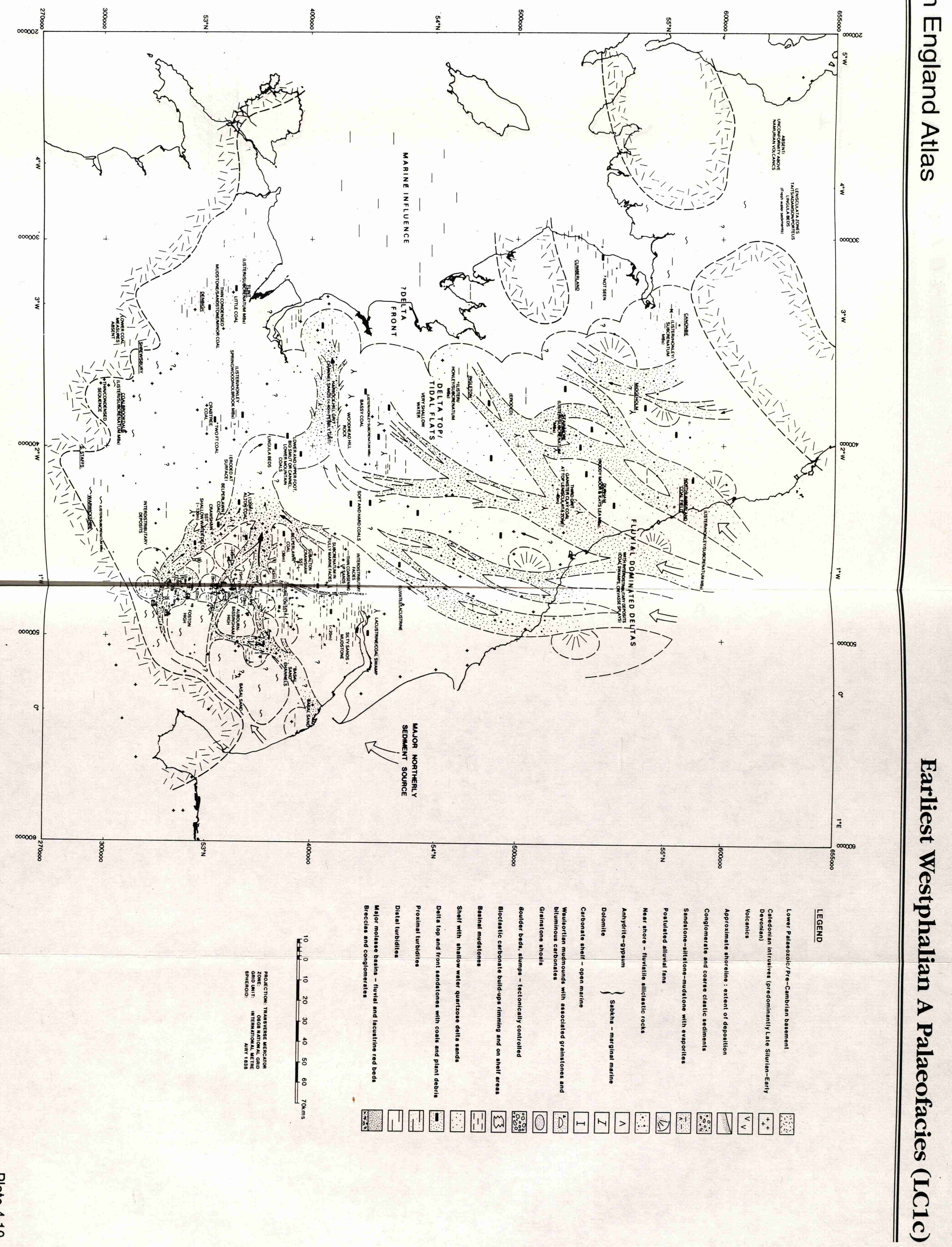


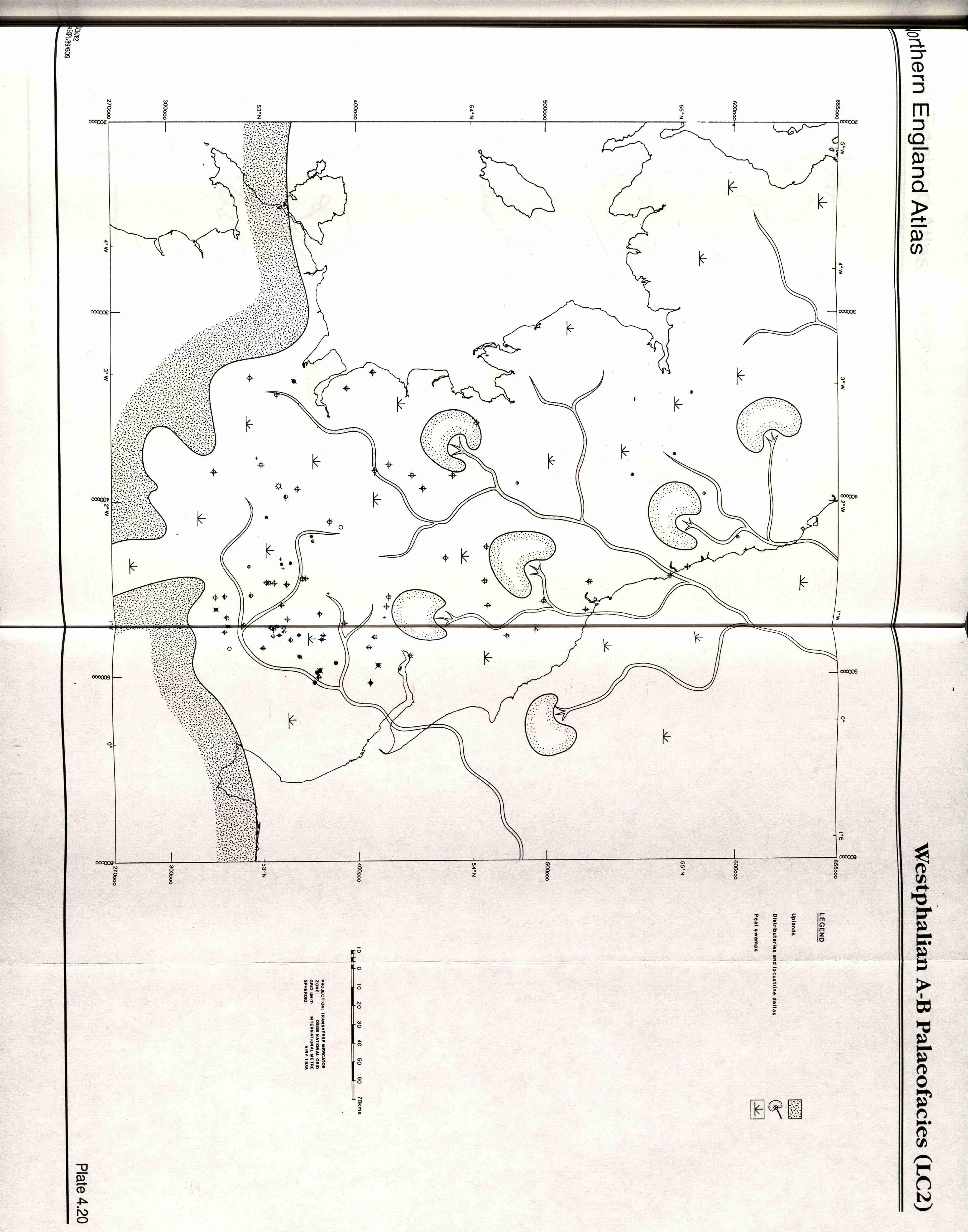




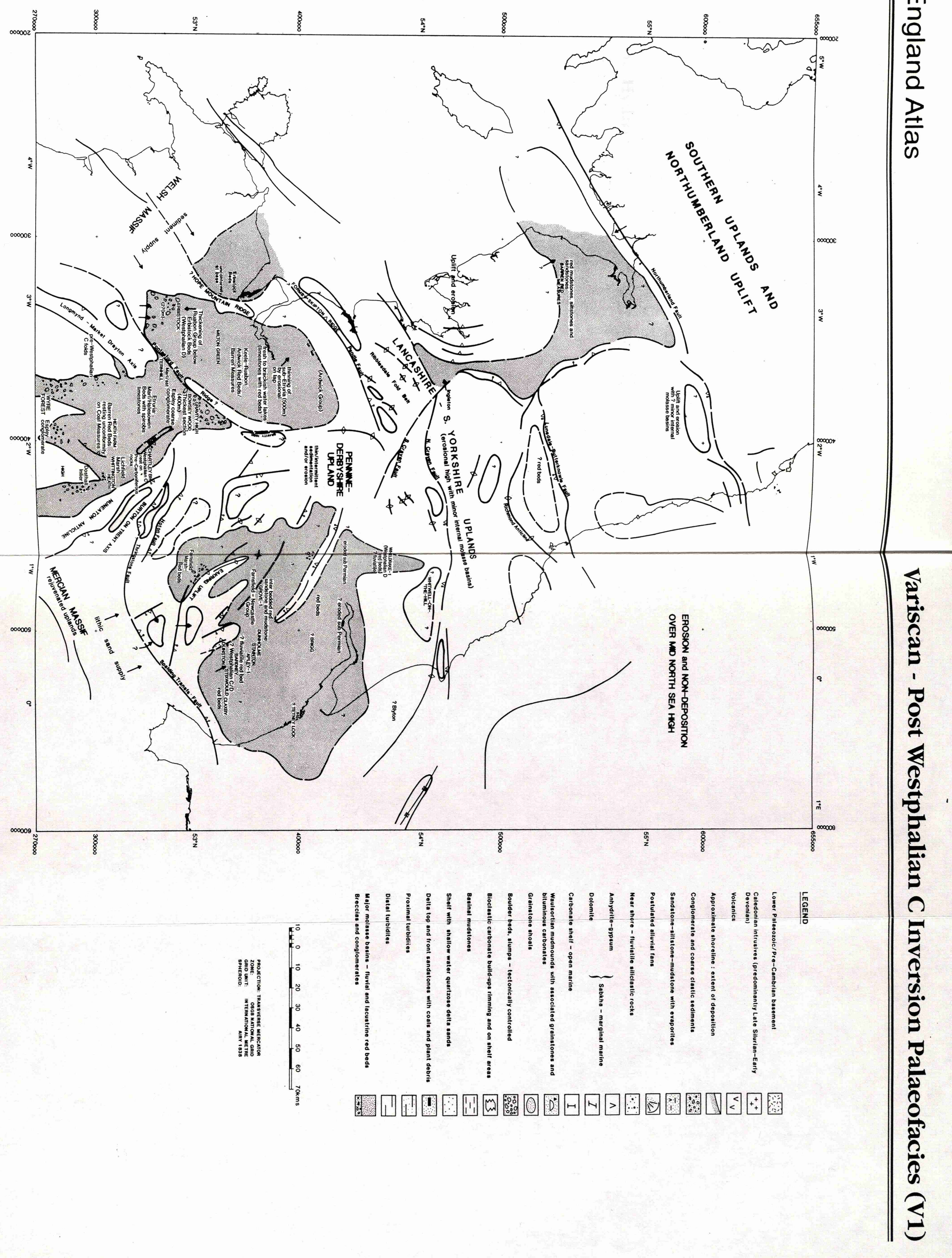


5. Hydrocarbon habitat and play fairway analysis 
号只只(人) (20)
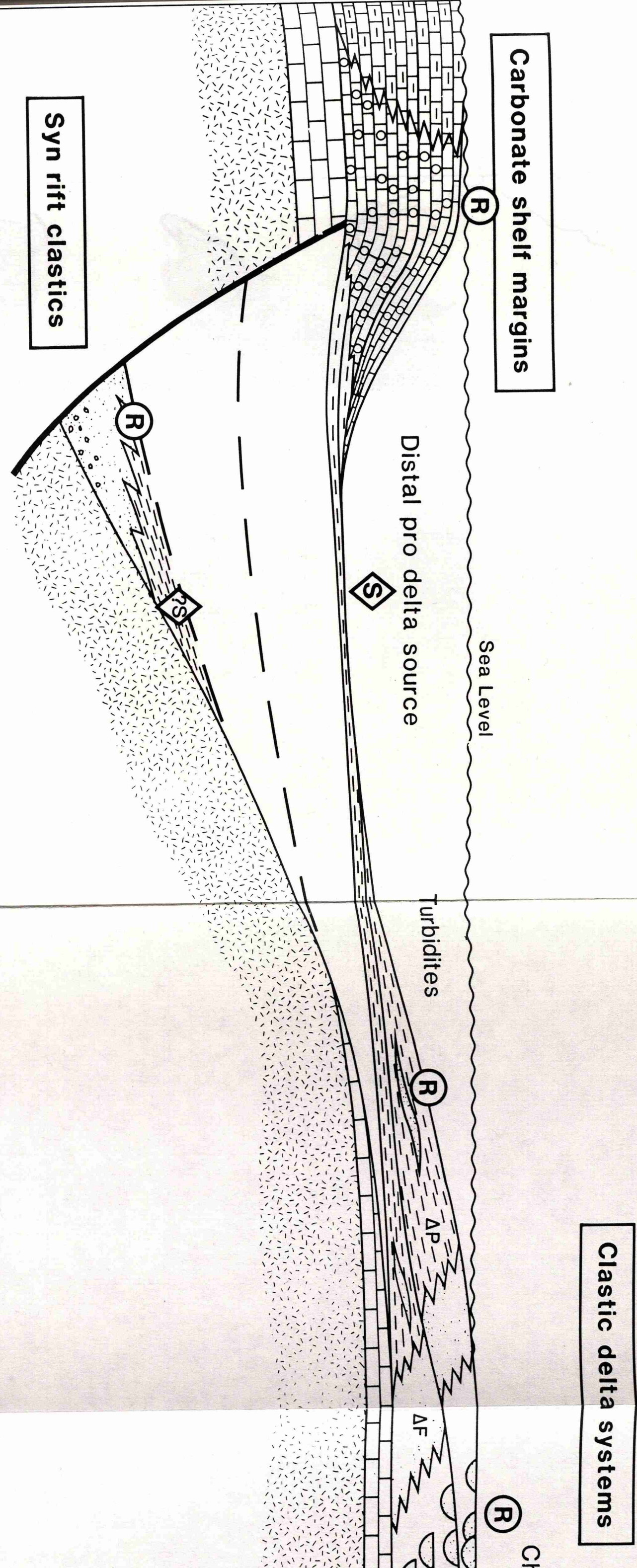

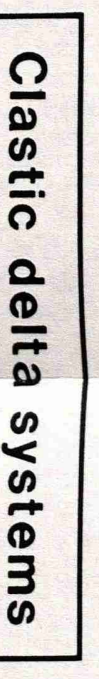




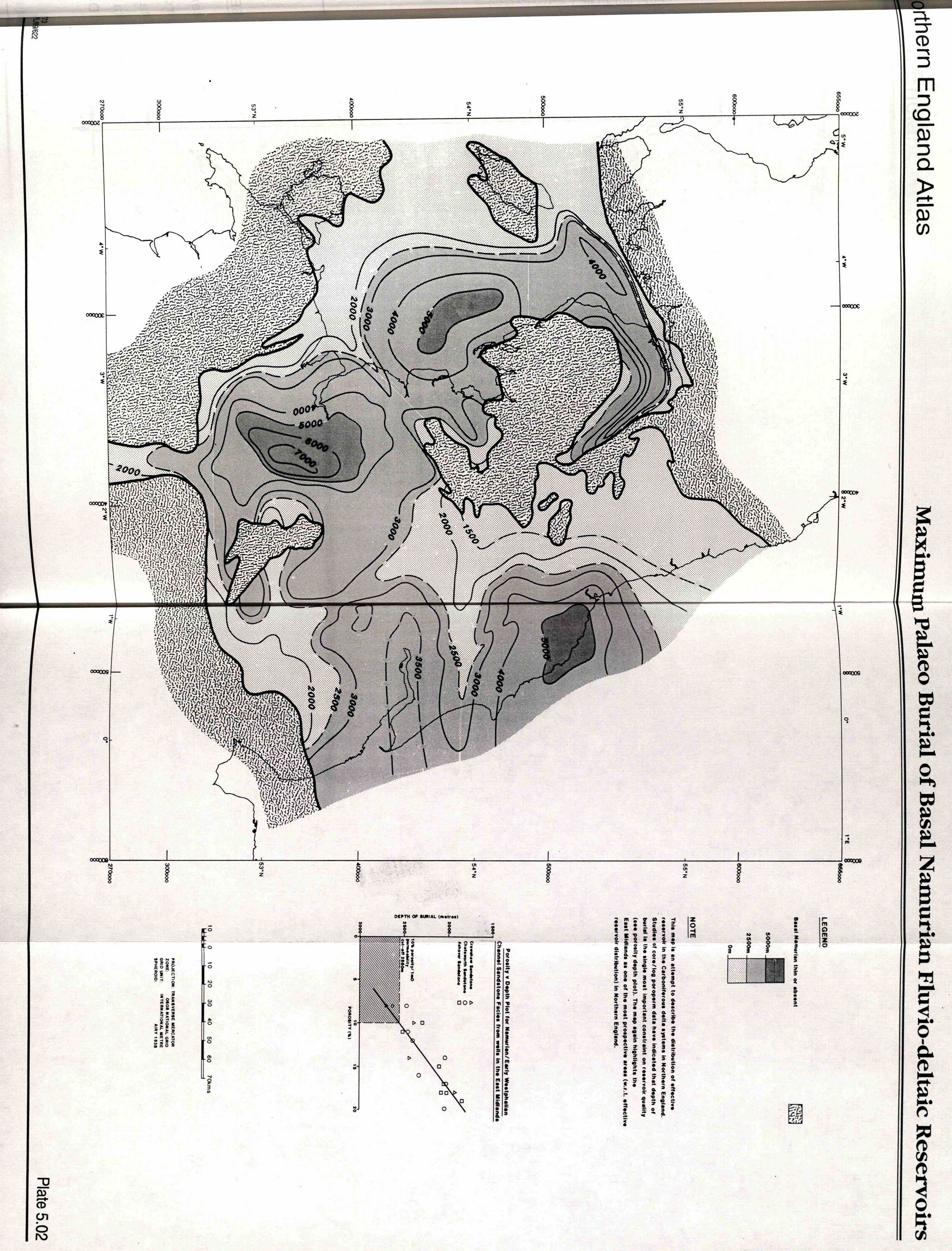




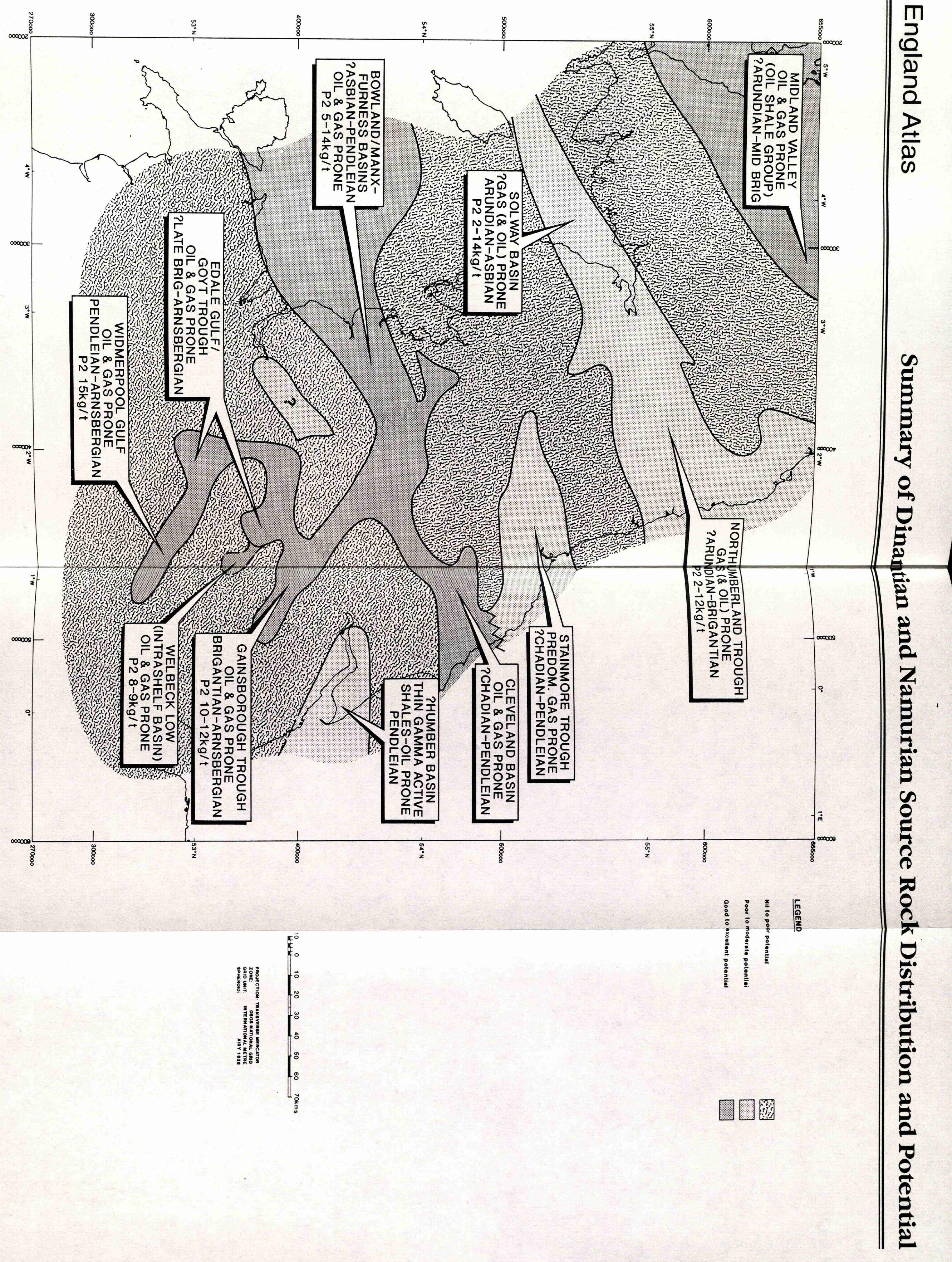




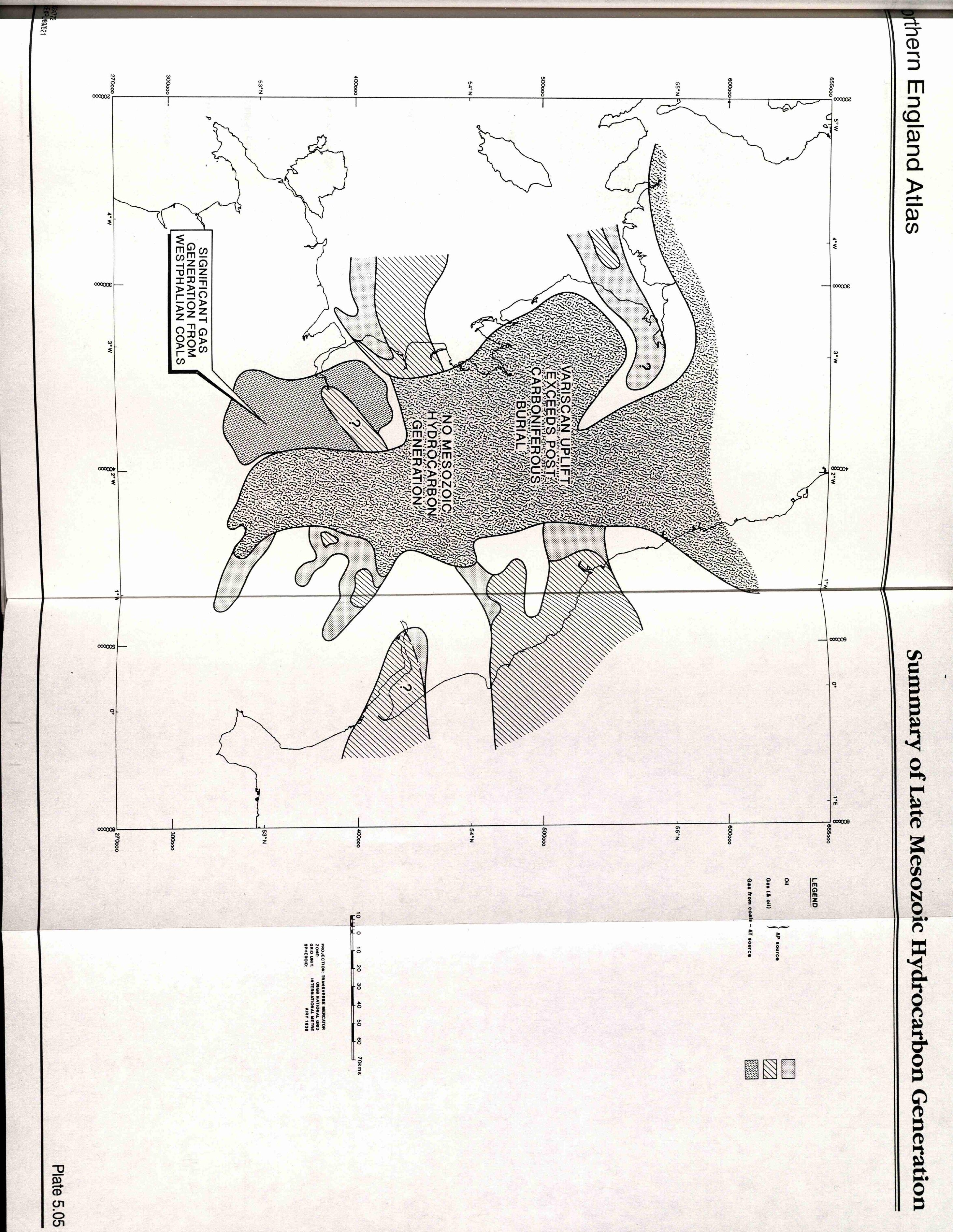





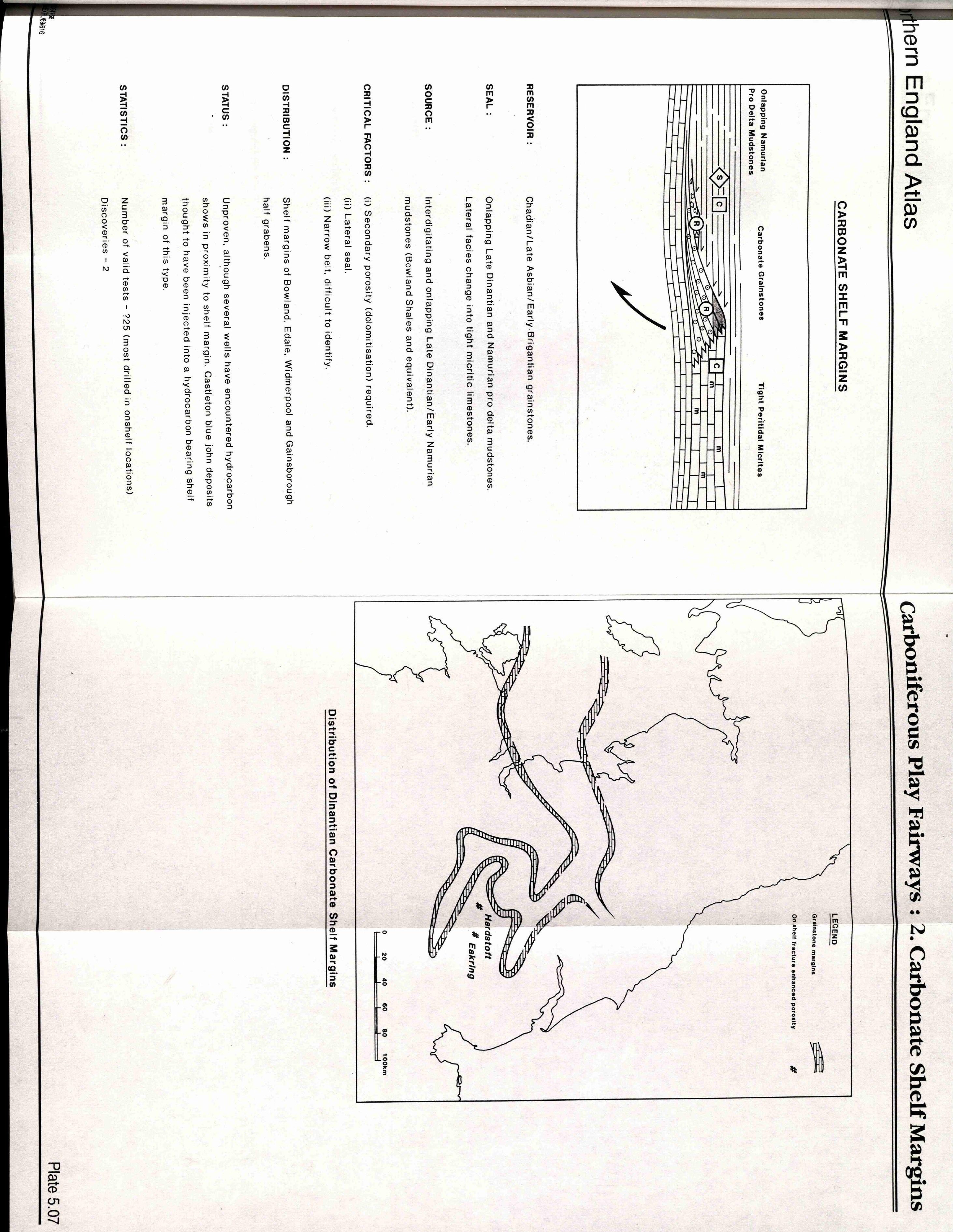



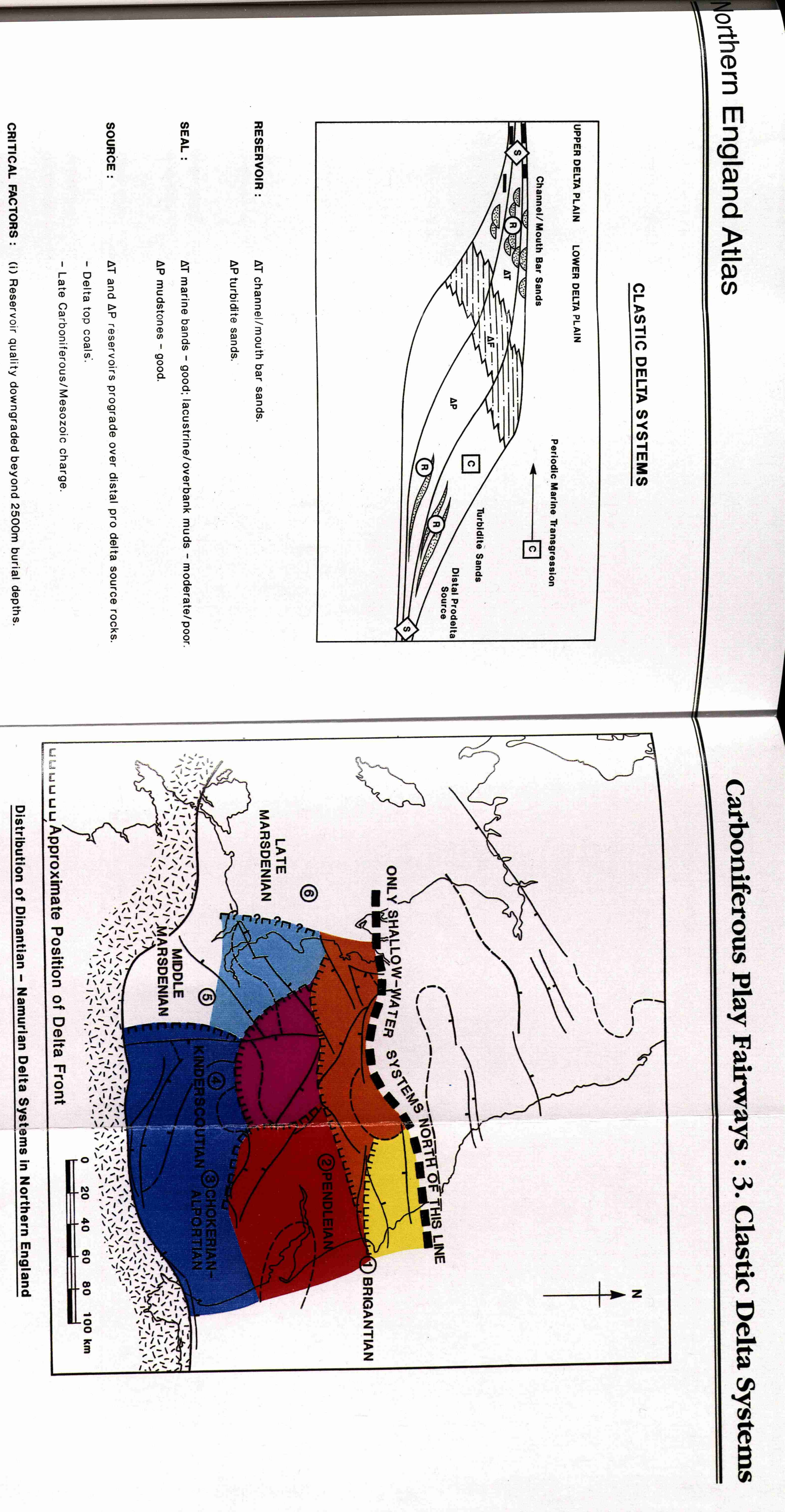

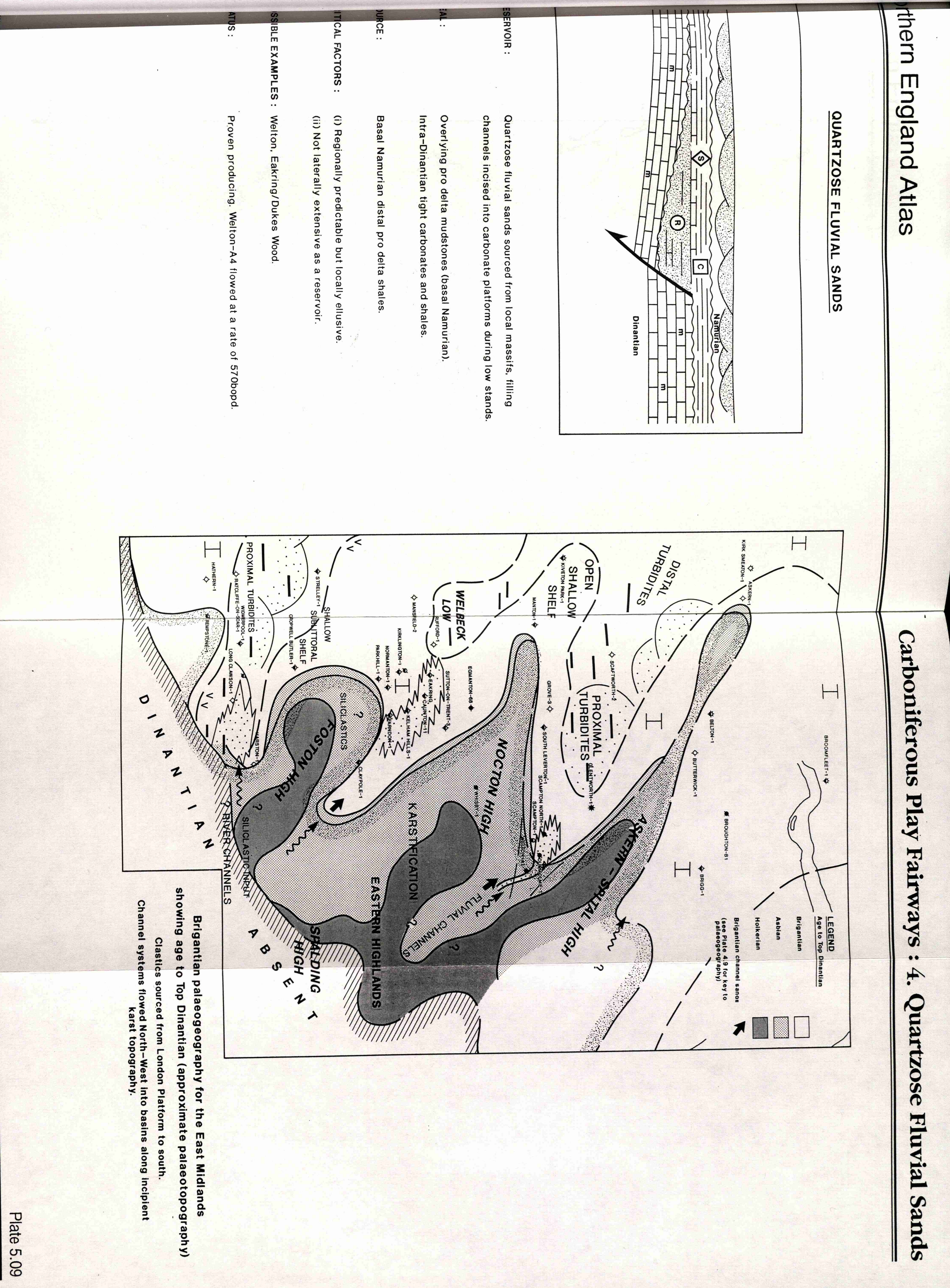

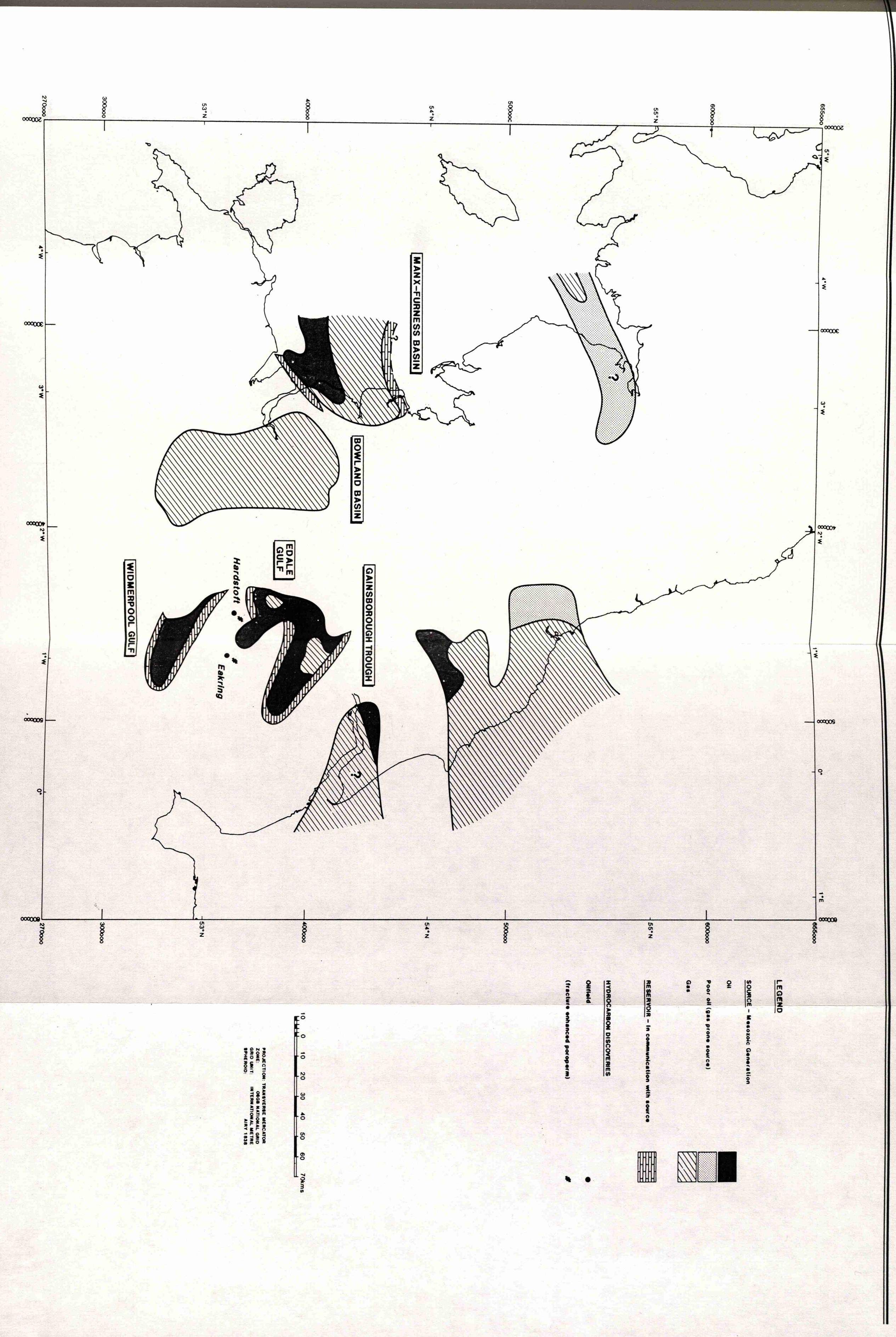

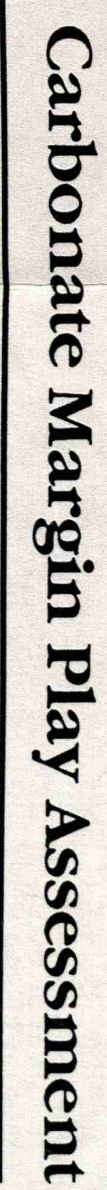



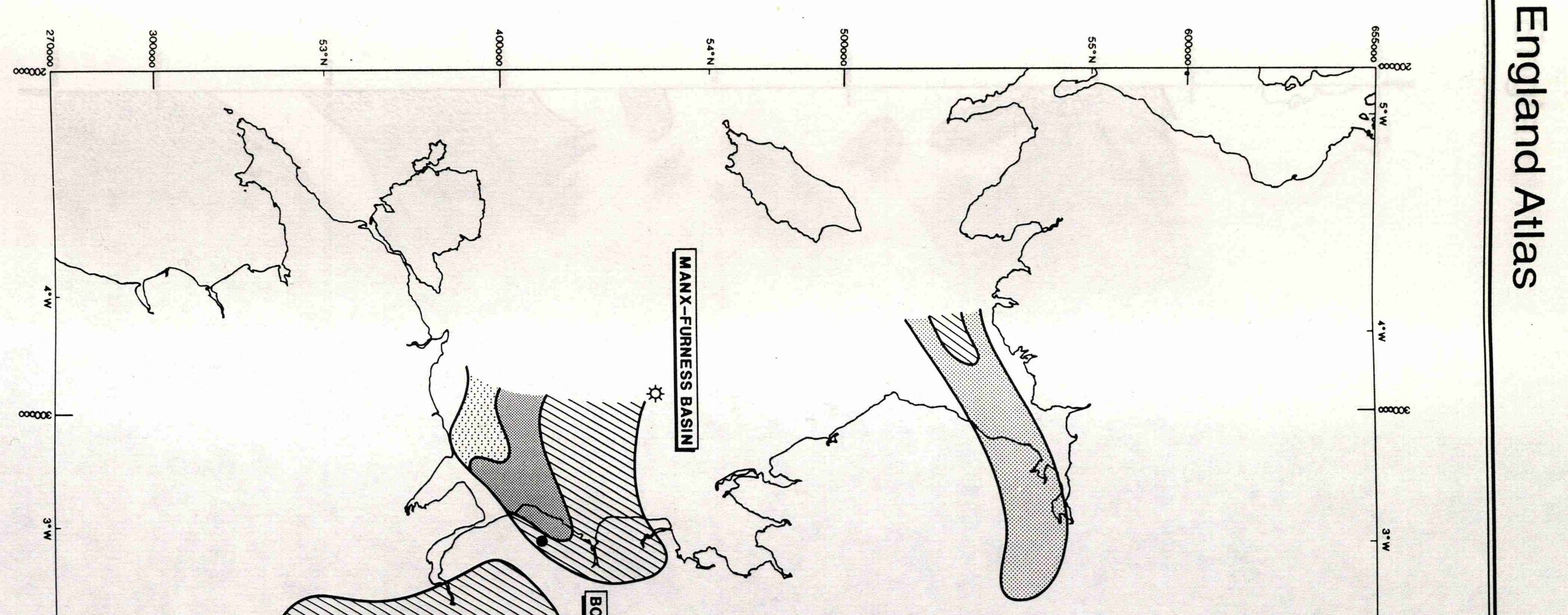

$-$
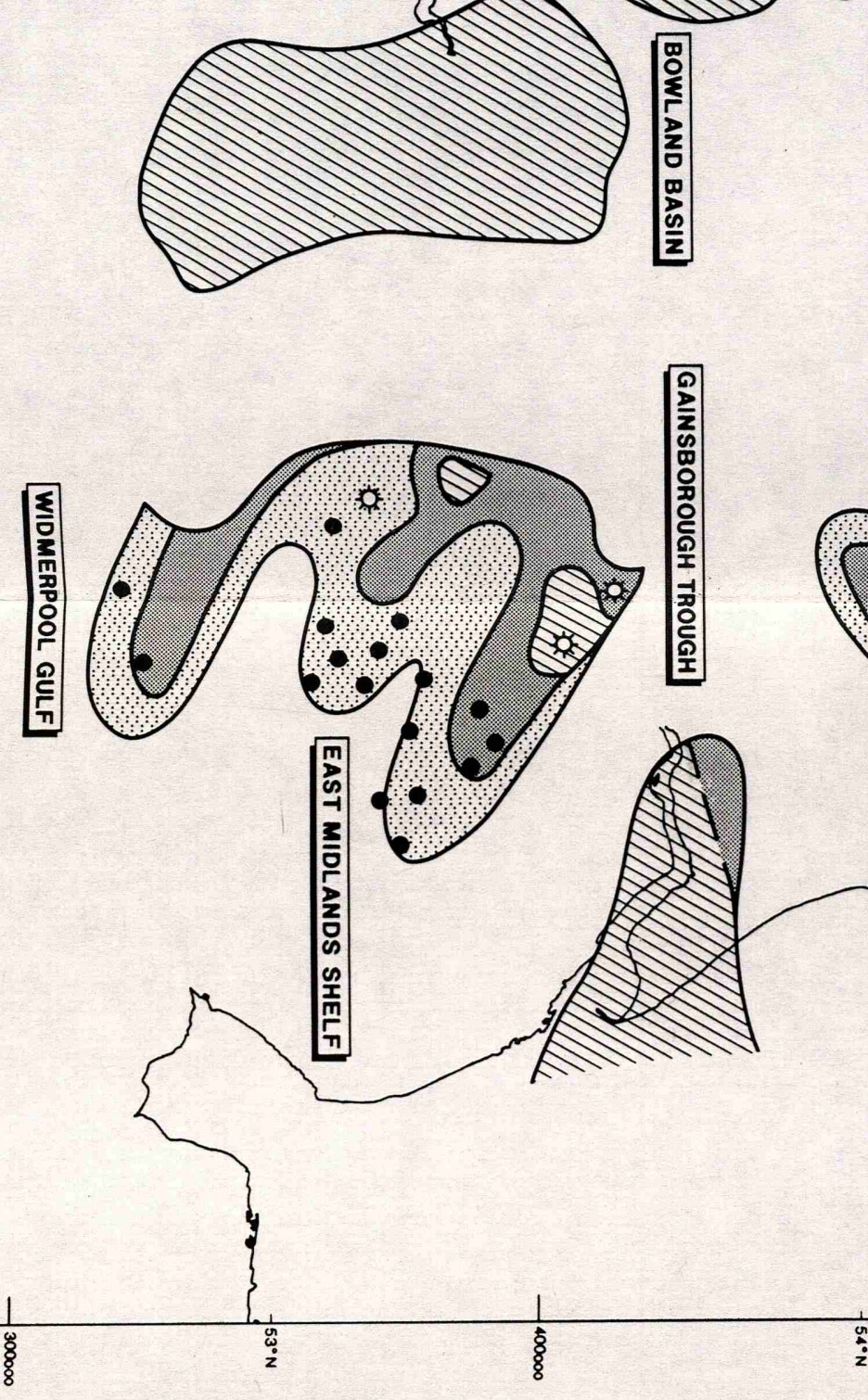

$-$

-

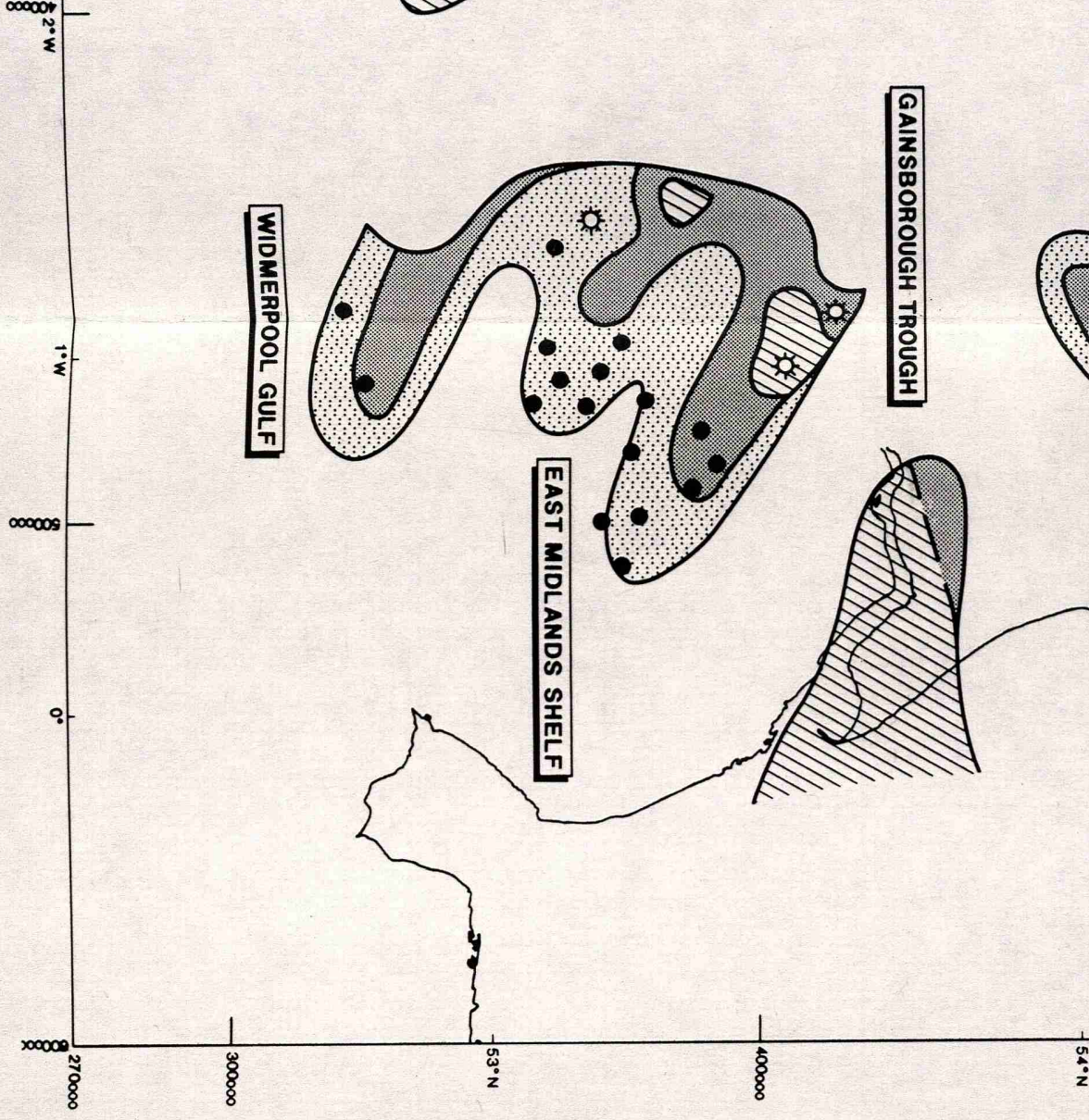

$\sqrt[n]{2}+x^{2}$

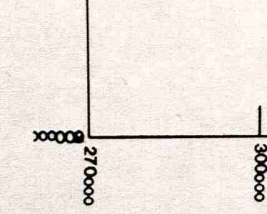

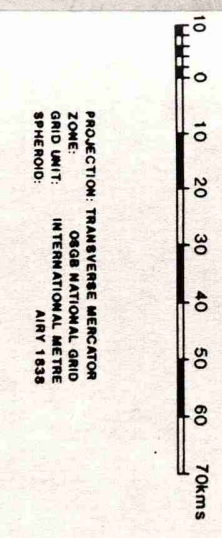

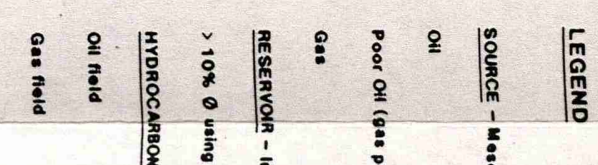

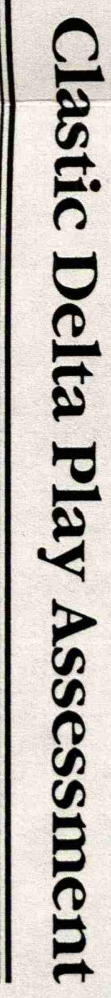

* $\$$ 


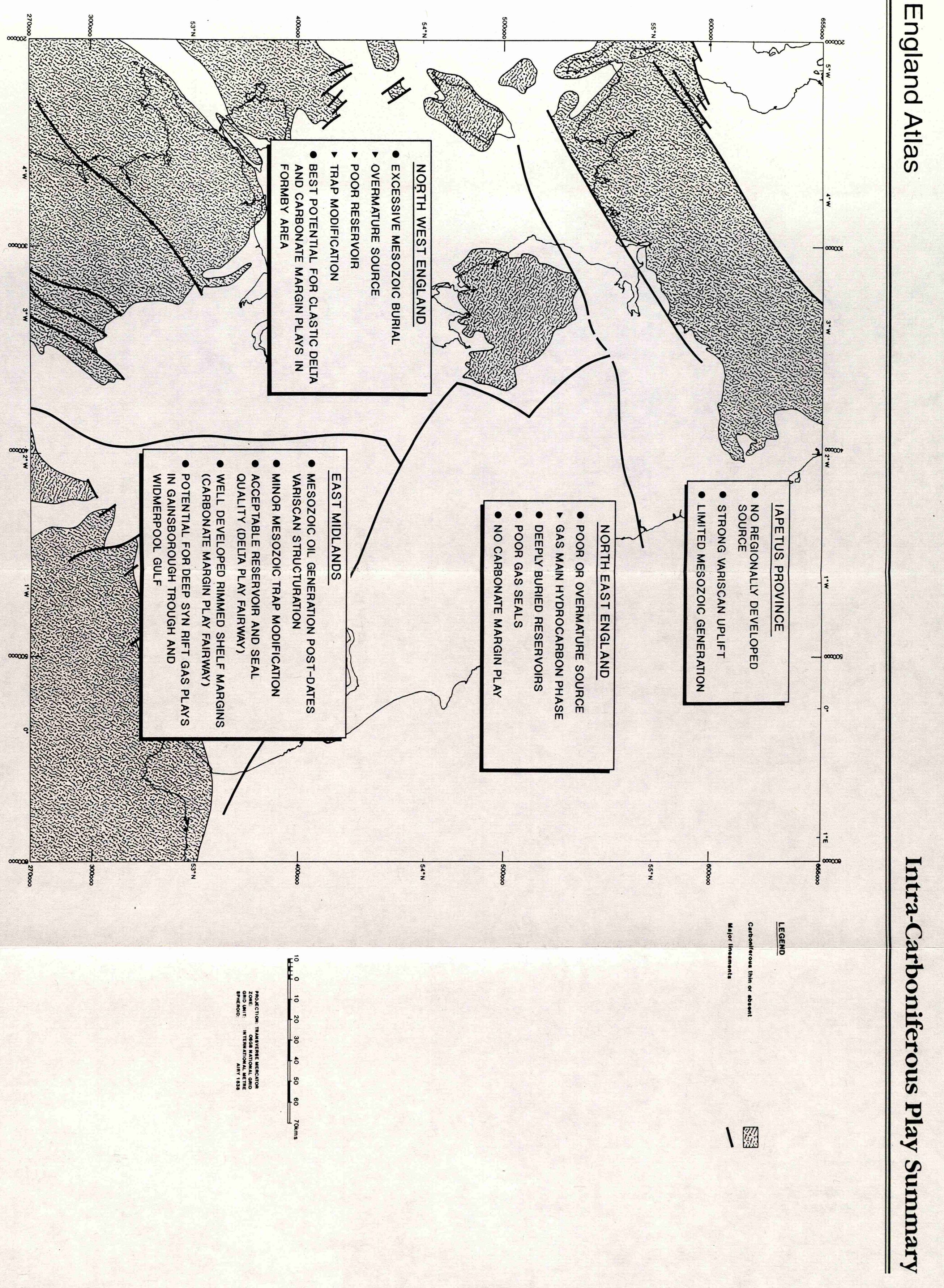


Appendix $\mathrm{H}$

Summarised well logs (1:10,000 scale) of key boreholes used in the regional seismic interpretation and palaeofacies mapping. 
SUMMARISED WELL LOG

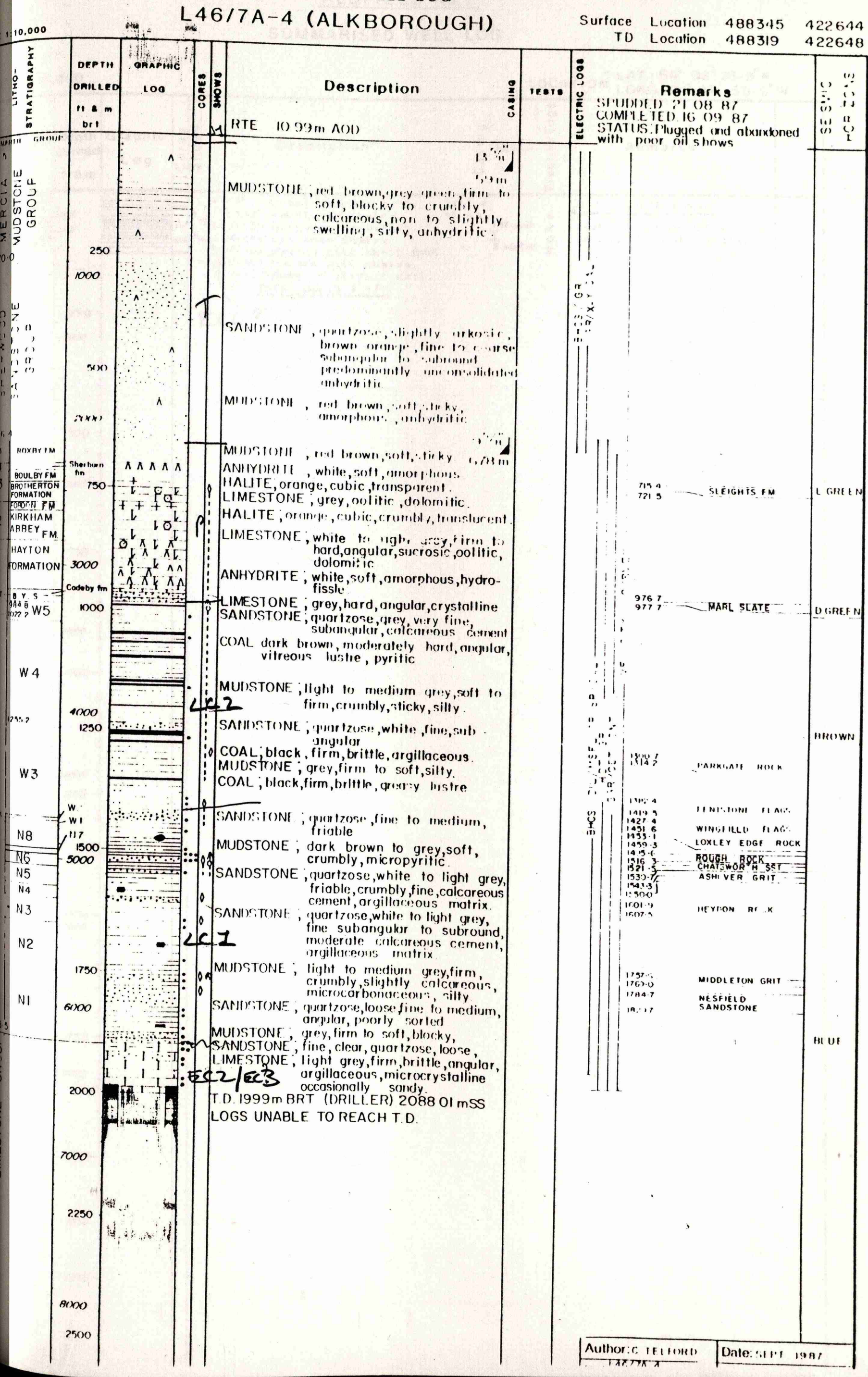


SUMMARISED WELL LOG

SCALE 1:10,000

LAT. : $54^{\circ} 06^{\prime} 28 \cdot 9^{\prime \prime} \mathrm{N}$

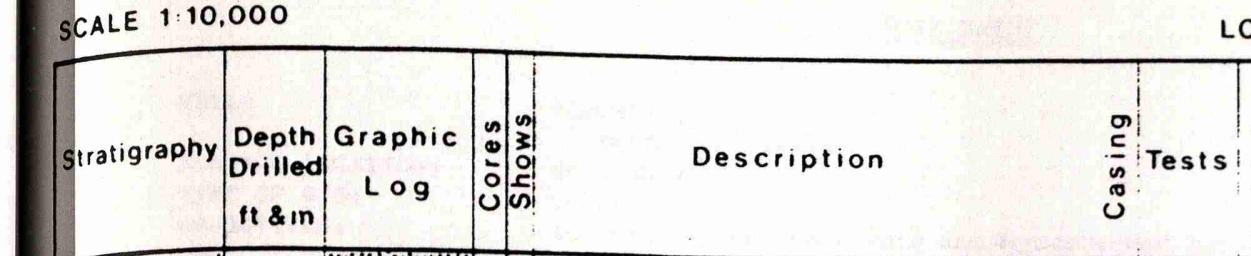

LOCATION LONG. : $01^{\circ} 37^{\prime} 55.6^{\prime \prime} \mathrm{W}$

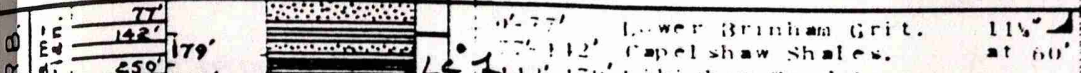

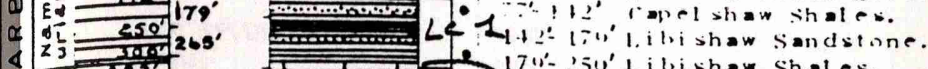

1

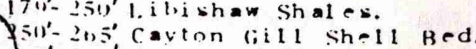

- Hos-300 ravion liill shales.

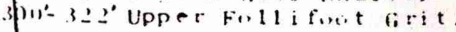

TUTAL. DEPTH +2" ft.

EC6?

$-1000$

500

$-2000$

$-$

$1000-$

F.

$-5000$

\begin{tabular}{l}
0 \\
0 \\
0 \\
0 \\
$\vdots$ \\
0 \\
$\frac{0}{\omega}$ \\
\hline
\end{tabular}

$I^{\text {Misrun }} \ddot{c}$

R.T.E. i, 25 ft. A. O. D.

Remarks 


\section{Edale Gulf}

DATA SHEET

WELL:

SURFACE LOCATION:

TYPE OF RIG

OBJECTIVES :

DATE SPUDDED:

DEPTH :

STATUS:

GEOLOGICAL DATA:

Chronostratigraphy

\section{O- CARBONIFERUUS}

Namurian

Kinderscoutian

SI

Alportian

Chokierian

Arnsbergian

Pendleian

Dinantian

- - - Brigantian

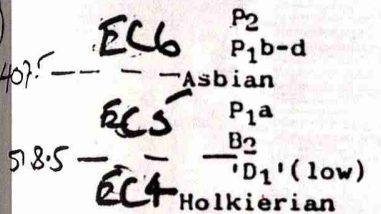

ALPORT-1,

North Derbyshire

SK 13609105

Cable Tool

CONTRACTOR:

OPERATOR:

RTE:

To evaluate the reservoir and hydrocarbon potential of the Dina Alport Anticline.

1939

$778.8 \mathrm{~m}$. brt. (2555 ft.)

$493.8 \mathrm{~m} . \mathrm{ss}$.

DATE COMPLETED:

1941

Plugged and Abandoned.

Tops

\begin{tabular}{cr} 
m.brt. & m.ss. \\
\cline { 2 - 2 } Surface & +283.5 \\
Surface & +283.5 \\
Surface & +283.5 \\
33.5 & +251.5 \\
42.4 & +242.6 \\
62.8 & +222.2 \\
145.1 & +139.9 \\
335.0 & 50.0 \\
335.0 & 50.0 \\
335.0 & 50.0 \\
364.5 & 79.5 \\
407.5 & 122.5 \\
1.07 .5 & 122.5 \\
454.2 & 169.2 \\
518.5 & 233.5 \\
617.8 & 332.8
\end{tabular}

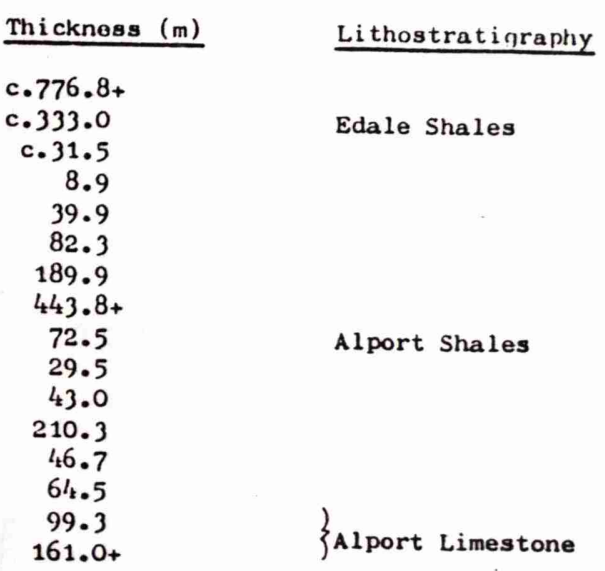

COREs: Continuously cored from 10m.brt. to T.D. Extensive collection curated at IGS Leeds.

SHOWS: $\quad$ Not known.

TESTS: None.

CORMENTS :

BP offered farmin on this well, but refused because of uncertainity of structural closure at depth and lack of shows in Asbian and older limestones at Gunhill-1.

'Basinal' facies in Brigantian and upper Asbian overlies massive shelf carbonates. Namurian characterised by very thick 'basinal' Pendleian (the gamma-active shale unit) which appears to be a good regional source rock.

Well located where 'Edale Gulf' merges with Craven or Bowland Trough.

REPORT REFERENCES:

Hudson, R.G.S, \& Cotton, G. 1943. Proc. Yorks. Geol. Soc., 25, 142-173.

Hudson, R.G.S, \& Cotton, G. 1945. Proc. Yorks. Geol. Soc., 25, 254-330.

Stevenson, I.P. \& Gaunt, G.D. 1971. Mem. Geol. Surv. G.B. Sheet 99. 


\section{SUMMARISED WELL LOG}

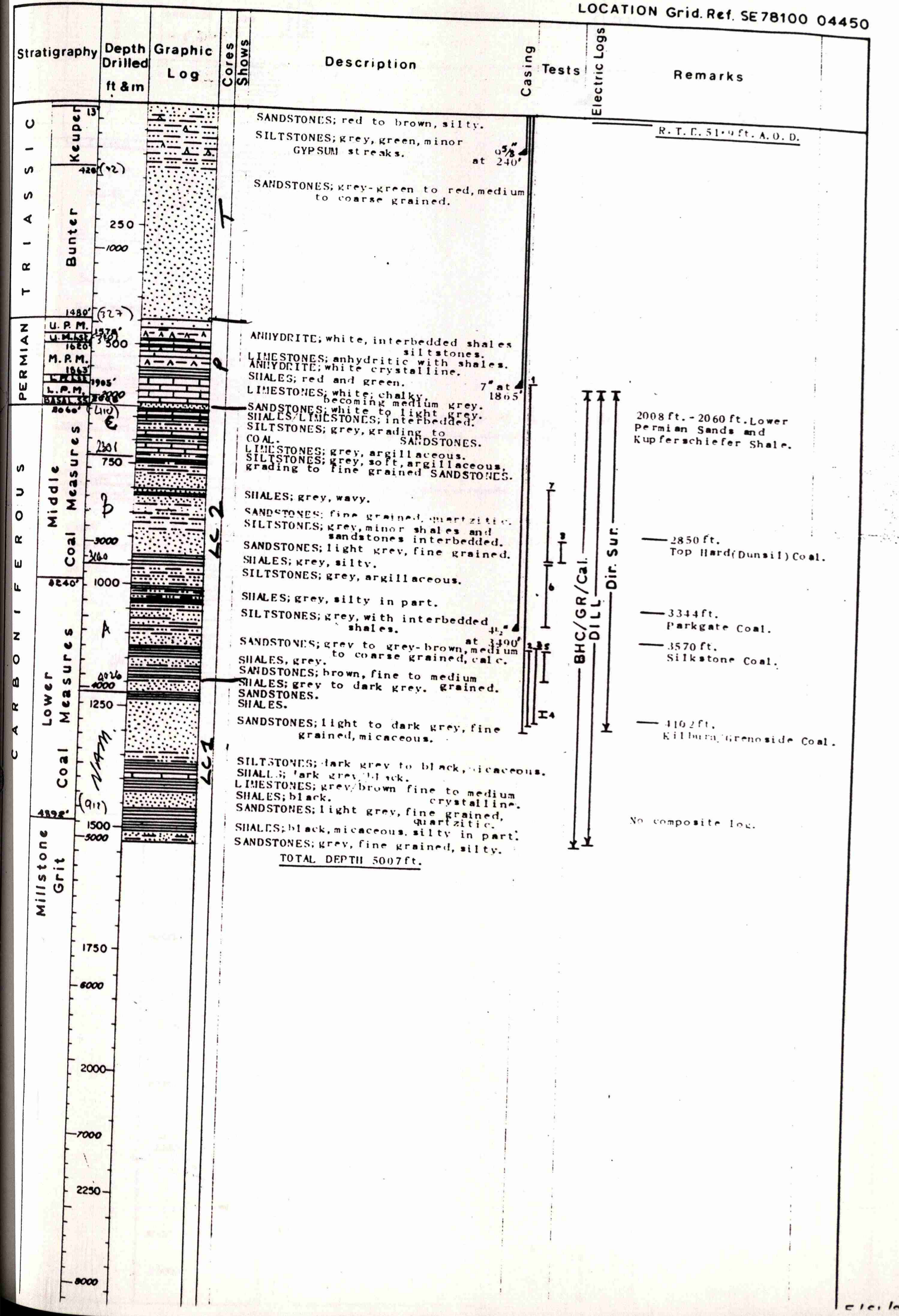


SUMMARISED WELL LOG

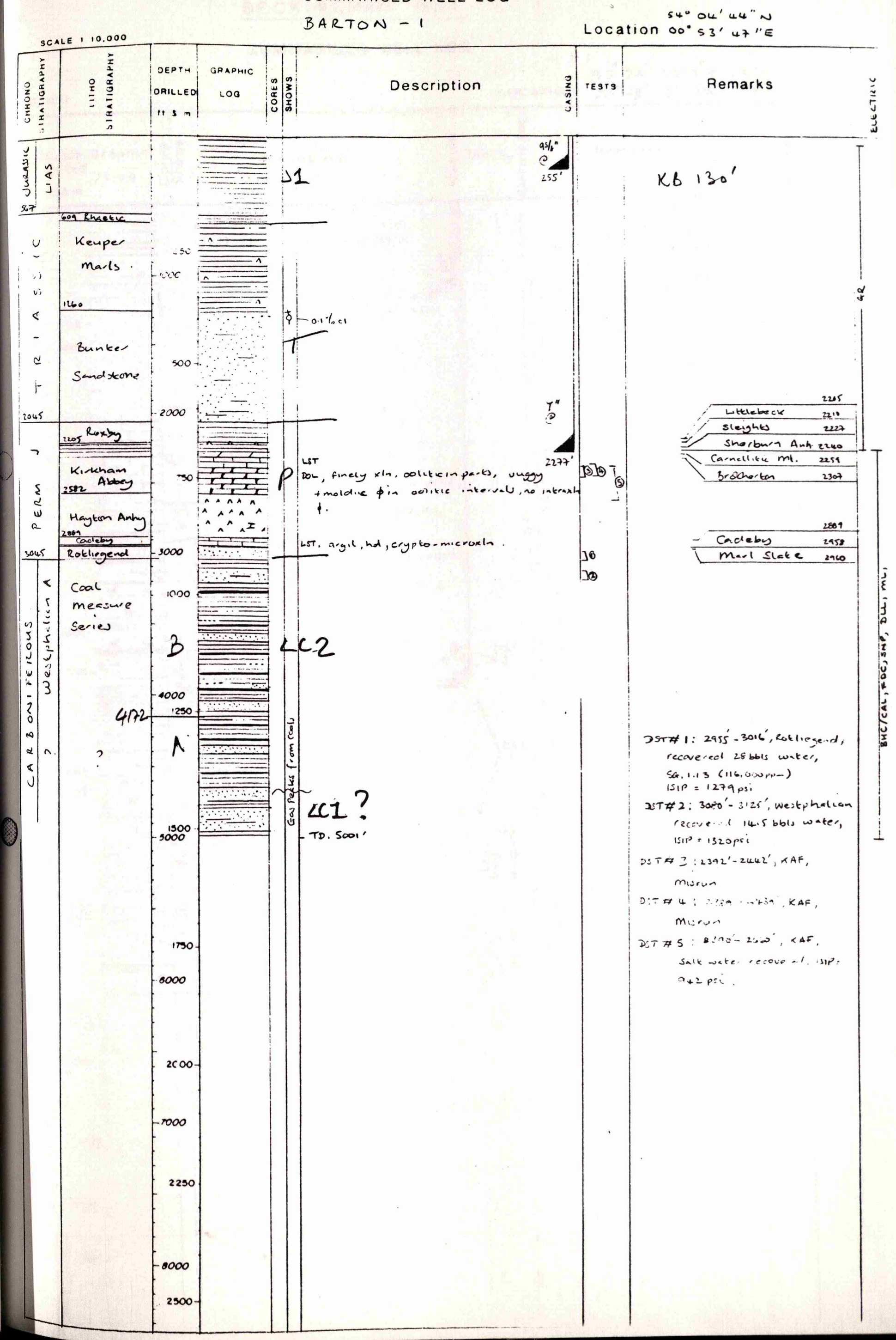


SUMMARISED WELL LOG

To'd 1945

UK LAND

SCALE 1: 10,000

LAT. : $53^{\circ} 34^{\circ} 1^{\circ} \mathrm{N}$. LOCATION LONG. : $00^{\circ} 49^{\prime} 34^{\circ} \mathrm{W}$

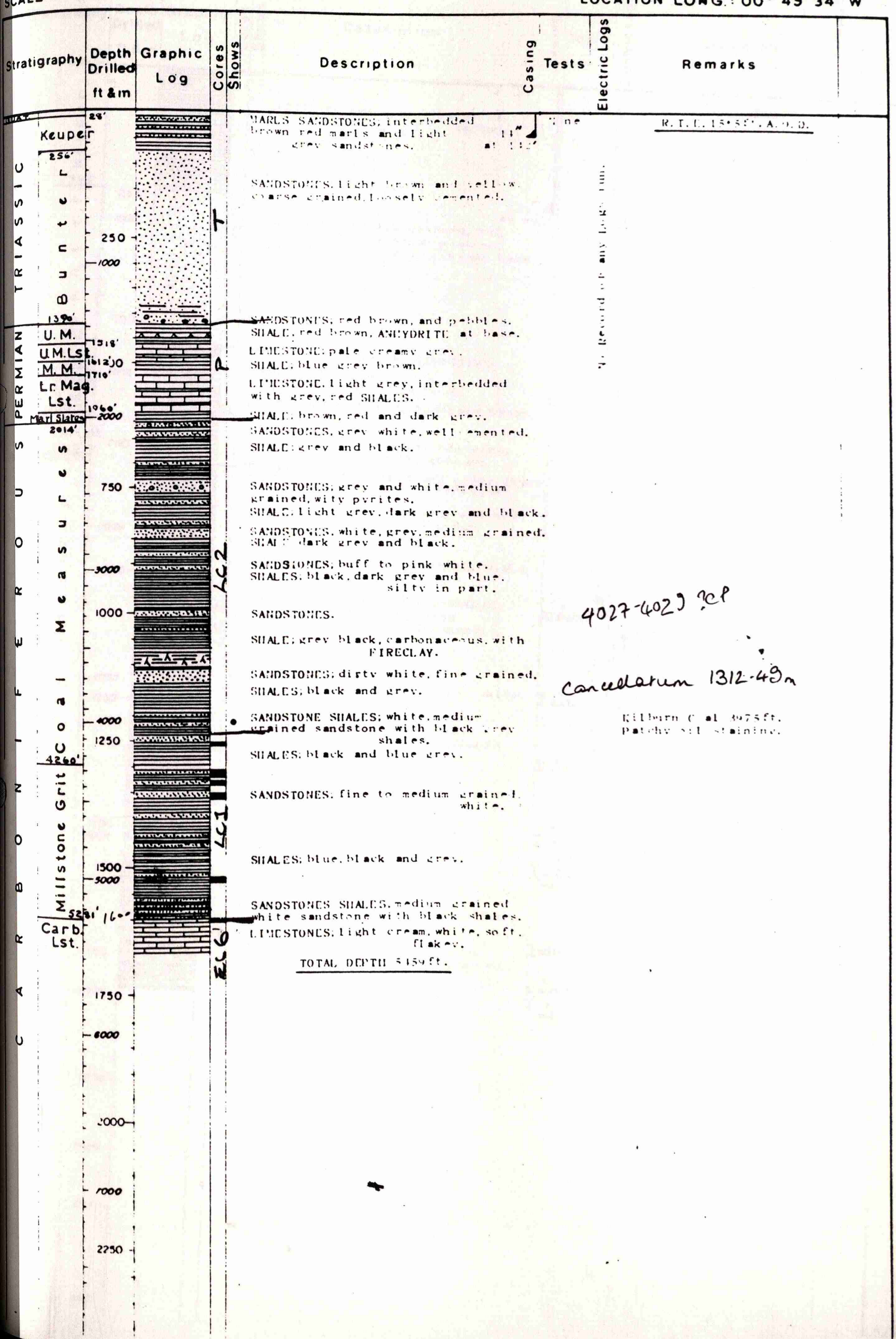




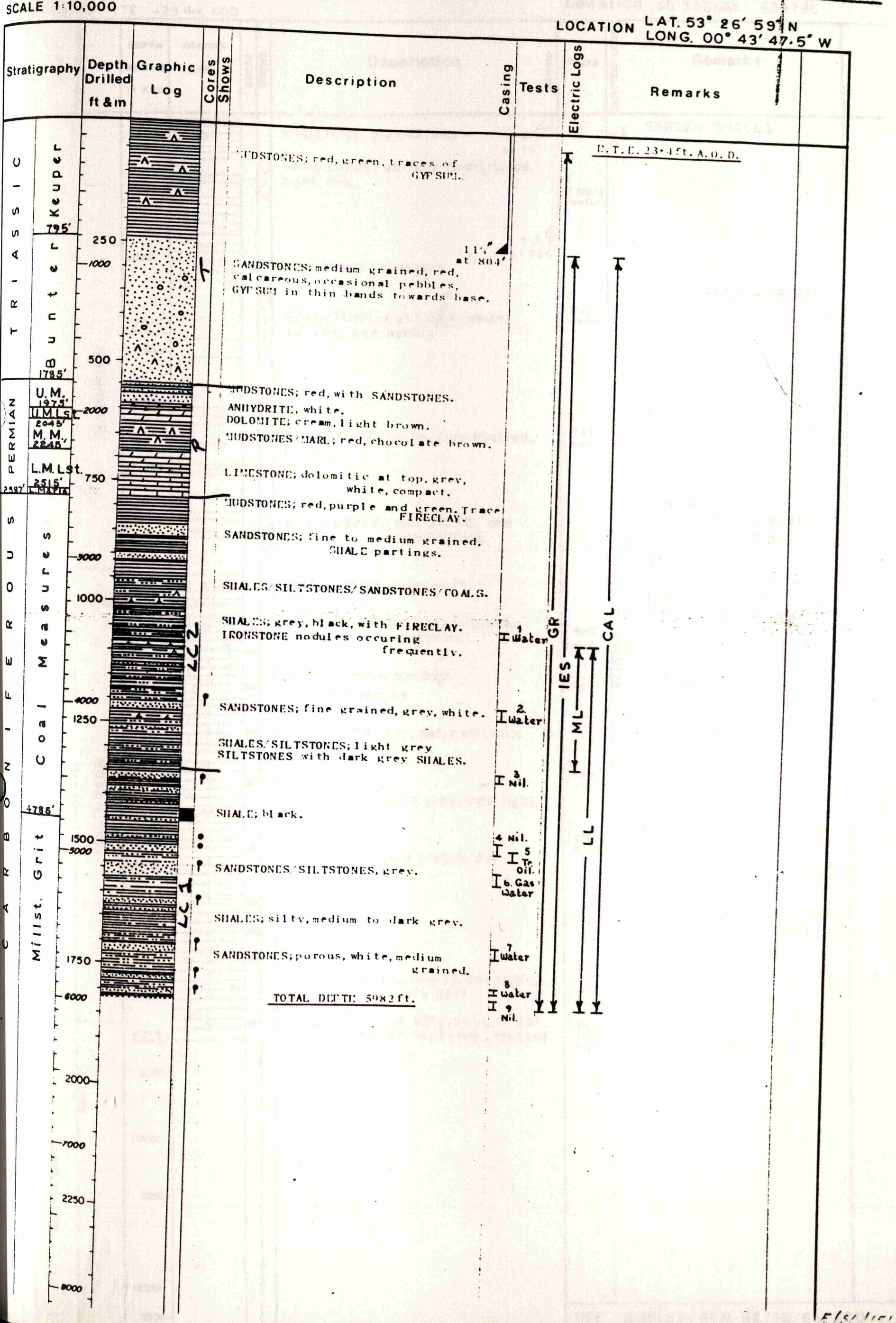


Laneashire stey OCALE $1: 10.000$ F.TE $+294 \mathrm{~m} \angle C D$

Location SO 392685

434790

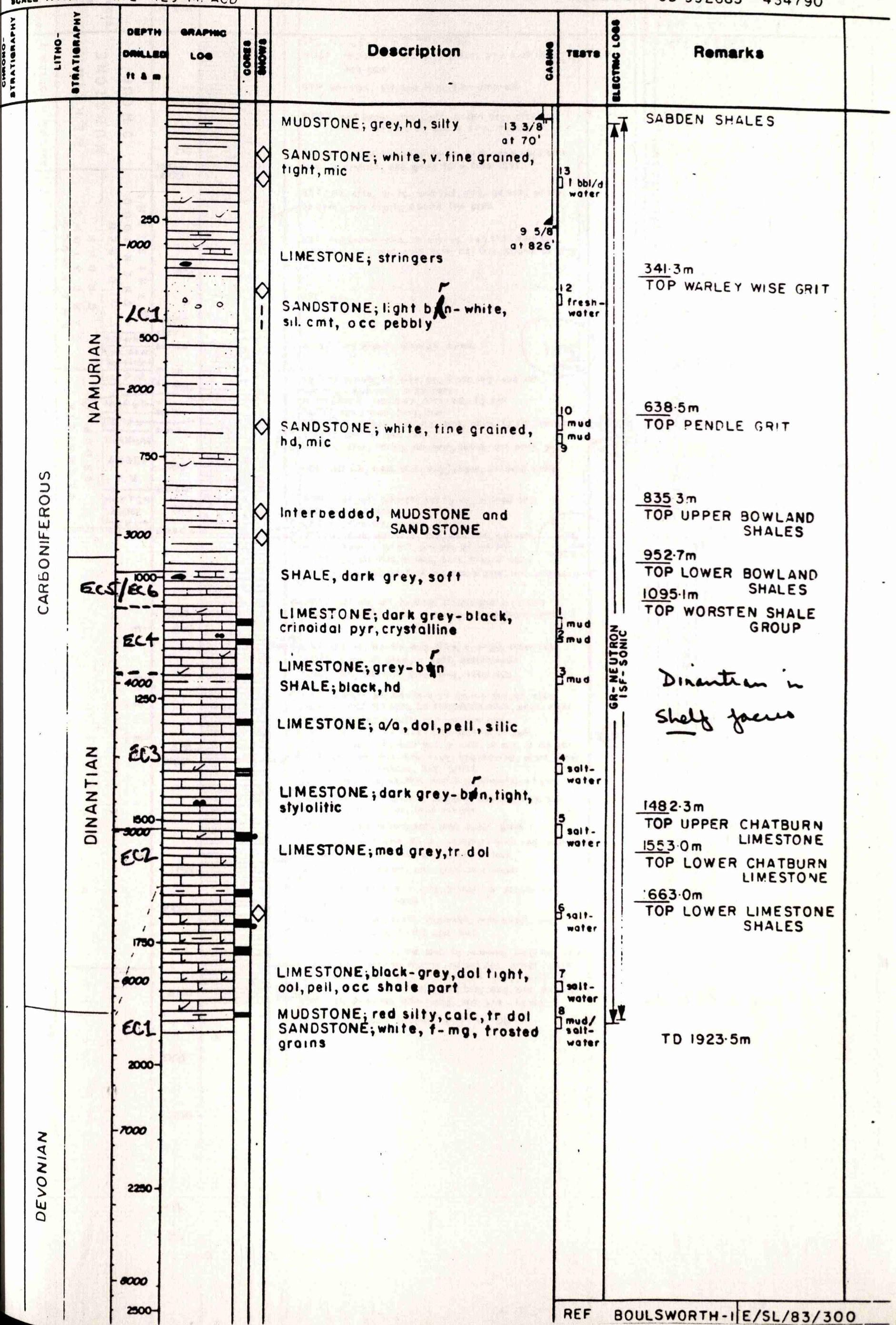




\section{BROOMFLEET}

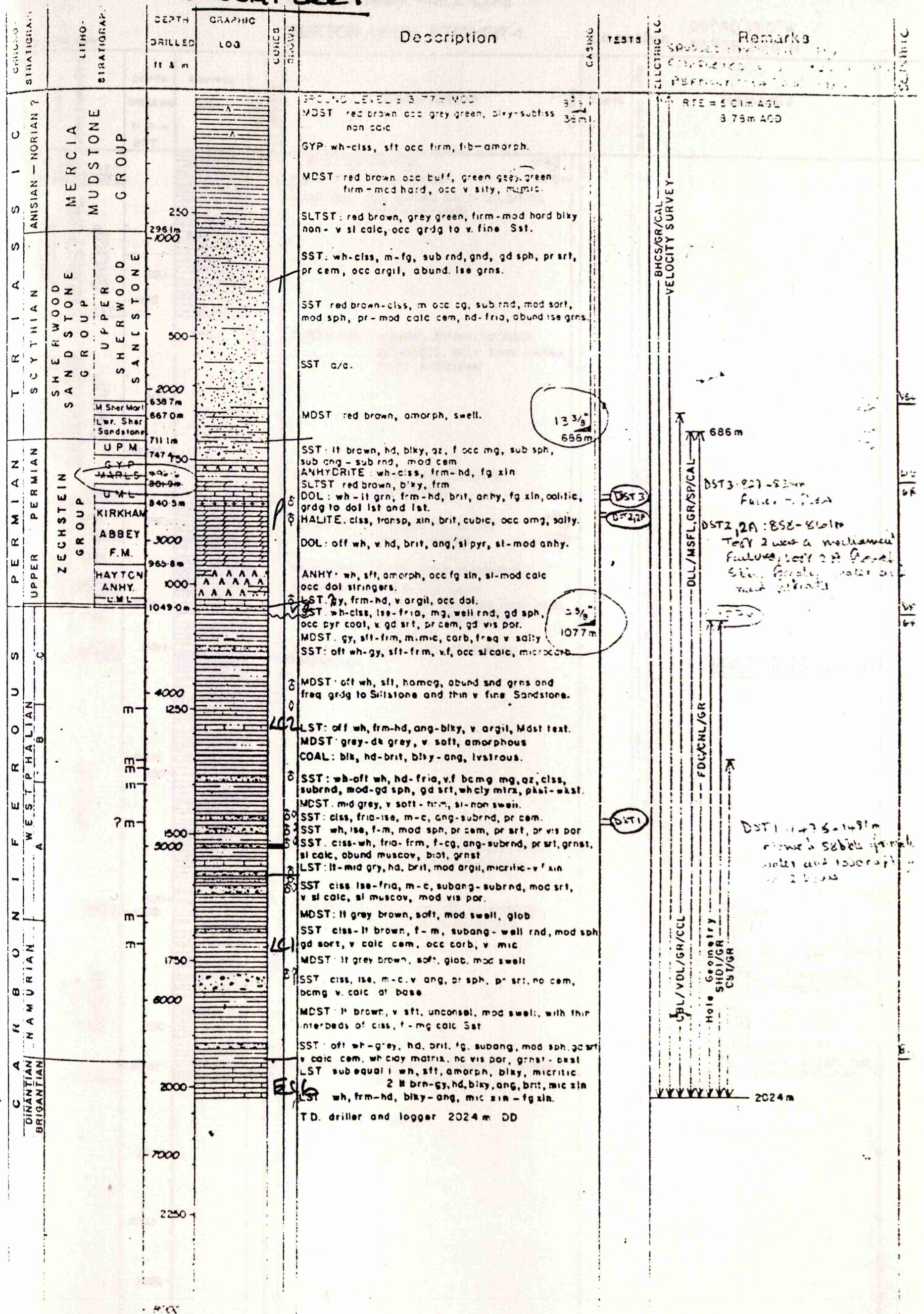


SUMmMAFSEO WELL LOO

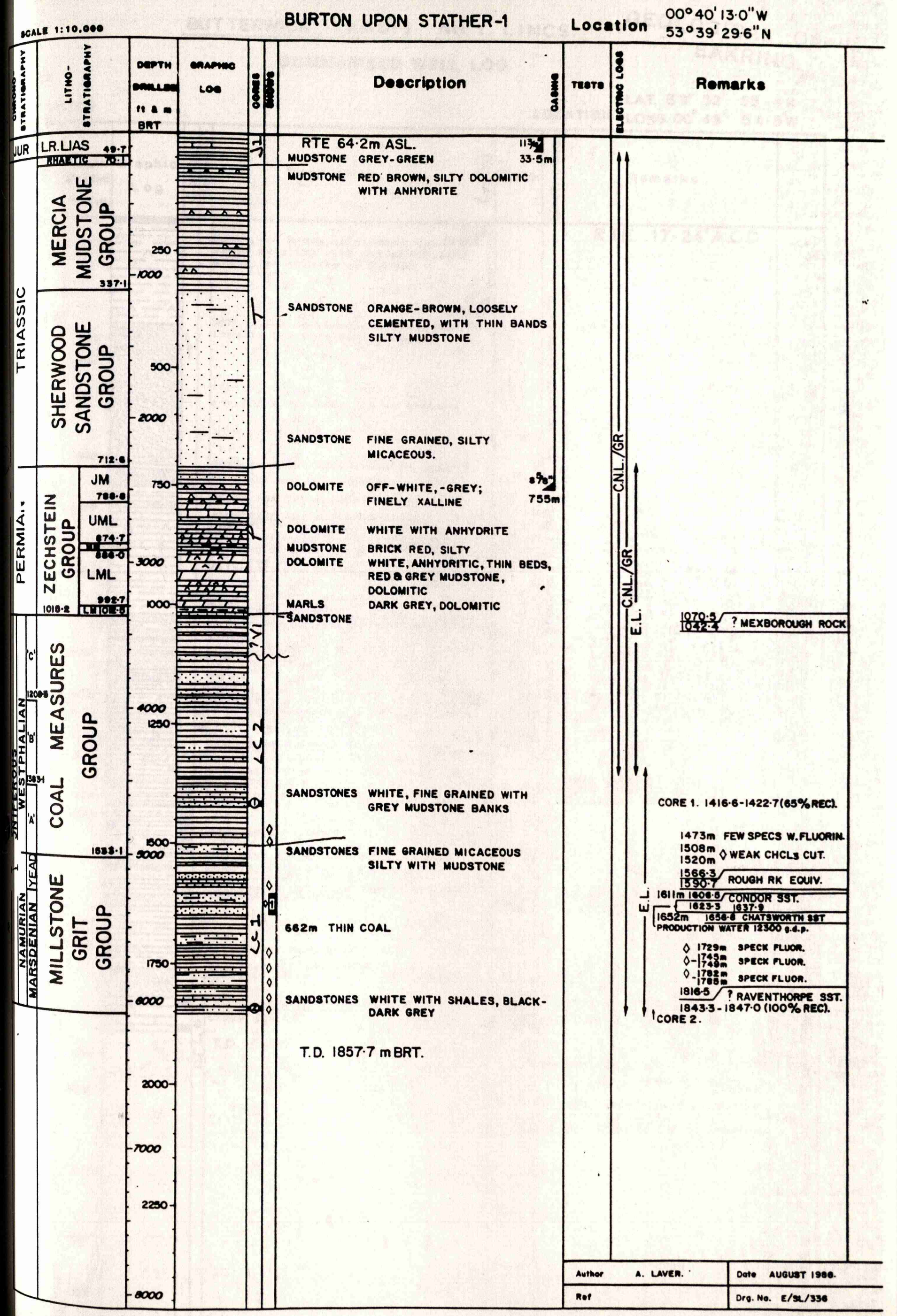


BUTTERWICK (EAST) NO 1. LINCS.

SUMMARISED WELL LOG

C. LAND

LLE $1: 10,000$

LAT. $53^{\circ} 32^{\prime} 25,3^{\circ}$

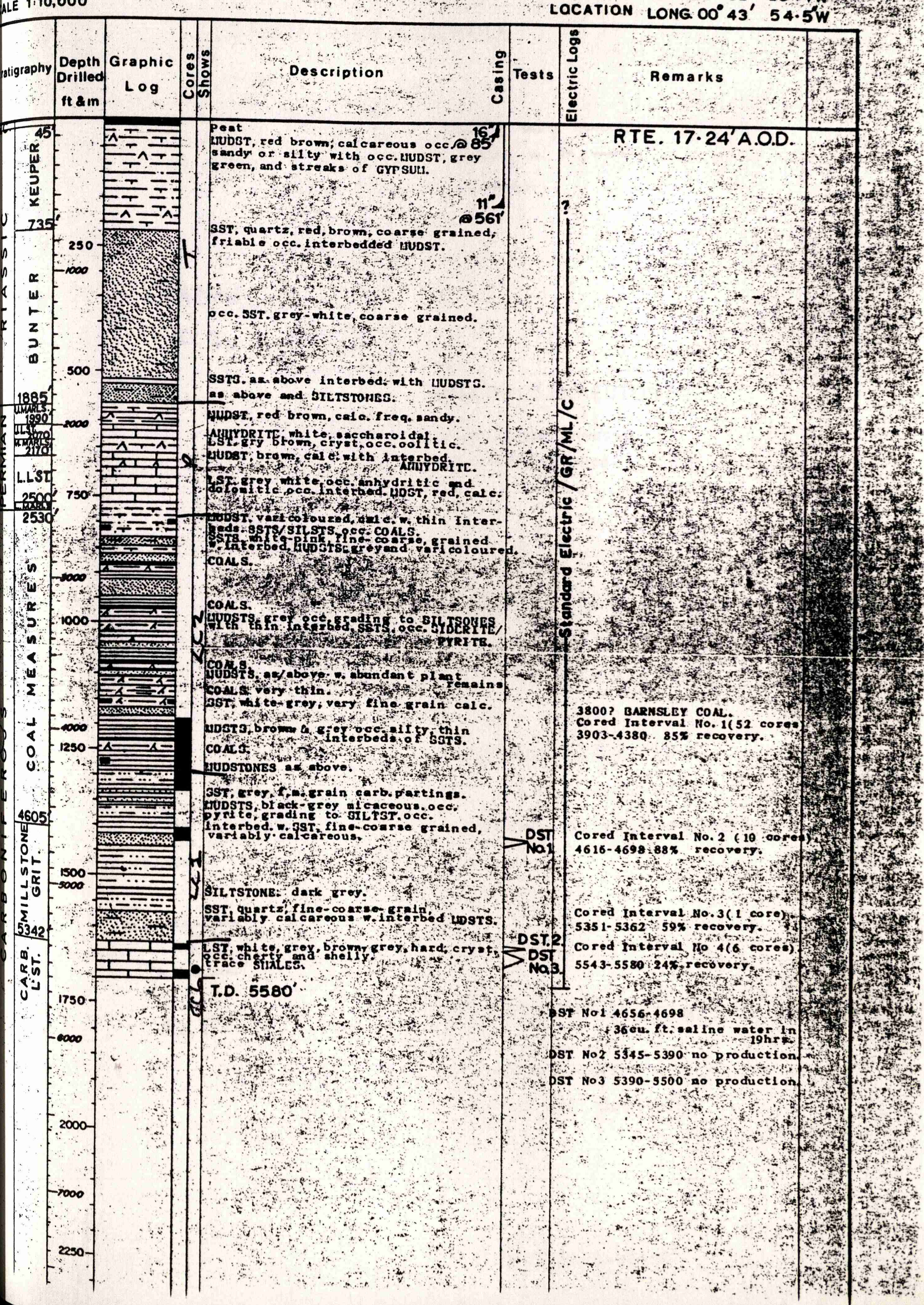




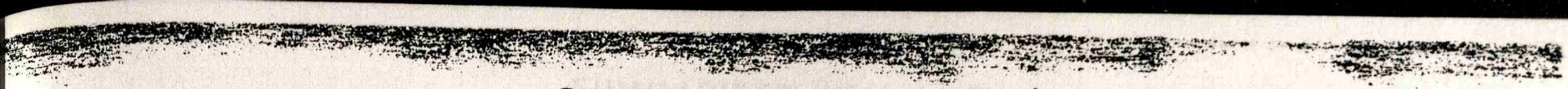

$\beta p$.

1957

CALOW NO. 1.

Eart Midlands Shely

SUMMARISED WELL LOG

ALE 110.000

LOCATION LAT.: $53^{\circ} 13^{\prime} 44^{\circ} \mathrm{N}$

LON G. : $09^{\circ} 23^{\circ} 17^{\prime \prime} \mathrm{W}$

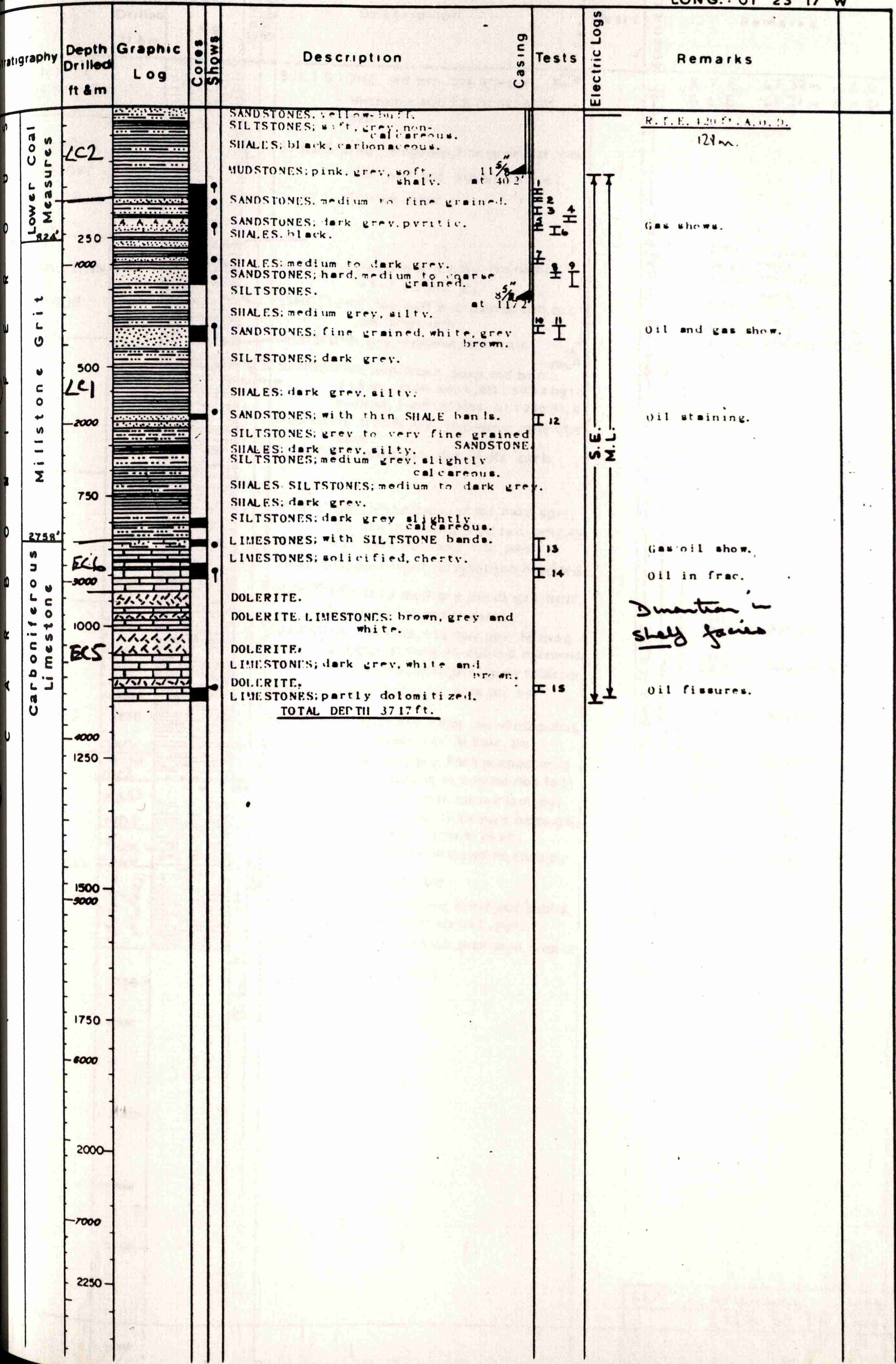




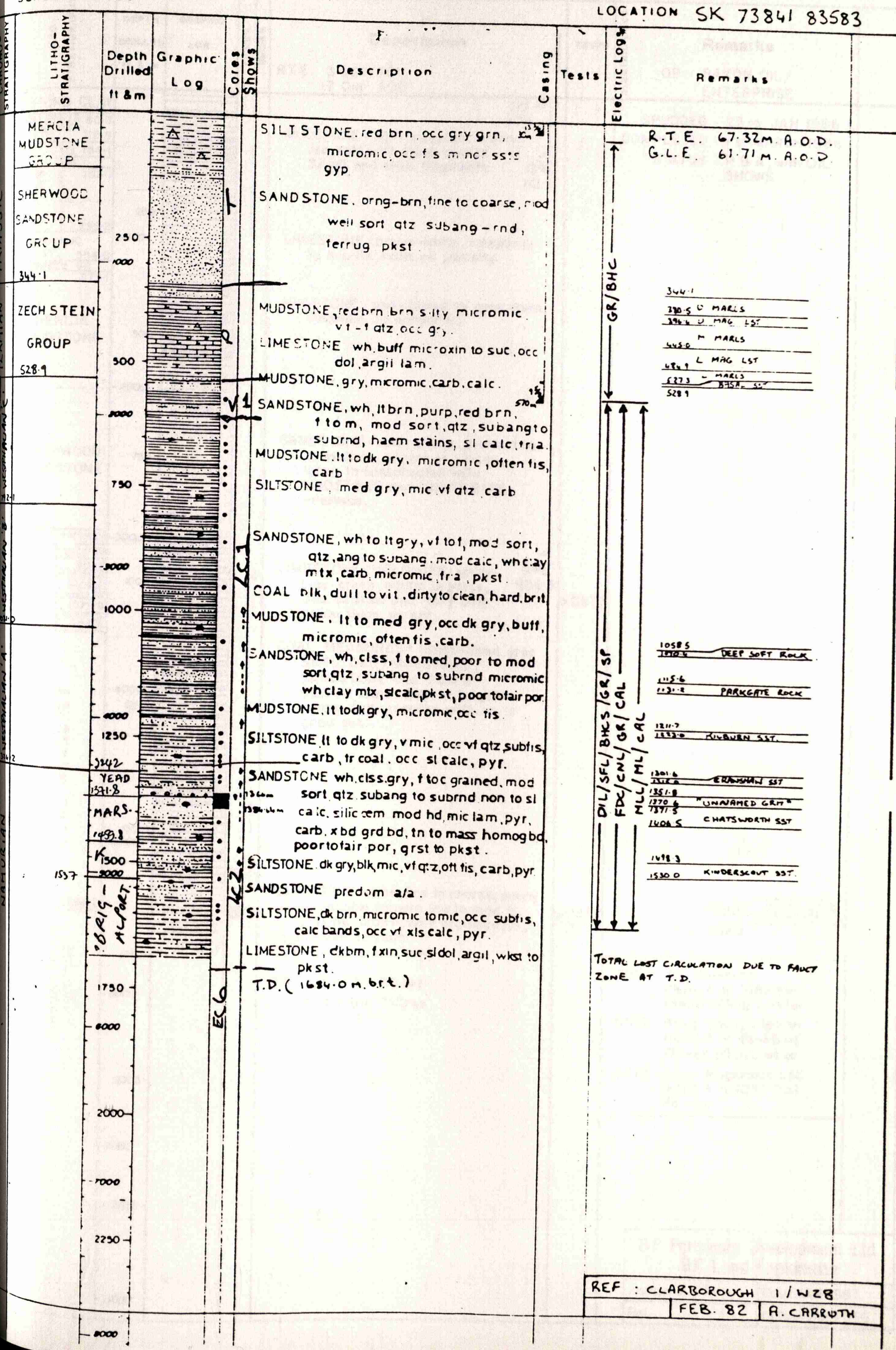


COLD HANWORTH-I Location 505391

382955

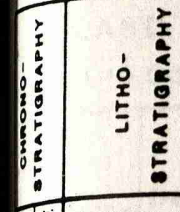

XOTFORD CLAY T XELLAWAYS 60.3

250 $-1000$ \begin{tabular}{l} 
Bh PENARTH GP. \\
\hline 2
\end{tabular}

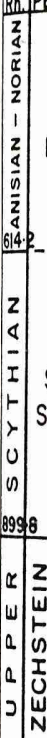

MERCIA MUDSTONE

HERWOOD SANDSTONE
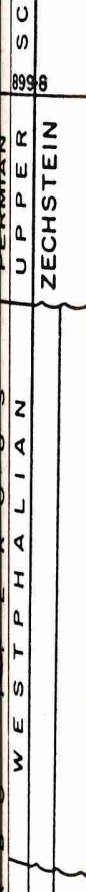

U.MARIST-3000

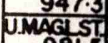

98.5 M.Th 1028. IMGLS

1000

$0-$
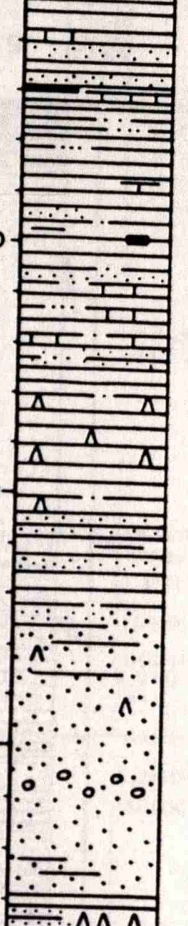

I

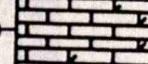

.
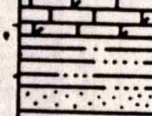

$\ldots \cdots$

$\underset{w}{w}$

1250

$\ldots$
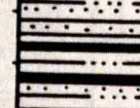

$\Sigma$

बे

u

100

लricis

$-6000$
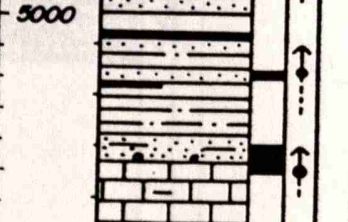

SANDSTONE : white, fine to coorse, poorly sorted, voriable cement, low to mod $\varnothing$.

LIMESTONE: brown, very orgilloceous,

hard, brown oil stain

TUFF : light green, hard

TD : $1764 \cdot 2 \mathrm{~m} \mathrm{DD} \mathrm{brt}$

$1745 \cdot 9 \mathrm{~m}$ TVDss

IMESTONE : brown -white, biosparite

ANDSTONE : pink, oronge, brown, fine loose to , pebbly in ploces,

MUDSTONE and ANHYDRITE occ. oil stain and very pole yellow fluor, no cut.

COAL MEASURES : Interbedded grey SILTSTONE/MUDSTONE,

SANDSTONE and COALS

ce. oll stoin, dull to bright good cut.

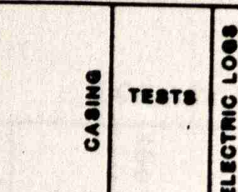

8
0
0
$\frac{8}{6}$
0

OP : SAXON OIL/ ENTERPRISE

SPUDDED : 23 rd JAN 1986 COMPLETED : I st MARCH 1986

STATUS : $P$ \& A, with OIL SHOWS.

MUDSTONE : red-brown to grey green,

IMESTONE/DOLOMITE: white- $95 / 8$ " grey-green, oolitic in ports, . 934.5

DSTI : Top Dinantion (1664.8 to $1689.8 \mathrm{~m}$ ) Flowed 179 bpd water

DST2 : Basal Sand, Silesion (1639.8 to $1664.8 \mathrm{~m})$ Flowed 95 bpd water

DST3 : Lower Mognesion Lst. (1025.9 to $1057.0 \mathrm{~m})$ No flow

B P Petroleum Development Ltd. UK Land Exploration 
CROWLE NO. 1.

SUMMARISED WELL LOG

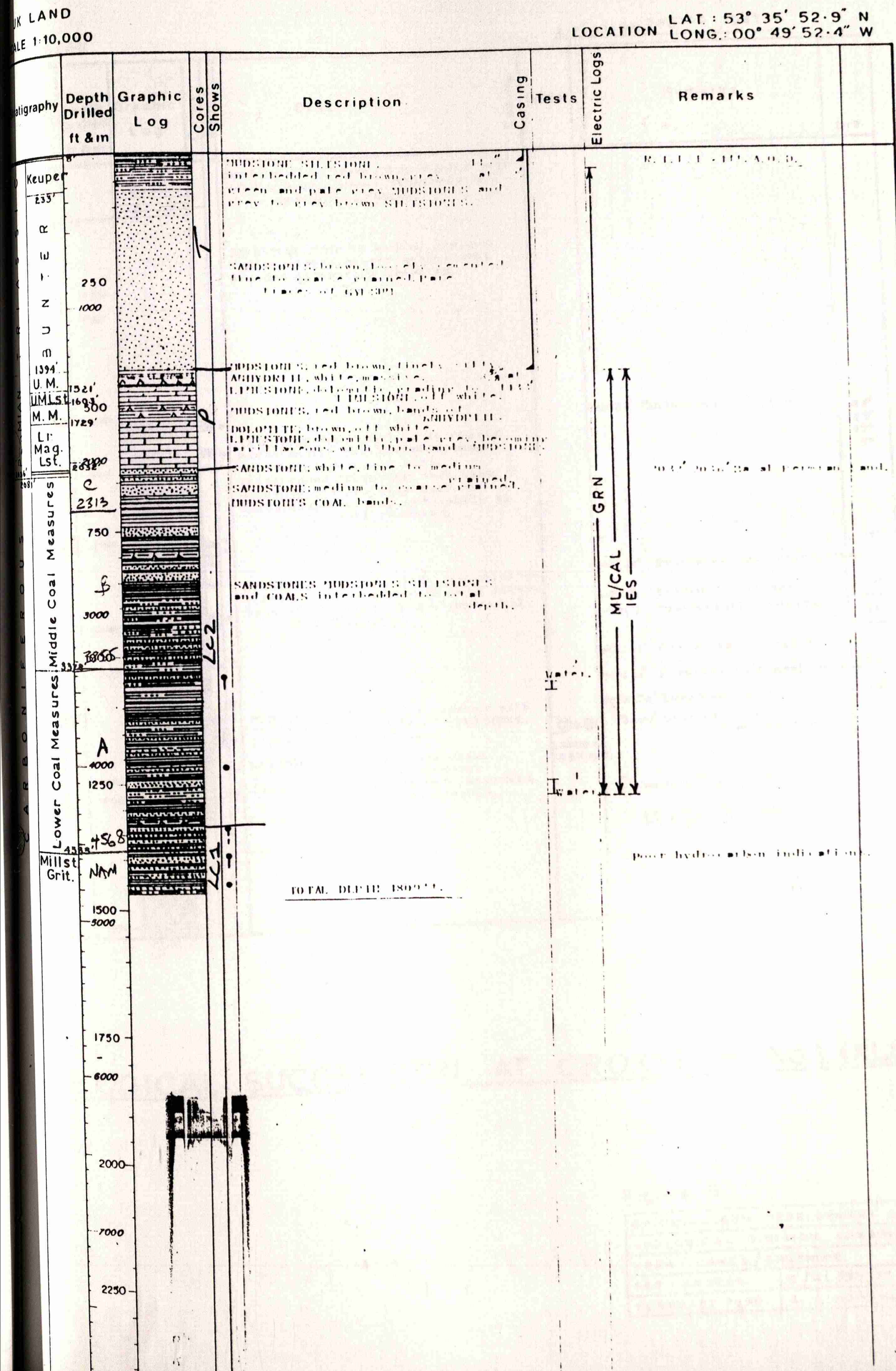


LAND PL 179

KLAND 10000

LOCATION TF 0085379195

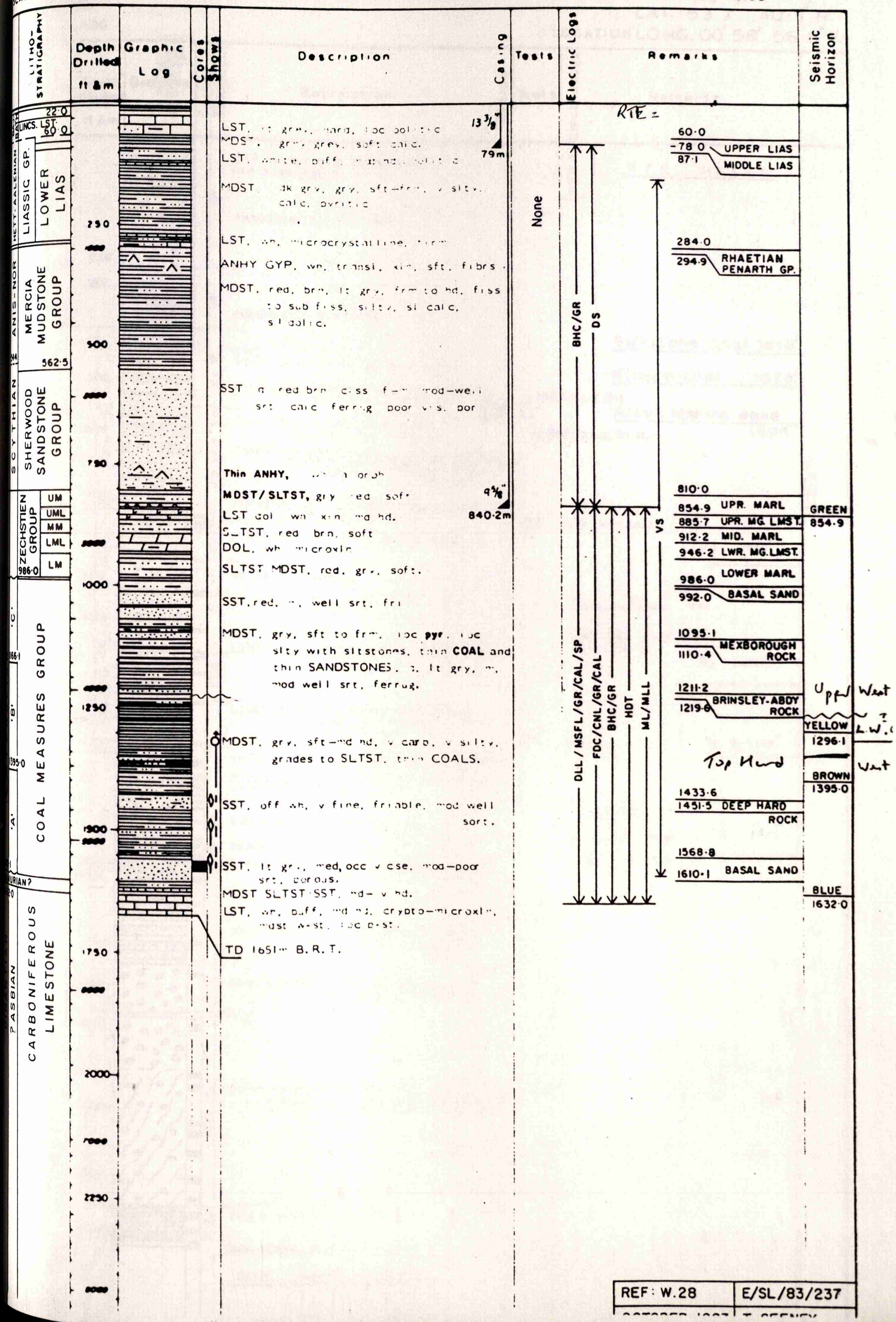


EAKRING To.T46. Eat Midland Shaf
EAT

K. LAND.

SUMMARISED WELL LOG

GALE $1: 10,000$

LAT. $53^{\circ} 7^{\prime} 40.5^{\prime \prime} \mathrm{N}$ \begin{tabular}{l|l}
-1 & at
\end{tabular}

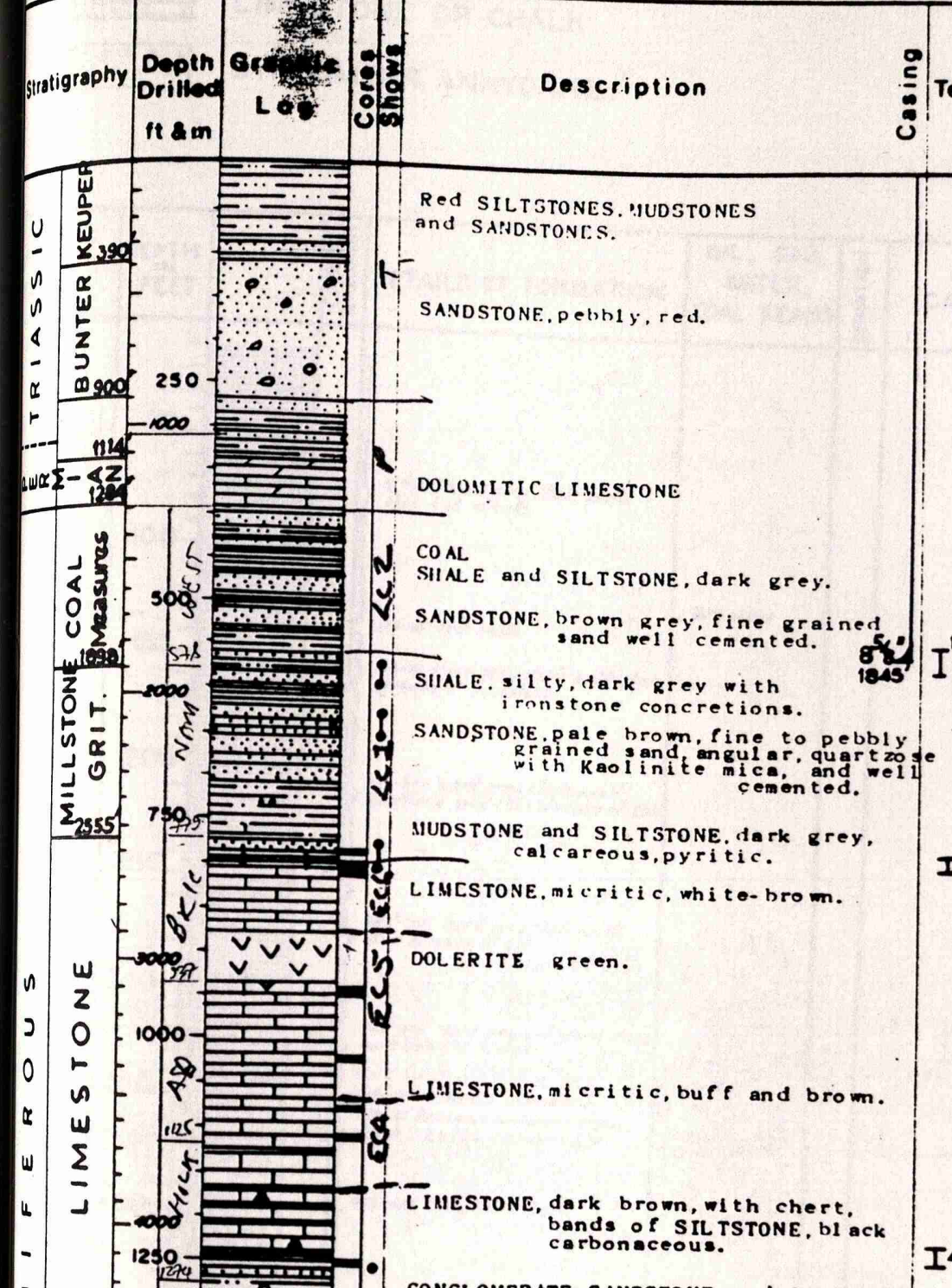

2
0
0
8

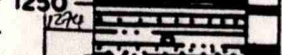

CONGLOMERATE, SANDSTONE and SILTSTOND

Silkst one Coal 1418

Kilburn Coal 1634

1600gpd.0il.

IT Alton Marine Band

2 9poogpd. to. Nil.

1895

I3. $0 \mathrm{IC}$ and sud.

D $2880^{\prime}$

Dunantrow in

stidi greis

D $3690^{\prime}$

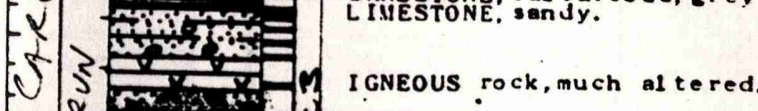

CONGLOMERATE And BRECCIA, red.

LINESTONE, light grey to dark brom ith parts sandy grading to

SILTSTONE Und SANDSTONE cal careous red and green, pebbly.

: FATCR

$s_{1} s_{2} 4180^{\prime}$

Dumantin -

basmal. syn c2 4843'

mit jacues.

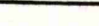

$\rightarrow 0$

sing

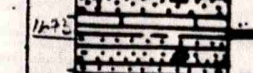

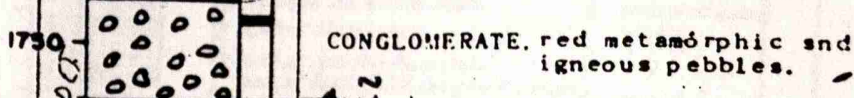

-

$3-\frac{1}{2}-101010$

$\begin{array}{ll}3 & \\ \vdots & 0 \\ 3 & 4 \\ 0 & \alpha \\ 3 & 0 \\ 4 & 0 \\ 0 & 0 \\ 1 & 0\end{array}$

CONGLONERATE and BRECCIA.

pebbles of quartzite, 1 mestone
metamo rphic and igneous rockc

steeply

dipping below

6300 leet"

F. E. KENT.

1967 


\section{SAND.}

$\because \because \because$ CONGLOMERATE.

SHALE OR CLAY.

\section{IIMESTONE OR CHALK}

"Y. GYPSUM OR ANHYDRITE.
COAL SEAMS

CHERT Edale - 1

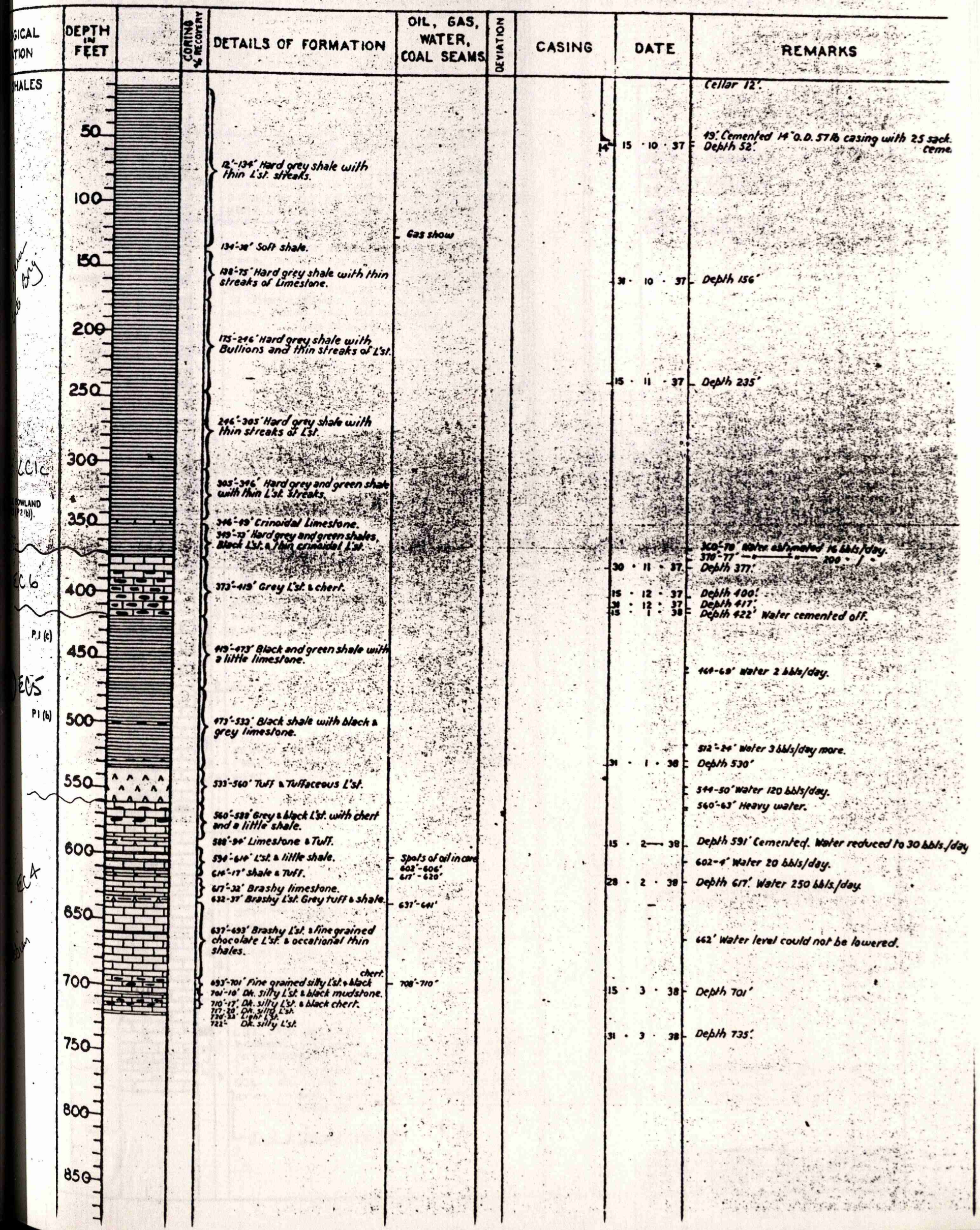


SUMMARISED WELL LOG

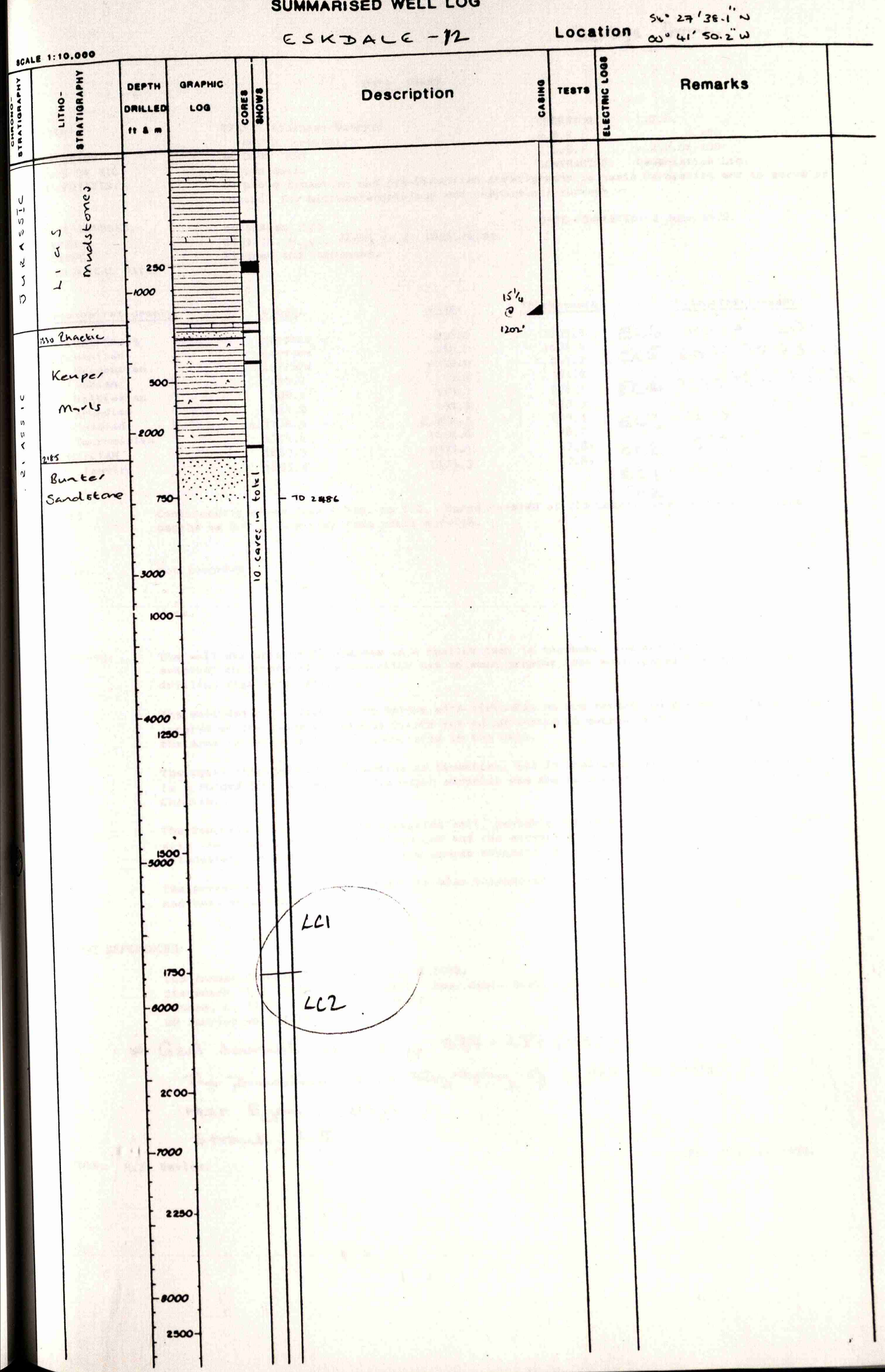




\section{Derbys. Dome.}

DATA SHEET

WELL:

LOCATION :

TYPE OF RIG :

OBJECTIVES :

DATE SPUDDED

DEPTH:

STATL'S:

GEOLOLICAL DATA;
EYAM-1 (Furness Quarry)

North Derbyshire

SK. 20967603

3 rigs used.

September 1970

1851.1m. b.9.1. (6073 ft.) 1621.1m.ss.

Plugged and Abandoned. $\begin{array}{ll}\text { OPERATOR: } & \text { I.G.S. } \\ \text { R.T.E.: } & \text { m.AOD } \\ \text { G.L.E.: } & \text { c. } 230.0 \mathrm{~m} . A O D\end{array}$

G.L.E.:

Cementation Ltd.

raphy in North Derbyshire and to serve as DATE COMPLETED: 2 June 1972.

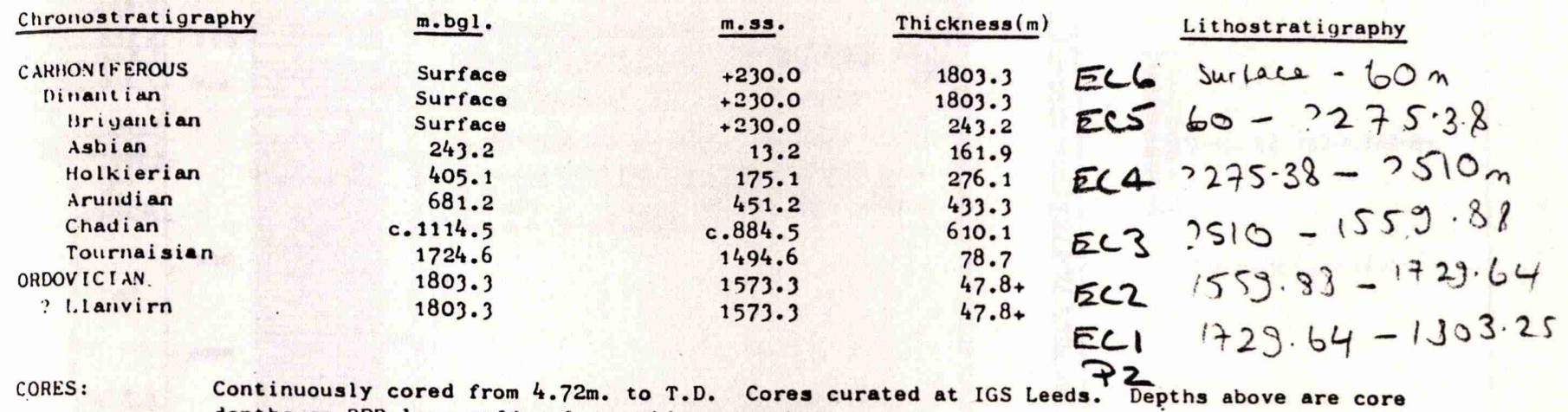
depths as BPB logs suffer from cable stretch.

SHOWS: Not recorded.

TESTS: None.

COMMENTS: The well was originally planned as a shallow test to basement, comparable to Woo Dale-1. The eventual thickness of the Dinantian was so much greater than anticipated that three different drilliliy rigs were used.

The well was cored from top to bottom with virtually no mud returns to surface. The well was located on the floor of Furness Quarry and an estimated 66 metres of Brigantian is known in the area in addition to that penetrated in the well.

The total thickness of 1869 metres of Dinantian, all in shallow water shelf carbonate facies, is record for the region. The major surprise was the extreme thickness of the Arundian and Chadian.

The Tournaisian is a thin transgressive unit, probably entirely Ivorian in age, and contrasts with the clastic sequence at Caldon Low and the anhydrites of Hathern-1 to the south. The extensively carbonised nature of the spores suggests the basal Dinantian is overmature.

The presence of Ordovician shales was also unexpected, as either Pre-Cambrian or Devonian had been expected.

REPORT REFERENCES:

IGS Annual Report for 1970, 1971, \& 1972.

Stevenson, I.P. \& Gaunt, G.D. 1971. Mem. Geol. Surv. G.B., sheet 99.

Dunham, K. 1973. Nature, 241, 84-85.

BP Eakring well file.

Geal Sournal Vol 20 if 227-237 (1885)

The Dinantian biostratigraphy of a deup borehole

near Eyam, Derbys.

Stronk, A.E.

AUTHOR: M.J. Davies.

DATE: October 1982 


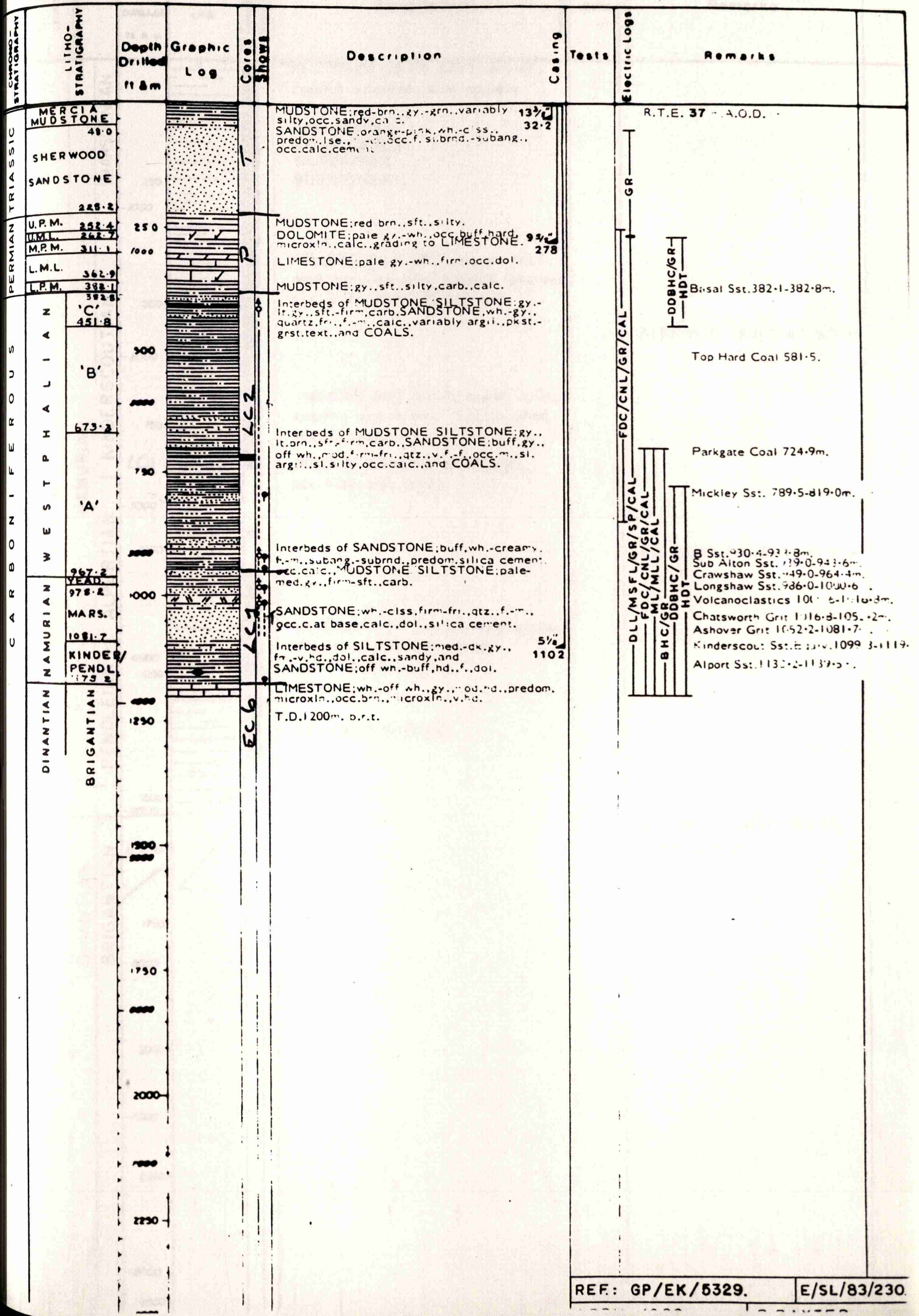


SUMMARISED WELL LOQ

FLETCHER-BANK-I
Bowland Basin

Location SD 806162 opprox

RTE $244 \mathrm{~m} \triangle O O$
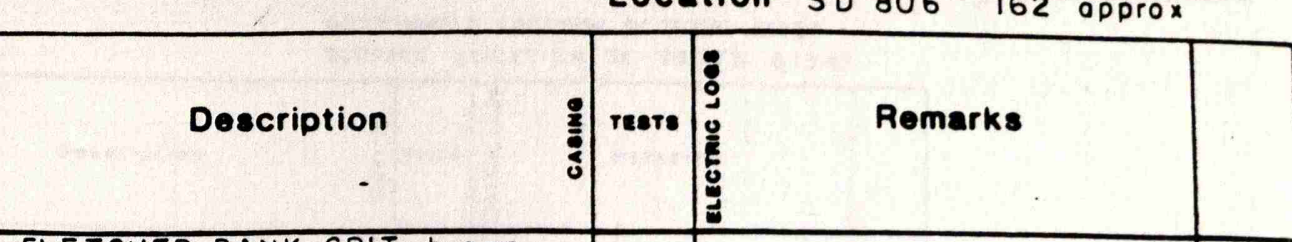

FLETCHER BANK GRIT; brow
coarse grained, OCC pebbly

Interbedded

SANDSTONES

SILTSTONES

MUDSTONES

KINJERSCOUT GRIT; UPDER unit, med graned oCC. coorse grained OCC. Silty, MUOSTONE part

POSSIBLE FAULT AT $576 \mathrm{~m}$

INOERSCOUT GRIT, lower unit, coorse groin occ. med.grained mass, hard

SABDEN SHALES; black, pyr, occ. fiss, occ. silty

PENDLE GRIT; grey, med.grained, mic, occ. silic cmt, hord, OCC SHALE port

NO SAMPLES $987-: 042 \mathrm{~m}$

BOWLAND SHALES

VO SAMPLES $1411 \mathrm{~m}-T .0$ T.D. $-1676 \mathrm{~m}$ 
$B P$

PL 178

U.K. LAND

SCALE 10.000$$
\begin{array}{|}
\hline s \\
\hline \\
\hline
\end{array}
$$

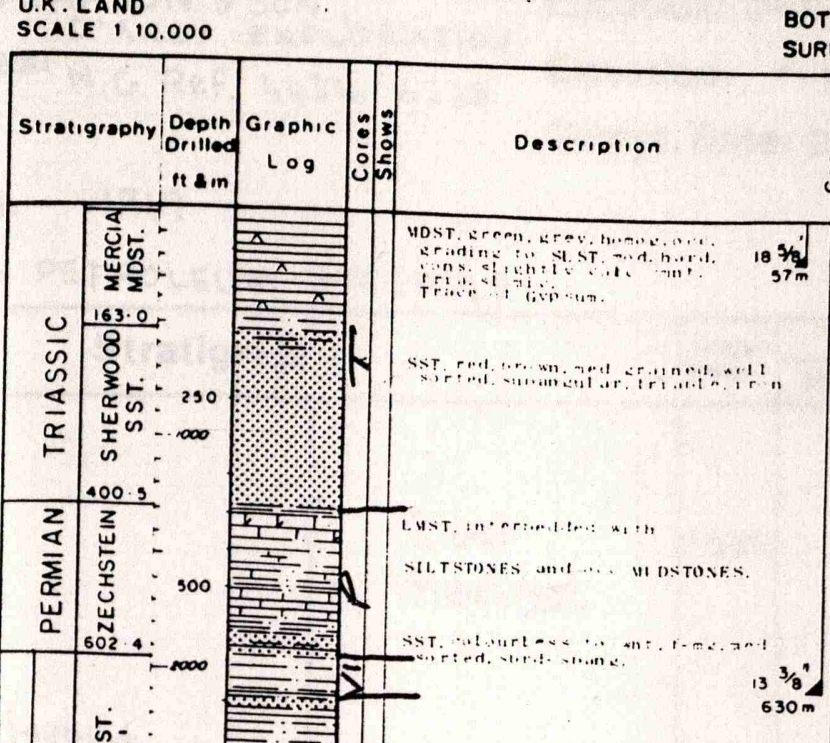

a) 点:

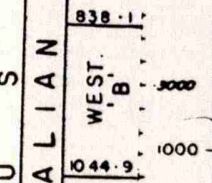

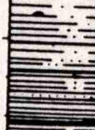

$>\varangle$

$00 \begin{gathered}x \\ a \\ 1 \\ o n \\ w\end{gathered}$

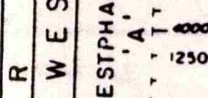

$4 \int_{4}^{2}$ $\stackrel{\omega}{3}:$ $1379.0 .0 .1361 .2 \ldots$
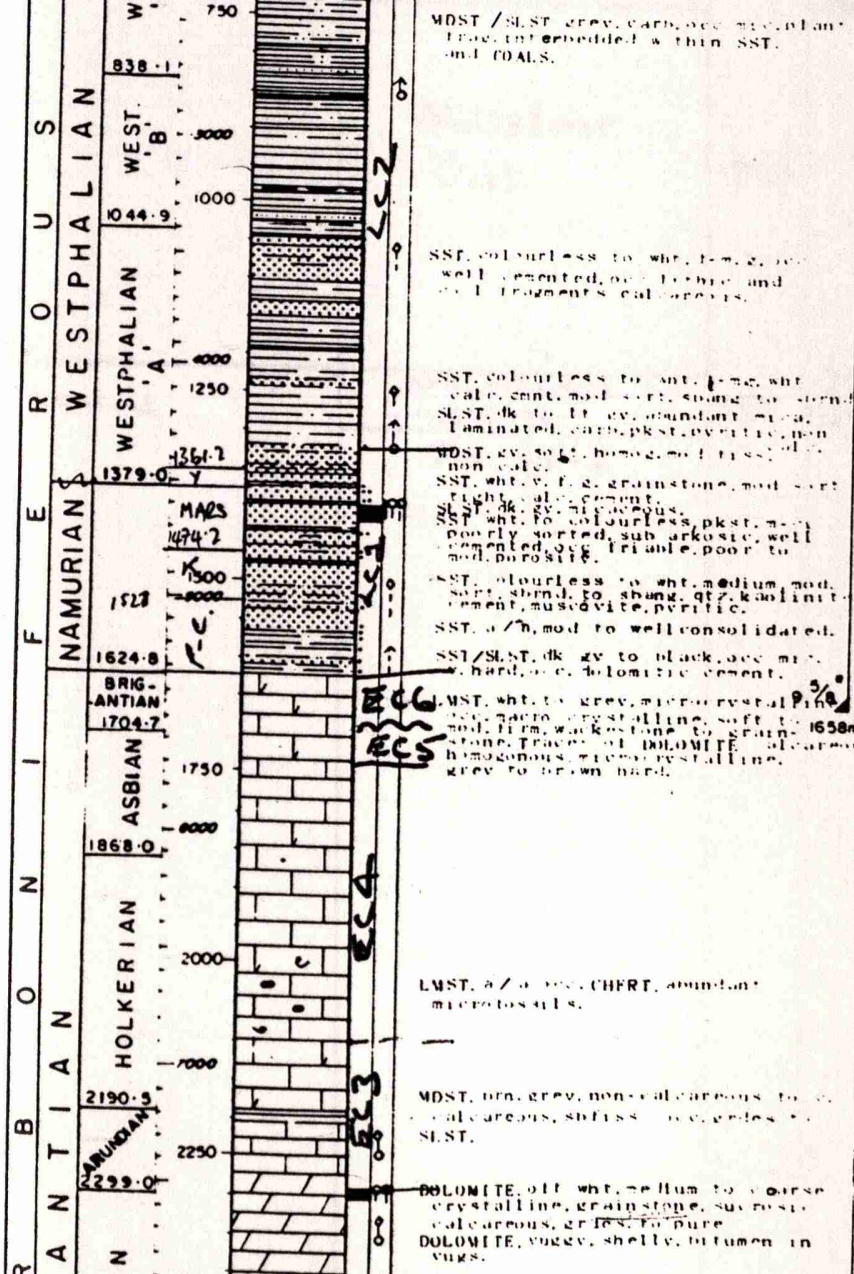

$\propto<<:$

(1474.2 2 $1520=0000$ - 1500 .

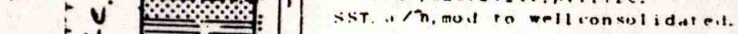

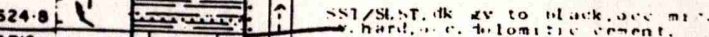

1704.7

范

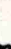

m

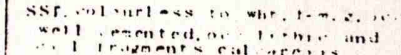

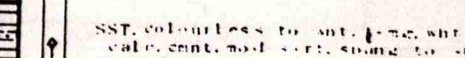

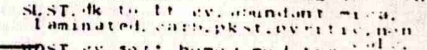

most.

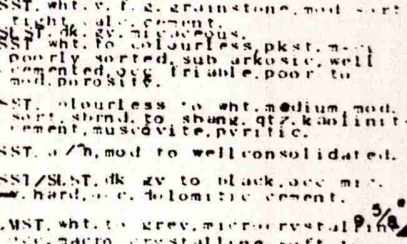

$1658 \mathrm{~m}$

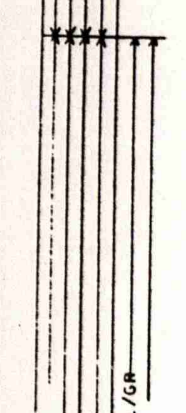

$\frac{\frac{400 \cdot 5}{426.5}}{452 \cdot 2}$

302

937.5 Lower mea lar

6210 Lamer Marl

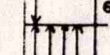

*TाT

bavel senditone

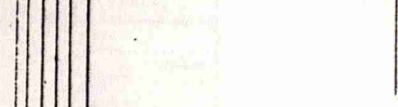

966.5 Top Hard Coal

$1065 \cdot 0-1088 \cdot 3$ Deep Soft Rock 1096.4 - 1117.7 Parkgate Rock $1138.9-1156.0$ Siltstone Rock

|ुसे $1256 \cdot 0-1260 \cdot 2$ Kilburn Sst.

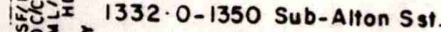
1) $1361 \cdot 2-1367 \cdot 6$ Crowshow Sst 1379.0-1397.6 Rough Rock E $1401 \cdot 7-1452 \cdot 1$ Cnat sworth Sot. 1472.4-1510.0 Kinderscout Ss $1535 \cdot 6-1562 \cdot 0$ Alport Sst.

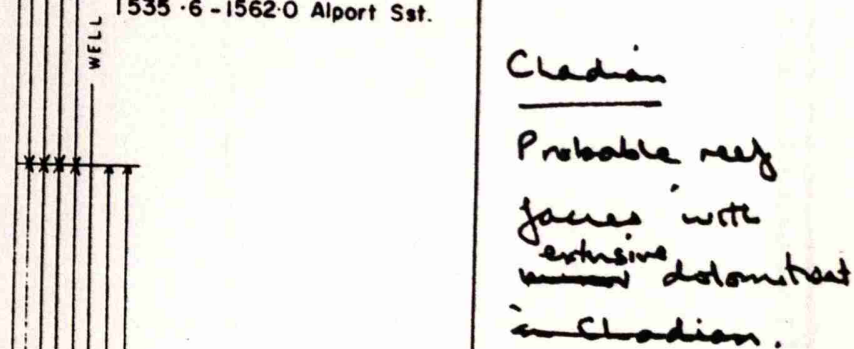

DST 1

220 bw pd

43000 ppo Nall.

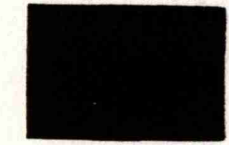

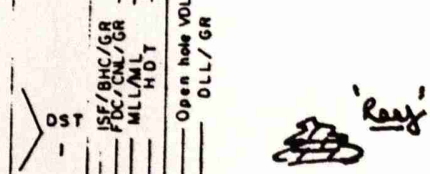
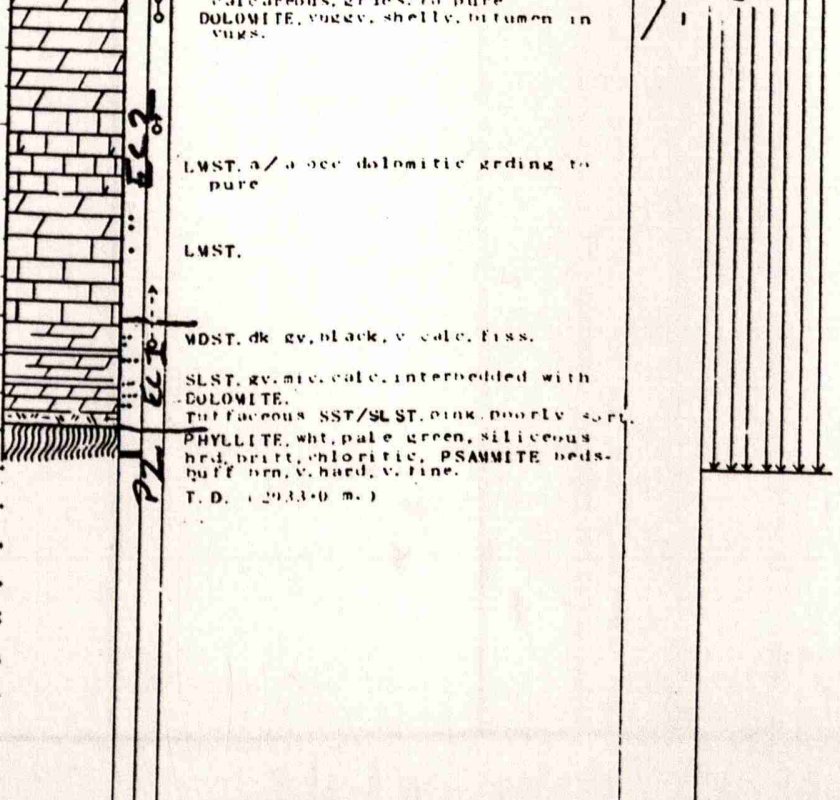
folor: PEARSON \& SON D DOARCY EXPLORATION LOCation: DERBYSHIRE

dinates: N.G. Ref. 44346238 Elevation: + 630' O.D.

Compl. Date: Deepened 1938

Well:

HARDSTOFT 1

Date: 1919

TYPE: PETROLEUM BOREHOLE

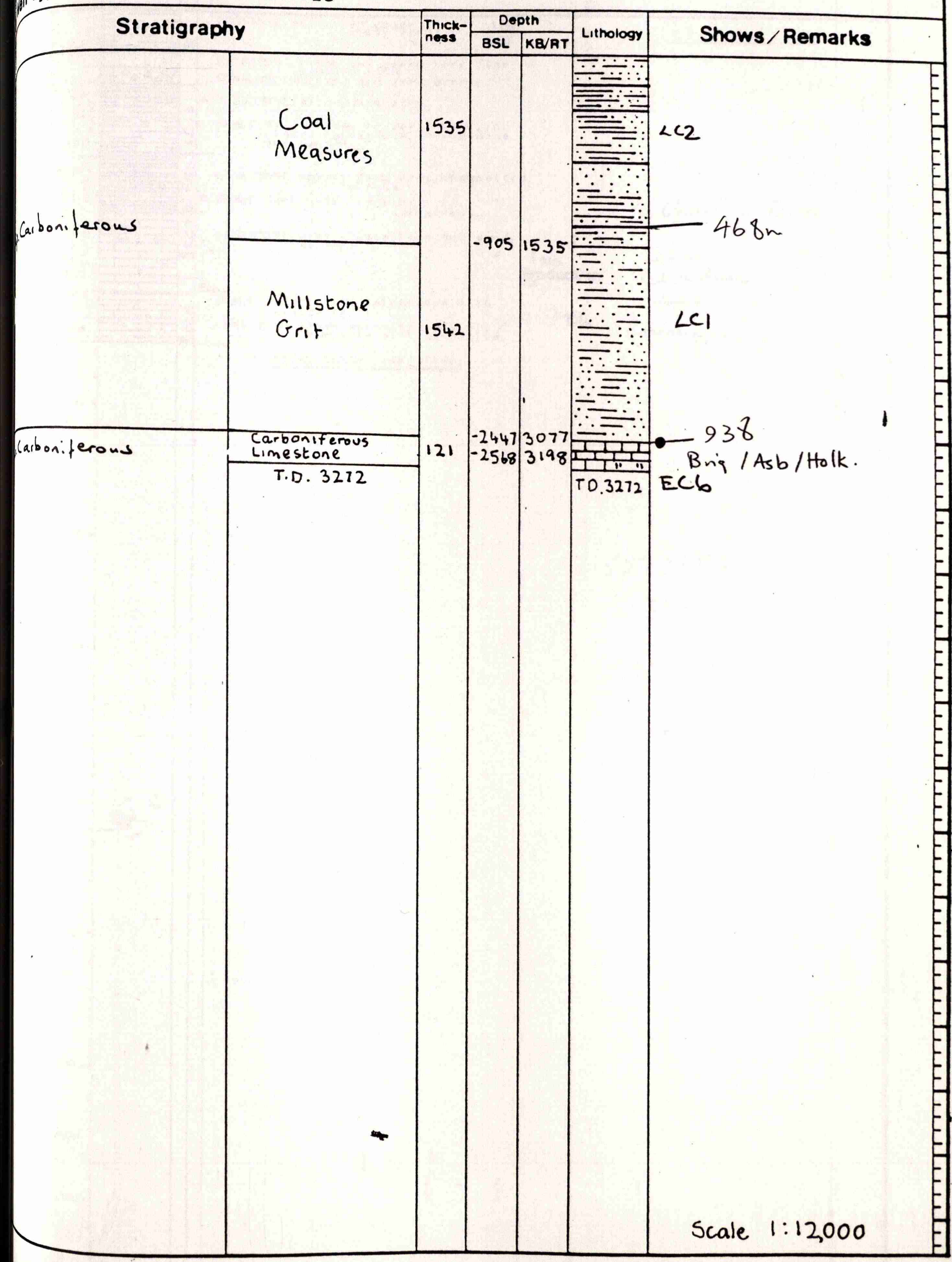


DARCY $1954 \frac{\text { HATHERN NO. } 1 .}{\text { SUMMARISED WELL LOG }}$

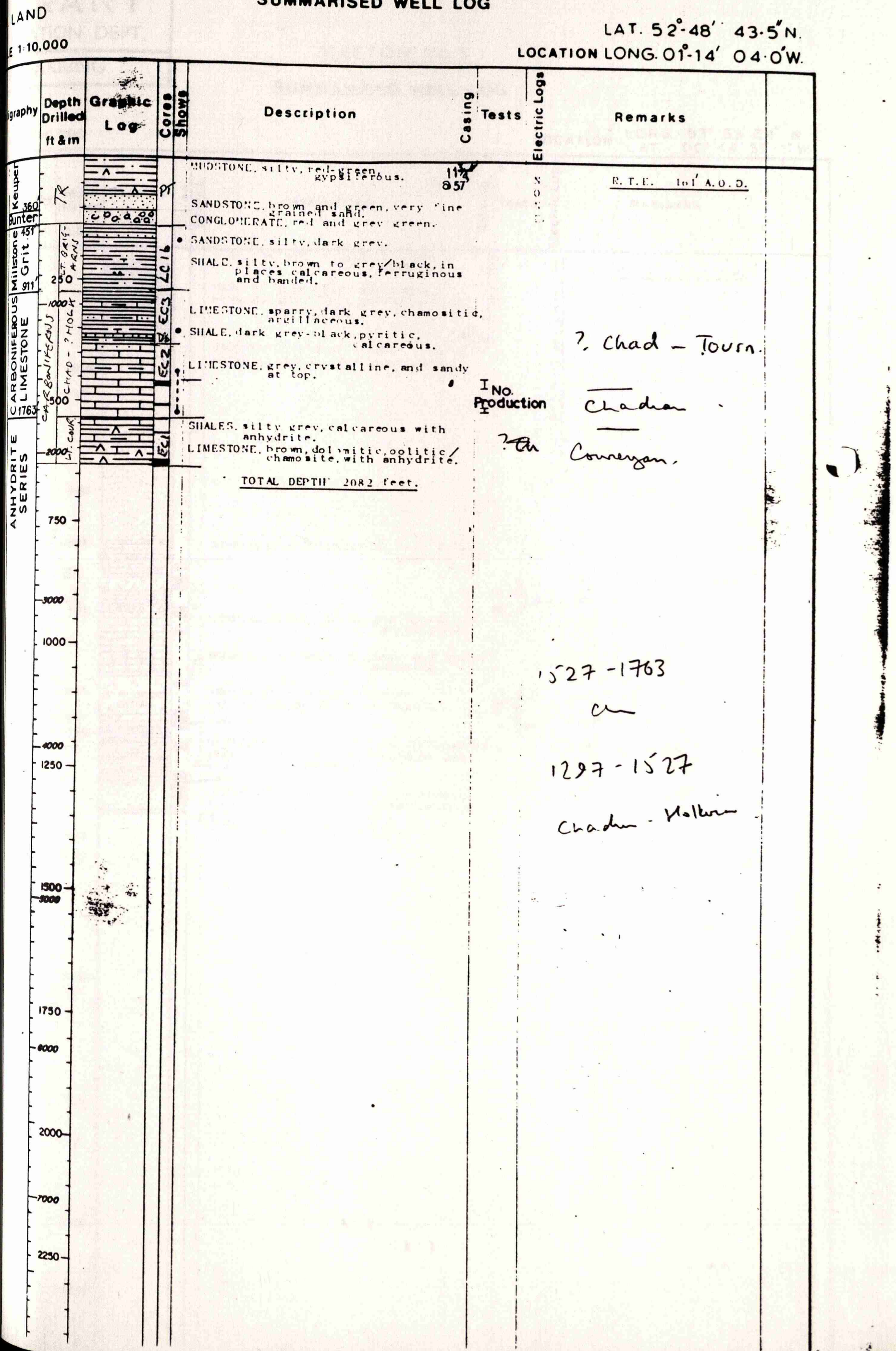


RARY DRATION DEPT.

\section{EAKRING}

E $1: 10,000$

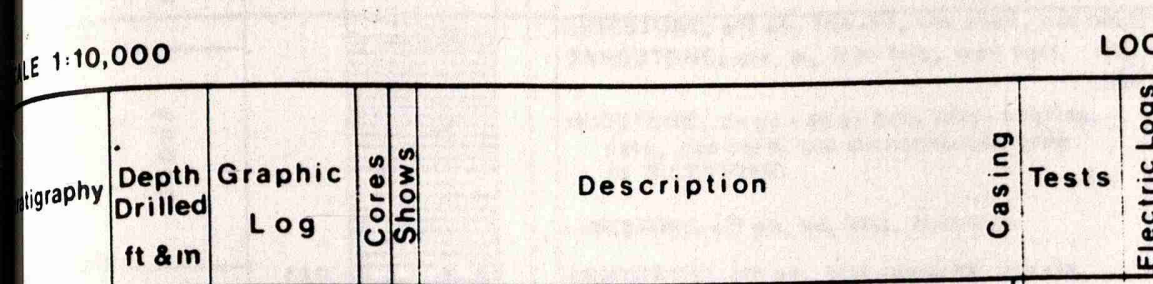

\begin{tabular}{|c|}
\hline$b$ \\
0 \\
0 \\
0 \\
$x$ \\
\hline \\
\\
0 \\
\\
20
\end{tabular}

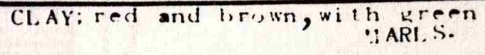

:IARL; re hlish brown and preen, al 1 si sity an
with fiypsur.

SUMMARISED WELL LOG

1.8. Mud tr.

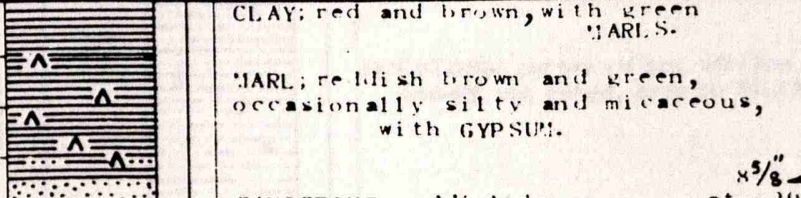

SANDSTO:E:; redili ih brom,

at $112\left(1^{\circ}\right.$

often micacents and blaconitic.

250

$-1000$

$\because \because \because \because \because \because \because \because$

$\because T$

500

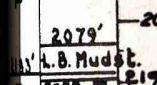

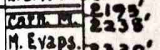

M. Evaps. 2 T. L. Lik. $20^{\circ}$

hinge. 750

2463

Mid. Mag
bit.

Lower

Anhydrite

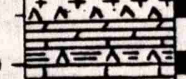

315:-

13194

1, 2183-2195' Upper Evaporites. 王\} ins. lies shons.

L MESTONC: pale green and whitelic.

kreen and white

DOLOMITE; bown, with sreen and whe.

ANIYYRI Tr:: white, with brown

al careuss DoLoutTE sirinkers. II

$3153-31+t^{\prime}$ lower rajnesian Limestone. $314.4-3237^{4}$ 3asal sands and breccias. 


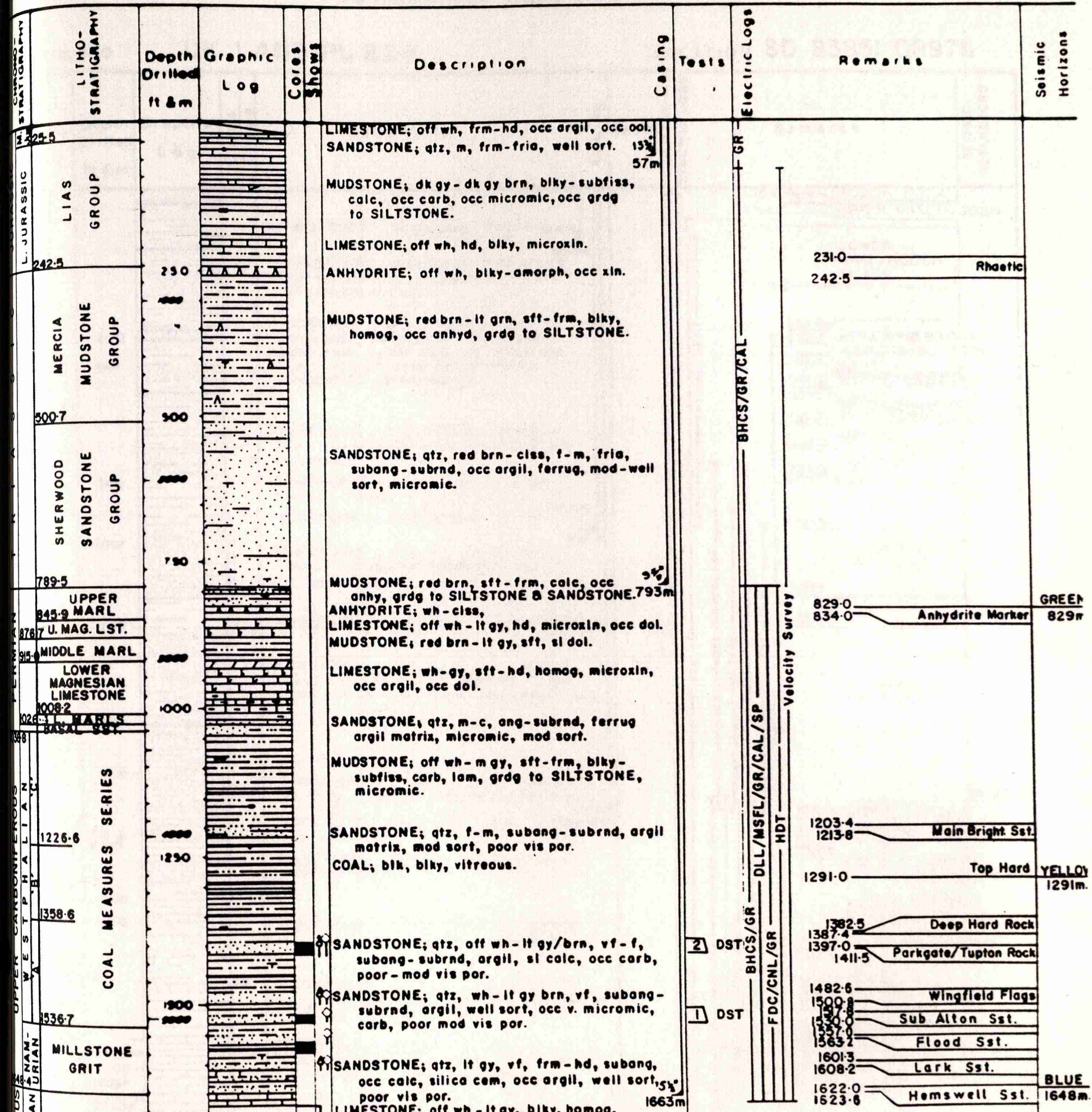




\section{0}

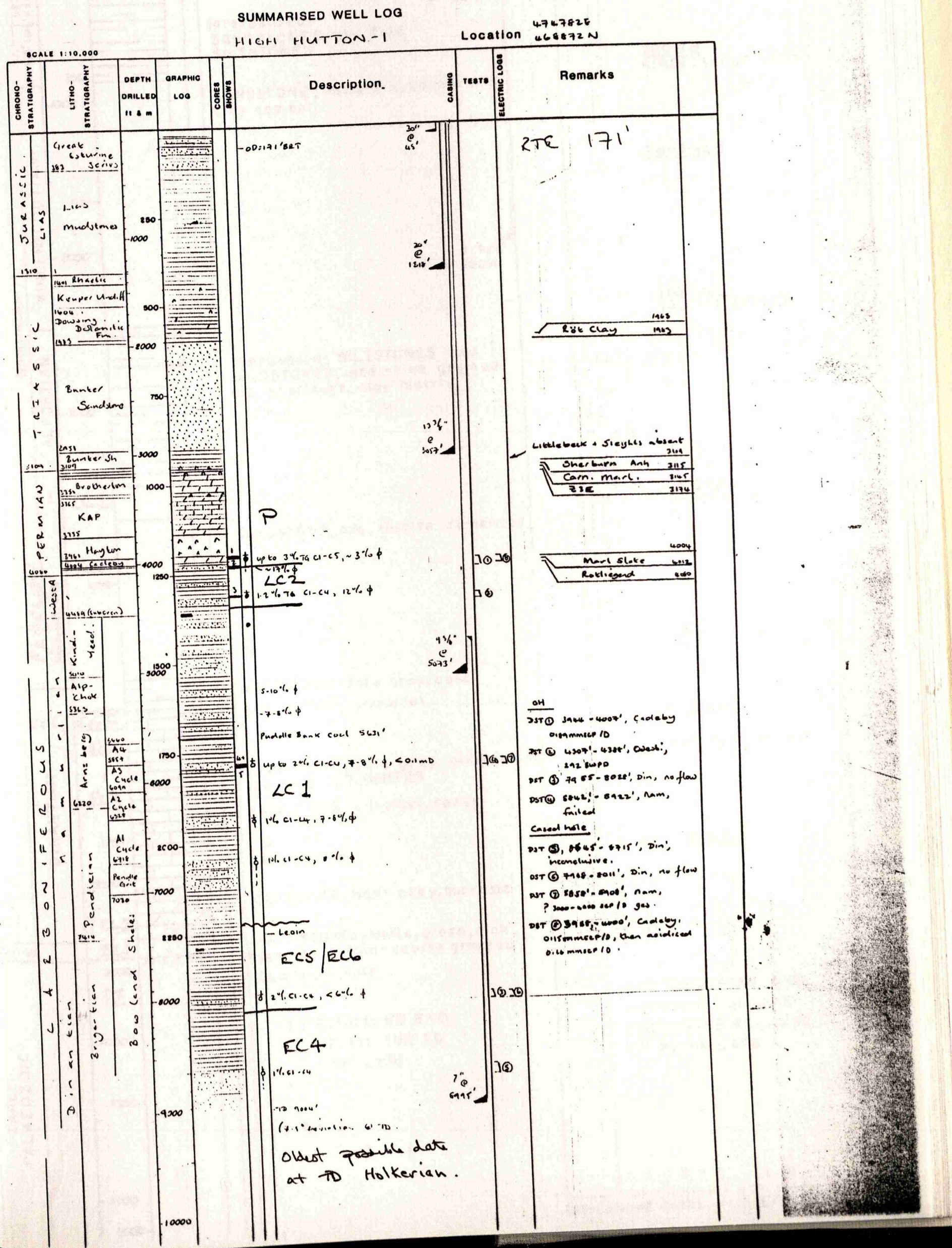




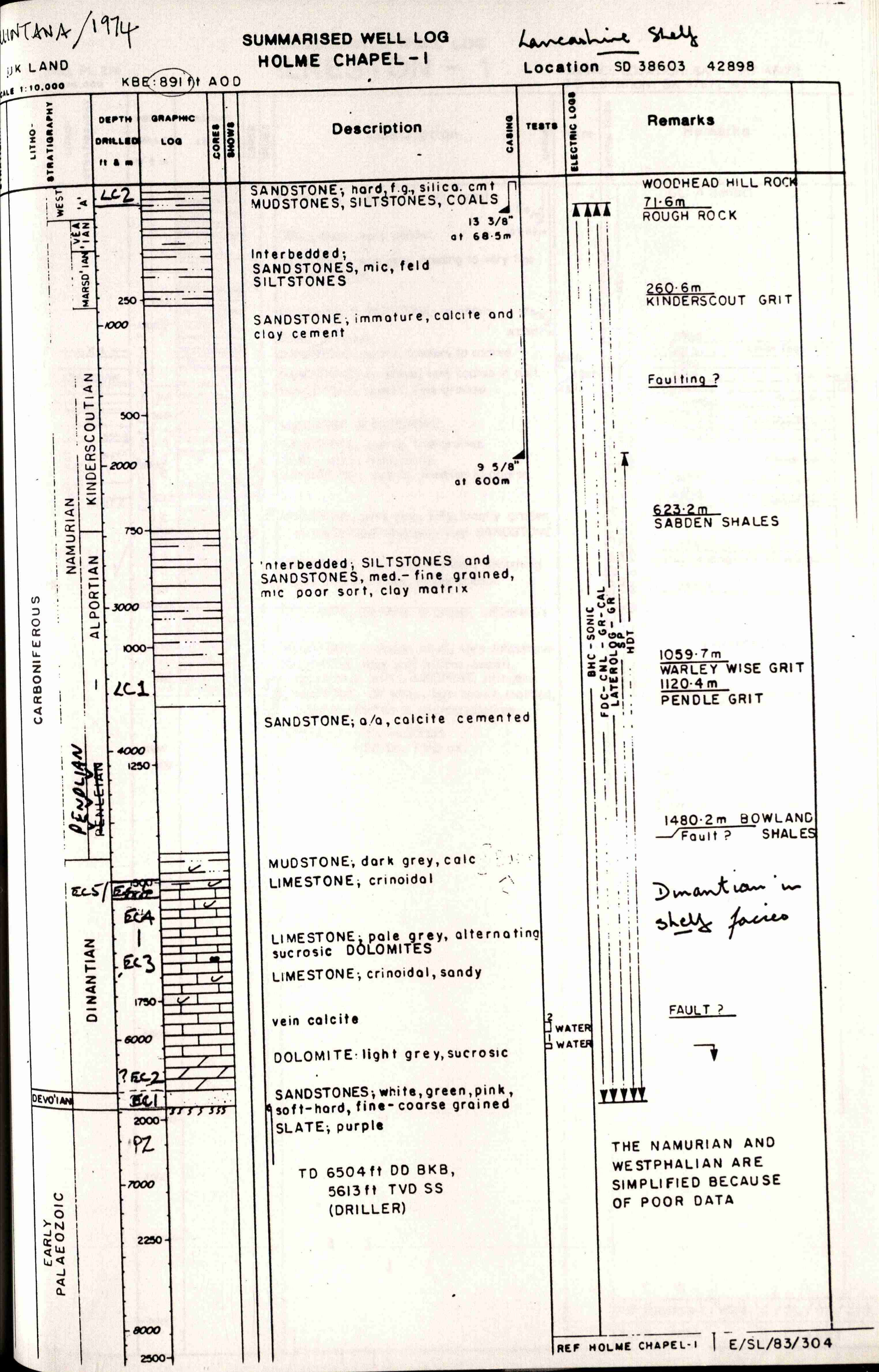


PL 214

SCALE 110.000

IRONVILLE 5

LOCATION SK 4299251418

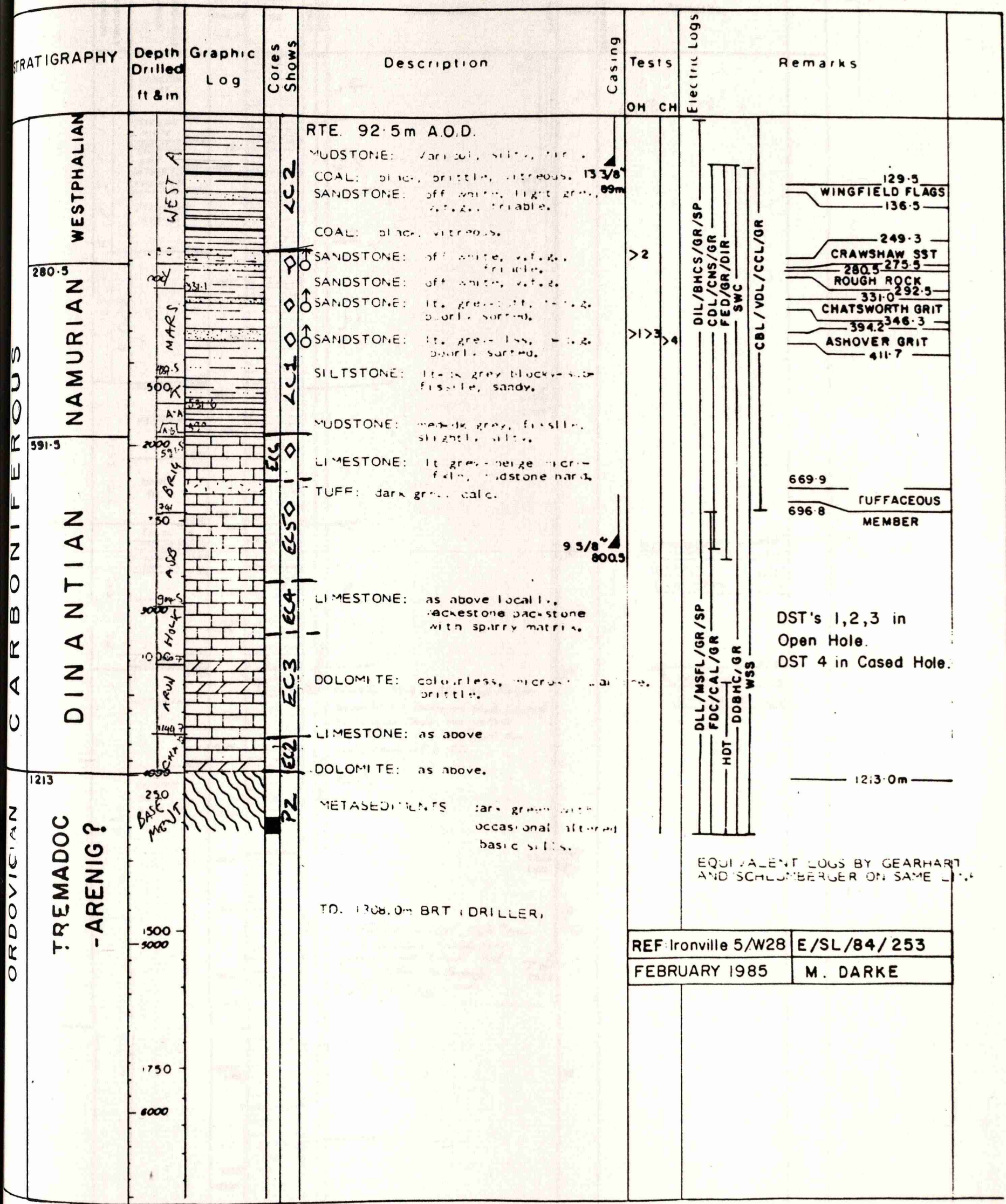


SUMMARISED WELL LOG

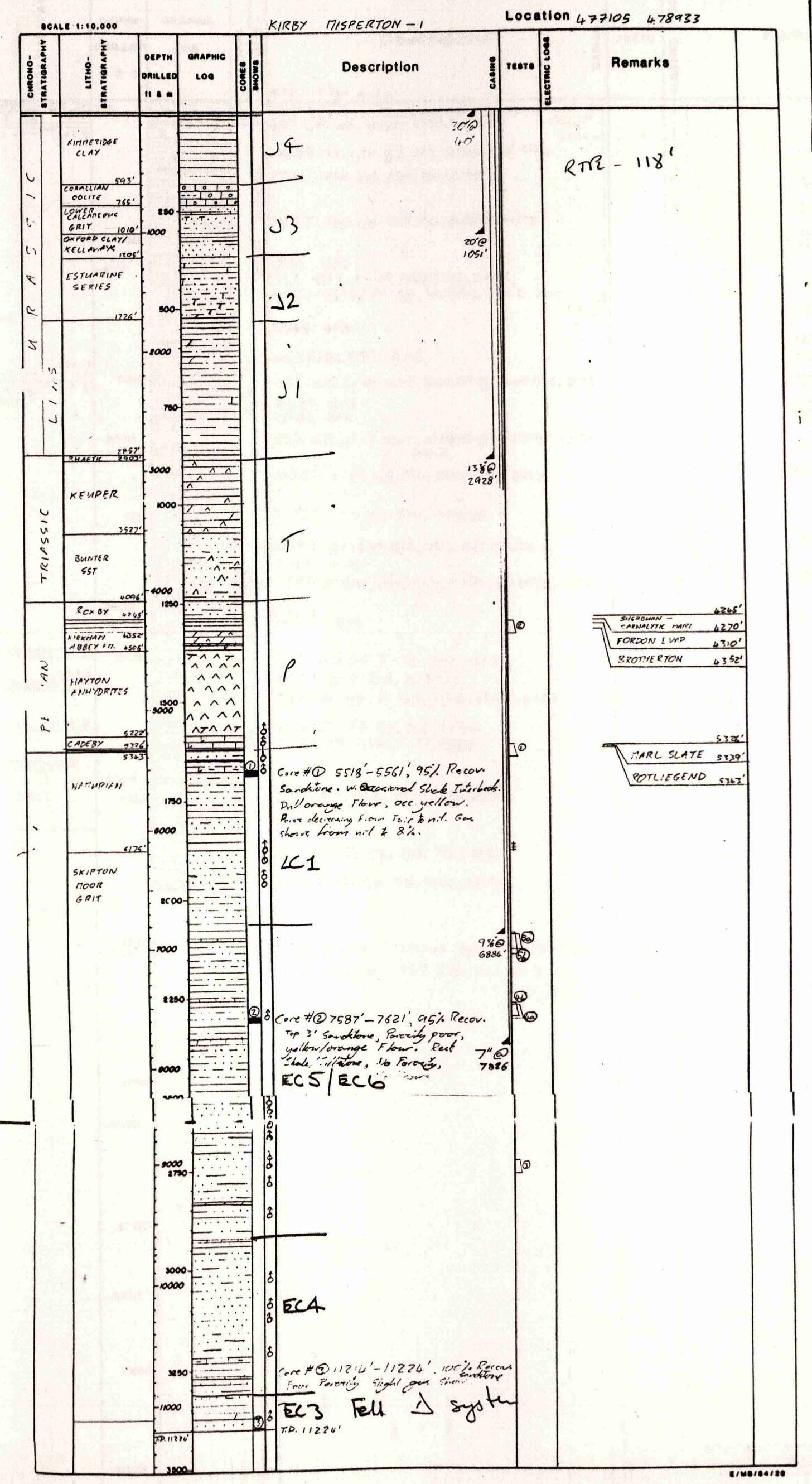


SUMMARLSED WELL LOQ

PL 213

LADYBROOK - I

Surface Location 452735

35958 .

T.D. Location 452853

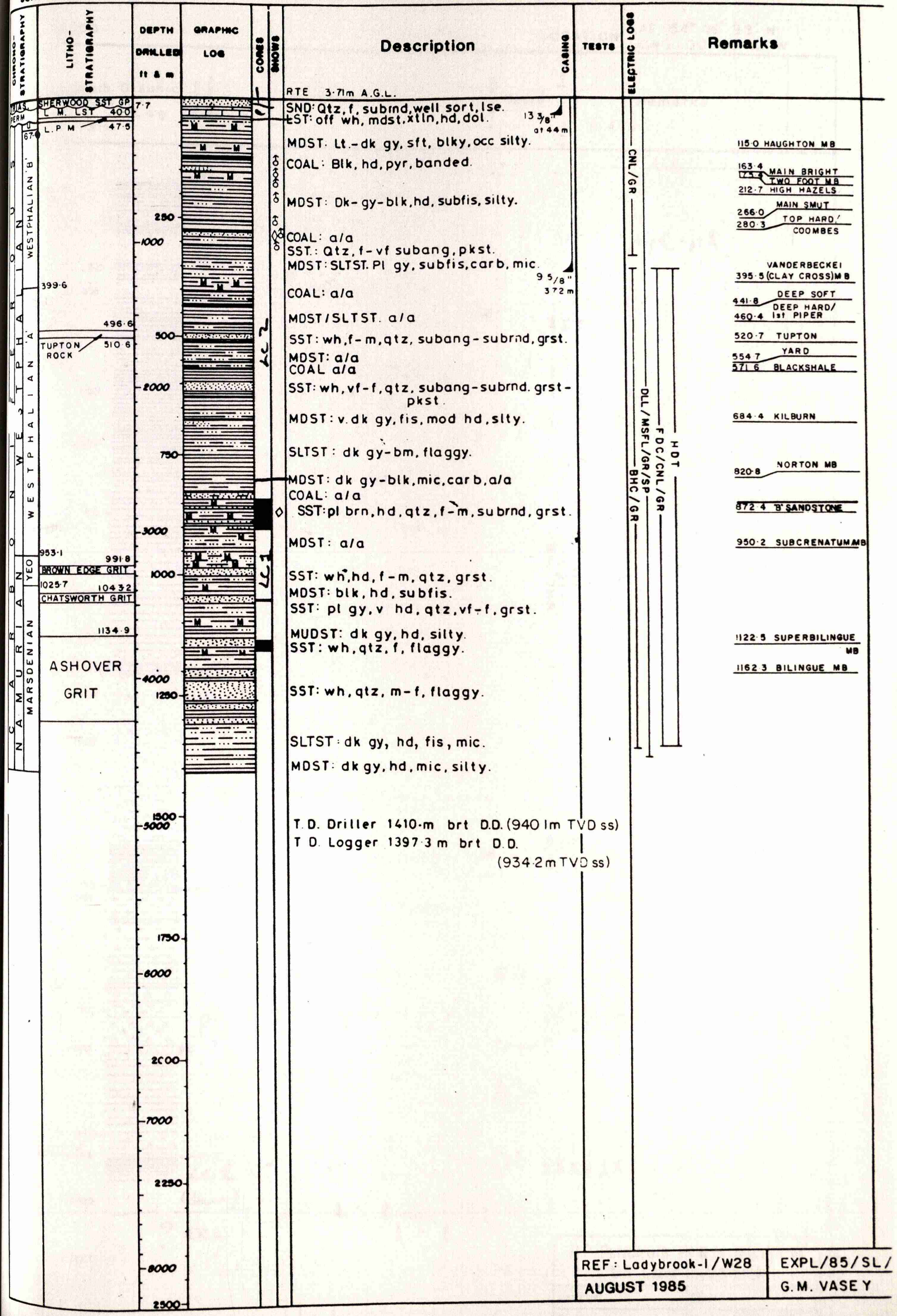




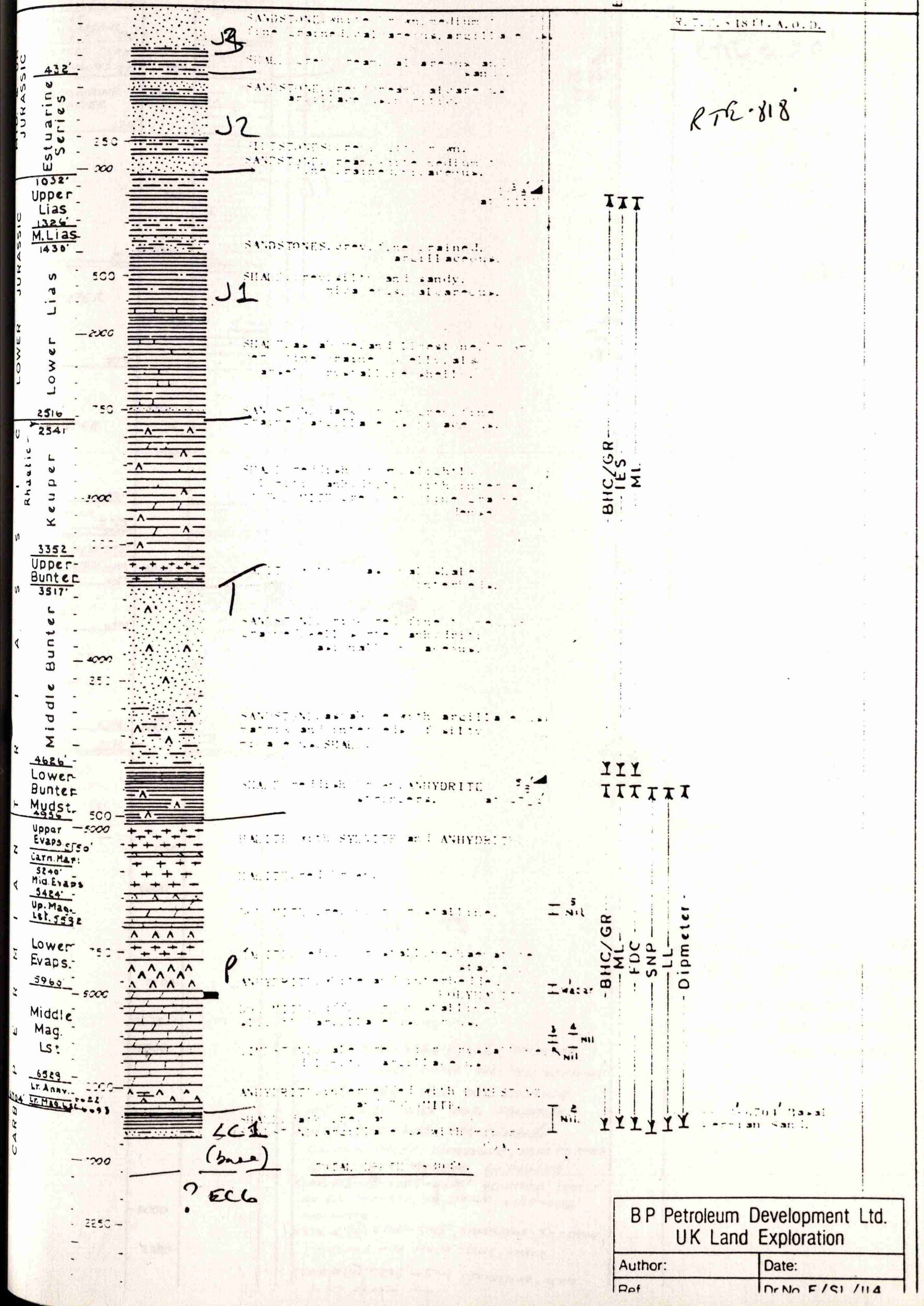


SUMMARISED WELL LOG

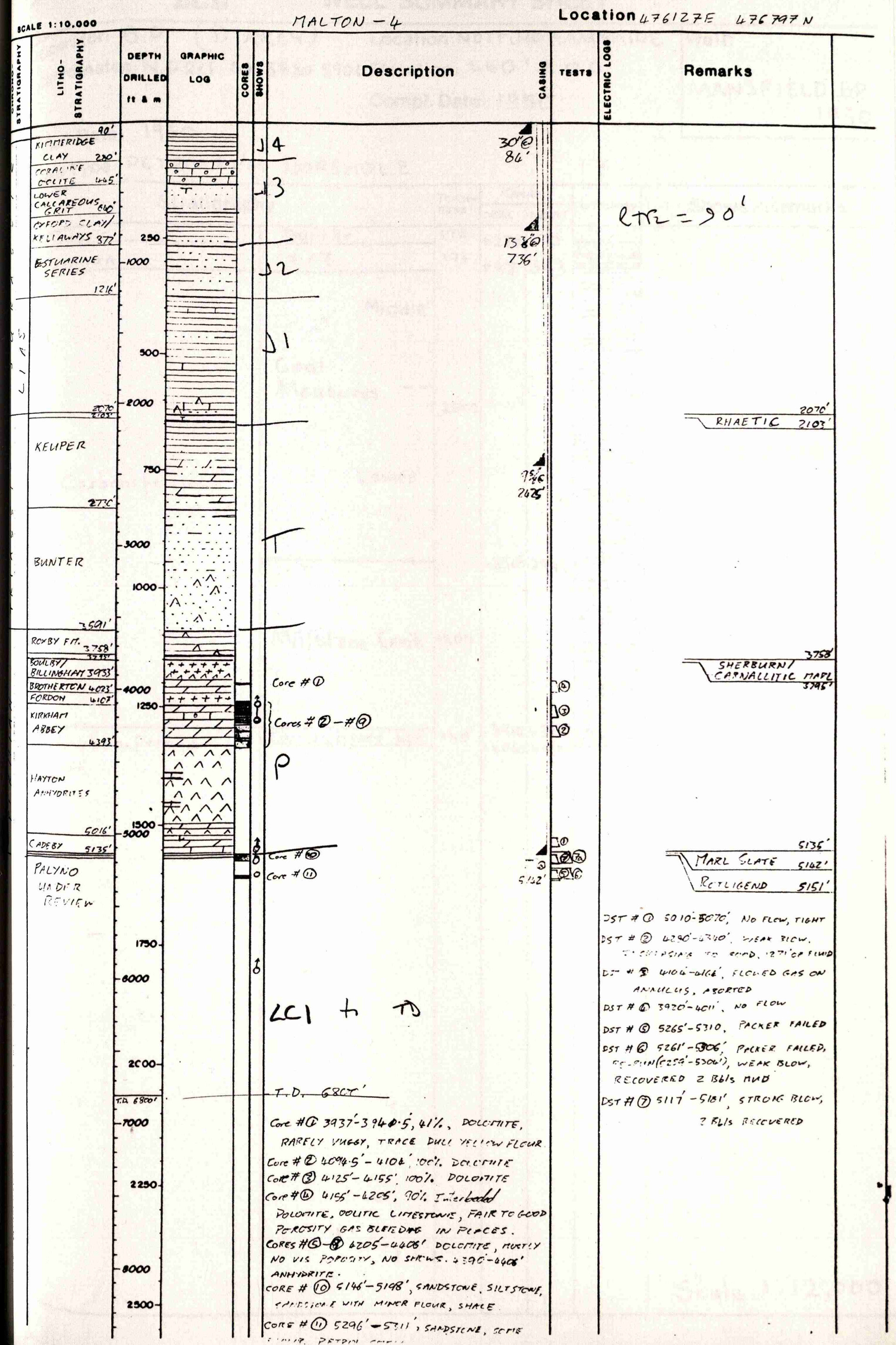


operator: B.P. (D'ARCY) Location:NOTTINGHAMSHIRE Well: coordinates: N.G.ReF. SK 55505906 Elevation: $440^{\prime}$ A.O.D.

Compl. Date: 1950 MANSFIELD BP 1950 Spud Date: 1950

Well TYPO: PETROLEUM BOREHOLE

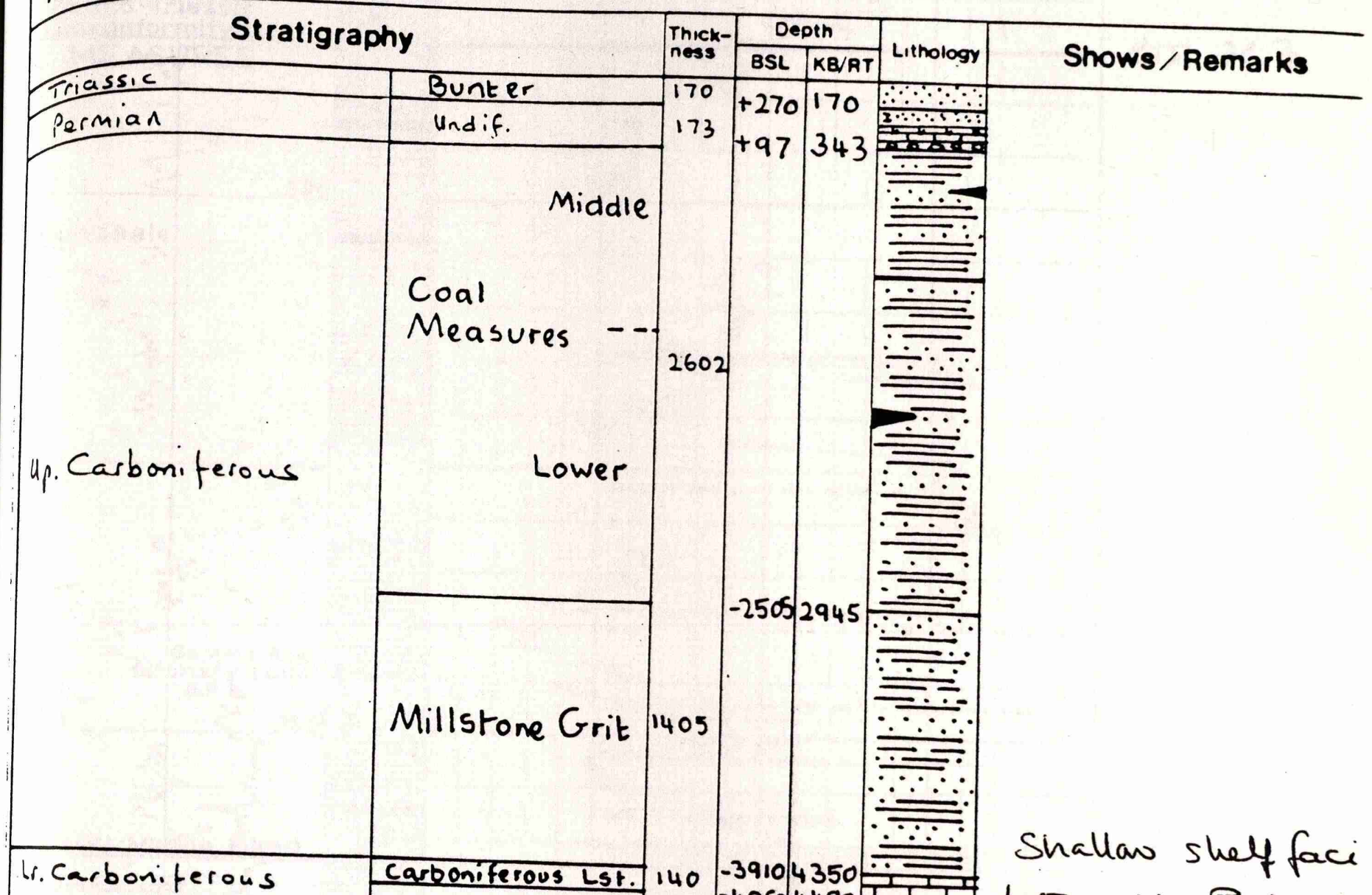
late-mid Brig. 
SUMMARISED WELL LOG

NEWTON

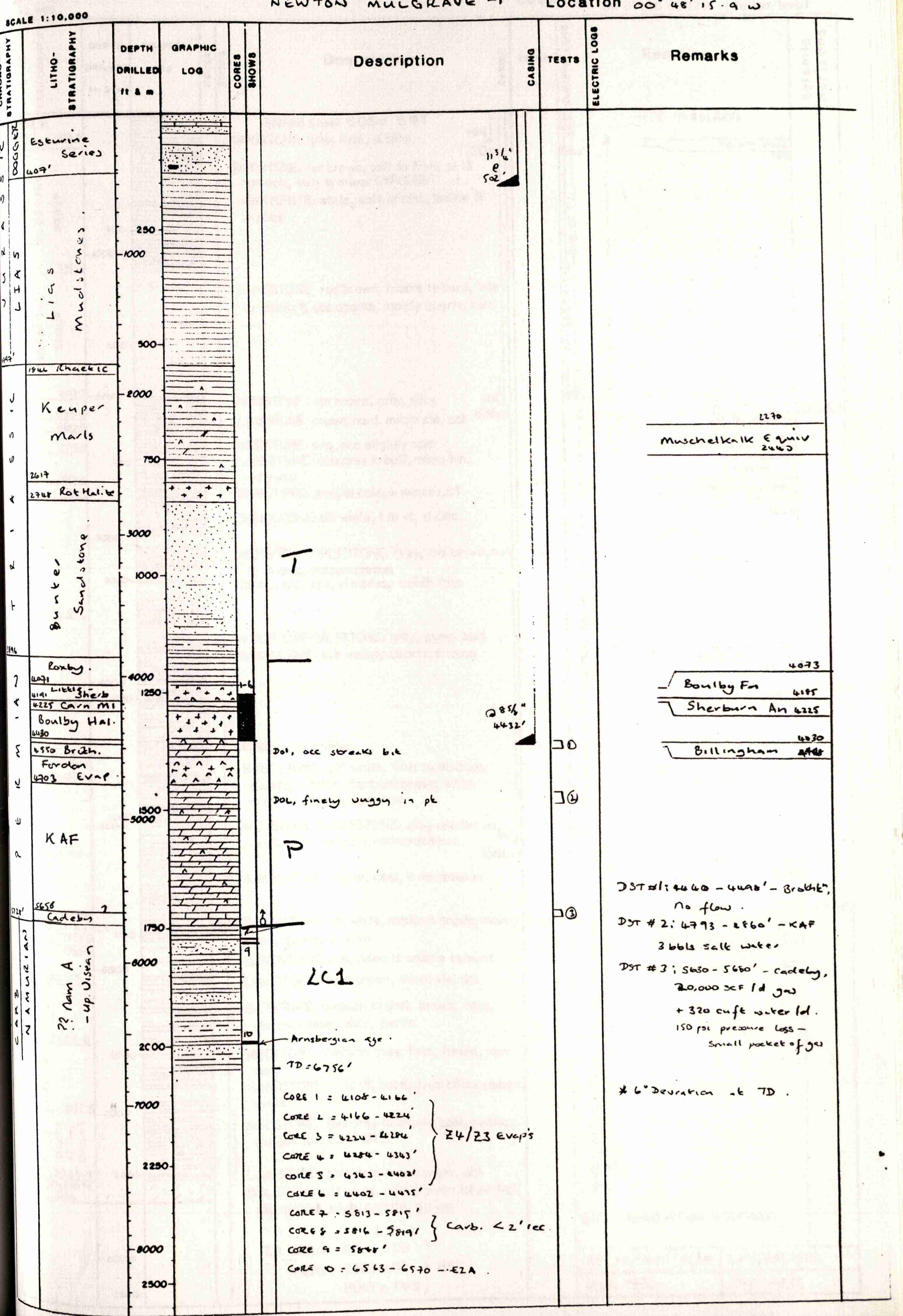




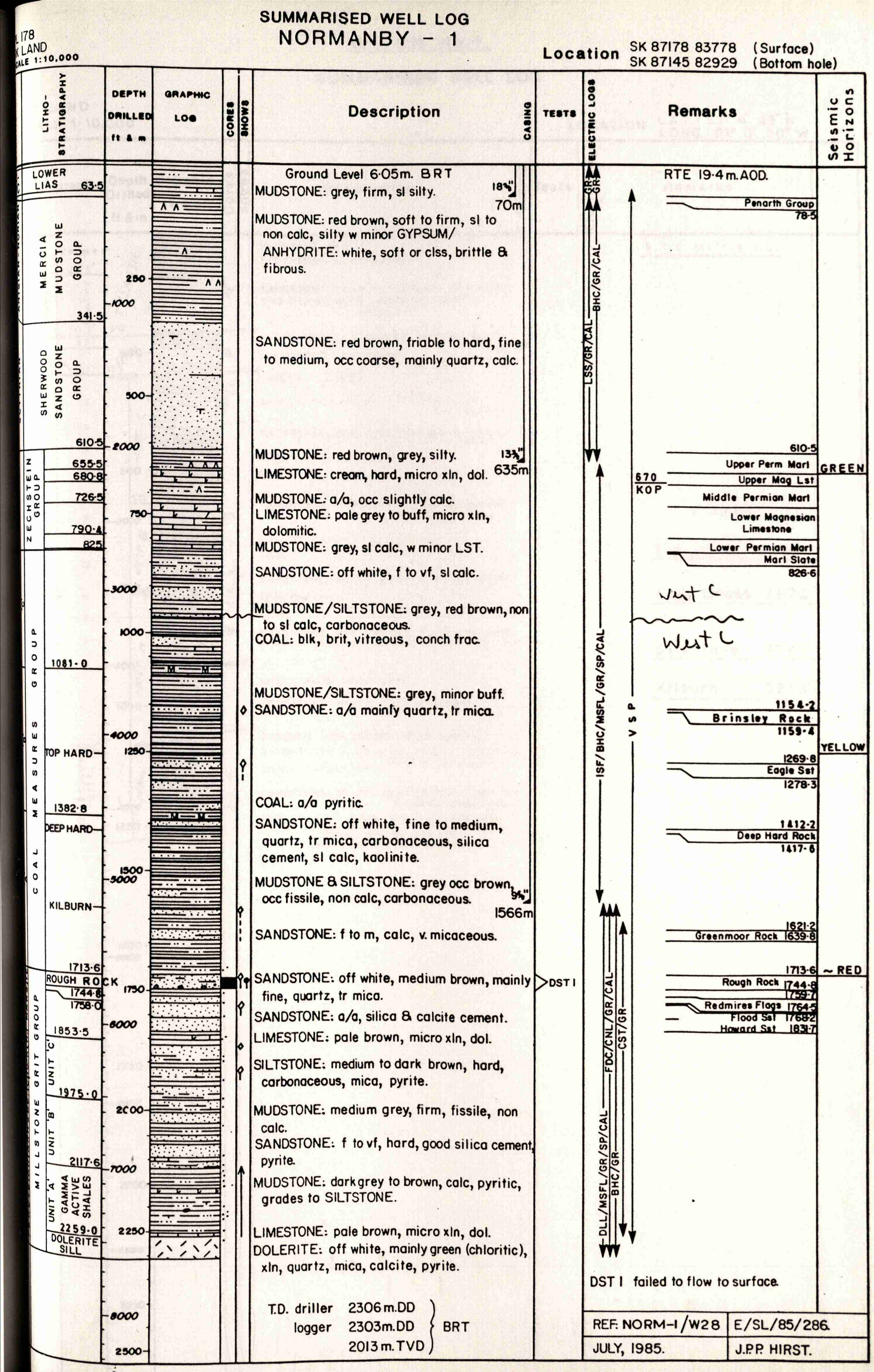


OXTON NO. 1.

SUMMARISED WELL LOG

U K LAND

LOCATION LAT: $53^{\circ} 4^{\circ}, 25^{\circ} \mathrm{N}$

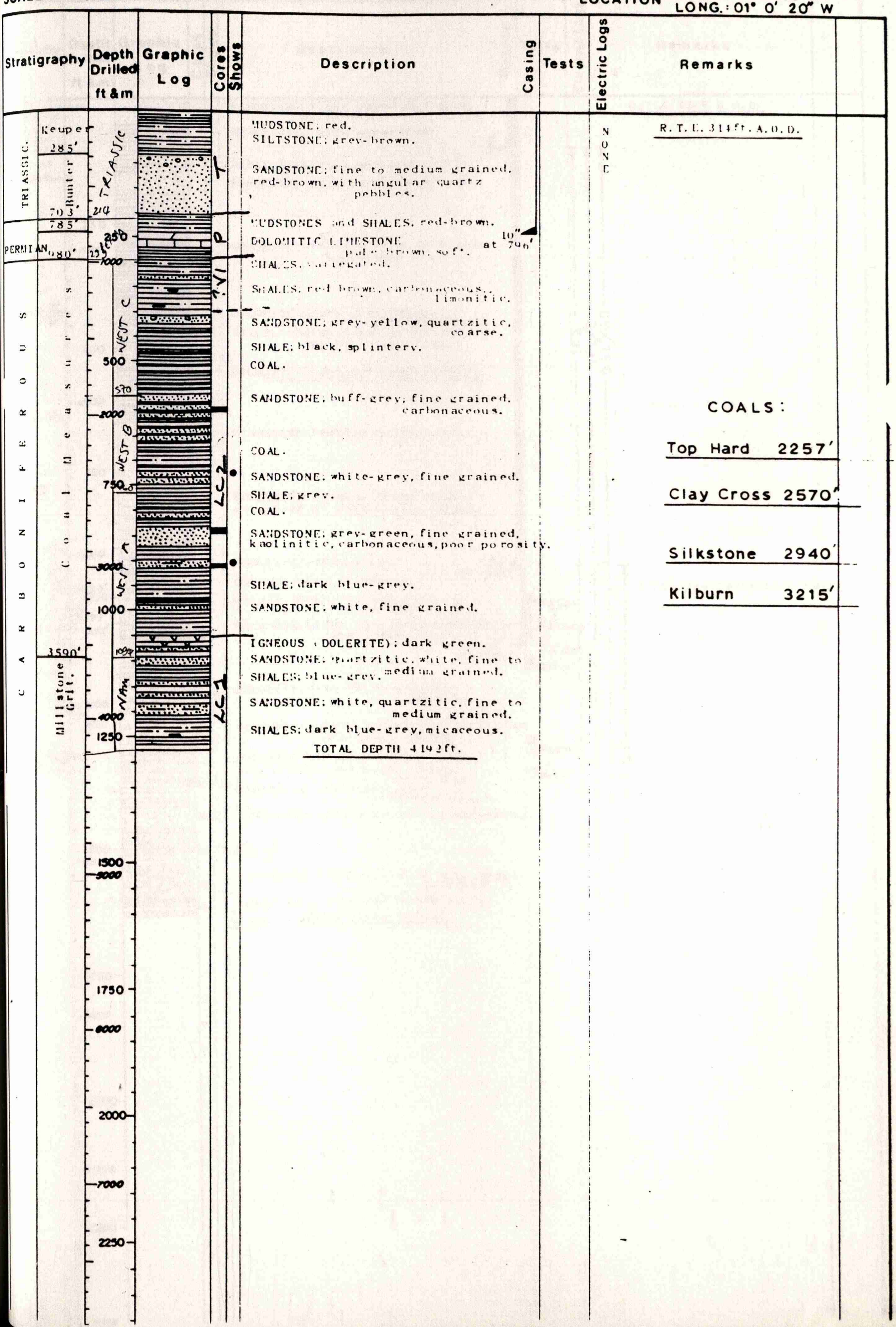


LOCATION LAT. : $54^{\circ} 24^{\circ} 46^{\circ} \mathrm{N}$ LONG.: $00^{\circ} 57^{\circ} .30^{\circ} \mathrm{W}$

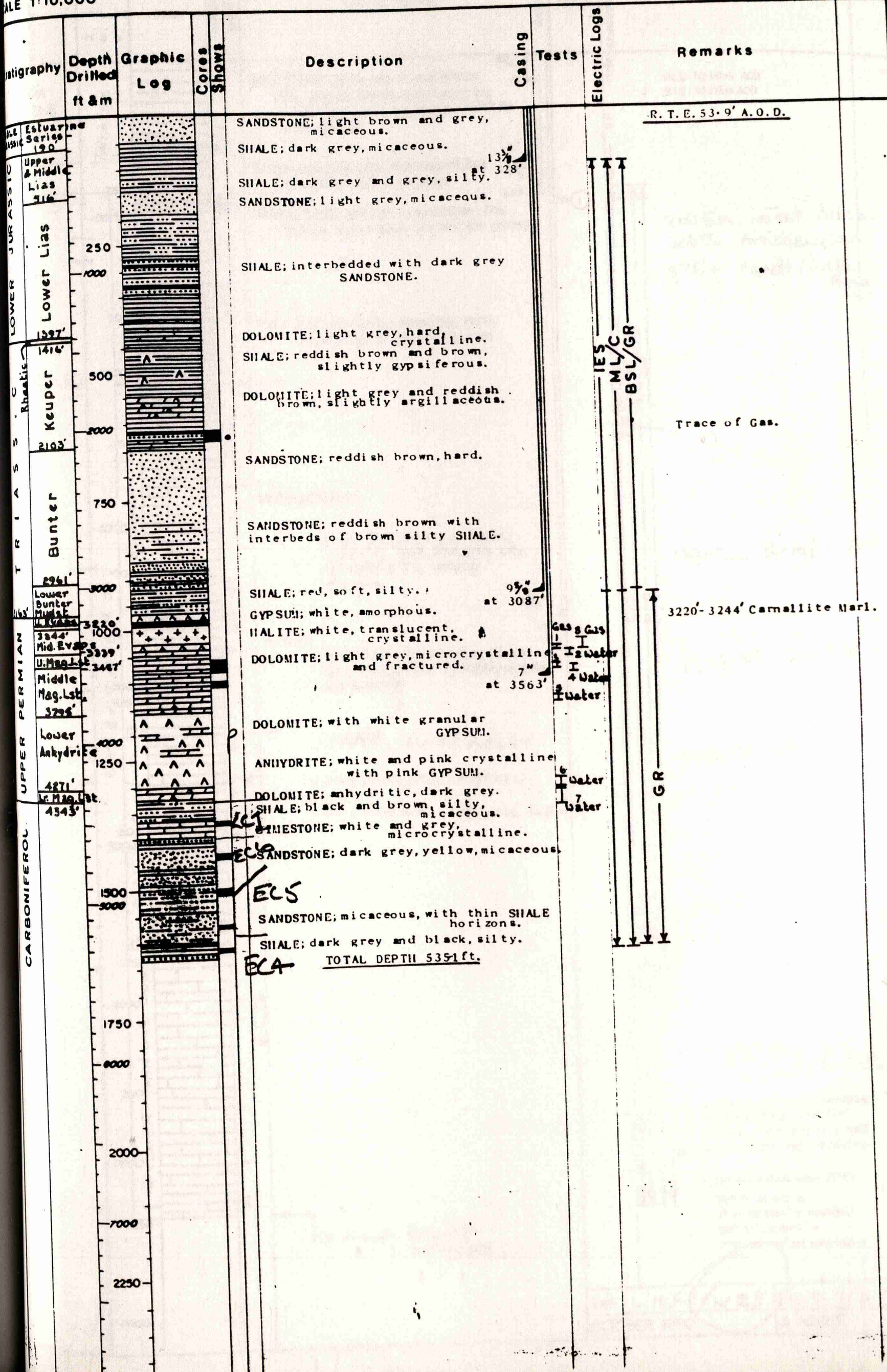


SUMMARISED WELL LOQ

L N/4-3

(Rotaliffe - on - soor)

Location

4 cone seaces (sumfice)

450ra 350100(TOTL DJTH)

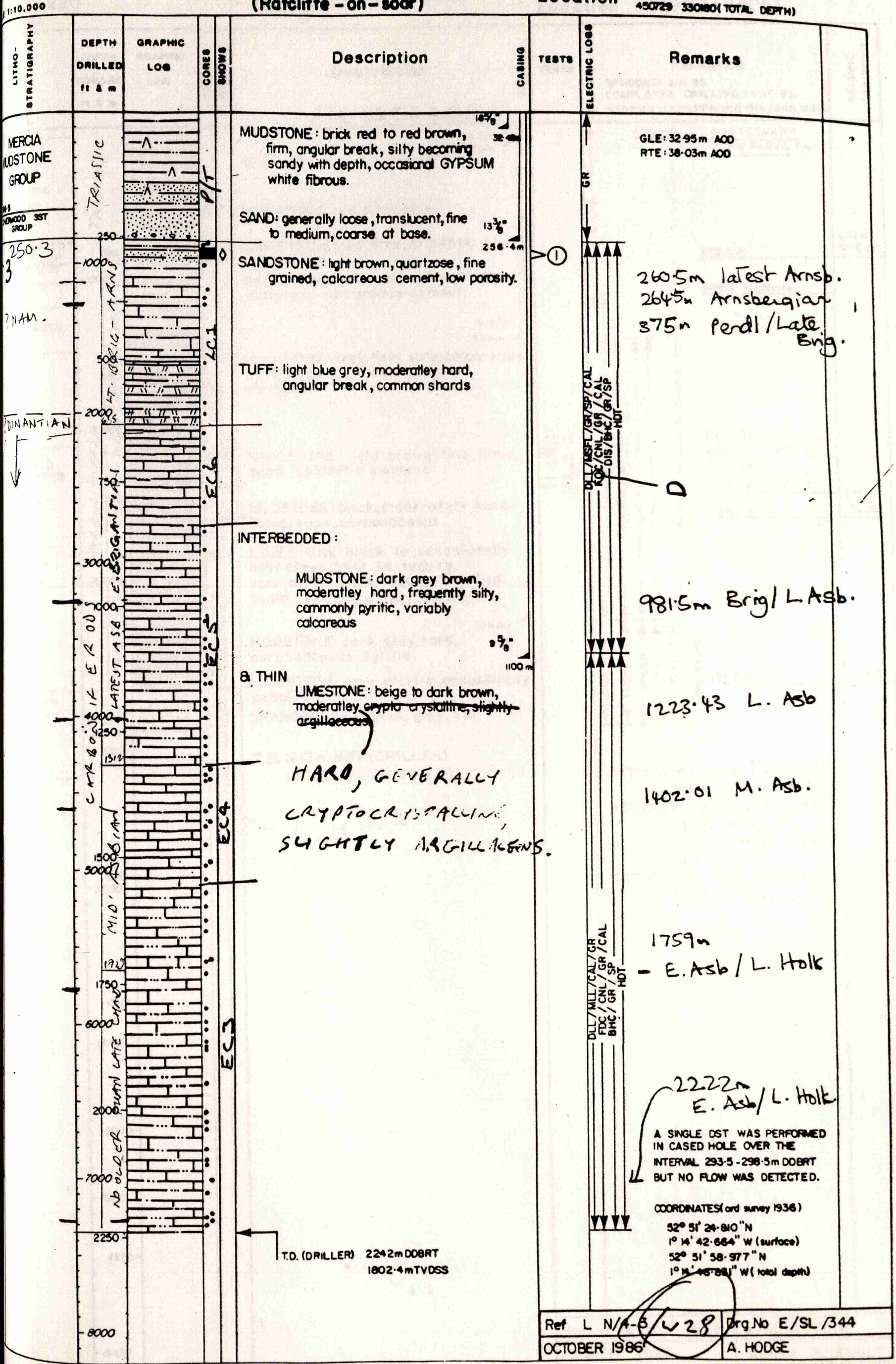




\section{ROSEDALE No. 1.
RO}

SUMMARISED WELL LOG

LE $1: 10,000$

LOCATION GRID REF: $: 7267394960$

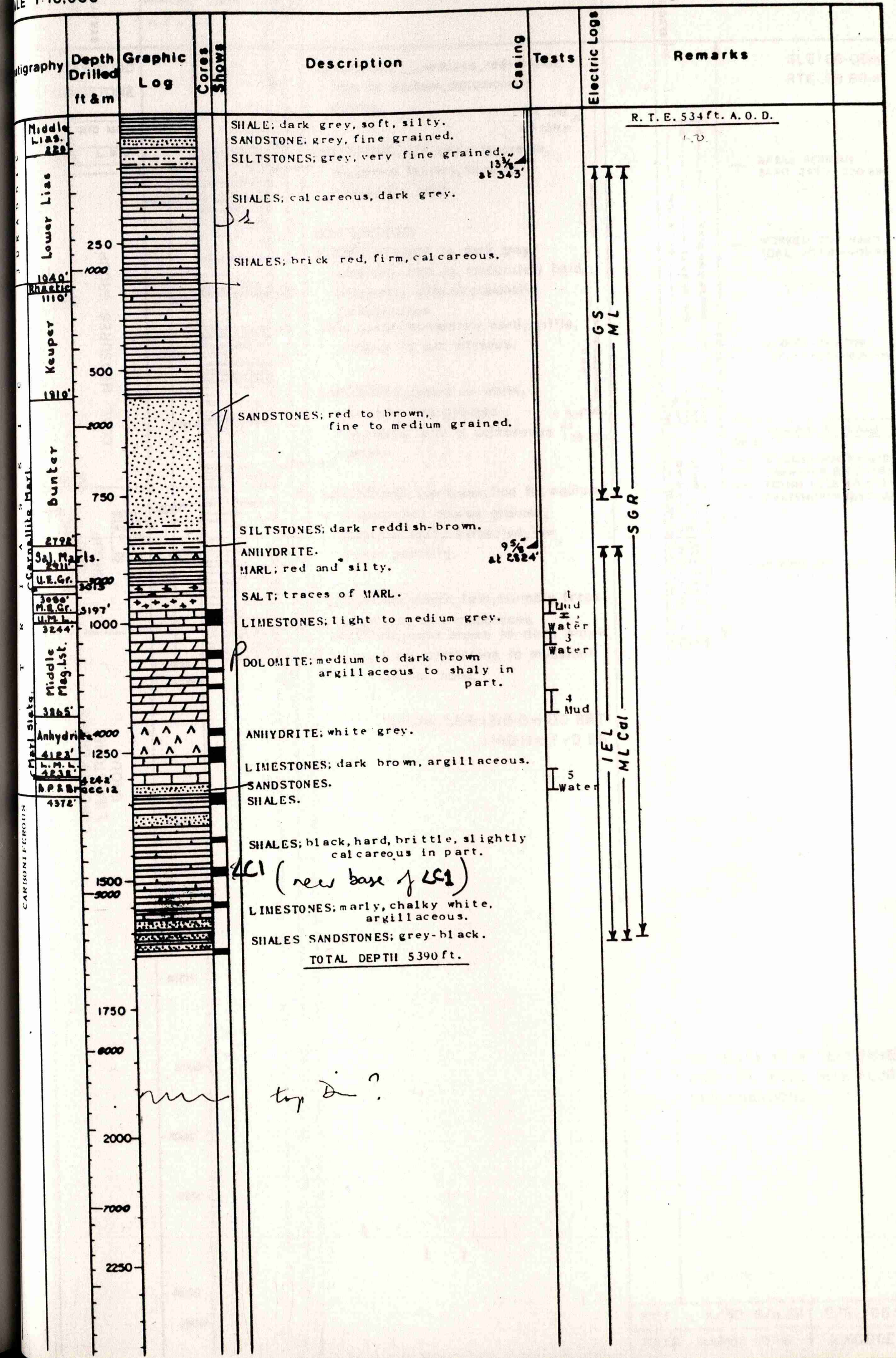




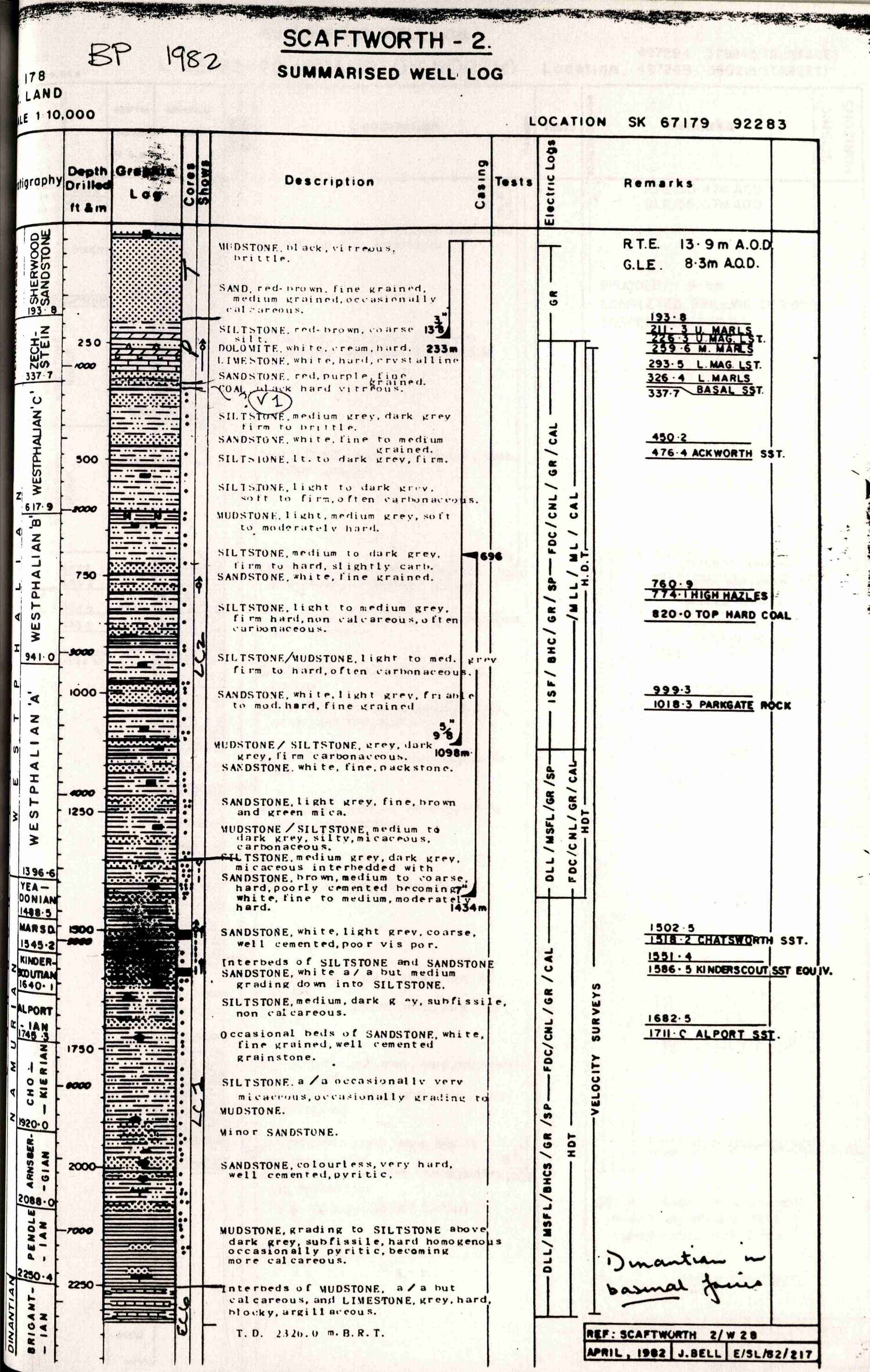




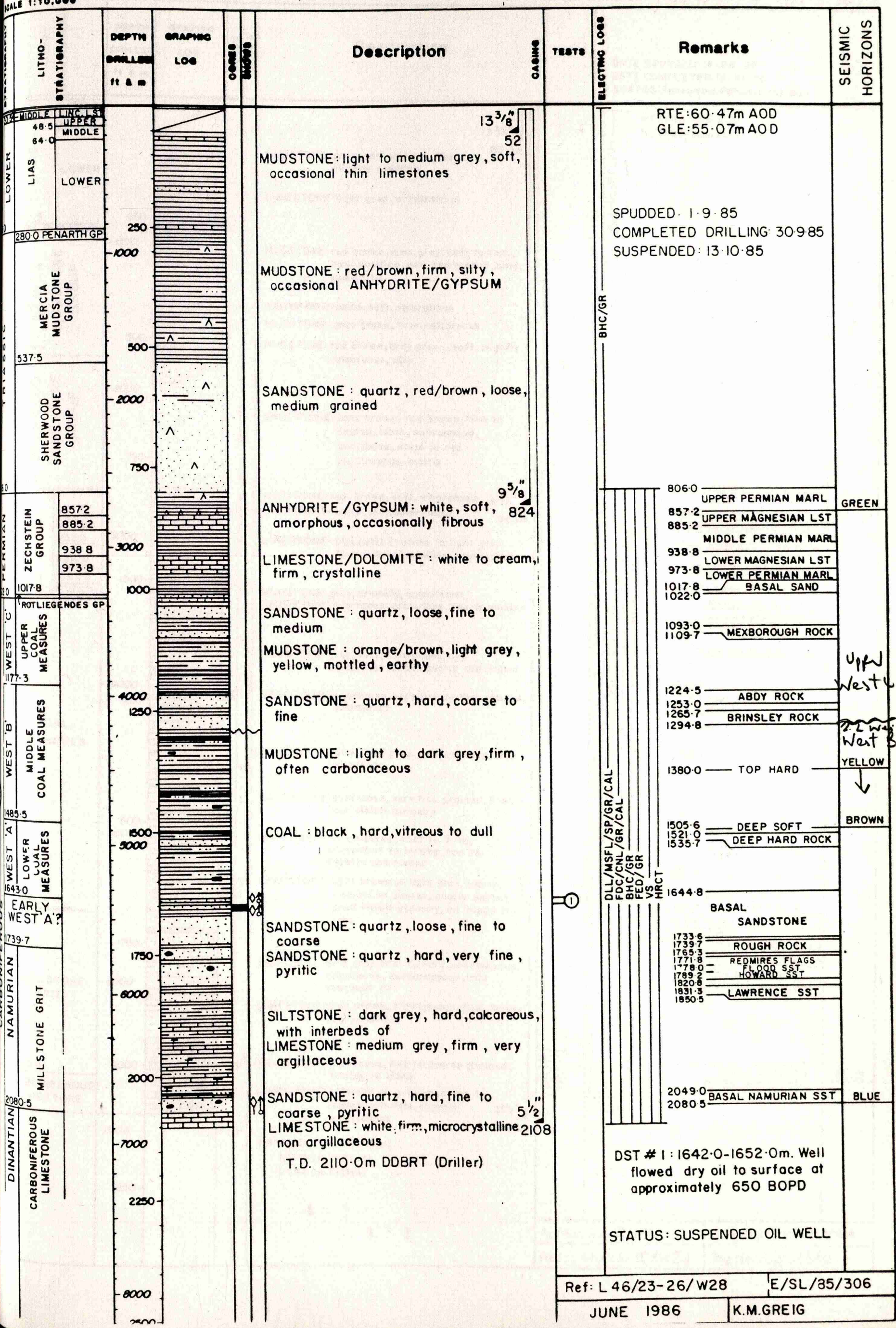


SUMMARISED WELL LOG

Surface Location

$53^{\circ} 18^{\prime} 29 \cdot 7^{\prime \prime} \mathrm{N}$

$00^{\circ} 31^{\prime} 03 \cdot 91 \mathrm{~W}$ T.D. Location $53^{\circ} 18^{\prime} 47.0^{\prime \prime} \mathrm{N} \quad 00^{\circ} 31^{\prime} 23.8^{\prime \prime} \mathrm{W}$ UK LAND PLI79B L46/23-30 (SCAMPTON NORTH-2) Target Location $53^{\circ} 18^{\prime} 41 \cdot 1^{\prime \prime} \mathrm{N} \quad 00^{\circ} 31^{\prime} 18.2^{\prime \prime} \mathrm{W}$

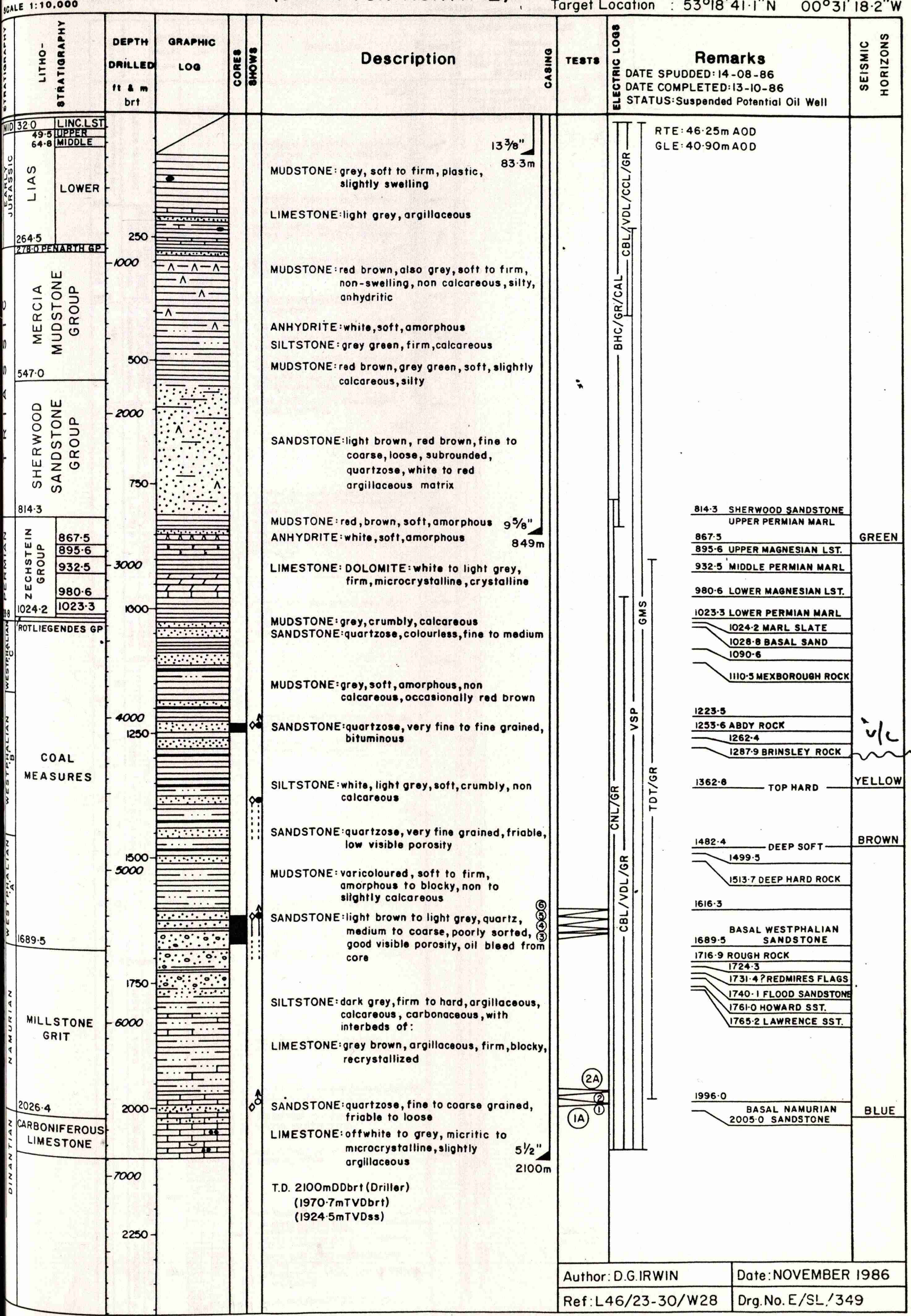


$54^{\circ} 36^{\prime} 25^{\prime \prime N}$

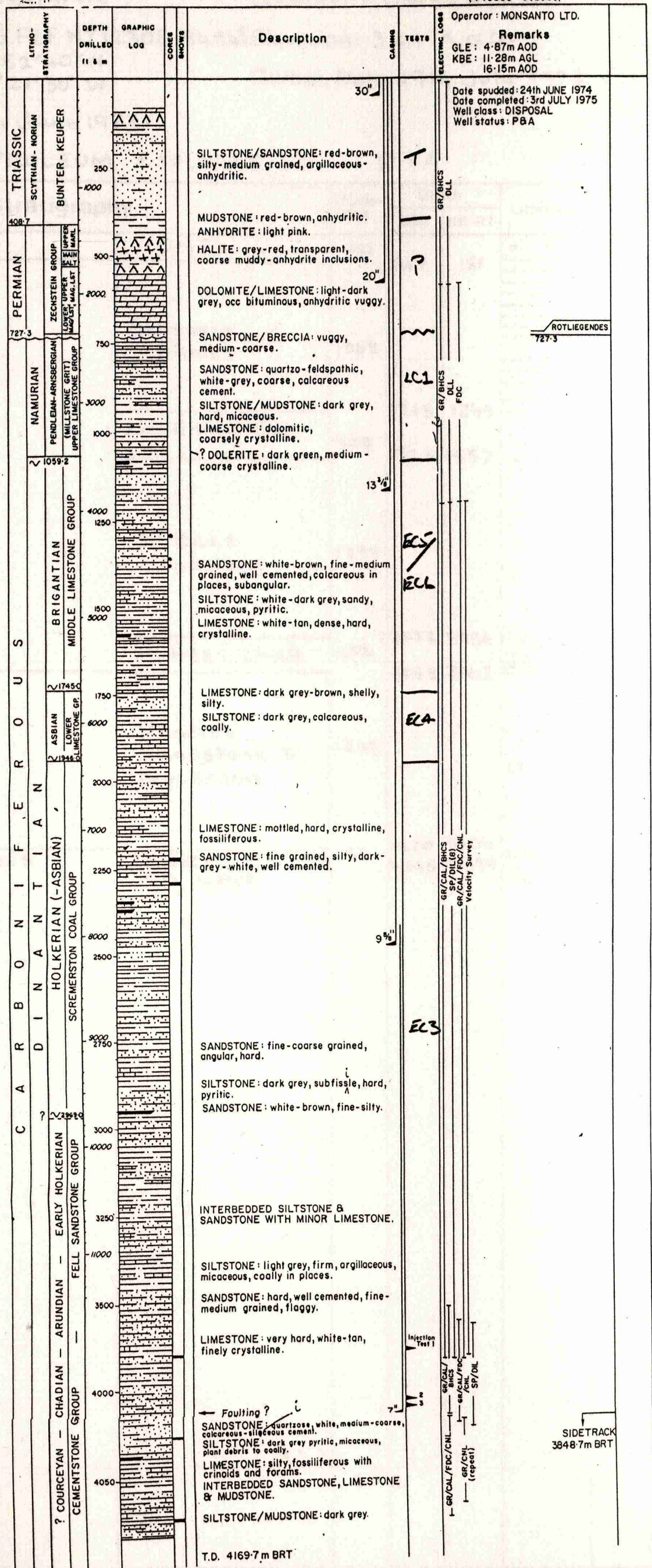




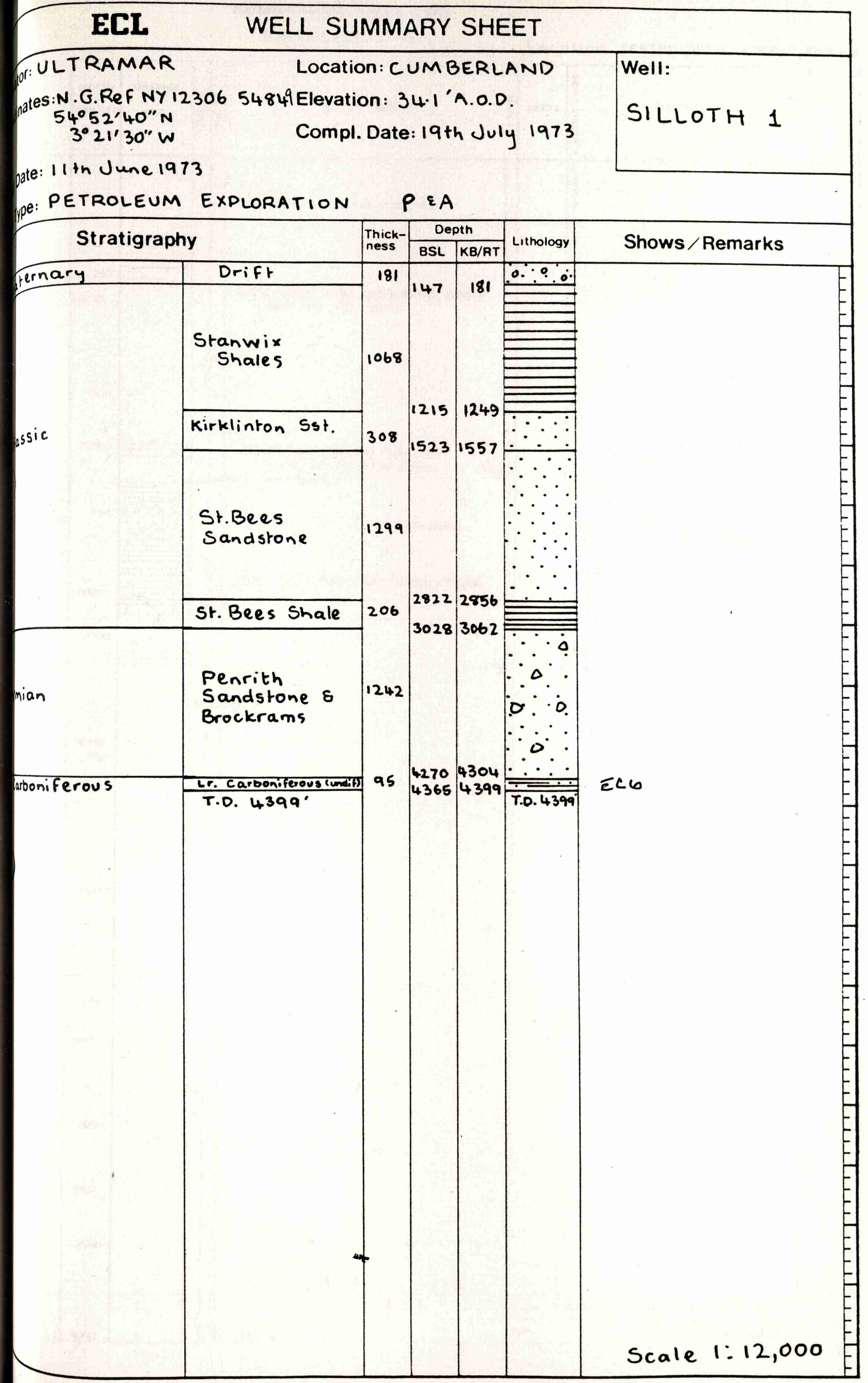


SUMMARISED WELL LOOG

SOUTHCLIFFE - I

Location SE87911:35220 E. YORKS, ENGLAND

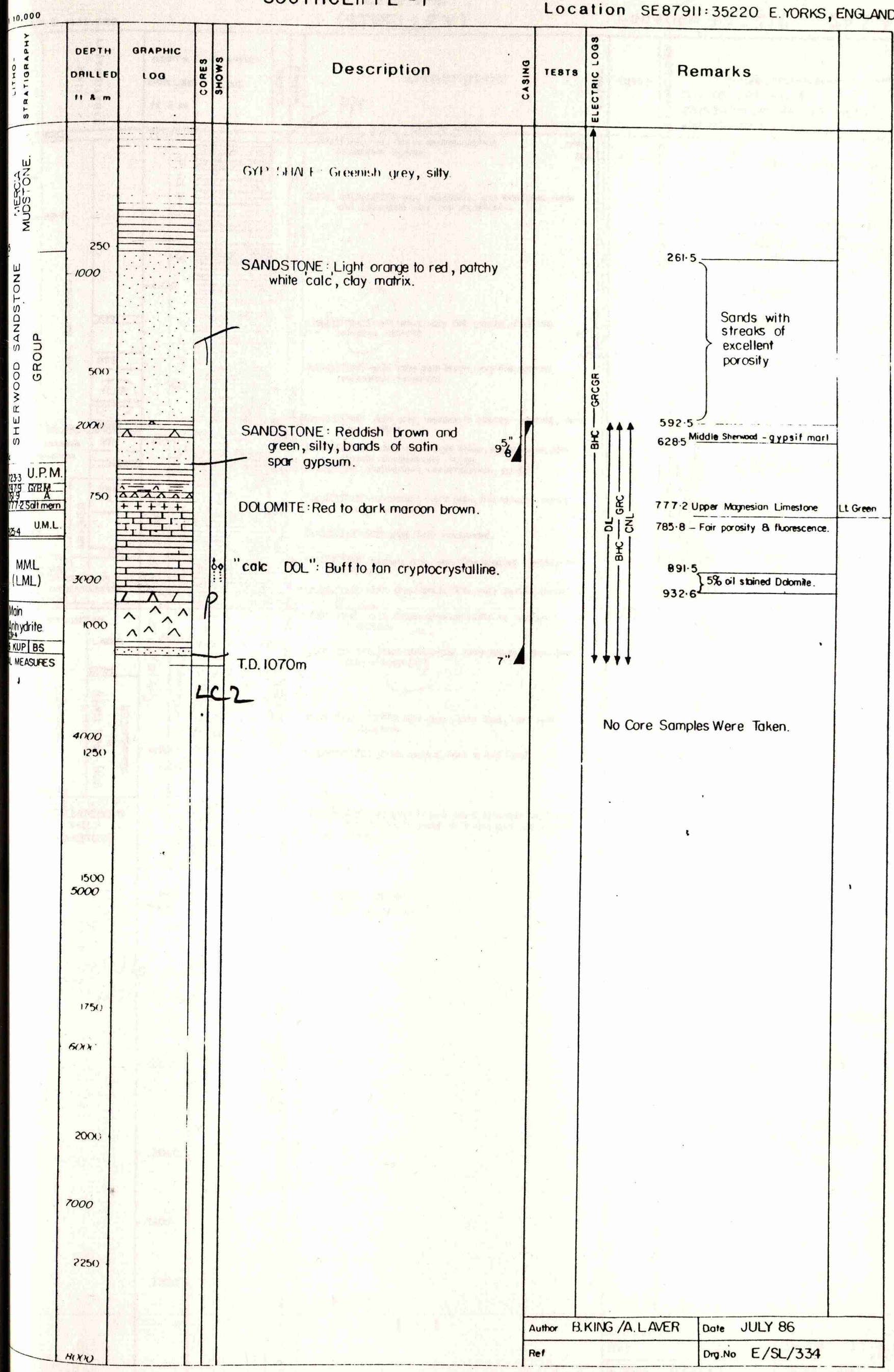


SUMMARISED WELL LOG

$L+N / 4-2$

SCALE 1:10.000

(STRELLEY)

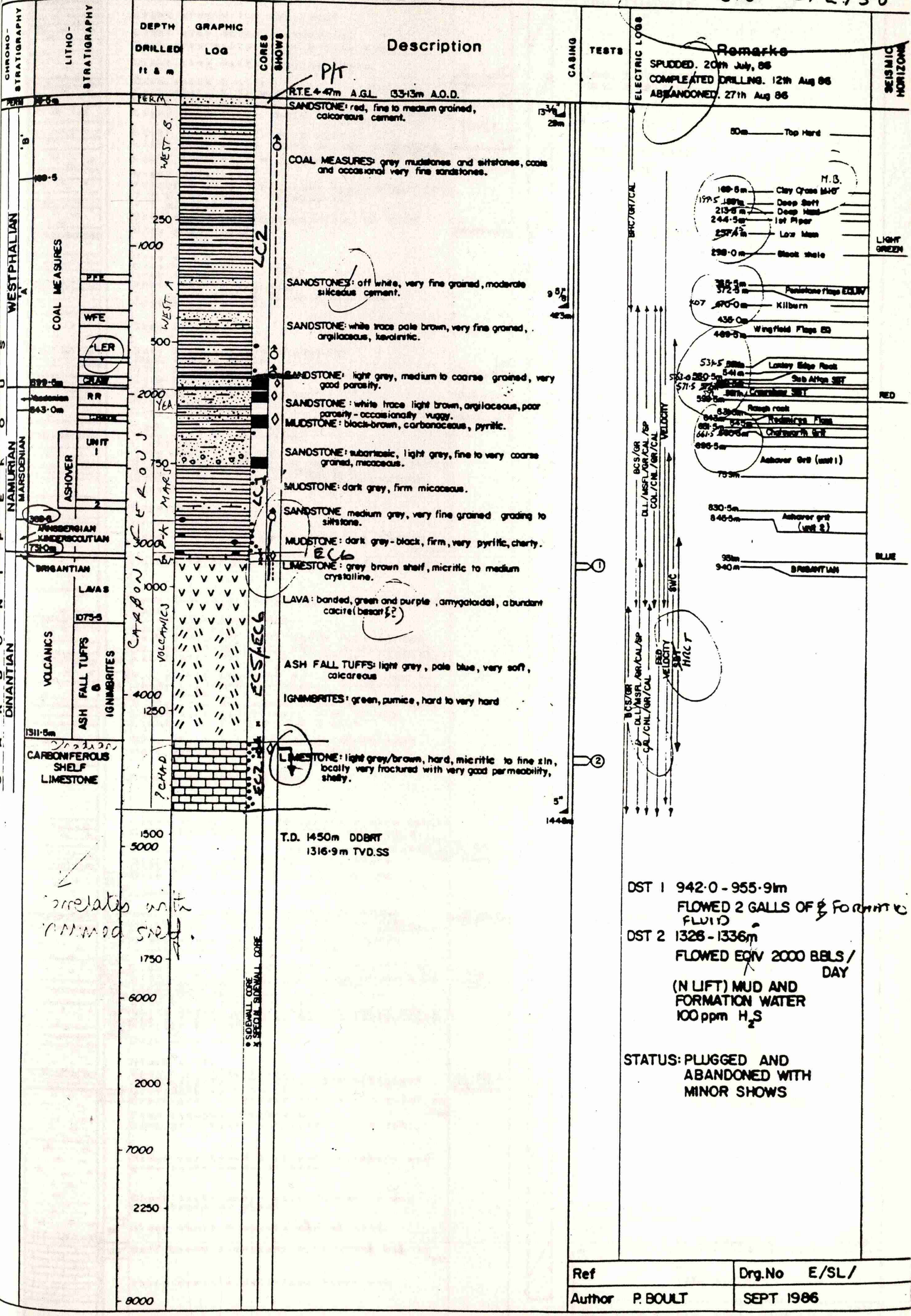




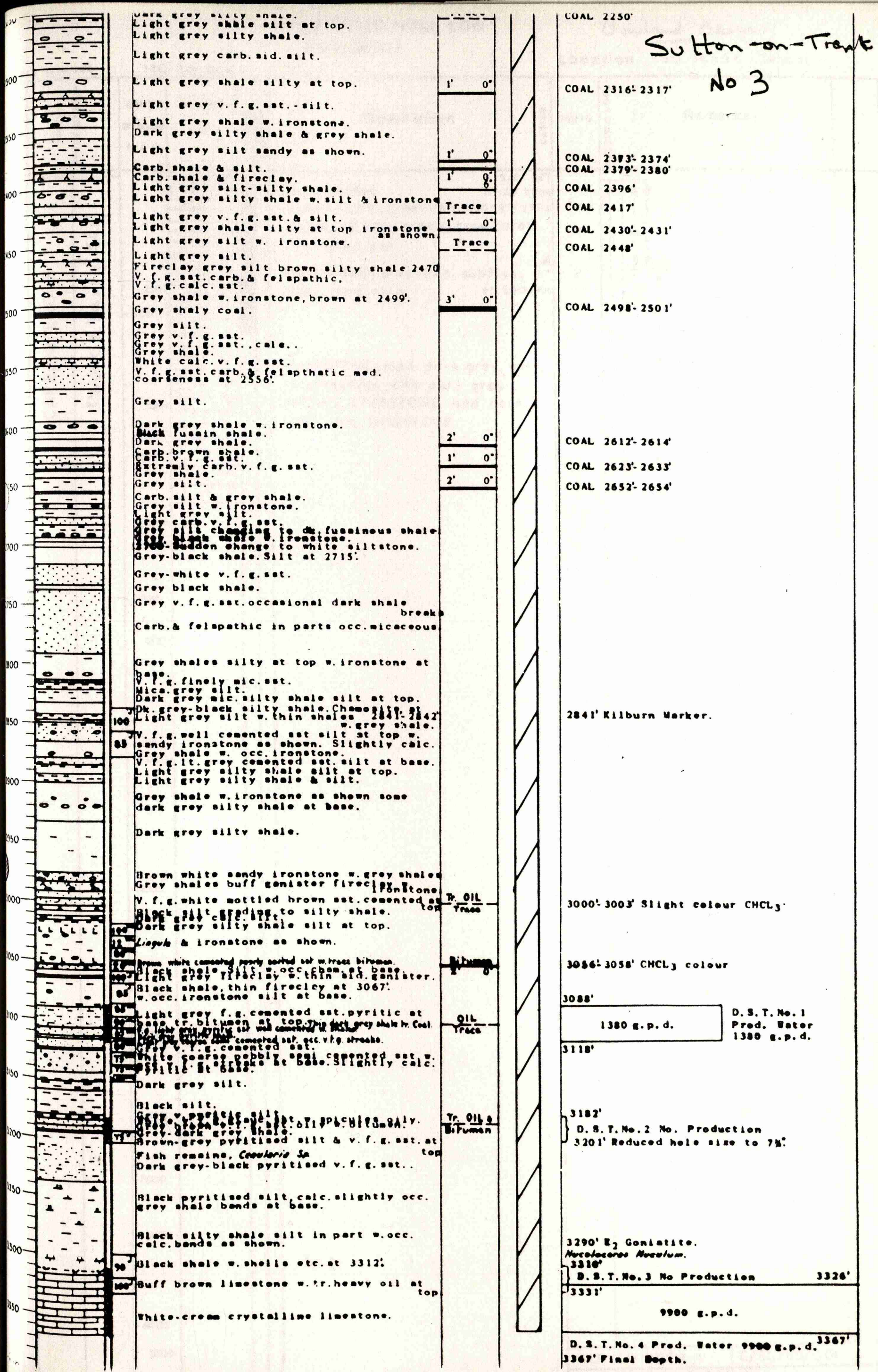


SUMMARISED WELL LOQ

Bouland Baim.

SWINDEN-I

Location SD 38597345051

ICALE $1: 10.00$

$140.8 \mathrm{~m} \mathrm{GLE}$
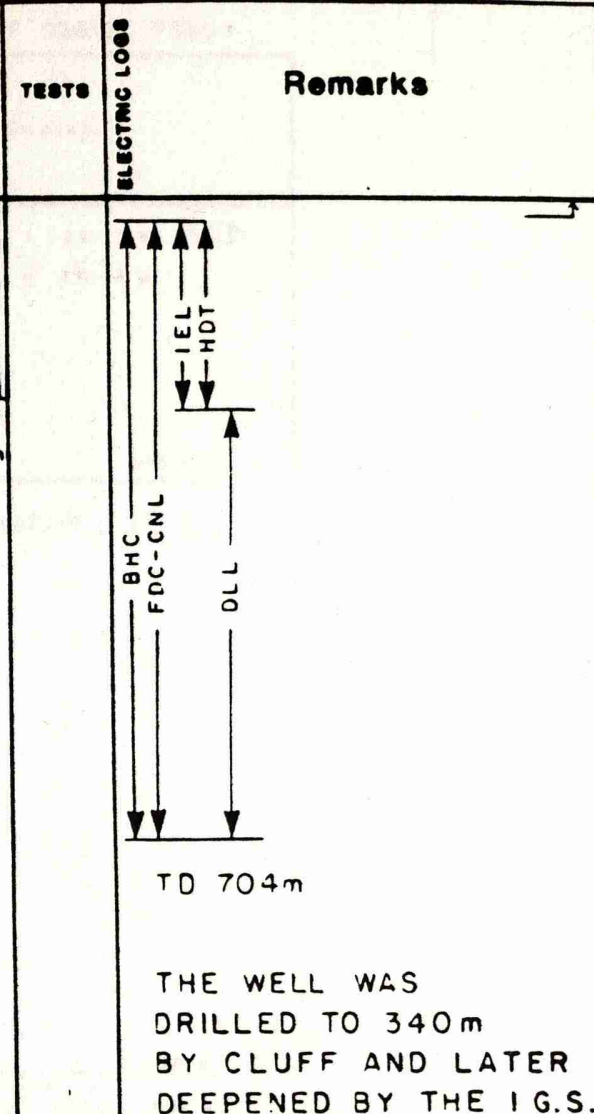

LIMESTONE; med. dork grey, silty, interlayered with dark grey ARGILL LIMESTONE and dork grey colc MUDSTONE MUDSTCNE; grey-bwn, subfiss, $7 "$ foss, med. hard of $200.84 \mathrm{~m}$ $-1000$

interbedded $25 / 81$, med. hard, foss.brach, cron.coral, froctured dol

$-2000$

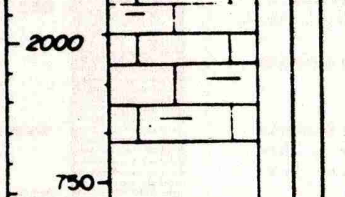

(1)


SUMMARISED WELL LOG

U.K. LAND

SCALE $1: 10.000$

SURFACE LOCATION TF 0361276807

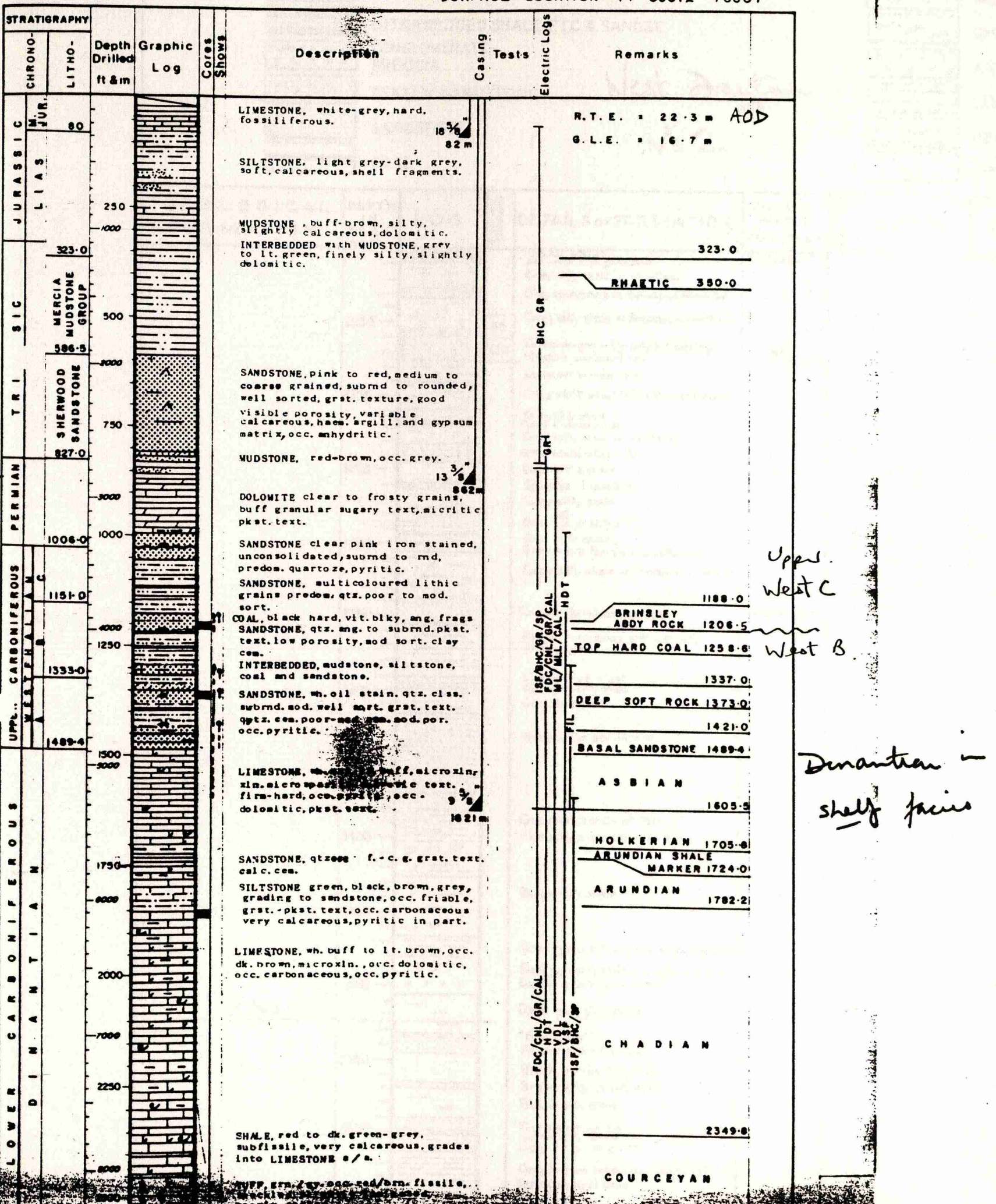




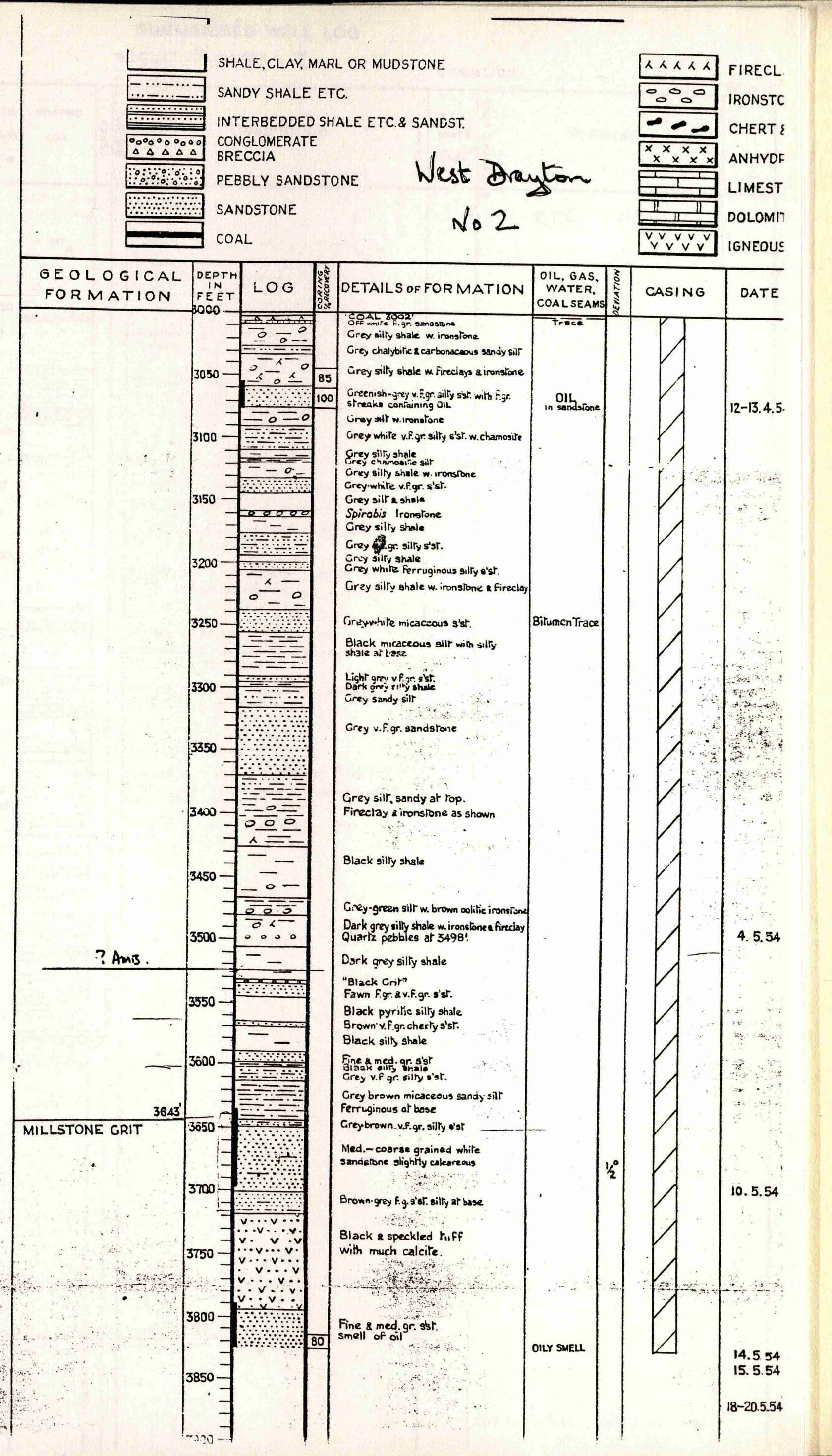


SUMMARISED WELL LOG

WEST FIRSBY - 1

Location

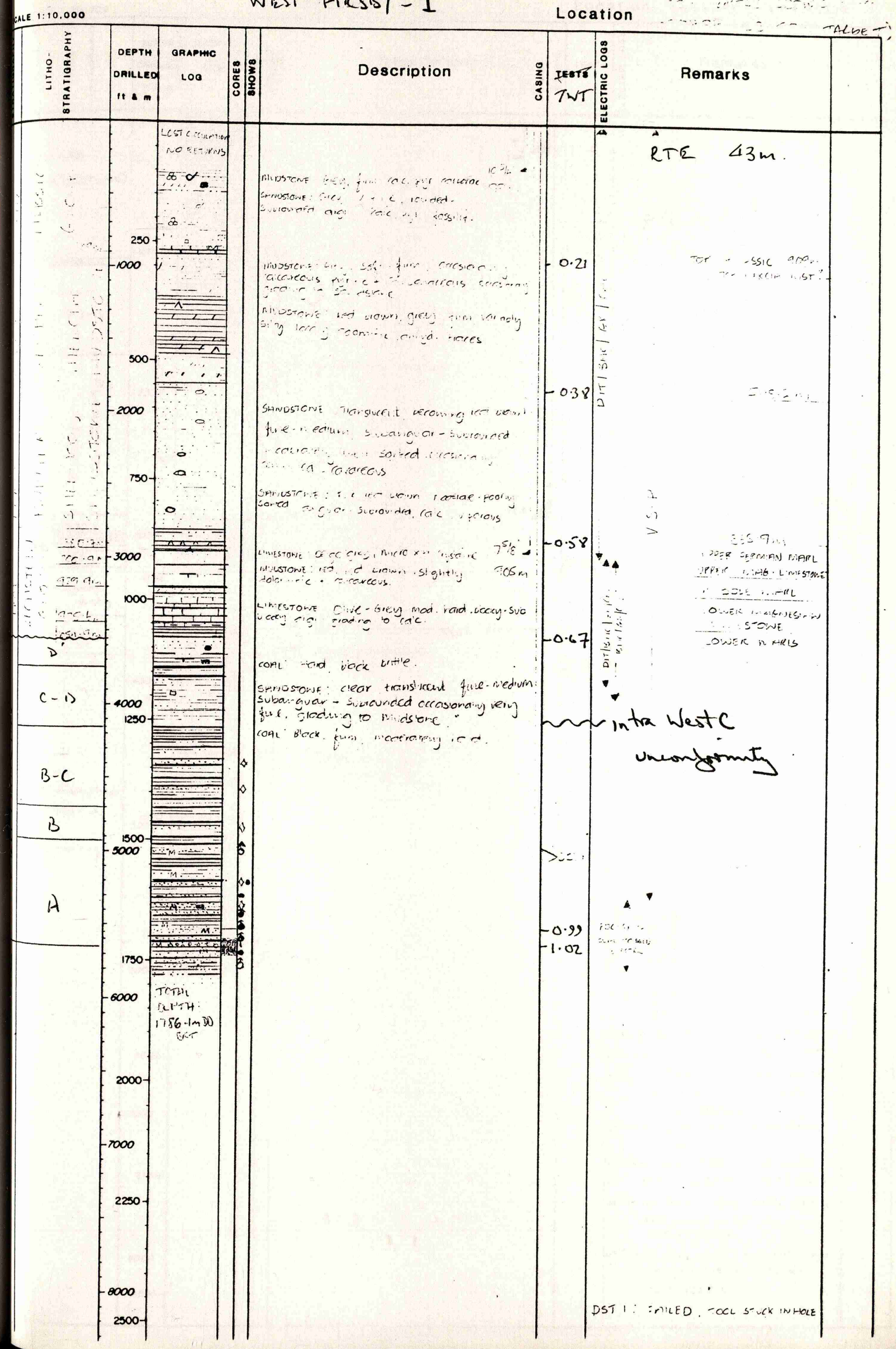


SUMMARISED WELL LOG

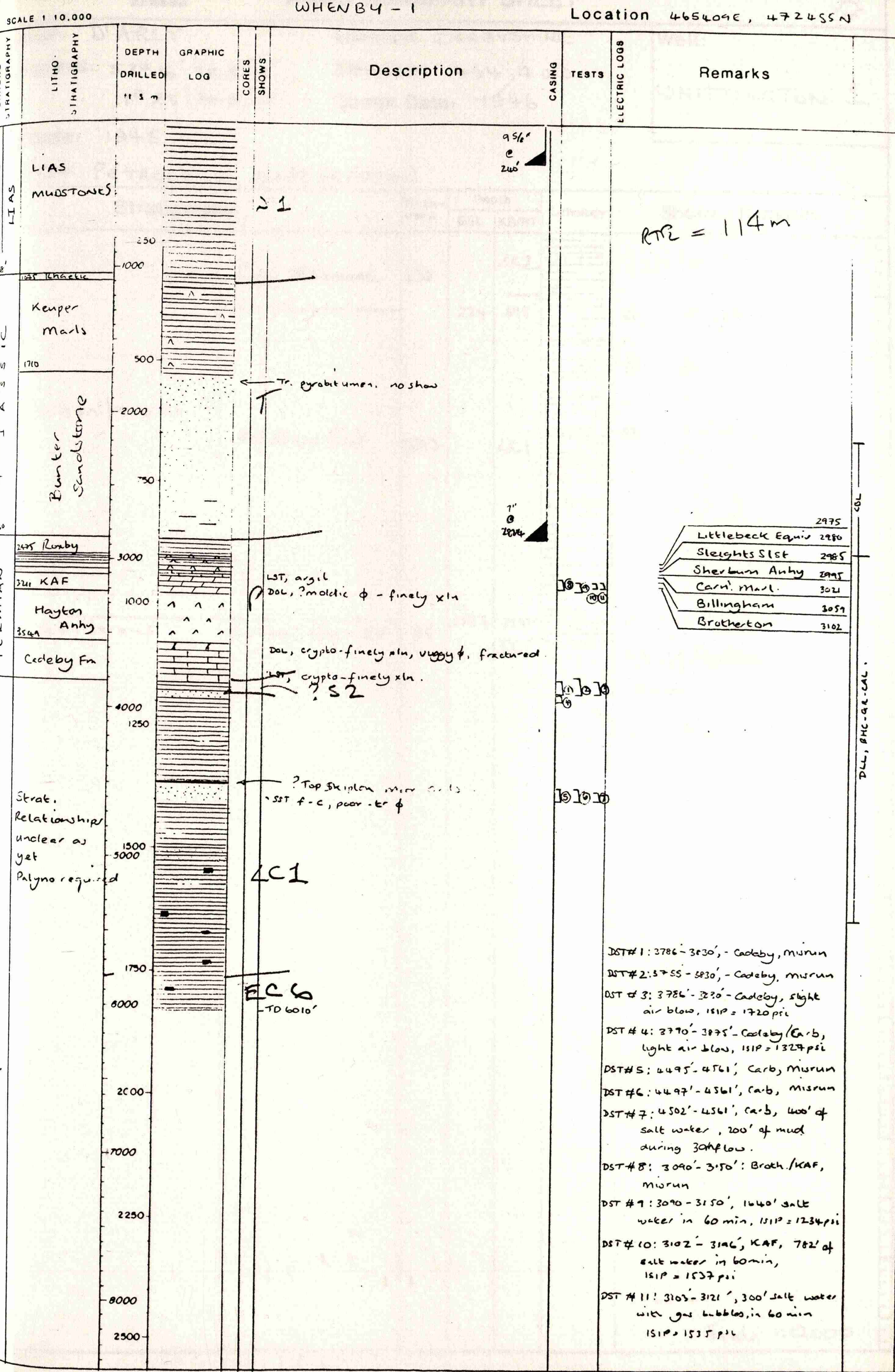


SUMMARISED WELL LOG

WHENBY - 1

Location

$465409 E, 472455 \mathrm{~N}$

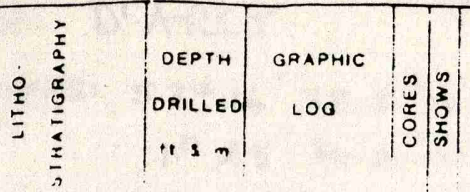

Remarks

LIAS

a MUOSTONES:

I $\approx 1$

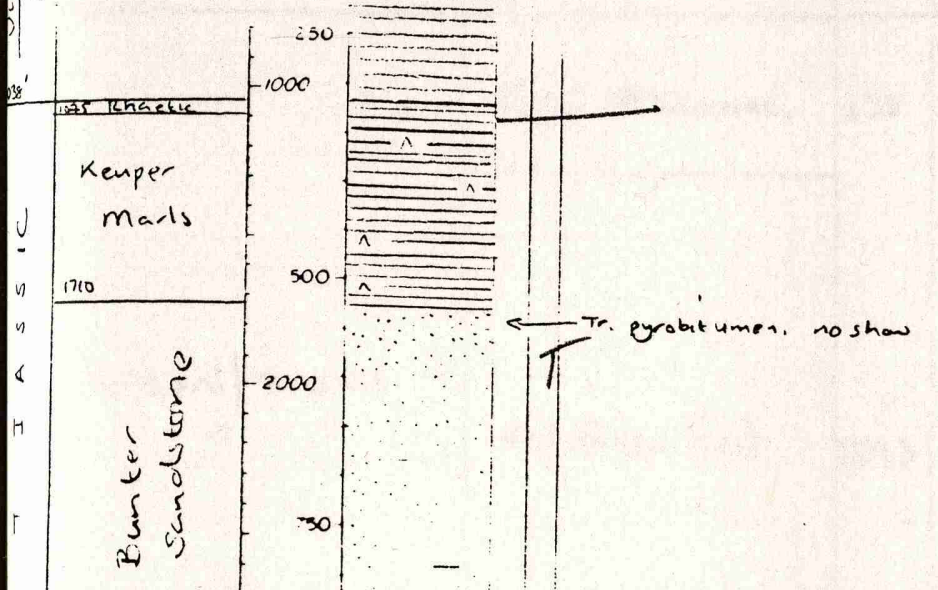

.

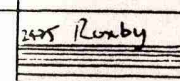

321 KAF

Hayton
3s49 Anhy

cacteby Fm

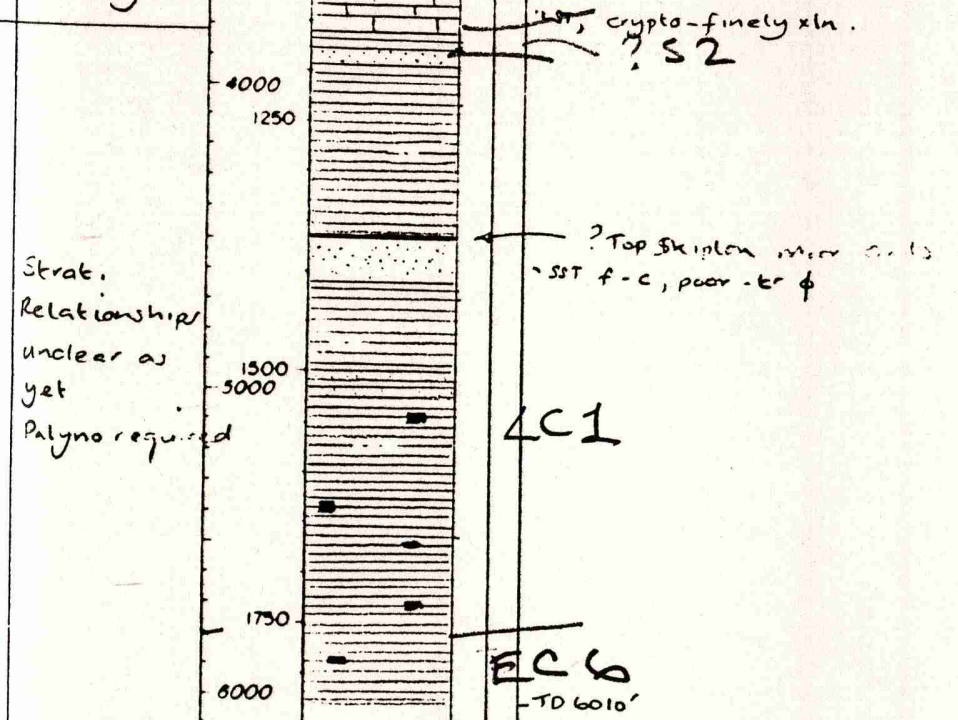

$.000 \rightleftharpoons$ T0 $6010^{\prime}$

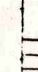

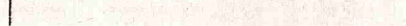

$1000 \frac{1}{11 n}$

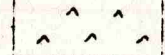

Dow, crypto.finely in, vugoy $\phi$, fractured.

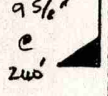

$R R_{2}=114 \mathrm{~m}$

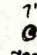

?

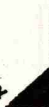

2000

$\rightarrow+\infty$

-

2250

$-\infty 000$

2500 
prator: D'ARCY LOcation: DERBYSHIRE

ordinates: $53^{\circ} 16^{\circ} 38.5^{\prime \prime} \mathrm{N}$ Elevation: $464^{\circ}$ A.O.D.

$1{ }^{\circ} 25^{\prime} 30.5^{\prime \prime} \mathrm{W}$ Compl. Date: 1546

Well:

WHITTNGTON 1

Date: 1945

HIll TYPE: PETROLEUM EXPLORATION

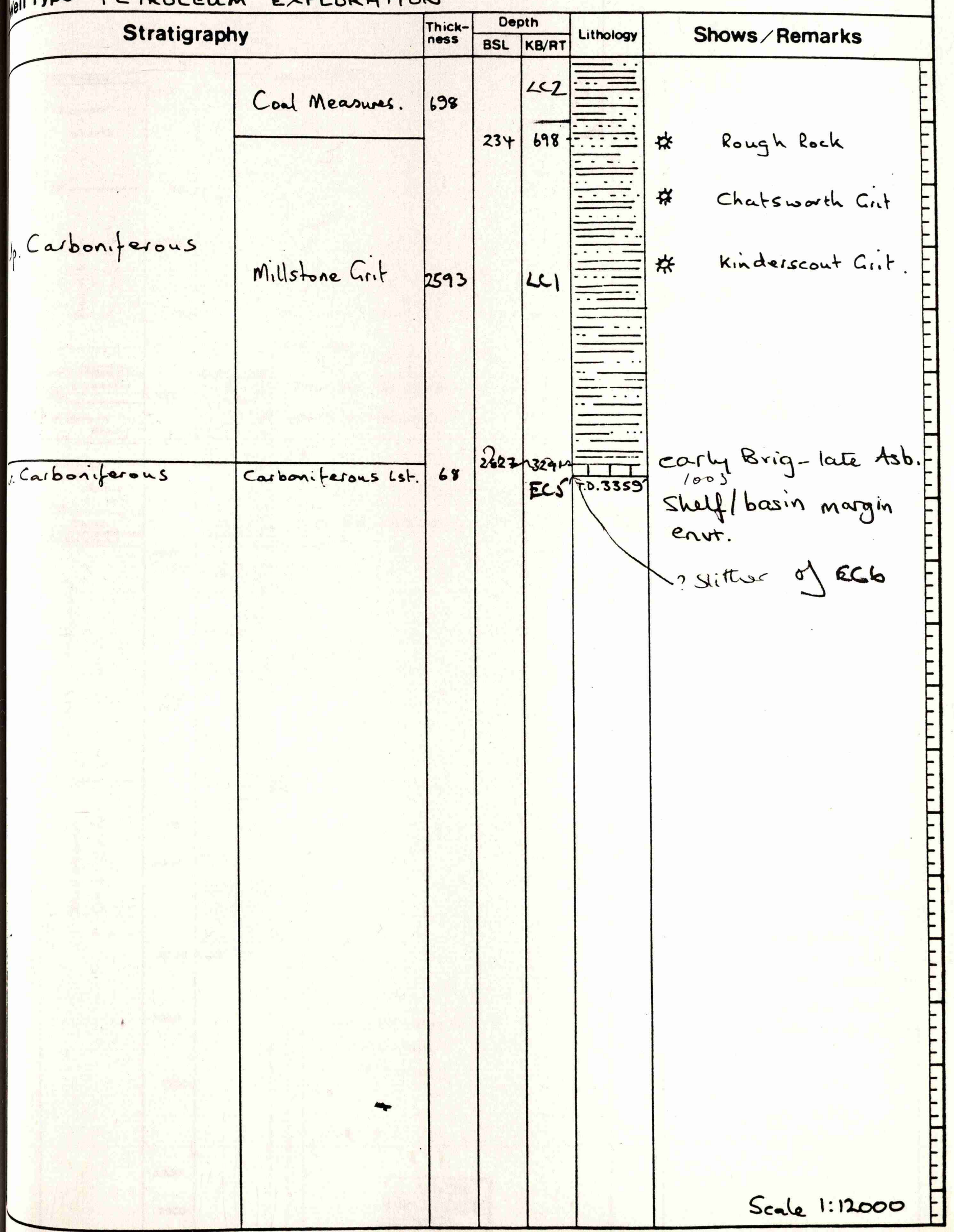




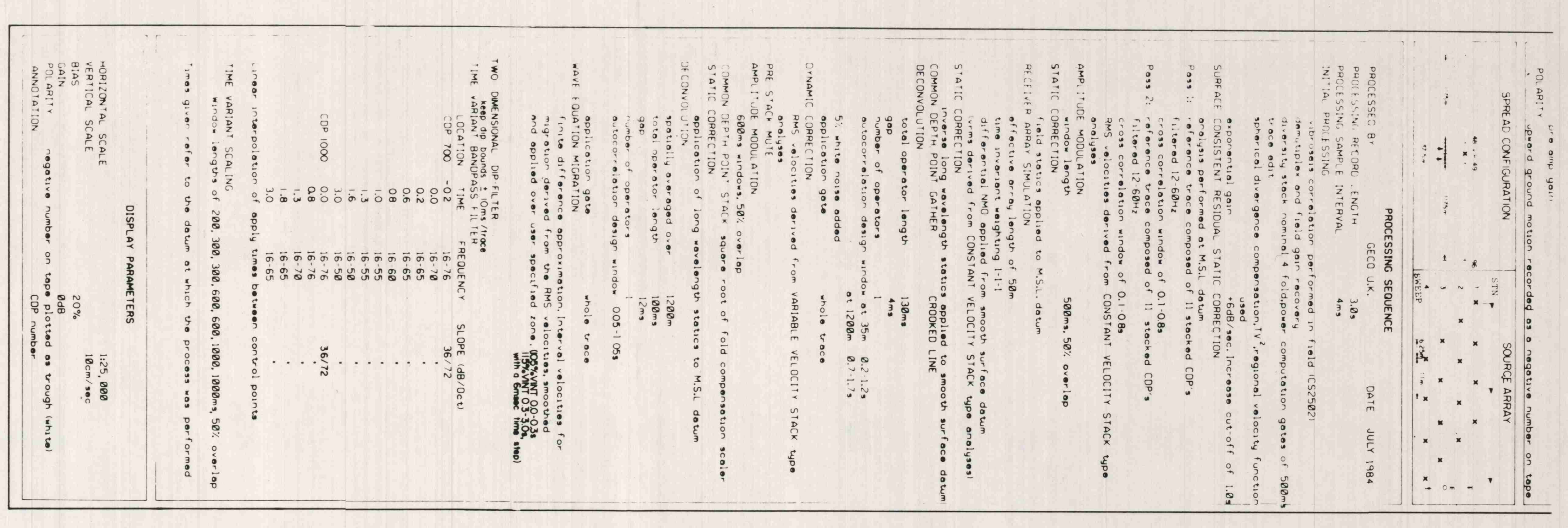

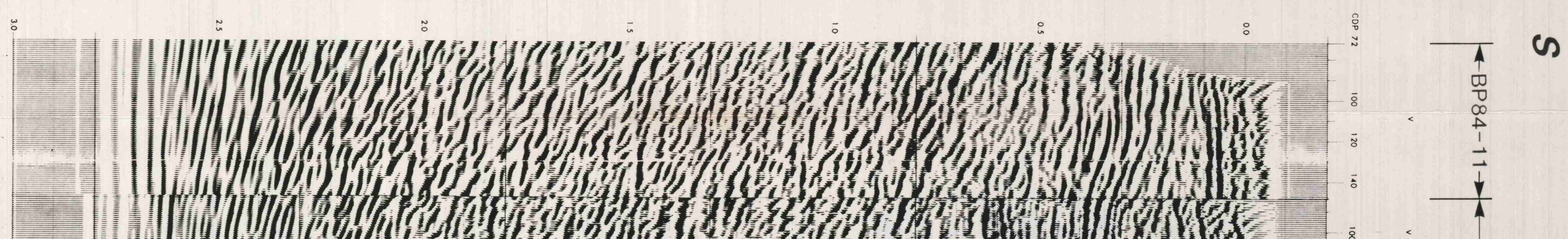

M M 1) 1. )

-

2. 8. 1 m. M. 1

$n$
$y$

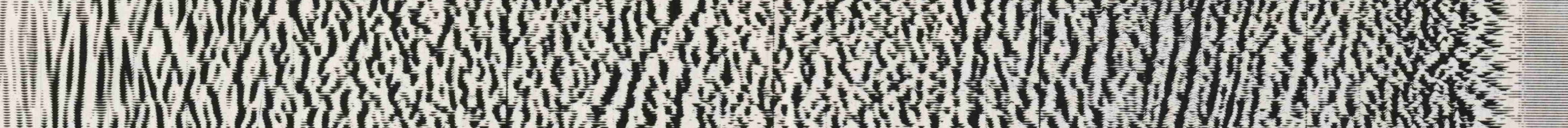
6. or.

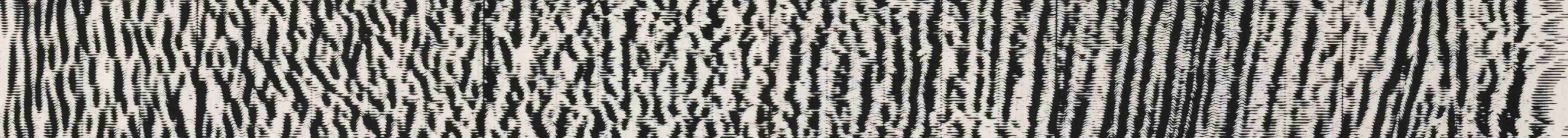
mom. m)

$-2(10)$

$\div$ -

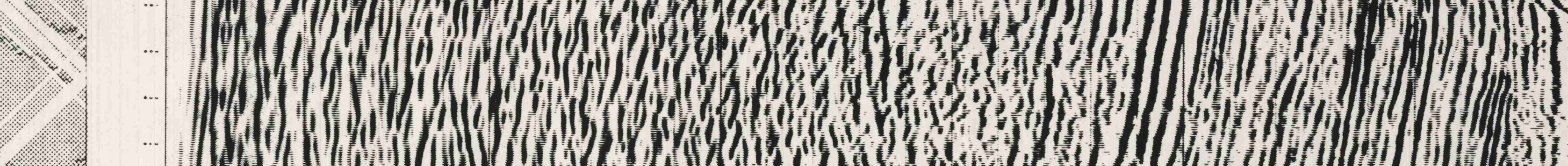

2.

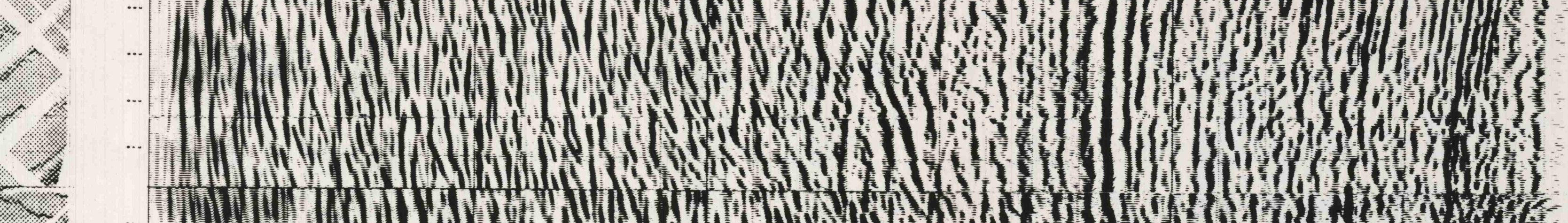

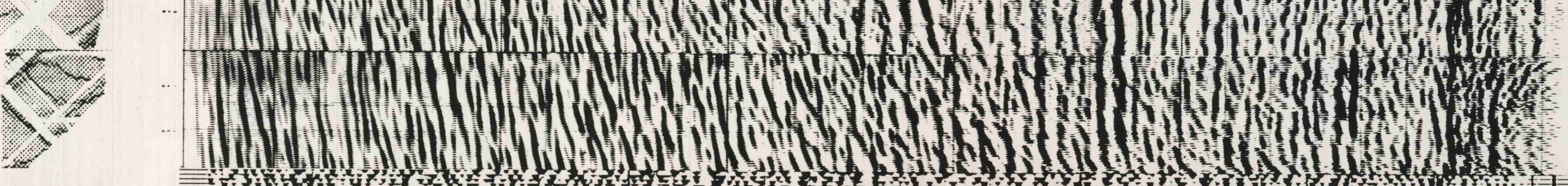

M W. 3. 3.7.7.

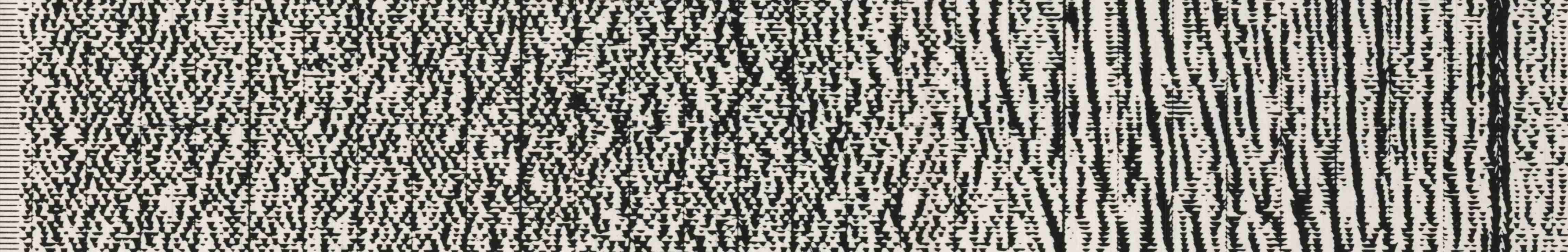

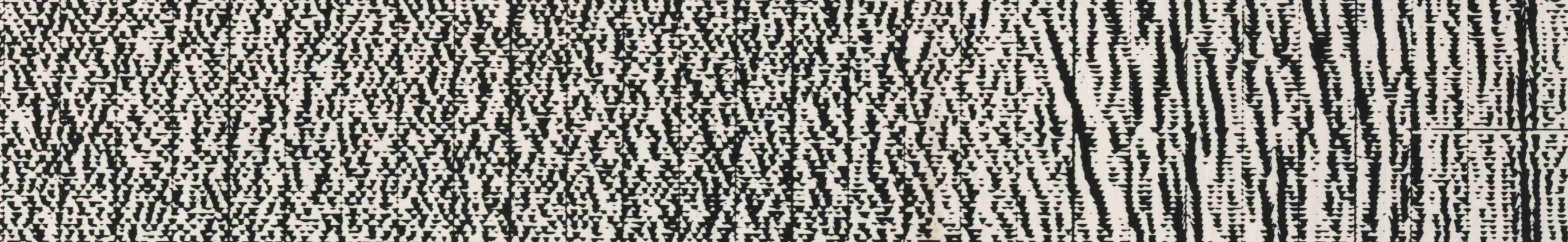

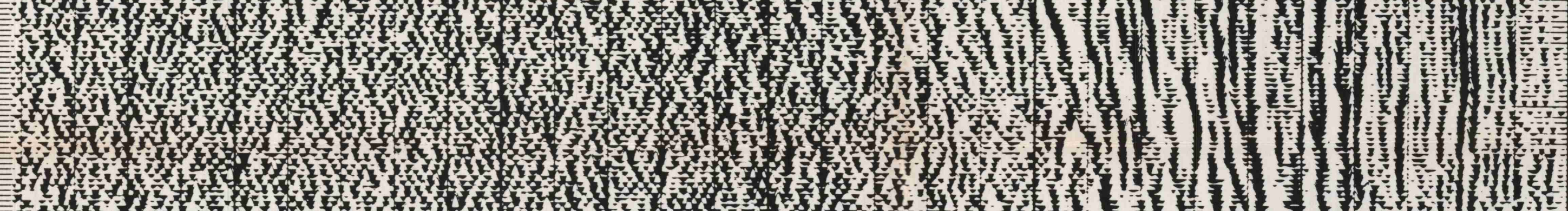
mW

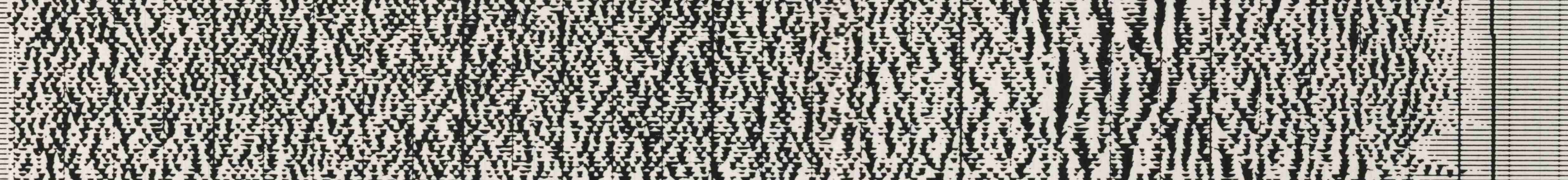

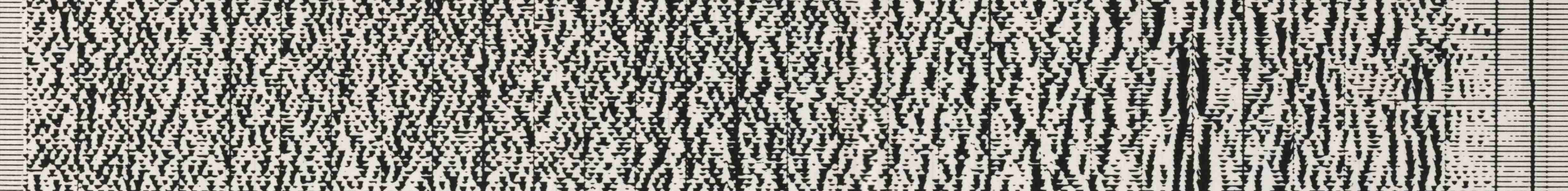

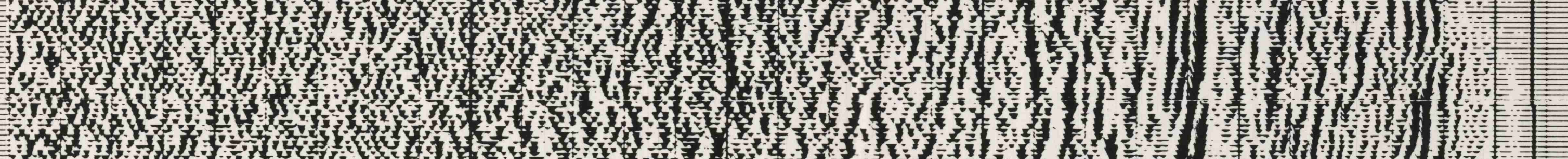
WrWW Whom WWWWW $W$ W

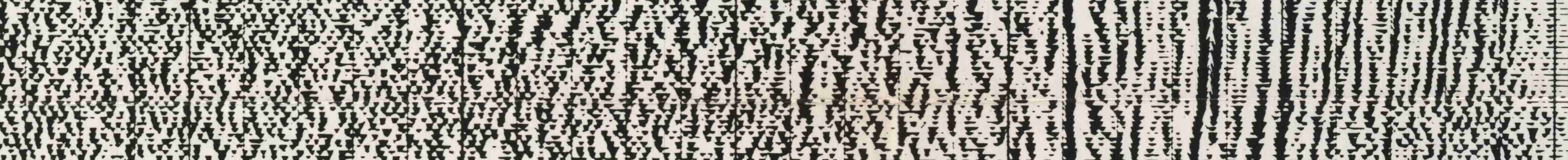

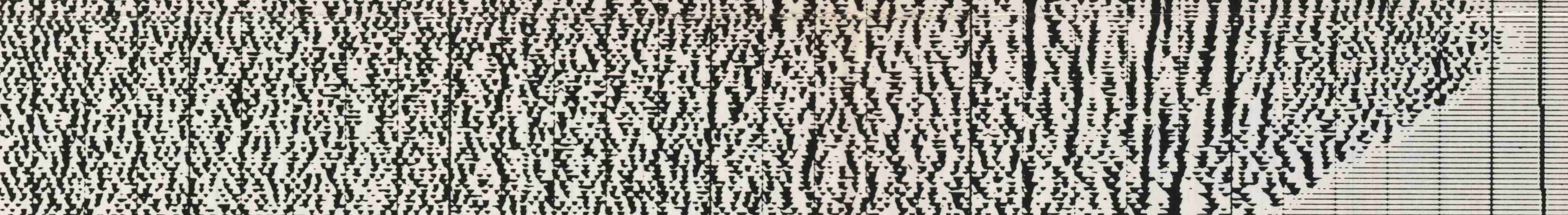

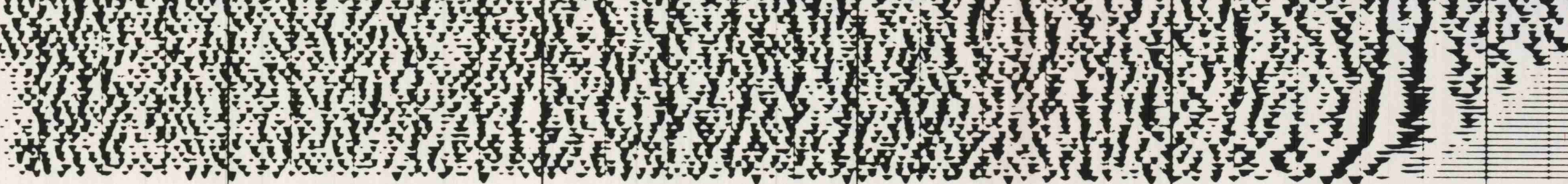

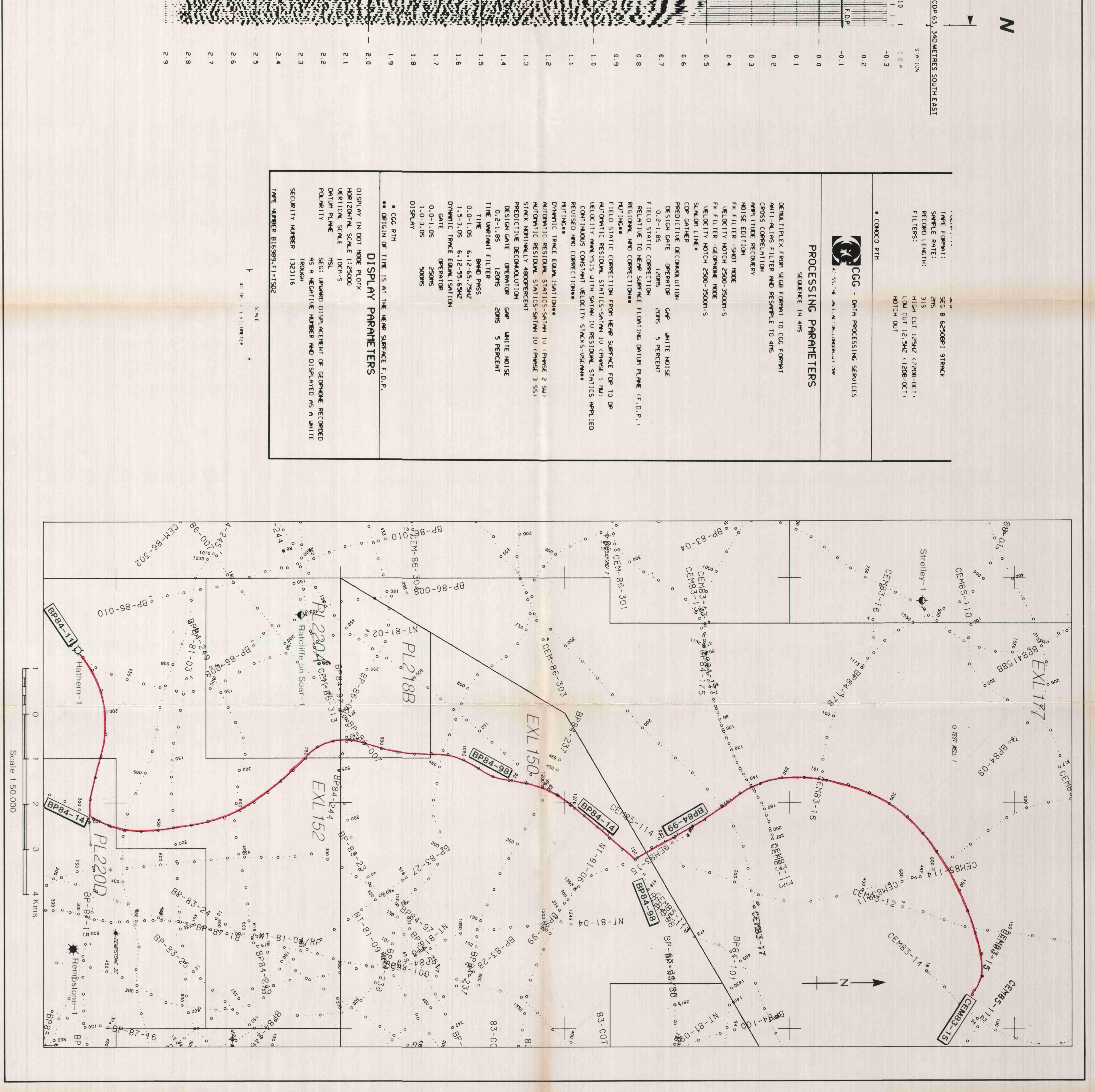

